\title{
ANNIVERSARY MEMOIRS
}

OF THE

\section{BOSTON SOCIETY OF NATURAL HISTORY}

\author{
PUBLISHED IN CELEBRATION OF THE
}

fiftieth Annibersary of the Society's foundation.

$$
\text { I830-1880 }
$$

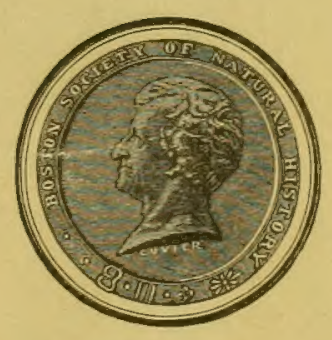

BOSTON :

PUBLISHED BY THE SOCIETY.

1880. 








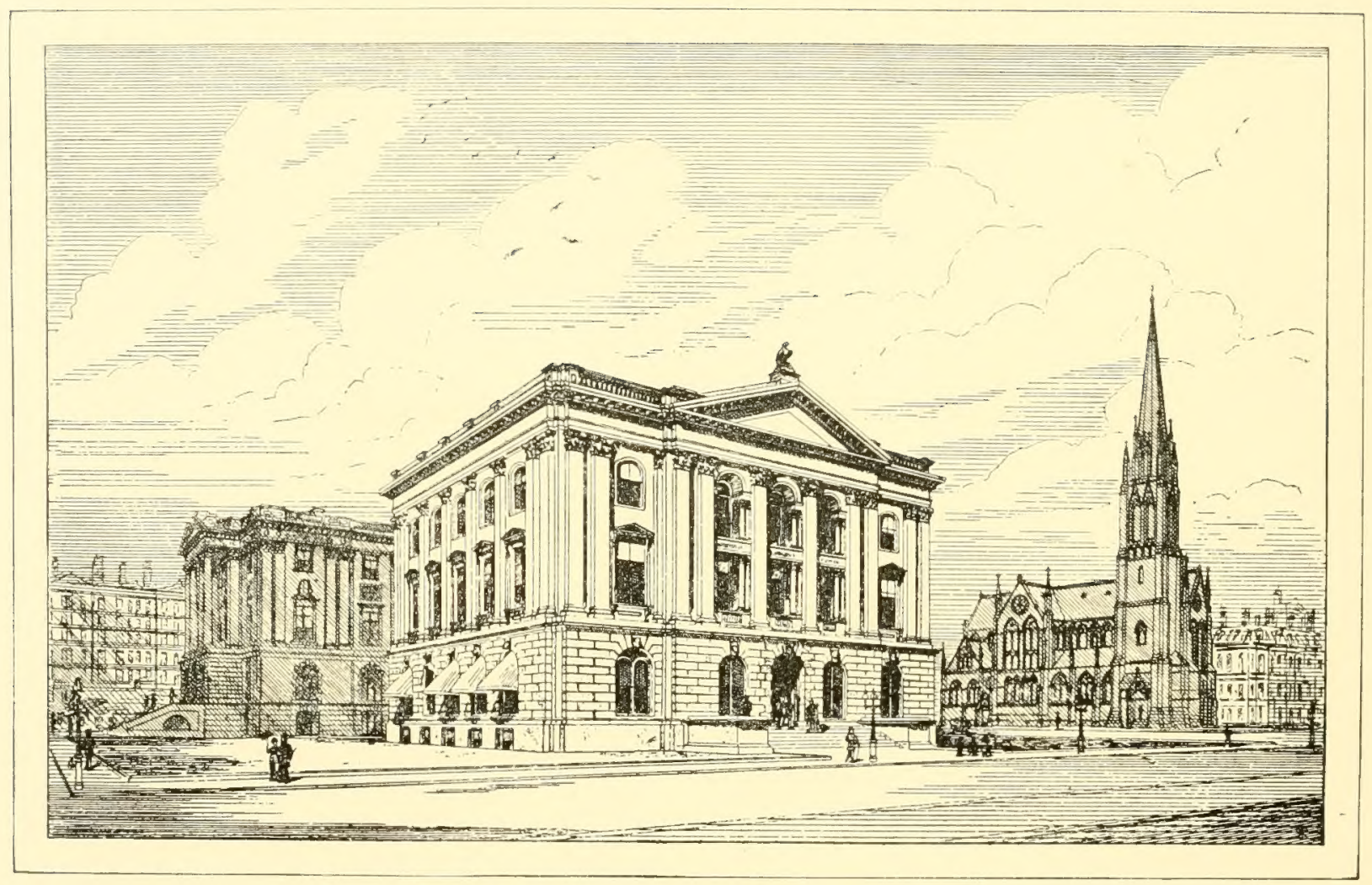

MUSEUM OF THE BOSTON SOCIETY OF NATURAL HISTORY. EREOTED 1863. 


\title{
ANNIVERSARY MEMOIRS
}

\author{
OF THE
}

\section{BOSTON SOCIETY OF NATURAL HISTORY}

\author{
PUBLISHED IN CELEBRATION OF THE
}

fiftieth Annibergary of the Society's foundation.

$$
\text { I830-I } 880
$$

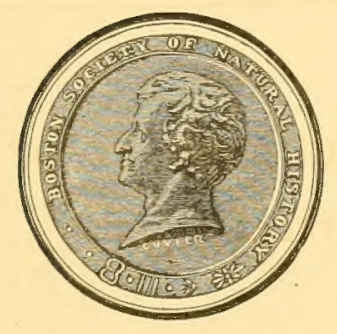

\section{BOSTON:}

PUBLISHED BY THE SOCIETY.

1880. 


\section{PUBLISHING COMMITTEE.}

Samuel H. Scudder, Edward Burgess,

Samuel L. Аввот, Alpheus Hyatt,

J. A. Allen.

PRESS OF A. A. KINGMAN.

BOSTON SOCIETY OF NATURAL HISTORY.

BERKELEY ST. 


\title{
TABLE OF CONTENTS.
}

\author{
SOCIETY ANNALS.
}

List of the Present Officers of the Society. (1.page.)

Prefatory Note, with extracts from the minutes of the annual meeting, May 5th, 1880. (3 pages.)

IIistorical Sketch of the Boston Society of Natural History, with a notice of the Linnaean Society of New England which preceded it; including biographical notices of all the Society's prominent past members, oflicers and benefactors. By 'Thoras 'T. Bouvé. (250 pages, six flonr plans, view of the Museum, and portraits of Benjamin D. Greene, George B. Emerson, Amos Binney, John C. Warren, Jeffries Wyman, 'Thomas 'I. Bouvé, Augustus A. Gould, D. Humphreys Storer and William J. Walker.)

\section{SCIENTIFIC PAPERS.}

N. S. Shater. Propositions concerning the Classification of Lavas considered with reference to the Circumstances of thcir Extrusion. (15 pages.)

Alpueus Iratt. Genesis and Evolution of the species of Planorbis at Steinheim. (114 pages, ten plates on nine sheets, one plate of sections; map and two sections in text.)

Samuer H. Scudder. The Devonian Insects of Nex Brunswick; with a note on the Geological Relations of the Frossil Insects from the Devonian of New Brunswick, by Prineipal J. W. Dawson, LL.D., F.R.S., etc. (41 pages, one plate.)

W. G. FanLow. The Gymnosporangia (Cedar-apples) of the United States. (38 pages, two plates.)

Theodore Lxwan. A nevo Structural Feature, hitherto unknown among Echinodmata, found in Deep-Sea Ophiurans. (1.2 pages, two plates.)

W. K. Broors. The Development of the Squid, Loligo Peatii Lesueur. (22 pages, three plates.)

A. S. PaCKard, Jr. The driatomy, Histology and Embryology of Limulus Polyphemus. (45 pages, seven plates.)

Edwatn Burgess. Contributions to the Anatomy of the Milh-Weed Butterfly, Danais Archippus Fabr. (16 pages, two plates; one cut in text.)

Samuel F. Clarke. The Development of a Double-headed Vertebrate. (6 pages, one plate.)

Cranles Sedgwick Minot. Studies on the Tongue of Reptiles and Birls. (20 pages, one plate; six cuts in text.)

EDtwatd S. MIorse. On the Identity of the Ascending Process of the Astragatus in Birds with the Intermedium. (10 pages, one plate; trvelve cuts in text.)

Lucier Carr. The Crania of New England Indians. (10 pages, two plates.)

Willinas James. The Feeling of Effort. (32 pages.) 


\section{LIST OF THE PRESENT OFFICERS OF TIIE SOCIETY.}

President.

SAMUEL H. Scudder.

Vice-Presidents.

John Cummings, Frederick W. Punnam.

Custodian.

Alpheus Hratt.

Honorary Secretary.

Samuel L. ABbot.

Secretary.

Edward Burgess.

Treasurer.

Charles W. Scudder.

Librarian.

Edward Burgess.

Committees on Departments of the Museum.

SINERALS.

Tuovas T. Bouvé,

R. H. Ricinatos,

M. E. Wadstorth.

$$
\text { GEOLOGY. }
$$

William H. Niles,

G. Frederic Witght,

PALAEONTOLOGY

Thomas T. Bouvé,

N. S. SHaLer.

\section{BOTANY.}

Jorne Cunnings,

Cirarles J. Sprague,

J. Amory Lowell.

MICROSCOPY

Samder Wells,

R. C. Grennlfaf,

B. JoY JeFFries.

COMPARATIVE ANATOMY.

Thomas Dwignt,

W. F. WHITNEY.
RADLATES, CRUSTACEANS AND WORMS.

H. A. HAGEN,

Alexander Agassiz.

MOLLUSRS.

Edward S. Morse,

J. Heniry Blake.

INSECTS.

Samute H. Scudder,

Eoward liurgess,

A. S. Packard, Jir.

FISHES AND REPTLES.

F. IV. Putnam,

THeodore Lraran,

S. IV. Garman.

BIRDS.

J.A. AlleN,

Samuel Cabot.

MAMMALS.

J. A. ALtLEN,

E. L. MATK,

George L. Goodale. 


\section{ERRATA.}

In the table of contents:

Fifth puragraph, for ten plates on nine sheets real nine p'itcs on right shects.

In the IIistorical Sketch:

Page 216, 22d line, real Charles W. Eliot.

"6th " from bottom, for from all read from that of all.

" 217,1 inth " after woith insert the chief causes of.

In Mr. Scutiter's memoir:

l'age $3: 3$, line 9 from the bottom, for confidentially read confitently.

In Dr. Farlow's memoir:

IPage 3, note 2, for Ustitarinées read Ustilaginées.

" 6, 9th line from top, for Euromyces rend Euriromyces.

" 7,18 th" " " " "hymeniferus real hymeniferous.

"9, 5 th " " bottom, for varics read vary.

"11,4th " " top, for Berko read Berk.

" 1 ,, 10 th " " " " fig. 17 read fig. 16 .

"18, 12th" " " "Gusperrini real Gasparrini.

" 20 , 6th \& 10 th lines from top, for theyoides real thyoides.

" 21,7 th line from top, for gymnosporengizen real Gymnosporanginem.

"24, 13 th " " " " "

" $\$ 1,10$ th " " " " " "tubereules read tubercles.

"31, $23 \mathrm{3}$ " " " " " " " " "

"32, 19th" " "before mesent insert the.

" 33 , 9th " " " "for $R$. lecesta read 7. . lacerata.

Owing to the absence of the writer during the printing of this article a considerable purt of the proof conll not be submitted to him for revision.

In P'rof. Morse's memoir:

Jage 7,17 th line from top, for fore read hind.

In Prof. James' menoir :

I'age 12, 10th line from bottom, for right read left.

" "9th " " " "eft read right.

"30,8th " " 6 top, for work read no woork.

expressed my sincere regret that we can no longer be led ${ }^{\prime}$ in this work by the President whose devotion we have been only too pleased to acknowledge by our ballots for ten years past; but as long as his life is spared to us we shall have his sympathy and wise advice, 
R. C. Grennlfat,

B. Joy JefFries.

COMPARATIVE ANATOMY.

Tmomas Dwignt,

W. F. WIITNEY.
DAMUEL UADUL。

$$
\text { MIAMMALS. }
$$

J. A. AlLen,

E. L. MARK,

George L. Goodale. 


\section{PREFATORY NOTE.}

The Boston Societr of Natural History, founded in 1830 by a few earnest men, has this year celebrated its fiftieth amiversary. Its growth during this period has been so considerable, it has gained for itself so firm a hold upon the esteem of our citizens, and its relations to the higher education of the people have been so significant, that it has been thought fitting to signalize this anniversary by the issue of a special volume of scientific papers, preceled by a detailed history of the Society, the preparation of which was entrusted to the President. Included in the history will be found the proceedings of the jubilee meeting, held on the twenty-eighth of April last. At the anmual meeting, held a few days later, the President, Thomas T. Bouvé, Esq., declinerl a reëlection; having been an officer of the Society for nearly forty and its President for ten years, no man living is so thoroughly identified as he with its life and interests during the most eventful period of its history; and it is therefore fitting that this statement should be followed by the tribute paid at the annual meeting to his untiring devotion to the interests of the Society, not only during his Presidency, but for nearly the whole period of its existence.

Boston, Dec. 15, 1880.

Publishing Commitee.

Extract from the minutes of the Annual Meeting, May 5, 1880.

Mr. S. II. Scudder, on assuming the presidential chair, discussed the mission of the Society, closing his remarks with the following words: At a previous meeting I have already expressed my sincere regret that we can no longer be led in this work by the President whose devotion we have been only too pleased to acknowledge by our ballots for ten years past; but as long as his life is spared to us we shall have his sympathy and wise advice, 
and we may be sure that in all the work the Society undertakes, it will have no stronger friend than he.

\section{Mr. John Cummings thereupon offered the following vote:-}

"In consideration of the fict that Mr. Bouve has declined to be a candidate for the first office of this siocicty, the members desire to express their grateful acknowledgment of the long and valualle service he has rendered as President, and their cordial thanks for his arduous lahor's, unremitted devotion, prudent and suceessful administration; nor can they part from him in this official anacity without the additional expression of their warm personal esteem."

No one ever associated with Mr. Bouvé, added Mr. Cummings, who dir not feed himself drawn to him by the strongest and tenderest ties. In his own experience he had never met a man with so much devotion to any cause as Mr. Bouvé had shown for the welfare of the Society.

Mr. Cummings's remarlis were warmly applauded and the motion was seconded by Prof. A. Irratt, who said, in respeet to Mr. Bouvés administration, that although from the first the present policy of the society had met the severest eriticism and sometimes disapprobation firon the intimate friends and advisers of the President, he had yet been able to keep his judgment unwarped and to consider those ideas, which were new to him, purely on their own merits. It is not too much to say that the Society's aims, which we have heard so highly praisent in this anniverary year, could not have been so developed without Mr. Bourés constant support. The feelings expressed by Mr. Cummings will be echoed in the heart of every officer of the Society, for we have always found our President full of kindness and consideration, as well as just and sound in judgment.

Mr. F. W. Putnam said he could not allow this opportunity to pass without a few words, which at best would be but a feeble expression of his feelings; for in addition to a long and cherished friendship that every year had strengthened, his official ties to Mr. Bouvé were doulle, and both were broken by his resignation, since, as might not be remembered by all present, the President of the Society was ex-officio a member of the board of trustees of the Peabody Museum at Cambridge; and while, as Curator of that Museum, he welemerl his firend, the new Prexident of the society, he was very sorry to lose one who hard been so long connected with the Museum and had ever been ready to give his kindly aid in furtherance of its objects.

Prof. W. H. Niles spoke of the large amount of work in the care and arrangement of the collections which Mr. Bouve had accomplished during the term of his presidency. Most of this hats been done after the business duties of the day, and how frequently he hats remained until called home by some one, none but his family know. When alterations in the building were going on, he habitually inspected the entire premises after all other' hiul gone, to wee that all was left in safety. The Suciety has steadily progressed in its usefulness and scientific position during the administration of Mr. Bouvé, and he 
now leaves the presidential chair with nothing to regret, and with the esteem and friendship of every member. Day by day, and year after year, he has brought here a large heart, full of geniality and goodness, and has been in himself a source of happiness to those who have known him as President. It would be a pleasure to reciprocate, in some small measure at least, his long-continued kindness, and this could be best done by each member's trying to make the Society so pleasant for Mr. Bouvé, that, as a souree of his future happiness, it should be second only to his home and his fimily. In conclusion, Mr. Niles said he did not doubt that each member present would like to express in some special way his personal respect and honor for him who was the dear friend of all and one of the best benefactors the Society ever had; and he hoped they might do so by rising as they voted for the adoption of the resolution proposed by Mr. Cummings.

The Chair accordingly called for a standing vote and the resolution was unanimously adopted. 
1830. ANNIVERSARY MEMOIRS OF THE BOSTON SOCIETY OF NATURAL HISTORY. 1880.

\section{HISTORICAL SKETOH}

OF THE

\section{BOSTON SOCIETY OF NATURAL HISTORY; \\ WITH}

A NOTICE OF THE LINNEAN SOCIETY,

WHICH PRECEDED IT.

BY THOMAS T. BOUVÉ.

BOSTON :

PUBLISHED BY THE SOCIETY.

1880. 
To

CIALLES JAMES SPLAGUE and JAMES CLARKL WHITE,

Companions with me for years in laborious work upon the collections of the Society, these parges are derlicated,

with the great respect and kind regards of

Tile Author. 
Historical Sketcil of the Boston Society of Natural History: with a Notice of the Linn zan Society, which preceded it. By Thomas T. Bouvé.

No history of our Society can well be given without some brief account of the attempts previous to its formation to interest the public in the study of Natural History. Before any organized efforts were made to this end but few publications even had appeared on the subject, and these are cited from remarks made by Dr. A. A. Gould in a sketch of the Linnean Society, which appeared in the Proceedings of the Boston Society of Natural History in 1863. ${ }^{1}$ The most valuable of them was one by the Rev. Manassah Cutler, entitled "Account of some of the Vegetable Productions naturally growing in this part of America, botanically arranged." Another was a pamphlet published by the celebrated Dr. Benj. Waterhouse, who seems to have brought with him from Holland "some general notions of Systematic Natural History." The pamphlet was entitled, "Heads of a Course of Lectures on Natural History," Cambridge, 1810, in which he distributes the lower animals under the heads of Ornithology, Amphibiology, Ichthyology, Insects and Vermes; which latter he mentioned as "outskirts of Animated Nature extending to the confines of the vegetable world." In a note he said he would "extend, contract or omit parts of his programme to suit his audience." As Dr. Gould quaintly remarks, it does not appear whether he ever had any audience at all. In addition to these publications some articles of a practical character were written by Prof. W. D. Peck, who occupied the Chair of Natural History at Harvard College from 1805 to 1822. They appeared in agricultural papers, and the most important of them purported to give a natural history of the slug worm and the canker worm. Dr. Gould, in referring to the Professor's work at Cambridge, says, "He gave such instruction as was demanded, which was very little." Harris's Natural History of the Bible, Mather's Magnalia, Thacher's Dispensatory, with some treatises on the medicinal properties of herbs, and a few other papers of little importance, complete the publications referred to.

\section{The Linnæan Societr.}

The time at length arrived for an organized effort to excite some interest on the part of the public in natural science, and the men were not wanting. On the 8th of December, 1814, there met at the house of Dr. Jacob Bigelow, a number of gentlemen, then prominent in the community, some of whom afterwards became eminent in their several professions, if not in natural science. They were, besides Dr. Bigelow, Wm. S. Shaw, Octavius Pickering, Dr. Walter Channing, Ezekiel D. Cushing, La Fayette Perkins, Dr. Geo. Hayward, Nathaniel Tucker, J. Freeman Dana, John W. Webster, and

$$
1 \text { Vol. Ix, } 335 .
$$


Dr. John Ware. Dr. Channing was chosen Chairman, and Dr. Bigelow Secretary, and a committee, composed of Dr. Bigelow, Mr. Pickering, and Dr. Hayward, was appointed to draft a Constitution for the Society, which they called the New England Society for the Promotion of Natural History. Two days after they met again by adjournment, and the Constitution reported by the Committee was read, discussed, and adopted. Among its provisions are some which may interest readers of the present day.

The 1st article provides that the Society shall consist of Immediate, Associate, Honorary, and Corresponding Members.

The 2d, that the officers shall consist of a President chosen from the Honorary or Immediate Members; Vice President, Corresponding Secretary, Recording Secretary, Treasurer, and Cabinet Keeper, who shall be chosen from the Immediate Members.

The 11th, that there shall be a meeting once a week.

The 12th, that any Immediate Member who shall unnecessarily be absent three times successively, shall forfeit his membership.

The 14th, that all specimens placed in the Museum shall be the property of the Society, and that no others shall have a place, except by express vote.

The 17 th, that no person shall be chosen an Immediate Member except by unanimous vote of all present; other members may be elected by a two-thirds vote, but none without nomination at a previous meeting.

The 18th, that there shall be a Standing Committee of five members, chosen annually, to provide a suitable room for the collection, employ one or more persons for service, and draw on the treasurer for payment of the expenses thereby incurred, under such restrictions as the Society may from time to time make.

The 19th, that each Immediate Member shall pay \$5 annually.

The 20th, that every Immediate Member absent from a stated meeting without excuse, shall be fined fifty cents.

Such articles have been quoted of the Constitution adopted as tend to show the animus of the members. Who can say that they were not thoroughly in earnest?

In subsequent proceedings of the Society it appears that fines were collected, undoubtedly for absence without excuse; but there is no recorded instance of a member forfeiting his membership by unnecessary absence.

It is not easy to understand the principle or the policy which dictated the selection in all cases of persons on whom was conferred Honorary, Corresponding or Associate Membership. In numerous cases individuals were elected to the former who cannot be supposed to have manifested much interest in natural science, and who too were residents of Boston. They were distinguished perhaps as Doctors of Divinity, or as Doctors of Medicine, but neither then nor afterwards were known as Naturalists. Among the Corresponding Members are found the names of several residing in the immediate vicinity of Boston, as Cambridge and Charlestown; which seems singular, for the perils of a ferriage across the Charles, which at an earlier date might have made these ports appear distant, were no longer to be incurred; good bridges then as now uniting the populations. But this is not all, some of the Corresponding Members were citizens of Boston itself.

From the records it seems that the number of Immediate Members at first, or soon after the formation of the Society, was about 20; of the Honorary, 19; of the Corres- 
ponding, 68, and of the Associate, 24. It is not clear what privileges these last had as members of the Society, except the implied one that they were not subject to assessment.

In the list of the early Corresponding Nembers, it is pleasant to find the name of Dr. William J. Walker, to whose great bounty the Boston Society of Natural History is indebted for its present standing among the leading scientific societies of the world, if not for its very existence; for there is much reason for the opinion that had the Society continued dependent on the voluntary labors of its members as would necessarily have been the case without his help, it would have met the fate of the majority of the societies of natural history, which have been formed under apparently favorable auspices, have flourished for a time, and then faded out of existence. But more of this when his large benefictions to the Boston Society of Natural History are mentioned in the course of this history.

It may be a matter of interest to the reader to have presented here some of the names of members connected with the Society, particularly of such as afterwards distinguished themselves in their several callings, or at a subsequent period became active members of the Boston Society of Natural History. Among them may be found : -

As Immediate Members:

Dr. Jacob Bigelow.

Dr. Walter Channing.

Benj. A. Gould.

As Honorary Members:

Hon. John Davis.

Hon. John Lowell.

Hon. Christopher Gore.

Dr. John Jeffiries.

As Corresponding Members:

Nathaniel Bowditch.

Josiah Quincy.

Dr. W. J. Walker.

As Associate Members:

Joseph Tilden.

Dr. J. C. Warren.

Dr. James Jackson.
Francis C. Gray.

Dr. Geo. Hayward.

Octavius Pickering.

Rev. James Freeman.

Prof. Wm. D. Peck.

Rev. Manassah Cutler.

Dr. John WVarren.

Prof. Benj. Silliman.

Robert Hare.

Prof. Parker Cleaveland.

Benjamin Pierce.

Rev. Wm. Ellery Channing.

Wm. Minot.

Richard Sullivan.

Francis Boott.
Dr. John Randall.

Dr. John Ware.

Dr. John W. Webster.
Rev. John Prince.

Rev. J. Lathrop.

Rev. J. T. Kirkland.

S. G. Perkins.

Dr. E. Hale.

Thomas H. Perkins.

Dr. Geo. C. Shattuck.

Rev. Edward Everett.

Nathan Hale.

The first officers elected were

On December 29th, in accordance with a vote previously passed, the several members having specimens to present to the Society towards the formation of a museum brought them forward, and it is recorded that a considerable collection was made. 
At a meeting held January 14th it apnears that much dissatisfaction was expressed at the name of the Society, and it was therefore voted that each member should propose in writing at the next meeting such name as he judged the most suitable. When the Society again met, on the 21st of January, 1815, the members, after due consideration, unanimously

Voted, That the Society shall be called the Linnæan Society of New England.

To understand the spirit and do justice to the labors of the actire members of this Society, let us look a little into their proceedings of the first year. February 4 th it was voted that each member shall, if possible, prepare some animal in the course of the week and present it to the Society at the next meeting. In the record of a following meeting it is stated that a consirlerable number of animals were presented to the Society, all of which had been prepared by the members in the course of the week. Whether these animals were of the dimensions of elephants or mice is not stated. At the same meeting the Recording Secretary was requested to draw up some popular directions for the preservation of specimens in Natural History, to be given to masters of vessels and others, and to report at the next meeting; and at the next meeting a circular letter was presented containing such directions. This was ordered to be printed.

The subjects brought before the members did not always pertain to natural history. At a meeting on March 4th a paper by the Hon. John Lowell was read, "On the resemblance between certain customs of the modern Italians and ancient Romans." It was voted to copy it into the common place book of the Society.

Besides the weekly meeting it was decided to hold once a quarter a general meeting, to which should be invited the Honorary, Corresponding and Associate Nembers, and at each such quarterly meeting a paper by some person appointed at the preceding meeting should be read on some subject connected with the pursuits of the Society. The first of these quarterly meetings was held on the 21st of June, and Judge Davis delivered what the record of that date states to have been "an elegant address on the advantages of natural history and the objects of the institution."

At the regular meeting held a few days afterwards, Dr. Randall, as the text expresses it, was unanimously chosen to perform at the next quarterly meeting. It was also voted that on the next Wednesday, the 2Sth of June, the day appointed by the Constitution for the Anmual Meeting, the Society should dine together at Richards' in Brookline. In accordance with this vote, the Inmediate Members met at Brookline and after transacting the business of electing officers for the year, they dined together, the record states, in company with the Ion. John Lowell and IIon. Josiah Quincy. This combination of scientific pursuits with feasting is not mentioned as a peculiarity of the members of this pioneer society, and even in later days it has not been found disagreeable or unprofitable. In some degree these Annual Meetings partook of the character of what has been more recently called in some of our societies "Field Days", for they were held at some selected place in the country, and a portion of the day was employed in obtaining specimens. Thus, at the first meeting, it is mentioned that "after dimner the members divided themselves into several parties for the purpose of making an excursion in search of specimens 
in the several branches of natural history." 'Towards evening it is further said: "they returned to town after having passed a delightful day."

Presentations of objects of natural history are frequently mentioned as having been made to the Society during the year, and sometimes those of other character, as for instance a likeness of Mr. Roscoe, of Liverpool, presented by Mr. Francis Boott. In June, the Society was the recipient of two living tigers, presented by Capt. Stewart, of the United States frigate Constitution. Whether it was more fortunate in receiving or losing them, it is now impossible to say; certain it is, they were by some means lost, and a Mr. Savage was held accountable; for in February, 1818, the record states that "a settlement was effected with Mr. Savage for the loss of the Brazilian tigers, which were presented to the Society by Capt. Stewart of the Navy," and it subsequently appears that the treasurer was authorized to pay out of the money received from Mr. Savage, rent due by the Society.

At the second Quarterly Meeting of the year, held in September, Dr. Randall read an interesting paper on the history and medical properties of the native plant Triosteum perfoliatum.

In October, the Museum was arranged into several departments, and members were allotted to take charge of them, as follows:

\begin{tabular}{|c|c|c|c|c|}
\hline \multicolumn{4}{|c|}{ First division of Minerals. } & D \\
\hline Second & " & $" 6$ & " & Dr. Channing. \\
\hline Third & 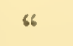 & $"$ & " & Mr. Dana, Sen. \\
\hline Plants & & . & : & . Mr. Tucker. \\
\hline Manmali & & $\cdot$ & - & . Dr. Bigelow. \\
\hline Birds & . & . & . & . Dr. Cushing. \\
\hline Fishes. & • & 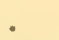 & . & - Dr. Ware. \\
\hline
\end{tabular}

\begin{tabular}{|c|c|c|c|c|c|}
\hline & \multirow[b]{6}{*}{ Dr. Hayt } \\
\hline & \\
\hline \multicolumn{5}{|c|}{$\begin{array}{l}\text { First division of Insects } \\
\text { Second } 66 \text { "6 }\end{array}$} & \\
\hline Third & $"$ & " & " & & \\
\hline \multirow{2}{*}{\multicolumn{3}{|c|}{$\begin{array}{l}\text { Shells . } \\
\text { Zoophytes, \&c. }\end{array}$}} & & & \\
\hline & & & & & \\
\hline
\end{tabular}

In November, a paper was read by Dr. Goodwin of Sandwich, on tadpoles found there

In December, Dr. Channing was requested to make up, from the duplicates, a box of minerals, and send to France, for exchange, and the Vice President was requested to use his exertions to procure a moose for the Society. Professor Cleaveland of Bowdoin College, a distinguished mineralogist, had been invited to deliver the quarterly address in December, but unable to visit Boston, was obliged to decline, and no address was delivered.

It has been thought well in view of the lesson to be derived from the experience of this Society, to give at some length an account of the proceedings of this first year of its existence with the intention of being more brief in mention of subsequent proceedings. Enough is known of the character and ability of the members of the Society, and enough has been shown of their devoted zeal in its service, to satisfy all that if ultimate success did not crown their efforts, the fault was not so much in them, as in the fuct, that more was undertaken for accomplishment through voluntary labor, than can ever be expected from men however zealous, who are engaged in professional or business life.

The second year of the Linnæan Society was marked by the same manifestation of zeal on the part of the members as was shown during the first. From the assessment of the members enough was raised to pay for some professional labor, and an artist, so called, was hired, who probably could mount specimens; as in January, a committee was appointed to 
procure animals, that he might find employment in preparing them. In February the room in which the cabinet was kept being unsatisfactory, one was hired over Boylston Hall, where the collection was placed, and where meetings were subsequently held. The Museum of the Society was opened to the public every Saturday afternoon.

In all the months of this year valuable donations of specimens were received. Among others specified may be mentioned a living bear, presented by Commodore Chauncy of the navy; a miscellaneous collection of objects of natural history from Bowdoin College; a valuable collection of birds from Africa; besides cases of insects, handsome minerals and benutiful shells and corals, from other donors.

The meetings were well attended, and there appeared throughout the year no loss of interest on the part of the members. The annual meeting was held at Fresh Pond IIotel, Cambridge, and the attendance was general on the part of the members. Judge Davis presided, and the day being pleasant, all found great enjoyment in excursions and in amusements until dimner, which they partook of together, returning to town in the evening.

In August Dr. Bigelow gave an interesting account of an expedition, undertaken by himself, and the other members of the Society, for the purpose of visiting the White Mountains in New Hampshire. Being equipped, as he states, with proper instruments, the height of the mountains was a scertained more accurately than it ever had been. His estimate of the height is not mentioned. Particular attention, the record states, was given to the mineral, animal, and vegetable specimens that were found in the mountains, and the whole paper abounded with curious facts and ingenious observations. All who in subsequent years had the pleasure of intercourse with Dr. Bigelow, need not be assured of the interesting character of the paper presented by him to those who were favored by hearing it. It would, undoubtedly, be read with great interest now, notwithstanding the general knowledge prevailing relative to the region mentioned.

The Society increased in numbers during the year, and there appeared no loss of interest on the part of the members. Save a few lines found in the report of one of the meetings in September, everything denoted great prosperity. But these few lines are enough to suggest to those of a later day, conversant with the history of natural history societies, the probable decay at a not distant time, of that zeal and interest so marked at this period. They may be found in the report of a committee appointed to obtain from the Legislature an act of incorporation. This report declares it inexpedient to petition at present, provided our expenses can be defrayed until we are united with the Athenæum. This is the first expression in the records implying what, alas, the history of most natural history societies shows to be inevitable when sustained only by the voluntary labors and assessments of members, and dependent on the uncertain contributions of friends; lack of adeculate means for the care and preservation of the rapidly augmenting collections and consequent disaffection. We shall later see, that notwithstanding the strenuous exertions of the members, and abundant success in collecting specimens, an increasing uneasiness manifested in a disposition to unite with another society and thus sacrifice its own identity; or, failing this, to dispose of its collections in a way that would not have been considered for a moment at an earlier period. 
'The time, however, has not arrived to dwell upon anything not agreeable in the record of the devoted workers of the Society. The Recording Secretary appears to have been quite elated at the progress made, for he writes in October: The zeal and activity of the members seem to be mabated, and if the collection continues to increase for a few years in the same proportion, it will surpass every establishment of the kind in the United States, and almost rival those of Europe.

The close of the year shows no less activity. In December a valuable paper was read by Dr. John Ware. Large and valuable specimens were set up under the superintendence of the committees, and arrangements were made, as the record states, for labelling all the birds, beasts and fishes belonging to the cabinet. A committee was also appointed to see what could be done in relition to furnishing permanent apartments for the collection of the Society, which implies, probathly, that, it had increased to a size renrlering more room necessary for its accommodation.

1817. Judging by the records of this year's doings alone, it might be thought that all was well with the Society, and that its contiuued existence and progress were secure. Donations continued to pour in, many of a very valuable chancter. Among them may be noticed a fine American elk, which is mentioned as one of the most interesting and valuable animals which our country affords. There seems certainly to have been no fears of calamity, for in the early part of the year a fine specimen of a female moose, from Maine, was purchased, and the hope is expressed that another year a male may be obtained, together with a reindeer, which the Secretary states will make complete the collection of the deer of the United States. Arrangements were also made with Capt. Waterman to procure specimens of natural history from the coast of Africa.

'The amnul meeting was held at Brookline, where the members, as usual, sat down to dimner. Valuable papers were presented, one on the mineralogy and geology of Cambridge and its vicinity, by Mr. S. L. Dana, Jr., containing, it is stated, "unquestionably more accurate information on the subjects upon which it treats than has ever before been communicated;" one on the luminous appearance of the sea, translated from the Transactions of the Swedish Academy by Judge Davis; and one on the medical properties of Phytolacca decandra, by Dr. Hayward.

It is distinctly mentioned by the Secretary, in June, that the usual business of collecting and preserving specimens had been regularly attended to.

On the 18 th of June, Dr. Channing delivered an address. At a previous meeting of the Society it had been voted to call a public meeting of the members, each of whom should have the privilege of inviting others to be present on this occasion, which was made one of great interest, many of the leading men of the state and eity being present. Among them, the Governor, Lieutenant Governor, Council, members of the Senate, and many ladies. The whole company were surprised at the size of the collection, and highly pleased with its general order and neatness.

At twelve o'clock the address was given, which was upon the importance of literature and science, particularly to the people of New England. The clains of the Society to the patronage of the public were urged with great force and ingenuity. A sketeh of the progress of the institution from its first foundation was given, and statements made showing the rapid growth of the cabinet. 
The interest excited by this meeting gave the Society reason to believe that the importance of its work was fully appreciated, and that the pullic alrearly felt disposed to protect and patronize it. It is sad to think how soon the hopes excited by the feeling manifested at this meeting were doomed to fade away.

Soom after this meeting, wonderful stories were circulated concerning a strange marine animal, said to have been seen in the harbor of Gloncester, and a special meeting of the Society was called for the purpose of talking measures to obtain information. Judge Daris, Dr. Bigelow, and Mr. Gray, were constituted a committee to write to, and have depositions taken of, all who had seen the animal. The committee reported, in September, that they had no doubt of the existence of an animal of extrandinary appearance and enormous dimensions, as there were many credihle witneses. They expressed the hope of getting more information soon. In October, a very, full report was made upon what was now designated as the seal serpent, and an account was also given of a small one, probably, the record says, of a "spawn," that had been taken at the water's edgre. The committee were of the opinion that the animals were of a genus wholly unknown to naturalists, and they dexignated them under the name of Scoliophis. from the singular curvatures of the spine, by which they possessed a vertical motion. To this they added the specific name Atlanticus. ${ }^{1}$

It is a subject of great regret, the Secretary wrote, that all the efforts that were made to take the great serpent proved wholly ineffectual, notwithstanding the zeal and activity of his pursuers.

1818. We have thus far traced the history of this Society from its formation, have dwelt upon the evidences of its rapid progress, and have had brought before us accounts of its great acruisitions, through which it had become possessed of a collection which, in the language of its Secretary, seemed likely to surpass any one of like character in this country and even rival the great collections of Europe. Henceforth we shall find evidence of declining vigror on the part of the society as such, notwithstanding great strugrgles on the part of many of its members to sustain it and grive it renewed activity; we shall see the interest in its meetings rapidly wane, and its valuable cabinet becoming ruined for the want of proper care; we shall see that even the hope for continued existence is giving place to utter despair, foreboding dissolution.

In January a committee was appointed to make propositions to the trustees of the Athenaum for a union of the two institutions, and if this could not be effected, to report what measures should be taken for the preservation of the cabinet.

Meetings were held in the succeeding months, but not with so much regularity as heretofore. At one of the meetings a valuable paper was read by Dr. J. W. Webster on the mineralogical character of the Island of St. Nicholas, which he had lately visited. This seems to have been the only paper brought forward during the year. The Immediate Members made an excursion up the Niddlesex Canal, upon invitation of Mr. J. L. Sullivan, and they dined together at Woburn, - their last dinner as a society.

\footnotetext{
1 Report of a Committee of the Linnaan Society of New England relative to a large marine animal, supposed to be a Serpent, seen near Cape Ann, Mass. Boston, 1817. 8vo.
}

52 pp. See remarks by Dr. Jeffries Wyman, Proc. Bost. Soc. Nat. Hist., 1X, 215. 
1819. During this year the meetings were not held with any regularity. Attempts were male to take charge of and preserve the specimens, but without success, and the members had the mortification of seeing a museum going to decay that had cost them so much labor and expense; but it seemed ineritable. They were mostly engaged in professional pursuits, ant of course could not give their personal services to the preservation of the collection; and the funds of the society were not sufficient to hire any one permanently.

1S20. Things remained in this condition until March, 1S20, when a meeting was called for the purpose of considering the expediency of disposing of the collection.

It was then voted, that if one hundred dollars per year could be obtained for ten years, the members would renew their efforts to preserve the institution.

In April it was reported that enough har been subscribed, and more, for the preservation of the collection. This seemed for a time to revive hope and inspire interest. Amendments were made to the Constitution, and a committee was appointed to attend to the preservation of the collection. A number of new members were elected.

In May, committees were chosen to eximine and report upon the state of. each department of the collection, and they were expected to attend at the hall of the museum every Saturday, from 3 to 6 o'clock. A committee was also appointerl to petition the legislature for an act of incorporation; evidence certainly of renewed hope.

The Society became incornoratel, and the first meeting under the act was held in June. Dr. Jacob Bigelow was elected President.

In August a specimen of a seal and several minerals were presented, and in October there were many minerals adiled to the collection. In December a movement was made towards the formation of a library, and in the following March (1821) rules and regulations were adopted for it. Notwithstanding, however, these signs of activity on the part of the Society, the records afford sufficient evidence of declining interest. The meetings were not well attended. Immediate Members resigned as such, and were made Associate Members, mainly for the reason that they could not attend to the duties of the former.

1822. In the early part of this year there yet appeared no evidence of yielding to the inevitable, and specimens, among them the bones of a camel, were received for the cabinet with satisfaction anr thanks. In August, however, we find that a committee had been appointed to consider upon the future disposal of the cabinet, which reported:

"That it appears, by the resignation and non-attendance of members, that it has become burdensome to individuals of the Society to support its meetings and collections as they have hitherto done; that it is expedient, therefore, to suspend its meetings and give up the room of the Society, and place the collection, or such part of it as can be preserved, in some place where it will occasion no further expense to the Society or its contributors; that a committee be appointed to remove it from its present location and place it in the hands of any other person or persons who will afford suitable rooms for its reception, the preference being always given to a scientific corporate body; that the present funds of the Society be devoted to removing, securing and enlarging the collection, at the discretion of the committee."

This committee was made permanent, with directions to appoint a Secretary, and to call a meeting of the Society on the application of three members. 
The expression that the funds of the Soeiety be devoted to enlarging as well as securing the collection denotes the existence of a vague hope at least of renovation.

The election of officers was made, as in former years.

1823. In March of this year a meeting was called by the Society, and the committee appointed in August of the previous year relative to the collection reported, that they had offered the whole of it to the Boston Atheneum, upon conrition that suitable rooms should be providerl for its reception and preservation, but that the Trustees had reclined to accept it; that they had subserguently offered it to the Corporation of IIarvard College or to the Board of Visitors of the Massachusets Profesorship of Natural IIistory, who jointly accepted the offer, anrecing to erect a building for the collection and to grant to the members of the Society free access to the collection and to the Botanic Garden.

This report after consideration was acted upon by a vote that the conditions on which the Corporation of Harvard College and the Board of Visitors of the Massachusetts Professorship of Natural History, propose to accept the cabinet of this fociety, be accerled to; and the committee were requested to make the transfer. This was done, and the balance of eash in the hands of the Treasurer, \$264.29, was also included in the transfer.

A vote was finally passed that all subscriptions and assessments not collected be cancelled. Thus came to an end the Limmean Society so far as exertion for the furtherance of the objects of its existence was concerned. It yet remained a corporate body, and years after, upon the formation of the Boston Society of Satural History, it was once more called together by its Secretary for the purpose of recovering if possible from Harvard College such part of the collection as yet remained worth removing, in order to present it to the new society. This reclamation was made on the ground that the College had failed entirely to comply with the conditions made at the time of the transfer; no building having been erected, and proper care not having been given for its preservation as a collection for promoting the study of natural history. In the sketch which follows of the doings of the Boston Society of Natural ITistory, it will he found that very little of the really extensive and valuable collection of the Limnain Socicty came into its possession, though all that remained of it was griven up by the College. It had grone to ruin for want of care, as hundreds of earlier collections had before it, and as hundreds will hereafter, if the views which the history of the Limnan Society are calculated to inculcate do not prevail in their aims and purposes.

That these views may be presented and dwelt upon has been the motive of giving so full an account of the doings of this Society, as its experience so well illustrates their truth. As stated in an earlier page, if success did not crown the efforts made by the members to build up a permanent institution, the fiult was not so much in them, as in the fact that they undertook more than it was possible for men engaged in professional or business life to accomplish, howerer zealous and devoted they might be. The views referred to and which it is thought desirable to inculcate, may be given in a few paragraphs. They are not new, for the same ideas ma be found expreseed in an address delivered before the Limman Society of London, in 1867, by its President, George Bentham, F.R.S., and also in an article by Dr. H. A. Hagen, published in the American Naturalist (Volume $\mathrm{x}, \mathrm{pp} .80$ and 135). 'They are as follows: 
No socicty organized for the pursuit of the study of natural history should undertake to form a large nuseum, mnless it is endowed with means fully adequate for the constant care and preservation of its collections, either through support of the government, or from funded property that will yicld income sufficient for such purpose. Large collections require enormous expense for preservation from destructive agencies, in the necessary supplies of jars, bottles, alcohol, and other articles absolutely required for use; and for the payment of competent curators; as experience demonstrates that none others than those who are paid for their services can be relied on to permanently do the work, without which, sooner or later, all there is destructible in a collection will certainly go to ruin. In the early period of an institution founded by voluntary effort and designed to be so sustained, the members, zealous and active, may for a time, and while the collection is not great, manage to arrange the specimens received, and keep them from destruction by care, but as the museum increases, this becomes onerous to them, and finally imposwible. Its impending destruction discourages the members, and the society itself, unable to bear the necessary expense of preserving what they look upon as an important element of existence, is finally dissolved. A society of natural history not supported by government, and inadequately endowed, should never undertake to make more than a very limited collection of specimens, and these should be confined to such as illustrate the natural history of the immediate neighloorhood, with perhaps a few others, typical specimens only, of forms found in distant regions. Where more than this is attempted by any society, continued existence and progress can only be predicted in case it possesses ample means to employ steadily a sufficient number of capable men to take charge of its museum, and exert a careful watchfulness over the specimens. No society can long exist that depends upon voluntary continuous labor on the part of its members, or on the voluntary subscriptions of its friends.

Nor is the collection of an immense number of specimens in every department of natural history a desirable thing for the general student. It is far more important that there shall be an epitome collection so arranged as to grive elementary instruction to visitors who seek knowledge and to whom a great multitude of specimens might be confusing. Of course there is no objection to the largest collection of known species where there are abundant means to obtain and care for them, but an arrangement of such should always be preceded by a proper synoptical series; the latter for the instruction of the general student, the former for the use of advanced naturalists who need such collections for comparison. A large collection has the effect of attracting great attention, and the wondering thousands who are drawn by its exhibition to visit it daily or weekly, enjoy an imnocent pleasure that is well worth providing for in all large communities, especially as the influence may often go far beyond gratifying curiosity. The collection of species local to the neighborhood, should perhaps be the aim of every society, as a knowledge of all the forms of life met in our daily walks is very desirable.

Perhaps the experience of no society better illustrates the truth of some of these remarks than that of the Limwan Society. It was formed by men of more than ordinary ability, and in a community ready and willing to aid it by voluntary contrilsutions. Its members were hard workers, and freely gave much time to its interests. But it had no funded 
wealth and could not look to government for support. It flourisher greatly for a considerable period and only showed signs of weakness when its rapidly increasing collections, garnered from every quarter of the globe, called for continuous labor and large expenditure of money. Engaged as the members were in professional or business occupations, they could not give the former, and they became tired of soliciting subscriptions to meet the latter. The result was inevitable.

\section{The Boston Society of Naturat History.}

In passing from the consideration of the doings, the experience and the dissolution of the Limnean Society to a review of the history of the Boston Society of Natural Inistory, the question naturally arises in the mind whether the new Society started under any better auspices, financially or otherwise, than the old, and if not, whether its aims and objects were so different as to render it less liable to ultimately meet with the same fate.

A careful reading of its records fails to show that pecuniarily it was any better provided with means in the early period of its existence, or that its aims and objects or its proposed methods of action were in the least different from those of its unfortunate prerlecessor. This is especially noticeable, as amonr its earliest members are found the names of several who had been active in the Linnæan Society.

As will be seen further on, the Society was at first dependent entirely on the annual assessment of its members; yet it proceeded at once to collect specimens for its museum without discrimination. thus involving itself in the same kind of expenditure for their arrangement and preservation. That it finally succeeded in establishing itself on a firm foundation will be seen to have been the result of fortunate circumstances that could not have been foreseen, much less depended upon, and without which success would probably have been impossible.

The first meeting of such persons as favored the formation of a new society was held at the house of Dr. Walter Chamning, February 9th, 1830. Dr. Chamning was made Chairman, and Mr. Simon E. Greene, Secretary. A committee was appointed to recommend at a future day such measures as it should judge advisalle for the formation of the Society, and for creating an interest on the part of the public in its objects.

Dr. George Hayward, Dr. John Ware, Mr. Edward Brooks, Dr. Amos Binney and Mr. Geo. B. Emerson, composed the committee. It does not appear whether other persons were present than the seven named, as the number that met is not mentioned. Of those whose names appear, three were active members of the Limnæan Society, viz. : Dr. Walter Channing, Dr. Hayward, and Dr. Ware. There were two other original members of the new Society who had been active in the Limnean, viz.: John Davis, LL.D., and Mr. Henry Codman.

At a meeting subsequently held, the date of which is not given, the committee made a report, which was adopted and a vote was passed, "That a Society on the plan proposed, be now formed," and this was followed by the appointment of a committee to wait upon persons favorable to the objects of the society and obtain their signatures; with authority to call another meeting as soon as a sufficient number had subscribed. 
Such a meeting was called together on the 28th of April, and was held at the room of the Trustees of the Athenæum at 7 1-2 o'clock P. M. Dr. Channing was chosen Moderator, and Theophilus Par ons, Secretary. The names of the subscribers were read, and a sketch of rules and by-laws for the government of the Society presented for consideration. It was then

Voted, That the name of the Society shall be The Boston Society of Natural History.

Then followed discussion on the rules proposed, and finally a committee was appointed to draft a constitution and code of by-laws and to report at the next meeting. Dr. Binney, Dr. Hayward and Simon E. Greene were made this committee.

Thus was formed this Society, destined to become one of the leading institutions of the kind in the world, into whose museum thonsands would gather weekly for observation and instruction, and whose publications would be known and valued in every civilized community.

The next meeting was held on May 6th, and the constitution and by-laws which had been proposed, after due convideration and with some amendments, were adopted. An adjournment for one week followed. On reassembling at the apnointed time the members proceeded to vote for officers and the following named persons were chosen to fill the positions designated:

\author{
Thomas Nuttall, President. \\ Geo. Hayward, First Vice-President. \\ John Ware, Second Vice-President. \\ Gamaliel Bradford, Corresponding Secretary. \\ Theophilus Parsons, Recording Secretary. \\ Simon E. Greene. Treasurer. \\ Seth Bass, Librarian.
}

\author{
Francis C. Gray, \\ Geo. B. Emerson, \\ Joseph W. McKean,
}

\section{Curators:}

\author{
Edward Brooks, \\ Walter Channing, \\ Francis Alger,
}

Amos Binney, Jr.,

Benj. D. Greene.

A committee was then appointed to make enquiries relative to the collection of the late Linnean Society, which had been presented to Harvard College upon certain conditions which had not been complied with, and to learn whether the whole or any part of it could be obtained for the cabinet of this Society. No farther meeting is recorded until August 9, though the adopted by-laws required that one should be held on the first Thursday of every month. At this meeting it was announced that Dr. Nuttall had declined to accept the office of President, whereupon the members present proceeded to fill the vacancy, and Benj. D. Greene was unanimously elected. Thus was completer the organization of the Society, and we find that the Council, now composed of all the officers, proceeded at once to take active measures for the furtherance of its oljects. The next day after the election of $\mathrm{Mr}$. Greene, it held a meeting and appointed a committee to arrange for a course of lectures, to designate the lecturers, and to decile upon their compensation; also one to procure rooms for the use of the Society. At the next meeting of the Council a week later, the committee on lectures reported in favor of a course of sixteen to be given besides an introductory lecture, and that tickets of admission be put at $\$ 3$ each, 
\$5 for a gentleman and lady, and 82 for each perwon additional. The subjects proposed and the number of lectures to be devoted to each were as follows:

Two on a general account of the Mineral Kingdom and Geology, particularly as connected with animal and vegetable remains; four on Anatomy and Physiology of the Tegetable Kingdom, with general accomt of the characters, relations, and uses of plants and their distribution; two on Anatomy and Plywiology of the Animal Kingelom, and of the principles upon which its scientific arrangement is founded, etc.; two on the Mammalia; two on birds; one on Reptiles and Fishes; two on Insects; one on Invertebrate Animals.

Subseduently the Committere reported that they hat decider upon the compensation for the lectures, and fixed it at $\$ 20$ for each. The persons selected to deliver the lectures, and who alecepted the invitations, were Dr. George Harward, Mr. Thos. Nuttall, Dr. Gamaliel Bratford, Dr. John Ware, Dr. Walter Chamning, Dr. J. V. C. Smith and Dr. D. Iumphreys Storer. The introductory lecture was free to the public. This course of lectures was commenced on the third Tuesday of October, and they were continued weekly. Where they were deliveresl, and by whom the introductory one was given, does not appear in the records.

These lectures yielded a net profit of $\$ 174.58$. Besides this course, there was another given under the auspices of the Society, before the close of the lecture season, by Mr. Nuttall, on Botany. This yielder $\$ 170, \$ 100$ of which was paid the lecturer and $\$ 5.50$ for expenses; the balance, $\$ 64.50$ going into the treasury.

It will be recollected that in the sketch given of the closing proceedings of the Linnawa society, it was stated that as the Trustees of IIarvard College had failed to comply with the conditions hinding upon them in accepting the collection of that society, reclamation had been made with the purpose of presenting whatever might yet he of value to the Boston Society of Natural History. This had been done at the instance of several members of the latter society who had likewise been members of the former, and who reasonably felt aggrieved at the want of care shown for the collection by its posessors. (Ine of these, Dr. Hale, remanked that "he felt it to be his duty as an officer of the Limman society, to express the opinion that something effectual should be done; that he would take the opportunity to agnin assert that Harvard University had forfeited all her right to the possession of the cabinet of the Linnæan Society. The members of that Society were not so faithless to the cause they had espoused as to desert it. When few in numbers and burdened with heary ansesments, they had relinguished their rich collection to the Corporation of said University, that body having passed at a formal meeting a vote to erect a suitable building to preserve the collection, for the benefit of students in natural history. That agreement had not been complied with, no building had been erected, and the specimens were scarcely to be found. Justice to the members of the Limnan Society compelled him to make these observations." It seems now but right to give here the remarks of one whose statement can be taken as authentic concerning the whole matter, as it furnishes more succinctly than anything else found, a full justification of the coure taken in presenting the valuable collections of the Limaan Society to the College. Provision was made as far as was posibible for its preservation, in 
placing it where it was thought it would be of great service to students in Natural History.

The result of the application which was marle to ohtain for the Society whatever might be left of value may be given in the few words taken from the record of the Annual Meeting of the Society in May, 1892, which are as follows: "In the coure of the year, an order was ohtained from the President of Harvard College for the surrender of such articles as might remain of the old Limmax Society, in pursuance of which a quantity of refuse matter was sent to the Society's room, but nothing of any considerable value was obtained."

Early action was taken to render the monthly meetings interesting, first, by referring specimens presented to such Curators as were the most interested in the department to which they belonger, to report upon at the next meeting. This added much interest to the proceedings, and led to better attendance. At that time, so little was known of many of the objects now fumiliar to all in the collections of natural history, that many which would now be received without remark, because of their well known character, excited not only much interest, but considerable discussion. It was at a time when a convoluted mass of chalcedony might have been seen in the Boston Iuseum, labelled petrified kidney, when at the store of a dealer in curiosities, within a stone's throw of the hall of the Society, fossil corals were exposed for sale as petrified flagroot, when Ammonites upon being discovered in the rocks were heralded in the papers as coiled snakes, sometimes mentioned as being as large as cart-wheels, and exciting wonder in proportion to their size. The writer well remembers receiving notice of a remarkable "6 petrified bug" in a museum at New Orleans, and upon its being procured and sent to him, finding it to be an excellent specimen of a Trilobite, originally, no doubt from the Trenton limestone of New York.

Soon after the organization of the Society a room was hired for its use in the Athenaum building in Pearl street. Here its collections were deposited and here the meetings, after the first two, were held until more suitable accommodations were obtained three years afterwards. The early meetings took place in the evening, but subsequently for several years in the afternoon, sometimes at 3 and sometimes at $3 \frac{1}{2}$ 'clock. They were held once a month until August, 153:3, but after this time twice a month.

In January, 1831, measures were taken to procure an act of incorporation for the Society, and in the same month, in view of the great lack of books on Natural History, it was Voted-That this Society considers a library of works escential to its success; and funds were appropriated to purchase the best elementary books in the different branches of natural history.

A Committee of the Council was also appointed at this time to apply to the Governor and his Council requesting that the gentleman making a Geologieal Survey of the State might furnish the Society with a suite of geological specimens. No further reference is made to this matter, and the request does not appear to have been favorably considered, as no such collection ever became the property of the Society. The State Collection itielf, was, however, deposited for several years in the Society's rooms.

A singular provision to obtain information was made in February, 18.31, by a vote passed, which was in substance as follows: 
That a blank book be provided and placed on the table in which may be written queries on subjects of natural history by any nember and such answers as may be given; unless the latter may be of considerable length, when they may be put on file.

March 18. 18:31. A special meeting of the Society was held to accept the Act of Incorporation, and to organize under it, which was done. The Constitution and By-laws were re-adopted, the only change mate being that of providing that the Ammual Meetings of the Society he held on the first Wednesday of May each year, and that stated meetings be held on the first Wednestay of every month. The same officers were elected the preceding year, excepting that Dr. Storer was chosen to fill the place of Theophilus Parsons who had resigned, and J. S. Copley Greene was chosen Curator in the place of B. D. Greene elected President.

May 4, 1831. In accordance with the provisions of the Constitution as re-adopted in March, the first Amnnal Meeting, so called, of the Society, wats held on this day. As an account of the receipts and expenditures during the perior from its organization to this time may interest the present generation of members, the items are recorded and given in full.

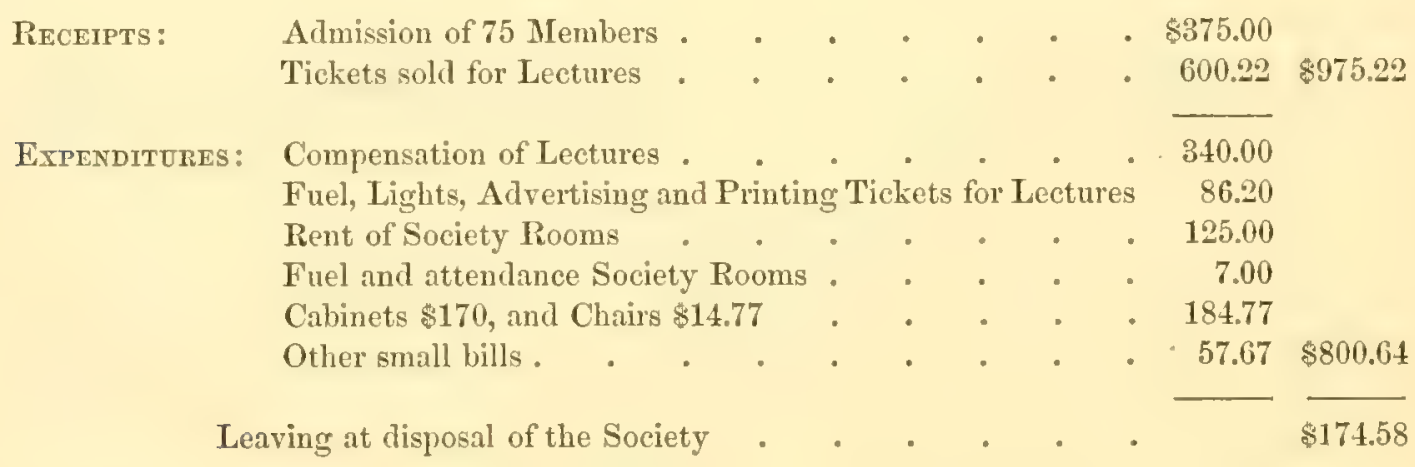

The Society proceeded to the choice of officers for the year, and the following named gentlemen were elected:

Dr. Benj. D. Greene, President.

Di. George Hayward, First Vice-President.

Dr. John Ware, Second Vice-President.

Dr. Gamaliel Bradford, Corresponding Secretary.

Dr. D. Humphreys Storer, Recording Secretary.

Simon E. Greene, Treasurer.

Dr. Seth Bass, Librarian.

\section{Curators:}

Francis C. Gray,

Dr. Amos Binney, Jr., George B. Emerson,
Dr. Joseph W. McKean, Rev. J. S. Copley Greene, Francis Alger,
Dr. Joshua B. Flint,

Dr. Augustus A. Gould.

To aroid frequent repetition the names of those elected each year will not be mentioned hereafter, except in a sunmary of the past officers of the society at the end of this 
sketch. The election at this time being the first under the act of incorporation, this list of those chosen is given in full.

A letter was received at this time from Professor Edward Hitchcock, then engaged in making a Geological Survey of the State, reapesting the air of members of the Society in furnishing lists of the animals of Minsachusetts, to be publisher with his report. The following were appointed hy the Council to serve as requested: Thos. Nuttall and Simon E. Greene, on Ornithology; Drs. John Ware and Joshua B. Flint, Mammalia ; Dr. J. V. C. Smith, on Ichthyology; Drs. Bass, Storer, and Bimey, on Mollusca; Drs. Harris and Gould on Entomology; Dr. B. D. Greene, on Zoophytes. They were to submit their reports to the Society.

In July, 1831, the Committee on lectures reported that it was expedient to have fifteen, and the following gentlemen were invited to deliver them: Dr. George Hayward, the $2 d, 31$ and 4 th, on the natural history of man; Dr. Joshua B. Flint, the 5th and 6th, on quadrupeds; Simon E. Greene, the 7th and Sth, on birds; Dr. McKean, the 9th and 10th on reptiles; Dr. D. Humphreys Storer, the 11th and 12th, on shells; Dr. Thaddeus W. Harris, the 13th, 14th and 15th, on insects. Mr. Francis C. Gray was afterwards appointed to give the introductory one.

This course of lectures was given the ensuing season, but no record is found of the result. That it was pecuniarily unsuccessful is, however, clear from a statement made when the question of another series came up in the following February, to the purport that the failure was disheartening.

In February, 1892, a proposal was received from Mr. Savage of the Savings Bank, for leasing a room in the building to be erected for that institution on Tremont street. This led to the appointment of a committee to confer with him, and finally to an arrangement by which the hall of the third story was engaged for the use of the Society.

In February also, the committee on lectures reported that a course for the next season was absolutely necessary for the prosperity of the society. They advised that seventeen should be given, and that Mr. Edward Everett be asked to deliver the introductory one; that the price of tickets should be $\$ 2$ for the single one, and $\$ 1$ for each additional; that the lecturers be requested to deliver them gratuitously; and that the whole arrangement for the course be to the important one of increasing the finances of the Society. The committee were instructed to engage Temple Inall for the lectures, and to make all necessary arrangements for their delivery.

$\Lambda \mathrm{t}$ a subsequent meeting of the Society, doubts were expressed relative to the success financially, of the proposed course for 1832-33, and apparently to ensure this it was voted to put the tickets at $\$ 1$. Whatever the effect of this reduction may have been, it is certain, from the Treasurer's report of the next year, that financially, the course was an exceedingly successful one, as it yielded a net profit of $\$ 720$ to the Society.

In Narch of this year, the committee on publication reported that it was expedient to publish a Journal, but nothing appears to have been done towards carrying the recommendation into effect, until sometime after. The report of the committee shows, however, the feeling at this period relative to such publication. There seems to have 
been for a considerable time an arrangement with the proprietors of Silliman's Journal, by which some of the papers read before the Society and some of its proceedings appeared in that periodical.

At the annual meeting of May, 1892, the report upon the collection in the different departments stated that rlonations were withheld from the Society awaiting its having proper accommodations for their preservation and exhibition.

At the election of officers the following changes were marle: Dr. John Ware was chosen first Vice President, in place of Dr. George IIayward, resigned; Mr. Francis C. Gray was chosen second Vice President, in place of Dr. John Ware. Dr. Amos Binney, Jr., was chosen Treasurer, in place of Mr. Simon E. Greene, resigned; Mr. Charles Amory was chosen Librarian, in place of Dr. Seth Bass, resigned. Dr. Winslow Lewis, Messrs. William B. Fowle, Clement Durgin. Dr. George W. Otis, were chosen Curators, inplace of Mr. F. C. Gray, Dr. Amos Bimney, Jr., Rev. J. S. Copley Greene, and Dr. Joshua B. Flint.

As in the sketch of the Linnæan Society the earlier proceedings were more fully describert, so in the accomt of this Society they are given in greater detail than will be possible to accord to the subsequent records, consistently with proper limits. It has seemed well to dwell somewhat at length upon early transactions, in order that the reader may better understand the character and scope of the work undertaken by the first members, and the better appreciate their earnestness and derotion. To do full justice to their merits, it would be necessiny to understand the great difficulty of procuring any information upon many of the objects sent to the society. It was sometimes impossible to make out their character, and often found indispensable to await the reception of works on natural history before any adequate idea could be expressed concerning them. Mr. Samuel II. Scudder, in a brief sketch of the history of the Society, given some years since, cuotes what seems particularly appropriate to repeat here. One of the original members recalling, in after years, the success of their undertaking, wrote thus of the difficulties encountered:

"At the time of the establishment of the Society there was not, I believe, in New England an institution devoted to the study of natural history. There was not a college in New England, excepting Yale, where philosophical geology of the modern school was taught. There was not a work extant hy a New England author which presumed to grasp the geological structure of any portion of our territory of greater extent than a county. There was not in existence a hare catalogue, to say nothing of a general history, of the animals of Massachusetts, of any class. There was not within our borders a single museum of natural history founded according to the requirements and hased upon the system of modern science, nor a single journal advocating exclusively its interest.s.

"We were dependent chiefly upon books and authors foreign to New England for our knowledge of our own zoology. There was no one among us who had anything like a general knowledge of the birds which fly ahout us, of the fishes which fill our water's, or of the lower tribes of anımals that swarm both in air and in sea.

"Some few individuals there were, distinguished by high attaimments in particular branches, and who formed honorable exceptions to the indifference which prevailed; but 
there was no concentration of opinions or of knowledge, and no means of knowing how much or how little was known. The lahorer in natural history worked alone, without aid or encouragement from others engaged in the same pursuits, and without the approbation of the public mind, which regarded them as busy triflers."

In August of this year Dr. Martin Gay reported in reference to some objects which he had been requested to give an accomt of, that it was impossible to do so, because of the want of necessary books.

In Octoher the Council held a meeting for the especial object of arranging the Hall, which the Society was to occupy, for the Cabinet.

In December, recognizing the importance of a permanent fund, it was roted in Council assembled-That all money received from Patrons and Life Members should be invested in bank stock for the purpose of creating one.

Probably the most important event of the year was the election to membership of Mr. Ambrose S. Courtis, whose subsequent benefactions were a great aid to the Society when, by reason of increased expenditure it had become considerably in debt, and when its efficiency - seemed likely to be much impaired, to say the least, for the want of means to carry on its work.

In March, 1833, the hall engaged for the Society over the Savings Bank in Tremont Street, being represented as ready or nearly ready for occupancy, a committee was appointed to remove articles to it, and in May following this committee reported that the cabinet had been transferred and would be arranged as soon as circumstances would admit. It was announced at the same time that the Historical Society had voted to deposit its collection of Natural History in the cabinet of this Society.

Arrangements were made early in the year for a course of lectures in the winter of 183:3 and 18:4, and the committee having this business in charge, reported that Audubon would deliver the introductory one, that the Rev. Dr. Greenwood would give two; Dr. Harris, three; Dr. Gould, one; Dr. Otis, one; F. C. Gray; one; and Dr. C. T. Jackson, two. It was subsequently stated that as Mr. Gray had declined to serve, Dr. Bradford had been substituted in his place, and that he would give two lectures. The committee considered it expedient to pay $\$ 15$ for each lecture.

Dr. J. V. C. Sinith, an active nember of the Society, who had devoted much time to the study of fishes, and had made quite a large collection of them, offered to sell all that he possessed at a very low price, and a committee appointed for the purpose of considering the subject, having reported in favor of securing them for the cabinet, they were purchased for the sum of $\$ 100$. The collection was contained mainly in 141 glass vessels, many having several specimens, and was generally in good condition. Besides the contents of the bottles, there were several dried preparations.

At the Annual election of officers in May, Mr. Clas. K. Dillaway was chosen Librarian in place of Mr. Charles Amory, resigned, and Dr. Chas. T. Jackson, Curator, in place of Mr. Clement Durgin, resigned.

The president, B. D. Greene, at one of the meetings of the Council of the Society this year, expressed a strong desire that a fund of \$\$000 might be raised, the interest of 
which should he devoted to paying the rent bills incurred by the Society. He wished that we might feel independent. and thought with such provision against indebtedness there would need be no doubt of success. He then pledged himself rendy to furnish $\$ 500$ for this olject. Mr. Charles Amory likewise plerlger himself to raise $\$ 400$. Nothing further seems to have been done towards the creation of such fund.

Pending the arrangement of the cabinet in the new hall, and the necessary preparation for its use, meetings were not held in June or July of this year.

The first meeting in the new hall was held on Aug. 7. The cabinet of the Society, increased by the collection purchated of Dr. J. V. C. Sinith, had been fully arranged during the summer months. The magnificent collection of shells belonging to Dr. Amos Bimey, Jr., and of minerals belonging to Dr. Chas. 'T. Jackson had also been deposited with the cabinet of the Society, and put on exhibition.

Surrounded by such evidences of prosperity, the members might well feel gratified at what had heen accomplished in the past, and reasonably hopeful for the future. They were rejoiced too, by the accession of a large number of specimens to the several departments of the Museum, that har long awaited a fitting place for their reception.

Before arljourning, it was voted that hereafter meetings be held twice, instead of once a month, as heretofore. Accordingly on the 21st of August the second meeting for the month was held, and a large number of members were present. At this meeting an address was delivered before the Society by the Rev. F. W. P. Greenwood, commemorative of the opening of their new hall. This very admirable address was published in full in the first volume of the Journal of the Society. As the first paragraph undouldedly expresses fully the feeling pervading the minds of all the members, it is quoted here.

"With good cause, gentlemen, may we congratulate each other at this meeting, on our condition and prospects as a Society. This spacions and delightfully situated apartment; these neat and well contrived cases and tables, already exhibiting treasures, the lustre of which is more pleasant to the eyes of science than the shining of silver and gold; this convenient furniture; these ample accommodations-are all indubitable evidences of our improved, established, and promising state. Everything wears a congratulatory aspect. Our countenances are full of animation. Even the mute representatives from the several kingdoms of Nature, which here in new order surround us, seem to participate in our pleasure, and, rejoicing in their deliverance from the damp and obscure region in which they have been hidden, to bid us welcome to upper air, and the comforts of our present aborle." Another quotation from the address of Dr. Greenwood will find an appropriate place in this history, before its conclusion.

It may be well to note, as showing the comprehensive ideas relative to the work of the Society, that a committee at this meeting was appointed at Dr. J. V. C. Smith's desire, to consult with him upon the expediency of forming a zoological garden. Nothing of course could come from this under the circumstances of the period, and the consummation of such a wish seems now but a remote possibility of the future.

Action was taken at a meeting of the council in October of this year, which shows that as yet the public were not admitted to view the Society's treasures, as a record 
states that a vote was passed to allow those who purchased tickets to the lectures the privilege of visiting the Society's cabinet one day each week.

Early this year a committee was appointed to inspect the rock specimens and minerals collected by Dr. Hitcheock in making the survey of the State, and, if thought best, to petition the Legislature to allow them to be deposited with the collection of the Society. This was done, and for many years following the whole state collection arranged in proper order was on exhibition with that of the Society.

1834. In February, a very triumphant vindication, by the Rev. John Bachman, of the accuracy of the observations and truthfulness of the statements of the honored and beloved Audubon, written agrinst attacks made upon his veracity which appeared in Loulon's Magazine, was read before the Society, and subsequently published in the first volume of the Joumal. It excited great interest at the time and was regarded as fully conclusive.

At the annual meeting in May, the Curators reported that the collection contined of Mammalia, 14 perfect ligamentary skeletons, 34 crania, 15 pairs holns and many teeth ; of Reptiles, 16 Chelonia, 60 Ophidia, 52 Saurians; of Birds, 40 species; of Corals, 30 species; of Fishes, about 100 species, well preserved; of Insects, about 4000 species, of which 2000 were numbered per catalogue; of Shells, 1600 to 2000 species; of Plants, about 800 specimens, nearly all from the neighborhood. Of the Insects it stated that the collection would soon surpass all in America.

Before the election of officers, an alteration in the Constitution and By-laws proposed at a previous meeting was made, by which the office of Cabinet Keeper was created. His duties were defined to be the general charge of the rooms of the Society, that the contents be kept in the best order, that he should select a competent person as a porter, who should be under his immediate control, and that when convenient he should attend personally at the rooms upon days of public exhibition.

Upon balloting, Rev. F. W. P. Greenwood was chosen Second Vice-President in place of Francis C. Gray, resigned; Dr. Amos Binney, Jr., Corresponding Secretary, in place of Dr. Gamaliel Bradford; Epes S. Dixwell, Treasurer, in place of Dr. A. Binney, Jr.; Dr. J. B. S. Jackison, Curator, in place of Francis Alger, resigned; E-tes Inowe, Calninet Keeper.

In October, the committee on lectures for the season reported that Professor Hitchcock of Amherst, Rev. F. W. 1'. Greenwood, and Dr. Flint, had been chosen to deliver them, and they alvised that 800 be paid for each lecture. 'This programme was pobahly carried out as there is no mention to the contrary. In November, Dr. Ware suggested applying to the Legislature for a grant in aid of the objects of the Society, and a committee was appointed to ask it. The result of this was a subsidy of three hundred dollars per annum, for five years, granted by the State, payment of which commenced in 1845.

1835. At the first inceting of the Society in January, the members were cheered by the announcement that one of their number who was in Europe, Mr. Ambrose S. Courtis, had provided in a will male by him that the Society should receive certain sums for specific purposes amomting in all to \$ij,000, and that to ensure the reception of a part of it soon, he had forwarded an order for the immediate payment of $\$ 2000$. This amount was received by the society. It is painful to ard, considering the fociety's finameial condition, that this whole sum was lost by the failure of a bank in which it was deposited. There were conditions annexed to the benefuction of Mr. Courtis, which were not entirely 
satisfactory, and a committee was appointed to correspond with him and suggest some modification of them.

Up to this time the meetings of the Council had not been held regularly, but only as occasion seemed to require. It was now, January 7 th, voted that they be holden twice each month, immediately after the regular meetings of the Socicty.

At the ammual meeting in May, it was reported that besides the $\$ 2000$ cash before mentioned, a note payable in five years for a like amount had been received from Mr. Courtis.

It was also reported that the usual success did not attend the lectures of the last season, the expenses having exceeded the receipts, $\$ 177.05$. The first "ammal" so called, issued by the Society, embracing the address delivered by the Rev. F. W. P. Greenwood, upon opening of the new hall; Remarks in defence of the Author of the Birds of America, by the Rev. John Bachman; Description of a Giblson, by Winslow Lewis, MI. D.; Cicindelae of Massachusetts, by Augustus A. Gould, MI. D.; and observations on a shell in the cabinet of the Society, supposed to be identical with the Murex aruanus of Linnacus, by Dr. Amos Binney, Jr., was reported to have paid for itself the first year. These papers compose part first of the first volume of the Journal of the Society.

At this meeting the Annual Address was delivered by Dr. Walter Channing. It is thus spoken of in the record. "Dr. Chamning laid the Society under grent obligntion by an exceedingly well-timed and interesting address. The objects and progress of the Society, its wants, its claims upon the members and the community at large, the reasons why it should live and flourish; all these considerations were dwelt upon with an earnestness and enthusiasm which could not but produce a corresponding impulse in the minds of his hearers."

The thanks of the Society were voted to Dr. Channing, and he was requested to deposit a copy of his dircourse with its papers, for the use of the members.

In a revision of the proceedings of the Society published some years later than this period, the statement is distinctly made that this address of Dr. Channing, which was highly commended by those who heard it, was printed, but a copy has been sought in vain. Unfortunately the manuscript itself cannot be found in the arehives of the Society, which is the more to be regretted as it is supposed to have embraced matter connected with its early history, that would have been interesting to present in these pages.

The only changes made in the officers this year were as follows: Dr. N. B. Shurtleff was chosen Cabinet Keeper, in place of Estes Ilowe, resigned; Dr. Thaddeus W. Harris, Mr. J. E. 'Teschemacher, and Dr. Martin Gay, were elected Curators in place of MI. William B. Fowle, Dr. George W. Otis and Dr. Joseph W. McKean.

In June of this year the curators agreed among themselves to each take charge of separate divisions of the cabinet. The curatorships were not assigned to special departments until three years later.

A solar microscope was received this year from Europe, the gift of Mr. Ambrose S. Courtis, who purchased it for presentation to the Society. This was put on exhibition for its benefit, the member's only being admitted gratis. In October the exhibition having censed to be remunerative was closed. In August, the committee on lectures reported that they 
had been disappointed in ererr way, and har not been able to obtain a single lecturer.

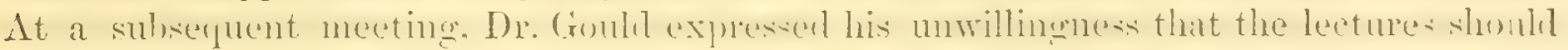
be entirely omitted, and offered himself to give a course on Botany in the Spring. The offer was accepted and a committee appointed to make the necessary arrangements.

1836. In April of this year, considerable discussion took place relative to the means of paying the debts of the sorciety, and it was manimnonsly roted at a Council Meeting to expend the money received from the State towards this end.

At a meeting this month it was announced that no one had accepted an invitation to deliver the ammul ardleses, and it was therefore roted to omit it and have the report of the Curators substituted.

The Annual Meeting was held May 4, the Rev. F. W. P. Greenwood in the chair.

From the Treasurer's report at this time, the liabilities of the society were shown to be $\$ 1476.76$ with a cash balance of only $\$ 56.69$ in his hands, and but $\$ 227$ due it from members, much of which might not be realized. The Courtis Fund was stated to be intact and amounting to $\$ 2057$, invested in Fulton and Granite Bauk stocks.

The officers of the previous year were reelecterl, with the following exceptions: Rev. F. W. P. Greenwood was chosen first Vice President, in place of Dr. John Ware, resigned; Dr. Walter Chrmming, second Vice President, in place of Rev. F. W. P. Greenwood; Dr. Martin Gray, Recording Secretary, in place of Dr. D. Humphreys Storer; Dr. D. Humphreys Storer, Curator, in place of Dr. Martin Gay. The thanks of the Society were presented to Dr. Storer, the late Secretary, for the great zeal, accuracy and fidelity which le had manifested in its behalf since the establishment of the institution.

The Cabinet of the Society had been enriched by the ardition of the skeleton of an elephant that hard died in a menigerie. The bones were stored and bleached in the house of Mr. James Blake, and a rote of thanks was passed to him for his great kindness in allowing this, and for the care shown by him in their preservation. To the skill and labor of Dr. Shurtleff the Society was indebted for putting them together and forming the perfect skeleton.

The Committee on lectures reporter in August that it was not expedient to have a course of lectures during the coming senson.

At a meeting held Dec. 7 , Mr. Epes S. Dixwell resigned the office of Treasurer, and Mr. Ezra Weston was elected to fill the vacancy thus created.

1837. The Legislature of the State was invited to visit the rooms of the Society.

In February of this year, a letter having been written to the Lergislature recommending a re-survey of the State, and that a collection of the plants and animals should be made under the charge of the Boston Society of Natural Inistory, a Committee was appointed by the Society to meet a Committee of the IIouse, to whose consideration the subject had been given.

In April, the Legrislature authorised the Geologrieal Survey by Prof. Mitcheock, and the following persons were commisioned subseduently to report upon the Botany and Zoology of the State: George B. Enerwon. Presilent Bo-ton Society of Natural History Chester Dewey, Profersor of Botany in the Berlswire Afedical Institute; Elyenezer Emmons, II. D., Professor of Natural History in Williams College; Rev. William B. O. Peabody, of 
Springfield; Thaddeus IV. Harris, M. D., Librarian Harvard University; D. II. Storer, M. D., Curator of Boston Society of Natural History; Augustus A. Gould, M. D.. Curator of Boston Society of Natural History.

These gentlemen met, and it was arranged anong them that Profexwor Finmons should undertake to report upon Mammalia; Rev. Mr. Peabody, upon the Birds; Dr. Storer, upon Fishes and Reptiles; Dr. IIarris upon Insects, Dr. Gould, upon Mollusea, Crustacea, and Radiata; Professor Dewey, upon the Ierbaceous Plants; and Mr. Emerson upon the Trees and Shrubs.

The Reports presented to the Legislature were published in 1839-1846.

It will be remembered that in January, 1835, the announcement was made to the members that Mr. Ambrose S. Courtis had provided in a will that the Society should receive certain sums for specific purposes, amounting to $\$ 15,000$, and that prepayment had been directed by him of $\$ 2,000$ of that amount. A copy of the will had been forwarded by him for examination by the Society, and a committee on its part had been appointed to suggest some modifications of its provisions.

It is not known whether the matter received his attention. Possibly his change of residence from place to place delayed the reception hy him of the communication of the committee until increasing illness prevented consicteration of it. Intelligence of his death was received a few months after. What is known of this early benefactor of the Society is but meagre. It will however be read with grateful interest,

Mr. Ambrose Stacy Courtis, for that was his full name, was born in Marblehead, Mass., on March 1, 1798. IIe received only a common school education, but early acquired a taste for literature and science, which often manifested itself in his subsequent life. Upon leaving school he entered a country store of his native place, and there was accustomed to devote all the spare time he had to classical and scientific studies. He afterwards came to Boston, and entered into partnership with Mr. Simuel Johnson, the firm being Johnson \& Courtis. The business was that of wholesale dry goods.

While actively engaged in that occupation, he kept up his interest in other pursuits, devoting much spare time, as when at Marblehead, in reading works upon his farorite pursuits. He accumulated property, but his health became impaired. In 1834, he retired from the firm of which he was a member, and travelled in Europe, hoping to regain his strength. In this he was dikappointed, and he funally died in Greece, August 27, 1836. His remains were brought home and buried at Mount Auburn.

On a tablet in the vestibule of the Musem, may be found the following inscription:

To

AMBROSE S. COURTIS

MERCHANT OF BOSTON

WHOSE GENEROUS BEQUEST IN 1838 WAS

FOR TWENTY-FIVE YEARS ITS CHIEF SUPPORT

THE BOSTON SOCIETY OF NATURAL HISTORY

ON THE FIFTIETH ANNIVERSARY OF ITS FOUNDATION

APRIL 281880

GRATEFULLY INSCRIBES THIS TABLET 
There seems to have been some anxiety on the part of the Society relative to the will of Mr. Courtis. In February of this year, at a meeting of the Council, extracts were read and consideren, and finslly a comnittee wis appointerl to take charge of the matter with power to take legal measures if necessary to protect the Society's interests.

At the Amnual Meeting in May, the Rev. Hubbard Winslow delivered an address on the relation of natural science to revealed religion, which was subsequently published by the society. It is spoken of in the records as an ingenions, eloquent and fervid ardress.

The Treasurer's report at this meeting shows the society had on hand but $\$ 180.17$, whilst it owed a note for $\$ 677$ with 10 months interest.

No money hat been expended on the library during the year, and the need of a fund for the purchase of books which were indispensable for progress was strongly felt. Dr. Storer reported upon the state of the collections, giving a very elaborate account of the condition of every department, with notice of the many valuable additions made to it during the year.

The most important acquisition was that of the great collection of insects purchased of Professor Hentz, the entomologist, then residing in Florence, Alabama. This was the fruit of seventeen years labor in this field of sturly, and was undoubtedly one of the best collections extant. Professor Hent wis very desirous that the whole collection should be possessed by some society of similar character to our own, rather than that it should be sold abroad. He had previously offered it to IIarvard College, together with his entomological books, for $\$ 1600$, but the offer hat been declined. Professor T. W. Harris, then Curator of the Entomological department of the Society, interested himself in obtaining subscriptions in its behalf, and after much exertion, oltained in this way enough to secure the collection, and also such portion of the library of Professor Hentz as was most needed for our Society. The insects alone cost $\$ 500$, the books $\$ 200$, and other incidental expenses, $\$ 39$, making in all $\$ 789$.

The principal donors to the fund were Dr. B. D. Greene, Dr. James Jackson, Dr. George C. Shattuck, Hon. Francis C. Gray, Hon. Jonathan Phillips, Dr. John Randall, the Hon. David IIenshaw and an anonymous person who gave $\$ 2.50$ of the amount.

The collection contained, by the count of Dr. Hirris after arrival, 14,126 speeimens, of which 12,811 were American, and 1315 foreign. There had been much delay in responses to the application for subscriptions, and Dr. Harris was annoyed in consequence. In mentioning the great accession to the cabinet at the annual meeting, he expresses himself thus: "I congratulate the society in the acquisition it has received, and although the tedionsly protracted negotiation has caused me much anxiety and vexation, and the small and lingering success which has attended my efforts in your behalf has subjected me to severe mortification and disappointment, I cannot but feel happy at the result. It is my hope that we shall have here in entomology, as well as in other departments, a standard collection, rich in genera and species, as complete as possible in the productions of our own country, arranged and with the names affixed to every described species. Our museum then will be useful, not only to ourselves, but to all others who may wish to refer to well authenticated specimens, to remove their doubts or confirm their conjectures." 
The reception and the magnitude of this collection has been particularly dwelt upon, because of what will follow in due time respecting its fate. It is necessary that there should be a proper appreciation of the value of this as well as of other important collections sulserpuently allowed to rerish, in orter that lessons may be derived from experience such as it is so well calculated to teach.

Previons to the election of officers, the highly respected and much beloved President, Benjamin D. Greene, tendered his resignation, greatly to the rexret of all. The following changes were made: Mr. George B. Emerson was chosen President, in the place of Dr. B. D. Greene, resignert; Dr. Amos Bimney, 24 Vice President, in place of Dr. Walter Chamming, revigned; Mr. Epes S. Dixwell, Correponding secretary, in place of Dr. Amos Binney; Dr. T. M. Brewer, Cabinet Keeper, in place of Dr. N. B. Shurtleff; Dr. N. B. Shurtleff, Curator, in place of Mr. George B. Emerson.

In August of this year, Louis Agassiz was elected an Honorary Member, and in November, Jeffries Wyman was elected a resident member of the Society. These atmisions are particularly mentioned, beanse of the great influence these gentlemen afterwards exerted upon its welfare.

As showing the financial trouble of the Society, it may be mentioned that at a meeting of the Council in November, it was reported that the rent of the hall, $\$ 150$, was due in two days, and that there were only $\$ 50$ on hand to meet the call. It was voted that the treasurer make the best arrangement in his power with Mr. Savage, respecting it.

The Committee to whom the subject of lectures was intrusted, reported that several members of the society har pledged themselves to bring forwall at times such exercises upon the subject of natural history as they thought would be interesting to the public, and recommended that the members should have the privilege of attending these, and of introducing members of their fimilies and strangers who might be in the city. The recommendation was adopted.

This seems to have led not exactly to what was suggested, but to the admission of ladies of the members' families and such others as they chose to invite, to the regular meetings; for at the next one, held Dec. 20, the record states that the occasion being the first on which ladies harl been invited. the President. Mr. Finerson, addressed the Society upon the subject of this invitation. He explained the objects of the Society somewhat at length, and said much to interest the audience in the study of natural history. $\mathrm{He}$ spoke of the many pleasures and benefits to be derived from some knowledge of Nature as shown in her works and operations, and concluded with some account of the advantage we have over the ancients in our more extended knowledge of these subjects.

The admission of ladies seems to have had for a time considerable influence upon the attendance, as the number of nembers reported as present at this and succeeding meetings was much larger than had been usual. There was a gradual falling off however, but how soon ladies ceased to attend is not mentioned in the reports of subsequent meetings.

1838. In January, the Council voted: That notice be given by written card posted up in the State House, that the IIuseum will be open every Wednerday, between 12 and 2 
o'elock. for visits from the public, and that the members of the Legislature be invited to examine it at those times.

By the advice of the Council, an alteration was made in the By-laws by which each Curator should have his particular department allotted him at the time of his election; le to have the privilege of selecting from among the members of the Society a person to assist him in arranging and labelling the specimens.

The Annual Address was delivered this year by Dr. Chas. T. Jackson, and was a very interesting and lucid discourse upon the various influences of the study of Natural History of Man, both in an individual and a social capacity.

At the election of officers the following changes were made: Dr. Angustus A. Gould was chosen Recording Secretary in place of Dr. Martin Gay; Dr. Jeffries Wyman, Cabinet Keeper, in place of Dr. Thos. MI. Brewer.

The Curators were for the first time elected for special departments; the following were chosen :

Dr. N. B. Shurtleff, for Comparative Anatomy; Dr. Thos. II. Brewer, Birss; Dr. D. IImupheys storer, Reptiles and Fish; Dr. Thaddeus W. IIarris, Insects; IIr. J. E. Teechematcher, Botany; Dr. Chas. T. Jackson, Mineralogy and Geology, State Collection; Dr. Martin Gay, Mineralogy and Geology, Society's Collection.

1839. In January, 1839, the Legislature was formally invited to visit the collection during the hours when it was open to the public.

Since occupying the hall in Tremont street, the library of the Society had been placed in cares much needed for portions of the callinet, and the librarian having made a proposition to receive it into his room in Tremont Row, where the books could be kept together, and where access could be had to them at all times, and at all hours of every day; it was voterl to accept the offer of the librarian, and that unoccupied cases in the attic over the hall be made use of by him for the reception of the books in his room.

The necessity for more room for the increasing collection had become so great, that many claims were at once presented by the curators of several departments for the space about to be vacated by removal of the library, and it became necessary to appoint a committee with power to assign it as they thought expedient.

At the Annual Meeting this year, the Treasurer reported receipts amounting to $\$ 1337.18$, and payments $\$ 1.67 .51$, leaving on hind $\$ 169.67$, with debts outstanding to the amount of $\$ 1001.96$.

The Report on the Cabinet stated that out of one hundred and twenty species of Massichusett: Finhes ninety were in the collection, and of the Reptiles every described species; all in gooul condition. The Annual Address was delivered by Rev. John L. Russell, on the pursuit and delight of the Study of Nature.

At the election the changes made in the officer's were as follows: Dr. Jeffries Wyman, chosen Recording Secretary, in place of Dr. Augustus A. Gould; Mr. John James Dixwell, Treasurer, in place of Mr. Ezra Weston; Dr. Simulel Cabot. Jr., Ciblinet Keeper in place of Dr. Jeffries Wyman; Dr. Jeffries Wyman, Curator of Mammals, in place of Dr. Winslow Lewis; Mr. Thomas J. Whittemore, Curator of Mollusks (office not previously filled). 
In June, at a meeting of the Council, it was voted that the Committee to whom was referred the affairs relating to the will of the late Ambrose S. Courtis, be authorized to complete the negotiations with the heirs of said Courtis on such terms as they may deem expedient, and to receive all money accruing therefrom, to be deposited in some bank for safe keeping.

Before the close of the year, a settlement was made with the heirs of Mr. Courtis, by which they were to be released from all oblimations, upon the payne+11t of $\$ 10,2.50$. For some reason not given, \$10,000 were finally received.

In Oetoher, Dr. Samuel Calsot resigned the office of Cabinet Keeper, and MIr. William I. Bowditch was elected to the position, but as he preferred a month later to have another substituted in his place, Dr. Samuel L. Abbot was chosen to succeed him.

In November, a report was made upon the disposition of the money from the Courtis bequest, and the members, feeling now that they could reasonahly expend something towards meeting wants long felt: Voted, to procure such books as were most needed for the library. They also appointed a committee to make an estimate of the cost of mounting the Birds of Massachusetts in first rate order.

In December, the librarian proposerl that the meetings through the winter should be held once a week at his room opposite the hall, provided he should be made a life member, and the expenses of the lights and fiuel he paid for by the society. 'This offer was accepted, and the meetings were accordingly held there.

It is pleasant to notice in looking over the proceedings of the Society, that it was enabled sometimes to aid others in scientific measures to serve the public, as it has often done in more recent periods. At one time we find Prof. Hitchcock appealing to it for information concerning soils; at another the specimens of the Cabinet were solicited by Prof. Silliman for use in illustrating his great course of lectures before the Lowell Institute. It is unnecessary to add that these calls were cheerfully met.

1840. In February, of this year, the Society was saddened by the death of one of its original founders and most interested members, Mr. Nimon E. Greene. This gentleman was a business man of great activity. In early years he was an officer in one of the city banks, but afterwards, and until the close of his life, was a broker in whom the utmost confirlence was placed. All of his contemporaries represent hirs as a man high minted and honorable in all his dealings, and of much public spirit. He was a nephew of Gen. Simon Elliott, and from him derived his name. In the formation of the Society be was not only one of the original members, but was the secretary of the first meeting of gentlemen fuvorable to the formation of a society for the sturly of natural history, which was held at Dr. Waltel Chaming's house. He was afterwards appointed, with Dr. Amos Bimney, Jr., to call upon such persons as it was thought would like to be associated in the project and obtain their signatures. At the first election of officers for the new Society, Mr. Greene was chosen Treasurer, which office he held for two years. when he resigned, receiving the thanks of the Society for the services rendered by him. At a meeting held Felmuary 12, the President feelingly alluded to the loss the Society had sustainerl, stating that Mr. Greene harl a great love for the sturly of nature, more particularly for the departments of Ornithology and Botany; that he had ever shown himself 
one of the firmest friends of the Society, ready to assist and co-operate with others in times of need, and on all occasions manifesting a strong interest in its prosperity and usefulness. The following resolutions, offered by the President, were unanimously adopted :

"Resolved, that in the death of our late valued and honored associate, Simon Elliott Greene, we, members of this society, feel that we have lost a firm, liberal, and enlightened friend.

"That we cherish fondly in our hearts the memory of his many virtues as a generous friend, an honorable merchant, a perfectly upright and honest man; and that while we mourn over our loss, we deeply sympathize with those whose bereavement, from their nearer connection with our friend, is still more heavy than ours."

Mr. Greene, though bearing the same family name, was not connected by ties of relationship, with the Presilent. II means were limited, but he manifested his continued interest in the Society hy a bequest of five hundred dollars in money, a fine collection of about twelve hundred species of shells, and several works on natural history.

In April of this year the meetings were resumed in the hall of the Society, and were continued weekly, as through the winter, until the Annual Meeting in May, after which they were held twice a month.

At the Annual Meeting held May 6, Dr. C. T. Jackson, who presented the Reports of the Curators, after referring to the additions made to the Cabinet during the year, made some pleasant remarks relative to the Society, of which a few lines may be appropriately quoted: "We have now shown to the world that a Society of Natural History can be supported in Boston, and trust that the time is not far distant when the public generally will feel that the establishment of such a Society has contributed not a little to the general weal. Our hall is already crowded with visitors at such times as we throw open the doors for general admission, and there cannot be a doubt respecting the beneficial influence which is exerted by this institution upon the minds of its young visitors. Many a student in science will look back with gratitude to those objects in your collection that first attracted his attention to the delightful walks of Natural History."

The only change made in the officers of the Society at the election was in Mr. Marshall S. Scudder being chosen Curator of Birds, in place of Dr. Thomas MI. Brewer, who resigned.

The Curatorships of Comparative Anatomy and Mammals were united at this time, and Dr. Nathaniel B. Shurtleff, who had held that of the former, was chosen to fill that of the combined departments. Dr. Jeffies Wyman, who hat been Curator of Mammals, retired.

Let us now review briefly the history of the Society during the first ten years of its existence, touching upon some general points not hitherto presented. It will be well to do this at the close of each decade, as thus perhaps a better idea may be conveyed, not only of the progress of the institution during each period in material prosperity, but of the change in thought relative to its proper mission as an educational institution, and the means necessiry for the accomplishment of its aims and purposes. 
Some statements have been made in the notices of the Anmual Neetings, of the Treasurer's reports showing excesis of expentiture over receipts, and the fict of an accumulating debt which threatenerd serionsty the welfure of the society, notwithstanling the annual sulsidy of s:300 received firom the State, and which wats granted for five yealrs. The Treasurer's Report for the year ending May, 1s 10, will show the financial contition of the Society, at the end of the ten years of its existence.

Its receipts for the year were as follows:

From the previous treasurer

Divicend on • • $\$ 15000$

Anpul a • • • 1800

A

Borrowed from the Courtis Fund in order to pay off indebtedness of the Society

50400

80000

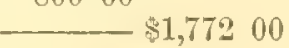

Payments as follows:-

Notes held against the Society and interest

Rent and taxes due for rooms prior to the past year

Amounts due incurred prior to year

Whole debt paid

Books added to library

Rent and taxes of Society's apartments

Printing and advertising

Miscellaneous expenses of cabinet

Current expenses of the cabinet

Entomological cabinet.

Care and attendance on the room, fuel, \&c.

Expense altering shell-cabinet

Commissions collecting fees, \&c. .

$\$ 76717$

27196

5125

- 1,09038

$\$ 2572$

28051

3277

1000

8942

5000

9047

6300

2705

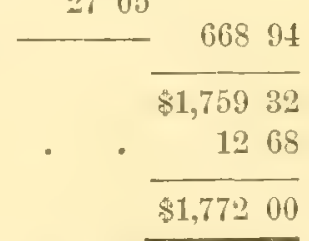

This account has been given in full, in order to exhibit more clearly the economy exercised in managing the affiirs of the Society, necessary if the Society was to be saved from the burden of a debt that could not he borne, yet destructive afterwards to portions of the collection of very great value, from that want of expenditure requisite to the proper care and preservation of perishable objects.

The Society had strugggled with debt during the greater part of its existence, and was for the first time free from its hamasing claims. This, however, was only brought about by borrowing from the fuml which it desired to hold sacred for special purposes; that received from the heirs of Ambrose S. Courtis, $\$ 10,000$. The claim that "we had now shown to the world that a Society of Natural History could be supported in Boston," having the aims and objects of the one existing, and relying on voluntary libor and 
voluntary contributions for the furtherance of its objects, is not sustained by the condition of affirs at this time, for it may well be asked how long the Society could have gone on with an increasing debt consequent upon increasing expenditure not to be avoided, if the bequest of Mr. Courtis had not relieved it from embarrassment; especially when it will be seen that with the additional means thus acquired, the best portion of its rich collections went to ruin for want of that necessary care which only paid service can be relied upon to render, and which could not be afforded.

The income from the Courtis fund was a great help, and a great encouragement. It enabled the Society to go on with its work in a manner that secured for it public approbation, of great service to it later when its increasing collections called for more room for their exhibition, and made an appeal for help necessary. It was not enough to enable it to adequately protect its perishable treasures. A much larger income was indispensable, but experience had not yet demonstrated this fully.

Sometime during this year, though no record is made of it, the Council agreed to appropriate the income of the Courtis Fund one-third to the Library, one-third to publications, and one-third to the Cabinet.

It may be interesting to the members of the present time to know something of the attendance of members in the early days of its activity.

The following table will show the highest and lowest number present, together with the average attendance each year.

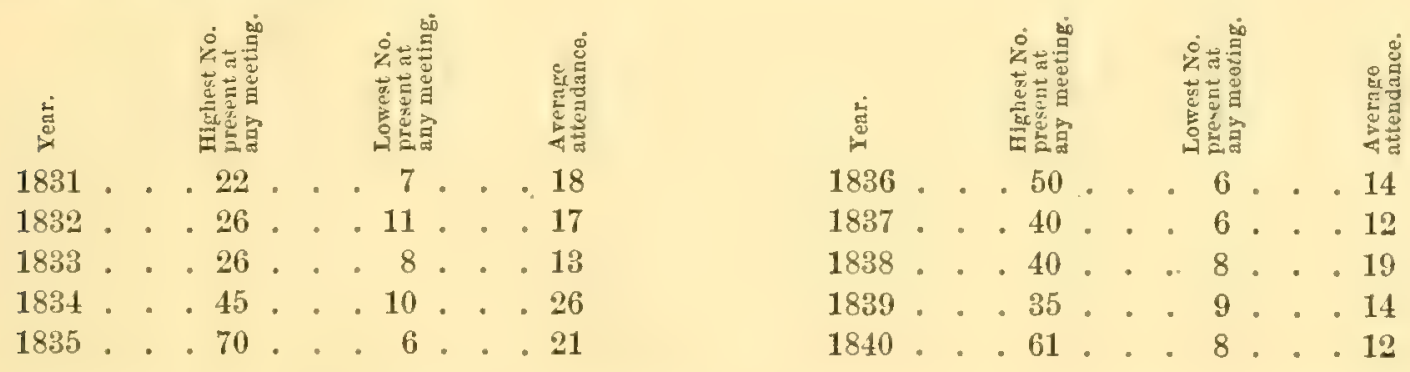

An increasing interest seems to have been felt in the meetings during the year ending May, 1834, as the average attendance is shown to be double that of the one previous. This was due in part at least to the removal of the Cabinet to the new hall in Tremont Street, over the Savings Bank, where subsequently the meetings were mostly held. The average afterwards fell off and became small in the years ending in May, 1836 and 1837, when it again increased considerably, as during the year ending May, 1838, there was an attendance of over 50 per cent. more than during the two previous years. This is likely to have been the temporary effect of ladies being permitted to accompany the members. There is no record of this permission being withdrawn, and the probability is that too few continued to feel such interest as to lead to the custom of their attendance becoming permanent. In the years following nothing is said of their presence and the average number of members at the meetings again fell off.

Respecting the increase of the Cabinet up to this period it may be said that there were but few meetings held when specimens were not brought forward and presented. Sometimes these donations were of great value, and deserve special mention. 
At one meeting, Park Benjamin presented ninety-two beautifully preserved bird-skins and a box of insects, from Demerara. Joseph Coolidge, forty-five bird-skins, with corals and other oljects from Bombay. John James Dixwell, one hundred and thirty-three specimens of bird-skins, in perfect order, with many fishes, from the vicinity of Calcutta. J. N. Reynolds, a magnificent collection of between four and five hundred bird-skins; a large collection of botanical specimens; boxes of minerals, organic remains, and of insects; a large and valuable collection of shells; skulls, fruits, and fishes, all from South America, the Islands of the Pacific, and the South Shetland Islands. Dr. James Jackson, a valuable IIerharium. Mr. J. S. Copley Greene, also, a valuable Herbarium. Dr. F. W. Cragin, of Surinam, magnificent donations of zoological aud botanical specimells.

Dr. D. Humphreys Storer was continually bringing forward specimens for the cabinet. At one time he presented seventy specimens all carefully put up by him, in glass bottles and labelled. To his generosity mainly was due the fact, that out of one hundred and twenty species of Massachusetts fishes then known, ninety were in the collection, and every described reptile of the State, with one exception. Alas, that through the want of proper care in after years, nearly all these should have been destroyed! Of this more will be said hereafter.

It would require pages to specify all the donors who enriched the cabinet by their contributions; suffice it, therefore, to mention the names of some who were particular benefactors in this way, viz., Doctors Augustus A. Gould, Amos Bimney, Jr., Winslow Lewis, John Flint, B. D. Greene, C. T. Jackson, J. V. C. Smith, G. C. Shattuck; Rev. F. W. P. Greenwood; Messrs. Joseph P. Couthouy, William B. Fowle, Estes Howe, Edward Tuckerman, Jr., Simon E. Greene; Commodore Downes, of the United States Navy; Messrs. George W. Pratt, George James Sprague, J. W. Mighels, H. T. Parker, and C. J. F. Binney.

It is impossible to state the number of specimens in all the departments of the cabinet. There were of fishes three hundred and forty-four species, of which there were, as has before been stated, ninety of Massachusetts waters alone, out of one hundred and twenty known. Of birds, there were of mounted specimens about seventy-fire, and of bird-skins not mounted, about fou hundred. There had been a much larger number of the latter, but the collection had suffered from the attacks of insects.

Of Reptiles no statement can be made excepting that already given, that the collection contained every known Massachusetts species excepting one, and that had only once been found within our limits. In the Mazological department there were 23 specimens. In that of Comparative Anatomy many, but the number is not given.

of Mollusks there were over 3000 species in the collection, but whether these embraced the private collection of Dr. Amos Binney, is not certain. At this time he had already proffered to give the whole of his to the Society, provided other grentlemen having collections would allow a committee to select from those species not possessed by him or the Society. This was complied with afterwards, so that all in the cabinet at the time soon became the property of the Society, with a great number in addition. 
The Entomological department was very rich, embracing as it did the great collection purchased of Hentz, but the whole number of species and specimens camnot be stated.

Of the Iferbarium there is no mention of the mannitude at this time, but it contained the valuable donations of plants made by Dr. Jas. Jackson and by J. S. Copley Greene.

Already the collections of the Society were beyond the ability of the curators to find proper space for in the exhibition cases, and it was necessary to put away inany in drawers out of view.

The Library as well as the Cabinet had constantly received donations during the ten years past, but as yet was very deficient in works necessary for students in every department. It consisted at this time of 660 volumes, hesides numerous pamplilets. But little money had been expended for books, as the funcial condition of the Society had not warlanted it. The largest donors to this department were Jurlge Davis, who in 1837 presented a great number of valuable works; and Col. Thomas H. Perkins, who in the last year of the decade presented a magnificent copy of Audubon's work on the birds of America. Other donors to the library of valuable books were Drs. D. H. Storer, John Ware, Amos Binney, Jr., Joseph W. McKean, B. D. Greene, and Messrs. E. Tuckerman, Jr., Edward Waren, Hemy Codman, Isaac McLellan, John Lowell, Jr., and Joseph Coolidige.

Addresses were delivered before the Society at its annual meetings, first in 1835 , and afterwards in $1837,1538,1839$, and 1840 , as already mentioned. Several of these were published.

At this time the first two volumes of the Journal of the Society and the contents of a large portion of the third had been published. All the papers were communication that had been made at meetings of the Society, and were of such character as to establish for it a high scientific reputation, both at home and abroad. It served greatly towards obtaining the works of foreign societies through exchange.

Communications of important character were made at almost all the meetings, and often interesting diseussions followed concerning the matter presented in them. The members who took the most conspicuous part in the proceedings dumg the first five years, were Dr. C. 'T. Jackson, Dr. D. H. Storer, Dr. A. A. Gould, Mr. George B. Emerson, Mr. C. C. Emerson, Mr. Epes S. Dixwell, Dr. J. V. C. Smith, Dr. J. B. S. Jackson, Dr. Walter Channing, and liev. F. W. P. Greenwood, though many others participated. During the later five years may be mentioned as the most frequent contributors to the interest of the meetings by their communications, Drs. C. 'I. Jackson, Augustus A. Gould, D. Humphreys Storer, 'Thomas M. Brewer, Martin Gay, 'Thadrleus W. Inrris, Amos Binney, Rev. F. W. P. Greenwood, Professors Jeffries Wyman and C. B. Adams, and Messi's. J. E. Teschemacher, Edward 'T'uckerman, Jr., George B. Emerson and Epes S. Dixwell.

The Council of the Society, consisting under the Constitution of the officers elected by it, and whose duty it was to control the expenditure of the money, select lecturers and decide upon the subjects to be treated upon by them; designate what books should be purchased for the library; nominate Honorary and Corresponding Members; attend to the publication of the Journal; and to transact any other business not inconsistent with the Constitution and By-laws; met in the early days only as specially called together, but subsequently, after the regular meetings of the Society. 
For the furtherance of its objects, Committees were annually chosen on the Finances, on Lectures, on Publications, and on Honorary and Corresponding Members. Those who were active on these Committees previous to this period were Drs. Harris, Binney, Gould, C. 'T. Jackson, Lewis, Storer, the Rev. Mr. Greenwood, and Messis. Emerson, Dillaway, J. J. Dixwell, Epes S. Dixwell, and S. E. Greene.

\section{Decade II. Mar, 1840-MAT, 1850.}

We now enter upon the second decade of the existence of the Society, with the gratifying fact of its freedom from debt, and its possession of a funded property sufficient at least with due economy to sustain its life and cmable it to do much in furtherance of its objects; but not enough to furnish the means necessary for the proper care and preservation of its increasing collections, as will be seen hereafter. At the first meeting after the annual one, there came to hand a large donation of very valuable specimens from Dr. Thomas S. Savage, a missionary at Cape Palmas, West Africa, mostly of just the character which afterwards suffered greatly from lack of care, viz., insects aud reptiles.

In June of this year, an official communication was received from the heirs of Mr.

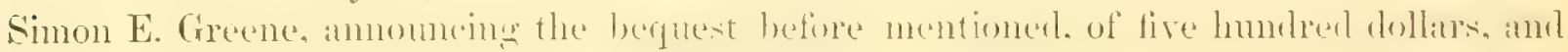
of some works on natural history.

In November, the lease of the hall occupied by the Society was renewed for three years, and also an arrangement similar to that of the previous year was made with the Librarian, by which the meetings through the winter were held at his room in Tremont Row, in the eveuings, once a week until Dec. 30th, and twice a month afterwards.

The Society had again an opportunity of making a part of its Cabinet serviceable to the public otherwise than by exhibition within its own halls, by granting permission to Prof. Wyman to use specimens from it, in illustrating his course of lectures before the Lowell Institute on Comparative Anatomy, given this season.

1841. Early this year, the usual invitation was extended to the Legislature to visit the Museum. On such occasions the Curators made it their business to be present, in order that such visits might be the more agreeable and instructive.

An attempt to render the meetings more interesting was made at this time by forming committees on the several departments of natumal history, who should be held responsible for the presentation of communications.

As showing a strong feeling against the absorption of the Courtis Fund in the expenditures of the Society, action taken in February of this year is noticed. It will be remembered that in order to liquidate outstanding debts before the last annual meeting, a sum of eight hundred dollars had been borrowed from this fund, and four notes of two hundred dollars each, on interest, had been given by the Treasurer to the 'T'rustees of that fund.

The Society now voted to apply the five hundred dollars, received by the bequest of Mr. Simon E. Greene, and the proceeds of a sale to be made of the one share yet held of the Granite Bank stock, to pay the first three notes; and that the fourth note should be paid out of any surplus in the hands of the Treasurer, during the current year.

For the first time in the history of the Society, we find the Council appropriating any amount of money for the use of the several departments of the Museum. The income from the Courtis Fumb now rnithed the Cunator's to expend something, though little, 
towarks the purchise and preservation of specimens. We aceordingly learn that \$50 were appropriater for the department of Ornithology sal) for that of Comparative Auatomy, and $\$ 25$ for that of Botany. Moderate sums have ever since been asked for by the Curators, as required in the several departments, and these have been granted when the state of the finances would justify the expenditure.

It will be remembered that Dr. Amos Binney, Jr., had proffered his whole collection of

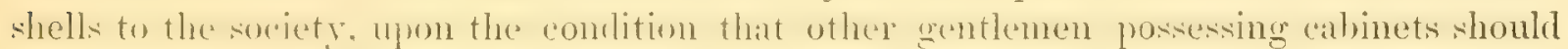
open them to a committee, who should be allowed to select from them such species as would serve towards completing the collection of the Society. At the annual meeting in May of this year, the Curator of the Conchological department reported that from the cabinets of Messrs. Dixwell, Greenwood, Emerson, Storer, Emmons and Warren, about six hundred species had been selected, most of which were new to the collection. He also reported that by the bequest of the late Simon E. Greene, his entire collection of about 1200 species had come into the Society's possession. 'The Curator, after referring to the accession of Dr. Binney's collection and that of Mr. Simon E. Greene, with the additions made from compliance with the conditions of Dr. Binney's gift, and by the donations received from various other parties, spoke of the cabinet of shells as standing foremost of all the public collections of the New World. By the reports of the other Curators for the year, it appeared that the donations to their departments had not been very important, except to that of Entomology. 'The additions to the Library were numerous and valuable, some being received from the bequest of Mr. Simon E. Greene and others from purchase by means of the money received from the Courtis fund.

'The 'Treasurer reported the entire receipts for the year $\$ 1837.41$; the entire expendi-

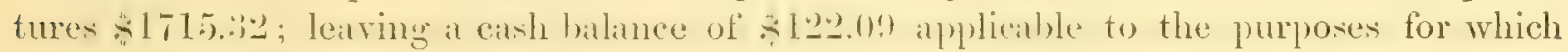
the income of the Courtis Fund had been specially appropriated, viz., the increase of the cabinet, the increase of the library and the publication of the Society's Journal.

After the rearling of the several reports, the President congratulated the Society on the evidence fumisherl by them of its prosperous condition. He remarked that $\cdots$ the constant cireulation of the rolunes joves the usefulness of the library and the increasing taste for study and investigation on those subjects for the pursuit of which we are associated. 'The state of the treasury shows the gratifying fact that the Society is out of debt and with a consilerible income annually applicable to its purposes. During the past year there have been twenty-five meetings, at which seventy-five reports, written and oral, were made, including the whole range of subjects embraced by the Society. Besides these, twelve other witten communications of interest. with letters recerverl. have occupied the time of the meetings. and afforded us the gratification of reflecting that we have not been quite idle in the work we have undertaken to do."

The following changes took place among the officers of the Society - Rev. Dr. Greenwood having declined to serve longer on account of ill health, Dr. Amos Binney, Jr., was elected First Vice-President in his place, and Dr. Charles 'I. Jackson succeded Dr. Binney as Fecond Vice-President; Dr. Frenterick A. Eddy was chosen Recording Secretary; Dr. A. A. Gould, Curator of Conchology ; 'Thonnas Bulfinch. Curator of Mineralogy and Geology (State Collection); S. L. Ahbot, Jr., Curator of Onithology, and Thomas T. Bouvé, Cabinet Keeper. 
The Society then listened to an interesting and instructive address from Mr. Teschemacher upon the progress of Natural Science. 'This was subsequently published.

Nothing of unusual interest occurred during the summer and fall months. When the season became too cold for meetings in the hall, the nember's met by invitation at the President's house in the evening, until February; after which they assembled at the room of the Librarian, $7 \frac{1}{2}$ 'I'remont liow, until spring.

1842. In April of this year a committee was chosen to make arrangements for the reception of the Association of American Geologists and Naturalists in the hall of the Society, where their approaching meetings were to be held by invitation of the Society. These meetings, the first in Boston, took place during the week eommencing April 25th and ending on Saturday the 30th. The most eminent scientific men of the country were present, including Profs. William B. and Henry D. Rogers, Dr. Samuel G. Morton, Prof. Hitcheock, Prof. Benjamin Silliman, Dr. James D. Dana and Prof. Locke. Mr. Lyell the distinguished geologist, afterwards Sir Charles Lyell, was also present. The meetings were of great scientific interest and importance, and several of the members, also members of the Association, took an active part in the proceedings and discussions, among other's Dr. C. 'I. Jackson and Ciupt. Joseph P. Couthouy.

The Association before adjouming passed a vote of thanks to the Boston Society of Natural History for the use of the hatl, and for the kind attention shown by its individual member's.

Previous to and in anticipation of the meeting of the Association, the Society had voted to hold a special meeting on the 27 th of the month, in order to invite the members of that body to hear the Annual Address which was to be delivered by one of their number, Dr. Samuel G. Morton, the celebrated ethnologist. 'This meeting so held, was largely attended by the members of the Society and by those of the Association. The President first gave a brief history of the doings of the Society the past year. This was followed by the address, which was upon the distinctive characteristics of the aboriginal race of America, and was extremely interesting and instructive. It was published by the Society in its Journal, Vol. IV, p. 190, and in pamphlet, Svo., 1842.

The yearly reports of the Curator's were not always ef such character as to give particular information concerning the extent of the collections, sometimes being limited to a statement of donations received, with remarks upon condition, etc. When presented in detail, it seems well to embody their substance here, in order that comparisons may be made hereafter if desirable. Some of the reports made at the amual meeting in May, 1842, are therefore dwelt upon at length. They were all quite encouraging.

In the Ichthyological department the whole number of species was given as 450 , of which 390 were from the Western Hemisphere, and 60 from the Eastern. Of the Massachusetts species alone, there were now 108, an increase of $T$ during the year.

Of the mineral Cabinet it was stated by the Curator that he had rearranged the collection, and that there were 610 specimens on the shelves, which probably comprised all worthy of exhibition.

The Curator of Entomology reported the enriching of this department by the addition of eighty species of African beetles presented by Rev. Dr. Savage.

The Curator of Comehology reported the continued prosperity of the department under his charge. During no former year had a greater amount of labor been bestowed upon 


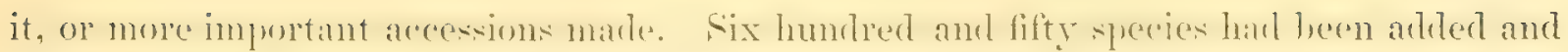
entered in the catalogue, and nearly a thousand names had been ascertained, and the labels applied. There were now in all 3900 species, not including duplicates, all of which had come into the possession of the Society by donation. Of the whole number, 1722 species had been contributed by Dr. Binney, 1197 by Captain Joseph P. Couthouy, 104 by Commodore Downes of the Navy, 95 by Mr. Dixwell, 54 by Mr. George B. Emerson, S5 by Mr. 'T'. J. Whittemore, 43 by Mr. George Brown, 44 by the Rev. Dr. Greenwood, 29 by Mr. John Warren, 33 by Mr. Stephen Emmons, 41 by Dr. Storer, 155 by Dr. Gould, and many had come from the bequest of Simon E. Greene. The want of room and the want of books on the subject were complained of, the members being almost wholly dependent upon the splendid library of Dr. Binney for information. 'This, however, was liberally open to the use of all who sought knowledge.

The Curator of the State Collection of Geology reported the addition to it of 1100 specimens collected by Professor Hitcheock on his resurvey of the State, making, with the previous collection, 2616 , besides the series of soils mumbering 227.

The Curator of Botany reported the addition of 1194 species, mostly foreign, to the department under his charge. No account of the whole collection was given.

The Curator of Ornithology reported the whole number of birds in the collection as 540 , very few being duplicates; 120 of these were mounted, of which 106, including 75 species, were of Massachusetts. Forty-three specimens were received during the year, the donors being Capt. Joseph P. Couthouy, Judge Amos of Bengal, Messrs. Teschemacher, H. Bryant, Lewis Ashmun, Charles Maryo, and Dr. J. P. Kirtland.

The Curator of Comparative Anatomy reported some additions to his department, but stated that the large skeletons were in bad condition from exposure to dust.

The Librarian reported the condition of the library as prosperous; 140 volumes, including 38 pamphlets, having been added during the year, presented by various individuals.

The Treasurer reported the whole receipts during the year, including balance at commencement, \$1350.29; whole amount expended, \$1213.36, leaving a balance of $\$ 136.93$.

The changes among the officers this year were, that Dr. Martin Gay was chosen Curator of Minerals, Mr. T. 'T. Bouvé of Geology, Mr. 'T'. Bulfinch, Recording Secretary, and Dr. Henry Bryant, Cabinet Keeper.

In May of this year the Diploma now in use by the Society was first adopted.

In June, it is recorded that Dr. Jeffries Wyman was made a delegate to represent the Society at a meeting of the British Association, soon to be held at Manchester, Eingland.

In September, there appears to have been some apprehension as to the safety of portions of the collection, as Dr. Wyman was requested to devote such of his leisure as he could command for the ensuing year, to its preservation and increase, and $\$ 200$ were appropriated for the purpose.

In December, the Council of the Society having learned "that a proposal had been made to take from their authors the notes, journals, and observations made by some of the corps of the late Exploring Expedition, and to place them in the hands of others for publication," and recognizing the injustice of such proceeding as well as the many other objeetions thereto, thonght fit to remonstrate against, it, which they emphatically did, by 
passing votes expressive of their views on the subject, copies of which were sent to the Hon. Secretary of the Navy, and to Hon. Robert C. Winthrop, the representative of this district in Congress.

1843. In the early part of this year ten members of the Society subscribed to Audubon's work on the Quadrupeds of the United States for presentation to the Society. 'They were George B. Emerson, N. I. Bowditch, Amos Binney, Jr., George C. Shattuck, Jr., J. Amory Lowell, George Parkman, William Sturgis, F. C. Gray, John Janes Dixwell and Amos A. Lawrence.

On May $3 d$, in the absence of many members who were attending the meeting of the Association of Geologists and Naturalists at Albany, it was voted to postpone the business of this meeting, the annual one, to the 17th inst. On that date, therefore, it was transacted. 'The Curators' reports were generally very gratifying. Dr. Cragin of Surinam had again enriched the cabinet by donations to the several departments of Comparative Anatomy, Herpetology, Omithology, and Ichthyology, and as usual in former years frequent contributions to them all had been inade by the members.

The Curator of Ornithology mentioned that the collection had increased during the year to 753 specimens mounted and ummounted, of which 172, comprising 131 species, were natives of Massachusetts.

The Curator of the department of Geology as disconnected with that of Mineralogy, made his first report. The whole collection was stated to consist of about 1000 specimens, 400 of which had been received by donations during the year, 200 of these being Silurian,

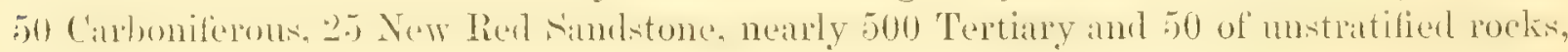
lavas, etc. The remainder were undetermined. It should be borne in mind that this department of Geology embraced the fossils of the several formations at this time, that of Palaeontologry not being made a separate one until years later.

The Librarian stated the increase of books during the year to have been 105 volumes and 55 pamphlets, making the whole collection 1071 volumes and 250 pamphlets, independent of the publications of the Society.

'The 'Trealsurer reported expenditures exceeding receiphts in the general aceomt showing a deficit of $\$ 258.45$, but of the Courtis Fund income he reported excess of receipts over expenditures $\$ 303.53$.

The annual address was delivered by Dr. Jeffries Wyman, and was a learned and interesting discourse on the progress of science during the past year.

Mr. George B. Emerson, who had served the Society with great fidelity as President for six years, having declined a re-election, Dr. Amos Binney was unanimously elocted in his place. The Corresponding Secretary who had likewise held this office for six years, also resigned, and Dr. A. A. Gould was elected to fill the vacancy. Dr. Charles 'I. Jackson was chosen First Vice-President, and Dr. D. Humphreys Storer, Second Vice-President. Other ehanges were in Jefries Wyman being elected Curator of Reptiles and Fishes: and A. E. Belknap, Curator of Conchology.

On the $2 d$ day of August of this year, there passed from earth one of the best of men; one whom all who knew, loved and revered. This man was the Rev. F. W. P. Greenwood. It is a joy to dwell on such a character, and it was a privilege of the early members of the Society to have associated with them one so much loved and respected, 
ant whose tastos led to his zealous coriperation with them in arlwancing its intereste until health and strengt? no longer permitted active exertion.

Dr. Greenwood was not one of the original members of the Society, but he was early connected with it and ever afterwards participated largely in its work. He became

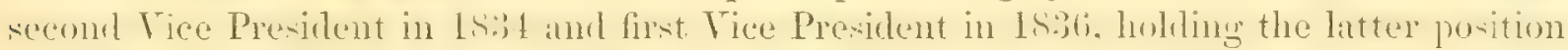
until May 1811, when by reason of failing health he resigned. As Vice President he was frequently callerl upon to presirle at the meetings of the society, and he often by conmmnications or otherwise, took part in the proceedings. In 1833 he delivered an address before it upon the opening of its new hall in Tremont street. This was published in the Jomrnal of the society and formerl its first article. This aldress has been before lodereed to; but some remarks in it bearing upon the importance of a collection of local species merit attention. IIe said: "It should he our object to attend particularly to the formation or completion of such collections as may give a good idea of the natural features of our own country and of our own section of our country. If I were traveling in Spain or Persia, I should desire expecially to examine some depository of the natural prouluctions of Spain or Persia. If I were traveling in our western states I should prefer seeing a musemn well stocked with their own curiosities to one well stocked with all curiosities but their own. And so, too, I presume a traveler in New Fngland will first of all desire to see those objects which illustrate the natural history of New England. For our own instruction and gratification. indeed, and for the advancentent of natural science amonest us, we shall gladly collect from every quarter and every coat and corner of the globe; from every sea and lake and river, whatever can be furnished for our purposes; and yet, for our siakes too, we shall least of all choose to be ignomant of the luemes and thing with which Providence has suromeled our own dwellings, of the plants which spring fiom our mative soil, the birds which fly in our own heavens, and whatsoever passeth through the paths of our own.seas."

We pass on to the Annual meeting of 1844, which was held on the 1st of May. The President in presenting the reports of the Curators for the year took occasion to make some remarks upon the early history, progress and present comlition of the Society, and then foreibly stating the pressing want of larese accommodations for the collections and for the library, appealed to the public for aid in supplying them.

The Reports then given, though generally satisfactory as to the conrlition of the specimens in the sereral departments, presenterl exceptions which were hut ton suggestive of what would inevitably follow under the system of reliance wholly upon voluntily care and labor.

The Curator of Entomology reported that the collection had been infested to an alarming extent by Anthreni, and great injury done; that in orter to hetter preverve the specimens he had been obliged to take a portion of them into his own kerping away from the Hall, and resort to active measures to destroy the pest that was making such ravages. Nothing, he said, but the utnost vigilance on his part enablerl him to lieep the collection from destruction, and he merger that provision should be mate for such glazed cates as would effectually exclude the enemy.

The Curator of Comparative Anatomy reported that by subjecting the specimens umder his care to over $180^{\circ}$ of heat in the steam oven of the Society, they had been freed from insects, and by the free use of poisonous washes future ravages prevented. 
The Curator of Ornithology likewise reported that specimens in his department had

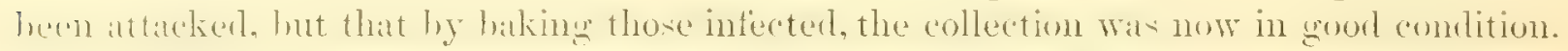

Thus it will be perceived that in three of the important departments of the Museum the collections had been seriously attacked and much injury done. Up to this period no

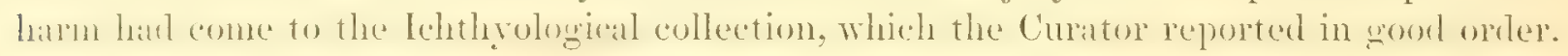

The only reports that specified to what extent the collection had been increased, were those of Ornithology and Geology. The mounted birds were given as 233, of which 195, comprising 151 species, are found in Missachusetts. Of ummounted skins the number given was 592 , making in all 825 specimens.

The number of specimens in the Geological Collection was given as upwards of 1000 , of which about one half were Tertiary, the remainder being of the older formations. Quite a number of these were yet undetermined, and the Curator stated would have to remain so, until the Library should be better furnished with works on the subject of Palacontology.

The most important addition to the Cabinet of the Society, during the year, was that made to the department of Herpetology by Dr. Cragin of Surinam. From him twentythree jats were received. containing nearly one humber specimens of Silurian, (1) hidlian. and Batrachian reptiles, all in an excellent state of preservation. The Curator deplored the necessity of storing these out of sight for want of room to put them on exhibition.

The officers elected were the same as chosen the year previous, except that Dr. A. A. Gould was made Curator of Conchology; Dr. S. Cabot, Jr., of Ornithology ; and Dr. H. J. Bigelow, Cabinet Keeper.

The Ammual Address was delivered by Professor Asa Gray, and gave an account of the recent progress and present state of Tegetable Physiology. It was exceedingly intere-ting and instruetive, and was listened to by a numerous and highly cultivated andience with marked attention.

In June of this year, the first notice was taken of the bad condition of the Buttonwoods in New England, which had always been, until within a short time, one of our healthiest and most beautiful trees. At the suggestion of Dr. J. B. S. Jackson, the Rev. John L. Russell was appointed a Committee to investigate the cause of the injury to them. Mr. Russell, whose attention had already been given to the subject, communicated the result of his observations at a meeting in August. His views appear in the Proceedings of the Society of that date. He ascribed the evil to the young wood being winterkilled, remarking that well ripened wood was always essential to vigorous health in perennial vegetation, and that for several years no such young wood had been seen. He thought that the great vigor in the larger limbs would eventually enable the trees to survive until favorable circumstances facilitated the ripening of the young wood, though doubtless some would perish. The views then given of the cause of the trouble have been sustained by experience, and are here briefly expressed because the subject has by no means lost its interest in the minds of those who admire stately and vigorous growth, such as was exhibited in the Buttonwoods of our neighborhood forty years ago.

1815. As showing the means sometimes adopted to obtain specimens for its collections, it may be mentioned that early this year the Society appropriated $\$ 25$, and various mem-

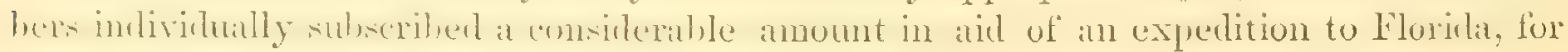
such a purpose, to be undertaken by Mr. John Bartlett. 
It harl been for some time apparent that the accommorlations afforded hy the ITall of the Society were entirely inadequate for the proper care and arrangement of the increasing collections.

At the Ammal Meeting in May, several of the Curators complained bitterly of this, and it hecane manifest to all that some measures should he adopted towards olstaining more room to meet this requirement. The Curator of Ornithology stated that less than one third of the specimens in his department were mounted. for the want of room to place them in, that the cases in which the mmounted specimens were placed were so accesil)] to moths and other destructive insects that the collection harl suffered consideribly, and there was consequently not much encouragement for him or others to make exertion for its increase, until assured that the labor would not be thrown away. Others of the Curators expressed themselves in like manner.

In the President's review of the doings of the Society during the past yenr, he likewise remarker upon the necessity for more room, saying that the time had now come when the crowder state of the collections and limited accommodations for meetings male it necessary to take earnest measures for the erection of a suitable building for the Society.

The present is a propitious time, he said, to commence an energetic movement for the accomplishment of this great object.

The members all feeling the necessity for decisive action, it was

Toted: That in the opinion of this Society, the time has now arriverl when a stremous effort should he male to raise sufficient funds to ensure the prosperity and permanence of the institution.

Toted: That a Committee he appointed to act persomally or through others, to be solected by them, to solicit subscriptions for the purpose of erecting a building for the use of this Society.

Drs. Amos Binney, Jr., C. T. Jackson, D. H. Storer, and A. A. Gould, were elected to compose this Committee.

'The Curators' Reports dir not mention generally the extent to which the collections: had increased. That of the Treasurer showed, independently of the Courtis fund, an excess of expenditure over the income of $\$ 142.85$, which added to excess of former years, \$327.22, marle an amount of debt due to the Courtis fund of $\$ 470.10$.

The income from the Courtis fund showed a balance of cash on hand of $\$ 421.88$, with \$ $\$ 70.10$ due from the General Fund. The understanding that the income from this fund should he equally divided between the Library, Publication expenses and the Cahinet. had not been complied with, in fact it seldom if ever was; the general expenses of the Society heing too great to armit of such compliance. The publications, moreorer, frequently required too much to allow the others a fair share. During this year they had over $\$: 300$ of the $\$ 618.66$ receiverl, whilst the Library hat ohtained only $\$ 28.55$, and the Cabinet nothing.

Among the pleasant events of the year just closed, may be mentioned two of considerable importance; one was the bequest of $\$ 2000$ from a gentleman then recently deceased, Jolm Parker, Esq., a merchant of the city, and the other a donation of more than fifty volumes to the Library by Dr. Francis Boott of London. 
One means of obtaining many books much wanted by the Society has not been yet referred to. At the time of the generous donation of the great work of Audubon, by ( $a l$. Thus. II. Perkins, there was alreaty a copy in the lihrary which hat been acepuired through the subscription of a number of the members. After the reception of the last copre, the consent of the donors of the first was asked and rearlily obtained, to its disposal l,y the society in exchange for other works. A Committe was therefore appointed hy the Conncil to effect such exchange. Messis. Little it Brown, who had alway manifisted a very livently feeling in hehalf of the Society, purchased the work. anpering to allow $\$ 625.00$, and to deliver in return for it such books as might be ordered from time to time through the Committee. As the works received in exchange were to be such as relaterl to Ornithology only, it was reveral years before the negotiation was completed; the Committee for this purpose meanwhile being annually reappointed.

Mr. John James Dixwell, who had served the Society as its Treasurer for six years, resigned at this neeting, and a rote was pasied expresing sincere regret at his retirement, and thanks for the acceptable. manner with which he had filled the office for so long a period. Patrick T. Jackson, Jr., Esq., was chosen to succeed him. The only other change annong the officers was that Edward Tuckemman, Eri. succeded Dr. A. A. Crould as Curator of Conchology.

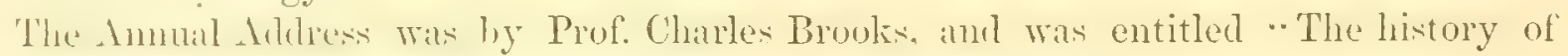
Philosophical Zoology from the earliest times to the present day."

In July of this year the Society had again the gratification of serving the cause of Science by a loan of several of its specimens from the collection of the Radiata to Dr. Dana, who was preparing his great work on the Corals of the U. S. Exploring Expedition.

In this year, too, the Socicty was enabled, by the publication of a report made by Prof. Jeffries Wyman at one of its meetings upon what purported to be the skeleton of a Sea Serpent, to do great service to the community by saving it from continued deception. There had been placed on exhibition in New York some fossil remains, consisting of a great number of vertebrae arranged in such a way as to give them the appearance of having belonged to a single individual. These, with what purported to be the head, measured in length about one hundred and fourteen feet. There were also teeth, ribs and paddles. The character of the remains was not understood by the exhibitor, Dr. Koch, and no obstacle was put in the way of as thorough an examination as could be made without separating the parts which had been, to a greater or less degree, cemented together. The name of Hydrarchus Sillimani had been given to this so-called

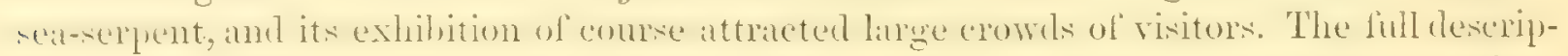
tion of the bones, as read by Dr. Wyman, may be found in the published proceedings of the Society. Suffice it here to state that the vertebrae were shown to belong, not to one individual, hut probilily to many of different ages, that so far as they coukl be studied they did not present any of the characters of an ophidian reptile; and that some at least of what purported to be bones, or portions of the bones of the paddles, were not bones at all, but casts of the cavities of a camerated shell. The teeth Dr. Wyman claimed to be those, not of a reptile, but of a warm blooded mammiferous animal, probably a Cetacean. 
This report did honor to the Society, and added much to the reputation of Dr. Wyman. It soon became well known that the bones were not those of a Reptile, but of a Cetacean belonging to a genus to which Prof. Owen hard given the name of Zeuglodon. They were found in the Tertiary deposits of Alabama and belonged undoubtedly to many individuals. Vertebrae and other bones of this animal may be now seen in the collection of the Society.

It may be well to state, as the annual reports of the Curators do not always give particulars desired relative to the collections, that during this year the Museum was visited by Prof. Lewis R. Gibhes of South Carolina, and that he carefully studied the Crustaceans in its cabinet and made a full catalogue of them. This represents that there were 58 genera and 91 species, some of them rare and until recently undescribed.

1846. But little happened during this year that would interest the general reader. From the reports of the Curators it appeared that a gratifying increase was made to the several departments of the Museum, and from that of the Librarian that there had been added 143 volumes to the Library, mostly obtained by purchase. No very considerable donations were mentioned. Great complaints of lack of room for useful exhibition of the specimens in the Museum were made.

The Treasurer reported a balance in his hands belonging to general fund of $\$ 20.72$ and a balance of income from permanent fund of $\$ 148.01$. The permanent fund now amounted to $\$ 12,000$.

The only change in officers was the election of Dr. John Bacon, Jr., to succeed Edward Tuckerman, Esq., as Curator of Conchology.

1847. The advent of Agassiz among us, was, as Mr. George B. Emerson afterwards characterized it, a most important event to all engaged in the study of natural history in our country. It was not alone that he possessed information most desirable for our education in science, and great ability to impart it, but largely because of a personal influence that he extended over all who came in contact with him. His noble mien, his personal beauty, his genial manner and expressive features, the earnestness with which he spoke whenever he sought to interest others in the pursuits he loved; all conspired to impress every one who approached him not only with admiration for himself, but with the great importance of the science he taught. It is to show what were the feelings of the members of the Society regarding him and his teaching, that this notice of him is given in this place, together with the action of the Society at a meeting held Feb. 3, 1847. IIe had but recently arrived, and had just completed his first course of lectures before the Lowell Institute. At the meeting referred to, Dr. D. Humphreys Storer submitted the following resolutions, which were unanimously adopted:

"Resolved, That this Society present to Professor Agassiz their heartfelt thanks for the gratification and instruction received by its members during his late course of lectures on the Plan of Creation.

"They would assure him that his lectures have griven an impetus to the study of natural history such as has never before been felt in this community ; and which, while they have excited the curiosity and called forth the admiration of the public, have more than realized the most sanguine expectations of this Scientific Society. 
"While as a body we would thus tender our acknowledgement to the liberal naturalint

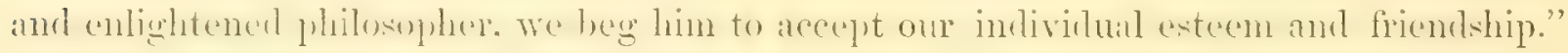

These resolutions not only received the signatures of all present, but of the members generally, who subserfuntly risited the library, all glatly avaling themselves of the opportunity to sign them.

In March of this year the Society received the sad intelligence of the death of its

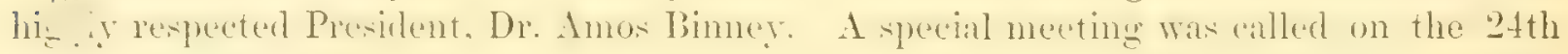
of this month to take such action as the feelings of the members should dictate. After remarks by the Vice President, Dr. C. T. Jackson, upon the melancholy event that had brought the members together, Dr. Storer moved the following resolution :-

- Itesoleed. That the unexpexterl tirlinges of the death of our murh valued frienr. Amos Binney. Escl. late Presilent of this society. fills us with inexpressihle sorrow. To us, we feel that his loss is irreparable. The founder of this Society, he was ever its steady, devoted, true frient; constantly evincing his interest by sugesting new plans for its artrancement; constantly proving his sincerity by his endeavol's to perfect them. 'I'o his encouragement, decision and perseverance we owe, in no slight degree, our present prosperous condition. With full hearts, we would acknowlentge our obligations, while we gratefully cherish his memory."

Prof. Asa Gray offered the following resolution :-

"Resolved, That the Council be requested to prepare, or cause to be prepared by such

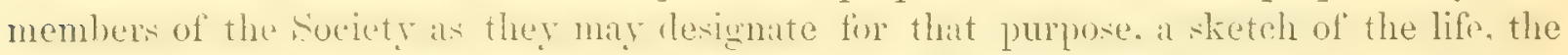
scientific labors and the services of our lite limented President, to be read hefore the Society and publisher in it: Journil, or in such other manner as the Society may direct."

These resolutions were unanimously adopted.

At a subsequent meeting of the Comeil Dr. Augustus A. Gould was appointed to prepare the memoir asked for. 'This was itone, heing male introductory. however. to the prethlication of Dr. Binney's work on the Terpestrial Nollusks of the Tnitert, States. From this memoir are taken. many facts here presented concerning the subject of it. Dr. Binney was born in Boston, October 18th, 1S03. He received his early education at the Derby Acarleny in Ifingham, and afterwads entered Grown University, from which he graluated in 18.21. Suhsequently hestulierl merlicine with Dr. George C. Shattuck of this city. and attended medical lecetmes at Dartmouth College. At this time his health fililed and he was obliged in comsenuence to wire up his studies. and hy the artries of his medical friends to travel extensively over this country and Europe. Whilst abroad he visited England, France. Italy and Germany, eiving his attention to the hospitals and to the great collec-

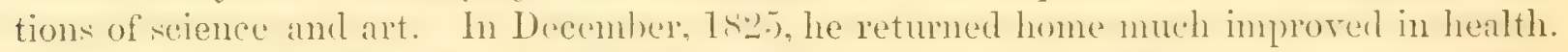

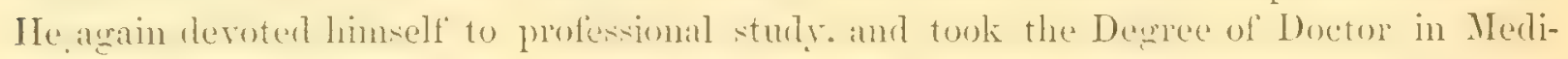
cine at Harvard University in 1826. The practice of his profession, however, he did not find congenial to his tastes and thinking it would not he so finvorable for his health als mercantile pursuits, he abandoned it, and engaged in trade and subsequently in mining operations.

While so employed he never lost his interest in scientific studies, which indeed absorbed a large part of the leisure time that could be spared from business. After suffering from some vicissitudes of fortune, and having finally obtainerl a competence, he 
Shetermined to derote his life expecially to science and art, intending "after his own finnily" to make the Boston Society of Tatural History and the Boston Athenaeum, the objects of his solicitude and bounty. His anticipations were not realized. His health again declined, and encouraged by his former experience he sought to regain it by a sea voyage and a sojourn in Europe. His intentions were, if health permitted, to make himself actuaintert with the scientific collections of the old world, and to select while there, at fine library of such scientific works as would be of service not only to himself but to $r^{\text {th hers }}$ engraged in like pursuits. He left home in October, 1846, was not improved by the voyage, and atter suffering much from di-eatse both in France and Italy, finally died at Rome, February 18, 18t7. His remains, in obedience to his wishes, were brought home for burial at Mount Auburn. As the memoir states, "Dr. Binney in person was above the middle stature, erect, robust and well formed. His complexion was dark, with very dark hair and eyes. His features were full and well formed. His dress was scrupulously neat, his mimners were dignified and hespolie the gentleman. His roice wils deep toncel, full and melodious, and his enunciation was remarkably distinct. In his opinions he was decided but not obstinate. He was elegant and refined in his tastes, and passionately foncl of the fine arts. IIe wats most happy in his domestic relations, an excellent father, monseakinhy anxious to train up his children. both hy eximple and precept, in all their duties to God and Man." An extract from his Journal quoted in the Memoir expresses well his feelings relating to his children. "May they," he wrote, "especially imbibe principhes of homor and religion. and maty it be their high aim to acruire and deserve the name of the Christian gentleman. May it be said of my house, not that all the sons were brave and the diughters virtuous, but that all the sons were upright and honorable, and all the daughters good."

The part taken by Dr. Binney in the formation of the Society, and his active zeal for its interests manifested ever afterwards, have been shown but inadequately in the pages of this history. To do full justice to the memory of all to whom it owed its origin, and who nurtured it in its infancy, would require volumes where but brief chapters can be given. He was, as has been stated, of that small number of persons who first met at the house of Dr. Walter Chamning on February 9. 18.30, to consider the question of forming a Society of Natural History.

He felt a great interest in the Journal of the Society and contributed several papers which appeared in its columns. To the Museum he presented specimens of great value, not only for his fivorite department of Conchology, but for any of them as opportunity favored. It will be borne in mind by readers, that he offered upon condition that other gentlemin opened their calinets to a committee of the society to select from them species not in his own, his whole collection of more than twelve hundred. The condition having been complied with, the Society was enriched through his generosity to the extent of about two thousand species. The first large donation of fossils and of minerals was made by him and the number of sperinens atgregrated about five humberl. Of mounted Linerican birds he also presented many. He had a large and valuable library of books on scientilie suingects, and these were alway's at the service of all who required them for invertigation. 
Up to the time when again foreed by disease to relinquish his labors, he continued to manifiest the same zeal in hehall' of the society as hall always been shown hy him firom its formation. His last work for it was in a strenuous effort to obtain subscriptions from the public that would enable it to posicess a building suitalble for its increaring collections, and he had well nigh succeeded before incapacitated from further exertion.

The Society could have met, apparently. no greater loss than that incured hy the death of Inr. Binney. 'This was felt deeply by its members as his intentions to devote time and means largely to its service were well known to them.

But they did not mourn his loss merely as that of one from whom, had he lived, the Society might have received continued benefits, but because they felt in common with all who knew him intimately, that a ledphul compranion, a goorl citizen, ame an wright man had passed away, one possessing all the traits that constitute the character which he prayed might be the high ain of his children to acepuire. that of a Christian gentleman.

In April, Dr. Samuel Cabot, in behalf of a Committee to whom had been allotted the duty of secking for the society a suitable edifice for its purposes, reported that the buileling in Mason street known as the Massachusetts Medical College was for sale at a reasomalle price, and that after a thorough examination. they julged it capable of being andptert perfectly to the wants of the Society. They therefore recommended its purchase, and that the necessary alterations be made.

After some discusion a vote passed unamimonsly that the Committee have authority to purchase the property and make the proposed alterations.

The Annual Meeting was held on the first Wednesday of May and the reports of the Curators were presented, but on motion being made, the reading of them was postponed until the next meeting, when the annual address would be delivered. The officers of the Society were elected, John Collins Warren, M. D., being chosen President. The only other change from those of the previous year, was that Dr. S. Kneeland, Jr., was made cabinet keeper.

The reports of the Curators were read at the next meeting. The specimens of the several departments, excepting that of Entomology, of which no report wat made, were represented to be now in safe condition, though not much increased in number. Those of the Ornithological department were two-thirk of them stowed away carefully in the gatret, sealed up, for want of more suitable accommodations. To preserve them from the Dermestes. which had attacked them seriously in spite of previous precautions, they hat heen immersed in corrosive sublimate. Twenty-seven or twenty-eight specimens had been received from that indefatigable friend of the Society, Dr. Cragin of Surinam.

As was remarked at the meeting, it must not be inferred from the reports of the Curators, that there was any less interest felt in the collections than formerly. It had been nerestary to refuse specimens for want of room to accommorlate them and it hat not been possible to arrange properly those already belonging to the Society.

The Vice President, Dr. Storer, made some very appropriate remarks upon the late President, Dr. Binney, and addressing his suceessor, walmly weleomed him to the seat he Was now occupying, pledging the hearty co-operation of his brother members and himself in aiding him to advance the interests of the Society. 


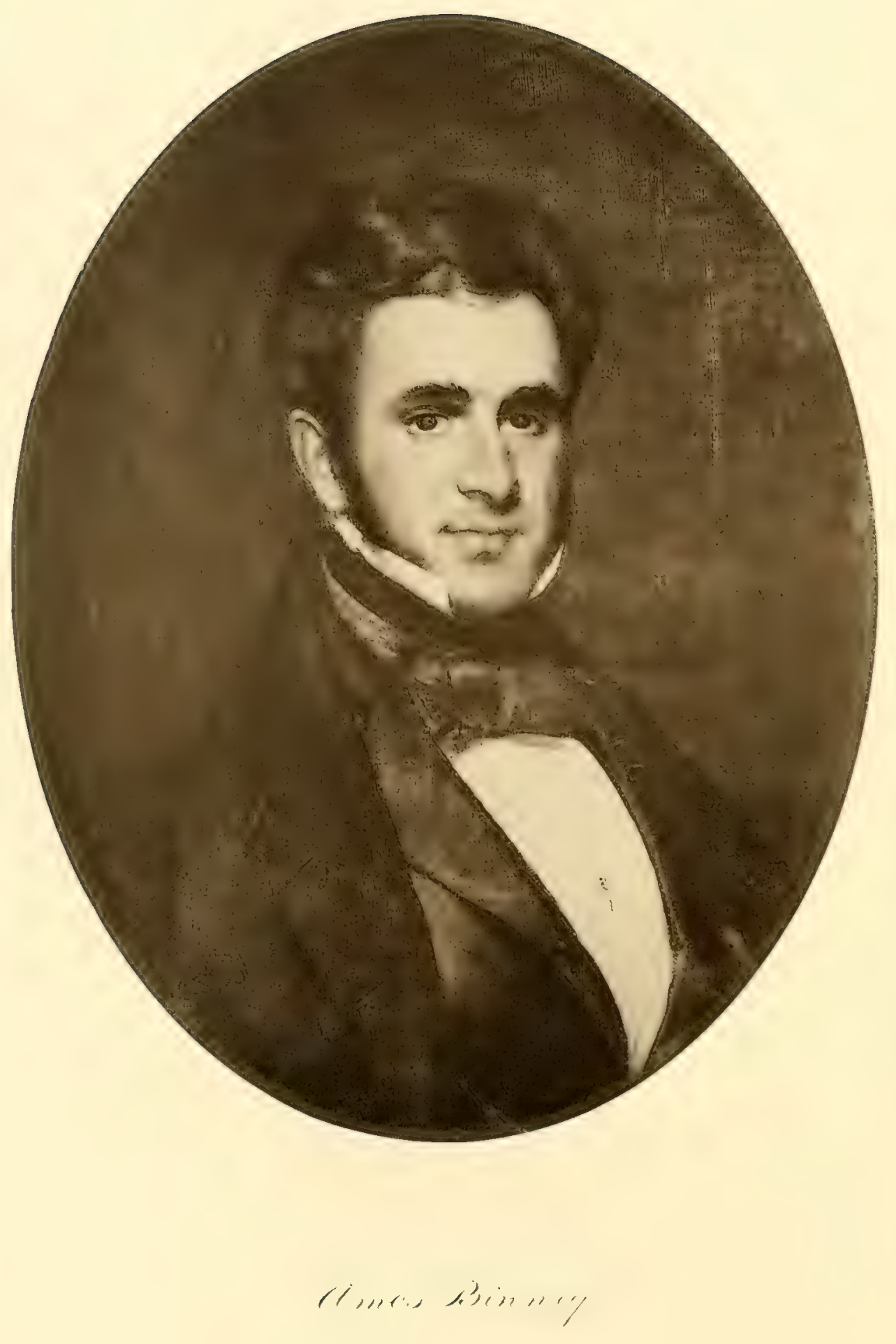


The President, Dr. Warren, expressed the gratification felt by him at the honor conferred in his election, and at the kind welcome given him.

An address by Dr. Augustus A. Gould, followed, and was principally upon the life, character and labors of the late President, Amos Bimey. He closed by congratulating the Society upon the prospect that the next annual meeting would be held in a new edifice, more suitable for its purposes.

From the 'Treasurer's report for the year it was shown that the whole receipts on general aceount had been st99.20. and the expenditures st9!).2(i, leaving a halance due the Treasurer of four cents. The Courtis fund account exhibited receipts including balance of previous year, $\$ 555.51$, and expenditures $\$ 358.26$, showing a balance on hand of $\$ 197.25$.

There was a special meeting, later in May, at the house of the President, to take further measures relative to the proposed new building. It would seem from the action

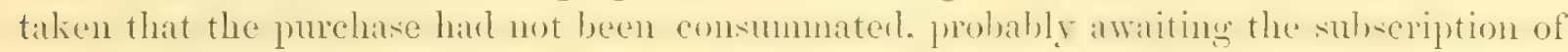
a sufficient amount to warrant it, as votes were passed directing the Treasurer to collect the monegs alrearly sulwather for the purpose; that the Building Committee be recquested to continue their efforts to increatse the sul,scription; and that they he authorized to conclude the purchase of the Medical College.

From the subsequent records of the year there is little or nothing to be learned of further action relative to the acquisition of the building it was proposed to purchase; yet before its close it had come into the possession of the Society, and such alterations had been made as were necessary to adapt it for the use of the museum and library.

1848. On the fifth of January, 1848, the Society met in the new building, and a large number of members were present. The President congratulited the society on the agrceable circunstances unter which the first meeting of the year wals held; spole of the difficulties under which it had liblored from restricted accommorlitions and natrow means; and enterl with expresing the hope, that with increased means of uxefulness, it would not permit the achievements of its maturity to contrast unfaromally with those of its youth.

The movement inaugurated by the late President to raise an amount of money by an appeal to the public sufficient to enable the society to possess a building of its own, had been quite succesful, the sum of 828 , tito having been contributerl for the purpose by eirhty-six individuals. The following resolutions were introduced by $\mathrm{D}_{1}$. Storer at this meeting:-

"Resolved, That the heartfelt thanks of this Society be presented to those gentlemen whose munificence has enabled us to call this temple our own.

"Resolved, That we will endeavor to prove our sense of obligation by a renewed devotion to the cause of science.

"Resolved, That we deeply feel the kinduess and liberality of George II. Dexter and Edward C. Cahot, Escr.., in arrising and aiding in the architectural arrangements of our building; and most especially do we feed indelsted to N. B. Shurtleff. II.D., for the skill lee hals exhibited in adapting, and the zeal and fidelity with which he hat for months superintended the advancing work."

At the next meeting, held January 19th, a vote was passed thanking Dr. Storer, Dr. Cabot and their associates for the earnestness and perseverance shown by them in raising 
funds towards the purchase of the new building and its adaptation to the use of the Society, and at a meeting in February a special vote of thanks to Dr. Shurtleff was passed for the great care taken, for the time given, and for the taste and skill exhibited by him in providing for the accommodation of the Society and its collections.

At the annual meeting in May the Treasurer reported that the whole amount received

From general sources was

$\$ 1288.96$

From Courtis fund .

1103.56

From subseribers to building . . . . . . . . 26999.75

Total received

$\$ 29392.27$

That the whole amount expended was

For general purposes
From Courtis fund .
Towards new building .
For repairs and alterations

Total expended

Leaving a balance of cash .

\section{$\$ 1300.35$ \\ 450.73 \\ 20000.00 \\ 7257.63}

There yet remained due,-

On the building

Interest

To architects and others .

$\$ 3000.00$

425.00

1295.00

$\$ 4720.00$

1720.00

Towards liquidation of this, subscribers to the building yet owe .

$\$ 3000.00$

The Lithrarian reported that during the year there had been received 120 rolumes, and 102 pamphlets and parts of volumes, most of them donations. Of the works received, twelve volumes had been selected from the library of the late Hon. Judge Davis, in aceordance with a provision in his will; Audubon's Quadrupers of America had heen presented by subseribers to that work; and other valuable publications had been the gift of Alcide D'Orbigny, and Dris. Kneeland, Shurtleff and Bacon. The whole number of volumes in the library now numbered 1260, and of pamphlets and parts of volumes there were 120.

The Curntor of Mineralogy reported that of the specimens in his department eight humbed only were thought worthy of a place on the shelves of the new building, where they hat been depositent and clatsified. Mr. Francis Alger harl presented eighty valuable specimens to the collection, and others, costing fifty dollars, hat been procured by subscription.

The Curator of Ornithology reported that there had been presented eighty birds by various persons during the year, and that he was ready to give from his own collection one hundred more, as soon as funds could be had to mount them. A valuable collection of eggs had been received. The donors to this department during the year, were Major Townend, Mes.r. G. M. Dexter, E. C. Cabot, W. Sohier, Robbins and Ogden, and Drs. Shurtleff, Read, Abbot and Bethune. 
The Curator of Ichthyology reported that the collection of this department was not in good condition, owing to the losses produced by the ravages of insects and the means used to eradicate them. To Capt. N. E. Atwood the Society was indebted for several fine specimens, two of which were of genera new to the waters of Massachusetts.

The Reports upon other departments were too meagre of information to call for notice here.

The same board of officers was elected, except that Dr. S. L. Abbot was chosen Recording Secretary, Waldo I. Burnett Curator of Entomology, W. O. Ayres of Ichthyology, Dr. Jeffries Wyman of Herpetology, and Dr. Wm. Reed of Conchology.

The annual address was delivered by Dr. D. Humphreys Storer, and was a very interesting historical sketch of the origin and growth of the Society up to that period. Dr. Storer availed himself of the opportunity to acknowledge the indebtedness of the Society to its numerous friends and benefactors, who at all times had been ready with a liberal hand to supply its wants and promote its interests, until by a crowning act of munificence it had been furnished with a building in every respect suited to its wants. $\mathrm{He}$ urged with great eamestness upon the members the duty of making redoubled efforts in the canse of science.

This address, of which the record gives the above account, was listened to with great attention by a crowded audience. The thanks of the Society were voted to Dr. Storer for it, and he was asked to furnish a copy for publication. It is to be regretted that he neither did this nor preserved the original manuscript, as there was undoubtedly much in it of historical value.

From the time that the Society took possession of its new apartments there was an increased interest shown on the part of the members, both in attendanee upon its meetings and in work upon the collections. The room of meeting, that of the Library, ${ }^{1}$ was a cosy one, and in the aftemoons some of the Curators were generally to be found there engaged in the examination and study of specimens, or arranging them on tablets. Here the $\mathrm{Cu}$ rator of Botany might often, for years, have been found at work upon the Herlarimm, and the Curator of Geology, then emluracing Palaeontology, striving in vain perhaps to obtain some knowledge of fossils, of which little could be learned, for want of the necessary books.

1849. At the annual meeting this year, the figures given, showing the extent of the collections, are repeated here. Several of the Curators as usual, omit a statement. 'The department of Mineralogy had been increased by the athition of iste specimens, making the whole number now about 1450 . . Of those received, about 200 had been presented by Francis Alger, the remainder by several donors. The collection of insects was reported as containing 14,000 specimens comprising about 4,(100 species. J. M. Bethune, Esq., had presented 540 species from the vicinity of Boston, and Dr. T. W. Harris 670 species. Great pains had been taken to exclude Dermestes and Anthreni, and to repair the ravages already made by them. The collection of birds had been increased by several donations, and now numbered somewhat over a thousand specimens, effectually secured against the attacks of insects.

The department of Ichthyology had received donations from Dr. D. Humphreys

1 The use of the Library room was sometimes granted to members of the Society who wished to lecture. Mr.
Desor was thus permitted to occupy it two evenings in a week, for a course delivered by him in the fall of 1848 . 
Storer, Mrs. IBimney, Dr. II. B. Storer and others. 'The collection contained 260 species. all reported in good condition.

'The Library now contained 1320 volumes, and 213 pamphlets.

'The 'Treasurer's account showed a balance of cash in his hands of $\$ 124.98$, and an amount of $\$ 1100$ due from subscribers to the Building, not paid. There was yet due by the Society on account of the Building, debts to the amount of about \$4500.

'The changes among the officers this year, were in C. C. Sheafe being chosen Cabinet Keeper; Francis Alger being made Curator of Mineralogy, and Dr. S. Kneeland, Jx., of Comparative Anatomy.

This year a proposition was made by an Association called "A Republican Institution" to deposit the books possessed by it in our library, and to grant for the use of the Society one half of a fund belonging to the Institution, of over $\$ 2500$, for the purchase of such works upon Natural History as the Society might select, with the understanding that the other half should be expended upon works of History, Biography, Geography, Politics and Finance; and that the whole, together with other books now owned by them, should be placed in our library on deposit; provided that the members of the Association should have the same privileges in the use of the Socicty's library, as the members of the Socicty. This proposition was accepted, and the sum of $\$ 1300$ was placed in the hands of the 'Treasurer for purchase of books on natural history.

Another event very gratifying to the members occurred this year. This was the munificent donation of two thousand dollars, made by Mr. Jonathan Phillips of Boston. By this most timely and helpful act, the 'l'reasurer was enabled to pay the debts of the Society, and to have the satisfaction of reporting it free from all encumbrances.

Most heartily the Council passed a vote of thanks, which was conveyed to Mr. Phillips in a letter signed by the President and Secretary of the Society.

1850. In the early part of this year the Society was called upon to mourn the loss of one of the original members of the Society, Dr. Martin Gay. He was a man of learning, and ardently devoted to science and art; of strict integrity, and of singular purity of life and thought. Perhaps the writer of these pages can give no better idea of him than by repeating from the records of the Society, the words in which he gave utterance to his feelings upon the announcement of the sad event.

"With Dr. Gay I was indeed most intimate, and I express, therefore, what I know, when I claim for him a degree of virtue, a nobleness of purpose, an exaltation of character, far beyond what is generally found in man. Conscientious to a great degree, every deed performed by him, every judgment given, first received the sanction of the highest sentiments of his soul; and, long as I have known him, I never heard him express an impure thought. Loving God, and loving man, his desire was to enlarge his own being that he might the better serve both. Too great by nature and culture to confine his regard to those of a class, or a sect, all who sought his friendship and were worthy, found in him ready sympathy. The bickerings and the jealousies that trouble smaller men, never reached him; but yet he was always ready to advocate manfully the cause that appeared to him just. Without guile, transparent to all whose motives were kindred to his own, he inspired and enjoyed the confidence of the community. His attainments were of a high order. Love of the beautiful in nature and art, and in spirit, was a ruling trait of his 
character. A fine scene, a good painting, or a noble action, would alike kindle his enthusiastic admiration. In truth we have lost from amongst us a presence which sanctified communion by its purity; a wisdom which was more than that of this world; and a loving soul which we trust has found acceptance in the land of the pure and the holy. God help us, that we may be as ready as was our brother, to bid adieu to present scenes of action, when we are summoned hence to be no more here forever."

All that was thus expressed before the Society of the character of Dr. Gay was recognized as being true of him by his associates in the medical profession, and in other Societies of which he was a member; and by a large number of friends, among whom he was respected and beloved. Dr. Gay was born in Boston, Feb. 16, 1803, and received his education at Harvard College, being a member of the class of 1823. His attainments as a chemist were of a high order. Judge Shaw, in a tribute to his memory before the Academy of Arts and Sciences, of which he was a valued member, spoke of him as an adept in medical jurisprudence, and as having a peculiar faculty of rendering scientific principles and processes intelligible to a jury.

From annual reports of the Curators of the Museum, May 1, 1850, and of the other officers of the Society, may be learned, so far as these give particulars, statements of the conditions of the sereral departments. and what progeres hat been mate during the two decades now passed in the history of the Society. Unfortunately they are too brief to be entirely satisfactory.

The Ornithological department is mentioned as in good condition, fire from insects, and as improved by the substitution of many good, in place of bad specimens. The whole number reported in the Cabinet was given as 1207. In the Geologival department but little change was reported as having occurred through the year. It may be stated, therefore, that the collection at this time consisted of about 10010 specimens desirable for exhibition, and about 500 duplicates. The Curator of Ichthyology reportert the collection in his derpartment to be in good condition, but gave no figures. As there were reported at the previous annul meeting. 360 species, and a lare number of dontions hat been receired during the year, there were probably about 400 species.

The Curator of Entomology reported that there had been no material increase in his department, and stated that he thought it more an object to take care of and to systematically arange what specinens were already in the Cabinet, than to add to their number. It may be presumed from this that there were about as many specimens in the Cabinet as mentioned the previous year, viz: 14,000, comprising about 4000 species.

The Curator of Comparative Anatromy reported many valualle additions. among other's the entire skeleton of the Ianited then the only one in the country; with the stuffed skin also. This had been obtained and presented by the President. A fine skeleton of a male moose hard likewise been presented hy him and had been beatifully momnted hy Dr. Shurtleff: The number of specimens was not reported in this department, and as this had been the case for several years, no statement as to how many there were can be made.

The Curator of Mineralogy reported the accession of about 100 specimens to his department during the year, but made no mention of the entire number belonging to it. Adding those received since the previous annual meeting to those then reported in the 
Cabinet, and we have about 1550 specimens as comprising the whole collection at this time.

The Curator of Herpetology made no report beyond stating that the collection was in about the same condition as it had been for some time. The number of specimens cannot be stated, as the reports for several previous years are too meagre in detail. It will be remembered, however, that every species of reptile belonging to Iassachusetts, with possibly one exception, was reported in a previous year as in this department, in good condition.

The Librarian reported the whole number of books in the Library as 3500 , including about 300 deposited, these being the property of "A Republican Institution."

The Treasurer reported a balance due him on general account of \$746.19.' This occurred from causes not likely to happen again, arising from the removal, such as adding iron shutters to the building. As there was a balance at the same time to the credit of the Courtis fund account of $\$ 983.88$, the Society could not be regarded as in debt. The Treasurer was afterwards authorised to pay himself out of the income of that fund. Mr. J. Elliot Cabot was chosen Corresponding Secretary at this meeting, and Dr. N. B. Shurtleff, 'Treasurer. The other officers were re-elected for the ensuing year.

Notwithstanding the favorable character of the Reports of the Curators at the annual meeting, upon the condition of the collections under their charge, there must have been indications of evil; as at the meeting of the Council held after that of the Society, a Committee of three was appointed to check the ravages of insects, with power to notify the various Curators of their presence in the specimens under their charge, and if need be to adopt measures themselves to free the cases from them. This implies not only the opinion that harm was likely to result from insects, but some question whether the $\mathrm{Cu}$ rators could be relied upon to free the collections from them.

The annual address was not delivered until June 5. It was by the Rev. Zadock Thompson, of Burlington, Vermont, upon the natural history of that state, and was a very interesting and instructive discourse.

There were some facts mentioned by Mr. 'Teschemacher at the annual meeting which, considering the gereat excitement following the recent discovery of gold in California and the consequent results, were certainly surprising. These were, that in a work printed in London in 1s1s. Phillips' Leetures on Mincraloger. it is distinctly stated that gold is found in large lumps deposited a few inches below the surface of the soil throughout an extensive district bordering on the sea; that Mr. Ellis, thirty years ago (about 1820) obtained from this region a mass of native gold mixed with quartz; and that in $1839 \mathrm{Mr}$. Alfred Robinon sent to Boston from California s10.0100 worth of gold in large lumps. It seems strange in view of such evidence of the existence of gold in large quantities in the soil of California, that no action was taken to obtain it, and that the finding of it by Mr. Sutter in 1847 should have been regarded as a new discovery. Phillips probably had learned from Spanish priests what he stated.

In November Mr. Wm. Read, who had served the Society for over two years as Curator of Conchology, resigned, and in December Mr. William Stimpson was elected to this office. 
In reaching the end of the second decade of the existence of the Society, some mention will now be made of what has not been before presented, respecting the attendance of members at the meetings.

In the year ending Nay, 1841, the average number was about 11. For the year 1842, 12 , for the year 1843,10 , for the year 1844,11 , for the year 1845 , 11 , for the year 1846 , 9 , for the year 1847,11 , for the year 1848,18 , for the year 1849,18 , for the year 1850 , 25.

It should be borne in mind that meetings were held then in the summer months as well as at other seasons of the year, when very many of the members would be likely to be away from the city. 'The average attendance from this cause, was unavoidably less than it would have been if meetings had been omitted in the hot season. There were, however, very rarely more than from fifteen to twenty present until the building in Mason street was occupied by the Society. The average attendance then increased very much, as the figures show, and during the last year mentioned it had more than doubled that of any one of the first seven, and it was not uncommon to have present over thirty members. 'This increased attendance arose largely from the interest atded to the proceedings by the presence of such distinguished men as Agassiz, Desor, Wm. B. Rogers and others, who took an active part in them. Those whose names appear the most frequently as making communications at the meetings during the first five rears of the decade are Drs. Gould, Storer, Wyman, Cabot, S. L. Abbot, C. T. Jackson, J. B. S. Jackson, Binney, and Messrs. Teschemacher, Emeroon and Bouvé; during the last five rears Drs. Gould, Wyman, C. T. Jackson, Storer, Kneeland, J. B. S.. Jackion, Burnett. Bacon and Cabot; Profs. Aganiz and Rogers; Messrs. Teschemacher, Desor, J. D. Whitney, Ayres, Alger and Bouvé.

Addresses were made at the Annual Meetings of 1841, 1842, 1843, 1844, 1845, 1847, 1848 , and 1850.

Donations were made to the several departments frequently, but to less extent than during the first ten years. The collection of Herpstology was enriched by many specimens from Dr. F. W. Cragin of Surinam; that of Ornithology by many from Dr. Cragin also, and by some from Dr. G. A. Bethune; that of Entomology by insects from Dr. Savage of Cape Palmas; that of Mineralogy by ahout 200 fine specimens from Francis Alger; that of Comparative Anatomy by many anatomical preparations from Dr. Jeffries Wyman; and that of Icthyology loy fises from J. G. Anthony of Cincinnati, Dr. F. W. Cragin of Surinam, and Capt. N. E. Atwood of Provincetown.

The American Board of Commiswioners for Foreign Misions presented many shells and plants, and Dr. Morton, Rev. Mr. Bachman, Mr. Audubon and many other', presented books.

The increase of the Library during the ten years had been from about 600 volumes to upwards of 3000 .

The financial condition of the Society was not much better than at the commenecment of the decade. The ineome derived from assessments and from the funded property had sufficed for its ordinary expenditures, and there remained a small balance of cash in the Treasury. Yet its means remained far from adequate to provide for the necessary care and preservation of its collections. 
In 1S41, the Society commencerl publishing its Proceedings, and the first two rolumes with a large part of the third, had been issued before the annual meeting of 1850 .

The Journal of the Society was issued with some degree of regularity, gaining for it much reputation both at home and abroad, by the character of its articles. At the time of the annual meeting in 1850, five volumes had been published, all of them containing papers of great value. mamy of them elaborate treatises upon the natural productions of our own State, of which may be mentioned those on the Fishes and Reptiles of Massachusetts, by Dr. Storer; on the Lichens of New England, by Edward 'Iuckerman, Jr.; on the Mosses of Massachusetts, by John Lewis Ruscell; on the shells of Mcissachusetts, by Dr. Augustus A. Gould and by Joseph P. Couthouy; and on the Coleoptera of Maine and Massachusetts, by Dr. J. W. Randall.

The members of the Standing Committees of the Council during the ten years past, should be mentioned here, as on them devolved a great part of the business of the Society other than that performed in the Museum.

They were the Presidents, Geo. B. Emerson and Amos Bimey, Jr.; the Librarian, Charles K. Dillaway; the Treasurers, John Jas. Dixwell and Patrick T. Jackson, Jr.; with Drs. Harris, storer, Gould. Bateon, Kineeland, Abbot, Caloot, Wrman, Shurtleft, and Messrs. Epes S. Dixivell and 'Thos. Bulfinch.

Dr. Storer served on two of these Committees, viz., those of Publication and the Library during the whole period, and several of the others a great part of the time.

\section{Decade III. May 1850 - May 1860.}

1850. In June, a letter was received from the President of the Society, stating that he harl procured through the Anerican Minister at the Court of st. James, a donation from the Hon. East India Company of a complete suite of casts from the fossils of the Himalaya Mountains. These were received in the following November, and were placed in the Cabinet of the Society. There were in all forty-one specimens, mostly of Mammalia. The collection was found to be peculiarly rich in Pachydermata, especially mastodons and elephants. Of reptiles there were casts of several bones of a gigantic turtle. Upon motion made, the thanks of the Society were passed to the Hon. East India Company for the very valuable donation made by them, and also to the Hon. Abbot Lawrence, and to Sir John Richardson, for their kind offices in aiding the President to secure it.

1851. In January of this year, two very remarkable Indian children, a boy and a girl, dwarfs, were exhibited in Boston and other cities of the United States, under the name of the Aztec children. They were quite small, of nearly the same size, and having much vivacity, drew the attention of crowds to visit them. As it was elaimed that they belonged to a race of similar beings found in Central America, they became objects of scientific examination. Dr. J. Mason Warren, after studying their characteristics, read a paper in which were presented his conclusions respecting them, viz::

1. That these children are possessed of a very low degree of mental and physical organization, but are not idiots of the lowest grade.

2. 'That they probably originated from parents belonging to some of the mixed Indian tribes. 
3. That they do not belong to a race of dwarfs, because history teaches the truth of the doctrine of Geoffroy St. Hilaire, that dwarfs cannot perpetuate their kind.

'These children were subsequently brought before the Society, and being placed upon the table, the members sitting around, amused all by their interesting and lively movements. There was nothing disagreeable in their appearance or manners.

The views of Dr. Warren were fully corroborated by a letter received from Mr. E. G. Squier, respecting their origin.

At the ammal meeting the usual reports were made, the several departments being represented as in good condition. 'That of Ornithology had received valuable donations from Mrs. (x. II. Shaw, Dr. Ienry Bryant, Mr. J. C.. Leighton. Mr. Theodore Lrman and others; that of Geology from the Hon. East India Co., Dr. C. 'T. Jaskson, Messrs. Moses H. Perley and Alexander Vattemare; that of Ichthyology from Mr. Horatio R. Storer, Dr. Henry Bryant, and Dr. Samuel Kneeland, Jr.

The Report upon the department of Comparative Anatomy was unusually full, embracing what had not before been presented for several years. From it is learned that there were in the collection at this time, 73 complete skeletons, 17 human skulls, and 143 of animals, including birds; 85 jars of specimens in alcohol; and 25 stuffed skins.

The Treasurer reported the total receipts during year, \$2218.59, expenditures, $\$ 1714.54$, leaving a balance of $\$ 504.05$ in his hands.

'Ihe Librarian reported the addition to the library of 353 volumes, and 130 pamphlets, and that the whole number of volumes in the Library was 2569, including 59 copies of the Society's Journal, and 28 of the Proceedings; unbound volumes 1280 , including 80 Legislative reports on the natural history of the State; and about 500 pamphlets or parts of volumes. The number of volumes in circulation during the year was 506 .

The only change made at the annual election, was in the choice of Horatio $R$. Storer as Curator of Herpetology in place of Prof. Jeffries Wyman.

1852. The Reports of the Curators at the annual meeting in 1852, were brief, and excepting that mon the Crustacea and Radiata, presented but little of interest. The collection of that department was represented to have suffered very seriously from the attacks of insects. Almost all the specinens of Crustacea had been nutilated, limbs detached, and in some cases lost. Many very valuable species had been entirely destroyed. Of the Radiata the soft parts had been completely consumed.

The Treasurer reported a balance of $\$ 754.56$ in his hands. The Librarian, alluding to the fict that the Smithonian Institution at Washingron had made such arrangements as to enable the Society hereafter to transmit abroad, and to receive from foreign Societies, publications at little expense, recommended a more liberal exchange of our Journal and Proceedings, for the works of such Societies.

Before the election of officers, final action had been taken upon a proposer amendment to the Constitution, by which the number of Curators was no longer limited. In July of the previous year, Dr. Thomas M. Brewer had been placed in charge of the nests and eggs of birds, and Mr. W. O. Ayres of the Crustacea and Radiata of the Society, aud at this election these gentlemen were made Curators of the two departments respectively. 
There had been in Feb. 1841, a department established, embracing the collections of Crustacea and Radiata, and] Dr. Amos Binney, Jr., had had charge of it for several months, when it appears to have been discontinued. Other changes at the election were as follows:

Mr. Charles Stodder succeeded Mr. Chas. C. Sheafe as Cabinet keeper. Mr. Charles J. Sprague was chosen Curator of Botany in place of Mr. Jas. E. Teschemacher, and Dr. Silas Durkee, who had been the previous July elected Curator of Ichthyology in room of Mr. W. O. Ayres, was rechosen for this position.

At a meeting of the Council in November of this year, Dr. Storer, as a Sub-committee of the Boston Society for Mediral Inprovennent. (hosen to airl D). C. E. Brown-réfuard in his arrangements for delivering a course of lectures on Physiology, submitted a proposition that the Society be advised to allow the use of the library room for such lectures. He

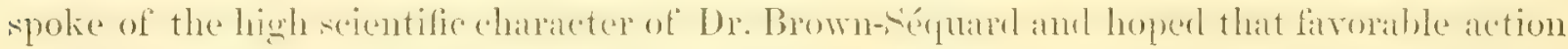
might be taken upon the proposition. Dr. Storer mentioned that the lectures would be illustrated by vivisections, and that these being very repugnant to his feelings he could not witness them, but yet on account of the addition to human knowledge which might result, he should favor the proposed action of the Council. Strong opposition was manifested by a number of the members of the Council, particularly Dr. Kneeland, Mr. Bouvé, Mr. Dillaway and Dr. Abbot. The subject was finally disposed of by a vote declining to lay the matter before the Society, on the ground that there was a restriction in the deed of their estate forbidding the use of their building for anatomical purposes.

1853. In February of this year the Society took action in favor of the prosecution of a geological survey of Oregon and Nebraska, by passing strong resolutions and transmitting them to Congress, recommending the necessary appropriations.

At the annual meeting the Curator of Botany reported great improvement in the collection during the year. The previous May only a small proportion of the specimens had been systematically arranged. Large bundles of plants from France, Italy, the Vosges mountains, the Cape of Good Hope, Florida and Kentucky, were in the same condition as when received. These had all been examined and provided with sheets of paper during the year.

'There had also been valuable donations, one from the I Historical Society, of a large number of plants procured many years ago by the Hon. Thos. H. Perkins. A package of New England plants collected hy the late Willian (bikes. particularly rich in White Iountain specimens, had been purchased by the Society. The Curntor had obtained over a hundred sperimens of plants growing in the Botunic Garden. Cambridge, through the kindness of Prof. Gray, many of them being new and umpublished species from Texas and New Mexico. The entire Herbarium had been revised and sheets provided for all the plants. The grenera had been placed in mimilla paper and arranged upon the shelves according to Endlicher's Genera Plantarmm. The Iferbarimm contaned representatives of I:300 generat and five or six thousand species. The Curator remarked that not being able himself to collect specimens away from the immediate neighborhood, he would be glad to receive the assistance of those who could, particularly in obtaining New England species.

'The report of the Curator of Botany was noticeable as showing an immense amount of 
work done in one year upon the Herbarium; work, too, that was not only desirable in order to make the collection useful, but absolutely necessary to prevent its destruction. It was the first of a series of years during which Mr. Charles J. Sprague devoted almost all his leisure afternoons and holidays to bringing order out of disorder, with the view of making available many thousand species before inaccessible to examination, and of preserving the plants and increasing the collection.

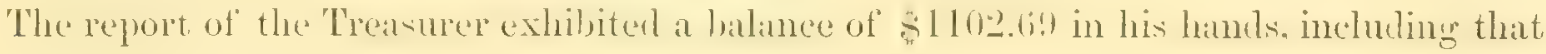
belonging to the Courtis fund.

Upon the election of officers Dr. J. B. S. Jackson was chosen Curator of Crustacea and Radiata, in place of Mr. W. O. Ayres, and Mr. 'T. J. Whittemore, Curator of Conchology, in place of Mr. William Stimpson.

At this meeting a motion was made by Mr. Bouvé and adopted, that a committee be appointed to take measures, if decided expedient by them, for the purchase of the collection of Ornithichnites, so callerl, belomging to the estate of the late Mr. Marsh, of (ireenfield.

The committee, consisting of Mr. James. M. Barnard, Mr. Francis Alger, Dr. Brewer and Mr. Bonve, feeting the great importance of securing for the society the collection soon to he disposer of at auction. ohtained by subscription a considerathle sum towards its purchase, and detailed two of their number, Mr. Alger and Mr. Bouvé, to be present at the sale. They attenterl and homght a lange part of the whole for about situm. Thus the society became the possessor of several of the large and valuable slabs covered with footprints, which now adorn the entrance hall of the Museum, and of many other specimens contained in the Cabinet. One of these, Prof. Hitchcock of Amherst College pronounced the best and largest slab of fossil footprints ever found, or that in his opinion ever would be found.

The President had prepared an address for the annual meeting, but was prevented by ill health from delivering it. It was, however, subsequently printed and distributed. In it was given an account of the early efforts made in Boston to encourage the study of natural history, which finally culminated in the formation of the Boston Society of Natural Ilistory. As there had been no previous annual address since 1850, a statement was appended giving an account of the proceedings of the Society during the three years since that date.

In November, by invitation, President Hitchcock of Amherst College addressed the Society, giving some of the results of his examinations in the Connecticut Valley. His remarks were replete with interest and instruction, and were followed by some on the same subject by Prof. Henry D. Rogers. 'The views presented may be found in the published Proceedings.

In December of this year, the death of Mr. James E. Teschemacher, long an active and very useful member of the Society, was announced, and the President was requested to draw up such resolutions in reference to this event, as should be judged proper by him. In accordance with this request, he presented at the next succeeding meeting, a notice of his life and writings, much of which is given here as follows:

"Our Society has experienced a great loss in the death of Mr. Teschemacher, one of its most valuable members, and we must turn aside a moment from the path of science to pay a tribute to his memory. This gentleman, who joined our Society in the year 1835, and has since that time been an able associate in our labors, and a large contributor to 
the advancement of science in our country, has suddenly terminated his mortal career at the age of sixty-three, from a disease of the heart."

'These remarks were followed by resolutions, one of which expresses "That a record be made in our transactions of the high estimation in which we hold the private qualities and scientific labors of Mr. 'Teschemacher, as manifested in his excellent papers on botany, mineralogy, some departments of geology, and particularly in his able and practical investigations of the carboniferous formations. We also regard his productions in the composition and improvement of soils, as a valuable and permanent contribution to the agriculture of the country."

A brief notice of Mr. 'Teschemacher was then read, and is here given.

"James Engelbert 'Teschemacher, of Hanoverian extraction on the paternal side, was born in Nottingham, England, on the 11th of June, 1790. At the age of fourteen he commenced his commercial career in a mercantile foreign house of eminence in London, where he evinced application and business talents of a high order; and amid the extensive transactions of mercantile life, in which during a long series of years, he was engaged, his fine comprehensive mind ever remained umshackled by any of the less elevating habits sometimes contracted in commercial pursuits. At an early period of his life he imbibed a taste for studying out of Nature's beautiful book, thus acquiring that purity and love of truth, so constantly pervading all his thoughts and writings. In the year 1830, Mr. Teschemacher accepted the offer of a partnership in a house of considerable

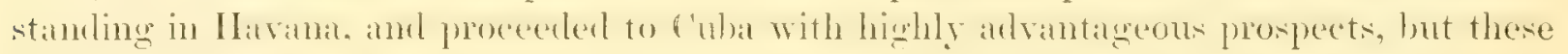
faded on his approach, and he returned to England. After a short time, he made up his mind to repair to the United States with his family, reaching New York Feb. 7, 1832. He finally settled in Boston, where during the space of twenty-two years he was unremitting in his exertions for his family. Of his untiring zeal and devotion to science, we need not speak; his hours of leisure, it may naturally be inferred, were few, but those few were einployed (apparently as a recreation) in the severe branches of study which frequently form the labor of a life, even with those who make science their occupation. 'Iruly may he be said to have improved the talents committed to his charge."

'To what was said of Mr.'T'eschemacher at the meeting, may be added that he was engaged daily in active business through all the years of his connection with the Society, but yet found time to do considerable work for it while Curator of Botany. In order to secure time for this, he was accustomed to visit the rooms of the Society, after an early breakfast, and stay until business required his presence perhaps an hour later. 'The published Proceedings of the Society attest to his interest in the meetings, and the character of the communications made by him to the value of his observations, and to the extent of his scientific knowledge. He was an excellent mineralogist, a good botanist, and a very accurate observer in both fields. One could not very well be a more careful and painstaking investigator. Had he been able to devote more time to scientific pursuits, he would undoubtedly have accomplished much more than he did in this direction, as he lacked neither ability, industry nor perseverance.

Besides papers to be found in the printed Proceedings of the Society and in its Journal, several addresses by him were published. One before the Society at its annual meeting in 1841, one before the IIorticultural suciety, and one before the IIrvard Natural History Society. 
1854. A vote passed by the Society in March of this year, shows that the members were already indulging the hope of yet better accommodations than those of the structure so recently purchased and adapted for their use. A thousand dollars having been received from the estate of the late Hon. 'Ihos. H. Perkins, subseribed by him towards the building now occupied by the Society, but not so appropriated, it was ordered that this sum be invested by the 'Treasurer as a commencement of a fund to be called the Building Fund, and that the income from it be aunually added to the principal.

The Society had an opportunity at this time to perform a graceful act in helping their unfortunate brethere of the Portland Society of Satural I Tistory, which had lately lost the whole of its valuable collection by fire. A vote was passed, that a complete set of the Jomrnal of the society be presented to the Portland Fociety, and another, that a series of duplicate shells belongmy to this society, be presenterl to the Portand society, whenever they are prepared to select and receive them.

It is sad to know that by a second great fire a few years afterwards, the recip ents of these donations again lost their entire collection.

At the annual meeting the lieports of the Curators were quite satisfictory, thongh the donations through the year were not numerous.

The Botanical department had received some additions of value from Prof. Asa Gray, Mr. B. F. Kendall and the Curator. 'These, with others obtained by exchange, had added about 800 specimens to the collection.

The department of Oojlogy was reported as now having about 240 specimens of eggs, belonging to 165 species.

The department of Geology had been enriched by the splendid collection of the Footmarks of Animals upon the Red Sandstone of the Comecticut Valley, obtained by purchase, and by the donation to it of a series of Silurian fossils.

The Curator of Herpetology reported that this department now contained about 480

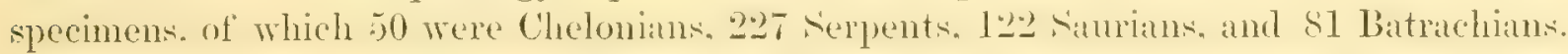

The Librarian reported a considerable increase of bound volumes and pamphlets. Among the most valuable works presented to the Society was the splendid one by Geoftroy sit. Ililaire and Cuvier, entitled " Ifistoire Naturelle des Mammiferes," three volumes finely bound, from the Hon. Francis C. Gray.

Upon the election of officers for the ensuing year, Dr. Samuel L. Abbot was chosen Corresponding Secretary in place of Mr. J. Elliot Cabot; Dr. Benj. S. Fhaw, Fiecording Secretary, in place of Dr. Samuel L. Abbot; Dr. Henry Bryant, Curator of Ornithology, in place of Dr. Samuel Cabot, Jr.; Dr. Jeflies Myman, Curator of Herpetology, in place of Dr. Horatio R. Storer.

This year the Society lost one of its most useful and active members, and science one of its most ardent votaries, in the death of Dr. Waldo Irving Burnett. To characterize his ability as wonderful. and his achierements as extraorlinary, is to speak morlerately of one who in the short life allotterl him had manifested such knowledere, and accomplished so much in scientific research. To express all concerning him that his memory deserves, would require too much space for this volume; but the reader who may desire to learn more than is here presented, will find a full and delightful tribute to his worth and ser- 
vices, prepared at the request of the Society, by Dr. Jeffries Wyman, and published in the fifth volume of its Proceedings. What follows is but a brief abstract of this paper.

Waldo Irving. Burnett was born in Southboro', Mass., July 12, 1828. He early manifested a strong love of study, and became so much absorbed in that of insect life as to cause a fear on the part of his father, who was a distinguished plyysician, that his health would suffer, and he was therefore subjected to some restraint. 'The passion for investigation was, however, too strong to be more than temporaxily checked. His mental activity was remarkable, enabling him to master all the studies of the academy where he was placed, with ease. In mathematics he became so efficient as to lead the teacher to confess that he was no longer able to instruct him. Later he became familiar with the French, Spanish and German languages, and had made progress in the Swedish.

At sixteen years of age he manifested a strong inclination to learn the nature of things, and became interested in all that claimed to give an explanation of the phenomena witnessed about him. He had, young as he was, commenced the study of medicine with his father, accompanying him on professional visits and being present at examinations of bodies after death. His father died when he was of the age mentioned, and he afterwards sturlied with Dr. Joseph sarecent of Woreester. in the 'Tremont Merlical sichool of Boston, and in the Massachusetts General IIospital. He did not receive a collegiate education.

In 1849, at the age of twenty-one, lie graduated in medicine, and soon after visited Europe, where he spent much of his time in attention to natural history and microscopic observations. There the symptoms of disease manifested themselves, and he returned to the United States with the hope that the climate of the more southern portion would be beneficial. For several years he was obliged by increasing illness to pass his winters in the South, but wherever he was he kept incessantly at work, accomplishing more than it would be possible for many well men to do, in investigation with the microscope; in writing the results of his investigations; and in giving lectures on microscopic anatomy.

While a medical student he became an active nember of our Society, and soon after Curator of Entomology. He also was admitted at the carly age of twenty-three to the American Academy of Arts and Sciences.

His communications to different scientific bodies and journals, considering the circumstances of his waning health and frequent travel, were astonishingly numerous and manifested a degree of activity, mental and bodily, that few could exert. Many of these communications may be found in the Journal and in the Proceedings of the Society.

To a speculative and inquiring mind like that of Dr. Burnett's, there would of necessity arise questions of perplexing character involved in the problem of life, and doubts did arise of a disturbing nature, which however, were afterwarls replaced by a settled and firm conviction, that if there was much to live for, and no man valued life more, there was still more to die for. He passed away on July 1, shortly before he completed his twentysixth year.

Resolutions, expressive of the great loss the Society had sustained by his death, and of condolence with his family, were passed by the Society.

At a meeting of the Council in November, the Cabinet keeper exhibited several cases of insects destroyed by the pests that finally caused the great loss of nearly all the valuable collection. 
1855. In the doings of the annual meeting this year, we find some evidence to show that the lack of proper accommodation for specimens was already felt in the building so joyously taken possession of scarcely eight years before. It was not entirely from want of sufficient room, but partly from the fict that there was more need of air and sunlight for the best good of the Museum. 'I'he Curator of Comparative Anatomy mentioned that the collections in his department had been injured by dampness in the cases. This evil he ascribed to the external circumstances of the building, for which there seemed no remedy so long as it should be screened from the light and heat of the sum, and from free ventilation.

The ('untor of Omithology reported some domations to his department, the principal of which were 41 specimens from Dr. F. J. Bumstead, 11 from Mr. C. J. F. Binney, 10 from Mr. E. Samuels and 8 from Mr. 'Thure Kumlein. He mentioned that he had commenced a catalogue of the specimens, but from the limited number of the books of reference feared he would not be able to perfect it.

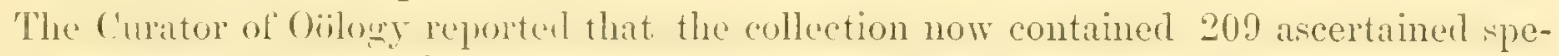
cies, 16 of which had been added during the year.

The Curator of Botany stated that the collection under his charge was in excellent condition and that several humberl spereies of native and foreign plants had been adderl to the collection during the year, some of the most valuable of which came from I. A. Lapham, Esq., of Wisconsin, and from Prof. Gray.

Several of the Curators made no reports.

The Librarian gave the whole number of books now possessed by the Society, as about 3500. He complained that books were frequently taken away from the library in his absence, sometimes without entering them in the record book, and though these were generally returned, there had been some loss. He did not know where to look for the property. He also stated that since the erection of the new theatre next to our building, the room hat become dark and damp, uncomfortahle to those occupying it, and injurious to the books. He thought if there was no prospect of having a new building, the interests of the society would require better accommodations for its hooks, and for those using them. Some alterations were subsequently made by placing windows where none were before, which considerably improved the room.

The 'Treasurer reported receipts from all sources, \$1,950.39; expenditures \$1,65-.18, leaving a cash balance in his hands of \$298.21.

At the election of officers, Dr. Jeffries Wyman was chosen Curator of Comparative Anatomy and Mammals, in place of Dr. Sammel Kneeland, Jr.; Dr. J. P. Reynolds, (urator of Crustacea and Radiata, in place of Dr. J. B. S. Jackson; Dr. J. Nelson Borland, Curator of IIerpetology, in place of Dr. Jeffries Wyman; and Dr. II. K. Oliver, Jr., Curator of Entomology, in place of Dr. Waldo I. Burnett, deceased.

At a meeting of the Council there was an appropriation made of $\$ 100$ for a Card Catalogue of the books and pamphlets, none laving been provided previously.

In the death of Mr. James Brown, which occurred in March of this year, the Society lost one of its best friends and patrons, one to whose memory is due some notice of his life and character. He was born in Acton, Mass., in 1800, and when a young man was poor, but highly respected for his industry and fidelity. He began business as a pub- 
lisher of books in Cambridge, but not long afterwards became an active partner in the firm of Little \& Brown, in Boston, a house which soon became well known all over the country for its publications, and for its high character. The business was very successful, and by it Mr. Brown became possessed of considerable wealth, through which he was enabled to gratify his taste, and to contribute much to the welfare of others. He keenly enjoyed the beatiful in Nature, and berame much interested in the stuly of Ornithology, in which department of natural history he possessed a valuable library.

He bequeathed to the Society this library, or the most valuable part of it, and through this bequest it became the owner of the works most wanted, which could not otherwise perhalps, have heen obtained, their cost heing probably not less than \$2000. Mr. Dillaway, the librarian. mate some remarks when amouncing this valuable acession to the library, and of which part are here given. He said, "This is not the first time we have been indebted to the liberality of Mr. Brown. On many occasions his purse and his influence have been freely offered in aid of our efforts for the promotion of natural science. In the list of on patrons, numbering eighty of the most liberal and public spirited citizens of Boston, his name now stands among the first. As my acquaintance with him has been a long one, commencing at a time when his whole property could not have purchased one of the volumes he has bequeathed to us-when industry, integrity and a generous heart were all his capital, and reaching to a period when he was able and willing to give his thousands to the promotion of literary, scientific and charitable objects, I may be permitted to exmess a belief that Boston has lost a citizen of whom she han good reason to be proud, and our Society a valued filend, whose memory we shall ever hold in honor.'

The Society appointed a committee to prepare resolutions suitable for the occasion, which were presented and adopted at a subsequent meeting. A vote of thanks was also passed to Mrs. Brown, for her grenerous donation of a portrait of the distinguisled Naturalist, 'I'hos. Nuttall.

1856. In February of this year, it was announced that the Society had lost by death, two of its oldest and nost highly esteemed nembers, Dr. Thaddeus W. Harris of Cambridge, and the Rer. Zarlock Thompson of Burlington, Vt. Their services to the Society and to science generally merit notice in these pages, and this will be grven by reporting the action taken at the meetings following the announcement.

Prof. Jeffries Wyman, in behalf of a Committee appointed to prepare resolutions expressive of the loss the Society had sustained in the death of their late member, Dr. Thaddeus William IIarris of Cambritge, offered the following, which were unanimously adopted:-

"Resolverl, That the members of the Boston Society of Natural History have leaned with deep regret, the death of their late asoociate, Dr. Thardeus William IIaris. That in lis death, the Society has lost one of its earliest and most respected member's, science a fuithful and zealous student as well as a conscientious observer, the results of whose lahors have enimently contributed to the extension of the knowledge of natural history; and have reflected dignity and honor upon American science.

"Resoleed, That the members of this Society sympathize with his fimily in the loss they have sustained in his death." 
Prof. Wyman in presenting the resolutions, referred to Dr. IIaris's wide reputation ats a naturalist at home and abroad, and to his scientific labors. He spoke of his researches as chiefly confined to entomology, though he had an extensive knowledge of other departments of natural history, especially botany. As an entomologist he ranked amonge those. comparatively few in mumber. Who with a strong linowledere of clasification, combined the faculty of correctly observing and accurately recording the habits of insects. His very valuable report to the Legislature of Massachusetts on Insects injurious to Vegetation, is an admirable testimonial of his industry and patience, his powers of observation, and his happy manner of portraying the subject of his thoughts. At the time of his death he was engaged in an investigation of the origin of some of the cultivated plants, and their subsequent distribution by human agency over the world.

In relation to the Rer. Zarlock 'Thompson, Prof. Wm. B. Rogers adrlesterd the meeting. speaking of him as a thorough and persevering worker in groologr and as posessing a large amount of accurate practical knowledge on the subject.

Dr. Samuel Kneeland read a sketch of Mr. 'Thompson's life, of which the following is an abstract. He was born in Bridgewater, Vt., in 1796, and at an early period showed a strong propensity for observing facts in natural science, and for mathematical applications. He graduated at the University of Vermont in 1823, and afterwards was occasionally occupied as a teacher. His chief lahors were those of independent investigations into the resources of his native state. He wrote the History of Vermont, and thereby became extensively and honombly known. In 1s.j.; he was appointerl State Naturilist, making it his duty to study its physical geography, geology, mineralogy, botany and zoology. On this work he entered with zeal, and had far advanced towards its completion, when his labors were closed by death.

IIr. Thompson delivered the anmual address before the Boston Society of Natural IIistory, in June, 1850, on the Geology of Vermont. He made several communications to the suciety. and through his instrumentality momy specimens were adeled to the Cabinet.

In view of these facts it seemed proper that the Society should take special notice of his death. Dr. Kneeland, therefore after his remarks, moved the following resolution, which was unanimously adopted:

"Resolved: That in the death of the Rev. Zadock Thompson, the Boston Society of Nitural Ifistory has lost a valuen friend, a distinguished member, and a sincere and truthful co-worker in the various departments of natural science."

It is certainly not a little singular that the next event to be dwelt upon here is the death of the venerable President of the Society, which occurred on the 4 th of May. Upon the 5th, a special meeting of the fociety was called to talie measures appropriate to the occasion, and a committee was appointed to prepare resolutions. It was also voted to attend the funeral of the late President, and to meet at the rooms of the Society for that purpose, on the morning of the 7 th inst.

At the annual meeting, May 7th, Dr. Chas. T. Jackson, Vice-President, in the Chair, Dr. D. II. Storer, on behalf of the committee appointed to prepare a series of resolutions expresive of the deep sense of regret which the Society experienced in its recent hereavement, rear the following report, which together with the resolutions, was adopted. 
Mr. President and Gentlemen : - We are again called upon to mourn; we meet here to sympathize in our common sorrow. Science has lost a true friend; her votaries, we would reverently bow to the stroke, while we deeply feel and gratefully acknowledge the goodness which so long averted the blow. IIe, who for the nine years has presided over this institution with paternal solicitude-who has performed every duty devolving upon him with the greatest cheerfulness, with unsurpassed fidelity-who with the enthusiasm of youth, would not allow the most inclement night of the last most inclement season to prevent his attendance at your meetings-but who was ever here to encourage you by his presence to increased exertion-has accomplished his work. IIe has left us forever.

Ile needs no fulsome eulogy. His claims upon the respectful and lasting remembrance of his professional brethren have already, elsewhere, been most eloquently portrayed. The debt we owe his memory can never be repaid; but, as naturalists, that debt we should recognize.

Upon the death of Dr. Amos Binney, our much loved President, Dr. Warren was selected to succeed him. From the day of his appointment his interest never flagged, but increased with his advancing years.

His first great desire was to see our valuable collection displayed in a more safe and commodious building-to accomplish which his efforts were indefatigable. A large portion of the means required to purchase our present accommodations, was procured directly by him, and but for the influence he was enabled to exert in his social relations, we could hardly have succeeded in our attempt.

Dr. Warren's labors were principally directed to the great object of exciting and keeping alive a taste for natural history, by constantly presenting its wonders to such minds as he thought susceptible of being thus influenced.

He delighted to gather around him those whose tastes were congenial — to enjoy with such the beauties of his country seat - to extend its hospitalities. How many of us have been made the happier by his yearly festival!

He has, however, done more than this. Three years since he prepared an address, which was published, presenting a histury of the rociety from its foundation. He became exceedingly interested in palneontology - he exerted himself to assist in procuring the magnificent lahs, contaning the ornithichnites from the Connectieut River, which ornament our vestibule. He also made a most valuable private collection of these footprints, and two years ago described some of the most striking of them in a small volume, with the title, "Remarks on some Fossil Impressions in the Sandstone Rocks of Connecticut River." At a great expense he purchased the most perfect skeleton of the Mastodon giganteus now known to exist; and his elaborate work upon that subject will ever remain a monument to his zeal, his industry, his munificence.

Just previous to his decease, he had prepared a paper on the animal of the Argonauta, all the available species of which genus he had collected, described and figured. This memoir he had completed, the last page of manuscript having been corrected by him within a week of his death.

This was his last labor - his dying legacy to science. Let us cherish his memory; and upon this occasion, upon this altar, renew our devotion. 


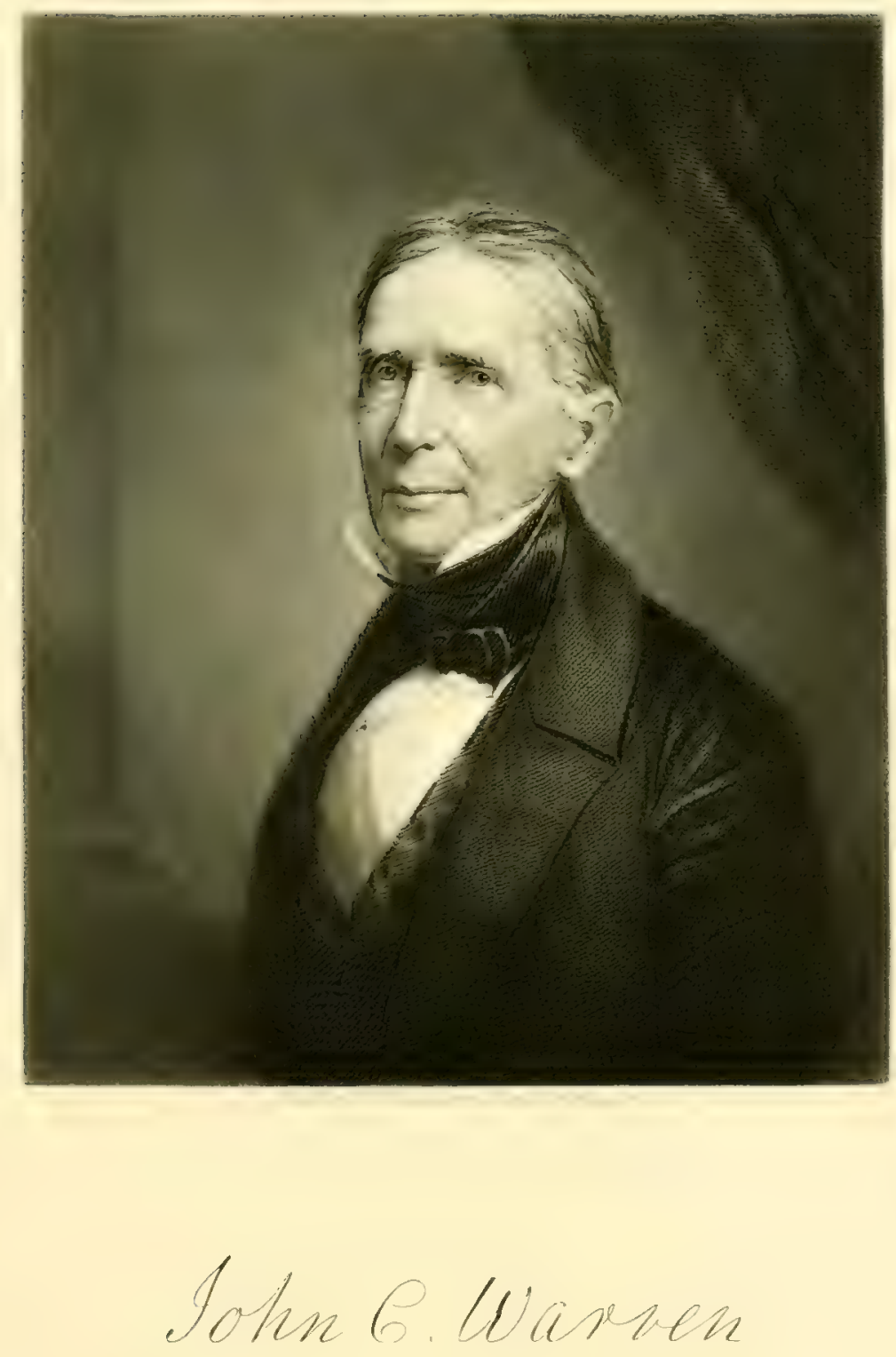



In compliance with the rluty devolving upon us, we would present the following resoletions:

Resolved, That in the sudden bereavement which has befallen our Society, we would not suppress the grief so deeply felt. For the long-continued, unwearied interest manifesterl by our late President in our prosuerity; for the realiness, the liberality with which he seconded every effort for our advancement; for the uniform courtesy with which he presided over our assemblages, and the kind-heartedness often evinced there; for his anxious desire to see around him a band of hothers engaged in the same emnobling pursuits, actuated by the same spirit, aming at the same end, we shall ever with gratitude remember him.

Riesoled, That some member of the Society be appointed to prepare a liographical sketch of our late President, to be presented to the Society at a future meeting.

Resolved, That our deep sympathy be extended to his afllicted family.

Prof. Jeffries Wyman was chosen in conformity with the recommendation of the committee, to prepare a biographical memoir of the late President. The Society then adjourned, out of respect to the memory of the deceased.

Dr. Wyman, in accordance with the wishes of the Society, prepared a very full biographical memoir of Dr. Warren, which was read by him at the meeting of Dec. 17, and which may be found in the published Proceeding's, Tolume VI. A list of Dr. Warren's scientific writings is appended.

At the adjomrned amual meeting held Maly 21st, the Curator of Ornithology called attention to a magnificent donation of birds from the Govermment IIseum of Natural Iistory, at Victoria. Among then were one hundred species or more, not previously in the Muscum. Other valuable donations had also been received from Dr. Samuel Knecland, Jr., Mr. Geo. S. Shaw of Cambridge, and Mr. E. Samuels.

The Botanical department had received from Prof. Asa Gray several hundred South European plants.

The Geological Cabinet had been the recipient of a fine series of Eocene shells from the Paris basin, presented by Geo. B. Emerson, Esq.

The Curator of Comparative Anatomy mentioned several valuable donations from Dr. J. V. C. Sinith, Geo. B. Eneron, Esq., and Dr. S. Kneeland, Jr. He called attention to the fict that specimens under his charge were injured from year to year, in consequence of the increased dampness and other unsuitable conditions of the building.

The Librarian reported that a card catalogue had been prepared for the use of the Library.

The officers for the ensuing year were then elected, with the exception of the President.

Dr. Jolın Bacon was chosen Curator of Mineralogy, in place of Mr. Francis Alger; Dr. Samuel Kneeland, Jr., Curator of Ichthyology, in place of Dr. Silas Durliee; and Dr. Silas Durkee, Curator of Entomology, in place of Dr. H. K. Oliver, Jr.

A Committee consisting of Dr. A. A. Gould, Prof. Jeffries Wyman, Dr. Samuel Cabot, Dr. N. B. Shurtleff, and Mr. C. J. Sprague were appointed to nominate a cancliclate for the office of President. This committee at the next meeting were further instructed to report the names of two or more persons as candidates.

At a meeting held on the 18 th of June, the Committee on nomination made a report which is not given in the records. 
The Society proceeded to vote, and upon collecting the ballots it was found that Prof. Jeffries Wyman was unanimously elected President. With his usual modesty he hesitated to accept the position tendered, doubting his ability to serve the Society satisfactorily as President. 'This led to an emphatic expression of feeling on the part of the members in favor of his accepting the office. He still hesitated, and finally begged the Society to give him time for consideration, which was granted.

At the next meeting, July 2d, Prof. Wyman announced his acceptance of the office of President, and entered upon its duties.

The first and the only excursion that the Society ever made as such, took place this year. A committee was appointed to consider the subject of summer excursions, of which Mr. Bouvé was chairman. In behalf of the committee he reported in favor of the plan, and proposed that the first one should be made to Hingham and the neighboring country. It was voted to assemble on board the Hingham Steamboat at 9 A. M., on Wednesday, July 23d, and it was understood that the Committee would make arrangements for proper conveyances at Hingham when the company should arrive.

Accordingly the Society met on board the boat at the time appointed. The day was beatiful and everything conspired to make it an agreeable and instructive one to the members. Upon landing at Hingham they were conveyed to Nantasket Beach in carriages, stopping on the way to examine a colony of night herons in the woods, and many trunks of submerged trees buried in salt water peat, which had become exposed by excavations. This grave rise to much conversation upon the breaking away of the barrier which had formerly kept the ocean back from this tract of land, and the consequent destruction of the forest. The next interesting locality was the site of an Indian cemetery near Nastasket Beach. Here the President, who had previously with his brother and Mr. Francis Boyd, had an opportunity of examining some of the graves, gave an account of what had been found there, which was quite interesting. Mr. Boyd, who resided near, invited the members to his house, where he showed them such relics as were in his possession from the cemetery, and also regaled them with a generous entertainment. After riding on the beach, the carriages were sent round to the Cohasset shore, and the members, wandering along the margin of the sea and climbing over the rocks, collected such specimens of shells, fish and marine plants as they met with, listening meanwhile to the remarks of such as were conversant with the objects found. Dr. David F. Weinland particularly called attention to the ovaries of the whiting, in which were eggs in process of embryonic development.

Upon again resuming seats in the carriages, a pleasant drive along the ridge road followed, with a stop to view the great trap drke which there protrucles through the granite rock. Here remarks were made upon the dyke and the enclosing rock, by Dr. Jackson, Mr. Alger and Mr. Bonvé.

After a further very interesting drive, the company arrived at the house of Mr. Bouvé at about 3 P. M., where they examined his mineralogical cabinet, listening to some explanations respecting the specimens, made by Dr. C. T. Jackson and himself.

Dimner followed; this having been partaken of with much hilarity, the members separated, some going into the woods to collect specimens, while the larger portion assembled under a grove near the house to listen to some scientific remarks upon what har becen seen during the morning. and other matters. This proved to be a very interesting gath- 
ering. Prof. Wyman gave an account of the horse shoe (Limulus), and the way in which it casts its shell. Mr. Francis Alger spoke upon the great Beryl formation in Grafton, N. II., and Dr. Jackson, upon the geology of the hill where the Beryls are found. Dr. Jackson then gave an account of trap dykes, as illustrated by what had been scen by them in the course of the excursion on the coast. Dr. Weinland gave an account of the reproduction of parasitic animals, and Mr. Charles J. Sprague exhibited and talked upon a parasitic fungus growing upon the body of a beetle.

Informal, but interesting and instructive conversation followed. The members then passed votes of thanks to those who had been instrumental in enabling them to pass the day so agreeably, and proceeded to take cars for Boston from the station only a few hundred feet distant.

Of course it has not been possible to make any reference to the many valuable papers brought forward and read at the meetings of the Society. To have mentioned even briefly the most important of them would have required that volumes should have been devoted to this historical sketch, where only pages are given. Moreover these may all be found in the Journal, or the printed Proceedings of the Society. When, however, an important discovery is montioned as having been made in our immediate neighborhood, it seems well not to omit notice of it.

Of this character certainly was the discovery of 'Trilobites in the slates of Braintree, scarcely a dozen miles from Boston. This was announced by Prof. Wm. B. Rogers, in August of this year, and specimens were exhibited. This afforded the first satisfactory evidence yet presented of the geological age of the stratified rocks of eastern Missachusetts.

A letter was received in November from Mrs. M. A. Isinney, tendering a portion of the library of the late Dr. Amos Binney for deposit with the books of the Society, upon certain conditions not objectionable. It was voted to receive them, and present the thanks of the Society to Mrs. Binney for the kind interest manifested by her in making the proposal. The number of rorks thus deposited were 35:3, and the number of volumes, including pamphlets, 1145. This accession to the library was of very great service to the members, the works deposited being many of them of great ralue for investigation, and not otherwise to be had by them.

1857. Early this year the Society lost from among its corresponding members no less than three, distinguished for their scientific attainments, viz.: Prof. J. W. Bailey, of West Point; William C. Redfeld of New York, and Prof. Michael Tuomey of Alabama. Resolutions expresive of the great loss that seience had sustained by their death, were pasied by the Society, introduced by remarks concerning their lives and labors. From Prof. Bailey a bequest was received of great value, consisting of his microscopic collection, and of a collection of Algae, with a great deal of material for microscopic research. Also a great many works upon microscopy, botany and histology. These embraced Ehrenberg's Mikrogeologie, Lindley and Hutton's Fossil Flora, and others of great value. The bequest was upon the condition that the collection should be kept in cases by themselves, and that the sons of Prof. Bailey should have such access to them for study or examination, as might be consistent with the rules of the Society.

At the annual meeting, the reports of the 'l'reasurer, Librarian and Curators were presented, and the substance of them is here briefly given. 
The Report of the Treastrer was very unsatisfactory, showing an amount due him of $\$ 1726$, largely arising from the fact that collections from members of the annual assessments had not been made, as they should have been. The Trustees of the Courtis

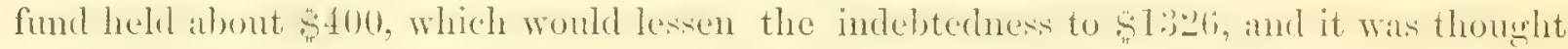
that $\$ 900$ might be realized from members who owed much more than this, but some of whom had not been called upon for several years. 'This would still leave an amount due the Treasurer of \$t:si. The Auditing Committee expressed the opinion that much money was lost to the Society by lack of promptness and want of system in collecting, and strongly advised that all the members should be annually called upon during some one month, for their assessments. They suggested too the importance of the utmost economy in expenditure, considering the unsatisfactory financial position of the Society.

The Librarian's report was more exhilarating, stating as it did, that not less than 1500 volumes had been added to the collection during the year. Of these over 1000 had been deposited by the widow of the late Dr. Amos Binney, in accordance with what she believed to be his wish, viz: for the use of members of the Society and others, who may resort to its library for scientific investigations, and to be sulject to the sane regulations as are the books of the Society. This collection is very rich in scientific works, and there is scarcely a department of science not represented.

The Library had also received, as before mentioned, through the bequest of the late Prof. J. W. Bailey, in addition to his valuable microscopical collection, a very valuable library of nicroscopic and hotanical works, mumbering in all eighty-four volumes, and one hundred and fifty pamphlets.

The whole number of books in possession of the Society including those deposited, was stated as follows:

Belonging to the Society, not including the bequest of Prof. Bailey, Bequest of Prof. Bailey, Deposited by "A Republican Institution," Bound Vols. Pamphlets and Parts. Deposited by Mrs. Binney,

$\begin{array}{r}767 \\ 1012 \\ \hline\end{array}$

Total, $\overline{4863}$ 300 150

$84 \quad 150$

767

450

The Curator of Mineralogy reported his department as indehted to Dr. S. Kneeland, .Jre, Mr. N. II. Bishop, Mr. Wm. IIaley, and Rev. S. Adams for specimens received from them during the year.

The Curator of Geology reported the additions to the collection under his charge as few and of little value, compared with those received in previous years.

The Curator of Entomology, in referring to the destruction in past years of specimens in the collection, stated that there yet remained many uninjured, and entitled to care and attention. These had been subjected to a heat of about 200 degrees, and the drawers containing them had had a constant supply of camphor.

Specimens of value had been received from Mr. Samuels, collected by him in California, and one beautiful Neuropterous insect was presented by Mr. Solomon Adams, of Lunenburg, found in Winter street, Boston.

The Curator of Iterpetolowy reported the collection under his charge as in good order, and that some valuable additions had been made to it, principally through the services of Mr. Samuels in California. From him between two and three hundred speci- 
mens had been received, many of which were new to our Cabinet. To Mr. Kennicott, one of on Corresponding Memhers in Illinois, the Society was also indebted for a considerable number of valuable specimens.

The Curator of Oology reported that the collection of eggs had received many additions during the year from Mr. E. Samuels, obtained in California.

No report from the Curator of Ornithology was made. Two specimens of South American birds had been presented to the collection by Mr. N. H. Bishop.

The Curator of Crustacea and Radiata reported that his department was indebted to Mr. Thos. Tallant of Concord, for some corals from California; Capt. Geo. E. Tyler for one large specimen; Capt. J. P. Couthouy for corals from the wreck of a Spanish vessel sunk off the Island of Magrlalena; Cipt. N. E. Atwood for Corals and a starfish; and to Dr. J. T. Parkinson for a crustacean from St. Simon's Island, Georgia.

The Curator of Ichthyology reported the collection of his department as in fair condition, and that the Society was indebted to Dr. A. G. Hamlin of Bangor, Dr. S. Kneeland, Jr., Mrs. Geo. S. Iillard, Dr. S. Durkee, Rev. J. P. Robinion, Dr. D. II. Storer, and to limself, for specimens received during the year.

The Curator of Concholorgy reported the following donations: $\Lambda$ collection of land and fresh water shells from Dr. James Lewis of Mohawk, N. Y. A box of land and fresh water shells from R. Kennicott, Illinois, some marine shells from Capt. N. E. Atwood, and a small collection of shells from John Jas. Dixwell.

The Curator of Botany reported that but little damage had been done to the herbarium during the year, and that the plants were generally in good condition.

At the election of officers for the year, Capt. N. E. Atwood was chosen Curator of Ichthyology in place of Dr. Simuel Knecelant Jr.; Theodore Lyman, Curator of Crustacea and Risdiata in place of Dr. John P. Reynolds, and John Green. Curator of Comparative Anatomy in place of Dr. Jeffries Wyman, elected President the previous June.

The reception of the splendid bequest of Prof. Bailey seemed to inspire some of the members with a desire for microscopic research, and in June a Section for the special purpose was formed, called the Section of Microscopy. 'This, all members of the Socicty interested in the object, were invited to join. It was provided that a Curator of the department should be chosen yearly at the ammal meeting, whose cluty it should be to take charge of all specimens belonging to it, and to presile at its meetings. It was al:o further provided that at the first regular meeting of the society each month, the presiding officer shall call for microscopical papers, remarks or exhibitions, and that these shall be in order during the continuance of the meeting, excepting that no business matter properly belonging to the annual meeting of the Society shall be superseded. 'The proceedings of this department were to be published in the Journal and Proceedings of the Society, subject to the decision of the Publishing Committee.

At the first meeting in June, Dr. Silas Durkee was elected Curator of the new department of Microscopy.

Mr. Charles J. Sprague announced the donation by Dr. Benjamin D. Greene, the first President of the Society, of his large and valuable Herbarium. 'This was stated to be particularly rich in specimens collected by the various exploring expeditions, both of Europe and this country.

In September of this year, the department of Crustacea und Radiata was divided, 
Mr. Theorlore Lyman who had been its Curator, becoming Curator of Radiata; and Dr. H. R. Storer, Curator of Crustacen.

1858. April. 'The President stated that a considerable sum of money had been subscribed for the purchase and stocking of an Aquarium, and that it would be advisable to appoint a Committee to attend to the matter. Accordingly Dr. Samuel Knceland, Jr., Mr. L. B. Stone, and Mr. Theodore Lyman were chosen for this purpose.

From the record of the amnual meeting in May, the following is presented:

The Report of the Auditing Committee upon the finances, exhibited a balance due the Treasurer of $\$ 2074.25$. To meet this there were available assets consisting of uncollected bills in the hands of the Collector, and a sum in the 'Treasurer's hands belonging to the Building fund. S1306.00, leaving the society in deht s.765.2.), and this provieling that all the uncollected debts should be paid in full.

The Librarian reported that since the last annual meeting there had been added to the Library, seventy-four bound volumes; and one hundred and five pamphlets or parts of volumes, exclusive of those deposited by "A Republican Institution," of which there had been forty-three bound volumes. To Dr. Benjamin D. Greene the Society was indebted for some of the most valuable works that had been presented. The Librarian in presenting his report took occasion to remark upon the small sum used for the purchase of books, stating it to be far short of what the reasonable wants of the Curators required. IIe strongly recommented that one-third of the income of the Courtis fund should be, as formerly, appropriated strictly for the increase of the library.

The Curator of Mineralogy, reported that his department had received donations during the year from Dr. Chas. I'. Jackson, Dr. Samuel Knecland, Jr., Dr. Henry Bryant, Mr. Thos. J. Whittemore, Mr. R. H. Eddy and Mr. S. M. Major. 'Those from Dr. Kneeland were numerous, comprising an extensive series of minerals from the Lake Superior region. 'That of $\mathrm{Mr}$. Eddy consisted of a considerable supply of native borate of lime from South America, valuable for exchanges, etc.

The Curator of Geology reported that there had been but few additions to the collection under his charge during the year. The large collection belonging to the State, illustrative of its geology, and which had been for many years under the charge of the Society, had been removed to the State House. 'This enabled him to place in sight all the specimens in the department of sufficient interest for exhibition, a considerable number having been previously kept in drawers for want of room in the cases.

'The Curator of Botany reported that extensive additions had been made to the Herbarium during the year. By the donations of Dr. Benj. D. Greene, and the bequest of the late Prof. Bailey, the number of specimens had been increased ten-fold. Dr. Greene's collection had been incorporated with our own, and the two mnited form one of the richest, most extensive and most valuable herbariums in the country. The bequest of Prof. Bailey had made our collection of Algae the most complete of any. The Curator expressed his intention to give particular attention to the plants received, to take measures for their preservation by poisoning every specimen, and to arrange them according to their genera and species. When this work was completed, he proposed to make a detailed report on the whole herbarium of the Society. 
The Curator of Conchology reported that but few additions had been made to the collection of shells. He complained of want of case-room to arrange species now ready for exhibition.

The Curator of IIerpetology reported the condition of the collection goorl. and stated that the most importint additions to it had been some specinens from Lake Superior, presented by Dr. S. Kneeland, Jr.

The Curator of Radiata reported that the collection had been increased during the year by donations from Dr. A. A. Gould, Prof. Agassiz and Capt. N. E. Atwood. He remarked that when he took charge of it the previous year, he found it in a state of confusion and disorder, but that now it was properly arranged, and the specimens mostly labelled. The collection embraced about one hundred species of Polypi, representing thipty-nine gencra, and about eighty-nine species of Echinodermata, representing about forty genera. Besides these there were a few Medusae in alcohol.

The Report upon the Entomological department was brief, being limited to a statement of the means used to prevent injury to the specimens, by baking, and the free use of camphor.

The Curator of the Microscopical section dwelt at some length upon the great value of the collection, and stated that from the duplicate material belonging to it, specimens had been furnished to a larye number of scientific persons in different parts of the country, who had applied for them.

No reports were inade by the Curators of the departments of Ichthyology and Crustacea, by reason of absence from the city.

At the choice of officers, the only changes made were in the election of Amos Binney as Treasurer in the place of Dr. Nathaniel B. Shurtleff, Alexander E. R. Agassiz, Curator of Entomology, in place of Dr. Silas Durkee, who had been made Curator of the department of Microscopy, and Dr. Samuel Kneeland, Jr., Curator of Ichthyology instead of Capt. N. E. Atwood.

In July the death of Dr. James Deane of Greenfield, a Corresponding Member, was announced. He had manifested great interest in the Society, and to him it was indebted for much advice and assistance in procuring the magnificent slabs with impressions of the foot marks of animals, which have since found place in the entrance hall of the Museum. A full sketch of the life and labors of Dr. Deane, read at a meeting of the Society, July 7, 1858, by the writer of these pages, may be found in the sixth volume of the Proceedings.

For the first time the Society took a recess in the summer. The members voted July 7 to have no meeting until the first Wednesday in September.

In September the death of another of the Corresponding Members was announced, that of Dr. Francis W. Cragin, of Surnam. Ile well merits notice here, as having been for many years one of the Society's generous benefictor's, from whom were received large numbers of donations, of great zoölogical and anatomical interest.

It will be borne in mind that as early as 1855 , complaint was made that owing to want of sunlight and proper ventilation, the collection of the department of Comparative Anatony was suffering injury from the dampness of the cases in which the specimens 
were contained. The trouble was incleasing. and subseduently the Curators of several of the departments reported injury from the sanc cause to the collections muler their charese.

The erection in 1853 of the Boston 'Theatre, a large building adjoining the Nuseum, which cut off its light and air, had produced a change, rendering the latter far less suitable for the requirements of the Society than when it was first occupied. Moreover, with the ever increasing collections of the several departments it had become too small for the proper exhibition of its cabinet.

As early as 1857, Mr. Jas. M. Barnard had suggested that in view of the necessities of the Society, and of the opportunity of purchasing at a low price a good site for a new building, some action should be taken to secure land for the purpose. The unsatisfactory condition of business affiris at that perjod, however, precluded any action.

1859. Early this year Mr. Wm. E. Baker of Boston presented a plan for the accommodation of the several institutions of art and science of the city in a large building, which he called the Conservatory of Art and Science, to be erected on the new land then being formed by the State on the Back Bay. 'There was certainly much in the project to commend it to the serious attention of the institutions referred to, but it did not meet with full approval. 'The zeal and pulplic spirit manifested by Mr. Bulier deserved the gratitude of all interested. 'The presentation of the plan proposed had the good effect to call attention to the necessity of some action in favor of securing early a grant of land from the State for the Society, and accordingly a committee was appointed, consisting of Dr. Cahot, Prof. Rogers. and Mesis. Bamard, Bouré and Whittemole, to act in connection with committees of other institutions in petitioning the Legislature for sufficient territory to meet the requirements of all. 'This was done, but the lateness of the season prevented action during the session.

The annual meeting was held on May 4.

The Report of the 'Treasurer, Mr. Amos Bimey, was very gratifying. An arrungement had been made with the former Treasurer, by which the amount shown by the accounts as due to him was liquidated without full payment in money. The income of the Society had been from all sources $\$ 1986$, an 1 the expenditures. s!) 4!.04. Ieaving in the Treasurer's hands, s. 10.36.96. Dexlucting from this amount a small debt, s.89.70, and there was shown as available assets, $\$ 947.26$. Besides this cash balance, the Society held ten shares of stock in the Bank of North America, at the market price, \$1035.

The Librarian reported that there had been seventy-five volumes, and one lnundred and twenty-six pamplilets and parts of volumes added during the year, of which thirty-seven had been deposited hy "A Repuhlican Institution;" six hmolred and eighty-nine volumes had been borrowed from the library.

The Curator of Minerilogy reported that only few donations had been made to the collection during the year. These were chiefly from Dr. C. T. Jackson and Dr. Samuel Kneeland. Jr. He stated that valuable aceesions might be expected when the Society could provide adequate accommodations for their arrangement and exhibition.

The Curator of Geology reported the condition of the collection good, but that there had been few specimens presented to it. A series of thirty-six vertebrae, twentysix framents of ribs and other bones of the Zenglorlon fiom the eocene deposits of Natbama, had been deposited by Mr. C. S. Hille of Burlington, N. J. These, and many other 
fossils from the same locility in the possession of that gentleman, would undoubtedly become the property of the society, it being his expressed intention to provide that this should be the case.

The Curator of Entomology reporter upon the great accesion to the department in Dr. Thaddeus W. Harris's collection of insects. The native specimens in this, he mentioned, had a peculiar value, for they included many typical species described by himself, Say, and other naturalists, and because of the completeness of the collection. It was stated to contain 4838 specimens of 2241 species of Coleoptera, 181 specimens of 76 species of (1)thoptera, 620 specimens of ahout :300 species of Hemiptera, 267 specimens of 146 species of Neuroptera, 1125 specimens of 602 species of Iymenoptera, 1931 specimens of 901) species of Lepidoptera, 796 specimens of 395 species of Diptera. In all 9758 specimens of 4660 species, besides quite a number not yet classified. The general collection was stated to be in good condition.

The Curator of Comparative Anatomy, Dr. J. C. White, reported that the department contained at this time the following specinens: crania 2.57, skeletons 88 , memlura disjecta 172, wet preparations 123, skins 43, dried preparations 10. Total 693. Nany of these were packed away and could not be put upon exhibition for want of room. The additions during the year had been few, but were valuable. Donations had been made by Drs. Kneeland, J. Mason Warren, E. S. Holden, J. C. Warren, Mr. C. B. Fessenden and Mr. J. C. Reinhardt. Dr. White stated that upon taking charge of the department he found the specimens almost without exception covered more or less with fungoid growths, the mycelium of which penetrates and destroys the organie parts of the bones. The liganentous skeletons had also been injured by the ravages of Dermestes. The growth of these fungi. of which three species hat been detected by him, was caused by the dimpuess and want of light and rentilation, unavoidalble in the builing. Dr. White hoperl that he had prevented further injury by carefully brusing the specimens and thoroughly washing them with an acid solution of corrosive sublimate, strychnia and camphor. He had also taken the precaution to place in each compartment dishes of chloride of calcium to alsorb the dampness.

'The Curator of Microscopy reported that such had been the drafts upon the crude material belonging to the collection receiver from Dr. Bailey that he thought the time had arrived when the kindness of the Society must be limited so far as related to donations from it. What remained he thought would be wanted by the active members of the Society in coming years for sturly. Ife advised, therefore, that there should be no further disposal of it, except when required for special and important microscopic researches.

Of the other departments nothing was stated important to present here.

The changes made in the officers at the election were as follows: Samuel H. Scudder was chosen Curator of Entomology in place of Alexander E. R. Agassiz; F. W. Putnam was chosen Curator of Ichthyology in place of Dr. Śmuel Kneeland, Jr.; Albert Ordway was choszn Curator of Crustacea in place of Dr. H. R. Storer.

In Tovember, a plin having heen proposed for a liurge building to accommolate both the Iforticultural society and the fociety ol Natural IIistory al petition was presented to the legislature asking the grant of one of the squares of land on the Back Bay for its erection, and another for the use of the contemplated Institute of Technology. Great eflorts 
were made by Prof. Rogers, Meswr. Emerson, Ross, Waterston and Bimer in behalf of the project through addresses before the Committees of hoth branches of the Lecrislature. Considerable opposition however on the part of many Senators prevented firvorable action at that time, though it did not cause defeat. The petition was finally referred to the next General Court.

18to. To awaken interest in the work of the Society, and to justify its clams in the minds of the public, it was thought best to have an address delivered at the time of the annual mezting in May, and Prof. Rogers was invited to prepare one for the occasion. It was read before a very large audience at the new hall of the Mechanic's Charitable Association in Bedford street. The record states that he "relivered a most eloquent and pertinent address on the progress of natural science for the last thirty years, dating from 18 s: 0 , the year in which the Society was oryanized. A large, highly intelligent and enthusiastic audience honored the oceasion with their presence, and the Society har great reason to be proud of this successful and brilliant revival of their annual address."

The Reports of the Treasurer, Librarian, and Curators at the annual meeting, furnish information which is presented as follows:

The Treasurer exhibited an account showing receipts for the year, including the balance on hand at its commencement, and also the proceeds of sales of bank stock held by the Society to be $\$ 3559.13$; and expenditures, including an amount paid to Dr. N. B. Shurt-

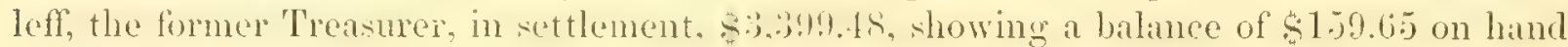
in cash, and no debt. The Society having disposed of its bank stock, held at this time no other property available for its future requirements.

The Librarian reported the accession to the library of 540 volumes and pamphlets during the year; about 300 volumes of these were very valuable works on entomology, from the library of the late Dr. Thaddeus W. Harris, which were purchased by J. P. Cushing, Esq., of Watertown, and generously presented by him to the Society.

There was nothing in the reports of the Curator's of Iineralogy, Geology, IIerpetology, Oology or Microscopy, calling for notice here, and none was made upon Ornithology.

The Curator of Entomology mentioned but few additions, but stated that much work had been done by him towards checking the further ravages of destructive insects.

The Curator of Radiata stated that the department had been indebted to Drs. Bryant and Winslow for several additions to it.

The Curator of Ichthyology reported an accesion of ahout 200 specimens. The donors had been Dr. Ilenry Bryant. who presented a rery valuable collection from the Bahamas, Dr. C. F. Winslow, a valuable collection from the Island of Maui, and the Musem of Comparative Zoology.

The Curator of Comparative Anatomy, Dr. James C. White, reported as might have been expected, con-idering his indefitigalle labor upon the collection of his department, that this was now in good condition and systematically arranged. Ile stated that the means adopted by him mentioned in the report of the previous year, to fiee the specimens from the ravages of insects, had been completely successful, and that even the growth of the destructive fungi had been prevented by the applications made. Every specimen too, had been numbered, and had had attached to it a label giving its name, locality and donor. A new catalogue had also been prepared for the whole collection. 
During the year 27.j specinems hat been atded to the calsinet, many of which were quite valuahle. (Of these may be mentioned a large collection of mammalian skulls and skeletons presented by Dr. Samuel Kneeland, Jr.; and the lower jaws of an immense sperm whale from F. W. Choate, Esq.

The Curator of Conchology reported that little or no progress had been made in his department for want of room to arrange specimens. The collection was stated to comprise about 4000 species. It had had donations as follows: from Dr. Aug. A. Gould, 37 species from Cumana and Hayti, new to the cabinet; from Dr. J. Lewis, a collection of shells from the Mohawk valley and neighboring lakes; from Dr. Simon Shurtleff, 23 species, many of which were new to the cabinet; and from Dr. C. F. Winslow, specimens from the Hawaiian Islands.

The Curator of Crusticea reported that the cabinct of his department was generally in good conlition, but that many of the dried specimens had sulfered from the ravages of insects. Ife had arranged, labelled and catalogned about half the collection, and hoped soon to finish the work upon it. He complained serionsly of the lack of room to properly display the specimens, and also that a considerable number were comparatively worthless because their localities were unknown. The donations had been numerous. Dr. Henry Bryant had presented a large collection from the Bahamas; Prof. Agassiz also a large collection from the Ifawaiian Islands, and the Essex Institute many specimens from our coast. In all, there had been added during the year 366 specimens, comprising 78 species and 55 genera.

The Curator of Botany reported that the Herbarium was in good condition. A series of valuable Swiss plants collected by Mr. Godet, and another of southern plants collected by Prof. Gibbes in the Carolinas were presented by himself.

At the election of officers the following changes took place: Dr. Augustus A. Gould was elected second Vice-President in room of Dr. D. Humphreys Storer, resigned; Dr. B. Joy Jeffries, Curator of Microscopy, in room of Dr. Silas Durkee, resigned; Mr. A. T. Ityman, Curator of Conchology, in room of Mr. Thomas J. Whittemore, resigned; and Dr. Samuel A. Green, Curator of Herpetology, in room of Dr. J. N. Borland, resigned.

Votes of thanks were passed to the retiring officers for their long and efficient services. Those of one of them call for particular mention.

\section{Dr. D. Humphreys Stoleir.}

Whatever reason there may be generally for hesitating in writing freely of the services of the living and yet active members of the community, there are none that should prevent full expression here of such as were rendered to the Society by Dr. D. Humphreys Storer during the first thirty years of its existence. Those for the Museum were invaluable, and it is due to him to make such mention of them while treating of the period of his labors, as will in some degree serve to do what the visible result of his own work as exhibited in the magnificent collection made by him of the Fishes of Massachusetts would have done much better, had this not been destroyed. 'This collection, obtained through arduous effort, put up by his own hands and presented by him to the Society, was allowed to go to ruin, throughl causes, perhaps univoidable at the time, but not therefore the less to be deplured. It wis mide by Dr. Storer when preparing his valuable report on the Fishes 
of Massachusetts, published by order of the Legislature of the State in 1839, and at the same time in the Boston Journal of Natural Jlistory. It embraced, as has been before stated, nimety out of the one hundred and twenty then known species of the coast, a large number of which were type specimens, and from which the descriptions of the species were drawn. When engaged in collecting and in seeking information concerning them, he visited the market daily and examined all that were to be seen there. He made the acquaintance of those engaged in selling fish and through them with the fishermen themselves, often going to their boats and interesting them in his work, so that many were led to aid him by bringing for his use every species that came into their possession. His ever genial manner served to make him very popular among them, and he thus became a welcome visitor whom they were ready to serve with alacrity. On obtaining any specimens wanted he conveyed them lome, or to the rooms of the Society, where they were studied for description and prepared for preservation. For the greater part of two seasons, that is, during the spring, summer and autumn months, when the temperature of the weather would allow of work in unheated rooms, he, in company with Dr. Augustus A. Gould, might be found busily engaged on specimens of their respective departments, from five o'clock in the early morning until their breakfast time. Mr. 'Teschemacher, who

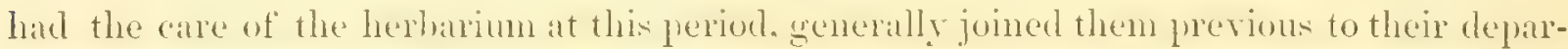
ture, having brealitisted before leaving home. Ile worked until his business engagements called him away, perhaps an hour later. These glimpses of the doings of some of the earlier workers are not unworthy of contemplation by those who occupy their places and who would do justice to their memory. Dr. Storer's labor on fishes and reptiles was often of a very disagreeable character, the specimens received requiring transfer and preparation, being often in a condition far from pleasant to work upon. Alas, that a great part of this labor should have resulted, so far as the Museum is concerned, in scarcely more than the valuable lesson it, with other experience, has taught; that the voluntary work of Curators camnot be relied upon alone, to preserve collections that are subject to ruin without constant supervision and care. In subsequent years nearly all the work of Dr. Storer's hands was allowed to perish. 'The Society will not have done its duty until it has replaced all the species obtained by him of the fishes of Massachusetts waters, every one being labelled as a substitute for the original presented by him. It is pleasant to know that this is recognized as a duty, and as one likely to be accomplished.

Mention has been made of aid afforded Dr. Storer by fishermen, at the time he was engaged in collecting specimens. 'I'o two of these he was very much indebted, not only for many of the species described by him, but for a great deal of information concerning them. He would feel it an injustice not to have their names recorded with his, in any description given of the work done by him. These men were Capt. Blanchard of Lymn and Capt. N. E. Atwood of Provincetown. The latter, particularly, furnished many species that could not otherwise have been procured, and which were of invaluable service.

Indirectly Dr. Storer did much for the Society in introducing to it Capt. Atrood. He became a Corresponding Member and ever after manifested great interest in its proceedings. When in the city, he has attended the meetings, and often addressed them, giving always a vast deal of information concerning fishes, their habits and the methods adopted for their capture, not possessed by any other man. 
Dr. Storer's services whilst an active member of the Society were by no means limited to his labors for the Museum; on the contrary, few, if any, were more earnest in devotion to its general welfare. Was there money wanted for any special purpose, what he could spare was freely given. Was an appeal to be made for help from others, he was never backward in taking steps towards rendering it effective.

The part he took in the meetings was a prominent one, and the communications made by him were often of great value. No one can look over the records of the Society without recognizing the importance of the work performed by him in building up the institution he loved so well. 'There was one trait manifested by him when an active member that will not be forgotten whilst yet members who were associnted with him live, and that was a disposition to encourage young and deserving members to take part in the proceedings.

Dr. Storer, thougl not strictly speaking one of the original members of the Society, may well be considered such, as he became an associate with them immediately after its formation, and in September of the same year was elected Recording Secretary, which office he held until May, 1836. He was a Curator before there were special departments of the Museum from 1836 to 1835 , afterwards of the department of Reptiles and Fishes from 1838 to 184 . Elected Vice-President in 1843, he remained in this position until 1860, when he resigned. He thus held office for the long period of thirty years, with honor to himself and with great advantage to the Society.

Of Dr. Storer's life and work otherwise than as connected with the Society the following is presented:

Dr. Storer was born in Portland, Maine, March 26th, 1804. He was educated at Bowdoin College; graduated there in 1822 and had the degree of LL.D. conferred upon him by that institution in 1876. His scientific tastes led him to associate himself, as has been mentioned, with the Boston Society of Natural History soon after its formation, but the particular attention he subsequently gave to ichthyology was entirely the result of fortuitous circumstances. When Dr. Hitchcock was authorized to re-survey the State in 1837 , he expressed a strong desire that there should also be made a more full examination of its Natural History. A committee of the Legislature therefore met the one on the part of the Society in conference, the result of which was that George B. Emerson, President of the Boston Society of Natural. History, Chester Dewey, Professor of Botany in the Berkshire Medical Institution, Ebenezer Emmons, M. D., Professor of Natural History in

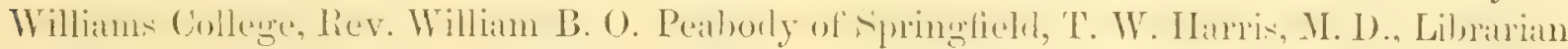
of Hirvard University, D. Humphreys Storer, M. D., and A. A. Gould, M. D., of Boston, Curators in the Boston Society of Natural History, were commissioned to take charge of

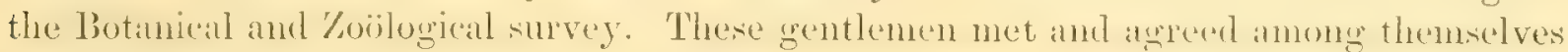
as to the part they should respectively take in the work. Prof. Emmons undertook to report upon the Mnmmals, Dr. Storer upon the Fishes and Reptiles, Mr. P'eabody upon the Birds, Dr. Harris upon the Insects, Dr. Gould upon the Mollusks, etc.

The division was unquestionably a wise one, but it required of Dr. Storer a scientific report within a year on a subject of which neither he nor any one else in the community knew anything beyonel what was known to the fish dealer and the cook. Inanghingly he lhas since remarked that he could scareely at the time liate told a flommer from any other 
flat fish. 'This was not all. There was not in New England an ichthyologist with whom he could consult, and searcely a book that would aid him in his investigations. Sufficiently diseonaging all this, but. Dr. Storer did not despair. If he knew but little of ichthyology, he had a scientific mind, sharply olservant, quickly pereeptive and nicely discriminating. Moreover he was indefatigable in performing whatever he undertook, never relaxing in his work until it was done and well done.

The Commissioners came to an understanding that they all should endeavor as far as possible to extend the bomndaries of knowledge in each department, and not confine themselves to merely presenting catalogues of species. It was soon perceived that the work expected of them could not posisibly be done within the allotter time, and leave was asked and obtained to defer the reports until a later period.

Before another year, however, had elapsed, several were ready, and we can only wonrler; in looking over the volumes produced, that so much could have been accomplished within so limited a period. 'The result of Dr. Storer's labor was what Dr. DeKay describert as a "masterly report" on the Fishes of Missichusetts. 'This was published by an order of the Legislature in August, 18:3, and also appeared in the Boston Journal of Natural IListory at the same time. Previous to this, Dr. Storer had presented some papers before the society on fishes, which had also appeared in the Jommal. In $\Lambda_{p}$ ril, 1815 , he communicated to the neeting of the Anerican naturalists at New IIaven, a very valuable paper called "A synopsis of the Fishes of North America." 'This was published in the Nemoirs of the American Acardeny. Subseruently there appeared in the same Memoirs what Dr. Storer termed his final report on the fishes of Massachusettin, the species being all illustraterl by fine engravings, and this was also published in a separate volume.

The third decade of the existence of the Society having now jassed, some mention will be made of what has not been referred to during the period.

The Journal of the Society had been published from time to time, but not quite with the regularity that distinguished its carlier issues. Volume VI and part of Volume VII hat appeared with many articles of great value. The Proceedings appeared more freruently. A part of Tolume III, and Volumes IV, V, and VI, and a consilerable portion of Volume VII had been printed and circulated. The scientific character of both series had been well sustained, and had helped much to extend the reputation of the Society abroad.

The average attendance on the meetings each year may be seen by the following table:

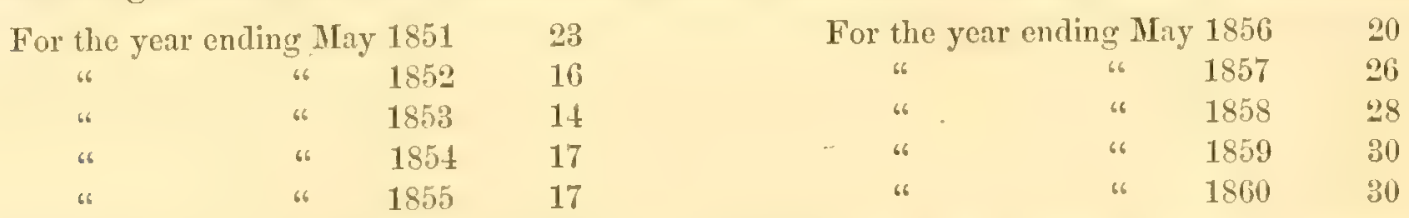

Those who took a prominent part at the meectings of the Society during the first five years of the ten, ly presenting commmications, participating in the discussions, or otherwise, were Dr. Charles 'I'. Jatckon, Count Desor, Dr. Wyman, Dr. Burnett, Dr. Gould, Dr. Durkee, Mr. W. O. A yres, Dr. Cahot, Mr. William Stimpson, Dr. J. C. Waren, Dr. Simmel Kneceland, Jr., Dr. A. A. Inayes, Prof. William B. Rogers, Mr. Teschemacher, Dr. Thomas M. Brewer, Dr. D. II. Storer, Dr. II. R. Storer, Mr. Charles J. Sirague, Mr. Wells, Prof. Henry D. Rogers, Dr. J. Mason Warren and Mr. Thomas 'I. Bouvé. 

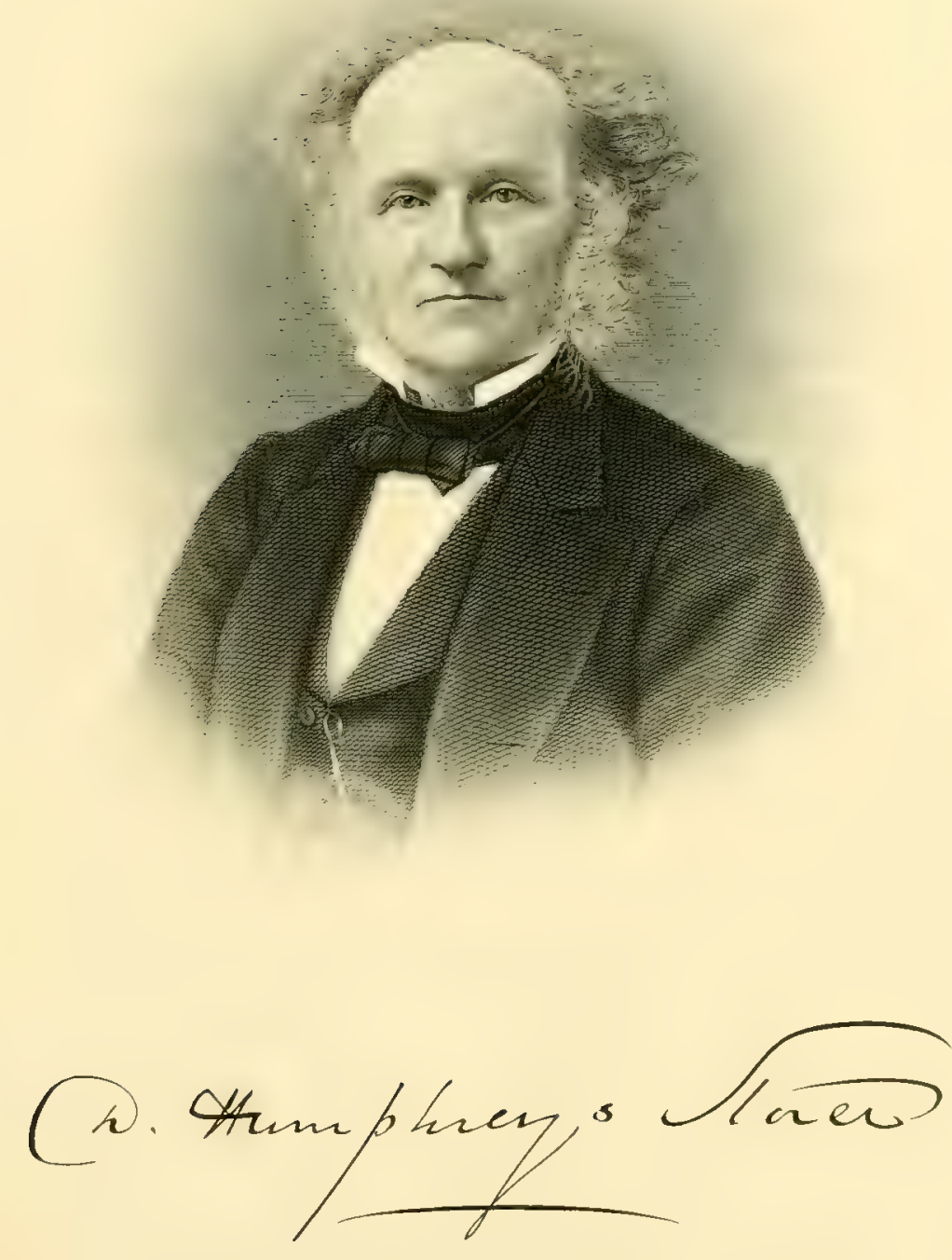
Those who were prominently active during the last five years of the ten were Dr. C. T. Jackson, Prof. William B. Rogers, Dr. A. A. IIayes, Mr. Charles J. Sprague, Dr. Thomas M. Brewer, Dr. Samuel Kneeland, Jr., Dr. Jeffries Wyman, Professor Agrassiz, Dr. Gould, Dr. J. C. White, Dr. Henry Bryant, Dr. Samuel L. Abbot, Dr. J. N. Borland, Mr. J. Whittemore, Dr, Silas Durkee, Dr. John Bacon, Jr., Mr. Charles, Stodder. Mr. Theorkere Lrman, Dr. B.. J. Jeffries, Dr. C. F. Winslow, Mr. Samuel II. Scudder, Dr. Samuel Cabot, Dr. D. II. Storer, Dr. Charles Pickering, Mr. John Green, Dr. D. F. Weinland, Capt. N. E. Atwood, Mr. Nathaniel H. Bishop, Dr. J. B. S. Jackson, Prof. H. D. Rogers, MIr. J. M. Barnard, Prof. 'Theophilus Parsons and Mr. Thomas 'T. Bouvé.

The financial condition of the Society at the close of the decade differed but little from that at the commencement. There had been during the ten years, periods of considerable indebtedness, but the economical course of the government had prevented its increase, and at the annual meeting, as stated in the Treasurer's report, there was a small balance in the 'Treasury.

The Library had increased from about 3500 volumes reported as in the possession of the Society in 1850, to nearly 5009, including 1012 deposited by Mrs. Binney, and 767 deposited by "A Republican Institution". Besides these there were 681 pamphlets, or parts of volumes.

The number of Resident Members of the Society at this time were about 206, exclusive of Life Members, of whom there were 18.

The standing Committees of the Comeil, through which much of the inportant business of the Society was transacted, had faithfully attended to the duties assigned them.

The members of each during the decade were as follows:

On the Library: Drs. A. A. Gould, S. Kneeland, Jr., Henry Bryant, and D. Humphreys Storer, and Messrs. C. K. Dillaway and Charles J. Sprague.

On Finance: Dr. N. B. Shurtleff, Messrs. J. J. Dixwell, Thos. Bulfinch, P. T. Jackson, Amos Binney, C. C. Sheafe, Jas. M. Barnard, 'Thos. 'T. Bouvé, and George B. Emerson. On the Library: Drs. A. A. Gould, D. Itumphreys Storer, S. Kneeland, Jr., John Bacon, S. Cabot, Jr., Henry Bryant, and Messrs. C. K. Dillaway and Chas. J. Sprague.

On Publications: Drs. D. Humplreys Storer, Jefries Wyman, Samuel Kneeland, Jr., Samuel L. Abbot, Samuel Cabot, Jr., Benj. S. Shaw, and Mr. C. K. Dillaway.

\section{Decade IV. MaY, 1860-MaY, 1870.}

Soon after the annual meeting, Mr. Arthur T. Lyman, who had been elected Curator of Conchology, resigned, and in June Mr. Nathan Farrand was elected his successor.

In October of this year the Society was notified that the late Jonathan Phillips had made to it the magnificent bequest of $\$ 10,000$. It will be remembered that in the latter part of 1849, when the Society was suffering from debt, this gentleman manifested his interest in its welfire by a timely donation of $\$ 2,000$, which relieved it from all liability.

The exertions of the members of the Society towards accomplishing the objects in view, viz., that of securing land from the State on which to build, and help from the public to enable the Society to erect a structure suitable for its wants, were constant. In December a Committee was appointed by the Council, consisting of Prof. Rogers, Dr. $A$. 
A. Gould and Mr. Amos Binney, to prepare a pamphlet setting forth the claims and wants of the Society. This was published and distributed among the member's of both houses of the Legislature.

In December also it was voted by the Council that a course of lectures be given during the winter by members of the Society, free to the public, and Profs. Rogers and Wyman, with Dr. Gould, were appointed to prepare a plan of such a course, with full powers to make all the necessary arrangements.

1861. The most important event of the year to the Society, and one of the most important in its history, was the munificent donation by Dr. William J. Walker of his estate in Bulfinch Street.

As this act was the first of a series of great donations on the part of Dr. Walker to the Society, it may be well to state what is known that led to such manifestation of interest in its welfare. For some time previous to the event mentioned Dr. Walker had boarded in the same house at Cambridge with the President of the Society, Prof. Wyman, and an intimacy had arisen between them which led the former to regard with attention whatever the latter was particularly engaged in. Noticing annong the documents brought home amb laid upon the table of their common sitting room by Prof. Wyman, some of the publications of the Society, Dr. Walker became interested in their perusal and finally in the work of the Society itself. This led to many conversations between them respecting the aims and objects in view, which resulted in the donation mentioned, and eventually in Dr. Walker becoming the great benefactor of the Society.

In announcing the pleasing event Prof. Wyman made the following remarks, which are worthy of mention here:

"I have great pleasure in stating that since our last meeting, Dr. William J. Walker has presented, and by the necessary legal process has conveyed to this Society, the estate recently occupied by him in this city. The property has been placed in the hands of trustees, to be devoted, under wise and liberal conditions, in such a manner as they may deem most expedient, for the promotion of our best interests and of the study of natural history. This is the largest gift that we have received from a single individual. Under any circumstances it would be munificent. Now it is both munificent and timely. It is all the more gratifying inasmuch as it was wholly unsolicited. It naturally follows, from the emotions which this beneficence calls forth, that we should rejoice at being the reeipients of such a gift, and, in accepting it, should express our gratitude and sense of deep obligation. But we must not rest here; there are other considerations to which we must allow a place at this time.

"Standing before a community identified with the study of natural history and the diffusion of a knowledge of it, we have been liberally endlowed in this and other ways. I believe that with our very inadequate means, we have done much to justify our benefactors and the public in their encouragement of us. But every benefaction has imposed, and every new one will impose, additional and more exacting obligations. Societies are often charged, and it is to be feared too often justly, as less faithful to their trust than individuals. We nust have care that such a charge may not apply to us. In accepting the gift now offered us, we bind ourselves, though tacitly yet firmly, to fulfil all the obligations which belong to it, implied no less than direct. 
"We have recently set forth our claims upon the community for patronarge. It should be remembered that the public, though it does not formally set forth its claims upon us, has them, and with a deeper interest in the study of nature than has been known before, judges us with a severer scrutiny and by a higher standard than at any previous period. So long as we make our collections useful and our studies conducive to the public good, and thus show ourselves faithful to our trusts, we are justified in the belief that we may confidently expect to receive hereafter, as we have received already, every necessary support and encouragement."

Professors W. B. Rogrers and Agassiz congratulated the Society upon the addition to their means at such an opportune moment, and Dr. Augustus A. Gould offered the following resolutions, which were unanimously adopted:

"Resulecl. That the society accepts with gratitude the donation of Dr. Wm. J. Walker on the terms stipulated.

"Resolved, That the accession of so munificent a sum to our funds at a moment when further expansion with our actual resources must have been very limited, greatly encourages us to new and more efficient exertion.

"Resolved, That it shall be our diligent care that the avails from the donation shall be applied prudently and practically towards the cultivation and diffusion of useful knowledge; specially aiming to modify the direction of our endeavors, as the spirit of the age may from time to time indicate."

The conditions upon which this donation was made have always been sacredly regarded by the Society.

During the session of the Legislature in the winter of 1860-61, strenuous efforts were made by several members of the Society, and of the Institute of Technology, to obtain the grant of land wanted for the use of each, particularly by Prof. Wm. B. Rogers and Mr. M. D. Ross, which were finally successful, the grant of one square, so called, having heen made on ecrtain conditions which secuner objectionable at first, but which turned out to be of no detriment. Of this "square" one third was to be for the use of the Boston Society of Natural History, the other two-thirds for the Mass. Institute of Technology.

In March, it having been intimated that possibly the city might be willing to buy the building of the Society in Mason Street, for the enlargenent of the Normal School IHouse near to it, a committee consisting of Mr. Bouvé, Mr. Binney, the 'Treasurer, and Dr. Kneeland was appointed to confer with the City Government on the subject.

In April, the Treasurer with such other nembers as saw fit to join him, were appointed a committee to solicit subseriptions for a building fund, and in the same month a Building Committee was appointed consisting of President Wyman, Mr. Binney, Professor Rogers, Dr. Jeffries and Mr. Bouvé, to consider and propose a course of proceedings in relation to the new hall, accompanied by such general plan of grounds and buildings as they might deem expedient, and to report from time to time to the Society, making no engagements without further authority.

The reports of the Curators at the annual meeting in May present but little of interest. Generally. complaint was made of want of room for the proper display of specimens, and the expectation expressed that when this lack should be supplied there would be a much greater disposition manifested to make donations. The Curator of Geology 
reported that his department was better circumstanced than the others so far as the collection belonging to the Society was concerned, inasmuch as by the removal of that belonging to the State, ample space was now afforded for the reception of specimens and their display.

The Conchological department had received between four hundred and five hundred specimens, many of them species new to the collection, the donors being the Smithsonian Institution, Mr. E. R. Mayo, Dr. A. A. Gould and Mr. H. Davis.

The Mineralogical department had received but few donations, but two of these were quite valuable, one being a large mass of amethystine quartz from Salto, Uruguay, the other a large geode of the sane from Uruguay, both the gift of R. B. Forbes; Esq.

The Curator of Comparative Anatomy reported that by the precautionary measures adopted, the collection had been kept in good order, and that donations of considerable value had been received, principally from. Dr. Henry Bryant and Mr. Du Chaillu.

The Treasurer's report was exhilarating. He congratulated the Society upon a state of financial prosperity umprecedented in its history. It had received during the year the legacy of the late Jonathan Phillips of $\$ 10,000$, a donation of an estate from Dr. Wm. J. Walker valued at $\$ 30,000$ and the grant of land from the State for the erection of a new structure.

The Librarian reported the number of volumes now in the Library as exceeding 5000 .

At the election of officers the only change made was in substituting Dr. Francis H. Brown Curator of Herpetology for Dr. Samuel A. Green, who had tendered his resignation.

A special meeting of the Society was called in July to consider upon accepting the offer of $\$ 28,000$ which has been made on the part of the city for the building of the Society in Mason street. It was voted to accept that price, and a committee consisting of Professor Rogers and Mr. Bouvé was appointed to complete the sale. 'This was subsequently done and the Society received the amount mentioned.

In August Mr. Amos Binney resigned the position of Treasurer of the Society through a letter to the President, in order that he might accept a commission in the military service of the United States. Mr. Thomas T. Bouvé was unanimously elected 'Treasurer in his place.

After the sale of the building in Mason Street had been consummated, it was determined on the part of the Society to temporarily occupy the Bulfinch estate for the storage of its collection and for meetings, until a new museum should be erected for its use. Accordingly the house was prepared for the reception of the collection and for the accommodation of the meetings, the parlors on the lower story being fitted up for the latter purpose, and occupied at the same time as a library. All this being accomplished, the Society in August left the home it had occupied for thirteen years, and where its growth had been such as to render more extensive apartments necessary for its expanding wants.

Not without kindly thoughts of many pleasing and instructive hours passed in the cosy meeting room of the Society, was the old building left for new quarters. Here, with the library arranged in the cases around and a large table serviceable for multifarious purposes, might have been seen almost every afternoon several of the Curators at work upon specimens or investigating their chatracter; here too, for several of the later years might have 
been heard at the meetings as able scientific discussions as any hall ever echoed to, for it was here that Agassiz, William B. Rogers and INenry D. Rogers made their power felt in warm though most friendly conflict of opinion, exciting the intense interest of all who had the good fortune to be present.

Dr. Kneelant malle a proposal to the Society to occupy with his fimily some roms in the Bulfinch st. house, and therehy ensure the greater siffety of the buildings and contents, on certain conditions. These were acceded to and Dr. Kneeland and family subsequently occupied the premises.

The Building Committee promptly and industriously devoted themselves to the work put into their hands. They studied the wants and requirements of the society, conferrorl among themelves as they met from time to time, as to the interior arrangenents suitable for the accommoration of the several departments, and subseruently consulted with architects respecting the exterior, and the cost of building. In the meantime one of their number, Mr. Amos Bimney, having entered the Army, Dr. Jas. C. White was substituted in his place, and the committee subsequently now consisted of the President, Dr. Jeffries Wyman, Prof. Wm. B. Rogers, Dr. Jas. C. White, Dr. B. Joy Jeffries, and Mr. Thomas 'T. Bouvé. They frequently met for consultation at the house of Professor Rogers, where they examined plans submitted to them and then discussed their merits. After two or three months of close attention to the subject, and after considering fully several plans brought before them, they finally reported to the Society in November, as their choice after mature and long deliberation, one offered hy Mr. Jonathan Preston. Dr. White explainerl the details of the plan and presented estimates of the cost, showing that a handsome building could he erected, and such portions finished as would serve the immediate wants of the Cabinet and Library for about $\$ 62,000$. The Report Was quite satisfictory and the society voted that the plan be accepted "as at once graceful and ample in its proportions and well adapted for all the purposes which the Society has in view."

The Building Committee was requested to have detailed specifications prepared, in order to obtain positive estimates of the cost of finishing such portion of the building as was referred to in the report, and it was empowered to make arrangements for the construction, if such estimate should show that the cost would not exceed the arailable funt increased by further contributions.

The Society also voted that the Building Committee be authorized to take such steps as they judged proper to raise an additional amount towards paying for the new structure, and also to add to the committee Geo. B. Emerson, Esq., and Rev. R. C. Waterston.

In November of this year, a fire occurred in Boston, by which a menagerie of wild animals was destroyed, the poor beasts being suffocated in their ages. The skims were greatly damaged by fire and water, but the bodies were generally not much injured. Through the exertions of Dr. White, the Cumator of Comparative Anatomy, he obtained for his department the animals, and they were dissected, part of them at the Medical College, and the rest at the private dissecting room of the President at Cambridge. Dr. White in making a report of the matter, stated "that the society may consiler itself fortumate in having secured so valuable an acquisition to its already extensive osteological collection. Such an opportunity will probably never occur again. It raises this department of the Cabinet far above any in the country in importance, and will enable us to 
grace our new halls with an almost perfect collection of skeletons of the large cats of the old and the new worlds."

The specimens obtained were, one fine male lion from Delagoe Bay, Africa; a very large lioness, mate of above; lioness from Cape of Good Hope, presented to Prof. Wyman; one male jaguar; female of same, presented to Prof. Agassiz; young Bengal tiger, female; hunting leopard, female, from Asia; young leopard, male, from Asia; cougar, male, from South America; ocelot, female, from Central America; civet cat, female, Asia; spotted or laughing hyena, male, Cape of Good Hope; jackal, Cape of Good Hope, presented to Prof. Wyman; young black bear; two raccoons, male and female; llama, female, from South America; American opossum; peccary, female, Brazil; three monkeys, one baboon, domestic goat, skull of gnu; eagle and various other birds.

1862. In January of this year, the Boston Marine Society presented to the Society a valuable collection of objects in natural history, and of specimens of the workmanship of different East India and Pacific nations, such as models of canoes and junks, war clubs and insignia of office, cutting weapons, bows and arrows, quivers and paddles, native cloth and tanned skins, etc., etc.

The presentation of so many objects of art, led the Council to recommend the establishment of a department of Ethnology, am in accordance with this suggestion. the Society formed such a department and elected Dr. Charles Pickering its Curator.

In March of this year, Dr. Kneeland entered the Medical Corps of the Army, and at his recquest a rote was passed that his family be allowed still to occupy rooms in the building as a residence. Dr. Kneeland was the third officer of the Society that the war had called into active service.

The Building Committee, now having in charge not only the construction of the proposed new edifice, but the raising of additional means to meet the cost, omitted no effort to accomplish the objects in view. They exhibited publicly the plan of the structure, with detailed specifications prepared hy Mr. Preston, and inviter proposals from mechanies for the execution of the work. No less than sixty-four were presented and considered, but not until subscriptions had been received sufficient to cover the entire estimated cost, was any contract made involving expenliture. To obtain subscriber's they took most efficient measures. They met together, they discussed plans, they consulted with others interested, they decided what persons should be appealerl to and finally distributed among themselves the names of such as each one would undertake to solicit, so that there might be no conflicting action. On account of the very great service rendered by Mr. M. D. Ross, for the Society at this time, it is proper to state that though not upon the committee he offered his valuable aid in furtherance of its objects, met with them. galve grood andrice. and finally took an active part in appealing to such parties for money as he thought he could best influence. To aid the committee in their wark they issued a circular prepared by Drs. Jeffires and White giving the reatons for the appeal mule to the publie, aceompanied by lithographic views of the exterior of the proposed building, as well as some representation of the plan for its interior arrangement. While thus engaged in preliminary movements towads personal appeals, what was their joy and how great their encouragement, to have the amouncement made to them, as was done by President Wyman, that a gentleman, 
whose name was to remain for awhile unknown, had oflered towards the Building Fund, the munificent sum of $\$ 20,000$, provided a like sum should be secured by subscription from other parties! This enabled the Committee to head the subscription papers quite effectively, and no doubt had great influence in securing signatures to them. 'The success which followed soon justified active measures for the construction, and contracts for the execution of the work, and for lelivery of material, such as stone, brickis, ite., immerliately followerl.

In May it was found that $\$ 20,000$ had been subscribed, and Professor Wyman was requested to communicate the fact to the gentleman who had made the offer alluded to. At a subsequent meeting of the committee Professor Wyman mentioned that he was none other than Dr. Wm. J. Walker, to whom the Society was indebted for the house it occupied, and stated that he was ready to pay over the $\$ 20,000$ at once.

At the meeting of the Society, June 4, the President announced the reception of the $\$ 20,000$ from Dr. Walker, and besides other appropriate action the following revolutions were passed:

"Resoleed: That the Society herehy tender to Dr. Walker their most grateful acknowledgement for the renewerl and munificent proof of his interest in their prosperity, and for the occasion and the incentive which it had afforted to other friends of the Society to contribute an equal aggregate amount.

"Resolved: That in view of this and the previous benefactions, by which Dr. Walker has marked his appreciation of our scientific labors and aspirations, we feel that to his liberality, chiefly, we are indebted for the enlargerl opportunities of usefulness now so brightly opening before us, and that, in offering him the homage of our gratefil hearts, we have no need to assure him of the enduring honor which will associate his name with the future successes and the whole history of the Society."

While yet engaged in getting subscriptions, the committee kept busily at work upon mattere pertaining to the building, and as soon as it becane clear that means enough would be secured to meet the cost, they made contracts for the principal part of the work, including the filling in of the land.

From the estimates made of the probable cost of the building completed, it appeared that not less than $\$ 57,000$ would be required exclusive of cases, but that by leaving unfinished certain portions not needed for early occupancy, about $\$ 80,000$ would suffice.

It was therefore voted not to exceed $\$ 80,000$ upon the building, exclusive of cases and furniture.

It has been thought well to give somewhat in detail the action of the Building Committee in the preliminary steps taken to erect the grand structure since occupied by the Society, and in obtaining the necessary means to accomplish its completion. To do anything like justice to the devoted servere of a most faithful and industrious committere wount require a much fuller record of their doings than can be given here. The result of their endeavors to erect a building satisfactory to the Society will be stated further on. Notice must now be taken of other matters of interest concenning the Society that transpired during the year.

The Reports of the Treasurer, Librarian and Curators were presented as usual at the annual meeting, and were, considering circumstances, satisfactory. 'The department of Comparative Anatomy had been enriched by the addition before mentioned of a valuable 
collection of the skeletons of animals suffocated at the fire in Portland Street, by the osteological collection of the late Dr. Lane, by a series of crania from Dr. Henry Bryant, and by a skull and nearly a perfect skeleton of a gorilla presented by Dr. Otis of the Navy.

'The department of Geology had also been enriched by the addition of specimens showing tracks of animals, purchased from Mr. Field of Greenfield.

The Curator of Ethnology, the department of which had been recently formed, acknowledged the reception of the varions objects of ant and manufacture presented to the society by the Boston Marine Society, as before mentioned.

At the election of officers, Mr. S. H. Scudder was chosen Recording Secretary in place of Dr. Simmel Kneeland, who had entered the service of the United states as surgeon in the axmy.

The office of Curator of Crustacea, made vacant by the resignation of $M r$. Albert Ordway, who had also entered the army of the United States, was not filled.

This year, so full of events gratifying to the members and cheering to their hopes for the future, did not pass without one that caused sadness in the hearts of all, but more particularly to such as had been associated in the work of the Society in its earlier years. Reference is here made to the death of Dr. Benjamin D. Greene, which took place on the 14th of October, and which was announced to the Society on the 15 th.

\section{Dr. Benjamin D. Greene.}

When the good and the wise participate in the formation and in the work of an institution, they leave an impress upon its character not to be eflaced, whilst the memory of their deeds is yet fresh in the minds of those who succeed them; and as what they were, and what they accomplished is not only a delight to contemplate but an inspiration to endeavor, it becomes a sacred duty to extend and perpetuate a knowledge of their worth and labors. It was the good fortune of the Society to have associated among its members at the period of its origin and in its subsequent history, some of the noblest and purest minded men that the community has produced. This is not expressed without due consideration, and will not be questioned when the names of Dr. B. D. Greene, Rev. F. W. P. Greenwood, Dr. John Ware, Dr. J. B. S. Jackson and Dr. Jeffries Wyman are recalled to mind as active workers, to say nothing of many others whose attainments and deeds justly earned for them the esteem and regard of all who knew them.

Among those mentioned, none enjoyed the respect and love of contemporaries more than the honored First President of the Society, Dr. Benjamin D. Greene, and a knowledge of his virtues is only necessary to cause his memory to be revered by all who come after, as long as the fociety hall exist. It is to impart this knowledge that the following account of him is given.

Dr. Greene was born in Demarara, in 1793, during a temporary sojourn of his parents there. In 1s12 he graduated at Harvad College in the same class with Charles G. Loring, Peleg Sprague, Henry Ware and others who became well known to public fime in later days. After leaving Cambridge he studied law at Litchfield, Conn., where was then a wellknown law school, and was later admitted a member of the Boston bar. His subsequent career cannot be better given than by quoting the words of a near and dear friend and 


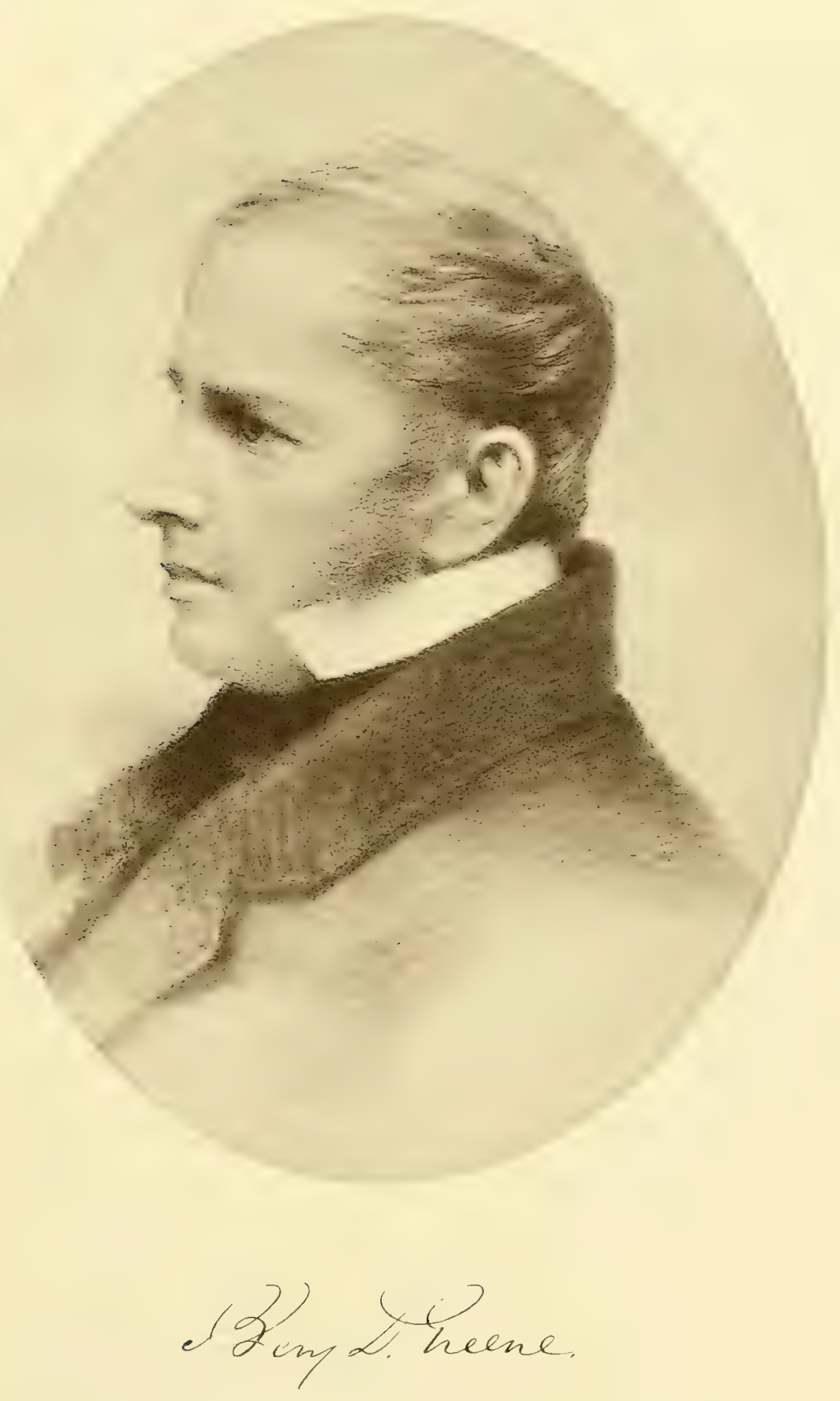




\section{,}


connection, Mrs. Robert C. Waterston, sister of Mrs. Greene, embodied in a letter respecting him. They were as follows: "Dr. Greene's studies at Litchfield were rather to acquire a general knowlexlge of law than from an intention to pursue it as a profescion, and his tastes for natural history, especially botany, led him to turn his attention to medicine. To pursue this study he went abroad and was a student in London, but more especially in Edinburgh, where he passed several years. Here he formed the acquaintance of men who were afterwards widely known in their different departments. Among then was William J. Irooker, afterwards Sir William Hooker, with whom a friendship arose which contimued through life. The intimacy was renewed on Mr. Greene's various visits to England and Scotland; and always maintained by correspondence and the interchange of botanical books and information, as weli as by mutual expressions of lasting affection.

"Mr. Greene's botanical studies greatly interested him both in Europe and America. Forgetful of time and even of hunger, he would go out in the country in the morning and not return until night, coming back laten with botanical boxes filled with specimens, and then spend halt the night in laying cach in its separate papers with the careful and tender touch peculiar to his hand.

"Thus besides acquiring two professions, he gained a reputation as a botanist in the front rank of that department of natural history. Added to these attaimments he had command of several modern languages. He knew much and said little. Constitutionally reserved and silent, it was impossible for him to impart what he had acquired.

"Once only I heard him express a regret that fluency of speech or writing had been denied to him. Few knew how richly his mind was stored on almost every subject. His taste for the fine arts made him a just judge of both music and painting. Of pictures he had a great love and knowledge. His ample fortune was the means, not only of adorning his own house with works of the old masters, and those of a more modern school, but also of encouraring and aicling many struggling workers in various departments of "man's endless toil and endeavor,' who but for him had been 'desolate and oppressed.' His library was well chosen and filled, and there he loved to abide - and when at last ho passed on to wider regions of knowledge, the works on natural history as well as his IIerbarium were at his request transferred to the Boston Society of Natural IIistory. Ir. Greene's life was one quite aside fiom the hurry and self-assertion of Anerican careers. Ile possessed many qualities, which, hat he prictised the profession of medicine, would have made him an able and certainly a beloved physician. His was the magnetic touch of a born healer, and the strength and tendemess of his presence in the sick room was of itself a restorative power. I knew well that character whose 'still waters ran deep.' Ilis low voice was seldom raised except to rebuke wrong, but the flash of his wrath was all the more startling, hecauce it so seldom fell from the calm and quiet sky of his serene days. After he left us in 1862, I arranged at my sister's request a simple monument to be placed over his resting place at Mount Auburn. An ivy plant climbs over the tablet and half hides a cross on it summit. typifying that sincere faith and reverence which lay in his soul, seldom outwardly revealed. To please a wish of my own heart there was cut on-the marble the grass which was named for Mr. Greene, by Thos. Nuttall, when he discovered it on the Western plains, the Crecnia Arkasia." To this beatiful and just tribute of one who knew more of $\mathrm{Dr}^{2}$. Greene in his domestic life, than any other who has written 
of him, it may seem unnecessary to add anything touching his private character and its influence. Yet the subject is too interesting not to dwell upon, especially as there are words of Dr. Asa Gray, not in print, concerning Dr. Greene, which should not be omitted here. In referring to a brief notice written by himself of Dr. Greene, published in the Proceedings of the American Academy of Arts and Sciences, and in which remarks were made upon his well known generosity in placing the results of his observations and his collections in the hands of those who could make the best nse of them for the advancement of science, he says that the notice given "does not make enough of the liberality, the winsomeness and the very quiet generosity of $\mathrm{Mr}$. Greene, which made itself felt in a most spontaneous, unobtrusive way, as if it were something in the atmosphere, a delicate, grateful, subtle aroma, rather than anything consciously put forth." Most fitting words these will be judged by all who had the pleasure of personal intercourse with the subject of them.

Of Dr. Greene as a botanist it may be said that he stood deservedly high in the estimation of those who knew lim best in this relation. He collected extensively the plants of our country, and studied them carefully, so that his knowledge of them was thorough. Dr. Gray, in writing of him, states that after he ceased to collect, from failing health, he still showed a real interest in his plants and from time to time "verbally gave me critical remarks such as would only be made by a keen and accurate observer."

Of Dr. Greene's botanical work less can be said than might be expected concerning the knowledge he possessed on the subject, and his desire that others should profit by his acquirements. No doubt this was largely due to that want of fluency in expressing what he knew either in writing or by speech, to which he himself feelingly alluded. Dr. Gray, who knew more discriminately what he accomplished in his favorite pursuit, wail that his retiring. contemplative, mambitions disposition rendered him averee to the toils. and wholly indifferent to the fime of athorship; that his services to science were in his helpfulness to others, by making butanical collections, and by forming a library of hotanical works; the plants and the books being always at the disposal of those who needed them for scientific research.

The action of the Society upon the death of Dr. Greene is presented as follows:

On the 15th day of October, as before mentioned, the Rev. Mr. Waterston announced to the society the death of the First President of the ruciety, Dr. B. D. Greene. He spoke of the high personal character and the attainments of the deceased, and of the great interest he had ever felt in the welfare of the Society. Remarks were also made by the President, Jeffries Wyman, and by Professor Agassiz and Dr. Pickering, expressive of their great respect for his memory. Upon motion made by Mr. Waterston, a committee was appointed to take such action as seemed proper in view of the sad event, consisting of Dr. Gould, Professor Rogers, Professor Agassiz and Mr. Waterston.

At the next meeting of the Society, held Nov. 5th, Dr. Gould made a brief address, giving an account of Dr. Cireene's participation in the formation of the riociety and in the proceedings of its early dars. after which Profesor Rogers followed, dwelling more at length upon some points of interest in the life and character of the deceased. "It is not often," he said, "that the possessor" of a liberal fortune is found giving his heart and time to the labor of seientific studies which, however emobling and replete with the finest of enjoyments, have as we know, nothing in sympathy with the luxurious ease and brilliant excitements of what is called society." 
"Such tastes and labors as marked the life of our late colleague are the exception, and we are therefore especially called on to honor the memory of him who furnished so beautiful an example. But qualities still more rare characterized the pursuits and conversation of Dr. Greene. No one could fail to remark his singular freedom from the ambitious impulses which, whilst they stimulate the labors of men of science, so often dim their aspirations for what is true and beneficent. With him the love of knowledge was a sufficient incentive and adequate reward. Delighted to store his mind with the beautiful truths gathered from the ample sources aromel him, and ever reaty to help other devoting themselves to kindred branches of inquiry, and indeed to any scientific pursuits, his singular modesty shrank from the least public exhibition of his various knowledge, and in the eyes of those who knew his solid and diversified culture, gave to his social character its most peculiar and winuing charm." Profersor Rogers clowed hy offering the following renolutions:

"Resolved, That while it is the duty of the Society to hold in grateful recollection all who at any time have participated in the labors or helped to enlarge its means of scientific usefulness, it is under especial obligrations to honor the memory of the founders and early patrons of the Society, whose earnest zeal gave the first strong impulse to the pursuit of natural history in the community, and whose liberal contributions and fostering care laid the foundation for those labors which have won for the Society an honorable place in the history of scientific investigation.

"Resolved, That the Society, while deeply regretting the loss which it has sustained in the death of its late associate, Dr. Benj. D Greene, has a sad pleasure in placing on record an expression of its grateful and enduring reverence for his memory as one of the most zealous of its founders and its first acting President, and as one of the most liberal of the patrons and co-workers of the Society.

"Resolved, That in expressing our sense of the great value of the services of our late associate in this Society, and of his work as a cultivator and promoter of natural science, we would dwell with affectionate interest on the gentle graces of character for which he was remarkible, and especially on the shrinking modesty and reserve which veiled so beantifully the knowledge and culture they were unable to conceal."

Nov. 19th, 1862, by vote of the Society, the names of all persons who had contributed one humbed dollars or upwards towards the ereetion of the new buikding, were entered in the records as Patrons.

1863. In April of this year there arrived from London casts from the bones of the Megatherimn in possesion of the British Musem, presented by Joshua Bates, Escl. These were subsequently mounted by Mr. George Sceva, under the direction of Dr. James C. White. The huge animal form thus reconstructed has since been one of the most striking features of our main hall.

At the ammual meeting in May it was amouneed that the society had been the recipient of a bequest of $\$ 9,000$ from our late associate and first President, Dr. Benjamin D. Greene.

The 'Treasurer's Report showert receipts of $\$ 72,507.76$, and expenditures $861,224.31$, leaving in his hamds 811.28 .3 .45 . Of the receipts $\$ 46,2$ tit had heen paid in especially for building purposes. and of the cxpenditures s.5,685.75 had been paid towards the new building. 
The Report of the Librarian mentions the munificent bequest of the library of Dr. Greene, comprising 1,500 volumes or parts, many of which were costly illustrated works, mostly upon botany. This was the largest addition ever made to the Library at any one time.

The Curators had but little to report except that the collections were safely housed, awaiting accommodations for exhibition in the new building.

At the election of officers for the ensuing year, Mr. William 'T. Brigham was chosen Curator of Mineralogy in place of Dr. John Bacon, and Mr. Thomas T. Bouvé was chosen Curator of Geology and Paleontology instead of Curator of Geology alone, which office he had previously held, the two being combined in one department.

The Building Committee had continned to act vigorously in the business of construction and finish. Already the structure was approaching completion, and questions concerning

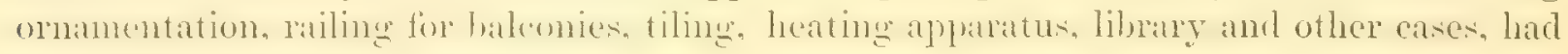
recently occupied their attention.

In October the announcement was made of the sudden death of Dr. George Hayward, one of the members of the Limman suciety and subserguently one of the foumlers and original members of the Boston Society of Natural History. He was First Vice-President from May, 1830 to May, 1832.

October 21st Mr. Alpheus Hyatt was elected Curator of Conchology.

On the 4th of November, the President of the Society reported on behalf of the Building Committee that the new building was nearly ready for occupancy and that the Library room was quite so. It was therefore voted - That the Library be moved forthwith and that the next meeting of the Society be held at the new building, if gas is previously introduced into it. It was also voted - That the Curators be authorized to remove their collections as soon as convenient. In accordance with the vote, and gas having been in the meantime carried into the library room, the Society on the 18th of November for the first time, met in their new and capacious building, 79 members being present. The library had already, since the previous meeting, been removed to the room, and now occupied the shelves of the cases.

In November of this year, another of the founders of the Society passed away, Mr. Francis Alger.

At the meeting held Dec. 2d, Mr. T. T. Bouvé remarked that before proceeding to business it seemed meet that the members of the Society should express their appreciation of the loss it had sustained in the death of their friend and associate, Mr. Francis Alger.

"Public spirited, he always felt a strong interest in all institutions designed for the welfare of the people, and often gave of his means for their endowment. Especially was he interesterl in the promulgation of knowledge relating to his farorite branch of science, that of mineralogy. 'To further this he was always ready to give specimens, inviting ihose interested in the study to select from his duplicates."

"But a few days since he suggested to me his intention to send some very large specimens of beryl and other minerals to adorn our grounds, and such was his interest in the society that I cammot but think his large collection would have come into our posession at an early day, if his sudden departure had not prevented the fruition of his wishes." 
At the request of the Society, Dr. Chas. T. Jackson prepared a notice of $\mathrm{Mr}$. Alger for the Proceedings, a considerable portion of which will be presented here.

. ()ur late astociate. Francis Alger, son of Cyrus Alger. was horn in Bridgewater, in this State, March sth. 1807. In youth he was not sturlious, and had only a common school erlucation. His taste for study commeneed in 1824, when his attention was first drawn to the science of mineralory. To his love for that science he attributed his after progres. in general learning and scientific attainments. One branch of uatural history leads to another, and Mr. Alger soon found himself engagred in the study of shells and plants, first the fossils and then their analogues in the living world. His library show how extensively he studied in the various branches of natural history; but it was to his first love, mineralogy, that he devoted his chief attention."

Having occasion to accompany his father on an excursion for business purposes to Nova Scotia, Mr. Alger collected minerals from near Digby Neck, and in the trap rocks of Granville, a list of which he published in the Boston Journal of Philosophy and Arts, upon his return home. Ie also published a brief description of Nova Scotia minerals in the Anerican Journal of Arts and Sciences.

In 1827, Mr. Alger and Dr. Chas. T. Jackson made a full exploration of Nova Scotia, and collected a large number of minerals, the species of which they described by a joint essay in the 14th and 15th volumes of the American Journal of Science, extra copies being freely distributed gratuitously to scientific men.

In 1829, Mr. Alger and Dr. Jackson again visited Nova Scotia, and making many new discoveries, prepared a revised memoir for the American Academy of Arts and Sciences.

Dr. Jackson in his notice went on to say, referring to their work together:

"In the second joint excursion a schooner was chartered for the voyage, and served as a home along the wild coasts of Nova Scotia. Though Mr. Alger was always very. sea sick when in the rough waters of the Bay of Fundy, he bore the afliction with great patience, and when on shore worked with the most enthusiastic zeal in exploring for minerals. It was a great pleasure to witness his joy when a new crystal oven in the trap rocks, or brilliantly sturlderl agate ball was broken open, disclosing to view the flowers of the mineral kingrom.' Ile farly danced with delight, and thonght no lahor too severe, when such rewards were to be won. His part in the Memoir was fairly borne, the work of writing the descriptions being carefully and equally divided. Soon after its publication, Mr. Alger was elected a Fellow of the American Academy, and took an active interest in the meetings, occasionally communicating some of his scientific observations.

"Having become interested in the iron and zine mines of Sussex Co., New Jersey, he made that locality, before well known to the scientific world, still more famous for its rare and unique minerals, and sprearl them broadeast over the mincralogical world. IIe often marle excursions into the state of New Hampshire, and purchased some of the interesting mines more for the sake of obtaining specimens of the minerals they produced than from any hope of pecuniary gain. He would never sell any mine without reserving the right to all the fune specimens of erystals that should be got out in mining. Finding that he could not extract and bring home to his cabinet a large beryl of five tons weight which exists in Grafton, N. II., he purchased the hill, had the crystal meorered of rock, and considered it as in his cabinet and one of his specimens. 
"IIis zeal, instead of cooling off, seemed constantly to be inflamed, and I never knew the time when his eyes would not sparkle at the sight of a new or beantiful mineral. In New York he met a young man who had a guard-chain made up of fine crystals of gold, every one of them far better than could be found in the cabinets of Europe. IIe at once bought the chain at a high price, and had the crystals carefully removed and added to his cabinet."

In 1549 Mr. Alger received the honorary degree of A. M. from Iarvard University.

Of Mr. Alger's personal charicter we know that he was a kind henrted man, a firm friend and worthy Christian. Ie was always disposed to apologize for the short-comings and faults of others, and he never spoke a hard word except of those whom he considered irreclaimably vicious, and such men he loathed and did not like even to name. Francis Alger's career in this world is now ended. He died in the field of his public duty. He was engaged in the city of Washington in perfecting. shrapnel to be employed in restoring the union of our divided States. Exposure to cold and wet weather, with fatigue and neglect of proper personal care of himself, brought on a sudden attack of congestion of the lungs which terminated in typhoid pneumonia, of which he died on the 27 th of November, in the fifty-sixth year of lis age.

Mr. Alger's scientific writings were mostly essays upon minerals publisher in the American Journal of Science and Arts, in the Proceedings of the American Association for the Advancement of Science, and in the Journal and Proceeding's of the Boston Society of Natural History. His most important work was what he modestly entitled "Alger's Phillips: Mineralogy." It was an edition of Phillipes Mineralogr increaved by Mr. Aliger's additions more than one half, the result of his labor for many years.

The Society passed the following resolutions:

"Resolved, 'That the Boston Society of Natural History has learned, with profound sorrow, the death of their late associate and frient, Francis Algrer, one of the founders of the Society and for years an efficient Curator in the department of Mineralogy.

"Resolved, 'That this Society recognizes in Mr. Alger a true lover of science, an active and carnest collaborator, animated with a kindly spirit, calculated to win the friendship of all who knew him, and to excite an interest in the branches of science to which he was devoted."

On December 2d, Mr. A. S. Packard, Jr., was elected Curator of Crustacea.

1864. The new year opened auspiciously for the Society, and yet there were sufficient reasons for anxiety concerning the future. Dazzled by the success which had followed their endeavors to secure for themselves a structure adequate to the requirements of a great institution, they but imperfectly realized the enormous expenses that necessarily attend such work as that to which they were now pledged. There was imminent danger that the income derivable from all sources at command would fall far short of the amount required to accomplish what was now expected of them. 'The following extracts from the records of the first meeting of the Society held January 16th, will show what reasons the members had for new joy and congratulation:

"Mr. 'T. T. Bouvé arose to speak of the financial condition of the Society and its enlarged needs in the new building, showing that the capital which had hitherto barely supported the Society, would now be manifestly insufficient for its maintenance. He then read a 
letter recently received from Dr. William J. Walker, to whom the Society was already so largely indebterl. wherein he promised to give 20.001 more on combition thit others would subscribe a like amount, the whole to be funded and used by the Society as a working capital. In conclusion Mr. Bouvé urged very strongly that every member should give his direct personal effort toward the raising of the sum requisite to secure so generous a donation."

Rev. Mr. Waterston thought "the time auspicious for the endeavor, since the Society, within the means given for the object, has erected a handiome and spatedos edifice, an ornament to the city, and most suitable for its wants. We have done all we proposed to do in the outset and have not overburdened ourselves with debt by overstepping the limits of the fund set apart for this spccial purpose, and now in order to secure a working capital which shall forever place in security our valuable collections, enable us to make a proper exhibition of these to the public, and put us upon a proper basis as an active, progressive Society, we call upon the public to subscribe for this object, $\$ 20,000$; failing to secure which, we have barely enough to maintain the building in proper repair, leaving out of consideration our necesities for the proper exhibition aml ult inate security of our calinet, and for the publication of our Proceedings and Memoirs."

Others spolie camestly upon the matter, ureing prompt action, and finally a Committee of Subscription was appointed, consisting of Prof. Jeffries Wyman, Dr. A. A. Crould, Dr. C. T. Jackson, Prof. William B. Rogers, Rev. R. C. Waterston, Dr. Samuel Cabot, F. W. Lincoln, Dr. Ineny Bryant, Dr. Charles Ware, Dr. D. Humphreys Storer, George B. Enerson, Thomas 'T. Bouvé, Dr. S. L. Abbot, M. D. Ross, R. C. Greenleaf, J. D. Philbrick, Edward Pickering, N. L. Hooper, Lemuel shaw, C. J. sprague, Charles C. Sheafe, J. D. Kidder, Thomas Gaffield, M. S. Scudder, and Dr. J. C. White.

This committee issued a circular setting forth the need of a working fund to carry on efficiently the objects of the Society and mentioning the munificent offer of Dr. Willitm J. Walker to grive $\$ 20,000$ towark this, if a like sum should be obtained by subseription.

To fucilitate ol,taining signatures for \$100, an alteration was made in the By-laws by which the payment of this sum would be requisite to constitute any one a life member, and it was understood that all parties subscribing that amount towards the working fund should be made life members.

In April, Mr. Bouvé announced the death of Dr. Edward Hitchcock of Amherst, an honorary member, and subsequently made a short address upon his character, ending with a presentation of the following resolution:

"Resolved, That the members of the Boston Society of Natural Ilistory recognize in the death of their late distinguished associate. Dr. Edward Hitcheoch, the loss to themselves, and to the pullic, of a man of comprehensive ability, of untiring devotion to the cause of science, and of great private worth."

A few days previous to the annual meeting of this year, died one who had been the first of the Fecond Vice-Presidents of the Society at the time of its foundition, Dr. John Ware.

He was the son of the Rev. Henry Ware, for thirty-five years Professor of 'Iheology at Harvard University, and was loom at Mingham. Mass., Dec. 19th, 1795. He graduated at Harvard in 1813, and received the degree of M. D. in 1816. In 1817 he removed to Boston, where by steady devotion to his profession, he gradually built up an extensive practice. 
In 1832 he was appointed adjunct Professor of the Theory and Practice of Medicine in Farvard University, and succeeded Dr. James Jackson in 1836, holding the chair until 1S58. He was President of the Mass. Medical Society from 1848 to 1852.

Dr. Ware was one of a family distinguished for the talents of its members. His father and several brothers were eminent as preacher's and theological writers; one, Willian, was the author of the widely known classical novels of "Zenobia" and "Aurelian;" and Henry possessed a fine poetical talent. More than one of the brothers achieved great success in the practice of medicine.

Dr. Ware's contributions to the literature of his profession were numerous and very able; and some of them exercised a great influence, especially the essays on delirium tremens and on croup. He was a most careful observer, a mature thinker, and very thorough as a teacher. His great liberality and candor were as marked as his ability; and his gentle and lovable nature rounded of a character which was appreciated as it deserved to be, by all who had the good fortune to be cared for professionally by him, or to enjoy his friendly intercourse. As a physician, he was wholly devoted and faithful, as he was in all other relations of life.

Dr. Ware died in Boston on the 29th of April, 1S64, in the seventicth year of his age.

At the annual meeting in May, the Treasurer, before presenting his report, announced the agrecable intelligence that the subseriptions to the working fimd had reached the required sum of $\$ 20,000$, and that consequently the $\$ 40,000$ was secured.

His report stated that the receipts for the year amounted to $\$ 21,955.90$, which added to

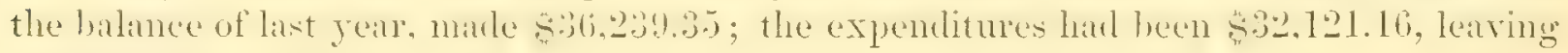
a cash balance of $\$ 4,118.19$.

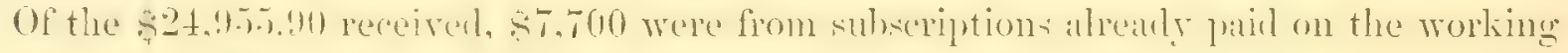
fund. Of the $\$ 32,121.16$ paid $\$ 27,773.07$ had been on the new building.

'The Librarian, Mr. Chas. K. Dillaway, after serving the Society for the long period of thirty-one years, having been elected in 1833, in tendering his thirty-first and final report, resigned the position so long and faithfully held, much to the regret of the members, to whom he was endeared by long and intimate association. 'The record of the meeting states that in presenting the report, Mr. Dillaway gave an interesting account of the progress of the Society in every department during his connection with it. The Library, he said, at the time of his first annual report contained about 200 volumes; now we have over 6000 of great value. In 1833 we had published nothing and had no exchanges; now our Joumal and Proceedings go to every kindred Society in America and Europe. Since the last ammual meeting there had been received from donations 915 volumes and 559 pamphlets and parts of volumes, including the munificent bequest of the late Dr. Greene; from exchanges 40 volumes and 1! parts of volumes, maling with some from other sourees an addition of 970 volumes and 778 parts of volumes. Since our removal to this building every book has been numbered, labelled, catalogued and placed upon the shelves, for a great part of which labor the Society was under obligntions to Mr. Samuel II. Scudder.

The warm thanks of the Society were voted to Mr. Dillaway for his long and efficient services, and he was requested by unanimous vote to make use of the rooms of the Society for private instruction as leretofore. 
The Curators having now placed their collections in the new building were enabled generally to report upon their magnitude and condition. It will be well to present here, now that the Society starts upon a new era of activity, the substance of what was stated respecting the cabinet.

The C'urat or of Ornithology "reporterl the collection of hirils, notwithitimding the time it was stored in Bulfinch Street, to be in as good order as when it was taken from the old building in Mason Street; that several large additions had been made to it since entering the new building, principally by the smithoniam Institution and lyy himselt; and that the whole number of mounted birds is now more than twenty-five hundred.

The Curator of Comparative Anatomy reported that the collection of his department had all been removed in grool comtition. and that the skeletons and parts of skeletons hard been arranged in the places allotted to them ; that the skins not in the hands of the taxidermist, for want of money, were in the cellar exposed to injury from insects. The collection was briefly described as follows:

IIammals : skeletons, mounted 73 , unmounted 25 ; parts of skeletons, 197 ; skulls, 279 ; teeth, 93.

Birds: skeletons, 25 ; parts of skeletons, 56 ; skulls, 87 .

Reptiles : skeletons, 13 ; parts of skeletons, 8 ; skulls, 21.

Fish : skeletons, 0 ; parts of skeletons, 57 ; skulls, 21.

Alcoholic specimens, 100; horns, 50; miscellaneous, 25; skins not estimated.

During the past year the large collection of mammalian skeletons which carne into the possession of the Society at the burning of the Menagerie in 1861, had been mounted in a very correct and beautiful manner by Mr. George Sceva.

Several valuable donations had been received, the prinipal donors being Dr. Henry Bryant, Mr. George Sceva, Mr. C. J. Sprague, Dr. Borland, Mr. W. H. Dall, Dr. B. Joy Jeffries and Mr. J. M. Barnard.

The Curator of Ierpetology reported that there were in the collection representatives of 500 species. During the winter and rpring much work wis done in arranging them and in placing a certain number of each species in fresh bottles and clean alcohol. Some specimens had become worthless and were thrown away. The reptiles of Massachusetts were tolerably well represented, but many common species were licking which the Cunator hoped to obtain before the next annual meeting.

The Curator of Ichthyology reported that the fishes had not been materially injured by their storage in Bulfinch street. IIe stated, however, that when they were carried there from Mawon street the poor specimens thrown away left a deficien'y in Maswachusetts firses which he expected might he supplied during the reason. 'This is the first indication given

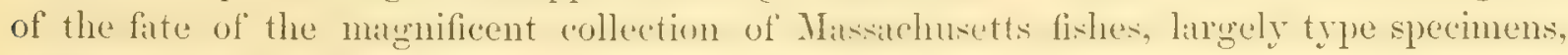
collected by Dr. D. Humphreys Storer, and presented by him to the Society. The want of jars and alcohol was strongly urged to the attention of the Society.

The collection was stated to consist of 280 species, 800 specimens from North America; 80 species, 250 specimens from the West Indies and Bermuda; 45 species, 62 specimens from the fresh waters of South America; 8 species, 9 specimens from Africa; 14 species, 16 specimens from Europe; 115 species, 197 specimens from the Hawaiian Islands; 60 species, 236 specimens of duplicates for exchange; 2.) species, 200 specimens dry, from various localities. In all 627 species, and 1770 specimens. 
The Curator of Crustacea reported that the collection had heen removed without serious injury. The additions during the year were a few native forms, presented by Mr. W. M.

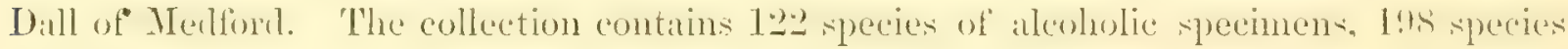
of dry specimens.

'The Curator of Oology reported that the original collections of the Society had been increased by the local collections of Mr. Thoreau of Concord and Mr. WV. H. Henck of Dedham. The number of specimens belonging to the department was not reported.

The Curator of Conchology reported considerable donations of shells from Dr. Gould, Dr. Gundlach of Cuba, and Mr. J. M. Barnard, together about 500 species, but made no mention of the number in the cabinet.

'The Curator of Botany reported an immense amount of work done by him in arranging the plants of the collection in the most scientific manner, and in thoroughly protecting them by means of poison from the attacks of insects. 'There were many packages still unarranged, but which had been carefully examined. A collection of dried plants had been commenced, and the Curator had incorporated his own private specimens with those of the Society. The number of seed vessels and fruits he reported as 230 .

The Curator of Mineralogy reported the safe removal of specimens in his department, and their faroralle arangentent for exhibition. He mentions the domation by Dr. Charles T. Jackson of a portion of his private collection which had been for a long time stored in the apartments of the Society.

The Curator of Microscopy reported the safe deposit of the collection of this department, embracing the magnificent gift of Prof. Bailey, in the room allotted to it.

The Curator of Ethnology made a full report upon the collection of this department. It emblaced stone implements of the aboriginal inhabitants of New England. collected by the late Mr. Thoreau; hat, bows, models of paddles and canoes of the Chinnook or maritime tribes around Puget Sound; hat, dress, models of canoes, and other articles from Russian America; pottery from Central America or Peru; sharks' teeth swords, war implements of the Kingmill Coral Islands; artiches from the Hawaiian Islants. some of them now unknown on those islands; stone adzes from the Hervey Islands; war club from the Samman Islands; articles from New Zeatand; clubs, female dress and hark cloth from the Fecjee Istamls; implements from various other localities; IIndoo idol, African krisses, Egyptian relies, Roman lamp, \&c.

The office of Cabinet Keeper was abolished at this time and that of Custodian created. The duties of this officer were defined as follows:

The Custodian was to be a person of acknowledged scientific attainments. He was to have general charge of the building and its contents, have free access to the collections at all times, and act in concert with the Curators, to whom he should bear the relation of advisor and assistant. In case of absence or neglect of Curators, he was to act in their stead and perform their duties. He was required to prepare and read at the amnual meeting a report of the state of the museum, compiled from the special reports of the Curators. He was to keep a Donation Book and record the names of donors, and perform such other duties as might be prescribed by the Council, and mutually agreed upon.

At the election of officers which followed the reports of the Curators, S. H. Scudder was chosen Recording secretary, Librarian and Custodian, and 1. E. Verrill Curator of Radiata in place of Theodore Lyman who had engaged in the service of the United States. 
It was voted by the Council at a meeting held on May 4th that the new building should be known as the "Museum of the Boston Society of Natural History."

On May 27 th the Council directed that the Museum be open to the public on Wednesdays and Saturdays, and that it also be open to the members and patrons, or to such as have tickets, on Thursdays.

The Committee of Arrangements for the dedication of the Museum announced that those only would be admitted to the ceremonies who presented tickets, which had been distributed to all the members and patrons.

\section{Dedication of the Museun.}

This notable event in the history of the Society took place on the afternoon of June $3 d$, the ceremonies being in the main hall of the Museum. At about 4 o'clock the President invited the Rev. Dr. Iill of Harvard University, to offer prayer.

After this service the President made some remarks appropriate to the occasion, expressive of gratitule felt for the liberallity of the Commonwealth and the munificence of individuals, which had resulted in placing the Society in the high position it now occupied. He then introduced Prof. Wrm. B. Riggers, who gave a brief history of the movements made by the Society, which had resulted in its possession of the beautiful edifice to which the audience were now welcomed. He alluded to the fact that even whilst the flames of civil war were lighting up the country, the legislature of the State made the grant of land the Society asked for, adding that for this gift it was as much indebted to Governor Andrew as to any other man.

Prof. Rogers then spoke of the progress of the Society and of the means it would now afford the student in scientific pursuits. He regarded the interest shown in the Society during these years of war as evidence of the desire of the community for truth, ending by gratefully referring to those who were strugghing through conflict for peace, without which many of the blessings we enjoy would vanish like smoke.

His Honor the Mnyor, F. W. Lincoln,.Jr., next addressed the assembly, and in the name of the citizens of Boston barle the members Gorl speed in all their honoralule efforts.

Rev. Dr. Waterston followed, giving a very interesting address upon the importance of such an institution as that of the Boston Society of Natural IIistory. Its objects, like those of the Public Library and the Institute of 'T'echnology, were important for the higher erlueation of the community. All citizens might take an interest in it with great advantage to themselves, for it furnishes the means of enlarging their sphere of knowledge. He thought it: suecess should be viewed with reverent gratitule, since all who participated in its benefits would find an increased enjoyment.

Lieutenant Lutke of the Russian Navy, aile-de-camp of the Grand Duke Constantine, who had been invited to be present, mate a few remarks expressive of his high gratification in being able to participate in the ceremonies of the dedication.

After further remarks hy Professor Rogers npon the taste displayed by the architect in the construction of the building, and the conscientious devotion constantly manifested by him while erecting it, the andience was invited by the President to remain and examine the collections. 
The account thus given of an excectingly interesting occasion is largely derived from the nerrspapers of the day, the records of the Society being meagre.

In June of this year the Society lost one of the most promising of its younger members, Carleton Atwood Shurtleff. He was particularly interested in entomology, and had recently prepared a paper upon the general plan of venation in the orders of insects, which was presented and read by Mr. S. H. Scudder at a meeting in September, accompanied by some remarks upon the scientific character and attainments of the deceased. The collection of insects and plants made by Mr. Shurtleff, and his scientific papers, were sent to the Society by the bereaved fimily, with the expressed wish that they should be regarded as a bequest from him who had manifested such an interest in its welfare.

The collection consisted of a considerable number of native plants, over a hundred bottles of alcoholic specimens, mostly insects, quite a large number of dried chrysalids of insects, and a cabinet of dried insects containing about six thousand specimens beautifully prepared, mostly from the vicinity, but including several hundred from China and Japan.

At a special meeting on the 12th of August, it was announced that the twenty thousand dollars offered by Dr. Walker, towards a working fund for the Society, on condition that other individuals should subscribe a like amount, was secured, as one hundred and thirty-five persons had subscribed twenty thousand, seven hundred and five dollars.

The income receivable from the amount given by Dr. Walker was subjected by him to certain conditions which are shown by the following extract from the agreement with him.

"The said aggregate sum of money (forty thousand seven hundred and five dollars), shall be invested and kept invested in some productive real estate, or if such cannot be conveniently obtained, in mortgages, bonds, stocks, or other personal property, and shall form a permanent fund, the principal of which shall not be infringed upon under any circumstances, but if through unavoidable casualties, or otherwise, any portion of said aggregate fund should be lost, the whole income of the remainder of said aggregate fund shall be retained and added to said fund until said loss is fully made up; all investments and changes of investments of said funds, are to be subject to the approval of the supervisors

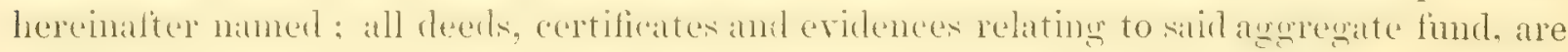
to be kept distinct from those of all other investments of said Society; and the accounts of the principal thereof shall be kept separate from all other accounts of the Society.

"John A. Andrew and Samuel K. Williams of said Boston, County of Suffolk, Jeffries Wyman of Cambridge, of the County of Middlesex, Thomas 'T. Bouvé of the said Boston, and George A. Kettell of Charlestown, of said County of Middlesex, shall be the supervisors of the funds of the trust hereby erected; and during their lives, the approval in writing of the major part of them, or of the major part of the survivors of them, or of their successors in the trust, shall be requisite to the validity of any sale or investment of the trust property.

"From one half of the income of the said aggregate fund representing the gift of the said William J. Walker, there shall be annually offered two prizes for the best memoirs, and in the Funglish language, on sulpjects proposed by a committee appointed by the Council of said Society, as follows:

"First, for the best memoir presented, a prize of sixty dollars may be ararded. If, however, the memoir be one of marked merit, the amount awarded may be increased to one hundred dollars, at the discretion of the committee. 
"Second. for the next best memoir, a prize not exceeding fifty dollars may be awarded at the discretion of the committee; but neither of the above prizes shall be awarded unless the memoirs presented shall be deemed of adequate merit.

"Third, Grand Honorary Prize. The sum of two hundred dollars shall be set aside each year from the income of the trust fund representing the donation of the said William $J$. Walker, and shall with the accumulations therefrom, form a prize fund; when said prize fund amounts to the sum of two thousand dollars, the Council of the Society may award and pary therefrom the sum of five humberl dollins for surh scientifice investigation, or discovery in natural history, as they may think deserving thereof; provided such investigation or discovery shall have first been made known and published in the United States of America, and shall have been at the time of said award, made known and published at least one year; if in consequence of the extraordinary merit of any such investigation or discovery, the Council of the Society shall see fit, they may award therefor the sum of one thousand dollars.

"After the said prizes shall have been thus awarded, the residue of said fund shall be retained, and a certain portion of the income of the trust fund, not exceeding two hundred dollars, shall be ammully appropriated by a vote of the Council of the Society, to the formation of a new prize fund of one thousand dollars, and when, and as often as said prize fund amounts to said sum, the Council of said Society may again award a prize therefrom in the manner above stated; provided, however, that the said prize shall not be awarded oftener than once in five years; and also, as said prize is to be awarded for merit solely, if no sufficiently meritorious investigation or discovery is brought to the notice of the Council, they may withhold said prize at their discretion, until an investigation or discovery of sufficient merit shall be published and made known.

"After the above appropriations have been set aside from the annual increase of said trust fund, given by the said Willium J. Wallier, the residue of said income is to be applied as follows:

"First, to pay for procuring the necessary means for the preservation and exhibition of the specimens belonging to the cabinet of said Society, such as the purchase of alcohol and other antiseptics, jars, bottles, barrels, and the materials for the proper mounting, labelling and displaying of the specimens, but not to expenses in the nature of salaries or wages, or for labor, or instruction, or for cases or other furmiture, nor for the purchase of specimens, but may be economically applied to the necessary repairs of the building in which the collections of the Society are preserved, and for gaslights and fuel.

"Second, should the whole income of the fund not be required for the above named purposes, the balance thereof may be reserved and used for such purposes in future years, or added to the principal of the fund at the discretion of the Society."

In Norember. the Curator of Entomology reporter the collection of insects of the Fociety in a dangerous condition, requiring prompt and close attention which he could not give; another evidence that without parties patil to con-tantly look after the collections, and ad-s equate means to provide all posible protertion for the sperinens. it was worse than useless to make them.

In this case a paper was circulated for subscriptions among the officers of the Society that enough money might be realized to hire an assistant. 
It will be remembered that a Section of Microscopy was founded in 1S57, and that for sometime afterwards it showed signs of activity, which were manifested less and less until all mention of its existence ceased to be made in the records. In December of this year, in response to an invitation from the Curator of Microscopy, sixteen gentlemen interested in the revival of the Section, met and appointed a committee of reorganization. 'This committee reported a series of rules for the government of the Section a fortnight later, which were adopted. Among them there was one providing that the meetings should take place on the second Wednesday of every month in the room of the department.

1865. At a meeting held on the 15th of February the Rev. Mr. Waterston addressed the merting upon some of the extucitional instrumentalities which he thought within reach of the Society, ending with a motion:

"That a committee of three be appointed to consider the subject of courses of lectures to the public school teachers of this vicinity with full powers to act."

This motion was strongly seconded by Mr. John Cummings, and upon his suggestion a vote was passed that the committee be nominated by the chair.

The Rer. Mr. Waterston. Dr. Augustus A. Gould ami Dr. James C. White were made this committee.

The action thus taken by the Society is well worthy especial notice for several reasons.

ne is that it clearly shows to whom is due the first conception of a plan to impart instruction to the teachers of the public schools. To the Rev. Mr. Waterston unquestionably belongs that honor. Another is that it indicates the early interest felt in such teaching by the gentleman who seconded with much earnestness the original motion. Many years afterwards several courses of lectures to the teachers of the public schools were given under the auspices of the Society, the whole expenses of which were generously borne by the gentleman alluded to, Mr. John Cummings.

Still another reason why this action merits attention is the surprising fact that there is not to be found in the subsequent records of the Society, or of the Council, one word implying that anything grew out of the proposition and motion of Mr. Waterston. It is hard to believe that this can be said relative to one of the most commendable acts the Society ever engaged in, and yet it is strictly true. Fortunately for the presentation of what

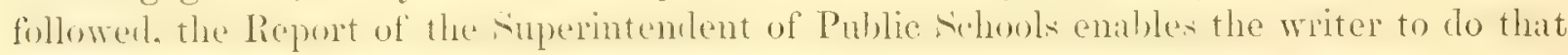
justice to the Society which its own records fail to do.

John D. Philbrick was then the Superintendent, and his report of September, 1865, to the Board of School Committee, embraces the following paragraphs:

"During the past year, an event worthy of record, and highly gratifying to the friends of education, may be found in the fact that one of the most important and well endowed scientific institutions in this community, male arrangements for a series of lectures on rifferent branches of natural history, which were prepared expressly for the teachers of the public schools of Boston.

"The large hall belonging to the Society of Natural History was thronged with earnest listeners. The lectures were amply illustrated by specimens and diagrams, and at the close of each lecture the rich and cxtensive cabinets of the Society were generously thrown open for the inspection of all present. At the introductory meeting, the teachers were alliessed by ILis Excellency Governor Andrew, His Honor the Wayor, President Hill of Harvard University, George B. Emerson, LL.D., and other eminent friends of education. 
"The lectures which followed in successive weeks were by Professor Wyman, President of the Society of Natural Historry. Profersor Rogers. of the Intitute of 'lechnologr. Dr. Augus-

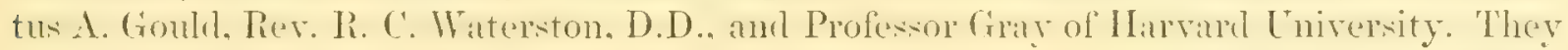
embraced branches of natural history of the deepest interest, and when it is remembered that here were assembled some six hundred teachers, having daily under their care more than twenty-seven thousand children, it may readily be believed that a fresh impulse must have been given, which could not fail to be beneficial and widely felt. Wholly aside from the valuable knowledge thus imparted and acquired, the memorable fact not to be overlooked or forgotten, is this, that one of the ablest bodies of scientific men in our community thus publicly extended the most courteous hompitalities to the tearhers of the pulplic schools, inviting them to meet, throngh successive weeks, at the spacious hall, arranging gratuitous lectures upon various brauches of natural history, by men especially qualified to give valuable information, and to awaken interest anong the teachers for whose particular advantage they were given."

At the clove of the last lecture, the teachers unamoung pated resolutions expersive of their recognition of the generous action of the society, thanking the lecturers wamly and especially the Rev. R. C. Waterston. for the interest he hat manitested in the surecess of the intellectual entertainments to which they had been invited.

On the 5th day of April, 1865, the President amnounced the death of Dr. William J. Walker, which event took place at Newport, R. I., on the $2 d$ inst. He remarked upon the great interest Dr. Wallier harl shown in our welfure, and offered the following resolution, which was passed unanimously:

"Resolved, That the Boston Society of Natural History recognize in the death of Dr. William Johnson Walker the loss of their greatest benefactor, and in view of his munificent gifts to this society and his heneficent aid to the cause of education and science, we would ever hold his name in honorable and grateful remembrance."

A motion was made at this meeting significant of the anxious feelings that pervaded the public mind at this important crisis in our country's experience. 'The rebel army under Lee had just heen forced from Richmond and was heing pursued hy Gencral Grant with all the forces at his disposal. Everybody was in hourly expectation of decisive news, and too much excited to calmly consider ordinary matters.

Dr. Augustus A. Gould therefore moved: "'lhat in view of the absorbing interests of the hour in national aftars, the Socicty arjourn, and hold an informal mecting for the expression of sentiment."

'This motion was passed, and the Society as such adjoumed. An informul meeting then followed, and hrief ardreses were marle on the subject that agritater all minds, by Drs. Wyman, Gould and Jeffries, Prof. Chadbourne, and Messrs. Ross and Bouvé.

Of the great benefactor of the Society, concerning whom action was taken by it as mentioned above, the following notice is presented:

\section{Dr. William Johnson WaLker.}

Dr. William Johnson Walker was born March 15th, 1789, at Charlestown, Mass. His father. Major 'Timothy Wallier, was a prominent citizen of the town, and came originally from Burlington, Mass., where he, ns well as his wife, was born. 
Dr. Walker was the second son in a large family of children. He was educated in the

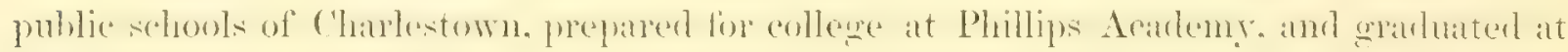
Harvard in the class of 1810 . He studied medicine with Dr. (afterward Governor) John Brooks at Medford, giving particular attention to the branches of physiology and anatomy. While yet a student, he won the prize of the Boylston Medical Committee at IIarvard College for an essay on Hydrocephalus, in 1813.

Graduating the same year at the Massachusetts Medical College, he sailed for France and entered the Paris hospitals, where he found unusual opportunities for study and practice on account of the scarcity of French students, caused by the rigid conscriptions of Napoleon. He had the advantage of being under the instruction of many of the ablest French surgeons of the time, and subsequently was a pupil of Sir Astley Cooper in London, where he spent six months in the hospitals. 'Ihen, returning home, he entered upon the practice of his profession in Charlestown, and soon established his reputation as a very able practitioner. IIe was appointed physician to the Massachusetts State Prison and consulting surgeon to the Miasirhusetts General IIopital. Ite pratetived in Charlestown about thirty years, but finally withdrew from his profession, and moved to Boston. 'This course was looked upon by his numerous patients with the greatest disappointment and sorrow, as he had devoted himself to them with the utmost faithfulness and kindness, and was universally beloved by all whom he had occasion to care for professionally, more especially by those who were poor and helpless.

Although probably while he practised, he had no superior in surgery, yet he was among his contemporaries quite unpopular as a man, owing to his marked peculiarities. But with all this, hel was very lind toward young physicians, and was much consulted by them. He had an extensive experience as a medical instructor, and was very successful. His well known accurate knowledge of anatomy and careful investigation into the natural history of disease, caused him to be widely looked up to, and his pupils were numerous.

Upon removing to Boston, he interested himself in financial and business matters, especially in manufactures and railroads, and from his great shrewdness in investments, rather than in speculations, rapidly amassed a large fortune, which he no sooner obtained than he set himself to expend in the most enlightened and generous manner. He gave away during his lifetime very great sums to various of the educational institutions of his native State and at his death left still larger amounts for such noble purposes. He was a most munificent friend to the Society of Natural History. The amounts of money which he gave outright and willed to the Society are elsewhese summed up in detail, and it is only necessary here to say that without his magnificent generosity, the Society would have been to-day in far different circumstances from those in which it finds itself; owing as it does in great measure to him the building in which is its home. It can never forget its great obligations to him, and will hold his memory in grateful remembrance.

Dr. Walker died in Newport, R. I., whither he had removed the latter part of his life, on the 2d of April, 1865. He had married in 1817, Eliza Hurd, daughter of Joseph Hurd of Charlestown. By her he had eight children, five of whom, with the widow, survived him.

On the 15th day of April a special meeting of the Council was held for the purpose of hearing a statement from the executors of the will of the late Dr. Wiliian J. Walker relit- 

. 


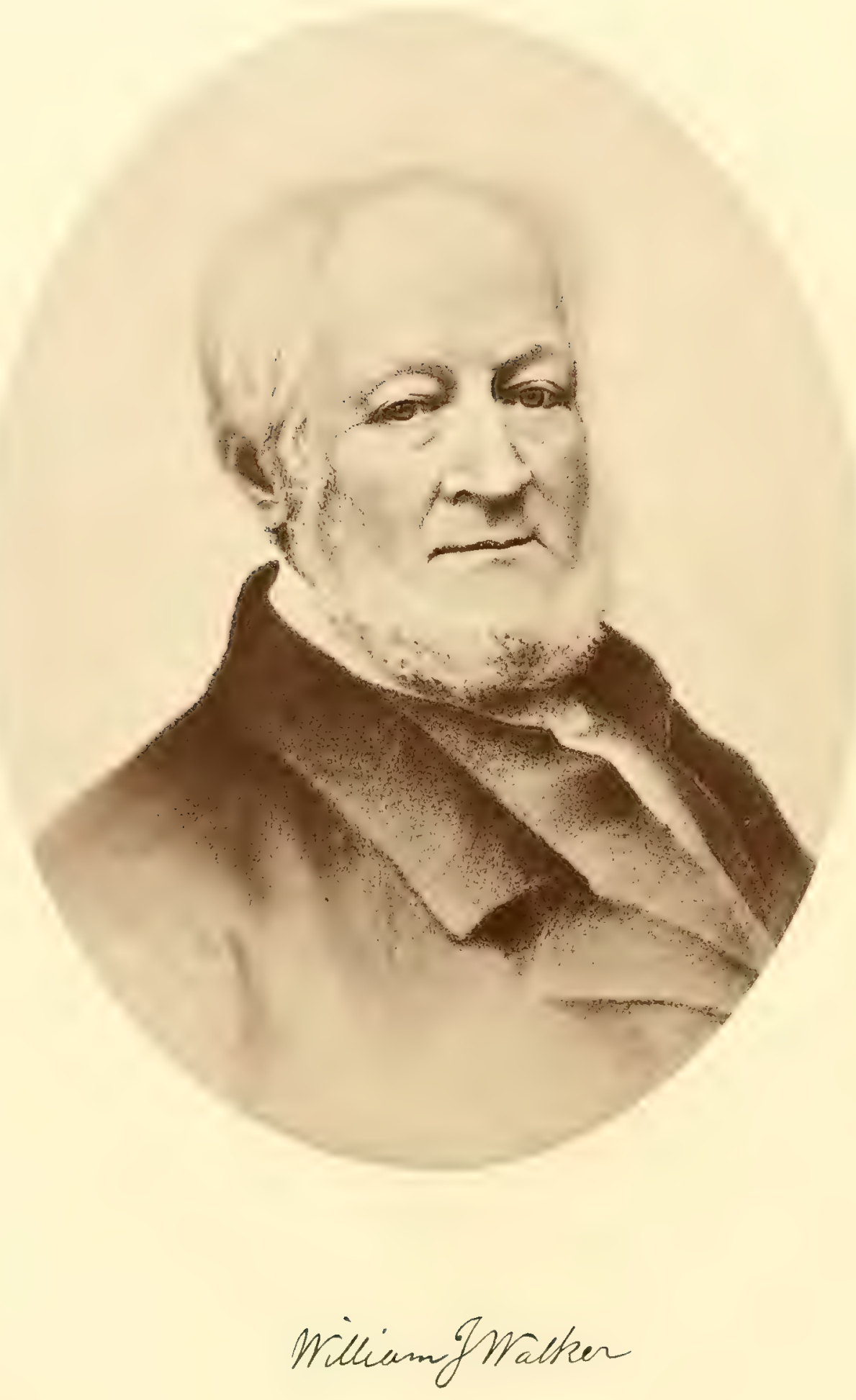


ative to the provisions of that instrument, and to take such action as might be necessary to see that the purposes of Dr. Walker were carried into effect.

The Treasurer, Mr. Bouvé, who was also one of the executors, read a statement of some of the provisions of the will, and gave some account of the property, by which it ap-

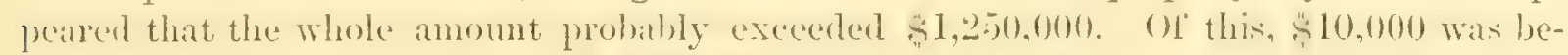
queathed to the Redwood Library, $\$ 26,500$ in valrious sums to friendis, ant there were annuities to be paid out of the estate amounting to $\$ 1,280$ during the lives of certain inclividuals mentioned. To his family was left $\$ 200,000)$, and to the Boston society of Natural II istory, the Massachusetts Institute of Techologry, Amherst Collegre and Tufts Collegre, the remainder of his estate in equal proportions.

It wats also provided that if his children, to whom the 8200,000 was left, die childless, then this amount also should be divided between the residuary legatees.

It was also stated by Mr. Bouvé that Mr. Wheeler, one of the executors, and a friend of the heirs, had asked in their behalf that the four residuary lengitees would consent to the further parment to them of $8: 3010,0001$ from the estate without conditions. Ife gave reasons why he thought this request had better be promptly complied with, and wished action taken upon the proposition whether the Society, as one of the four residuary legatees, would consent to such payment. If this were done, and the others concurred in it, each would soon receive from $\$ 175,000$ to $\$ 180,000$, with a fitir prospect that this would at some time be increased to $\$ 200,000$, whereas if it were not done, the whole sum might be lost in litigation, or much lessened after years of strife, of which there was imminent danger.

Following this statement by Mr. Bouvé, a motion was made that he be authorized to act for the Society with full porvers. Upon his suggestion, however, that it would be better to have parties selected for the purpose who were not also executors of the will, Dr. Gould and Prof. Rogrers were appointed, and authorized by an mimimous vote to make such settlement on behalf of the society with the executor's and the heirs-att-law of the late Dr. William J. Walker, as they should see proper.

The ammual meeting of the Society was held on May 34 . The report of the retiring Treasurer, Mr. Bouvé, who declined re-election, was in substance as follows:

That as Treasurer of the general account of the Society, he had on hand at the begiuning of the year, . . . . . . . . . . . . . . • .

And that he had received since, including amount borrowed of the Courtis fund and return of amounts loaned, . . . . . . . . . . . . . . 115,432.32

And that he had paid on account of new building and furniture.

Joumal and Proceerlinge, . . . . . . . . . . . . . . .

General expenses, . . . . . . . . . . . . .

Cabinet, . . . . . . . . . . . . . . . . .

Library, . . . . . . . . . . . . . .

Temporary loans, . . . . . . . . . . . .

Investments of Walker fund,

Interent,

Sllowing a balance rhe him of
$\$ 12,527.12$ 129.04 $3,014.38$ 838.32

71.89

$62,010.00$

41,105.00

2.51.x1

8.397 .05 $\$ 119,947.56$ 
As Treasurer of the Conrtis Fund he reported that it consisted of an amount due from

the Society itself, borrowed

and a mortgage note of

$\$ 8,339.71$

$3,000.00$

As Treasurer of the Bulfinch Street Estate he reported receipts anounting to • \$ \$1.073.00

And expenditures of . . . . . . . . . . . . . . . . . . . 341.39

Showing a balance on hand of . . . . . . . . . . . . . \$731.61

As Treasurer of the Walker fund, he reported receipts amounting to . . . . . \$1,226.97

And expenditures of . . . . . . . . . . . . . 1,050.02

Showing a balance of . . . . . . . . . . . . . \$ $\$ 14695$

The balances in his hands belonging to the Bulfinch Estate and Walker fund amount(id to. S.T.

Balance due him on general appropriations, . . . . . . . . . . 397.05

Actual balance in his hands of all the accounts rendered, . . . . . . . \$481.51

He presented estimates of the value of the property belonging to the Society at different times for purposes of comparison; in May, 1862, the value was $\$ 85,001.49$; in May, 1863, \$133,497.80; in May, 1864, $\$ 14 \%, 512.47$; at the present time, $\$ 167,881.51$.

These estimates included the buildings and furniture, but not the library or the cabinet.

In retiring, the Treasurer said he would not undertake to estimate the value of our property, in the estate of our late benefactor, Dr. Wm. J. Walker. It was sufficient for him to know that in resigning the office of Treasurer. he left to his successor the pleasing task of showing on the next amniversary, means of usefulness beyond what the most sanguine expectations could have looked for.

On behalf of the Building Committee. Mr. Bouve amounced that the full cost of the new building, including commissions for architectural services, but not including the cares, had been $\$ 94,393.80$, and that the cases had cost $\$ 10,003.36$, making the total amount expented $8104.3: 4.16$, a result with which the Society had reason to be gratified, considering that such a structure with the cases would have cost much more if the construction had been delayed, by reason of the greatly enhanced prices of material and lahor. With this report presented as a final one, the committee asked the Society to aceept the building and discharge them from further duty, which was done with warm thanks.

By the Custodian's report it appeared that much work had been done in the several departments towards perfecting the arrangencent of the specimens and adopting means for the salfety of such as were perishable. Not without great regret, howerer, did the members learn of the extent of the injury done to the collections by the ravages of insects, and of the absolute unfitness of the cases throughout the building for the preservation of the specimens from dust and destructive vermin. Already had it become apparent that there yet would have to be a large outlay in substituting other cases before the treasures of the cabinet could be regarded as secure. It had not been recognized when those now in use were constructed, that they should be made practically air tight in order to render them suitable for what they were designed.

The Library now contained 11.191 rolumes and pamphlets. The additions through the year had been 1319, or between 11 and 12 per cent. The greater part of the increase was stated to have come from exchange with kindred institutions. 
The Botanical department had had during the year an accession of ahout 1800 New England plants, the bequest of Mr. C. A. Shurtleff, and over 1200 Creman plants from Col. Joseph Howland.

The Geological and Palacontological department had receiver in exchange a series of casts of large animals from Prof. Warl, a collection of fossils from the Andes presented by Dr. Winslow, and a natural cast in Red Sandstone of the bones of one of the animals that probably made impressions upon the rocks of the Connecticut river.

The most important and interesting addition to the collection during the year, was the cast of the Meratherium presented by the late Joshua Bates of London, and which had been mounted on a platform in the eastern part of the main hall. This was done by Mr. Sceva with artistic skill, under the superintendence of Dr. Janes C. White, and it is believed in a posture consonimt with what the character and habits of the minnal required. The whole collection of the department was stated to consist of about g..5) specimens.

The Mineralogical collection was reported to have undergone a thorough revision during the year. The specimens suitable for exhibition and arranged upon the shelves, numbered about fifteen hundred.

The department of Comparative Anatomy and Minmmals had received an accession of eighty-four specimens in all, including seventeen skins of mammals. Slicletons of the white whale, porpoise and dromedary had been set up, and much work done by the Curittor, in making sections of skulls representing the various orders of mammalia. The Curator again called attention to the unsafe condition of the skins in his department.

The Ethological department had received from many donors, prineipally Commorlore Charles Stewart, Dr. C. F. Winslow, Mr. E. A. Brigham, Mrs. James Phillips, and the Smithsonian Institution, articles from Jipan, Siam, California, M[exico, and from localities in Massachusetts, all of which had been placed in the collection.

The Onithological department was represented to be in goon condition, but the Curator complained sadly of the unsuitableness and imperfect construction of the cases.

The Oölogical collection had heen increased by donations from Dr. Henry Bryant, Dr. A. S. Packard, Jr., John R. Willis, Erc., of IIalifix, and Dr. Chas. T. Jackicon, in all numbering forty-five specimens.

The Conchological department har received a donation from Dr. IIenry Bryant, of a collection of shells from Cape St. Lucas, and from Dr. Guntlach of a series of Cuban shells identified by him.

The Herpetological department was reported as containing about five hundred species, half of which had been identified and arranged for exhibition, the others remained unarranged for want of bottles, alcohol, \&c.

The Ichthyological department had received many additions, the donors being Prof. F. Poey of Havana, the Lyceum of Natural IIistory of Williams College, Dr. II. Bryant, the late C. A. Shurtleff, Mr. S. M. Buck, MIr. W. A. Nason. MIr. W. M. Dall, Mr. E. T. Snow, Mr. II. C. Whitten, Dr. C. F. Winslow, Dr. B. S. Shaw, MIr. David Pulsifer, and the Curator, F. W. Putnam.

The department of the Radiata had received donations from Dr. II. I. Bowditch, Dr. Samuel Knceland, John B. Willis, Est., Dr. A. S. Packard, Jr., and the Essex Institute of Salem. The Echinoderms had heen fully catalogued and arranged, with the exception of 


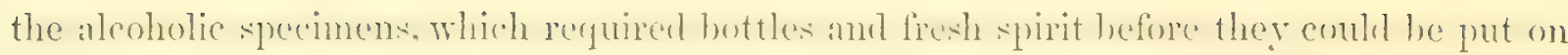
exhibition.

To the collection of Crustacea a large number of specimens had been added during the year.

The collection of the Microsopieal department remainerl about as before reported, but few additions having been made to it.

It was sad to learn what indeed had been partially known before, that a large part of

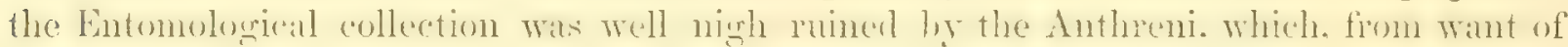
secure cases and continuous care, had been able to attack the specimens and accomplish

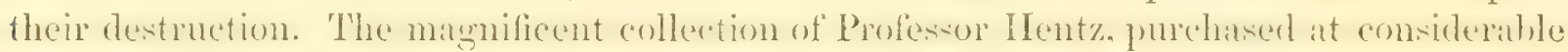
cost many rears since thromgh private sulscription, and being then altowether the fincst in country, might be said to be entirely destroyed, inasmuch as not one-fiftieth part of the whole remained fit to serve the student for purposes of comparison and identification, much less to place on exhibition. The same could be said of all the old collections presented to the Society by Dr. Gould, Dr. Harris and others.

How forcibly in this statement is brought to mind the truth often alluded to in these pages, that it is worse than useless to form linge collections of perishable objects mlesis the nealls are at hand to command the accommolation and the umremitting care and watchfulness necessary for their preservation.

The late collection of Dr. Harris, purchased and presented to the Society by several sentlemen after his death, and that of the late C. A. Shurtleff, which cane to the society by herpest, were reported to be in far condition. These were receiving proper attention, and a large number had been put upon exhibition.

'The whole number of specimens of every kind added to the cabinet during the year, the Curator stated to be 21,155, of which half were insects, the bequest of Mr. C. A. Shurtleff.

The very efficient Curator of Botany, Mr. Charles J. Sprague, much to the regret of every member of the Society, resigned his office at the annual meeting, after a long service of twelve years, during which time, he had brought order out of disorder, so far as the herbarium of the department was concenert, and accomplished an amount of work in iclentifying, arranging and poisoning the plants, of incaleulable value to the society, and such as few persons in active business could have found time to do.

The thanks of the Society were unanimously voted to him, and also to the retiring 'Treasurer for their services in its behalf.

At the election of officers, Folward Pickering was chosen Treasurer, in place of Thomas T. Bonvé; Thomas T. Bouvé Curator of Mineralogry in place of William 'T. Brigham; and IIorace Mamn Curator of Botany in place of Charles J. sprague. 'The office of Custodian was left vacant, Mr. Seudder declining to act longer as such. In the August following, Dr. A. S. Packard, Jr., was appointed by the Council Acting Custodian.

In ()etoles of this year, Dr. Ienry Brynt announced his intention of presenting to the

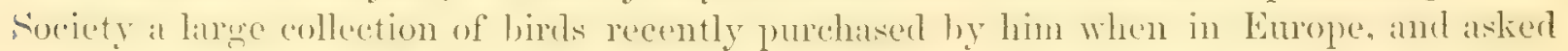

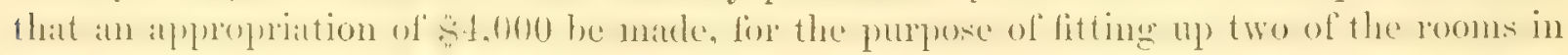
the second story for their reception. This was voted, and a committee consisting of Dr. 
Bryant and Dr. J. C. White, was appointed to attend to the proper construction of the cases.

The collection, which was purchased by Dr. Bryant of Count Iafresnaye de Falaise for the purpose of presentation to the Society, was the largest and most valuable private.one in Europe. It contained nearly 9,000 specimens, all finely mounted, and from 4,500 to 5,000 species. Of these, 700 to 800 were from North and South America, many heing type specimens described by the Count himself, an able ornithologist..

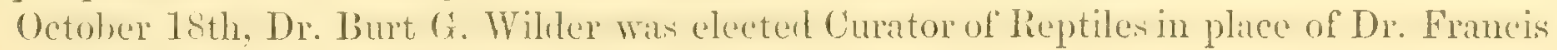
H. Brown, who had resigned at the previous meeting.

A special meeting of the Society was called to consider the subject of creating the office of Director of the society. Whese luty it should be to alminister the aftairs of the Musem and Library, with the intention of inviting Dr. Jeffries Wyman to take such oflice.

With great unanimity of feeling and action it was voted to invite Dr. Wyman to fill

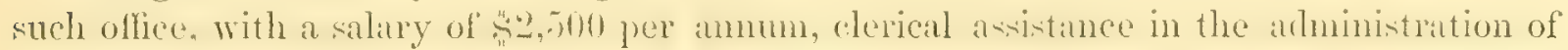
the Library and such scientific assistance as might be necessary. To the great regret of all the members, Dr. Wyman, after much consideration, declined to accept the position tendered him. The office designed for him was not therefore created.

In December, the Treasurer announced the reception by him of the first instalment of the Walker berpest, amounting to $\$ 100,0010$ in various storks, and that it harl now become the duty of the 'Trustees to assume the management of this property.

1866. From the report of the Acting Custodian, Dr. Packard, made at the annual meeting in May, we learn that there were twenty stated meetings of the Society, and eight of the Microscopical section. These had been well attended, and the communications presented were of an interesting and instructive character. Forty-four Resident and eleven Corresponding Members had been elected.

The society had again resumed publicution, after having onited to issuc any of its Proceedings for a year, and not having continued its Journal beyond Volume VII, printed in 18tig. In resuming pullication it was thomght hest to change the form of the Jommal from octavo to quarto, and also to change the title to "Memoirs." It was also decided not to furnish the Proceedings to members free of cost, as hitherto, the state of the Treasury not warranting it. The first part of Volume $I$ of the Memoirs, and nearly one half of Volume $\mathrm{X}$ of the Proceerlings, including the records of the meeting held in 1 stit and 1865, were mentioned as having been issued.

The Treasurer's report for the year showed that there had been an excess of expenditure over receipts, not including borrowed money, of $32,590.19$. The anount expended, however, included $\$ 5,030.61$, the cost of fitting up rooms with cases for the Ornithological collection.

The Librarian reported an accession of 981 volumes, parts of volumes and pamphlets, of which 707 had been received in exchange for our publications. He stated that the Library now contained 7622 volumes, 2097 parts of volumes, and 2162 pamphlets.

The Curator of Microscopy stated that the collection was in good preservation, though not in such order as it should be. Donations had been received from Dr. S. A. Bemis, Dr. C. F. Winslow, and Messis. C. G. Bush and J. S. Melvin. 
The meetings of the Fection had been well attended, with artvantage to its members and to the Society.

The Curator of Comparative Anatomy reported the addition to his department of 2 skeletons, 10 parts of skeletons, 20 skulls, 4 skins of mammals, 5 mammals in spirit, and

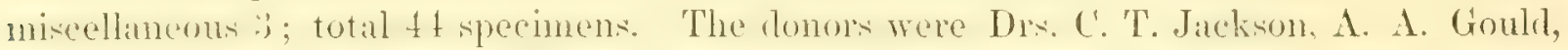
A. S. Packard, Jr., H. Bryant, B. J. Jeffries, S. Kneeland, and Messrs. H. Mann, C. A. Kirkpatrick, J. K. Warren, and the Boston Milling and Manuficturinge ('ompany.

The specimens belonging to the department were represented to be in good order with the exception of the slins.

The Curator of Ornithology reported the collection in good order. He stated that the Lafrewalye collection. hefore mentioned as purehased by him for the society arrived safely in the autumn of the previous year, and upon being unpacked had been found in perfect condition. He himself had personally superintended the packing while in France. The whole number of specimens received had been found to be 8,656 .

The Curator of Ichthyology reported valuable donations to the department from the Smithsonian Intitution. of it sperimens of North American fi-hes; from Dr. A. S. Packard, Jr., of 10 species comprising about 100 specimen- Labrador fishes, and from the Curator of about 40 species comprising 1000 specimens from Lake Erie, and about 20 specimens from Dr. B. S. Shaw, Messrs. C. J. Spratgue, W. II. Dall. J. S. Lewis, Simnel IIubbard, R. C. Greenleaf and Caleb Cooke. The latter presented a fine specimen of the rare Leptocephalus gracilis Storer, one of six collected by him on Nahant beach.

To the Entomological Cabinet about (601) specimens had heen added, the principal donors

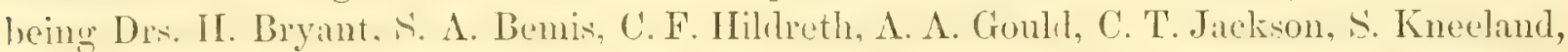
Jr., C. F. Winslow, Messrs: A. R. Grote, Samuel Hubbard, S. H. Scudder and Prof. J. L. Smith.

To the collection of Crustacea 440 specimens had been added. Of these, 50 species, comprising about, 240 specimens, represented the Crustacean fauma of Labrador, and 25 species, comprising 80 specimens, that of Maine. The Worms, now united with the Crustacea in the department, incluted 5.5 species, of which 30, comprising 115 specimens, were from the coast of Labrator; and 14, comprising bij specimens, from Maine, had been obtained by the Curator.

The donors to the department of Crustacea and Worms, were Drs. A. S. Packard Jr., B. S. Hihaw, 1. A. Gould; Messr.s. E. R. Mayo, Samuel Hubbard, C. Stodder, F. G. Sanborn, C. C. Sheafe; and Captain E. Smith.

The Conchological department had received about 1,500 specimens, many of them of great value, the donor's being Dr. A. S. Packird, Jr., Dr. Gundlach, Dr. Henry Bryant, Dr. A. Chapin, Dr. C. T. Jackson and Mr. A. Coolidge.

The department of the Radiata han received from the Essex Institute 10 species, from

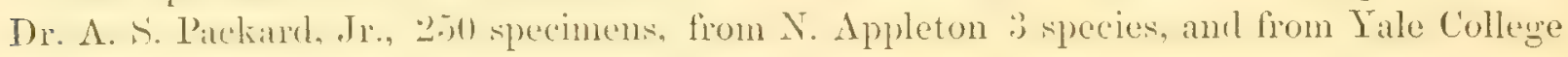
in exchange 59 specimens, comprising 34 species.

The Curator of Mineralogy reported the whole number of specimens on exhibition to be about 2,000. The department had received donations from Drs. C. T. Jackson, Henry Bryant. A. S. Patckird, Jr., the A gaisiz Natural Inistory Society, Prof. Jeffries Wyman, and Messrs. G. P. Huntington and W. H. Dall. 
The department of Botany had received very valuille donations of mosses and lichens from the former Curator, C. J. Spritgue, Evq., comprining about 500 species. Specimens had also been presented by Drs. C. Pickering, C. F. Winslow, A. S. Packard, Jr., S. Kneelannd, Jr., and MIess.s. Gumning, E. R. MIayo, II. M. MIcIntire, William Nelson and S. Wells, Jr.

The Curator of Iterpetology reported 69 additions to the department during the year, the donors being Drs. A. S. Packard, Jr., S. Kneeland, Jr., C. F. Winslow, and Messrs. S. Hinckley, F. Andernach, D. White, and Captain Barber.

The Ethmological department had received a few domations from Dr. H. Bryant, A. E. L. Dillaway and Horace MeMurtrie.

To the Oölogical department there had been no additions.

In June, the sad intelligence of the death of Prof. Henry D. Rogers of Glasgow was received.

Henry Darwin Rogers was born at Philadelphia, in 1809. He early became interested in scientific pursuits, and while still quite young engaged as State Geologist of Pemnsylvania in an extended and very thorough survey of that State. His great work on the geology of Penn:ylvania, subsequently published, placed him at once in the front rank of American geologists, and his later heport on the Geology of New Jersey was a valuable contribution to science.

IIis eminent attainments led to his heing invited, in 185\%, to take the chair of Regius Professor of Geologry and Natural History in the University of Glastow, Scotland. IIe accepted this position, which he filled to the time of his death, which took place on his return from a visit to his native land, at his residence. Shawlands, near Glawgow, May 29th, 1866, in the fifty-eighth year of his age. He was a brother of Professor William B. Rogers, and for several years was a resident member of the Society; while so, manifesting much interest in its welfare. Valuable communications were frequently made by him, reports of which may be found in the Proceedings.

In September a special meeting of the Society was called upon the occasion of the death of one of its founders and most eminent members, Dr. Augustus A. Gould. This event was amnounced by the President, and a committee, consisting of the President, Thomas T. Bouvé and S. II. Scudder, was appointerl to report a suitalle address upon the occasion. A vote was unanimously passed that the Society attend the funeral, and four members were appointed to act as pall-bearers in comection with those appointed by the Suffolk District Medical Society. 'The four were the President, Dr. C. T. Jackson, Mr. George B. Emerson, and Mr. C. K. Dillaway. The services were at the Rowe Street Baptist Chureh, of which he was a member, and were attended by a large concourse of friends.

$\Lambda$ the regular meeting on Sept. 19th, on behalf of the committee appointed at the special meeting the President read the following notice:

"Dr. Augustus Addison Gould, for many years one of the Vice-Presidents of this Society, died at his home on the morning of the 15th day of September. By this sad and sudtem event, the Society loses one of its most honored and respected associates, and science a disinterested and truthful worker. From the beginning of our existence to the day on which he died, his hand was never weary in our service. Through many years we have leaned on him for his wise counsel; his thought and labor more than any other have helped 
us in our progress, and it is to his name and fame at home and abroad, that we are very largely indebted for what we most prize in our own. It is not we alone that suffer from his death. Ilis interests were broad and catholic and embraced whatever was good and excellent, and his helping hand was not withdrawn whenever sought, whether in behalf of the interests of science, education or humanity. The loss to these will be truly great. For all his disinterestedness he was not without his reward. 'The profession of which he was so distinguisherl an ornament ghanly bestowed upon him its highest grifts, and the community of which he was so worthy a member gave love and honor for his many graces of character and for his work in life so full of christian excellenee. With hearl aml hand still husy and with a heart still earnest in his chosen work and still warm in all his relations to friends and kindred, it was God's will that he should pass away. The Society would express its gratitude for the example of his life, and offers its deepest sympathy to those to whose hearts his death brings so much sorrow."

Dr. Wyman then stated that a more full notice of the scientific labors of Dr. Gould would be presented by the committee at a later meeting.

Dr. C. 'T. Jackson followed with remarks upon Dr. Gould's character and work, passing in review the various stages of his scientific career; and Mr. C. K. Dillaway read an interesting antohography of him which hat been written in 1850, and which he had in his possession as secretary of his college class.

It was then voted that a copy of the notice of the committee be furnished to the press, and that out of respect to the memory of our lamented friend and associate the Society adjourn without the transaction of business or the hearing of scientific papers.

A considerable portion of the obituary notice of Dr. Gould, prepared by Dr. Wyman in behalf of the committee and published in the Proceedings of the Society, Volume IX, page 188 , is here given:

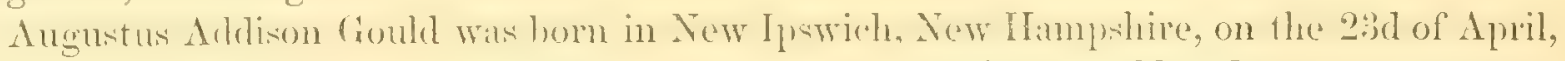
1805. His early life was passed there, and as soon as he was old and strong enough to labor, the larger part of the year was given to his father's farm, and the rest to the common school. At the are of fifteen he took the whole charge of the furm; nevertheless a part of the year was devoted to study, and some progress was made in the classics. By the careful husbanding of the odds and ends of time and a year's teaching at an academy, he was prepared to enter college, and entered at Cambridge in 1821. With his college life came a struggle, the forerunner of many such by which his strength was to be tried. He had alreary come to know something of the barrier which limited means had put between himself and the things he aspired to, and now this assumed larger proportions, such as to most persons would have been disheartening. College duties and exercises demanded his time, nevertheless his education must be paid for, and he must do largely towards earning the means; and so by strict economy, by performing various duties for which indigent students received compensation, and also by hard work in vacations and on those days which others gave to relaxation, he says he at length fought his way through, and attained to respectable rank.

In college he was noted anong his classmates for industry, and it was there, too, that his taste for natural history began to show itself. He became familiar with the most of our mative plants and to the end of life never lost his love for them. After leaving college, he 


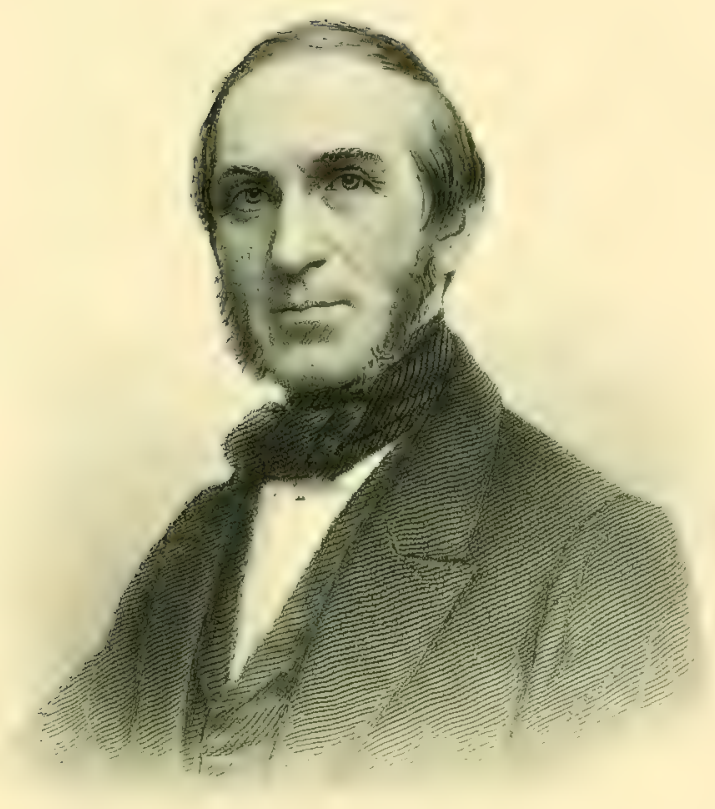

- Mugnistus a ti' Gould, 

held the office of private tutor in Maryland, and at the same time began the study of medicine. The rest of his pupilage was passed in Boston, and the last year of it at the Masischusetts General Hospital as house sturlent. He was graluated in merlicine in 18.30 , and at once heran the practice of his profescion, having given grood grounts to his friends for experting future eninence. But his strugestes with poverty were not yet ended. Until his profession could yield him a support, he was obliged to go out of it, to cam the necessaries of life. 'To this and he undertook burdensome taskis; one of them, the cataloguing ancl classification of the fifty thousand pamphlets in the library of the Beston Atheñum, was Herculean, as any one may see who will take the trouble to look over the four large folio volumes he wrote out, monuments of his patient industry and handiwork, and for which he got only a pitiful return.

The study of natural history was nearer to his heart than all other pursuits, and to that he could alway turn, and did, whenever he could command a few spare hours or moments to do so. As a matter of course, he became a member of this Society. 'This was soon after its organization, and to the time he died he labored for us without stint. When his sturlies began to assume a methodical shape, his first investigations were in the class of insects, of which, at one time, he had a larese collection. Anong his first pulslished work, was a monograph on the Cicindelae of Massachusetts, printed in $15: 34$, and in 1510 he published an accomnt of the American species of shells belonging to the genus Pupa, in regard to which he found much confusion. These shells are very small, and Mr. Say, who manel all the species previonsly described, gave no figures, and consecuently naturalists fell into error. "I have received from our best conchologists," Dr. Grould says, "a single species under four of the names that Mr. Say applied to as many different species." Dr. Goukd then points out how, hy the use of the mieroscope, and a careful study of their minuter details, the classification of them might be improved. The palper was illustrated hy about thirty figures carefully drawn by himself, with the aid of the microscope.

In 1841, he read before this society a paper entitled "Results of an examination of the species of shells of Massachusetts, and of their geographical distribution." 'This is the more noteworthy since the geographical distribution of animals had at that time attracted but little attention, and none amongst us. Now it involves one of the rost important zoölogical problems.

Dr. Gould also points out in this paper the influence of shore outlines, and shows from a comparison of species, that Cape Cod, which stretches out into the sea in a curved clirection some forty or fifty miles, forms to some species an impassable barrier. Of two hundred and three species, eighty do not pisis to the south, and thirty have not been found to the north. In the same paper he calls attention to the importance of the fact that certain species appear and lisappear sudilenly, and of the necessity, in order to construct a correct catalogue of the shells of any region, to extend observations through a series of years, a consideration by which many naturalists, even of the present day, might profit.

One of the first result of the joint action of the members of this Society, and of which it has more reason to be proud than any other, was the part taken by some of them in the series of admirable reports on the natural history of the state, presented to the General Court in compliance with a lerishative enactment. 'The report on the Invertebrate Animals, excepting insects, was by Dr. Gould. 
The Molluses were Dr. Gould's farorite subject for study and his attention was chiefly given to them. Up to this time, few if any attempts had been made to give as complete a zoölogical survey as practicable of any particular region of the United States. As regards

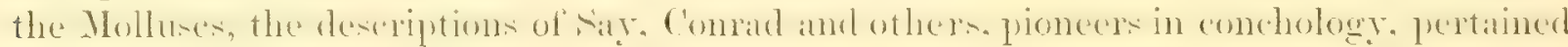
more to the Middle and Western States, than to New England. Their writings were fragmentary and scattered through the narratives of travels, journals of science, and even newspapers. It was no small labor, therefore, to become acquainted, merely as a preparation for his task, with the writings of his predecessors. 'To make his report as complete as posible, and to accertain what changes in the classification of Molluscresecent important progress growing out of the study of them would indicate, he opened correspondence for information and exchanges with European naturalists interested in the same branch of study, who obligingly and courteonsly lent their atid, and out of this correrpondtence grew up long continued friendships.

The report fills a volume of nearly four hundred pages, illustrated by more than two

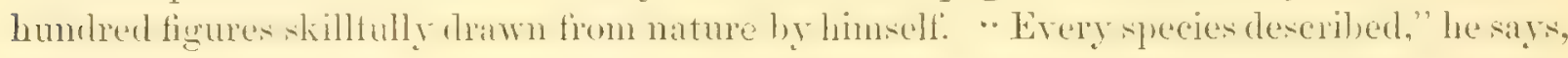
"indeed almost every species mentioned, has passed under my own eye. The descriptions of species previously known, have been written anew, partly that they be more minute in particulars, and partly with the hope of using language somewhat less technical than is ordinarily employed by scientific men." The number of species described was about two hundeed and serenty-live of Mollusces and nearly one hundred of C'rustaceans and Ridiates.

As a contribution to zoölogical science, this report gave him an honorable name and an eminent position among the naturalists of Europe and America,

Dr. Gould edited the admirable work entitled "The Terrestrial Air-breathing Molluscs of the Cinited States," prepared. hut left unfinished at the time of his death, hy his intimate friend, Dr. Amos Binney, formerly the respected president of this society, and whose name we hold in grateful remembrance, not only for lis contributions to science, but for the munificent bequest which fills so large a space on the shelves of our library.

In 1848 he was associated with Prof. Agassiz in the preparation of the Principles of Zijologry.

His largest and most inportant contribution to natural history was the description of the shell: of the [nited states Gixploring Expedition. This wats prepred under circumstances somewhat embarassing. The collection was not made by himself, but by the late Capt. Joseph P. Couthony, Well rementrered as one of the most zealons and aletive members of this Society. Capt. Couthouy had drawn up full notes on the external characters of the soft parts, habits, geographical description, and other important points. Before the voyage was completed he left the expedition, but the notes and collections were sent to Washing ton. 'The former were unaccountably lost, and no trace of them was found. 'The collections, when they came into the hands of the Navy Department, were repacked by incompetent hands, the arrangement of them disturbed, lahels in many cases lost, and the whole thrown more or less into confusion. Dr. Gould was called upon to save this wreck, but in accepting the task was obliged to submit to various arbitrary restrictions, and to leave undone many things he deemed of much importance.

The Otia Conchologica was the last of his printed volumes, but this was merely a reprint in a comdensed form of the deseriptions of species of shells previonsly published 
separately in different works. Besides the works alrendy mentioned, there is a long catalogue of communications made to the Boston Society of Natural History, which may be referred to as showing that he did not allow himself to become a mere specialist, but kept his mind awake to the relation of individual forms to higher and more general truths.

We must not forigt that Dr. Gould was a member of the medical profession, and that his time was of necessity chiefly devoted to this, while the scientific labors we have been considering were the yield of spare moments made useful. He was an active member of the medical societies of this city and of the State, and held oflices of trust in them. The

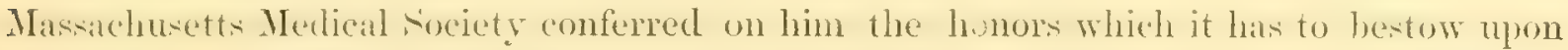
its fellows. In 1s.jis he delivered the annul address, which wals marked for the sommelness of it: views and the charateristic clearness and elegance with which they were presented Ile took for his text the artrice of Harvey to the hoyal Collere of Physichins of Lomrlon when he founded the annual oration which bears his name, and in which, among other things, he enjoins upon the oritor "an exhortation to the members to study and search out the secrets of nature by the way of experiment." Dr. Gould was elected president of the Medical Society, and his term of office encled within a few monthe of his death. IIe was for sereral years one of the physicins of the Massachnsetts General Hospital, was an efficient member of the Boston Society for Medical Improvement, where he often communicated valuable observations, and took an active part in its discussions. He labored much and long in preparing the vital statistics of the State from the official returns.

At one of the meetings of the National Academy of Sciences, of which he was a member, he presenten an important paper on the distribution of certain diseases, erpecially consumption, in reference to the hygienic choice of a location for the cure of invalid soldiers.

As a citizen, Dr. Gould made a principle of going out of the ordinary routine of life to lend a helping hand wherever it was desired, and he could. He served the public in many capacities; in the religious society of which he was from early life a member, and in the public schools, where he took an active interest in all attempts to improve the ways and means of instruction. He from time to time gave public lectures, and although in this capacity he could not he said to be lorilliunt or highly arcomplisherl, yet his mostentatious manner and simplicity, his knowledge of his subject and hearty interest in it, always gained him attentive listeners, who went away instructed.

In lis temperament he was genial, and drew friends aromed him, retaining the old and attracting the new. If came to the social gathering with joyous face and kindly feelings. Inis love for natural scenery was gemuine and hearty, and whatever peronal enjoyment came from this source, it was always enhanced if others partook of it with him. There are too many naturalists who stand in the presence of nature all their days, but see her not. To them the world offers nothing but the forms they would technically deseribe and arrange in their cabinets. Take away this object and all becomes a waste, for they are neither warmed nor enlivened by the world around them. Not so with our associate; no one toiled more industrionsly than he over individual forms and specific reseriptions; but all this aside, every aspect of nature touched him to the innermost. Those who have been intinate with him know how his face would light up while in the presence of the least as well as of the greatent natural objects! the flower of a day, or the sturdy tree 
that had known its centuries of life, the quiet or the grander scenes of the world. His emotions were not those of an enthusiast, but rather came of a clear perception and calm contemplation of the things around him, and of his own responsive nature.

His life, all too poorly and inadequately represented in this sketch, was throughout a consistent one, and to the end each day was full to the round. He was still endeavoring to improve what had been done before, and looking forward to the accomplishment of new and better ends, when suddenly it was closed. He had been less well than usual; on the afternoon of September 14th, 1866, he manifested the usual symptoms of an attack of Asiatic cholera, soon after fell into a state of collapse, and on the following morning just before the dawn, he died.

The office of Custodian, it will be remembererl, was created in May 1864, and Mr. Samuel H. Scudder was elected to fill it. He held it one year only, when it became vacant and remained so until October $3 d$ of this year, Dr. Packard performing its duties temporarily by appointment of the Comcil. The great importance of having the constant services of some able person who would at the same time perform the special duties appertaining to this office and also act as Lilmarian and Liecording Secretiry, led the Committee on nominations to propose Mr. Sculler again to the fociety for Custorlian, and he was elected. An arrangement was then made by the Council with him, by which it wat angreed that he should give his undivided attention to the wants of the society throughout the year, excepting such time as might be allowed him for a vacation of from one to two months, and that he should perform all duties of Custodian, Librarian and fiecording Secretary. The Society to provide permanent assistance in the Library department as heretofore, and also in the special manipulation of specimens which require immediate care for their preservation.

Before the death of our lamented associate, Dr. Gould, there had been some negotiation with him for the purchase of his cabinet of shells, as he had expressed a willingness to part with it to the Society at a price much less than he would be willing to accept from any other party, as he desired it should finally have a place in the Museum. The only reaton why the purchase hard not loeen consummated was that Dr. Gould first wished to put it in goorl order, and to properly label all the specimens. This work he did not find leisure to do, and consequently much time of an able conchologist would be required to perform it. It was deemed therefore inexpedient to compete with others who offered more than the Society could afford to pay. This was more to be regretted because of its having been the eollection of one so much revered by the members, and becante it contained many type specimens of species described by him. A large number of the species were, however, already in our cabinet.

In November, the Society, upon motion of Dr. J. C. White, passed resolutions expressing appreciation of the value of the gift of Mr. Pealody to IIarvard Lniversity for the fomdiation of a Museum and Profercorship of American Archacology and Ethnology, and great pleasure in the recognition on his part of the relation of this society to that important department of Science in the selection of its President for one of the Trustees of the munificent endowment made by him.

By the terms of this donation, the President of the Society is, ex-officio, one of the Trustees. 
At the meeting of Nov. 21, Mr. Thos. T. Bouré was elected Vice-President of the Society, to fill the vacancy made by the death of Dr. Gould.

A Section of Entonology was formerl at the neeting of Nov. 2Sth. Members of the Society only to he members of the section, the President of the Society to he ex-officio President of the rection, and the Recorting Fecretary of the Society Recording Fecretary of the section. The meetings to be held on the evening of the 4th Wednesday of each month.

1867. In January of this year, Palaentology, which had been combined with Geology, was raised to a separate department, and Thomas T. Bouvé was made its Curator. Wm. T. Brigham was chosen Curator of Geology.

Early in this year the Society was the recipient of a munificent bequest from Miss Sarah P. Pratt. This larly had long been interested in the study of conchologr, and had marle a large collection of shells olutaned from every quarter of the globe, many of them being of rare species. The whole calsinet, consisting of more than 4000 specimens, was berpueathed to the society, together with her library and works on conchology, and the sum of s. 10.000 to be held as a fund for the increase and maintenance of the rlepartinent devoted to that science.

As with individuals, so with institutions, events often succeed each other of the most diverse character, those of a joyful following such as are painful, and the reverse. Not a week had clapsed after the announcement of the beruent above-mentioner, when news was received of the death of one of the great benefactors of the Society, Dr. Henry Bryant. At a meeting held on the 20th of Fehruary, after some remark's by Mr. Bouvé expressive of the feeling that pervaded and sadrlened all hearts, a committee consisting of Dr.s. S. L. Abbot and J. C. White, and J. E. Cabot, Esq., was appointed to prepare a notice of the professional and scientific life of the deceased.

In behalf of this committee, Dr. S. L. Abbot subsequently read hefore the Society a very full and discriminating notice of Dr. Bryant, which appearer in Vol. XI of the published Proceedings, and from which the following brief abstract is given.

Dr. IIenry Bryant was born in Boston, May 12, 1500. Me entered I Invard University in 1836, graduated in 1840, then studied medicine in the Tremont Medicat Feliool, from which he received the degree of Doctor of Merlicine in 1s1:3. IIe afterwarls studied in Paris and subsequently joined the French army in Africa as a volunteer surgeon, in which capacity he served during the winter campagn of 1846. He returned home in 1847 and commenced the practice of his profuscion. His health failing him he was obliged to grive up practice, and he ever after devoted himself to the study of Ornithologr, which harl always been a favorite pursuit with him. The precarious state of his health compelled him to take a great deal of outdoor exercise, and his active, energetic temperanent led him often to the most distant parts of the country for the purpose of collecting specimens of Ornithology. He had a singular power of endurance, and invalid as he was, a most stoical indifference to considerations of personal comfort on these expeditions, which sometimes lasted for months, many of them being out of the country among the West India Islands.

On the outbreak of the civil war, he offered himself as a candidate for the position of assistant surgeon in the regular arny, and after a very severe eximination was accepted, but subsequently was appointed surgeon of the zoth regiment Massachusetts Volunteers, being promoted to be brigade surgeon, in September, 1861. IIe was afterwards Med- 
ical Director in the army of General Shields, in the Shenandoah Valley. While engaged in this service he was severely hurt by his horse falling upon him, and confined to his bed for a portion of the many months during which he suffered from his injuries. Yet, althongh it was even thought for a while that he might have to undergo amputation of his foot, he continued on duty all the time, and in the midst of his sufferings organized the military hospitals at Winchester. In August, 1862, he took charge of the Clifflburn hospital near Washington, and in December, 1862, was ordered to assume the care and operation of the Lincoln hospital. in Wishington, which under his thorough and most exeetlent administration, was regarded as a model hospital. But close confinement and excessive mental labor broke down his health and strength, and he was eventually compelled in May, 1863, to resign his commission. His faithful service in his country's cause very nearly cost him his life, so utterly exhausted had he become by unremitting work.

After the close of the war he went to Europe twice, and in December, 1866, visited Porto Rico. For some weeks he travelled about the island, suffering extremely from ill health all the time, hut working at his firsorite pursuits uninternittingly, mil the lis of February, when he was taken with what proved to be his last violent attack of illness, while on an expedition in the country, and died the next day.

Dr. Bryant was no common man. He was peculiar in certain ways, but much of this peculiarity arose undoubtedly from his ill health and bodily suffering. His thoroughness, intellectual honesty, and faithfulness to duty were marked characteristics through his whole career. He was as true as steel, through and through genuine, and with far more kindliness and wider sympathy than he ever liked to show. Dr. Bryant was elected a member of this Society in November, 1841. He served as Cabinet-keeper for a part of 1843, and took charge in 1855 of the Entomological collection for a time. From 1854 to the time of his death, he was Curator of Ornithology.

He was a most munificent friend to the Museum of the Society, his donations embracing reptiles, fishes, crustaceous insects, minerals and birds. His most valuable gift was the magnificent Lafresnaye collection of birds, which amounted to mearly nime thousand fine specimens. Extensive pecuniary aid was also received from him whenever the purchase of collections was desirable for the museum.

Dr. Bryant married in 1848, Miss Elizabeth B. Sohier, daughter of W. D. Sohier, Esq., of Boston.

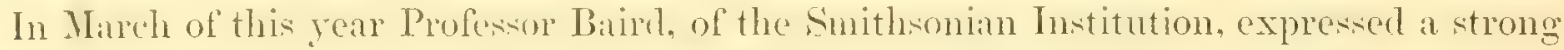
desire that the fociety should cooiperate with that institution in extending the system of explorations undertaken by it, in return for which the Society should receive the first choice among the duplicates of oljects of natural history. He desired a yearly appropriation of $\$ 500$.

There was a unanimous wish on the part of the Council to act favorably upon the proposition which resulted in a vote: "That the sum of $\$ 500$ be placed at the disposal of the

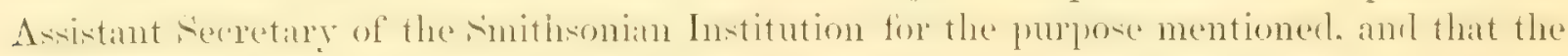
Secretary intimate the desire of the Council to assist further at a future time."

April. The necessity of refraining from any account of the scientific papers brought before the Society or of the discussions that took plare at the meetings, in order to confine this sketch within reasonable limits, has often preventerl even a reference to much of 
public interest. There was one subject, however, brought before the meeting of April 17th of this year, which is here mentioned, because there is yet quite as much diversity of opinion upon it as at that time, and some readers may be interested to learn where to look for the views of two distinguished members of the Society whose investigations led them to diametrically opposite conclusions. 'This subject was practically what was likely to be the result of the introduction here of the common house-sparrow of Europe. Dr. Charles Pickering ahly presented his irleas on the fuestion, maintaining that nothing hut evil would follow their increase ; that its habits were of the most destructive character and that it had been the enemy of mankind for five thousand years. Dr. Thomas M. Brewer, on the

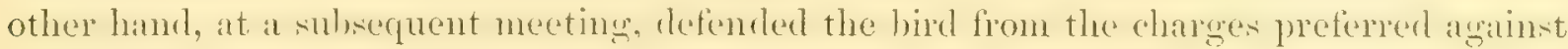
it, claimed that it had already accomplished much good in the destruction of insects, and cited the authority of many authors in proof of its great usefulness. The papers presented were meagrely reported, but may be found in the eleventh volume of the Proceedings.

The establishment of the Museum of American Archaeology and Ethnology at Cam-

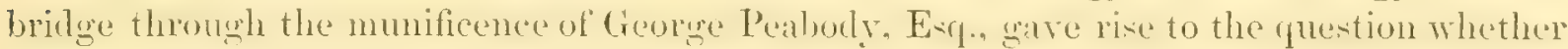
it was worth while for the Society to continue its department of Ethnology. After much consideration it was judged best to abolish it, and this was accordingly done by a vote of the Council. The collection was afterwark presented to the Peaborly Minemm of Ancriean Archaeology and Ethnology at Cambridge.

Some of the rooms of the Museum which had remained unfinished were at this time prepared for use by laying the floors and building cases. The lecture room was also finished.

Just before the annual meeting the Society was the recipient of a bequest from a former patron, Mr. Paschal P. Pope, of $\$ 20,000$. This large sum was most gratefully received. Mr. Pope had been a succesful merchant and had acemulited a laroe fortune, the wreater portion of which he berueathed to vilrious pulslic institutions. Ite hat the reputation of being a highly honorable man, and died at an advanced age, much respected by all who knew him.

At the annual meeting, May 1st, the Custodian reported that there were now held every week meetings of the general Society, or of the sections of Entomology and Microscopy. There had heen thirty-five meetings of the society; forty-fone communications on various branches of natural history had heen rearl; forty-one Resilent, seven Corresponting, and four Honorary Members elected. 'The first number of the Memoirs in quarto had been issued, and the first ruarter of Tolume XI of the Proceding comploted. The museum had been open one hundred and one days, with an average of three hundred and twelve visitors per diem.

The Library had increased in size, mainly through the efforts made to effect exchanges for our publications by the Librarian when in Europe. It will perhaps surprise readers to learn that an amount equivalent to 400,000 octaro parges of the publications of the foretety had been sent away during the year.

The donations to the cabinet had been less numerous than usual. Including the bequest of Miss Pratt, there had been added 20,202 specimens. Among these and worthy of mention, was a valuable collection of volcanic specimens fiom the Hewailan Islands. pre sented by Mr. Wm. T. Brigham. 
The Treasurer's report showed receipts from all sources, of $\$ 13,281.23$, and expenditures of $\$ 11,022.93$.

There had been no essays offered in competition for the annual Walker prize.

The chinges in the officers at the election were in $A$ phens. IIyat being chosen Curator of Palacontologry in place of Thomats T. Bouré; J. Eliot Calsot, Curator of Ornithologry, in place of Dr. Irenry Bryant, deceased ; and Edward s. Murse, Curator of Conchology, in place of Alpheus Hyatt.

At a meeting in June of this year, the death of Thomas Bulfinch, long a member of the Society, and for six years its Recording Secretary, was amounced by the Rev. R. C. Waterston, with appropriate remarks upon his life and character.

Mr. Bulfunch was deservedly held in great esteem by all the members of the Society. IIis filthful derotion to his duty, his genial manner, his loving and sympathetic nature, all conspired to endear him to them and to malie his losis deeply felt, particularly to those with whom he was associated in the work of the Society in earlier years.

On motion of Dr. C. T. Jackson, Mr. Waterston was requested to prepare a fitting tribnte to the memory of the departed for the Procentings which he did by an exceedingly interesting sketch of his life and character, and which may be found in Volume XI. The following is a brief abstract from this paper.

Thomas Bulfinch was born July 14th, 1796, at Newton, Mass. He was the second son of Charles Bulfinch, whose reputation as an architect at that dia stood among the highest in the profesion. Gratuating from IIarrarel Lniversity in $18 \mathrm{l}$ t. he numbered anomg his classmates Prescott the historian, the Rev. Dr. Greenwood and the Rev. Dr. Lamson. After leaving college, Mr. Bulfinch was chosen usher in the Latin School. Here he remainer fourteen months, when fexling no very strong inclination for either of the professions, he entered upon the active duties of a business life. Two years were thus spent in Buston. when he was led to remore to Washington, where his father was engaged as architect in the erection of the Capitol. Here he rexiled seren years, when in 1825 he returned to Boston, entering into a copartuership with his relative. Mr. Joseph Coolidge. This connection continued until 1832, when he was chosen to a responsible position in the Merchant's Bank, which he held until his death, a period of thirty years.

Devoted as he was to the duties devolving upon him as a man of business, he had tastes aside from this, yet nore congenial to his nature, which he followed with quiet but persistent enthusiasm. Thus it was that he became an active member of the Society and its Recording Secretary.

His mind balanced for a time between science and literature. There was that in both which awakened his admiration and exerted an attractive power. At length, literature gained the ascendancy, though science always continued to possess a peculiar charm.

In 1.5.j he published the Dge of Falle, in which he relates the stories of Mythologry, Greek and Roman, in a way to render them attractive to the lovers of general literature.

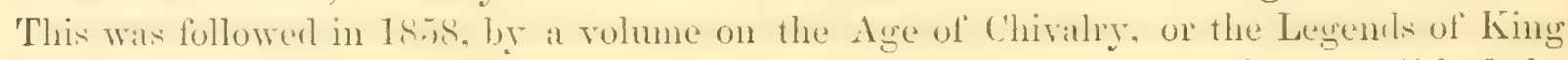
Arthur, presenting in the same spirit pictures of a later age. In 1863 he published the Legends of Charlemagne, or the Romance of the Middle Ages.

There were other works of less importance, all of which were the fruit of care, written in hours rescued from the pressure of active business. 
Mr. Bulfinch d.avter much time to social intercourse among a circle of firiends who highly appreciated his worth. Monlest he wats, hut not morose, for a mole grenial and grenerous nature could not be found. Keenly sensitive to the gentle sympathies of life, he truly lived in his affections, and never was he weary of extending kindness, not only to companions and friends who valued his friendship, but to the needy and tried, youngr or old, whoever they might be.

Much nore might be sairl of Mr. Bulfinch, but it is not needed. His excellences were familiar to all. Ilis quiet and respectful manner, his gentlemanly comsideration, his conseientions fidelity, his love of leaming, his Christian trust and faith; these were an indispensable part of himself.

Members of the Society and other visitor: to the Library will recall with pleasure, not ummixed with salnesi, a very agreathle young lady of great excellence who at this period and for several years was an assistant in the Library. Her beauty of person, her vivacity, hor pleasing ardress and manners, combined with her intelligence and readiness to meet all the requirements of her position, made her a general fitvorite. She wats the raughter of the Rev. Mr. Blaikie, a Presbyterian clergyman of the city. She left the service of the Society because of her marriage, and soon after died, to the great grief of all who had been associated with her.

It was quite apparent hefore the close of this year that further assistance than what had hitherto been employed was required in the Museum, il the collections were to be preserved from ruin. It was therefore voted in Council to employ Mr. F. G. Sanborn as assistant in the MIseum from the lst of January, to act under the direction of the Custodian:

Two courses of lectures were authorized by the Society for the winter of 1867-8. One griven by Edward S. Morse, consisting of six on the natural history of the mollusca, or shell fish, on Siturday afternoons, commeneed Dec. Tth, and continued weekly. The other by Horace Miamn, consisting of eight, on structural hotany, commenced March 7 th. The lecturers were paid $\$ 25$ for each lecture, and an admission fee of $\$ 1$ for the course was charged those who attended. The cost of giving these lectures exceeded the amount received from the sale of tickets, $\$ 114.37$.

1868. From the Report of the Custodian, made at the annual meeting in May, we learn how much had been done during the year towards preparing unfinished portions of the building for use. Besides the lecture room, in which for the first time the annual mecting was held, the rear library room had been furnished for use and was now occupied, two exhibition rooms fitted up, and new cases built for several of the departments. A printing office lad been prepared in the basement, and the Janitor's apartments remodelled.

There had been twenty general meetings of the Society, seven of the Section of Microscopy, and nine of that of Entomology. The average attendance at the general meetings was about forty, and at each of the sections about nine.

There had been eighty-six communications made, of which fifty-six were at the greneral meetings of the Society, the others being at meetings of the Sections. One Honorary, two Corresponding, and forty Resident Members had been elected. 
There hat heen issued of the pullieations of the society. the second and third parts of the Memoirs, and the fourth and concluding part of the first volume was in press. 'The eleventh volume of the Proceedings had been completed, and a new edition of six signatures of the eighth volume printed.

Great additions to the Museum had been made during the year, the most important being a very fine series of humming birds, embracing over 700 specimens, com-

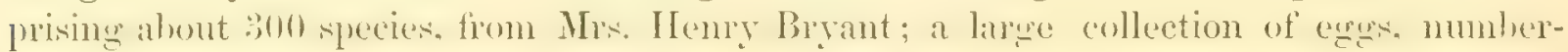

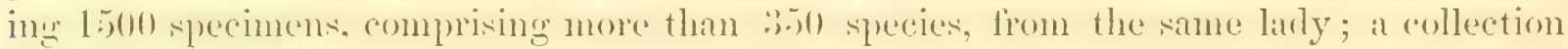
of more than 2000 Guatemalan birds purchased; a large donation of several thousand rock and fosil specinens from Dr. C. 'T. Jackion; and a collection of skulls from Arizona, given by Dr. J. IV. Merriam.

The collections of the several departments were reported generally to be in good condition. thongh that of Entomology hat suflured sone injury fiom the ravages of Anthreni.

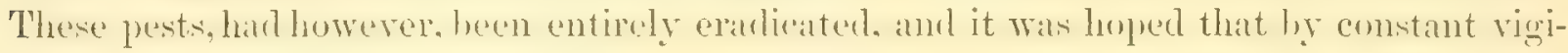
lance they would be prevented from doing farther harm. Some remarks made by the Custodian before closing his report, are worthy of notice. He said, in referring to the growth of the Society: "The small collections received at first had a certain charm of novelty which attriteted the lovers of nature, and were undoulstedly a principal means of sustaining the interest of its members; hut the times have greatly changerl for while the number of members who give their personal attention to the care of the collections is scarcely preater thin in former years, the collections have increased an humbed fold, and the ratio of increase does not seem to lessen. Now it is manifestly impossible for such a state of things to continue, if the Musem is to maintain an appearance creditable to the name and honor of the Society. On this account several years ago a regular Custodian was appointed for the sume reason the Comncil found it necesiary, within a few months, to engage the services of a regular assistant, whose labors have been already felt in every department. On similar grounds, I believe that in a short time, the services of many assistants will be indispensable; inded I an convinced that at least one or two more are needed at the present moment, and that from this time forward the greater part of the work of the Mustum should be done by resular silarierl asistants, under the direction of the officers."

The report of the Treastrer showed, including all sources of income available for general purposes, an excess of expenditures over receipts of $\$ 208.05$.

Dr. J. C. White, notwithstanling urgent solicitation that he would continue to hold the position in which he hat finthully served the Society, positively declined reablection. IIe had heen Curator of the department of Mammals ame Comparative Mnatomy for nearly ten years, devoting a considerable portion of his time to laborious work upon the collection, not a small part of which his wise and skilful management saved from destruction. Ile was, moreover, very ellicient in obtaining specincus for the department, thus contributing to its large increase.

At the election, all the officers were re-chosen excepting Dr. White. No one was substituted in his place.

It may be remembered by the reader that in 1837 permission had been given to members to bring with them to the meetings ladies of their families and such others as they 
might choose to invite, and that the temporary effect of this at leat had been bencficial, leading to a better attendance on the part of the members themselves. As stated subsequently. there is no record of the permision having been withliawn, lunt as latlies ceased to atteml. it is fair to presume they did so from lack of interest in the proceerlings. 'Twenty years hald clipherl, and agrain an effort was made to have their attendance. The Council at a meeting in . Tune of this year roted: "That members have permission to invite ladies to attend the second meeting of each month."

Previous to the summer recess the Lecture Committee of the Council reported in favor of having three courses of lectures during the next succeeding winter, one course of four by Dr. Jeffies on the anatomy of the eye, one by Mr. W. H. Niles, of ten or twelve on the Geolorical Ifistory of North America, and one by Mr. Wm. T. Brighiam on some hotanical subject. The report was accepted and adopted.

In ()ctober Dr. Burt Gr. Willer resigned his position as Curator of IIerpetologr, loeing about to remove from the State.

November 1Sth, Dr. Chas. F. Folkom was elected Curator of Comparative Anatomy, and J. A. Allen Curator of Herpetology.

In November the death of Mr. Uctavius Pickerings, long a member of the Society and one of the fomders of the Linnacan, was amnounced with appropriate remarks hy the Presilent.

$\Delta$ the next meeting, the Society was called upon to deplore the loss of another member by the death of Mr. Horace Mimn, the youngest offieer in its service, Curator of Botany. The remarks upon the occasion by Mr. Wm. T. Brigham, his intimate friend, were very appropriate and the following particulars are abstracted from them.

In his earliest youth Mr. Mimn imbibed a love of nature from the teachings of his father, and in opposition to the arlvice of many of his friends who wished him to have a collegiate education, entered the school of Prof. Agawiz as a student of zoijlogy and geology. He Was at the same time deeply interested in botany, and it was fiom this taste that his friendship with the spealier commenced. In company they visited the IIawailan Istands and studied the peculiar flora of that group. Soon after his return to Cimbrilge, Mr. Mimn was appointed assistant to Dr. Grity, and subsequently instructor in botany in Harvard College. Besides the work of arranging the Thayer Herbarium, and of airling Dr. Gray both in preparing material for his classes, and in revising prof for his two botanical manuals, he worked steadily in spare lours, often late into the night, upon his Hawaian collections, many thousand specimens of which were deternined, labelled and distributed. IIis enumeration of Hawailan plants, which has given him a good botanical reputation, was published by the American Academy of Arts and Sciences, of which body he was elected a fellow on the very evening of his death. As the result of these Inawain explorations, five new genera and sixty-seven new species were added to the flora.

Early in October, Mr. Minn yielded to the solicitations of his fivends, and recigned his college classes; but the worst forms of pulmonary complaint had gone too far to be checked; and although at tines his recovery was hoped for, he continued to fail rapidly, and passed away on the evening of November 11th.

1869. Mr. Edward S. Morse, then residing in Salem, was engaged to work on the shells of the Pratt collection, for three alternate days of each week through the year, the other three days being devoted to work on the collections of the Peabody Academy. 
A new arrangement was also made with the Custodian, by which he was to give his undivided attention to the duties of the po-ition through the year, with the exception of five weeks between the first of Miy and the first of November, and three weeks between the first of November and the first of May, he to have permanent assistance in the Library and Museum.

Upon application to the City Government, two police officers were detailed for duty at the Museum on public days of exhibition.

An idol obtained in purchasing other objects from Guatemala was, by rote of the Couneil, presented to the Peabody Museum. Authority was also obtained from the Marine Society by which the antiquities formerly given by that institution were transferred to the same Museum.

The Trustees of the Society, after calling attention to the greatly increased expenses of the year, and mentioning the necessity arising therefrom to sell stocks to the amount of $\$ 4,000$ to meet indebtedness, made a protest against such large expenditures.

The Council voted that authors should be allowed twenty-five copies of their productions from the publications of the Society, free of expense.

From the Report of the Custodian at the ammal meeting in May, and doings of the Society for the year ending Nay, 1869, may he learned as usual much of interest. There had been twenty general meetings of the Society, ten of the Section of Entomology, and six of Microscopy. At the general meetings, the average attendance of members hat been thinty-three, of the Section of Fntomology twelve, and of that of Microscopy eight. The mumber of ladies who attended in response to the invitation of the Society, of course is not inciuded. Very few, however, arailed themselves of the opportunity offered. One humdred and five scientific communications had been presented by forty-nine persons, of which the titles are given in the report. Five Corresponding and twenty-nine Resident Hembers had been elected during the year.

There had been three courses of lectures given during the winter and spring; the first by Dr. B. Joy Jeffier, consisted of four upon Optieal Phenomena, the second by Mr. W. II. Niles, of twelve upon the Geologieal History of North America, and the third by Mr. Wm. T. Brigham, of twelve upon Plant Life. The first, not having been advertised and the sulject being of limited interest, failed to draw many hearers, the second was attended by an average of sixty-ix persons, the third by an audience averaging about ninety-nine persons. The last course was in the evening, which may in part account for the greater attendance.

The Custodian dwelt with satisfiction upon the large amount of the Society's publications, as well he might if only their extent and value were considered, and the conceruent cost ignored. When, howerer, it is learned that what was done in this way led to an excess of expenditures over receipts to the amount of thourinds of dollars and obliged the 'Trustees of the property of the society to encruach largely upon its capital to meet this excess, one is inclined to judge there was little cause for exultation. A few years of such lavish expenditure could have had but one result.

The isine from the press of the publications of the Society hat been double that of any previons year, being not less than an edpuivalent of one thousand two hundred and twentynine octavo pages. The twelfth volume of Proceedings begun a year previous, had 
reacherl the four hundredth page. The amnual report, the first issue of the publication called the "Anmual." a physical map of North America, the fourth part of the Mimoirs, and the first volume of the Occancional papers hat all appeared, the latter containing the Entomological correspondence of the late Dr. T. W. IIarri, embellished with steel plates and rood cuts.

It will be remembered that in 1867 , an appropriation of 500 was made by the Council towark the expenses of some explorations to be made unter the anspices of the simithsonian Institution, with the understanding that the seciety should receive the first choice among the duplicates of olpjects of Natural History collected by the explorers. Under this arrangement the Society received within the first year a series of birds from the Island of socorro, the natural history of which had been explored by Col. Ciravon. The specimens received were of pereuliar interest, being nearly all new to science, and distinct from the species of the neighboring continent, or of islands nearer the coast. Only a portion of the sum appropriated having been called for, the Comncil again voterl in 186s, that $\quad 200$ should be at the disposal of the smithsonian Institntion for further explorations by Col. Grayson in Central America, and $\$ 100$ towards an expedition to be made by Prof. Sumichrast in Tehumtepec, the $\$ 300$ being what remainerl mexpended of the original appropriation.

During the past year, after leaving the Island of Socorro, Col. Grayson had been studying the natural history of the Sierra Madre, from which, however, returns had not been made of objects obtained by him. A fine collection of birds had, nevertheless, been presented to the society, by Prof. Henry of the Smithronian Institution, collected at Costa Rica.

From the Isthmus of Tehuantepec, for the exploration of which by Prof. Sumichrast the Society contributed $\$ 100$, news had been received of a very promising character. The Smithonian Institution had already received specimens which hat been distributed for identification.

One of our own members, Mr. W. H. Dall, had been employed by the Society for several months selecting specimens from the smithsonian duplicates, partly in return for the contributions made by the Society towards the explorations referred to, and partly as a donation from the Institution.

Already many fossils and mollusks had been received by the Society, and a collection of the nests and eggs of birds was expected to arrive.

The visitors to the Museum had exceeded thirty-six thousand. It had been open to the public one hundred and four days.

In the department of Mammals and Comparative Anatomy, a movement had heen made towards obtaining specimens of all our New England mammals, and to make room for them, the Ethnological cullection was to be removed. A black bear and an antelope, one the donation of Mr. W. T. Adams, the other of the City, had already been received.

The collection of birds had been increased by a donation of twenty-five specimens of the land species of Massachusetts, from Mr. L. L. Thaxter of Newton. Mrs. Bryant had again shown her interest in the Society by the gift of a large and valuable collection of unmounted birds from the West Indies and Central and North America, and from Profexson. Ifenry of the smithsonian Institution, eighty specimens from Costa Ricit haw been received, all labelled by Mr. Lawrence. 
The collection of Nests and Eggs of birds had been entirely rearranged. A statement was mate showing the collection at this time to consist of the engen of seven humbed hirds, of which four hundred were American. A large number of duplicates, valuable for exchange, had been presenterl hy Mrs. Bryant, and about. two humberl and fifty neests and egrgs by the Smithsonian Institution.

The Curators of the departments of Peptiles and Fishes mentioned great deficiences in the representation of Massachusetts species, and in the latter the need of help in order to identify and label the specimens.

The Entomological collection was stated to be in better condition than it had been a year previous, much attention having been given to its improvement and preservation.

In referring to the condition of the department of MIollusks, the Custodian made some remarks of more than temporary value. With the exception, he stated, of work done by the last Curator, there is no evidence of any attention having been bestowed upon the specimens for fifteen years. It was now in a worse condition than it had been years before, showing that gratuitous aid hat proved a failure. The Curator's entire attention hat heen given to the Pratt collection, the arrangement of which would be completed before other work was done in the department.

Of the other collections nothing was said of sufficient importance to repeat here.

The report of the Treasurer was startling. It showed an excess of expenditures over receipts of more than 86,000 , and a diminution in the value of the siociety's property of over $\$ 13,000$. Much of this latter was accounted for by the reduction in the estimated value of the stocks which had been received under the Walker bequest, but it was only too evident that there had not been a due economy exercised in the administration of the husiness of the Society. Well might the Trustees protest as they ditl and well it was, too, that the Council heeded their wanning. The leswon tameht was not lost upon the members, and finally ler to measures tending to prevent, under any ordinary ciremustances, more expense of means than income warranted. Among these was that of requiring from the Trustees at the commencement of each year an extimate of the probiblile receipts from the various sources tabulated, and also one showing what expentitures might be incurred in the different departments based upon such receipts; there being a clear understanding that under no avoidalile cireminstances should there be expended more than the income. This met the hearty approval of all, and the policy adopted hats been faithfully anthered to ever since. It was not, however, intended that the expenditure yet necessary in finishing the rooms of the Museum and in supplying cases should be paid for from the ordinary income. Whatever was done in this way it was expected would necessarily be paid for in part, at least, from the principal of the Society's property. At the meetings of the Council forlowing the general meeting, there was much disen-sion concerning retrenchment, a strong disposition being manifested to reduce expenses within the probable income.

$\Lambda$ t a regular meeting in. June the Rev. Robert C. Waterston reminded the members of the approaching centennial anniversary of the birthday of Humboldt, and suggested the public celebration of it by the Society. He remarked that it was wholly unnecessary in such a presence to speak of Alexander Von Humboldt in order to impart information concarning one whose illustrious reputation in so many departments of knowledge had made his name funiliar over the civilized world. Yet in view of what he had done for science 
by his explorations on this continent, it seemer particularly approprate that a fociety like this should do honor to his memory. He further remarked that there was one among the members, preëminent in science, who had been his pupil and his personal friend, Louis A gassiz, who was specially qualified to speak upon such an occasion. 'That to hear him menof acience and letters from erery part of the combly would glanly assemble to listen and to respond.

Although the matter had not been apparently thought of by any of the members, all present hestrily concureed in the sentiments expresied by Mr. Waterston, recognizing that in the Society thus paying a tribute of respectful homage to one of the noblest of men, it could not but do itself great honor. The proposal therefore met with a hearty response, and the following resolution, offered by Mr. Waterston, was unamimously adopted:

"Resoled, That it is highly derirable that the Boston society of Natural IHistory shouk hold a public celebration of the centennial anniversary of the birth of Alexander Von Humboldt, and that a committee of five be appointed to consider the whole subject and empowered to make all arrangements." The President appointed on this committee the Rev. Robert C. Waterston, Dr. Samuel Kneeland and Mr. Samuel H. Scudder. To these were subserpuently atherl the President, Jeffries Wyman, IIis IIonor the Mayor, N. B. Shurtleff, and Col. T. W. Higginson.

It is due to Mr. Waterston to state that a large part of the work attendant upon the celebration was done by him. That it might be a thorough success and redound to the credit of the Society and the community, he gave up his whole time to it, remaining in the city during the hot summer months, and exerting himself to the utmost that nothing might be left undone that would and to the interest of the occasion. Ile not only arranged for the meeting at which the address was to be delivered, but for a reception in the erening, at which distinguished men should be invited to speak, and he inducent the City Govermment to take part in it and to provide an entertainnent at the expense of the City.

The celcbration which followed on the 1 th of September was in every respect a success, far excededing the anticipations of all who had fitrored it. Probably nowhere throughout the civilized world was the dily more appropriately observed. The adhess hy dealsiz was worthy of the man and the occasion. It was delivered at the Music Hall before an audience which filled every available place in it. Delegates from the leading literary and scientific societies of New Lingland and representatives from the colleges of Yale, Bowdoin, Brown, Dartmonth and Harvard were present, as were likewise His Exeellency the Covernor of the Commonwealth, His Honor the Mayor of the City ant members of both branches of the City Government. President Wyman presided at the meeting.

The evening reception was at Horticultural Hall. A lange and distinguished andience attented it, including inviterl grests from literary and scientilic societies, members of the City Govermment, and many gentlemen interested in the canse of education firon every part of the country. Interesting mementos of Humbohlt, incluling several porthits of him, were placed upon the platform and about the hall. The Rev. Mr. Waterston presided, and after welcoming the delegates from the different societies present and making some appropriate remarks, introduced successively the liev. Frederick II. IIedge, Mr. lialph Wallo Emerson and Prof. E. J. Young, all of whom male interesting aldresices. Anong the portraits exhilsited, was one by Mr. Wight, painterl at Berlin in $185^{\circ} 2$ from life, 
when Humboldt wats eighty-three years of age. It harl heen loaned to the committee for the occasion by the artist. The chairman, calling attention to it, stated that an order had been given to the artist to execute an exact copy. 'This would be unveiled, and if it was found in every respect satisfactory, he, the chairman, would take great pleasure in presenting it on this centennial anniversary to the Boston Society of Natural History. 'The covering was removed and the resemblance was found to be so perfect as to call forth spontaneous applause. A letter from the artist was read giving an account of his personal observation of Humboldt when he was engaged upon his portrait: Accompanying it was an autograph note of Humboldt, which was also presented to the Boston Society of Natural IIistory by the chairman. In behalf of the Society, Dr. Charles 'T. Jackson, Vice-Presiident, accepted the portrait and autograph with expression of thanks. He stated that Humboldt himself had declared that the original by Wight was the best ever painted of him.

Dr. Jackson then gave some pleasant reminiscences of IIumboldt, whom he had often met in Paris at Cuvier's lectures in 183J. He also made some interesting remarks upon his works and character.

The chairman then called upon his Honor the Mayor, who, in responding briefly, said that the City Government, being lexirous of expresing its respert for the memory of Alex-

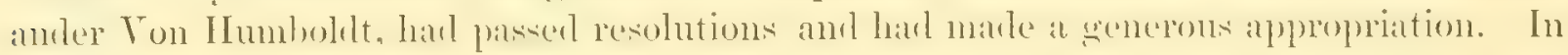
behalf of both branches, he invited all present to partake of a collation prepareel for them in the hall below. The company accepted the invitation and proceeded to the place assigned, where they enjoyed an excellent supper, during which at intervals the Germania band added their enlivening music to the entertainment.

After refreshment at the talles, a poem upon IIumboldt, prepared for the oceasion by Oliver Wendell IIolmes, and another by Mrs. Julia Wart IIowe, were rear. During the evening, several communications from distinguished persons unable to be present, were presented, one from the Hon. Theo. S. Fay, one from Prof. William B. Rogers, one from the Rev. Noah Porter and one from John G. Whittier. The address by Agassiz, with a full aceount of the proceedings at the evening meeting, maty be found in pamphlet form published by the Society.

In Octolyer, Dr. C. F. Folsom resigned his position as Curator of Comparative Anatomy and Mammals.

At a meeting of the Council, held Nov. 17th, it was voted that the net proceeds of the celeluration of the Centemial Amiversary of the birth of IImboldt, together with the money received from the sale of Prof. Agassiz's address previous to Jan. 1, 1870, and the money subscribed at the solicitation of the Society's Committee, be given to the Trustees of the Musem of Companative Zorilogy at IIarvard College, in trust, for the establishment of an endowment under the title of the "Humboldt Scholarship," the income of which should be solely applied, under the direction of the Faculty. toward the maintenance of one or more young and needy persons cheaged in sturly at sad Huseum.

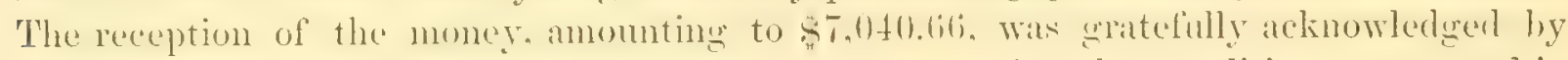
the Trustees of the Inusem of Companative Zoulogy, moler the conditions expressed in the vote of the Council. 
Ifention wals marle in givine an areount of the proceedings at the evening reception on the diay of the ILumboldt celebration, of a fine portrait presenterl her the Rev. Mr. Waterston to the Society.' This may now be seen in the Library of the Museum.

The hearty thanks of the Society were passed to Mr. Waterston not only for the val nable portrait and antorgaph. but for the unflarging energy with which he hat labored for the success of the Humboldt celebration. 'Testimony was borne to the untiring zeal

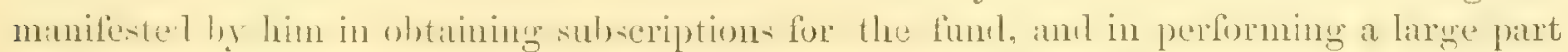
of the work consequent upon the celebration. The Society also expressed its obligations to Prof. Agassiz for his able address, a copy of which was asked for publication. Thanks were also voted to the (Orphens. Musical Association, and to Mr. Carl Kerrahn, for their welcone aid in the performances of the occasion; also to Mr. J. H. Paine, who presided at the organ.

1870. On January 19th, Dr. Thomas Waterman was elected Curator of Comparative Anatomy and Mammals.

At the meeting of April zuth, in view of contemplaterl changes in the administration of the Society, certain alterations were made in the Constitution and By-laws to go into effect on and after the ammual meeting. The most important of these arose from the substitution of Committees for Curators in the care of the Museum.

The Constitution was made to express that the officers of the Society shall consist of a President, two Vice-Presidents, a Corresponding Secretary, a Recording seecretary a Librarian, a Custodian and a Committee of three on each department of the Museum, etc., etc.

The By-laws were so altered as to define that the Committees should be entrusted with the care of the Inserum; that they should be designated for proticular departments at the time of their election, and consist of not more than three members, one of whom should be named lyy the nominating eommittee to act as chairman. The duties mentioned were such as the By-laws previously active expressed for those of the Curators.

Annual meeting. The Custodlian's report gave the following summary of the doings of the Society during the year:

There hat been eighteen general meetings, the average attendance at which har been thirty-two : eight of the section of Entomology, with an average attendance of eleven: and seven of the seetion of Hicroscopy, with an average attendanee of nine. Forty-seven scientific communications had been made by twenty-five persons, all of which had been printed in full or by title in the Proceedings.

One Inonorary, three Corresponding and thirty-nine Rexident Ifembers had heen elected.

Three courses of evening lectures had been arranged for by the Council. One of twelve, entitlerd sketches of Animal Life, by Mr. Eilward s. Morse, delivered in the early part of the season, had an average audience of seventy-six persons; the second, consisting also of twelve, given by Mr. William T. Brigham, entitled The Earth we live on, had an audience areraging ninety-eight prerson; the third, not concluted at the time of the ammul meeting, consisted of four, entitlent Familiar Tallsis about Insects, given by Mr. F. G. Sianborn. The average attendance at these was about sixty.

Of the Publications it was stated that from economical considerations the issue of a large number of the Memoirs had been postponed. Of the Proceedings the twelfth volume had been printed, and a part of the thirteenth. The address of Prof. Agassiz at the recent cele- 
bration of the Ilumbelit ('entenaly, with an accoment of the crening's festivities, forming an octavo pamphlet of one hundred and seven pages, had been also published and distributed.

The Custodian expressed strongly the feeling that a further postponement of activity in this direction could not fuil to be disastrous. Yet there had been sent abroad of parts of Memoirs and of the Journal, of copies of Harris' Correspondence, of the Proceedings, what was equivalent to about two hundred and sixty-five volumes of the Proceedings, and over 200,000 octavo pages. Besides all this the Society had distribited in behalf of the Commonwealth, three hundred copies on the Report of the Invertebrates of Massachusetts, recently published by the State.

'The judicious action of the Legislature, the Custodian remarked, in placing its scientific publications where they will be of the greatest permanent benefit, merits the commendation of all who, like ourselves, are aiming at the widest diffusion of knowledge.

An enumeration of the books in the Library had been recently made. 'They were counted as bound, whether containing more than one volume, as frequently the case, or not; and the parts had been estimated at their proper proportions of the volumes to which they belong, and the pamphlets counted separately. The enumeration therefore gave the number as proportionably smaller than previous estimates. There were found to be 9396 volumes, and 2675 pamphlets. Of these volumes ten hundred and ten were of a general literary character, mostly deposited by "A Republican Institution"; eight hundred and six were botanical; four hundred and fifty-three entomological; four hundred and two geological and mineralogical; five hundred and ten encyclopaedic; six hundred and thirteen upon vertebrates; five hundred and thirty-six upon travels and local fauna, and forty-one hundred and seventy-three journals and publications of Societies.

The Custodian annomced the death of our esteemed coadjutor, Col. A. J. Grayson, to whose explorations it will be recollected the Society contributed in comnection with the Smithsonian Institution. It had been the strong wish of both parties interested, that he should visit the vierra Marlere of Nonth Western Mexied, that he might make there a cinceful investigation of its fauna. He arranged to be there in June, that being considered the most favorable month for his purposes. Prior to that period he visited the Island of Isibella off the coast to sturly the habits of sea lowl during their breeding searon, and there he contracted a malarious disease that led to his death in August.

The anount contributed by the society heing unexpenderl, was returned hy his wile to - the smithonian Institution. By adrice of Prof. Henry, this was transfered by rote of the Comneil to Prof. Sumichrast, to be used in the explorations undertaken by him on the Isthmus of Tehuantepec.

An arrangement had been made by the Custodian with the Secretary of the Smithsonian Institution, by which a large number of unasorted specimens of various chancter Were sent to the society with the understanding that they should he returner in orkterly conclition, compensation for the laber being marle hy a selection from the duplicates for the Cabinet.

The number of visitors to the Museum during the year exceeded forty thousand. It was open to the public one hundred and four days. 'The largest number present on any one day was seven hundred and eighty-one. 
The C'ustorlian reporterl the collections of the different departments of the Society to be in good condition. That of Mammals and Comparative Anatomy had received a stuffed sperimen of the great Antaretice real collerterl in the exploring expedition of Commolore Wilkes. A living opossum and its young had also been received from Dr. C. Kollock of South Carolina, and had been mounted in characteristic attitudes. Other interesting specimens had been received from the Union Street menagerie.

In the Ornithological department, the mounted birds had had special attention, every specimen having been taken down, thoroughly examined, and where necessary treated with benzine and other materials. The cases had all been made as nearly air tight as possible and in fact every possible measure adopted to prevent the further ravages of insects. 'To accomplish this, four or five persons had worked continuously for two months. Donations had been received from the Smithsonian Institution, F. E. Everett, S. Mixter, H. A. Purdie and others.

Quite extensive additions had been made to the collection of nests and egrss, mostly in exchange. To Mr. B. P. Mann and Mr. S. Mixter, the department had been indebted for the presentation of many specimens.

The Entomological collections were reported in better condition than at any time within ten years. Mrs. Stratton, Mr. H. Edwards and others, had presented many specimens, and there had been a valuable accesion from Tehuantepee rollected by Profesion sumichrast.

There hat been considerable work done upon the Reprtiles, and one humberl and fifteen specimens had been added to the collection. A marked deficiency of native species was mentioned, particularly of turtles.

The Fishes, numbering three thousand eight humbed and ninety-six specinens, were reported in good order and mostly identified.

Some work had been done by Mr. S. I. Sinith upon the Crustacen, and the whole collection placed in satisfactory condition.

The Curator of Mollusks reported much progress in mounting the gisteropods of the Pratt collection, and mentioned that a valuable series of British shells had heen received from the Smithsonian Institution, and many specimens from Mr. H. Edwards and others.

The collection of Radiates had been greatly improved, and a large portion of the corals and sponges mounted in an erect position upon black tablets.

The Botanical department had received an important addition in the herbarium of Hon. John Amory Lowell, containing many thousand species carefully labelled, mounted aud catalogued.

By the subscription of some gentlemen, a ring of the bark of a Redwood tree of California had been purchased, measuring forty feet in circumference. This had been mounted under the direction of Mr. Brighnum, the acting Curator, and now forms a conspicuous object in the entrance hall of the Museum.

The arduous task of rearranging and labelling the entire Nineralogical collection had been completed by the Curator, and the whole was now in perfect order. The number of specimens was about 2800 .

Mr. S. II. Scudrler, the Custodian, in presenting the ammul report, took occasion, as this was to be the final one by him, to review somewhat at length the experience of the Society in the past, and to suggest considerations in relation to its future policy. He said that "while some collections need a good deal of revision and many are not yet entirely 
supplied with the miform sytem of labelling lately ardopterl, the Musem is in much better order and in a much safer condition thin it has been at any time since our removal to this building. The Library has increased, and the lectures have proved a success, but in our publications and in the interest of our meetings, we have sadly fallen off."

The Custodian further remarked upon the great importance of the publications of the Society as a means through which the researches of the members might be promptly made known, and the fame which it has fairly won at home and abroad be sustained.

In relation to the Museum, after mentioning its large collections, he expressed the view that, with some exceptions, they embraced sufficient for all the purposes of the Society. That its principal aim should not be to sustain a great museum or an industrial one, but rather seek to maintain first, a popular educational one, in which all and none but the characteristic forms of life and inorganic nature should be displayed, and second, a complete local collection, restricted at widest to our New England flora and fauna. 'To effect this, it was important that more silled labor should be regularly employed, and a man of broad scientific culture placed at the head of the Museum, with its interests alone in charge.

The Custodian then spoke of his endearors to faithfully perform the cluties of his office, and expressed wamly his appreciation of the devotedness of those who had been engatged to assist him in the various departments of the Society's operations.

Upon motion of Mr. F. W. Putnam, who thought something more was due the retiring Custodian than a simple vote of thanks for his services, it was unamimonsly roted that the rules be suspended and Mr. Scudder be made a Life Member of the Society.

The Treasurer's report showed, including all sources of income available for greneral purposes, a balance of receipts over expenditures, of $\$ 160.49$.

The Prize Committee reported through Dr. J. B. S. Jackson, that only one essay had been offered in competition for this year's prize, and this was not deemed worthy of it. They ammonced for the sulvecet of the prize for 1572, "The Darwinian question; its bearings on the development of animal life."

Letters from the President. Dr. Jeflies W wman, at this time in Europe, positively reclining to be a candidate for the office so long held by him, had been received. The Nominating Committee lowever, thinking that he might he induced again to accept the position, asked further time for convideration hefore any action was taken in electing a President. They also arked further time hedore presenting names for the Committees on the derartments of Mammals and Comparative Anatomy, as the Council hard, but a few hours before the meeting. diviled the department of Comparative Anatomy, which hefore cmbraced Minmmals, into two departments. They likewise asked further time hefore nominating the Committee for the department of Microscopy.

The list of officers proposed by them was then presented, the Rev. Joshua A. Swan

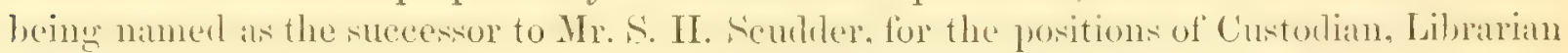
and Recording Secretary. A strong objection was made to the nominee for the former oflice, many present faroring the election of $\mathrm{Mr}$. Alphens Hyatt. A prolonged and very carnest discursion followed, the whole poliey of the society and the comparative merits of the two persons mentioned for the position being athy presented. Those who participated in the discussion were N. S. Shaler, J. B. S. Jackson, J. C. White, E. S. Morse, R. C. 
Greenleaf. F. W. Putman, W. II. Niles, T. II. Brewer. W. T. Brigham, J. D. Runkle and Thomas 'T. Bouvé. Upon balloting, it was found that Mr. Alpheus Hyatt was elected C'ustodian and Mr. swan, Lihnarian and Recording secretary, the majority of the members thus electing two officers to fill the three positions, insteal of one as hitherto. One oljection to this was the lingely increased expense therely incurred, but the result was generally satisfactory.

The Committees chosen for the several departments were as follows:

On Birds.

Thomas M. Brewer, M. D, Samuel Cabot, M. D., J. A. Allen.

On Fishes and Reptiles.

D. Humphreys Storer, M. D.,

F. W. Putnam,

N. E. Atwood.

\section{On Insects.}

F. G. Sanborn,

A. S. Packard, Jr., M. D.,

Ldward Burgess.

On Crustacea and Radiates.

A. S. Packard, Jro, M. D.,

A. E. Verrill,

Alexander Agassiz.
On Nollusks.

Edward S. MIorse,

John Cummings,

Levi L. Thaxter.

On Palaeontology.

W. II. Niles,

N. S. Shaler,

'Thomas 'T. Bouvé.

On Botany.

William 'T. Brigham,

Charles J. Sprague,

J. Amory Lowell.

On Minerals and Geology.

'Thomas 'T. Bouvé,

Charles T. Jackson, M. D.,

William T. Brigham.

The election of Committees for the denartments of Comparative Anatony, Mammals and Microscopy was postponed to allow time for further consideration.

The fourth decade of the existence of the Society was now completed. It had been a period of great events in its history. Its commencement found the country involved in a war which, by rapidly wasting its resources, threatened alike its material prosperity and its progress in art, science and literature. There was sadness in the hearts of men and an mulefined dread of evil pervading their minds, tending to concentrate all thought upon the movements of armies and the tidings of conflict. Thank God, too, there was an unfaltering faith in the final success of the struggle for the nation's integrity, which kept alive hope and encouraged exertion for the advancement of all movements promising future good to the community. 'Thus was it that in the midst of a dreadful civil war the Society wat enabled, through the mutiring derotion of its own member's and by the exertions, the contributions and becuests of many friends, to erect the fine structure that now adorns the city, and to place therein the great collections of natural history that now minister to the delight and the instruction of multitudes.

In referring to the period of the civil war, it may not be amiss to state that besides the members of the society mentioned as having resigned their official powitions in it to enter the service of their country, there were several others who took an active part in the conflict. Among them was one whose great interest in the welfare of our institution for 
many years as shown by his exertions in its behalf when in distant regions, entitles him to respectful notice in these pages. That he died by the hands of the enemy makes it all the more a duty to render a tribute to his memory.

Joseph P. Couthouy was born in Boston, January 6, 1808. He was educated at one of the schools in the town, and when yet a lad, made a voyage in his father's ship. His tastes leading him to prefer a sea life, he applied himself to the calling he had chosen, and became, when old enough, the captain of a vessel.

He early developed a love for science, and had progressed in his studies to such an extent that when the American Exploring Expedition was organized under command of Lieutenant Wilkes, he was appointed one of the scientific corps to accompany it, his specialty being that of Conchology. The expedition sailed from Inampton Roads, Aug. 18th, 1838 , and, although the state of his health obliged him eventually to abandon his share of the enterprise at the Samoan Islands, yet he had already made very valuable collections of shells and illustrated his numerous notes and descriptions concerning the many species obtained, with drawings and colorings which would have been of invaluable assistance to Dr. A. A. Gould, who subsequently published the elaborate report on the shells secured by the expedition, had not these papers been in some unexplained way lost or destroyed when the cases containing the specimens were umpacked after arrival.

Captain Couthouy afterwards went to South America and the islands of the Pacific Ocean, making numberless valuable observations on the natural history of the countries which he visited.

In the year 1854, he was engaged to take command of an expedition to the Bay of Cumana, for the purpose of exploring for the wreck of the Ananish man-of-war sin Pedro, lost there nearly half a century previonsly, which was supposed to have hatd a great anount of treasure on board. After three years spent in an unsuccessful search for this, the vessel returned to the United States, and was lost in a violent smow storm on Cape Cod, the crew being saved with the greatest difficulty.

When the war of the rebellion broke out, Captain Couthouy offered his services to the government. They were at once accepted, and he was placed in command of the U. S. barque "Kingfisher," in which he wats actively engaged against the enemy. Being transferred to the command of the U. S. steamer "Columbia," he joined the blockading sfruatron of the South Atlantic, and upon his ressel being wrecked in a storm at Masonhoro Inlet, he was eaptured and sent as a prisoner of war to Salishury, where he remained three month.s. After being exchanged he was pliced in command of the monitor "() sage" of the Mississippi river spuadron under Admiral Porter, and subseruently, being transferred to the "Chillicothe" of the same squadron, was ordered up the Red River. In this expedition he met his death. On the $3 d$ of April his ship was engaged with a large body of rebel troops on the shore. Captain Conthouy was on deck directing the fire of his gums, when a rebel sharp-shooter on the bank fired at and mortally wounderl him. IIe died the next day, universally regretted by officers and men, and by no one more than the Admiral, who, in a letter to the Secretary of the Navy, bore witness to his zealous, patriotic and estimable character.

Captain Couthouy was a man of rare and varied ability. He was a fine linguist, and spoke with great elegance the Spanish, French, Italian and Portuguese languages. An 
interesting example of the beatuty of his pronumeiation of the Spanish was given the writer by one of his intimate friends. Being in Spain at the time of the Carlist wars, he was repeatedly under suspicion on the part of the officers of the government, who could not believe him to be a foreigner, the purity of his accent and thorough knowledge of the language leading them to think that he must necessarily be a native Spaniard. He had also in the (ontrove of his travels mastered more than one of the unwitten languages of the South Pacific Islands.

He was described by intimate friends and associates as being a man of the utmost fascination of manner, and one whose wide and varied information made him one of the most interesting of companions.

Elected a nember of the Society on the 6th of April, 1836, he was often before it while at home, at the meetings, with communications or remarks relating to facts of scientific interest which had come to his knowledge during his wide-spread investigations abroad. He also, from time to time, presented many specimens to the Society.

His memory should be held in tender regard by the Society, for while, in former years, an active and valued associate, his death in battle in the service of his country added another to the list of those who have passed away, leaving, through faithful work in the cause of science, a lasting lustre on its roll of membership.

Captain Couthouy married Miss Mary G. Wild of Boston. His wife died in 1857, and at the time of his death, in 1864, he had three daughters living. His only son had died previously.

It having been necessary in quite a number of instances during the first half of this

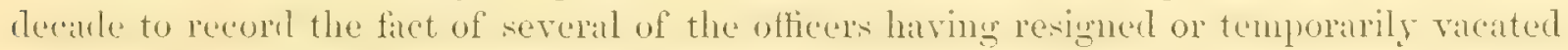
their positions in order to engage in the military or naval service during the war for the suppresion of the rebellion, it is fitting that the part which was taken in the great conflict by members of the society should be recognizerl; and the following roll gives the names and branch of the service to which they belonged, of such as are, or have been, borne upon its list of membership.

D1. Samuel Knneeland, Surgeon 45th Mass. Infantry, Brevet Lient. Colonel. .

Dr. Henry Bryant, Surgeon 20th Mass. Infuntry, Brigade Surgeon U. S. Vols.

Dr. Samuel A. Green, Asst. Surgeon 1st Mass. Infantry, Surgeon 24th Mass. Infantry.

Dr. Burt G. Vilder, Asst. Surgeon 55th Mass. Infantry.

Dr. B. Joy Jeffries, Sergeant 1st Corps Cadets M.V.MI, Acting Assistant Surgeon U.S.A.

Dr. Francis H. Brown, Acting Assistant Surgeon U. S. Army, Private 12th unattached company Mass. Infantry.

Theodore Lyman, Colonel U. S. Vols., äide-de-camp to Major General Meade.

Albert Ordway, Lieut. Colonel 24th Mass. Infantry. Brevet Brigadier General.

Amos Binney, Major and Paymaster U. S. Vols.

Dr. John Stearns, Surgeon 4th Mass. Heary Artillery.

Dr. Lucius M. Sargent, Jr., Surgeon 2d Mass. Infantry, afterwards Major 1st Mass. Cavally. Killed in battle.

Dr. Hall Curtis, Asst. Surgeon 24th Mass. Infantry, Surgeon 2d Mass. Heavy Artillery.

Dr. Robert 'T. Edes, Passed Assistant Surgeon U. S. Navy.

Dr. Z. Boylston Adams, Asst. Surgeon 7th Mass. Infantry, Surgeon 32d Mass. Infantry, afterwards Major 56th Mass. Infantry.

Dr. A. S. Packard, Jr., Asst. Surgeon 1st Mainc Veterau Volunteer Infantry. 
Dr. Calvin G. Page, Surgeon 39th Mass. Infantry.

Dr. Franklin Nickerson, Acting Assistant Surgeon U. S. Navy.

Dr. Ii. P. Sprague, Acting Assistant Surgeon U. S. Army.

Dr. Algernon Coolidge, Acting Assistant Surgeon U. S. Army.

Dr. Ldward Wigglesworth, Jr., Hospital Steward 45th Mass. Infantry, Volunteer Surgeou.

Dr. J. Collins Warren, Volunteer Surgeon U. S. Army.

Dr. Francis C. Ropes, Assistant Surgeon U. S. Army.

Dr. H. M. Saville, Surgeon 4th Mass. Infantry.

Dr. George Derlyy, Surgeon 23d Mlass. Infantry, Brevet Lieut. Colonel.

Dr. H. P. Bowditch, Major 5 tth Mass. Infantry, Captain 1st Mass. Cavalry, Major 5th Mass. Cavalry.

Dr. John McLean Hayward, Surgeon 12th Mass. Infantry.

Dr. C. F. Crehore, Asst. Surgeon 15th Mass. Infantry, Surgeon 37 th Mass. Infantry, Medical Inspector on staft" of Major General Sedgwick.

Di. Oliver F. Wadsworth, Asst. Surgeon 5th Mass. Cavalry, Brevet Captain U. S. Vols.

Dr. Allston G. Bouvé, Private 6th Mass. Infantry.

Dr. John Homans, Assistant Surgeon U. S. Nary, Asst. Surgeon U. S. Army.

Dr. William Ingalls, Surgeon 5th and 59th regiments Mass. Infantry.

Dr. William Ifenry 'Thayer, Surgeon 14 th New Iampshire Infantry.

Dr. John C. Dalton, Asst. Surgeon 7th New York V. M., Surgeon U. S. Vols.

Dr. S. W. Langmaid, Acting Asst. Surgeon U. S. Army.

Dr. Charles W. Swan, Acting Asst. Surgeon U. S. Army.

Dr. Samuel G. Webber, Asst. Surgeon U. S. Navy.

Dr. Charles B. Porter, Acting Asst. Surgeon U. S. Army.

Dr. Frederick S. Aiasworth, Surgeon 22d Mass. Infantry.

Dr. Thomas B. Hitcheock, Asst. Surgeon 42d Mass. Infantry.

Dr. George J. Arnold, Acting Asst. Surgeon U. S. Army.

Dr. Charles E. Ilosmer, Private, Steward U. S. Navy, Acting Asst. Surgeon U. S. Navy.

Dr. John G. Park, Acting Asst. Surgeon U. S. Nary.

Dr. Charles 'Thacher IIubbard, Asst. Surgeon U. S. Navy.

Dr. James E. Wallker, Acting Asst. Surgeon U. S. Army.

Dr. Henry G. Clark, Inspector-in-chief of the Sanitary Commission.

Dr. J. Nelson Borland, Inspector of Hospitals for the Sanitary Commission.

Dr. Samuel L. Abbot,

Dr. Henry I. Bowditch,

" Surgeon to the Board of Enrolment in

Boston during the war, and Volunteer Surgeon in the Army.

Dr. Samuel Cabot, Jre, Inspector of Hospitals for the Sanitary Commission and Volunteer Surgeon.

Dr. William Edward Coale,

Dr. Calvin Ellis,

Dr. Augustus A. Gould,

Dr. J. B. S. Jackson,

Dr. Francis Minot,

Dr. Benjamin S. Shaw,

Dr. Charles E. Ware,

Dr. Henry W. Williams,

D1. WV. WV. Morland,

Dr. Winslow Lewis,

Dr. Henry K. Oliver,

Dr. D. D. Slade,

$\begin{array}{ll}6 & 6 \\ 6 & 6 \\ 6 & 6 \\ . & 6 \\ 6 & 6 \\ 6 & 6 \\ 6 & 6 \\ 6 & 6 \\ 6 & 6 \\ 6 & 6\end{array}$

Rev. Waren II. Cudworth, Chaplain 1st Mass. Infantry.

T. Wentworth IIiggiuson, Captain 51st Mass. Infuntry, Colonel 33d U. S. Colored Troops (1st South Carolina Infintry).

Francis A. Osborn, Colonel 24th Mass. Infantry, Brevet Brigadier General U. S. Vols.

Joseph P'. Couthouy, Acting Volunteer Lieutenant U.S. Navy. Killed in battle.

Alphens Hyatt, Jr, Captain tith Mass. Infuntry. 
T. W. Clark, Colonel 29th MIass. Infantry.

Edward C. Cabot, Lieut. Colonel 44th Mass. Infantry.

Hiram S. Shurtleff, Captain 56th Mass. Infantry.

Nathaniel S. Shaler, Captain 5th Kentucky Artillery.

Nathaniel Bowditch, 1st Licut. 1st Mass. Cavalry, A.A.G. U. S. Vols. Kílled in battle.

Charles WV. Folsom, 1st Lieut. and Q.M. 20th Mass. Infantry.

II untington F. Wolcott, 2d Lieut. 2d Mass. Cavalry. Died in the service.

Edward T. Bouvé, 1st Lieut. 32d Mass. Infantry, Captain 4th Mass. Cavalry, Major 26th N. Y. Cavalry.

Joseph H. Lathrop, Serreant $4: 3$ Mass. Infantry, 1st Lieut. and Mdjutant th Mass. Cavalry.

John E. Alden, 2d Lieut. 1st unattached company Mass. Infantry.

Nathan Appleton, 1st Lieut. 5th Battery Mass. Light Artillery, Capt. and A.D.C. U. S. Vols.

Louis Cabot, $2 d$ Lieut. 1st Mass. Cavalry, Capt. 2d Mass. Cavalry, Major 4th Mass. Cavalry.

Fletcher M. Abbott, 1st Lieut. 2d Mass. Infantry.

John Ritchie, 1st Lieut. and Q.M. 54th Mass. Infantry.

William E. Endicott, $2 d$ Lieut. 30th unattached company Mass. Heavy Artillery.

Lorin L. Dame, 1st Lieut. 15th Battery Mass. Light Artillery.

Albert S. Bickmore, Private 44th Mass. Infantry.

A. P. Cragin, Private in a Mass. Cavalry regiment. Killed in battle.

John Jeffries, Jr., Major 1st Corps Cadets Mass. Volunteer Militia.

George Brooks, Private 45th Mass. Volunteers. Died in the service at Newbern, N. C.

Robert M. Copeland, 1st Lieut. and Q.M. 2d Mass. Infantry, Major and A.A.G. U. S. Vols.

Alfred P. Rockwell, Captain 1st Battery Conn. Light Artillery, Colonel 6th Conn. Infantry, Brevet

Brigadier General U. S. Vols.

Stephen II. Welı, Captain 1sth Mass. Infuntry, Colonel 56th Mass. Infuntry, Brevet Brigadier General.

E. R. Cogswell, Corporal 44th Mass. Infantry.

Jonathan Dorr, Private 44th Mass. Infantry.

Nathaniel Willis Bumstead, Captain 45th Mass. Infantry.

Carleton A. Shurtleff, Medical Cadet U. S. Army.

Joseph T. Rothrock, Private 12th unattached company Mass. Infantry, Captaiu Pennsylvania Cavalry.

Copley Amory, 1st Lieutenant 4th U. S. Cavalry.

Rev. George H. Hepworth, Chaplain 47 th Mass. Infantry.

William Ellery Copeland, Private 4tth MLass. Infantry.

Lewis W. 'Tappan, Jr., Captain 45th Mass. Infantry.

The writer can scarcely hope, notwithstanding great care taken, that no errors will be found in this roll of honor. He would especially regret the omission of the name of a single member of the Society, who manfully went forward to serve the nation in its hour of peril.

Eirly in the decar?e now passed was received the bequest of Mr. Jonathan Phillips of $\$ 10,(100$. This was followed hy the grant of land from the State on which the Museum was afterwards erected. Then came the first of the series of donations from our great benefictor, Dr. William J. Walker, of his house in Bulfinch Street, followed hy the second and third of $\$ 20,000$ each, and finally by the great bequest from him which established the institution on such a firm foundation as to secure its perpetuity so long as wisdom shall prevail in its councils.

The Society had also been the recipient during the decade of the bequests before mentioned, from Paschal P. Pope, \$20,1000; Miss Sarah P. Pratt, \$10,000, with a large collection of shells; Dr. Benjamin D. Greene, $\$ 9,000$, with a large library of valuable books; and Mr. Henry IIarris, s.j.,0)0. It had likewise received for the establishment of a fund 
for the Library. \&.j, 1000 in the name of IImt ington Frothingham Wolcott, who rlied in the military service of the country in the war of the rebellion.

Of the donations made towards building and other purposes in the early part of the

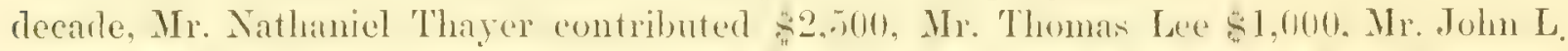

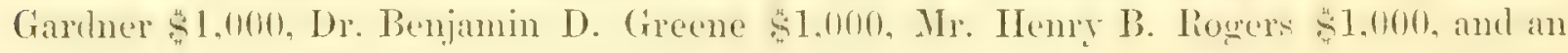
anonymous friend $\$ 1,000$. A considerable amount of the money subscribed towards the

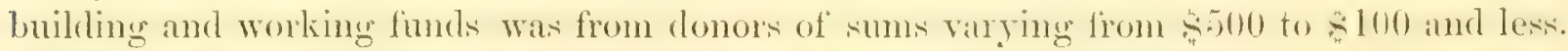
Besides money, the society receiver during the decalle the matenificent donation of the Lafresnaye collection of birds from Dr. Henry Bryant.

There was a very valuable donation made to the Society by Mr. James M. Barnard in 1864, notice of which has not been given. This consisted of a large collection of fossil echinoderms made by Dr. A. Krantz of Bonn, and was second in the country only to that in the Museum of Comparative Zoölogy in Cambridge, presenting as it did good types of nearly every group of the class.

Mr. H. F. Wolcott mentioned above was a young member of the Society whose great interest in it led to the endowment after his death of the fund referred to in his name by his father, Mr. J. Huntington Wolcott, as a memento of that interest, and as a recognition of what would have been pleasing to him if living. The fund is known as the Huntington Frothinghem Wrolcott Fumd, and now amounts to over sfo.000, the interest at first having been allowed to accumulate and having been added to the capital. It is held is trust, the income alone being available for the purchase of books for the Library. The service of this fund to the Society has been very great, as without it, there would not have been means to supply works actually indispensable for the use of the members. Mr. Wolcott was born in Boston, February 4th, 1846, and died June 9th, 1865.

In mentioning the hequests of Mr. Jomathan Phillips made during the decade, no such notice was given of this benefactor of the society as seems fitting should appear concerning him. A few brief remarks are therefore added here.

Hon. Jonathan Phillips was born in Boston, April 24th, 1778. He was the son of Lieutenant Governor William Phillips and was educated for mercantile life, but never engaged in much active business. Upon the death of his father in 1827 he became the possessor of a very large fortune, and the remainder of his life was mostly passed in literary culture, travel, and in taking an active share in many of the benevolent and educational movements of his day, all of which he generously aided. He was at one period a member of the Senate of Massachusetts, hut his tastes and inclinations were such as to lead him to shrink from public life. For a number of years he held the office of President of the Massachusetts Bank. He was an associate with Dr. Willian Ellery Channing, Rev. George Ripley, Dr. Charles Follen and many other prominent men, in the well-known Progress Club, and was a very intimate friend of Dr. Channing. Among many other bequests and donations he contributed 50.000 in aid of the Boston P'ullic Lithrary, first making a clonation of \$10.000 and afterwards bequeathing hy will s.20.0(0), the interest of which sums alone is avalable for use. He bequeathed likewise the sum of $s 00,000$, to the City in trust, the income of which is to be expended in adorning and embellishing the streets and public places. 'Io this last-mentioned bequest, the City owes the statue of 
Josiah Quiney in front of City IIall, that of John Winthrop in Scollay Square, and that of Samuel Adams on Washington Street.

Mr. Phillips died in Boston on the 29th of July, 1860, at the age of eighty-two years.

Of the publications during the ten years, the seventh volume of the Journal and the last of the series, was completed in 1863 . The Memoirs in quarto form which succeeded the Journal had been delivered to members in parts from 1863; the whole of the first volume leing completed in 1869. Of the Proceedings the twelfth volume and part of the thirteenth had been issued.

The members of the several standing committees of the Council during the decade were as follows:

On Publication. Drs. Jeffries Wyman, Augustus A. Gould, S. L. Abbot, Samuel Kneeland, Charles Pickering; and Nessrs. S. II. Scudder, William T. Brigham and Charles J. Sprague.

On the Librory. Messrw. Charles K. Dillaway, Charles J. Spratgue, S. H. Scudder, IIorace Mann, J. Elliot Cabot; and Drs. John Bacon and A. S. Packard, Jr.

On Finance. Messrs. Thomas T. Bouvé, James M. Barnard, Edward Pickering and Amos Binney.

The average attendance at the general meetings during the ten years was as follows:

$\begin{array}{cccc}\text { For the year } & 1860-61 & 37 \\ \text { " } & \text { " } & 1861-62 & 37 \\ \text { " } & \text { " } & 1862-63 & 33 \\ \text { " } & \text { " } & 1863-64 & 1864-65\end{array}$

$\begin{array}{ccrr}\text { For the } & \text { year } & \mathbf{1 8 6 5 - 6 6} & 34 \\ \text { " } & \text { " } & \mathbf{1 8 6 6 - 6 7} & 39 \\ \text { " } & \text { " } & 1867-68 & 40 \\ \text { "6 } & \text { " } & \mathbf{1 8 6 8 - 6 9} & 33 \\ \text { " } & \text { "6 } & \mathbf{1 8 6 9 - 7 0} & 32\end{array}$

The average attendance at the meetings of the Section of Microscopy after its formation was for the months December $186 \pm$ to May 1865, 9; for the year 1865-66, 9; $1866-67,12 ; 1867-68,12 ; 1868-69,8 ; 1869-70,9$.

The average attendance at the meetings of the Section of Entomology after its formation was for the months November 1866 to May 1, 1867, 12; for the year 1867-68, 9; $1868-69,12 ; 1869-70,10$.

The members who took the most active part in the proceeding's of the Society during the first five years of the decade were Drs. Jeffries Wyman, C. T. Jackson, B. Joy Jeffries, James C. White, Charles Pickering, Augustus A. Gould, IIenry Bryant, Burt G. Wilder, C. F. Winslow, William Stimpson and Thomas M. Brewer; Profs. Louis Agassiz, William B. Rogers and H. J. Clarke; Messrs. S. II. Scudder, F. W. Putnam, Alexander Agassiz, A. F. Verrill, Horace Mann, C. J. Sprague, Charles Stodder and Thomas T. Bouvé. Those who were most active during the last five years were Drs. Jeffries Wyman, C. T. Jackson, B. Joy Jeffries, James C. White, Charles Pickering, Hermamn A. Hagen, J. B. S. Jackson. Thomas M. Brewer; Messrs. S. H. Scudder, Charles Stodder, William 'T. Brigham, R. C. Greenleaf, N. S. Shaler, Horace Mamn, B. P. Mann, F. G. Sanborn, E. Bicknell, C. S. Minot and Thomas T. Bouvé.

Walker Prizes. In accordance with the provisions in an agreement made with Dr. William J. Walker by which the Walker Prize Fund was established, offers were made for the best and second best memoirs presented on subjects proposed by a Committee of the Council, as follows:

Subject for 1865: "Adduce and discuss the evidence of the coëxistence of man and extinct animals, with the view of determining the limits of his antiquity." 
Subject for 1866: "The fertilization of plimts by the ageney of insects, in reference both to cases where this ageney is absolutely necesary, and where it is only accessory."

No estays having been presented, or none deemed by the Comncil worthy of a prize. the same subjects were proposed again for the years 1867 and 1868 , but still without bringing forth any response from writers. Other subjects were therefore proposed for the two subsequent years, viz:

For 1869: "On the range of arctic and alpine plants in Northern America, with an enumeration of species."

For 1870 : "The reproduction and migration of Trichina spiralis."

$\Lambda$ s with the case of previous subjects, neither of these last elicited any response, or any of sufficient merit in the estimation of the Council to call for an award. It will be seen later that those proposed for the immediately succeeding years were more successful in calling forth essays upon them.

The property of the society at the end of this decade, besides the building, and the collections and lifrary which were of inestimable value, consisted of investments belonging to the various funds amounting in the aggregate to $\$ 186,898.20$; this included, however, several bequests left under restrictions, a part of the income of which must be expended only for special purposes, and can never be available for general uses or expenses.

The library at this time had nearly doubled in size during the ten years, and consisted of 9396 volumes, and 2677 pamphlets, as before stated. But if the members had cause to rejoice at the material prosperity of the institution, they too had often cause to lament the loss of faithful workers for its interests, many of whom hat been companions in their labors. Among those taken by death during the ten years were Dr. B. D. Greene, Dr. Geo. Hayward, Mr. Francis Alger and Dr. Augustus A. Gould, all original members of the Society; Dr. Wm. J. Walker, its great benefactor; Dr. Henry Bryant, Mr. Octavius Pickering, Mr. 'Thomas Bulfinch, Mr. Horace Mamn, Mr. Huntington Frothingham Wolcott, Mr. Carleton Atwood Shurtleff and Capt. Joseph P. Couthouy.

\section{Decade V. Mat, $1870-\mathrm{MLAT}, 1880$.}

1870. The fifth decade commences with the office of President vacant, by the resignation of Dr. Jeffries Wyman; with MIr. Alpheus Hyatt, Custodian; Rer. Joshua A. Swan, Recording Secretary and Librarian; Dr. Samuel L. Ablot, Corresponding Secretary; Mr. Edward Pickering, Treasurer; Mr. F. G. Simborn, Assistant in the Musemm; Miss Lillias Blaikie, Assistant in the Library, and Mr. George Coles, Janitor.

It will be recollecterl that at the amnual meeting the Committees for the several departments of Comparative Anatomy, Mammals and Microscopy were not elected. At the first meeting succeeding, the following persons were chosen to these respectively:

Mammals. J. A. Allen, Thomas Waterman, Jr., M.D., J. B. S. Jackson, M.D.

Comparative Anatomy. Thomas Dwight, M.D., Jeffries Wyman, M.D., J. C. White, M.D.

Microscopy. Edwin Bicknell, R. C. Greenleaf, B. Joy Jeffries, M.D.

The following changes were made in the members of the Committees as elected at the annual meeting: J. A. Allen was transferred from the Committee on Ornithology to that 
of Fishes and Reptiles, taking N. E. Atwood's place on the latter; and J. Elliot Cahot was chosen one of the Committee on Ornithology.

It was decided to change the Janitor's room from the north-west corner of the basement to the south-west corner, at an expense of $\$ 1500$, it having been found that from lack of sunshine in the apartments, the health of menbers of his fimily had been seriously impaired.

Under the new condition of affirs inangurated by the election of Mr. Hyatt as Custodian, certain changes were desirable in the Regulations and By-Laws. The Librarian, besides such duties as defined hitherto, was given the sole direction of the Janitor so far as related to work expected of him in the delivery of pullications, care of office, lecture room, \&c. He was also to have sole charge of the assistants in the Library. The office hours were fixed at from 9 A. II., until the closing of the Lilhary in the afternocn, except an intermission not exceeding two hours at noon. A vacation of two months was allowed him during the year.

The Custodian, in addition to duties defined in By-laws, was to have the immediate charge of the Museum, and the sole direction of the assistants employed there. Also the sole direction of the Janitor, excepting in such duties as are mentioned in the authority given the Librarian over him. He was empowered to decide in all cases relative to the arrangement, care or use of the collections not otherwise specially provided for, and his decision was to be binding, unless overruled by the Council. When any department suffered by neglect or other cause, he was authorized to take charge of it and report to the Council. He was required to prepare a report as early as possible on the state of the Museum, and a plan for the definite arrangement of the collection, so as to best illustrate what the Society had in view by the formation of its Museum. He was required to give twentyfour hours each week at lenst, of undivided attention to the Museum; six hours each for four days, or eight hours each for three days. A vacation of two months was granted him.

The Assistant in the Museum was authorized to act for the Custorlian in his absence. A vacation of six weeks was allowed him, the time to be fixed by the Custodian.

The Assistant in the Library was required to act for the Librarian in his absence. Her attendance was fixed at seven hours per day. She was to be allowed six weeks vacation during the year, the time to be appointed by the Librarian.

It was understood that an appeal might be made to the Council on the part of any one employed who felt aggrieved.

At a meeting of the Society on the 1st of June, a Committee was appointed, consisting of five members, to present a candidate for the office of President at the next meeting. Mr. Edward Pickering, Dr. C. F. Winslow, Mr. Chas. J. Sprague, Mr. R. C. Greenleaf and Mr. William H. Niles composed this Committee.

At the next meeting, held on the 25th of June, Mr. Edward Pickering, the chairman, reported that the name that first suggested itself to the Committee was that of the First Vice-President, Dr. Charles T. Jackson, one of the earliest, most constant and devoted of the friends of the society. Upon his unwearying interest in its welfure, his liberal contributions to its treasures, his courtesy as a presiding officer, his well known seientific attainments, it was not necessary to enlarge. But the reception of the following letter prevented the Committee from offering his name as a candidate. 


\section{Edwatro Pickentra, Esq., Chairman of Committee of Nomination.}

Dear Sir: IIaving been informed that the Committee on the Nomination of President for the Boston Society of Natural History are disposed to offer my name as a candidate for that office, I beg leave to say to the Committee, through you, that however highly I consider the honor, I cannot consent to become a candidate, since my health, which is often impaired, especially in the winter, might be inadequate to the very important duties and constant attention required of the first officer of the Society. So far as my health and ability will permit, I shall always be happy to labor for the interests of the Society, and whatever influence $I$ can exert will be in its fivor.

A younger man than myself I believe would be able to serve the Society much better than I can, and my personal preference would be in fivor of the promotion of the Second Vice-President, Mr. Thomas 'T. Bouvé, to the Presidency of the Society.

Most cordially thanking the Committee for their fivorable consideration, I have the honor to be

Your obedient servant,

Charles 'T. Jachson.

Under these circumstances the Committee proposed for the office of President of the Society the name of the Second Vice-President, 'Thomas T. Bouvé.

The report was accepted.

Dr. C. F. Wins low moved that the Society proceed to ballot for the candidate nominated.

This led to considerable discusion, there being the feeling on the part of some present, that the proposed action was hasty, and that no harm could result from postponing the election to a future period. A ballot, however, was ordered by a large majority of the members, which resulted in the election of Mr. Thomals T. Bouve to the Prevideney of the Society, there being but two dissenting votes.

Early in this official year a letter was received from Prof. Runkle of the Institute of Technology, expressing a desire for the coïperation of the Boston Society of Natural History with the Institute. This wals warmly responted to by the Council, and the President. Mr. Bonvé, was requested to write an answer to Profescor Runkle expressive of the realiness of the Society to meet his wishes, it heing thought that an arrangement might be makle which would be of service to both institutions in the furtherance of the purpose each had in view, to extend a knowledge of science in the community.

A plan was subseruently adopted by which the Institute had permission to use the halls of the Museum and the collections for the instruction of its students, subject to such restrietions as the Council might impose for the preservation of the specimens, it being monlerstood that the Fociety should be paid a certain sum therefor, and that the Institute should rleposit the collections and charts of the late Prof. II. D. Rogers with the Society, grint the use of the IIuntington Iall for lectures, if required, and contribute specimens of natural history towards an edncational series. Under this arrangement, Dr. Simuel Knecland delivered several lectures on Zoülogy in the lecture room of the Society the first year, and the Custodian delivered a course on Palaeontology.

It is well, perhaps, before proceeding to detail further the doings of the Society, to dwell at some length upon the necessity of a change in the management of its interest.. which hat led primarily to the election of Mr. Hyatt as Custodian, and subsequently to the adoption of a more defined policy in its administration. It is manifestly unjust to 
the memory of the many distinguished and devoted memluers of the Society who, from its earliest period to that now under consideration, were active in its aflairs, to imply that no plan of organization, oy policy of administration had been acted upon. A common sentiment influenced all of them, that of affording means by which a better knowledge of matural history might be attained hy themselves and diseminated in the community, and to aret upon this they deliberately planned for the acomplishment of their purposes and organized means for the object. They established a Museum, they founded a Library, they held meetings, gave lectures, and published scientific palpers. Simply, they did not define their course of action or their arrangement of the Museum, as more advanced knowledge and experiener suggested in 1870 . What they did wals in accortance with the best thought prevailing anywhere in relation to such institutions as that of the ruciety.

If the several departments of the Museum they formed were not placed in such sequence as to form together as now, the best means for the education of visitors, the collections of each were arranged in thorough scientific order. 'The time had however come for a more definite statement of what was proposed on the part of the Society, especially as views were held by some members tending to prevent such change in its policy and in the arrangement of the collections as seemed desirable for its best good. 'The Custodian, MIr. Ilyatt. was therefore required, as has been before mentioned, to prepare a report as eally as possible, on the state of the Museum and a plan for its definite arrangement, so as to best illustrate what the Society had in view in its foundation. 'This he diel woon after, and a vote was passed by the Council, adopting the proposed plan as a basis for action until the annual meeting in 1871.

This plan was not limited in its application to the Museum. The paper presented by the Custodian and arlopted by the Council, was termed "Proposed Plan of Organization," and embracerl views and sugrgentions concening the meetings, the publieations, and the library, as well as the Museum. The essential details of this plan may be found in the ammul report for the year emling May, 1871, published in the fourtecnth volume of the Proceedings. Here only such portions of it will be referred to as tenderl to excite opposition and to lead to a conflict of opinion and action upon measures decmed exsential to the interests of the Society.

After stating that the Museum of the Society was intented especially for the instruction of teachers, general students and the pullic, and that therefore its collections should be arrangerl according to some easily understood and comprehensive plan, illustrating the general laws of natural science, the Custodian added, "All the different departments should be connected as closely as possible, and form together a series of lessons in the structure of the earth and its constituent parts, and in the organization of the plants and animals living upon its surface."

A clear understanding of the defective general character of the arrangement of the Museum, as judged in the light of present experience, is necessary in order that the reasom for an ralical change in the location of the several departments in the building, involving large expenditure of time and money, may be manifest.

As recently as when the new building of the Society was constructed, it is doubtful if in any of the great museums of the world, the importance was recognized of arranging the several departments in such relation to each other as would best serve educational interests; certain it is, that not a member of the Society gave a thought to it. The only idea 
that moved the minds of the Curators in selecting rooms for the collections was that of obtaining such as would meet the requirements of each department without reference to the rest. Thus it happened that those brought in contact had no relation to each other, and others closely allied by nature, were far remote in location. On the lower floor, where are two exhibition rooms, one was appropriated to Botany, the other to Geology, whilst the department of Minerals, which should have had a place with that of Geology, and immediately preceding it, was far away in another part of the building.

To act upon the advancerl views expressed by the Custodian upon the arrangement of the departments in consecutive series, a radical change was necessary, involving great expense, particularly in the reconstruction of cases, so that there might he a proper adaptittion of them to new usess. Perhaps it was fortmate that as constructed originally, none of them were fit for the purposes designed. They were, undouldedly, as suitable as those senerally then found in Museums, but experience had taught the Curators that there was a necessity for much better, if the collections were to be salved from ruin. This fact made it easier to accomplish the radical change in arrangement desired on scientific considerations, as it was seen that the necessary expenditure would accomplish a double object. 'There was no intention to do all or much at once, towards effecting the change, but only to establish the policy of placing the collections in such consecutive order as suggested, and act upon it as time and means would allow. The President heartily approved of the change. He was strongly averse to encroaching on the principal of the property of the Society for any but the most weighty reasons, but he regarded the end to be attained as fully justifying the mean, and he gave the policy of re-arrangement of the Huseum all the individual and official influence he could bring to bear in its support.

Besides the re-arrangement of the several departmentis, the proposed plan contemplated the formation of separate New England collections in each, and an epitome collection of the organic sections of the Museun, containing the types of the regetable and animal kinglom, classified to show the approximations of the lower, and the great differences of the higher orders of each, with the zoölogical succession of the types of each. It will be seen in the remaining parges of this volume how steadily the policy was athered to of effecting the object mentioned, and how gradually but surely the great work was accomplished; although not without opposition, and not without the manifestation of unpleasant feeling on the part of some who failed to recognize the wisdom of what was proposed. 'This was to be expected, even on the part of members devoted to the interest of the Society. The Custodian indieated his appreciation of this in the following remarks upon the plan submitted.

- The difficulties to be encountered in carrying out the details of any scheme, will be nreat or small, precisely in proportion to the feeling which governs the officers entrusted with its execution. If a broad, catholic spirit of consideration for the interests of the Museum obtains, there need be no doubt of its ultimate success. On the other hand, if regard for the interests of any special departments is allowed to interfere with the uniform arrangements and proper seientific use of the whole Museum, no very beneficial results can be anticipated." 'The course pursued has, it is believed, received the commendation of all naturalists who have made themselves aequainted with it, and witnessed the results. 

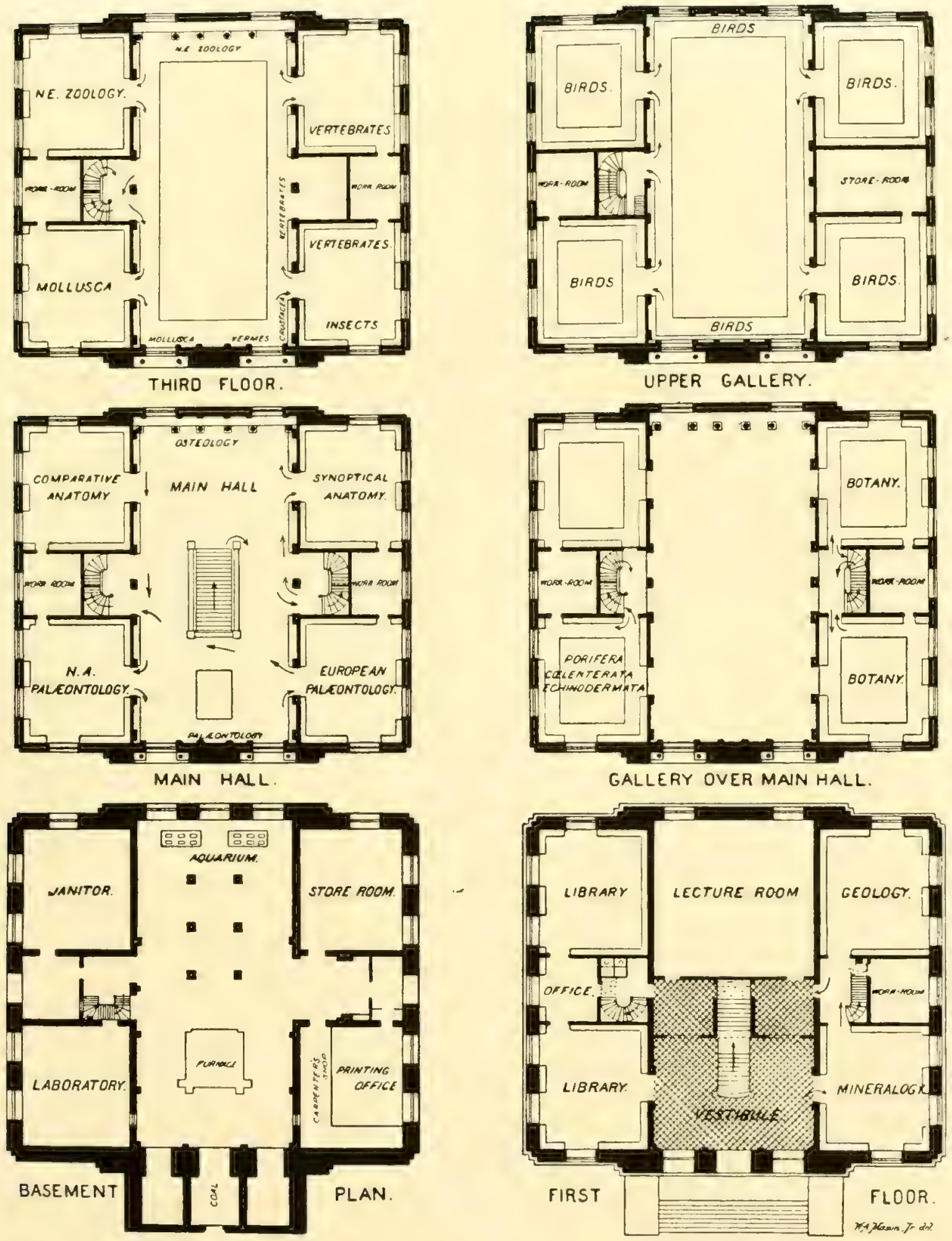

MUSEUM OF THE BOSTON SOCIETY OF NATURAL HISTORY. 

In October of this year, a large fin-back whale was exhibited in one of the docks of the harbor, exciting much interest in the community, and attracting a large concourse of visitors. The matter was brought before the Council by a motion being made that Dr. Thos. Dwight, Jr. and the Custodian be a committee to procure if possible the skeleton of this huge animal for the Museum. At the next meeting Dr. Dwight reported that the carcass had been presented to the Society by Mr. Harvey T. Litchfield, had been accepted by the committee, and had been towed to and stranded upon Spectacle Island. Upon the suggestion of Dr. Dwight, three hundred dollars were voted to cover expenses of transportation, cleaning, and delivering the skeleton at the Museum.

This fine specimen now adorns the main hall of the Huseum, being suspended from the roof of the building. Dr. Dwight gave a large part of a year of scientific labor in the preparation and final arrangement of the skeleton in the position it now occupies, and to him the Society is mainly indebted for such an important acquisition to its collection. The skeleton is undoubtedly the finest in the country, and its perfection is largely due to his personal care and watchfulness over the carcass until all the bones were safely removed.

The lack of means at this time necessary to accomplish all the objects the Society had in view for the instruction of the public in science, weighed upon the minds of the active members, as indeed it has ever since. They were, therefore, much gratified to learn from the President that he had had an interview with Mr. John Amory Lowell, the Trustee of the Lowell Institute, who had kindly expressed a willingness to provide for several courses of lectures from the Lowell fund, to be given in our building under the auspices of the Society; the lectures to be selected by the Council, and the subjects to be such as pertained to natural history.

In accordance with this favorable provision for continued instruction by lectures, seven courses were given during the season of $1870-71$. The first six lectures were by the Rev. J. L. Russell, on Cryptogamic Botany, the second course of two lectures by Prof. J. S. Newberry, on the Cañons of the Colorado and Ancient Civilization of America, the third course of six lectures by Dr. Thos. Dwight, Jr., on the Comparative Anatomy of the Mammalia, the fourth course of four lectures by Dr. P. P. Carpenter, on a General Sketch of Mollusca, the fifth course of two lectures was by the Rev. R. C. Waterston, on some of the remarkable natural features of California; the sixth course of twelve lectures by Prof. W. H. Niles on the Principles of Geology, and the seventh course of six lectures by the Rev. E. C. Bolles, on the Revelations of the Microscope. These lectures were generally attended by large numbers and were of a very interesting and instructive character.

In December, 1870, Miss Blaikie, whose services as assistant in the Library had been very valuable, and whose presence had always diffused cheerfulness, resigned on account of her approaching marriage. The thanks of the Council were presented to her for the very efficient manner in which she had discharged the duties of her office.

1871. By vote of the Council in January of this year, as one of the precautions against fire; smoking in every part of the building was prohibited. On Feb. 7th, Mr. John Cumming presented to the Society five hundred dollars to be applied for educational lectures to teachers during the next winter, that of 1871-72. Mr. John Cummings, the President, Mr. Bouvé, the Custudian, Mr. Hyatt, and Mr. Wm. Mr. Niles, were appointed a Committee to employ the gift in accordance with the wishes of the donor. This was the first open 
manifestation marle hy Mr. Cummings of his intention to afford an opportunity to the teachers of Boston to become acquainted with natural history. His mind had for some time dwelt upon a plan by which the public might possess a better scientific culture than hitherto, and thus share in its refining influences. The general lectures delivered each winter, though undoubtedly of great service to many, seemed to him to accomplish but inardecuately the olject he ham in view. Ife finally came to the conclusion that by interesting the teachers in the several branches of science, and by affording them an opportunity of receiving practical instruction, better and more lasting results might follow than from any other comres. Posersing themselves a knowledge of botany, of mineralogy, or of any other branch, they could not fail to exert a great influence upon the many thousand minds that came under their instruction, in favor of its study, and thus another generation be led to show greater interest in pursuits of an elevating tendency. The members of the committee other tham Mr. Cummings himself, feeding a sreat interest in the proposed plan, early issued a circular to the teachers, calling attention to the generous proposal made by him, and invited their co-operation. A committee on the part of the masters of the Cirammar schools wat appointerl to learn the feetings of the teachers generally on the matter, and to report results. 'The circular referred to, after mentioning the proposal of the donor, stated that teachers of every grade were invited; that the lectures

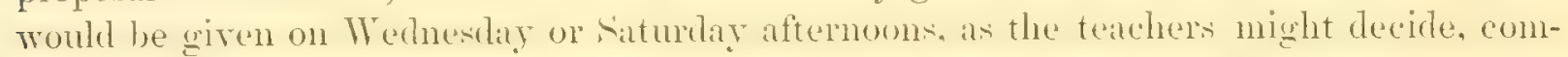
mencing in October and continuing through the winter at the Museum of Natural History; that the earlier courses would be on Physical Geography, Botany and Geology, and that they would be given by Professors familiar with the olject method of teaching and skillful in the use of chalk; that it was designed that the lectures should be practical and familiar, questions and answers to he allowed, and the whole subject slowly developed; that the Professors were anxious to know how large classes they could rely upon before leaving the Museum for summer work, and therefore asked all teachers who desired to avail themselves of the offer to sign the circular.

It was gratifying to find that the movement excited great interest on the part of those to whom it was adliteswed. manifested hy the prompt signing of the circular by upwards of seven humdred teatchers. The great success which followed this preliminary action will be given in the account of proceedings hereafter.

In March of this year, a bequest of one thousand dollars was received from the late Mr. Sidney Ilomer for the general purposes of the Society. The Council subsecuently roted to appropriate the amount for New England mammals.

The assistant in the Museum, Mr. Sanhorn, was anthorized to devote two mornings ench week to giving instruction at the Bussey school of Agriculture, upon his consenting to have his salary reduced, and MIr. P. S. Spriague was cmployed to work in the collection of Insects.

At the annual meeting in May, the Custodian read his report for the year. Much of it was deroted to general considerations concerning the ohjects of the policy of the society which, having been referred to earlier, will not be dwelt upon here. (of the meetingw, it wats stated that there hat been eighteen of the Society. with an average attentimee of fortyone persons, eight of the section of Ificroscopy with an average attendance of eleven, and 
seren of the section of Entonology with an average of ten. Thirty-seven written communieations hat been made by thirty-six persons. Of these, thirteen were pre-ented in the section of Entomology and thirteen in the section of Microscopy.

Of the publiention:, eleven signatures of the Proceedings, completing the thirteenth volume, had been issued, and of the Memoirs, one paper, Historical Notes on the Earthquakes of New England, by William T. Brigham, had appeared.

The Library harl received during the year by gift, purchase or exchange. 215 volumes, 76.5 parts of rolunes, $18: 3$ pamplilets and 22 maps and charts. The use of the Library had been extented to members of the Institute of Techology and to others pursuing some branch of natural science, who made application.

Of the departments of the Museum, the Custodian reported as follows:

That of Mineralogy had received a large accession by the purchase of a fine series of specimens, and by the presentation of several, and the reception of others by exchange. The whole collection was in perfect order, and every specimen labelled.

The Geological collection was in good order, and fully arranged and labelled. There had been no important additions.

The Palaentological collection had had much work done upon it in identifying and labelling the specimens.

The condition of the Botanical cullection was stated to be good, heing entirely free from insect. It contained about 25,000 specimens labelled and gilued to papers, and many hundred duplicates for exchange. A considerable nnmber of plants fiom various expeditions yet required much study and work for their identification and arrangement.

The department of Comparative Anatomy had been enriched by the important addition made to it of the skeleton of the whale before mentioned, of the reception and mounting of which the particulars have been given.

The corals and the sponges of the Radiata had been rearranger by Mr. Sanborn, and placed on black tablets. The labelling wats reported, however, as incorrect in many cases, and it was recommended that measures should be taken to secure the services of Prof. A. E. Verrill for the naming of the species.

Much work had been done on the Insects by Mr. P. S. Sprague, and it was stated that the cases recently procured would obviate all danger of future damage from moths and Anthreni. Valuable additions to the collection had been made by Messrs. Samborn, Swan, Trouvelot, Sprague, Dickenson, Minot, and Scudder.

The department of the Mollusea required much attention from able conchologists. The services of Dr. P. P. Carpenter were obtained for a short period on the general collection, and Mr. L. Lincoln Thaster continued work on the New England collection.

The collection of Fishes was in good order and Mr. Putnam had been engaged in labelling the specimens, which work was reported as nearly completed.

The Reptiles were stated to be in the same condition as the previous year. The collection was reported as small, and needing many additions.

The department of Ornithology had received many valuable additions of fresh eggs of Aretic birds from the Smithsonian Institution, and some rare specimens of birds from Mr. Thure Kumlein.

The Custodian had adopted many expedients to stop the ravages of the Anthreni, but 
with only partial success. Constant work alone, he said was the most effectual. Every bird had been soaked in benzine or naptha. The great want was such cases as are the best adapted to keep out the pests that do the injury. Those in use were not fit by their construction to contain specimens liable to attack.

The department of the Mammalia was reported as rapidly improving. The New England collection had received many accessions obtained by expenditure of a portion of the

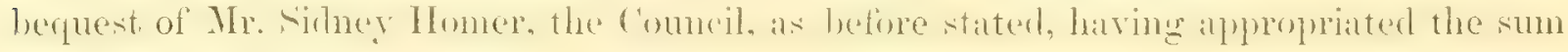
thus received for the purpose of adding to this collection.

At the election of officers, Mr. R. C. Greenleaf was chosen Second Vice-President, and Mr. J. A. Allen one of the Committee on birds in place of MIr. J. Elliot Cabot, resigned.

Walker Prizes. At a meeting of the Society in June, the President, Mr. Bouvé, presented the report of the committee on the Walker prizes.

To Prof. Albert N. Prentiss of Ithaca, New York, the first prize of one hundred dollars was awarded, and to Mr. Daniel Milliken of Hamilton, Ohio, the second, of fifty dollars, for their competitive essays "On the mode of the Natural Distribution of Plants over the Surface of the Earth."

In October, Mr. F. W. Putnam called the attention of the Society to the great loss the Chicago Academy of Science had suffered in the destruction by fire of their valuable collections in the various departments of natural history and of archaeology, and offered a resolution of sympathy on the part of the Boston Society of Natural History, and the offer of such of our publications and duplicate specimens as might be acceptable. This

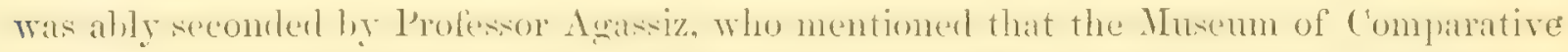
Zoülogry hat suffered greatly hy the fire, ats all of 'ount Pourtalés' collections on the Deep Sea dredging expedition were deposited there. The resolve was unanimously passed.

At a meeting of the Council it was voted that Miss Lucinda Foster be employed to succeed Miss Blaikie as assistant in the Library.

The death of the Reverend Jo-hua Angustus swan, the Recording Secretary and Librarian of the Society, occurred on the 31st of October. At the meeting on Noveinber 1st, the President, Mr. Bouvé, paid the following tribute to his memory:

"I know not how to utter the deep grief I feel and which I lsnow is shared by you all in the death of our dear companion, Mr. Swan, the Secretary of the Society. No one, I am sure, who has had the plea-ure of personal intercourse with him, but will feel that he has lost a near and dear friend. To me his presence even has always seemed a benediction. I do not think I ever was so much impresed by the personal character of any man with whom I have come in contact as with that of Mr. Swan. He seemed always overflowing with love for, and a de-ire to aid, all about him. What might excite in other men feelings of bitterness or anger, moved him only to sorrow, and no one was more charitable in his judgments of the acts of others. Truly we have lost from our circle a man devoid of guile, upright in coniluct, lovable beyond expression, pure in heart and fiithful in every duty. God grant that his family, so dear to him, may have strength to bear the loss that falls so much more heavily upon them than upon all others."

The following resolutiou, with others offered by Prof. J. D. Riunkle, was then unanimously passed: 
"Resolverl, That in the death of Mr. Swan the Society recognizes the loss of not only a highly eflicient officer and member, but of an associate spreatly respected for his attainments as a scholar. ardnired for his noble qualities as a gentleman, and loved for his many virtues as a man and a Christian."

Before the close of the year it had become so evidently necessary to have cases of better construction for the birds than those in use, and in furtherance of the plan of reorganization arlopted, the Council voted that the entire income from the Bulfinch Street fund for one year, he expended in litting up cases in the upper gallery for that purpose.

1872. In February, Mr. Edward Burgess was elected Recording Secretary and Librarian of the Society in place of Rev. J. A. Swan, decensed.

The necesity for the presence of police officers on public exhibition days to preserve order and to see that the specimens of the Society suffered no harm, was now so apparent that at the meeting on Narch 6th, the President was authorized to petition the City Government to appoint such officers.

At a meeting of the Section of Entomolong, on the 27th of March, the denth of an active member of that section, Mr. William IIales Dale, was feelingly referred to, and the following resolution unanimously passed:

"Resulverl, That in the death of our late associate, William IIales Dale, we mourn the loss of one whose many graces had endeared him to us, and whose researches in natural science, now abruptly arrested by this inscrutable dispensation, commanded our highest respect."

This gentleman bequeathed to the Section of Entomology his cabinet of insects, and five hundred dollars.

The annual meeting of the Society was held on May 1st. From the report of the Treasurer it appenred that the receipts, including donations amounting to $\$ 1249.20$, and a bequest of $\$ 500$, exceeded the expenditures $\$ 3649.89$.

The Custodian's report for the year embraced much matter of importance, but nothing more gratifying that what he expressecl relative to the Teachers' School of 'science, by which name he dexignated the school formed through the liberality of Mr. John Cummings. It will be recollected that this gentleman in the early part of the previous year presented to the Society $\$ .500$ to be applied for educational lectures to teachers, to be given during the succeeding winter. This sum he afterwards increased to cover all expenses occurred in carrying out his design, so that instead of $\$ 500$ he really paid $\$ 950$ to the Society. The remarks upon the result are here given.

"The Teachers' School of Science was conceived and has been carried into successful operation during the past winter, under the patronage of Mr. John Cummings, a well known member of the Society. Under the clirection of the Committee in charge, courses of lessons have been given in Physical Geography, by Prof. W. II. Niles; on Mineralogy, by W. C. Greenough; on Zoology, by the Custodian; and one is now in progress by Dr. W. G. Farlow, of Cambridge, on Botany.

"Prof. Niles delivered the first six. He undertook to give the more general features of the earth's surfice, and then to apply these general principles to the explanation of the physical characteristics of Massachusetts. The success of this comrse may be judger by the average attendance, which was about six hundred teachers of all grades, and by the 
fact that the methorls of tearhing gengraphy in some of our public schools are now undergoing a change in favor of the more natural method introduced by him.

"The necewity of actually handling and dissecting specimens olliged the Committee, after consultation with the masters of the Public Schools, to confine the issue of tickets to ahout two for each school. This limiter the average attendance at the succeeding lessons, six on mineralogy, eleven on zoology, and ten on botany, to about fifty-five. Specimens were distributed and studied at every lesson, and we know that in many instances the instruction was repeated at the schools. We have without doubt excited an interest in natural history, which must speedily effect a marked improvement in the system of public instruction.

.. The lectures of the first course by Professor Niles were given in the commorlious hall of the Institute of Technology, the others in the lecture room of the Suciety. The materials for the course of zoilogy were lingely furnished by Prof. S. F. Bairl, Uniterl states Commissioner of Fisheries, and those of the botmical course by Prof. Asa Gray, from the Botanic Garden at Cambridge.

"'The expenses of the Society in comection with these lectures were hut trifling, and it received dontions incidental to their delivery of conviderable value. Among these-were a full suite of the marine animals of Wood's ILoll, a full ani complete collection of the fauma of the southern coast of Massachusetts, and also a complete collection of the marine animals of the const of Minine. These collections were purchised for the Teachers' School of Science by XIr. Cummings, but as the duplicates were sulficient for the distribution at the schools, a series from all of them was first selected for the $\lambda$ Inseum to be the property of the Society. Many of the species thus obtained were not before in the cabinet. The visit of the Custodian to Wood's IIoll to procure the specimens required for the school, enabled him fortumately to procure a complete set of the skins of sharks, rays, skates and other large fishes, which were collected by the vessels and the men in the employ of the U. S. Commissioner of Fisheries."

The Custodian, in addition to what has been given above, stated that at his solicitation Mr. Charles J. Sprague had generously given two hundred dollars towards preparing the skins mentioned above for the New England collection.

The rearringement of the Museum in accordance with the plan arlopted hy the Society, had been commenced by removing the birds to the upper gallery. where suitable cases had been prepared for their reception. As the experience of the Society may be of service to some who reat these parges. the statement of the Custodian concerning there cases is given entire. "Extraordinary precautions were taken to render them absolutely insect tight. The lumber was very carefully selected and kept heated while the work wats going on. All joints were tongued, grooved and glued. The tops, bottoms and siles were built into the plastering, the sashes grooved and tongued and locked by wedge-shaped bolts. The latter were arranged so as to draw the sashes up tightly and firmly against the tongues at the top and bottom and completely close the fronts of each case. Morse's patent lurackets were used to suspend the shelving, which hangs upon the wall and has no comnection with the fronts. The success of these precautions is shown by the air tight condition of the cases. By suddenly opening or closing a sash, one can readily crush in or burst out the neighboring glass panes. 'The resistance of the air is so great that it has 
to be overcome by a stearly slow pressure. The plan was similar to one adopted in the Smithsonian Institution and was recommended by Professor Baird."

The Custorlian reported that the effort to free the Ornithologieal collection from the further ravages of Anthreni hat been suceesuful. Some of the birds hat been so batly affected as to rectuire their being operated upon over twenty-five times before they were entirely freed from the pests.

In the Conchological department much work had been done by Dr. P. P. Carpenter, and hy exchange with him a valuable collection of British shells had been procured for the Society.

In the department of Entomology also much work har been done hy Mr. Sprague in completing the greneral collection of Coleoptern placed in the rail cases of the upper gallery. The specimens of Coleoptera were mentioned as numbering about 10,000, and are in the improved boxes adopted by the Council.

The Mineralogical department had received by donation from Mrr. F. Alger, the large specimens of beryl which have since occupied the window recesses in the hall of entrance to the Museum, exciting the interest of beholders.

The Geological department hat been enriched by the presentation on the part of the Technologieal Institute of the magnificent mass of hematite iron ore and jasper which may be seen with the beryls alove mentioned in the hall of the Muserm. From Mr. L. S. Burbank a series of specimens hat been received illustrative of a paper by him upon the Eozoon cimadense, from Dr. S'. Kneeland some lavas, and from Mr. Thomas 'T'. Bouvé a set of polished marbles.

The other collections were mentioned as in fair condition. Iuch work was constantly required upon many of them in consequence of defective cases.

Of the publications two quarterly parts of the fourteenth volume of the Proceedings had been issued, and four articles of the Memoirs.

The Library had received 424 volumes, 943 parts of volumes, 268 pamphlets and 32 maps and charts.

There had been eighteen general meetings with an average attmudance of thirty-two persons, nine of the section of Microscopy with an average of ten, and eight of the section of Entomology with an average of eleven. Six Corresponding and thirty-four Rexident Members had been elected. There had been eighty-two communications, of which seventeen were before the Entomological section and twelve before the Microscopical section.

Previous to the election of officers, the department of Geology and Minerals was divided, and at the election the following members were chosen on the respective committees: Geology; Willian II. Niles, William T. Brighrum and Thomas T. Bouvé;-Minerals; Thomas T. Bouvé, Charles T. Jackson, M. D., and L. S. Burbank. The only other change made at the election was in substituting Dr. Samnel Kneeland in place of Mr. J. A. Allen on the Committee for Fishes and Reptiles.

Leave of absence was granted in June to the Custodian for one year, his salary to be relinquished until his return to the duties of his office. ILe wished to visit Europe and make himself acquainted with its museums and men of science.

Walker Prizes. In June the Council awarded the first prize of one hundred dollars 
to E. D. Cope. and the second of fifty dollars to Benjamin F. Ferris, for their competitive essays on "The Darwinian Question; its bearing on the Development of Animal Life."

In August of this year, the Council passed votes implying some action on the part of members not entirely satisfactory, and at the same time defining limits for the future, viz.:

All donations shall be submitted to the Committees of departments, before final deposition.

All work rooms in use by Committees are to be regarded as private and shall not be exposed to intrusion except by members of the Council.

In September, Prof. Shaler proposed that notices of each meeting be mailed to members designating the subjects that would be brought before it, hoping this might lead to better attendance. Before this time simple notice of other meetings had been published in two daily papers. 'The suggestion of Prof. Shaler was approved and adopted.

In October, the Council, in view of the fact that the City Government did not furnish regularly such police officers as were necessary on public days, passed the following vote:

"'That in consequence of injuries done the Society's building and collection by visitors, the Museum will be closed to the public after October 19th, until measures can be taken to properly protect the property; and the Secretary is instructed to advertise the same in six daily pilpers for one week." This determined action led to oflicers being furnished for a while satisfactory to the Society.

During the summer of the year, there had been three field excursions of the members of the Entomological section, resulting in their obtaining a linge collection of specinens. The places risited were first Mattapan and vicinity. second Pealouly, and third, Waltham and Waverly.

1873. The Museum of the Society was closed to the public on the first day of March, because the police officers had ceased to attend. 'This led to an interview on the part of the President, with the Mayor and Chief of Police, resulting in a promise on their part that officers should be present on public days.

At the annual meeting in May, in the absence of the Custodian abroad, the Secretary, Mr. Burgess, presented the yearly Report upon the condition and operations of the Society. From this is given the following abstract.

During the year, two ILonorary, one Comesponding, and twenty Resident Members had been elected.

There had been eighteen general meetings of the Society, six of the section of Entomology, and six of the section of Microscopy. The average attendance at the general meetings had been twenty-five, showing perhaps a diminished interest in them.

There had been four courses of Lowell Lectures given under the direction of the Society, and a fifth was in progress. The first was upon "The Principles of Zoölogy," by Prof. Edward S. Morse, and had an average audience of sixty persons; the second upon "Mineralogy," by Mr. L. S. Burbank, and had an average audience of forty persons; the third upon "Evenings with the Microscope," by the Rev. E. C. Bolles, and had an average audi. ence of two hundred and fifty, and the fourth on "Chemical and Physical Geology," by Prof. 'T. Sterry Hunt, and had an average attendance of one hundred and fifty. 'The fifth course by Mr. B. Waterhouse Hawkins, upon "Comparative Anatomy," so far as they had progressed, had had an average attendance of fifty.

The Teachers' School of Science was necessarily suspended, much to the regret of a great number who desired to arail themselves of its privileges. The publications had 
heen satisfictory. Two numbers of the Memoirs and two parts of the Proceedings had been issued.

The additions to the Library during the year had been 277 volumes, 852 parts of volumes, 189 pamphlets and 20 maps and charts.

In the Museum the necessary alterations in the cases had progressed as fast as regard to finmedal considerations warranted. New and armirable ones for the reception of the valuable I Ierharium presented by John Anory Lowell, Esq., had heen marle and were in use.

The change in the location of the collections of the various departments so as to bring them in the designed relation to each other had proceeded steadily, and at this time the work was so far accomplisher as to enable visitors to the gralleries, by entering the first and passing round to the right, to sturly the zoülogical collection in order, beginning with the sponges and passing to the higher groups.

A beginning had been made on a comprehensive system of labelling, a great step towards publishing a visitors' catalogue, so important as a means of instruction.

Much work had been done on the collections during the vear by Messis. Fmerton and Sirrague, the former having labelled over 2,000 bottles of Crustacea and many of New Fngland worms and rarliates, and the latter being engaged nearly all the year on insects. Dr. Carpenter had likewise done much in studying our Mollusca and in labelling them. They were sent to him at Montreal for identification.

Valuable donations had been received from many parties, among them birds from the Smithsonian Institution, insects from Mr. Sanborn and Mr. Ernest Papendiek, a fine fossil tree from the Joggins Mine, Nova Seotia, presented by the Institute of Technology and a beautiful Japanese crystal globe by Mr. Thomas Gaffield.

The collection of Minerals had been much enriched by a large and valuable addition made to it by purchase from Dr. Beadle of Philadelphia. The expense was but trifling to the Society, as two members paid a large sum towards the purchase, and considerable money was received from the sale of duplicates.

The number of visitors to the Museum seemed steadily to increase, schools often coming with their teachers. It was open to the public daily during the Peace Jubilee, so called, when the City provided special police for its protection.

'The 'Treasurer's account for the year exhibited an excess of receipts over expenditures of $\$ 1,342.98$. The Society suffered a loss of $\$ 6,280$ from the great fire of November, 1872 , it having held stocks in insurance companies that hecame worthless. It was obliged to pay also assessments to the amount of $\$ 2,346$, levied by the companies.

The changes made in the officers at the election were as follows: John Cummings was chosen on the Committee of the department of Geology, fiom which Willium T. Brigham and Thomas T. Bouvé resigned. J. Henry Blake was chosen on the Committee of Mollusks in place of John Cummings, tranferred to Committee on Geology. Richard Bliss, Jr., was chosen on the Committee for Fishes and Reptiles in place of Dr. D. Humphreys Storer resigned. J. H. Enerton was chosen on the Committee for Hammals in place of Thomas Waterman, Jr., M. D., resigned. Simmel H. Scudder was chosen on the Committee for Insects in place of F. G. Samborn.

In June of this year the gallery was added, with the cases, to the rear library apartment. The want of more room for books had been long felt but was now indispensable. A case was also built for the reception of the moose which harl been procured for the Society. 
At a meeting of the Council it was roted to present the specimens helonging to the Society which were formerly in the Ethmolosical department to the Peaborly Museum.

Walker Prizes. The first prize of sixty dollars was awarded in June to Dr. A. S. Packard, Jr., for an essay by him on the subject proposed for this year " On the derelopment and transformations of the common house-fly."

The Graml Honorary Prize was awarded this year by the Comncil to Alexander $\Lambda$ grassiz for his investigations in the Embryology, Geographical Distribution, and Natural History of the Echinoderns, and the sum of one thousand dollars, the highest amount the Council was authorized to grant, appropriated for the purpose.

In November, Mr. William T. Brigham offered to present to the Society the casts of the busts of several naturalists, if it would pay the cost of transportation from Europe. The offer was accepted with thanks; these busts, being those of Cuvier, A. L. de Jussieu, Adrian de Jussieu, Buflon, Limmeus, and Charles Girard, were subsequently received and now adorn the main hall of the Museum.

A meeting of the Council was called by the President on December 15th. Upon assenbling, he addressed the members, stating that in view of the great calanity that had hefallen the community and particularly upon all interested in scientific culture and progress, by the death of our distinguished member Louis Agassiz, he had thought it well that they should come together and take such immediate action in relation thereto, as might seem fitting upon the occasion. He then recommended as a manifestation of respect to the memory of our honored associate, that the usual second monthly meeting be omitted on the next Wednesday evening and that we communicate to the fumily of Professor Agassiz our wish to be present at his obsequies if this should be agreeable to them. The proposed action was taken.

\section{Louis Agassiz.}

1874. The meeting of the Society on Jamuary 7 th partook largely of a memorial character, the proceeding, generally relating to the death of our distinguished member, Prof. Louis Agassiz. After calling the members to order, President Bouvé addressed them as follows:

Since we last met an event has occurred that has brought deep sorrow to our hearts, and indeed moved with grief those of the whole community; for whilst in the death of the great naturalist we have lost a distinguished IIomorary Member, a pioneer in the paths we love to treall, one whose name deservedly ranks high among the most illustrious of those who have explored the world of matter and of life, the great body of the commiunity has lost one whom it has long and justly regarded as pre-eminently the great teacher in science, the man of all men, who inspired the love of knowledge, and who was never weary in his efforts to impart the best he knew to every seeking soul.

Truly all alike, learned or unlearned, high in attamments and position, or only humble seckers of truth, may well weep the losis of him, whose presence alone was to everybody an inspiration.

To those of us who have been in any degree sharers in his labors, or companions in literary or scientific circles, his loss is irreparable. 
The fine physical form, the countenance ever beaming with fecling and intelligence, the expressive utterances, and above all, that subtle influence which came from the whole being of the man, alas! that these are now only matters of memory.

But it is not for me to dwell upon the event I have alluded to. For a fit expression of the loss surtained hy the society, we have the privilege of looking to one whose valuable serviees to it in its earlier days we have not forgotten, and who was one of the first among scientific men to welcome to our shores and our companionship the great naturalist. I need not sily I refer to our former President, Mr. George B. Emerson, whom I now have the pleasure to introduce to you.

Upon the close of the President's remarks, Mr. George B. Emerson gave an interesting address, a large part of which is here presented.

I think you, Mr. President, for the great honor you do me by inviting me to say something before, and in behalf of, your Society, in commemoration of the most distinguished naturalist that has appeared among us. You know how reluctantly I consenterl to speak, and I feel how inadequately I shall be able to represent the Society. Yet I camnot but admit that there is some apparent propriety in your request. I was one of those who formed this Society. All the others who first met, except one, are gone; Dr. B. D. Greene, Dr. J. Ware, F. C. Gray and the rest. My old friend, Dr. Walter Channing, alone, in whose office most of the first meetings were held, is still living. Morcover, while I was in the seat you now occupy, it was agreed by my associates that it was very proper and desirable that a survey of the State, botanical and zoölogrical, should be made, to complete that hegun by Prof. Hitcheock in Geology. At their request I presented to Gov. Everett a memorial suggesting this.

Our suggestion was graciously received. Gov. Everett brought the subject before the Legislature, in which some friends of natural history in the IIouse of Representatives had already been acting toward the same end ; an appropriation was made, and he was authorized to appoint a commission for that purpose. On that commission four members of this Society were placed; the reports of three of whom, Dr. Harris, Dr. Gould and Dr. Storer, have been, and still continue to be, considered of signal and permanent value, and Mr. Agrassiz himself regarded them as among the best reports ever made. It hat given and still gives me the greatest satisfaction to know that the Society has been continually going forward, and that it is now more prosperous than ever.

A little more than twenty-seven years ago, as I was sitting in my study, a message came to me that two gentleman desired to see me. 'They were immediately admitted, and Dr. Gould introduced me to Louis Agatssiz. His noble presence, the grenial expression of his face, his beaming eye and earnest, natural voice, at once gained me, and I responded cordially to his introduction. IIe said, "I have come to see you, becanse Dr. Gould tells me that you know the trees of Massachusetts; I wish to be made acquainterl with the Carya. I have found the leaves and fruit of several species in the Jura Mountains, where they were deposited when those mountains were formed; but, since that time. none have been found living in Europe. I want to know them as they are now growing."

I told him that I knew all the species foumd in New England, and should be what to show them to him. "But I have," I said, "presently to begin my morning's work. If you will let me call on you immerliately after dimmer, I wall be ghat to take you to them." 
At the time fixerl. I called on him at his lorderings and took him, in my chaise, first to Parker's Hill, where one species of hickory grew, then through Breokline, Brighton and Cambridge, where two others were found, and to Chelsea, where a fourth, and one that might he a variety, were crowing. I pointed ont the chancteristics of each species in growth, branching. batk, fruit and leaves, and especially in the buts. He listened with the most eaptivating attention, and expresied surprise at my dwelling upon the peculiarities of the buds. "I have never known the buds to be spoken of as characteristic," said he ; "that is new to me."

We drove on to Chelser Beach, which stretches off several miles, - apparently without end, - and, as the tide was very low, was then at least a quarter of a mile wide. Ile was charmed with everything, expressing his pleasure with all the earnestness of a happy child, hardly able to restrim himself in his admiration and delight. He told me that he hat never before been on an sea-beach, but that he was familian with the undulations and wave marks on the old beaches laid open in the Jura Mountains.

I need not say what a pleasinnt drive this was. I harl long felt great interest in various departments of Natural Ilistory, but had heen so fully occupied with my own duties, as a teacher, that 1 had been able to indulge myself fully, and that for a small part of the year, in one only. Ilere wats a companion who was intimately acruainted with all, and with the most distinguished men who had heen advancing them, and who was ready and happy to communicate wealth of information upon every point I could ask about.

The news of the death of Aganiz ceatsed a throls of anguish in millions of hearts. Such a death is a loss to mankind. What death among kings or princes in the old World, or among. the aspirants for power, or the possessors of wealth, in the New, could produce such deep-felt regret?

He is gone. We shall see his benignant face and hear his winning voice no more; but we have before us his example and his works. Let us dwell, for a few moments, on some features in his life and character. as an inspiration and a guide, expecially to those who mean to devote their leisure, or their life, to natural history, or to the great work of teaching! What a chinge has taken place, in the whole civilized world, and especially in this country, in men's estimation of the value and interest of these pursuits, since he began his studies. To whom is that change more due than to Agassiz?

He was endowed by nature with extraordinary gifts. His fascinating eye, his genial smile, his kindliness and rearly sympathy, his generous earnestnes, his simplicity and al)sence of pretension, his transparent sincerity; - these accomt for his natural eloquence and persuasiveness of speech, his influence ats a man, and his attraction and power as a teacher. For the development and perfecting of miny of his highest and most estimable qualities of mind and character, Mr. Agrassiz was doubtless indebted to his noble mother, who, judying from every thing we can learn, wals a very rare and remarkable woman. To the quiet, homely, household duties, for which the Swiss women are distinguisherl, she added unconscionsly, very uncommon mental endowments, which she wisely cultivated by extensive reading of the best authors, and by converiation with the most intelligent persons.

Trained by such a mother, Agassiz grew up in the belief of a Creator, an infinite and all-wise Intelligence, Author and Governor of all things. He was sincerely and humbly 
religious. During his whole life, while exploring every secret of animal structure, he saw such wonderful consistency in every part, that he never for a moment doubter that all were parts of one vast plan, the work of one infinite, all-comprehending Thinker. He saw no place for accident, none for blind, unthinking, brute or vegetable selection. Though he was a man of the rilrest intellect, he was never ashamed to look upwards and recognize an infinitely higher and more comprehensive Intellect above him.

Arrassiz's mother-tongue was French, but both this and German were in common use in the Pays de Vaud. He lived, for years afterwards, in several parts of Germany, and thus attained, without special study, the rich language which we Americans have to give so much time to acquire; and he lived, long, a studious and laborious life in Paris, where he became intimately acpuainted with Curier and other distinguisherl naturalists, and perfectly familiar with the Erench language in its best form. IHore than once, when he was putting his note-hook into his pocket, he told me he knew not whether he had made his notes in German or in Frencl.

Agitsiz's universality of study and thought suggest a precious leson. It is never safe to give one's self entirely to one study or to one course of thought. The full powers of the mind cannot so be developed. Nature is infinite; and a small part of one kingdom cannot be understood, however carefully studied, without some knowledge of the rest.

Agassiz took a large, comprehensive view of the whole field of natural history; his thorough erlucation and intimate accuaintance with the works of the highest men in several walks, Von Hartius, Cunier, Humboldt, and others, mate it possilsle for him to do it, and he then fixed on certain department, and, for the time, he galve himself entirely to one.

Whenever Mr. Agasiz undertook a special work, he prepared himself for it hy a careful sturly of whatever hat been done in that particular line by all others. He harl seen, everywhere, indications of the action of ice. He determined to investigate. He began by reading all he could find upon the subjeet, and then set himself to observe, patiently and carefully, what was taling place in the glaciers themselves. IIe gave the leisure of several years to this examination, and then fult himself ready to observe the eflects of similar action in former ages and distant rengions. The opinions of such an observer, after such a preparation, cannot be without authority and value; and it is not surprising that he should not himself have been willing to yield them to those of others who had never given the same study to the subject.

His example as a teacher hat been of inestimalle value, as showing the importance of the best and largest possible preparation, teaching by thingss really existing and not by books, opening the eye to the richness and beauty of nature, showing that there is no spot, from the barren sea-beach to the top of the mountain, which does not present objects attractive to the youngest beginner, and worthy of, and rewarding, the careful consideration of the highest intellect.

In 185, with the aid of Mrs. Agrassiz, who, from the beginning, did a great deal of the work, Mr. Agrassiz opened a school for young ladies. For this he was, in all respects, admirably well qualified. The charm of his mamer, his perfect simplicity, sincerity and warm-heartechess, attracted every pupil, and won her respect, love and admiration. He knew, almost instinctively, what we teachers have to learn by degrees, that we cannot 
really attract, control and lead a child, and help to form his habits and character, without first loving him; that nothing in the world is so powerful as real disinterested affection. Ife gave, himself, by lectures most carefully prepared, an hour's instruction, real instruction, every day. All his pupils retain their respect and love for him, and some keep the notes they made of his talks, and rearl them with delight. 'The school was continued for seven years, with great success, attracting pupils from distant parts of the country.

One of the secrets of his success as a teacher was, that he brought in mature to teach for him. The young ladies of a large school were amused at his simplicity in putting a grasshopper into the hand of each, as he came into the hall ; but they were filled with surprise and delight, as he explainerl the structure of the insert before them, and a sigh of disappointment escaped from most of them when the lesson. of more than an hour. closert. He hat opened their eyes to see the beanty of the wonderful make of one of the least of Gorl's creatures. What a lesson was this to young women preparing to be teachers in the puhlie schools of our Commonwealth, showing that in every field might be found objects to excite, and, well explainert, to answer the questions, what? and how? and why? which children will always be asking.

If hat all the elements necessiry to an eloguent teacher: voice, look and manner, that instantly attracted attention; an inexhaustible flow of language, always expressive of rich thoughts, strong common sense, a thorough knowlerlge of all the suljects on which he desired to speak, a sympathy with others so strong that it became magnetic, and a feeling of the value of what he had to say, which became and created enthusiasm. He thus held the attention of his audience, not only instrueting and persuading them, but converting them into interested and admiring fellow students.

The advent of Agassiz is to he conidered a most important event in the Natural IIistory of the country. The example of his character, his disinterestedness, his consecration to science, his readiness to oblige even the humblest and most morlest, his superiority to relf-interest, his sincerity and absence of all pretension, his enthusiasm in all that is noble - all these recommented not only him, but the science he professed. Never was a life more richly filled with sturly, work, thought; and all was consecrated, not to the benefit of himself, but to the promotion of science for the good of his fellow creatures.

For many years Mr. Agassiz has seemed to live only for the advancement of natural history, by the building up of his Musemn, for which he hat collected material, of the greatest posible diverity, which would, properly cared for and arranged, form a Museum superior in numbers and variety to any similar collection in the workl. Shall this great work be allowed to fail?

Let every person who honors the name of Agassiz, say No! Let every one who regrets that the great main support of the woble structure is taken away, resolve that it whall not fail, but that, so far as depends on him and what he can do, it shall go on and be built and filled, and stand firm, a glorious temple of science forever.

At the conclusion of Mr. Emerson's address Rev. Dr. R. C. Waterston in response to an invitation from the chair, spoke as follows of Prof. Agrassiz's connection with the Centennial Anniversary of the birth of Humboldt:

At a meeting of the Boston Society of Natural History, June, 1869, it was moved and voted that a celebration of the Centennial Anniversary of the birth of Alexander von 
Inumbollt. hy this Society, was highly desimble. It was also sumgested that Professor $A$ gassiz be invited to deliver an address upon the occasion. The invitation was extended to Professor Agassiz and accepted. Various circumstances connecterl with that memorable occasion, at a time like the present, come to the mind with peculiar power.

In Professor Agassiz's public address, his introductory remarks were, "I am invited to an unwonted task. Thus far I have appeared before the public only as a teacher of natural history. To-day, for the first time in my life, I leave a field in which I am at home, to take upon myself the duties of a biographer."

Thus this Society had the privilege of inviting Profesor $\Lambda$ gassiz to a duty (most nobly fulfilled), which without this invitation in all probahility he would never have entered upon. That being as he himself expressed it, the first time in his life he had mndertaken such a task; it was also, as we now know, destined to be the last. This event which, on every account, hard great interest, for these reasons possesses a solemn and sacred import. That anniversary we would keep in grateful remembrance, forming as it does, in comnection with many reminiscences, an added and, may we not say, an indissoluble tie between us and him.

At the time when the invitation was extended to Prof. Agassiz, he was overwhelmed with work; while by previous lahor, both body and mind had already been overtaxed. Under such ciremintances, it would have appeared next to impossible for him to comply with the request of the Society, yet so desirous was he to meet their wishes that he undertook the task.

On the 3d of July Prof. Agassiz wrote as follows:-

"For weeks past I have intended every day to write to you, but the fact is that just now I have scarcely time to breathe, and with the sincere desire of accepting the invitation tendered to me through you, I have been trying to free myself in some degree of the tasks before me. It is not so easy to do this as it seems.

"However, I write now to say that I will do my best so far as it depends upon me, to make the Amniversary of Humboldt worthy of his memory, and serviceable to science in the country. The task will be a difficult, and in some respects a painful, one to me, none the less because of my personal relations with him. But I will do my best, and I beg you to believe that the confidence placed in me by those who wish to make this oceasion a marked day, has gratified and touched me deeply.

"I wish you would express this sentiment in my behalf, and add that my great canse of hesitation has been the fear that I night not satisfy the expectations of those who have thus honored me.

Believe me,

"Ever truly yours,

"Lovis Agassiz."

In a note dated July 21st, he says, "I have been completely prostrated this week."

Yet notwithstanding this exhaustion (doubtless far beyond what was imagined by his most intimate friendis, and, added to this, serious illness among the members of his own family, his son leaving for Europe, on account of his health, the very day upon which the inddress was delivered), Professor $A$ gassiz most conscientiously devoted himself through the 
sultriness of an intensely hot mid-summer, to the work of preparation. Few are probably aware what a mind like his would, under such circumstances, consider requisite. Nothing was to be taken for granted; not even the memory of former investigations would be accepted without passing through the process of examination. Every step was to be measured, with critical exactness, through the long progress of Ilumboldt sereientific career.

Is there not exemplified in this fact, one of the marked characteristics of Prof. Agassiz's mind? Abolute thoroughness; sifting crery question and principle down to its first clements; tracing every thonght, from its earliest germ through each sucessive development, until the final result is reached.

In order to secure freedom from all interruption during these researches, he asked for a room at the City Library, which was readily granted. Here he could gather about him papers and books, which during his alsence would remain undisturbed. Mr. Winsor, the efficient and olliging superintendent, tells me that for more than a month Prof. Agassiz passed at least three or four days of each week, from nine o'clock in the morning until gencrally three o'clock in the afternoon, and that during this time he called for more than two hundred volumes in different languages, always desiring to read each work as it originally came from the mind of the author. Thus every work which Alexander von IIumboldt ever wrote passed under careful review; not only every volume, but every pamphlet, with the exception of one, which could not be found in this country.

On the 4th of September he wrote me,

"I have only yenterdily finished gathering my materials, and have not yet begun preparing my address."

He adds - "My friends will never know what anxieties I have to go through on this occasion."

Six days after this I received the following:-

"Mr Dear Sir:

"Nahant, Sept. 10th, 1869.

"I have succeeded this evening in bringing to a close my druft of an address; not exactly as I would like to deliver it, but such as I may be compelled to read should the occurrences of the day unfit me for an extemporized discourse, which I believe might be more effective."

It would thus appear that even after the address was written, he hoped to give, not what he had embolied in mamuscript, but the result of which that would be the basis, in the form of an extemporized discourse, for which, as all know from his constant halit of speaking without notes, he possessed the very highest qualifications.

However, to meet every contingency, he adds:-

"As I go to-morrow to Cambridge, I will try to have my illegible manucript set in type, that I may myself be able to read it. At the same time I shall see how my diagrams are progressing, and if satisfactory, forward them at once to the Music Hall.

"Very truly yours, 
On the 13th of September he wrote:-

"DeAr Sir:-

"I hope I may have a proof of my address for your reporters by the time I reach Boston to-morrow, which I shall hand to you. My diagrams went to the Music ILall saturday afternoon, with the palm-branch worn on Humboldt's funeral.

"The pen taken from his desk the day he died, and sent to me, I shall bring myself, fearing it might be lost if left with bulkier objects.

Very truly yours, "L. Agassiz."

Such were some of the preparatory labors connected with the address which was to be heard on that Centennial Anniversary hy literary and seientific men from every part of the country. Seldom has there been an occasion in the history of New England, which has brought together so brilliant an assemblage of able soholars and prominent men in every department of thought.

At the evening reception, Mr. Ralph Waldo Emerson, in speaking of what he termed the "delightful address in praise of ILumboldt," concentrated his extimate in this characteristic declaration, "our eminent profeswor never delivered a discourse more wise, more happy, or of more varied power."

These words expressed the universal feeling. And the address, so cordially welcomed by those who heard it, was received when published with equal favor on both sides of the Atlantic.

This very day, I was reading a letter by Sir John Hersehel expressing his commendation; and in the Life of Alexander von IIumbolt, edited by Professor Karl Bruhns, director of the observatory at Leipzig, the address by Agassiz is referred to, both in the preface, and in the body of the book. In the latter, a lengthy extract is introduced. [See Vol. II, pp. 179, 180 and 181.]

There were several occasions upon which Alexander von Humboldt extended such attention and kindness to Agassiz, at a time when encouragement was most needed, that it seems but an act of justice and gratitude to recall them here. The first was related by Agassiz some fifteen years ago, at a meeting of the American Academy of Arts and Sciences, soon after Humboldt's death.

"May I be permitted," he said, "to tell a circumstance personal to me? I was only twenty-four years of age when in Paris, whither I had gone with means given me by a friend, but I was at last about to resign my studies from want of ability to meet my expenses. Professor Mitweherlich was then on a risit in Paris, and I had seen him in the morning, when he hat asked me what was the cause of my depressed feelings, and I told him I had to go, for I had nothing left. The next morning as I was seated at breakfast, in front of the yard of the Hotel, where I lived, I saw the servant of Humboldt approach. He handed me a note, saying there was no answer and disappeared. I opened the note, and I see it now as distinctly as if I held the paper in my hand. It said:

'Mr Friend:-

'I hear that you intend leaving Paris in consequence of some embarrassments. This shall not be. I wish you to remain here as long as the object for which you came is not accomplished. I enclose you a check of $£ 50$. It is. a loan which you may repay when you can." " 
That one act of IImmboldt, at the tuming point in the life of Agassiz. may have affected the whole course of his active career. If Sir Humphrey Davy could say "My best discovery was Michael Faraday," -- what shall we say of this discriminating instance of generous encouragement, which perhaps gave to us Agassiz as a man of science.

In the address upon Ilumboldt, Agassiz speaks of his studies at Munich, whose University had opened under the most brilliant auspices, and where nearly every professor was prominent in some department of science or literature. "These men," he says, "were not only our teachers but our friends. We were the companions of their walks and often present at their discussions." "My room," he adds, "was our meeting-place, bedroom, study, museum, library, lecture-room, fencing-room, all in one. Students and professors used to call it the little Academy."

It was at this time that Humboldt was preparing for his Asiatic journey. Agassiz was anxious to accompany him, and asked that he might join the expedition as an assistant. This was the beginning of his personal acquaintanceship with Humboldt.

A graphic picture is presented of the student's life in Paris, in the days of Louis Philippe, when Cuvier, just the age of Humboldt himself, was active and ardent in research, his salon frequented by statesmen, scholars and artists.

Cuvier was then giving a course of lectures, in the College of France, on the History of Science. "Humboldt," says Agassiz, "attended these lectures regularly; I had frequently the pleasure of sitting by his side, and being the recipient of his passing criticism." At this period, Humboldt had his working-room at the Rue de la Harpe. "There," continues Agassiz, "it was my privilege to visit him frequently. There he gave me leave to come, to talk with him about my work, and consult him in my difficulties."

At this time Agassiz was twenty-four years of age, and Humboldt sixty-two.

"I had recently," says Agassiz, "taken my degree as Doctor of Meclicine, and was struggling, not only for a scientific position, but for the means of existence also. I have said that he gave me permission to come as often as I pleased to his room, opening to me freely the inestimable advantages which intercourse with such a man gave to a young investigator like myself. But he did far more than this, occupied and surrounded as he was, he sought ine out in my lodging."

Here he gives a most interestiug nccount of a visit from Humboldt, at $\Lambda$ gassiz's narrow quarters, in the Hoted du onelin des Plantes. Alter which is an invitation firom Ilumboldt to meet him at the Palais Royal, - where they dine,_ "a rare indulgence," says Agassiz, "for a young man, who could allow himself few luxuries." "Here," he adds, "for three hours, which passed like a dream, I had him all to myself. How he examined me, and how much I learned in that short time! How to work, what to do, and what to avoid; how to live, how to distribute my time; what methods of study to pursue; these were the things of which he talked to me, on that delightful evening."

When we reflect upon the extended reputation acquired by Agassiz before he left Europe; of that visit to this country which led him gladly to adopt it as his home, and of the untiring zeal with which he devoted to it the best years of his life; shall we not hold in grateful remembrance the man who gave to him, at the most critical moment, the cordial hand of friendship, and who hy his cheering words, inspired fresh ardor, and a hope which no after trial could extinguish? 
It is more than a pleasant pieture, it is a lesion for all time, and should awaken, through generations, the desire generously to encourage and wisely to aid.

It was in this spirit that a "Humboldt Scholarship" became associated with the Humbollt Anniversary. Thromgh perional solicitation on the part of the committee the smm of seven thousand dollars was subseribed to form a permancut fund, the income of which, muler the direction of the Faculty, was to he solely applied to the aid of young and neerly sturlents, while pursume their preparatory studies at the Huscum of Companative Zorilogy, in Cambridge. The foumling of this scholarship was the voluntary proposition of this Society as a token of sympathy and hearty good-will.

The gratification of Professor Agassiz was at once expressed. In a note written July 3d, he says:

" Your proposition to connect a scholitrhip with the Musem of Comparative Zooilogy, in commenoration of this occasion, has had great weight with me. I believe that such an arrangenent will not only be an ever-returning memento of the solemnities of this 14 th of September, but, if properly contucted, will contribute to the real advancement of Natural History among us."

The origin of this scholarship was by some misapprehended. It was supposed to have been suggested, directly or indirectly, hy Professor Agassiz. This is an entire mistake. No one conld feel more sensitive than he himself did upon this sulject. IIis feelings are frankly expresicel in a note which I received from him, after he had read a paragraph in the daily papers, referring this movement to him.

"Mr Dear Sir:-

"In a paper to-day, giving an account of the proposed celebration, 'a plan' is alluded to 'of Mr. Agassiz for founding a Humboldt Scholarship in the institution of which he is the head.'

"This is no doubt a simple error of the press, but I should be very sorry to have it stand. It would have been very ungracious in me, and would have shown, to say the least, a great want of delicacy, had I suggested an endowment for the Huseum in which I am personally interested. It was, as you know, a proposition made spontaneously, without any reference to me. And though I rejoice in it and feel doubly unwilling, on account of this offer, to shrink from the responsibility connected with the invitation of your committee, yet the suggestion coming from me, under the cireunstances, instead of being appropriate, would he wholly unbeconing. You will excuse me for troubling you about this, but I am sure you will see that it places me in an awkward position."

If in any mind there should exist even the shatow of a misapprehension upon this subject, these works will serve to explain fully both the feelings of Prof. Agassiz and the exact facts of the case.

At the close of his public address of the 14th of September, he says:

"I have appeared before you as the representative of the Boston Natural History Society. It was their proposition to celebrate this memorable anniversary. I feel grateful for their invitation, for the honor they have done me. I feel still more grateful for the generous impulse which has prompted them to connect a IImboldt Scholarship, as a memorial of this occasion, with the Museum of Comparative Zoölogy at Cambridge." 
Thus, Mr. President and gentlemen, while we cannot but deeply mourn the vast loss which this community and the whole country has sustained by this bereavement, we rejoice in that friendly relationship which so long existed between us, and are thinkful that one of the last great public utterances of his life was griven under the anspices of this Society.

And now that his life, so beneficently crowded with activity and usefulness, has closed to us in this sphere of heing. we are grateful that our mutual eflorts entallisher what will not only be a perpetual hond of mion between this Society and the institution of which he was the honored head, but which, we trust, through successive years, may prove a source of practical help and encouragenent to numberless stulents, who, by their future cflorts, may extend the boundaries of knowledge, thus aiding in the work of human progress, while they carry forward to yet further completion, those investigations and discoveries which, in our own dar. have given immortality to the names of IImmbolt amb of Agasiz.

There was much feeling manifested at this time concerning the safety of the Museum and collections, now of inestimable value. At a meeting of the Council, the Custodian bronght up the question of prohibiting the use of workroums after dark. This led to the appointment of a committere to talie the whole subject of securing the building and contents against fire. At a subsequent meeting, the President, in behalf of this committee of which he was chaiman, reported. recommending sererul changes in regard to unsafe gas fixtures, and the erection of stand pipes for water. By vote, the committee was authorized to do all they deemed wise and necessary in the matter.

In January, the Presilent. Mr. Bouré argain brought before the Council the necessity of contimued action in order to place the collections of the IItsem in proper sequence, in accorlance with the plim of arrangement which had heon adopted. IIe thought that extensive changes were desirable at once. These would involve the fitting up of two galleries in the side rooms of the main hall for the reception of the Botanical collection, as well as the fitting up of the north rooms on the first hoor for the Mineralogical and Geological collections. To carry out these changes would require an expenditure of about five thousand dollars. After discusion, a committee was appointerl, consisting of Messrs. Bouré, IIvatt. Brighan, Cummines and scudeler. to comsider the matter and report at the next meeting to be held a week later. When the Council again met, the President in behalf of the committee presenter plans and estimates relative to the proposed alterations. He staterl, howerer, that the majority of the committee recommented that the Botanical collections he placert in the enallery on the north side of the main hall. rather than on the south side. To this, Mr. Brigham, in behalf of a minority of the committee, strongly remonstrated. A prolonged discusion followed. The Comeil, after mature deliberation, finally voted, with but one dissenting voice, to make the alterations as proposed by the majority of the committee, and full authority was given the President, Custodian and Treasurer to carry them out. The Council also voted that the southeast room in the basement be fitted up as a work room under the direction of the same parties.

As indicative of thought given by members of the Society to matters affecting the public interest not pertaining especially to its work, it may be stated that in February of this year, the Council passed a vote for presentation to the city authorities remonstrating 
against licensing "Jourdain's Musem of Anatomy" so callerl, on the ground of its tendency to offend decency and public morality, whilst subserving no good purpose.

It being understood that persons were in the habit of entering the building during the evening hours for other purposes than that of working upon the collections, the Council voted in March: That after the closing of the huilding. no perwon shall be allowed to pass into it, except through the apartments of the Janitor.

Some alterations were proposed and adopted in the Constitution and By-laws at this time, the most important of which was the ardition to the latter of a section. providing that whenever any existing or anticipated vacancy in the list of oflicers wats to be filled by election. a nominating committee should be appointerl hy the fiociety at a stated meeting to bring in at a sulserquent meeting one or more nominations of persons to fill such vacancy. And providing also that no peroon should be elected to any office until his nomination had been under consideration by the Society at least two weeks.

In April of this year, Mr. S. H. Scudder spoke of the great importance of a re-survey of the State of Hassachusetts, topographical, geological and hiological. It was the first in the Union to provide for a survey, but while almost all the principal States had now finished or begun a second one, no steps had been taken by Massachusetts in this direction. The original survey was wonderfully well done, yet incomplete, and the advance of scientific knowlenlge since rendered a re-survey very desirable. The American Acarlemy of Arts and Sciences had taken the matter into consideration and had appointed a committee to memorialize the Legislature on the subject.

Prof. Niles, Mr. John C'ummings and the President all adthessed the meeting in faror of the project, and finally it was voted on motion of Mr. Putnam: That the President appoint a committee including himself to petition the Legislature for a re-survey of the State. Messrs. Niles, Cummings, Putnam, Jeffries, Iyatt, and Morse with the President, were accordingly made this committee.

In the following May Mr. S. H. Seudder reported that the subject of a re-survey of the State hard duly come before the Legislature and had been referred to the Committee on Education with every prospect of a favorable report. IIe also referred to the question of a public park now agitated, thinking that the idea of the establishment of a zoological garden should be considered by the Society in connection with it.

The amnual meeting was held on May Gth, Vice-President. R. C. Greenleaf in the Chair.

The report of the Treasurer showed that the expenditures of the Society had exceeded its receipts $\$ 1874.12$. Among the former, however, was included the sum of $\$ 1754.22$ paid for insurance of property for five year's. The alterations and improvements in the building indispensable for the safety of the collections, and to bring them into proper relation to each other, had cost $\$ 3423.81$.

The report of the Custodian, Mr. Hyatt, who had returned home and resumed the duties of his office, after appropriately referring to the decease of Prof. Agassiz, gives a summary of the work of the year, from which the following is presented.

Mr. Iyatt's visit to Europe afforderl an opportunity to fill out the Palaeontological collection. A fair collection of species from Western Europe was needed in order that we should be able to compare them in a general way with their synchronous representatives in North America. T'o meet this want Mr. John Cummings generously furnished the 
necessiry means for their purchase. By grood fortune Mr. Iyatt was able to buy the very valuable collection of ()herfinanzath Fece of stuttgart. This was rely rich in the fosils of the 'Tertiary. Fecondary and 'Triatsic periods, and also contaned a far reperesentation of the Carboniferous, and some of the Devonian and Silurian types. All these had been selected with great care, and Herr Eser had expended the leisure hours of nearly forty years in accumulating them.

Speaking of this collection, the Custolian rematied that the "unirgue specinens which it contains are both remarkable and numerous. Many of these were found during the builhling of the extensive fortifications at Lhe, and were sedections from all the fossils obtained, which were sent by the chief architect to Herr Eser. The most valuable single

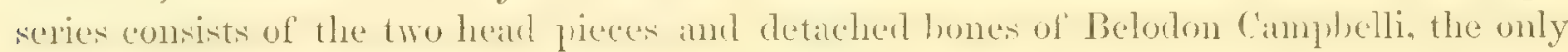
remains of this remarkable animal ever found. "There are specimens of tertiary plants, which are of such delicacy that they are mounted like botanical specimens on paper."

Besides the collection mentioned, Mr. Hyatt purehased also while abourl, through the

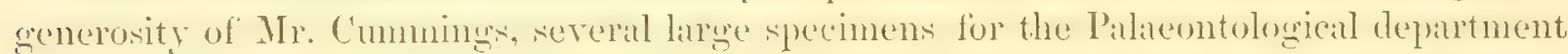

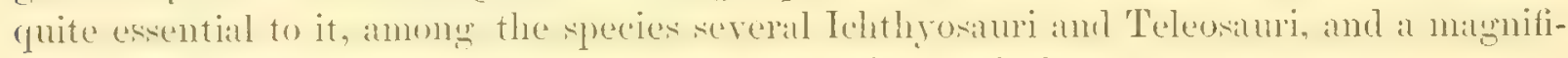
cent plate of the expanded species of the Pentacrinus Briarius.

A splendid collection of Devonian fossils collected near Ithaca, New York, had also been arked to the Palateontological series, partly by donations of Mr. John Cummings and Mr. Thos. T. Bouvé, and partly by purchase.

'The illness of Mr. Frarerue had interrupted work in the Entomological department. It was reported hy Mr. Enerton, free from destructive insects. Dr. Carpenter had continned work on the IIollusca. To the Comparative Anatomy department a prepared skeleton of a horse makerel had been added. Work on the Fishes had been begum by Mr. Putnam, Chairman of the Ichthyological Committee.

'The Ornithological collection hal been frepuently inspected through the year. It was reported as free from insects. Considerable work had been dome in the Botanical department by Mis. Carter, employed at the expense of Mr. John Cummings, to inspect and arrange the duplicates.

During the year five Corresponding and thirty-one Resident Members had been elected. There had heen seventeen greneral meetings of the Society, eight of the section of Entomology, and seven of the section of Microscopy.

The plan of notifying each member hy postal cart of the general meetings and of the papers to be read at each, allopted in the autumm, hart heen attended with great success. The numbers present since Oet. 10̈th, have averaged sixty-four, whereas the arerage mumber the previous year tras but twenty-five. The greatest number of persons present at one meeting was one humberl and twenty-four, the largest society meeting ever held in this building.

Only one course of the Lowell Institute Lectures was given. This was by Dr. Thos. Dwight, Jr., upon living animal tissues.

The disastrous effects of the great fire of November, 1872, had prevented the continunce of the lectures to tenchers, so generously provided for hitherto by Mr. John Cummings. 
Of publications, four articles in the Memoirs had appeared, and four parts of the Proceedings. The library had received during the year three hundred and twenty-three volumes, eight hundred and thirty-three parts of volumes, one hundred and twenty-four pamphlets, and forty-nine maps and charts.

Respecting the alterations that had been going on, the Custodian remarked that a considerable part of the year had been taken up in making them. There would undoubtedly be experienced some difficulty in the arrangement of details in the separate collections but the natural sequence of forms, whether mineralogical, geological, or zoölogical would be as fully and better illustrated than it ever has been in any printed work embracing similar gromets, an achievenent heretofore considered unittainable in Museums of the size of this. He deprecated having ascribed to himself the whole credit of the extraordinary success thus firr obtained, mentioning that the President had urged the adoption of the plan of oreanization presented in the amnual report of 1870-71, and had ever since given it his energetic support.

At the election of officers for the year ensuing, Mr. Samuel H. Scudder was chosen First Vice-President, and Mr. John Cumnings Second Vice-President of the Society, talking the powitions hitherto held hy Dr. Chas. T. Jackson, and Mr. Richard C. Greculeatf.

T. Sterry Hunt and L. S. Burbank were chosen upon the Committee on Geology, from which John Cummings resigned; R. H. Richards was chorem upon the Committee on Minerals, in place of Dr. Charles 'T. Jackson; John Cummings was chosen one of the Committee on Botany in place of William T. Brigham.

On motion of Dr. Kneeland the thanks of the Society were unanimously voted to the retiring Vice-President, Mr. Greenleaf, for his valuable services. The following resolution presented by Mr. George Washington Warren was also unanimously passed:

"Pesolect, That this Society desires to place upon its records, its high appreciation of the eminent services rendered by Dr. Chas. T'. Jackson, one of its Vice-Presidents, and of the high honor conferred upon the Society hy his long association with it; and it would respectfully tender to his afllicter fimily its sincere condolence for the malary which has overtaken him, and has so abruptly terminated, for a season only, it is greatly to be hoped, his scientific researches, which have been of inestimable value to the public."

It was voted that a copy of the resolution be sent to the family of Dr. Jackson.

Six years have now passed since the above mentioned action was taken by the Society, and as the hope expressed of the renewal of scientific work on the part of Dr. Jackson, has not been and is not likely to be realized, ${ }^{1}$ there can be no more fitting occasion to dwell upon his connection with, and his services to the Society. He was not, strictly speaking, one of its original memhers, but he, soon after its foundation, was acting among them, and in 1833 was elected to the office of Curator.

To no man was the Society more indebted for constant and active zeal in its welfare than to Dr. Charles T. Jackson during the first forty years of its existence. Others surpassed him in laborious work on its collections when nearly all done upon them was by voluntary eflort; others in exerting ereater influence in the community for its advantage; but none in a constant manifestrtion of interest in its proceedings as shown by so long and uninterrupted a participation in them, and by the generous donation of a large por- 
tion of his mineral collection. No man among the members perhaps manifested more genius for scientific work. Had the truly brilliant suggestions of his mind been always followed up by prompt endeavor to obtain practical results, he would have been recognized everywhere as a great discoverer and benefactor. This is not the place to discuss questions relative to his instrumentality in the introduction of ether as an ansthetic agent. Suffice it here to express what is clearly true that the friends who knew him the most intimately and who were his constant companions, ever felt that much more was due to him than the world awarded. Whatever may be said, however, upon mooted points, all who were members of the Society in his days of activity will agree that he served it well and faithfully and that he richly earmed its gratitude. Possessed of a good memory, and having a great fund of information upon almost all suljects that came up for discusion at the meetings, Dr. Jackson became much relied upon to take part when there was any lack of speakers, and thus often largely contributed to the interest of proceedings that might otherwise have been dull. Moreover, he frequently read papers of great value which appeared in the publications of the Society.

In the Council meeting first held after the annual one of the Society, the usual committees for the year were formed, and a new arrangement was made with the Custodian, by which it wats understood that he should give all his time to the society excepting such as was resuired by him for his regular lectures, and he hedel responsible for the building and all the employees under his charge; these to be considered his assistants and not those of the other officers or of members of the Council. The Custodian or the Huseum assistant to be present during office hours. The Secretary to be present only when necessary, and the second assistant to be a general assistant under his charge.

In furtherance of the plan still in progress to arrange the collections in consecutive order, the Council voted, upon representation of Mr. Bouvé in behalf of the committee on alterations, that it wats necessary to fit up the gallery on the south side of the building for the reception of Protozoans and Radiates.

Walker Prizes. The subject proposed for the Walker annual prize for 1874 was "The comparative structure of the limbs of birds and reptiles." No essay of sufficient merit for an award was presented.

In June of this year, the subject of a Zoölogical Garden came before the Society and the Council. At a meeting of the former, it was voted, upon motion of Mr. G. Washington Warren, that a committee be appointed by the Chair to urge, in the name of the Society, betore the Park Commisioner's and the City Council, the importance of providing for the extahlishment of a Zoiblogical Garden and Aquarium in comneetion with one of the proposed public parks, and that said committee have power to call a special meeting of the Society whenever it maly be thought expeedient to consider such recommendation ats the committee may suggest in relation to the subject.

Whether this committee was appointed and if so what they did, is not reported in the records. The matter is quoted as indicating the readiness of the Society to coöperate with the City govermment in any movement that may be made towards the estallishment of a Zoölogical Garden. 



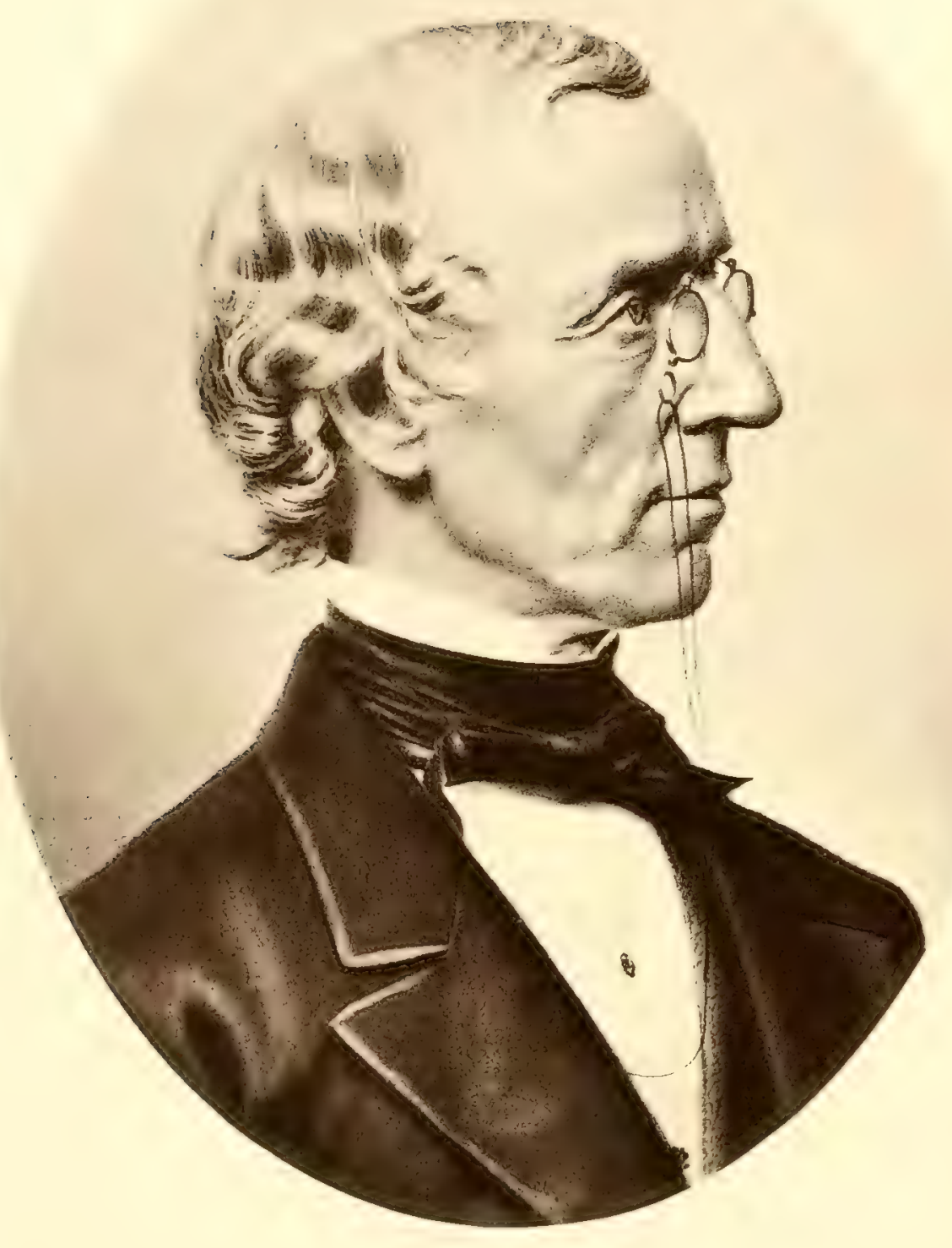

$$
\text { Jestres Waman }
$$




\title{
JEFFRIES WYMAN.
}

\author{
Died 4th Sept., 1874.
}

\begin{abstract}
TrE wisest man could ask no more of Fate
Than to be simple, modest, manly, true,

Safe from the Many, honored by the Few;

Nothing to court in World, or Church, or State,

But inwardly in secret to be great;

To feel mysterious Nature ever new,

To touch, if not to grasp, her endless clew,

And learn by each discovery how to wait;

'I'o widen knowledge and escape the praise;

Wisely to teach, because more wise to learn;

To toil for Science, not to draw men's gaze,

But for her lore of self-denial stern;

That such a man could spring from our decays

Fans the soul's nobler faith rutil it burn.
\end{abstract}

Jayes Russell Lowell.

The first meeting of the Society in the autumn was held on October 7 th. There were one humdred and fourteen persons present, many of whom had come expressly to testify their great respect and regard for the memory of Dr. Jeffries Wyman, whose death had occurred on the fourth day of the previous month. The President addressed the members as follows:

After our usual summer vacation we meet together with more than accustomed emotion; for mixed with the joy of greeting one another after separation, there is a consciousness of irreparable loss that weighs heavily upon our spirits, a recognition that there have gone away from us a force and a virtue which have so long been a help and inspiration, that we camnot but fecl a sense of bereavement such as no words of mine can adequately express. Sad indeed is it for us and for all, that such nobleness of nature, such wealth of acquired knowledge, such purity and simplicity of life, as were manifented in JefFries Wrans, should pass from the world; for rare, too rare, are to be found examples of such exalted character and attainments.

To our Society Professor Wyman was a great benefactor; not in the sense of a donor especially, but in the higher sense of one imparting to it such honorable fame as enhanced greatly respect for it, both at home and abroad. To him also was the Society mainly indeloted for the interest shown in our work hy the late Dr. Walker, and which led directly to its large endowment with means of succers.

But pleasant as it would be for me, as a personal friend, to dwell upon the transcendent virtues of one whom I have always regarded with the highest respect and most affectionate esteem, I feel it would be unbecoming to further occupy your time in view of those present, who have come here with their tributes of love to the memory of our dear departed friend. I therefore close by inviting others to address you, first ealling upon Dr. Asa Gray, who, from his great regard for Professor Wyman has kindly prepared a notice of his life and work to read on this occasion. 
Dr. Gray said:-

When we think of the associate and friend whose death this Socicty now deplores, and remember how modest and retiring he was, how averse to laudation and reticent of words, we feel it becoming to speak of him, now that he has gone, with much of the reserve which would be imposed upon us if he were living. Yet his own perfect truthfulness and nice sense of justice, and the benefit to be derived from the contemplation of such a character by way of example, may be our warrant for reasonable freedom in the expression of our judgments and our sentiments, taking care to aroid all exargeration.

Appropriate and sincere eulogies and expressions of loss, both official and personal, have, however, already been pronounced or published; and anong them one from the governors of that institution to which, together with our own Society, most of Professor Wyman's official life and services were devoterl,-which appears to me to delineate in the fewest words the truest outlines of his character. In it the President and Fellows of Marvard University "recall with affectionate respect and admiration the sagacity, patience and rectiturle which characterized all his scientific work, his clearness, accuracy and conciseness as a writer and teacher, and the industry and zeal with which he labored upon the two admirable collections.s which remain as monuments of his rare knowledge, method and slitl. They commend to the young men of the University this signal example of a character modest, tranquil, dignified and independent, and of a life simple, contented and honored."

What more can be or need be said? It is left for me, in compliance with your invitation, Mr. President, to say something of what he was to us, and has done for us, and to put upon record, for the use of those who come after us, some account of his uneventful life, some notice, however imperfect, of his work and his writings. I could not do this without the help of friends who linew him well in early life, and of some of you who are much more conversant thim I an with most of his researches. Such aid, promptly rendered, has been thankfully accepted and freely used.

Our associate's fither, Dr. Rufus Wyman,-born in Woburn, grarluated at IIarvard College in 1799, and in the latter part of his life Physician to the MIcLean Asylum for the Insane,- was a man of marked ability and ingenuity. Called to the charge of this earliest institution of the kind in New England at its beginning, he organized the plan of treatment and devised the excellent mechanical arrangements which have since been developed, and introduced into other estahlishments of the kind. His mother was Am Morrill, daughter of James Morrill, a Boston merchant. 'This name is continued, and is familiar to us, in that of our associate's elder brother.

Jeffries Wyman, the third son, derived his baptismal name from the distinguished Dr. John Jeffries, of Boston, under whom his father studied medicine. IIe was born on the 11th of August, 1814, at Chelmsford, a tomship of a few hmolred inhabitants in Middlesex Co., Miss', not far from the present city of Lowell. As his fither took up his residence at the IIcLean Asylum in 1818, when Jeffries was only four years old, he received the rudiments of his education at Charlestown, in a private school; but afterwards went to the Academy at Chelmsford, and, in 18\%6, to Phillips Exeter Acadeny, where, under the instruction of Dr. Abbot, he was frepared for college. He entered 
IIarrard College in 1829, the year in which Josiath Quiney took the presidener, ant was graduated in 1833, in a class of fifty-six, six of whom became professors in the University. II was not remarkable for general scholarship, but was fond of chemistry, and his preference for anatomical studies was already developed. Some of his class-mates remember the interest which was excited among them by a skeleton which he made of a mammoth bull-frog from Fresh Pond, probahly one which is still preserved in his musen of comparative anatomy. His skill and taste in drawing, which he turned to such excellent account in his investigations and in the lecture room, as well as his habit of close observation of natural objects met with in his strolls, were manifested even in boyhood.

An attack of pneumonia during his senior year in college caused much anxiety, and perhaps laid the foundation of the puhnonary affection which burdened and fintlly shortened his life. To recover from the effects of the attack, and to guard against its return, he made in the winter of 1833-34, the first of those pilgrimages to the coast of the Southern States, which in later years were so often repeated. Returning with strength renewed in the course of the following spring, he began the study of medicine under Dr. John C. Dalton, who harl suceeented to his father's practice at Chelmsford, but who soon removed to the adjacent and thriving town of Lowell. IIere, and with his fither at the MICLean Asylum, and at the Medical Colleme in Boston, he passerl two years of profitable study. $\Lambda t$ the commencement of the third year he was elected house-student in the Merlical Department, at the Mitsichustts General IIospital, - then under the charge of Doctors James Jackson, John Ware and Walter Channing-a responsible position, not only most adrantageous for the study of disease, but well adapted to sharpen a young man's power of observation.

In 1837, after receiving the regree of Doctor of Medicine, he cast about among the larger country towns for a field in which to practice his profession. Fortunately for science he found no openimg to his mind; so he took an office in Boston, on Washington Strect, and accepter the honorable, but far from lucrative post of Demonstrator of Anatomy under Dr. John C. Warren, the Hersey Professor. His means were very slender, and his life abstemious to the verge of privation; for he was unwilling to burden his father, who, indeed, had done all he could in providing for the education of two sons. It may be interesting to know that, to eke out his subsistence, he became at this time a member of the Boston Fire Department, under an appointment of Samuel A. Eliot, Mayor, dated Sept. 1st, 1838. He was assigned to Engine No. 18. The rule was that the first-comer to the engine house should bear the lantem, and be absolved from other work. Wyman lived near by, and his promptitude generally saved him from all severer labor than that of enlightening his company.

The turning point in his life, $i$. e., an opportunity which he could seize of devoting it to science, came when $\mathrm{Mr}$. John A. Lowell offered him the curatorship of the Lowell Institute, just brought into operation, and a course of lectures in it. He delivered his course of twelve lectures upon Comparative Anatomy and Physiology in the winter of 1810-41; and with the money eamed by this first essay in instructing other's, he went to Europe to seek further instruction for himself. IIe reached Paris in May, 1841, and gave his time at once to IIuman Anatomy at the School of Nedicine, and Comparative Anatomy and Natural History at the Garden of Plants, attending the lectures of Flomens, Majendie, and 
Isonget on Physiology, and of de Blainville, Isidore St. IIilaire, Valenciennes, Duméril, and Milne-Edwards on Zoölogy and Comparative Anatomy. In the summer, when the lectures were over, he made a pedestrian jomrney along the banks of the Loire, and another along the Rhine, returning through Belgium, and by steamer to London. There, while engaged in the sturly of the IInuterian collections at the fioyal Collerge of surgeons, he received information of the alarming illness of his fither; he immediately turned his face homeward, but on reaching Halifax he learned that his father was no more.

He resumed his residence in Boston, and devoted himself mainly to scientific work, under circumstances of no small discouragement. But in 1843 the merns of a modest profesional livelihood came to him in the offer of the chair of Anatomy and Phy wology in the medical department of IIamplen-Sydney College, estal)lished at Richmond, Virginia. One advantage of this position was that it did not. interrupt his resillence in Buston except for the winter and spring; and during these months the milder clinate of Richnond was even then desirable. He discharged the duties of the chair most acceptably for five sessions, until, in 1847, he was appointed to-succeed Dr. Warren as Hersey Professor of Anatomy in IFarvard Collerge, the Parkman profersorship in the Nerdical School in Bo-ton being filled by the present incumbent, Dr. Holmes. Thus commenced Prof. Wyman's most useful and honoral,le comnection as a teacher with the University, of which the President and Fellows speak in the terms I have already recited. He began his work in IIolden Chaped, the upper floor being the lecture-room, the lower containing the disinecting room and the anatomical museum of the College, with which he combined his own collections and preparations, which from that time forward increased rapidly in number and value under his industrious and sillful hands. At length boykton Hall was huilt for the anatomical and the chemical departments, and the museum, lecture and working-rooms were established commodionsly in their prevent quarters; and Prof. Wyman's department assumed the rank and the importance which it deserved. Both human and comparative anatomy were taught to special pupils, some of whom have proved themselves worthy of their honored master, while the anmual courses of lectures and lessons on Anatomy, Physiology, and for a time the principles of Zoülogy, imparted highly valued instruction to undergraduates and others.

In the formation and perfecting of his museum - the first of the lind in the country, arranged upon a plan both plyyiological and morphological - no pains and labors were spared, and long and arduous journeys and voyages were made to contribute to its riches. In the summer of $1849,-$ having replenished his frugal means with the proceeds of a secont course of lectures before the Lowell Institute (viz:, upon Comparative Phy-iology, a good condensed short-hand report of which was published at the time), - he accompanied Captain Atwoot of Provincetown, in a small sloop, upon a fishing voyage high up the coast of Labrador; in the winter of 1852, going to Florida for his health, he began his fruitul series of explorations and collections in that interesting district. In 18.54, acconpanied by his wife, he travelled extensively in Europe. and visited all the museums within his reach. In the spring of 1856 , with his pupils, Green and Bancroft, as companions and assistants, he sailed to Surinam, penetrated far into the interior in canoes, made important resentedes upon the ground, and enricher his nusem with some of its most interesting collections. These came near being too dearly bought, as he and his companions took the 
fever of the country, from which he suffered severely, and recovered slowly. Again, in 18.j8-?, accepting the thoughtful and generous invitation of Capt. J. M. Forbes, he mate a voyage to the La Plata, ascended the Uraguay and the Parana in a small iron steamer which Captain Forbes brought upon the deck of his vessel; then, with his friend George Augustus Peahody as a companion, he crosed the pampas to Afendera, and the Cordilleras to Santiago and Valparaiso, whence he came home by way of the Peruvian coast and the Isthmus.

By such expeditions many of the choice materials of his musem and of his researehes were gathered, at his own expense, to be carefully prepared and elaborated by his own unaided hands. A vast neighboring museum is a splendid example of what munificence, called forth by personal enthusiasm, may accomplish. In Dr. Wyman's we have an example of what one man may do unaided, with feeble health and feebler means, by persistent and well-directed industry, without eclât, and almost without observation. While we duly honor those who of their abundance cast their gifts into the treasury of science, let us not - now that he cannot be pained by our praise - forget to honor one who in silence and penury cast in more than they all.

Of penury in a literal sense we may not speak; for although Prof. Wyman's salary, derived from the Hersey endowment, was slender indeed, he adapted his wants to his means, foregoing neither his independence nor his scientific work; and I suppose no one ever heard him complain. In 1856 came unexpected and honorable aid from two old friends of his father who appreciated the son, and wished him to go on with his scientific work without distraction. One of them, the late Dr. William J. Walker, sent him ten thousand dollars outright; the other, the late Thomas Lee, who had helped in his early education, supplemented the cmlownent of the IIersey profersornhip with an equal sum, stipulating that the income thereof should be paid to Prof. Wyman during life, whether he held the chair or not. Seldom, if ever, has a moderate sum produced a greater benefit.

Throughout the later years of Prof. Wyman's life a new museum has claimed his interest and care, and is indebted to him for much of its value and promise. In 1866, when failing strength demamiled a respite from oral teaching, and reeguired him to paiss most of the season for it in a milder climate, he was named by the late George Peabody one of the seven trustees of the IInseum and Profesworship of American Archacology and Ethnology, which this philanthropist proceeded to found in Harvard University; and his associates called upon him to take charge of the establishment. For this he was peculiarly fitted hy all his previous studies, and by his predilection for ethologingal incuiries. These had already engaged his attention, and to this class of subjects he was thereafter mainly devoted,- with what sagacity, consummate skill, untiring diligence and success, his seven amnual Reports - the list published just before he dierl,- - his elaborate memoir on shell-heaps, now printing, and especially the Archaeological Museum in Boylston IIall, alundantly testify. If this museum be a worthy memorial of the founders liberality and foresight, it is no less a monument of Wyman's rare ability and devotion. Whenever the enduring building which is to receive it shall be erected, surely the name of its first curator and organizer should be inscribed, along with that of the founder, over its portal.

Of Prof. Wyman's domestic life, let it here suffice to record, that in Dec., 1850, he married Adeline Wheelwright, who died in June 155., leaving two daughters; that in 
August, 1Sfi, he married Amma Williams Whitney, who died in February, 1S6t, shortly after the birth of an only and a surviving son.

Of his later days, of the slow, yet all too rapid progress of fatal pulmonary disease, it is needless to protract the story. Winter after winter, as he exchanged our bleak climate for that of Florida, we could only hope that he might return. Spring after spring he came back to us invigorated, thanks to the bland air and the open life in boat and tent, which acted like a charm;- thanks, too, to the watchful care of his attached friend, Mr. Peaborly, his constant companion in Floridil life. One winter was parser in Europe, partly in reference to the Archeological Museum. partly in hope of better health; but no benefit was received. The past winter in Florida produced the usual amelioration, and the amount of work which Dr. Wyman undertook and accomplished last summer might have tasked a robust man. There were important accessions to the archæological collections, upon which much labor, very trying to ordinary patience, had to be expended. And in the last interview I had with him, he told me that he had gone through his own museum of comparative anatomy, which had somewhat suffered in consequence of the alterations in Boylston Hall, and had put the whole into perfect order. It was late in August when he left Cambridge for his usual visit to the White NIountain region, by which he avoided the autumual catarrh; and there, at Bethlehem, New Hampshire, on the th of September, a severe hemorrhatge from the lungs sudtenly clowed his valuable life.

Let us turn to his relations with this Society. He entered it in October, 1837, just thirty-seven years ago, and shortly after he had taken his degree of Doctor in Pedicine. IIe was Recording secretary from 1839 to 1841 ; Curator of Ichthyology and IIerpetology from 1841 to 1847, of Herpetology from 1847 to 1855, of Comparative Anatomy from 1855 to 1874 . While in these latter years his duties may have been almost nominal, it should be remembered that in the earlier days a curator not only took charge of his portion of the Museum, but in a great degree created it. Then for fourteen years, from 1856 to 1870, he was the President of this Society, as assiduous in all its duties as he was wise in council; and he resigned the chair which he so long atorned and dignified only when the increasing delicacy of his health, to which night-exposure was prejudicial, made it unvafe for him any longer to undertake its duties. The record shows that he has made here one hundred and five scientific communications, several of them very important papers, every one of some positive value; for you all know that Prof. Wyman never spoke or wrote except to a direct purpose, and because there was something which it was worth while to communicate. He bore his part also in the American Academy of Arts and Sciences, of which he was a Fellow from the year 1843, and for many years a Councillur. To it he made a good number of communications; among them one of the longest and ablest of his memoirs.

Dr. Gray then went on to give a brief account of Prof. Wyman's scientific work, as recorded in his pullished papers which have appeared in the Journal and Proceedings of this Society, in the Proceedings of the American Acarlemy; in the Buston Mrerlicall Journal, in Silliman's Joumal and in the Smithsonian Contributions. Of several of them he presented interesting anilyses which may be found in the pullished records of the meeting. After notice of what he had done Dr. Gray continued his remarks as follows: 
The thought that fills our minds upon a survey even. so incomplete as this is: How much he did, how well he did it all, and how simply and quietly! We knew that our associate, though never hurried, was never idle, and that his great repose of manner covered a sustained energy; but I suspect that none of us, without searching out and collecting his published papers, had aderpuately estimated their number and their value. There is nothing forth-putting about them, nothing adventitious, never even a phrase to herald a matter which he deemed important.

His work as a teacher was of the same quality. He was one of the best lecturers I ever heard, although, and partly because, he was the most unpretending. You never thought of the spealier, nor of the gifts and acquisitions which such clear exposition were calling forth, - only of what he was simply telling and showing you. 'Then to those who, like his pupils and friends, were in personal contact with him, there was the added charm of a most serene and sweet temper. He was truthful and conscientious to the very core. His perfect freedom, in lectures as well as in writing, and no less so in daily conversation, from all exaggeration, false perspective, and fictitious arlormment, was the natural expression of his innate modesty and refined taste, and also of his reverence for the exact truth.

Respecting the views of Jeffries Wyman upon the subject that has most deeply moved the minds of profound thinkers in our day, Dr. Gray remarked:

In these days it is sure to be asked how an anatomist, physiologist, and morphologist like Prof. Wyman regarded the most remarkable scientific movement of his time, the revival and apparent prevalence of doctrines of evolution. As might be expected, he was neither an advocate nor an opponent. Ha was not one of those persons who quickly make up their minds, and amounce their opinions with a confidence inversely proportionate to their knowledge. He could consider long, and hold his judgment in suspense.

And further on he adds:

Upon one point Wyman was clear from the beginning. IIe did not wait until evolutionary dectrines were about to prevail, before he judged them to be essentially philosophical and healthful, "in accordance with the order of Nature, as commonly manifested in her works," and that they need not disturb the foundations of natural theology.

Perhaps none of us can be trusted to judge of such a question impartially, upon the bare merits of the case; but Wyman's judgment was as free from bias as that of any one I ever knew. Not at all, however, in this case from indifference or unconcern. He was not only, philosophically, a convinced theist, in all hours and under all "variations of mood and tense," but personally a devout man, an habitual and reverent attendant upon Christian worship and ministrations.

Those of us who attender his funeral must have felt the appropriateness for the oceasion of the words which were there read from the Psalmist:-

"The Heavens declare the grlory of God, and the firmament showeth his handy-work. ..... O Lord, how manifold are thy works! In wisdom hast thou made them all; the earth is full of thy riches; so is this great and wide sea, wherein are things creeping imnumerable, both great and small beast.s. Thou sendest forth thy spirit, they are rreated, and thou renewest the face of the earth." 
These are the works which our associate loved to investigate, and this the spirit in which he contemplated them. Not less apposite were the Beatitudes that followed :-

Blessed are the meek; blessed are the peace-makers; blessed are the merciful; blessed are the pure in heart.

Those who knew him best, best know how well he exemplified them.

Upon the conclusion of the address of Dr. Gray, Mr. F. W. Putnam offered the fullowing Resolutions:-

"Pesoleed, That in the death of Jeffries Wrman the Boston Society of Natural IIistory mourns the loss of a most honored member and efficient officer; one who was untiring in his labors for the Society during his long and active connection with it as Curator, Secretary and President; and that, in his death, Science has lost a most thorough and careful investigator, and the cause of education and truth a most devoted and conscientious disciple.

"Resoleed, That as memhers of a Society who gare to Professor Wyman the highest honor and position we could bestow, we acknowledge our indebtedness to him for the thoughtfulness and care with which he guided our labors for so many years, and, while filled with sorrow at our own loss, we ask the privilege, by transmission of these resolutions, of extending our sympathy to his bereaved family in their great trial."

These resolutions were seconded by Dr. D. II. Storer, who said :-

Mr. President, I most cordially second the adoption of the resolutions which have been presenterl. The scientific reputition of on departed friend was universally acknowledged, but the beauty of his life was equally worthy of admiration. I never knew a gentler purer, nobler spirit. As a brother I loved him, and I mourn him.

The Resolutions were unanimously adopted.

The following letter from Prof. Rogers was then read:

\section{To President Bouvé,}

Newport, Oct. 6, 1874 .

IIy dear friend:- I regret that it will not be in my power to attend the meeting of the Satural Ilistory Society to-morrow evening, as I should greatly desire to unite with you in an affectionate tribute to the memory of Prof. Wyman, whose long services as President of the Societr, and whose peculiar excellences as a student of nature must ever claim our regard and admiration.

From my first acruaintance with him, while engaged in the delieate microscopic dissections with which he illustraterl the work of the late Dr. Amos Binney on Lant-shells, until within a few years past, I have had frequent opportunities of marking his scientific progress; and although but little accuainter with the inquiries to which he chiefly devotert himself. I have understood enough of his libors to appreciate his singular patience and accuracy as an observer, his ingenuity in devising experiments, and the caution and conscientiousness with which he was accustomed to report the results of his investigations.

These qualities, early recognized by his scientific co-workers abroad as well as at home, placed him in the front rimk of the promoters of the biologieal sciences. To these intel- 
lectual gifts were added a modesty and self-firretfulness which, while they were unfirorable to the more popular recognition of his merits, have rendered his example preëminently worthy of imitation by all honest seekers after truth. Yours faithfully,

Witlitan B. Rogers.

In October the President received a letter from Miss Susan Wyman, Administratrix, stating that the will of her father, Dr. Jeffries Wyman. har an item rearling: "I offer to the Doston society of Natural History my collection of Comparative Anatomy. they paying therefor the sum of three thousand dollars." After considerable discussion it was voted to refer the matter to a committee appointed by the Chair. Dr. B. Joy Jeffries, Dr. 'T. M. Brewer, and Mr. Chas. J. Sprague, composed this committee. In November, the committee on the berpuest reported recommending the romeil to aresept the offer mank in the will, and also, in consequence of the increased value of the collection, to pay $\$ 5000$ instead of $\$ 3000$.

Iuch discussion followerl. it heing suggesterl that posilhy there might he fircts not yet before the Comeil concerning the later wishes of Dr. Wyman in regard to the dispowal of the collection which might influence action. A decision upon the matter was therefore further postponed, and the President was recquested to confer with Dr. Morrill Wyman, and to report the result to the Council two days later. This he did at a large meeting of that body, there being twenty-one members present. Much more discusion followed, some members thinking the expense too great for the Society to incur, others that the wish of the late President as expressed in the will should be respected even at some sacrifice. None oljected to increasing the amount to $\$, 5000$ provided the collection was received.

It was finally voted to accept the offer made in the will, and also in consequence of the increased value of the collection since the execution of that instrument, that $\$ 20000$ arditional be paid. Drs. Dwight and White were appointed a committee to take all necessary action to remove the collection and have cases prepared for its reception.

1575. The Report of the Custodian at the ammal meeting in May, was as usual full of interest to the members. Respecting the work in the building for the protection of the collections yet in progress, he stated "that such as had been proposed to be done within the year has been completed. More than half the cases are now secured against the entrance of dust and insects, and the most valuable prepartions can be safely truster to their protection. If any member of the Society will take the trouble to walk through our rooms, he will easily satisfy himself' of the necessity of these changes. 'The comlition of the collections which still remain in the old eases, whose loose doors camnot be secured cither against dust or insects, show this very plainly. The tables in the Palacontologieal and Conchological collections, though but recently completed, are more or less disfigured by dust, and where more perishable specimens exist, as among birds and mammals, the amount of damage done will in a few years be irretrievable."

Much work hat heen done upon the collections during the year. Mr. Emerton had been occupied in removing those of the Geological department, and also the sponges, corals and echinoderms.

The minerals had heen rearranged by the President, so as to make a most attractive display in the newly fumished room at the right of the main entrance. In the gallery of this room he had placed a special collection of New England species. 
The Eser Palacontologrical collection, presented hy Mr. John Cummings, had been thoroughly revised by Mr. Croshy. and was being mounted for exhibition by Miss Carter, whose efficient services to the Society were due to the generosity of Mr. Cummings. IIr. Crosty had been also engagerl upon the American fossils, and they were being momited by Miss Washburn, for whore desiralle assistance the suciety had been likewise indebted to Mr. Cummings.

During the summer of the past year, the Custodian, assisted by Mr. Rathbum, worked for the U. S. Fish Commisioners under the charge of Prof. S. F. Bitird, to whom the Society was indebted for the ample opportunities given the Custorlian and his assistant for collecting. The valuable additions thus made to our New England collection had been revised and placed in complete order.

The Custodian, in mentioning some work done in preparing models illustrating some of the living forms of the Mollusea, remarked that the experiment had shown the practicalility of rendering our collections useful as a means of couveying accurate knowledge to general students, teachers and the public, and he strongly deplored the insufficiency of funds in every department of the IIuseum, necessary to this being done, except in that of Conchology, which the bequest of Miss Pratt provides for.

The 'Teachers' School of Science had been resuned with grood results, Mr. Cummings liberally furnishing the means. A course of about thirty lessons on Ninerals had been given by $\mathrm{Mr}$. L. S. Burbank of Lowell, and the usual plim of presenting specimens used at the lectures had been followed. In order to test the practical results of these gifts, enruiries were made which resulted in showing that in as many as fifty instances the specimens were being intelligently employed in the instruction of students of the teachers.

The Society may therefore congratulate itself upon being the birthplace of the first practicable movement for introducing the study of the natural sciences into the public schools of Boston.

The Botanical collection had received daily attention from Mr. Cummings, and had been much improved by his own work and that of Miss Carter. A beautiful as well as valuable addition to this department har been made by Mr. Edward 'T. Bouvé, consisting of the preparations of the leaves and stems of New England trees and shrubs pressed under panes of glass so that they can be readily studied without injury to the specimens. These were accompanied by other specimens of the wood and batrk of each species. When completed, as it will be as rapidly as possible, this collection will occupy a prominent place among the New England plants.

Among the donations worthy of mention was one of birds, shells and insects, received as a beciuent from the family of a deceased fellow-member, Mr. F. P. Atkinson. Although very young, Mr. Atkinson had already shown much interest in the study of natural history, and had attracted the friendly attention of many of the members of the Society, who deeply regretted his early death.

'The evening lectures given from the Lowell fuml by the Trustee, Mr. John Amory Lowell, consisted of four courses, and in all twenty lectures. Six were upon the "Chemistry of the Watere," hy Dr. T. Sterry IIunt; six upon "Injurious Fungi," hy Dr. W. G. Farlow; six upon "American Archæology," by Mr. F. W. Putnam; and two upon the "Village Indians of New Mexico," by Mr. Ernest Ingersoll. 
There hat heen eighteen general meetings with an arerage attendance of fifty-four persons, five of the section of Microscopy with an average attendance of eight persons and six of the section of Entomology, with an average of seven persons. On two occasions one humber and fourteen persons harl been present at the general meetings. One IIonorary, four Corresponding and thirty-seven Resident Members, had been elected; seventy-five communications had been presented.

Of the Publications, two quarterly parts each of volumes sixteen and seventeen of the Proceedings, and four articles of the Memoirs had been published.

The additions to the Lilnary harl been 297 volumes, 820 parts of volumes, 201 pamphlets, and 19 maps and charts.

The Treasurer's Report showed an excess of receipts over ordinary expenditures of \$248.81. There hat been besides extraordinary expenses, viz.: for alterations in Huseum and cases, $\$ 10,689.01$, and for the Wyman Collection, s.5, (100), making a total of $\$ 15,689.01$.

The changes marle in the officers, consisted in the resignations of William II. Niles from the Committee of Palacontology, J. H. Finerton from the Committee on Mammals, A. S. Packard, Jr., and $\Lambda$. E. Terrill from the Committee on Radiates, Crustacea and Worms, and the election of Dr. H. A. Hagen on the last mentioned Committee.

Walker Prizes. The subject proposed for competitive essays for this year was "Protective coloration in any class or classes of animals." No article was presented in response, or none deemed worthy of a prize.

In Mray, the Council of the Suciety, recognizing the importance of the zoilongical and botanical observations made by the U. S. Signal Service Bureau, passed resolutions expressing its interest in the continuance of such observations and their extension, as being of great vilue, afforling as they do, datal for important generalizations respecting not only the migrations of birds and the relation of their movements to atmospheric changes; but also rexpecting the influence of great extremes of temperature, the lateness or forwardness of the season, etc., upon the development and maturation of useful and other plants and the increate or decreatse of insect pests; thus possessing not only scientific importance but as likely to lead to valuable practical results, especially in relation to agriculture.

In view of these considerations and of the fact that such observations are beyond the power of private individuals to malse, the Council deemed a special appropriation a wise expenditure of the public money.

liesolutions expressing the alove were tramsmitted to General Albert J. Meyer, Chief of the Signal Service Bureau.

A little incident in May was too expressive of the feelings existing on the part of the members towatrdic one of their number to be passed over without mention. Prof. Willian B. Rogers, who had not for a long period, by reason of illness, been able to attend the meeting of the societr, was present. prepared to offer a communication. Upon the President's introducing him with a few appropriate words of welcome, there immediately followerl such hearty platurlits from all the menubers as comld not fail to testify how great the respect and warm the love felt by them for their distinguished associate.

In October of this year, through the bequests of Mr. and Mrs. C. S. Hale of Burlington, New Jersey, the Society came into the possession of a considerable collection of 
Cretaceous and Tertiary fossils, inchding series of the Vertebrae of the Zeuglodon and of the Mosasaurus.

Mr. Hale upon a visit to Boston, many years ago, visited the rooms of the Society, then in Mason street, and wiss so much gratified with what he saw of the arrangenent of the cabinet, and of the care taken to exhibit the specimens to the best advantage. that he proffered to semt bones of the Zenglodon which he hat obtainert himself in Alabama, and place them in the society's collection, intimating that they might afterwards be presentert. They being received were properly placed for examination, duly labelled, and designated as deposited by him. These were the vertebrae mentioned as included in the bequest. The specimens received numbered ahout two thousant, of which over one thousand were catalogued and placer in the Carbinet. The others were put aside for exchange. Berilen the fossils there were several books upon natural history received, also bequeathed to the Society.

The painting of Prof. Agassiz hy MIr. C. Y. IIamilton, which has since been conspicuous among the prortraits possessed by the society, was purchased by the subscription of several of the members.

1876. The writer of these pages has not found it consistent with his feelings to often make personal reference to his own part in the proceedings of the Society. To avoid doing so altogether would be manifestly unjust to those who have been his supporters during his long service as chief executive officer, and to the rearler who ask for truth and not its obscuration. An event occurred at the meeting prior to that of the annual election which can not be passed over in silence with due regard to others than himself, and it may be added with justice to his own feelings of gratitude for some of the happiest moments of his official life. He had determined to resign the position he held, really desiring relief from responsibility, and fully ratisfied that the horiety would suffer no detriment from a change. To his surprise he was called upon at his house prior to the meeting by one of the most honored members, the President of another institution, who, speaking for himself and others, urged that the resignation should not be tendered. The writer had, however, too long considered the matter to readily yield, and went to the meeting firm in purpose to do as he had proposed. To his greater surprise he found there not only a very unusual number of members, but many who had not been in the hathit of attending. What was real as a valedictory wats listened to with great attention, after which a call to proceed to the business of the meeting was made. Instead of responding to this call, one alter another of those whom the writer most respected, addressert him in such terms of affectionate remonstrance against his resignation, ats to induce him not only to withdraw it, but to feel that henceforth what had heen regarded as a burden would be a joy, that the performance of the duties of his office would be sweetened as never hefore by the recognition that the respect and regard which he felt towards all the members were fully reciprocated by them.

The very laudatory remarks matce by the Custodian upon this matter the writer camot present here. He loes not feel at liberty to refinan from giving one paragralyh from his Report.

"An event, which in its results was very satisfactory to the officers of this Society, occurred at the meeting when the President offered his resignation. I allude to the 
"plurobation of the policy which har governed the Society during his presideney, expressert by many of our most influential members. The officers of the Society felt themselves to be identified with the President in this matter; and consequently, the ovation which he receiverl, and the absolutely unanimous vote of a lare and select nneeting of the suciety, requesting him to withdraw his resignation, were peculiarly grateful to them."

At the annual meeting in May, very important alterations were made, in the Constitution and By-laws, which were primarily sucsested by the desire on the part of many that women should be eligible as members of the Society. Others objected to this, partly because of the necessity that sometimes arose to speak upon matters not appropriate to discuss in the presence of ladies. Independently of considerations aflecting the ardmission of women, a large number favored the creation of a new grade of members, to be known as Associate Members, who should be adnitted to its neetings and take part in scientifie discussions, but who slould not be entitled to vote for the officers of the rociety, or participate in its business management. All those hitherto known as Resident Members to constitute a higher grade to be known as Corporate Members. New admissions to this grark only to be by election from Associate Hembers of at least a year's stamling and who either were professionally engaged in science, or had aided in its advancement.

The views of those faroring an adtlitional grate of members finally prevailer. They hat bern emboried in the proposed alterations to the Constitution, and the amendments had received the requisite three fourths vote of the members present at two consecutive meetings. 'They were finally adopted by a nearly unamimous vote. In the proposed alteration of the By-laws made, the article relating to the election of Corporate Members had been made to express, by a vote of the Society at the previous meeting, that only male Associate Members should be chosen. When final action was called for, Mr. Cummings moved that the word mile be omitted. After much discusion the motion previnled by a vote of forty-eight to twenty. The amendments to the By-laws were then adopted.

Thus after much deliberation and wam discuswion, the Society finally by decisive action ceased to make any sexual discrimination in the admission of members.

At the election of officers no changes were made, all serving the previous year having bcen reëlected.

The report of the Custodian was as usual full of interest to the members. Of the Minexalogical collection, it was said that accesions had heen male by the purchise of some Tesirable specimens from the Jackison collection and that there were in all belonging to the department 32030 trays and single specinens on exhibition, $34 t$ of which were in the New England collection.

In referring to the Botanical collection, it was stated that the New England colloction of specinems had been completerl, poisoned and catalongerl by Miss Carter, and that it contained neirly every species found within the New England States, there heing 1984, comprising 3207 specimens. Much work had also been done upon the greneral collection.

The preparation of the leaves and stems of New England trees and shrubs had been placed on exhibition hy the donor, Mr. Edward 'T. Bomvé, filling, with the aceompanying wood sections and specimens of fruit, one entire gallery. With these had been placed a series of plates from the last edition of "The 'Trees and shrubs of Matsitchusetts, presented by Mr. George B. Emerson, showing the natural colors of the leaves, flowers and fruit. 
Altorether, the Custorlian remarked, this collection must be convidered one of the mast attractive and instructive in the Museum.

The Bailey Microsenpical collertion hat had much labor devoterl to it hy Miss Washbum, who hard spent the greater part of the winter in catalugning it. Dr. IIenry Corman had continued his work mon the Burnett collection of mounted parasites. In the Comparative Anatomy department, Dr. Thomas Dwight hat finisherl the incorporation of the Wyman Anatomical collection with that of the Society, and hat prepareel miny sections showing the structure of bones for the cabinet. There had been an accession of the skeletons of a large sea-lion and of two fur seals, through the liberality of Captain Charles Bryant, the superintendent in charge of the Fur Seal Islands.

$\Lambda$ collection of sponges had been acquired by purchate and would form the beegiming of a collection of Protozoat. Very valuahle though mall collections of Australiam spouges had been received from Dr. W. G. Farlow and others, malking the dried collection of these animals the finest in this country.

The collection of New England Fishes har been consilerably enlarged throngh the facilities afforded the Custodian by the kindness of Prof. S. F. Baird of the U. S. Fish Commission.

In the department of MIollusen, consiterable work had been done upon moilels by the assistants in the Mrteum, and Dr. Brooks had heegun the preparation of an accompanying suite of anatonical preparations for earh mortel. An important adilition harl heen made in the shape of suites of motels showing the principal stages in the derelopment of the characteristic trpes of the Molluscal. Dr. P. P. Carpenter hard eontinued the work of classifying and labelling the shells.

All the Amelids had been reviewerd, sorted, ant the Entozon named by the Custorlian.

The Insects had receiver much attention from Mr. Ifenshaw, who reportert that the entire collection was free from Anthreni. To the collection of the Mammalia, a fine Polar hear had been presented hy lBishop, Willians, the skin of a fine grathomd hy Mr. Ardisom Child and a specimen of the eelehrated breed of Ancon sheep by Mr. George William Bond.

The Custollian mentioned that consilerable assistance had heen receiver during the year from the voluntary labors of Mr. Edward G. Gardner.

During the year another room had been fitted up with improved cases for the reception of New Finglind fishes, reptiles, birds and mammals, and much hat been done in provirting for the protection of the Museum against fire. A large service pipe had been introduecel. which would give an ample sulply of water. and exery workmom was provided with screw faucets. One large faucet with hose attached would be always ready in the cellar,

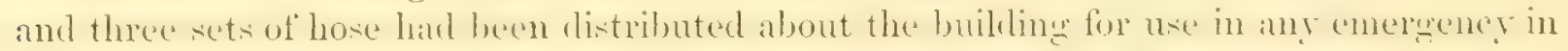
the work-rooms. On the roof two faucets, one on each wing, had been placed, to which hose could be attached. Buckets of water, with a Johnson pump had also been placed in each workroom, and three patent gas machines in different parts of the building.

The Custodian spoke of continued improvement in the condition and work of the Laboratory under the management of Mr. Crosby. There had been four female students, besides the usual number of students from the Technological Institute. 
The Teachers' School of Science had been carried on through the liberality of Mr. Cummings. The statement of the results is given almost verbatim from the Report of the Custodian as follows: Fourteen lectures or practical leswons in Lithology hatd been given hy IIr. L. S. Burbank, during the winter, at which the average attentance hat been ahout go out of 100 members. This was a remarkable fact, considering that the cliss included a large number of the busiest teachers, the masters of the public schools of Boston and the vicinity. Each member of the class was provided with tools, consisting of a small hammer, magnet, file, streak stone of Arkansas quartzite, a bottle of dilute acid with rubler stopper and ghlass rod, and the sale of hardness previously used in the Mineralogical class of the preceding winter. All there were purchased by the members of the class except the scale of hardness, reserved for future use. One hundred sets of rock specimens were distributed gratis, affording each of the teachers a series. Most of these were large enough for cabinet specimens, and many of the sets liarl been pliced in the collections of the city schools, and used in the instruction of the pupils. The specimens were largely collected in Irasiachusetts. The course was supplementerl by a series of excursions for field work in the vicinity of Boston.

Of the Lowell free lectures given under the direction of the Society ly the grenerosity of John Amory Lowell, Trustee, four courses were given during the winter. These courses consinted of six lectures, hy Prof. E. S. Morse, on six New England animals and their nearest allies; six by Prof. G. L. Goodale on Botany; six l,y Prof. T. Sterry IIm t on Ancient Rocks of North America ; and two hy Mr. L. S. Burbank on Mineral Veins and Ores. The course on Botany was the best attended, the numbers present averaging 192.

The arditions to the Library during the year hid heen 327 volumes, 1108 parts of volumes, 217 pamphlets and 67 maps and charts.

Of the Puldications there har been iswed two parts of each of the seventecnth and eighteenth volumes of the Proceedings, and three numbers of the Hemoirs. A secont volume of the Occational papers had also been published, of 171 pages and 21 plater.

The Report of the Treasurer exhibited an excess of expenditures over receipts of $\$ 522.39$.

At the election of officers, L. F. de Pourtalès was chosen on the Committee of Radiates, Crustacea and Worms, and Jules Marcou on the Committee of Palacontology.

Walker Prizes. The sulject for which the ammul prizes were ollered for this year was "An original investigation of the structure, development, and mode of life of one or more of the fungi which injuriously attack useful plants, such as the potato, the onion, the cranberry, etc., to be prefaced by an exposition of our present knowledge of the structure and development of the lower fungi." No essays were offered on this subject.

At a meeting of the Council in May, a vote was passecl, upon the motion of Prof. Shaler, that no existing Council shall formally or informally plectge any part of the Socicty's income for a future year.

During the summer recess this year, there passed away hy leath one of the original founders of the Society, Dr. Walter Channing.

Dr. Channing was not only one of the original members of this Society, but he was also one of the founders of the Limnean Society which preceded it. He took an active part in the early formation of both. Upon the organization of the Buston Suciety of 
Natural IIistory, he was elected one of its Curators, and subsequently became one of its second Vice-Presidents. He was born in Newport, R. I., on the 15th of April, 1756. 'The celebrated Dr. William Ellery Channing was his eldest brother, and Edward 'T. Channing, who long and ably filled the chair of Rhetoric in Harvard College, was a younger brother. Walter entered Harvard College in 1804, but did not graduate from there, a great rebellion among the students having led to his leaving the institution and devoting himself to the study of medicine in Boston. He afterwards pursued this study with great zeal in the schools of Philadelphia, Edinburgh, and London. In 1812 he established himself in the practice of his profession in Boston, and in the same year was appointed Lecturer in Obstetries at the Medical College. 'Three year's later he became Professor there of that branch of medical practice, the duties of which position he performed for nearly forty years.

In the practice of his profession Dr. Channing exhibited marked ability, especially in the department to which he gave particular attention. In the reform movements of his day he took great interest, and his pen and voice were very active in advocating them. In social life he was genial, and had the rare gift of being able at all times to interest listeners by the brilliancy of his conversation, enlivened as it ever was by ready wit.

A characteristic anecdote is, that when asked by a stranger who wished to see his more eminent brother, if he was the D1. Channing who preached, he replied, "No! it is my brother who preaches; I practice."

Dr. Channing died in Brookline, Mass., on the 27 th of July, 1876, at the age of 90 years.

In October the attention of the Council being called to the fact that at the meetings of the section of Microscopy the attendance had become very small, a vote was passed to discontinue the notification of them.

\section{Edifard Pickering.}

At the meeting, December 6th, President Bouvé addressing the members, remarked; "The Society is called to deplore the loss of a valuable member and officer in the death of our late Treasurer, Edward Pickering. Previously to our last meeting, Mr. Pickering had been ill for a day or two from a trouble in his throat affecting the vocal organs, and making it painful for him to converse freely, but he kept about his usual occupations until a few hours before we met, when feeling umable to be with us, he sent to me his regular financial statement for presentation to the Council in the evening. The trouble with him seemed similar to that he had before experienced, and there appeared no reason to anticipate its sad result.

"All, I am sure, were surprised and shocked to learn on the following Tuesday that he hand passed away early that morning. Mr. Pickering. though not strictly speaking a seientific man, was much interested in whatever conduced to the education of the community, and he consequently felt great interest in the well being of the Society. He became a member in 1860 , since which, he has always been a regular attendant on our meetings, and I think, from his highly appreciative mind, enjoyed much the proceedings. In 1865, he was elected Treasurer of the Society and he beeane also ex-oflicio one of the Trusteen, 
mecting the requirements of these positions with great devotion and efficiency. Our departed friend acquired the high respect of all who knew him, by his general intelligence, his marked intergrity, and his faithfulness to all the duties of the various offices he was called upon to fill, and he won the love of all who knew him intimately by his kindly sympathy and his Christian gentleness."

On motion of Mesirs. Scudder and IIyatt, it was voted that the Secretary send a copy of Mr. Bouvé's remarks to the family of Mr. Pickering, as an expression of the Society's respect and regard for him.

In December a very fine cast from the bust of Prof. Louis $\Lambda$ gassiz, by Preston Powers, was presented to the Society by the Rev. R. C. Waterston .

In Council a vote was passed allowing the use of the Laboratory of the Society to the Boston University for instruction in Zö̈logy; the lessons to be given by Mr. Hyatt, as Profestor of the Technological Institute, or his aswistant Mr. Crosky, and a suitable rent to be paid the Society.

1877. In January of this year, the death of Mr. F. B. Meek of Washington, a Corresponding Member, and one of the most eminent of American palaeontologists, was announced by the Secretary. At the next meeting the following resolutions were passed by the Society.

"Resolved, That the members of the Society have heard with the deepest regret of the decense of one of the most highly esteemed of their Corresponding Hembers, Mr. F. B. Meek of Washington. Their admiration can add but little to his reputation, which is secured by the numerous works of which he has been the author. They feel, however, that a testimonial is due from them to the memory of a man whose knowledge of the whole field of American palaeontology was unsurpassed, and whose life was a model of laborious special investigation and therefore unrewarled by public commendation. As students of natural history, they desire also to record their respect for a life of such modest simplicity and devotion to science for its own sake, that it merits, and will, it is hoped, receive the highest praise from the hands of Mr. Meek's fellow laborers.

"Ressolved, That this resolution be recorded in the Proceedings of this Society and that copies be forwarded to the friends of the deceased."

At a meeting of the Society February 2d, Charles W. Scudder was elected Treasurer.

In Council a vote was passed to procure a crayon of the late President, Dr. Jeffries Wyman, of life size, with a suitable frame. This was subsequently done, and the fine portrait obtained may now be seen in the Library room of the Huseum.

This body also upon hearing that another attempt was to be made to obtain a license for the exhibition of Jourdain's anatomical collection, again successfully remonstrated against one being granted, on the ground that it would be subversive of public morals.

In March, the President annomeed the death of Mr. Eilward Bicknell, the well-known Microscopist, and for several years a member of the Council of the Society.

A petition having been presented to the Council that the Museum of the Society should be opened to the public on Sundays, a committee was appointed to take the matter into consideration and to report upon the subject. This committee consisted of three, the President being of the number. At the next neeting, the committee reported adversely, on the ground mainly that the Society could not afford the additional expense that would be incurred by compliance. The report was approved unamimously.

In March also of this year, Dr. B. Joy Jeffries called the attention of the Society to the 
necessity of action on the part of the United States Government to prevent accidents by reason of color blindness in the army, navy and merchant service, and the need of the State governments also taking measures to prevent casualties on the railroads from the same cause. Whilst the possible danger arimg from color blindness harl been mentioned before, this was the first time in this country that the necessity of control on the part of the authorities was bronght forward and urerl. The action of the rovermment, state and National, and of the railroad corporations since, has proved Dr. Jeffries' position correct.

In April, the Lacrislature of the state having anthorized the licensing of such persons to shoot birds for scientific purposes as the Society might designate, a committee was appointed, consisting of the Custodian, Mr. Iyatt. Dr. 'Thomas M. Brewer"and Mr. J. A. Allen, to issue certificates to such persons as they deemed, upon due enquiry, proper to receive such license.

Many persons desiring admission to the Museum on other days than public days, the Council voted to admit such as the Custodian judged proper, upon the payment of a small entrance fee, to cover such additional expense as might be incurred thereby.

At the annual meeting in May, the reports of the Custodian, and of the Secretary, made in accordance with a new provision in the By-laws, were presented. An abstract from these follows.

During the year one additional room had heen fitted up with new cases and brackets, for the reception especially of the birds and mammals of the systematic collection. For further protection against loss hy fire, telegraphic commmnication hat been established with the fire engine house on Dartmouth Street by which, in case of necessity, engines could be had for service at the building within a few minutes after giving an alarm.

'The 'Teacer's' School of Science was continued, as in previous years, by the liberality of Mr. Cummings. The only course of lessons griven, was by Prof. Goodale of Harvard College, but this was a very comprehensive one, comprising twenty-one lectures on Morphological, Physiological and Fystematic Botany. The lessons were, as usual, illustrated by specimens which were distributed to the pupils. By the use of blank forms, which were given with the flowers. each teacher was enabled to analyse the specimens independently and record his observations, thus preventing confusion and allowing the instructor to cover more ground than would otherwise have been possible. 'The analysis of the flowers for the determination of the peculiarities of the floral structure by each teacher, was regarded by Prof. Goodale as an important element in the instruction given. The attendance was large, averaging one hundred.

In the Laboratory much work had been done of a satisfactory character. 'The collections for the use of students had been largely increased, and it was hoped they might be made complete before another year. The room and the collections had been protitably used by students of the Institute of 'Technology and of the Boston University.

The condition of the collections was reported to be good, and the progress made in arrangement, labelling, ete., quite satisfactory.

In the Nineral department the only change marle was by the ardition of new specimens, the greater portion of which had been presented by the President.

In the Palaeontological department under the charge of Mr. Crosby, much had been done by Miss Carter and Miss Washburn, for whose very valuable services the Society was indebted to the grenerosity of Mr. John Cummings. The former had mounted, 
catalogued, labelled and placed on exhibition, all the fossils of the Triassic and the Cretaceous periods, together with the larger part of the European Jurassic; whilst the latter had re-arranged, catalogued, and re-labelled all the fossils from the Devonian to the Cretaccous periods inclusive. A great amount of work too had been done in identifying the new specimens, the additions to the collection having been very numerous. The Jurassic, Triassic, and Carboniferous plants of North America had been tripled in number and value by accessions from the Rogers collection, and the Devonian and Cretaceous fossils much increased by additions from the Hale and Cleveland collections.

The Botanical department, under the charge of Mr. Cummings, had received much attention, and great progress had been mate in the revision of the general collection by Miss Carter.

The collection of the department of Comparative Anatomy had had much labor bestowerl upon it by Mr. Van Vleck. More work was necessary upon this collection than anticipated, and there yet remained much to do before its arrangement would be completed.

The cataloguing of the Microscopical collection had been finished by Miss Washburn early in the year. The whole was reported as consisting of ebof slides and preparations; of these, jot were preparations of parasitic insects acquired by purchase from the Burnett estate; 1838 were received in the berpuest of Professor Bailey, and consister largely of foraminiferae and diatoms; 195 were miscellaneous preparations of worms, crustacea and embryos of various kinds, prepared by Mr. J. II. Fmerton when assistant in the Museum, and 113 were preparations of the anatomy and skeletons of sponges, prepared by Mr. Crosby and the Custodian. Besides these, there was reported a great quantity of unmounted material. Subsequently to the close of Miss Washburn's work, the collection was euriched by the presentation to it of 477 slides prepared by Mr. William Glen, formerly of the Museum of Comparative Zoïlogy of Cambridge. These were purchased and given to the Society by Mr. R. C. Greenleaf and Dr. A. D. Sinclair. This collection was especially rich in sections of the spines of Echini and the tongues of Mollusks. Ineluding this accession and some specimens of miscellaneous character presented by Messis. E. Samuel, C. S. Busch and others, the Society collection was reported as containing, exclusive of duplicate material, 3356 slides and preparations.

The collection of Corals and Echinoderms was reported as mulergoing revision by $\mathrm{Mr}$. Van Vleck, who was likewise preparing the specimens for labelling. The Poriferae were receiving the same attention from the Custodian.

In the Molluscan department valuable work had been contimued by Dr. W. K. Brookis upon the models of the animals, anatomical preparations of them, and in explanatory outline drawings. He had also completed the re-arrangement of the shells. Much to the regret of the Society, Dr. Brooks removed to Baltimore, having been appointed assistant professor in the Johns Ilopkins University. After his departure the work upon the collection of the Molluscal was continued under the direction of Mr. Van Vleck, who reported that about one third of the specimens on exhibition had been re-libelled by Miss Washburn. Dr. P. P. Carpenter of Montreal had continued the work of identificition and had completed a large part of the terrestrial shells.

In the Entomologieal department Mr. Henshaw had continued his valuable labors. The New England collection of the Coleoptera had been completed, and the Nenroptera, Orthoptera, Hymenoptera and Lepidoptera re-arranged. Very important additions 
to the collection of Coleoptera had been marle from the collection of Mr. Spracue, the late assistant of the Museum. The Society was permitted, in accordance with the verbal request of Mr. Sprague, to select from the specimens left by him all that might be valuable to its collection, and thus additions were made to it of 600 species and 2000 specimens.

A revision of all the New England collections at this time showed them to consist of Ifymenopteral, 157 species; Lepirloptera, 711 species; Coleoptera, 1810 species; Orthoptera, 59 species; Neuroptera, 65 species.

To Dr. Hagen the Society was indebted for a revision and identification of all the Neuropteral, and to Mr. Burgess for the revision and inlentification of the Dipterat of the Harris collection. The entire Harris collection had been transferred to the new style of boxes, and was considered safe from the ravages of Anthreni. It is due to Mr. Henshaw to state that he voluntarily gave professional labor in the department of Entomology, equal to about seven hours daily during the year, the means of the Society not enabling it to adequately compensate him for his services.

The alcoholic collection of Reptiles had been sent to the Museum of Comparative Zoölogy for identification by Mr. Garman, who had kindly consented to examine and name them. It was understood too, that under the instruction of Mr. Alexander Agassiz, the director, he would add such species from the duplicates of the Museum as were needed in the collection of the Society. Mr. Garman had already been instrumental in increasing our collection of fishes in the same manner, and the Society had to some extent reciprocated the favor by sparing specimens from its duplicates.

The Custodian closed his remarks upon the collections of the Museum by stating that there was now a New England collection in every department, and that there was a great need of a new gallery around the main hall, which should be devoted exclusively to the New England department, so that a visitor could see arranged in one continuous series all the natural products of New Lingland. It is certainly a matter to be deeply regretted that the Society has not since been able to put up, such a gallery as suggested by the Custodian.

From the Secretary's Report, the following is given: to the Library there had been added of volumes, 357 ; parts of volumes, 977 ; pamphlets, 188 ; maps, charts and photographs, 98 ; making 1620 accessions in all. Nothing had been done in binding for want of the necessary means. The use of the Library seemed to be regularly increasing. During the year 1019 books had been borrowed by 119 persons.

The publications of the Society had been considerably less than during previous years. Two parts, conchuding Vol. XVIII, of the Proceedings, had been isued, and the first part of Vol. XIX was in press. Of the Memoirs, the second part of Prof. Hyatt's Revision of North American Poriferae was in press.

The meetings of the Society had been well attended, and the interest in the communications presented well sustained. In consequence of the formation of the Boston Microscopical rociety, the section of Microscopy had been given up. The section of Entomology had held monthly meetings, with a small but regular attendance.

'The section of Botany formed within the year hat held bi-monthly meetings, and these had been fairly attended.

During the year four Corresponding Members, six Rewident, under the old Constitution, and twenty-five Associate Members under the new Constitution, had been elected. 
Of the Lowell free courses of lectures, there had been given under the direction of the Society; six on Comparative Embryology, by Dr. Chas. S. Minot; four on North American Archaeology and Ethnology, by F. W. Putnam; three by Maj. J. W. Powell on the Cañons of the Colorado, Indian Life in the Rocky Mountains, and Indian Mythology; six by Prof. N.S. Shaler, on the Geological problems of Boston and its vicinity; and five by S. H. Scudder on the Organization and Metamorphoses of Butterflies. The courses were very interesting and well attended.

From the report of the 'Treasurer there was an excess of receipts over expenditures of $\$ 1081.12$, the most of which, however, it was necessary to reserve for Prize purposes in accordance with the conditions of the Walker bequest.

At the election of officers for the ensuing year the only changes made were as follows:

In the department of Microscopy, Samuel Wells was chosen on the Committee, in place of Edwin Bicknell deceased, and in the department of Fishes and Reptiles, S. IV. Garman was chosen in place of Richard Bliss, Jr.

It is pleasant to observe the persistent efforts made to prevent the expenditures of the Society from exceeding its income. At the first meeting of the Council, after the annual meeting of the Society, the 'Trustees reported that after a careful examination of the invested funds, they estimated the income for the year then commencing, applicable to the general purposes of the Society, as not likely to exceed $\$ 8500$. "To all who are conversant with the state of affilirs in the business world," they said, "the estimated reduction from the income of the past year will not be surprising, though most unwelcome. Let us be thankful it is no larger, and by a wise and careful economy endeavor to discharge the manifest duty of keeping our expenditures within the limits of our income." The following appropriations were recommended:

For salaries and wages, $\$ 6000$; gas and fuel, $\$ 100$; general expenses, $\$ 900$; cabinet, $\$ 300$; publications, $\$ 900$.

These appropriations allowed of no contingences, but it seemed impossible to lessen any of them.

Walker Prizes. In October of this year the first prize of sixty dollars was awarded to Mr. C. Riley, for his essay upon the subject proposed for this year, viz.: A complete life history of the army worm, Leucania unipunctata, and its parasites.

In November the Lahoratory of the Museum was rented to the Technological Institute for a course of thirty lectures, upon the payment of ninety dollars.

1878. In March of this year occurred the death of Dr. Charles Pickering, a greatly respected member of the Society, whose interest in its proceedings had been for many years manifested by constant attendance at the meetings and often by taking part in them. A man of very remarkable scientific acquirements, and of peronal character corresponding to his intellectual attainments, he merits more than a passing notice.

\section{Dr. Charles Pichering.}

Dr. Charles Pickering was born at Starucca, Susquehanna County, Pennsylvania, November 10th, 180;. Iis fither, Timothy Pickering, Jr., was born in Philadelphia, October 1st, 1779, graduated at Harvard College, entered the navy, served creditably as midshipman under Decatur, and resigned in 1801. His grandfather was Colonel Timothy 
Pickering of the Revolutionary Army, a friend of Washington. and a member of his Cabinet. The Colonel had aequired large tracts of "wild land" in western Pennsylvania, and after retiring from the Cabinet, removed thither with his son, whose wife, Mrs. Lurena Pickering, subsequently became the mother of the subject of this notice and his brother Edward.

In the year 1809, Timothy Pickering, Jr. died, and his father afterwards returned to Massachusetts, settling in Wenham, near sillem. Ife hrought with him his son's wife and her two boys, and it was under his supervision and that of their mother, an admirable woman, that they were brought up.

Charles early showed a taste for natural history, roaming about the country in search of birds, eggs, insects, plants and quadrupeds, with specimens of which he would return from his excursions loaded. He entered Harvard College in 1823, but did not graduate with his class, subsequently taking the degree of M. D. at the Medical School in 1826. His love for natural science increased with his years, and while living at Salem, he was associated with William (Jakes in botanical investigation, and it is thought that the two first explored the White Mountains together.

He was elected a correspondent of the Academy of Natural Sciences of Philadelphia, November 28th, 1826, in the twenty-second year of his age; and the next year he removed to Philadelphia, and became a member of that society. 'The scope of his varions scientific attainment, even at that early periorl of his life, may be estimated from the fict that he served on the Zoülogical Committee for ten years (from December 25th, 1829); on the Botanical Committee for eight years, half this time as chairman; on the Publication Committee four years; on the Library Committee a year; as Librarian five years, and as Curator for four years, discharging all the duties of these several positions with the utmost faithfulness and efficiency.

He prepared a Catalogue of American Plants in the Academy's collection, in 1834, and was intrusted with the transfer of the great collection of plants bequeathed to the Society by Von schweinitz. His great services in collecting and arranging the extensive herbarium of the Suciety, merited and received its thanks, presented through a resolution unanimously passed on motion of Prof. Henry D. Rogers. He also was made the recipient of the grateful thanks of the Society on motion of Dr. Samuel George Morton, for his services in selecting from Mr. Maclure's library the 2300 volumes designed for the Academy.

He was elected a member of the American Philosophical Society, January 15th, 1828, having previously (Oct. 1!th, 18.27), read before this Society his paper "On the Geographical Distribution of Plants." He was a member of the Yale Natural History Society, and read, conjointly with James II. Dama, hefore that society the "Description of" a Crustaceons Aninal, helonging to the genus Caligus, C. Anericanus," published in silliman's Journal, Vol. XXXVIII. He served as Recording Secretary of the Pennsylvania Horticultural Society, from February 1830, till September 1837.

On the organization of the U. S. Exploring Expedition under Lieutenant Charles Wilkes, Dr. Pickering's reputation was such that he was at once selected as chief zoölogist, and plated on board the flayship Vincemnes. The experdition sailed from Hampton Roads, Aug. 19th, 1838, and on its return reached Sandy IIook, June 10th, 1842. During the four year's voyage, Dr. Pickering turned his attention to anthropology and to the 
study of the geologienl distribution of animals and plants; especially to the latter, as affected by, or as evidence of, the operations, movements and difusion of the races of man. To the collections and investigations of Dr. Pickering and Profesor Dana, the scientific fame of the expedition is principally due.

In (Jetoler, 184:), Dr. Pickering again went alhoar, visiting during his tour Egypt, Arabia, India, and eastern Africa, more particularly for the purpose of verifying observations mate while with the Exploring Experlition. On his return he settled in Boston, and oecupied himself in preparing his " Races of Man and their Geographical Distribution," published in 1848, being Volume XI, of the Exploring Expedition. In 1850, appeared in the "Edinburgh New Philosophieal Journal," his "Enumeration of the Races of Man."

In 1854, his work "The Geographical Distribution of Animals and Plants," was published. This work constituted Volume XV of the Exploring Expedition.

The proceedings of the American Academy of Arts and Sciences, contain the following articles hy Dr. Pickering: Olservations on the Egyptian Computation of 'Time, appearing

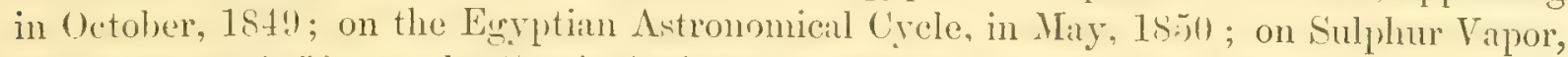
in December, 1856; on the Coptic Aphahet, in Nirch, 18.,9; on the Geographical Distribution of Species, in March 1859, and December 1860; and on the Jewish Calendar, in October, 1864.

In June, 1867, he prepared a paper "On the Gliddon Mummy case in the Museum of the Smithonim Institution," pullished in Volume XVI of the Sunithonian Contributions to Knowledge.

In 1876, was pul,ished at Salem the "Geographical Distribution of Animals and Plants; Part II; Plants in their Wild State."

The great work of his life was "The Chronological History of Plants." This truly remarkable production, to which he had devoted sixteen years of indomitable industry and laborious research, was going through the press at his own expense at the time of his death. While the form in which it is cast will prevent its use as a book for popular study, to the thorough student and teacher it must ever be unequalled as an exhaustive authority on the subjects of which it treats.

Dr. Pickering was elected a member of the Boston Society of Natural History, March $3 d, 1858$. As a member, his attendance upon meetings was constant, and his communications, whether elaborately written out, or merely remarks upon the subject at the time before the society, were always indicative of thorough knowledge and acquaintance with the matter. The range of his general information was very extensive, and whether he was speaking of Feejean pottery, or rare botanical forms found in the mountains of $\mathrm{Kew}$ England; of the character of the alluvial deposits of south Americun rivers, or the origin of the Esquimaux; whatever he might have to say was interesting and instructive in a high degree. Most of the present members of the Society will recall his controversy with the late Dr. Thomas M. Brewer, relative to the introduction of the European sparrow, in which Dr. Pickering took very strong ground adversely to the naturalization of the bird, quoting a formidable array of authorities in support of his position, and predicting very undesirable results in case the proposed experiment should be attempted-and prove successful-as to the ability of the sparrow to exist in this climate. 
Dr. Pickering, while it could be truly said of him by one of his biographers, that there was probably not a more learned naturalist in the world, was yet one of the most modest of men. His simplicity of character, inflexible integrity, loyalty to truth, tranquillity of temper, and kindly though somewhat reservel disposition, were thoroughly consistent with his great and extremely accurate acquirements, and that love of knowledge which wats his grand paswion. The following extract from a biographical notice published with his "Chronological History of Plants," speaks thus of him:

"We doubt if any one naturalist ever united in himself so far as he did, the qualities of an exact original observer on the most enlarged scale, and of an inquirer into all that had been learned before. His minute, laborious and extended explorations into all possible records of past ages, seemed of themselves more than enough for the work of a lifetime. ** * He not only visited every quarter of the earth, but went through the whole range of history, wherever it could bear upon his subject, in quest of anything that might help him better to understand "The Races of Man and their Geographical Distribution," ". The Geographical Distribution of Animals and Plants," and " The Chronological History of Plants."

Dr. Pickering married in 18.51, Sarah S., daunghter of the late Daniel Hammond, Eirl. He died of pneumonia, in Boston, Mareh 17th, 1sis, laving a widow but no children.

In April the death of Prof. C. F. Ifartt, a lighly valued Correnponding Member of the Society, was announced. As he was for some time an active member of the Society, it is due to the eminence attained by him as a scientific explorer and investigator, to give some account of the great work achieved by him in the short time of his active life. The sketch here presented is drawn entirely from an elaborate and excellent paper prepared by Mr. Richard Rathbun and published in the nineteenth volume of the society's Proceedings.

Professor Hartt was born in Fredericton, New Brunswick, August 23d, 1840. He graduated from Acadia College in 1860. At an early age he manifested much interest in the study of natural history, and whilst in college labored zealously in exploring geologically the Province of Nova Scotia, in doing which he made large collections. Subsequently he gave much attention to the study of the rocks in the vicinity of St. John, New Brunswick, and it was by his researches there that he first became extensively known to the scientific world. The discovery there of fossil insects in the Devonian shales, led to Profersor A massiz' knowledge of him, and to his being invited to hecome a student in the Iuseum of Comparative Zoölogy, where he passed much time during the succeeding four years, making great progress in science and preparing himself for future usefulness. During this period he made excursions to his native province and to Nova Scotia, making investigations of important character. To Lim, the scientific world is indebted for very much of the knowledge possessed by it of the ancient strata of New Brunswick. Mr. Hartt was appointed by Professor Agassiz one of the two geologits who arempanied the Thayer expedition to brazil in 1 sis.) and it was whilst engaged in this service, that he became so much interested in the geology of that empire as to lead to his extensive work there in after years. He made a second trip there in 1867. 
In 1 S6s he was appointed Profeson of Natural IListory in Vassar College, which position he soon resigned to take the head of the department of Geology in Comell University, which he held until the time of his death.

Whilst at Cornell, when not engaged in the duties of his position, he prepared his report as geologist of the Thayer expedition. 'This embraced so much of value upon the subject treated, as to lead to its being published in a volume by itself under the title of "The Geology and the Physical Geography of Brazil." It formed a large octavo volume of over six hundred pages.

In 1870, Prof. Hartt organized another expedition to Brazil, taking with him Prof. Prentice and eleven of the students of Cornell University. This party, after exploring in the vicinity of Para, proceeded to the Amazonas where were found the first Devonian fossils east of the Andes in South America. Prof. Hartt soon after made another trip to the Amazonas in company with Mr. O. A. Derby, with important results. He returned to Ithaca in 1872, where he remained from two to three years, giving such time as he could spare to sturlying up the material ohtained in his Amazonian trips, aided hy two assistants, Mr. O. A. Derby and Mr. Richard Rathbun, and in preparing papers for publication. These appeared in various seientific journals.

In 185, , the govermment of Brazil, appreciating the labors of Prof. IIartt, invited him to submit a proposition for the systematic geological exploration of the Empire. He accordingly proceeded to Rio Janeiro, where he was received with great enthusiasm. The suggestions made in his proposition were not fully complier with from economical consinterations, which is much to be regretterl, consirlering his early death. In MIay, 1s7j, Prof. Hartt was made chief of a commission for the geological survey of Brazil with six assistant, anong whom was Mr. Rathbum, also a member of the Boston Siociety of Natural History. The party was soon in the field, and its active work continued almost minterruptedly until the close of 1877. The amount of work done during this period was immense, and the investigations made of the most important character. No wonder that the Empreror upon his return from a visit to the Museums of North America and the old world, should have expresied his astonishment when he found that the small party which he had left eighteen months before working hard among the rocks of a portion of the Empire, had createrl a linge Museum containing the collections made, and having connected with it biological, chemical and photographic laboratories.

This brief notice of Professor Hartt will be closed by a few words griven in alstract from the paper alluded to, prepared by Mr. Rathbun.

"In order to judge of the real character and value of his investigations, we must refer to his publications. 'There, however, grive us but a glimpse of the vast store of knowledge he harl accumulated. It has left a number of volumes in manuscript, which when puhlished, will ard greatly to his seientific standing, by making known to the world the variety and excellence of the work he had accomplished. Judging from his brilliant beginning, we are confirlent in asserting that had he lived, he would have won for himself a place by the side of such investigators as De le Beche, Hurchison, Logan and others, like whom, he was a pioneer in the special field of research he had entered." 
The reports of the Custodian, Secretary and Treasurer were looked forward to with much interest, the memhers enerally realizing the diffeulty of accomplishing the neecessary work of the Society within the means at its disposal, without incurring debt or lessening its funded property. When listened to at the amnual meeting, they gave great satisfaction, showing as they did much progress in several departments of the Museum, continued growth of the Library, a fair amount of publication, and good attendance at the meetings. It will be horne in mind that the period was one of prolongerl husiness depression, rendering the income from the Soeiety's funds quite momertain, ame that the Commeil at the beginning of the year had decided to limit the expenditures to the least possible sum consistent with the Society's future welfare. The Custodian commenced his report by deploring that this decision, though necessary, hat prevented continued improvement in the cases, and thus anrested work, the accomplishment of which alone could rember the collections secure from damage by dust and insects.

From the remarks of the Custodian upon the state of the collections, the following is presented.

The Minerals remained in the good condition of the previous years and had received valuable accessions from the President.

The Palaeontological collections had had much labor bestowed upon them by $\mathrm{Mr}_{\mathrm{r}}$. Croshy, the assistant in the Musemm, and by Miss Washburn and Misis Carter, who had aided him in mounting and labelling the specimens. 'The whole department was stated to be divided into sections according to locality, and collections of it arranged entirely to illustrate the stratigraphical relations of fosils. There were of the North American collection on exhibition. 1040 genera embracing $203 \pm$ species, and $783 \pm$ specinens. 'These had been derived from the following sources: Mass. Institute of Technology, 2223; C. S. Hale collection, 1013 ; Cleveland collection, 627 ; various, 3971 ; making a total of 7834.

The nost raluahle parts of this collection are specimens of Paraloxites from Braintree, embracing the original from the Jackson Cabinet; a fine suite of Crinoids from Mr. J. M. Barmard; the coal plants of the Rogers Cabinet; the fine animal impressions on stone from 'Turner's Falls; the reptilian bones from the red sandstone of the Connecticut valley, presented by Prof. W. B. Rogers, and the fossils from Attleboro, Mass.

Of the Eser collection of European species, there were on exhibition 1306 genera, embracing 2563 species, and 8809 specimens.

The Botanical department under the charge of Mr. John C'mmmings had heen steadily prongesing. Theee-fifths of the flowering plants had becu revised, and work had only been suspenderl awaiting the reception of a further number of the "Genera Plantarum." Mis, Carter had heen engaged much of the time in assorting, condensing and properly arrangimg duplicates. She had al:o sorted. mounted and labelled a large and valuable collection of lichens under the direction of Mr. C. J. Sprague, who reported that "this formed the Lichen-herharium of Dr. 'Thomas Taylor, an Irish botanist, to whom Sir W. J. and rir Joseph Hooker communicated the whole of their extensive eollections of lichens grathered during many exploring expeditions. Dr. Taylor puhlished descriptions of these plants in the London Journal of Botany, 1844-46, and many of the specimens are "the originals of the descriptions. Mr. John Amory Lowell purchased the collection of 
Dr. Taylor's heirs, and afterwards presented it to the Society, with the rest of his herbarium.

The knowledge of the structure of lichens has advanced much since Dr. Taylor's day, and the nomenclature has undergone extensive changes, so this herbarim, though containing over a thousand species, might have remained complaratively useless to the American student had it not been for the voluntary services of Prof. Edward T. Tuckerman. He examined and named very nearly the entire series, a work which no one else in this country could have done, and has given it an authentic value, otherwise unattainable.

The decease of Dr. P. P. Carpenter of Montreal, to whom had been intrusted the work of naming the collections of shells, harl prevented its final completion. Fortunately for the Society, not mach remained undone. At the time of Dr. Carrpenter's death, he hat in his possession at Montreal a very large portion of the collection belonging to the IIuseum. The specimens were sulsecquently received in admiralble condition, not one having been lost, and all had been unpacked and arranged in the cabinet by Mr. Van Vleck. Miss Washburn had been engaged in re-mounting, labelling and cataloguing them.

The Systematic collection of Molluca, consisting of 630 genera, represented by 2600 species and 9000 specimens, had been completed by Mr. Van Vleck, and placed on exhibition.

The alcoholic collections of Reptiles and Batrachians had been in large part revised and named by Mr. Garman of the Museun of Comparative Zoïlogy. Considerable additions har been marle to them hy the kinthess of IIr. Garman, who selected fiom the duplicates of the Musem by permission of Mr. Agassiz, the director, such specimens as were needed for the collection of the Society.

The New England collection of birds had been much increased by donations from various parties, and by exchange. Eighty species had been added, some of which were of great rarity. The donors were Messrs. Weeks, E. A. \& O. Bangs, C. B. Corey, F. B Loring, W. B. Greene, H. D. Morse, Wm. Brewster, Arthur Smith, Geo. A. Boardman, and H. O. Ryder.

The Entomological collection harl been enriched by valuable donations received from Meswrs. Smith, Bryant, Thaxter and Mrs. Mïring. Mr. Henshaw's labors in this department had been continued.

To the Anatomical collection a number of preparations had been added by the assistant, Mr. Van Vleck, and by Dr. Thomas, a student in the Museum.

To the collection of Echinoderms had been added a suite of Ophiurans received from the Museum of Comparative Zoölogy. These having been identified and named by Mr. Theodore Lyman, the labelling may be relied upon as correct.

Of the Laboratory, the remarks of the Custodian are presented in full, as they give briefly a good ideat of the practical means taken to advance the knowledge of natural history in the community.

"The work in this department has greatly increased. The educational collections, if they continue to be improved at the same rate, will, within a year or two, be entirely completed, with of course, the exception of those rarer preparations and specimens which never seem to be within the reach of moterate means. They embrace typical zoijlogical, 
palacontological and scological collections, already sufficiently perfect for the ordinary purposes of general instruction.

"The room and the collections have been used by the Institute of 'Technology for a class in Palicontology; hy the Boston Lniversity for a class in Zuilogy and another in Botany; and by the Teachers of Boston, for a class in Zoülogy. 'This last was composed of the teachers of natural history in the High Schools of Boston, and other teachers, mumbering about thirty in all.

"'The lessons are necessarily given on Saturday, and are limited to two hours, though the laboratory is open throughout the day for those who wish to remain.

"This course was instituted in order to support the movement made by the School Committee to introluce the teaching of Zoiilogy into the ILigh Schools. Iiss Crocker, the supervisor having this branch under her charge, applied to the Custodian for assistance, and the Council of the Society assenting, the laboratory and its fucilities were placed at her disposal. The course will not be finished until the spring of 1879 , and will comprise nearly one hundred lessons, illustrated in the usual way by the study and dissection of specimens. The instruction so far, has consisted of a series of practical lessons, given by Messis. Croshy and Van Vleck, interspersed with lectures of a nore general character, by the Custodian."

'The 'I'eachers' School of Science was continued, as in previous years, through the liberality of Mr. John Cummings. One course of twenty lectures was given by Professor Goodale of Harvard University. 'The teachers were provided with printed synopses of the lectures as aids in taking notes, and with dried and named specimens of native plants. About one hundred and fifty sets of these were distributed during the course. 'The average attendance was about one hundred and twenty.

From the report of the Secretary, Mr. Enward Burgess, it was shown that the condition of the departments under his charge was satisfactory.

Of the Library, he stated that the increase was very constant. The additions during the year had been in slight excess of the previous year, and were as follows: volumes 255, parts of volumes 966 , pamphlets 236 , maps and chants 1999 . From lack of the necessary means, no binding had been done.

Of the Publications, two parts of the Proceedings of the Society had been issued and a third was nearly ready. The second volume of the Memoirs had also been concluded.

Of the meetings, there had been sixteen general ones of the Society, at which the average attendance had been forty persons; nine of the section of Entomology and eleven of the section of Botany, at each of which the average attendance had been about ten. Nearly forty papers read at these several meetings had been published.

From lack of means, the society wat not enabled to give any public lectures during the winter.

Of members, four IIonorary, seven Corresponding, and twenty-two Associate, hat been elected during the year.

The Report of the Treasurer showed an excess of receipts over expenditures of $\$ 1336.73$, a considerable portion of which could only be used for specific purposes. The receipts available for general purposes had been sologs.75, and the expenditures for general purposes, $\$ 8903.5 \%$; leaving a balance of $\$ 194.93$, showing that the society 
throngh great economy had succeederl in accomplishing its purpose of limiting expenliture within its income.

At the election of officers for the ensuing year, Theodore Lyman was chosen on the Jommittee for Fishes and Reptiles in place of Dr. Samuel Kneelamd, rexigned, and Jules Marcou was left off the Committee on Palaeontology, by reason of prolonged absence ebroad.

Previous to the adjournment of the annual meeting, Mr. Charles J. Sprague, in view of the great aid given him by Prof. Tuckerman, in enabling him to put on exhibition a very sonsiderable portion of the Cryptogmous plants of the Society, offered the following resJution, which was passed unanimously:

"That the thanks of the Society be conveyed to Prof. Edward Tuckerman, for the voluntary, generous and invaluable service he has rendered it by elaborating and naming the Lichen herbarium of Dr. 'Thomas 'Taylor, now forming a part of its collection; a service which no one in this country but he could have performed, and which gives to the herbarium an authentic value it could not otherwise have possessed."

At the Council meeting subsequent to that of the annual meeting of the Society, the Trustees reported that they har made an estimate of the probable income of the society For the year entered upon, showing that not much over $\$ 9000$ could be relied upon as available for general purposes. Considering, however, that there would be a call for the payment of insurance on property for five years, amounting perhaps to one thousand lollars, they advised that appropriations be made to the extent of $\$ 9500$ in order to cover his item.

The Society being at consideral)le expense of time and money in carrying out the intention of the legislature of the State in giving it authority to designate persons who should have the right to kill birls for scientific purposer, voted to charge for the certificates so issued, the sum of two dollars each.

Walker Prizes. The subject proposed for the Walker prizes was the same practically as that of 1876, two years before, and upon which no essay had been presented, viz: "An original investigation of the structure, development and mode of life of one or more of the fungi which injuriously affect useful plants."

This second attempt to interest writers in treating upon this sulject was not successul in eliciting essays, as none were presented.

In August of this year, the Society lost a young member by death, to whom it seems fitting to pay a tribute of affectionate remembrance by a brief mention of his life, and of the interest manifested by him in natural history.

Gurdon Saltunstall, the son of Henry and Georgiana C. Siltonstall, was born in Silem, on the 15th day of August, 1856, soon after which the family made Boston their winter residence. Being obliged, by trouble in his eyes, to leave school, and having at a very early age exhibited a strong inclination to acquaint himself with objects of natural history, he was led, in January 1871, when but fifteen years of age, to become a member of the Society, in the work of which he was exceedingly interested, proffering his services in aid of the Custodian and the working members, and identifying himself with their labors in almost every department. In turn, he was aided by them in the acquisition of the knowledge he sought, and thus the association was of anvantage to hoth hinsectl and the Society. 
The summer of 1872 he pasere at Eastport with the United States Fish Commission, stulying and preparing speciness for the Society, and in a subseguent year he worked with this Commission at Noank, with Professor Hyatt.

In 1873 he was able to return to school, where he rapidly and thoroughly mastered the necessary studies and entered IIarvard College with honor in the Freshman class of 1874 , in which le passed one year with great credit, taking high rank as a scholar and gaining the respect and affection of his associates and instructors. But early in his second year his health suddenly gave way and he was obliged to leave home. Passing part of one winter at Nassau, he sent valuable specimens and information to the Society, his association with which was always one of his greatest pleasures. In this association he exhibited such kindly and lovable traits of character as served to endear him to all the working members, and they sadly deplored the necessity of his leaving home for his health, and still more sadly learned of his early decease.

He died at Pau in France on the 21st of May, 1878, beloved by all who knew him, and happy in the assurance of immortal life.

At a meeting of the Society held Oet. 2d, Mr. Seudder, being in the Chair, alluder feelingly to the death of Prof. Henry, a distinguished IIonorary Member, which had recently occurred, and at the close of his remarks introduced Dr. Asa Gray, who addressed the Serciety upon the life and character of "that eminent man whose death, full of years and honors, had been so sensibly felt throughout the country and the scientific world."

Leaving to others the duty of portraying his great scientific services and researches, Dr. Gray gave a brief sketch of Prof. Henry's life, mentioning his birth at Albany, N. Y., near the close of the last century, his restricted opportunities for early education, his becoming a pupil at the Albany Academy, and afterwards receiving an appointment as Professor of Natural Philosophy at that institution. He then spoke of his brilliant discoveries in electricity and magnetism, which mate his name prominent throughout the scientific world, and his acceptance in 1846 , of the office of Secretary of the Finithonian Institution. Referring to this, Dr. Gray remarked, that to the simple sense of duty which impelled Prof. Henry to interrupt a career of research of almost mequalled brilliancy, by an undertaking which was sure to absorb his best years in administrative and perplexing cares, was to be attributed the result that the noble bequest of Smithson "for the increase and diffusion of knowledge among men" was rescued from waste and misappropriation. Dr. Gray insisted that the great benefits which the seientifie world at large, and science in America especially, are receiving from the Institution, were mainly owing to the practical wistom, the catholic spirit, and the just conception of the fommler's intent, and the indomitable perseverance of its first Secretary and Inmager. In concluding his remarks, of which this notice gives but a brief abstract, Dr. Gray spoke of "the serene simplicity and loftiness, as well as kindliness of spirit, shown by Prof. Ifemry, of his derotion to what he deemed his duty, often exhibited in the extreme patience with which he attended to the applications of projectors and crotchety discoverers who sought his advice." Much of the prominent influence which he wielded at Washington, was attributed "to his transparent and spotless character, the complete subjection of all considerations of personal advantage, or even of personal ambition, and the atmosphere of purity in which his official as well as private life ever moved, and upon which never fell even the shadow of a shade." 
The fall and winter of this official year were characterized by a degree of work done in direct instruction by the Custodian, and other officers of the Society and assistants, so unexampled in character as to call for special and full notice.

The study of natural history had been recently introduced into the public schools, and it was thought by those who had heen instrumental in effecting this, particularly by Miss Lucretia Crocker, the supervisor of that department, that the teachers generally of the schools should have such instruction in the several branches, as could be well given under the auspices of the Society. An appeal to its officers was therefore made by Miss Crocker for assistance, and as this was urged as essential to success, the call was cheerfully responded to. The opportunity of interesting the children of the public schools in natural history through lessons given to the great body of their teachers, seemed too much in the line of the Society work to be lost, and strenuous efforts were at once made to do all that was possible in furtherance of the object.

The Council appointed the President, Mr. Bouvé, Vice President, Mr. Cummings, and the Custodian. Mr. Iyatt, to take charge of the matter, giving them full authority to armare for the lectures, obtain specimens for illustration and distribution, and to approve bills for such expenses as might necessarily be incurred, it being understood that, excepting the time and labor devoted to the object, the cost should be defrayed by subscription.

The wonderful success that attended the movement will be presented in the annual report of the Custodian at the yearly meeting in May.

\section{Dr. J. B. S. JACKson.}

1879, January 15th. After calling the meeting of this date to order the President said:

Since we last met, Death has once again entered our circle and borne from us one of the oldest and most highly respected of the active members of the Suciety, Dr. J. B. S. Jackson.

To those of you who have not been members for more than the last decade or two, there can be but little appreciation of the feeling experienced by those of us who were contemporary, or nearly so, with the founders and early members of the Society, when one of their number passes the limit that divides the seen from the unseen. Among these were men of noble characters and impulses, with whom to be associated was to be impresised with such sense of their great execllence and purity of purpose as no subsequent experience through life conld obliterate. Claming but little linowledge of natural history, but strongly appreciating the importance of its study both for themselves and the community, they came together for mutual help in the acquisition of knowledge, and to combine their efforts for its disemination, modestly expresing in the preface to the first number of the Journal "that having but small claims to the character of naturalists, they nevertheless are desirous of contributing something to the common stock of information."

In the greater light of the present day, and reflecting upon the little aid attainable by them through books or collections, we may well exclaim, Noble men! Simple seekers of truth, not only for your own good but for that of all others; you grandly did your work! And so they did. The many volumes of their papers and proceedings attest this: the State reports upon the geology; the invetebrate animals; the fishes; the insects injurious to vegetation; the trees and shrubs of Missachuretts; all by early members resident 
or corresponding, speak unceasingly of the value of their lahors. Ant the magnificent development of the Society until it has become what it now is, with its great collections and its wide felt influence, - how much of this is due to their early strivings who shall say? Certainly all is but the fruition of their hopes and desires.

Among these early members were Dr. Benjamin D. Greene, an accomplished hotanist and the first President of the Society; I)r. Augustus A. Gould, the author of the Reeport upon the Invertebrates of the State, and who became one of the most able naturalists of New England; Dr. D. Humphreys Storer, the author of the very valuable Report upon the Fishes of New England; Dr. Amos Binney, an accomplished conchologist, afterwards President; George B. Emerson., author of the great work upon the Trees and Shrubs of the State, and who also subsequently became President of the Society; Dr. Martin Gay, an able chemist; Dr. Charles T. Jackson, well-known as an accomplished chemist, mineralogist and geologist; Francis Alger, the author of a valuable work on mineralogy; the Rev. Dr. F. W. P. Greenwood, who seemed more divine than human in the loveliness of his character; Dr. T. W. Harris, author of the Report on Insects injurious to Vegetation, and last o mention, though by no means the least in his influence upon the affairs of the Society and its character, Dr. J. B. S. Jackson, whose loss we now deplore.

The particular investigations of Dr. Jackson were generally not of a nature to bring him prominently before the Society as an instructor in any branch of natural history, his labors being largely confined to a class of subjects more grenerally interesting to sturlents in pathology. Yet the Journal of the Society presents to us several papers of great value to naturalists, and the Proceedings contain remarks made by him at various times embodying much useful information.

Dr. Jackson was elected a member in the fall of 1831, the Society having been incorporated the previous February.

In 1837 he reat before the Society a paper which was pullished in the Joumal, giving an anatomical dexcription of the Gallapagos 'Torteire, which wats a valuable contribution.

In 1842 the Journal gives an account read by him of the dissection of two adult dromedaries, male and female.

In 1845 there is in the Journal a paper upon the dissection of a spermaceti whale and three other Cetaceans.

Of his remarks made from time to time upon scientific subjects and published in the Proceedings of the Society, may he found some of interesting character upon the teeth of Detphimes globicepss, upon fosil hones of the Mestadon gignateus from Schooley's Moumtain, N. J., and upon bones from Indian tumuli.

As said before, Dr. Jackson's most important work was in pathology rather than natural history. He became Profersor of Pathological Anatomy in the Medieal sighool of Harrard University in 1847 , and was ever after a most diligent laborer in its interests, investigating with great patience and with keenness of observation arising from constant experience, the mortid eflects of divease upon the orgins, and writing out fully and carefully the results of his examinations, which have been of invaluable service in the cause of medical science. Much of his work for many years was in the building of the Cabinet of the Society of Medical Improvement and its arrangement for study, and in the care and arrangement of the Warren Museum. Of these two fine collections Dr. Jackson published 
descriptive catalognes, containing much matter of great interest to students in merlicine and surgery. Others can write and speak more wisely and instructively of these great services than can the writer, who has only been associated with him in the Society of Natural History and as a personal friend. Mis work for the Society has been spoken of, but what he did for it in labor and through publications was but a small part of the aid he was able to render. No member ever felt more interest in its wèlfure, and if this was not manifested to the same degree in actual devotion to work upon its collections and to investigations in natural history subjects, it was only because his valuable time was preoccupied by the duties owed to his official position. He was always in the habit of attending the meetings of the rociety, and always "xhibited a strong desire that they should be made as instructive as possible to younger members, to such particularly as were entering the paths of science. He was ever urgent, too, that all the specimens of the collections of the Society should be so distinctively and fully arrangerl and labelled that all visitors might clearly understand their character and relations. ITe indeed sometimes felt impatient that this was not already accomplished, so important dirl he regall it as a means of exlucition; though he did not fail to recomize that with the means at the Society's disponal this work must necessarily be slow. He lived to see great progress towards the realization of his wishes in this rewpect, and if his life had been spared a year or two longer his fullest desire might have been satisfied.

One marked peculiarity of Dr. Jackson was his great interest in the advancement of worthy members to positions of honor and usefuness in the Society. Entirely free from any ambitious desire for office himself, he wished to gratify the feelings of those whom he thought deserving and to whom position might be an inducement to exertion. It is pleasant to dwell upon the special characteristics that made our departed friend a useful member of the Society, but with what additional pleasure can we recall the traits that made him the delightful companion, the beloved friend, the dear hushand and father; that led all with whom he came closely in contact to regard him with affection and respect. Simple, mostentatious, true in all the relations of life, honest in the expression of his convictions, and pure in heart, he lived amongst us a blessing to his friends and the community, and has passed away leaving only the most tender memories. May we be helped by his example to live and do our life's work so that it may be said of each of us when we likewise depart, what may be truly said of him: Those who knew him the best loved him the most.

At the close of the President's address, Dr. D. H. Storer said:

Mr. President : - I rise merely to express my thanks for your faithful and most appropriate remarks respecting our departed friend. I should have regretted not to have heard them. I rejoice that nothing ever occurred to alienate him from the Society - that he continued to feel the same interest, and to evince the same zeal in its prosperity as long as he was with us.

Jackson and Wyman I always associated together - in my heart they were one - ever faithful and true.

Again I thank you, Mr. President, for your heartfelt tribute. 
At the annual meeting the reports of the Custodian and Secretary were as usual interesting and gratifying.

The Mineralogical cabinet was stated to be in good condition and order.

The Geological collection had heen undergoing re-arrangenent, this being necessary by recent advances in science, especially in Lithology. The principal accession to this department consisted of a suite of 250 specimens of the rocks of New Hampshire, collected in the recent geological survey of that State, by Prof. C. H. Hitchcock.

The revision of the Palaeontological collections had been finished. To the North American had been added forty specimens of Cambrian, Nilurian and Devonian foririls, collected by Prof. F. II. Bradley and given by Mr. John Cummingw; nearly ono suln-carboniferous crinoids, obtained by exchange from Prof. A. H. Worthen, State geologist of Illinois; 125 specimens of C'retaceons fossils from 'Texas, obtainerl lov purehase; and 100 specimens of Cretaceous vertehrate remains from Killsas, purchased from the State greologist, Prof. B. F. Mudge.

The New England collection had received twenty specimens of fossiliferous rock from the drift of 'Truro, Cape Cod, probably Eocene.

The North American collection, with the accessions reported, consisted of:

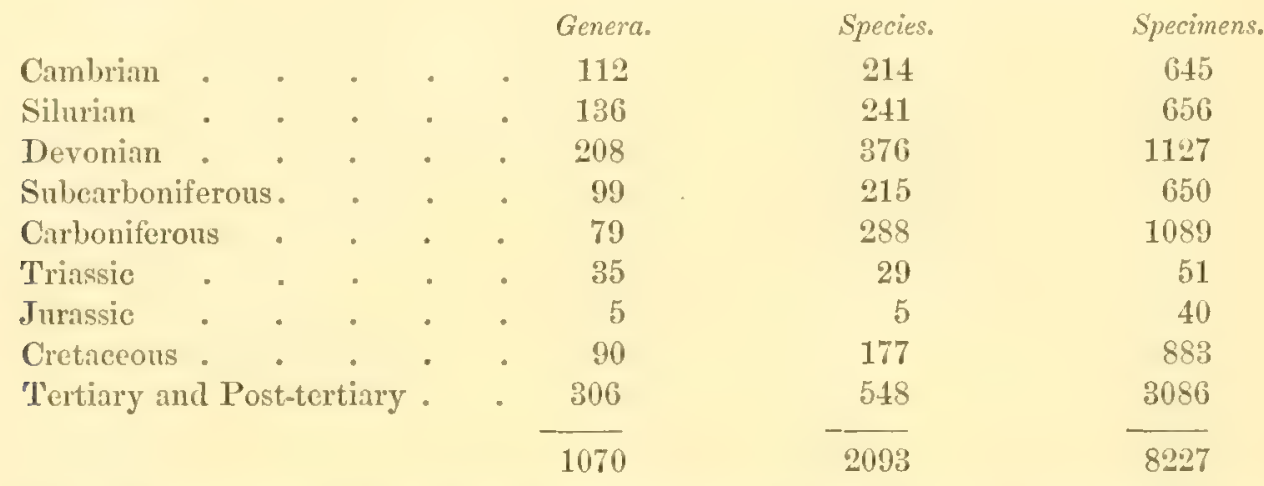

The Triassic fishes and plants, and most of the foot-tracks, a good collection of Devonian bivalves, and several other small lots of fossils wanting identification, were not included.

The South American collection, including the West Indian, was mentioned as insignificantly small, numbering hut twenty-four genera, twenty-eight species, and one hundred and seventy specinens, all 'Tertiary, or Post-tertiary, excepting one Cretaceous. The Afriam was said to be still more lacking, comprising only five gencra, six species, aud fourteen specimens, all 'I'ertiary.

'The Asiatic collection, including specinens from the Malay Archipelago, Australia and Oceanica, had been mounted during the year. This was stated to contain many large yecimens, dhiefly cants of the Miocene Mammalia from the Nivalik Iills, also Cretaceous fishes from Mit. Lebanon, casts of Carboniferous shells from Australia, and casts of the bones of the Inomis and Palaenteryx from New 'bealand. The whole embraced 46 genera, 84 species, and 170 specimens.

The principal work done on the European collection during the year had been to mount the Palacozoic fossils. There had been an accession to these of 380 specimens, 
received from Mr. John Cummings in exchange. The European specimens at this timo numbered 13,655 .

The atrgrenate of the several collections of the Department was as shown by the following table :

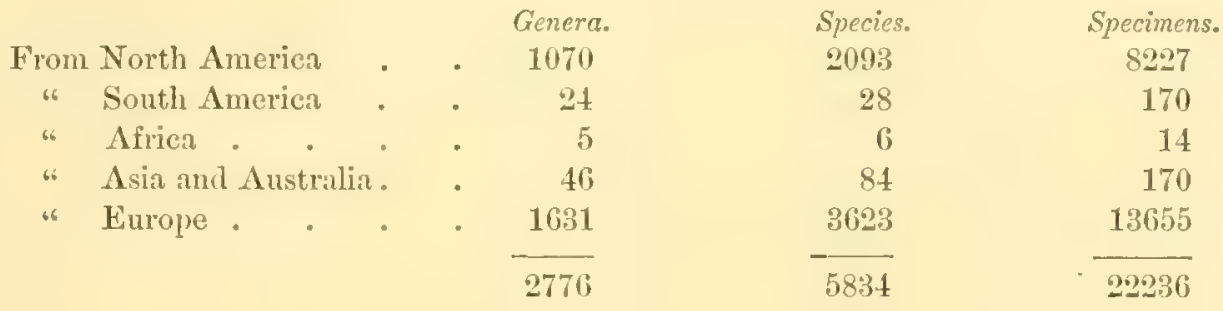

The Custodian in referring to the fact that the laborious work of the arrangement and catalogumg of the Palacontological collections wis finisherl, justly aseriberl, not only the magniturle of these to the great liberality of Mr. John Cummings, but also their condition, which was attributable entirely to the valuable services of the two assistants employed by him.

In the Botanical department, the work of sorting the duplicates and supplying the deficiencies in the general collection had steadily progressed under the direction of Mr. Cummings. The specimens of rood, fruit, etc., on exhibition had been catalogued, mounted on tablets, and labelled by Misis Cinter. They numbered 2583 specimens, representing:304 genera, and 4!20 species. To Mr. Chas.J. Spracte this department was indehterl for 250 specimens of dried plants from Florida, collected by Mr. A. H. Curtiss, and for 50 rare New England species, collected by Mr. C. J. Pringle, of Vermont. Mr. E. T. Bouvé hard continued his work on the trees and shrubs of New England, and arded a number of species to the collection.

In the Anatomical department, a new section had been established. In this section had been brought together preparations made by Mr. Van Vleck, exhibiting the general anatomy of the invertebrates and the typical forms of the different sub-divisions of the animal kingdom.

The New Enghurl collection of Birds har been considerably increased through the exertions of Dr. Brewer, thirty to forty species having been added.

The Entomological department had received several important donations, one from Mr. F. C. Bowditch, of useful insects of all orders; another from Dr. C. S. Minot of his entire collection of insects, containing very desirable additions to the New England collection. A part also of a collection made by the late Mr. Gurdon Saltonstall had been received from his family, and several valuable specimens of which the Society stood in need from Mr. Rolaud Thaxter.

The remarks of the Custodian upon the other collections do not call for repetition.

In the Laboratory there had been much activity. 'The room and the collections had been used for the past year by a class in Zoülogy and Palaeontology from the Mass. Institute of 'l'echnology; one in Zoölogy, from Boston University; and one in Zoölogy composed of the teachers of the Boston High Schools. 'This last class was particularly mentioned in the report of the previous year. 'The course of instruction had been prolonged and was not yet quite finished. 
Reference was marle on a preceding page to the epreat work accomplished, through the instrumentality of the Society, in direct instruction during the last antumn and winter months. The importance of what was done justifies the presentation of nearly the full statement of the Custodian, though it involves some repetition.

"Teachers' School of Science. The Teachers' School of Science has this year attained extraordinary size and importance. So sudden and unexpected was this development that for the last six months it has almost completely arrested all efficient work in other directions. The stuly of nuture having heen introduced in a definite form into the public sehools, and the supervisor of this department, Miss Lucretia Crocker, having asiured us that our assistance would be of great benefit, and was in fact essential, it was determined to institute appopriate coures upon elementary Botany, Kooilogy, and Mineralory, if the means of paying the expenses could be raised. Mrs. S. T. Hooper and Miss Crocker undertook and successfully completed this part of the work, and also a considerable amount of harassing clerical labor, which subsequently arose out of the success of their own exertions. Fortunately for their schemes these ladies met with substantial appreciation from Mrs. Augustus Ilemenway, who both subseribed most liberally, and also encouraged them to aceept the very consilerable pecuniary responsibilities, which began to block their way at the very begiming of operations. In fact, without these assurances of further support and interest, we should not liave dared to begin.

"These obstacles arose from two causes, the number of applicants, and the necessity of providing identical specimens for all. The specimens and materials for two hundred, which was the maximum number anticipated at first, could have been readily furnished, but when the applicants ratcher six hundred, it hecame exceedingly questionable whether such a number could be provided for, and properly instructed by one person, all at the same time. Feeling, however, that the cause of science demanded that these difficulties should be met and supported, and relying on the hearty eoüperation of Professor Goodale and the ladies mentioned above, the course was begun.

"The association and sympathy of Mrs. Elizabeth Agasiz with the mndertaking has been particularly gratifying, since Prof. Louis Agassiz was the first naturalist who ever tanght a popular audience in this country with the specimens in hand.

${ }^{6}$ The enterprise was in large part the work of women and affords pleasing evidence of the activity and usefulness of this new class of members in our Society.

"The following is a list of the donors:

Mrs. Augustus Hemenway _ _ \$ \$1000.00

Mrs. Quiney A. Shaw . . . $\quad 500.00$

Mrs. John M. Forbes . . . . 100.00

Miss A. S. Hooper 。 . . . . 100.00

Mrs. H. P. Kidder . • . . . 100.00

Miss M. A. Wales . . . . 50.00
Mrs. Sarah S. Russell . . . . $\$ 50.00$

Mrs. John E. Lodge • $\quad$. $\quad$. $\quad 50.00$

Mrs. Richard C. Greenleaf . . . $\quad 50.00$

Miss Anna C. Lowell . . . . 50.00

Mrs. E. W. Gurney . . $\quad 50.00$

"Smallux sums were contributed by Mrs. Elizabeth C. Agasiz, Mrs. Sammel Hooper, Miss S. Mimm, Mism E. Mason, Miss M. C. Jackson, Miss Stone, Miss Ahby W. May, Mrs. James Freeman Clarke, Miss Cora II. Clarke, Miss Lucretia Crocker, Mrs. Thomas Mack, Mrs. 1. S. Farwell and others.

"Many of these ladies were very active in securing the success of the course and the Society thanks them and others; especially Mrs. E. D. Cheney, Miss I. M. Mrms, Miss C. I. 
Ireland and Mrs. Samuel Wells for their personal efforts in behalf of the Teachers' School of Science.

"The teachers themselves, at our solicitation, joined in making up the fund. The contributions from this source amounted to $\$ 789$.

"Notwitlsstanding this generous assistance, it would hardly have been possible to carry on the sereral courses without the friendly aid and direct assistance in various ways of the following institutions and persons.

"The Institute of 'Technologry, which most generously gave us the use of Huntington Hall, upon the payment of a merely nominal sum for cleaning and heating.

" The Murem of Comparative Zoïlogy, under the direction of Mr. Alexander Agrassiz, which, through Count Pourtalés, Dr. Hermamn Hagen, and Mr. E. C. Hamlin, at various times assisted us l,y donations of specimens from the respective departnents superintended by these gentlemen.

"Mr. Ilenshaw, my right hand assistant in all the work of preparation and distribution, whose untiring energy contributed largely to secure the success of every lesson; Miss Hintz, of the Normal School. who drew with remarkable skill the diagrams used in the Zoölogical course, and enabled the Custodian to illustrate fully all subjects; Mr. Van Vleck for aid in the preparation of models; Mr. L. S. Burbank; Miss Nunn, Professor of Biology at Wellesey College; Mr. Robert Mc Carthy. of New Tork; Captain IIorsfall, of Steamer Canopus; Mr. Eugene G. Blackford, of New York; and the proprietors of the Parker Iouse and Tomng's Hotel, for donations of specimens and assistance in various ways.

"Mr. E. G. Gardiner, Mr. E. A. W. Hammatt and Mr. G. H. Barton of the Institute of Technology, have also kimblly assisted at the lectures in various capacities. To many of my own students, teachers and others I am also indebted for assistance.

"since the lectures were begun in 1871 , they have been continued without interruption, except during the winter of $1872-73$, under the patronage of Mr. John Cummings; and previous to this winter about 75,000 specimens of minerals, plants, and animals had been studied and distributed to teachers of the public schools. The applications for tickets rose during those years from an average of 55 to 166.

"The number of recorded applications for the course now approaching completion is 616 , or nearly four times as many as in previous years, and the number of specimens which will hare been distrilsuted during this winter alone cannot fall short of 1000,000 .

"After an introductory lecture in which the superintendent of the Public Schools, the President of the Society, and the Custodian delivered addresses appropriate to the occasion, Professor Goodale completed a course of six lessons on Botany in which he instructed the whole audience of five hundred with apparently as much readiness as if it had heen hut fifty. Mr. Jackson Dawson, Mr. Watson and Mr. Greenleaf were of great assistance to Professor Goodale in the procuring of the vast number of live plants and the great amount of other material required for his lessons. Mr. Charles W. Spurr, 522 Harrison Arenue, Boston, prepared, for the purpose of illustrating the subject of wood sections, 500 packages of excellent specimens of the following woods: tulip-tree or whitewood, rosewood, ash, oak, pine, mahogany, walnut, butternut, maple, cedar, birch, cherry, elm and holly. Many of these were in duplicate, exhibiting both plain and figured texture. The 
specimens, more than ten thousand in all, were gratuitously presented to the class by $\mathbf{M r}$. Spurr.

"The Custodian followed with twelve lessons on Zö̈logy, which will be completed on the 10th of this month, and Mr. Burbank is to continue with five on Mineralogry. The average attendance on fair days, so far, has been about five hundred.

"The course was supplemented by the publication of a series of small pamphlets, under the general title of Science Guides, which were intended to assist the teachers in the application of the knowledge imparted by the lectures. These are described in the Report of the Secretary.

"Perhaps the most gratifying and encouraging facts are derived from an exanination of the statistics of the past seven years. Thus out of the 616 applicants of this winter, there are 155 who had attended at least one previous course, ${ }^{1} 119$ who had attended two or more previous courses, and 44 who had attended all of the courses. Some of these last, I may add, are masters of public schools."

The Secretary's report was interesting, as he compared the condition and the work of the departments under his charge during the ten years then closing. As in this volume it will be better to present such comparisons at the close of another year, they are here omitted.

Of inembers, twenty-four Associate, five Corporate, and fourteen Corresponding had been elected. Of the meetings there had been sixteen of the general Society, seven of the section of Botany, and eight of the section of Entomology. The average attendance had been twenty-two at the general meetings, eight at the Botanical, and eleven at the Entomological. The meetings of the last had been unusually interesting.

The history of the Botanical section begun, as stated by the Secretary, "under hopeful auspices three years ago, is far from satisfactory." "With so much popular interest in the study of Botany, the result was unexpected, and is to be regretted."

The condition of the Library was stated to be good and its usefulness never to have been so great-1169 books having been taken out by 123 persons.

The Society was indebted to the Museo Civico of Genoa for a valuable and complete series of its publications; to Prof. Joachim Barrande of Prague, for a set of his extensive works; and to Prof. J. O. Westwood of Oxford, for a number of his papers. The additions to the Library are as follows: volumes, 252; parts of volumes, 1005 ; pamphlets, 214; maps and charts, 221; total, 1692 .

Of Publications, two numbers of the Memoirs, and three quarterly parts of the Proceedings had been issued.

A new volume of Occasional Papers, the third, had been put in press, and would soon be printed. Besides these, a series of Guides for Science Teaching had been prepared for use in the courses of lectures to the teachers, three of which had been published and distributed, the cost being defrayed by sales. The three already issued were, About Pebbles, by Prof. Hyatt; A ferw Common Plants, by Dr. Goodale; and Commercial and other Sponges, by Prof. Hyatt. These were to be followed by other numbers. The Secretary stated the exchange list as numbering 352 Societies or Journals, of which 50 were United States and Canadian.

I It must be rememberel that the highest number of attendants at lessons reachel in previous years was 166. 
The 'Treasurer's account for the year showed that the income applicable for the general purposes of the society harl not come mp to the estimate made at its commencement. and that the expenditures had been about three hundred dollars in excess of such income. As, however, insurance on the property had been paid for five years in advance, the spinit of the policy not to expend beyond the income had been adhered to. There had been an excess of all receipts over expenditures of $\$ 835.90$, all of which and probably more it would be necessary to reserve for prize and other special expenses in accordance with the conditions attached to the use of the Walker Fund.

At the election of officers but few changes were made, and these only in the Committees on the departments of the Museum. M. E. Wadsworth was chosen on the Mineral Committee instead of L. S. Burbank, Rev. G. Frederick Wright on the Geological Committee instead of 'T. Sterry Hunt, W. F. Whitney, M. D., was added to the Committee on Comparative Anatomy, C. O. Whitman was chosen on the Committee of Mollusks, in place of L. Lincoln Thaxter, and E. L. Mark in place of Dr. J. B. S. Jackson, deceased.

At the meeting of the Council following the general anmual meeting of the Society, the trustees presented their estimate of the probable income of the society, applicable for general purposes for the ensuing year, as \$8538.16. As a portion of the income for special uses, anounting to several hundred dollars, might be expenterl for general purposes, they recommended that $\$ 8800$ be appropriated for expenditure, not well perceiving how less could be used without detriment to the interests of the Society.

Walker Prizes. The subject proposed for this year was "The structure, history, and development of some cryptogamous plant." One essay was presented, but it was not deemed worthy of a prize, and no award was therefore made.

In October the Woman's Elucational Aswociation having rednested the use of the lecture room of the Society for hotanical lectures on Mondays and Fridays, the Council granted the request upon the condition that the expeuse of heating the room, and of the janitor's services, should be pair by the Association. The Comeil appointed at this time committees to act upon special matters as follows: On the grand Walker Prize, soon to be awarded, Professor IVm. B. Rongers, Profersor Goodale, and Colonel Theodore Lyman ; on tablets to be placed in the entrance luall of the Museum, commemorative of its great benefactors, Rev. Robert C. Waterston, Edward Burgess, and Alpheus Hyatt.

The Council also voted that the President appoint a committee to consider and report upon a plan for the reception of the American Association for the Advancement of Science, that body having decided to meet in Boston the coming summer.

In November, the Council granted to Mr. L. S. Burbank permission to use the lecture room of the Society for a course of geological lectures, he paying only such expenses as might be incurred for janitor's services, etc.

In December, a vote was passed by the Council authorizing the Committee on Publication to attempt the publication of an illustrated quarto volume of the Memoirs as a part of the Society's celebration of the semi-centennial anniversary of its foundation, by soliciting subscriptions for such memoirs at ten dollars per copy. 'The committee was also authorized to begin to prepare and arrange for the publication when five hundred dollars were subscribed. 
In December, a petition to the Society having been presenter for the formation of a section of Microscopy, signed by Mesis. S. P. Sharples, Simuel Wells, R. R. Andrews, Edward Burgess, J. Frank Brown, David Hunt, Jr., Francis A. Oshorn, R. C. Greenleaf, A. Hyatt, G. F. Waters, and W. F. Whitney, the consent of the Corporate Members was given at two meetings in accordance with the By-laws, and the section was thus formed.

1880. Walker Grand Honorary Prize. In January, the Committee on the award of the Walker Grand Ionorary prize, having manimously recommented Dr. Joseph Leidy, of Philadelphia, as eminently worthy to receive it, for his prolonged investigations and discoveries in zooblogy and Palaeontology, as presented in publieations mante by him, it was voted by the Council that the grand prize be given to Dr. Leidy, and that in consequence of the extraordinary merit of his work that the sum awarded be one thousand dollars.

In January, also, the Custodian reported to the Council that the Committee of the department of Comparative Anatomy objected to his proposed re-arrangement of the collection of that department, and asked that the question at issue might be referred to the next meeting for decision. Thus was brought before the Council the very important matter of determining whether the collection of Comparative Anatomy, like the other collections of the fociety, should be arranged in subordination to the great plan proposed and arlopted at the commencement of the decade for the whole museum, or if the collection of that department should remain an exception, not becoming a part of a series, the full completion of which was essential to illustrate in the best manner the greneral laws of science.

At the next meeting of the Council, which was held January 21, there was a very full attentance, and a warm discussion took place upon the proposed action of the Custodian in which Dr. Dwight, representing the Committee of the department of Comparative Anatomy, - Professors Hyatt and Shaler, Colonel Lyman and Messis. Allen and Buuvé took part.

The great work that had been done by members of the committee upon the collection in past years, demanded that all said by them against a change should be thoughtfully and respectfully considered. There was therefore, no disposition to hasten a decision, and accordingly a vote was passed referring the matter to a committee of three to be appointed by the President. Colonel Theodore Lyman and Messis. S. II. Scudder and Simuel Wells were named as this committee, and instructed to report at a mecting to be held a week later. Upon the Council again coming together a report was presented by the chairman of the committee favoring the proposed re-armangement, wherempon Dr. Dwight said he would not further oppose the execution of the plim of the Custodian, though he personally believed the collections would be injured by the change.

The Council then passed a vote with but one dissentient voice, approving the proposed action of the Custorlian in carrying out the plan of 1870 , with regard to the department of Comparative Anatomy.

Thus was settled, not without much feeling, but amicably, a question, the decision of which in favor of the proposed change, was regarded by the great majority as most important for the welfare of the Society, whilst a number of members influential through eminent service in its behalf, thought the proposed action uncalled for and detrimental. 
It may be concerler that much worthy of consideration was said in s!pport of their views, but it is believed that all students of nature will finally concur in the opinion that the decision made was a wise one.

\section{Dr. Thomas Mato Brewer.}

At the general meeting of the Society on February the fourth, the President, Mr. T. 'T': Bouvé said :

Since we last met, the Society has lost one of its oldest and most valued members, Dr. Thomas M. Brewer.

It grieved me as an old personal friend to learn when in a distant state, that the disease, by which as I knew before leaving home he was prostrated, had terminated fatally, and that I should not again receive his pleasant greeting on earth, or even have the sad satisfaction of being present at the funeral services following his departure. 'The long intercourse between us had always been of the most agreeable character, and I feel that I have reason to mourn that it has so unexpectedly and mournfully terminated. This is not the place, however, for me to indulge in the expression of personal bereavement, but rather to dwell on the great loss the society and community have met in the death of our beloverd associate.

Dr. Brewer was born in Boston, Nov. 21st, 1814. He graduated at Harvard College in 1835, and in the Medical School in 1838. He labored in his profession for several years, but his tastes and inclinations were stronger for other pursuits. He was fond of literary labor, and, having strong political tentencies was early led to write for one of the leading Whig papers of the period, the Boston Atlas, and at length to become one of its editors, in which capacity he manifested marked ability both as a writer and close observer. Subsequently he becane interested in the firm of Swan and 'Tileston, a publishing house which was afterwards changed to that of Brewer and Tileston. He retired from business in 1875 and then visited Europe, where he remained two years. He had become well known by his ornithological labors and received consequently very gratifying attention from many distinguished scientific men whilst abroad.

In the cause of popular education he was very zealous, manifesting at all times great interest in the public schools of the city. He was long a member of the Boston School Committee, and served in this capacity with great devotedness. His last election to this office was in 1879 , for the term of three years.

Dr. Brewer was elected a member of this Society October $7 \mathrm{th}, \mathbf{1 8 3 5}$, and soon became well known by his valuable contributions, mostly upon his favorite subject of ornithology. It is pleasant to recall the fact that his first communication to the Society was in defence of Nuttall and Audubon, the distinguished naturalists, the latter his wam personal friend, against some unjust attempts in a foreign magrazine to detract from their well earned and deserved reputation. Not long after he presented a highly interesting paper upon the Birds of Massachusetts, in which he gave an account of over forty species not embraced in the State report of Dr. Iitcheock upon the Geology and Naturil History of the State. From that early period, now nearly half a contury since, he never ceased to manifent great interest in the welfare of the Society, by freruent communications and in such other ways as his health would admit. 
Apart from what he performed for the Society, he accomplished much for scientific knowlerleg by contributions to several pullications of great value, and by articles which he furnished for some of the popular magazines.

As these remarks will be supplemented by particular mention of Dr. Brewer's scientific writings in a sketch furnished by his friend Mr. J. A. Allen, it will not be necessary for me to make further reference to them, and I need only add that, had he lived free from the business cares that until recently absorbed most of his time, much more might have been looked for from him relative to the habits of birds, particularly of such as find a home permanently or temporarily in New England.

We of the Society will greatly miss his efficient labors in striving to complete the collection in the department of New England Ornithology, for the development of which he manifested much and increasing interest.

In the death of Dr. Brewer our Society has lost a most valuable member, and the community, a grood and wise citizen, one of whom it may be truly said: He was always faithful to the duties of every position in which he was placed, and ever ready to work where he recognized that his labors would promote the public welfure.

The following notice of Dr. Brewer's scientific labors by Mr. J. A. Allen, was also contributed.

The death of Dr. Brewer removes another of the older American ornithologists, of whom there now remain two only whose period of scientific activity extends back to the time of Audubon and Nuttall. Dr. Brewer's first formal contribution to ornithology, entitled "Some additions to the Catalogue of the Birds of Mastichusetts in Prof. Hitchcock's Report, etc., was published in 1837 , in the first volume of the "Journal " of this Society. These additions mumbered forty-five species and increased by one-fourth the list of hirds previously known as inhabitants of this State. Previously, however, he had furnished valuable notes and rare specimens of birds to Audubon, who in his great work on North Anerican birds, makes frequent mention of his indebtedness to "his young friend, Mr. T. M. Brewer of Boston."

In 1840, he became more generally known as an ornithologist through his edition of Wilson's "American Ornithology," - the only American edition of Wilson's work, except Ord's, published prior to 1871. 'The "Brewer Edition," from its comparatively small cost, placed this delightful work within the reach of a wide circle of readers, to whom the more expensive original and Ord editions were innccessible. It was enriched by the addition to the original text of the symonymy and critical commentary of Jardine's edition, and by a very useful and carefully digested synopsis of all the birds at that time known as North American.

In 1857 was published the first part of his " North American Oölogy," which forms part of volume IX of the "Smithsonian Contributions to Knowledge." The full title of the work - "North American Oölogy; being an account of the geographical distribution of the birds of North America during the breeding season, with figures and descriptions of their eggs" -indicates very fairly its scope and character", but in addition to the topics thus indicated, the work gives a pretty full exposition of the breeding habits of the species treated, so far as then known, and also full tables of synonymy. Owing to the great 
cost of the illustrations, the work was not continued beyond the fir t part. which treats of the Birls of Prey, the Swifts, Swallows, Goatunckers and Kingfishers. This work, until within the last year; was the only special treatise extant on the subject to which it relates, and will ever hold the place of a standard work. It is, moreover, a work which brought to its author great credit, and throngh which he became wirlely known as an ornithologist of high standing.

In 1874 appeared "A History of North American Birds," under the joint authorship of S. F. Baird, 'T. II. Brewer, and R. Ridgway, in three quarto volumes devoted to the "Land Birds." The this work the whole of the biographical part, forming probably two-thirds of the letterpress, was contributed by Dr. Brewer, and throughout evinces his thorough fimiliarity with the literature of the subject, and shows the hand of the master in all that relates to his special department of a work which marks an era in the history of North American ornithology.

Dr. Brewer's minor papers appeared at intervals throughout the long period of forty years, and embrace important contributions to our knowledge of American birds.

He has left the manuscript for the completion of his share of the great work on North American birds already mentioned, the final revision of which he had just completed; also material for the contemplated continuation of his "North American Oölogy." His collection of egggs - the accumulation of a long series of years, - is doubtless one of the best private collections extant.

Dr. Brewer having been engaged during the larger part of his life in absorbing professional or commereial pursuits, his contributions to ornithology must have been largely the work of such limited time as could be spared from his business engagements, and only within the last few years was he able to devote himself wholly to his favorite studies. Although an authority of unsurpassed eminence in his special province, - that of North American Oölogy, - his labors were mainly restricted to this field, taken, however in its broader sense. Removed suddenly, apparently when there were years of activity and leisure before him for scientific research, his loss is one not easily replaced, nor its importance readily appreciated except by those who knew him intimately and were familiar with his comscientions manner of investigation, his warm sympathy, and the thorough loyalty of his friendship.

At a meeting of the Council on the 17th of March, the President called the attention of the members to the fact that the 2Sth of April would be the semi-centemnial anniversary of the formation of the Society, suggesting that a public celebration of the event should take place.

After discussion it was unanimously voted, that the President should appoint a committee, including himself as chairman, to arrange for a proper celebration, with full powers to take such measures as they judged expedient. The committee as formed consisted of the President, Mr. John Cummings, Mr. S. H. Scudder, Mr. Charles W. Scudder, and Mr. Edward Burgess. It will be remembered that the Council in December had passed a vote in view of this year being the semi-centemnial one of the foundation of the Society, that there should be published an illustrated quarto volume of its memoirs as a part of the Society's celebration of the event, if subscriptions could be obtained for copies 
that would yield five humbed follars. As more than the necessary number of names hard alrearly been secured, preparation was made for the issue of such a volume. Subseruently the President was solicited to write for the same volume a sketch of the history of the Society, from its foundation to the close of the fiftieth year of its existence. 'This, after much hesitation, he consented to do, recognizing the importance of having such a sketch prepared, whilst yet some of the founders of the Society were alive and able to give information concerning their early brother menbers, and fearing that otherwise it would be left undone.

The committee appointed to take measures for the celebration of the semi-centennial ammiversary were faithful to their trust, taking active measures to ensure success. It soon became manifest that the occasion was to be one of great interest, all persons addressed being found ready to coöperate with the committee in eatrying out their plans. Cheer-

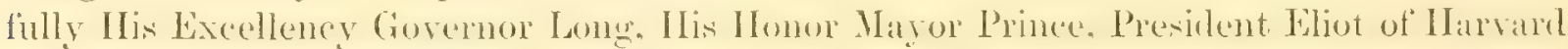
University, Dr. Samuel Eliot, Superintendent of the Public Schools, Mr. Agassiz, Direc-

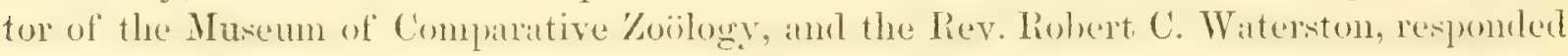
to calls upon them to take part in the proceedings. 'The committee's labors were multifarious; they had printerl for use at the nereting and for distribution, an introduction to the General Guide to the Misem then in preparation by Prof. Hyatt; they had moved the elephant from his elevated position, and other linge animals from their alecustomed plater, and had erected across the north portion of the main hall a platform to accommodate the speakers and distinguished visitors. This was carpeted and furnished with chairs, the rest of the hall having settees over the floor.

At the general meeting of the Society, April 21st, the Nominating Committee having reported a list of officers for election at the annual meeting, to take place on the 5 th of May, in which Mr. Bourés name was mentioned for President. he andresied the meeting", referring to his having consented four year's previously, at the hind solicitation of menbers, to withdraw his resignation then tendered, stating that there were several reasons why he should decline re-clection at the present time, and urging that the Society would not ask him to reconsider his determination.

Mr. Fendder expresied the hope that the President's withdrawal was not imperative, and dwelt upon the work done molex his administration, which had resulted in the final crystallization of the policy of the Society.

Remarks were also made by Mr. Hyatt, Mr. Burgess and Mr. Nathan Appleton, expressive of regret at the contemplated action of the President. He, however, warmly thanking the speakers for their kind expressions, reiterated his resolve to resign. It was therefore voted to recommit the report to the nominating committee for reconsideration. This being done they withdrew, and after consultation re-entered the meeting, and presented an amended report, nominating for Prexident in the place of Mr. Bouvé, simmel H. Scudder. The report was then accepted.

At this meeting the molels of the sun and the earth were presentert to the fociety by the Buston scientific Socicty. These consist of a gilt ball representing the sun, three inches in diameter, and a white plate on which is a black spot three one-hundredths of an inch in diameter, which symbolizes the earth. 'These were placed one on the centre of each arch at the side of the stairs in the main hall of entrance to the Museum. They 


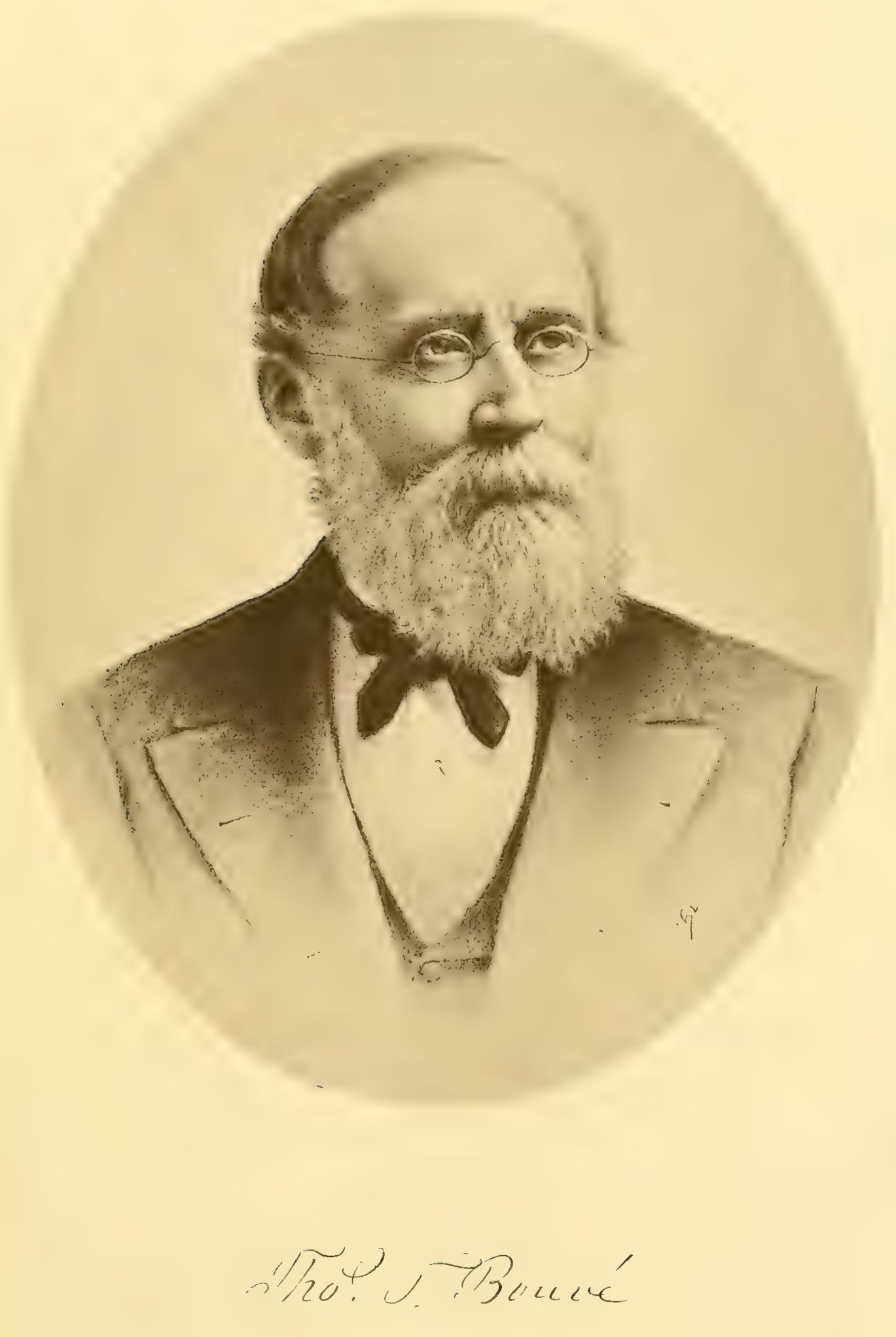



represent approximately the proportionate size of the sun and the earth, and their distance from each other relative to size. The proportionate scale of the models and their distance apart is about a foot to three millions of miles, or about one inch to two hundred and fifty thousand miles.

A vote was passed, that the President appoint at leisure a committee of three to consider the desirability of abolishing the Committees in the departments, and of devising a different plan for organizing the Council, and to propose the necessary change in the Constitution and By-Laws for this purpose. 'The President subsequently appointed as this committee, S. H. Scudder, Dr. B. Joy Jeffries, and Edward Burgess.

'line Semi-Centennial Celebration of the Foundation of the Societr; April 28.

The amiversary day was pleasant and all things conspired to render the occasion interesting and joyous. 'The spacious platform which had been erected across the north portion of the main hall was occupied by the President, the speakers, the officers of the Society and a large number of ladies and gentlemen. A large audience, composed of members of the Society and very many prominent men and women of the city and State, filled the floor of the hall and such portions of the galleries as were convenient to use. Amongst the distinguished persons present, were His Excellency Governor Long, President Eliot of Harvard University, Prof. Asa Gray, the illustrious botanist, Alexander Agassiz, Director of the Museum of Comparative 'Loölogy, Count Louis François de Pourtales, Dr. Samuel Eliot, Superintendent of the Public Schools, Miss Lucretia Crocker, Supervisor of the Public Schools, Dr. D. Humphreys Storer, Judge G. W. Warren, Prof. F. W. Putnam, Rev. Robert C. Waterston and Mrs. Waterston, Ilon. Josiah Quincy, Prof. E. S. Morse, Colonel Theodore Lyman, Dr. J. C. White, Mr. Justin Winsor, Librarian at Harvard University, and Mr. John Cummings.

At half past three, the time of commencement, the President, Thomas 'T. Bouvé, after' calling the assembly to order, began his address as follows:

Members of the Society, my Associates in its service, my Companions for many years in its labors, its trials and its achievements :- I congratulate you. I think we have reason to congratulate each other that we come here surrounded by a host of sympathizing friends; and ladies and gentlemen, whose names we have not the honor of having recorded on our rolls as members, as a representative of the Society, I bid you a hearty welcome here to commemorate its formation and to rejoice in its success.

With these very few words of greeting, for the time will admit of no more, I proceed at once to present what I have prepared for the occasion. It is an account of the doings of those who took an active part, before the Society was formed, in interesting the public in natural history. I do this becume their lahoris have not been duly appreciated, and because the lessons which their experience is designed to teach certainly require that we should take time to do it. What I hold in my hand is intended as an introductory chapter in the history of the Society of Natural Ilistory on which 1 am engaged, - a memorial rolume to be issued this year.

The President then proceeded to present the early steps taken to inculcate a love for the sturly of nature in this community, particularly dwelling upon the formation of the Tin- 
naean Society, its history and its decline. He then gave a brief account of the movements made towards the formation of a new Society, which culminated in the existence of the Boston Society of Natural History. As nearly the whole address is embraced in the opening pages of this volume, no further mention of it is necessary here.

At the close of the President's remarks a telegran was handed to him from Prof. William B. Rogers dated Washington, D. C., expressing regret that he could not be present, and rejoicing in the prosperity of the Society. His Excellency Governor Long was then introduced. ${ }^{1}$

\section{Address of Goveinot Loxe.}

When I was invited to be present at this interesting amniversary, thoroughly grateful for the courtesy, I felt at first that neither personally nor as an official of the State ought I to take any other part in it than that of a looker-on. But I remembered that the seeds of your noble institution, Mr. President, like those of so many of the best fruits of New England, were sown not altugether by the scientists nor by any one profession, but by common men who lifted up their eyes above the ordinary toil of life, and who for themselves and their fellow-men reached out to higher levels of knowledge and usefuhness. I remembered too that your first great endowment came from a merchant - type of the unbroken line of the peerless merchants of Boston - who was little known among scientific scholars, yet contributed from the accumulations of his thrift to a higher culture than his own, and that this was only the begimning of a series of generous contributions from citizen after citizen, which culminated at last in ample revenues from your chief benefactor, who was not less distinguished for his wistom in affiirs than for his professional acquirements. And I remembered more than all, that the Commonwealth, which from the days of her founders until now never yet has failed the cause of education among her children, had from the first been the stearlfast friend of this society, giving it incorporation, aidling it in its early years with a modest but saving annual subsidy, and, in 1861, making to it the munificent donation of land on which its foundations now rest secure,-- a donation that came not only with the good will and the God-speed of the Commonwealth, but with all the sympathy and inspiration of the soul of Governor Andrew, who, next to his devotion to human rights and hate of human wrongs, cherished the love of that enlarging learning which he knew is from the meanness of wrong to the nobility of right the slow but sure highway.

And so as one of the many citizens of Mnssachusetts, and also as one in oflicial station representing her, I am emboldened, at your request, Mr. President, to unite my voice in the acclaim that hails this fiftieth amniversary of your existence. Memory and imagination, - those exquisite poets of the human mind,- memory that looks tenderly back over the past, and imagimation that idealizes and yet in all its mounting knows that it fails to picture or command the future--are making this occasion not the mere boast of fifty years' success, but a tribute to what man has done, and a stimulus to what man yet a thousand times more shall do in behalf of the happiness, the delight, the knowledge, the ennobling of his fellow-men, unlocking from every nook and corner of the earth, and displaying in every form and motion of life, the beneficence of God. What a stride from those first small days, - that parlor sofic that once held you all, - those modest rooms, to this splendid temple, which I trust is to be your permanent home, where shall not only gather your rare and beautiful collections, but cluster with them also the memories of the

1 The addresses at the Semi-Centennial meeting as presenter, will the exception of that of $1 \mathrm{r}$. Waterston, were taken from the reports made of them for the Boston Dilig. Advertiser. 
zeal and devotion that have marked so many of your memhers. The birds of Bryant, the insects of Inurris, the shells of Gould, the fossils from the Sivalik Mills, the contributions of a thousand helpful hamds from every quarter of the globe suggest something more than their scientific value. For they are still alive with the generous love of science which prompted their bestowal, and which, clinging to them still like the scent to the vase, wreathes your walls, more beautifully than the chisel of the artist and in more enduring material, with the names and the features of those of whom I have spoken. Yes, and of Greene and Wyman and Jackson and Greenwood and Brewer and a hundred others.

If fifty years have wrought all this from such a slender beginning, what shall not fifty years more achieve? Everything, indeed, for science; everything for the increase of human knowledge. But more than all elie, speaking for that Commonwealth which means not a function of government, but means the common weal of the people and of all the people of Massachusetts, her humblest, her weakest, her most dependent, those who sadly and heavily bear the burdens, who hew the wood and draw the water, I love to think that your labors, much as they delight you, will still more bear fruit for them, and that you are fulfilling the time when the student of science, exulting in the treasures that come to his exploring, and touching at his fingers' ends the keys that turn every element of the physical world into an agrency of usefulness, not only finds his own cup full, but is the benefactor of the whole human race, alleviating the weight of toil, shortening the hours of the drayage of labor, enlarging the calacities and material of a brighter, happier, more generous life for all alike, and letting every soul go freer and freer in its up-springing and response to God.

The President next introduced Dr. Samuel Eliot, Superintendent of the Boston Public Schools.

\section{Address of Dr. Eliot.}

In opening his speech Dr. Fliot observed that he did not understand why he was called upon to represent the eity of Boston in the absence of Mayor Prince. The only title, saill he, which I can so much as imagine entitling me to speak in behalf of Boston, is that, to some extent, I am, for the time being, a representative of the public education of the city. Boston has no brighter jewel in her crown, Boston has had no higher function in all the long years of its past, than that which has made her the teacher and the mother of so many thousands of her children. Indeed, this education given in the public schools of various grades and names, and the work of such a Society as this, interests me very deeply. I think, as I stand here, of the scenes that I have looked upon in this and the arljoining building, where the teachers of our public schools have gone at the invitation of this society, and, through individual genius and the contributions of the friends of this Society, have received lessons which they, in their turn, have given to their children. And when I think of all that this involves of nearness to nature, which forms so true an essential of education, and which, without such help as this Society has given, would be to-day little more than a name among our teachers and our pupils, I feel that I have the right, in behalf of the public schools of Boston and of the whole community, to thank the Society of Natural History for the help which they have given us. Nearness to nature, as I said, is one of the great essentials of education, but it has been one of the most diffi- 
cult essentials to secure even in our comparatively late day. Anything that helps us to secure it; anything that brings nature closer to the schools, and the schools closer to nature, is doing good far beyond the limit of the schools. Think, for a moment, of the homes from which the pupils of our public schools come, of the absolute ignorance of nature, of all the beauties connected with her, or of the mysteries which extend so completely over all. Think of the clouds that may hang heavily over house after house and tenement after tenement within the limits of our city, and think how grateful the people must be, that from this Society as its source, is flowing in streams through the schools sweet and healing water, and is now reaching these homes; that there is no home now so far away but that nature is reaching it, and day by day will take possession of it. 'That is the inestimable service, Mr. President, which I am here to acknowledge, and I do it with a most glad and most grateful heart. It is not merely of the lessons and teachers of which I have spoken. Here are these collections, whose founders are everywhere generously commended. If the doors are open the light goes out through them and lights the earth, and we may be glad if we can even add a hundredth part to the radianee that is everywhere spreading abroad from them. As gratitude, Mr. President, is always a lively sense of favors to come I want to express my gratitude for the help that is yet to be given by this Society to those who come after us, and the next half-century will be even more fruitful than the last half-century has been, in maintaining the highest interest in the schools and homes which Boston claims as her own.

\section{Address of President Eltot.}

President Charles Eliot, of IIarvard University, upon being introduced to the audience said :

This Society has two distinct oljects - (1) the promotion of natural history loy stimulating anl aiding advanced study and original research, and (2) the enlightemment of the common people coucerning animate and inmimate nature. What I have to say touches each of these two objects.

It would carry us into a discussion too solemn for this occasion to attempt to state the primary reasons. which should induce men to study nature devotedly, although no tangihle benefits could ever flow from that study; for I have never been able to find any better answer to the question - what is the chief end of studying nature - than the answer which the Westminster catechism gives to the question, what is the chief end of man namely, "to glorify God, and to enjoy him forever."

I shall al k your attention to a proposition which contains only a secontary, though sufticient, reason for fostering the study of uatural history - to the proposition that the human race has more and greater benefits to expect from the successful cultivation of the sciences which deal with living things than from all the other sciences put together. I by no means formet what mechanies and physics have brought to pass within a hundred years. They have already reduced the earth to one-tenth of its former size, as regards the carriage of persons and goods, and for the transmission of thought, will, and fict, they hid fair to make the whole surface of the globe as one room. They have made it easy, on the one hame to concentrate populition in dene masses, and on the other to reach new soils and 
shores, and to distribute to all countries the peculiar productions of each. These wonderful achievements of mechanics and physics, aided by chemistry, produce indirect effects upon the well-being of man, some good effects and some bad, with a probable preponderance of good; but their direct influence upon human character and happiness is not large. The reduction in size of our earth, our country, or our town, which railways, telegraphs and telephones have brought about is in itself no satisfaction. Rapid locomotion is not an object in itself. Does the average man get any more happiness out of his little span than he did one hundred years ago? or does he have a longer span? And if he does, have the inventions of the past century in mechanics and physics been a direct cause of the improvement? The answers to these questions are not ready and clear. We hesitate to give an affirmative reply. 'The fact is, that mechanics and physics deal only indirectly with human misery,- namely, climatic influences, not understood, and, therefore, not to be guarded against, violent and umpredictable extremes of heat or cold, wetness or dryness, ravages of noxious plants and animals, diseases both of men and of useful animals and untimely death. All these evils belong to the domain of natural history, and for ultimate deliverance from them we must look to the student of natural science.

It is astonishing how little progress has been made by the race in discovering the means of overcoming these evils. Civilized society to-day would be almost as helpless as Pharaoh was against the plagues which afficterl the Egyptians, - the river water suddenly, made so foul that the fish in it died, frogs, lice, flies, a murrain upon cattle, boils, hail, locusts, dark fogs and the dread pestilence which struck one race and spared another upon the same soil. These are evils which, for the most part, we find resistless to-day. Every now and then some city's water supply is rendered unfit for use by an extraordinary production of multitudinous little plants or animals; the plant-louse destroys the vines in a wine-producing country, and brings the whole population to want; pleuro-pneumonia kills the cattle, now in this district, now in that; an obscure fungus causes the potato to rot, and a sudden famine is the result; the Colorado beetle, once a rarity in the collections of entomologists, swarms over a continent, devouring vast crops, and forcing the husbandman to abandon, for a time at least, the cultivation of various useful plants; in some of the Westsern States the harvest depends, not so much on the foresight and skill of man as on the favorableness or unfavorableness of the season to the development of grasshoppers. Indeed, thus far, any single-minded and prolific worm is more than a match for man. Think, too, of the diseases which afllict humanity, and are the source of by far the greater part of the sufferings and sorrows of men! There are the regular diseases to which we are so accustomed that we consider them normal phenomena, the new diseases, which appear or reappear at considerable intervals, and the occasional pestilences. Man is still so ignorant of the causes and sources of these various disorders, of the conditions which develop them, and of the means of eradicating and resisting them, that he is inclined to regard disease as a part of the order of nature, over which he can win no control.

But in view of all that science has accomplished within the lifetime of this Society, shall we not declare that this idea of nature and of man's relation to his environment is cowardly, stupid and ungrateful? Can we not clearly foresee that by the patient, thorough, cumulative study of natural history in all its branches, men will gradually arrive at a knowledge of plants and animils, and of the farorable and unfavorable conditions of life 
for all plants and animals, which will give them control over many evils which they now find wholly mysterious and irresistible? I can only touch very briefly upon some of the grounds of this belief.

The physician or surgeon of the last century was hardly wiser than Hippocrates or more successful; but any old physician or surgeon would tell us to-day that the means and methods of observation, diagnosis and treatment have wonded fully improved during his lifetime; that many operations are now successfully performed which were formerly supposed to be impossible; that the whole subject of preventive medicine and public hygiene has been developed in his day; and that he has seen the beginnings of the scientific study of heredity, that most fruitful and promismg field of scientific and philanthropic research. Thanks in part to the progress in physics and chemistry, natural history possesses new and powerful implements of research, and new methods of inquiry which are of infinite promise. The morbid anatomist observes, not the gross external appearances, but the abnormal cellular changes which produce, or are, disease; the physiologist studies the processes of living animals; the chemist is constantly making natural organic products by artificial means; the embryologist his hecone conversint with those slight differentiations in the egg which are the starting points of wide diversities; substantial begimmings of weather knowledge appear; the whole earth has been explored, and now for the first time the fauna of the ocean abysses is made known.

Antiquity had its great students of nature, but they lacked the means of diffusing, preserving and accumulating their discoveries. The past four centuries have had abundant means of recording and transmitting from one generation to another all the scientific truth which they became possessed of. It is in this steady, patient and orderly accumulation of facts concerning living things that the hope of winning for man new powers over the gravest natural evils really lies. This Society has a part in making that pregnant record.

There is another aspect of your work which seems to me very important. You propose to maintain for the public an exhibition of all forms of vegetable and animal life in their wondrous and endless variety. Hither people may come and see their fellow-heings in the widest and truest sense. Moralists tell us that the best development of an individual man is not to be reached through introspection, self-reference and an overweening anxiet $y$ about his own salvation. They say to every man - look out and not in. The same exhortation might well be addressed to the human race. Mankind needs to look out, and not in; to realize that it is but one, though a noble one, among countless races and tribes of creatures which inhabit or have inhabited this atom of an earth, and that its welfure is not the sole end of creation, or the one absorbing interest of the Creator. A few years ago all men believed that the whole boundless universe centred upon man. That delusion has lost its hold, except perhaps within the well-protected domain of dogmatic theologr. But there are still many people who cling to the kindred conceit that this earth, at least, was made for man. It is a belief which will not survive much acquantance with the vast solitudes of the earth which teem with other life than man's - the everglades, the jungles, the mountains and seas. It is a belief which a thoughtful man or child will be apt to qualify or resign, as he studiously examines such a collection of natural history as this Society strives to maintain. 


\section{Address of Mr. Alexander Agassiz.}

Mr. Alexander Agassiz was the next speaker. In the first part of his address he mentioned the difficulties through which the Society had passed. An interesting extract from his remarks is given below :

The scientific man should he without nationality. rearly to welcome progress from any quarter. Science is bound neither by country nor creed in its relation to new information. An important publication, a new line of research, a brilliant hypothesis, should appeal to us, not because it is American, German, French or English, nor because it is on the wirning side in the questions of the day. It is, of course, natural that a country comparatively young in scientific culture should turn to oller institutions for its standards, should be constantly tempted to compare its own learnel societies and their doings with those of more ancient date and established influence. But while measuring our progress by theirs with honorable emulation. let us not make the mistake of also measuring our scientific men by a reflected light only, making our own resognition of them wait upon that from the other side of the water. Every nation should be proud of its great men, and may be excused for overrating them, but it should also add to an excusable national vanity an independence capalsle of recognizing, appreciating and sympathizing with the men who are raising the intellectual standard of their country to that of older ones. The pioneers of science in this country were neither remote imitators nor simply commentators; they have not only laid the foundations of natural science in this country, but they have extended its boundaries on many fields. Nor should we assume that they had need of a kind word of recognition from the other institutions or individuals. Let me not, however, be understood for a moment as disparaging the intelligent criticism of press or colleagues at home or abroad. I only wish to distinguish between that and the notoriety so easily gained by constant appeals to the public either in person or through scientific quacks.

Since, however, the true investigator rarely has either the time or the disposition to become the expounder of his own work, it is not always possible for the public to draw the line between those who speak from their own knowledge and the scientific litterateur who forages in any field where booty is to be gained. We have met to-day to honor the pioneers of science in this country by a grateful recognition of what has been accomplished from the small beginnings of fifty years ago. Taking up some of the more prominent names of the early days of the Natural History Society we must award the highest place to men like Wyman, Harris, Bigelow, Gould, Storer and Binney, whose investigations have paved the way for their successors of the present day. They were men of no ordinary stamp. They were men who in any country would have been recognized as leaders in science, and whose fame will live when many of us are forgotten.

'The speech closed with a high tribute to the late President Wyman. 


\section{Address of Rev. Robert C. Waterston.}

On a semi-centennial celebration like this, while we have reason to congratulate the members of the Society of Natural History here assembled, on the great success which has

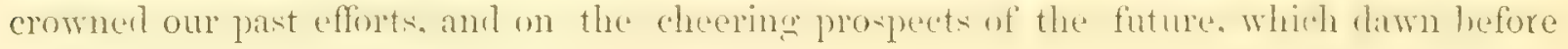
us like the morning of a yet brighter day, still we camnot but recall with feelings of sadness and solemnity the many who have libored with us in the earlier history of the Society, no longer here. Largely to their unwearied efforts are we indebted for the prosperity we now enjoy. Constant inspiration comes to us from the remembrance of their quickening zeal, their love of knowledge, and their generous desire to communicate to others, what they so profoundly valued themselves. How heartily do we wish they could be with us, on this eventful day. And yet, as we look around upon these walls, and gaze upon the life-like portraits of the past officers and benefactors of the Society, it seems as if, in very truth, they were actually here, participating with us in the privileges of this occasion.

Before us, is our first President, Dr. B. D. Greene, with his calm expression of blended sweetness and power. A love of nature pervaded his life. Extensively on this continent, in the tropics, and in most of the countries of Europe, he diligently pursued his botanical researches. Blessed with ample means, he was able to malie his investigntions under every advantage. Years which might have been given to luxurious repose, were by him gladly devoted to eamest study. Thus did he acquire a knowledge seldom surpassed, and while constantly consulted by younger botanists, never did he decline to impart from his abundant resources. We do not forget that his rare herbarium, containing the results of long personal industry, and the fruit of more than a quarter of a century of intercourse and exchange with Sir William Hooker and other distinguished botanists in every section of the glole. inchuling plants gathered during the first Expedition of Sir Joln Franklin, constituting in all an invaluable collection for quality as well as quantity, we do not forget that this he presented to the Society, together with between one and two thousand volumes of botanical works from his library; and that at the time of his death, he enriched the Society by a munificent bequest.

And here by his side, is "the beloverl physician," Dr. Augustus A. Cionld, who from his large professional lahors, could always find time for the benefit of this rociety. In the department of conchology he was an acknowledged anthority. The collections here bear testimony to his zeal. I well remember the interest he awakened by one of his lectures to teachers within these walls. Many of his hearers stopped and expressed their wish to visit in his company the sea-shore, that they might gather shells on the sands and listen to his instruction in the midst of Nature. IIe made arrangements with them on the spot, and within a week they went together to a neighboring beach, and there they passed such a day as they will never forget.

And here is our friend Professor Jeffries Wyman, who shunned popularity, rather than sought it, and who cared always to be and never to seem. His aim was ever 'Truth, simple, absolute 'Truth. Indefatigable in his researches, he would never abandon any investigation until it was thoroughly completed, and would leave nothing for students who should come after, but astonishment at what he had accomplished. While engrosiced in his studies 
I doubt if he would have been disturhed though an armed force had camonader the building. It was sairl of Constable the artist, that in the fields he would sit so calmly in his contemplation of the landscape, that the field-mice would creep into his pocket. I think they mirht have done the same with Professor Wyman, though I would not answer for it that they might not become, under his hand, interesting specimens in Comparative Anintomy. Lnawsuming in manner, and with a mortal arersion to pretentious conceit, no man valued true merit more heartily than he did, or was more earnest to assist strugghling cindeavor. His name is now honored as widely as science is known.

And here we look upon the face of Agassiz whose benignant smile is to-day, as it ever was, a benediction. How absolutely with him the man of science became the acknowledged Tnstructor. Whether in the halls of legislation or the popular as sembly, or before a convention of teachers, or in his own private lecture-room, he was the Educator. He seemed born for this rocation. His gift of speech, his genial spirit, his srmpathetie and magnetic power, made all listen with avidity. He knew not only how to gather, but how to impart. Whether he was discoursing upon glaciers or embryology, upon the structure of animal life, coral-reefs, star-fish, or an oyster, he was alike able to arrest and rivet attention, learling the mind from point to point, wondering and delighterl, until rising above the individual it graped the mirersal, and seeing the hidden liaw, it recognized through that, the Divine Intelligence.

With voice, manner, look, he held entranced the hearer, leading him onward from stage to stage in the line of progress. In all he did, he was preëminently the teacher of the individual, the community, the nation. "I have been," he said, "a Teacher ever since I was fifteen years of age. I am so now, and I hope I shall continue to be all my life." He did so continue, and so he still is; through the memory of his life, and through the words he has left us, he is emphatically the Liducator; kindling a desire for knowlerlge and the love of progress. The increasing interest in the study of natural history, seen everywhere, how much he did to awaken!

While we look upon that countenance, do we not all recall those jrords of Longfellow, addressed to Agrassiz on his fiftieth birthdily, where Nature is represented ats spealking:

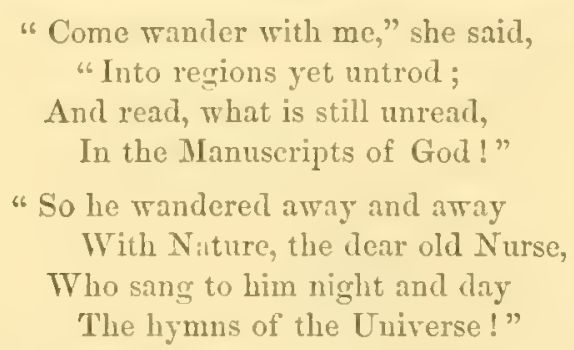

And even thus, by night and by day, to every true-hearted Naturalist, Nature pours forth her celestial melodies:
"And whenerer the way seems long,
And our hearts begin to fail,
She will sing a more wonderful song, -
Or tell a more marvellons tale !"

The members of this Society lnow full well the deep joy that is a walkened through that harmony with Nature which comes from the study of her works. The vast collec- 
tions of wonders treasured up within these walls, are infinitely more to the naturalist than curiosities. They are revelations of eternal laws. They are the condensed history of the ages. They converse, in a mysterious language, of things that were; unfolding the marvellous processes that are ever going on in the hidden laboratories of the earth.

According to our power of observation, the development of our faculties, the extent of our knowledge, and the elevation of our own nature, will be what we shall here find and enjoy. Such collections as are within these walls will help us to ascertain whether the works of the Almighty have a language which we can interpret. Here, according to our susceptibility, will a love of knowledge be stimulated, the intellectual energies quickened, and all that is best and noblest in our nature called into activity.

Not as a place for idle amusement were these walls erected. Not to gratify a vague inquisitiveness were these collections gathered. Not for spimning the gossamer theads of fanciful speculation were these halls and lecture-rooms dedicated. But for the highest culture of which man is capable. For the acquirement of solid information. For the opportunity of studying results gained by scientific explorers all over the globe. We cannot personally accompany Sir Edward Parry and Sir John Richardson to the Arctic regions, or with Humbolit climb Chimborazo, or penetrate the forests with Audubon, or sail in "Her Majesty's ship" the "Beagle" round the world, but we can come here and study the result of such labors. All that is of deepest interest between the equator and the two poles, is here brought together. In books of voyages and travels, in works upon botany, zoölogy, and palaeontology; through specimens of rocks, ores, and fossils, gathered from every zone: what branch of the natural sciences may not here be investigated? Here is opportunity for observation and thought, analysis and comparison. Who will affirm that such an institution is not an essential part of our wliole educational system, from the elementary School, up to the University; yes, and onward through that continued education which shall extend to the utmost limit of life?

This educational principle was recognized from the very commencement of the Society, its avowed purpose being "the encouragement and promotion of the Science of Natural History," which it was distinctly stated, the friends of the Society not only desired for themselves, but that the interest might be extended far beyond their own circle.

They were, however, few in number, and with limited means; a scanty library and a meagre collection, with as yet but feeble response from the public. This now populous city was then not much more than a village, and the very taste which the founders of this institution sought to direct and foster, had first to be created. We can hardly know how they surmomted the difficulties they had to overcome. Still they persevered until at length they became estal)lished in a huilding of more adequate accommodation in Mason Street. Through every stage, there was a recognition of the same educational principle, and, as their opportunities were enlared, this purpose hecame more and more prominent. Not only scientific students and intelligent citizens availed themselves of its ardvantages, but often entire schools, with their teachers, visited the Museum for a day's study; the curators and officers of the Society giving explanations in their several departments, thus rendering the occasions of real service to both masters and pupils.

As the collections accumulated, and the beneficial influence of the Society became more fully demonstrated, a larger field constantly opened; and an appeal was at length made to the Commonwealth for an appropriation of land upon which a more suitable building 
might be erected. The motive urged was, that the institution would thus be established "on a permanent basis of augmented usefulness." It was declared that the result of its thirty years' efforts had been a rapid advancement of knowledge, with an almost universal dissemination of a love for the natural sciences, that now there was a general recognition of its claims to an honorable rank in our system of public education, while it was acknowledged that its labors tended to promote both the intellectual and material prosperity of the Commonwealth.

Thus while it was well understood that scientific men and professional students were to have every advantage within command of the Society, still it was also understood that the classification of all the collections, and their entire arrangement, was to be such that the public generally should have opportunity of gaining correct knowledge, and that such practical aid should be rendered to our schools, as might be invaluable in its results.

My recollection of this Society goes back to the time when it had its rooms in the old Athenæum in Pearl Street. The building in Mason Street I often frequented, and at the time when the plea was made for aid from the Commonwealth, I had the privilege of being one of the petitioners, and acted with the committee, addressing the members of the Legislature at the State House. I recall, as if it were yesterday, the interest of that time. I had just returned from Europe, and during. an absence of several years had enjoyed opportunities of observing the working of such institutions abroad, and feeling strongly that the eflucational principle was of the utmost importance, I dwelt upon it in my statements. 'That this view had weight with the members of the Legislature, I have reason to know, and upon this consideration the generous aid of the Commonwealth was granted.

I well remember an address by Professor Agassiz, at that time, in the House of Representatives, on which occasion he dwelt upon the desirableness of trining the young, from their earliest years, to observe and study the works of God in Nature, uring this as among the best means of disciplining the intellectual powers, purifying the taste and exalting the character. He insisted that the study of the phenomena of nature was one of the most potent means of developing the human faculties, and that such education should be introduced into the schools as soon as practicable, and made an indispensable part of all education; he trusted that the time when the importance of this view would be fully recognized was only so far remote as was necessary for the preparation of teachers capable of properly imparting this instruction. The only difficulty, he added, is to find teachers equal to the task, and the task is no small one. The whole force of his argument went to prove that an institution like this, to aid teachers in their preparation, was of inestimable importance. Here, as we may easily understand, those who have an aptitude for such studies, may find materials, examples, illustrations, sugrgestions, all bronght to their band arranged and classified. With such advantages the study of natural history may be interwoven with the whole system of education, and become one of its most essential features.

After this building was completed, additional funds were requisite, to carry out the work contemplited. 'The Commonwealth had granted the land. The building was erected by generous contributions. Now, therefore, that forty thousand dollars in addition was to be given by its earnest friends, it was not simply to render it more attractive to citizens and strangers, but it was avowedly to make it "one of the first Educational Scientific Institutions in the Country." 
This society has not rested satisfed with making profession of this purpose. It has lived up to its profession and its purposes have been faithfully carried out. Every promise has been kept, and every reasonable anticipation realized.

Persons who are not thoroughly acquainted with this Society, can hardly understand the amount of talent and labor which has been concentrated in this work. What selfsacrifice on the part of individuals, unremitting perseverance and toil have been necessary to complete every arrangement.

No one knows better than yourself, Mr. President, that no money could pay for the thought and labor which has been freely rendered here by the officers and friends of this institution, while their love for the Society and the cause to which it is devoted, has been in their estimation an ample reward.

After the dedication of the building, the work first inaugurated was a series of lectures and addresses in this hall to the Teachers of the Schools of Boston. Between six and seven hundred teachers availed themselves of the privilege. At the introductory meeting the Governor of the Commonwealth, Jolm A. Andrew; the Mayor of the City, F. W. Lincoln; the President of Harvard University, Thomas Hill; the Secretary of the Board of Education, Joseph White; the Superintendent of Schools, John D. Philbrick; and George B. Emerson, one of the earliest members of the Society, took part, making it a memorable occasion.

After this there were lectures on successive weeks by Professor Jeffries Wyman, Dr. Asa Gray, Dr. Augustus A. Gould, Professor IV. B. Rogers and others. These lectures were amply illustrated, covering botany, conchology, and general zoölogy. 'Ihe instructors of over thirty thousand children were present. The ablest scientific men in the country on those days imparted freely of -their knowledge, suggesting the best means of conveying instruction, and giving a fresh impulse to the eclucators assembled, who, on their part, warmly appreciated the interest thus shown, and hailed it as one of the new instrumentalities for their improvement.

This hope on their part has not been disappointed. The Society has been consistently faithful to its avowed purpose, and whenever their limited funds have been inadequate to meet the necessary expenditure, generous assistance has been liberally furnished by public-spirited friends.

To render the collections of the Society more instructive, a careful rearrangement has been made throughout, involving immense labor. 'Thus through all the departments the educational requirements have been recognized, and the successive stages in the history of creation are visibly unfolded to the eye, exemplifying the actual results of scientific knowledge and principles. The hasty observer can have but a feeble conception of the sublime meaning embodied in this careful and scholarly arrangement, but the more fully it is comprehended the more profound will be the appreciation.

'Teachers and pupils may often be seen together, thoughtfully pursuing their investigations from hall to hall. Some with artistic skill making drawings, others taking notes, and many more lost in astonishment, and filled with admiration and delight.

But added to this, regular classes have been formed to whom systematic instruction has been given. 'The study of natural history having been definitely introduced into the public schools, a new zeal has been awakened among the teachers. With some teachers, anditional knowledge is a necesity, while with all it is evidently a pleasure. The differ- 
ent branches are pursued under the guidance of able professors in connection with this Society. What is known as the "Teachers' School of Science" has acquired positive importance. Professor IHyatt, the Custodian, has been unceasing in his efforts, and has been gratified at the extraorlinary success which has followed his labors. This special work has been going on for the last ten years, but never with such marked results as during the past year. 'The number of applicants for admission to these lectures has been four times larger than in any previous period. Over six hundred persons recorded their names as students, while the average attendance on each pleasant day was five hundred. There have been distributed among these students more than one hundred thousand specimens. Yes, during the present year there has actually been given away - not one thousand, or ten thousand, or fifty thousand, but - though one can hardly eredit it - one hundred thousand specimens, all of which may be studied by the teachers at their homes, or used for illustration in their schools.

We talk of the wonders of the telephone; yet here is a still more felicitous method of communication; six hundred intelligent teachers, going forth from this place to convey the knowledge gained to thirty thousand young people, full of life and eager to learn. Thus has this Society become more emplatically than ever before - an educational power in the community.

Still it would be unjust to infer, from the facts which have been considered, that the larger portion of the attention of this Society has been given to teaching even instructors. Accomplished naturalists, through its collections and its library, find ample material to extend their investigations. Many come here to test their theories, or more fully to establish their conclusions. Besides which, many of the members, in the course of the year (on their individual account, and for professional purposes), visit distant parts of the country, or take even a wider circuit. They may be found along the whole coast of New England, searching her rocks and sands, or dredging in the deep-sea, or exploring the Gulf-stream, or among the Florida reefs, or skirting the shores of the Great Lakes, or passing down the Valley of the Mississippi, or climbing the Rocky Mountains and the Sierra Nevada, or descending the Western slope, or threading the Pacific Coast, or penetrating to Alaska, and China, and-Japan. And when they return, they come to tell us of their experiences, bringing additions to our collections, and recounting in addresses and lectures the result of their scientific investigations. Has not one spoken of Iceland, and another of Labrador? One of Indian relics and Western mounds? One of Colorado witl its extensive parks and prolific mines of silver and gold? One of the Calaveras and Mariposa groves with their colossal trees, the famous Sequoia giganted, and the Yosemite Valley with its unequalled waterfalls and stupendous granite domes? One of Alaska, and another of China and Japan?

It is certainly not claiming too much when we say that at the regular meetings of this Society one may hear as interesting and instructive accounts as can be found recorded in all literature. And thus to members, and to all who have the privilege of being present, such opportunities are exceedingly attractive. These addresses and lectures are not the less entertaining because they are instructive. 'The stories of the Arabian Nights are not more wonderful than are often these narratives. 'Travellers' Stories they are, but none the less true because stranger than fiction. Sindbad the sailor saw no greater treasures than are those which at times are added to our collections. Some of these are as of yes- 
terlay, while other's take the mind hack to that early time "when the morning stars sang together and all the sons of God shouted for joy!"

Mr. President, I congratulate you on this interesting anniversary, and I am sure the members will unite with me in saying that the time of your official connection with this Society covers one of the brightest periods of its history.

At the close of the address of the Rev. Mr. Waterston, the President, expressing the great satisfaction felt by the Society at such a large attendance on the part of its friends, invited all present, with the aid of the "Introduction to a General Guide to the Museum," which had been distributed among them, to look over the collections, either then or at a more convenient time. The lateness of the hour prevented more than a very cursory examination of them.

In the evening a reception was given by the President, at his residence in Newbury Street, to the members of the Society and many ladies and gentlemen interested in its work. Thus the day was appropriately closed in the enjoyment of social intercourse, and all parterl, fecling that the celebration of the semi-Centennial Ammivereary of the foundation of the Society had been thoroughly successful.

The annual meeting of the Society was held on the fifth day of May, Vice-President S. H. Scudder being in the Chair.

After the reading of the records of previous meetings the report of the Custorian, of the Secretary and of the Treasurer were presented. From these, abstracts will be here given.

The Custodian commenced by stating that in some respects the official year just closed was one of the most important in the history of the Society. It was marked not alone by being the termination of the first half century of its existence, but by the fact that the Museum had begrun at last the career for which preparation had been making during the past ten years.

of the publications he remarked that they were very creditable, but that it should not be forgotten that paucity of resources had caused the frequent refusal of important papers; that this was greatly to be deplored. since properly illustrated publication is often the only reward of scientific labor, and the prompt issue of memoirs is essential to the successful attaimment of the chief object of all scientific associations that seek to encourage the spixit of original research.

The material results, as exhibited in the collections, the library, and the publications, were very valuable as credentials of a prudent and economical administration. 'The Society might rest well satisfied with the position which these had earned for it in the estimation of a community which rightfully demands such guarantees of the proper use of trust funds. These, however, were not the best fruits of its exertions. 'Ihese seem to lie in the fact that the community is hesming dimly to comprehend that an institution of this kind creates an atmosphere around it which is beneficial to. them and to their children, and also that it works directly for their intellectual improvement.

The celebration of the anniversary of the formation of the Society was dwelt upon at some length by the Custodian, but as a full account of this has already been given it is not necessary to repeat his remarks. Much was said by him also relative to the resignation of the President which will be here omitted. 
The preparation of the general guide to the Museum, the numbering of the cases, the lettering of the rooms and galleries, and the construction of two new floor cases were mentioned as having been completed during the year. Synoptical collections for the departments of Mineralogy, Geology and Palateontology hat also been made and were or soon would be on exhibition.

In the department of Geology much had been done by Mr. Crosby, assisted by Miss Carter. About 2500 specimens of rocks had been catalogued and nearly 2000 of these nounted and labelled. These included a collection of specinens illustrating a synopsis of the classification of rocks, a systematic or lithological collection, a collection illustrating structural geology, and one of historical geology.

The important subject of dynamical geology, the Custolian stated, must remain umrepresented until floor cases could be furnished. The lack of means at present prevents this from being done. The principal aceesion to the department of Geology consisted of four hundred specimens contributed by Mr. Crosby.

The Palaeontological collection had been increasert by a small but quite valuable series of Crinoids purchased by the Laboratory fund.

'The labelling and cataloguing of the Mollusea had been completed hy Mr. Van Vleck, assisted by Miss Washburn. To this department a very valuable addition had been made by the purchase of the Blaschka models. These were made of glass and represented very closely the living animal. There were 74 specimens in all, representing 17 genera and 44 species of the soft bodied Cephalopods and naked Gasteronoda.

The Corals and the Echinoderms had been rearranged, mounterl and labelled during the year, this work having also been done by Mr. Van Vleck, assisted hy Miss Washburn.

In the department of Entomology, Mr. IIenshaw had been engaged in selecting specimens for the formation of a synoptical collection representing the anatomy of insects, and considerable progress had been made by him in identifying and aranging the species of the general systematic collections.

The department of Comparative Anatomy had been eutirely rearranger so as to bring it into harmony with the rest of the collections of the Museum. In the wall cases of Room G, a synoptical collection had been placed illustrating the type characteristics and anatomical peculiarities of the different classes of Vertebrates. $\Lambda$ similar collection of Invertehrates will occupy the two floor cases which had just been erecter in the same room. The osteological portion of the collection in the main hall remained nearly as before, but the special homologies of the limbs and systems of organs, ete., anong Vertebrates had been placed in Room F. To Dr. W. F. Whitney, the Society is indebted for the entire rearrangement of these last, and for much assistance in other portions of the work.

'The irlentification and labelling of the New England collection of fishes hat been commenced by Mr. Van Vleck. A large number of species obtained at Annisquam by the efforts of the Custodian, had been added to this collection.

Of the Amphilia, 55 species had been identified, arrangerl and catalogned. Of the New England species, of which there are 25 in all, 23 were reported as in the collection.

In referring to the department of Ornithology, the Custodian alluded to the death of the distinguished ornithologist, Dr. Thomas M. Brewer, and of the great service rendered by him to the Society in this department, whilst in charge of its general collection. To 
his exertions also the Society owes its fine collection of eggs and nests, and also the New England collection of hirk. This last he would have muloultedly marle connlete had he lived a year or two longer.

Some work had been done in arranging and labelling several of the groups of birds, by Mr. Henshaw, assisted by Miss Washburn.

The terse remarks made by the Custodian upon the mammals need no abbreviation or variation. They are therefore given verbatim: "The less said about the mammals the better. They are a disgrace to the institution, but there is no way of getting a respectable collection except by buying specimens, and this is impossible for us."

In the department of Botany the Custodian stated that considerable progress had been made towards the formation of a synoptical collection of plants, so that each order and some of the sub-orders shall be represented by one species which will be mounted, framed, and appropriately labelled. Already ninety specimens, representing eighty-five orders and sub-orders had been finished. The arrangements of the general collection according to Bentham and Hooker's Genera Plantarum had progressed under the direction of Mr. Cummings, and much had been done towards supplying deficiencies in this collection.

It had been the habit of the Custodian during the vacation period of the summer months to pass much time in dredging and fishing off the coast, with the purpose of obtaining for the Society specinens necessury for the completion of the New England collections, and in this work he had been aided by assistants in the Museum and others. Of the labors of the previous season he thus speaks: "The summer of 1879 was spent at Ammisquam by the Custodian and a party consisting of Mr. Van Vleck, Mr. E. G. Gardiner and Mr. E. R. Warren. The collecting was more successful than during the previous season, but still the need of a large boat and greater facilities is imperative." 'Io supply this need, the Custodian intended to have another and more capacious boat ready for use before another summer.

The Laboratory. In this department there had been much accomplished of satisfying character. Instruction had been given as usual to classes from the Boston University and the Massachusetts Institute of Technology. Besides these another class of twenty-six persons, all teachers except four, had entered upon a course-which is to last for two winters, or about one hundred hours, two hours being devoted to it every Saturday morning. A small class of advanced students have been taking a course in biology, given by the assistant, Mr. Van Vleck.

Teachers' School of Science. It will be remembered that at the time of the last ammual meeting of the Society, and when the report for the previous year was presented, the very successful course of lectures to the teachers then in progress was not quite completed. Those given by the Custodian were soon after brought to a satisfuctory close, and a series of five on mineralogy followed, delivered by Mr. Burbank. 'These were very instructive, and the interest in them was shown by the average attendance being kept up to the last. A geological excursion by the lecturer and a part of the tenchers was made to Marblehead after the course was finished.

The report of the Secretary, Mr. Burgess, was very gratifying, griving as it did statistics showing much activity and progress in the several departments mentioned.

Of members, twenty-six Associate had been elected during the year, but no Corporate, 
Corresponding or IIonoriry. Fire Asociate or Corporate members had resigned, and four had died. The whole number of Associate and Corporate members was stated to be 451.

There had been an average attendance of thirty-nine persons at the sixteen general meetings of the Society. The largest number present at any one time was eighty-one, the smallest nineteen. Eight mectings of the section of Entomology had been held, the average attendance at which had been eight persons. The meetings of the botanical section had been given up in consequence of the non-attendance of a sufficient number of members to render them interesting.

In December of the past year, by consent of the Society, the section of Microscopy was revived, and monthly meetings had since been held, though without a very promising attendance.

Of the library, the Secretary stated that the additions to it during the year exceeded those of any other in the Society's history. These were summarized thus:

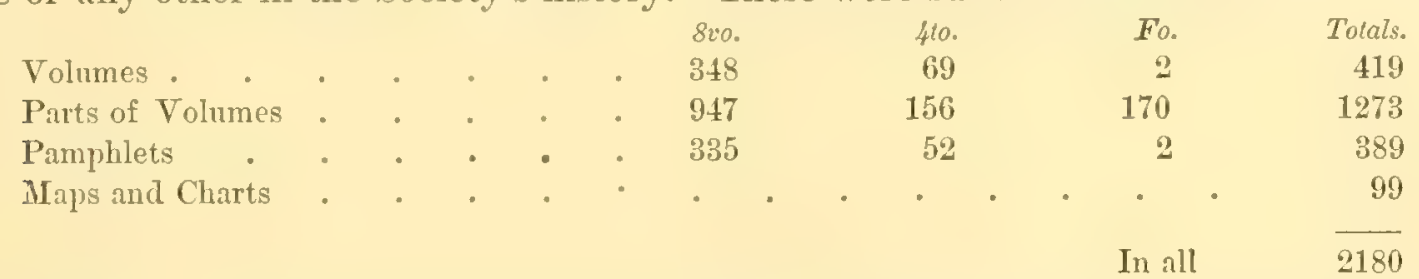

Besides the constant use made of the books by members and others at the Library, there had been borrowed 1110 volumes during the year, by one hundred and twentythree persons.

Of the publications two parts of the twentieth volume of the Proceedings, and a third article for the third volume of the Memoirs had been issued, the last being a revision of the Palneozoic Cockroaches of the world, by Mr. Samuel H. Scudder, 113 pages, 5 plates. Of "Oecasional Papers" a volume had been published, being the third of the series, containing Mr. W. O. Croshy's contributions to the Geology of Eastern Masisachusetts, "26to pages, with 5 plates and a colored map.

In addition to these, No. 6 of the series of Guides for Science 'Teaching, by Professor Hyatt, had been printed, also a pamphlet introductory to the general guide to the Museum, also by Professor Hyatt. Copies of this last publication were presented to the audience at the celebration of the semi-centennial anniversary of the Society.

The Committee on Publications having suggested that a special volume should be published commemorative of the fiftieth anniversary of the Society, the Council voted that this should be done provided a sufficient number of subscribers could be obtained for such volume at the rate of ten dollars a copy, to justify the necessary expenditure. 'To ensure the success of this project the Rev. Robert C. Waterston, with characteristic generosity, had already given one hundred dollars. It was understood that the volume should contain a history of the Society, and a series of scientific papers, and be entitled "Anniversary Memoirs of the Boston Society of Natural History."

Walker Prizes. Relative to the Walker Prizes, the Secretary stated that no essay had been presented on the subject proposed for 1850 , viz.:

"The evidences of the extension of the 'Tertiary deposits seaward along the coast of Massachusetts." 
Mention was made of the award of the Grand Walker prize during the year to Dr. Leidy, but as this has been particularly related on a former page, no further statement is required here.

The Treasurer's report showed that there had been an excess of expenditures over the receipts of $\$ 698.95$. As, however, the payments included the $\$ 1000$ awarded for the Grand Walker prize, and as such prize is only payable once in five years, the spirit of the determination that expenditures should be kept within the limits of receipts was not violated.

At the election, the officers chosen were as follows. The full list is here presented that it may be seen in whose hands the destiny of the Society was entrusted at the close of the first half century of its existence, and at the commencement of a new era.

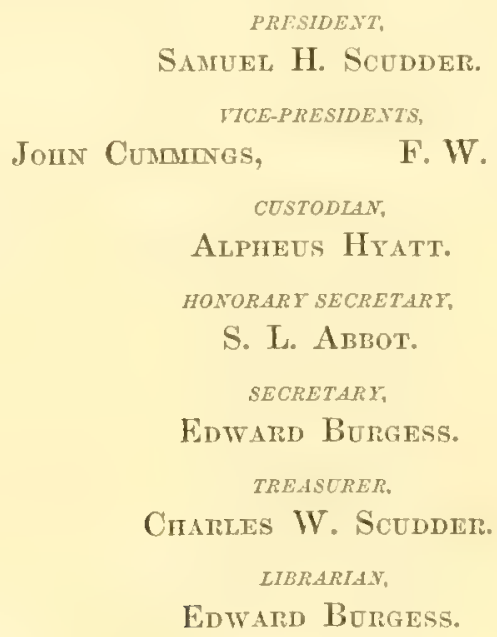

Edwatid Burgess.

Committees on Departments of the Museum.

MINERALS

Tromas 'l'. Bouvé,

R. H. Richaldos,

M. E. WADsworti.

GEOLOGY.

Wirliat H. Niles,

G. Frederic IVright,

I. S. Burbank.

PALAEOYTOLOGY:

Thomas T. Bouvé,

N. S. Smaler.

BOTAVI:

Jome Cummers,

Cinarles J. Sprague,

J. Amoer Lowell.

MCROSCOP Y:

Sardel WELls,

R. C. Giefinfare,

B. JOY JEFFRIES.

COMPARATTE ANATOMY.

Thonas Dwight,

IV. F. IVHITNEY.
RADIATES, CRUSTACEANS AND WORUS.

H. A. Hagex,

Alexander Agassiz,

L. H. Pourtarès.

MOLLUSKR:

Edward S. MIorse,

J. Hente Blake. INSECTS.

Samuel H. Scudder, Edvard liurgess, A. S. Packard, JR. FISHES AVD REPTLES. F. IV. Putnay, Theodore Lrana, S. IV. GarmaN. DIRDS.

J. A. Allen, Sajiele Cabot. M.AMH.ILS.

J. A. ALLEN,

E. L. MARK,

Grokge L. Goodale. 
On the announcement of the ballot the President elect said, "that in occupying the position to which he had been called, he could only express the wish that the choice had fallen elsewhere, for he felt he owed the Society any service he might be able to render. Any one as long acquainted with its government as he had been, must be alive to the responsibilities of its highest office, but knowing the hearty support which would be given to one aiming to carry out the objects of our Society with singleness of purpose, he could not foster such misgivings as naturally arose in undertaking them."

Mr. Scudder then sketched briefly the Society's work, more particularly dwelling upon its chief aim, popular instruction. The highly complimentary remarks towards the writer and compiler of this history which followed, not only made by Mr. Scudder but by many others, and the action taken by the Society, were of too personal a character to admit of his presenting them here. Nothing certainly could have been more grateful to his feelings than such a manifestation at the close of his long official life as President of the Society.

The Standing Committees elected by the Council for the official year 1880-81 were as follows: Library, Edward Burgess, W. H. Niles, W. F. Whitney. Publications, S. H. Seudder, S. L. Abbot, Edward Burgess, Alpheus Hyatt, J. A. Allen. Museum, Alpheus Hyatt, S. H. Scudder, 'Ihomas T. Bouvé, John Cummings, Edward Burgess; Walker prizes, William B. Rogers, Alexander Agassiz, F. W. Putnam. Membership, S. H. Scudder, MI. E. Wadsworth, B. Joy Jeffies, Edward Burgess, George L. Goodale. Lectures and meetings, S. II. Scudder, M. E. Wadsworth, Edward Burgess, F. W. Putnam, W. H. Niles. Bird certificates, Edward Burgess, J. A. Allen. Trustees, Thomas 'T. Bouvé, John Cummings, C. IV. Scudder.

The fifth decade had now passed. If it could be said of the fourth that it was a perior of great events in the history of the Society, the same could be said of the fifth, though those of the latter were of a less striking character. During the fourth, large donations and bequests were made, enabling the Society to erect its magnificent museum and to take a position among the leading institutions of the kind in the world, publishing freely its Memoirs and Proceedings, and making exchanges with kindred societies, thus acquiring for itself respect at home and abroad. During the fifth, scarcely a donation or bequest of any amount was received, though the lack of means was felt in every department. This prevented such expansion of the work of the Society as was deemed desirable, and made it dependent on the individual contributions of its members, mainly upon one of them, to accomplish much that it was able to do. What particularly characterized the last decade was the great change effected in its plans and purposes, but more in its modes of action and in the arrangement of its collections; not through revolution but by evolution, the result of advanced views in relation to museums and teaching, growing out of the experience of the Society itself and of kindred institutions at home and abroad. No longer would it suffice that great collections should be made in the different rejurtments of natural history, however well arranged and labelled the specimens might be in each; it was necessary that all should be subordinated to a comprehensive plan, so that they should bear a proper relation to each other, and, moreover, include synoptical series which should furnish to those seeking knowledge a key to the proper understanding of the whole. A further development of thought upon the Museum led to the formation of at 
separate local New England collection in each department. Now to accomplish this. and to provide for the safety of the fast increasing collections, it was absolutely necessary not only to prepare rooms unfinished at the commencement of the decade, but to reconstruct all the cases first erected in the building becanse of their defective character, as has been mentioned on an earlier page. This change alone, with the necessary relabelling and other work upon the specimens, was the labor of years, but one of vast importance to the future influence of the Museum as an educational instrumentality. This great work could not have been done in the thorough manner it was, had not the more important change been first made of placing at the head of the Museum a scientific man whose single duty it was to act as a Custodian, and to furnish him with paid assistants to work upon the collections. Fortunately for the Society, Mr. Alpheus Hyatt, a man of large natural endowments and of broad comprehensive views, was elected to this office. To him was due the conception of the plan finally carried out for the arrangement of the whole Museum. It was the good fortune of the writer to be associated with him in this work and to give the influence of his official position as President of the Society in having it fully and frithfully done

The financial resources of the Society were somewhat impaired during the decade by the fitting up of the rooms alluded to and the reconstruction of the cases. It also suffered by the great fire of 1872 , having held a considerable amount of stock in insurance companies which became worthless, and by being called upon to pay assessments to mutual companies in which its property was insured. If thus for rensons not arising from any fault or bad management the income of the Society was lessened, the Council may well point with satisfaction to the fact, that the ordinary expenses were not allowed to exceed the income. 'To prevent this from being the case, however, much was left undone that ought to have been done, and it was only by the pecuniary aid of neighbors and friends that the Society was recently able to enclose the grounds about its Museum with a suitable curbing of stone, and properly grade them.

'The Society lost by death during these ten years, many of its most highly valued and honored members, Louis Agassiz, Dr. Jeffries Wyman, Dr. Charles Pickering, Edward Pickering, Dr. John B. S. Jackson and Dr. Thomas M. Brewer, all of whom were conspicnous in its ammals. It lost, too, by removal, some who in the early part of the decade were prominent in its proceedings, one of whom was Dr. Sterry Hunt, the eminent geologrist, and another, Dr. Samuel Kneeland, who for many years was a very efficient officer and member, and often contributed specimens of considerable value to the collections. It may truly be said of the latter that during his long connection with the Society he seldom, if ever, left home without bringing back with him something for presentation. He was almost a constant attendant too upon the meetings, and frequently took an active part in them.

The members of the Society who took the most prominent part in the proceedings at the general meetings and at those of the sections during the first five years of the decade were S. H. Scudder, Dr. 'Thomas M. Brewer, Alpheus Hyatt, Dr. H. A. Iagen, F. W. Putnam, N. S. Shaler, Dr. 'T'. Sterry IIunt, 'Thomas 'T. Bouvé, Dr. Samuel Kneeland, Dr. Charles T. Jackson, W. H. Niles, E. S. Morse, Dr. Charles Pickering, Edwim Bicknell, F. G. Samborn, Charles Stodder, Dr. Thomas Dwight. Jr., Dr. W. G. Farlow, Elwand Burgess, R. C. Greenleaf, Prof. C. H. Hitchcock, Dr. C. S. Minot, B. P. Mann, Rev. J. B. Perry, L. 
S. Burbank and J. A. Allen. Those who took the most prominent part during the last five years were S. H. Sculder, Alpheus IIyatt, F. IV. Putnam, M. E. Waulworth, Edward Burgess, W. H. Niles, W. O. Crosby, E. P. Austin, Dr. H. A. Hagen, Dr. Thomas M. Brewer, Dr. IV. G. Farlow, Dr. C. S. Minot, Thomas T. Bouvé, Dr. 'T. Sterry ILunt, L. S. Burbank, Dr. Simmel Kneeland, Dr. B. Jov Jeffries, Rev. George F. Wright, and Dr. G. L. Goodale.

'The average attendance each year during the decade at the general meetings was as follows:

$\begin{array}{rrrrr}1870-71 & 18 \text { meetings, an attendance of } & 40 \\ 71-72 & 18 & \text { "6 } & \text { "6 } & 32 \\ 72-73 & 18 & \text { " } & \text { "6 } & 26 \\ 73-74 & 16 & \text { "6 } & \text { "6 } & 51 \\ 74-75 & 18 & \text { "6 } & \text { "6 } & 57\end{array}$

$\begin{array}{rrrrr}1875-76 & 18 \text { meetings, an attendance of } & 33 \\ 76-77 & 19 & \text { " } & \text { "6 } & 33 \\ 77-78 & 16 & \text { " } & \text { "6 } & 35 \\ 78-79 & 16 & \text { " } & \text { "6 } & 31 \\ 79-80 & 16 & \text { " } & \text { "6 } & 40\end{array}$

The average of all these is somewhat larger than during any previous ten years, being thirty-eight. That of the previons ton years was thirty-six. The great increase of attendance in the years 1873-74 and 1874-75 was due largely perhaps to the change made in giving notices of the meetings, the custom leing first arlopted in the fall of 1873 to designate the subjects that were to be brought before them.

The attendance at the meetings of the sections was as follows:

Of Entomology,

1870-71 5 meetings, average attendance, 10

$\begin{array}{rllll}71-727 & \text { " } & & & \end{array}$

$72-737$ "
$73-746$

$\begin{array}{rllll}73-746 & 66 & & \end{array}$

$\begin{array}{rllll}74-75 & 5 & 6 & & \end{array}$

Of Microscopy,

1870-71 5 meetings, average attendance, 11

$\begin{array}{rllll}71-725 & 6 & \end{array}$

72-73 1 meeting, attendance, 12

$\begin{array}{rrrrrr}1875-76 & 4 & \text { meetings, average attendance, } & 8 \\ 76-77 & 1 & \text { "6 } & & \text { "6 } & 8 \\ 77-78 & 6 & \text { "6 } & \text { "6 } & \text { "6 } & 9 \\ 78-79 & 9 & \text { " } & \text { "6 } & \text { "6 } & 10 \\ 79-80 & 7 & \text { " } & \text { " } & \text { "6 } & 8\end{array}$

1873-74 I meeting, attendance, 12

74-75 2 meetings, average * 9

The little interest manifested in this section led to its dissolution in 1S75. Its revival was authorized by the Council in 1879, and one meeting followed with an attendance of nine persons; it was the only one.

Of Botany, section formed in 1876,

1876-77 8 meetings, average attenclance, 27

$77-782$ " 2 " 18

1878-79 6 meetings, average attendance, 7

Interest in this section was shown as long as able botanists appeared to address the members. As soon as this ceased to be the case the attendance fell off.

The large and important part of the work of the Society done through the Committees of the Council makes it proper to give the names of all such nembers as have served upon these during the decade. They are as follows:

On the Library. C. K. Dillaway, J. E. Cabot, Dr. T. M. Brewer, William T. Brigham, Dr. A. S. Packard, Jr., Elward Bureses, Willian H. Niles, Sammel II. Scudder, Alpheus Hyatt, N. S. Shaler, J. A. Allen and S. W. Garman.

On Walker Prizes. Dr. Jeffries Wyman, C. J. Sprague, Thomas 'T. Bouvé, Dr. Asa Gray, Alexander Agassiz and William B. Rogers. 
On Lectures. Thomas 'T. Bouvé, Rev. Joshua A. Swan, John Cummings, John D. Runkle, Alpheus Ilyatt, Eilward Bureress, Dr. James C. White, F. W. Putnam, Dr. B. Joy Jeffries, M. E. Wadsworth and William H. Niles.

On Publications. Thomas 'T. Bouvé, Dr. Samuel L. Abbot, Dr. Thomas Dwight, Dr. Thomik U. Brewer. Dr. A. S. Packidrd. Jr., Rev. Joshua A. Swan, Edward Burgess, Samuel H. Scudder, J. A. Allen, Alpheus Hyatt and John D. Runkle.

On the Fimmere Committee und us Trustes. Charles J. Sprague, Thomas T. Bouvé, Edward Pickering, John Cummings and Charles W. Scudder.

On Meetings. J. A. Allen, Dr. A. S. Packard, Jr., Dr. J. B. S. Jackson, Dr. H. A. Hagen, Edward Burgess, Dr. James C. White, N. S. Shaler, L. S. Burbank.

On Nominutions for Membership. Dr. S. L. Abbot, F. W. Putnam, Samuel II. Scudder, Dr. B. Joy Jelfries, Elward Burgess, Dr. 'Thomas Dwight, samuel Wells, Alpheus Hyatt, Thomas T'. Bouvé.

On the Museum. Alphens Hyatt, Thomas T. Bouvé, John Cummings, Samuel H. Scudder, Edward Burgess and F. IV. Putnam.

The publications of the Society during the decade were, the second volume of its ILemoirs in (fualo, 560 pitgen, containing twenty important papers read or presented at its meetings, and three numbers of the third volume; a part of the $13 \mathrm{th}$ volume of the Proceedings of the Society, not issued at the time of the annual meeting in 1870, with six full rolunes from the 1 th th the 19 th inclusive, and three parts of the 20 th volume; two rolumes of it: Uecasional Papers, one. The Spinlers of the United States, a collection of the Arachnological writings of Nicholas Narcellus Hentz, M.D.; the other, Contributions to the (reology of Ealstern . Massachusetts, by W. O. Crosby; six numbers of a series of Guides for Science Teaching; alio a pamphlet introductory to a general guide to the Nuseum to be hereafter published.

The library had increased largely since 187(), when the whole number of its volumes was given as 9396, and of pamphlets as 2677. The number of volumes at close of the deaule, comnting them as bound, whether containing more than one, as was often the case, or not, and estimating the unbound parts in proper proportion, was over 14,000, and that of the pamplilets including maps and charts, was but slightly short of 6000 .

Before proceeding to express such general views upon the Society, as press themselves upon the mind after sketching its history, and in view of its present condition, it will not be amiss to refer to the original members yet living, after the lapse of half a century since they took part in its formation. Of these there are four, Theophilus Parsons, Dr. Edward Reynolds, Dr. D. Humphreys Storer and Mr. George B. Emerson, all men who have distinguished themselves in their several walks of life, and whose association would have conferred honor upon any Society. Two of these, Dr. Storer and Mr. Emerson, were active members during many years, and both of them held high offices in it. Of the former and of his services to the Society, a full notice has been given in these pages. It is a pleasant duty to present here some account of the latter. 


\section{George B. Emerson.}

George B. Emerson was horn at Wells, Maine, then a lat of Massachusetts. Septemher 12th, 1797. His father was Dr. Emerson, a well known physician, and a man of cultivation and taste. He graduated at Harvard in 1784, and was an excellent Latin scholar, besides being well read in bistory and English literature. IIs house was a favorite resort for the judges and lawyers who attended the sessions of the Supreme Court of Massachusetts, held semi-annually at York and at Portland, and young Emerson thus early became acquainted with such men as Judge Jackson and the reporter, Dudley Atkins Tyng, gentlemen distinguished for their ability, as well as the refinement of their manners.

Dr. Emerson was chairman of the School Committee, and always was particular to see that the master was a well educated man, and a proper person to have the charge of children. His sons were sent to school during the winter season, but kept at home during the summer, where the practical education that they received on their father's farm, both in the knowledge which it imparted of common ways of country life, and familiarity with common things, and in the information which they derived from acpuaintance with the vegetable and animal life around them in the fields, wools, rivers and sea, is spoken of by the subject of this notice as being of the most valuable character. The father evidently evinced great good judgment in his managenent of the education of his boys.

Young Emerson early familiarized himself with the trees, shrubs and plants of the neighborhood, reading eagerly all books on botany which came in his way and learning what he could from his father relating to that science. He also was an interested reader of books of travel and poetry, and at the proper time was led to the study of Latin and Greek, becoming fimiliar in certain ways with the chssics before entering Dummer Acarlemy at Byfield, where he went to prepare for Harvard. He entered college in 1S13, being in the class with Caleb Cushing, George Bancroft, S. J. May, Fanuel E. Fewall, and other since well-known men. His experience in college was a pleasant and profitable one, varied as it so often was in the case of boys from the remote country districts, by occasional teaching of country schools during the long vacations. While at Harvarl he very nearly lost his life by the experiment tried both by himself and his chum, of cutting down the term of sleep from the normal quantity to four hours a day; devoting the time stolen from needed rest to over-study. A severe illness and long consequent sojourn at home were the price of this ill-considered action.

He graduated in 1817, and after recovering from another severe illness, the result of overwork, accepted a position offered him of master of an excellent private school, at Lancaster, Mass. Here continuous trouble with his eyes, brought on by inattention to general health and too much study previously, was a great amnoyance to him; still his school was a great success, his ability as a teacher being fully exemplified. He continuer at Lancaster for two years, and then accepted an invitation from President Kirkland to become a tutor in the mathematical department at Harvard. Here he was again thrown on terms of intimacy with some of his early college friends, Calel, Cushing, Edward Everett and others, besides meeting most agreeably George Ticknor, then a lecturer on French lit- 
erature, Professor Farrar, Dr. Bowditeh, the sreat mathematician, Rev. Mr. Norton and other prominent men of the time.

A trip to the White Momntains ahout this period, with a party of his college friends, is most delightfully described in his little volume of "Reminiscences."

In 1820 was established in Boston the English Clasical Fehool, and Mr. Emerson was chosen its first principal. After a remarkably stceessul experience as teacher in this institution, he in 18:3 organized his celebrated school for young laties, which was for many years regarded as unequalled in the educational advantages to be enjoyed by all who were in it as pupils.

In the formation of the Roston Society of Naturil IListory, Mr. Enerson took an active part, and in 1837 he was chosen President. At that time the scientific survey of the State was determined by the member's to be of the utmost desirability, and Mr. Emerson was deputed to memorialize the State govemment. upon the subject. This he did, laying his memorial before Governor Everett, by whom it was most cordially and graciously received. In due time the Governor informed Mr. Emerson that the legislature, both houses of which justly appreciated his menorial. harl anthorized the executive to appoint six proper persons to conduct the survey of the State, and had passed an appropriation to cover the expenses thereof; and he requested thit. Mr. Fmerson should sugrgent the names of such scientific men as he thought competent for the work. The result was that the gentlemen appointed were almost entirely those named by him. The Governor desired that he should hold himself responsible for all the reports presented; hut his friends in the Society, knowing his alsility, were not satisfierl except hy his taking a more active part in the survey; and he eventually divided the botany with Dr. Dewey, the doctor taking all other plants and Mr. Emerson the trees and shrubs. The report which he subseguently made to the legislature was not only admirable in its scientific features, but was most charming from a literary point of view. It takes one out with the writer into the fields and woods, and makes the reader at once the interesterl student and the personal friend, so to speak, of the tree or shrub which the writer may be describing at the time. This report was made up from the observations and study of nine successive years, nearly three months of each of which he gave to the work, visiting all parts of the state in its prosecution.

Mr. Enerson published, in 1875, a new edition of his Report on the Trees and shrubs, superbly illustrated by colored plates, a full set of which, suital,ly framed, he presented to the Society to be placed in the collection of New England Trees and Shrubs, and which may now be seen in the botanical gallery devoted to that section.

The well-known "Memorial of the American Institute of Instruction to the Massachu. setts Legislature," was prepared and placed in the hands of the Governor by the President, Mr. Emerson; and the result of this course was the formation of the Boand of Education with Horace Mann, then President of the Senate, as its secretary. The cause of education took a new departure from this time forth. and the good effect of this action, in which Mr. Emerson was prominent, was inestimable.

Mr. Emerson's zeal in the cause of good education sprang very largely from the affection for the young, which has always during his lifetime kept pace with his great love of nature. The influence which he exerted anong his pupils through this feeling of personal 


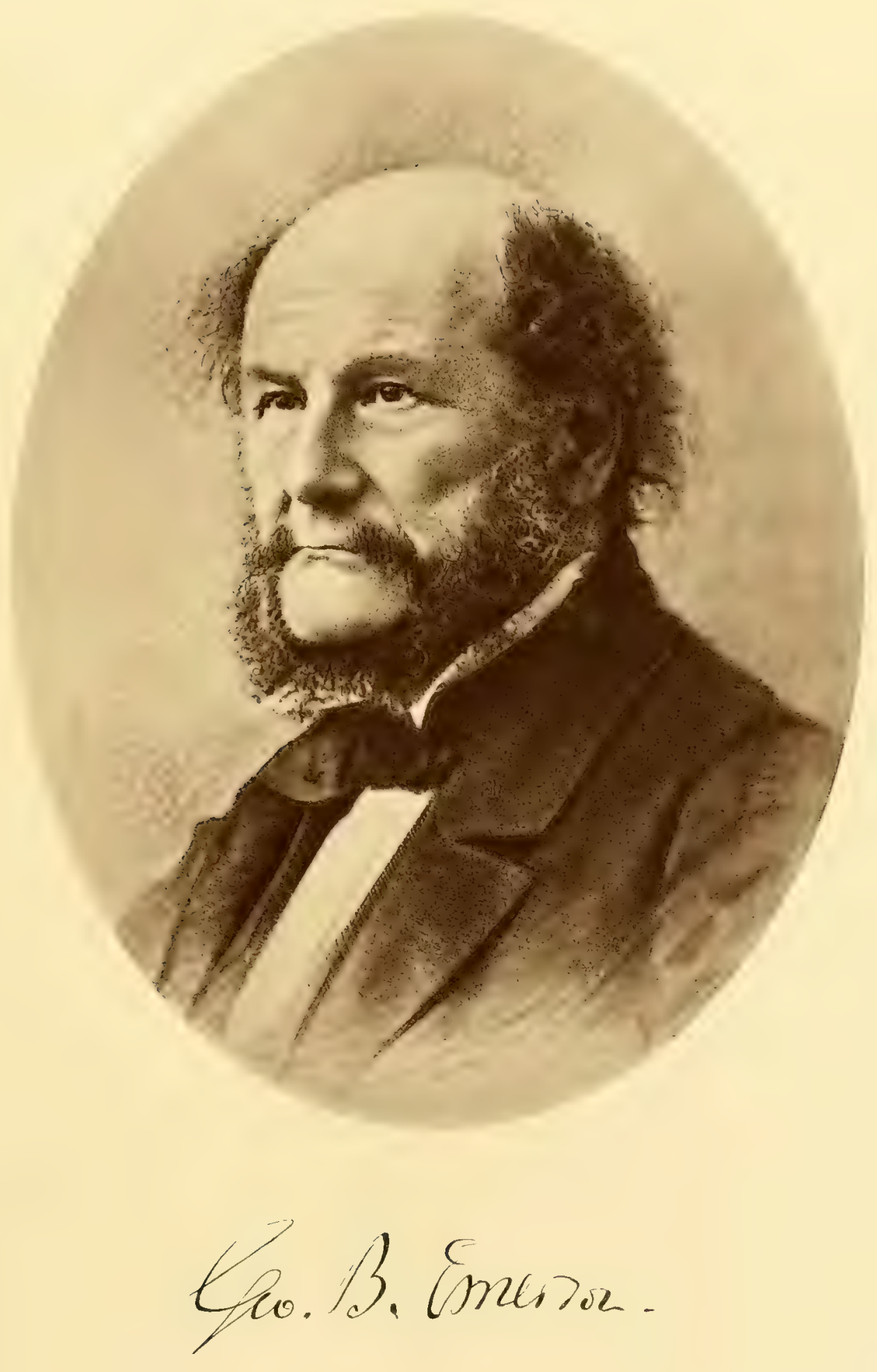



interest has been very warmly spoken of by many of them. His religious tendencies were very decided. He had wished in his boyhood to go to West Point, but his mother's earnest desire to the contrary had dissuaded him from this course, and his subsequent tastes led him to study with the intention of entering the ministry, for which profession he would seem to have been particularly fitted by nature. 'The young ladies of his school always looked to him as a friend and adviser, and have many of them alluded feelingly to the few earnest words spoken by him in the morning service as of more value to them than all the ordinary instruction in the school.

Mr. Emerson's interest in the Society has always been very strong; manifested to a greater or less degree by his presence at meetings and by occasional participation in the proceedings. His last prominent appearance before the Society was in 1874 , when he delivered the memorial address upon Louis Agassiz.

The history of the Society has now been traced from its formation to its present proud position as one of the leading scientific institutions of the world. We have dwelt upon the reasons that endangered its continued success in the early period of its existence, and have witnessed the untiring devotion of its members, some of whom gave voluntarily, years of life to its service. We have seen too that only by the large donations and bequests of its great benefactors did it escape the fate of the Limnaean Society which preceded it, and of many other similar societies not sustained by government aid, and depending on the unpaid labor and contributions of their members. 'That these gifts were mainly due to a recognition of the disinterested devotion of the members of the Society to the work undertaken by them, and of the importance of that work as an educational and elevating influence in the community, is unquestional)ly true, markedly in the case of the largest benefactor of all, Dr. William J. Walker, who, through Dr. Jeffries Wyman, for whom he had great regard, and others, made himself well acquainted with the leading members of the Society, and with their designs and purposes in the matter of educating the community in natural history, before making it the recipient of his bounty.

It becomes the members of the Society, especially such as have been instrumental in shaping its destiny, to ask whether it has met the reasonable expectations of its founders. Inve their hopes for its growth and its influenes been fulfilled? As au associate with the original members, and as having been acquainted to a considerable degree with their thoughts and feelings, the writer unhesitatingly answers Yes! far beyond their most sangruine hopes and expectations. Not that they limited in their own minds the possibility of achievenent, but they simply hal no conception that in the lifetime of any of them the Society would have one of the best structures in the world for exhibition, with collections of great magnitude in all the departments of natural history, mequallerl in arrangement for instruction; or that it would carry on such educational work as has been done, and is now doing, through the 'Teachers' School of Science and other instrumentalities.

Nor does it less become the members to ask, especially in view of the fact that for further progress in the work carried on by then they will yet be obliger to rely on additional aid, whether the Society has faithfully administered the trusts reposed in its care; and whether the wishes of those who endowed it with means by which it has become what it is, have been fully regarded in the use of the property placed at its disposal. 
To this the writer also responds unhesitatingly in the affirmative, sustained by the gratifying fact that among the nearest representatives of the great lonors may be found those best pleased with all the Society has done.

For the better understanding, on the part of the members of future generations, of the condition of the affairs of the Society at the present period, it may not be amiss to state concisely what are its possessions, just what it is now doing, with what means, its present needs, and what are the hopes and the aspirations of those who are now its active members. First then as to its possessions. It owns the building known as the Museum, its cases, furniture, library and the collections contained therein, free from all incumbrance. The value of the building with cases may be estimated at the cost, $\$ 150,334.86$, as it certainly could not be erected at the present time without a larger expenditure. The money value of the library and collections cannot be given. The former embraces as before stated, over 14,000 volumes and nearly 6000 pamphlets.

The collections may be said to be of inestimable worth not only to the Society, but to the community, for a considerable portion of unique and type specimens in the several departments could never be replaced. There is lot on the part of the public an adequate conception of the extent of these collections and of the ureat importance that they should be properly eared for, seientifically arrangerl and fully labelled in orden that they may continue in all the future to serve as they now do, to help in the education of those who seek to know something of the works of the Great Creator of all things, and who are not able to attend the scientific schook where this knowledge is specifically taught. The following statement will show the magnitude of the cabinet at this period.

\section{Mineralogical Collection.}

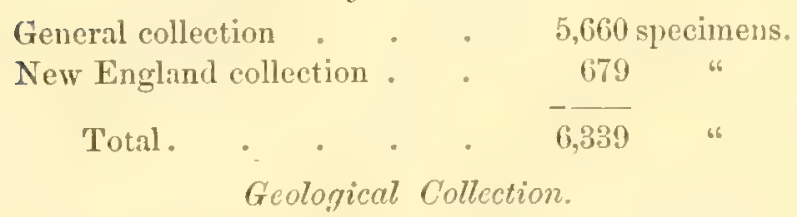

Catalogued and on exhibition . $\quad 3,265$ specimens.

Others yet uneatalogued . $\quad$ - 1,700

Total.

$\overline{4,965}$ "

The New England rocks are all included in the 1700 yet uncatalogued, and they amount, in round numbers, to 1500 specimens.

\section{Palacontological Collection.}

Europe 13,691 specimens.

North America, exelusive of New England 7,678

South America 。 . . . 170

$\Lambda$ sia and Australia . . . 170

Africa . . . . 14

New England . . . . 550

Mounted anil arranged . . 22,273
Unmounted, North America .

New England

800 specimens.

Anatomical Collection.

Skeletons, preparations and other specimens

4,153 specimens.

Bailey collection . . . $\quad \mathbf{1 , 8 3 9}$ specimens.

Bunett " . . . 566 "

R. C. Greenleaf and Dr. A. D. Sinclinir

collection . . . 4 480 "

Rourers collection - . . 275 "

Received from MIessrs. A. Hyatt and

W. O. Crosby ․ . 114 "

Received from Mr. E. Samuels $\quad 24$ " " " others . 62 "

Total.

$\overline{3,360}$ "

\section{Sponifes.}

A general collection not yet in a condition to determine number and species; also a Iarge collection of New England specimens not yet examinerl. 


\section{Rartiates.}

Coelenterates.

Coelenterates.
General collection including New
Englind species . Echinolerms.
General collection .
New England collection.
Total . . . .

General collection - . $\quad \begin{gathered}\text { Species } \\ \mathbf{1 5 0}\end{gathered}$

New England collection . $\quad 150$

Total .

\section{Crustacea.}

General collection . .

New England collection .

Total

$$
\text { Insects. }
$$

$\begin{array}{cc}\text { General collection. } & \\ \text { S } & 10,000\end{array}$

Harris " . . 4,36t

New England collection . $\quad 3,000$

Total

species. Specimens.

$200 \quad 1,000$

Species. Specimens.

1201,000

$25 \quad 700$

1,700

specimens.

400

400

800

Species.

400

150

Specimens.

1,000

1,500

$-\overline{2,500}$

Specimens.

35,000

11,023

7,600

53,623

Nollusks.

General collection . $\quad \begin{gathered}\text { Species. } \\ 5,400\end{gathered}$

New England collection . $\quad 160$

Total

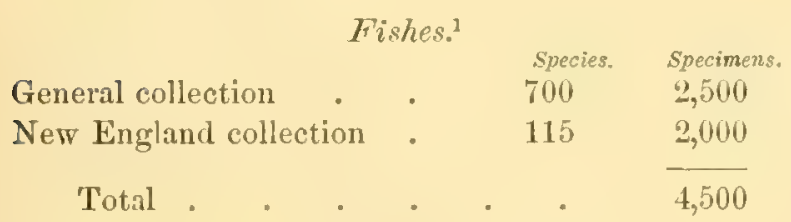

Amphibia.

General collection - $\quad 70$

New England collection . 14

Total .

Specimens.

32,000

Specimens. 324 100

424
Reptiles.

Species. Specimens.

General collection . $\quad 200 \quad 740$

New England collection . $\quad 23 \quad 77$

Total . . . . 817

\section{Birds.}

General collection of mounted birds .

Specimens.

11,801

New England collection of mounted birds

Total .

$\frac{527}{12,328}$

Birl skins about. . . . . 5,000

Eggs of birds albont . . . . 5,200

\begin{tabular}{cccc} 
& Mammals. & & \\
Genecies. & Speeimens. \\
New England collection &. & $5 t$ & 67 \\
Total . & . & 30 & 51 \\
\hline
\end{tabular}

Besides some alcoholie specimens and skins.

Botanical Department.

\section{Herbarium.}

General collection . . . 28,885 specimens.

Lowell " . . . 20,986 “

New England collection . . 3,277 “

Total .

$\overline{53,148}$

On Exhibition in glass cases.

General collection - . 2, 2,666 specimens.

New England collection . . 406 “

'Total .

3,072

The New England specimens on exhibition consist of :

30 framed lithographs presented by Mr. George B.

Emerson.
182 mounted specimens of trees and shrubs, presented by Mr. Edward T. Bouvé.

194 specimens of wood and fruit, presented by $\mathbf{M}$. Edward T. Bouvé.

Besides the Museum Building, the Library and the collections mentioned, the Society holds property in notes, honds and stocks, amounting in value to $\$ 154,405$, estimating the bonds and stocks at their par value, which is below what they would now sell for in the market.

${ }^{1}$ It has been stated in this history, and the statement has been repeated, that the epecimens of Massachusetts fishes presented by Dr. D. Humphreys Storer were nearly all allowed to perish for want of care and attention. The author is happy to be able to say that a considerable number of these, about one half, have recently been found in the general collection, identified and placed on exhibition. 
As to what it is now doing. It is engaged, through the constant and arduous work of the assistants in the Museum, in perfecting the work that has been going on for several years, of rearranging, placing upon tablets, rebottling and relabelling the specimens according to their several needs in all the departments, and in exerting proper means for their preservation. None but those engaged in such work can understand the labor and the watchfulness constantly required to prevent injury through many causes, but more particularly through the destructive action of vermin, ami from the evaporation of liquids in which thousands of specimens are immersed. The modern cases, it is true, are generally secure from the admission of pests, but frequent examination of their contents is not less necessary. The opening of a door for a moment may sometimes admit an anthrenus, the progeny of which it may require weeks to eradicate. Constant vigilance can only preserve the perishable portion of natural history collections from ruin.

It is striving constantly to render its collections more educational, not only by such arramgement as will facilitate their stuly, but by models and anatomical preparations giving the internal structure and showing the habits of animals.

It holds meetings on the first and third Wednesday evenings of each month, except during the warm season, at which scientific communications, either written or verbal, are made by members, followed often by discussions upon the matter prevented. All important communications and remarks are published in the Memoirs or Proceedings of the Society, together with any business transacted. Besides the general meetings there are others held of such sections as may be active. There have been three, those of entomology, microscopy and botany, but only one of these, that of entomology, can be said to exist at present, otherwise than nominally.

In its Laboratory it is doing much for those who seek knowledge in natural history. Instruction is griven to a class of the students of the Boston University in Biology and Zoölogy; to a class of the students of the Institute of Technology in Zoölogy and Palaeontology; and to a special class of teachers of the Public Schools in Zoölogy. The laboratory room and the working collections therein are used also by other persons engaged in teaching or studying. The accommodations of the room are inadequate for all who give and seek instruction, not affording proper conveniences for either. About seventy persons now make use of it.

Respecting the very important educational work the society has done through the 'Teachers' School of Science, it is a matter of great regret that lack of means prevented its continuance through the past winter. The maintenance of this has hitherto entirely depender on contributions from individuals who, recognizing the great benefits arising from the instruction of teachers, have voluntarily proffered aid. Whilst, therefore, it cannot be said that just at the present period the Society is carrying on this work, it may nevertheless, soon be the case, as it stands ready with its unequalled facilities to recommence the courses of instruction whenever it can have the necessary help. ${ }^{1}$

\footnotetext{
1 Since the period at which the historical sketch closes, two ladies of Boston, to whom the city owes much, Mrs. Quincy A. Slaw and Mrs. Augustus Hemenway, with unsolicited generosity, tendered the necessary means for the con-
}

tinuance of the 'Teachers' School of Science during the following season. Several courses of lessons to the teachers of the Public Sclsools are, therefore, being given at the time of the publication of this volume. 
In its publications the Society is doing a great work. The issues are of such character as to constantly enhance its reputation at home and abroad, and enable it through exchange with foreign bodies to secure for the use of the members and others engaged in the study of natural history, memoirs and journals indispensable to students, and which the Society could not otherwise obtain. Exchanges are made at the present period with three hundred and sixty societies and proprietors of scientific journals. To meet the call for the various publications of the Society, its Memoirs, Proceedings, and Occasional Papers, an edition of eight hundred of each issue is printed.

In addition to all that has been mentioned, the Society is sustaining its Library, which is not only open to members but to all engaged in scientific investigation, upon proper application, and under reasonable restriction. By an agreement with the Institute of Techmology, its students are allowed the privilege of consulting the books and taking them out for study. The use of the Library is now much greater than at any former period, and is constantly increasing.

Now what are the means at the present period upon which the Society can rely to go on with its work? They are manifestly not its ownership in what is visible, its beautiful building, its growing library, and its grand collections. These are of inestimable value, but they are all of them sources of great expense, not of income. 'To sustain these, to continue publication, without which there can be but little progress, and to do such educational work as is now called for, a much larger funded property is required than that now held by the Society. This amounts, as has been stated, to $\$ 151,405$ at the par value of the stocks held by it, and from this an income can scarcely be looked for exceeding eight thousand to nine thousand dollars per annum. Assessments on members increase this from one to two thousand dollars more.

Now when it is borne in mind that from this income it is incumbent upon the Society to pay on an average about three hundred dollars yearly for prizes; to have in its employ an accomplished seientific mam in general charge of its Museum, with several ahle asistants; a secretary and librarian, also of scientific attainments, with assistants in the library; and a janitor to look after the building and contents; to say nothing of the necessary repairs, fuel, gas, etc., the question may well be asked how an income that will scarcely meet the living expenses of many individual families in the community, can suffice for such requirements. In truth it has only been by exceeding economy that these absolutely necessary expenses have been kept within the income. All of extraordinary character have been met by help from individual members and others. It has been found almost impossible to spare any reasonable amount for additions to the cabinet, and consequently the New England collections in the several departments which it is very important to complete, are yet very far from being so. What was long since stated by the Custodian of the New England collection of mammals yet remains true: "It is a disgrace to the Society." This is the more unfortunate from the fact that some of the larger animals may ere long become extinct in our borders.

IIaving now presented a statement of the possessions of the Society at this time, what it is doing and the income upon which it depends to sustain its work, a few words upon its requirements, its hopes and its aspirations, may be added. 
As to its requirements, these have partially been given in mentioning its means and their inadequacy; others equally necessary but not so pressing will be here referred to.

It needs to huid another andlery in the Musemm as orignally designed, in order that the New England collections in the varions repartnents may he bromght torether. It needs means to enable it to bind thousands of volumes in its library, periodicals received by exchanges, and other works which it has hitherto been unable to do. 'Thanks to the Huntington Frothinghan Woleott fuml, it will heneforth be able to take care of hooks received, but it requires a large sum to bind those obtained in the past and which suffer from want of it.

Of its hopes, they are that it may not only be able to go on with its work, but that it may progress, and that the requirements for this may not long be wanting. Doing what it is in fostering the taste for a study refining and elevating in its tendencies, it feels that its efforts should not be allowed to become futile through lack of necessary means to continue its work without constant struggle.

Of its aspirations for the future, they are such as all will commend who recognize that progress is a duty, viz. : That it may be able to meet the increasing call from a growing community for instruction in natural history, to such as camnot avail themselves of the advantages afforded otherwise, by an expansion of its laboratory and other ficilities; that it may, before a long period has elapsed, be able to add an aquarial garden to its collections, both for the study of the habits of a portion of the animal kingdom and as an additional attraction to visitors of the Museum; and that as these desires cannot have full fruition without more extensive accommodations, that the day may not be far distant when it shall possess the ability to enlarge the Museum building so as to best serve its designs and purposes; that it may also be able to publish the increasing researches of its members with the illustrations they require; which it is now by no means able to do, many memoirs being diverted to other channels of publication which would naturally be offered to the Society were it able to do more than at present.

The names of some of the most able naturalists of the country, including several of the most distinguished of the age, are to be found on its roll of active members during the half century, as Louis Agassiz, Jeffries Wyman, Asa Gray, Augustus A. Gould, Wm. B. Rogers, ILenry D. Rogers, 'Thomals Nuttall, Charles Pickering, D. Humphreys Storer, George B. Emerson, Amos Bimmey, ('harles T'. Jatekon, Thaddeus IV. Harris, Count Desor. Others of its members if less illustrious as scientists have been men of such excellence of life and character as to have endeared them to all the community. Who that knew in life Dr. Benj. D. Greene, the Rev. F. W. P. Greenwood, Dr. John Ware, Dr. Martin Gay, Mr. Thomas Bulfinch, and many others worthy of mention with these, will not feel that its annals have indeed been sanctified by a spirit of purity and simplicity throughout all the years of the half century now closed. If anything has made the writing of these pages a pleasing task to the author, it has been the contemplation of such exalted worth as marked the lives and deeds of so many of his associates. This has sometimes impresied him with a fereling that the atmosphere alout him was hallowed by their presence.

The writer in his concluding remarks cammot do better than to commend to the government of the Society, the expresive words of its great benchactor, in berpueathing to it 
the property, without which it could not have continued its work, and to express the hope that the request so touchingly urged may not only he sacredly regarded through coming years, but that the policy indicated may be observed in relation to all property that the generosity of others may hereafter bestow upon the society; to the end that its means of usefulness be not imparirerl, and that its elevating and heneficent influences be continued through all generations.

The words referred to are as follows:

"Finally, I request the recipients of the above bequeathed property to realize that no inconsiderable portion thereof has been gathered as the fruits of a laborious vocation, exercised through anxious days and sleepless nights; that it is given to them, in trust nevertheless, to be expended so as to inure to the greatest advancement of sound education in the departments as above specified, and the public good. I request that its investment may be safely guarded; that its expenditure may be subject to the strictest economy; yet that it may be appropriated liherally where the oljects aimed at justify an open hand, and cannot be afforder the cause of erlucation and the public good at less expense."

With due regard to what is here expressed, the permanence of the Society is at least secure, and it may reasonably be presumed that the means of progress will not forever be wanting. 


\section{PAST OFFICERS OF THE SOCIETY.}

Thomas Nuttall, Benjamin D. Greene, George B. Emerson, Amos Binney;

George Ilayward, John Ware,

F. W. P. Greenwood, Amos Binney,

John Ware, Francis C. Gray, F. W. P. Greenwood, Walter Channing, Amos Binney, C. T. Jackson,

Gamaliel Bradford, Amos Binney, Epes S. Dixwell,

\section{S. L. Abbot,}

Theophilus P'arsons, D. Humphreys Storer, Martin Gay, Augustus A. Gould, Jeffries Wyman, Frederick A. Eddy, T. Bulfinch,

Edward Burgess,

Simon E. Greene, Amos Binney, Epes S. Dixwell, Ezra Weston, Jr. John James Dixwell, Patrick T. Jackson, Jr.,

Seth Basa,

Charles Amory, Charles K. Villaway,
Elected. IIay, 13, 1830. Aug. 9, 1830 . IIay 3,1837 , May 17, 1843

Iay 13, 1830. May 12, 1832 . May $4,1836$. May 5,1841 .

May 13,1830 May 12, 1832 May 7,1834 . May 4, 1836. May 3,1837 . May $5,1841$.

Hny 13,1830 May 7,1834 . May $3,1837$.

May $3,1876$.

May $13,1830$. Sept. $2,1830$. May $4,18: 36$. May 2,1838 . Hay 15,1839 May 5, 1841. May 4, 1842.

May $3,1876$.

May $13,1830$. May 2, 1832 . May 7,1834 . Dec. 7, 1836. May 1, 1839. May 14, 1845.

May 13, 1830. May 2, 1832 . Jay $1,1833$.

PIESIDEXTS,

\section{Retiren.}

Aug. 9, 1830.

May 3, 1837.

May 17, 1843

MI:ay $5,184 \pi$.
Elected.

May 5, 1847.

June 18, 1856 .

June 15, 1870 。

IIay 5,1850 .

May $\mathbf{1 7}, 1843$. May 6,1874 .

Mry 5,1580 .
Retiren. May 4, 1856, 1 May 4,1870 . May $5, \mathbf{1 8 8 0}$

May 6, 1874. May 5, 1880.
Miny 4, 1836.

May $5,1811$.

May 17,1843 .

Samuel H. Scudder,

John Cummings,

SECONN VICE PRESIDENTS.

Yay 12, 1832.

May 7,1834 .

Mry 4, 1836.

IIay 3,1837 .

May 5, 1841.

May $17,1843$.

D. Humphreys Storer, Augustus A. Gonld, Thomas T. Bouvé, Richard C. Greenleaf, John Cummings, Frederick W. Putnam,

CORRESPONDING SECPETARIES

May $7,1834$.

May 3, 1837 .

Augustus A. Gould,

ILay 17,1843

J. Elliot Cabot,

S. I. Abbot,

Name of office changed.

HONORARY SECRETARY.

RECORDING SECRETARIES.
Sept. 2, 1830.

May 4, 1836.

Nlay 2,1888 .

May $15,1839$.

Mar. 17, 1841.

April 20, 1842.

May 3,1848 .

Name of office changed.

SECRETARY

TREASURERS.

May $2,1832$.

May 7,1834 .

Dec. $7,1836$.

Iry $\mathbf{1}, \mathbf{1 8 3 9}$

Мay 14, 1845.

May 1,1850 .

LIPRARIANS.

May 2, 1832.

May 1, 1833 .

May 4, 1864 .
S. L. Abbot,

Benjamin S. Shaw,

Samuel Kineeland, Jr., Samuel H. Scudder,

Joshua A. Swan,

Edward Burgess, Amos Binney,

Thomas T. Bouré,

Edward Pickering,

Charles W. Scudder,
IIny $\mathbf{1 7}, 1843$. May 2, 1860 .

Nov. 21, 1566. Nay 3,1871 .

May 6, 1874 .

May 5,1880 .

May 17,1843 May 1, 1850. Nov. 2, 1853

May 3,1848 . Nov. 2, 1853 June 16,1858 . May 7,1862 .

Nay 4,1870 .

Feb. 21, 1872 .
Nay 2,1860 Sept. $15,1866$. June $15,1870$. Nay 6,1874 . May 5,1880 .

$\operatorname{May} 1,1850$ June 1, 1853. May 3, 1876.
Oct. 19, 1853. June 2, 1858 . May $T, 1862$. IIay 4, 1870 . Oct. $31,1871.1$ Hay 3,1876 .
May 1,1850 . May 5,1858 . Sept. 4, 1861. May 3, 1865 . Feb. 21, 1877 .

May 4, 1864. May 4,1870 . Feb. 21, 1872 .
Miay 5, 1858. Sept. 4, 1861. Nay 3,1865 .

Nov. $21,1876.1$
IIay 4, 1870 . Oct. $31,1871.1$
1 By death. 
Estes Howe

Nathaniel B. Shurtleff, T. M. Brewer, Jeffries Wyman, Samuel Cabot, Jr, William I. Bowditch, Samuel L. Abbot,

Samuel H. Scudder, Samuel H. Scudder,

Benjamin D. Greene, Francis C. Gray, Walter Channing, Edward Brooks, Amos Binney, Jos. W. Mckean, George B. Emerson, Francis Alger, J. S. Copley Greene, Joshua B. Flint, Augustus A. Gould,

Charles Pickering,

Nathaniel B. Shurtleff,

Nathaniel B. Shurtleff, Samuel hneeland, Jr., Jeftries Wyman, John Green,

\section{Electer.}

May 7, 1834.

Mav 20, 1835.

May $3,1837$.

Iny 2, 1838.

Iry $1,1839$.

Oct. 2, 1839.

Nov. 5, 1839

Mry 4, 1864. Oct. 3,1866 .

May 13, 1830. May $13,1830$. IIay 13, 1830 . Say 13,1830 . Jan 13, 1830. Jay $13,1830$. Iay $13,1830$. May 18, 1830 . Sept. 2,1830 . May 4, 1831. May 4, 1831 .
Retired.

May 20; 1835 .

Nay $3,1837$.

May 2,1838 .

May $1,1839$.

Oct. 2, 1839 .

Nov. 5,1839

Dec. 30,1840 .
Elected.

Dec. 30,1840 .

May 5, 1841.

May 4, 1842.

Nov. 1, 1843

May 5,1847 .

Iay 2, 1849.

May 5,1852 .
Retired.

Mar. 17, 1841.

May 4, 1842.

Oct. 4, 1843 .

Nay 5,1847 .

Nay 2, 1849 .

May 5, 1852.

Jay 4,1864 .
CUsTODIANS.

May 3, 1865. Alpheus Hyatt, May 4, 1870,

May 4, 1870.

CURATORS.

Sept. 2, 1830. Winslow Lewis, Jr. May 2, 183.

May 2, 1832. William B. Fowle, May 2, 1832.

May 4, 1831. Clement Durgin, May 2, 1832

May 4, 1831. G. W. Otis, May 2, 1832.

May 2, 1832. Charles T. Jackson, Mar 1, 1833.

May 20, 1835. John B. S. Jackson, May 7, 1834.

May 3, 1837. Thaddeus W. Harris, May 20, 1835.

May 7, 1834. J. E. Teschemacher, May 20, 1835

May 2, 1832. Martin Gay, May 20, 1835.

May 2, 1832. D. Huraphreys Storer, May 4, 1836.

May 2, $1838 . \quad$ N. B. Shurtleff, May 3, 1837.

The curatorships were assigued to special departments for the first time in 1838 .

Feb. 5, 1862 .

May 1,1867

CUFATOR OF ETINOLOGY.

The Curatorship of Ethnology founded in 1862, was abolished in 1867.

CURATORS OF MAMMALS.

May $2,1838$.

May 1, 1839.

Jeffries Wyman,

May 1, 1839.

May 6, 1840 .

CURATOR OF COMHARATIVE ANATOMY.

May 6, 1840.

CURATORS OF COMPARATIVE ANATOMY AND MAMMALS.

$\begin{array}{llllr}\text { May 6, 1840. } & \text { May 2, 1849. } & \text { James C. White, } & \text { Dec. 1, 1858. } & \text { May 6, } 1868 . \\ \text { May 2, 1849. } & \text { June 7, 1854. } & \text { C. F. Folsom, } & \text { Nov. 18, 1868. } & \text { Oct. 6, 1869. } \\ \text { June 7, 1854. } & \text { May 6, 1857. } & \text { Thomas Waterman, } & \text { Jan. 5, 1870. } & \text { May 4, 1870. }\end{array}$
Nov. 17, 1858

Jan. 5, 1870 .

Iay 2, 1838 .

May 20, 1835

May 1, 1833.

May 20, 1835 .

May 2, 1838 .

May 2, 1838.

May 2, 1838 .

Mlay 2, 1838.

Mray $4,1836$.

May 2, 1838.

May $2,1838$.

May 4, 1870.

The Departments of Jfammals and of Comparative Anatomy were united in 1840, and again separated in 1870.

Thomas M. Brewer, Marshall S. Scudder, S. L. Abbot,

Thomas MI. Brewer,

D. Iumplireys Storer,

Jeffries Wyman, Horatio R. Storer, Jeffies Wyman, J. Nelson Borland,
May 2, 1838. Jay 6, 1840 .

Dec. 16,1840 .

July 2, 1851 .

May 2, 183 s.

May $3,1848$.

May $7,1851$.

Jan. 4, 1854.

Dec. 6,1854 .
CURATORS OF BIRDS.

$\begin{array}{ll}\text { May 6, 1840. } & \text { Samuel Cabot, Jr., } \\ \text { Dec. 16, 1840. } & \text { Henry Bryant, } \\ \text { May 1, 1844. } & \text { J. Elliot Cabot, }\end{array}$

May 1, 1844.

May $3,1854$.

May $1,1867$.

Mas 3, 1854.

Feb. 2, 1867.1

May 4, 1870.

CURATOR OF BIRDS (nests and eggs).

May $4,1870$.

CURATORS OF REPTILES AVD FISII.

May 17, 1843. Jeffies Wyman, The Curatorship was separated into two divisions in 1848 .

May 17,1843

May 3, 1848.
May 7, 1851. Samuel A. Green,

Dec. 21, 1853. Francis H. Brown,

June 7, 1854. Burt G. Wilder,

Miay 2, 1860.
J. A. Allen,
May 2, 1860.

May 1, 1861.

Oct. 18, 1865.

Nov. 18, 1868.
May 1, 1861.

Oct. 4,1865 .

Oct. 7,1868 .

May 4, 1870

${ }^{1} \mathrm{By}$ death. 
$\begin{array}{lc}\text { W. O. Ayres, } & \begin{array}{c}\text { Elected. } \\ \text { May 3, 1848. } \\ \text { Silas Durkee, } \\ \text { Samuel Kneeland, Jr., }\end{array} \\ & \text { July 16, 1851. } \\ & \\ \text { Thay 21, 1856. } & \\ \text { Waldo 1. Burnett, } & \text { May 2, 1838. } \\ \text { Heary K. Oliver, Jr., } & \text { May 2, 1848. }\end{array}$

T. J. Whittemore, Augustus A. Gould, A. E. Belknap,

Augustus A. Gould, Edward Tuckerman, Jolin Bacon, Jr., William Read,

\section{Amos Binney, \\ William 0. Ayres, \\ J. B. S. Jackson,}

\section{H. R. Storer,}

Albert Ordway,

Theodore Lyman,

J. E. Teschemacher, Charles James Sprague,

May 2, 1838 May 5, 1852 .

Silas Durkee,

Charles T. Jackson,

Sept. 2, 1857.

Sept. 2, $1857^{\circ}$.
June $5,1839$. Miay $5,1841$. May $17,1843$. May 1, 1844. May 14, 1845 . May 6, 1846. May 3,1848

Feb. 3, 1841 . May $18,1853$.

The Curatorship was separated into two divisions in 1857 .

May 5, $1841 . \quad$ William Stimpson,

May 17, 1843 T. J. Whittemore,

May 1, 1814. Arthur T. Lyman,

May 14, 1845. Nathan Farrand,

May 6, $1846 . \quad$ Alpheus Ifyatt,

May 3, 1848.

Edward S. Morse,

Nov. 20,1850 .

CURATORS OF CRUSTACEANS AND RADITES. July 16, 1851 .

Elected.

Retired.

Retired.

July 16, 1851

May 21; 1856.

Sept. 3, 1856 .

N. E. Atwood

Samuel Kneeland, Jr.

F. W. Putnam,

Dec. 17, 1856

May 5, 1858.

May 4,1859 .

Mlay 5,1858 .

May 4, 1859.

May 4,1870 .

CURITORS OF INSECTS.

May 3, 1848. Silas Durkee,

July 1, 1854.1 Alex. E. R. Agassiz,

Sept. 5, 1855. Samuel H. Scudder,

CURATURS OF MULLUSK.

$\begin{array}{llll}\text { May 5, 1841. } & \text { John P. Reynolds, } & \text { May 2, 1855. } & \text { May 6, 1857. } \\ \text { May 18, 1853. } & \text { Theodore Lyman, } & \text { May 6, 1857. } & \text { Sept. 2, 1857. }\end{array}$

CURATOIS OF CrUSTACEANS.

May 4, 1859.

Alpheus S. Packard, Jr.,

Dec. 2, 1863.

May $4,1870$.

Dec 18, 1861.

CURATORS OF RADLATES.

May 4, 1864.

Addison E. Verrill

May 4, 1864.

May 4, 1870.

CURATORS OF BOTANY.

May 5, 1852. Horace Mann, May 3, 1865 .

CURATORS OF MICROSCOPY.

June 3, 1857. May 2, $1860 . \quad$ B. Joy Jeffries,

May 2,1860

May 4, 1870

CURATORS OF MLNERALS AND GEOLOGY (State collection).
May 2, 1838.
May 5, 1841.
T. Bulfinch,
May $5,1841$.
May 4, 1842.

CURATOR OF MINERALS AND GEOLOGY (Society collection).

Martin Gay, May 2, $1838 . \quad$ May 4, 1842.

The State Colfection was withdrawn from the Society's Museum, and the Curatorship of Mineralogy and Geology divided, in 1842.

Martin Gay,

Francis Alger,

John Bacon,
May $4,1842$.
May 2, 1849.
May 21,1856

May 4, 1842.
CURATORS OF MINERALS.

May 2, 1849. William T. Brigham,

May 21, 1856. Thomas T. Bouré,

May 4, 1863.
May 4, 1863.

May 3, 1865 .
May 3,1865 May 4, 1870 . The department of Palaeontology was added to that of Geology in 1863, and raised to a separate department in 1867.

Thomss T. Bouvé, May 4, 1863.

\section{CURATOR OF GEOLOGY AND PALAEONTOLOGY.}

CURATORS OF PALAEONTOLOGY.

Thomas T. Bouvé, Jan. 2, 1867. May 1, 1867. Alpheus Hyatt, The office of Curator was abolished May 4, 1870 and Committees on the several departments were elected. 


\title{
CON'TENTS.
}

\author{
Notyce of the Linnaean Society, pp. 3-14.
}

Early publications and instruction in natural history, 3.-Organization, Dec. 8, 1814, of the N. E. Society for the promotion of Natural flistory, 3.- Members and rules, 4-Change of name in 1815 to Linnaean Society of New England, 6.-Collection of specimens and addresses, 6.-Division of the Museum into departments, 7.- Sea-serpent Stories, 10.- Signs of dissolution, 10.-Attempts to unite with the Athenaeum, 12.-Decision to dispose of the collections, 12.-Lessons taught by the failure of the Linnaean Society, 13.

The Boston Sochety of Natural History, Decade I, May 1830-May 1840, pp. 14-36.

Formation of the new Society and election of officers, 14, - with Thomas Nuttall as President, who declined to serve, and Benjamin D. Greene is chosen, 14.-Lectures arranged, 15. - Attempt to recover the collections of the Linnean Society, 16.-Character of the meetings, 17.- Quarters taken in Pearl Street, 17.-First Annual Meeting and reports, 18.-Geological survey of the State, 19.-Difficulties before the early students of natural history, 20.-Removal to Tremont Street, 21.-Attempts to raise a permanent fund, 21.- Extent of collections, 23.-Gift from Ambrose S. Courtis, 23.-Publication of a "Journal," 24. - Second Survey of the State, 25.-Death of Ambrose S. Courtis, his bequest and notice of his life, 26.-Purchase of the Hentz Collection, 27.-Resignation of Mr. Greene and election of

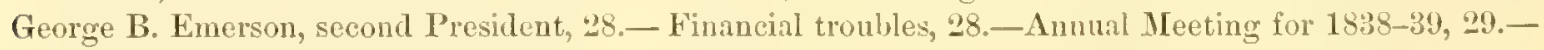
Settlement of the Courtis bequest, 30.-Aid given to naturalists, 30.-Death of Simon E. Greene, 30.Annual meeting, 1840, 31.- Review of the decarle, 31.

\section{DeCADE II, MAY 1840 - MAY 1850, pp. 36-56.}

Bequest of Simon E. Greene, 36.-Annual meeting, 1841, 37- Meeting of the American Association of Geologists and Nituralists, 38. - Anmual reports for 1812, 38. - Adoption of a Diploma, 39. - Annual reports, 1843, 40.-Election of Dr. Annos Binuey as third President, 40.-Death of the Rev. F. W. P. Greenwood, 40.- Annual meeting of 1844, 41, - and of 1845, 43.-Endeavors to raise funds for the Society, 43.- Bequest of John Parker, 33.- The "Sea-Serpent" again, 44.-Annual reports 1846, 45.Death of Dr. Amos Binney, 46.-Annual meeting, 1847, 48.-Election of Dr. J. C. Warren, fourth President, 48. - Purchase of the Menlical College and removal to Mason Street, 49.-Ammual reports for $1818,50,-$ ant for 1819, 51. - Deposit in the Library of the books of "A Republican Institution," 52.Donation of Jonathan Phillips, 52.-Death of Dr. Martin Gay, 52.-Annual reports for 1850, 53.Early discoveries of gold in California, 54.-Review of the second decade, 55.

\section{DeCade III, May $1850-$ MaY 1860, pp. 56-81.}

Annual meetings 1851 and 1852, 57, - and of 1858, 58.-Purchase of the fossil foot-prints from the Connecticut Valley, 59.-Death of James E. Tesehemacher, 59.-Annual meeting of 1851, 61. - Death of Dr. Waldo I. Burnett, 61.-Annual meeting of 1855, 63.-Death of James Brown, 63.- Death of Dr. Thaddeus W. Harris, 64,- and of the Rev. Zadock Thompson, 65.-Annual meeting, 1856, 66.-Election of Dr. Jeffries Wyman, fifth President, 68. - First and only field meeting of the Society, 68.-Deposit from Dr. Binney's Library, 69.-Deaths of Corresponding Members, J. W. Bailey, W. C. Redfield, and Michael Tuomey, 69.- Annunl meeting of 1857, 69.-Formation of a Section of Microscopy, and bequest of the collection of Prof. Bailey, 71.-Donation of the B. D. Greene Herbarium, 71.-Annual meeting, 1858, 72.-Deaths of Dr. James Deane and F. W. Cragin, 73.-Thoughts of a new building, 74.- - Annual meeting 1859, 74,-- and of 1860, 76. - Sketch of Dr. D. Humphreys Storer, 77.- Review of the third decade, 80 . 
Decade IV, Max 1860-May 1870, pp. 81-138.

Bequest of Jonathan Phillips, 81.-Constant exertions for a grant of land for a new building, 81.-First donation from Dr. William J. Walker, 82.-Grant of land to the Society and the Massachusetts Institute of Technology, 83.- Annual meeting 1861, 83. - Sale of building on MIason Street and temporary removal to Bulfinch Street, 84.-Plans for the new building, 85. - Large osteological additions, 85.Gift of ethnological collections from the Boston Marine Society, 87. - Suceessful efforts of the Building Committee, subseriptions of $\$ 20,000$ obtained and the second gift from Dr. W. J. Walker, 87.-Contracts for the new Building, 87.-Annual reports for 1862, 87.-Death of Dr. B. D. Greene, 88. - Gift of the Megatherium cast, 91.-Annual meeting of 1863, 91.-Denths of Dr. George Hayward and Francis Alger, 92 - First meeting in the new building, 92. - Financial shadows, 94.- New offer of $\$ 20,000$ from Dr. Walker on condition of raising an equal amount, 95.- Death of Dr. Edward Hitchcock, 95, - of Dr. John Ware, 95.- Resignation of Mr. Dillawny, the Librarian since 1833, 96.-Annual meeting 186t, 96.-Office of Custodian ereated, and election of S. 1I. Scudder, 97.-Dedication of the new Museum, 99.-Death of C. A. Shurtleff, 100.-Subscriptions to its Working Fund completed, 100. Conditions as to use of the anount received from Dr. Walker, 100. - Establishment of Walker Prizes, 100. Reorganization of a Section of Microscopy, 102. First course of lectures to Teachers, 102. - Death of Dr. William J. Walker, and sketch of his life, 103.- Bequests of Dr. Walker, 105.Annual meeting, 1865, 105.- Cost of the Museum, 106. - Ravages of insects, 106. - Gift of the Lafresnaye Collection of Birds by Dr. Henry Bryant, 108. - Attempt to make Dr. Wyman Director, 109.Annual meeting, 1866, 109.- Establishment of the "Memoirs" as a new series of the "Journal," 109.Death of Prof. Henry D. Rogers, 111.-Death of Dr. Augustus A. Gould, 111.-The Custodianship, 116. - Formation of a Section of Entomology, 117.-Bequest of Miss S. P. Pratt, 117.-Death of Dr. IIenry Bryant, 117.-Cooperation with explorations of the Smithsonian Institution, 118.-Discussion on the House Sparrow, 118. - Abolition of the Department of Ethnology, 119.-Completion of some unfinished rooms, 119.-Bequest of Paschal P. Pope, 119.-Annul meeting, 1867, 119.-Death of Thomas Bulfinch, 120.-Public lectures, 121.-Annual meeting 1868, 121.-Admission of ladies to meetings, 123.-Death of Hornce Mann, 123.-Annual meeting 1869, 124.-Results of the Central American explorations, 125. - Excessive expenditures, 126.-Celebration of the centemnial anniversary of Humboldt's birth, 127.- Founding of a IIumboldt Scholarship in the Museum of Comparative Zoölogy, 128. - Formation of Committees in charge of the different collections, 129.-Annual meeting 1870, 129. - Resignation of MIr. Scudder from the Custodianship, etc., and of Professor Wyman from the Presidency, 132.- Election of Prof. A. Ilyatt, Custodian, and Rev. J. A. Swan, Secretary and Librarian, 133. - Review of the fourth decade, 133.-Part taken by members of the Society in the war of the rebellion, 133.- Joseph P. Couthouy, 138. - Gift of the II. F. Wolcott Fund, 138.

Decade V, MaY 1870-MaY 1880, pp. 140-243.

Duties of the salaried officers, 141.-Election of Thomas T. Bouvé, President, 142--Plan for arranging the Museum proposed by Professor Hyatt, 143.- Skeleton of a Fin-back whale secured, 145.-Arrangement with the Trustee of the Lowell Institute for series of lectures under the Society's auspices, 145.-Establishment through John Cummings of the Teachers' School of Science, 145.- Bequest fiom Sidney Homer, 146.-Anuual meeting 1871, 146.-Death of the Secretary, Rev. J. A. Swan, 148. Election of Edward Burgess, Secretary and Librarian, 149.-Death of William I. Dale, and his bequest to the Section of Entonology, 149. - Annual meeting 1872, 149.-Annual meeting 1873, 152.-Award of the first Grand Walker Prize to Alexander Agassiz, 154.-Death of Prof. Louis Agassiz, 154. - Precautions against fire, and progress of the re-arrangement of the Museum, 164. - Attempt to induce the Legislature to authorize a new survey of the State, 165.-Annual meeting 187t, 165.-Gift of the Eser Paleontological Collection by Mr. John Cummings, 166.- Dr. Charles T. Jackson, 167. - Thoughts of the establishment of a Zoölogical Garden and Aquarium, 160.-Death of Dr. Jeffries Wyman, 169.-Purchase of the Wyman Collection of Comparative Anatomy, 177.-Annual meeting, 1875, 177.-Bequest of the C. S. Iale Collection of Fossils, 179.- President Bouvé wishes to resign, but 
is lead to reconsider it, 180.- Alterations in the Constitution,-Corporate and Associate membership, 181.-Annual meeting 1876, 181.-Death of Dr. Walter Channing, 183.-Death of Edward Pickering, 184.-Denth of Prof. F. B. Meek, 185.- Consideration of opening the Museum on Sundays, 185.Annual meeting 1877, 186. - Death of Dr. Charles Pickering, 189.-Death of Prof. C. F. Hartt, 192.Annual meeting 1878, 194.-Death of Gurdon Siltonstall, 197.-Death of Prof. Joseph IIenry, 198. - Remarkable work of the 'Teachers' School of Science, 199. - Death of Dr. J. B. S. Jackson, 199.Annual meeting 1879, 202 - T'eachers' School of Science, 204.-Vote to publish an Anniversary volume, 207.- Award of the second Grand Walker Prize to Prof. Joseph Leidy, 208. D Discussion relating to the Collection of Comparative Anatomy, 208.-Death of Dr. T. M.,Brewer, 209.-Plans for a fiftieth anniversary celebration, 211.- Resignation of $\mathbf{M r}$. Bouvé from the Presideney, 212.-- Fiftieth anniversary celcbration, $\boldsymbol{A}$ yril $28,1880,213$ - Address of IIr. Bouvé, 213,- of Governor Long, 214,-- of Dr. Samuel Eliot, 215, - of President Eliot, 216, - of Mr. Alex. Agassiz, 219, - of Rev. R. C. Waterston, 220.-Close of the celebration, 226.- Annual meeting 1880, 226. - Election of oflicers, with Samuel II. Scudder as President, 230.- Review of the fifth decade, 231.- Original members yet living, 23t.Sketch of George B. Emerson, 235. - Present condition of the Society and the hopes of its founders, 237. - Statistics of the Library and Museum, 238 - Funded property, 239_—Present work, 240_- Inadequacy of means, 241.-Aspirations, 242.-Wishes expressed in Dr. W. J. Walker's will, 243.

List of past officers of the Socicty, 244 .

Contents, 248.

List of portraits, 250 .

\section{PORTRAITS IN TIIIS VOLUME.}

Benjamin D. Greene, M.D., First President of the Society. Heliotype from a life-size crayon portrait in the possession of the Society. Opposite page 89.

George B. Esrersox, LL.D., Second President. Heliotype from an enlarged photograph. Opposite page 236 .

Axros Bryxey, M.D., Third President. Ileliotype from a portrait in oil in possession of the Society. Opposite page 49.

Jonn Coluns Warnen, M.D., Fourth President. Steel engraving from a daguerreotype by J. A. Whipple. Opposite page 66.

Jeffries Wranas, M.D., Fifth President. Heliotype from an enlarged photograph finished in crayon, in the possession of the Society. Opposite page 169.

Tromas T. Bouvé, Sixth President. Ieliotype from a crayon portrait in possession of his family. Opposite page 212.

William J. WaLKer, M.D. IIeliotype from a crayon in possession of the Society. Opposite page 105.

Augustus A. Gould, M.D. Engraving by H. Wright Smith, from a dagnerreotype by Sonthworth \& IIawes, originally published in the Annual of Scientific Discovery for 1861. Opposite page 112.

D. Humphieys Storer, M.D. Steel engraving, prepared for the "Biographical Encyclopedia of Massachusetts of the Nineteenth Century," published in New York in 1879. Opposite page 80. 
1830. ANNIVERSARY MEMOIRS OF TIIE BOSTON SOCIETY OF NATURAL HISTORY. $18 s 0$.

\title{
PROPOSITIONS CONCERNING
}

\author{
THE

\section{CLASSIFICATION OF LAVAS,} \\ CONSIDERED WITH REFERENCE TO THE CIRCUMSTANCES OF THEIR \\ EXTRUSION.
}

BY N. S. SHALER.

BOSTON :

PUBLISHED BY THE SOCIETY.

1880 . 



\title{
Propositions Concerving the Classification of Lavas, Considered with Reference to the Circumstance of their Extrusions.
}

\author{
By N. S. Shaler.
}

THE lavas of the earth are not easily divided into distinct physical groups; a division on the basis of their chemical history has not yet been satisfactorily made, even Richtofen's ingenious classification, which at first was accepted with considerable confidence, and seemed to promise a basis for future enquiry, not appearing to satisfy the conditions in all the various regions where volcanic rocks of different ages are found. The question of the physical and chemical history of the various molten rocks is still so much open to debate that almost any suggestions which promise to aid our understanding may be deemed warranted. I therefore venture to present the following considerations concerning the physical history of the known groups of lavas. In this paper I propose to limit myself to the mechanical history of the formation and the extrusion of lavas, avoiding the field of chemical inquiries as far as it may be possible to do so. For convenience, I have arranged the following matter in the form of propositions which are taken up in succession. I regret the appearance of dogmatic assertion this form gives, and also regret that the limits of the paper, as well as my knowledge of the work of others, do not enable me to indicate the precise points in which the suggestions differ from those which have hitherto been made.

Outflows of lava are pretty clearly divisible into three classes, viz:

1. Those of ordinary volcanos, characterized by the fact that the escape of gas under great pressure brings about the extrusion of the lava.

2. Massive outflows of lava flowing not from a cone, but from a fissure, and showing no trace of the gas action which is the most conspicuous feature in true volcanic action.

3. Inclosed dykes, $i$. e., dykes whose fissures did not reach the surface, but stopped short of it within the rocks which they penetrate.

Besides these we have in various dykes and volcanic chimneys, occasional relics of the old channels up which the lavas that were forced out in volcanic or marine eruptions found their way to the surface. It is often impossible to determine to which of these last named classes such ejections belong, but they are easily separable from the third group, $i . e$, that of enclosed dykes. 


\section{The Latas of Ordinary Volcayos.}

The immediate problems connected with the formation and extrusion of the lavas from voleanic cones are perhaps on the whole less perplexing than those we shall have to consider in the other classes of volcanic outhreaks; nevertheless, we find ourselves at the very outset in the midst of a maze of discordant opinions. After carefully weighing the diverse facts and theories which have been accumulated about the problem as far as they are known to me, I am inclined to maintain the following propositions as sufficiently supported to be worthy of presentation.

1. The formation and ejection of the lavas of ordinary volcanos is due to the invasions of heat into sedimentary deposits; invasions brought about by the deposition of sediments on the sea-floors, and the consequent vaporization of the waters and other volatilizable substances contained in the deeply-buried rocks, - which substances were deposited at the time the buried rocks were laid down.

This proposition is supported by the following facts, viz.: In the first place, the active volcanos of the earth are limited to the vicinity of areas of sedimentation, and their activity ceases when in the course of geographical change, the seas leave their neighborhood. Several times in the discussion of this problem, the sugrestion has been made that the water which contributes the larger part of the gases poured out by voleanos, penetrated from the surface through the rocks to the heated deep-lying beds, and being there raporized was the source of the gases which propel the lavas and other substances from the volcanic vent. Although Daubrée has shown, by some very interesting and singularly overlooked experiments, that water will penetrate rocks against a considerable gaseous pressure, this theory seems to me essentially untenable, inasmuch as the penetration of water through the rocks beneath the land must be even more energetic than through the rocks beneath the sea, for the reason that the hydrostatic column is hicrher beneath the land; we are therefore driven to regard the water contained in the gases of the volcano as originating in the water that is imprisoned in the rocks by stratification. In the second place all the lavas that have been submitted to a careful microscopic study, show that the temperatures to which they have been subjected are not high enough to melt any other than the easily fusible rocks. This is proven by the numerous fragments of more refractory rocks which they frequently contain. This is evidence of a very filir kind, to show that lavas are not derived from great depths, and that they are formed from rocks which had previously been consolidated.

That the ejection of the lavas from ordinary volcanos is due to the action of the gases, is pretty well proven by the fact that most volcanic eruptions are essentially explosions of gaseous substances. Inasmuch as these gases are diffused in the atmosphere, or precipitated as rain, they leave no distinct record of themselves, but there is no reason to doubt that the volume of gases which have been poured out, hy such a volcano as Etna for instance, must amount to many thousand times the mass of the cone that we find there. At the time of fullest activity, such criters are discharging gras with a greater speed than the gases of gumpowder are discharged from a cannon's mouth at the moment of explosion, for they sent their ejection higher than they could be sent by any artillery. In many volcanos this 
speed of ejection if continued for a month, would set free a mass of gras equal to the atmosphere covering over fifty thousand square miles of the earth's surface. 'The actual weight of gases thrown out in a month of the most vigorous eruption, must in many volcanos exceed one thousand million tons, or a waight greater than half a cubic mile of ordinary volcanic rocks, or a large fraction of the mass of such a cone as Etna. This estimate, which being only approximative is not worth exhibiting in detail, makes it clear that the volume of the escaping grases and their power is sufficient to propel the lava from the depths where it is found to the surface.

2. The gases erupted from a volcanic cone, and to a certain extent the lavas, are principally derived from a great horizontal distance from the point of escape.

This proposition seems to me to stand on a tolerably sure footing. It is clear that the gases which escape from an ordinary volcanic cone during its formation would, even in their solid form, occupy a much greater mass than the cone itself. Moreover, we know that these gases are mainly the grases of water, and that compact redimentary rocks camnot contain more than about two or five per cent. of this fluid. To find a source for the water which escapes from a volcanic cone we must assume it to have been derived from a great horizontal area about the cone. Assuming that in the case of Vesurius the stratified rocks which give rise to the gases are limited to a depth of one or two hundred thousind feet (a conclusion to which we are led by the relatively low temperature at which the lavas are extruded), then we must believe that a part of the supply of gas is derived from distances of hundreds of miles horizontally from the vent. If we reckon the average diameter of the crater in all its history, at one half a mile, which is probably much within the facts, and assume that the whole time in which the crater has been diwcharging gases at a high pressure since its beginning to have amounted to an aggregate of only five years, probably a very small estimate, then it would have discharged in vapor much more water than could be contained in the rocks over an area of something like forty thonsand square miles. So if we assume that the gases of volcanic eruptions are principally of water, and that this water was contained in the rocks as it is ordinarily contained there, then we must admit that the feeding ground of a volcano extends over a very wide area.

The attitude of the rocks about a volcano comes in to support this conclusion in a very striking way. While in certain cases there is a subsidence of the beds to be noticed very near the crater, the general level of the region about the crater, even the largest, has never shown any distinct evidence of subsidence. When we remember that the cones of a volcano are the seats of a very rapid erosion, owing to the high angles of the slopes, the incoherent mature of the materials, their generally low specific gravity, and the torrential rainfalls that accompany great eruptions, causing the cones to wear down at an average rate of many feet in a thousand years, and also take into account the vast bulk of the gaseous emanations, it' is clear that unless the supply of ejected matter came from a great distance on either side of the volcano, we would not find this absence of sinking about the cone.

Moreover the well determined interaction between certain volcanos hundreds of miles away from each other, shows that the gases must have this horizontal 
movement, else the eruptions of one volcano could not cause the others to become dormant. It does not seem to me necessary to assume that this horizontal movement of the gases takes place through rocks in a state of complete fusion. It is a well recognized fact that certain substances, iron for instance, are more permeable to gases when highly heated than when cold, nor need we assume that the movement of the gases is very rapid; it may be, and probably is, rather slow, otherwise the repetition of periods of repose and explosion could not well be explained.

3. The lavas of ordinary volcanos do not represent the melting of the whole section, where they originate, but only that part of the section which it is possible to melt at low temperatures.

This proposition is deduced from the fact that all our lavas are characterized by the large proportion of silex which they contain; none of them save the basalts fall below fifty per cent. of silex, and most of them exceed this amount. Now at the low temperature at which all of our lavas were formed, it is pretty certain that the limestones and clay slates, or, indeed any other elements of our ordinary geological sections, except the sandstones and other very siliceous rocks, would not become melted, though they might slowly part with their vaporizahle sulstances. The result would he that the production of lavas would depend in a large degree upon the existence, in the section through which the gases made their way to the vent, of siliceous deposits, which could become fused at temperatures as low as probably prevailed in the region whence they came. 'This will enable us to account for the invariably siliceous character of our lavas. At the same time, it suggests that in part, at least, the peculiarities of character of volcanos may be explained by the irregular distribution of fusible deposits in the earth's crust. It has long been observed that the quantity of lavas voided by volcanos varied greatly; those in the Eifel district being singularly wanting in lavas, while those in other regions, as for instance, in the Sandwich lskuds, throw out great quantities of lava. The ashes, which are in good part, at least, the product of the friction of fragments of melted rock upon each other, the rapilli, volcanic bombs, etc., which vary in quantity with the amount of lava, will not be thrown out in large quantities when the molten rock does not abound. In this way we see that the height of a volcano or the mass of the cone is in no way a fair measure of the energy of the escape of gases; the Eifel volcanos, such as Laacher See, with their low walls of debris reminding us in their form of the lunar volcanos, may have discharged gases in exceeding abundance, yet have produced little lava, possibly on account of the absence of siliceous materials in the section whence they are derived.

It is easily seen that this view aids us in understanding the absence of subsidence in the foumdations of the great volcanos, notwithstanding the vast ejection of fluid and solid matter from their cones. Taking only the very siliceous deposits which to not usually form a large part of the section, the lava-making forces would not be likely to remove a considerable vertical thickness from the region just beneath the cone.

4. The conversion of solid rocks into lavas is in part at least due to the energy of the movement of the imprisoned gases.

This seems to me to be fairly well shown by the phenomena of volcanic eruptions. Whenever a new volcano breaks out, or whenever a cone long in 
repose again becomes active, their immediate products, gases, are the first to be thrown out; only after a considerable time, do we have any outbreak of lava. This is essentially what we should expect on general mechanical grounds. The evidence of a relatively low temperature in the lavas shows us that the heat beneath volcanos is not nearly so great as it is in an ordinary blast furnace; even if elevated to the temperature that man fiequently produces in the arts, there would be nothing to keep many of the enclosed ummelted fragments from being completely fused by the action of their molten envelopes.

The interaction of the gases which escape from volcanos in the full tide of eruption, is too complicated for understanding. It will be worth while, however, to consider some of their effects. In the first place it is clear that the great expansion that takes place in them must have an effect in lowering their temperature, and that of the substances through which they pass. It is not possible, however, to separate this action from the other effects, in the way of increased temperature which their evolution produces. The movement of the gases would tend to produce this increase of heat in either of two ways : by the direct mechanical effort of their friction; or by the recombination near the mouth of the volcano of the gases which had been separated in the more remote regions whence the volcano draws its supplies of matter. I am inclined to give little value to this action. There is, however, a way in which the gases act to liquify the lava which is worthy of attention. When the pressure of the contained gitses becomes very great, they must necessarily tend to squeeze the rock containing them out in the direction of least resistance. The softening that would give this liberty of movement, is most likely to occur in sandstones and other highly siliceous rocks, and it is in them that we find the largest proportion of water to be volatilized. At the time of their deposition our sandstones often contain as much as one fifteenth of their bulk of water, while the other more compact rocks do not usually contain more than from one fiftieth to one liumdredth of their bulk of that substance. The escape of gases from the other more refractory materials would, as far as it escaped, have to pass through the rigid framework of the rock. Experience in coal and other mines show us pretty clearly that the densest of our rocks are somewhat permeable to gases, and that these gases, mrler the pressure of their generation from chemical changes, will make their way out through the interstices of the particles which compose the rock. In this way the gases of heated rocks, which are the more permeable to such substances by virtue of their heating, probally find their way towards the volcanic outlets. So we may reasonably assume that the gases which are the main spring of volcanic activity, pass towards the vent in either of two ways: by driving the rock before them when it is fluid enough to admit of it, and by interstitial movement when this is not possible.

\section{The latas of Massive Firuptions.}

I propose now to consider the outlines of the probable history of that class of eruptions commonly termed massive. It is only of late years that it has been made tolerably plain to us that extensive outflows of lava occasionally, though rarely, take place without passing through the craters of true volcanos. As yet we know but little of these extrusions; they seem to have been formed in only a few of the known volcanic districts of the globe. They have been observed in the Cordilleras of North and South America, in the Deccan, 
and in Transylrania, and less certainly elsewhere. It seems to be pretty clearly made out that the escape of these lavas to the surface has been through a fissure of considerable extent, and not through the cones of ordinary volcanos. It is also probable that there has been no great uprush of gases at work in propelling these lavas. It is easily seen that these eruptions present a problem of no small difficulty to those who may hold the opinions concerning the origin of lavas which $I$ have embodied in the preceding propositions. If lavas are produced in the esentially solid earth and extruded by the action of heat operating through the motion of imprisoned gases, how is it that we have these very extensive outflows of lava taking place without the aid of any great amount of gas? It seems to me that it is important that these difficulties should be met, and shall therefore present certain considerations which seem to me to offer a far explanation of the means whereby such lavas come to the surface.

1. The massive lavas are only found in regions where volcanic activity and mountainbuilding forces exist in the same field.

As the geographical distribution of volcanos has been a matter of the utmost consequence to the theories of their origin, we may fairly begin our study of this particular species of volcanic activity by considering its distribution. It seems to me to be a fact of the utmost importance to us, that the massive lavas are entirely wanting in many regions characterized by intense volcanic activity. yet remote from mountains which are the product of recent uplifts, and that such outflows are equally wanting in many great chins, where the mountain-building forces have been exercised witl the greatest energy.

In the whole of the Alpine district, where the most intense disturbance of the crust can be seen, or the Appalachian axis, where throughout the whole of the recorded geologrical time the momntain-building forces have been in operation, these massive lavas are entirely wanting. It seems evident, therefore, that molten rock is not of constant occurrence on the deeper sections beneath the ground whereon our high mountains rest; that its formation and extrusion probably depend upon the combination of mountain-huilding forces, and the ordinary volcanic conditions in the same territory. The only way in which these two classes of forces can combine to produce such lavas may be represented in the following proposition.

2. The lavas thrown out in massive eruptions have been slowly accumulated beneath the surface of the earth near the foci of ordinary volcanos, and owe their ejection to the strong lateral pressure brought to bear upon them by the compressive movements caused by the mountain-building forces.

There can be no doubt that at a certain depth beneath volcanic cones there is a great mass of lava more or less perfectly fluid, which may remain in this condition for geological periods, after the outbreaks of gases have ceased to take place. This lava parts with its heat with such slowness, that if the mass and the depth at which it lies are considerable, there is hardly any limit to the length of time during which it may remain molten. Now when the mountain-building forces bring very great pressure to hear upon such lavas, they will tend to yield to the strain more easily than the solid rocks, and will be forced up through the old rocks, or through the fissures 
which would form in the movement of the superjacent beds. We see in all our great mountain systems evidences of a certain spewing out of the deeper lying beds. 'The well-recognized fan structure of the Alpine and other massifs, exhibit this. Even in the simpler monoclinal mountains, such as the Malvern Hills, on the line between Worcestershire and Herefordshire, we often have evidences of the forcing up of these lowest lying rocks, though they never, so far as is known to me, show the ejected rocks flowing in the fashion of lavas, except. where there is reason to believe that these regions had formerly been the seat of true volcanic action.

The Cordilleras of North and South America, the Deccan and the Transylvania distriet are all regions where this pressure could naturally come upon the reservoirs of lava through the action of the compressive mountain-building forces. On the other hand, owing to the fact that volcanos are not not often associated with mountain chains, but are more commonly apart from such axes, we have few regions where mountain-building forces have been brought to bear upon volcanos, so we cannot properly be surprised at the rarity of the occurrence of massive lavas, if we put the interpretation on their origin which is here suggested. It seems to me pretty clear that there is no other power except this compressive action of the mountain-building forces which can be adduced to explain the outflow of lavas when they are not impelled up by the gases of ordinary eruptions. We see that in such eruptions from cones there is great difficulty in forcing the lava out. even by the aid of the most powerful uprush of gas; now as in the massive eruptions the gaseous element of the eruption was evidently small in quantity, we must suppose that some other form of pressure had been brought to bear upon the lava, and this could not well be any other than that arising from the horizontal compression of the beds that comes about in mountain building.

It should be remarked that in all ancient volcanic outbreaks we are more apt to have the compact and nearly horizontal lava streams preserved, than the steep and incoherent cones whence they came. No geological features are liable to such rapid eflacement as volcanic cones. 'The high angle of their slopes, the incoherent nature of the materials that compose them, and the shocks to which they are subjected, lead to their very rapid destruction; so that the older the volcanic district, the more likely we are to mistake the ruins of a crater lava system for the evidences of a massive outbreak. This consideration should give us caution in the classification of lavas from this point of view,

\section{Inclosed Lavas.}

This third and last of the groups of lavas includes all dykes of whatever nature that have not been formed in the pipes through which volcano ejections have made their way to the surface, or in other words all lavas deposited in fissures, the upper ends of which were not open to the surface of the ground. In the immediate neighborhood of volcanic cones these lavas have often been formed in a peculiar and local way as diversions from the main pipes of the volcano. 'These 1 would exclude from the general class of inclosed lavas, regarding them as mere parts of the true volcanic lavas. 'Thus limited, this class of lavas remains by far the most extensive group of volcanic products. In most of our older crystalline rocks this group of lavas is very numerously represented. We could name many sections having areas of from one hundred to five hundred thousand square 
miles, where every square mile would give several examples of such injections. In the older rocks of Xew Fngland these dykes generally exceed a dozen in number to the sipure mile, and often rise to hundreds in such areas. Yet there are considerable areas of Archaean rocks, where such injections are very rare. The results of my personal enquiries into the origin and distribution of dykes are briefly stated in the following propositions, viz:

1. Dykes or enclosed lavas are only formed when rocks have been buried by subsequent accumulation to considerable depths beneath the surface, metamorphosed during such burial, and also subjected to the action of mountain-building forces.

A glance at the section from the Atlantic Coast in North Carolina westward into the centre of the Mississippi Valley or from the Laurentian IIills southward to the Ohio, will show the peculiar differences in the frequency of their occurrence which may be traced in rocks of different ages. Whenever the section passes through the old Archaean rocks we find a very great abundance of dykes, the injections distinctly showing their igneous origin. When we pass above the level of the Archaean and enter into the lowest Cambrian section these intrusions disappear, and veins, $i$. e., deposits formed by the filling of fissures through water action abound. I have never seen a single dyke in the Cambrian rocks of East Tennessee or Southwestern Virginia, though they are extremely effected by mountain dislocations and cut by the deep faults that traverse every part of our Eastern Ameriean rocks. There are some of these faults that give a vertical throw of over ten thousand feet, and must penetrate to very great depths in the crust, yet in no case have they afforded a passage to lavas. Within the limits of the State of Kentucky, an area of about 40,000 square miles, I am satisfied that there is not a trace of dyke injection, though vein stones with contents that require us to suppose that they have been deposited by heated waters abound there. I am not aware of the existence of a single dyke within a radius of two hundred and fifty miles from the city of Cincinnati, though the geology of this region is pretty well known to me.

In all these regions where dykes abound, the metamorphic character of the rocks enables us to make sure that they have been subjected to extensive alteration from heat, and in most if not all cases this heat has been brought into the strata by the protective effect of thick sections, that rested on the surface at the time the dykes were formed, but have since been eroded. Horeover, in all cases the regions extensively traversed by dykes have been greatly disturbed by mountain-building forces. We search in vain for horizontally disposed rocks penetrated by dykes or for recent beds that are marked by such injections.

2. Dyke stones are injected into fissures formed by the rupture of beds through contractions due to metamorphosis, or to the contortion of beds, and their materials represent the more siliceous deposits of the subjacent rocks of the section.

The formation of the fissures which give rise to veins and to dykes is clearly due to allied causes. Considered as fissures, they are all clearly to be put into the same class. They are both formed by strains in the rocks; they both first exist as openings, into which their contents are brought either slowly by the action of water, or rapidly through the action of igneous forces. Although we never find gash veins, $i$. e., fissures that only have a limited extension downwards, filled by dyke stones, we find true fissures, or those 
with an indefinite downward extension, filled either with vein or dyke stones, according to the conditions of the rocks in which they occur. It is perfectly clear that the fissures in which the vein stones occur often existed as gaping fissures before the deposits they hold were introduced into them, and we are justified in believing that the fissures containing the dyke stones were formed in the same way. As before remarked, vein stones are characteristic of the higher lying and less metamorphic rocks. Though they are found among the rocks containing dykes, they occur there, it seems to me, as deposits made at another period than that which gave birth to the dykes.

There seems to me no good reason to suspect that the furrows containing dykeshave been to any extent riven by the injection of the dyke, as is assumed by many writers. It is likely that the inrukhing of materials having the weight and fluidity that belonger to the molten lava would have exercised a certain rending effect upon the rocks in which the dyke was formed, but there are abundant reasons for disbelieving that the fissure itself could have been originally riven by the actual force of the injection.

The hypothesis of the derivation of these lavas from the more siliceous beds of the subjacent section is a less easily demonstrable part of our proposition. It rests upon the following classes of evidence. In the dyke stones of any district we usually find a very decided difference in composition among the several classes of injections that are found there. In some cases, dykes of one well distinguished class can be found in one set of beds, and yet not appear in those of a lower kind. This class of facts has not been made the subject of careful study by our geologists, yet from my own observation I am satisfied of the truth of this assertion. No one can observe with care the distribution of the dyke stones of New England without being convinced of the truth of this proposition. The rocks on the shores of Maine and Massachusetts give some distinct examples of this class of facts. The dykes of peculiar felsite porphyries of the Marblehend district are not found below the level of the stratified deposits of this age; $i$. e., they do not exist over the older parts of the field wherein they lie. The amygdaloids, with porphyry deposits contained in the beds, are not found beyond the area of the conglomerates of the Cambrian age. The great series of highly metamorphosed slates and shales like York Harbor and Bald Heal on the coast of Maine, contain a wonderful set of melaphyre dykes which are not found in the subjacent granitoid rocks, though there is good evidenee that these underlying rocks have not been much changed since the series of slates were formed. Basalts, ejections of the general massive character of those which make up the Palisades of the Hudson, and the extensive dykes of the Connecticut Valley, are not found beyond the limits of the rocks of Triassic age in those districts. Though the same general classes of basalts are found in other regions near by, they never take on the peculiar facies which they have in these districts. While many of these peculiarities in the distribution of injected rocks may be explained in other ways, I am strongly inclined to believe that they cannot generally be explained, save by the hypothesis that they are dependent on the peculiarities of the sections in which they are found. That is to say, they are formed from the deeper lying highly metamorphosed rocks of each district, and carry the peculiar stamp which is thereby imposed upon them. I do not mean to deny that many of the dyke stones 
come from depths below the levels to which geological sections ever give us access. Nor do I mean to question the fact that the present superficial character of many of our traps depends upon comparatively recent alterations of their constitution by the agents of decomposition; allowing for all there perplexing accidents. it secms still that the diversity in the lavas of different geological distriets, and indeed their diversity in the same distriet, can only be explaned by the hypothesis of their local and comparatively superficial origin.

The second part of the last proposition rests upon the well known chemical composition of the lavas, and also upon the fact that the highly metamorphosed rocks seem in all cases to show more complete alteration of their very siliceous elements than of the refractory clays and limestones. It is fairly a matter of surprise when we consider how large an element the sandstones form in all our metamorphosed sections, that we so rarely find extensive beds of rocks of this nature in our deposits which bear the marks of high temperature. I am inclined to think that it is reasonable to suppose, that the deposits which were originally very siliceous have been forced out by the expansion of their gases as livas, and now appear in the neighboring dykes, or have been driven to the surface as true volcanic ejections and have since been lost by erosion.

The depth of the overlying rocks which is required before the rents in the rocks can be filled by dykes is a matter that cannot be determined. It is evident that it must be great, for as in parts of Eastern Tennessee it is clear that the surface has lost a section of at least ten thousand feet in thickness, since the close of the Cirbonifirous, owing to the peculiar intensity of the denudation there; yet there is no trace of dykes in the district, though there are many veins.

3. Dykes formed from the melting of particular parts of a section, may penetrate either downward or upward from the point of origin.

The opening of fissures in metamorphic rocks brought about by contraction or other strains, will necessarily lead to the frequent downward extension of dykes. If the section contains extensive beds of fusible materials on one level, and infusible materials above and below, the result will necessarily be the penetration of the lava into any fissures that may be contiguous with it, whether these fissures extend downwards or upwards from the fusing bed. This suggestion may be of nogreat importance, yet I have seen places where it would aid in the understanding of the distribution of certain dyke stones.

4. The pressure of the superincumbent unmelted beds coöperates with the pressure of the gases contained in the fusible bed, to impel the molten or semi-molten matter into the dyke fissures; and also to a certain extent the friction thus brought about aids in the fusion of the lavas.

The pressure of a vertical section having a depth of twenty thousand feet, amounts to about $4,000,000$ pounds per square foot. This pressure will dloubtless be sufficient to aid the flow of any of the mass-rocks which are somewhat softened by heat, and the contained water. As soon as the movement begins, the heat derived from friction. will greatly aid in the fusing of the lava. In many of our ancient dykes the superincumbent deposits have doubtless much exceeded twenty thousand feet in thickness, so that the pressure maty have much exceeded the 2,000 tons to the square foot, which would be given by five miles 
in depth of rocks of average weight. Indeed such a pressure would be sufficient to squeeze into movement rocks that were not nearly enough heated to flow at ordinary pressures. ${ }^{1}$

It is worth while to notice that this downward extension of dykes would give an appearance tending to support the present opinion that dykes are derived from an indefinite depth. It also tends to mask the fact of the limitation of the origin of certain classes of dykes to certain horizontal areas, and it may happen, if this hypothesis be true, that a dyke that appears to arise from the deeper regions of the earth may have been derived from certain beds which have since disappeared from the region where it is found. It is obvious that this will make the inquiry into the origin of dykes a matter of much more difficulty than it would be if we could assume that such lavas always rose upward from their point of origin.

The question will naturally he asked, why, if the dyke stones are derived from sections near the surface of the earth, they are not frequently seen at their point of origin? To this it is a sufficient answer that we have never sought for such phenomena, and where they would be found we should always have a considerable amount of disturbance that would tend to make the indications of their origin difficult to decrpher and not calculated to arouse the attention of the observer. A thin layer of easily fusible rock might be forced into the chasm formed by the opening of a fissure so as to permit the beds above and below it to rest upon each other; or, if a thicker bed, it might appear as a horizontal prolongation of the dyke that had been formed from it. Moreover, there would be a great disturbance made, at the point where the molten rock emerged from its bed into the fissure, which would tend to confuse the record of the event. Despite this difficulty there are some cases in which I have observed what has seemed to me fair evidence of the local origin of certain traps. Sot infrequently trap dykes may be olserved to rum out downwards, which requires us to suppose either that they have been injected downwards, or that they have originated above the point where we find them. In other cases I have observed small dykes that extended downwards into a horizontally disposed mass of dyke matter and could not be traced below a certain level. It is true that the difficulty which we find in determining the true extension of a dyke on account of its frequent doublings and twistings limits the value of such evidence, yet it seems to me that, if we start without the prepossession in favor of the origin of all lavas below the observable level of the earth's crust, we can better reconcile the facts with the hypothesis of their local and superficial origin than with any other.

It is worth while to notice in this connection that some of our conglomerates show the effect of heat in softening the mass of the deposit. It often happens even when the mass is apparently not much metamorphosed, that the more siliceous pebbles are softened and squeezed into each other in a surprising way. I have always found that the siliceous elements of the mass have been the most affected by the action; sometimes this action is limited to a slight change of form of the pebbles or the indenting of one by the other, as in the Roxbury conglomerate or

\footnotetext{
1 It seems to me this theory of the origin of dyke stones is better than that which we would derive from Mallett's ingenious hypothesis. While the falling together of the rocks could not develop a great amount of heat, this
}

squeezing of matter for great distances, would in a way localize the heat arising from the downward falling of a great mass of rocks upon a small bulk of materials. 
the conglomerates of the Swiss Niocene, but not inferuently it groes much further, and the pebbles are drawn out into very long forms, often to several times their original length, while the sandy matrix has clearly been found in a semi-fluid condition. On the island of Aquidneck in Narragansett Bay, this elongation occurs in particular localities, I believe in all cases near extensive fuults, while a mile away the pebbles will be found essentially unchanged in form. Between this pasty condition and the fluidity that would make a dyke stone there is no essential difference. I have endearored to show that at certain points the Roxbury conglomerate appears to pass into an amyglaloidal trap, retaining its conglomeratic characters, even where it is distinctly fuser, and pasing insensibly into a completely amorphous mas. ${ }^{1}$ Again, at Marblehead Neck, the porphyries seem to pass from an apparently stratified mass into true dyke stones. Instances of this rather indeterminate sort could be multiplied, but as this paper is not intended to furmish a detailed inquiry into the facts that support the propositions it sets forth, I will not go further with the statements.

While included lavas or dykes represent the less vigorous forms of the forces that in their more intense forms give us true volcanis ejections, they yet differ from them in the evidence of gaseous action. It seems to me reasonable to suppose that there is an incomplete series of phenomena connecting dykes and voleanos. When the ejection serves only to fill the vacuum of a fault or gan fisure, and has not the impulse necessiry to force axide the obstructions and make its way to the surface, we have an ordinary dyke; when the uprush of expanding gases is great enough to break a way to the air, the result is a volcano.

The question arises, is it likely that the ordinary dykes which are so abundant in our Archacan rocks, have in many cares, been the tubes up which came the products of volcanic eruptions? A little consideration makes this appear improbable. In the first place even the smaller class of volcanic cones have vents some hundreds of feet in diameter, while it is unusual to have a dyke of such size. Moreover, we must believe that the long continued passage mpwird of the volcanic products through a fiscure, would necessarily bring about a great change in the character of the walls that bound it. They would be to a great extent melted, and could not help showing marks of the strong uprush of the volcanic products. In fact our dylies almost always have their walls so little disturbed, that we can trace the corresponding sides of the hreak for great distances, and the change in the country rock from heat, is usually singularly small. This shows pretty clearly that our dykes are not often to be classed as volcanic channels.

It may be noticed that we sometimes fund evidence that the paths taken by dykes afterwards become more opened, and veins take their place beside the dyke, showing that even when the temperatures are high enough to enible the penetrating waters to carry gold, silver, and other metals, the opening of a fissure may not give passage to volcanic matter. This would seem, at first sight, to militate against the view of the orisin of dykes presented in the preceding propositions, for the temperature, if sufficient to enable water to convey such metals, would seem to come very close to that necessary to melt the most fusible substances. But we do not know the actual temperatures at which water can carry the various metals. They may be soluble in temperatures much below 
that at which dyke stones will melt. The very fact that they are deposited argainst lavas, proves that they can be carried at a lower temperature than that at which the dykes stones can be melted.

It remains to be noticed that dykes do not generally show much evidence of gas action. We cannot regard this element of force as the principal power at work in their injection. Were it a very generally efficient cause, our dykes should show us the blebs or gas centres which are so common in volcano lavas. These are manifestly wanting in the greater part of our included lavas.

To sum up the most important part of these propositions concerning included lavas in a few words, we may say that there is good reason for suspecting that they are in many cases indigenous in one particular series of metamorphic rocks; that they are derived from the most easily molten parts of the section, $i$. e., the very siliceous beds; that they may extend upwards or downwards from their point of origin; that they are in the main impelled into the position where they are now found by a combination of the pressure of the superjacent beds and the formation of a vacuum by the opening of a fissure; and, finally, that they differ from volcanic ejections in the absence of a powerful escape of gas, which in the volcanic outbreak is the agent that forces the ejected materials to the surface. 



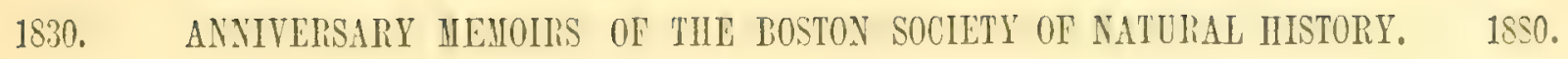

\section{THE GENESTS}

OF THE

\section{TERTIARY SPECIES OF PLANORBIS AT STEINHEIM.}

BY ALPHEUS HYATT.

BOSTON:

PUBLISHED BY THE SOCIETY. 1880. 



\section{The Genesis of the Tertinky Species of Plaxoris at Steinnem.}

\section{By Alpheus Hyatt.}

TIIE following work arose from the interest excited in my mind by the brief account of the Steinheim fosils, given by Dr. Ililgendorf, in the "Monatsbericht d. K. Prenss. Akardemie d. Wissench. zu Berlin," for July, 1866. My attention was attracted to this paper soon after its publication, because, if true, it was the only reliable statement of the theory of evolution, which could be considered a demonstration of the practical applicability of that doctrine to the life history of any considerable series of animal forms ; and as by previous studies I had tried to prepare for the appreciation of such problems, it was with a feeling of most intense pleasure that, in 1872, I found myself in the neighborhood of this famous locality.

Through the introduction of Prof. Fraas, of Stuttgart, I was enabled to make my investigations and pursue my studies with every facility. During the first visit, as the time was limited, and it was somewhat late in the autumm, the work was confined almost wholly to the survey of the pits. A hole was dug in the Old Pit, down to the dark brown clay which forms the base of these deposits. Specimens were collected in abundance, by the bag-full, without regard to what they might be, and secured on the spot in paper loags and boxes containing labels, inclicating, hy a prearranged system of notation, the precise level from which they came. Not anticipating any new or original results from the work, I was simply careful to obtain ummixed samples from every stratum and the intermediate partings of limestone. After the return to Camnstadt, where I was then residing, a large part of my leisure during the winter was spent in sifting the material, picking out the shells, studying and drawing with a camera-lucida the different varieties, making one hundred and eighteen drawings in all.

The process of examination was conducted as follows: 'The bags were opened one at a time, according to their formations. The contents of each bag was sifted by a series of three graded and nested sieves, made for the purpose, over a large plate or basin. These allowed only the fine dust to escape into the dish. All of the four lots, thus divided according to their sizes, were examined at each operation, and the shells found secured in pill-boxes, marked with the same label as the bag; after each bag was finished a general examination was made, and the species of each separate bay compared with others, even if they came from a spot only a foot or a few inches removed.

In this way the greatest attainable security from any accidental mingling was obtained, and the contents of separate bags, even from the same formation, were never mixed until 
they had been thoroughly studied. The small size of the third sieve of the sifter also secured a very thorough examination of the sand, so that I think almost every one of the thousinds of shells brought home, except some of those of very small size, such as young, etc., really passed once if not oftener, under observation.

In my opinion, this method, in such cases as that at Steinheim, is far superior to the ordinary one of examining formations and collecting therefrom such specimens as strike the eye. Such collecting is langely governed by the preconceived ideas of the collector and he camnot, however honest, avoid seeing by preference, and involuntarily selecting the things which are forecast in his own mind. There is also great danger that he will be content with any evidence which fills out his ideal, and stop short of the discovery of the exceptions, which, though few in number, are essential to the verification of his logical conceptions.

Illustrious examples in all fielis of science are involuntary witnesses to the truth of these remarks, and show also, that even repeated observation and mechanical means cannot always correct the personal equation or eliminate the errors arising from this source. My effort has been to use such clumsy mechanical means as the present state of zoölorical seience perunits, and of the success of these, others must be the judges; in this case the writer can only appear appropriately as an advocate.

My studies led me to think either that Dr. Hilgendorf had made the most serious mistakes with respect to the stratigraphical position of the forms, or that I had collected them without sufficient care. Determined to leave as little risk of error as possible, in this respect, I again visited Steinheim early in the following spring, as soon as the snow began to leave the ground. Though this time, as before, almost continually suffering from adverse weather, I succeeted in collecting larely. The old hole was reopened in the Old Pit, widener, and specimens again collected. Another hole to the northwart, hut within the limits of the pit, was sunk to the Jura clay. A hole wals also dug in the Little Pit, but not so successfully, owing to the rainy weather, which rendered the work of undermining the sand dangerous. In the East Pit, although a more persistent attempt was made in two places, the abundance of water rendered it too difficult to go beyond the limits shown in the section. The Cloister Pit was dry, but here I did not deem it necessary to go deeper than was essential for the development of the upper series of formations. The most exact measurements were made upon the face of every stratum, and quite a number of sketches showing the position and character of the limestone partings and sandbeds. In fact, every possible precaution was taken to insure accuracy, so far as the work went. ${ }^{1}$ The plotting of the sections consisted of the reduction of the measurements to one one-hundredth part of those actually taken, and are approximately correct as shown in the table of the Geological Sections.

As remarks have been published which show that some importance is attached to the length of time actually spent by me at Steinheim, it becomes necessary to state, that it was about five weeks in all : once two weeks, and at another visit three weeks. Where such earnest controversy exists, as that to which the Steinheim shells have given rise,

1 No collections were made from the limestone partings during the second visit, except where these contained alditional forms. Such a collection would have been too bulky for transportation. and I found by careful examination of cach limestone layer, that no additional information was obtainable, except in isolated instances. 
such points as these are seized upon by one or the other of the contending parties, and magnified iuto importance. Short as my stay was, it was quite sufficient for the githering of bitgs of simt, each contaning humlrerls of specimens from every layer which I saw, so that the positive facts stated were proved, some of them by repeated instances. This account is given priucipally in order to enible others to juntge as nearly as possible how much weight theoretical opinions may have harl in governing my results. Fur the same reason also, I have preferred photographs to drawings. The distinguished draughtsman, the late Mr. Sonrel, to whom Prof. Agassiz and others owed so many of their most beautiful plites, has ascisterl me by his advice, and has photogriphed the first three plates in a manner which will be appreciated by all who have attempted to deal with such difficult subjects. The remaining plates were made by Mr. Black of Boston, who took the greatest pains to produce good results. The shells were mounted upon pieces of slate with cement, and then enlarged by the camera. This, though not large enough in the first three plates to show all the characteristics of many of the smaller forms, is still sufficient for the immediate purposes of this memoir. The remaining plates are on a larger scale, and give the separate series and their theoretical relations more in detail. These contain true $P$ l. levis, from Undorf, sent me by Prof. Dr. Sandberger, and the clo-enes of the revemblances between these and the pit forms is thus shown. Those who camot creslit the evolutionary hypothesis, are ardrised to try to separate these out from the rest of the form: on plates $1-T$, without previously consulting the names of the species, and then to compare results with the descriptions of the plates.

Useless repetition has been avoided, and the nine hundred and fifty-three specimens photographed, and twenty-eight drawn with the camera-lucida, a total of nine humdred and eighty-one, do not by any means exhibit all the variations. Each one was selected after having been landled, examined, and claswed with its congeners many times. The principal varieties were all previously drawn by myself, with a camera especially constructed for the purpose, before the present plan of figuring by the wholesale was thought of, but none of these are reproduced in the plates.

In spite of previous experience, I had hoped to find a perfect demonstration in the concrete of the theory of the transmutation of species. That I was rightly and legitimately disappointed in this, I have endeavored to point out in the chapter on the geology of Steinheim. The Pit deposits certainly do exhibit the fullest, and perhaps one of the most complete series of genetically connected forms, which it is perhaps possible to obtain, but there is here, as well as in the adjacent limestones and in those on the rim of the basin, a deficiency of data, which no explorations can make absolutely perfect. It is my wish to be here fully understood, not as meaning that there is any deficiency of observable facts. On the contrary, the varieties are so abundant, that it becomes difficult for the impartial investigator to avoil becoming hopelessly confuser, but notwithstanding this excess of riches, the record is and must ever remain exceedingly incomplete. An infinitule of details are necessarily alswent, the animals themselves must ever remain unknown, and we are forced here as elsewhere to construct our genetic tables upon theoretical grounds, which must necessarily change from day to day as knowledge progresses. 
The adoption of the name Planorbis, was made after due consideration of the different views advanced, but especially after a close study of the affinities pointed out by Prof'. Sandberger, in his renowned work on the "Land-und Siiswasser-Conchylien der Vorwelt." The name of Valvata does not seem to apply, for two reasons; the entire absence of the least remnant of an operculum, although $I$ searched for this part with a microscope in the loose sands as well as in the limestones; and the peculiar aspect of the striae of growth which are curved, even in the unwound forms, instead of being annular, as in the Valvata forms.

The affinity with Carinifex, which Prof. Simulberger insists upon for most of the series, does not appear to me so close as that with many species of Planorbis. His authority with regard to a matter of this sort would naturally and rightfully have more weight than mine, but he describes $P l$. Steinheimensis, and some other forms, which I am entirely unable to separate from the carinated varieties or species, as members of the genus Planorbis, whereas the remainder appear under the generic name of Carinifex. 'The young of Carinifex Campbelti, the only form I have been able to obtain, either from the Smithsonian Institution, the Museum of Comparative Zoölogy, or any of my correspondents, is entirely distinet in form from most of the young forms of $P$. discoideus and $\mathrm{Pl}$. trochiformis, though to others it bears a very close resemblance. I am not at all surprised that Prof. Sandberger should join the two in view of this similarity, but on account of the evident connection of $P l$. trochiformis with $P l$. levis, I cannot support him in this conclusion. In my opinion, it must be regarded as a similarity produced in the shell of distinct animals in widely separated localities.

The nomenclature adopted for the various forms, is similar to that of Dr. Hilgendorf's, in so far as the main forms are represented by distinct names, generally the same as those proposed by him, with the omiscion of the name "multiformis." and the internediate forms are designated by two names placed one above the other, thus steinheineusis. In this way the derivation of these forms ant their intermediate character is conveniently expresed in one and the same term. I have used the binomial nomenclature instead of the trinomial, because the latter is clumsy; and I can see no reason for the prevalent practice of designating under the same specific nane all forms which may be joined by intermediate forms or by the study of their development. It is evident, that all of the principal forms of the $P l$. trochiformis series differ from each other quite as much as the universally recognized and distinct species of the main body of the genus. If they had been found in different localities, there would be no hesitation in describing them as species. A binomial nomenclature, therefore expresses exactly the sense which it is considered desirable to convey, namely, that the forms dealt with in this memoir are, as compared with others of their own group, of specific value, and ought, from a taxonomic point of view, to be so considered.

In conclusion, it seems essential to add, that, in spite of the great care taken at the time the explorations were made to render the evidence as perfect as possible, many things were necessarily neglected. Thus a fuller exploration of the Valley Rocks, especially with regard to the relations of the Cloister Ridge Rocks, and the Pit Deposits can only be attained by these or similar means. Doubtless Dr. Hilgendorf's forthcoming memoir will supply many of these deficiencies. Nevertheless, the existence of a Lower 
Steinheim Period, underlying the santy strata of the pits, can he approximately proved, and this renters the task of acenuting for the origin of the forms in the pits less difficult. It removes the question of the origin from an ancestral form with equal umbilici, a single variety of a species, as figured by Hilgentorf; to that of evolution from several distinct varieties of one species with unequal umbilici, $P l$. levis Klein, which is, after all, only a form of $\mathrm{Pl}$. oxystom ; and also gives a greater allowance of time for the production of the forms.

In order to enable the rearler to contrast the theoretical views of Dr. Hilgendorf and those given in the first chapter of this essay, and on Plate 9, the following table is appended, copied from Dr. Hilgendorf's paper, above quoted.

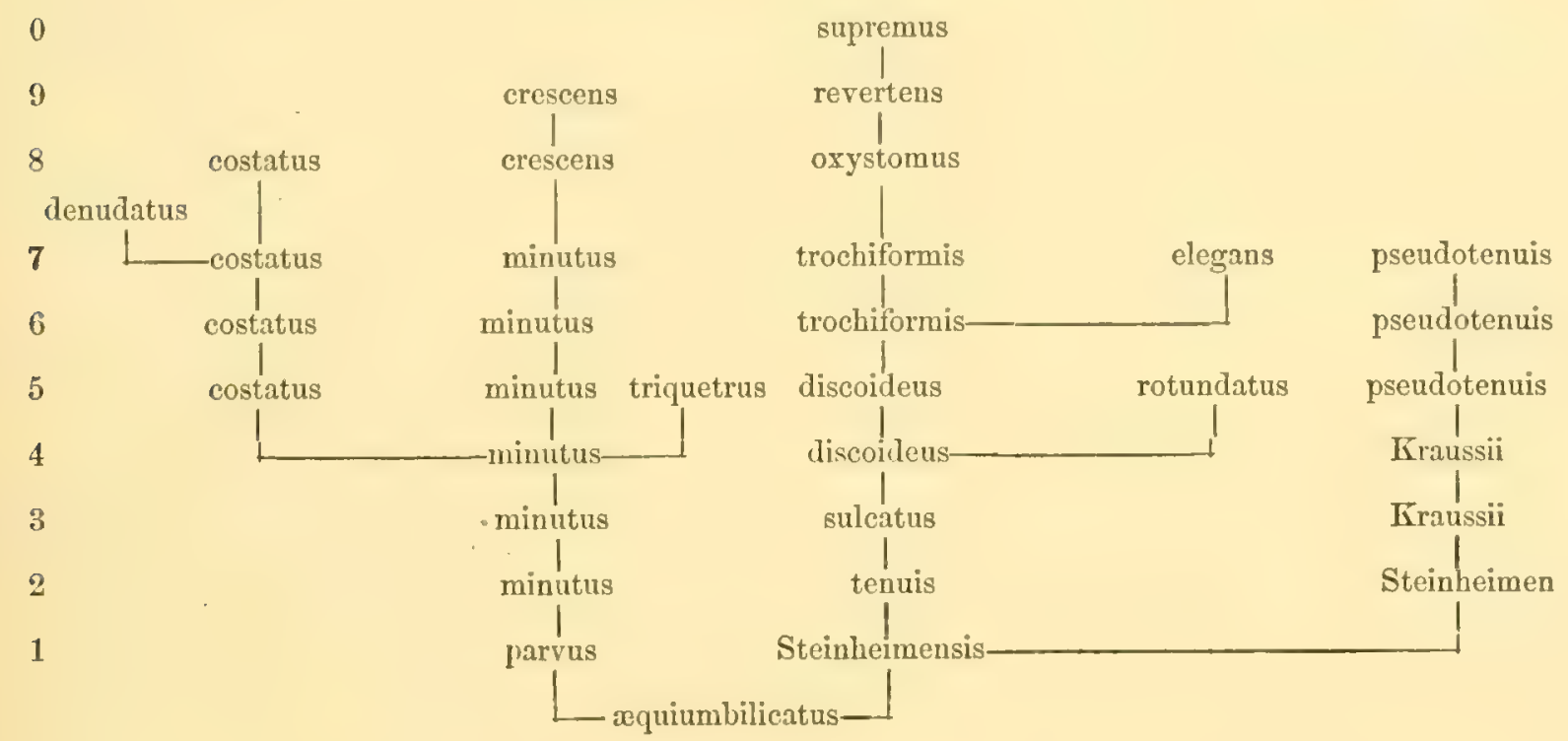

That Dr. Hilgendorf found these forms in these relations can hardly be doubted; his reputation and the thoroughness of his' explorations I do not call in question at all, nor do $\mathrm{I}$ in any sense doubt that he and others found the $P l$. Steinheimensis at lower levels than where I found them in my explorations. Our differences rest wholly upon a series of facts which have evidently been treated by two distinct methods. of research, and have led to different results. But it will be observed that these differences are not irreconcilable. The fact being that I require more evidence than is found in the Pit Deposits to prove the genesis of the Planorbis trochiformis, ont of $P l$.

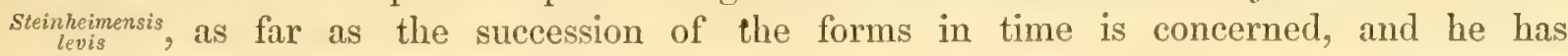
accumulated an immense mass of ficts, going to show that the Pit Deposits are all sufficient, and contain the whole history of the series. This question, and other's comnected with it, are discussed in the following pages, and it only remains for me to express my earnest thanks to Dr. Hilgendorf for a valuable series of his type specimens and for his courteous frankness in sending me accounts of his work while in progress, and to regret that he has not yet published his last researches. Dr. Sandberger has also treated me with great kindness, and I have to thank him for material assistance, especially for specimens 
of Pl. levis, without which I could not have continued my work. The owners of the Pits in Steinheim were uniformly kind and obliging, as were all the persons with whom I came in contact at that place, and the accomplishment of my explorations rendered easier and much facilitated by them.

\section{General Retations of the Series.}

The genealogical series illustrated on Plate 9, are constructed in accordance with facts discussed in the chapter on the "Descriptions of the series," hut they also possess certain peculiar characteristics of their own, which require explanation.

A glance will indicate what the main assumption is, that all of the forms found in the Pit Deposits are the direct descendants of four varieties of a species, which is taxonomically the normal form to which all the primordial forms of the four series can be referred. In other words this form, $P$. levis, stands at the focus of all the affinities of the four series, and is related to them in such a manner that we can only explain the arrangement of the facts by supposing that this is the ancestral form from which they sprang. The geological position of $P$. levis also justifies this conchusion with regard to all the series, since it is a common form in the adjoining Tertiary rocks, as is admitted lyy all authors.

These series, having heen the result of no preconceiver plan of arrangrement as far as the author could judge, were considered to be approximately natural, and were assumer to be a reliable hasis for working hypotheses, in spite of the fact, that no certain data with regard to succession in time were obtainable, except in the case of the supposed ancestral species. This assumption rests largely upon well known laws of hererlity, such as these, that an animal found to repeat the stages of another animal of a closely allied species in the young, with the ardition of new characteristics in the adult, may be considered to be either a lineal descendant of that species, or of some form common to both; that in such cases as these, whether the forms or species oceur mixed on the same level, or on different levels, there is but one natural arrangement, which has been illustrated on Plate 9.

Such an arrangement in a diverging series can also, by varying the primal norm or starting point, be used to represent the relations of a brood of individuals, or a species, or a number of species; in fact it is precisely the same as Darwin's diagram of lines liverging from a point of origin; and after seventeen years of investigation I am entirely unable to propose any fundamental improvement in this mode of presenting natural affinities. It represents with the same accuracy the parallel succession of characteristics of the individuals, and also the parallel reproduction of similar forms in varieties, species and larerer groups, having as approximately determined by their intermediate forms, embryology and structure a common origin. It represents also the relationship in time of groups upon rlifferent levels in geological history, and their parallelisms and differences. It represents these relations equally well for retrogressive, or progressive series according to the values we may assign to each line, and can be made to coincide with the true time ratio or relation in time of all the forms. 
It scems, therefore, no improbable assumption that the four series, if they answer all the requirements, are natural series, and that the living forms they represent, once had the relations here approximately depicted, and that, though the relationship in time has not yet been cleared up, it is probable that these forms did originate from each other in the succession assigned to them in plate 9. ${ }^{1}$ It will be understood by all intelligent readers, however, that this, like all other arrangements, is an intellectual generalization from the facts and only, as stated above, an approximation to the natural order in which the animal probably occurred, or was evolved. For example, the different series did not occur as they are placed upon the plate. If the greological succession had been confirmed as first laid down by Hilgentorf, then the true relations in time of the different forms would have been given. Thus instead of placing artificially the representative forms, nos. 10 and 5, on the same level as is here done with these and others, they would have probably been on different levels, representing corresponding differences in the time or formation in which they occurred. The representation or similarity of form, however, would have remained unchanged, and all the deductions here drawn from such comparisons.

I make no pretence of originating this method, nor can, so far as I know, any one else. It has grown with the science of Natural History, and nearly every naturalist uses it more or less, whether he recognizes the ultimate meaning of gradations in their serial arrangements, or ignores them.

Theoretically, then, the normal primordial form $P$ l. levis can be considered as having had four varieties before its migration into the Steinheim lake, and as having subsequently reproduced these, or their immediate descendants in this new field. These are as

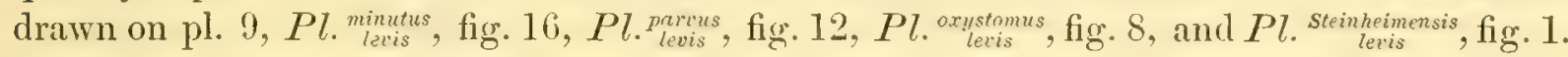
These four principal series, shown on pl. 9, and numbered in sequence 1-7, 8-11, $12-15,16-28$, were developed from these four varieties after their migration into the Steinheim lake. While the original forms on the first line had the closest relationship with each other, their descendants gradually diverged, until finally no hybrids connected the different series with each other. This is a somewhat bold assertion to make with regard to such closely allied animals as these must have been, and it may possibly be forced to give way to more complete evidence than that at present possessed by the writer. It cannot, however, be refuted except by an absolutely perfect series of intermediate forms. Tested by the ordinary methods of comparison pursued, especially by paleontologists, every one of these forms are connected by hybrids, and the whole presents to the ordinary observer a chaos of similarities and differences. The hybridity must appear not only in the adults, but in the absolute identity of the young

\footnotetext{
1 Since the above was written I have had the satisfaction of reading in a late work of Prof. Dr. Neumayer an unreserved confirmation of a precisely similar investigation with regard to the Arietes, a family of Ammonites occurring in the Lower Lias, which has been treated according to the same method. Prof. Neumayer followed the ordinary practical method of tracing the series by the graded resemblances of the adult forms, and connected the Arietes with the predicted ancestral species Fauna d. Untersten Lias. Abh. d. K. K. Geol. Reichsan'l. Bd. 7, hft. 5. Wien, 1875.
}

\footnotetext{
${ }^{2}$ This series is divided on the plate into three sub-series, $16-20,18$ to $21-24,21$ to $25-28$. This last sub-series is also divided in the chapters on the "Descriptions of Series," into two sub-series, but here these are resolved into one, this plate having been finished before the two sub-series were distinguished. For all the general purposes of discussion in this chapter, they can however be treated as a united sub-series without confusion, since the differences are entirely those which arise from the greater or less prominence of the costae or ribs, as they are sometimes called.
} 
forms, since it is frequently the case that the adults of two species are closely similar when the young are distinct.

The four main varieties, or species found in the Pit Deposits, figs. 2, 9, 13, 17, pl. 9, are not comnected by hybrids, and are distinguished from each other by a practiced eye with less difficulty than would seem possible to any casual observer, however well tramed in other fields. ${ }^{i}$ The remaining representative forms, such as 4-19 and 5-10, are also not comected, and are quite distinct in the characteristies of their particular series. The First Series, as has been stated, is as represented on pl. 9, divided sufficiently for general consideration into three sub-series. The first sub-series leads up to distortus, fig. 28, a variety of $\mathrm{Pl}$. costatus, fig. 26-27; the second to denudatus, a variety of $\mathrm{Pl}$. mimutus, fig. 21 ; the third to turbinatus, fig. 20, a variety of $P$. triquetrus, fig. 19. The Second Series is capped by $P l$. crescens, fig. 15, the Third Series by $P l$. supremus, var. turritus, fig. 11, and the Fourth Series by $P l$. trochiformis. These four series and sub-series may be classified under three beads, according to the meaning of their ontological characteristics.

A, the purely progressive series, or those in which the special characteristics of the series are developed more and more decidedly, and new ones added in each successive species or form as in the Second, Third, and Fourth Series.

$\mathrm{B}$, the purely retrogressive, or those in which the differences observed in the Pit forms, when compared with $\mathrm{Pl}$. levis, are not maintained in the progressive sense, but in which disease interferes with progress, and leads to the production of distorted variations, as in the second sub-series 21-24.

c, the partly retrogressive and partly progressive series, in which the differences are increased by the addition of certain minor peculiurities, but the forms become nevertheless distorted by disease or decrease in size, as in the first and third sub-series.

The resemblances of the forms $1,8,12,16, \mathrm{pl}$. 9, are of course due to their close affinity as varieties of $P l$. levis, those of $P l$. Steinheimensis, fig. 2, $P l$.oxystomus, fig. 9, and $P l . m$ immlus, fig. 18, belong, however, to a distinct species, and must be considered representative forms. They belong, in two cases, to 2 and 9, to progressive series, and 18 to the partly progressive and partly retrogressive third sub-series.

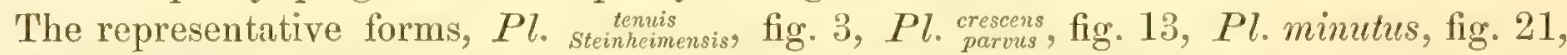
and $P l$. castatus fig. 25, have even closer resemblances in outline than the original four varieties of $P l$. levis, and yet, on account of the absence of hybrids or intermediate forms, are unquestionably more easily distinguished from one another, than these four original varieties. The same observations apply to $P$ l. tenuis, fig. 4 , and $P$ l. triquetrus, fig. 19 ; Pl. discoideus, fig. 5, and Pl. supremus, fig. 10 ; Pl. $\begin{gathered}\text { trochifirmis } \\ \text { discoidtus }\end{gathered}$ fig. 6, Pl. supremus, var. turritus, fig. 11, Pl. triquetrus, var. turbinatus, fig. 20.

\footnotetext{
1 In justice to myself it ought to be remarked, that the method pursued in drawing the different figures on pl. 9, was as follows: Each series was picked out without reference to the formations, merely to show the zoological relations. After all were drawn with the camera-lucida, no transfers were permitted, therefore the shells are all reversed. This defect, however, was considered preferrable to the risk of errors sure to occur in any attempt at trans-
}

fer by tracings, or otherwise. After all the figures of each series had been made, they were arranged upon a dark brown tablet. I had but a slight suspicion even of the remarkable nature of the ontological relations here described, until the final arrangement of the figures on the plate had to be considered and carefully studied, in order to show as many of the natural relations of the species and series, as possible. 
Figs. 5-10 and 6-11-20, at first sight do not seem to be very close; but if we

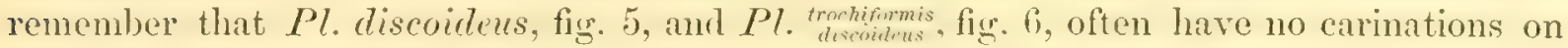
the lower side, and if we compare these and such forms as are figured on pl. 2, line c, fig. 1-6, with the sulcated forms of $P l$. supremus, the resemblances will be seen to be quite as close as in other representative forms. Here also there can be no doubt of the absence of hybrids.

$P l$. trochiformis, fig. 7, stands alone in spite of its general resemblance to denudatus, fig. 24, because the similarities to the latter are not exhibited in the form and characteristics of the whorl itself, but are simply such as any spiral shell might have to any other allied form, with a similar spiral mode of growth.

This tendency reaches a climax in both the second sub-series and the Fourth Series, and thus, though $P l$. trochiformis and denudatus (trochiform variety, pl. 9, fig. 24), have very distinct whorls, the general outline of the whole shell in each is similar. This is especially the case when we compare an old or distorted $\mathrm{Pl}$. trochiformis, pl. 2, line r, fig. 10, in which the last whorl is partly unwound, with denudretus, in which the young whorls are also closely wound, and the last whorls only open. This peculiarity has a distinct meaning from that of the representative characteristics described above, and will be diseussed farther on.

At present it will be better to concentrate attention upon the representative characteristics in the progressive series, (Second, Third, and Fourth Series). As has been said above, we can readily account for the production of representative forms on the lower lines, because these are really one and all but slightly different from the four original varieties of $P l$. levis, and resemble each other necessarily on account of their close affinity, though not joined by hybrids. But how can we account for the fact that still more divergent forms, which follow and which have less affinity with $P l$. levis, should resemble each other, species for species, with such remarkable closeness? New modifications are introduced in these species, which are not present in the original species. These new characteristics consist of alterations in the forms of the whorls, and the advent of sulcations, accompanied by a more decidedly asymetrical mode of growth. These modifications could not have been inherited from Pl. levis, since they did not exist in that species, nor in the lower representative forms, pl. 9, figs. 2-9-18.

These considerations enable us to separate the representation in the parallel series into two kinds, that which occurs by the inheritance of a similar form and characteristics from the parent form, $P l$. levis, and that which results from the introduction of new characteristics in each series, which are similar to those produced in corresponding forms in other series, and which could not have resulted from intercrossing of the different species in the separate series.

Two of the progressive series, the Second and Third, present us no forms strictly parallel or representative to $P$. tenuis, fig. 40 . This can be readily explained by the fact that these series retain with great pertinacity the characteristics of the varieties of Pl. levis, from which they sprang. The Second Series remains smooth and devoid of sulcations, though the outer side of the whorl becomes angulated in $P$. crescens. The Third Series retains the gibbous form of the under side of the whorl, and does not flatten the whorls at all, as in $\mathrm{Pl}$. temis. Nevertheless, the general tendency to increase the 
asymmetry of the spiral, and to introduce decisive sulcations and carinations, finally asserts itself, and eventually produces representation. Thus, Pl. supremus becomes very similar to some of the varieties of $\mathrm{Pl}$. discoideus, and $\mathrm{Pl}$. $\begin{gathered}\text { trochiformis } \\ \text { discoideus }\end{gathered}$, particularly to those forms which either retain or revert to the smooth character of the under side first observed in Pl.levis. This Third Series also fails in producing any modification comparable with Pl. trochiformis, fig. 7, for the same reason, because of the preponderance of its inherited peculiarities. Thus, although the last whorl is very asymmetrical, and quite similar in shape to trochiformis, the young internal whorls are peculiar and always have an upper umbilicus, and are therefore enveloped by, rather than elevated above, the outer whorls. This condition is frequently excessive in Pl. levis, and is the natural result of the discoidal mode of growth during the early stages of the shell. ${ }^{1}$

These facts, when viewed as a whole, show that the progressive series are all more or less parallel, and may be said in general terms to have the following succession of form, First, a universal tendency to increase the spiral; equivalent to the deepening of the lower at the expense of the upper umbilicus, thus eventually producing more or less trochiform shells. Second, the forms are modified in the following succession in each of these series, starting from (1) the smooth forms, there occurs (2) a gradual increase in the flattening of the sides of the whorl, both above and below, accompanied by (3) the introduction of longitudinal sulcations and (4) carinations.

There is, then, in spite of the diversity maintained by the differences, which have arisen in the original progenitors, and which continue to be inherited throughout all the members of each genetic series, certain uniform tendencies which have led to the genesis of certain similarities in the form and even in the minor characteristics of the species in different series. Farther than this, it may also be said that these uniform tendencies, as expressed in the spirality of the growth and the introduction of new characterstics, have a certain uniform succession.

The phenomena, therefore, indicate the action of some general cause which controls the tendency to variation first observed in the varieties of Pl. levis, and brings about a certain uniformity in the production of forms and representative characteristics in each progressive series.

The First Series and its sub-series are also subject to the control of the same law so far as the tendency to increased spirality is concerned, but in other respects they deserve special consideration. The similarities of the lower representative forms, figs. $25,21,18$, are evidently accounted for in somewhat the same way as those of the progressive, viz.: they are close to the point of origin. Unlike these, however, they are so nearly related, that the hybrids or intermediate forms are numerous. It will be observed that they possess the flat form of whorl also found in the Second Series. We are on this account able to compare figs. 25, 21, with 13, and Pl. costatus, fig. 26, with $P$. crescens, fig. 14. The representation of $P l$. major, fig. 27,

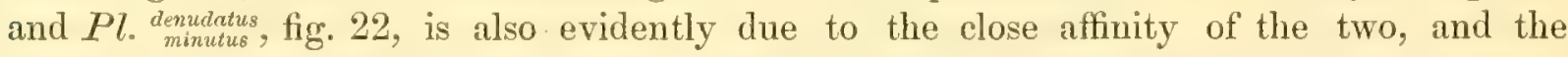
tendency of the whorls to become uncoiled and to degenerate in outline generally, as may be seen by observing the apertures of the shells. Fig. 28, Pl. costatus

\footnotetext{
1 There are, however, forms much more like trochiformis line 1, fig. 4-11, but of these no full grown ones seemed than fig. 11, see $P l$. oxystomus, var, rotundatiformis, pl. 3, any closer than the one figured.
} 


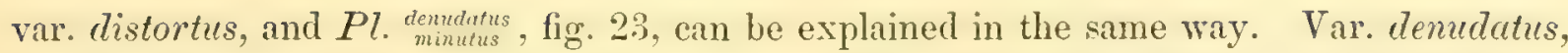
fig. 24, crowns one sub-series standing alone, as did also the remarkable $P$. trochiformis, the latter as the extreme of the progressive series, and the former as the extreme of the retrogressive series.

These sub-series are not all purely retrogressive. The second sub-series is almost wholly so, because it does not ard a single new character to those observed in $P$. mimutus , except the tendency to form a spiral. It goes steadily without a break, from the closest coiled, smooth, discoidal form of the latter, to the extreme spiral, trochiform, and partly uncoiled denudatus, and remains throughout diminutive in size, smooth and with a cylindrical and extremely embryonic form of the whorl. The first sub-series, however, while it agrees entirely with the second in the size and form of the whorl and shell, and the tendency to increased spirality, nevertheless adds a new characteristic, the enlarged transverse striations or ribs, and increases in size in some species, as in figs. 26 and 27.

Thus only the second sub-series is almost entirely retrogressive, and yet both the first and second have diminutive shells, and the first has also diseased forms, which present a tendency to uncoil the shell. This last characteristic is only observable in isolated instances in the species of the purely progressive series. Thus it occurs as figured on pl. 8 , line a, fig. 1, to an incomplete degree in the extreme old age of $P l$. Steinheimensis; and for a similar reason in a very large $P$. tenuis, pl. 1 , line $\mathrm{k}$, fig. 11 ; in $P$ l. discoideus, in different degrees, pl. 1, line $\mathrm{g}$, fig. 10 ; line $\mathrm{i}$, fig. 6 ; as a pathological condition of the individual either due to wounds, disease or premature old age; in Pl. oxystom to a most extraordinary degree as figured by Sandberger, and to a less degree in figs. 7, 8, 9, line p, pl. 3. These instances, however, are very instructive, since in fig. 8 , the scars of severe wounds are apparent on the shells, whereas figs. 7 and 10 exhibit no cicatrices, and are evidently the result of some weakness caused by disease in the animal ; in Pl.trochiformis, pl. 2, line r, fig. 10, and other specimens as previonsly described, it occurs as the result probably of some disease. PI. 8 is especially devoted to these senile and diseased specimens, which will be described more fully further on.

The uncoiling of the whorls must therefore be looked upon as a sign of weakness in the animal, and as the result of pathological conditions, whether these be normal as in the final retrograde transformations of advanced senility and disease of any kind affecting the adults and young; or traumatic and abnormal as in the cases cited where wounds and other accidents may have caused disease in the animal, followed by a weak condition in which the usual increase of the shell by growth could not be maintained. Therefore there is the strongest reason for calling the second sub-series a purely retrogressive series, and the first partly retrogressive, since not only do they show retrogression by the size of the species, and their failure to produce comparable series of new and varied forms with newly introduced characteristics, but they show common variations, which can be compared with the pathological variations and metamorphoses of the shells of individuals of the progressive series. It will be observed by all who read this memoir attentively, and study the plates especially, that these uncoiled forms do not occur, except in the cylindrical whorled forms which are transitional from $\mathrm{Pl}$. minutus to denudatus and distortus, and this cylindrical characteristic is decisively retrogressive. It can occur only in those individuals which do not inherit 
the more flattened and more involute whorls of the full grown $P l .{ }_{\text {lezis }}^{\text {minus }}$, but retain throughout life with very slight changes, the cylindrical form of the very youngest stages of that shell. Like the mncoiling, it indicates the weakness of the anmals, which fail in the power of growth and cannot continue even the normal rate of increase in the size of the shell which distinguished them in their later stages, and adult condition.

It is very evident, however, that all of these retrogressive characteristics cammot be considered as pathological in exactly the same sense as the results of individual cases of disense among the progressive species. They here affect three entire series of forms which exhibit their impaired natural powers in various degrees, in one series as has been shown, mingled with the advent of new characteristics, and in another, the third subseries, so completely subservient to these new characteristics, that the forms become representative, notwithstanding their derivation from $P l$. minutus and decrease in size, with those of the progressive series.

The gradations and the numbers, and perfectly normal aspect of these shells as regards their thickness, external markings and so on, as well as the increase in size noted in first sub-series show that we must look to some canse which has affected their entire development and lessened their powers of growth, finally leading through heredity to evidently normal and general distortion. The retrogresive sub-series of the First Series, furnish therefore, a very sharp contrast with the picture presented as a whole by the purely progressive series.

In the Second, Third and Fourth Series, there is a purely progressive tendency towards increase in involution, in size, in spirality, and in the addition of new characteristics. In the retrogressive sub-series on the other hand, there is a progression in some respects, and a retrogression in others.

The progresive characteristics are, however, but feebly manifested. Thus the decrease in size from $P l$. levis to $P l$. minutus, fig. 18 , is the most marked characteristic, and after that the increase in size is confined to the normal members of the costatus group, the finely costate and the coarsely costate shells, which are similar to fig. 26 , and lines $h$ and $k, p l .4$. The distorted forms corresponding to these, figs. 22-24, 2s, pl. 9, and lines d, e, f, g, k, pl. 4, are nearly all small, and these are more numerous in the first or costate sub-series, than the larger shells. In the third sub-series no increase in size can be truthfully predicated, as may be seen on pl. 4, lines a, b, c, though in these forms as has been stated, there are carinations and sulcations, and slightly turbinate forms produced, which are decidedly progressive in these characteristics. These facts seem to show clearly that each sub-series has a history of its own in which both progressive and retrogressive tendencies are active in different degrees.

The tendency then to produce forms steadily increasing in spirality, is the only progressive characteristic common to all the series shown in the table, and is evidently a prepotent characteristic of all the Steinheim species, as it is in fact of most of the divisions of the shell-bearing Lamellibranchiata, Gasteropoda, and Cephalopoda.

Eliminating this characteristic and laying it aside for future consideration, let us now turn to the very evident selection which has been exercised between the retrogressive and progressive characteristics of the different series and sub-series. It has been shown, that 
the retrogressive characteristics of the first and second sub-series could be compared with the pathological conditions, normal and abnormal, of occasional diseased and senile individuals of the progressive series, but that they were distinct as far as they showed that whole series were affected. They were therefore spoken of as the results of normal pathological conditions of the animal, which were inherited with ever increasing effect in successive species, occasioning distortions and retrograde metamorphoses, and finally leading to the extinction of the race.

In the same words we can formulate the life history of a diseased individual, since, as has been shown, a similar series of changes are produced in the forms and characteristics of the diseased individuals of the progressive series, and that these, though in a more confined field, are identical in their results, leading also to the death of the individual.

In the individual the effects are shown in the disturbance of the laws of growth producing abnormal or premature weakness; or in the natural exhaustion of the powers of growth, causing senility. A wound and its results, whatever they may be, can unquestionahly be so classified, since it is primarily a severe shock to the system, which lays additional burdens upon the powers of growth, and is usually followed, if severe, by retrogressive metanorphoses, or premature old age. ${ }^{1}$ Senility and its accompanying metamorphoses also fill under the same law, though here there is no accident, and we must refer it to the action of well known physiological laws. Thus, when the powers of incremental growth during the life of any individual reach that point at which actual increase in the size of its organs is no longer perceptible, physiology teaches us, that the organs are maintained in size and the performance of their functions by an arlequate supply of nutriment; but that, after a time, the individual becomes mable to digest sufficient food to supply the waste occasioned by the performance of its functions. Then, that those peculiar transformations take place, consisting of the loss of functions and the gradual decrease in size and entire or partial absorption of parts and organs, which constitute what are called the retrograde metamorphoses of old age.

Senility, therefore, simply expresses the normal wearing out of the powers of vitalized tissue to sustain itself against the perpetual friction with the disintegrating, wasting, and ultimately unfavorable effect of existing physical surroundings. When we compare these effects of unfavorable enviromment in producing distortions and decrease in size of the individual, with the corresponding distortions and decrease in size of the retrogressive sub-series, there is a certain similarity which leads to the supposition that the latter are also probably due to an unfavorable environment. In other words, that the continuous action of unfavorable environment upon a race, eventually prorluces variations in form and characteristics in the successive but genetically comnected species, which show that their growth not only as individuals is interfered with, but that the distortions and retrogressive characteristics thus produced tend to be inherited, and affect the whole series of forms.

We are justified, therefore, in assuming, that in all probability the sub-series were retrogressive, because the environment in the Steinheim lake was so unfavorable; that the

1 The exceptions in which additional normal characteristics or abnormal ones are produced are very rare and can be disregarded. 
physical causes represented by that term acted upon the organization of the animals unfayorably, occasioned a weak pathological condition leading to deterioration in size, and to the production of senile-like characteristics and deformities, and the final but gradual extinction of the different sub-species. In other publications I have used the term geratology, and shall employ that same term here to indicate such correspondences and such phenomena.

Having met the question of the general retrogression in size and form, by the hypothesis of an unfavorable enviromment, the question naturally arises, how shall we account for the progression of the progressive series? How then could this environment act upon such closely allied shells, in such an opposite way as to cause the decease of some races and be entirely healthy for others?

We habitually refer such questions among animals, and in man, to the immate strength or pliability of the constitution of the race or the individual, and account for the survival, growth, and development of races and individuals by this reference to their supposed ability either to resist change in their surroundings, or to become modified in accordance therewith.

This principle is one of the hest established results of paleontological research. It is founded primarily upon the perpetual dying out of races in geological times, simultaneously with the close of formations and the incoming of closely-allied, but modified forms in later formations. It is sustained by the existence of persistent types which resisted change to such a degree, that they are but slightly modified through long periods of geological time, although passing through revolutions in the enviromment which destroyed the larger proportion of their allied forms. It is sustained by the advent and comparatively short life of those forms, which suffer greater modifications in each successive formation. Among living animals it is a matter of daily experience to find some races incapable of enduring variations in the surroundings, to which others rearlily accommodate themselves, and even thrive under. Precisely the same environment, therefore, may produce results diametrically opposed to each other, even upon different individuals of the same species or closely allied forms, provided there is anything in the constitution either directly acquired or inherited, which enables the organization of one to resist or fit itself to conditions which the other camnot healthfully enclure. It being therefore a matter of fitness or unfitness of the organization, a question of inherited or acquired power and capacity, which we can refer to the constitution of individuals, species, or races, we must now inquire, whether there are any signs of greater strength to encounter, or ability to accommodate themselves to change manifested in progressive series. The facts already stated show this. The individual shells are larger, stearlily increase in size in the successive species of each series, and show distortion only in isolated individuals as the results of disease, or only in the very advanced age of others equally exceptional. This latter fact is very curious, and would be puzzling if I had not already been familiar with the extraordinary fact, that many animals have no old age ; e.g., Amoeba, most of the Insecta, and probably most of the Crustacea. Old age, in fact, being the result of an exhausted or outgrown organization, it can only take place in animals which have complicated organs, and which also live so long, or use them so actively that they become worn out by perpetual effort to sustain the waste occasioned by their surroundings. The absence 
of well-marked old age metamorphoses in most of these large shells, is therefore another sign of the innate strength of the progressive series.

The progressive series are. therefore, not persistent but variable types, and consequently we can consider them as possessing a capacity of adjusting themselves to the changes in their environment, which affected the retrogressive series unfivorably. The reference of these matters to the organization itself as a primary standard is farther sustained by the behavior of each of these series.

Thus each series is distinct from every other in the amount of change which it exhibits, and in the partly retrogressive series we see the contention of two oppusing tendencies. The representative characteristics, the sulcations and carinations, and increasing involution of the whorl, are equally with the increase in size and spirality, marks of strength. If so, the third sub-series exhibits most decidedly this battle of the tendencies, and assuredly the first sub-series, where the size is temporarily increaterl, is a still stronger instance of a similar kind.

Here we appear to have a display of energy or force which probably did not arise in the retrogressive species themselves, but was inherited from $P l$. levis, and we see it in these races unsuccessully resisting the deadly influences of the unfivorable environment. 'These races, therefore, present in this respect, as well as in their forms, changes which may be compared to those in the life of any individual of the progressive series, which passes through a full series of changes or metamorphoses; that is, one which has not only a series of young and adult progressive changes, but also a series of retrogressive or old age changes.

If we analyze the phenomena presented by such an individual, we find, first, that it is smooth, discoidal, and in a word similar to $\mathrm{Pl}$. levis; then that the whorl shows a flattening taking place above and below, with an increase in the amount of involution, and in spirality; then sulcations begin to appear, and longitudinal carina, then as it passes its adult condition, and is affected by disease or by old age, there is a tendency to suppress the longitudinal carinations, and substitute more prominent coste or transverse lines of growth, to decrease in size, and destroy the spiral. All of these last are changes attributable to weakness in the organization of the animal. The prominence of the transverse costa is due to longer periods of rest in building up the shell, and the consequent accumulation of shelly secretions at intervals; the decrease of the size in whorl self-evidently to the same cause, and this also accounts well for the loss of symmetry in the spiral, which can only be maintained by a constant increase in the building up of the shell. Here we perceive the same contest of tendencies. There is the inherited strength of the constitution building up the organization in size. and in all its progressive characteristics, and resisting functional waste. There is then, in all outgrown specimens, though to an unappreciable degree in some, a retrogression, and in others a well marked retrogression, in which the functional waste overbalances the supply of nutriment, and the organization loses its progressive characteristics in a series of retrogressive changes. The contest is decided at last as it must always be, in favor of function, the representative of physical forces, which exhausts, conquers and kills by continuous friction. Thus, we can readily understand that each of these series, whether progressive or retrogressive, can so far as its collective life is concerned, be compared in the closest manner with the life of an 
individual, and similar correspondences be traced in both, and also that the tendencies exhibited are of two kinds in each, one towards a building up of the organization, and the other directly opposed to this.

We cannot understand these remarkable concordances between the changes shown in the succession of the forms in allied or genetic series, and the metamorphoses of the individual, unless we can attribute them to a similar cause. The fact, that during the growth of the individual, the increase in bulk, and all increments, whatever be their nature, must be due to an excess in the supply of nutriment over and above what is needed to repair the waste of the body, alone shows that there is a force at work within the organization. The action of this innate power of the organism therefore is fundamental, and lies at the base of all changes whatever, except the strictly retrogressive, and it becomes evident that the sane force which causes growth also occasions all progressive changes.

It is sometimes the case that, as in the third sub-series, the force described produces a series of progressive characteristics without increasing the size; but this, and also the very frequent decrease in bulk of full grown animals when compared with their larval forms, as in many butterflies and moths, etc., and in some frogs, may be accounted for by the greater development of furctional activity. The phenomenon is similar to the stunting of the growth of an animal by the too early and powerful use of its organs. The growth power is nsed up in the assimilation of the formative material for the new parts produced, and their functional waste is so great that there is no material for increase in bulk.

If we apply the presence of this unknown power or force within the animal to the explanation of the characteristics of the series, we are struck by the ease with which all the phenomena of parallelisms are resolved. By reference to the laws of growth and development the naturalist is able to explain why it is that all the forms and modifications on the progressive grades, show similarities to the metamorphoses of the growing intividuals; why all the forms of the descenting grades compare so closely with the senile metamorphoses of the individual; why it is that some series, like some individuals, have no pereeptille and others have a very complete series of old age metamorphoses; why all the forms and characteristics of the procressive series succeed each other in similar order in every series, occasioning the reproduction in each series of an independent but similar parallel series of forms and characteristics; why it is that there is a similar succession in the development of the characteristics in each representative species; why it is that different tendencies, one towards the production of progressive, and the other towards the production of retrogressive characteristics, can appear in the retrogressive series in different combinations or quantities according to the series; why it is in fact that the whole series of modifications in the group and its series, can be approximately compared with the life of one individual. The uniformities of series of animals as compared with each other then become like the uniformities observable in the growth of closely allied individuals, like their parallelisms in growth and in old age or disease, all due to the force of the inheritable constitution, enabling the animal to take advintage of farorable surroundings for a time, or to resist the effects of its unfavorable environment more or less successfully. In all cases the individuals and its series must change by growth along certain lines of modifiation, which it is but reasonable to suppose we shall some day be able to map out beforehand for a series of forms with the same precision that we can now forecast the metamorphoses of any given individual in a given species. 
'The parallelisms of the species or forms in the different series are, however, produced by characteristics, which, as we have noted above, are not inheriterl from Pl. levis, anrl could not have been inherited from any previously existent species, since they originate independently in the forms of each series. This condition of affairs casts doubt upon these unqualified statements of the paramount influence of the forces of growth as stater above, and leads to the following questlon: Are these parallelisms adaptations, and can they possibly be attributed to the direct action of the uniform external environment upon the forms of the different series? This can hardly be answered in the Steinheim locality, but still there are indications that here, as in other groups, these parallel characteristics are not due to similar inorganic influences. The lower forms probably arose in the First Period if my observations are correct, and only a part of them, the $P$ l. trochiformis in the Fourth Series, the forms of the First Series and its three sub-series during the Second Period, in the pits, and those of $P$. crescens in the Second Series were evolved, during the same time. It does not appear, then, that the inorganic influences, which were probably very dissimilar, if we can judge by the deposits, during these two periods, could have been the cause of the representation. Fortunately, however, the phenomenon of representation is quite common in the animal kingdom, and we can look elsewhere for a solution of this question. I have described a large number of species of Ammonites, and in no case was it possible to attribute the independent production of similar forms in distinct series to the action of similar physical environment. On the contrary, the most remarkable cases of parallelism took place frequently in series occurring in different formations and distinct faunae, just as the remarkable parallelism of the Marsupials with the rest of Mammalia. The unquestionable case of the Marsupials of Australia, ma serve as a means of estimating the effects of the environment. While this certainly cannot be said to determine either the growth of the individuals in parallel lines, or to be the cause of the production of the parallel forms, it may nevertheless be essential to the full exhibition of both phenomena.

It must be remembered that in the Marsupials we have, probably, the lowest mammalian type, as well as the oldest, and the greater number of representative forms which we now find in Australia, are characteristic of the present period, and they are not found in the fossil European, nor in the existing or fosil American forms. There is, then, something peculiar in the environment in Australia, which makes it possible at least for these forms, which represent Rodentia, Carnivora, etc., to be produced there. It is evident that, if the land had already been possessed by these classes of typical mammals, or if they had not belonged to the base of the mammalian stock, no such expansions of the marsupial type would have been possible. It required these two elements; the growth force of a basic mammalian type and room for it to grow and reproduce, or a free environment. This was the case also in the Steinheim lake. Planorbis levis is an immature or low form, the field into which it entered was free, and it developed all it, latent growth force, in order to fill it with species. In the same way the Ammonites did not exhibit their greatest expansion until after the lowest competing type, Nautilus, having expended its growth force in the Carboniferous, began to die out.

This hypothesis then would attempt to account for the production of so many similar forms in distinct series, simply by the fact, that the series had room to expand, or to grow 
and reproduce to the fullest extent in this field; that they did so in precise accordance with the laws of growth, and the succession of characteristics in the individual. This is very crident from the fuct that Planorbis exhibits no such tendencies in other localities where it is surrounded by competing forms. It has become plain probably to the "begeisterte Darwinianer" by this time, that this is in fact an application of the law of natural selection, but he will also see that it is accompanied hy such important modifications, that. it is reconciled with the laws of growth. Thus it may be said that the struggle for existence, and the survival of the fittest, is a secondary law grafted upon laws of growth, and governed by them in all its manifestations.

The law of natural selection, as generally understood, assumes in the first place the existence of an animal type, of its descendants, and of a tendency to variation (indefinite and mulimited) in every one and all of there descendants. from which (an indefinite and unlimited) selection may take place during the struggle for existence between competing forms destroying the weak and permitting only the strongest and fittest of these variations to survive.

The truth is, as far as my studies have gone, that there is no such thing as indefinite or unlimited variations in any species. They may perhaps be considered innumerable, but they are not indefinite or unlimited. 'This obvious proposition, if admitted, leads at once to the question, what are the limits within which a species may vary? Making special studies for this purpose among the Ammonites, the limits of variation in the species have been found to correspond to the growth changes in an individual. Some individuals may retain a portion or a large part of their earlier developed characteristics (not embryological), some may make considerable modifications in their hereditary adult characteristics, amounting even to new additions in many instances; some may occupy the other extreme, and either as diseased individuals, or as individuals under circumstances very unfuvorable to normal growth, show premature senile and retrowade metamorphoses and distortions. This also is a picture of the grander variations of any large or small group of Ammonites, and of the present group of Planorbis. Pl. levis may vary from the equiumbilicated discoidal form, to the unequiumbilicated form similar to $\mathrm{Pl}$. oxystomus, or the more depressed whorls of $P l$. parrus, and each of the varieties may have minor sub-varieties founded upon innumerable minor differences in the spiral, more or less angular outer sides, and so on, but there is evidently a well defined law in their development. The variations consist in the retention of the earlier or young form with no additional progressive characteristics, or if these are added they consist of modifications or exaggerations of some part, found more or less developed in other forms, whether these oceur in the lakes of America or other continents.

It has already boen shown that the representative forms were divisible into two kinds. Those whose similarities could be accounted for, because they differ very slightly from Pl. levis, retaining in part its form and smooth whorls, and those subsequently produced which were new in the Steinheim lake, and, that the former, which are due to the retention of ancestral characteristics, are replaced by the latter.

Thus the equiumbilicated discoidal form is lost entirely in $P$. tenuis, $P l$. triquetrus, and $P l$. crescens, except in the young of some specimens. In Pl. discoideus, it is not even found in the young which are asmmetrical at all ages. except perhaps the young- 
est zones of growth in the shell. This decrease is evidently brought about by the prepotency of the newly introduced tendency to inçrease the spirality, and develop the square form of the whorl and the sulcations and carinations.

The retrogressive series, as may be readily seen, have an increase in the adult retrogressive characteristics, which obeys the same law; the farther removed the species is from the original form the less it is apparent, either in the romg or in any of the adult forms. Thus, in following up the series we find, that in any one form during the adult stages the representative characteristics displace the ancestral characteristics in inverse proportion to the affinity of the forms in which they appear for the ancestral form.

This law is applicable even to those resemblances occurring between the forms of the old and young, such as have been traced between the oldest and youngest stages of the individual among the Ammonites, by D'Orbigny and the author, and by many authors hetween Baculites and Orthoceras. These resemblances are accompanied in these cases, as in man, where there is considerable resemblance in the form of the body and the parts at the extremes of life, by entirely distinct structures, and are evidently due to the partial or entire absence of parts and organs. In the young this is found only before or during the stage of development in the parts; in the old however, only after or during the stages of absorption of the parts. 'The retention of the cylindrical or semicylindrical whorl in the adult of demdatus and distortus, are precisely comparable with such geratologous characteristics. 'The extreme young are closely coiled and similar to the young of $P l$. levis, and the subsequent aspect of the shell is brought about by retrogressive changes counteracting the normal tenclency of the growth. They are not arrests of development, but geratologous metamorphoses. True arrests of development and reversions, if the latter can really he separater from the former, are precisely the exceptions which are needed to show the uniformity of the law under ordinary conditions, and its subordination to unfavoralle or extraordinary external conditions.

This law is equally applicable to the parallelisms of individuals of the same brood, same variety, species, genus, or family. The differences which appear in the individual adults, and which distinguish them at this stage from their own young, or their own embryos, are for the most part those which show their affmity to other individuals of the same brood, variety, species, genus, and family.

These new or differential characteristics replace those of the earlier stages, which, as is well known, are inherited from ancestors, who, with the exception of animals having the larval stages much prolonged, have first acquired them during growth in their adult stages. In fact, one cannot understand such series as are here shown, or as may be constructed from a study of the affinities of animals, when arranged with a due regard to the embryology, geological surroundings in different formations and occurrence in time, and their adult characteristics, without assuming continuity of descent. This being granted, all observations show that one and the same general law covers all series, whether retrogressive or progressive, namely, that the representative characteristics of the individuals and their differences in structure at the adult stage are inversely proportional to their relative removal in time, and the surrounding conditions or environment, from the egg or from some assumed or observed parent type. 
It is impossible to construct a series and begin to investigate the causes of the origin of the forms without assuming continuity of deseent, and the action of time and changed conditions in modifying the organization, as has been done by morlern experimental zoologists.

If this position is the true one, then similar physical causes acting through similar periods in time, upon the same or different genetic series of animals, ought to produce results or modifications in which not only the action of time and the enviromment upon the animal, but also the reaction of the laws of heredity and growth, would be distinctly manifested. This has seemed to me to be the case among the Steinheim series, and among the Ammonites, and to account for the sudden appearance of geratologous resemblances, arrests of development and rerersions, all of which are pathologrical; and due, like other pathological conditions, to unfavorable surroundings.

There are two extreme classes of cases which might be considered exceptions to such a law, one class embraces what paleontologists call persistent types, and another those curious parasites, which like the Epizoa and others among Crustacea, or the parasitic Vermes lose in the adult a portion or nearly all of their typical characteristics.

The persistent types are such animals and their fossils, as in Lingula, Nautilus; Iyrmecobius among mammals; Ceratodus among fishes; and a host of other forms, which exhibit at the present day very nearly the same forms as those of the same grenus found in Paleozoic or Mesozoic time. Even if this statement be doubted, as it may reasonably be with regard at any rate to the Lingulæ, as stated by $\mathbf{M r}$. Dall, and with the Nautili, there still remains the fact that these types are persistent, or do not present any modifications of their organization at all proportionate to the changes through which they passed. Paleontologists have noted these peculiar and remarkable instances. but failed to call attention to the fict that many groups present a greater or less number of species which can be classed in the same category with these more noted examples, and that, after all, this is not an uncommon phenomenon.

Almost every group of Ammonites contains such species, and I have tried to show in previous publications that all of these persistent species or forms were among the lower, or earlier occurring, members, or more embryonic forms of the groups to which they belonged. When taken in conjunction with the fact that none of the extremely persistent forms exhibited geratologous transformations, these facts appeared to show that the reason why time and changing conditions had no more effect, was due to the enormous power of reaction in the organism itself, its growth force, which enabled it to withstand the action of the shifting enviromment, and to adjust itself to these changes without materially morlifying its own organization. Such a case is also presented here, and it is $P l .{ }^{\text {lerrus }}$ leris,$P l$.oxystomus, and $P l$. Steinheimensis which have the greatest range in time, and are found in all the formations.

If it be true that growth force has anything to do with the life of a series, as it has to do with the life of an individual, then there ought to be some common ratio between the power of reproduction in the series and in the individual, and between the life power of these persistent types and the point at which they sprang from the ancestral tree. In fine, if growth force has any meaning at all, and has, as is here claimed, an influence upon the life of a series in the same way that gravitation acts upon the 
heavenly bodies, determining the morphological cycle of their successive species. then types could only be persistent when they sprang from a point of origin near to the source of the whole group to which they belong. The instances of persistent types are all of this character, as far as I know them, and preëminently what Prof. Agrassiz would call embryonic types, when comparing them with the higher organisms of their own group.

The greatest contrast with these is afforded by the parasitic types, which vary from those which are in the fully adult condition, still recognizable as Vermes, Crustacen, Mollusca, etc., to those in which all the type characteristics are obliterated in the adults, but still preserved in the young, and finally to those in which the type is difficult to recognize at any period. Of the first classes there are many examples, of the second fewer, and of the third very few illustrations.

A large portion of the Epizoa among Crustacea, Entoconcha anong Mollusea, Linguatula among Arthropoda. are fumiliar illustrations of the second class; while Gregarina and Taenia, may posibly helong to the last, to which some of the males of several genera of the Cirripedia make a near approach.

It is difficult to escape from the conclusion, that the loss in the adults of the alimentary canct and other parts and organs, which are found in the young of the second class, must be attributed to the parisitic enviromment; no other adequate cause whatever has as yet been presented, and the loses take place in those parts which are especially affected, and become useless on account of the parasitic environment namely, the alimentary canal, limbs, the shell, etc. In these cases, we can only account for the second and third classes, by supposing that the differences arise from the greater or less completeness of the parasitic mode of living, which time and habit have increased, until the environment finally conquered the tendency of the growth, and of the laws of heredity to repeat in the young the inherited characteristics of the type. How fast, or how slowly this was accomplished in specific cases, is not the question, but simply whether there were two opposing forces at work, one represented by heredity and growth, and the other by physical causes or the environment, and I think this assumption is highly probable. With regard to the third class of cases, it would be difficult to determine whether they represented distinct types in the animal kingdom in some cases; but the gradation which is presented in the males of Cryptophialus anong Cimipedia, where the young are almost as degraded in organization as the adults, shows that the environment has acted either throughout a long time or quickly and effectually, so as to destroy the type characteristics even in the earlier stages.

This would then be an extreme exhibition of the power possessed by physical causes to alter the primitive organization, and in fact $I$ do not see how we can otherwise account for this result when we look at the results of modern research and the serious modifications produced by the experiments of Schmankewitch upon Artemia and Branchipus among Crustacea, of Cirl Semper upon Lrmmeus among Mollusca, and of Siebold and others upon Batrachians.

But although this power be granted in the abstract, and as a corollary of all the relations of animals to their environment, the fact remains that under all but the most extraordinary conditions, animals maintain their type characteristics. They show this by 
growing through a series of stages in the young, which repeat more or less fully the adult characteristics inherited from their ancestors, and hy producing series of new forms, more or less parallel with those of other congeneric series, which are also new, or in part the direct result of inheritance from the parental type form.

Thus, although it may be said that the environment, which here consisted of an unoccupied field, or one which may at least be inferred to have been unfavorable for the growth of other competing shells, was favorable to the fullest expansion of the type, nevertheless the precision with which the series were evolved, and their concordances camnot be explained by any hypothesis based solely upon these influences. Agrain, if this be doubted, and the uniform action of the uniform environment be assumed as possible, then how account for the manifest differences arising in the primary $\mathrm{Pl}$. levis, and becoming hereditary in the series. These characteristics are not representative, but essentially differential, in fact the only ones which in the lower forms indicate affinity, and enable us to begin to thread our way through the complicated labryinth of represen-

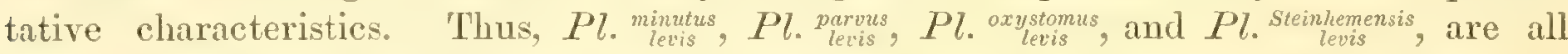
more or less distinct and possess certain differences which are subsequently increased in each of the progressive and in some, but not all of the retrogressive series.

Thus, $P l$. parvus has the sub-acute outer side of the whorl less perceptible than in $P l$. parvus, but it is a distinction constant in the series. Reversions to $P l$. levis might of course, and probably would, occur, if we could know the facts by the actual experiment of hatching broods, but these would only add strength to the present proposition, since they would only be adults retaining the form of the young, which until a late stage, even in $P l$. crescens, is identical with $P l$. levis. $P l$. ${ }^{\text {oxyystomus }}$ levis has the narrow umbilicus and gibbous whorls in the lower side of some varieties of $P l$. levis, and we have only to consult the plates to see how persistently this is maintained in $\mathrm{Pl}$. supremus. $P l$. Steinhemensis has the form of whorl of the more angular and flattened varieties of $P l$. levis, with a tendency to increase this to an excessive degree in Pl. discoideus.

But here a curious interference is observable. An apparently retrogressive or reversionary characteristic, the gibbous or rounded and smooth character of the under side of the whorls described in many of the $P l$. discoidens, appears, and is increased in the successive forms causing so close a resemblance to $P$ l. supremus, that a derivation of that form from these was actually traced out by Hilgendorf. I have shown, however, that this is probably erroneous, and that they are in distinct genetic series.

All of the changes of form in the First Series as previously pointed out, are representative, so that the only characteristics which can be compared to the class now under discusion are the prominent costa, and the small size of the whorls when considered as one series.

Having now this peculiar category of characteristics before us, it is easy to see that they represent the essential differences of the weries, and are quite distinct in their nature. They are permanent when once introduced, and essentially progressive, or rather cumulative, in each series, except where they are modified by the introduction of some prepotent representative or reversionary characteristic, as in Pl.trochiformis. ${ }^{*}$

1 Though even here they are present in the early stages of all forms with one exception (the variety with rotundatus like young). 
They arise as differences and remain differences, and have at no time any value as representative characteristics. They, however, appear in the same forms as the representative or parallel characteristics; and the question now arices, can they al:o be reduced to the control of the same law of succession in the series and in the individual?

Evidently there is no such succession, for if we take an individual out of any of the series, and attempt to show this, we are met at once by the insuperable difficulty that there is nothing to compare it with in other series. These characteristics, therefore, present themselves with remarkahle clearness, as increasing by heredity throughout the series, or as in the case of the Fourth Series increasing only in a certain number of species, and being then partly stuereded by an evidently prepotent tendency in the remainder of the species to revert to the rounded form of the whorl, or they are absent as in the geratologous series, the second sub-series. Here, I think we have the key. The geratologous series, if the comparisons made above are approximately correct, owes its purely retrogressive character to the disadvantageous nature of the surroundings, and in these the differential characteristics are not developed, while in all others they are developed in precise proportion to their rank as progressive series. Thus in the first subseries, the fine crowled costa or the enlarged widely separated costa or size, form alone the progressive characters of the series. In the third sub-series, the development of the third carination is decidedly progressive, as is also the serial difference of the Second and Third Series, and even the Fourth as far as it goes.

Not only do these differential characteristics as a whole progress, or increase, but they are progresive in the differences, which they present within each series. That is to say, that the gibbous underside of the whorl in $P l$. suprems is only a little more gibbous in $P l$. supremus than it is in $P l .{ }_{0}^{\text {oxystomus. }}$ levis . The whorl of $P l$. parrus is more angular in $P l$. crescens, the flattened lower side of $P l .{ }_{\text {Strinhmensis }}^{\text {leris }}$ still flatter in $P$. tenuis and $P$. discoideus, the costre of $P l$. costatus are largest in var. major of the largest size. There is then uniformity in the way in which these differences of the series act, they are all progressive, but their progress in each series.consists alone in their increase in intensity of expression or size in each series. Thus their uniformities are in the strongest possible contrast to the uniformities of the representative characteristics. These do not agree with each other in the same series, but have their uniformities in the representative forms of different series, whereas the differential characteristics have all their uniformities in the same series, and do not agree with each other in different series. The increase of intensity in each series is, as above stated, directly proportional to the more or less progressive character of the series, being nothing in the exclusively geratologous series, and most intense in the most progressive or Fourth Series.

If, therefore, the alsence of the differential characteristics can be accounted for by the action of disadvantageous surroundings in the second sub-series, it becomes evident that the existence and permanency of the same cliss of characteristics in other series must be due to the selective action of the same surroundings. This conclusion can be farther sustained by the great increase in size of the First Series, or most progressive or differential one, and the gradual decrease in size of each series towards the left of plate 9. Proportionate size and weight are acknowledged by physiologists as the most 
reliable basis of estimating relative health of individuals, and, other things being equal, the favorable or unfavorahle character of their surromdings. These facts and the peculiar reversions of $P$. trochiformis in some of its characteristics, appear therefore to be perfectly well accounted for by Darwin's theory of natural selection. In no other way can we possibly account for the selection of but four out of the varieties of $P l$. levis, and the continuous propagation and increasing intensity of the differences which they exhibit. An examination also of the figures of the nearest allied forms of $P l$. levis, such as $P l$. Steinheimensis, will show any one how many variations are lost in each form or species of the series, and how few are continued. This can only be accounted for upon the supposition that those which survived posisessed in some way advantages indicated by their peculiar variations, which enabled them to propagate those variations, and suppressed their less fortunate neighbors.

It is impossible to imagine any uniform inorganic cause acting upon the comparatively coustant organization of $P$. levis, and producing therefrom a number of radiating series, genetically distinct from each other, and with all the other marks of independent constitutional and hereditary traits above cited, unless we allow with Darwin a basis of original, constitutional differences indicated by the tendency of $P$ l. levis to vary. Then it is easy to see how the physical enviromment would cause a selection to take place in the differential characteristics of the varieties, and how the same causes continued, would permanently fix the farouble differences in the race or series, causing it even to increase in intensity until another change, as in $P l$. arsmideus, might cause selective alteration of the original differences, or even a reversion of these.

All of these consiclerations when taken together appear to show that the following propositions may be considered as reasonable:

(1.) The extraordinary modifications and series of shells found at Steinheim are in one way exceptional, and owe their existence to exceptional conditions.

(2.) These conditions appear to be the isolation of the modified descendants of $P$. levis, due to the absence of competing types, and the character of the environment.

(3.) This environment was suitable for the propagation and perpetuation of the distinctive peculiarities of three series, and unfavorable in various degrees to those of the sub-series of the First Series.

(4.) That while the perpetuation and survival of the differential characteristics can be thus accounted for, we must look to other causes for the production of the parallel forms and the regularity of succession of these forms, as shown in the arrangement in the different series, and in the development of the individual.

(5.) That this cause lies in some law of growth and heredity which reacts against the tendency of the physical environment to produce variations and differences, and produces parallelism in the development of different individuals of the same species, of different species in the same series, and in the succession of forms in the different series, and also limits the tendency to variation within definite boundaries in the species, especially in $\mathrm{Pl}$. levis.

(6.) That while the influence of the environment must be admitted as paramount in exceptionable instances, it for the most part produces these exceptions in extreme cases of parasitism, and the Steinheim shells are not parasites, and cannot be assumed to have been 
under similar influences in respect to the laws governing the size and genesis of the series, they ought, therefore, to come under the same laws as other forms occurring in other localities.

(7.) That this appears to be the case except in so far as they are a very limited group, confined to a very limited field, a field free from competition, and extremely favorable to their growth for that and other reasons.

These conclusions heing approximately arrived at our next inquiry is very naturally, what is this law of heredity and growth which maintains the type, causes parallelisms and constrains variation under ordinary conditions, but still, in certain cases, is forced to give way to physical influences.

Ruling out the lost or transient forms which are not perpetuated we see that the fundamental law here, as elsewhere, is that all the characteristics are inherited after they are once introduced.

Our first inquiry, then, must be as to the mode in which they are inherited. Is there any law which embraces this class of phenomena in some general statement?

In former essays, especially written for this purpose, I have tried to show that there was such a general law which is so plain and simple that I have wondered that no authors have made it the basis of investigation except Prof. Cope and myself.

In every series of animals which I have studied the same fact appears, namely, that in a given number of generations inherited characteristics of every kind tend to appear in the descendants at earlier stages than that at which they first occurred in the ancestral forms. Whether characteristics are normal or abnormal, provided they are fixed in the race either by the action of natural selection or by the direct working of physical causes, they are inherited according to this law.

Though led to this discovery, if it is such, by close observation of small series of Ammonoid forms, I have since applied it, with greater or less success, to every series of animals which have come under observation, and in fact it is a corollary of the doctrine of evolution.

The law of Biogenesis which is now quite generally adopted in Europe, though long since used habitually by the students of Prof. Agassiz ${ }^{1}$ in this country, and regarded by them as an essential basis of investigation, leads naturally to a search for some such uniformity in the inheritance of characteristics as that described above. How can an animal in its transient stages of growth resemble the permanent adult characteristics of ancestral forms without the action of some such law?

A negation is not proof, though so often regarded in that light, nor is it proof that in some individual cases a disease or characteristic is inherited later in the life of that particular individual. These instances, and they are not very frequent, are exceptions, and this investigation simply shows that the ordinary action of this law, which has been called the law of accelerated development or acceleration by Cope and myself, has been interfered with by the action of external causes. The only proof against it must be of such a character as that upon which it is founded, namely, the investigation and published description of some genetically connected series of closely allied species, which do not develop in accordance with or verify its provisions.

\footnotetext{
1 Prof. Agassiz did not give bis law an evolutionary called "Hæckel's law" in Europe. application nor a name, Hrckel did both, and it is now
} 
A general and confused conception exists that certain characteristics either appear "in utero", or tend to be inherited at earlier or later periods in the life of individual descendants, and, then becoming fixed in the organizations, are transmissible at corresponding stages, and also, that in sone way, some of these characteristics become fixed in embryo, and thereafter are invariable for that particular division of animals.

The law of acceleration appears to me at present to show the manner in which characteristics, which are perpetuated, finally either disappear or become fixed in the young, or even in embryo. This conclusion may be followed out by any one who will arrange a series of animals or their shells, according to their adult affinities and their developmental characteristics. He will then see that adult characteristics which are introduced in ancestral forms, tend to reappear at earlier and earlier stages, as he travels along the series.

Though it is perhaps impossible for us to trace any type back to its beginning, and thus substantiate this law for the truly cmbryonic characteristics, the conclusion is inevitable that if it is a true expression for the mode of inheritance of any series of animals, it was probably also true for their ancestors.

Why, then, the invariability of the embryonic form and characteristics, as among the Ammonoids and Nautili? The explanation appears to me to present no great difficulty. All perpetuated characteristics when crowded into the younger stages, and tending to appear at younger and younger periods, must either replace the original embryonic form and characteristics, or be crowded out by the constant incoming of new characteristics, which are continually being originated and tending like them to be inherited by the law of acceleration.

Embryonic characteristics are subject to great variations, under the action of corresponding changes in the environment. Witness the different degrees to which parasitism has encroached upon the type characteristics of the males of Cirripedia and of the Epizoa, shortening the periods during which the young show their typical Crustacean forms and characteristics, and the inference becomes almost irresistible, that Trenia has lost its original type characteristics at all stages of development by the same process.

In what other way can we describe this as taking place, except by the law of acceleration, by the earlier and earlier inheritance in successive generations of differential characteristics first introduced in the adult stages of their ancestors by the influence of the parasitic environment?

It is evident that suitability to the parasitic mode of life determined the selection of these crustacean forms, otherwise we cannot understand their being found in such habitats, or the pliability of their organization, or the fact that their young are locomotive, and seek out the hosts in which we find them when full grown.

In the same way we cannot understand the disappearance of perpetuated characteristics in the young except on the hypothesis that they have become useless and are absorbed to make room for the new ones which are inherited from later ancestors. They are met on the one side by the embryonic type characteristics, which are the last to give way even in the parasites, and on the other by the action of the law of acceleration, and they must disappear or become embryonic. But room for them in the embryonic stages does not appear to be found, except perhaps to a very limited degree. This we know from the 
comparative uniformity of these stages wherever they have been observed, except in a few extreme cases above described, and their almost exact parallelism in different individuals of the same type, and by the observations of Barrande, Chalmas and the author among the embryos of fossil Trilobites, Ammonites and Nautili.

Why, then, are these embryonic characteristics usually so invariable, ${ }^{1}$ and why do they resist even the efforts of the parasitic environment to crowd them out by the action of the same law of heredity by which they first became embryonic?

If they first became embryonic by the action of the law of acceleration upon "the adult characteristics of some ancestral form, all traces of which are now lost, why did they not in their turn disappear?

An answer to this in detail must be deferred to a paper I am now preparing, an abstract of which will, I hope, in due time appear in the Proceedings of the Boston Society of Natural History. Here I shall try to show that this invariability rests not only upon the power of the earlier and more embryonic organisms to resist change produced by the enviromment, but also upon the greater protection from the working of physical causes afforded to the young during the earlier periods of its existence.

The environment is more uniform as regards temperature, food, and so on, in the egg, than at any subsequent period. Starting with the common origin of the ovum, I think it can be shown that the uniformity of the enviromment of the earlier stages, whether held "in utero" or cast out to take care of itself, whether carried and protected in pouches or at the breast, is not assumed without a sufficient basis of evidence. If it be granted, that there is a growth force in organisms, which is the basis of all hereclity, and which resists the working of physical surroundings, tending to preserve the type and sustain the uniformity of the organization, which limits variations and produces parallelisms, the conclusion becomes inevitable, as in the Steinheim shells and the persistent and embryonic types, that the nearer an animal is to the point of origin of its type the stronger or more potent will be all of its uniformities, and the less subject to variation from changes in the environment.

If then we can join to this any general law of uniformity in the environment at early stages, we have two efficient causes working in unison to maintain the stability in geologic time, and the invariability in heredity of existing types, as shown by the characteristics of the embryo.

Deferring the proofs of this position to a future opportunity, it only remains to add by way of caution, that I recognize in the term growth-force an expression of a purely physical cause, which is shown by the fact that organic forms can and do habitually grow in opposition to the forces of gravitation, as well as exist and perpetuate thenselves in spite of the action of physical forces of the environment, which even under the most favorable circumstances suffer them to exist but a very limited time, killing them off in inverse proportion to the innate powers of resistance, or growth force, manifested by them. I do not pretend to assume that this force is antecedent, correlative, or consequent upon the production of organic matter, I simply assume its active existence,

1 Comparative invariability is here meant, for as I have shown, Fossil Cephalopoda, Bull. Mus. Comp. Zool., vol. 3 , there is considerable variability in the earlier stages of Silurian Goniatites, as compared with the same stages in more recent descendant forms. See also H. J. Clark, "Mind in Nature," on the differences of the egg in different types, etc., and authors on the structure of the egg at early stages. 
and use the word force as all of us are obliged to do for a cause, which we can recognize, but cannot see. This battle of a force from within, against a force from without, is perhaps the strongest argument for natural selection which can be adduced. But it also shows that natural selection, even if it is as general as is claimed, is the expression for a series of results caused by the action and reaction of these forces, one upon the other.

The views of Wagner upon the necessity of isolation for the production of new forms, have specially interested me in connection with the Steinheim shells, since they show certainly the effects of isolation in an extreme case. Although the Steinheim basin is an evident exception, and although it is much more difficult to apply the law of isolation in ordinary cases, still Weismann has shown us how this can be done, and how the prevention of indiscriminate crossing, "amixie," may be called in to assist isolation in the production of new forms. This view appears to me to receive the strongest possible confirmation when applied to the differential characteristics of the Steinheim Series, since, as I have pointed out, the four species were selected from a number of varieties of $P l$. levis, after these had migrated into this isolated basin where their surroundings were favorable, and the field unoccupied. But the uniformities presented by these series appear to me to indicate the existence of other causes, which must be taken into account if the phenomena presented by them are to be fully and correctly explained.

The law of acceleration in the inheritance of characteristics is very often difficult to recognize among shells, but not fortunately among the Steinheim species. The rounded whorl of $P l$. Steinhtimensis, hegins to be confined to the early stages in the $P l$. Stcinheimensis, and in those like figs. 4-19, line e, pl. 1, which have angular whorls in the full-grown, it is found at still younger stages, and finally disappears altogether in Pl. discoideus, with some exceptions, and is replaced in the young by a form like that of $P l$. temis, fig. 4. This form is again replaced in the young of the extreme forms of Pl. discoideus and $P l$. trochiformis, by a more spiral form resembling the adult of $P l$ elegans, the whorl has the same flat, angular upper side, and rounded lower side. The increasing spirality of the adults is carried back into the easy stages in the same way and at the same time as the other characteristics. In $\mathrm{Pl}$.crescens, this acceleration is less noticeable than in other forms, but even here the inheritance of the acute, angular, outer side of the whorl takes place much earlier in $P$. crescens, fig. 15, than in the transition form, fig. 1t. In the young of $\mathrm{Pl}$. discoideus and trochiformis, all traceable derivation from $P l$. Steinheimensis is lost, being crowded out by the angular sulcatus or elegans form. This also occurs in $P l$. triquetrus var. turbinatus, fig. 20, when compared with true $P l$. triquetrus, fig. 19 and $P$. minutus.

The inheritance of strix in the first sub-scries proceeds according to the same law, but the presence of numerous hybrids makes it difficult to follow it out.

The small sac-like shell which occupies the apex, belongs to the later embryonic stages, and as such is present in mearly all Gasteropoda, except such as retain a still earlier and flatter or more open form, and all the Ammonoids and Belemnoids, and, though absent in the Nautiloids, its former presence is indicated by a scar which occupies the apex of the whorl.

I have not a sufficient acquaintance with the local peculiarities of the Planorbida in other habitats to determine whether there is any general modification in all of the shells, 
or even a majority of them, which may have been caused by the physical peculiarities of the environment, and which can be attributed solely to their action.

The tendency to increase the spirality in each series at first sight appears to be a uniform result which might be attributable to the habitat alone. But, as has been shown, this is a general tendency expressed without regard to locality in nearly all series of the Mollusca, and shows very forcilbly what the author means by the tendency of growthforce to reproduce under the most diverse circumstances similar forms in similar succession.

The well-known researches of Mr. J. A. Allen ${ }^{1}$ and other American naturalists among birds and mammals have shown that such general modification in the colors, bills, tail and wing feathers of birds, and in the pelage and size of ears and feet in mammals, do take place in given localities, and are attributable probably to certain well defined local causes, such as humidity, temperature, etc. My own similar results obtained from the commercial forms of the keratose sponges, ${ }^{2}$ and Mr. Scudder's ${ }^{3}$ in the insects, also seem to show that there are such general effects on the organization which may be separated from other categories of characteristics.

There is not the slightest reason for regarding any of the series, as purely scalariform and distorted, except the first and second sub-series. These also agree in form with the Planorbis found in the famous locality of Magnon, where the environment is evidently unfavorable to the race.

To these instances I can happily add another of peculiar interest which occurs in a marl bed at Lawlor's Lake, near St. John, New Brunswick. My attention was first called to this locality by the kindness of Prof. E. S. Morse, who sent me a lot of shells collected there by Prof. C. F. Hartt, late Director of the Geological Survey of Brazil, whose untimely loss was regarded here, as well as in the country of his adoption, as a public misfortune.

Since the receipt of these I have personally surveyed the locality in company with Mr. G. F. Matthews, a well known geologist of St. John, attached to the Canadian Survey. Residing several weeks in the vicinity, I gathered a large collection, which is now undergoing the process of sifting. The shells are all scalariform and distorted so as to resemble closely in form and aspect the third sub-series and the Magnon Planorbes, but they all belong to the genus Valvata (an unquestionable identification).

It is also worthy of remark, that a true Planorbis is found abundantly side by side with the distorted Valvatæ, so similar to Pl. levis, that I think it may prove to be identical. This is also distorted but to a less degree. It would be premature to attempt to give a description of the probable condition of the lake when the distortions were produced in Valvata, but I hope to be able to present, in course of time, a joint memoir written by Mr. Matthews and myself. It may be observed, however, that none of the distorted Valvatre now exist in the lake itself, upon the banks of which, and in immediate contact with the water, lie the deposits of marl containing the extinct shells. In all these instances of pure distortion, as well as in others observed by me in speci-

1 Bulletin Mus. Comp. Zool., Vol. 2.

${ }^{2}$ North American Poriferæ, Mem. Bost. Soc. Nat. Hist., ${ }^{3}$ Revision of Oedipodidx, Proc. Bost. Soc. Nat. Hist., Vol. 2, pt. 2, 1877. 
mens of Planorbis from this vicinity, or from the West ${ }^{1}$ there is no difficulty in determining that they are the result of the umusual and unfavorable conditions to which the individuals or races were exposed. They all show one thing, namely, a disturbance of the regular growth of the spiral, resulting in some extreme cases in the complete unrolling of the whorls.

This enables us to separate them at once from such series as are presented in the third sub-series, and Second, Third, and Fourth Series on pl. 9, and adds considerably to the evidence here produced. This question undeservedly assumed great prominence in the discussion of the Steinheim shells, at the meeting of the Naturforschende Gesellschaft at Munich, several naturalists hastily adopting the view that most of these shells were distorted forms.

I must also be permitted to point out another serious error which the retrogressive sub-series illustrate. Many investigators evidently pucture a retrogressive series as a departure from the normal form of any group, which can only be represented by a line ruming backwards, so that to them the fan-shaped arrangement of lines is not a true presentation of the affinities of any given number of series. They demand a series of radii emanating from a centre to all points of the periphery of a sphere. The utmost that can be granted to the graphic presentation of such an arrangement is a hemisphere of radiating lines. A centre of distribution being granted, that centre is a form or fixed point in geologic time, and from that we can only truthfully depart in lines of genetic descent, radiating in time upwards, or horizontally, perhaps, but never backwards.

This common sense view of the relations of affinity and time is farther borne out by the fact, that in no case are retrogressive series actual returns of forms really identicalwith those previonsly existing, unless they are the direct descendants of those forms. The Baculite is not an Orthoceras, nor is Bactrites, though they are all wonderfully similar. 'The Epizoa are never Protozoa, nor is Entoconcha a worm. Nor are the distorted forms of Magnon, ${ }^{2}$ though Planorbes, identical with their distorted brethren of the Stemheim basin, though this is a case where identity could perhaps be found, if the enviromment was exactly similar, and they belonged to the same species. If the retrogressive sub-series can be represented by lines going backwards, where are the more ancient forms with which they are identical?

It camnot be claimed that the Iagnon specimens should be graphically represented in this way, hecause they are similar to those of Steinheim; for it is evident that they are simply parallel forms. As compared with the normal Planorbis, they can be more truthfully represented by the extreme lateral line of a fin-shaped arangement of lines having a centre, in some existing species of Planorbis.

The habit of representing affinities by the sphere of radiating lines is in direct opposition to all that we know about genesis, growth, and development, retrogressive or progressive, and the relations of these phenomena to time and the surfaces upon which animals live. I may add, also, that it is rarely employed by any, but mere zoülogists.

1 U. S. Geol. and Geog. Survey of Colorado, Dr. F. V. Hayden, 1874. Report by Ernest Ingersoll, p. 402.
2M. Louis Piré. Planorbis complanatus (forme scalaire). Ann. Soc. Malacol. Brussels, vol. 6, 1871. 


\section{Geology of Steinheim.}

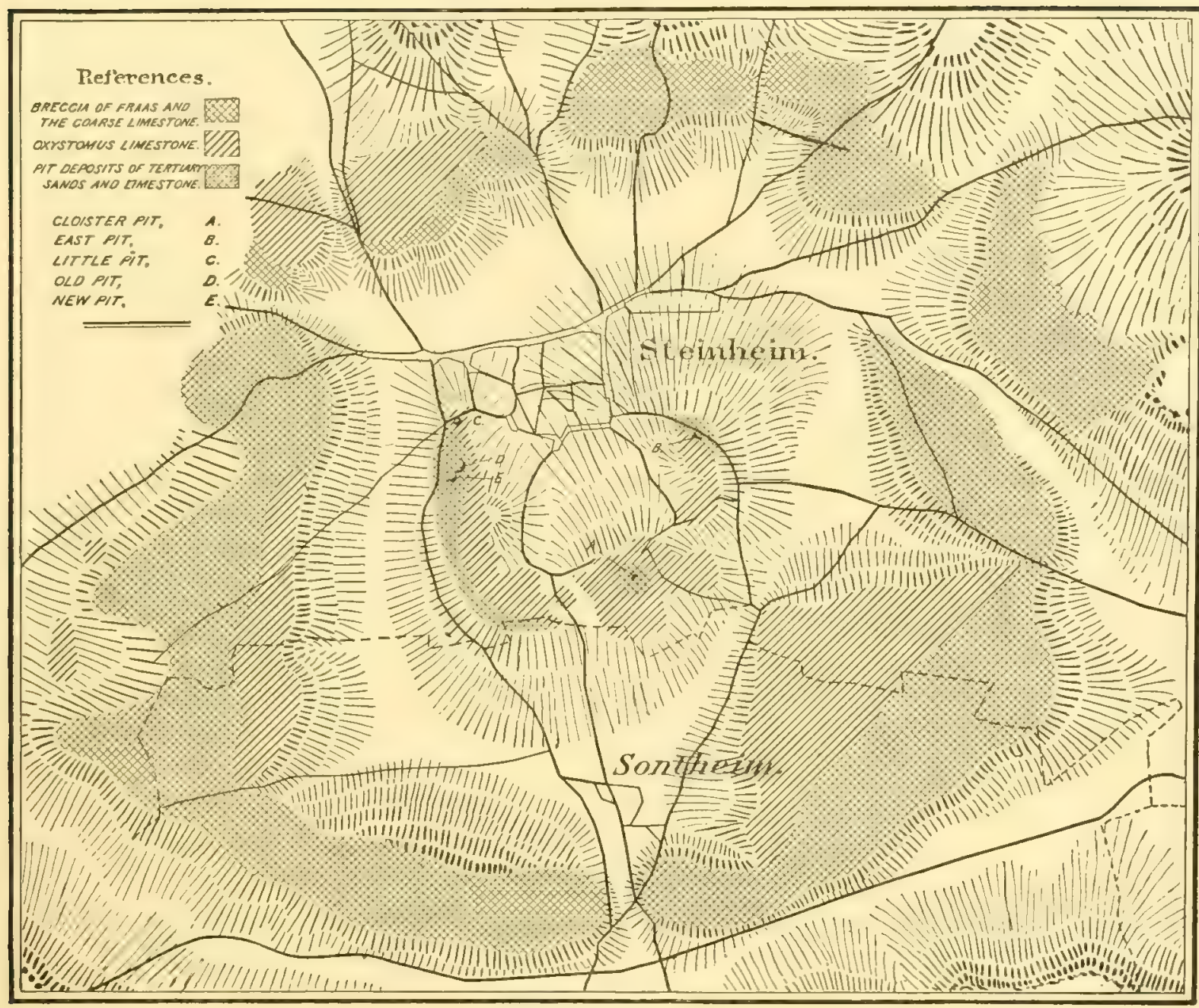

GEOLOGICAL MAP.

The village of Steinheim in the kingdom of Wurtemburg, stands at the height of about $1867 \mathrm{Wg}$. feet above the level of the sea. ${ }^{1}$ It is not far from Heidenheim on the eastern slope of the elevated plateau forming the Wurtemburger Alb. This village, from which the formations described in the following pares acquire their name, and the village of Sontheim, are situated in a valley which is circular in form, surrounding a central hill; Steinheim lying just to the north of this elevation, and Sontheim a short distance to the south. The valley externally, is surrounded by a circle of ridges more or less discontinuous where they have been cut through by the drainage of the surrounding highlands. The underlying formations of these ridges is the White or Upper Jura. Those of the central hill, where the overlying Tertiary limestones and sands have been removed by denudation, comprise representations of all the principal formations from the Lias to the

1 Equal to about 1822.5 English feet, or about 555.5 metres. 
White Jura, $A$ and $B$ included. Prof. Quenstedt and Prof. Fraas have given minute descriptions of the geology, and the map accompanying the official report of the latter to the government of Wurtemburg, is here reproduced with certain essential changes in order to illustrate this description. Though differing with regard to the structure of the underlying portions of the central hill or Cloisterberg, these investigators and Prof. Sandberger agree in considering the valley to be due primarily to a synclinal depression of the White or Upper Jura, which is the surface rock of the larger portion of the surrounding and more elevated parts of the Alb.

According to this view then, we start in our history with a more or less closed kettle shaped valley in which the Tertiary rocks, clays and sands, which form the subject of this memoir, were depositerl. These belong, according to all authorities, to the Miocene, and according to Sandberger to the upper part of that formation.

Surrounding the entire edge or rim of the liettle is found a peculiar coarse breccia of the older or Jurassic rocks, cemented together by freshwater limestone. My visits to these rocks were directed wholly to the search for the beds described by Hilgendorf as containing $P l$. aequimmbilicatus and its descendants, and therefore, the geological observations made were merely incidental. I first endeavored to find these rocks as directed by Hilgendorf on the west side of the basin, but did not succeed on account of the stormy weather and my uncertainty as to their exact position. Subsequently, and also in the face of a cold storm, I succeeded in finding two of the formations described by Fraas as occurring upon the Burgstall south of Sontheim, or "Die Landzunge zwischen dem Stubenthal und Steinheimer Thal." Prof. Fraas writes of this locality very fully, and the cursory observations made by me accord precisely with his descriptions. The Coarse Breccia lying externally, or next to the Jurassic rocks, I did not visit, but found the Coarse Fresh-water Limestone of Frans in place. This rests immediately upon and passes into the coarser and underlying Breccia, and contained only poorly preserved fossils, but by careful comparison I have been able to ascertain that they unquestionably belong to the oxystomus series. The natural sections which are abundant leave no room for doubt that the larger number of the forms have a deeper upper umbilicus than is common even in $\mathrm{Pl}$. oxystomus, and approximate more closely to the typical form of $P l$. oxystomus. There are also several moulds of $P l$. suprumus. The umbilicus is large above and deep, as in that species, and the upper ridge and sulcations plainly though slightly marked.

A fossil somewhat better preserved than others, showed in section a curious intermingling of characteristies. The last part of the outer whorl had the angular aspect of $P l$. levis Klein as figured by Sandberger. The front part of the same whorl was of somewhat blunter aspect, like $P l$. levis, as figured by Klein, the size being also about that of the specimen figured by Klein. The upper umbilicus was much shallower than in $P$. oxystomus, and the lower umbilicus wider. In fact it seemed to be a form combining characteristics of $P l$. levis, $P l$. Steinheimensis, and $P l$.oxystomus. This specimen leads to the supposition that $P l$. Steinhemensis should be regarded as a variety of $P l$. levis, a view sustained by IIilgendorf's observations, and by fifteen authentic specimens of $P l$. levis received through the kindness of Prof. Sandberger. They were collected at Undorf, near Regensburg, and contain several marked varieties. 
Eight of the specimens have exactly the form and characteristics described and figured by Sandberger. $P l$. oxystomus is represented by one full-grown specimen, with rounder whorls in the young, and only the outer whorl angulated. This leads into one full-grown specimen exactly illentical with Klein's figure of Pl. levis, with whorls somewhit flatter on the upper side, always rounded externally, and slightly stonter, so that the umbilicus is deeper. This last is supplemented by one in which the whorls become still stouter, and the umbilici on both sides perceptibly deeper, which is absolutely identical with Pl. oxystomus in the general aspect and characteristic outline of the whorl, but differs slightly in the more open character of the lower umbilicus.

'lwo young specimens were until a late period of growth absolutely identical with $P l$. Steinhemensis, var. oequirmbilicatus, and one acquires an angular outer whorl when not quite half grown. 'This one and the $P$. levis forms with angular outer whorls in the adults cannot be distinguished from the typical specimens of $P l$. minutus, part of parvus of Hilgendorf, such as are figured on pl. 3, line $\mathrm{k}$, fig. 1-4, and many others, which a reëxamination of my Cloister Pit material has brought to light. The full-rrown specimen described as having only the outer whorl angular, is not distinguishable in any way from the young shells described as transition forms between var. parvus and the Steinheimensis forms of the pits. The specimens mentioned as identical with Klein's figure and the one described similar to oxystomus, can be in no way separated from $P l$. oxystomes, especially forms which can be readily picked out of any large number from formation $m$, of the Cloister Pit. In fact, these specimens show conclusively that $\mathrm{Pl}$. Steinheimensis, Pl. oxystomus, etc., are varieties of $\mathrm{Pl}$. levis, and explain the confusion of characteristics which must necessarily result as long as this is not recognized. All the gaps were not filled in the pits with intermediate forms, which would be so considered by an exacting judge opposed to all theoretical views of the transmutations of specific forms. This failure is here accounted for, and the gaps closed up by the forms found in the rocks of the Lower Steinheim Period, and the more ancient Tertiaries.

Other specimens, with rounded outer whorls, are not infrequent in the Coarse Limestone, which the receipt of Prof. Sandberger's specimens of $P l$. levis have enabled me to identify as precisely similar to the stouter forms of the $P l \cdot{ }^{\text {oxystomus }}$ levis . No specimens were found which could be said to have whorls identical in all respects with the angular whorls of $P l$. levis, figured by Sandberger. Gillia utriculosa was also found.

Fraas' description states that the Coarse Limestone passes into regularly stratified fine grained limestone, his "Valvaten-Kalk," which I have called Oxystomus Limestone, to accord with the views taken here of the affinities of the fossils.

This contains according to Prof. Fraas' account of this locality only the discoidal forms found in the oldest layers of the Pits. "Die Valvaten gehören der neideren, flachen Form an, die in der Sandǵrube von Steinheim im unteren, ältesten Lager sich finden."

The specimens of rock hammered out by me and apparently in place contained specimens of $P l$. levis, var. pareus IIilg., $P l \cdot{ }^{\text {oxystomus }}$ levis and $P l$. oxystomus with their young. Pupa antirua and Gillic utriculos were also found, but were rare. Remains of fishes were frequent as described by Prof. Fraas, but all fossils were less abundant than in the surface limestones next to be described. 
The "schmieriger Sand," probably a deposit of clayey sand described as underlying the Oxystomus Limestone, was not visible at any point in my path in such a way that I could determine its relations to the surrounding rocks. A large number of loose pieces of a thin bedded limestone, slightly coarser in texture than the Oxystomus Limestone, were found lying scattered on the soil of the lower part of the hill from the junction of the Sontheim and Cloister ridge roads to the western end of the Burgstall. Pl. supremus is very abundant in these pieces, and one form also occurred, a variety with a slightly elevated spire, which I have describer as Pl. oxystome var. cochlentr. This also occurs in formation $m$ of the Cloister Pit in great abundance. 'Though we find this to be a turretted form with the whorls flattened on the upper side and so similar in the young to those of the

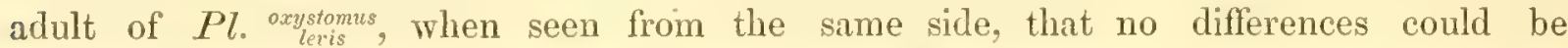
detected, nevertheless the lower umbilicus was deep, the increase of the whorls in size by growth exceedingly rapid, and the whole shell evidently similar to $P$. oxystomus, var. cochleata. Closer investigation showed that this view could be sustained by an almost uninterrupted series of intermediate forms, and by innumerable young shells, which covered the surface of the slabs. Pl. levis Sand. also occurred, but this was rare and I could not detect any specmens having forms intermediate between this and the former. Gillia utriculosa, Gillia sp. unknown and Pupa antiqua were also found. The fossils are not sufficiently peculiar to identify those fragments as belonging to any rock in place and I only mention them here because they contain the rare form of cochleata.

The formation next described by Fraas as occurring on the road to Neuselhalderhof, I did not visit, but the fossils are fully described by him, and differ from all hitherto mentioned. The rock itself he describes as succeeding the Coarse Breccia on the lower part of the hill, but he does not attempt to synchronize it with the formations just described on the Burgstall. The fossils consist of Pl. solidus 'Th., Pl. declivis Br., Pl. platystomus Klein, Pl. exustus Desh., Pl. Hilgendorfi Fraas, Helix sylvestrina Ziet., Helix gyrorbis K1., Lymmeus sociatis, Ancylus deperditus Desh., Neritina thuiatitis Lim. Of all these it will be remarked that only Lymneus socialis and Helix sylvestrina are found subsequently in the neighborhood of the Cloisterberg, either in the rocks or in the Sand Pits, and that not a single one occurs in the formation on the Burgstall. To determine precisely the relations of this formation with regard to those on the Burgstall, would require a re-examination of the locality, but this is hardly necessary. Prof. Fraas has described it as lying within the Coarse Breceia, and considers the fauna as related to the older Tertiary Molasse of Teutschbuch. Hilgendorf describes the formation as a "hard, thick, yellowish-gray limestone," and besides the fossils enumerated by Fraas, says that it contains the $\mathrm{Pl}$. aequiumbilicatus Hilgend. Steinberger refers this Pl. aequiumbilicalus to $\mathrm{Pl}$. levis Klein, and says in his famous work so often quoted (page 579), that this species occurs in the Planorbis shale (Nehiefern), over the limestone containing Helix sylvana, and mentions, as found with it, Lymmens dilatatus Noulet. Samdberger describes the whole fiuma of the Neuselhalderhofer or Sylvana Limestone as older than the Cloisterberg deposits, and adds the following significant remarks: "The enormous number of such species as Carinifex multiformis, tenuis, oxystomus, Gillia utriculosa, Planorbis costatus, 
Kranssii, and so on, which until now have been found in no other Tertiary formation, astonishes one at first, and occasions one to overlook the manifold relations which exist between the Steinheim fauna, that of the Upper Freshwater Molasse, and that of the Sylrana Limestone, which (list) appears at Neuselhalder, under such circumstances that it must at any rate be considered as the next oldest Tertiary formation of the neighborhood." This opinion is supported by a long list of all the fossils found in this and other localities, and other remarks which will be quoted more fully hereafter. Prof. Sandberger is an acknowledged authority upon the Tertiary shells of continental Europe, and this opinion, therefore, is of the greatest weight, especially when it is accompanied, as in the present case, by a wealth of illustration, and a detailed text which most fully supports the position.

Again the same authority does not describe the Neuselhalderhof rocks, under the heading of Steinheim, but under that of the "Land und Suisswasser Conchylien des Kalkes mit Helix sylvana, und der oberen Süsswasser Mollasse der Schweiz Schwabens und Bayerns," and speaks of it as follows: "The Upper Miocene Limestone with Helix sylvana again appears to the north-west of Ulm, first at Neuselhalderhof" (one hour from Steinheim), and then describes its occurrence at a host of other places in various parts of Germany, in scattered detached masses, the remnants of the former deposits of an equally large number of fresh-water lakes of the Upper Miocene period.

Though none of these authors state distinctly the relationship of the Sylvana Limestone at Neuselhalder to other rocks or by what it is immediately underlaid, they all agree that it must be a remnant of a former period and it contains as stated by Hilgendorf the elements from which the shell fauna of the Steinheim lake-basin were in all probability directly derived. It is equally clear that it occupies according to Sandberger a position underneath the Planorbis bed, a formation in which he found Pl. levis var. aequiumbilicatus Hlg. on the Neuselhalderhof road.

These facts support the proposition advanced by Hilgendorf, that the ancestors of the Planorbis forms of the Pits are found in the Pl. levis, var. aequiumbilicatus of the Neuselhalder rocks. Though I cannot for reasons previously given trace all of the forms to this variety, it is evident, that in the main proposition, the descent of the Pit forms as a whole from the Neuselhalder and perhaps other Tertiary varieties of $P l$. levis, Dr. Hilgendorf is amply sustained.

More or less doubt must of course hang about conclusions based upon anything but a series of close observations, and therefore I cannot at present do anything more than suggest the probability that this First Period really represents two, one including the Sylvana Limestone and the Coarse Breccia, and the other beginning with the Planorbis rocks. I am also bound to state certain alternatives by no means improbable, namely, that the remmants of an older fauna as shown in the Neuselhalderhof rocks may have lived side by side with the new fauma for a considerable length of time, or on the other hand, that the fauna of the Sylvana Limestone merely represents an unsuccessful migration from a neighboring fauna, which gained only a temporary foothold in the lake. Both of these alternatives appear to me to be unsatisfactory, but in such a locality nothing but the keenest exploration can settle such a question, and that has not yet been given to this point by any person, so far as I know. 
To the east of the road to Heidenheim and on the low ridge crossed by the road, I took a sample of rock which I considered at the time to be irlentical with that occurring in the East Pit; the more massive character of the deposit struck me at the time, but being influenced by the conclusions of former authors I did not pay much attention to the locality. I supposed that it was nothing more than a fragment of the limestones from which I had already collected in the East Pit, and took only one hand specimen, and that only as a precautionary measure. ${ }^{1}$ This is to be regretted since its connection with the Sylvana Limestone and the Cloisterberg rocks is very remarkable. The fossils show that the gradual character of the transition from one fauna to the other cannot be safely denied. $P$. discoideus is represented by a full array of varieties, but the flatter forms predominate such as are figured on pl. 1, line e, fig. 10-12; like these also the young in the few cases examined had the true discoidean character. The extreme varieties, the stout form similar to fig. 19, line f, pl. 2, or the thin form shown in figs. 10, 11, line h, pl. 1, are rarer than the normal forms, though the observer is very apt to think the latter very abundant until a close examination is made. $P l$. tenuis was sought for, but not found.

Two forms occurred which are probably the young of $P l$. steinheimensis, but it is not possible to determine whether they were these or the young of Pl. Steinheimensis. The upper umbilicus was entirely wanting; and the whorls had the shape of $P l$. tenuis, but without its angularity, or flatness on the lower side, or its narrow umbilicus.

Besides these there occurs a specimen of Hyalina subnitens Miill., and Vitrina Suevica Sand. Though casts, these are well enough preserved to give positive grounds for their generic identification. The second of these two species is described by Sandberger ${ }^{2}$ as occurring in the Sylvana Limestone, on the west side of the valley, and the first as in the same formation at Möringen and Undorf. Both are very rare, and it is quite remarkable that they should occur in a single hand specimen of this rock taken at random from the first available point. Lymneus socialis of large size was very abundant.

The exposures of rock on the southern side of the Cloisterberg ridge are divisible into two portions. The lower part occupies the lower border of the ridge extending in places nearly to the top. Its structure, though finer than the Coarse Limestone on the Burgstall, is very similar, and it was evidently deposited under similar conditions. Both are evidently the product of speedy deposition in waters saturated with lime, as shown by their coarse, irregular, granular structure, and numerous cavities which have led to the frequent description of the latter as tufaceous.

I surveyed these rocks on every available occasion, and obtained many hand specimens without, however, being able to determine with certainty either that they were connected with the rocks to the eastward of the Heidenheim road, or what were their upper boundaries. All varieties of $P$. discoideus are abundant, except those with very deep sulcations on the lower or umbilical side; these are very rare, as are also the deep, thickwhorled forms like those on pl. 2, line f, fig. 19. The prevalent variety is similar to that described above, from the rocks in the valley to the east of the Heidenheim road. They differ, however, in the young, which is more immature in aspect and precisely resembles in a large number of forms the adult of $P l$. temis. This is, therefore, an intermediate variety and must be designated as $P l$. discoideus. Specimens of $P l$. Steinhermensis,

\footnotetext{
I I have called this the Valley Rock, to distinguish it from

2 Op. cit., p. 602.
} other formations. 
such as are described farther on are extremely rare, but still do occur occasionally, though they can only be determined when the young can be seen as in natural sections.

$P l$. tenuis occurs quite frequently, and also a variety, which is slightly turretted. The young are a little flattened, and have narrow umbilici on the lower side, so that they can be at once distinguished. The upper side, and the form as a whole, resembles fig. 6 , line c, pl. 1, but the lower umbiiicus is much narrower, and there are no marks of sulcations. There is one specimen of the young of this species with no umbilical depression in the upper side, a truly turretted variety, which resembles precisely the figure of $\mathrm{Pl}$. Lartetii Noul., as figured by Santberger, on the upper side, but is more rounded on the lower side.

Lymneus socialis, of large size, was very abundant in places, occupying the rock to the exclusion of other forms. Gillia utriculosa Sand., was present in considerable numbers, in the forms figured by Sandherger. Casts of the stems of Chara appear, but are rare.

The rocks which I have called the Upper Tier, form the summit of the crest, and like those of the Lower Tier are much denuded, the surface being worn out into pillars of fantastic shapes, and rough looking knolls. The composition is similar to that of the Lower Tier, but much harder and denser in places, though nowhere is the porous characteristic, formerly described, entirely lost. The fossils are much less numerous than in the Lower Tier with the exception of the Chara stems which are very abundant in some places.

$P l$. discoidens is very rare, but $P l$. discoidens is of more frequent occurrence. $P l$. tenuis is the most abundant fossil, but is almost wholly represented by the very flat form, which is quite rare in the Lower Tier. The slightly turretted variety, which is quite common in the Lower Tier, is found here also, but is much more infrequent. All the specimens are very small or young, with the exception of $P l$. tenuis.

Several young specimens were collected, which were identical with those previously described in the Valley Rock as the young of $P l$. steinnuimensisis. These are here unquestionably the young of forms which in the adult have the characteristics of $P l$. tenuis. Nevertheless these young have rounded whorls and open unbilici on the lower side, until a much later stage of growth than that at which the angular whorls, etc., are nsually acquired in $P l$. temis. One full grown specimen was similar to Sandberger's specimens of Pl. levis, to my $P l .{ }^{\text {oxystomus }}$, and also similar to the specimens figured on pl. 1, line b, figs. 13-15. Its evidence makes the relation of the most extreme forms of Steinheimensis and Pl. levis very clear. It has the peculiar flattened aspect on the upper side and shallow umbilicus of many forms of Steinheimensis with the whorls on the outer and lower sides exactly like those of $P l$. oxystomus leris . Besides these, several young specimens occurred, which were not separable from the young of $P l{ }_{0}{ }^{\text {oxystomus }}$, and were undonbtedly identical with them.

Lymneus socialis of large size is present, but quite rare. In one hand specimen of a peculiar gray limestone on the lower border of the Upper Tier on the west side of the Cloisterberg, were found several specimens and fragments of Pupa contiqua, and a broken cast of a specimen of Helix. A fragment of a tooth with thick dark-brown enamel, like that of some small rodent, was also found. 
No stratification was observed, and consequently it was not possible to determine whether the rocks dipped towards the valley or not. These characteristics indicate a continuous deposition, or rather precipitation of calcareous matter, since it is hardly possible to conceive that any metamorphic changes could have taken place sufficiently extensive to destroy the marks of stratification. It would seem a fact that these rocks must have been deposited under circumstances very similar to those which occurred when the brecciated limestones of the outer rim were formed.

This is evidently the view taken by Prof. Fraas, since he alludes to them in the following words: "Diesem Griesfels orler den Breccienkalk begegnen wir zum erstenmal bei Steinheim, das von einem solchen Schuttgebriges regelmässig unlagert ist." 1 And again, "Sobald man sich aber dem centralen Kilosterberg, und den Dorf nähert, wiederholen sich gleich den Breccien Erscheinungen aus dem Ries: regellose Massen älteren Juras, die in tertiären Sand und Kalk drin stecken." ${ }_{2}$

Sandberger ${ }^{3}$ describes these rocks under the name of "die klotzigen Kalke," and says, that though no stratification is found by which the superposition of the fossils can be definitely determined, they contain the same association of fossils as in the strata of the Pit, up to the introduction of "Carinifex multiformis."

The statements with regard to the geology, are entirely in accordance with my own observations, except the portion of Prof. Fraas' remarks which refer to the underlying structures of the Jura. With regard to these, I am not capable of judging between his and Quenstedt's views, nor has the question an important bearing upon the age of the rocks under consideration. Whether the Cloister ridge is an irregular mass, as stated by Fraas' or an anticlinal ridge, as held by Quenstedt, it is, according to both authorities, cipped by the tertiary deposits here called the Cloister ridge rocks, and these alone are concerned in the present discussion. When we attempt to compare the fauma of the opposite sides of the valley, we are at once struck by the great differences between the fiuna of the Cloister ridge and Burgstall rocks. Pl. levis? Pl. oxystomus and Pl. oxystomus in the rocks of the Burgstall present the characteristic association of forms found in the fumna of the Cloister Pit, formation " $m$," rather than what their geological position would lead one to expect, though, as has been shown, these species are really the direct descendants of $P l$. levis, and their occurrence here ought not to surprise any one. On the other hand the rocks of the Upper Tier on the Cloister ridge, though they resemble the Coarse Limestone closely in texture, and may be of the same agre, have a very different set of fossils. Pupa antiqua, Lymneus socialis, an unknown Helix, the tooth of a rodent; $P l$. steinhemimensis, $P l$. tenuis, $P l$. discoidens, and $P l$. discoideus are all distinct

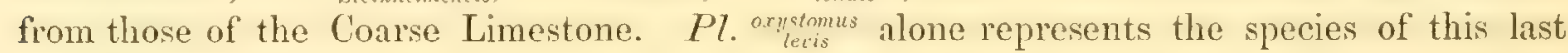
named formation.

The fossils of the Upper Tier are, as remarked by Prof. Sandberger, similar to those in the lowest of the Pit deposits. In the next or Lower Tier this likeness to the fauna of the Pits is increased, but the change consists more in the relative proportions of the species than in the introduction of new forms. Lymneus socialis, Gillia utriculosa, Pl. temuis, $P l$. ${ }^{\text {discoideus }}$ tenuis,$P l$. discoideus, are abundant, and $P l$. Steinheimensis very rare. The prevailing form is, however, as in the Pit formations, $P l$. discoideus, except in places where Lymneus socialis excludes all other forms.

$$
1 \text { op. cit., p. } 13 .
$$


It the rocks to the anst of the Heinlenheim roarl hat contained any Planorbis, Lrmmeus or Gillia it might have been said that the Cloister ridge and these rocks together, contained a fauna precisely intermediate in character between the Burgstall and the lower strata of the Pit Deposits. The presence of Hyalina subnitens and Vitrina suevica, however, both fossils of the Sylvana Limestone, may be perhaps explained in the same way as the reappearance of $P l$. nuystomus in formation $m$ of the Cloister Pit, namely by colonization from some neighboring part of the lake where they had continued to exist. With these exceptions, the fama of these Heidenheim road rocks certainly presents a somewhat remarkable character and contains an association of species which appear to follow on very naturally after those of the Lower Tier, and fill the gap between these and those of the lower strata of the Pit Deposits. This rock is very similar, as remarked by Quenstedt, to the limestones of the Pit Period, and at first sight seems to be filled by the normal varieties of $P l$. discoidens, to the exclusion of other forms, and has altogether a more recent aspect than the rocks of the Cloister Ridge.

The forms, however, do not indicate a geological transition, because it is in the Lower Tier that the predominance of discoideus occurs and not in the Upper. The Upper Tier appears to lie upon that here called the Lower Tier, though with regard to this the data are not such as would render this view unquestionable. The division between the two Tiers is uncertain and not sharply mariad off by any line of stratification. It is possible that what now is the Lower Tier does not underlie the Upper Tier, but may have once covered the summit of the hill and been superimposed upon the rocks now exposed by denudation above. In this case the anomaly of the prevalence of "discoicers" in the lower bed instead of the higher, would be done away with.

Whatever results may How from future investigations upon the relations of the rocks of the circular. valley, it does not seem to me probable that the bearing of these facts upon the origin of the fauna of the Pits can ever be materially altered. The rocks contain a fama, which is probably older than that of the Pits, and shows that the forms which here and there appear suddenly at the lowest levels in the Pits had their origin in a former period of which these rocks are the imperfect remnants. 'The richness and the sudden development of the forms of the lowest stratum of the Pits at the two places examined by me require an explanation, and that given by IIilgendorf does not seem to me wholly satisfictory. Granting that the spots examined by me were nearer to the shore line, and his firther out in deeper parts of the lake, and that he found only Pl. Steinheimensis and Pl. parvus in the lowest stratum of the Pit deposits, the fact remains that my explorations reached the bottom of the deposits in two places. If the fauna I found was not contemporaneous with that which he found, the shores must have been very steep, and have prevented the burying up of the shore-line faunas until all the deeper parts of the lake were filled. This, however, is a difficult matter to prove, in view of the fact that the strata have been more or less elevated since they were deposited.

The Cloister Rirlge has suffered greatly from denudation, and standing on the summit alongside of one of the pillars or knolls, which still remain, the conclusion, that the entire valley or basin must have been originally covered by rocks of a similar kind, which have been, however, almost wholly removed, seems to be well supported. 
Fraas and Quenstedt both attribute the formation of the circular valley and the superficial aspect of the Cloister Ridge largely to denudation, and I think the inference is very well founded that a considerable proportion of this must have taken place before the formation of the lower strata of the Pits. 'These partially consist in the lower part of the Little Pit of a peculiar coarse sand, containing fragments of rock, buth resembling in color and texture the Closister Rirlege rocks, though in the small number of fragments examined no fossils were found. 'The dark, reddish-brown color of the sand in the lower strata of the Pits predominates, whereas, in the upper parts above $e$ and $f$, this is not the case, and pure white shell sand is more abundant. Above these again comes in some of the sections a sort of rubble, like that of the basal strata, containing Lymnea again in abundance, whereas, in the intermediate deposits, it was but sparsely represented. I was under the impression when at Steinheim, that the Cloister Ridge rocks were considered older than the Pit Deposits, but nevertheless spent a considemble portion of time in studying the relations of the two, and made a series of observations, in order to find out their relations to each other, knowing that but little attention had been paid to this part of the field.

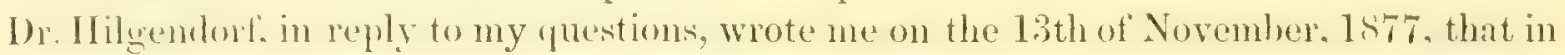
the Old Pit the massive Fresh-water Limestone of his Section $2^{1}$ was surely a tufa similar to the Cloister Ridge rocks. "' 'Der massige Siisswasserkalkstein' welcher die Grundlage des Profils M 2 billet (p. 481) ist sicher ein Tuff gewesen ahnlich den Felsen, die den Klosterberg kronen." He also states that he found in one of his excavations a block of "Temus 'Tuffi," resting upon the Jura, which was four and one-half metres thick, and adds that they (the Cloister Ridge rocks) agree with the older layers of the pits. The view that the Cloister Ridge rocks and the lower Pit Deposits were formed at the same time is rendered improbable by all the facts stated above; by the composition of the lower Pit Deposits; by the difference in the structure of the rocks, which show that conditions existed which made the lake at this period very different, a reservoir of lime-laden water unfavorable, either from this or some accompanying cause, to the existence of such vast numbers of shells as nppeared in the purer waters of the Pit Period; by no signs of transition between the two, and by the position and inclination of the strata of the Pits, whish dip away from the unstratified Cloister Rilge rocks, indicating a want of conformability, which, however, could not be proved because no contacts were exposed.

'The influeness which effecterl the deposition of the Cloister Ridge rocks, were independrut of any periolical changes which conld so materially alter the quantity of serliment held in suspension by the water at any season of the year as to produce regular strata of slight thickness. Whereas, within a few feet occur the Pit Deposits regularly stratified in such a way that we can say with certainty that there were periods of quiet waters for the limestones and clays, and periods alternating with these during which much coarse sediments were transported and deposited in the form of sands and rubble, etc.

I am aware that the deposits of water impregnated by mineral springs, may take place in very narow and confined areas, but that such a thickness of rock exceeding that of the Pit. Deposits. Would have heen deposited on the Cloister Rirlge in the immediate vicinity of the Pit Deposits, in the middle of a lake, and yet been wanting in the larger number of 
the forms which are so abundant in the Cloister Pit, which is surrounded by them, appears highly improbable.

In fact the enclosed pieces of rock, the general composition and inclination of the strata, and the fossils of the lower Pit Deposits, all seem to indicate for them an origin later in time, and a partial derivation of the material from the Cloister Ridge rocks.

The uppermost P'it Deposit found by me on the hill immediately above the Old Pit, and containing Lymmea socialis and described as a rubble derived from the Cloister Ridge rocks, also indicates a similar origin.

'The structure of the Cloister Ridge rocks indicates a contemporaneous origin with the lower rocks on the Burgstall, as noticed hy Professor Fras, hut the fosils are not inlentical. No exposure of any rock under the Lower 'Tier was seen, although diligently sought for, and I was disappointed in this last hope of obtaining positive proof of identity between the rocks on the Burgstall and those on the Cloister Ridge. The impression made by the fossils and the rock structure was such that under ordinary circumstances, and in a less important locality, I should hardly, however, have hesitated to consider the Cloister Ridge rocks as belonging to a somewhat later, if not contemporaneous part of the same general deposit as those of the Burgstall.

The Pit Deposits do not extend far out into the valley, but are limited to remmants clinging to the sides of the central hill. The underlying clay, the White Jura 3 , has been described as occurring wherever wells or cellars have been dug in the village, and was found by Dr. Hilgendorf and the author in the Old Pit at the base of the deposits. According to Dr. Hilgendorf, however, the White Jura forms the base of the East Pit, and the Opralines Clay, a much older formation of the Brown Jura, the base of the Cloister Pit. 'This last fact shows how great the denudation must have been which took place before the Pit Deposits began to be laid down on the south side of the hill.

It is very evident also from the singular want of exact agreement between the layers of adjoining localities, as for example in Sections 7 and 8 , representing two nearly opposite sides of the New Pit, that the physical conditions varied considerably within a few yards, and that while limestone or clay was accunulating in one spot, sand was being laid down in another immediately adjoining, and the same for greater distances, and in a larger sense. As, for instance, the sands and limestones of the Cloister Pit are in direct contrast with the great prevalence of clay in the corresponding parts of the New Pit and East Pit. There must have been, therefore, very considerable variation in the state of the water in these different spots. thungh in such close proximity to each other. Nevertheless, with all this local variation, there is a regularity in any one section in the succession of limestones, clays, and sand, which strikes the observer at first as absolutely uniform. Thus though no great amount of uniformity exists such as would enable us to synchronize the strata with exactitude in different localities on the sime level, there is ereat miformity in the alternation of limestone and shell sand, or clay and shell sand, and this may be seen to be the groverning fact in any one of the sections. These minor local differences of structure can not be used to explain the greater differences of the Cloister Ridge rocks, since in no case are the partings of limestone formed "in situ" of a similar structure. They are everywhere a shell limestone of greater or less funeness, hut never vesicular, or similar to the limestomes of (Boister Rinlge rocks except in the lowest parts of the Pit Deposits. 
II. Ami Boué in an article entitled "Les dépots Tertiaries et Basaltiques de la parti du Wurtemburg et de la Bavière," 1 describes these Cloister Ridge rocks as a calcareous tufa deposited upon the strata of sands and clays. This hypothesis is, however, inadmissable, since no observer has seen any of the Pit deposits between the underlying Jura rocks and the Breceiated or Cloister ridge Limestones in any locality. The Clovister liblere rockis are described as resting directly upon the Jura in all cases, and so also is the Breccia of Fraas,

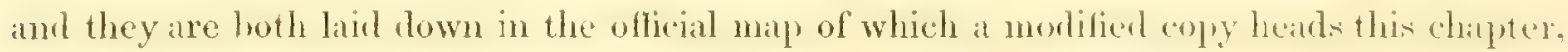
in accordance with these views. The existence of the Lower Steinheim Period though advanced here in distinct terms for the first time, is really to be infered from the writings of Quenstedt, Fraas, IIigendorf and Sandberger. Every one of these authors allude either directly or indireetly in such terms to the Neusclhalderhot rocks containing a distinct and older faun than that of the Upper Steinheim (or Pit) Period.

The Geological Matp of Steinheim, page 33, shows the central hill with Steinheim to the north and Sontheim to the south. The Neuselhalder rocks are situated to the westward and are marked like the Breccia of Frass, as are also the Cloister lidge rocks forming a half circle on top of the central hill, and also the rocks of the Burgstall, southeasterly from Sontheim. 'This was done to place clearly in view the association of rocks supposed to form together the strata of the Lower Steinheim Period.

\section{Review of Geological Sections.}

Hilgendorf gives five different and detailed sections in the Old Pit, which do not agree very closely, nor in view of the great disparity of even adjoining parts of the same pit, depart much from the sections here given. His remarks about the New Pit, however, show that here there was a very marked dilference. He describes this as very deficient in limestone, whereas, a glance at my Sections 7 and 8 will show that the opposite condition occurs at the present time. 'This agrees also with the fact that for a long time previous to my visit this had been the pit preferred for the excavation of sand, and had been very much enlarged. 'The two following sections are quoted from the two, which were continued down to the base of the deposits, by Dr. Hilgendorf.

DR. HILGENDORF'i FIRST SECTION.

Limestone; formerly the tloor of the pit.

Clayey sand.

?.4. Clay with three strips of shell-bearing sand.

(Shell-sand with $\mathrm{Pl}$. m. sulcatus.

3 Clay.

( Shell-sand with $P$ l. m. sulcutus.

Clay.

Shell-sand.

$\frac{3}{2}\{$ Clay.

Llayey-sand with $P l$. nn, lenuis and sulcalus,

(underneath clay with a thin layer of $P l . m$.

$2\left\{\begin{array}{l}\text { Tenuis and below with large angular pieces of } \\ \text { Jura-limestone. }\end{array}\right.$
Or. HILGENDORF'S SECOND SECTION (LOWER PATT),

Clay.

Shell-sanil.

Clay.

Limestone.

Clay.

shell-sand.

Clay.

Shell-sand.

Clayey-sand.

Shell-sand.

(Clayey-sand.

$\frac{3}{2}\{$ Shell-sand.

Clay.

2 Claycy-sand with two shell layers.

1 Massive Fresh-water limestone.

1 Ann. des Sei. Nat. 1824. Vol. 2se, p. 5-12. 
It will be observed, however, that, in the two holes sunk in the Old Pit, under my directions, the pieces of Jura limestone began to be thrown up as soon as the pick entered the dark clay layer. Dr. Hilgendorf, in none of his sections, found the dark clay layer, which forms the base of these two sections. Nevertheless, No. 2, in his First Section, consisted above of" clay layers containing $P l$. temis, and below the large angular firaments of Jura limestone, which show that he had here reached the bottom of the deposits. It seems as if no other inference was possible, since everywhere this indicates the same fact, and is accepted as the limit.

I cannot synchronize his sections and any of mine with success, as in fact might be anticipated from the great variation which occurs often within a few feet between the details of the stratification.

His second section, given on p. 4S0-81, is the most complete of all, since here he obtained his $P l$. m. Stcinheimensis. With relation to this there are some statements which have confused me in searching for the exact situation of this form. All of his sections described are in the Old Pit, and only a general description is given of one in the New Pit, and of the "dritte Grube" which is the Cloister lit - the East Pit he does not. mention. In the New Pit he distinctly states that he did not reach the Steinheimensis layer; and in the Cloister Pit he saw the Steinheimensis zone, but not "in situ," ("nicht in situ gesehen.")

This narrows the places in which this zone was first observed to one section, his second section.

On p. 492 in his account of $P l . m$. Steinheimensis, and its genetic series, he writes as

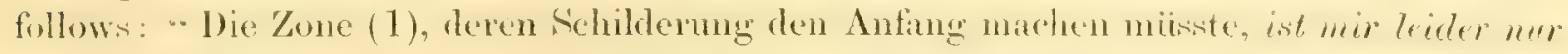
mangelhaft bekannt, da sie bei meinem letzten Besuch der Gegend unzugänglich war. Sie enthält die echten Steinheinensis; doch zeigen schon hicr einzelne Exemplare eine Andeutung von tenuis - Kemmzeichen; am Ende der letzte Windung tritt oben eine

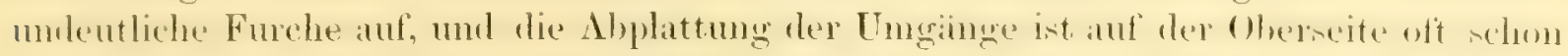
recht merklich. Doch kein einziges Exemplar wiirde mit einem temis verwechselt werden kömmen. Dagegen kommt in der nïchsten 'Lone, (der untersten, zu der ich in der alten Grube gelangte), ein temis-artiges Aiissere den meisten Exemplaren zu, nur die scharfe Kante auf der Unterseite ist bei keinem Exemplare ausgebildet, so dass ein eigentlicher lenuis (unter etwa 1000 Exemplaren) noch nicht zu finden ist. Diese erscheint erst in der nächsten Schicht in der Begleitung von echten, meist involuteren Steinheimensis; beide Zonen zusammen geben eine Reihe von Exemplaren die von der schönsten Rundung eimes Steinheimensis zu der breiten scharf kanntigen Form des temis jede Abstufung zeigen, Doch scheint in den temis Zonen schon eine kleine Liicke zu sein, so dass ans ihr allein eine Reihe nicht mehr gut herstellbar ist. Man kann die 3 Schichten als Steinheimensis-zone, Uëhergangszone des Stcinheimensis zu tenuis, and temis-zone bezeichnen."1

In this deseription he declares the second zone to be the lowest which he reached in the Old Pit, although the first zone is put down in his second section. This discrepancy however, disappears, when taken in conjunction with the fact that he describes zones 1 and 2 in the section, as two layers of shells contained in one

1 The italics are all my own, except, of course, the names of the species. 
layer of clayey sand. The lowest of these consisted of true Steinheimensis shells, and the upper of Steinheimensis shells. In this statement, then, we see that Dr. Hilgendorf did not find two distinet deposits, but one deposit with two distinct layers of shell. Unfortunately, the conditions of the problem demand that there should be a wider separation than this, or else there comes in the doubt that in this case, at any rate, there may have been the overlapping of local and contemporaneous colonies, so common in these deposits. 'This same section also assures me that in my sections in the Old Pit, the bottom of the deposits at that place was reached. I carefully kept separate' ${ }^{\prime}$ until after I had drawn and studied them, the samples of fossils gathered from pockets in the Jura clay itself, and these contained specimens of the Pl. multiformis, which were not only important in respect to being found in this position, but still imore so from the fict that they were transported shells. 'This was the conclusion arrived at by comparing them with other. specimens. They were encrusted with brown limestone, and otherwise romghened like rolled shells. They imply that I'l. multiformis existed before this lowest layer was deposited, and that the few specimens found were transported from some other locality where living specimens existed, and had been in the water long enough after the death of the mollusks to acquire their rolled aspect, and encrusted outer surface.

I farther assured myself from the owner of the pit before digging the hole, that the floor of the pit had not been disturbed since Dr. Hilgendorf's visit, and dug near the spot pointed out to me as the one where he had sunk a pit. This, however, proved to be a mistake, since the limestone was unbroken, and Dr. Ililgendorf claims that the section No. 6, of my digging, was nearer the hill, and not so deep as those explored by him, except his No. 4, and that I struck the Jura clay at a much less depth, so that in place of Nos. 1-2, I found only his bed 5, equivalent to his discoideus zone.

He states that the fish remains occurred in his zones 6 and 7 , while they occurred much lower in my sections - namely in bed $c$. His zones 6 and 7 , however, are the equivalents of $k$. $l$. in my sections, and the whole thickness of my sections were between 40 and 55 feet in the Old and New Pits. This is a very significant fact, since he states that the total thickness of all the strata were 45 Wurtemburg feet - about 42 English feet. "Die gresamme Mïehtigkeit der hoohachteten Schichten wiirde sich auf etwa

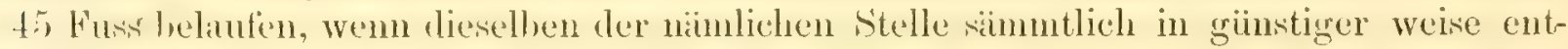
wickelt wären."

'The mumber of zones which could be distinguished petrologically was, as stated by him, about $40 \mathrm{in}$ all; but this I could not use for comparison, the number of layers differing so greatly, that no reliable comparison could be made. The total thickness, also, must have been eonsiderably lesienerl in the Old Pit at the time of Dr. Hilgendorf's visits, since he did not find the oxystomus and supremus zones here, but in the Cloister Pit, whereas, these were well shown in the New Pit immerliately arljoining the Old Pit, at the time of my explorations.

It is of course understood in all these cases, that no pains were spared to make every sample perfectly reliable, and that in no ease was a lole sunk except through unbroken limestone, nor was anything gathered from an

cxposed surface, or without digging under the limestone layers, etc. No one but a tyro would think of neglecting such precautions. 
I am, of course, bound to believe Dr. Hilgendorf's explicit statement that he was obliged in order to reach the Jura, to dig much deeper than I did, and there are certain facts in my own sections which confirm this. He dug to the Jura in his Sections 1 and 2, lefore the Pits were opened so fir into the side of the hill, and was therefore larther ont in the valley, and this corellates with the facts in my Sections 5 and 4, as compired with 6. In 6 the lowest formation $a$ is really equivalent to $a, 3 \mathrm{in} \mathrm{No}$. 5, which was only a short distance to the northward, and is replaced by a layer of limestone in No. 4, which was a considerable distance to the north and east. This is shown by the position of the limestone immediately between the clays above, and the coarse layer below, in No. 4.

Thus all the layers found below $a, 3$ in No. 5 , and the limestone just above $a, 3 \mathrm{in}$ No. 4, are absent in No. 6. The first of these is the coarse layer $a, 2$, in Section 5 , and $a, 3$, in Section 4 . The great increase in the thickness of this, is carried out in the Little Pit in the other beds also, so that it can safely be inferred that the beels grow deeper outwards in this direction, as well as probably to the westward where Dr. Hilgendorf dug. 'Thus $a, 1$, in Section 5, is shell sand and clay, becoming two layers and possibly more of clay, with at lenst three thick limestone partings in No. 4.

'The conditions governing the deposition of the layers between these three places, therefore, must have been very different, though groing forward at the same time, amb at a short distance from each other, and two of them, 5, 6, in nearly the same depth of water. This conclusion is sustained also by the aspect of the layers containing fish remains, which occur in $b, c, d$, according to the observations made upon the adjacent Sections 3, 4, 5, and 6 . The pit formations, in fact, show everywhere the exceeding variability of the conditions under which deposits took place in arjacent spots, for they cammot be dignified by the name of localities.

The fossils found in $a$ of Section 6 , comprised nearly the whole range of forms, and indicated also by the worn character of some of the trochiformis shells that they had colonized this locality from some other part of the lake. Those found in the lower part of $a$ in contact with the Jura contained eight specimens of $P l$. trochiformis, all in one spot together, with intermediate varieties truchurmus, while at another place in the hole, only three feet distant, none were found of this species. No divisions were seen in this stratum, but the specimens were fewer in the upper part than in the lower. Fish remains occurred in a soft calcareous parting immediately between this and formation $b$.

This last fact is important, since it confirms the opinion that in all probability $a$ in Section 6 is equivalent to $a, 3$, in Section 5 .

Do the fossils differ in Section 5)? The list given shows that in formation $\ell^{2}$, 3 , only the following are found, $P$. Steinheimensis, tenuis, discoidens. If I had gone no farther, the

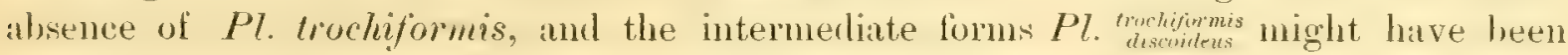
considered very significant in favor of Dr. Hilgendorf's view.

But the next lower formation $a, 2$, Section 5, at a lower level, contained the same gen-

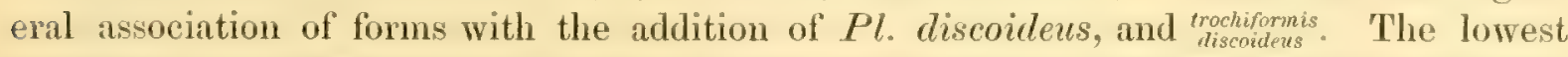
formation $a$, 1, contained even a more complete asociation of forms, and was not reparable from $a$ in Section 6 , with which the specimens were finally mingled on plate 1 in order to complete the illustration of this stratum, which in both cases rested on Jura clay. But there was a much greater abundance of $P l$. sulcalus, and the $P$. frochiformis was exceedingly rare, only one specimen being found, and that a rolled shell. 
If we assume in accordance with the contained fossils, that these layers belong to the Trochiformis zone, the difficulties become greater instead of less', as we shall see firther on.

Dr. Hilgendorf in his communication "Neue Forschung in Steinheim," Zeitseh. d. Dentsch. geol. Gesellsch., 1877, p. 450, writes that he tried to find during his reexamination of all these localities, single specimens of the higher varieties in the lower strata, but without success, and also that no less than five other competent observers failed in the same quest. 'This is very strong evidence, especially when taken in connection with the fact, that Dr. Hilgendorf, with a zeal which must make every one desire to agree with him, sunk no less than ten holes to the Jura, and took photographs and sections, going over all his observations again and again six times, with great care. Altogether the amount of time, trouble, and study he has expended is very remarkable, and worthy of the highest success, which I most heartily wish for him.

But although my observations cannot compare with his in these respects, there are certain facts which even the great mass of evidence he is able to bring to bear upon this subject, do not seem to make clear.

My two sections 5 and 6 reached the bottom of the deposits at the places where they were male. Whatever formations they represent, whether deposited in deep or shallow water, rest upon the original bottom of the lake. The trochiformis fossils are not only the remains of fresh, but also of rolled shells. These were found at a greater depth in Section 5 than in Section 6. 'Therefore, if bed $a$ in Section 6 was the equivalent of Dr. Hilgendorf's Discoideus or Sulcatus bed, or even if $a, 1$ in Section 5, was so high, how was it, that on three occasions, and two different places, I found Pl.trochiformis there.

Dr. Hilgendorf's Trochiformis bed unquestionably lies immediately undemeath $m$, the Oxystoms bed, in all my sections, and, if $\alpha$ in my section is part of the Trochiformis zone, then the Trochiformis bed would extend from $m$, to the Jura, a greater thickness, and a larger number of beds than could be included in that formation, and yet preserve the sequence of the forms as described by him, since under this again must come five out of the ten zones described by him.

His recent researches may possibly remove these doubts by showing how this can be accounted for, but there still remain other facts.

Unquestionable Pl. oxystomes occurred in the New Pit, much lower than m, the first true Oxystomus zone of the Old Pit and of the Cloister Pit, namely in $h$, Section 8, together with $P$. crescens, ${ }^{1}$ which also ought not to have occurred until the Oxystomus zone was reached. $P$. oxystomus also occurred in Section 6, in bed $i$ again in company with $P l$. crescens.

Another point in this connection is the occurrence in $\alpha$, 3 , of Section 4 , in a formation lower than a Section 6, and equivalent to a 2 in Section 5, of a specimen of $\mathrm{Pl}$. Mminutus. This is such an intermediate form as is figured on pl. 4, fig. 2, which does not occur until $e$ is reached in the Old Pit, pl. 2, line $e$. This specimen was found when hunting 
very carefully, by digging into the sides of the Pit, for the few specimens of $P$. tenuis which accompanied it. ${ }^{1}$

But what is more important, and to me most inexplicable in this matter, is that I filited to distinguish throughout any beds which could be considered as corresponding to those described by Dr. Hilgendorf as sulcretus, disnideus, discoideus, trimhifirmis, trochiformis and oxystomus.

There were here and there beds, such as a 3, Section 4, which held only Pl. tenuis,

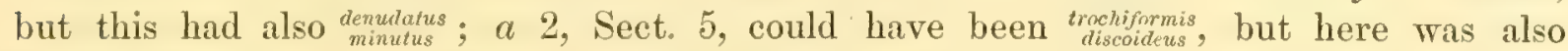
trochiformis; and a 3, Sect. 5, could also have, but for this, been considered a true Discoideus bed.

Pl. minutus came in formation $d$, Old Pit - but how account for the earlier appearance of $P l$. demudutus in a 3 , Sect. 4, so much earlier, before the fish layers, and in what would otherwise have been a perfect $P l$. tenuis bed. In the New Pit the same difficulty occurs with $P l$. oxystomus and crescens which, as described above, put in an appearance too early, and spoiled the definition of the $P l$. trochiformis formations.

So also, in the East Pit, formation $d$, e, otherwise a perfect $P l$. discoiders formation, with $P l$. triquetrus, and $P l$. costatus and mimutus as deseribed by Dr. Hilgendorf, contained one or two broken specimens of $P l$. oxystomus. Not much in themselves, but very significant when taken in connection with other facts, and also when it is considered, that to obtain these, I sifted considerable material taken from this very thick formation.

In this Pit, however, I could easily trace the kind of evidence brought forward by Dr. Hilgendorf, and from $d, e$ to the true Trochiformis bed $h$, which would give a very perfect series from $P l$. discoideus or sulcatus to $P l$. trochiformis.

I can think of no way to account for these discrepancies, except the different results of different methods of research. My collections are much smaller, and my observations more limited than those of Dr. Hilgendorf, and therefore it may seem to some reader's that it is presumptuous on my part to oppose his results, but from another point of view this only makes it more difficult to account for the exceptions which were found.

I feel myself, that the conclusions with regard to the Cloister Ridge rocks need more positive evidence than I have been able to bring forward, but the fitcts with regard to the occurrence of fossils in the Pit Deposits, are not in any case theoretical. The identifications are made after comparison with a set of types sent me by Dr. Hilgendorf, and after prolonged and repeated observations, and the discrepancies occur in species of marked characteristics, and easily identified. The method of research excludes error in any other respect as much as is possible in such investigations.

'The theory also, which I have advanced, that the Cloister Ridge rocks really contained a more ancient fauna than the Pit Deposits, is substantiated by the geological facts, the fauna contained in them, the "temis Tufa," found lying on the Jura Clay, by Dr. IIilgendorf, and described by him in a letter to me, the structure of the lower beds of the Pit Deposits, and so on.

Again, the situation of the Cloister Pit, where Dr. Hilgendorf found a full series of beds near the highest elevation of the ridge, and which must be at least a hundred feet

1 The sides of the Pit above in which the Pl. denudatus also occurs in formation $e$ were removed well back, and this shell differs in color from them, and agrees with the bleached, dead white $P l$. tenuis found with it. 
higher than the Old Pit, seems to show that the relative depth to which one may dig in reaching the Jura does not count for much. The elevations which have taken place, and which of course primarily affected the Jura clay also, make it impossible to say that the strata represented in a hole, six feet deep in one spot, may not be of equal age with strata resting on the Jura, in a hole fifteen or twenty feet deep. The foldings of the formations and the. broken aspect of the limestone layers above, show that restricted local and vertical movements in the formations have taken place, and that a general movement of the Cloister Ridge upwards has also taken place. This last would account for the greater thickness of the formations as a whole as we go outwards from the ridge, but not for the greater thickness of the same beds. If this is a fact, such formations as $a 1,2$, Sect. 5 , are older than $a 1$, Sect. 6 ; and $a$, Sect. 4 , older than $a$, Sect. 5 .

The great uncertainty in this problem is the variability of adjacent beds, as in $m-p$, of the two sections in the New Pit, or $d, e, f$, of the two sections in the East Pit.

Of course, if the fossils followed each other in regularly arrangeable series, as described by Dr. Hilgendorf, in a number of places, and throughout the entire series of formations from the Jura clay to $m$ inclusive, in every pit and excavation, there could be no doubt, but, if they fail in a single section, it is fatal, provided the number of exceptions found are sufficient to eliminate errors of observation due to the accidental intermixture of higher occurring species in lower formations; and this appears to me to be the real state of the case.

The following section of 'Sandberger's is given in detail, because it was taken in the East Pit, which is likely to vary exceedingly with farther exploration, and also presents more difficulties than the others.

\begin{tabular}{|c|c|c|c|c|c|}
\hline \multicolumn{2}{|c|}{ SANDBERGER'S } & ION. & \multicolumn{3}{|c|}{$\begin{array}{c}\text { Equivalents. Section 2, } \\
\text { East Pit. }\end{array}$} \\
\hline No. & Shell-sand & $\begin{array}{c}\text { Metres. } \\
?\end{array}$ & No. & Form & tions. \\
\hline 2 & $16 \quad 66$ & 1.10 & 2 & Shell-sand & \\
\hline 3 & Limestone & 0.01 & 3 & Limestone & \\
\hline 4 & Shell-sand & 0.20 & 4 & Shell-sand & \\
\hline 5 & Limestone & 0.01 & 5 & Limestone & \\
\hline 6 & Shell-sand & 0.22 & 6 & Shell-sand & \\
\hline 7 & Limestone & 0.02 & 7 & Limbersone & \\
\hline 8 & Shell-sand & 0.30 & 8 & Shell-sand & \\
\hline 9 & Limestone & 0.01 & 9 & Limestone & \\
\hline 10 & Shell-sand & 0.08 & 10 & Clay & \\
\hline 11 & Limestone & 00.2 & 11 & Limestone & $\mathrm{f}$ \\
\hline 12 & Shell-sand & 0.30 & 12 & Shell-sand & \\
\hline 13 & Clayey-sand & 0.16 & 13 & Clay & \\
\hline 14 & Limestone & 0.58 & 14 & Limestone & \\
\hline 15 & Shell-sand & 0.45 & 15 & Pocket shell-sand & \\
\hline 16 & Clayey-sand & 0.15 & & Clay surround'g 1 st & \\
\hline 17 & Limestone & 0.02 & 16 & $\begin{array}{l}\text { Yocket of sliell- } \\
\text { sand and also oc- } \\
\text { cupying centre. }\end{array}$ & $g^{1}$ \\
\hline 18 & Shell-sand & 0.50 & 17 & Pocket shell-sand & \\
\hline 19 & Limestone & 0.04 & 18 & Clay & h \\
\hline 20 & Shell-sand & 0.50 & 19 & Shell-sand & \\
\hline
\end{tabular}

\begin{tabular}{|c|c|c|c|c|c|}
\hline S & BERGER'S & TION. & EQU & $\begin{array}{l}\text { IVALENTS. } \\
\text { EAST }\end{array}$ & $\begin{array}{l}\text { Section } 2 \\
\text { I'T. }\end{array}$ \\
\hline No. & & $\begin{array}{c}\text { Metres. } \\
0.03\end{array}$ & No. & & Formations. \\
\hline $\begin{array}{l}21 \\
22\end{array}$ & $\begin{array}{l}\text { Limestone } \\
\text { Shell-sand }\end{array}$ & $\begin{array}{l}0.03 \\
0.12\end{array}$ & & $\begin{array}{l}\text { Limestone } \\
\text { Shell-sand }\end{array}$ & \\
\hline 23 & Limestone & 0.05 & 22 & Clay & \\
\hline 24 & Shell-sand & 0.28 & 23 & Shell-sand & \\
\hline 25 & Limestone & 0.02 & 24 & Clay & \\
\hline 26 & Shell-sand & 0.09 & 25 & Shell-sand & \\
\hline 27 & Limsentone & 0.06 & 26 & linestone & \\
\hline 28 & Shell-sand & 0.14 & 27 & Shell-sand & \\
\hline 29 & Limestone & 0.04 & 28 & Limestone & \\
\hline 30 & Slsell-sand & 0.12 & & & \\
\hline 31 & " & 0.03 & 29 & Shell-sand & ا \\
\hline 32 & 6 & 0.62 & & & \\
\hline 33 & Limestone & 0.05 & 30 & Limestone & \\
\hline 31 & Shell-sand & 0.97 & 31 & Shell-sand & 1 \\
\hline 35 & Limestone & 0.16 & 32 & Limestone & $\mathrm{m}$ \\
\hline 36 & Shell-sand & 0.85 & 33 & Clay & \\
\hline 37 & Limestone & 0.09 & 34 & Limestone & \\
\hline 38 & Shell-sand & 1.30 & 35 & Shell-sand & \\
\hline 39 & Limestone & 0.25 & 36 & Limestone & \\
\hline 40 & Shell-sand & 0.25 & 37 & Clay-sand & \\
\hline $\begin{array}{l}41 \\
42\end{array}$ & $\begin{array}{l}\text { Limestone } \\
\text { Shell-sand }\end{array}$ & 1.20 & 38 & Shell-sand & $-x$ \\
\hline
\end{tabular}

My own Section 3, was not taken directly up the face of the cliff, but in two connected parts of the cliff, and Section 2, from a hole in the centre of the pit.

1 The correspondence here is much confused on account of the distribution of the shell-sand in pockets in the midst of the clay. 
. 


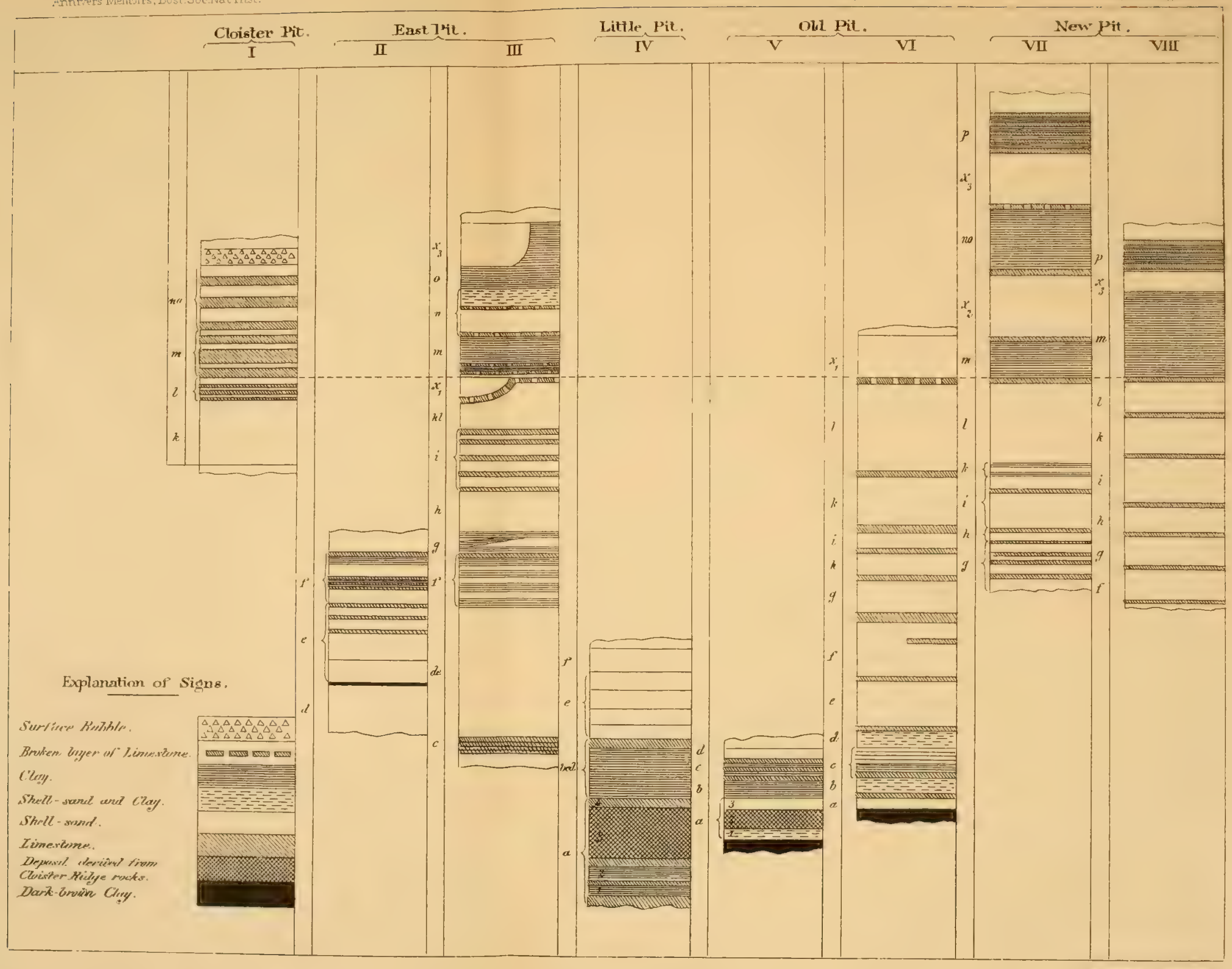


It is quite curious that under these circumstances, such a close agreement could have been obtained as is exhibited in the preceding table. In this table, however, I have taken the liberty to transform the word sand into shell-wand, otherwive Simlberger's table is given literally. This was done, because in my own notes and sections all hard sand is put down as shell-sind, whether entirely composed of shells and their framents, or largely made up of detritus.

The sections from 1-8 inclusive, were taken from the precipitous sides of the various pits, which are located on the Geological Map. The measurements were taken with a rule or tape in millemetres, from the face of the strata, and in no case estimated. Nevertheless, the thickness of the limestone partings are quite often exaggerated, in order to make them of an appreciable thickness in the printed sections, where, if reduced to $\frac{1}{1} \overline{0}$, they would in some cases be too thin to show the cross-bars which indicate their lithological character.

It may be said that there is general prevalence of the clay layers below in the lower parts of Sections 4, 6, and probably also in 2, 3, and 7, 8, if they had been penetrated sufficiently; and that these clay bands are for the most part destitute of fossil shells. Above the fish layers $c$ the sand predominates until we reach formation $m$, when the clay again appears in excess. It will be observed that this coincides with the three great faunal groups which may be made, the period of the $P l$. Steinhemensis which is rare above the fish formation $c$; of $P$. trochiformis, which is so abundant from formation $d$ to $l$, inclusive; and of $P l$. oxystomus which is equally characteristic of formations $m$ to $o$, inclusive. This is apparently contradicted by the prevalence of clay in formations $f$ to $i$, inclusive, in sections 3 and 4 . We can, however, account for these as unfossiliferous partings between the layers of shell-sind, corresponding to the limestone partings of the the other sections.

Notwithstanding this apparent correspondence between the kind of bottom obtaining in the lake at any one time and the species of shells living at that time in the waters, there are many failures which prevent the application of this rule in detail. Thus, the oxystomus series, which is prevalent in the clays of formation $m$, in Sections 3 , 7 , and 8 , are equally prevalent in the sands of the corresponding formations in the Cloister Pit, and in the Coarse Limestone of the Lower Period. Pl. trochiformis, also, which appears usually only in the shell-sands, is very abundant in the upper clays of Section 8, and the formation $p$, of Section 7. All species seem to be found in about equal abundance in the limestone partings, but are rarer and often entirely absent in the thin clay layers, or partings described above, and in some of the thicker beds.

Nevertheless, the general tendency of the observed facts, leads to the conclusion that the entire series of animals found below formation $m$ preferred to inhabit localities in which sand was being deposited, or had sandy bottoms, and those from formation $m$ upwards were either equally well fitted for clayey or sandy waters, which seems the most probable conclusion, or preferred to dwell in clayey localities.

This conclusion derives additional probability from the fact that the return of the trochiformis fauna, which occurred in formation $x$, in the East Pit, Old Pit, and New Pit, was accompanied by a deposit of shell sand. 
The dip of the strata is quite irregular, considering the limited boundaries of the pits, varying from $10^{\circ}$ to $30^{\circ}$ of inclination outwards on all sides of the central hill. This elevation, to a certain extent, evidently took place before the formations of the pits were entirely completed. This is shown by the poeket containing the Pl. multifomis and $P l$. discoideus shells in the New Pit, and also by a similar pocket in the East Pit.

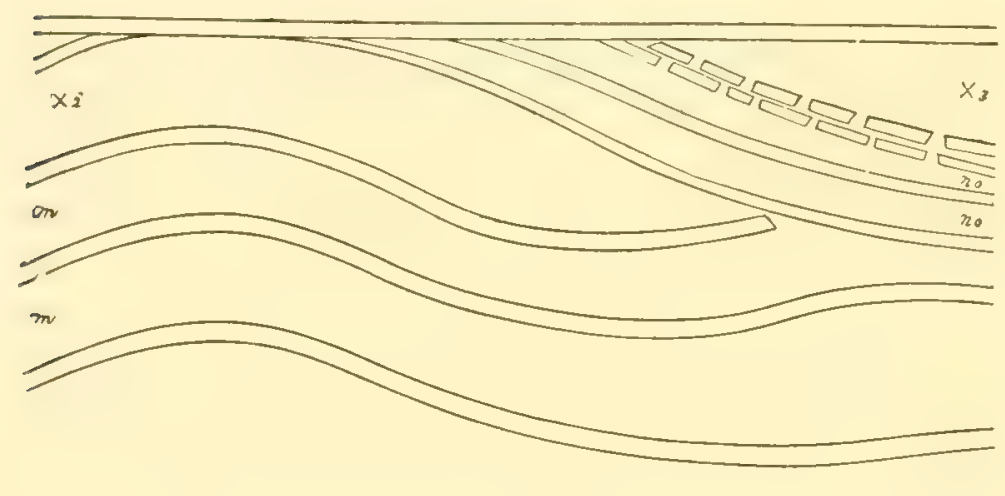

SECTION 9.1

Formations $m$ and $x 2$ of Section 9 were evidently deposited one upon the other in the New Pit. The only way to explain the appearance of the rood-cut, after this, is to imagine that the folding took place along the lines of elevation. The rood-cut represents a section at right angles with the dip, so that the folds run across the strike of the layers.

Subsequent to the folding, a certain amount of denudation must have removed part at least of the bed $x 2$, and the upper part of the bed $m$, in order to permit the deposition of $x o$, and $x$ ?.

Whether the same tendency to fold continued, caused by the resumption of the process of elevation on either side of $x 3$, and gave the basin-shape to $n o$, deepened the folds on either side, but did not alter them otherwise, leaving $x 3$ a symmetrical hollow, or saucer-shape, is doubtful. They seem to belong to the same system of folds as $x 2$ and the want of $x$ above is probably due to local denudation. On the face of the pit on the north side of $x 3$, this is shown by the anticlinal bend in $m$, but even more perfectly by the fact that $n o$, and $m$ become exactly parallel farther to the north.

Section 10 shows that somewhat similar conditions must have obtained in the East Pit at about the same time. Unfortunately I had confused the samples from $x$, with those from $k$, and consequently only rely on my notes made upon the detailed section. These speak of trochiformis in two places as prevalent, but not abundant; whether, therefore, other fossils occurred with this I cannot say.

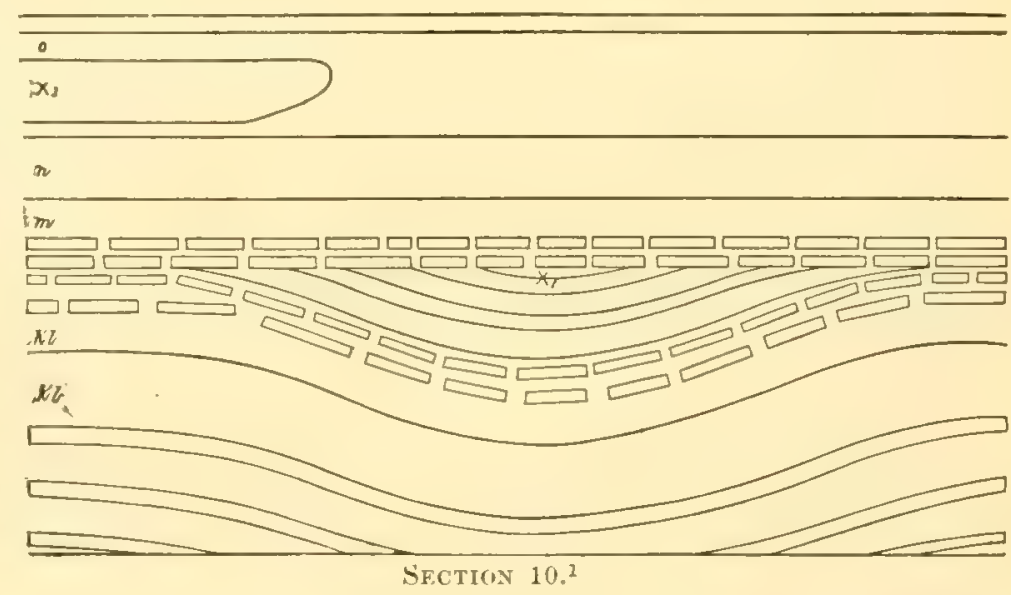

Here the bed $x$ is in both cases a pocket-in one case in a fold, and in another evidently occupying a hollow in an undisturbed clay layer. It is very evident that formation 
$x 1$ of Sect. 3, and Section 10 above, and of Sect. 6, is not the same as formation $x 2$ of Sect. 7 , since they are separated by the clay bed $m$, and for the same reason formation $x 3$, of Sections 3 and 7 , is not the same as $x 2$, since these are separated by formations $n$ and 0 . There are really, therefore, three series of formation $x$, due to the colonization and re-colonization of the same spots by the persistent forms of $\mathrm{Pl}$. discoideus and Pl. trochiformis. How is it possible for $x$ bed fauna to alternate in this way with clay in pockets, or in folds, as the case may be, or with beds of pure shell-sand and shell, without recognizing their resemblance to the same mode of occurrence of similar pockets in many of the clay layers below? That they were ruins of the older trochiformis formations and were swept into these well defined local depressions is of course possible, but it is an assumption which an experienced collector would be slow to adopt. It is a well-known fact that deep holes in water-ways are usually more or less filled with dead shells of various kinds, but these usually exhibit decisive marks of the rough handling they have received from the currents.

This does not appear in the shells of the $x$ beds so far as I have observed them, and even in such a small lake as Steinheim this must, I think, be asked for. Many shells are unquestionably water-worn and, if so, why not all in these beds if, as claimed by Dr. Hilgendorf, they are made up of wholly transported materials.

The upper layer of limestone in the Old Pit, and all the layers of limestone above formation l, in the East Pit are fragmentary. These fragments lie more or less closely together, and look very much like contimuous layers broken up in place by the bending of the strata. Whether these may be taken as evidence that the strata lying upon them at the time of their last elevation was not of great thickness, it would be hazardous at present to say. One fact, however, seems to indicate something of this sort. The limestone above $l$, was probably free from any great pressure at the time the folds took place, which formed the pocket at $x 1$, in section 10 , as also was that of $l$ in the Old Pit. This sugrests that the same condition of aftairs probably occasioned the breaking up of the succeeding layers in the East Pit.

The formations seemed to have been disturbed in the East Pit, and in the Old Pit, at about the same time, that is after the deposition of $x 1$ upon $l$, or $k, l$. This did not seem to affect the strata in the New Pit, however, until after the deposition of clay beds containing fossils, which caused me to synchronize them with $m$ and $n, o$, in the East Pit, and the bed $x 2$ which was deposited between them.

The broken aspect of the layers of limestones were not, when I saw them, similar to the descriptions given by Dr. Hilgendorf in "Neue Forschung in Steinheim," p. 452, but possessed in all the cases observed by me, a regularity which I could only account for as the result of the bending of the strata after deposition. It is well known in this country that not very dissimilar effects occur from the compression of gneiss occasioned simply by the removal of the superincumbent rocks. The upper layer relieved from the weight, in some spots forms miniature anticlinals and synclinals, and in others bursts with considerable violence in the quarries of Monson, Mass., where these phenomena have been observed by Prof. W. II. Niles. ${ }^{1}$ I could not understand the reg-

\footnotetext{
1 Proc. Bost. Soc. Nat. History, XIv, 80.
} 
ularity which the upper layer of limestone in the pits presented, if the pieces were transported there, and thrown loosely together.

It will, however be observed, that formation $m$, of the Cloister Pit, presents a fauna closely similar to $m$, in the other pits, and that of $n o$ above in all of the pits is quite as similar to $m$, as the fauna of $x 3$, above is to that of $x 1,2$, below, wherever that bed occurs twice. There is, it seems to me, just the same reason for maintaining that $m$ and $n o$ are composed of drift, as there is for maintaining that $x$ is made up in this way. In conclusion, I would say also, that there are the most positive reasons for the belief that $x$ in Section 8, represents the upper and not the lower bed $x$, of Section 7. I find it so mentioned in my notes and sketches taken on the spot. I was, however, unable to say whether $m$ in Section 8 represented $m$ alone, or both $m$ and $n o$, of Section 7, with absolute certainty, since the south-east corner of the pit was concealed by a recent and heavy full of loose materials. One thing, however, can be said with certainty, that a bed corresponding to lower $x$, on the east side of the pit, as represented in Section 7, is not to be found on the south side, and the thickness of the clay on that side is very nearly equal to that of the two clay beds on the east side, and it has every appearance of being continuous with those two, If, therefore, lower $x$ is drift, it had a very limited distribution, since it is certainly not found on the south side of the New Pit. This also corresponds with the unquestionably mere pocket-like aspect of the upper $x$ deposit in the East Pit, and is evidently not in harmony with the supposition that this is a bed of detrital matter, as represented by Dr. Hilgendorf, spreading over the entire bottom of the lake.

I do not consider this point of any great consequence, or worthy of much debate, since it makes not the slightest difference with resard to the main question, whether $P l$. trochiformis lived after the $P l$. oxystomus bed was deposited, or not; though it is of vital importance to determine whether oxystomus preceded trochiformis in time.

One statement, however, of Dr. Hilgendorf's is of great importance, since it shows that very considerable changes likely to disturb the regularity of the deposits in very confined areas, as is claimed here, did occur in one case, whether they occurred in the latest Trochiformis bed or not. On p. 452, ${ }^{1}$ he states that in the Sulcatus bed he found broken Steinheimensis clays "Platten," "tenuis Gesteinen," blocks of porous sulcatus tufi, clayey sand and Jura pieces, all mixed in the greatest confusion, and two metres thick. 'This mass evidently was of very limited extent and shows how great are the local peculiarities likely to be found in any one spot from the transportation of material.

As he says, these mixtures are apt to escape a careless observer, and I might add also, any one perhaps, not especially looking for them. In this extraordinary mixture, however, of the Sulcatus zone, he found no intermixture of the higher occurring forms. 'This fact he justly regards as very important to his hypothesis, since the rocks also are all older than the stratum or zone in which he found them.

The characteristics and situation of the bed $l$ appear to make it very suitable as a standard for the comparison of all the formations above and below its level. It occurs immediately between the beds containing the trochiformis fauna, and those containing the oxystomus fauna, and it affords a strong contrast in its fossils and lithological characters, and is also apparently universal in its distribution. These reasons have induced me to

\footnotetext{
${ }^{1}$ Nene Forschung in Steinheim, Zeit. d. Deutsch, geolog. Gesellsch. 1877.
} 
adopt it in the table as a fixed level through which I have drawn a dotted line. Departing from this in any section, it becomes possible to synchronize the different formations.

If we assume that the usual sedimentary matter held in suspension by the waters of the lake was clay, and that these waters were saturated with lime, we have an explanation of the rapid formation by deposition of the plates of limestone. 'This being the necessary consequence of the undisturbed action of the water, we should have the dense limestone lavers deposited on the bottom wherever the currents were not disturbing it and spreading out the conser sand derived either from the Cloister Ridge rocks or the aljacent surfaces of the Jura.

The constant shiftings of the local currents, due either to the obstacles they themselves had built up or other disturbing causes, would produce this aspect of regularity in each section of the layers, as well as the want of correspondence in the synchronous deposits of even adjoining sections.

The widely distributed formations could never be limestones, but might occasionally be composed of materials derived during floods from the surrounding country, that is of clay or sand. A glance at the sections will show that this is the case since $e$ is of shell-sand, $m$ of clay, and none of the limestone-tables are continuous. The general changes, the predominance of shell-sand during the Trochiformis period, and of clay during the Oxystomus period, would also seem to be accounted for by a greater or less prevalence during a certain number of successive seasons of similar deposits, due to changes in the localities from which the greater part of the drainage was derived, or to other local causes.

In this condition the Steinheim deposits of the Pits assume the aspects which might be expected to arise in a land-locked lake with a central island. 'The deposits would be formed in some places from the debris washed off of the rapidly disintegrating surface of the island, and in others, even in close approximation, the ortinary formation of limestone or the precipitation of fine samdy material, or flocculent clay, might take place in quieter water, or farther from the shore. Any of our inland lakes present similar conditions wherever local streams empty into them. During heavy rains as at dffierent seasons of the year, the debris of the beaches and bottom is subject to noticeable variation within very short ranges.

Another fact in this direction indicates also that the amount of time represented by the Steinheim Pit Deposits must have been very limited. Strata slowly formed are marked off in exceedingly thin lnyers, since but a small amount of fine sediment is held in suspension by the water, and slowly deposited during a given period of time. The thicker layers result from a larger amount of sediment which has been held in suspension and falls with greater rapidity. This accounts for the finer bedding of the clays, fine grained sandstones, limestones and so on, as contrasted with the coarser rocks and rubble.

The strata and sometimes entire thick beds of shell-sand bear no marks of stratification, and must, therefore, have been built up by continuous and rapid deposition. The clay layers are of various degrees of thickness, but usually an inch or more, and very rarely of paper-like thimness, and this is true also of the limestones. The fish-layers of formation $c$ are particularly instructive in this respect. The fishes being necessarily very destructible, testify to several things: first the rapid deposition of the 
layers, which are an inch or more in thickness; second, the prolonged continuance of conditions about equally favorable to the rapid formation of limestone, or of clay strata; and third, the unfavorableness of the waters, at this time, to the existence of the fish, which must have died in vast numbers.

None of these facts, so far as the Pit Deposits are concerned, are in favor of the vast periods of time which have been claimed by Darwinists, in order to account for the changes which are supposed to have taken place in the fauna of the lake during the Upper Period.

There is only one fact which would seem to interfere with this conclusion. Some of the "shell-sand beds" are mostly composed of broken shells, and it may be inferred that they are wholly made up in this way. This may possibly be so, in some instances, in the midlle part of the deposits, but is of local occurrence and not a general characteristic. The limestones would come under this head more than any other, as might have been anticipated from their chemical constitution, but even here in most eases the matrix is an even-textured argillaceous limestone, and is not invariably composed of shell fragments alone.

It is very evident that the formation of the strata, either by precipitation or deposition, was going on all the time, either as clay, limestone, or shell-sand, all over the area described. The apparently regular interruption of the deposition of the clays and shellsands by beds of limestone are too local to indicate in any very positive way the constant recurrence of periods of time or seasons when the waters of the lake were generally affecter, and contained so little transported sediment of any kind, that limestone layers could be formed on the bottom which would be continuous. These facts, the local distribution of the beds of shell-sand in some clay strata, as in Section 3, and in several instances not sketched in the section, in the East Pit and New Pit, the dark clay band $d$, Section 2, in the midst of shell-sand, all appear to show that the unstratified beds were sirept into the spots where they are now found by currents of greater or less strength, and built up continuously during a period of time limited by the extra supply of water rushing down from the drainage of the island, or the neighboring lills, or both. This extra supply of water could only recur at certain seasons of the years; therefore the unstratified beds either represent rainy seasons, and the internittent local currents which they would naturally produce, or constant currents shifting in position from year to year, or season to season.

If the latter theory is accepted it becomes exceedingly difficult to interpret the regularity with which the coarser beds were locally interrupted by the limestone layers, without assuming that there were years or periods of years, during which the currents flowed constantly bringing in shell-sand, and then shorter or longer periods of months or years of rest. These would occur at regular intervals during which the currents flowed somewhere else to return again by some inexplicable fatality directly over the same spot, begin to increase in volume, and move so fast that shell-sand could be again transported.

The latter hypothesis appears to me to present by far the greatest difficulties, besides being contrary to experience. If we adopt the former, the Stemheim Pit Deposits show a very limited thickness, for the nost part of loosely aggregated materials which must have been heaper up in a shorter time than one would be led to suppose by the number of new fossil forms produced and by a cursory examination of the strata. 
I cannot, of course, presume to say that the period of time represented by the Pit Deposits was or was not long enough to allow of all, and more than all the changes which took place in the fauna, but simply point out the fact, that no grounds exist for the assumption that they represent any very prolonged peciods of time, such as have been habitually, and, in my opinion, erroneously claimed, by most naturalists, as essential for serious morphological changes in animal series.

Professor Cope's researches among fishes and reptiles, the author's among the Ammonites, and, at a later date, Mivart's work on the "Genesis of Species," have all given a large amount of evidence, which tends to show that vast periods of time are not necessarily essential to the production of new species, or even new generic or family forms. Nor is yet the converse true, that animals which have lived through great periods of time, and many greological changes, are necessarily and correspondingly altered in their organization. The testimony of all paleontologists bears witness to the last statement, but the first requires more proof, and for this I must refer my readers to the authors above mentioned.

In the chapter on the geology of Steinheim, an attempt has been made to show how great the denudation of the surface of the rocks of the Cloister Ridge must have been, and that a part of it probably took place before and during the deposition of the lower part of the Pit Deposits. The evidence that a great amount of denudation has occurred since the Pit Deposits were formed, would not need to be summed up to any one who had seen the locality.

The whole area of the circular valley must have been at one time covered to a considerable depth by stratified deposits similar to those of the Pits, either resting upon the denuded limestones of the Lower Period, or what is more probable, merely abutting against these remnants on the sides of the valley. These have almost entirely disappeared, since what is left adhering to the sides of Cloister Ridge can only be considered as the merest fragments of what the mass originally was. What the vertical height of these deposits must have been is of course wholly problematical. Sufficient evidence has been brought forward to show that, though the elevation of the Cloister Ridge took place before the Pit Deposits were formed, this elevation was continued certainly after their deposition was completed, and probably also went on more or less while they were being deposited. This of course, would be an element in the problem, as well as the determination of the extent to which the neighboring heights and the outlets, which once bordered and limited the depth of the waters of the lake, had suffered from sub-aerial denudation. This portion of the problem, therefore, can only be safely approached by a local greologist, and it would be idle for any one else to attempt an estimate. That the Pit Deposits were much thicker than they are at present, and that they present in every way only fragmentary evidences of what the fauna of the lake was, as well as of its geological history, can hardly be gainsaid, unless different conditions governed in former periods from those which we now find in similar localities.

It remains only to add that ample provision for the removal of any required thickness of deposits once probably existed in the drainage of the surrounding mountains. A proportion of this even now passes through the valley of Steinheim to the Steubenthal as described in Quenstedt's article previously quoted, and ample evidence of the former existence of a more powerful stream, may be found in the official geological map of Wurtemburg, "Heidenheimer Blatt," and its accompanying text by Prof. Fraas. 


\section{iV. Descriptions of Series and Sub-Series.}

FIRST SERIES.

\section{Planorbis minutus.}

Planorbis muttiformis mimus Hilg., Monatsher. d. Akad. d. Wisiensch., Berlin, July, 1866 , f. 15.

Pl. Zietenii (pars) Sand. Land und Süssw. Conchyl. d. Vorwelt., p. 645.

Pl. hemistoma Klein, Jahreshefte Ver. Naturg. Württemb. 2 vol. 1847, pl. 1, fig. 25.

This remarkable species seems to have in the aspect of the whorl, and the general thinness of the disc-like form a very close affinity for $P l$. crescens. It differs, however, in the greater involution of the whorls in the healthy forms which precisely resemble $P l$. Kranssii, in the aspect of the umbilici when viewed from above or below. - This part is narrower, and the internal whorls less exposed than in $P l$. crescens. It is plain that a flattened form of Pl. Kroussii would be precisely intermediate between these two. After much search, I found a specimen which was a trifle flatter than the usual square form, the outline being similar to that of $P l$. minutus, but it was still considerably larger than the ordinary specimens of this species, and could not be considered a hybrid. A close comparison between the largest mimutus. and Pl.pareus, was more successful. The typical mimutus forms have a narrow umbilicus, as compared with $P$ l. parvus, in any of its varieties, but this characteristic is exceedingly variable in the species, and many of the specimens have a wide umbilicus on the lower side. If we compare these with the young of $P$. parvus, as figured on pl. 3, line $a$, fig. 6, 20-22, they will be found to be almost identical.

Var. minutus can by no means be considered the ancestor of var. parvus, on account of eloser affinity of the latter for Pl. levis, and Itilgentorf has also found it in company with Steinheimensis in the lowest formation. Both IIilgendorf and Sandberger decided that the affinity of this species was closer for Pl. levis than for var. Steinheimensis, and this is also my own conclusion. My observations agree also with those of Hilgendorf, in respect to the derivation of crescens from parvus, and with both his and Sandberger's, in tracing a close affinity with $\mathrm{Pl}$. minutus. They differ, however, in preferring to trace a direct connection between $P l$. minutus and $P l$. levis, through the normal forms of both species, rather than through the aequiumbilicated varieties of Steinheimensis.

Again, if we compare a large minutus with the forms of $P l$. parvus having an angular outer whorl, pl. 3 , line $k$, fig. 1 , this similarity strikes the eye very forcibly. Compare also the figures of parvus on $\mathrm{pl} .3$, with the those of minutus, line $a, \mathrm{pl} .4$. This connection with parvus settles the question of size, since this variety of parvus is certainly an intermediate species in this respect, between minutus and Pl. levis. I have, therefore, separated this angulated form of parvus, figs. 1-4 and 11, line k, pl. 3, under the name of minutus, to distinguish it from the normal forms of parvus, which lead into $P l$. crescens.

It only remained, therefore, to find some form of a full-grown specimen from Undorf, which would show the characteristics of $P l$. minutus $\begin{gathered}\text { meris } \\ \text { lest }\end{gathered}$ This, on the reception of Sandberger's specimens, was accomplished, and is figured on pl. 9, fig. 16. 
Starting then with $P$. levis, we can trace this series through a valriety found in the Pits which we call the ${ }_{\substack{\text { minutus } \\ l+r i s}}^{(\text {equal } P l . m . ~ p a r t u s ~ H i l g . ~ i n ~ p a r t), ~ i n t o ~ t h e ~ m o r e ~ a n g u l a t e d ~ v a r i e t i e s ~}$ of $\mathrm{Pl}$. minutus. This last figured on pl. 9, fig. 17, and line $e$, fig. 16, pl. 2, is the $P l$. triquerus of Hilg. Notwithstanding this name it will be found by comparison with such forms as have just been mentioned, as $P l$. mimutus, that it differs only in size. This leads into a variety of $P l$. minutus, fig. 18, pl. 9, and fig. 1, line e, pl. 2, in which the brealth and angularity of the inner part of the aperture is still maintained, but the shell is otherwise a variety of $P$. minutus, and has the thinner proportions of the young whorls observable in this species. Both this and fig. 17, pl. 9 seem to fade by imperceptible gradations into fig. $19, \mathrm{Pl}$. triquetrus, also figured in nos. 1-3, pl. 4, line $c$. Or they may be traced into the less involute forms of $P l$. mimutus. These have exceedingly cylindrical whorls, and umbilici entirely open on both sides, and connect the more involute or levis-like minutus forms, with the uncoiled $P l$. denudatus.

Remarks: On pl. 4 this genetic series is fully illustrated. Line $a$ exhibits various varieties of $P l$. minutus. These appear to be identical with the $P l . m$. minutus, var. $\beta$ teres of Hilgendorf in part, and in part are equal to his $P l$. $m$. minutus, var. a typus.

I think that figs. $1,3,5,7$, line $a$ would be considererl as belonging to the first named. The figures on line $a$, however, are arranged with the view of exhil,iting the varieties which tend to deflect the whorl by growth agrainst the spiral. Fig. 7 is an extreme form in this respect. Figs. 2, 4, line b, are typical minutus forms, and connect directly with Pl. riquetrus figs. 7-8, line $b$. These have a closer umbilicus on the lower side (compare figs. 2 and 6 , line $b$ ), and in this respect approximate to Pl. tripuetrus. This last named species is figured on line $c$, figs. 1-5. Pl. triquetrus, var. turbinatus figs. 5 and 9 , line $b$, the latter a section, exhibit very distinctly the tendency towards trochiform growth of the spiral, which is common in all the species and varieties at Steinheim. This also, is the proper place to notice the modes of variation among Steinheim shells.

It will be observed that the varieties of any one of the forms previously described fluctuate between two extremes so far as the spiral is concerned. As in the case before us these extremes are indieated by a tendency to reverse the spiral in some forms, and to increase it in others. This correllates with a widening of the umbilicus on the lower side in the former, and a narrowing of the umbilicus in the latter.

These two again correllate with more cylindrical whorls in the former, and wider or larger whorls in the latter. The latter correllation is important, since it enables us to draw one more important distinction between the healthy and unhealthy series, or the progressive and retrogressive, as I have called them. Thus on the summary Plate, pl. 9, series 2-4, exhibit this in a marked manner, and so also does sub-series 3, which thus shows another progressive characteristic besides those previously enumerated.

If there is any truth in the assumption that health marks the favorable character of the surroundings, and that such correllations are signs of healthy growth, then the sub-series previously assumed upon other grounds to be diseased or unhealthy, might show the universal tendency to form a spiral, but ought to be deficient in healthy characteristics. I have already shown this to be the case in different degrees according to the character of the sub-series, and I now have to add, that they are in a measure 
exceptions to this law of correllation, since in sub-series second, the whorls become less in respect to their breadth, or more cylindrical as has been previously stated. It will also be seen by looking at pl. 4, that there is a decided increase in size in the costate sub-series, as was to be anticipated in correllation with the partialiy progressive characteristic of the well-marked costre which appear in this sub-series. The contrast between the large and comparatively healthy specimens of this sub-series and the smaller distorted ones, is very well shown also on lines $h$ and $k$, as contrasted with $g$ and $i$. This tendency to such correllations as here described, show that the varieties of each species are quite closely parallel with the greneral progress or morphology of the most advanced group, the Fourth Series.

Thus not only does every species vary from a more or less aequiumbilicated to a more or less asymmetrical rotundatus or trochiform-like shell, but the whole series of changes in form of the Fourth Series is similar. See pl. 9, figs. 1-7.

To this I might add if space permitted, many other examples among the fossil Ammonites and living animals. In fact, in my experience, the general limits of variation are indicated in the range of form of almost any numerously represented species of a group. The difference between the morphological range in a species of this kind and the group to which it belongs being one of degree, one of quantity rather than quality, ${ }^{1}$ or otherwise there could be no parallelism between the morphological variations of form in the species and the series of forms, which are comprised in the group to which the species belongs.

\section{Planorbis triquetrus.}

Planorbis multiformis triquetrus Hilg., Op. cit., fig. 17.

Var. typica.

Fig. 15, pl. 9, leads into shells, fig. 9-2.3, line $y$, pl. 2, in which the upper side becomes slightly channelled, and sometimes the lower side also, as in Hilgendorf's figure. We are here presented with a remarkably close parallelism with the thinner forms of $\mathrm{Pl}$. tenuis, but it is not very difficult to separate even large perfect forms of $P$ l. triquetrus from the young of forms which are figured in the two lines below on the same plate.

Var. turlinatus. This includes three specimens, which, as in figs. 20, pl. 9, or figs. 5, 6, 9 , pl. 4 , line $b$, become more trochiform than var. typica.

\section{Planorbis denudatus.}

Pl. multiformis denudatus Hilg., Op. cit., fig. 19.

Hilgendorf's arrangement of the derivative forms which may be designated by this name, appears to be defective, in so far as he traces the uncoiled, smooth or "denudatus" variety, to the coiled and round whorled "costatus." My collection gives a perfect series, without break of any kind, from the perfectly smooth $P l$. minutus to a completely asymmetrical shell, which differs but slightly from Hilgendorf's figure of Pl. denudatus.

It must always, however, be understood that parasites
do not come under this law, nor any range of forms however
closely connected, which have been placed in exceptional
surroundings. As previously stated, the environment is the supreme modifier, and the reaction of the organization against the environment, and the maintenance of the type by this reaction, cannot survive in the presence of continuously exceptional surroundings. 
Thus, figs. 1-5, 7-8, 10-14, line e, 6-8, line $g$, pl. 2, show this series perfectly enough, though too slightly magnified to be convineing with regard to the smoothness of the shell. I have been unable to detect any costa on any of these shells, and have seen much more turbinate forms than fig. 8 , line $g$, almost completely uncoiled. I have, however, not yet succeeded in finding the exact equivalent of Hilgendorf's figure, which must be very rare. ${ }^{1}$ The forms which have the young so completely trochiform, usually have the last-formed whorls widely uncoiled instear of being so contracted as in his typical specimen.

On pl. 4 this series is shown fully and may be followed from the minutus forms through such specimens as figs. 6-9, line $c$, and the more uncoiled forms on line $d$, to the completely trochiform and uncoiled shells photographed on line $e$. None of these show any costæ.

The decrease in the breadth of the whorl of the specimens on lines $d$ and $e$, as compared with the specimens less uncoiled on line $c$, and the true mimutus forms is also perceptible. The flat form of the young in figs. 10-11, line e, can also be perceived, though less perfectly because the minute size of fig. 11 threw the lower part out of focus.

This young is like the young of $P l$. minutus, and of $P l$. levis, but $I$ failed in finding an adult of any of these forms which could be considered identical with it. This was not a surprising result, since any resemblance occurring at so early a stage with any adult form in the shell alone was not to be anticipated, especially with the adult of any proximate ancestor.

The law of accelerated development by heredity, which has been noticed in other series, is here also demonstrated. The uncoiling begins at earlier and earlier stages in the different species, and it is the same story with the increase in spirality. If any arrangement in series is in general terms a fair presentation of the natural accession of the forms, then this law must be admitted. It will be found to hold equally well when applied to any serial arrangement of species based on all the attainable evidences of affinity, in the identity of the extreme young stage, the resemblances of the succeeding stages to supposed or traceable ancestral forms, and the similarities of the adult, old age, and diseased forms.

I have already sufficiently traced the resemblances between these retrogressive uncoiled species and the partly uncoiled, diseased shells of the progressive series photographed. Figs. 4-5, line $a, 4-5$, line $b$, and $1-2,6$, line $c$, pl. 8 , are particularly instructive in this connection, since figs. $4-5$, line $a$ are senile deformities, figs. $4-5$, line $b$, the results of normal disease, and the remainder doubtful or due to wounds.

The series traced by Dr. Hilgendorf between this species and costritus, can undoubtedly be formed, but it seems to me perhaps more natural to consider the costate forms as a distinct sub-series. They can certainly be separated quite as easily as any other set of species, if we recognize the fact that the different series all have a tendency to reproduce similar series of forms, which may be arranged in parallel lines. 
This appears also to have been the result arrived at by Sandberger, though from his conclusion, I must also differ in part, on account probably of the opportunities afforded by a larger amount of material, which has enabled me to trace the connection of costatus with minutus.

\section{Planorbis costatus.}

Planorbis costatus Klein, Op. cit., pl. 1, fig. 24.

Pl. multif. costatus Hilg., Op. cit., fig. 18, 18 a.

Pl. costatus Sand., Op. cit., p. 647, pl. 2,8, fig. 5.

Var. $\begin{gathered}\text { costatus } \\ \text { minutus }\end{gathered}$

In order to understand what follows it becomes necessary to trace the relations of the strix of growth, and the costa of the shells. It will be observed that the strix of growth are of various degrees of fineness and prominence in all the species of the Steinheim Planorbidae. Sometimes they are hardly observable, since they are not prominent enough to be seen with the masister eye, though visible with a magnifier of four diameters, as in $\mathrm{Pl}$. minutus and demudatus. There are all degrees of this in Pl. Steinheimensis for example, until we find specimens in which they are plainly visible by the naked eye. In other species, such as $P l$.tenuis, discoideus, trochiformis, oxystomus, and supremus, they are distinct enough in many specimens to catch the light, and be visible in the photographs, and in all specimens with the naked eye.

This is also an effect of old age, as in the older portions of the whorl of the senile specimens of $P$ l. supremus, fig. 1-4, line $d$, pl. 8. In these, and in many others, any cause which retarls or arrests growth, causes an increase of shell deposits at the lines of growth, and a consequently greater prominence of the strice. That these more prominent stria may be also a hereditary characteristic in perfectly healthy shells is demonstrated by such series as $P l$. levis to $P l$. crescens, and others, and by $P l$. discoideus var. sulcatus, etc.

In $P l$. crescens they are visible under a magnifier, as in $P l$. Steinheimensis and $P l$. levis, and in none of these, or in equally finely preserved shells of $P l$. minutus, is there any tracable difference except in point of fineness. This fineness also differs in different shells of the same species, precisely as it does between different species, being finer in some than in others, according to the rate of growth of the animal. Between each projecting ridge or striation there is a (usually, but not invariably) sunken smooth band of exceedingly variable width in the same shell. At intervals there are stria, more elevated than the rest, more elevated than those on either side of them, which are the costio proper. They are formed by an arrest of the growth at this point, occasioning a slightly greater thickening of the shell. The rim of the opening not being absorbed in these shells, when growth is resumed at the usual rate of increase, and the true strix begin to be again formed, there remains a larger and more prominent ridge. These costa will often occur is some specimens of a species, and not in others. They are quite rare in those species which, like $P T$. Kransii, have very fine stria of growth, but can be distinguished in some specimens. Care must be taken in both this and $P l$. minutus to obtain shells which have not been acted upon by any re-agent. The larger number of 
the shells of $P l$.minutus, and a very large proportion of $P l$. Kraussii appear to have been subjected to the action of an acid sufficiently powerful in many instances to cancellate the outer surface, and destroy the strix. It is, however, easy to distinguish the perfect shells after a close examination, though sometimes the stria are so fine and equal, that at first sight, even under a magnifier, the shell appears to be absolutely smooth.

The costre are not found on some specimens of $P l$. Kroussii or $P l$. minutus, but in others they are distinct, though in the latter more difficult to see than in the former, on account of the size of the shell. The coste in their turn are apt to be confounded with the still larger and more oparque ridges left by the building in of mouth rims, which have marked long periods of arrest of growth in the shell. I have not been able to reduce them to any law on account of the perfect way in which they are generally covered up when growth is resumed. In recent species of Planorbida it is quite possible to trace them occuring at regular intervals by their opacity and color, and they are evidently due to seasonal arrests of growth, but in the fossils they are too readily confounded with the strix, though occasionally noticeable. When the shell attains its growth, however, the arrests of growth appear not to be wholly limited by the seasons. The building period appears to be shorter and more irregular, and in distorted specimens this is particularly noticeable. See, for illustrations of this, the figures of Pl. supremus, pl. 4, already described, and the following, fig. 9, line g, fig. 13, line $h$, pl. 1; figs. 2, 4, line $c$, fig. 5, line $m$, pl. 2; figs. 1, 7. line $g$, fig. 1, line $n$, pl. 3; figs. 3-5, line $a$, figs. 1-4, line $d$, pl. 8, all simple forms. A noticable case of distortion combined with senility is that of fig. 10, line $r$, pl. 2, which is repeated on line e, fig. 2, in a different position.

These were not specially selected to show these peculiarities, but are very good ordinary examples of the pathological conditions described. In any shell there may be every condition from that of the young or full-grown healthy shell marked with striæ, costæ, and permanent mouth-rims, to its old age form, in which the costre are susperseded by permanent mouth-rims occurring at rapid intervals, and finally to the last stage of debility, in which the latest built mouth-rim projects only slightly beyond the former and greatly narrows the aperture, as in fig. 4, line $c$, pl. 8 . The thickness of the permanent mouth-ring varies greatly in different adult individuals, even of species like $P l$. oxystomus, which habitually have a very thick lip in the adult. As a general rule, however, the mouth-rims are thinner in the young shells of all forms, whether species, or varieties, or individuals, than in the adults; and especially so in those which thicken the lips or rims during their subsequent growth. This peculiarity aids in the concealment of the cicatrix or ridge of the permanent mouths during growth, so that these become apparent in most shells from the Steinheim Pits, only when the edges have been broken during the season of rest, or after the shell has reached the full adult size, and forms a thicker rim than is nsual in the young.

The first of the series of the costate forms are not distinguishable from the typical $P l$. minutus, or from the varieties intermediate between that species and $P l$. denudatus, except by the presence of distinct fine costre. These do not occur in the young shells of the forms most closely allied to $P$. minutus, but only on the last whorl in the full grown adult shell. This point I have established by 
repeated observation, it being very important in its bearing on the law of acceleration. Thus figs. 8 , line $k, 1-2$, line $f$, pl. 4 , are shells in which they appear only on the last part of the last whorl, fig. 3 , line $f$, at an earlier period on this same whorl, fig. 4 , line $f$, at a much earlier stage, at least half a whorl sooner in the growth.

In all of these the costre are closely approximate. 'Though there is very considerable variation in this respect, the differences between these and var. major, as shown on line $f$, pl. 4 , and on lines $g$, and $i$, where they are of about the same size, being distinguishable by a practiced eye in almost all shells.

Line $g$ shows a variety identical with Hilgendorf's var. typica of $P l$. costatus, and figs. 1-5, line $i$, the equivalents of his var. platystomus of the same species. The costæ are very wide apart in the latter, which in my view are the young of the larger specinens of the coarsely costate forms on line $k$ above, while the specimens figured on line $g$ are the young of those shown on line $h$, in which the sime peculiarities of the costa are observable. The extremely uncoiled forms are in all cases, of course, regarded not as young forms, but as diseased shells, which as previously observed, would of course be undersized in comparison with more healthy individuals of the same species.

I have not succeeded in finding any hybrids or shells of an intermediate character between these and the corresponding uncoiled smooth forms of Pl. demuntus. The different forms may be in general terms distinguished into two varieties: 1st, shells with sharply defined crowded costre. 2d, Shells with widely separated costax. These may have their variations in the costæ. (1), having either sharp, forward projecting, rim-like costæ; (2), thick, vertical lip-like costae; (3), thick costae overhanging, opposite to the direction of the growth of the shell. These modifications are due to the way in which the costae are built up. In the first place, the re-building of the shell is begun on the inside of the old whorl, leaving the edge of the mouth projecting forward like the free edge of a frill, fig. 9 , line $g$, pl. 4 . The second is accomplished by the curious way in which the new growth is begum, immediately along the flaring edge of the mouth so that the resulting costa are of double thickness. The third is occasioned by a slight overlapping of the old edge of the mouth by the new growth, so that the most abrupt portions of the costa are the posterior sides, instead of the anterior, as in the first instance.

Varieties 1-2 may be subdivided in precisely the same way, but the peculiar ways in which the variations are occasioned in var. 2, are more easily observed.

Notwithstanding these facts, however, it is noticeable that the last two kinds, or abnormal costie, are very lare in the finely costate series, and very common in the coarsely costate, or $2 d$ variety.

The distorted varieties are precisely parallel with $P l$. denudatus, so far as the form of the whorls and the spiral is concerned, but bear the most indubitable maris of their derivation from the various costate races above described. They are of all degrees of uncoiling except the absolutely uncoiled, that is, one in which the extreme young is not closely coiled. The whorls may not touch anywhere, after the first part of the first whorl is built, but this is invariably in close contact with little bag-like ovishell, due to the prepo-

${ }^{1}$ This variety is figured in the coarsely costate specimen, ety, fig. 7 , line $i, \mathrm{pl} .4$. fig. 1, line $k$, pl. 4. See also for the next described vari- 
tent inherited tendency to form a closely coiled shell during the protected stages of the earliest period of growth. I failed to find any finely costate forms, with distorted or open whorls.

Line $h, p^{3} .4$, gives photographs of the variety mojor of IIilgendorf, and he probahly also includes in this variety the coarsely costate forms on line $k$.

Var. major (Pl. multiformis var. major Hilg.), fig. 15, line 6, pl. 3, is an exceedingly fine specimen of the largest size. It is comparatively rare even in formation $n$ of the East Pit, where it was most abundant. It was, however, not difficult to ascertain that it was divisible into sub-varieties, having fine and coarse costae, but these are invariably more or less widely separated, and therefore belong to the coarsely costate series.

The following table depicts these relations diagramatically for the purpose of placing them in a clearer light.

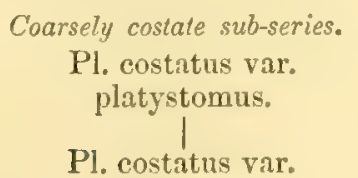

obtuso-costatus.

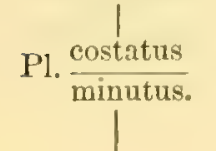

Finely costate sub-series.

Pl. costatus var. distortus.

Pl. costatus var acuto-costatus.

Pl. $\frac{\text { costatus }}{\text { minutus. }}$ |
Smooth shelled sub-series.

$\mathrm{Pl}$. denudatus.

Pl. minutus.

Pl. minutus.

Pl. min

Pl. mimutus and its immediate affinities are shown by three sub-series. Each of these have the cylindrical and less involute forms corresponding to $\mathrm{Pl}$. mimutus, and the completely trochiform and partly uncoiled cylinchical whorled forms, the equivalent of $\mathrm{Pl}$. demulatus. Thus each of the three sub-series presents a similar succession of forms, the ancestral, or closely allied, the highly differentiated or distinct forms of the third line and the diseased and closely representative forms of the fourth line.

I do not think that the accepted limitation of a species to one or more series of forms connected by hybrids or intermediate varieties, is of any use whatever in estimating the value of the characteristics in cases like that under consideration. The value of these must be determined with reference to all the members of the group in which they occur; this alone can give their approximate taxonomic meaning. Thus, by reference to the Planorbidae generally, we can show that the modification represented by forms in the smooth and costate series, are really more distinct than most of the species of the genus Planorbis. If the intermediate forms were lost or destroyed, there would be no doubt on this point. If the word species can be used to mean anything at all, it must be restricted in given groups to certain limited series of modifications, having a certain approximately determinable value. If the term can be used at one time to designate so great a series as is included from minutus to costatus, or Steinheimensis to trochiformis, or even discoideus to trochiformis, I can see no reason why at another time it may not be used for all these forms together, as Hilgendorf has done.

Fig. 15, line 6 , pl. 3, has no costae on the last part of the outer whorl, and this represents the extreme old age condition of the costate series. This return of the smooth 
condition of the young shell is exictly comparable with the conditions attending senility, as observed first hy D'Orbigny anong the Ammonites, and subserquently by the author, among these shells, and also in other departments of the animal kingdom. It is apt to mislead the observer, since, although it occurs in the life of the same animal, and in the same organs, it belongs to a class of resemblances which are not generally understood, and have been neglected by all but a few observers. The absorption of, or more exactly speaking the failure of the animal to build up, the costae during the last stages of its existence, canses the whorl to revert to its early smooth condition, and while the latter is due to heredity, the former is evidently pathological in its origin. If a represents the young and its inherited characteristics, and $b$ the new characteristics added during growth to $n$ the adult stage, then $a+b+n=m$, the adult forms. The amount of resemblance between the senile stage and the young. therefore, depends upon how much or what parts of $b$ and $n$ are subtracted by absorption or decay during old age, and as it is never the whole $b+n$, which is destroyed by senile disease, the resemblance produced can never be identical, though they may appear so to the eye in some organs or parts.

Another way of explaining these phenomena is admirably illustrated by the numerous cases which have been eited of the sudtem return of youthful and apparently long forgotten facts, songs, etc., in the memories of old people. They are evidently the survival and the sudden reappearance of youthful characteristics, which have been hidken under a mass of differential characteristics. There being removed the basal form becomes once more visible.

The foundations of a building are the first to appear, then become invisible under the superstructure, and become visible again only by the decay and destruction of that which they supported.

\section{SECOND SERIES.}

\section{Planorbis parvus.}

Planorbis Zieteni (A. Braun) Sandb., Op. cit.

Pl. m. parvus Hilg., Op. cit., fig. 4.

The shells which represent this variety, pl. 3. line $\alpha$, figs.6. 20-22. have a defined upper umbilicus and closely resemble in all essential characteristics those young forms of $P$. Steinheimensis, which have the mouth deflected downwards and the third carina exceptionally well marked. Figs. 10, 11, line b, pl. 1, represent specimens of this class, which are a trifle stouter than the true parvus and are evidently the young of Steinheimensis, since at earlier periods than the one figured the whorls have all the peculiarities of Steinheimensis. The third carina, which is so prominent in figure 11, does not appear until the shell has attained a stage considerably older than that in which this carination usually makes its appearance in parvus. This is the case also in the more compressed forms of Steinheimensis, such as fig. 9, line m, pl. 1, though in some of these the resemblance of the nearly full grown shells to the young and alult shells of pareus is even closer than in fig. 11, line b, pl. 1. This is undoubtedly attributable to their more disc-like or flattened forms.

The specimens forwarded by Prof. Sindlserger resolved the difficulties encountered in the Pit Deposits and explained admirably the close affinities above described between 
the young of steinheimensis and the adult of prerves and the very evident differences between the full grown shells of each variety. They are both probably distinct varieties of $P$ l. levis derived directly from that species. Some of the specimens of one of the valricties of $\mathrm{Pl}$. levis from Undorf are identical with pareus and have been previously described. ${ }^{1}$

Hilgendorf regarderl prervus as intermediate between mimutus and var. dequiumbilicatus, and also as in the same grenetic series as crescens. Sandherger on the other hand joined minutus, teres, and crescens under the name of Zieteni Braun as a distinct species.

\section{Planorbis crescens.}

Pl. m. crescens Hilg., Op. cit., fig. 16.

This species is perhaps the least variable of any of the Steinheim forms. The connection with the preceding is clearly made through some specimens slightly stouter than the norm, but these are exceedingly rare in my collection.

The mouth and last whorl may be central or turned downwards. I have so far seen none with these parts deflected upwards or against the spirnl. Some of those with the mouth in the middle have nearly equal umbilici, but these are extremely rare forms. Those with the mouth turned downwards and the upper umbilicus only slightly marked, as in figs. 9-12, line c, pl. 3. and those with no upper unbilicus, as in figs. 13,14 , on the same line, are very numerous. Quite a trochiform variety ends the tendency to variation in this direction, of which I have found one specimen, pl. 9, fig. 15, but even in this one the whorls retain the same attenuated aspect and form. The third carina is prominent in all of these, and in some the fourth makes its appearance, especially in those like figs. 13, 14, line e, pl. 3. The striae of growth are particularly well defined in this variety, even at the earliest stages, and in all specimens.

Remarks. On pl. 5, the entire genetic series as here described, is figured. The four shells on line a are undoubtedly $P$. levis, from Undorf, and show the close relationship

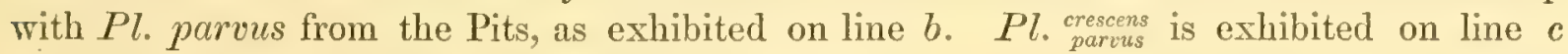
and on line $d$ the ordinary forms of $P l$. crescens.

The angularity of the outer whorls resulting from the development of the third carination is evidently a mark of affinity with $P$. levis, in which this is a constant characteristic. The gradual flattening of the form of the whorl is shown in the right and left series of figures, and the close resemblance in form of the whorl to that of $P l$. levis, in fig. 2, line $b$. Compare this with some of the forms of $P l$. levis, on pl. 7, which are in the same position. This flattening of the angularity of the whorl, and the openness of the lower umbilicus, fig. 5 , line $d$, are both low characteristics, and show that the series has altered but very little in the characteristics which were derived from $P$. levis. The increase in size is notable, and this must be classed with the progressive series. The progression in the flattening of the whorls and the angularity of the outer whorl which takes place in the adult also characterizes the young, and is inherited at earlier stages in each form, until, in fig. 2, the young begin to show the crescens form at a very early age. 
No very decidedly diseased or aged forms were observed, but the spiral is often slightly irregular.

The peculiar gibbous aspect of the whorls in fig. 7 , line $b$, is exaggerated by the photograph, as it is also in fig. 1, on the same line, and may mislead the observer into the belief that he is looking at specimens of oxystomus. This, however, can be readily corrected by comparing them with true oxystomus, on pl. 6 , lines $a, b$.

The apparent contrast between the two figures above mentioned, on line $6, \mathrm{pl} .5$, and the two corresponding figures of $P$. levis, on line $\alpha$, is hardly perceptible in the specimens themselves, which are really very large specimens of $P l$. parvus.

\section{THIRD SERIES.}

\section{Planorbis oxystomus. \\ levis}

The shells figured on pl. 1, line $m$, figs. 10-14, approximate to, but are still readily separated from those figured on pl. 1. line $a$, figs. 12, 13. These last are slightly different

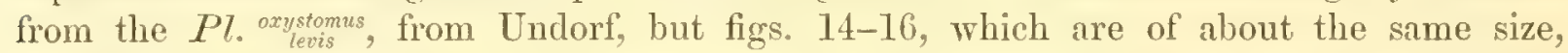
would not be separated by the most conservative naturalist, if found at Undorf. The full-grown forms, figs. 12 , l\%. line $a, p l .1$, are larger, and approximate to true Pl. orystomm, pl. 3 , figs. 8, 9, line $k$; in fitct, they are so nearly illentical with these that the young alone show their affinity to $P l$. oxystonus leris The young have the shallower umbilicus on the lower side, and that side of the outer whorl is flatter at the same age than in true Pl.oxystomus. Fig. 12, line $a$, pl. 1, even shows the peculiar mouth-rim and general outline of Pl. oxystomus.

There is one noticeable characteristic in the shells of $P l$. Steinheimensis, which may also be cautiously used in separating the varieties just described, from those of Pl. oxystomus. The striae of growth are not so decisively marked in Steinheimensis. Shells with striations as prominent or as deeply incised as is usual in $P$. oxystomus are rare. 'The surface of the former has a smoother aspect than that of the latter, and this is almost invariable in the young, while the young of many varieties of $P l$. oxystomus have very distinct striae. But though rare. such shells do oceur, and some of them are found in the intermediate varieties just described.

\section{Planorbis oxystomus.}

Pl. oxystomus Klein, Jahresh. Wurtt, Vol. 2, pl.'1, fig. 27.

Pl. m. oxystomus Hilg., Op. cit., pl. fig. 7.

Pl. m. revertens Hilg., Op. cit., pl. fig. 8 .

Pl. m. supremus Hilg., Op. cit., pl. fig. 9.

Carinifex oxystomus Sandb. Op. cit., p. 643, pl. 28, fig. 3.

Variety revertens Hilg. $={ }^{\text {oxystomus }}$ lecis , pars.

After prolonged comparisons I am unable to find any characteristic by which this variety in some of its forms can be separated from the narrow umbilicated forms of $P l$. oxystomus
levis 'These, like those figured on line $k$, fig. 6 , and line $p$, figs. 10-11, pl. 3, have shallower umbilici on the lower side, with whorls less gibbous than is usual, and a mouth which neither flares nor contracts, and has a very thin inner lip. 
Variety typica.

The second variety, or true norm, which I take to be identical with Hilgendorf's figure, has the mouth and part of the last whorl considerably contracted, the lower umbilicus quite deepr, and the lower sides of the whorls giblous but rounded, figs. 12-18, line $k$, and fig. 12, line $b$, pl. 3 .

The third variety, figs. $2-9$, line $m, \mathrm{pl}$. 3, has a mouth similar to the first variety in some specimens, but in others there is a lip of medium thickness on the inner side. ${ }^{1}$ This form is an exaggerated repetition of that of figs. $12-16$, line $a, p l .1$. The closeness of the resemblance in form is due to the rotundity of the lower side, and the depth of and narrowness of the umbilici in both forms.

\section{Planorbis supremus.}

Pl. m. supremus Hilg., Op. cit., fig. 9.

First variety.

This begins with a form precisely similar to the preceding. except in the upper umbilcus. This deepens by growth, and the first carina and sulcation begin to make their appearance. The lower side also, is sharper, and the fourth carina stands out quite prominently. The mouth is central. Figs. $6,10-12$, line 0 , figs. $7-9$ same line, are intermediate between these and the last described form of oxystomus on line $k, \mathrm{pl} .3$.

Second variety.

This differs only in having the mouth bent downwards. The first carina and sulcation become very prominent, and the fourth carina also, as in figs. 1-7, line $n$, and 1,5 , line $p, \mathrm{pl} .3$.

Another form is represented by figs. $8-13$, line $n$, and fig. 1, line $o, \mathrm{pl} .3$. In these the upper umbilicus becomes shallower, and in fact almost disippears. This is one of the nearest approaches to a turretted form observed in this variety, and it is accompanied in fig. 8 , line $n$, by the development of a distinct sulcation on the upper side. A typical variety of oxystomus occurs on line $"$, fig. 14, pl. 3 , in formation $h$, East Pit. This differs from the series just described in the upper umbilicus. This is shallower, and the inner whorls are therefore more exposed in the young. Almost without exception, these have the fourth carina strongly developed, but there are some in which the upper umbilicus is deeper than usual, and the whorls more cylindrical.

This variety leads by the closest gradation into the stouter form figured on line $b, \mathrm{pl} .3$, figs. 1-6, and line $l$, figs. $1-3$. The next step is shown in figs. $9-10$, line $b$, and $5-8$, line $c$, in which the lower umbilicus may be either quite wide or very narrow, and the upper side begins to lose the umbilical depression.

In fig. 13, line $b$, fig. 1 , line $c$, and figs. $4-7$, line $l$, pl. 3 , this tendency is consummated in a truly turretted form.

Variety turrita.

In figs. 9-11, line $l$, pl. 3, the whorls increase with great rapidity below the fourth carina, and narrow lower umbilicus, assuming a trochiform aspect.

I have one specimen of this last, considerably larger then the one figurest, with a form similar to that of "elegrans" IIilgendurf. It is noticable that although the first and fourth

\footnotetext{
${ }^{1}$ It should be noticed here that the specimen figurel on line $a, p l .1$, fig. 12 , has a thickened inner lip, also a characteristic which is exceedingly rare in $\mathrm{Pl}$. Steinheimensis, in which this portion of the mouth is usually represented
}

by a very thin or almost imperceptible film, while in $P l$. oxystomus the opposite is the case, the thin film being exceptional, and the thick deposit the rule. 
carinae are distinctly indicated in fig. 1, line $c$, and the first, second, third, and fourth in some other specimens of the turretted varieties, there are no accompanying indications of sulcations on the upper sides of the whorls. These are usually round, but may become somewhat flattened, though in no case have I found suleations. The limits here given for this species correspond quite closely to those given by Sandberger, since he also included unter one name the three principal varieties described by Hilgendorf. The difference in our views is due to the intermediate forms, which in my opinion bridge the chasm between this and Pl. levis. With regard to the affinity with Carinifex, I have written elsewhere.

The whole series is given on pl. 6 .

Figs. 1-3, line $\alpha$, are $P$ l. levis, from Undorf. Compare fig. 1, line $a$, with fig. 1 , line $b$; also fig. 2 with 4 , line $a$, and fig. 3 with 7 , line $a$. Line $b$ is the $P l \cdot{ }^{\circ o y y s t r m u s}$, from formations $l$ and $m$, of the Cloister Pits. Thus it can be seen, that it is not necessary even to descend to formation $a$ of the pits, in order to obtain forms showing the probably direct derivation of $\mathrm{Pl}$. oxystomus from $\mathrm{Pl}$. levis.

Fig. 3, line $b$, is important in this connection, because it shows very distinctly that a perfectly preserved shell of $P l$. orystrmus exhibits the bright and polished surface and striae which are common in $P l$. levis.

The transition from $P l$. lecis to $P l$. oxystomes is also still farther confirmer by the two young specimens, figs. 4-5, line $d$; fig. 5, being $P l$. levis, from Undorf, and fig. 4 , the young of a typical $P l$. oxystomus, from the Cloister Pit.

$P l$. oxystomus var. ${ }^{\text {oxyztomus }}$ ilevis is shown in figs. $4-7$, line $a$; these are even closer to $P$ l. levis

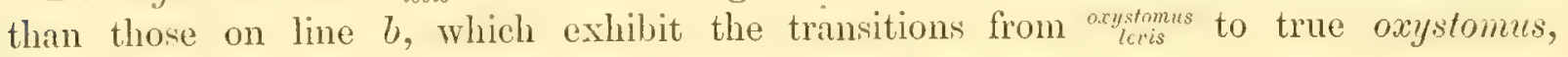
occupying lines $c$ and $d$.

$P l$. supremus is represented by the figures on line $e$.

The series is ronghly shown by the range of figures numbered 1 in each line, and these exhibit the general tendency to increase the spirality. The tenlency in each variety to increase spirality of growth in some shells, is also observahle. Thus, in Pl.oxystomus. line $c$, fig. 6 is quite trochiform, only inferior to fig. 1 , line $d$, a specimen of the same variety.

This last is apparently (quite as turbinate as fig. 1, line e, a specimen of Pl. supremus; but in reality it is not of the sime species as this, since the umbilicus is more open, and wider.

The oxystomus-like widening of the whorl in course of growth, fig. 1, line $c$, is not observable in any of the forms of $\mathrm{Pl}$. levis, in the youngest stages of growth, which have

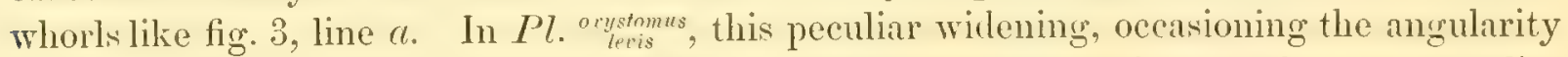
of the aperture on the lower side, is more pronounced in the adult, and appears earlier in the life of the individual. In $P l$. oxystomus, line $c$, fig. 5, this is still more pronounced, and inherited at a still earlier stage.

In $P l$. supremus the broad whorl occurs at a very early age, so that the young are often identical with the typical form of oxystomus; and subsecquently the first carination, or the first and second with the sulcation between them, appears during the growth of individuals.

It is interesting, also, to note that some specimens which have no pronounced carinations or sulcation, but are smooth, like oxystomus, have to be classed with this variety on account of the peculiar shape of the whorls, as in the turbinate form, fig. 1, line $e$. 
Another interesting peculiarity is the obliteration of the upper umbilicus in several turbinate forms, as in fig. 1 , line $d$, and its approximate obliteration in figs. 2 and 6 , line c. It must be understood, however, that even in fig. 1 , line $d$, there is a minute upper umbilicus in the extremely young shell, as seen at the apex.

A very curious tendency in the whorl to depart from the regular mode of growth is apprarent in figs. 6-9, pl. 3, line p. The whorl, either through a wound as in fig. 8 , received at an earlier age, or through some weakness caused by sickness or unfavoralle conditions, ceases to increase by growth according to the usual proportions. This contraction gradually leads to the distortion of the spiral. Sandberger figures one of this species much much more remarkable than any here. The mouth strikes off almost as a tangent to the curvature of the spiral, and extends out to a distance very much beyond that of any of the specimens seen by me, except perhaps fig. 5 , line $b$, pl. 8 .

The distorted forms to whose illustration plate 8 is devoted, are largely taken from $P l$. oxystomus, and it will be observed that most of them are var. revertens IIilg. $={ }^{\text {oxyytomus }}$.eris .

Figs. 3-4, and perhaps 5, line $a$, figs. 1, 6 , line $b$, are from specimens of typical $P l$. oxystomus, while figs. 2-5 line $b$, and all of line $c$, are taken from ${ }^{\text {oxystomus }}$ levis . Some of these cases are evidently due to wounds, the effect being distinctly marked on the shell. That the wound in such cases affected the health of the animal is evident, because in other cases of shells similarly scarred, no distortions are observable in the subsequent building up of the shell. Figs. 3, line $\alpha$, 2, line $b$, and all on line $c$, are undoubtedly due to such accidental causes. The other shells show no derangement in their striations or sears. These distortions may or may not have been due to diseases arising from other causes, but

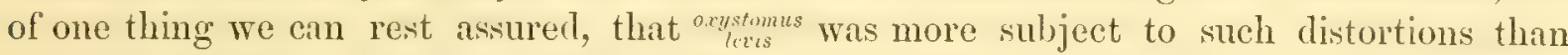
any other species or form belonging to any of the progressive series. If it is desirable to test the conclusions drawn from such diseased specimens in chapter 1, it can be readily done by comparing figs. 1-3, line $c$, and 4,5 , line $b$, with the uncoiled forms of the retrogressive sub-series, or better still by observing the close parallelism of fig. 5 , line $b$, with fig. 23 , of pl. 9 .

Another remarkable result of disease, whether it may be from accident or otherwise, is a reversion to the peculiar angularity of form conspicuous in some varieties of $P l$. levis. This is not very well shown in the plate on account of the positions of the specimens, but is partially shown in fig. 2 , line $b$, which was especially intended to exhibit this peculiarity. It results from a perceptible flattening of the diseased portion of the whorl, as well as from a general diminution in size. The diseased specimens of Pl. supremus, figured on line $d$, are very large, and they are distorted only towards the latter part of the last whorl. The distortions consist of enlarged striae, and simultaneously the size of the whorl decreases, occasioning at once a deflection from the regular increment of the spiral, which tends to become turbinate. ${ }^{1}$

These phenomena appear to indicate the slow rate of growth consequent upon old age. This is also shown very well in fig. 1 , line $n, \mathrm{pl} .3$, when the same enlarged striations are seen on the last part of the last whorl, and it is this part alone which is deflected to

1 I do not wish to be understood as implying that the tendency to become turbinate is always a diseased or retrogressive characteristic. While this is often the case, it is equally unquestionable that $P$. trochiformis is a thoroughly healthy species, as are many other turbinate forms. 
form the extreme spirality observable in another view of a precisely similar specimen in fig. 2, by the side of the first described.

FOURTI SERIES.

\section{Planorbis Steinheimensis.}

Variety aequimbilicatus.

Pl.m. Steinheimensis var. aequiumbiticatus Hilg., Op. cit., fig. 1.

Forms which are aequiumbilicated are quite rare in the lower formations of the Pits. One is figured in section on line $b$, fig. 17, pl. 1, another on line $a$, fig. 2 ; almost all others only approximate to this condition and ought perhaps to be placed with the inaeduiumbilicated forms. They are the true transitions from the latter, but also possess the more cylindrical or equal-sided and less involute whorls of the aequiumbilicated variety, such are those figured on plate 1 , line $\alpha$, figs. 1, 3, 4, line $c$, figs. 1, 19, and line $m$, figs. 1-7.

In the aequiumbilicated variety there are several suh-variations. Those with the mouth and last whorl or whorls turned upwards, those with these parts central, and those with these parts turned down as in fig. 7 , line $m$, pl. 1.

In the inaequimmbilicated variety there are similar variations in the direction of the last whorls, but here the downward or spiral tendency is of course predominant. In the aequiumbilicated variety I did not find a tendency to flatten the upper or lower sides, but it must be taken into consideration that very few specimens of this variety were found.

In the inaequimbilicated variety, especially in the sub-variety with the mouth turned upwards, there is a decided tendency to flatten the upper sides of the whorls and this is correllated with a corresponding tendency to angulate or produce a ridge-like angularity in the whorls on the outer side, both above and below and on the inner lower side near the umbilicus. For convenience sake I have called these ridges the second, third, and fourth carinae, reserving the designation of first carina for the innermost umbilical ridge on the upper side, which appears so prominently in Pl. discoideus. Forms may be picked out which show this tendency ${ }^{1}$ in every way in the sub-variety with the mouth turned downwards, though the second carina is very rarely seen.

In some specimens only the third carina is seen, and these are remarkably similar to Pl. levis as figured by sandherger. In others the fourth carina alone, or third and fourth carinate with a slight flattening of the lower side occur, and the second and fourth carinae, but in none did I find the third carina alone.

The forms united under this name have, besides the characteristics above given, the following: the whorls are more cylindrical, and the increase in the size of the whorls by growth is less marked than in Steinheimensis proper, and therefore the involution a trifle less.

Variety Steinheimensis.

Pl. Steinheimensis Hilg., Monatsb. K. Preuss. Akad. Wissensch., Berlin, July 1866, p. 485 , fig. 2.

Pl. Steinheimensis Sandb., Op. cit., p. 644.

1 It must be observed that I here speak of a hardly perceptible angularity such as is shown in the outline of the

mouth and lower side of fig. 5 , line $m$, pl. 1. 
This species or variety may be distinguished from the preceding, principally by the more rapid increase in the size of the whorls by growth, and the consequently slightly greater brealth and involution of the last whorls. The young are habitually asymmet. rical, as in the section fig. 7 , line $a$, pl. 1 . No absolute line can, however, be drawn between this and the preceding. The varieties are very numerous, and I camnot pretend to enumerate all of them. The most significant, if it may be so expressed, are the following:

1. Those with the mouth turned upwards, or against the spiral ; line $b$, fig. 3 , pl. 1 .

2. Those with the mouth central; line $\alpha$, fig. $9, \mathrm{pl} .1$.

3. Those with the mouth turned downwards; line $m$, fig. 13, pl. 1 .

All three of these varieties may occur with perfectly rotund, smooth whorls, without the slightest indications of a carina-like angularity or ridge, in any light, or in any position in which they may be held. There is, however, this observable peculiarity : the larger number of carinated specimens have the mouth central or turned downwards, rarely deflected against the spiral.

All three of these principal varieties may also occur with the curinations described in the preceding form, and in one case a distinct third carina appeared, fig. 1 , line $n$, pl. 1 , which will presently be described in detail.

Specimens with the mouth turned upwards, have a tendency to flatten the upper side of the whorls. The second carina is very rarely indicated in these, but the third very often. Sometimes it is alone, but usually it is accompanied by a well defined tendency to flatten the lower side, and produce the fourth carina also, as in fig. 3 , line $b, \mathrm{pl} .1$.

The same peculiarities, word for word, may be attributed also to those having the mouth central. Those figured on line $b$, figs. $6-10$, pl. 1., have only one carina, the third, indicated as in the mouth of fig. 6 , inside of which it is well shown, though rather too delicate and unpronounced to be shown in others. Figs. 4, 5, have the third and fourth carinae indicated, especially the specimen shown in fig. 4. Fig. 4, line $n$, plate 1 , exhibits this peculiarity more markedly than it can usually be shown by photography.

In this variety also a sulcation makes its appearance as a faint depression on the upper side, as shown in fig. 2, 5, line $n, \mathrm{pl} .1$. The extraordinary form, figured on line $n$, pl. 1, fig. 1, not only has the third and fourth carinae, but shows a peculiarly broad, dorsal aspect, and has indications of the second carina, and a very slight depreswion or sulcation on the upper side, quite equal to that in No. 5, on the same line, though hidden by the flare of the mouth. 'These characteristics are well marked, according to the usual fitshion in other specimens, on the last whorl, for about three-fourths of its length. A constriction occurs in this specimen, caused evidently by some accident to the shell, which was probably the immediate cause of the appearance of these unusual characteristics. After the repair of this injury, the third carina appears as a regular ridge with a definite linear depression on either side.

The old age of Steinheimensis is indicated in this and other large specimens by a slight decrease in the amount of involution of the last quarter of the last whorl, and this peculiarity is well marked in this shell, so that the distinct carination appears to arise in the old age of this form. 
The variety with the mouth turned downwards, in the normal direction of the spiral, fig. 11, line m, pl. 1, has the third and fourth carinæ well developed. Fig. 13, line h, pl. 1, exhibits throughout its adult stage a form inseparable from that described above, on line $n$, fig. 1 , but in old age the whorl is deflected in the normal direction. At the same time the sulcation appears, and with it the first carina is indicated, and the second carima becomes quite prominent and much better defined than I have seen it in any other specimen. The aspect of the whorl, the decrease in its involution, and the enormous comparative size of the shell show that these exacrerated features are the products of senility. A tendeney to produce the second, third and fourth carinae is also observable in quite a number of specimens with a decinled and symmetrical flattening of the upper, outer, and lower sides of the rwhorls, but no sulcations; this is the case with fig. 16 , line $b$, pl. 1 , which can only be separated from $P l$. temuis, line $c$, fig. 2 , by the absence of any linear sulcation or depression on the upper side.

Besides the above, there are still other modifications which it is necessary to mention. These consist of exceptionally flattened forms. All of those previously described are more or less stout, but there are some which do not partake of this characteristic, such as are figured on line m, pl. 1, figs. S-9. All, incluling the ahove just described, have rather wide and open umbilici on the lower side, and cylindrical or flattened whorls, but there are some forms, with stout whorls, in which this is exchanged for a tendency to narrow the umbilicus, and these, though difficult to distinguish at first, are soon rearlily picked ont after a little practice. They are then seen to be distinct, and by comparison with $\mathrm{Pl}$. levis, are recognizable as the intermediate forms of $P l$. oxystomus levis figs, 14,16 , line $a$, pl. .1.

\section{Planorbis tenuis.}

Planorbis temis IIilg., Op. cit., fig. 3.

Carinifex tenuis Sand., Op. cit.

Variety steinheimensis.

Certain forns which I have included under this name are not distinguishable from certain forms of Steinheimensis. They nearly all have faint but unquestionable marks of a sulcation on the upper side, but so have some unquestionable specimens of $P l$. Steinheimensis, and that this is an artificial line can be readily shown by the comparison of such specimens as fig. 16, line $b$, and fig. 2, line $c$, pl. 1. The latter I have often referred to $P l$. Steinheimensis, when studying that species, because of its very faint sulcations, and also on account of the extreme smoothness of the shell and its close resemblance to true Steinheimensis forms, especially figs. 3, 4, line $a$, pl. 2 . There is the same story to be recounted with any characteristic which may be selected.

First sub-variety.

This is represented by a flat shell with the first, third and fourth carinate indicated, but the second almost absent. They are not distinguishable from such forms as fig. 14, line $c$, pl. 1. They are rounded and smooth on the upper side, but flattened as in tenuis on the lower side, with the third and fourth carinae well developed. Some of these have also almost imperceptible sulcations on the upper side on the last whorl. 'These differences disappear in fig. 13, same line, which is really a flattened Steinhemensis form with inter- 
mediate form and characteristics. Fig. 13, line n, pl. 1 must also be joined to this sub-variety. The form has not a very close resemblance owing to the deflection of the mouth, but the third carina is well developed and the shell is intermediate to figs. 14 and 15 same line.

Second sub-variety.

It is not possible to arrange these varieties in a line with reference to Steinheimensis, and therefore the successive numbering of the sub-varieties means nothing so far as the genesis and relative rank is concerned. The forms figured on pl. 1, line $a^{7}$, figs. 1-4, have both the first and second carinae, and the sulcation on the upper side is indicated. Fig. 16, line $e$, shows a passage form from these directly to Steinheimensis. The under sides of the whorls in this variety are rounder than in the first variety, stouter and not so involute.

Other sub-varieties might be described in the transition forms, such as fig. 1 , line $b$, pl. 1. This is an extremely thin shell, more or less flattened on both the upper and lower sides of the whorls, and with the faintest possible sulcation.

Near the mouth or the upper side, it is evidently very closely allied to such flattened forms of Steinheimensis as fig. 9, line $m$, pl. 1, or intermediate between these and the still more flattened form on line $n$, fig. 8, which leads into forms figs. 9-12 on the same line, belonging to the true tenuis group. We must also add to this list fig. 6 , line $n$, pl. 1, which fills the gap between fig. 7 of the tenuis group and Steinheimensis.

The specimens described in the Lower Steinheim Period, as occurring in the Cloister Ridere rocks show with considerable clearness that $P l$. temeis is really a derivative of $P l$. levis, and that the transition forms here described between this and $\mathrm{Pl}$. Stcinheimensis must be accounted for either as hybrids or as descendants from Cloister Ridge species.

Variety Kraussii.

Planorbis Kraussii Klein, Jahresh. Würt., 1847, plate 1, fig. 28.

Pl. multiformis Kraussii IIilgend., Monast. K. Preu. Akad. d. Wissensch., Berlin, July 1866, pl., fig. 12.

Pl. Kraussii Sand., Conchyl. d. Vorwelt, Supp., p. 646.

This species at first sight appears to be separable from $P l$. Steinheimensis on the one side and $P l$. temuis on the other. The close and thorough eximination of the shells, however, gradually obliterates all distinctions. It can, therefore, if one chooses, be properly considered one of the varieties of $P l$. Steinhuimensis.

If we compare the full grown shell with the young of $P$ l. temis, line $f$, fig. 1-7, pl. 2, we find that the young of certain forms are with difticulty separated from $P l$. Kranssii, e. $g$., fig. 4, line $f$, and fig. 3 , line $d$, pl. 2. The young of the more immature of the tenuis forms are like the specimens of $P l$. Kraussii.

This would answer very well for all the forms with flattened upper sides, figs. 1-S, line $d$, and figs. 13-16, same line, pl. 2, in which a triquetrus-like outline is attained by the flattening of both the upper and lower sides. This explanation, however, lardly applies to such forms as figs. 9-12, and 17, on the same line. These are almost purely Steinheimensis-like, so much like the latter that if they had been found in the same formation, I should have called them by that name. 
The umbilicus on the lower side is narrow, and it will be observed that the young are quite stout in some specimens, as in figs. 11, 12, line $d$, pl. 2. Since the above was

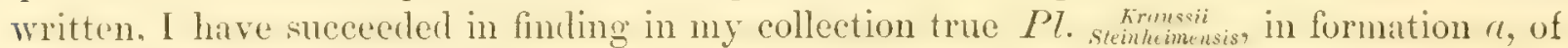
the Old Pit, line $f$, figs. $1-3$, pl. 1.

The prominence of the third carination in $P l$. Kraussii is precisely what was previously observed in $\mathrm{Pl}$. Steinheimensis, and besides this the adults of many develop the second carina and become flattened externally on the last whorl, as in the young of $\mathrm{Pl}$. tenuis. Occasionally, also, as in fig. 2, line $d$, pl. 2, a faint sulcation becomes visible on the upper side.

It is possible that the specimens figured on pl. 2, from the higher formations of the Pits, are the survivors of the forms of formation a, and perhaps may he considered as somewhat dwarfed. Their resemblance to the specimen from formation 7 , figured on pl. 2, line $q$, fig. 12, as $P l$. Steinheinensis, is apparent at a glance.

The specimens of Kraussii figured on line $d$, pl. 2, figs. 13-16 are similar to some of the more compressed young of $P$. temis, like those of figs. 7,13 , line $n$, pl. 1 , and figs. 1-2, line $f$, pl. 7 , and are identical with the more immature young, and some of the full grown shells of $P l$. tenuis of the Cloister Ridge rocks. Sandberger appears to have been unable to separate this form in the Pits from $P l$. tenuis, but there is no difficulty in doing this mil the young of the temis forms are studied. The ardults are quite distinct. Hilgentorf's opinion that this species is a direct derivative from Pl. Steinheimensis is amply sustained by the material I have examined, but whether this ought also to be considered intermediate between Steinheimensis and his Pl. psendotenuis is more doubtful. This last I have had no means of sturlying, except through two specimens sent me hy IIigendorf. These are very minute, delicate, thin-shelled specimens, with the third carina only developed, which forms a sharp ridge on the lower sile and outer edge of the whorl. The shell has the aspect of the young of Pl.temis, but I have unfortunately not the time now for a re-examination in order to test this question. If his material enables him to trace a close series of transmutations this can be established, but in the absence of this exact proof, I should certainly at once class it as the young of a variety of $P l$. tenuis, traceable to such forms of $P l$. steinheimensis as are figured on pl. 1 , line $c$, fig. 14.

There is not a single specimen of Pl.pseudotemuis figured on my plates, and this shows the extreme rarity of the shell, a fact I was not aware of until the receipt of Dr. Hilgentorf"s type specimens. If this series is finally established by Dr. Hilgendorf, then another distinct series of a retrograde character will have to be added to those described in these pages. The specinens of $P l . m$. Fransii received from him are of the true steinheimensis type, and show none of the tenuis-like characteristics here described as varieties of this species. Fig. 9 , line $f$, pl. 2 , is identical with these.

\section{Variety temuis.}

The sul-varieties appear to he almost wholly derived from forms of the preceding decribed varieties, either of Steinheimensis or steinhuisensis. 'Thus the first sub-variety which shows a tendency to become turbinate, such as that figured on line c, pl. 1, figs. 2-12, appears to be commected directly with the steinhemensis forms, sinilar to fig. 16, line $b$, previously described. 
The majority of this variety, however, have the square form of the whorl with the sulcations and carine well developed. The mouth in these may be deflected agrainst the spiral slightly, as in fig. 16, line c, pl. 1, and perfectly flat on the upper side, as in figs. 15, 17, 18, on same line. They are inseparable from the preceding variety, though in many forms they tend to grow in a sub-turretted form, fig. 8, line $d$, pl. 1, and line e, figs. 14, 15, and line $o$, fig. 1-3, fig. 6, and line $f, \mathrm{pl} .7$.

These last lead without break into forms such as figs. 4-7, line o, which have an extraordinary development of the first carma with a sub-turretted shell, or with a flat shell, as in figs. 2-10, line e, 11. 1. Then a sub-variety, probably connected with the last, in which both the first and fourth carine are vory prominent, as in figs. 11-13, line $e$, pl. 1.

The forms on line $n$, pl. 1, figs. 9-12, are much compressed, with sicles flattened and convergent outwardly, showing a whorl, which commects them with the extremely flattened form, fig. 8, same line; and also fig. 1, of line $b$, on same plate.

If one examines this last mentioned compressed form, and fig. 8 , line $n$, there is in both a slight want of symmetry, which comsists in the greater prominence of the zone which would be occupied by the third carina, if it were present.

This is perhaps one of the most curious of the genetic series traced out directly from specimens, which are identical with Steinheimensis, on account of the almost imperceptihle changes of form by which it is accomplished, and by reason of the extreme viriation of some of the varieties.

\section{Planorbis discoideus.}

\section{Variety discoideus.}

This transition form, when that term is used in its most conservative sense, as applicable to shells which exhibit characteristics which make it impossible to decide whether they belong to discoideus or to tenuis, is not found in the Pit Deposits. It is, however, found in the Cloister Ridge rocks and has been previously described.

'These forms entirely fill the gap, since they meet the only objection which can be urged against the intermediate position of the Pit forms; they have young which "precisely resemble the adult of Pl.temis." 'There is indeed so close an approximation to true transition forms that I have more than once had to alter the nomenclature of this series. Thus the gap which exists between the form of $P$. temis figured on line e, fir. 1 , pl. 1, and those of Pl. discoideus figured on line $f$, figs. 4, 17, pl. 1, is so slight that hardly any naturalist would hesitate to unite the former with the latter. Nevertheless the young of the form figured on line $f$ camnot be considered as similar to the adult of the form figured on line $e$, since it is stouter.

For a precisely similar reason I have also been obliged to separate the compressed forms of discoidens figured on line $h$, figs. 10-12, and line $p$. figs. 1-2, pl. 1, from $P l$. temis, though among these it is possible that further search would detect Pl. "liscoiturs.

\footnotetext{
1 This would generally be considered as of no value, but it must be remembered that the basis of the reasoning here
} 


\section{Variety discoideus.}

The sulcatus form is simply a compressed variety of $P$. discoinleus with a remarkably square mouth and whorl as in figs. 7-14, line $g$, line $h$, and $8-10$, line $p, p l .1$. The squareness and angularity of the under side is well depicted in figs. 2-3, and 7-9, line $h$. There is a prevalence of these forms in formation $a$, but they are accompanied by true discoideus, and every attempt to separate the two has been attended by great confusion in my own mind.

The typical forms of $P l$. discoideus involutus Hilg. are shown in figs. 10-17, line $f$, and 1-6, line g. I have applied this nane to still more involute and more easily distinguishable forms, the extremes of this variety.

Figs. 1-7, line $g$, show a still stouter form in which carinations and sulcations are more marked, but the mouth at an early age has not the angularity of $\mathrm{Pl}$. discoideus; figs. 14--17, line $f$, the carinations are still more distinct, and the mouth is angular in the young. Figs. 10-13, line $f$, show a trifle stouter and more trochiform shell with perfectly developed carinae, and sulcations both above and below.

After this, the difficulty in following the series consists only in settling the affinities of the adults of the numerous varieties; the young remain quite similar in form, though differing greatly in being more or less carinated or suleated. They accord in this respect usually with the adulti, as for example, fig. $7-14$, line $f, p l .1$, and the various series of lines $d, e, f, p l .3$. In this way it may be shown that the species really most closely related to $P l$. tenuis are the somewhat flattened but trochiform and unconnected forms like fig. 7 , line $l$, pl. 1, and not the deeply sulcated and carinated forms like sulcatus, however flat they may be.

The first variation is that cited above, in which the upper sides of the whorls have the first carina well developed, the second rounded off, with the third and fourth on the lower side prominent. This leads into a number of allied forms, such as figs. 9, 10, line $e$, pl. 1, which become very turretted, and on the other hand into exceedingly flat forms like fig. 4, same line, in which all four carinae are well developed, but the sulcations not well marked. Figs.s. 15-1S, pl. 2, line $f$, shows a similar series of modifications, and these are evidently the young of the trochiformis-like varieties, on line $n$, figs. 3,4 , and line $m$, figs. 3, 4, and which lead in trochiformis same line, figs. 1, 2.

A series might also be formed with the variety elatior Sand. as a type, fig. 16, line $i$, pl. 2. This also, it seems to me, is not sufficiently described when included with the discoidens series, and placed as Sandberger places it among the trinsition forms from true discoideus, to his variety intermedius, sub-variety communis, figs. 1-2, line $m$. Though quite closely allied to this series, there is a certain outline to the mouth, and an aspect of the whorl, which is reproduced in trochiformis, figs. 6, 7, line $r$, pl. 1, and a series could be doubtless formed connecting the two.

Going back acgain we may take up almost any other line of characteristics, and follow them out to a similar result.

Let us take, for instance, the true sulcatus form, already studied in part. In this we find the flittened tenuis-like form, line $h$, pl. 1, figs. 10-12, and line pr, figs. 1, 2, becoming stouter, 3-10, same line. On line $h$, figs. 2,3 , we can see them more trochiform, and on 
line 1 , fig. 12, so excessively altered, that it is difficult to recognize the same variety. But observe closely the shape of the inner whorl in this and in fig. 13, then it will he seen that these are flat on the lower side, and in all respects similar in shape to fig. 3, line $i$.

Still another form of this variety is shown on pl. 2, line $b$, fig. 1-4, in which the turretted forms are not so, and may be traced directly back to the thinner forms mentioned above, through fig. 6, line $i$, pl. 1 .

Within the limits of these series, there are a great many varieties which appear to be simply individual, or else to obtain only in a limited number of individuals, and to have no special meaning. Such is the appearance of an anomalous carination, along the centre of the whorl, as in fig. 5 , line $k, \mathrm{pl}$. 1. The existence of this appears to me unaccountable, as a normal characteristic, and it is not perpetuated. The peculiar mode of growth shown in figs. 17-19, line $e$, and fig. 18, line $d$, pl. 1 , in which the regularity of the spiral is abandoned, seems to be another characteristic equally unparalleled.

Besides these anomalies, there are numerous individual characteristics appearing with exceedingly limited range, which can be better accounted for. There are largely mere excensive developments of certain parts, as certain carinations, or suppression of others. Very often these have a meaning, which is very important. They are often really characteristic of a series, as the extraordinary development of the first carina in a large number of the sulcatus series. Again they may be of more linited application, but even more significant and instructive.

If we observe any series of square forms, such as $7-14$, line $g$, pl. 1, there will be some with the upper and lower sides of nearly equal breadth, and others in which the lower side is narrower; never broader. In such extremely square forms as no. 19, line $f$, and fig. 11-14, line $i, \mathrm{pl} .2$, this is quite as well marked as in other series, fig. 10-11, line $c$, pl. 2, being the young of such forms, showing the the narrowness, as does also fig. 13, line $i$. Sometimes this tendency is accompanied by a tendency to suppress the carmations on the lower side. When carried to its extreme, as in the series figs. 1-6, line $c$, this produces a whorl, which is rounded and smooth on the lower side, as in fig. 6. If we now compare these forms with line $k$, fig. $6,{ }^{1}$ pl. 1 , we shall see that this is one of those transitions to Pl. trochiformis, which are distinguished by having smootli lower sides.

In the same way, where the carinae are not atrophied, it will be observed that the narrowing of the lower side always takes place in the transition forms to $P l$. trochiformis in proportion as they become more turretted.

I do not mean to trace out a series on this character, because no one can examine a series without seeing that the narrowing of the lower sile and the sometimes correlative atrophy of the ribs is not characteristic of series, hut is an inclividual variation, gaming in importance and represented in a larger number of individuals, as we approach the turretted forms. See also in this respect the transition forms, figs. 1-4, line $r$, pl. 2. We can say also, with approximate accuracy, that in any series there is a constant tendency

1 The Pl. elegans of Hilgendorf. 
to produce flattened forms with prominently developed carinations, but that this is countericted by a still stronger tendency to produce turretted forms, with the carinations and sulcation of the lower side more or less depressed or atrophied, and that side correspondingly more or less rounded. It will be seen at once that these tendencies produce in one direction the squarest whorls and mouths, and in the other the triangular or trochiform shape of the whorl and mouth.

The specimen figured on line o, fig. 15, pl. 1, is the young of discoideus, with a very close resemblance to the var. rotundatus, Hilg, differing only in the greater angularity of the lower side. It is the young of a $P l$. trachitormis variety, and not of the true $\mathrm{Pl}$. trochiformis. There is one remark of importance to be marle in this comnection, that this young form is intermediate between the flattest of the rotundatus-like young, next to be described, and the young of the immature forms of discoidens, figured below on line $l$, figs. 7-9.

Var. rotundutus, as described and figured by Hilgendorf, is equivalent to the young of several forms of $P l$. trochiformis.

Sandberger alludes to it as a full-grown variety of his intermedius, distinguished by its smoothness, hut in this sense it is not identical with Hilgendorf's figure, which relates to the young alone, as may be seen in the following remarks.

If we compare the young of $P$. discoideus displayed on pl. -2 , line $i$, figs. $1-9$, and line $h$, figs. 1-17, with the tenuis forms on line $f$, fig. 1-12, we shall first ascertain one very important fact, which has been stated before: that the young of $\mathrm{Pl}$. discoidens differ in the smooth forms from the young of $P l$. tenuis, in being stouter, even from a very early period, though in all other respects they are identical. The discoideus series is finished by the older specimens, figs. 13-17, line $f$.

The continuity is unbroken on line $h$, and fig. 18 makes an easy transition with its more or less rounded whorls, from discoideus to the forms of rotundatus.

These do not entirely abort the third carina which is still to be seen in fig. 23 , line $h$. They do, however, inherit a tendency to become trochiform, at a very early age, and with this a tendency to round the lower side of the whorl, and suppress the third and fourth carins. If now we attempt to follow up the characteristics, we are led into such forms as figs. 4, 5, 6, line $p$, pl. 2, with a linear third carination, which are undoubtedly young of $P$ l. trochiformis, as figured on line $q$, fig. 18.

The $P l$. trochiformis, fig. 8 , line $n$, is tracable in all its stages down to the undoubted rotundatus forms, fig. 12, same line, and figs. 15-18, line o. Figs. 9-10, line o, are identical with $\mathrm{Pl}$. discoideus, and at first seem really to belong to that species. They bear nearly the same relation to that species as fig. $(i$, line $c$, differing only in having the nitrow umbilicus and peculiar sharpness of the lower whork, which show that they are the young of the same varieties of trochiformis as rotundatus.

As a separate designation for a variety, the name rotundatus therefore has no existence, unless accepted as noted by Sandberger, but even then it is open to this difficulty, that very dissimilar varieties of $P$. trochiformis may be devoid of carinae. They may be as distinct as the transition form, fig. 4, line $r$, pl. 2, and the $P l$. trochiformis, fig. 9, line $k$, pl. 1 .

This study of the young forms, however, leads to the conclusion that we must 
look to the true discoidens line for the origin of the major portion of the trochiform varieties. That this is the case, will be established by looking at any large collection of specimens. ${ }^{1}$

In the majority of the varieties of $P l$. trochiformis, the upper sides of the whorls of the young are exposed at the apex of the shell, and these are smooth, not sulcated, and have two carinae generally blunt, as in the true discoideus.

Others, however, equal to the variety pyrguliformis Sand., Pl. trochif. turbinatus Hilg., are more prominently carinated, as on plate 2, figs. 9-12, line $s$, and have flattened apices; and the young, as seen externally at the apex, seem to be identical with the young of such forms as are figured on line n, figs. 1-2, plate 2, which are flattened forms of discoideus, distinguishable from the true sulcatus variation by the absence of a deep sulcation on the upper side.

Occasionally, however, the apices of some true trochiform varieties are similar to those of the young of other virieties than discoideus. Thus, in the case previously pointed out, the young of the forms on line $r$, figs. 6-7, plate 2, indicates a descent from the variety elatior, fig. 16, line $i$, same plate, and to this might be added other similar forms like fig. 8, also on line $r$, plate 2 , and also fig. 8, line $k$, plate 1 . These appear to be identical with Klein's $V$. multiformis, var. trochiformis, and in part with Sandberger's multiformis, var. trochiformis communis.

Fig. 3, line o, plate 2, which is the young of the Pl. trochiformis, fig. 5, line $r$, has the flattened apex and some of the characteristics of elegans Hilg., but also resembles the discoideus involutus, and the discoideus rotundatus forms. From this, which often has prominent carinations, we are able to pass into $P$. trochiformis turbinatus Hilg., line $s$, figs. 9-12. These forms have the flattened and sharply carinated young like those of the less turbinate elegans Hilg., as shown on line $\iota$, fig. 15, plate 3 , with a broken young specimen of $\mathrm{Pl}$.trochiformis (fig. 16) for companion. Compare then again with selected forms of $\mathrm{Pl}$. discoideus in which the young are remarkably flattened and sharply carinated above (as fig. 13, line $c$, plate 2, figs. 1-3), line $k$, figs. 12-14, line $g$, plate 1 , and similar figures of discoidens on plate 3 . The paucity of intermediate forms in this series is very marked, and caused Dr. Hilgendorf, as in the case of rotundatus, to invert the natural order of the series. He derives both of these forms from $P l$. trochiformis, whereas in tracing them out as in the case of revertens it will, I think, be found that the young, which always indicate the true line of descent, show closer affinity with discoidean than with trochiform varieties. In this connection see figs. $6,7,8$, line $k$, plate 1 (fig. 6 being very like $P l$. elegans, though evidently intermediate between discoideus and trochiformis); also 5-10, line $b$, plate 2, and then compare fig. 15, line a, plate 3, with flat discoiders above. The resemblance of the young to these full grown forms will at once become apparent. So far as my experience goes the only retrogressions from trochiformis, which I have been able to find, are like those figured on plate 8 , which are diseased forms showing, as previously described, a tendency to depart from the spiral as in fig. 10, line $r$, and fig. 11, line $s$, plate 2 .

The conclusion from these observations seem to be that $\mathrm{Pl}$. trochiformis arises from the almost simultaneous changes of a number of closely allied varieties. These are mostly

\footnotetext{
1 The name of the species, Planorbis trochiformis, which ought to have been at the head of these remarks, has been accidentally omitted on p. 78 , above third paragraph.
} 
discoidens. The extremely flat and square whorled varieties with their prominent carinte and sulcations being, however, more rarely represented by true trochiform descendant, than those forms of discoidens in which these parts are less prominent, and the form from the begimning of the series more asymmetrical. These in the trochiform descendints appear in the young as the rotundatus-like form, by which the greater part of all the trochiform specimens are characterized. Thus the direct line of descent from $P l$. Steinheimensis is shown to be prepotent, or to have a greater number of descendants than any other form.

It is useless to attempt to reduce these proportions to numbers, but it may be generally stated that in any formation the trochiform varieties with rotunlatus-like young greatly outnumber all others; so much so that those with a distinct flattened form of the apex have to be sought for, and become rarer and rarer until the extreme is reached in sulcatus-like young of elegans.

The value of this statement has been tested by the revision of boxes of Pl. trochiformis from nearly all the formations, the results of the sifting of several samples from each formation in the New Pit, besides a mixed box containing thousands, and a similar review of material in the Old Pit and East Pit. There is, however, one notable distinction which is represented also in a measure in the plates. The forms with rotundatus-like young occur much more abundantly in the East Pit than in the Old or New Pit, where the forms with discoideus-like young, the Pl. trochiformis, as figured by Hilgendorf, appear to be equally, if not more abundant in some formations.

It will, however, be noted even in this connection that all of the rotundatus-like young as well as the larger forms with rotundatus-like young figured on plate 2, came from the Old Pit. The cases of distorted spirals also are much more frequent among the specimens with flattened discoidean apices than in those with normally formed or rotundatus-like apices. This fact correllates with another of equal importance, namely, that in some case a true elatior-like whorl may be caused by a wound. Thus in one specimen in my collection, of a $P$ l. trochiformis with a typical rotundatus-like young, very smooth and rounded on the apex, a wound has interrupted the deposition of the shell when nearly half grown. The new whorl, when growth was resumed, was not only begun considerably inside of the spiral projected by the earlier whorls, thus narrowing the spiral considerably, but a first carination was prorluced, and a form of the whorl similar to that of elution instear of such a form as in plate 2, line $s$, fig. 6, which would have been produced in due time if no wound had taken place.

These facts and others mentioned previously, are very curious and appear to indicate less strength on the part of the promincitly carinated forms to resist external or internal causes of disease, producing a lessened size of the whorl and distortions of the spiral, which are only very rarely found in those forms having the rotundatus-like young. Thus the descendants in the direct line of descent from Steinheimensis are not only more numerous, but healthier than those of other varieties. The largest specimens are those of the transition forms from the flat variety of discoideus to Pl.trochiformis, such as are figured on line $m$, plate 2 , and others with the rotundatus-like young.

The descendants of the sulcatus and elatior varieties are generally smaller, especially when distorted, but when perfectly nornal may be quite up to the average size of 
the direct line, except in the case of those of $P l$. trochiformis, which have the discoidean young and are descended from those just referred to, as figured on line m, pl. 2. Thus the forms in the direct line of descent have the advantage in point of size, as well as in the other characteristics mentioned.

Besides these numerous varieties, there are still others which cannot strictly perhaps be attributed to disease or any definable cause. One of these is precisely similar to fig. 4 , line $r$, plate 2, in the rotundatus-like characteristics of the apex, but is extremely attenuated or tapering. The whorls, however, are perfectly regular, and the external aspect of the spiral smooth and more regular even than in fig. 4. This seems to be the variety vermetiformis Sand.

Another variation, which may be the trochiformis communis Sand, is that represented by the peculiar stout-whorled spiral of figs. $4-9$, line $k$; figs. $2-5$ and $6-8$, line $s$, on plate 2 , have also rotundatus-like young.

The distorted specimens, line $r$, figs. 9-10, plate 2, also deserve special attention. These have rotundatus-like young; but the last whorl, as shown in fig. 10, has an excessively thick inner lip, and strikes off from the regular line of increment. In botll cases, the coarseness and the crumpled look of the aberrant part of the whorl indicates a diseased condition to which doubtless the distortion must be attributed.

There are also extraordinary forms frequently found at the apex, showing that the young, as in fig. 1, line $s$, plate 2, must have presented a remarkable spiral during the two whorls, owing to the sharp projection of the second carina due to the contraction of the spiral. This was undoubtedly, I think, a pathological condition, because if it had been continued the adult would have been much distorted, perhaps even unrolled, as in $P l$. denudatus Hilg. It will be perceived that these results agree only in part with those of Hilgendorf. That author traces Pl. trochiformis through discoideus and sulcatus in linear succession, to $P l$. tenuis, then to $P l$. Steinheimensis, and lastly to $P l$. aequiumbilicatus.

The changes or variations from sulcatus and discoidens varieties into trochiformis were probably simultaneous or nearly so. At any rate, though this cannot be proved, there is a strong antecedent probability in its favor, owing to the sudden appearance of these forms in such great numbers, the precise parallelism of the different series, the frequency of hybrids and a parallelism so exact that it can only be explained by supposing that it was produced by the intercrossing of all the varieties.

This conclusion I find after a re-examination of the material to be substantiaily correct so far as the evidence as found in the Pits is concerned.

Throughout the preceding observations any reader can see by referring to the figures from what Pit and formation the different shells came, but in the following remarks no attention is paid to the formation, that not being considered important.

There are upon plate 7 , six specimens of $P l$. levis from Undorf; three of them are easily picked out, having been mounted on white paper, but can any reader distinguish the other three from the Pit forms of $P l$. Steinheimensis, which are associated with them, before reading the following descriptions.

This series is arranged entirely with the view of showing the zoological affinities of the series, independent of their geological relations. 
The shells are more magnified than in the first three plates, and carefully selected to show their affinities.

Line a, fig. 1, Pl. levis, from Undorf, compares with figs. 3, 5, Pl. Steinheimensis. The latter have peculiarly deep umbilici on the upper side, which is a characteristic of $P l$. levis, and are otherwise just like fig. 1 ; the forms could not be separated if found together. Fig. 2 shows the typical form of Pl. levis, from Undorf. Fig. 6, also, from Undorf, exhibits the ancular whorl of Pl. levis, and compares equally closely with fig. 7 , $P l$. Steinheimensis and fig. 8, a young specimen of the latter. Compare also fig. 2, line $b$, from the Pits, with $P l$. levis, Undorf, fig. 3; fig. 1, line b, Pl. Steinheimensis, with fig. 4, Pl. levis, Undorf; figs. 5, 7, 8, line 6 , from the Pits, with figures on the line below, and fig. 6, from Undorf. It is observable, however, that while in Pl. levis a decided angularity is found in the outer edge of the mouth-rim, owing to the prominence of the third carination, this is not the case with Steinheimensis, as a rule. It is a rare exception in the last named, and none of the normal specimens examined by me, even though they had this third carination as strongly shown as in fig. 6, line $a$, plate 7 , possessed an angulated aperture.

Fig. 3, line c, shows a remarkably fine specimen of Pl. Steinheimensis, which has the cylindrical form of the whorls common in var. aequimmbilicatus IIig., but is not aequimmbilicated. It is decidedly asymmetrical, and shows the tendency to form a turbinate whorl, which is so common in all the forms. Line $c$ exhibits forms of Steinheimensis intermediate with regard to the stoutness of the whorl, etc., between those in the three lower lines, and line $d$. These specimens also show, as do those below, that in some specimens the same variations occur also in the young. Line e, figs. 1-4, are more or less symmetrical forms, all normal, healthy, full-grown, but not outgrown, or old specimens, as in fig. 13, line $h$, pl. 1. Fig. 7 , line $d$, is $P l$. Steinheimensis, from the rocks of the Upper Tier of the Cloister Ridge; figs. 5-7, line e, are Pl. steinhenumensis from the Pits.

Figs. 1-3, line $f$, complete the transition to $P l$. tenuis, figs. 4-5.

The asymetrical forms of tenuis are shown in fig. 6-7, same line, and on line $g$, all of which are temis forms. Fig. 6, line $g$, is the stoutest true tenuis form which I have been able to find in my collection, and it will be seen that a hair's breadth more and a shade more of prominence to the third carina would make it impossible to say whether it was temuis or discoinleus.

The remaining specimens on this plate exhibit the ordinary forms of discoidens, those having rotundatus young. Figs. 3-6, line $i$, are true rotundatus Hilg., and figs. 1, 2, same line, the transitions from $P l$. discoideus to these.

It remains now only to trace the law of acceleration in this series. If we select any of the transition forms, $P$. stinhimensis, and examine the younger stages, we should find, as in fig. 1 , lime b, fig. 13 , line $c, p l .1$, that the only traceable resemblance to $P l$. tenuis, the sulcation, occurs on the last part of the last whorl, or during the full grown adult condition only; that such shells as firs. 14-15, line c, exhibit the same at an earlier age, accompanied by carinae, and finally fig. 16, at a still earlier age; so that it is difficult to say whether the young is like $P l$. Steinheimensis, except at a very early stage.

Finally in many specimens of $P$. temuis it becomes difficult to recognize the form of $P$. Steinheimensis at all on account of the early period at which the flattened whorl, 
carina, sulcation and narrow umbilicus make their appearance, figs. 5-10, line e, pl. 1 . The square form of the whorl as inherited by $P l$. discoideus passes through a similar series of descendants, in which it becomes more pronounced and stonter in the young by degrees, until the young themselves from being similar to temuis become stout whorled and discoidean, as well as the adults, fig. 16, line $b, \mathrm{pl} .2$, fig. 14, line $g$, pl. 1 . The turbinated form of the shell is wholly an adult characteristic in many specimens of discoidens, figs. 2-3, line $h$, pl. 1, fig. 12, line $p$, and may be traced with all its accompanying characteristics through several series to $P$. trochiformis, where the different series culminate in shells which have young that are so trochiform-like at an early age, that only the very youngest periods retain any resemblance to discoideus.

In some of these it is easy also by breaking down the shell to see one of the common results of this mode of inheritance by acceleration. Namely, the Steinheimensis form is almost, and in some few cases entirely, unrecognizable. It is skipped by the development, and so also is the tenuis form, the discoiders form alone surviving in the young. ${ }^{1}$

With regard to the proper identification of these forms, and those described by Klein in Jahresh. d. Vereins für vaterland. Naturk. in Württ., 1847, p. 60, fig. 7, line $h$, pl. 1, seems to me identical with Klein's $V$., multiformis var. planorbiformis, pl. 2, fig. 14 .

Fig. 7 , line $k$, pl. 1 , seems to correspond with Klein's $V$. multiformis var. intermedia, pl. 2, fig. 15. Fig. 8, line $r$, pl. 2, is almost exactly identical except in size with Klein's figure of $V$. multiformis var. trochiformis, pl. 2, fig. 16. Fig. $T$, line $l, p l .2$, is equally close to Klein's figure of $V$. multiformis var. turbiniformis, pl. 2, fig. 17. Fig. 11, line o, pl. 2, is apparently identical in every respect with Klein's $V$. multiformis var. rotundata, pl. 2, fig. 18.

Feeling that it would be futile to attempt a revision of the names of the different varieties, I do not attempt here or elsewhere, to do anything more than assist those who may feel disposed to take upon themselves this thankless task, with such observations as I may have made.

Sandberger's diagnosis, in which he divides this group into three, is the best which has been devised, with the exception of rolundatus, which, as shown, is only a name for a young specimen, and is therefore placed in brackets.

First variety ${ }^{2} \mathrm{~A}$, planorbiformis; containing sub-variety $a$, sulcatus, sub-variety $b$, discoideus, sub-variety $\beta$, elatior.

Second variety B, intermedius; containing sub-variety $a$, communis, sub-variety $b$, eleguns, [sub-variety $c$, rotundatus].

Third variety $\mathrm{C}$, trochiformis; containing sub-variety $a$, communis, sub-variety $b$, pyrguliformis, sub-variety c, vermetiformis.

\footnotetext{
This phenomenon was what led to the adoption of the name "acceleration."
}

2 In place of "variety," I should have written group, and in place of "sub-variety" the word species in most cases, but this is merely a difference in taste. 


\section{HYATT ON THE TERTIARY SPECIES}

\section{Lists of Fossils by Sections.}

\section{Old Pit, Section 5-6. Formation "a." \\ Stratum " $a, " 1$, and $a$.}

This, the lowest observed stratum, was explored in two places in the Old Pit by means of holes sunk through the fish layers, $c$, to the dark Jura clay beneath. At the lowest points fossils were carefully collected, which are figured on plate 1 , lines $a-k$, and $k-l$. Lines $a-k$ include the varieties obtained during the first visit to Steinheim, in the first hole sunk to the Jura-clay level, and also those collected during the second visit in a new hole at a short distance to the northward and still within the limits of the Pit. Lines $k-l$, include a selection of the varieties obtained in the lowest stratum during the reopening and reëxamination of the first hole dug and described above, in order to establish the fact that Planorbis trochiformis occurred in the Old Pit associated at the lowest level with $P l$. Steinheimensis, var. aequiumbilicatus.

The descriptions and plates show that the following species, with many intermediate forms, were obtained from the lowest part of the deposit, in contact with the Jura or darkbrown clay.

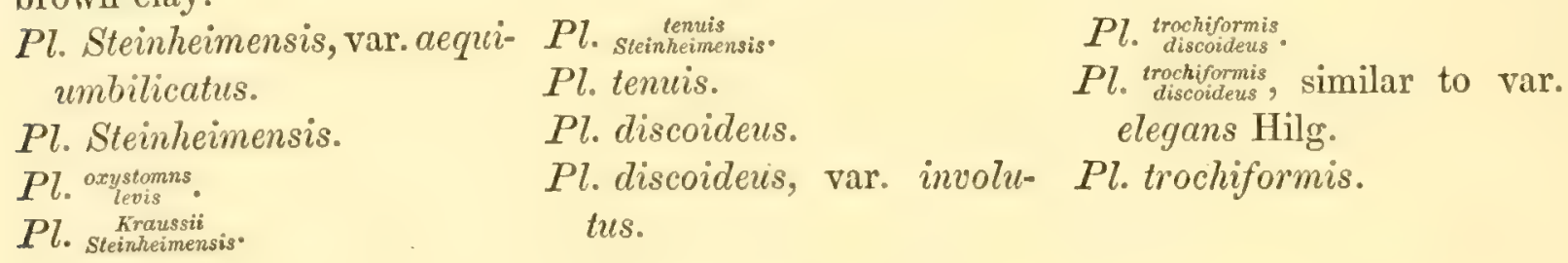

\section{Stratum a2, Old Pit.}

This consisted, like the first stratum, of a brownish colored, coarse sand, but was devoid of clay, and contained also stones or small boulders. The following species were found, and are figured on plate 1 , lines $m-p$ :
$P l$. Steinheimensis
$P l$. oxystomus.
$P l$. Steinhuimensis.
Pl. discoideus.
Pl. tenuis.
$P l$. $\begin{gathered}\text { trochiformis. } \\ \text { discoideus. }\end{gathered}$
Pl. Steinheimensis.

\section{Stratum a3, Old Pit.}

This consisted of sand of a similar coarse quality and color to that of $a 2$, but contained no large stones. The fossils were as follows, and are figured on plate 2 , line $a$, and line $b$, figs. 1-4.
Pl. Steinheimensis, var. ae-
quiumbilicatus.
Pl. Steinheimensis.
$P l$. Steinhuis
Pl. tenuis.
Pl. discoideus.

\section{Summary of Formation " $a . "$}

The geological characteristics of the lowest observed stratum in each of the two holes sunk to the level of the bottom clay differed. In the first hole, at the base of Section 6 , it was almost entirely shell-sand, but in the second hole, at the base of Section 5 , the sand 
was largely mixed with clay. The strata $a 2$ and $a 3$, in Section 5 , both contain the typical forms of stratum $a 1$, but not quite so fully represented in $a 2$ as in $a 1$, or in $a 3$, as in $a 2$. They seem, therefore, to be diminishing at the end of this period, in this part of the lake. The deposits of $a 2$ are distinct from $a 1$; they consist of masses and granules which resemble in character the adjacent porous limestone, or the older rocks described previously as forming the mass of the Cloister-ridge. Without the contained fossils it would not have been possible to have synchronized the two formations, namely, the single stratum at the base of Section 6, and the three strata at the base of Section 5. The fossils, however, include a similar association of forms. Pl. Steinheimensis, Pl. tenuis and $P l$. discoideus are abundant, and $P l$. trochiformis is comparatively rare.

\section{Formation "b," old Pit.}

This contains no fossils, but was situated immediately under Formation $c$, in both of the holes dug in the Old Pit. It contained shell-sand, and a considerable proportion of clay, in Section 6, and was almost wholly of clay in Section 5.

\section{Formation "c," Old Pit.}

This consisted, in the first hole dug, of $250 \mathrm{~mm}$. of clay, in layers, and $250 \mathrm{~mm}$. of limestone layers, all more or less filled with fish remains; in Section 5, however, in the second hole, the limestone occurred in layers regularly divided thoughout by layers of clay. No shells were found associated with the fish fossils. The general distribution of this Formation and its peculiar fossils makes it very valuable as a fixed level, from which to estimate the relationship of other formations.

\section{Formation "d," Old Pit.}

This consisted, in the locality first explored in the Old Pit, of clay and sand mixed, $300 \mathrm{~mm}$. in thickness, and in the second place, Section 5, of sand exclusively, the thickness being approximately $270 \mathrm{~mm}$. The fossils were scarce and difficult to gather, because this formation formed the floor of the Pit in both sections.

The following fossils were obtained:
$P l$. discoiders.
Pl. trochiformis.
$P l$. minutus.

They are figured on pl. 2, line $b$, figs. $5-16$.

\section{Formation "e," Old Pit.}

This consists of shell-sand $1 \mathrm{~m}$. in thickness, and abundance of fossils, especially of the smaller forms. The color differs somewhat from this ordinary shell sand, and it appears of darker or brown color, as if made up of the debris of darker limestones on the hill.

The following fossils were obtained:
$P l$. discoideus.
$P l$. trochiformis.

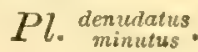
$P l$. denudatus.
$P l$. minutus.
Pl. costatus.

$P l \underset{\text { costatus }}{\text { minutus }}$

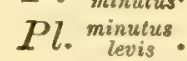

They are figured pl. 2, lines $c, d$, and $e$, figs. 1-17.

Pl. tenuis, var. Kraussii. 
Formation "f," Old Pit.

This consisted of the usual quality of white shell-sand, and contained the following fossils :

$P l$. tenuis.

$P l$. denudatus.

Pl. triquetrus.

$P l$. discoideus.

$P l .{ }_{\text {denudatus }}^{\text {minuthis. }}$.

$P l$. costatus minutus.

Plate 2, line $e$, figs. 18-27, line $f$, line $g$, figs. 1-16.

\section{Formation "g," Old Pit.}

This is composed of the common white frialle shell-sand, but contained no fossils.

\section{Formation "h," Old Pit.}

This consisted of the ordinary white, friable shell-sand, and contained the following fossils :

Pl. discoideus.

$P l$. discoideus

like young).

$P l$. discoideus (var. elatior $=P l$. triquetrus.

Plate 2, line $g$, figs. 17-23, line $h-l$.

\section{Formation "i," Old Pit.}

This consisted, where examined, mostly of the debris of broken shells, but contained numerous fossils in good preservation, but very few species.
$P l$. discoideus.
Pl. ${ }^{\text {trochifirnmis }}$ discoideus.

Plate 2, line $m$.

\section{Formation "k," Old Pit.}

This consists of the common quality of white, friable shell-sand, and contained the following fossils:

$P l$. tenuis. Pl. trochiformis.

$P l$. discoideus.

$P l$. trochiformis (rotundatus-young).

Plate 2, lines $n, o$, and $p$, figs. $1-13$.

Formation "l," Old Pit.

This consisted of white shell-sand, and contained:
$P l$. Steinleimeimsis
$P l$. trochiformis.
$P l$. denzinatus
$P l$. tenuis.
$P l$. trochiformis (var. pyrgu-
$P l$. denudatus.
$P l$. discoideus.
liformis Sand).

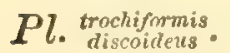
$P l$. minetus.
$P l$. costatus.

Plate 2 , line $p$, figs. 14-20, and lines $q, r, s$.

\section{Formation "x," Old Pit.}

This has the admixture of broken shells and perfect specimens which is very often 
found in other formations, and I cannot see why it should be necessarily considered as entirely composed of transported materials, as described by Hilgendorf.

$P l$. discoideus, $P l$. trochiformis, and one well-preserved specimen of $P l$. oxystomus were obtained.

\section{Formation "1." (Uncertain.)}

The absence of the upper or clayey formations from " $m$ " upwards, in the Old Pit, had attracted my attention from the first.

In order to ascertain whether this had been due to denudation, I ordered a hole to be dug on the top of the hill at some distance from the Old Pit, and a little to the north of a line connecting the Old Pit and the East Pit. This was sunk about eight feet; the first two feet or so through a bed of rubble, containing large specimens of Lymnaa; the remaining five feet, through a bed corresponding more to Formation $l$ of the Old Pit, than to any other. $P l$. trochiformis of the same varieties as those figured on plate 2 , lines $r, s$, were very abundant, but distinguished by the almost invariable absence of the carination on the lower side.

Pl. costatus and mimutus were also quite abundant, especially the latter; in both also the specimens were large, and the ribs in the latter very coarse and prominent, as in the variety major Hilgend. Var. Kraussii was also found, but of rare occurrence.

The bed could not be said to be continuous with $l$ in the Old Pit, although in all probability it was synchronous, and bed w was entirely ahent, its place beng ocenper by the rubble, which occurs frequently just under the surface soil on the hill, and appears to be composed of drift from the Cloister-ridge rocks.

This result was interesting, in so far as it confirmed the conclusions attained elsewhere, that the beds often differ so essentially, although but a short distance. removed from each other, that it is not possible to determine whether they are exactly synchronous. One fact is worthy of special remark. The rubble had also occurred at the very highest point known, the top of the Cloister Pit, Section 1, but the oxystomus layers were absent, and the rubble on the north side of the hill rested directly on the trockiformis beds, which agree in their fossils with formation $l$ of the Old Pit more than with the higher beds $x$; which, however, have similar fossils.

\section{Netw Pit, Section 8, Soutil side.}

This section was made on the south side of the New Pit, where the formation differed somewhat from those on the east side, as shown in Section 7. It would have been idle to repeat the figures of the usual $P l$. discoidens and trochiformis shells of the Old Pit, and other species which have been already so fully given. These occurred abundantly in some of the strata, and more rarely in others, until in Formation m, they gave way to the usual fauna of the oxystomes zone. I have accordingly only figured those forms which were not previously found at what have been considered as corresponding levels in the Old Pit, or which seemed to require special consideration. 
Formation "f," New Pit, South side.

This consisted of the usual shell-sand, but many of the specimens were incrusted with lime, and had the aspect of transported shells. Pl. crescens makes its appearance, but is rare.

Pl. temis. Pl. discoideus.

Pl. trochiformis.

Pl. 3, line $a$, figs. 1-3.

Formation "g;" New Pit, South side.

This also consists of shell-sand and fossils, but not so abundant as in $f$. $P l$. discoideus and $P l$. trochiformis.

Formation "h," New Pit, South side.

This consists of shell-sand, and contains :-
Pl. parvus.
Pl. oxystomus.
Pl. discoideus.
$P l$. crescens.
Pl. minutus.
$P l$. trochiformis.

Pl. 3, line $\alpha$, figs. 4-14.

Formation "i," New Pit, South side.
Pl. parvus.
$P l$. oxystomus.
$P l$. crescens.
$P l$. trochiformis.
Pl. trochiformis var elegans,
(Very rare).

The absence of $P l$. discoideus is a fact worthy of remark.

Pl. 3, line $a$, figs. 15-23, line $b$, figs. 1-11.

\section{Formation "k," New Pit, South side.}

This consists of shell-sand and contains :-
Pl. oxystomus.
$P l$. costatus var. major.
Pl. trochiform is.
$P l$. crescens.
$P l$. discoideus.

Pl. 3, line b, figs. 12-17.

Formation "1," New Pit, South side.

This consists of shell-sand, and contains:-

Pl. oxystomus. Pl. minutus.

Pl. trochiformis.

$P l$. discoideres was not found.

Pl. 3, line $c$, figs. 1-4.

Formation "m," New Pit, South side.

This consists almost wholly of clay, and contains:- $P l$. oxystomus, $P l$. crescens, but no $P l$. discoideus; and $P l$. trochiformis becomes exceedingly rare.

Plate 3, line c, figs. 5-16.

\section{Formation "x," New Pit, South side.}

This consisted of the usual shell-sand and broken shells with Pl. trochiformis and Pl. discoideus, well preserved and very abundant. 
Formation "p,". New Pit.

This consisted of alternate thin layers of clay and limestone, containing remains of $P 7$. oxystomus, $P l$. crescens, and $P l$. trochiformis, the last very abundant in the lower part, and very rare in the upper part of the formation.

$$
\text { New Pit, SEction 7, East side. }
$$

The species of the formations in this section did not seem to require figuring. The beds are remarkably distinct in aspect from those of the more regular layers on the south side of the same pit, as shown in section 8.

\section{Formation "g," New Pit, East side.}

This formation was made up of alternate layers of limestone and shell-sand, containing the usual Pl.trochiformis and discoidens, but no other forms were present, or represented in my collection.

\section{Formation "h," New Pit, East side.}

This narrow streak of shell-sand was perhaps one of the most remarkable deposits which it was my good fortune to find. It was an almost solid bed of shells, consisting largely of

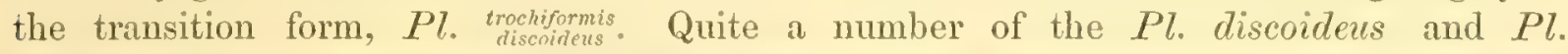
trochiformis were also present in all varieties and some very remarkable forms, produced by distortion of the spiral, arising from wounds.

\section{Formation "i," New Pit, East side.}

The lower part of this formation presented a very close resemblance to Formation " $n$," of the East Pit, Section 3. It contained lumps of limestone, in a fine sandy clay, and it is not improbable that these show the mode of formation of the numerous dividing layers of limestone, since they are of all degrees of hardness and exhibit frequently no definite outlines when in place.

$P l$. parvus was found, but not very abundant. $P l$. crescens was more abundant than the preceding. $P l$. oxystomus was quite rare. $P l$. trochiformis was abundant, but not so frequent as in the upper part. Var. Kroussii was alo found, and $P l$. minutus, but not abundantly.

\section{Formation " $\mathrm{k}$," New Pit, East side.}

This consists of a thin layer of shell-sand hetween two layers of clay, and was evidently of very limited extent. The clay on either side contained no fossils.

$P l{ }^{{ }^{\text {oxystomus }}}$ = varis revertens, and the turbinate and flat forms were very abundant. $P l$. crescens was also abundant. $P l$. trochiformis and $P l$. oxystomus were the most characteristic and numerous of all others.

Formation "1," New Pit, East side.

This consisted of shell-sand. The usual list of shells were found, Pl. trochiformis being perhaps the most abundant form.

Pl. minutus.

Pl. oxystomus.
$P l$. crescens.

$P l$. trochiformis.
$P l$, tenuis var. Kraussii. 
Formation "m," New Pit, East side.

The clay bed in this section was by no means so thick as in Section 8, though it probably only corresponds to the lower part of Formation " $m$ " in Section 8 . The collections made from this bed are particularly favorable to the views taken by Hilgendorf of the genesis of Pl. oxystomus from Pl. trochiformis.

They appear in my collection labelled as transition forms, and would without other evidence be considered sufficient to prove his position. A most perfect series can be built up between Pl. trochifomis and the extreme discoidal variety of var. revertens, which I think would be considered sufficient even by the most sceptical person, if no other evidence was forthcoming.

The confusion arises from the number and variety of the Pl. trochiformis with rotundatus young, and the close resemblances of these young forms to certain varieties of Pl.oxystomus, which were also present in considerable numbers.

$P l$. crescens was abundant and of large size.

Formation "х2," New Pit, Fast side.

This consisted of the ordinary materials of the shell-sand filling a lenticular pocket, which disappeared on following it a short distance towards Section 8.

Formation "t n, o," New Pit, East side.

This was a bed of clay of the usual fine texture, and containing specimens of $P l$. oxystomus and $P l$. crescens, but no other species.

Formation " $\mathrm{x} 3$, , New Pit, East side.

This consisted of the usual materials, and was apparently continuous with $x 3$, in Section 8 , and just above it laid the layers of limestone and shell-sand of

Formation "p," New Pit, East side.

This bed is directly traceable into formation $p$, of Section 8 , and contained the same species of fossils.

\section{Little Pit, Section 4. \\ Formation " a," Little Pit.}

This was situated considerably to the northward of the Old Pit, on the first road to the eastward. It was only a small excavation, but I employed a laborer to open it to the depth of about ten feet. The weather, however, was very unfavorable for such work, and the digging difficult on account of the thickness and frequency of the limestone. I therefore abandoned it before reaching the Jura clay, but succeeded in ascertaining the fact that the layers increase in thickness to the northward.

Above the two clay layers respectively marked 1 and 2 of Formation $a$, occurred a thick deposit of drift material, often very coarse, and exactly resembling the porous limestone drift of Section 5, formation a2, but much thicker. Here shells were more abundint, and I olstimed a few specimems of $\mathrm{Pl}$. temis, and one uncoiled specimen of 
$P l$. demudatus. This last was very carefully collected, and there is no doubt in my own mind, that it came from this formation, but though I sought diligently for specimens, I could not find another. Above this we find Formations $b, c$ and $d$, running together, and consisting of layers of clay containing the fish remains.

\section{Formation "e," Little Pit.}

The lower part of this formation consisted of the same brown porous limestone drift as formation $e$ in the Old Pit, and the fossils of the lower part also agreed very closely with those of that formation. The upper part contained a large admixture of the ordinary friable shell-sand, and a somewhat distinct fauna.

\section{Lower Part.}

$P l$. minutus, $P l$. costatus, and $P l$. demudatus were particularly abundant, with $P l$. discoidens.

$$
\text { Upper Part. }
$$

Pl. discoideus, and Pl. trochiformis are alindint, and with them numerous specimens of the form of the young, known as rotundatus.

$$
\text { Formation "f," Isittle Pit. }
$$

The prevailing fossils here, as elsewhere, were $P l$.trochiformis and $P l$. discoidens.

$$
\text { East Pit, Section } 3 .
$$

This section was taken on the south side of the Pit, and continued as far down as possible by a hole dug to the fish-layers of formation $e$. Any attempt to penetrate this, though made here in two places, was frustrated by the influx of water.

$$
\text { Formation "c," East Pit. }
$$

This consisted of clay in layers containing the usual fish fossils, but no shells.

$$
\text { Formation "d, e," East Pit. }
$$

This is very thick, and consists of layers of shell-sand of greater or less density, but otherwise not distinguishable. They have the same lumpy character and brown color of the corresponding formations in the Old Pit. Pl. discoidens was abundant.

$P l$. mimutus and costatus were also abundant. Pl. triquetrus was also found. A broken specimen or two of orystomes. was found, a fact which was carefully ascertained.

\section{Formation "f," East Pit.}

This formation is naturally divided into three parts just in the southwest corner of the sandpit, where one hole wat dug, by streaks of clay interpolated between the theer thicker layers of shell-sand. $P l$. discoideus is particularly fine in the lowest, but generally not very large. The usual spiral transition forms are not very abundant, the large majority being of the deeply chamnelled sulcatus form. A few also are smooth, but none of them 
approximate very closely to trochiformis. Pl. sulcatus had the same peculiarities in the middle bed. In the upper bed, however, nearly all the forms, without approximating very closely to $P$. trochiformis, showed the trochiform tendency in being more or less spiral, either throughout life, or only in the adult; only a very few of the flat sulcatus form were found in this part. $P l$. minutus occurred but very rarely in the lower part, while in the middle part it was much more numerous, and also associated with $P l$.costatus. In the upper part they were even more numerous, and associated with $P l$. costatus. One specimen had the tumnelled form, but the whorls were not open. Var. Kraussii follows nearly the same rule, being scarce in the first, quite numerous in the second, and still more abundant in the third part.

One broken specimen of $P l$. oxystomus was found in the middle part in which only a portion of the centre, and an outer whorl is left unbroken.

\section{Formation "g," East Pit.}

This consists of clay, but has two pockets or layers of shells. $P$ l. discoideus was very abundant, with numerous specimens of the rotundatus young of $P l$. trochiformis in all varieties, $P l$. minutus and costatus, and $P l$. parvus, and rarely $P l$. crescens.

\section{Formation "h," East Pit.}

This consists of shell-sand. $P l$. discoideus, and $P l$. trochiformis, with all the intermediate forms were very abundant. $P l$. minutus and $P l$. costatus were also very abundant, and uncoiled forms of both species. Var. Kraussii and $P l$. crescens also occur, but not so frequently.

\section{Formation "i," East Pit.}

This consists in the lower part of two strata of clay, with three of shell-sand, and in the upper part of one layer of shell-sand between two of limestone. The shells were not abundant, and much thinner than in the preceding formations. Pl. trochiformis most frequently occurred, but not in good preservation. Pl. mimutus, Pl. costatus, and $\mathrm{Pl}$. crescens were also fumd. A specimen similar to Pl. psendotemis Hily., probably the young of $P l$. tenuis, occurs for the first time in these formations.

\section{Formation " $\mathrm{k}, 1$," East Pit.}

This consisted of shell-sand and could have been divided into two parts according to the fauna, but this hardly seemed essential since the deposit was continuous. The lower part contained $\mathrm{Pl}$. minutus, $\mathrm{Pl}$. costatus, and a large proportion of the uncoiled or costated denudatus-like varieties. $P l$. crescens, and $P l$. oxystomus also occurred, the latter in great plenty. Pl. trochiformis was also abundant, but the most interesting form zoijlogically, though not frequent, was the pecurbotenuis-like species, which seems to be the young of the $P l$. temis figured on line $f$, figs. 1-6, plate 2.

The shells of $P l$. minutus, in the upper part, were whiter and more fragile than in the lower, and Pl. oxystomus was almost entirely abscut; otherwise the fama presented the same characteristics. 
Formation " $\mathrm{xl}$," East Pit.

'This formation occurred in a pocket of limited extent.

\section{Formation "m," East Pit.}

The lower part of this formation was divided by a layer of broken pieces of limestone. Both parts consisted of clay. Specimens of Pl. trochiformis, Pl. oxystomus var. revertens, and $P l$. oxystomus, $P l$. crescens, $P l$.tenuis, $P l$. minutus and $P l$. costatus var. major were also found. The upper part contained the same forms with the exception of $\mathrm{Pl}$. costatus and $\mathrm{Pl}$. trochiformis in one spot, while in another, almost adjoining, these were also found.

\section{Formation "n," Fast Pit.}

This consisted also of two parts. The lower of an argillaceous shell-sand, and the upper of an exceedingly fine sand filled in the border with nodules of the same material, but of lithographic fineness, and very soft. The lower portion alone contained fossils.

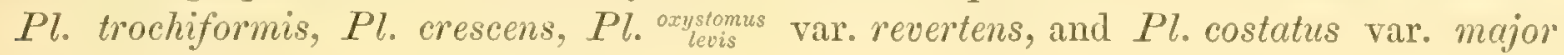
occurred, but none very abundantly.

\section{Formation "o," East Pit.}

This consisted of clay more or less permeated by reticulated veinings of limestone, arising from percolation from above, giving the whole a loose tuficeous aspect, reminding one of the limestone on the surface of the hill. Only a few specimens were found. $P l$. oxystomus var. revertens, $P l$. oxystomus, $P l$. crescens, and $P l$. costatus var. major.

\section{Formation "x3," East Pit.}

This appeared to be similar in character to what was found in the Old Pit, but contained $P l$. oxystomus in considerable abundance.

\section{East Pit, Section 2.}

It is not necessary to describe in detail the formations shown in this section. It is taken from an excavation in the centre of the Pit. Three such excavations were examined, and an attempt made to sink this one deeper, which was unsuccessful on account of the influx of water. It is evident, however, here, that the strata are apt to become thicker, as we progress outwards from the hill. The fossils were about the same as in the corresponding formations of Section 3.

\section{Cloister Pit, Section 1.}

This pit, which had become filled with debris, was reopened to a depth sufficient to uncover the beds containing abundance of the Pl. discoidens and trochiformis. None of these formations compare very closely with those of the other pits, and it is to be regretted that I did not continue the excavations to the base. 
Dr. Hilgendorf in his last exploration, however, has repaired this omission. He found that the base of the section rested upon Opalinus clay, an older formation of the Jura than those which are at the bases of the other sections. He also ascertained that the lowest beds contained only $P l$. Steinheimensis, a fact of the greatest importance to his theory. This, however, does not seem to me to be conclusive, even though confirmed in other sections, for reasons given elsewhere. In fact, the occurrence of the true Pl. Steinheimensis bed in these elevated deposits makes it very difficult to account for the absence of this bed in lower situations, such as those represented by Sections 5, 6.

\section{Formation "k," Cloister Pit.}

This consists of shell-sand and contains the following fossils in the lower part:- Pl. discoidens, Pl.minutus. Pl. discoideus was the only fossil Planorbis found in the upper part.

Plate 3 , line $c$, figs. 17-19, and line $d$.

\section{Formation "l," Cloister Pit.}

Consists of layers of shell-sand, with the usual limestone partings, and contains

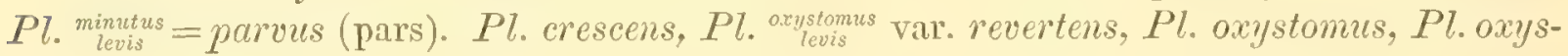
tomus var. cochleatx, $P l$. supremus var. turrita, $P l$. supremus, $P l$. discoideus, $P l$. ${ }_{\text {trochiformis }}^{\text {discoideus }}$, $P l$. trochiformis.

Plate 3 , lines $e-k$, and line $l$, figs. 1-14.

\section{Formation " $\mathrm{m}$," Cloister Pit.}

This is like "l," lithologically, and contains:- $P l$. ${ }^{o x y s t o m u s}$ vevis var. revertens, $P l$. oxystomus, Pl. supremus var. turrita, P.l. discoideus, Pl. trochiformis.

Plate 3 , line 7 , figs. $15-17$, and lines $m-p$.

\section{Formation " $\mathrm{n}$, o," Cloister Pit.}

This consisted of sand layers with limestone partings like formation $m$, but contained no fossils. Above this occurred a bed of rubble consisting of disintegrated rock, apparently derived from the Cloister-ridge rocks and resmbling in chatracter that previously encountered on the north slope of the hill, but containing no fossils. 


\section{Lists of Species by Formations.}

Lotver Period, or Period of Rock Deposits.

Neuselhalder Rocks.

Pl. solidus.

Pl. declivis.

Pl. Larteti or comulus.

$P l .{ }^{\text {oxystomus }}$ levis.

$P l .{ }^{\text {oxystomus }}$ levis.

Pl. parvus.

Pl. Steinheimensis.

$P l$. Lenuis

Pl. discoideus.

Pl. oxystomus

Pl. discoideus.
Pl. platystomus.

$P l$. exustus.

Coarse Limestone.

Pl. oxystomus.

Oxystomus Limestone.

$P l$. oxystomus.

Valley Rock.

Pl. discoideus.

Cloister-Ridge Rocks.

(Lower Tier.)

Pl. tenuis.

(Upper Tier.)

Pl. Steinheimensis.

Pl. tenuis.
Pl. Hilgendorfi.

$P l$ levis.

P7. supremus

$P 7$. supremus

Pl. discoideus
tenuis.

$P l$. tenuis, turreted variety.

$P l$. discoideus

Upper Period, or Period of Pit Deposits.

Formation a.

Pl. Steinheimensis var. aequiumbilicatus.

Pl. Steinheimensis.

$P$. oxystomus

Pl. Kraussii

Pl. minutus.
Pl. steinheimensis.

Pl. tenuis.

Pl. discoideus.

$P l$. discoideus var. involutus. Pl. denudatus.

Pl. trochiformis

Formation d.

Pl. discoideus.

$P l$. trochiformis.
Pl. minutus.

Pl. costatus.
Pl. $\begin{gathered}\text { trochiformis } \\ \text { discoudens }\end{gathered}$ var. like elegans

Hilg.

Pl. trochiformis.

$P l$. temis, turreted variety. 
Formation e.

$\mathrm{Pl}$. discoideus.

$P l$. trochiformis.

Pl. minutus.

$P l$. denudatus

$\mathrm{Pl} .{ }_{\substack{\text { minutus } \\ \text { ltris. }}}$

Pl. discoidens.

Yl. denudatus

$P l$. denudatus.

$P l$. costatus

Pl. Steinheimensis.

$P l$. discoideus.

$P l$. trochiformis.
$P l$. demudatus.

$P l$. costatus.

$P l$. costatus

P7. iriquctrus

Formation $\mathbf{f}$.

$P l$. costatus.

$P l$. triquetrus.

$P l$. tenuis.

$P l$. crescens.
Pl. trochiformis (rotundatus-

like young).

Pl. triquetrus.

$P l$ oxystomus.
$P l$. trochiformis.

Pl. Kraussii.

$P l$. minutus.

Pl. oxystomus.

Pl. pseudotenuis.

Formation $\mathrm{g}$.

$P l$. trochiformis (rotundatus- $P l$. costatus.

like young).

$P l$. mimutus.
Pl. parvus.

$P l$. crescens.

\section{Formation $\mathbf{h}$.}

$P l$. Steinheimensis.

$P l$. trochiformis var. pyrgu- $P l$. oxystomus.

$\mathrm{Pl}$. discoideus.

liformis.

$P l$. discoideus (rotundatus- $P l$. vrochiformis

like young).

$P l$. discoideus var. elatior.

$P l$. trochiformis.

Pl. triquetrus.

$P l$. parvus.

$P l$. crescens.

Formation $i$.

Pl. Steinheimensis.

$P l$. discoidens.

Pl. Steinheimensis.

P7. trochiformis

Pl. parvus.

$P l$. crescens.

$P l$. oxystomus.

Pl. trochiformis.

Pl. Kraussii.

Formation $\mathrm{k}$

Pl. tenuis.

Pl. oxystomus.

$P l$. crescens.

$P l$. discoideus.

$P l$. costatus var. major.

trochiformis

$P l$. trochiformis (rotundatus- $P l$. oxystomus var. reverlike young.)

Pl. Steinheimensis. tens.

Pl. tenuis
Pl. minutus.

$P l$. costatus.

$P l$. denudatus.

$P l$. costatus var. distortus.

Pl. Kraussii.
Pl. minutus.

$P l$. oxystomus

$P l$. costatus.

$\mathrm{Pl}$. tenuis.
Pl. minutus.

Pl. costatus.

P'l. costatus var. distortus.

Pl.temis.

Pl. pseudotenuis. 
Formation 1.

Pl. Steinheimensis

Pl. tenuis.

Pl. discoideus.

Pl. trochiformis

Pl. trochiformis.

$P l$. trochiformis var. pyryuli- Pl. crescens. formis.

$P l$. oxystomus

Pl. parvus.

Pl. minutus.

$P l$. denudatus

Pl. denudatus.

Pl. oxystomus.

Pl. Kraussii.

Pl. oxystomus.

Pl. Steinheimensis.

$P l$. oxystomus

Pl. oxystomus.

$P l$. crescens.

Pl. trochiformis.

Pl. crescens.

$P l$. oxystomus.

Pl. crescens.

Pl. oxystomus.

$P l$. discoideus.

$P l$ oxystomus.
Formation $\mathrm{x}$.

Pl. discoidens.

Pl. trochiformis.

Formation $\mathrm{m}$.

$P l$. trochiformis (rotundatus- $P l$. costatus.

like young.)

$P l$. ${ }^{\text {oxystomus }}$ levis var. revertens.

$P l$. tenuis.

Pl. minutus.

\section{Formation $\mathbf{n}$.}

$P l$. trochiformis.

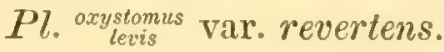

\section{Formation o.}

$P l$. trochiformis.

$P l$. costatus var. major.

Formation $\mathrm{x}$ bis.

$P l$. trochiformis.

Pl. oxystomus.

Formation p.

$P l$. crescens.$$
\text { P.. oxystomus. }
$$

Pl. trochiformis.
$P l$. costatus.

Pl. ${ }^{\text {oxystomus }}$ lexis var. revertens.

Pl. oxystomus var. turritus.

Pl. supremus.

Pl. pseudotenuis.

$P 7$. supremus

Pl. Steinheimensis.
$P l$. costatus var. major.

Pl. supremus.

$P l$. supremus var. turritus.

Pl. costatus var. major.

$P l .{ }^{\text {oxystomus }}$ levis var. revertens. 


\section{APPENDIX I.}

On page 27 I have written, that I wondered no authors except Prof. Cope and myself had made the law of acceleration an object of investigation.

This statement is not wholly correct, since I find in a work just received, "Studien uber die Stammes-geschichte der Ammoniten," by Leopold Wirtenberger (Leipzig, Ernest Gunther, 1880, 8vo., pp. 110, with four Stammtafeln), that the author has used this law of heredity, though evidently misunderstanding its fundamental character, as one of the laws of heredity, and explaining it as the result of the action of the law of natural selection. It becomes interesting, also, to observe how closely his statements and facts agree with those previously made in my publications; for example, on page 28 , he writes as follows: "Wenn nämlich eine Verånderung welche fiur die granze Gruppe eine wesentliche Bedeutung erlangit, zum erstenmal auftritt, so ist dieselbe nur auf einem 'Theil des

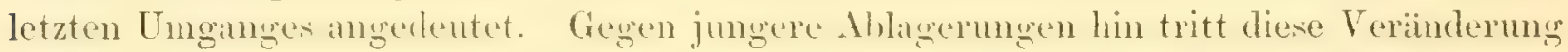
immer deutlicher hervor und schreitet dann, dem spiralen Verlaufe der Schale folgend, nach und nach immer weiter gegen das Centrum der Ammonitenscheibe fort; d. h. sie ergreift allmählich immer melu auch die inneren Windungen, je höher man die betreffende Form in jungere Schichten hinauf verfolgt."

"When, for instance, a variation which attains a substantial importance for the whole group, makes its appearance for the first time, it is exhibited only upon a part of the last (outer) whorl. 'This variation comes out ever more distinctly as the strata are younger, and advances, following the spiral trend of the shell, step by step, towards the centre of the spiral: that is to say, they (the characteristics) strike gradually more and more towards the inner whorls, as one follows the forms from the older into the younger (later formed) beds."

This statement is an exact transcript of what I lave repeatedly written in various essays upon the Ammonites. and also grives the fundamental facts upon which all my investigations have been based for fourteen years.

Compare the above, for example, with the following sentences from p. 203, of my memoir in Vol. 1st of the Memoirs of Bost. Soc. Nat. Hist., read Feb. 21, 1866, and published in 1867 .

"The young of higher species are thus constantly accelerating their development, and reducing to a more and more embryonic condition, (or entirely passing over) the stages of growth corresponding to the adult periods of pre-existing or lower species."

"In other words, there is an unceasing concentration of the adult characteristics of lower" species in the young (or inner whorls) of higher species, and a consequent displacement of othere embryonic teatures (in these inner wholls), which hat themselves, also, previously belonged to the adult periods of still lower forms."

With reference to the characters of the Ammonitoid shells, on p. 94, he says: "dass dic Verånderungen an den Sculpturen, sowie an den iibrigen Charakteren der Ammonitensehalen sich zuerst aud dem letzten (itussern) Umgange dersolhen bemerklich machen, und dass damn eine solche lerählerung hei den natchfolgenten Generationen sich nach und mach immer weiter geren den Anfung des spiralen Gehiuses fortwchiebt, bis sie den grössten Theil der Windungen beherrscht." 
"That the variations of the sculpture, as also those of the other characteristics of the shells of Ammonites first make themselves visible upon the last (outer) volution, then such a variation advances in the following generations step by step always nearer to the beginning of the spiral, until it covers the greater part of the (inner) whorls."

The difference between our statements ${ }^{1}$ is that Wiirtenberger speaks of the inner whorls and I use the word "young" in place of the word "inner whorls," because the immer whorls of all shells represent the first formed or younger stages of growth.

I also in the first quotation use a phrase "entirely passing over" which has been included in parentheses because it refers to the skipping of characteristics in development, a phase of the law of quicker inheritance, or acceleration in heredity, which Herr Wirtenberger also mentions, but which is not included in his first statement. I might also refer if I chose to similar quotations from Prof. E. D. Cope of Philadelphia, showing that he, simultaneously with me, discovered the same law though giving it a somewhat different application than either Wuirtenberger or myself.

Now we have only to understand, that the outer whorls are built during the full grown or adult period, and the inner by the animal during the younger stages, in order to perceive that this is a statement that the Ammonites inherited the adult characteristics of their ancestral forms at earlier and earlier periods in successive generations.

This is the law of acceleration, and it is specifically given by Herr Wurtenberger in various places in his book, notably on p. 9S, where he attributes the preservation of any characteristic differences which may arise, to natural selection, and says that they may be inherited earlier or later in the life of individual descendants.

'Then as the earlier inheritance of these characteristics would be of advantage to the individual in the struggle for existence, IIerr Wurtenherger thinks that succesive generations would tend to inherit them at earlier and earlier periods. 'The objections to this seemingly simple and straightforward explanation are numerous. Animals do not inherit the new characteristics which their parents may have acquired at later periods than those in which they appeared in the parent, but at the same time, or earlier in the immediate descendants, and eventually always earlier in the more remote descendants. I have as yet seen no evidence that the descendints inherit a characteristic at a later period than that at which it first appeared in an adult ancestor.

Even if this asiumption should he proven it would still remain necessary to estahlish the nature of the characteristics inherited, whether they really were advantageous or not.

Noting can exceed the confidence with which the strict Darwinist assumes, without any appeal to observation, that all characteristics which are inherited are necessarily advantageous. Exactly the reverse is very often true. The disadvantageous, the advantigeous, the parallelisms and the differences, are all subject to the law of acceler-

\footnotetext{
1 In order to see liow closely we have followed the same pith it is also necessary to compare the statements on pages 27 and 28 of this Memoir, and in the following essays: "Development of the shells of Ammonoids and Nautiloids." Proc. Bost. Soc. Nat. History, Vol. 14, p. 398. "This is the law of acceleration, or the perpetual reduction of adult characteristics to earlier and earlier periods in the growth of
}

the later existing individuals, until finally many characteristics altogether disappear." "Cephalopods of the Museum: Embryology"" Bull. Mus. Comp. Zool., Cambridge, Mass., Vol. 3, No. 5, p. 70-71. "Evolution of the Arietidae." Proc. Bost. Soc. Nat. Hist., Vol. 17, p. 238. "Genetic relations of Stephanoceras," in same, Vol. 18, p. 379, last paragraph, p. 382. 
ation described above, whereas the law of natural selection can only act when there is a choice of characteristics, and where those characteristics are differences, variations newly introduced. not ret fixed in the organization, and unguestionahly arlvantageons. Animals or plants must act and react upon each other, and then and not before then, can we have any law like that of natural selection, and it is exceedingly questionable whether natural selection applies at either extreme of life. Man is certainly by his own acts capable of modifring and perhaps controlling the result of the battle of life. and it is very probable that the action and reaction of the first beginnings of life in the past history of the world, was no more than could be accounted for by the known action of physical forces upon the simplest of organisms.

Natural selection certainly has nothing to lo in the embryo, nor yet in the extreme old age of the individual. If, as $I$ have constantly tried to prove, the individual life is a true exponent of the life of the group to which it helongs. the embryo to the progressive past, the adult to the present, and the old age to the degraded or retrogressive future of an exhausted or diseased type, then it may with approximate certainty be assumed that natural selection acts at neither of the extremes of the variation of a given group, neither upon the phenomena of their first alpuearance. nor mon those inlicating their decline and leading to their disappearance.

Natural selection, in fact, is imply one of the transicut conditions of the physical surroundings, having no value as a cause of origin of chinacteristics, but simply acting on certain categories of these characteristics, atter they have originaterl, and helping to take them out of the list of transient characteristics and fix them in the organization. Once fixed they are inherited, and, unless as described above, interfered with by a reversal of the ordinary physical conditions, by extreme parasitism, etc., they become a part of the younger stages of growth in accordance with the law of acceleration, and are either finally skipped, crowded out altogether, or become embryonic and part of the type form.

Herr Wiirtenherger has, also, observerl this peculiarity of the skipping or omission of accelerated characteristics, which originally caused the use of the name acceleration as applicable to these phenomena, and used also in this respect words which are almost identical with those which I have employed in describing the same phenomena in previous essays.

"Denn es ist leicht einzusehen. dass die fortgesetzte Wirkmg der frihzeitigeren Vererbung der fortwiahrend im Lebensalter auftetenden Abinderungen dahin fïhren muss, die früheren Entwickelungsstarlien näher zusammenzudrängen, zu verwischen oder zum 'Theil ausfallen zu lasien, wenn die der eigentlichen Entwickelung der Organismen nicht iiber alle Massen hinaus verlängert werden soll."

"For it is easy to perceive, that the prolonged working of the earlier transmission ${ }^{1}$ of the changes which are perpetually appearing in older life ${ }^{2}$ must lead the earlier stages of development ${ }^{3}$ to shorten up, to disippear wholly or partly, or else the individual development of the organism would be prolonged beyond all just measure."

1 In successive indiviluals, forms or species.

${ }^{3}$ Of descendant individuals, forms or species.

2 Of the more ancient or ancestral individuals or species. 
I have enteavored in this memoir to explain these accelerations or skippings from which

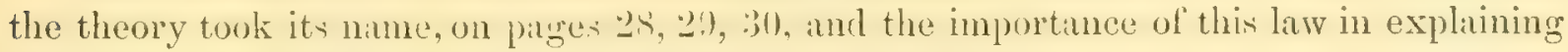
the partial or total obliteration of type characteristics in the embryos of some parasites, as well as in the ordinary cases which occur in every group of animals.

IIerr Würtenberger deals with the Planulatus, Amaltheus, and Pettos groups, on all of which I have published papers, and since he has quoted Waagen, who cites my work, and since Iferr Wiirtenberger also knew of my work on the "Embryology of the Cephalopods," as is shown by his allusion to my name at the foot of page 35 , it would be very interesting to know how he escaped noticing that I had discovered and formulated the law which he justly considers an important law of heredity, and to the exposition of which he had devoted his book.

In a note to page 35 he gives Branco the credit of having done in 1879 the work which I had done in 1872 in my treatise on the Embryology of the Cephalopods, and casually mentions that I har alreatly done something of the same sort on the Goniatites, a small sub-division of the Cephalopods.

Here, unfortunately, he did one of his own countrymen an injustice, since this was one of the parts of my work which was not original, it having been copied almost bodily out of Guido Sandberger's previous revearches, I ean, however, congratulate Herr Wuirtenberger upon his recognition by full ruotations of that much abused naturalist. Haleckel, who, notwithstanding his great offences against the conservatism of reasoning in science, has given a better analysis than any other living naturalist of the laws governing the relations of animals to their surroundings and to each other. His critics, whose name is legion, do him a monstrons injustice in allowing themselves to dwell wholly upon the errors and the faults they can find, formetting themselves, and blinding other's to the sulstantial services to science of this justly celebrated naturalist. My own indebtedness to him and to his works is very great, as must be that of all those who strive to get some idea of fundamental laws.

Though differing from him on essential points, still in his Generelle Morphologie der Organismen he has given substantially the same view of the action of heredity in preserving the type, and of the relations of growth to heredity and of heredity to the modifieations produced by the direct action of physical influenees, as has been set forth in this memoir. The differences lie principally in the estimate of the importance of the law of natural selection, which he considers as of wider application than I think is at all justified by any proofs which have so far been produced.

\section{APPENDIX II}

On page 14, in paragraph next to the last, and again on page 31 in the first paragraph, I allude to the general tendency to spiral mode of growth in all shells.

I had in this memoir no opportunity to enlarge on this subject, and when the remarks were written har not yet publisher any observations on this interesting subject. Since then, however, in an evening lecture given before the American Association for the Advancement of Science during the meeting of 1850 , at Boston, I gave some account of the facts as they stand throughout the Molluscal, and attempted to prove, so far as the absence of experiment would permit, the hypothesis that the spiral forms of all shells, whether Ceph- 
alopods, Gasteropods, or Lamellibranchs, ant their peculiar shapes, can he accounted for by the different ways in which the attraction of gravitation would act upon the excreting horder of the mantle throngh the weight of the shell itself, or by the natural growth of this part when freed from the weight of the shell.

Thus the oyster, pecten, ete., show during the adult stages distortions and a peculiar horizontal growth which can only be accounted for by the support they receive, either

from permanent attachment, or by resting on one valve.

The evidence here seems to show that the shell must grow in the direction resulting from the action of the two forces, the movement and growth of the tissues and the opposing force of gravitation. The extraordinary shapes and combinations of asymmetry and symmetry in different parts of the same animal as exhibiter in the mollusea, all seem to be resolved when we can account for the influence of gravitation upon a fixed or moving organism, allowing for the reactions occasioned by growth and heredity.

\section{APPENDIX III.}

The remarks on p. 76 , with regard to $P l$. psendotemis, are misleading. Since this page was printed I have undertaken with the help of two as wistants to revise and re-arrange my collection. This has led to the finding of several specimens of Pl.psendotenuis. These show that $P l$.pseudotenuis is a form which is genetically connected with $P l$.minutus. It has all the characteristics and peculiar aspect of that species in the roung, and is never so stout at any period as $P l$. Kranssii. The latter has a shell which resembles it in color and general aspect but not in its proportions, and is also approximate to 17. psentotemis, very elosely in some specimens which have a prominent thick carination. 'These are very closely similar to $\mathrm{Pl}$.pseudotenuis, and I think led Dr. Hilgendorf to trace pseudotemuis into Kraussii instearl of into $\mathrm{Pl}$. mimutus with which it seems to be connected. There have also been found two specimens of $P l$. pseudotenuis with a sulcation on the upper side of the whorl, which confirms this conclusion; as any one will see, even from an examination of Hilgendorf's own figure, that such a sulcation would render even the extreme form of $\mathrm{Pl}$. pseudotenuis very similar to $\mathrm{Pl}$. triquetrus, which Hilgendorf himself considers a member of the minutus series. Var. Kraussii p. 89, fifth paragraph, is $P l$. pseudotemuis. One specinen of $P l$. pseudotenuis has been found in Formation $f$, New Pit, one in $k, l$, East Pit, one in $x$ same Pit, and one in $l$, Old Pit.

This revision of the collection has also led to the discovery of several diseased forms of $\mathrm{Pl}$. trochiformis, which are very interesting. They are dwarfed. The spiral is partly unwound and then closed up again in course of growth, but is even then much contracted. In fact a very slight increase in the characteristic tendency of the growth, as shown by our specimen would make a whorl larger, but not very unlike $P l$. denudatus in general appearance.

\section{APPENDIX IV.}

In revising the collection my assistants have also succeeded in finding in Formation $d e$, referred to on page 49 , line 18 , as containing only "two broken specimens of $\mathrm{Pl}$. oxystomus" and alio on 1.93, line 22, two well preserved young specimens and one nearly full grown. 


\section{APPENDIX $V$.}

The Geological Map on p. 33, does not exactly represent the views of the strata given on the subsequent pages, it having been copied from the official geological map of the Steinheim locality, sometime before the text was written.

Thus the Cloister-ridge Rocks near Steinheim are represented as the equivalent of the Oxystomus Limestone near Sontheim, whereas they more nearly resemble the Coarse Limestone. The rocks on the west side of the amphitheatre, and the two spots of rock also shaded like the Oxystomus Limestone, and lying the west of these, again, are the Neuselhaklel locks, and not at all like the Oxystomus Limestone, which contains a much younger fauna.

Page 9, line 8, read animals for animal.

\section{CORRECTIONS.}

Page 11, line 39, read fig. 4 for fig. 40.

Page 12, note, line 2, read var, cochleata for var. rotundatiformis.

Page 14, line 30, read line $i$ for line $h$, omit line $f$.

Page 28, line 28, after last, insert the words a large part of.

Page 30, line 24, after fig. 4, insert $p l .9$.

Page 30, line 28, read early for easy.

Page 32, line 25, read immediate for direct.

Page 35, line 2, $\mathrm{Pl}$. oxustomus in place of $\mathrm{Pl}$. $\begin{gathered}\text { lenis } \\ \text { oxystoms. }\end{gathered}$

Page 39, line 6, read umbilicus for umbiicus.

Page 49, line 22, read trochiformis for Trochiformis.

Page 62, line 11, read to for by.

Page 63, line 19, read $p l .8$ for $p l .4$.

Page 63, line 22, read $p l .8$ line e fig. 2 in place of line e, fig. 2.

Page 67, line 21, read line $c$ for line $e$.

Page 75, line 22, read Steinheimensis for "levis."

Page 75 , line 31 , read sub-varieties for "varieties."

Page 77, line 7, after "line 0 ," insert $P l .1$.

Page 78, line 2, after "line $h$," insert except fig. 13.

Page 78, line 14, insert Pl. trochiformis as title in centre of page.

Page 78, line 36, read $p l .2$ for "pl. 1."

Page 80, line 33, read traceable for "tracable."

Page 94, line 24, the Pl.pseudotenuis Hilg. there mentioned is not a true pseudotenuis. 


\section{EXPLANATION OF THE PLATES.}

\section{Plate I.}

Magnified 2 diameters.

LIST OF SPECIES.

Pl. Steinheimensis var. aequiumbilicatus, line a 1-4, b 17, c 1, 19, m 1-7.

Pl. Steinheimensis line a 5-11, b $2-16, \mathrm{~d} 5, \mathrm{f} 18, \mathrm{~h} 13, \mathrm{~m}$ 8-11, n 1-5.

$P l$. oxystomus line a 12-16, m 12-14.

$P l$. Fintressii line f $1-3$.

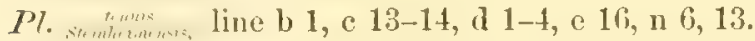

Pl. tenuis, line c 2-12, 15-18, d 6-17, e 1-15, k 11, n 7-12, 14-15, o 1- 7 .

$P l$. discoideus, line f $4-17$, g 1-14, h 1-12, i 1-12, k 1-5, 12, 1 1-10, o 8-14, 16 (named specimen), p1-13.

$P l$. discoideus var. involutus, line d 18, e 17-19.

$P l$. trochiformis line $\mathrm{k}$, 7 , line 015 .

Pl. trochisionisis (var. elegans Hilg.), line k 6.

Pl.trochiformis (=trochif. typus Hilg.), line k 8-10, 1 11-12.

\section{Check List bY Lines.}

Line a, figs. 1-1 Pl. Steinheimensis var. aequiumbilicatus, 5-11 Pl. Steinheimensis, 12-16 Pl. oxysermus

Line b, fig. $1 \mathrm{Pl}$. steinheinimensis, ${ }^{2}-16 \mathrm{Pl}$. Steinheimensis, ${ }^{1} 17 \mathrm{Pl}$. Steinheimensis var. aequiumbilicatus.

Line c, fig. $1 \mathrm{Pl}$. Steinheimensis var. aequiumbilicatus, 2-12 Pl. tenuis, 13-14 Pl. steinheinumsis, 15-18 Pl. tenuis, $19 \mathrm{Pl}$. Steinheimensis var. aequiumbilicatus.

Line d, figs. 1-1 Pl. steinteinisensis, $5 \mathrm{Pl}$. Steinheimensis, 6-17 Plotenuis, $18 \mathrm{Pl}$.discoideus var. involutus.

Line e, figs. 1-15 Pl.tenuis, $16 \mathrm{Pl}$. Steinhteimensis, 17-19 Pl. discoideus var. involutus.

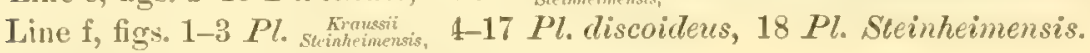

Line $\mathrm{g}$, figs. 1-14Pl. discoideus.

Line h, figs. 1-12 Pl discoideus, $13 \mathrm{Pl}$. Steinheimensis.

Line i, figs. 1-12 Pl. discoiders.

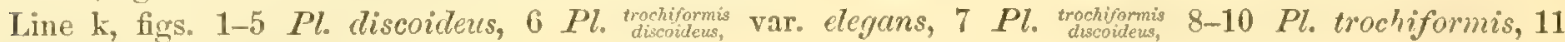
$P l$. tenuis, $12 \mathrm{Pl}$. discoidens.

Line 1, figs. 1-10 Pl. discoideus, 11-12 Pl. trochiformis.

Line m, figs. 1-7 Pl. Steinheimensis var. aequiumbilicatus, 8-11 Pl. Steinheimensis, 12-11 Pl. oxysetonus

Line n, figs. 1-5 $\mathrm{Pl}$. Steinheimensis, $6 \mathrm{Pl}$. secinheimensis, $7-12 \mathrm{Pl}$. tenuis, $13 \mathrm{Pl}$. Steinheimensis, 14-15 Pl. tenuis.

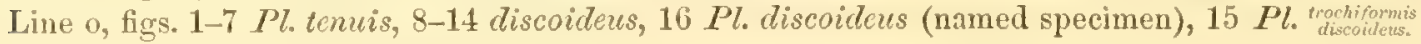

Line p, figs. 1-13 Pl. discoideus.

\section{Check List by Sections and Formations.}

Formation a.

Stratum a 1, Second IIole, and a, First IIole, ${ }^{2}$ Old Pit, Sections 5, 6.

Pl. Steinheimensis var. aequiumbilicatus, line a 1-t, b 17, c 1, 19.

Pl. Steinheimensis, line a 5-11, b 2-16, d 5, f 18, h 13.

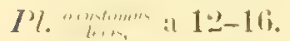

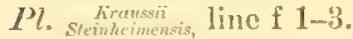

$P l$. Steinhtimensuse, line b 1, c 13-14, d 1-4, e 16 .

1 Figs. 10-12 are very similar to Pl. m. parvus Hilg. " lines k-1, a special suite from the First IIole, Sect. 6 taken

2 Lines a-k show a mincring of forms from both holes; during $\mathrm{my}$ second visit to Steinheim. 
Pl. tenuis, line c 2-12, 15-18, d 6-17, e 1-15, k 11, o 8-10.

$P l$. discoideus, line f 4-17, g 1-14, h 1-12, i 1-12, k 1-5, 12, l 1-10.

Pl. discoideus var. involutus, line d 18, e 17-19.

$P l$. trochiformis line $\mathrm{k} 7$.

$P l$. trochifornis (var. elegans Hilg.), line k 6.

Pl. trochiformis, line k 8-10, 1 1-12.

\section{Stratum a 2, Second Hole, Old Pit, Section 6.}

Pl. Steinheimensis var. aequirmbilicatrs, line m $1-\bar{\tau}$.

Pl. Steinheimensis, line m 8-11, n 1-5.

Pl. oxystomus line m 12-14.

Pl. Sterinuisisensis, line n 6,13 .

Pl. temuis, line n 7-12, 14-15, o 1-7.

$P l$. discoideus, line o 8-16, p 1-13.

$P l$. trochiformis line o 15.

\section{Plate II.}

Magnified 2 diameters.

List of SpEcies.

Pl. Steinheimensis var. aequiumbilicatus, line a 1-2.

$P l$. Steinheimensis, line a $3-4$.

Pl. Irraussii, line d $1-17$, f 9.

$P l$. Steinheimensis, line a $7-8$, q 12 .

Pl.temuis, line a 5-6, 9-12, e 18-27, f 1-8, 10-12, p 9-13, q 5-11.

Pl. discoideus, line a 13, b 1-6, 16, c 1-13, f 13-19, h 1-18, i 1-14, k 1-2, m 3-4, 6-9, n 1-7, q 13-16.

Pl. discoiders (var. elatior Sand.), line i 15-17.

$P l$. trochiformis line m 1-2, 5, q 17-18, r 1-4.

Pl. trochiformis, line b 7-10, d 18-19, k 3-11, l 1-11, n 8-12, o 15-18, r 5-10, s 1-8.

$P l$. trochiformis (var. pyrguliformis Sand.), line s 9-12.

$P l$. discoideus (young with forms similar to rotundatus Hilg.), line h 19-23.

$P l$. trochiformis (young of normal varieties identical with rotundatus Hilg.), line o 1-14, p 1-8.

Pl. mimutus, line e 1-5, 7-8, g 1-2, 4, p 14-20, b 11-15.

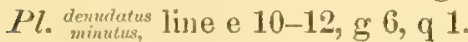

Pl. demudatus, line e 13-14, g $7-8$.

Pl. constatus line e $6, \mathrm{~g} 5$.

Pl. costatus, line e $9, \mathrm{~g} 3, \mathrm{q} 2-4$.

Pl. minutus line e 15-17.

Pl. triquetrus, line g 9-23.

Check List tis Lises.

Line a, figs. 1-2 Pl. Steinheimensis var. aequiumbilicatus, 3-1 Pl. Steinheimensis, 5-6 Pl. tenuis, 6-8 Pl. Steinheimennis, 9-12 Pl. tenuis, $13 \mathrm{Pl}$. discoideus.

Line b, figs. 1-6 Pl. discoideus, 7-10 Pl. trochiformis, 11-15 Pl.minutus, $16 \mathrm{Pl}$. discoideus.

Line c, figs. 1-18 Pl. discoideus.

Line d, figs. 1-17 Pl. temis var. Kraussii, 18-19 Pl. trochiformis.

Line e, figs. 1-5 Pl. minutus, $6 \mathrm{Pl}$. costatus minutus, 7-8 Pl. minutus, $9 \mathrm{Pl}$. costatus, 10-12 Pl. demudatus $13-14 \mathrm{Pl}$. demuclatus, 15-17 Pl. minutus 18-27 Plo tenuis.

Line f, figs. 1-8 Pl. tenuis, $9 \mathrm{Pl}$. tenuis var. Kraussii, 10-12 Pl. tenuis, 13-19 Pl. discoideus. 


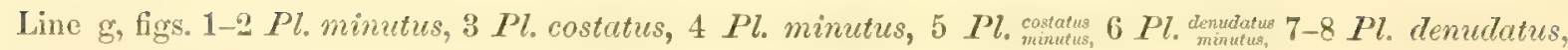
9-23 Pl. triquetrus.

Line h, figs. 1-18 Pl. discoideus, 19-23 Pl. discoiders (rotundatus-like young).

Line i, figs. 1-14 Pl. discoideus, 15-17 Pl. discoideus (var. elatior Sand.).

Line k, figs. 1-2 Pl. discoideus, 3-11 Pl. trochiformis.

Line 1, figs. 1-11 Pl. trochiformis.

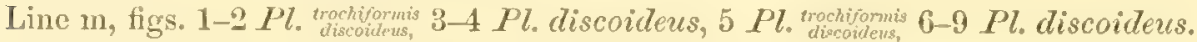

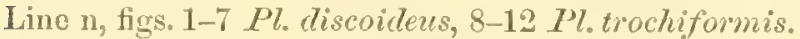

Line o, figs. 1-14 Pl. trochiformis (rotundatus young), 15-18 Pl.trochiformis.

Line $\mathrm{p}$, figs. 1-8 Pl. trochiformis (rotundatus young), 9-13 Pl.tenuis, 14-20 Pl.minutus.

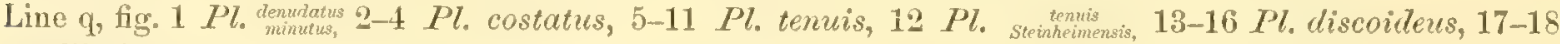
Pl. terochijormis

Line r, figs. 1-4 Pl. trochisomianis $5-10 P l$. trochiformis.

Line s, figs. 1-8 Pl. trochiformis, 9-12 Pl. trochiformis (var. pyrguliformis Sand.).

\section{Check List by Sections and Formations.}

\section{Formation a.}

Stratum a 3, Second Hole, Old Pit, Section 5.

Pl. Steinheimensis, var. aequirumbilicatus, line a, figs. 1-2.

Pl. Steinheimensis, line a, figs. 3-4.

I'. Steinheimensita, line a, figs: 7-8.

Pl. tenuis, line a, figs. 5-6, 9-12.

$P l$. discoideus, line a, fig. 13, b, 1-4.

\section{Formation d, Section 5.}

I'. cliscoideus, line b, figs. 5-6,16.

Pl. trochiformis, line b, figs. 7-10.

$1 ?$. minutus, line b, figs. 11-15.

Formation e, Section 6 .

I'. discoideres, line c, figs. 1-13.

$P$ l. trochiformis, line d, figs, 18-19.

I'. Kraussii, line d, figs. 1-17.

I'. minutus, line e, figs. 1-5, 7-8.

Pl. denutatus line e, figs. 10-12.

I'l. denudatus, line e, figs. 13-14.

I'l. costatres, line e, fig. 9.

I'l. costatus line e, fig. 6 .

Pl. minutus line e, figs. 15-17.

\section{Formation f, Section 6.}

Pl. Tŕraussie, line f, fig. 9.

I'l tenuis, line e, figs. 18-27, f, 1-8, 10-12.

$Y \%$. discoideus, line f, figs, 13-19.

$I$ '. minutus, line $\mathrm{g}$, figs. 1-2, 4 .

I'l. denudatus line g, fig. 6.

I'. denudatus, line $\mathrm{g}$, figs. 7-8.

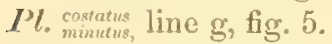

I'l. costatus, line g, fig. 3.

1?. triquetrus, line g, figs. 9-16. 
Formation h, Section 6 .

Pl. triquetrus, line g, figs. 17-23.

Pl. discoideus, line lu, figs. 1-18, i 1-14, k 1-2.

Pl. diseoiders (rotundatus-like young), line h, figs. 19-23.

I'l. cliscoideus (var. elatior Sund.), line i, figs. 15-17.

1'. trochiformis, line $\mathrm{k}$, figs. 3-11, 1 1-11.

\section{Formation i, Section 6.}

ग. discoidens, line m, figs. 3-4, 6-9.

Pl. $\begin{gathered}\text { tramhiomis } \\ \text { discoulcus, }\end{gathered}$

\section{Formation $\mathrm{k}$, Section 6.}

II. discoideres, line n, figs. 1-7.

Pl. trochiformis, line n, figs. 8-12, o 15-18.

P: trochiformis (rotundatus-like young), line o, figs. 1-14, 1, 1-8.

Pl. tenuis, line p, figs. 9-13.

\section{Formation 1, Section 6.}

Pl. minutus, line p, figs. 14-20.

Pl. denudatus line q, tig. 1.

Pl. denulatus, line $\mathrm{q}$, figs. 2-4.

$P l$. tenuis, line q, figs. 5-11.

Pl. Steinhuimensis, line q, fig. 12.

Pl. discoiders, line q, figs. 13-16.

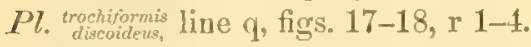

Pl. trochiformis, line r, figs. 5-10, s 1-8.

Pl. trochiformis (var. pyrguliformis Sand.), line s, figs. 9-12.

\section{Plate III.}

\section{Magnified 2 diameters.}

List of Species.

Pl. discoideus, line e, figs. 17-19, d 1-11, e 1-12, f 1-14, g 1-9, h 1-10, i 5-9, 1 15-17.

Pl. Thartitumis line i, fig. 1.

Pl. trochiformis, line a, figs. 16 , i $2-4, \mathrm{~m} 1$.

Pl. trochiformis var. elegans, line a, fig. 15.

7\%. minutus, line a, figs. 8-13, c 2-4, d 12-16.

Pl. costatus (var: major Hilg.), line b, fig. 15.

Pl. parvus, line a, figs. 6-7, 20-22.

Pl. minutus (parvus Irilg. pars.), line k, figs. 1-4, 11.

Pl. crescens, line a, figs. 1-5, 17-19, 23, b 16-17, c 9-16, i 10-14.

Pl. oxystomus (var. revertens Hilg.), line k, figs. 5-10, m 10-14, p 6-14.

Pl. oxystomus, line a, figs. 14, b 1-14, c 1, 5-8, k 12-18, 1 1-3, m 2-9, o 2. .

Pl. supremus, line 1, figs. 12-14, n 1-7, o 3-12, p 1-5.

Pl. oxystomus var. cochleatus, line 1, figs. 4-11.

Pl. supremus var. turritus, line n, figs. 8-13, o, 1 . 
Check 'List by Lines.

Line a, figs. 1-5 Pl. crescens, 6-7 Pl. parves, 8-13 $\mathrm{Pl}$. minutus, $14 \mathrm{Pl}$. oxystomus, $15 \mathrm{Pl}$. trochiformis var. elegans, $16 \mathrm{Pl}$. trochiformis, 17-19 Pl. crescens, $20-22 \mathrm{Pl}$. pareus, $23 \mathrm{ll}$. crescens.

Line b, figs. 1-14 $\mathrm{Pl}$. oxystomus, $15 \mathrm{l}$ 'l. costutus vir. major, 16-17 $\mathrm{Pl}$. crescens.

Line e, fig. $1 \mathrm{Pl}$. oxystomes, 2- $1 \mathrm{Pl}$. minutus, 5-8 Pl. oxystomus, 9-16 Plocrescens, 17-19 Pl.discoideus.

Line d, figs. 1-11 $1 \%$. discoideus, 12-16 $\mathrm{I}^{\prime} \mathrm{l}$. minutus.

Line e, figs. 1-12 Pl. discoideus.

Line f, figs. 1-14 $\mathrm{Pl}$. discoideus.

Line g, figs. 1-9 Pl. discoideus.

Line h, figs. 1-10 Pl. discoideus.

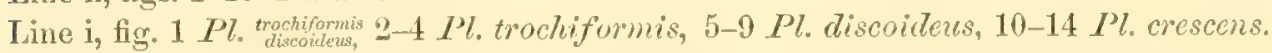

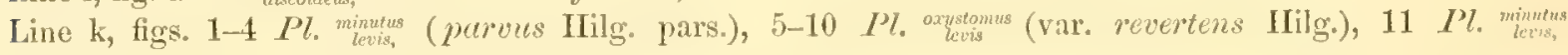
(parvus Hilg., pars.), 12-18 Pl. oxystomus.

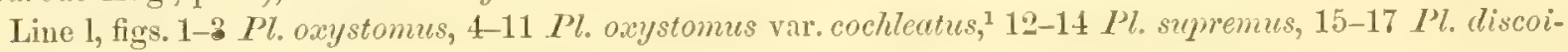
ders.

Line m, fig. $1 \mathrm{Pl}$. trochiformis, 2-9 $\mathrm{Pl}$. oxystomus, 10-14 I'l. oxpecomus

Line n, figs. 1-7 Pl. supremes, 8-13 $\mathrm{l} l$. supremus var. turritus.

Line o, fig. $1 \mathrm{Pl}$. supremus var. turritus, $2 \mathrm{Pl}$. oxystomus, 3-12 $\mathrm{Pl}$. supremus.

Line p, figs. 1-5 Pl. supremus, 6-1 1 l. oxpysomus

Crieck List by Sections and Formations.

New Pit, South side.

Formation f, Section 8 .

Pl. crescens, line a, figs. 1-3.

Formation h, Section 8.

Pl. parous, line a, figs. 6-7.

$P l$. crescens, line a, figs. $4-5$.

$P l$. oxystomus, line a, fig. 14.

Pl. minutus, line a, figs. 8-13.

Formation i, Section 8.

Pl. trochiformis var. elegans, line a, fig. 15.

$P l$. trochiformis, line a, fig. 16.

Pl. parvus, line a, figs. 20-22.

Pl. crescens, line a, figs. 17-19, 23.

$P$. oxystomus, line b, figs. 1-11.

Formation $\mathrm{k}$, Section 8 .

Pl. oxystomus, line b, figs. 12-14.

$P l$. crescens, line b, figs. 16-17.

$P l$. costatus var. major, line b, fig. 15 .

Formation 1, Section 8.

Pl. oxystomus, line c, fig. 1.

Pl. minutus, line c, figs. 2-4.

Formation m, Section 8.

Pl. oxystomus, line c, figs. 5-8.

Pl. crescens, line c, figs. 9-16.

1 This species is erroneously refurred to as var. rolundaliformis on p. 12 . 
Cloister Pit.

Formation k, Section 1.

Pl. minutus, line d, figs. 12-16.

Pl. discoideres, line e, figs. 17-19, d 1-11, e 1-12, f 1-14.

Formation 1, Section 1.

$P l$. mintus line $\mathrm{k}$, figs. $1-4,11$.

$P l$. crescens, line $\mathrm{i}$, figs. $10-14$.

$P l$ oxystomus line k, figs. 5-10.

Pl. oxystomus var. cochleatus, line 1, figs. 4-11.

$P^{\prime} l$. supremus, line 1, figs. 12-14.

Pl. discoideus, line g, figs. 1-9, h 1-10, i 5-9.

$P l$. trochiformis line i, fig 1 .

Pl. trochiformis, line i, figs. 2-4.

$P l$ oxystomus, line l, figs. 1-3.

Formation m, Section 1.

$P l$. oxysetomus line $\mathrm{m}$, figs. $10-14, \mathrm{p}$ 6-14.

$P l$. oxystomus, line $\mathrm{m}$, figs. 2-9, o 2 .

Pl. supremus, line $\mathrm{n}$, figs. 1-7, o $3-12, \mathrm{p} 1-5$.

$P l$ supremus var. turritus, line $\mathrm{n}$, figs. $8-13$, o 1 .

Pl. discoiders, line 1, figs. 15-17.

Pl. trochiformis, line m, fig. 1.

\section{Plate IV.}

Magnified 8 diameters.

Line a, figs. 1-7 Pl. minutus.

Line b, figs. 1-1 $P$. minutus, 5-6, $9 \mathrm{Pl}$. triquetrus var. turbinatus, 7-8 Pl. trimuetrus

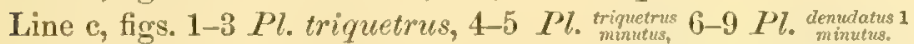

Line d, figs. 1-5 Pl. denudatus ancoiled in varions degrees, $6-10$ same, but more turbinate.

Line e, figs. 1-5 $\mathrm{Pl}$. denudatus, uncoiling excessive, but turbination slighter than in 6-8; 9 broken adult, whorl of, 10, the young of the same shell perfectly flat and in part closely coiled, 11, young stage of another broken out. This, though not a distinct figure shows that the coiling is in the same plane in the young.

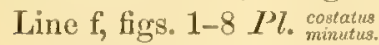

Line g, fig. 1, Pl. costatus, $2 \mathrm{Pl}$. costatus var. distortus, 3-10 Pl. costatus.

Line h, figs. 1-7 Pl. costatus ( $\mathrm{Pl}$. costatus var, major of Hilg.), var, acuto-costatus.

Line i, figs. 1-5 Pl. costatus var. platystomus, 6-12 Pl. costatus (= major IIilg. pars.), var.obtuso-costatus, much distorted.

Line k, figs. 1-7 Pl costatus var, obtuso-costatus (=Pl. major Hilg. pars.), 8 Pl. $\begin{gathered}\text { costatus } \\ \text { minutus. }\end{gathered}$

\section{Plate V.}

Magnified $5 \frac{1}{3}$ diameters.

Line a, figs. 1-4, Pl. levis from Undorf.

Line b, figs. 1-7, $P l$. parvus.

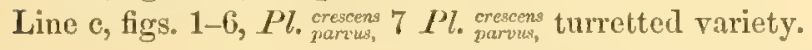

1 The different forms of $P l$. denulatus, $P l$. costalus var. distortus and $P l$. costatus var. platystomus would probably have been more clearly understood if I had given them separate specific names and called them respectively $P$. denu- datus, $P$ l. distortus, and $P l$.platystomus, but having neglected doing this, and even in one place on page 10, spoken of $\mathrm{Pl}$. denudalus, as variety denudalus, $I$ thought it best to make no alterations in the nomenclature used in the text, $\mathrm{p} 65$. 
Line d, figs 1-7 Plocrescens. Fig. I line d shows a specinen of the young, which at a very early age begins to show the compressed form of the whorl, which distinguishes the adult of $P l$. crescens. In fact the three young specimens on this line form a series in this respect, fig. 2 being the most compressed, fig. 6 next, and fig. 4 the least, althongh figs. 2 and 4 are of the same age and fig. 6 a little older. 'The adults of all of the three would have been about equally compressed in form.

\section{Plate VI.}

Mingnified $5 \% \frac{1}{2}$ diameters.

Line a, figs. 1-3 Pl. levis from Undorf, 4-7 Pl. oxysetomus (= revertens Hilg.).

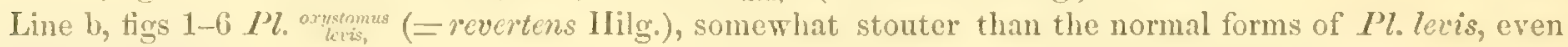
in the young, firg. 5 .

Line e, figs. 1-5 Pl. oxystomus with extremely stout whorls even in the young. In this variety the young are very similar to the rotundatus-like young of Pl. trochiformis, see pl. 2, line o, figs. 1-14, line p, figs. 1-8. 'I'hey, however, are distinct in the aspect of the upper umbilicus, in the carinations and shell, and outline of the opening of the whorl, especially in the younger stages. Compare also figures on lines o and p, pl. 3 , with figures of young of $P l$. oxystomes var. cochleutus, 1 l. 3, line 1, figs. 4-11, which also have extremely stont whorls in the young. Fig. 6 is a fine specimen of the transition from the normal variety to the turretted form, variety cochleatus of $I^{\prime} l$ oxystomus. ${ }^{1}$

Line d, fig. $1 \mathrm{Pl}$. axystomes var. cochleatus, full grown shell, ${ }^{2}$ figs. 2-1 Pl. oxystomes, normal variety, showing the identity of a young shell, fig. $t$, with a shell of the same size of Pl.levis, from Undorf.

Line e, fig. $1 \mathrm{Pl}$. supremus var. turvitus, figs. 2-4 Pl. supremus.

\section{Plate VII. ${ }^{3}$}

Magnified 4 diameters.

Line a, figs. 1-2 Pl. levis, Undorf. Figs. 3-5 are deeply umbilicated forms of Pl. Steinheimensis which are similar to fig. $1 \mathrm{in}$ this respect and in the form of the whorls. Fig. 6, Il. levis, Undorf, to compare with figs. 7-9 $\mathrm{Pl}$. Steinheimensis, adult and young with a similar form of whorl. Fig. 10 an unusually turbinate form of $I \%$. tenuis.

Line 1, figs. 1-2 $1 \%$. Steinheimensis for comparison with figs. 3-4 Pl. levis, Undorf. Fig. 5 Pl. Steinheim. ensis with sub-angular onter whorl for comparison with fig. 6 Pl. levis, Undorf. Figs. 7, 8 I'l: Steinheimensis, younger stages of same varicty as fig. 5 .

Line c, figs. 1-3 $P$ l. Steinteimensis with very slight unsymmetrical and cylindrical whorls, figs. $4,5 \mathrm{Pl}$. Steinheimensis normal variety (see specimens) with eylindrical whorls, figs. 6, 7, normal variety with unsymmetrical whorls and a deeper, narrower umbilicus on the lower side than in the preceding. Fig. $8 \mathrm{Pl}$. Stein heimensis var. aeruiumbilicatus?

Line d, figs. 1-6 specimens of $P \%$. Steinheimensis with stouter whorls transitional to those of line e. Fig. $7 \mathrm{l}$. temeis, from the rocks of the Uper Tier of the Cloister Ridge. 'This has young like the adult of $P$. Steinkeimensis.

Line e, fig. $1 \mathrm{Pl}$. Steinheimensis with an extremely turbinate tendency expressed in the last whorl. Figs.

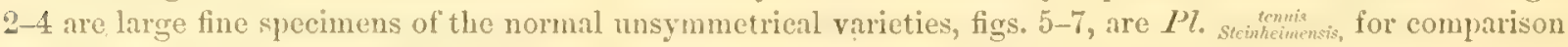
with these and others below, for example compare the umbilicus of fig. 7 , with fig. 6 , line $c$.

Line f, figs. 1-3 Pl. steinheimensis, somewhat more advaneed stage of transition, figs. $1-7 \mathrm{Pl}$. tenuis.

Line $g, P$. Zenuis.

Line $h, P l$. discoideus, figs. 1-4 flatter variety with acute carinations, figs. 5-7 stouter varieties with generally less acute caxinations.

Line $\mathrm{i}, 2 l$. discoideus with rotundatus-like young, showing transitions to the varieties of $P l$. trochiformis having similar young.

${ }^{2}$ See in this connection remarks on page 70.

2 This shell has a much shallower umbilicus than the one

figured on pl. 9, fig. 11, and deseribed on p. 12.

3 See for discussion of figures on this plate, p. 83. 


\title{
Plate VIII.
}

\author{
Magnified 4 diameters.
}

Line a, fig. $1 \mathrm{Ml}$. Stcinheimensis, same as fig. 13, line h, pl. 1, an aged specimen of extraordinary size, showing the deflection and contraction of the last formed or oldest part of the outer whorl; fig. $2 \mathrm{Pl}$. Steinheimensis, also very large and beginning to show senile changes, same as fig. 18 , line f, pl. 1. Figs. $3-5 \mathrm{Pl}$. oxystomes; fig. 3 has the spiral deflected as the result of a wound, possibly also in part as the result of old age; figs. $1-5$ are probably both distorted solely by senile or geratologous metamorphoses.

Line b, figs. 1-6) $P l_{0}{ }^{\circ \text { orystomus }}$ (=revertens, Hilg.); figs. 1 and 6 are normal forms with spiral deflection probably due to old age; fig. 2 shows a cicatrix which has produced a precisely similar effect upon the size and direction of the last part of the last whorl ; fig. 3, probably distorted from some normal disease or old age; figs. 4,5 are undoubtedly weak or disensed specimens in which the spiral is very greatly deflected as in $P l$. demudetur.: ${ }^{1}$

Line c, figs. 1-6 $P l$. minutus lems, These specimens are all distorted apparently from the results of wounds or injuries received during the building of the last whorl.

Line d, figs. 1-1 $P l$. supremus; all are more or less deflected, and the striae enlarged as the result of geratologous changes. ${ }^{2}$

Line e, figs. 1-3 I'l.trochiformis, fig. 1 shows a deflected spiral probably due to disease. Fig. 2 is a front view of fig. 10, line $1, \mathrm{pl} .2$. The distortion or deflection of the whorl is evidently caused by the age and perhaps also, diseased condition of the specimen, as may be seen from the enlarged striae and thickened shell. Fig. 3 is distorted on account of a severe wound. ${ }^{8}$

\section{Plate IX.}

Magnified 4 diameters.

Figs. 1-7 Fourth Series showing transformations from Pl. levis var. Steinheinensis Undorf, fig. 1(= fig. 1, line a, 1). 7), to I'l. trochiformis fig. 7. Fig. $2 \mathrm{Pl}$. Steinheimensis, $3 \mathrm{Pl}$. Steinheinensis, $4 \mathrm{Pl}$. tenuis, $5 \mathrm{Pl}$. discoideus, 6 Pl. trochiornis

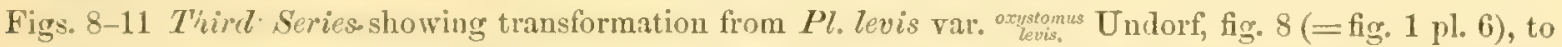
Pl. supremus var. turritus, fig. 11. Fig. 9 though spoken of in the text p. 10 and elsewhere as $P$. oxystomus, is really a specimen of revertens Hilg. $=P l$. oxystomus out of the Sand Pits, Steinheim, and onght to have been supplemented by a figure of true $P l$. oxystomus such as fig. 1 , line $c, 1 l .6$, but this plate was already finished before I became aware of the need of another figure. Fig. 10, Pl. supremus, is the flat and sulented variety of this species.

Figs. 12-15 Second Series showing transformations from Pl. levis var. prarvus Undorf, fig. 12 (= fig. 1 pl. 5 ), to $P l$. crescens, trochiform varicty, fig. 15 .

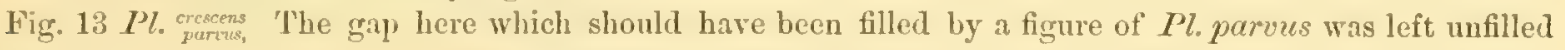
purposely on account of the number of figures necessary, see pl. 5, lines b, c. Fig. 14, Pl. crescens, normal variety.

Figs. 16-28 First Series, figs. 16-20, third sub-series includes $1 \%$. levis var. minutus Undorf, fig. 16 (= fig. 2, line a, pl. 7), $1 \%$. minutus fig. 17 , also $P l$. minutus, fig. 18, which has cylindrical whorls showing one of the transition forms from $P l$, minutus to the normal $P l$. minutus, fig. 21 at the base of the next sub-scries, ${ }^{4}$ also fig. 19 , true $P l$. triquetrus, and fig. $20, P l$. triquetrus var. turbinatus.

Figs. 21-24, second sub-series includes $P l$. minutus, fig. 21, normal smooth form, which leads into $P l$. denulatus
ninutus, and described in the text on pages 59 to 66 .

\footnotetext{
${ }^{1}$ See also deseription on p. 13, of other forms, and discussion on pp. 15,17 .

${ }^{2}$ Compare, also, pl. 3, figs. 1-2, line n, 5, 6, line g, 4, line h; pl, 2. figs. 2,3 , line $h$, fig. 6 , line i.
}

\footnotetext{
${ }^{3}$ Compare, also, fig. 11 , line s, pl. 2.

4 'The transition forms from $\mathrm{Pl}$. minutus to $\mathrm{Pl}$. triquetrus are photographed on Pl. 4.
} 
Figs. 25-28, first sub-series includes as previously mentioned p. 65, two sub-series, the acuto-costate and the obtuso-costate, but as they are both exactly parallel in the production of the distorted varieties, platystomus and distortus, it was not considered necessary to go to the expense of making up and photographing another plate. Fig. $25 \mathrm{Pl}$. conetus finutus, fig. $26 \mathrm{Pl}$. costatus, the costae are coarser in these figures than in the specimens and so also are those of $I^{\prime} l$. costatus var. distortus, figs. 27,28 , but they show accurately the forms of this subseries.

NoтE. These plates are described in the text as having been photographed by Sonrel and Black, but the negatives prepared by them could not be used by the Heliotype Company, and the whole were successfully rephotographed by the latter. 


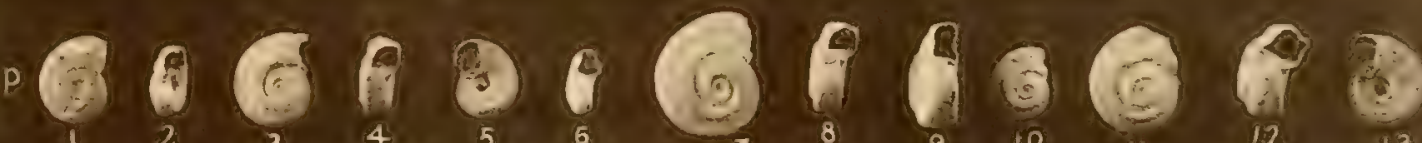

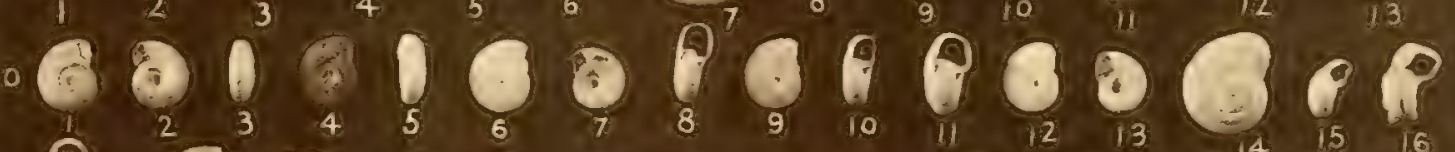

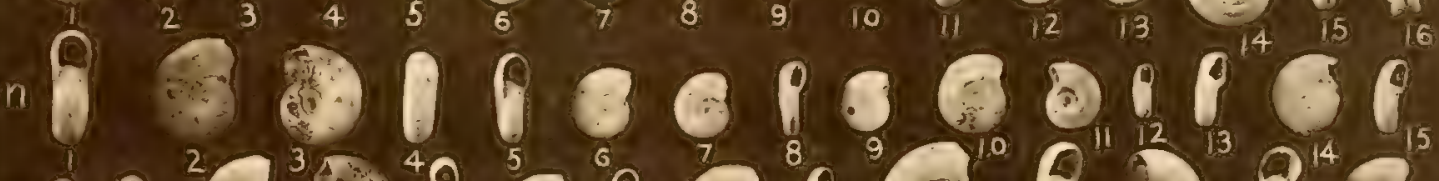

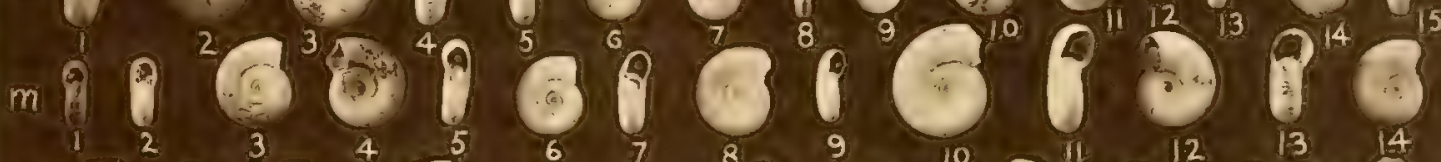
- 0 O $0.090^{\circ} \circ$ - $0000 \% 0<10$ (4)

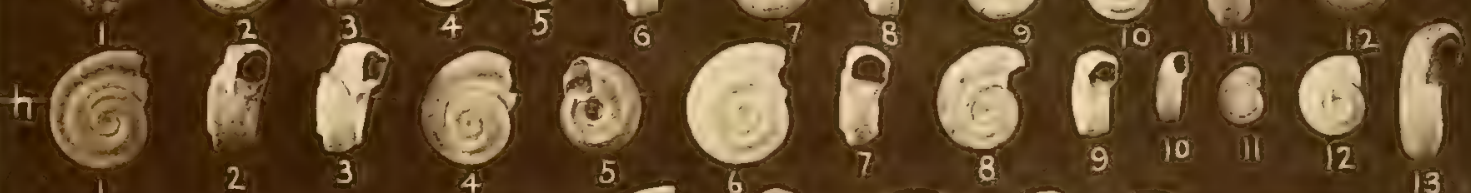

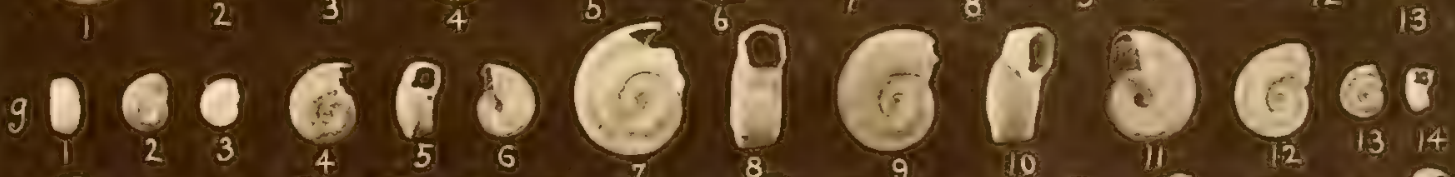

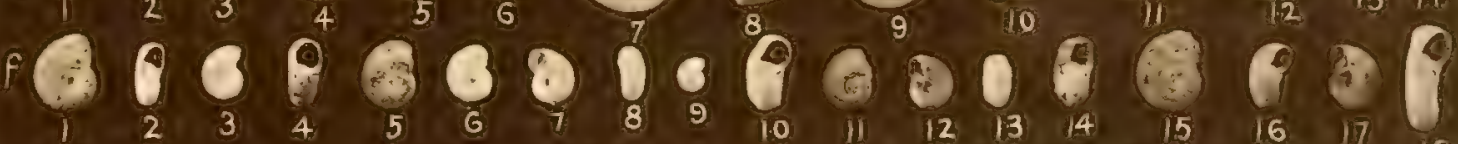

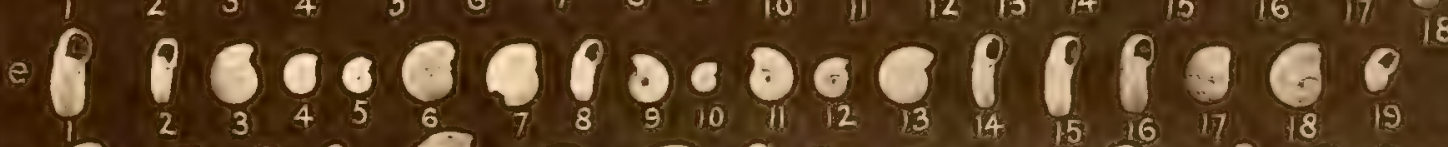

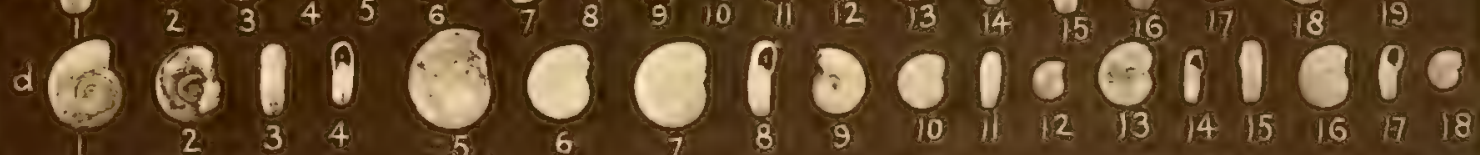
- O O OPOQ O OP P O

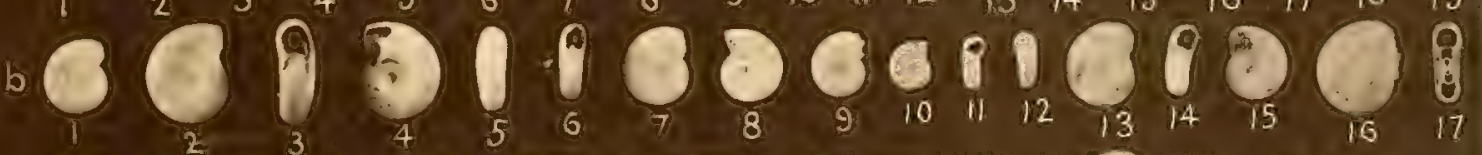

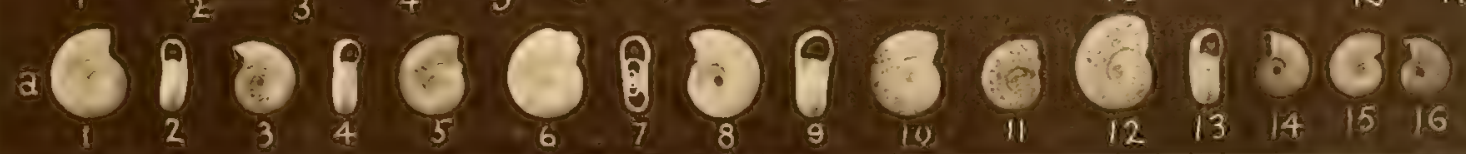



$\triangle 000: 00,90^{\circ}$

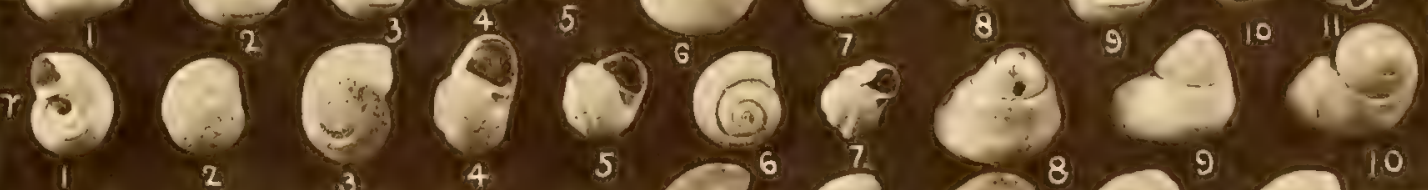

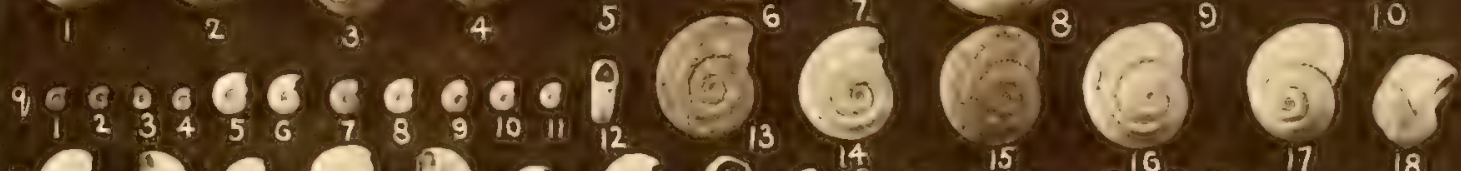

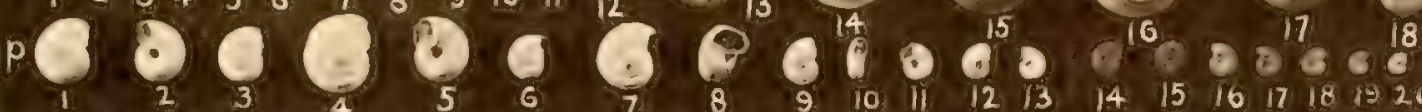

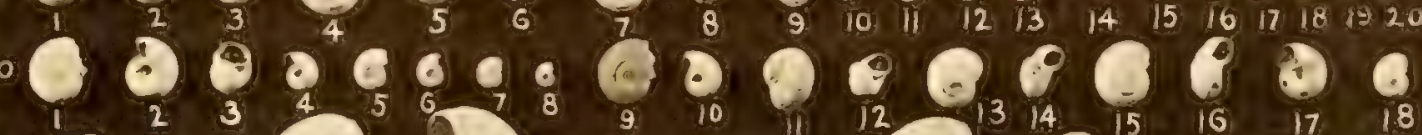

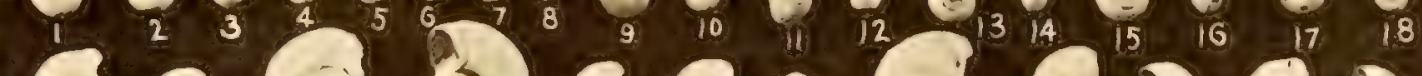

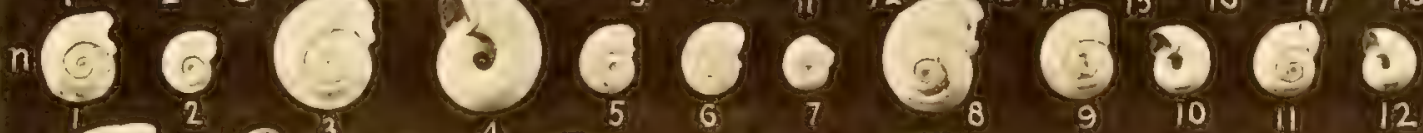
$90^{3} 0^{4} \bigcirc 009$

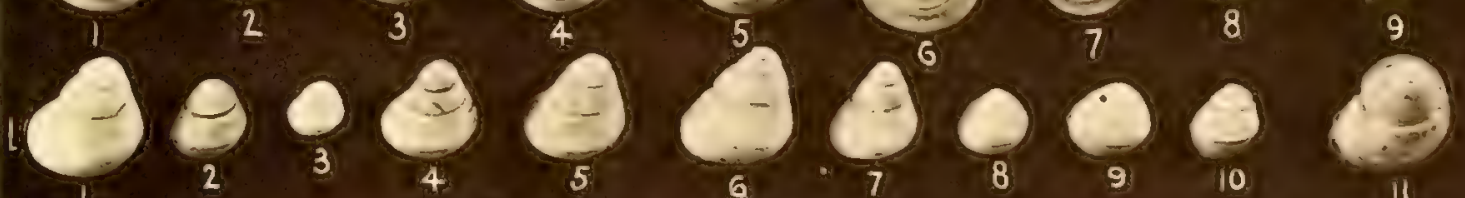

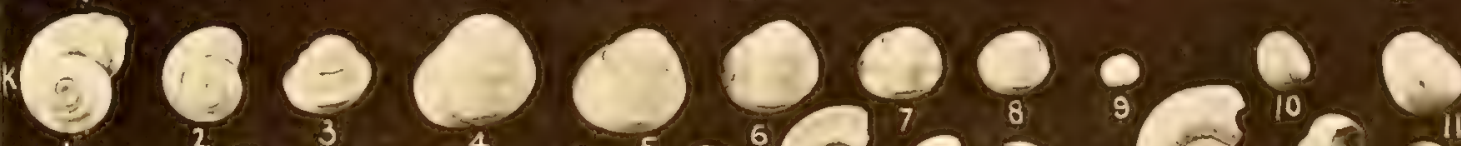

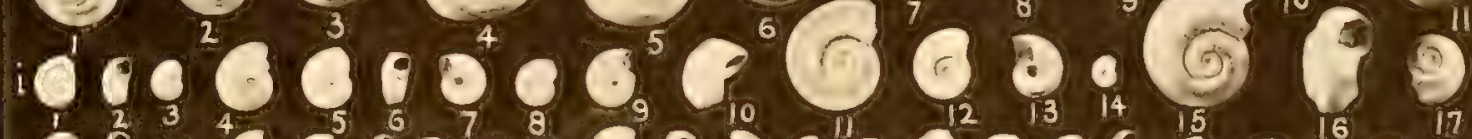

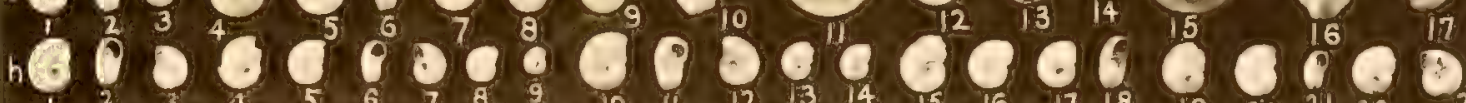

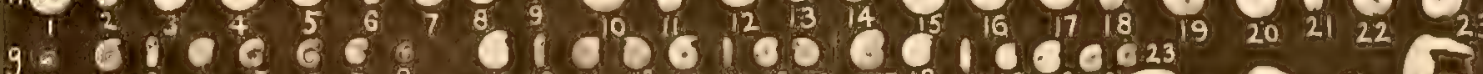

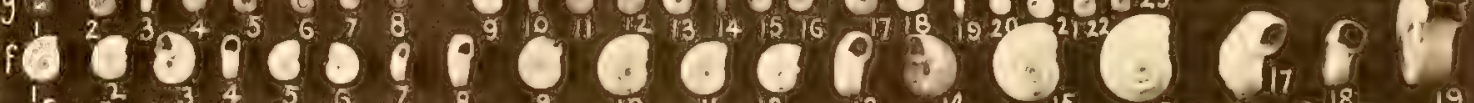

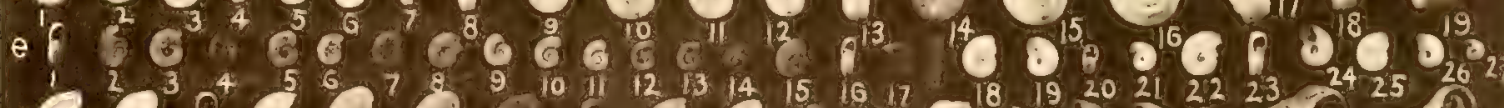

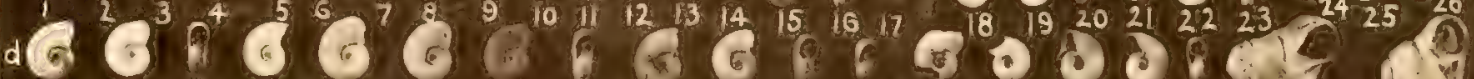
$\begin{array}{lllllllllllllllllllll} & 2 & 3 & 4 & 5 & 6 & 7 & 8 & 9 & 10 & 11 & 12 & 13 & 14 & 15 & 16 & 17 & 7 & 4\end{array}$

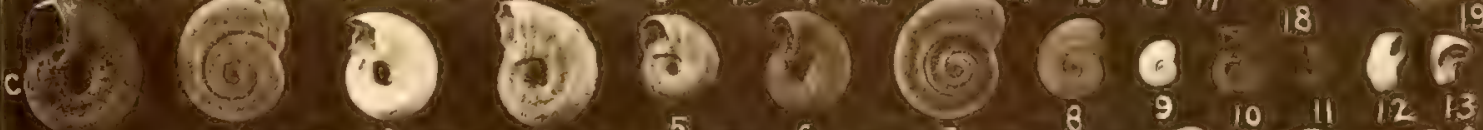

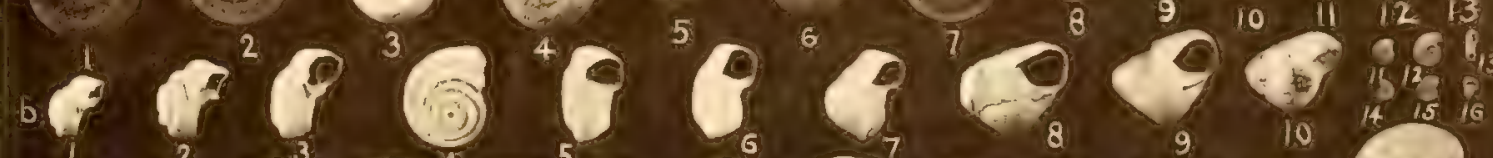
$60^{2} 00.00 .00000$ 

6606810698\%

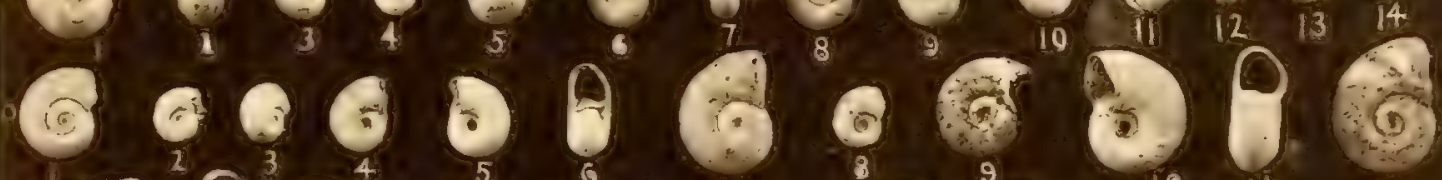
$\left.66^{3} \mathrm{c}\right)$ - 6 6 $930 \%$

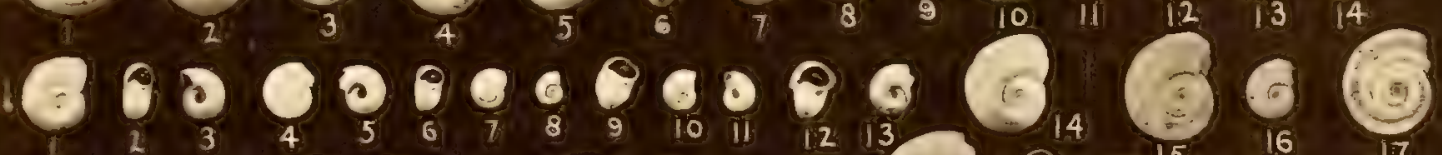
$00000810 \%$ Q $600 \%$

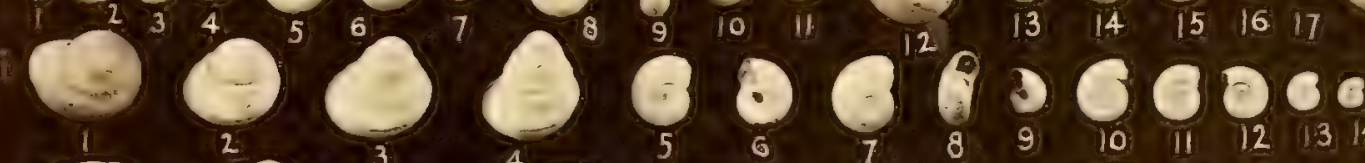

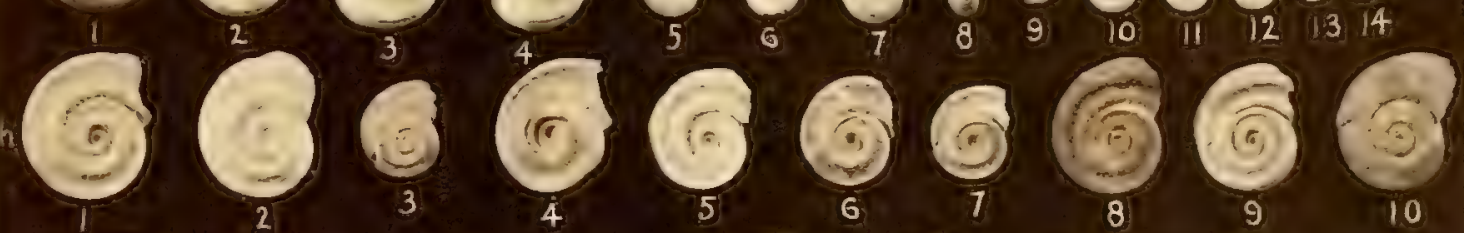
(6)6응 (응 00000900600

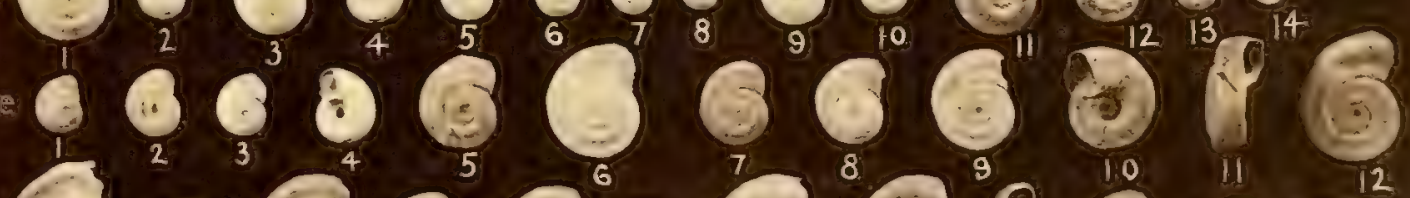
(6) 0 (6) $60 \% 6 \%$

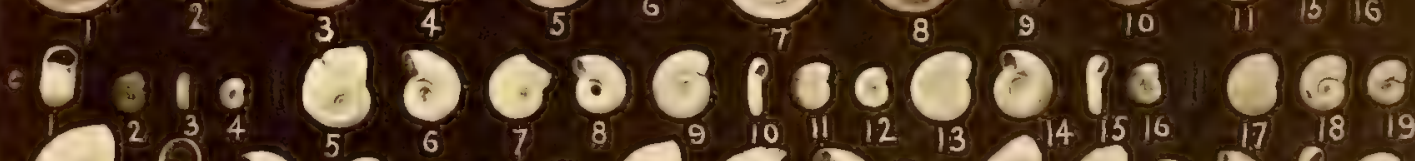

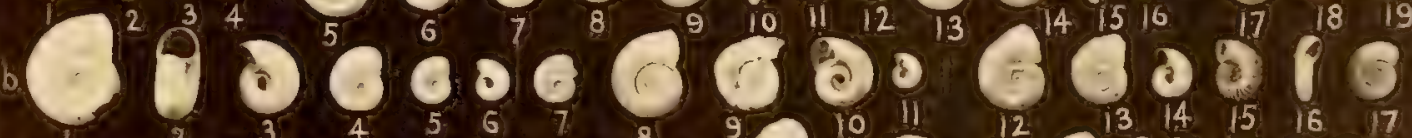

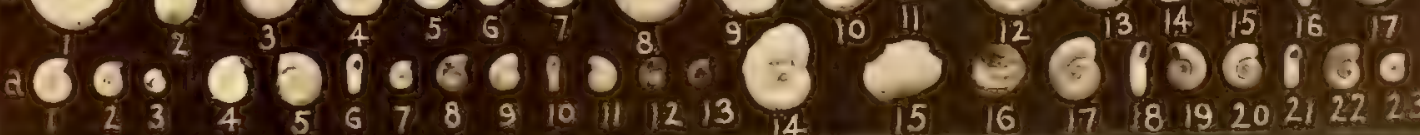





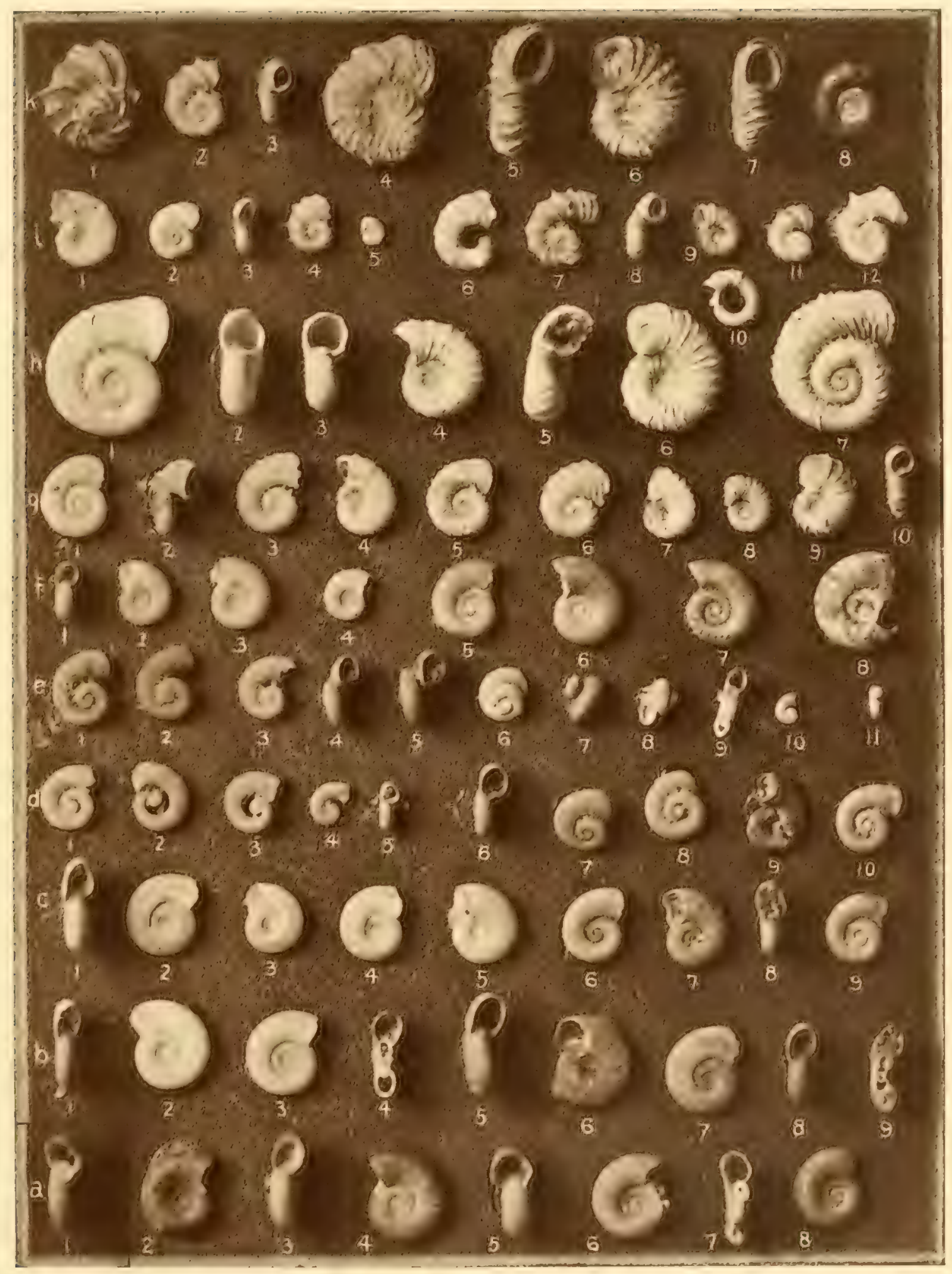





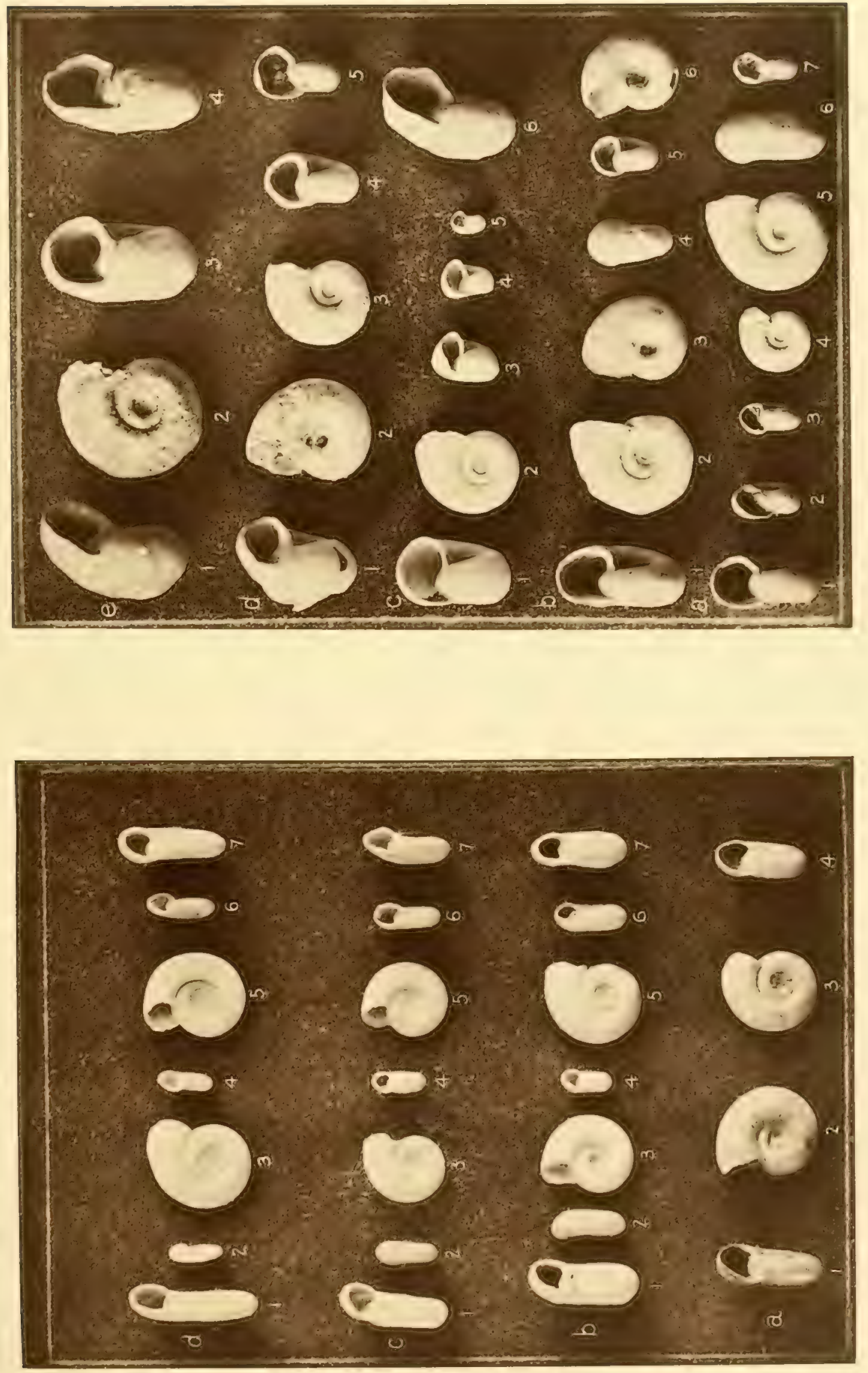





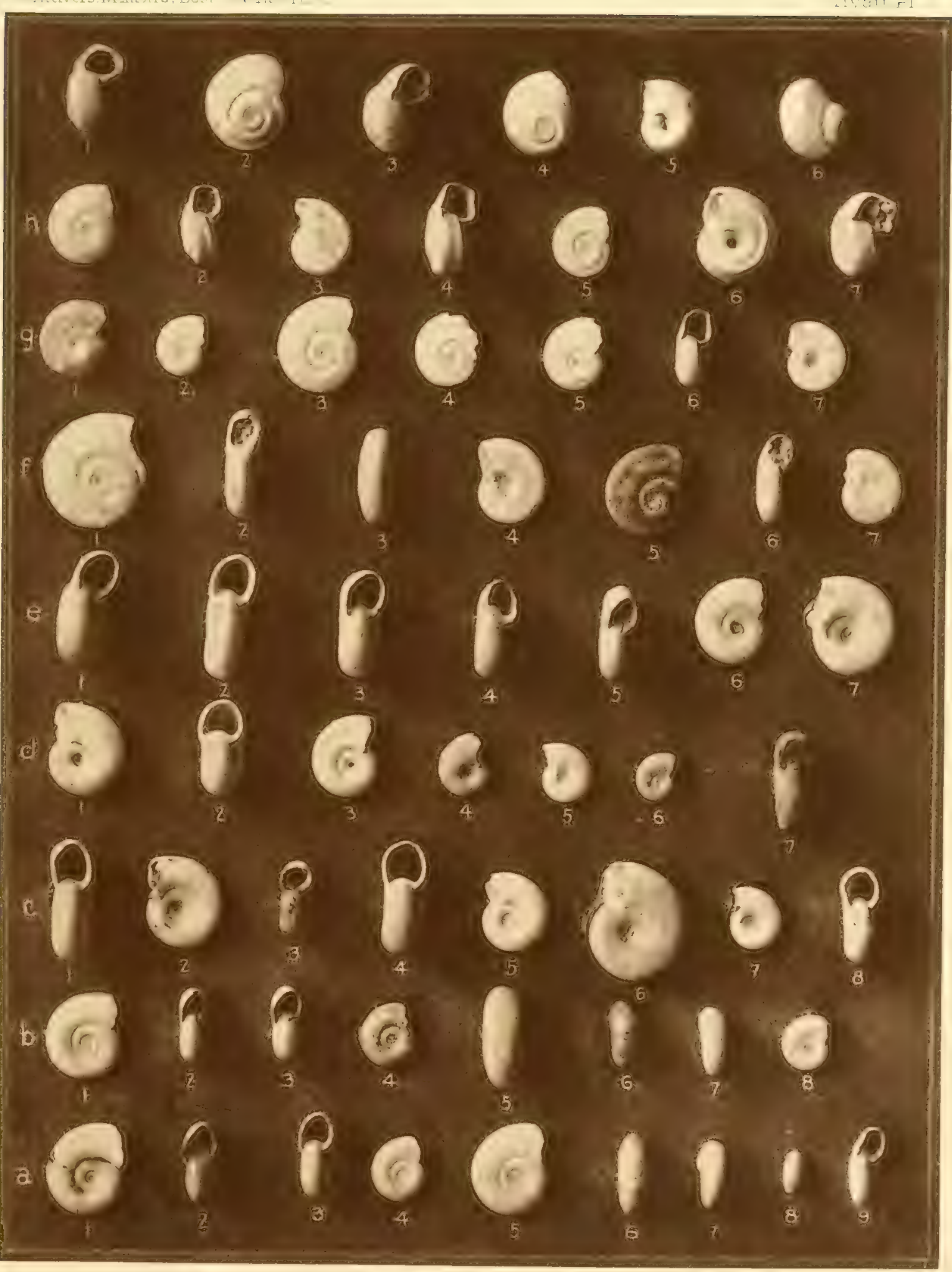





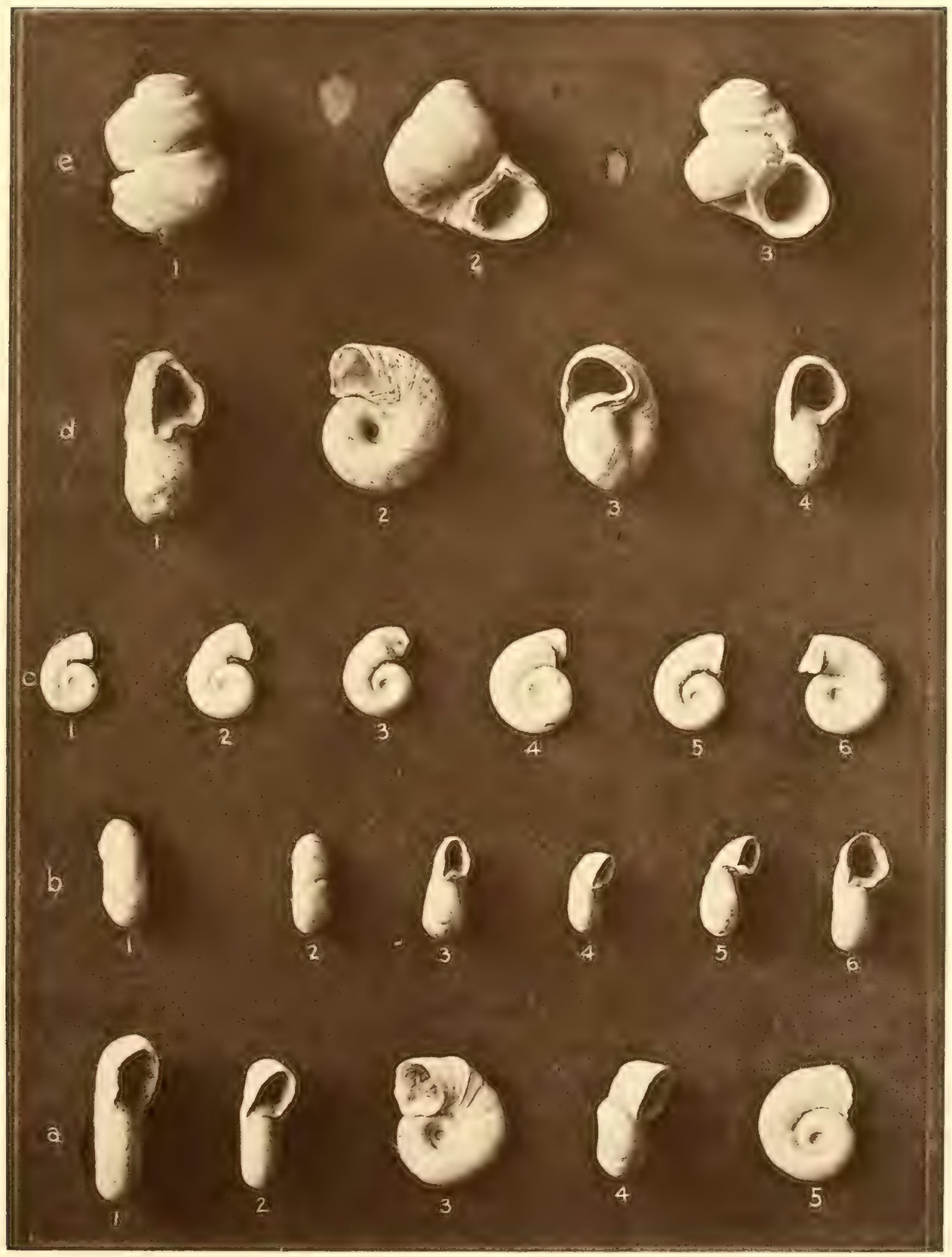





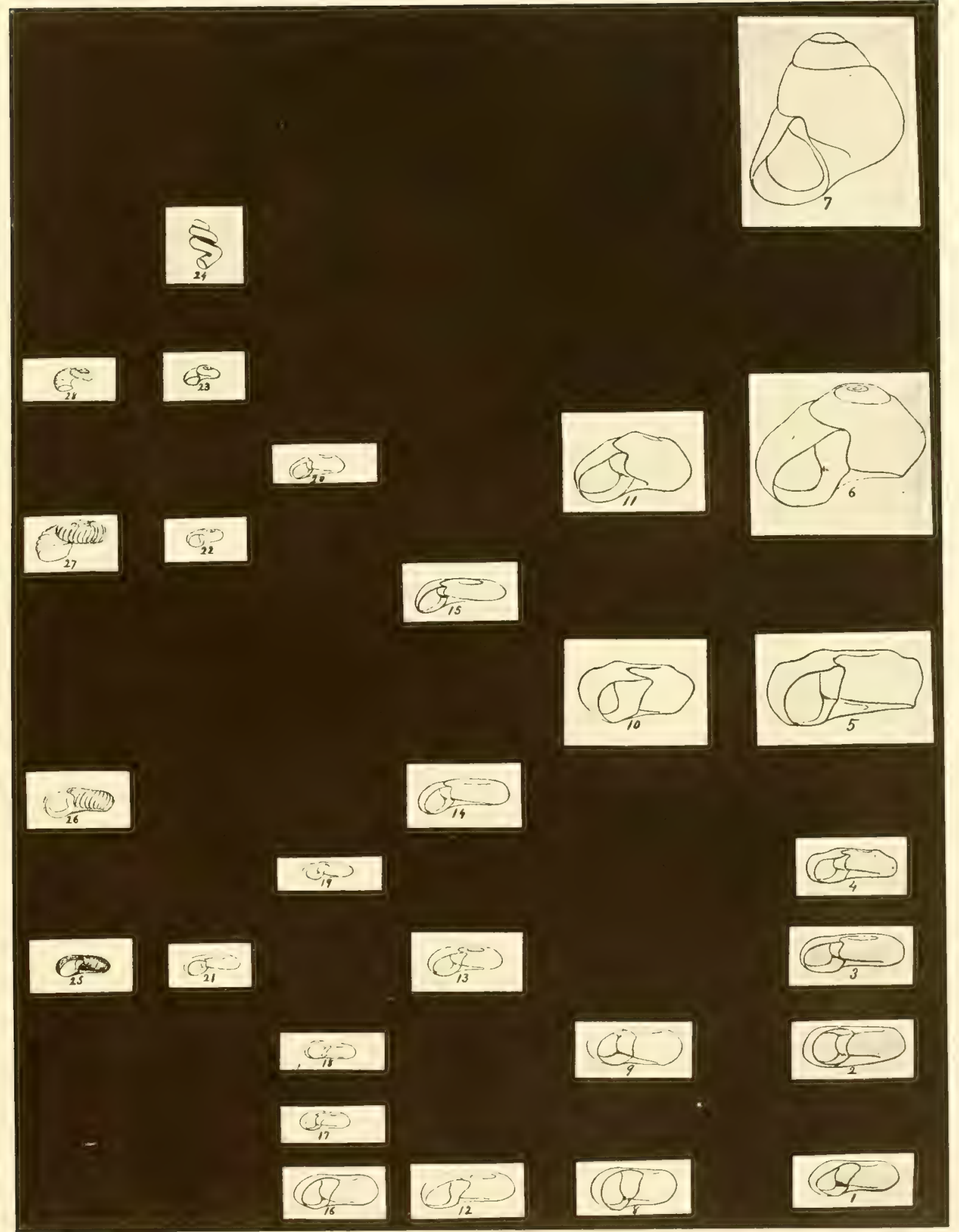



1830. ANNIVERSARY JEMIOTS OF TIIF BOSTON SOCIETY OF NATURAL IIISTORY.

1850.

\section{TIIE DETONIAN INSECTS OF NEIT BRUNSWICK.}

BY SAMUEL H. SCUDDER.

BOSTON :

PUBLISHED BY THE SOCIETY.

1880. 


\title{
The Devoninn Insects of New Brusnimick.
}

\author{
By Samuel H. Scudder.
}

CONTENTS.

\author{
I. Introduction. \\ II. 'The structure of the wings in Ephemeridae; \\ with a note on a jurassic may-1ly. \\ III. Platephemera antiqua. \\ IV. Gerephemera simplex. \\ V. Homothetus fossilis. \\ VI, Dyscritus retustus. \\ VII. Lithentomum Hartii.
}

VIII. Xenoneura antiquorum.

IX. General summary.

X. Note on the geologicnl relations of the fossil insects from the devonian of New Brunswick. By Principal J. W. DAwson, LL.D., F. R. S., etc.

XI. Explanation of the plate.

\section{Introduction.}

INVESTIGATION of fossil remains of the oldest insects is nearly always extremely difficult and perplexing, and often very unsatisfactory in its results. The interest, however, necessarily attaching to the begimnings, of life, warrants any labor that may be expended upon them. Especially is this true of the fragments treated of in this paper, because they are as yet the only insect remains which have been found in rocks older than the carboniferous formation in any part of the world. The writer may be pardoned for adding that they possess a special attraction for him, as among the specimens which first directed his particular attention to fossil insects, and he only regrets that so long a period as fifteen years should have elapsed before their full discussion.

The remains consist entirely of broken wings, and were discovered in 1862, by the late Professor C. F. Hartt (at the time of his death director of the geological survey of Brazil), while searching for plant remains in the devonian shales near St. John, New Brunswick. The locality - called Fern Ledges by Mr. Hartt, from the abundance of plant remains which occur in the black shales that are interstratified with the prevailing sandstones - is about a mile west of the town of Carleton, not far from St. John. The rocks form a series of ledges, exposed on the sea-shore between high and low water marks. The beds of sandstone and shale, of which they are composed, have a seaward dip of about $45^{\circ}$, and a strike of about W. $10^{\circ} \mathrm{N}$., corresponding very nearly to the trend of the shore. The fossiliferous shales between the enclosing sandstones are worn away by the action of the water, leaving the fossils accessible in only a few places. The whole deposit is of very limited extent; it reaches along the shore for about three hundred and twenty-five paces, exposing a thickness of strata of about forty-five meters, with a width of about ninety meters. 
The specimens discovered were six in number, some of them with their reverses. They are now in the museums of the natural history societies of St. John, N. B. and Boston, Mass. I am much indehted to Mr. G. F. Matthew, of the former institution, and to Professor A. IIyatt of the latter, for the opportunity of studying these specimens anew at my leisure.

The plan of the present paper will be seen by a glance at the table above. As the simpler devonian insects, first described, have certain special relations with the Ephemeridae, their description is preceded by an account of the wing structure of the modern May-flies, as a basis of comparison; each of the devonian species is then separately describerl, and its affinities discussed, and the whole is followed by a general summary. The stratigraphical question being, in this instance, of epecial importance, Principal Dawson has kindly prepared for me a statement of the case with which the article closes. ${ }^{1}$

\section{The Structure of tile tVings in Ephemeridae; with $\Lambda$ note oN $\Lambda$ Jurassic SPECIES.}

The following statement considers mainly the direction and division of each of the principal veins, and the comparative areas covered by them.

The marginal vein forms the costal border. The mediastinal vein is absent or, perhaps, amalgamated with the scapular in Lachlania, Oligoneuria and Tricorythus; in all others it is simple, and extends to, or almost to, the tip of the wing, keeping at a very short and nearly uniform distance from the margin, with which it is generally connected, especially on the apical half of the wing, by frequent cross veins. On the basal half, the cross veins may be as abundant as apically, but they are generally rarer, and may be entirely absent, even when frequent apically; or they may be absent throughout. In very rare instances, as in Coloburus, an intercalary vein may be found in the apical half of the wing between this vein and the costal margin.

The scapular vein is simple, and reaches the tip of the wing, excepting in the three genera mentioned above, where it may perhaps be said to be amalgamated with the mediastinal, as shown by its forking near the middle of the wing in Tricorythus; in Lachlania, however, it terminates not at the tip, which possesses only the marginal vein, but near the middle of the costal border. It is always connected with the vein below by a greater or less number of, usually many, cross veins.

The externomedian vein is always compound, and always covers at least half, usually much the greater part of the wing. It always divides at the very base, and the upper branch is alway's forked, while the lower may, although rarely, remain single, and is usually forked to a less extent than the upper branch. Three is, therefore, the smallest number of nervules which may reach the margin in the area covered by

\footnotetext{
1 Besides the references given in the bibliography under each species, notices of the devonian insects will be found in the following places: Hart, on the Devonian plantlocality of the Fern Leldges, Lancaster, N. B., in Bailey's Observations on the Geology of Southern New Brunswick, pp. 131-40. 8vo., Fredericton, 1865; reprinted in substance, in
}

Dawson's Acadian Geology, 2d ed., pp. 513-23. 8vo. London, 1868. Darwin, Descent of man, I, 360. 12mo., London, 1871. Stett. Ent. Zeit, xxviI, 145-53, passim. Trans. Entom. Soc. Lond, 1871, 38-40. American Nituralist I, 445, 62526. Proc. Boston Soc. Nat. Hist., X, 96, XI, 150-51. Memoirs Boston Soc. Nat. Hist. III, 13-21, passim. 
the vein, and this number we find in Oligoneuria and, perhaps, in Lachlania. The portion of the area of this vein covered by the upper branch and its forks is almost always greater, generally considerably greater, than that covered by the lower branch; an exception to this will be found in Polymitarcys where the lower area is greater, owing to unusual breadth of wing combined with narrowness of the area covered by the intermedian vein, which has been crowded out of much of its natural ground by this lower branch. Some of the allies of Polymitarcys, especially "Asthenopus and Pentagenia, also have this area of the lower branch larger than usual, although not larger than that of the upper branch, and some other genera not placed near it exhibit a similar propensity; but as a general thing, the area covered by the lower is scarcely more than half as large as that covered by the upper branch, and not infrequently it is less than one third its extent. The upper branch usually forks close to the base, occasionally at the very base, and sometimes the upper of the forks is amalgamated at the base with the scapular vein, as in Asthenopus, Tricorythus and Chloeon, and to a certain extent in Coenis, so as to give it the appearance of originating from that vein, and of complete independence of the externomedian; whether thus severed from its comnections, or plainly arising from the externomedian root, this upper fork of the upper branch runs in proximity to the scapular vein, parallel or subparallel to it, and, excepting where the venation is occasionally simple (as in Olicroneuria, Sc.), always emits from its lower surface in the central portion of the wing one, two, or three nervules; the first and second of these nervules are usually pretty near together at base, but all grenerally reach the border at unequal distances apart, the inequality being made good by intercalary longitudinal nervules; these intercalary nervules often curve at their inner extremities toward or to one or another of the adjoining nervules, assuming then the appearance of regular branches, while the nervules proper are themselves oftener detached from their base; so that it is sometimes difficult to tell whether a given vein should be considered normal or intercalary. The lower fork of the upper branch is occasionally simple, as in the Tricorythus, but usmally fork once at about the middle of its course, rarely near the base, and very frequently encloses an intercalary nervule between these branches, but no intercalary nervules (excepting such as often break up the extreme margin into an irregular meshwork of veins) ever intervene between the upper nervule of this fork and the lower nervule of the upper fork, nor between its lower nervule and the upper nervule of the lower branch of the externomedian vein, excepting in the rare instances where this lower nervule is detached from its base, and takes on the form of an intercalary nervule.

This lower branch, as has been said, is usually forked to a less extent than the upper branch, but a conspicuous exception is found in Polymitarcys where the branch is nade up of a large number of sub-convergent simple rays, directed from the outer margin toward various parts of the upper internomedian nervule, but generally lost before reaching it. In general. however, its area is only about half that of the upper branch ; it usually forls close to the base, and each or either of its branches may a gain subdivide once; all other nervules in the area are sure to be intercalary; where it forks only once there is usually a single intercalary nervure midway between the branches, which seems to belong to one or the other of them and to represent its fork; while between it and either branch there 
may be other shorter intercalaries; the only exception to this greneral statement is the case of Polynitareys already cited, where after division at the base the uper fork must be looked upon as breaking up at once into three rays, while the lower severed from its connections breaks up similarly into a couple of forked rays; the amount of abnormal divergence in this case ma he better seen, by stating that it is the only genus of Ephemeride in which this area is carried aromel the lower outer angle of the wing; in all others it stops short of, usually far short of this angle; here it reaches around it half way along the anal margin. The genus agrees, however, with all the others in that all the branching occurs in the basal half of the area. In Oligoneuria and Lachlania the branch is simple and undivided, unless the apparent branch in the latter should be looked upon as such, and not as a cross nervure, like the more directly transverse veins above it.

The area of the internomedian vein is never great, although always more extensive than that of any other vein but the externomedian, and it always includes the lower outer angle of the wing, excepting as above specified in Polymitareys, and excepting also in the full-angled Tricorythus, where the anal area disputes its sway. Its construetion is grenerally similar to that of the lower branch of the extermomedian vein, although from the form of the area covered by it, its absolute appearance is very different; moreover, one rarely finds in it any intercalary nervures, excepting such as sometimes line the extreme border, the smaller nervures almost always originating from the main stems; the exceptions are found in Leptophlebia, Cloeon, and Baetis. The vein alnost invariably forks at its extreme base, and from the upper of these branches sends either, rarely, a single shoot, or, much more fierquently, a half a dozen, occasionally a dozen simple or forked shoots to the margin. In the interesting fossil described in the note at the end of this section these shoots appear to originate from the lower branch, the upper remaining simple, just as rarely occurs in living forms as $e . g \cdot$, in some species of Leptophlebia.

The anal vein invariably plays an insignificant part, and is apparently sometimes wanting. Its area seldom reaches even half way along the anal margin, but in Tricorythus it extends even around the lower outer angle, fairly upon the outer margin. Here it is composed of a single vein with three or four short but widely divergent branches; usually it is forked at the hase, and occasionally one or the other of these forks imitates the rayed branch of the internomedian by sending a number of parallel branches, often closely crowded, to the margin.

This account of the neurition of the Ephemeridac is hased upon much more extended material, and a longer study than that formerly given by me in my first quarto paper on fosil neuroptera, and corrects it in several important particulars, especially in the account of the internomedian vein, which was eroneously stated to be simple ${ }^{1}$ and in the fuller statement of the divisions of the externomedian vein.

\section{Note on a Jurassic May-fly.}

Hexagenites Weyenberghii, gen. et sp. nov.:-A fragment of a wing only is preserved, in which the entire costal area and base are wanting. 'The neuration of the parts that remain

\footnotetext{
1 This statement was evidently the result of some oversight, since in the digest given on a subsequent page of the

same memoir it was remarked that the internomedian vein was "similar in character to the vena externomedia."
} 
is perfect and indicate an insect whose alar expanse was nearly $45 \mathrm{~mm}$., and which is most nearly related to Hexagenia; the first inferior nervule of the upper fork of the upper branch of the extermomediun vein is thrown off some way before the midlle of the wing; the lower branch forks at some distance beyond the middle of its course, and encloses between its branches a single intercalary nervule which extends nearly to the widely spreading fork. At a short distance from the base of the wing the lower branch of the externomedian vein has divided into three branches, the middle one nearer the upper than the lower, all of which continue undivided to the margin; two intercalary nervures of unequal length occur in each of these interpaces, extending almost half way to the base in the lower interspace, besides many short ones near the margin; the lowest of these branches is considerably curved and subparallel to the inner margin. 'The internomerlian vein probably divides at the very base into two branches, the upper of which is simple, runs subparallel to the lowest externomedian nervule, striking the angle of the wing, while the other branch is in close proximity to it and throws off a large number of sinnous simple branches to the anal margin, in doing which its outer half follows an irregrular course by a slight change of direction with each cmission. The cross-veins are moderately frequent and subuniform throughout the portion of the wing which is preserved excepting in the internomediun area, and the border is much broken by intercalary nervules into cells which are quadrate and generally much longer than broad. The anal area must be very contracted and the form of the wing clowely resembles that of IIexagenia.

The specimen is from Solenhofen, and is in the British Museum. The description is drawn up from a very clear sketch magnified 7 diameters, taken with the camera and published by Rev. Mr. Eaton in the 'Transactions of the Entomological Society of Lonton, 1871. Pl. 1, fig. 10. The species is dedicated to my friend Dr. Weyenbergh, of Cordoba, who has done so much in increasing our knowledge of the Jurassic insect fuuna of Bavaria.

\section{Platephemera antrqua. Pl. 1, figs. 5, 9, 10.}

Platephemera antiqua Scudd., Can. nat., (n.s.) IIr, 205, fig. 2 (1867);-Iв., Geol. mag., IV, 387, pl. 17, fig. 2 (1867) ; - IB., Dawson, Acad. Geol., 2d ed., 524, fig. 181 (1868); Iв., Amer. nat., I, 630, pl. 16, fig. 3 (1868); - IB., Geol. mag., r, 173, $175-76$ (1868); Pack., Guide ins., 77-78, pl. 1, fig. 3 (1869);-Nichols., Man. pal., 185, fig. 128 (1872); -IB., Anc. life hist. earth, 145, fig. 89 (1877); —DANA, Man. geol., 2 d ed., 273 , fig. 550 A (1874); - Rowм., Leth. geogn., pl. 31, fig. 9 (1876).

Mentioned without name, as the first species, in my letter to Mr. Inart on the Devonian Insects of New Brunswick (1865);-Bailey, Obs. geol. south. New Brunsw., 140 (1865) ; - Amer. journ.sc., (2) xxxix, 357 (1865); - Can. nat., (n. s.) II, 23 (1865); Trans. entom. soc. Lond., (3) II, 117 (1865). See also Amer. journ. sc., (2) xL, 277 (1865).

The wing was ample (whence the generic name) and gigantic. Probably a third of the wing is wanting at the base, besides the greater part of the extreme outer edge, but the fragment preserved enables us to jurlge, probably with considerable accuracy, both the general structure and, by the direction of the nervules and of the mingins, the general 
form of the wing, which is presumed to be much as outlined on the plate. The wing was probably more than $60 \mathrm{~mm}$. in length, and about $27 \mathrm{~mm}$. in breadth; the alar expanse was therefore at least $125 \mathrm{~mm}$., and probably $135 \mathrm{~mm}$, and the two figures have been so placed as to indicate this expanse.

This is more than double the ordinary size of the larger Ephemeridae and the largest mentioned in Eaton's paper on these insects has an expanse of only is mm., and the largest of the jurassic species only $65 \mathrm{~mm}$.

The costal margin is very gently arcuate; the apex probably somewhat pointed, toward which the upper veins are directed without additional arcuation; the greatest breadth was prohably a little before the midtle of the wing, and the outer perhaps half as long again as the anal margin. The marginal vein runs close to but does not form the margin of the wing, the latter being indicated in the figures on the plate by a dotted line.

The mediastinal vein runs as close as possible to the margin, and is not connected with it by cross veins; these two veins apparently run side by side to the apex, when the marginal disappears and the mediastimal takes its place close to the horder. The scapular vein runs sub-parallel to the mediastinal, but at double the distance from it apically as basally, the change occuring rather abruptly near the midlle of the preserved portion of the wing; it is connected with the vein above by straight cross-veins at tolerably regular, rather frequent intervals.

As usual in this family, the extemomedian vein is apparently divided, probably not far from, or at the base, into two stems, and the upper of these stems is again divided, probably at some ristance from the base, into two principal branches; the main portion of the upper branch rums parallel to, but somewhat distant from the scapular vein, approaching it, however, apically, and is everywhere connected with it by cross-veins, very much as in the mediastino-scapular interspace; it throws off from its inferior surface several inequidistant feeble offshoots; the first originate a little before the middle of the wing, and run irregularly but with a gentle downward curve to the outer margin; they have between them and between the outermost and the main branch a number of equally irregular intercalary nervules, all of which are connected together by cross-veins, and thus form over the whole area a mesh work of irregular but usually hexagonal and longitudinally elongated cells, making it imposible to distinguish between nomal and intercalary veins, since the latter are as prominent as the former, and invariably arise from cross-veins; while whatever nervules lie next the main branch are united with it by frequent and, equally irregular cross-reins falling from the main branch quite in the mamer of the offshoots proper, and forming cells only slightly larger than the others, although generally transversely elongated; together there are about nine rows of cells between the main upper branch and its first offshoot. The lower branch of the upper stem is simple and, originating apparently near the midile of the basal half of the wing, diverges at first slightly from the upper branch, afterwards a little more rapirlly, and in its apical fourth curves downward considerably, and is somewhat irregular in its course; its direction is in general pirillel to the offihoots. and expecially the nearer offshoots of the upper branch, and on the border it is separated from the apex of the upper branch by nearly one-third of the outer matrin of the wing; in its simplicity this branch resembles the same nervure in 'Trieorythus, which is peculiar in this particular among modern Ephemeridae. As in 
modern Ephemeridx generally, there is no intercalary nervule between this lower branch of the upper externomedian stem and the first offshoot of the lower branch, but this interspace is filled with simple and frequent cross veins.

'The lower externomedian stem is apparently formed on the same plan as the upper, a feature which appears to have no counterpart among living Ephemeridae; apparently it is composed, like the upper, of two primary branches, which seem to part from each other very nearly at the same consilerable distame from the base, about one-third the distance to the margin), a feature uncommon but not unknown in living Ephemeridae; but instead of having a single independent intercalary or two between the forks, it has severil off shoots which depend from the upper branch, just as the offshoots of the upper branch of the upper stem do, while between them in the outer half of their course other intercalaries arise, depending from angular cross veins - the whole united by frequent cross veins (again as in the upper area), to form a mesh-work of irregular cells generally pentugonal, although not often longitudinal; there are thus included between these forks about six rows of cells. The interspaces directly adjoining either side of the lower branch of the upper externomerlian stem are sightly wider than the interspaces between the nervules in the area of the lower externomedian stem, possess no intercalaries, and are divided by frequent cross veins. The lower branch of the lower externomedian stem also curves downward at the tip, like the lower branch of the upper stem; the area of the lower externomedian stem repeats, therefore, and on only a little smaller scale, the structure of the area of the upper stem, instead of exhibiting, as in recent forms, distinctive features.

That portion of the fragment of the wing lying below what we have here considered the lower simple branch of the lower externomedian stem, and which is shown in fig. 10 and not in fig. 9, is so fragmentary and so separated from its basal connections that it is difficult to decide to what area of the wing it belongs; it consists of four rows of cells separated by curving nervules a little more uniform in their course than the minor nervules ahove, with slightly less frecpuent cross veins; the cells being slightly largere and more regular, frequently quarlrangular ant usually longiturlinal; this fiehl belongis of course either to the externomedian or the internomedian area. The greneral similarity of the structure of the fields would lead one at first to suppose it to belong to the extcrumedian area, in which case of course our description of the lower stem and its branches should be modified to receive it. As, too, the form of the fragment would indicate that a very considerable part of the region about the anal angle is lost, the reference of this field to the internomedian area would give that area a very great and very unusual preponterance in the wing. But its reference to the externomedian area, which is certainly possible, would involve quite as great an anomaly; for in that case the lower externomedian stem must be supposed to consist of two branches, the lower lying beyond the present fragment and probably simple, the upper forked and reproducing on a smaller scale the whole of the upper externomelian stem, inclu ling the minor offihoots depending from the uppermost branch of each. In this case the area of the lower stem would exceed that of the upper, which occurs in very rare instances in modern Ephemeridice and then only by crowding out of room the lower areas, which the probable wide expanse of this wing would not allow unless this lower area is of an exceedingly disproportionate size. 'The translation of the facts which I have offered in my description, on the other hand, while it 
requires a very unusual development of the internomedian area, leaves the lower externomedian field in its usual proportionate extent as compared to the upper field, and is further supported by several considerations: chiefly by the probability that where repetitions of structure are found- a mark of simplicity much more common among ancient than among recent insects - they are far more apt to occur between repetitive parts than between those which may not be so exactly compared. On the hypothesis sustained above, this repetition occurs in the fields embraced between the two similarly disposed sets of branches into which one vein is divided. On the other suggested (and apparently the only alternative, for the open interspaces on either side of the lower branch of the upper externomedian stem seem to fix that nervule unquestionably) the repetition would be between the whole of one set of branches of this vein, and one portion only of the two of which the other set of that vein is composed. Other arguments may be advanced from the character both of the nervules and of the cells formed by them and the cross veins, which differ slightly from those in the field next above, a difference greater both in extent and in nature than that existing between what we have considered the upper and the lower externomedian fields. Further than this, the slight change of direction in the course of the outer margin, resulting in a slight emargination of this border of the wing, although apparently not found at all in living Ephemeridae, would be far more likely to occur, does far more frequently occur in other insects, between two adjoining areas than in the middle or other part of one.

Considering then the field under discussion as belonging to the internomedian aren, we must describe this as plainly of very unusual extent, and as filled as it never is in living types with a large number of intercalary nervules.

It may be remarked that none of the many intercalaries in this wing arise independently, and that they are not more abundant at the extreme outer edge of the wing, as is frequently the case in modern types. The former feature is the more noteworthy, as the independent origin of the intercalary veins in Ephemeridae would naturally be taken as a mark of inferior organization; and yet it does not occur in this oldest member of the group, nor yet in the jurassic species from Solenhofen, described on a previous page; in this last, however, the edge of the wing is more broken by intercalaries than the parts removed from it.

The length of the fragment preserved is $42 \mathrm{~mm}$. and its greatest breadth, $25.5 \mathrm{~mm}$.

The points in which this insect presents the most striking differences from modern types, and upon which we would establish the genus Platephemera, are: the very similar instead of distinctive structure of the framework of the two sets of branches of the externomedian vein, and of the respective areas included between them; the excessive number of the intercalaries in the area included between the lower set of externomedian branches, and their attachment (in the apical half of the wing) to the upper of these branches - from which the previously mentioned peculiar feature mainly depends; the simplicity of the lower branch of the upper externomedian stem in an unusually ramose wing; the unusual extent of the internomedian area and its rich supply of intercalaries; the density and polygonal form of the cells formed by the cross veins below the upper externomedian vein; the emargination of the outer border; and finally the vast dimensions of the wing. 
If we look to other early typas for species akin to this we shall find a whole group of carboniferous insects with reticulated wing;, to which this is evidently related. To this belong those forms to which the generic numes Dictyoneura and Breveria have been given in the old world, and Paolia and IIaplophlebium in the new. Several new forms, as yet unpublished, are known to ma from the Amsrican carboniferous rocks. In all these genara, but especially in Dictyoneur، and Haplophlebium (which perhaps should not be separated from each othor), the wing is very much larger and slenderer (like a dragon-fly's wing) than the fragment of this devonian sving will allow us to suppose it to be. As in these wings, the mediastinal vein is present, and usually runs into the marginal at some distance from the tip of the wing, and the general relation of the principal veins is similar in all; in none of the others, however, do we find so distinct a meshwork of subordinate veins, nor can they be resolved as here into sats depending from the two principal branches of the externomedian vein. So that while a general similarity of structure may be conceded, there is no occasion for considering the insects as closely a ffiliated.

The distinction between Platephenera and Gerephemera will be pointed out in treating of the latter insect.

This insect comes from plant-bed No. 7 of Professor IIartt, and was the only insect found at that horizon.

In his "Monograph on the Ephemeridae," Rev. Mr. Eaton treats of the fossil species which have been referred by. one and another author to this family, in a very summary manner, ${ }^{2}$ asserting that: "when a fossil comprises only a fratgment, or even a complete wing of an Ephemerid, it is hardly posible to determine the gemus, and impossible to assert the species. The utmost that can be learned from such a specimen is the approximate relations of the insect. Neuration by itself is not sufficient to define the species or even the genera of recent Ephemeridae."

While we should not wish to deny the claims of Mr. Eaton to a profound knowledge of the structure of the Ephemeridae, we venture to doubt if he would assert that there are not features in the wing structure of some genera not fo and in others, and which are, therefore, in so far characteristic of those genera; and it might be worth while to consider whether a careful study of such differences would not reveal some further differences not discernible upon a cursory examination. One should be slow to hazard sweeping statements of a negative character; and after all, it may be enquired, what more is desired, or at least expected, than "the approximate relations of an insect" found fossil in the older rocks. That is precisely the aim of palaeontology the world over; and those who discourage efforts to discover these relations are simply bidding us close one of the volumes of the book of life, quite as valuable as that they study.

In further comments in the same place, Mr. Eaton asserts of the insects of the Devonian discussed in this paper, that "they have all been regarded as allies of the Ephemer-

1 Trans, Entom. Soc. Lond., 1871, 38-40.

2 The manner in which Mr. Eaton has confounded names in this section of his work is pretty fair evidence that he has not griven the papers he quotes that close attention which would entitle him to use the languarge of ridicule toward their authors. In the three pages he devotes to this topic, Dyscritus is twice given as "Dyscritius"; articulatus twice as "antiquorum "; occillentalis once as "Brownsoni"; Bronsoni trice as "Brownsoni" , Dana twice as "Scudder" ; Scudder six times as "Dawson." 
idae." I do not know by whom; certainly not by myself, who first described them. Platephemera he says, may possibly belong to the Ephemeridae, "but there is nothing in the figures to make this certain." "The better figures published with this should be sufficient proof that Platephemera belongs where I originally placed it. The neuration agrees in all essential features with that family, and indeed, considering the antiguity of the creature, shows marvellously little divergence froms existing types. And although Mr. Eaton has nothing to say of the wing structure of the Ephemeridae as a whole, in distinction from that of other neuropterous families, I can hardly believe that any one who has studied it from the standpoint of the substantial unity of wing structure in all insects, could fail to discover that the Ephemeridae have a special development of wing neuration distinct from all others, permitting formulation, and to which Platephemera conforms to so close an extent, that until we have further light by the discovery of more complete remains we are amply justified in considering it as an antique type of Ephemeridae.

\section{Gerephemera simplex. Pl. 1, figs. 8, Sa.}

\section{Gerephemera simplex Scudd., Geol. mag., v, 174-75 (1868).}

Mentioned without name, as the fourth species, in my letter to Mr. Hartt: On the devonian insects of New Brunswick, p. 1; Bailey, Obs. geol. south. New Br., 140; Amer. journ. sc., (2) xxxis, 357 ; Can. nat., (n. s.) II, 235 ; Trans. Ent. Soc. Lond., (3) II, 117 all in 1865 .

In the specimen and reverse as first seen by me, scarcely more could be said of this insect than the brief notice alrearly pullished; nothing appeared but a sight firagment of the tip of a wing, and this would not have been dignified by a name had not the extreme interest attaching to fossil insects from the horizon at which it occurred seemed to demand it. The portion preserved was the upper half of the outer border with the extremities of the veins impinging upon it, and two of the principal veins near the tip of the costal margin; these two veins are as usual in the Ephemeridae and probably represent the marginal and mediastinal (or scapular), and show that the latter reached the border scarcely above the tip of the wing.

Since my first examination, however, Mr. G. F. Matthew has worked out a considerable part of the wing on one of the stones belonging to the St. John Society, which, though very different in certain parts from what would have been anticipated from the portion first exposed, bears out in a measure the statement that was hazarded concerning it, although it proves that the generic name chosen was unfortunate. In this removal of the stone from the surface of the wing, a fragment of the tip with its two veins was flaked off; but as careful drawings had been taken of it, I have replaced the two lines indicating the veins mentioned above upon the drawing made of the wing as it now appenrs. This gives us indeed a much better clue to the probable form of the wing than we could possibly otherwise have, for the considerable and constantly increasing divergence of the upper and lower veins of the continuous portion of the fragnent leave a very strange effect; and, without the aid these two vein-tips furnish, leave the form of the apex of the wing decidedly problematical. 
The wing is that of a very large insect, the fragment, which reaches neither base nor tip, being $60 \mathrm{~mm}$. Iongr, and rendering it probable that the alar expanse was at least 1.j0 $\mathrm{mm}$. and more probably $175 \mathrm{~mm}$. The apex of the wing was pointed, the costal and outer margin probably meeting at a rounded angle of about $60^{\circ}$. The costal margin must have been very strongly arched near the middle of the apical half, while the apical part of the outer border is nearly straight. The wing was probably elongated, not very broadly expanded in proportion to its length, as I at first presumed from not having counted on such an extended development toward the base. - In the middle of the onter half of the wing the width is about $2.3 \mathrm{~mm}$., and from the comse of the fragments of the two borlers it is probable that the width nowhere exceeded $25 \mathrm{~mm}$. or about two-sevenths the length of the wing. The fragment preserved contains considerably less than half the area of the wing comprising most of the central portions. The whole anal area is lost as well as what is apparently most or all of the internornedian area, extending far along the outer margin ; the merest fragment of the costal border, $2-3 \mathrm{~mm}$. long, is preserved, apparently about the middle of the wing; the tip of the wing and outer half of the costal margin are broken away, but a couple of veins at the tip are supplied, as already stated, from a piece that was accidentally removed. This imegular fragment, extending diagonally across the outer half of the wing, with a basal extension along the middle line, is traversed by principal nervures bound together hy a net work of mostly very irregular and very feehle, occasionally more regular and distinct cross veins, forming irregular, mostly longitudinil, unequal, polygonal, rarely quadrangular cells. The veins may be grouped into an upper set of parallel, equidistant and rather approximate, nearly straight, slightly upeurver nervures, three or four in number, traceable only near the middle of the wing; and a lower set of two, traceable throughout the apical half of the wing and extending nearly hall waty from the midcle to the base; these are parallel, more distant, directed gently downwarl and so divergent from the other set, and toward the apex curved considerably downward Between the veins of the upper set the cross veins are infrequent and mostly straight, forming quadrangular cells; while in the lower set they are more frequent and very irregular, forming polygonal cells which, toward the apical margin, are very indistinct from the feebleness of the cross veins.

The area formed at the apex of the wings by the divergence of the two sets of veins, is filled by branches from the superior surfice of the uppermost of the lower set of veins, supporting a mesh of cross-veins.

'The principal vein of the wing then-the only one which appears unquestionably to support a number of branches - is the uppermost vein of the lower set. And since in all palaeozoic insects having true net-veined wings, one never has to pass beyond the externomedian vein, in starting from the costal margin, to find the first extensively branched vein, there can be little if any doubt that this should be considered as belonging to that vein, and not to a lower one. The only difficulty about this interpretation is that in the middle of the wing, there are above this vein no less than five equidistant and almost equally distinct veins. The first of these, forming the margin, is the margimal vein, and the next is the mediastinal. It is impossible to consider this marginal as the mere thickening of the border, and the vein next removed from the bonuer as the true marginal vein, for both the margin itself would be too broad, and the marginal wusid 
then be an elevated, and the mediastinal a depressed vein (see fig. 8a), which is never the case in such insects. The nervure at the margin then is certainly the marginal, and that next to it the mediastinal vein. Only one vein, the scapular, can lie between the mediastinal and the externomedian, yet between our unloubted mediastinal and our presumed externomedian there are no less than three veins to be disposed of.

Two of these lie in the depression following the mediastinal vein, while the third is upon the side or the upper edge of the ascending portion of the area, which on the opposite sirle of the depres sion lies at the level or aloove the level of the mediastinal rein (see fig. Sa). It seems, therefore, highly probable that the two low-lying veins are branches of a scapular vein which probably divides not much further toward the base; and that the third vein in question is the main externomedian stem, of which the branching vein below is only a principal basal offshoot; indeed the very fact that the branches of this offshoot are thrown off from its superior surface leads to the presumption that it is itself a branch from a vein above; for, while an area between two branches of one vein may not very infrequently be filled by superior offshoots from an inferior branch, it would certainly be abnormal for a wide area to be filled by superior offshoots from an upper branch, or even from a main stem itself. Presuming then upon the correctness of these interpretations, the structural basis of the wing is as follows:

The marginal vein forms the border. The mediastinal vein is simple, and, running nearly parallel to the marginal vein, probably terminates by impinging upon it not very far from the middle of the outer half of the wing; from it run frequent oblique delicate cross veins to the border. The scapular vein divides into two longitudinal veins before the middle of the wing, probably considerably before it; for even before the middle of the wing, and for as great a distance beyond it as it can be traced, the two branches are exactly parallel to each other and the mediastinal; all the longitudinal interspaces in the middle of this part of the wing are equal; the forks are connected with each other (and the upper with the mediastinal?) by tolerably frecpuent faint cross veins at right angles to the nervures; and in the middle of the wing and beyond it, at least for a short distance, have a gentle upward direction, and even curve very slightly, almost imperceptibly, in the same direction; beyond however, they must curvestrongly in the opposite direction, for the pair of detached veins toward the tip of the wing have a decided downward direction, and these forks, whether the same or not. mut in that part of the wing have a similar direction; probably they are the same, and if so they show that they retain a similar distance apart until they strike the costal margin, one just before or at the tip, the other a little earlier.

The externomedian vein must divide into two principal veins near the base of the wing; the upper branch follows elosely the course of the veins above, and lies as far from the nearest as the latter from the next; a little beyond the middle of the wing, however, this space is slightly increased, and an intercalary vein, straight and similar to the others, hut fimter, takes its rise from an oblique bent cross vein; all the other cross veins in this interspace and on either side of the intercalary vein, are like the others in the scapular interspaces, and the whole area in which these straight and directly transverse cross veins lie, namely that between the mediantinal and upper externomedian veins, forms a deeply sunken but broad sulcus, the floor of which is nearly flat, and not $\mathrm{V}$-shaped as usual in folds in this 
part of the wing; probably it is otherwise further toward the base of the wing before the division of the scapular vein, for the sides of the sulcus are tolerably steep, and where only a simple vein occupied the sulcus, as is ordinarily the case in neuropterous wings, the sulcus would be angular. The lower externomedian branch at the middle of the wing is already as far from the upper branch as that from the upper scapular branch, and continues to diverge from it with a very gentle curve, which increases apically, so that it strikes the border with the same direction as the veins above; in the interspace between these two branches runs a feeble intercalary vein, slightly irregular in direction, sending off cross veins to one side and the other, forming longitudinal irregularly pentagonal cells; as the interspace widens these become more irregular, until at about two-thirds the distance from the base of the wing to the tip of this branch, a superior offshoot from this branch is emitted, having a course alout midway between the two branches, but very soon taking a somewhat zigzag direction, and assuming altogether the appearance of the intercalary, to which it sends frequent cross veins; a short distance further on, or at about the end of the second third of the wing, this emits a second off hoot, rather more prominent and regular than the first, which parts rapidly from the branch, and, remaining near the first, afterwards takes the apical direction of all the veins; it is bound to the upper offshoot by frequent cross veins forming small polygonal cells; between it and the lower externomedian vein is another very feeble intercalary arising from a cross vein, and becoming, like its lateral offshoots, nearly imperceptible toward the outer margin; as indeed do all the other cross veins and intercalaries, so that they were nearly unobserved when the margin alone was exposed, and many of the cross veins fail to compass the interspaces.

What can be seen of the internomedian vein is traceable slightly further toward the base of the wing than the preceding, but as the wing is broken here, it is impossible to say whether it is basally divided, and the portion visible is the upper branch, or whether what we see is the whole vein; in the former case the upper branch, in the latter the vein proper, runs sub-parallel to the lower externomedian, very slightly diverging from it, and in the middle of the wing (where it is broken, but where its connections leave no doubt whatever of its course) is as distant from it as the two externomedian branches at the same point; a single, distinct, pretty regularly zigzag intercalary runs midway between it and the lower externomedian branch, connected with tolerable regularity to the veins on either side by alternating, straight, transverse or oblique cross veins, generally forming rather regular, longitudinal, pentagonal cells, which become exceedingly irregular, obscure and broken next the outer margin of the wing; just below the apical offshoot of the lower externomedian branch it throws off an inferior branch, which is nearly straight, and is apically as distant from it as is the next vein above; between these branches is a very irregular interealary vein, rewembling in its comections the apical part of the intercalary above. The parts of the wing below this branch are wanting.

The relations of this insect to living types is far more obscure than in the case of Platephemera. It has certain resemblances to Platephemera and also to the carboniferous Palaeodictyoptera to which it may possibly belong, but it is certain that the limits of the Ephemeridae, even including Platephemera, are not elastic enough to ardmit it, and its divergence from Dictyoneura and other net-veined insects of early time is so great that it 
reference there would seem to obscure its real isolation. In fact there seems to be not only no family of insects into which it can be placed, but even no sub-order living or extinct, into which it would naturally fall. There is no known insect in which five parallel and distant nervures follow the course of the costal margin, and of which only two arise from the same root; and so far as my observations have gone, I have found no neuropteroum insect (to which of living groups this is plainly the most nearly allied), in which the externomedian vein is the first extensively branched vein, and in which at the same time, the upper branch of this vein is simple. In Ephemeridae (to which group one would most naturally compare it from its general appearance), the extemonedian vein, ats already stated, is always compound, and its upper stem is always forked. In this insect on the contrary, the upper stem is simple (which is the more remarkable from the forked character of the scapular, always simple in Ephemeridae) and the lower forked, its branches being superior and herein differing remarkably from ordinary types.

Gerephemera then is not only further removed from modern Ephemeridae than is Platephemera, but can be even less closely affiliated with Platephemera than the latter with modern Ephemeridae. It has, nevertheless, some distinctive points in common with it. Such are its great size and the probable great expanse of the internomedian area, the differing character of the net-work above and below the uppermost externomedian branch, the polygonal nature of the mesh-work caused by the cross-venation (in common with many other old insects), and the somewhat uniform character of that network next to and away from the border. In common with modern Ephemeridae, but in distinction from most other insects, must be mentioned the common feature of intercalary nervures, which here, as in Platephemera, are never free at their origin.

As points of special distinction from Platephemera may be mentioned the broad area given to the veins above the externomedian vein, the forking of the scapular vein, its course at the bottom of a deep and broad sulcus, the occurrence of a straight intercalary in the scapular-externomedian interspace, the entire structure of the externomedian vein (differing altogether from Platephemera) and the elongated slender form of the wing, which resembles much more closely Dictyoneura and Haplophlebium.

From these latter genera again, to which we should perhaps consider it most closely allied, this insect differs remarkably in the structure not only of the externomedian vein, but in the wide extent of the wings above that vein, and the number of nervures which fill it. It would appear also to differ in the character of the reticulation above the externomedian vein, a matter of less importance, but in which it agrees with Platephemera. 'The difference in the frame work of the wing, however, is so great and so deep seated, that there can be no doubt of at least its family distinction from all known types. Whether or no it is worthy of being classed as subordinally distinct, I leave to future discussion. But in allusion to the apparent fact that the peculiar nature of its neuration has not left its mark on modern types, I propose to call the family group in which it should be placed Atocina. ${ }^{1}$ It will be sufficiently distinguished from other ancient types (as from modern) by the forking of the scapular vein, the course of the externomedian, its distant removal from the costal margin, and its peculiar division.

'This insect and Xenonemra come from the lowest of the Lancaster Shales which furnish insect remains, called plant bed No. 2, by Professor Hartt. 


\section{Hoмотиetus fossilis. Pl. 1, figs. 1, 2.}

Homothetus fossitis Scudd., Can. nat. geol., (n. s.) III, 205, fig. 3 (1867); - IB., Geol. mag., Iv, 387, pl. 17, fig. 3 (1867); - Iв., Daws., Acad. geol., 2d ed. 524-25, fig. 182 (1868); - Is., Amer. nat., I, 631, pl. 16, fig. 7 (1868); - IB., Geol. mag., v, 172, 176 (1868); РACK., Guide ins., 77-78, pl. 1, fig. 7 (1869).

Mentioned without name, as the second species, in my letter to Mr. Hartt: On the devonian insects of New Brunswick, p. 1; Bailey, Obs. south. New Br., 140; Amer. journ. sc., (2) xxxix, 357 ; Can. nat. geol., (n. s.) II, 235; Trans. ent. soc. Lond., (3) II, 117,-all in 1865 .

The wing representing this insect is the most complete of the devonian insects, and would leave little to be desired were the base more complete; unfortunately the reverse of this specimen was never found, or it might supply the missing parts: To judge from the strong convexity of the costal margin, it is a front wing. It has the general appearance of a Sialid of moderate size, and the form of the wing closely corresponds. Although a fragment from the middle of the costal margin, and the whole outer half of the lower margin with the apex are missing, the form of the wing can be estimated with considerable probability. The costal margin is in general strongly convex, but is flat in the middle third, the basal portion rapidly ascending, and the apical as rapidly descending; the apex was probably rounded, but a little produced, and the hinder border pretty uniformly and fully rounded, making the middle the bromlest part of the wing. where the breadth is probably contained about three times in the length; toward the base the wing narrows rapidly, but at the extreme base more gradually above so as to be almost pedunculate.

The marginal vein forms the border. The mediastinal vein is at first inclined slightly downward, then ascends as gently, parting slightly from the marginal, but again in the middle of the wing commences most gratually to approach it, ruming towat the extremity of the wing in close contact with it, but apparently not joining it until just before the apex and beyond the preserved part of the fossil; throughout it partakes of the course of the margin, but in a less exaggerated form, ascending slightly beyond the basal part, then straight in the middle, gently arcuate apically; it is connected with the margin, so far as can be made out, by a single straight cross vein somewhat before the middle of the wing.

The scapular vein follows a sinilar course as the mediastinal, always about as far removed from it as it is from the margin, excepting in the apical third; where its distance from the mediastinal is slightly greater, so as to carry its termination, no doubt, exactly to the tip of the wing; no cross veins can be seen to connect this vein with the mediastinal. No other veins can be traced at the extreme base of the wing between the scapular and the lower margin; but at a short distance (about $2-3 \mathrm{~mm}$.) from the base of the scapular vein, and where its course turns from a descending to a longitudinal direction, a strong transverse vein depends from it, directed a very little obliquely outward, and reaching fiom onethird to one-half way to the lower margin of the wing; and from near and at the lower extremity of this stout transvere vein, other longitudinal veins arise. 'The uppermost arises from the middle of the lower half of the vein, at a distance from the scapular much greater than the scapular from the costal margin at this point; at first it tends uprard, parallel to 
the costal margin, but very soon divides into two main stems. These two stems I take to be: the upper the main scapular branch, of which the transverse vein is the base; the lower the externomedian vein, amalgamated with the former at the base, the two being comparable, as will be shown further on, to the same nervures in the Odonata. The connection of the main scapular branch with the veins preserved in the field beyond cannot be directly traced; but from the position of the latter the following account must be substantially correct. It runs in a nearly straight course to the middle of the apical half of the wing, where from not following the arcuate course of the main scapular vein it has diverged considerably from it ; here its straight coure suddenly terminates, but it passes to the same point on the apical margin (just below or at the apex), by a gentle arcuation subparallel to but distant from the main scapular vein, with which it appears to be nowhere connected by cross veins. This main scapular branch emits two basal and several apical inferior offishots; the apical off-hoots are thrown off at wide angles, at subequidistant intervals from the arcuate portion of the main branch, the first at its bend being ahruptly and widely forkert not far from its origin, the others being simple and the interspaces apparently free from cross veins. The basal offshoots are probably thrown off (their origin is destroyed) at a little distance either side of the end of the basal third of the wing; and. unlike the apical offiloots, certinnly diverge at a rery slight angle, and are each similarly forked; the first from the base is forked near its origin, and its upper fork is again divided narrowly about half way to the margin, the general course of all the nearvules of this basal off shoot being hroally arenate. The other and outer basal off hoot soon runs parallel to the main scapular branch, and is connected with it by a straight oblique cross vein in the middle of the wing, where it forks; a short distance further on a piece is broken from the middle of the wing, and the part beyond is displaced a little with reference to it, and apparently folded a little so as to obscure the exact course of these forks; which seem to become involved with the fork of the first of the apical offishoots, with which, as well as with each other', they are comnected by weak, inecquidistant, straight, direet or oblique cross veins.

The externomedian vein can be traced in all its parts, excepting. an insignificant portion of the tip of the outer of its branches; the main stem takes an arcuate course, parallel to the basal oftshoot of the main scapular branch, and terminates on the lower margin just beyond the middle of the wing; half way from the transverse basal vein to the margin it throws off an inferior branch, which soon becomes parallel to it (and where it becomes so is connected by a cross vein to the vein below) and, by an interpolated vein, which appears as a baseward continuation of this inferior branch, to a bent cross vein in the same interspace, just beyond the middle of the basal half of the wing; this cross vein is bent on the externomedian side of the interspace. The internomedian vein is compound, being broken at the lower extremity of the transverse basal vein (before which it is not seen) into two compound branches, each throwing off a couple of inferior curved offshoots to the margin, which are connected together by two sets of cross veins, - one belonging only to the nervures of the upper branch, and in continuation of the direct cross nervure in the externo-internomedian interspace; the other set covering both branches and broken, each succeding vein being carried successively further in, the general course of the whole series being across the middle of the internomedian 
area, sub-parallel to the outer series; one or two of the nervules in this area are briefly forked next to the border. The anal veins cannot be seen.

The length of the fragment is $40 \mathrm{~mm}$.; the probable length of the wing $42 \mathrm{~mm}$; its breadth at the middle is $14 \mathrm{~mm}$., reduced at base to $4 \mathrm{~mm}$.

The most important vein in this wing is the scapular, whose branches occupy about half the outer margin; the externomedian is comparatively unimportant, the internomedian occupying a larger area. The more striking features of the wing besides this are: the origination of the principal scapular branch (from which all the scapular nervules arise) and the externomedian vein from a common stem, having its source in a transverse basal nervule; and the meagreness of the transverse neuration, which in no place shows any sign of reticulation. The print first mentioned finds no parallel anomg insects excepting in the Odonata, where it is almost precisely similar. There, as I attempted to show many years ago in treating of the structure of the wings of recent and of fossil Neuroptera, the transverse vein termed the arculus in modern nomenclature should be considered as made up of two veins meeting each other; for the upper of the two longitudinal nervures which always originate from it belongs to the scapular vein, while the lower belongs to the externomedian. Here, these two veins appear, at least, to be amalgamated at the base, but it is not impossible, and would indeed seem a priori more probable, that they run side by side by side to the arculus, and are merely connate in appearance from the preservation of the fossil. However, this may be, it would seem as if we had in this peculiar structure the presence of an arculus as a forerunner at this early day of the specialized type of Odonata; the main scapular branch arising from the arculus is here, as in all normal modern Odonata, the principal vein of the wing, ${ }^{1}$ from which most of the subsidiary branches arise; in these two points this fossil wing is distinctively and decidedly Odonate in character; but if one looks further, one fails to find expected features, now, and even in jurassic time, invariably corellated with those mentioned; especially is a nodus to be sought in vain; the marginal vein runs without break to the tip of the wing; for, although it cannot be followed from want of its perfect preservation, all the neighboring veins can, and the number is similar throughout. So too the fine meshwork of Odonate wings is not only absent, but what cross neuration exists is confined to a dozen or so straight veins for the whole wing. If, however, we consider this uppermost offshoot from the arculus as the main branch of the scapular, and simply imagine the arculus-structure removed, so as to bring this main branch directly and plainly dependant from the scapular vein, one cannot fail to see how close the entire structure would be to what we find in the Sialina. In the latter group indeed, there is no such separation of apical and basal offshoots to the main scapular branch as here, but all the scapular nervules take their rise, not from the vein itself, but as here from a principal scapular branch, arising far back on the scapular vein; the general relations of the different areas of the wing are also much the same in both, while the cross venation is very similar. Here as there, the internomedian vein and its branches are of more importance-cover a wider area and bifurcate far more - than either the externomedian vein on the one side, or the anal on the other. We have here, therefore, as I pointed out

\footnotetext{
It is termed vena principalis in the modern nomenclature of students of Odonata. In some Calopterygidae it does
}

not arise in the same way as in other Odonata, but has transferred its origin to the scapular (median) itself. 
when first calling attention to this fosill, the distinctive features of two tolerably well separated groups combined in one individual: certain features of the wing are distinctively Sialid in character; others occur nowhere but in the Odonata. Yet these two groups belong, one to the Neuroptera proper, the other to the Pseudoneuroptera, and we find here the earliest proof of their common origin, in a wing whose type is more distinctly synthetic than any other known. It seems also to bring new and unanticipated evidence in support of my view of the homologies of the vein arising from the arculus in Odonata.

It is plainly impossible for us to place this insect in any known family of Neuroptera. It must be considered the first known member of a family, forming the connecting link between the Neuroptera proper and Pseudoneuroptera, and will be evidence, in so far as it goes, of a closer commection between these two groups, than between the latter and Orthoptera. For this family I would propose the name of Homothetidae, and would characterize it as a family of Neuroptera (sensu latiori), allied to Sialina, but in which the principal scapular branch, instead of originating as in Sialina directly from the main stem, usually near the middle of the wing, arises in common with or close beside the externomedian vein, from an arculus near the base of the wing, connecting the scapular and internomedian veins; and in which, further, the basal and apical offshoots from this main scapular stem are differentiated, instead of exhibiting a similar and uniform character.

'This insect was found in plant bed No. S, of Professor Ilartt's section, the highest in the series as developed at the Lancaster locality.

\section{Discritus vetustus. Pl. 1, fig. 4.}

Dyscritus vetustus Scudd., Geol. mag., v, 172, 176 (1868).

Mentioned without name, as probably idcntical with one of the other species, in my letter to Professor Hartt: On the devonian insects of New Brunswick, p. 1; Bailey, Obs. geol. south. New Br., 140 ; Amer. journ. sc., (2) xxxix, 357 ; Can. nat. geol., (n. s.) II, 234 ; 'Trans. ent soc. Lond., (3) I, 117 - all in 1865.

The insect briefly mentioned hitherto under this name has not before been figured, and is the least important of the devonian wings. It consists of only a small fragment of a wing, which shows a bit of the lower margin with three or four curved veins running toward it, and comnected rather uniformly with one another ly cross reins forming fuadrate cells. It is plainly distinct fiom all the oflers, for the equivalent region in no case is similarly liroken. In Lithentomum Harttii the corresponding region is indeed not preserved, but the cross veins in the neighboring parts, although weak, straight and direct as here, are so very infieguent and irregular that we camnot presume the parti which are wanting below them to be very different.

The veins preserved are four in number. The uppermost has two inferior branches at short distances, of which only the extreme base of the outer is preserved, while the imner is traceable throughout its extent; it parts from the main vein, which in the brief portion preserved rums nearly parallel to the lower margin, at an ordinary angle and passes in a regular arcuate downward course to the margin. The three veins below this take a course sub-parallel to this, and are sub-equidistant; the upper, at the base of the 
part preserved, is a little nearer to the vein above, and to its first branch, than to the vein below, and may possibly, not improbably, he a branch of the first vein mentioned, parting from it further toward the base than the fracture of the specimen allows us to see; the two veins below it seem to belong together; the bit of margin preserved, covering only two interspaces, is slightly convex. The cross veins are weak, but tolerably uniform, and either direct or slightly oblique, or occasionally a little irregular; they are nearly equidistant as a general rule, but more frequent in the outer of the two interspaces touching the margin than elsewhere. The length of the fragment is $15 \mathrm{~mm}$.

The fragment then consists of some curved veins striking the lower margin of a wing, one at least of which is one of two or more inferior and, so far as can be seen, simple hranches of a principal longitudinal vein, whose course would make it terminate either at the very tip of the wing, or, if it afterwards curved considerably, very near the extremity of the lower margin. This principal vein probably belongs either to the scapular or externomedian, while the lower curved veins appear like branches of the internomedian vein. The wing cammot therefore he refered to the vicinity of either Platephemera or Gerephemera, both on account of the relations to each other of the veins, and of the nature of the reticulation, the latter being certainly polygonal in this region in hoth these genera; while the irregular course of the veins themselves in Platephemera and their considerable apical divarication in Gerephencra constitute peculiarities not observed in the simple fragment under discussion. So far as the course of the veins is concerned it can be much better, and indeed very well, compared to Dictyoneura and its allies; but in all these insects the interspaces are filled with a minute polygonal reticulation (wherever it is preserved), which is such a characteristic fature that Dyscritus can hy no posibility be considered as very closely allied to them.

The neuration is altogether different in Xenoneura, finding nothing at all comparable in this regrion. The longitudinality of the veins throughout Lithentomum seens to forbid any close comparison with it. But in Homothetus we do find some points in common. with Dyscritus; for while the reticulation is much more sparse in the former, there is a certain regularity about it similar to what we have in the latter, while the curving of the internomedian veins and their parallelism certainly resemble in a general way the same features in Dyscritus. And if we presume the fragment of Dyscritus to be broken from near the middle of the wing, we may see a not distant resemblance hetween the longitudinal vein of Dyseritus and its two visibly connected branches, and the main branch of the scapular vein in Homothetus; while the upper, independent, curved vein of Dyseritus may be taken perhaps for the externomedian vein, and the other two nervules for branches of the internomedian vein. The resemblance is at least sufficient to make us believe we have here a clue to its relationship; while at the same time it differs so much from it that we camnot associate the two even generically ; for if they are to be compared in this way at all, the lower stem of the main scapular branch, as seen in Homothetus, must either have become single and simple in Dyscritus, or it must have assumed the longitudinality and mode of bifurcation of the upper stem.

There is nothing, however, in the fragment to show what the connection of the main scapular branch may have been, and consequently nothing to prevent the reference of this wing to the Sialina, where the relations of the veins would be the same. Judging 
by comparison of what we have presumed to be similar parts, we may suppose this wing to have been slightly larger than that of Homothetus foswillis, and its probable length not far from $50 \mathrm{~mm}$.

Whatever views are held of the special homologies of the reins, its right to generic distinction from Homothetus, to which it is most closely allied, must be concerled on the ground of the greater simplicity of the neuration.

On aceount of the insignificance of the fragment, however, and the consequent impossibility of any sure clue to its affinities, it would not have been worth while to confer upon this wing a distinctive generic name, even granting its generic discociation from all others, were it not for the extreme interest attaching to any insect fragment of such high antiquity.

The remains were found in plant bed No. \&, of Professor IIartt, the highest in the Lancaster series.

\section{Lithentomua Harttir. Pl. 1, fig: 3.}

Lithentomum Harttii Scudd., Can. nat. geol., (n. s.) mII., 206, fig. 4 (1867); - Ів., Geol. mag., IV, 387, pl. 17, fig. 4 (1867); IB., Daws., Acad. geol., 2d ed., 525, fig. 183 (1868); - Iв., Amer. nat., I, 630, pl. 16, fig. 5 [Hartii] (1868); - Iв., Geol. mag. v, 172, 176 (1868); - PaCk., Guide ins., 77, 78, pl. 1, fig. 5 (1869).

Mentioned without name, as the third species, in my letter to Professor Hartt: On the devonian insects of New Brunswick, p. 1; Bailey, Obs. geol. south. New Br., 140 ; Amer. journ. sc., (2) xxxIx, 357 ; Can. nat. geol., (n. s.) II, 235; Trans. ent. soc. Lond., (3) II, 117 - all in 1865.

The relic to which this name has been given is the central upper portion of a wing in a very fragmentary condition, but with a bit of the upper margin sufficient to enable one to determine pretty positively the homologies of the veins. A fragment of Calamites hats unfortunately covered the base and lower part of the wing, but one or two of the veins appear through it at what must be the very base of the wing, and help to determine its nature. The fragment preserved is $36 \mathrm{~mm}$. long, and $15.5 \mathrm{~mm}$. broad; but the wing was probably $55 \mathrm{~mm}$. long, and perhaps $20 \mathrm{~mm}$. broad, if one may judge from its general appearance only; it certainly represents a large insect.

The marginal vein forms the border. The mediastinal vein in the basal half of the wing, and probably for some distance beyond, runs parallel to and at considerable distance from the border, with which it is connected by very weak oblique cross veins at irregular intervals, which toward the base are considerably more oblique than further outward; this weak construction of the costal margin renders it probable that the wing was a hind one. The scapular vein in the basal quarter of the wing runs in very close proximity to the mediastinal, then parts from it a little, and continues sub-parallel to it, but a little nearer to it than the latter to the border; there appear to be no cross nervules between these veins, but a slight and irregular tortuous longitudinal line like a mere puckering of the membrane; at some distance before the middle of the wing this vein puts forth at a slight angle an inferior branch, which takes an arcuate course sub-parallel to the vein, and is forked about as far beyond the middle of the wing, apparently, as it arose anterior to it, both offshoots taking a longitudinal direction. 
The extemomedian vein next the base of the wing is somewhat distant from the scal)ular, is afterwards still further removed from it, and; in the middle half or more of the wing, has a somewhat irregular, sinuous, longitudinal course, sub-parallel to the scapular vein ; just before the end of the basal quarter it appears to have a straight oblique inferior branch widely divergent from it; this is the vein next the lower margin of the fragment; by its course it would appear to be a branch of the externomedian, but it is not imposible that it may be the internomedian vein; whichever it is, it forks in the middle of the second quarter of the wing, each fork being straight, simple and slightly divergent. From the point where this inferior branch appears to be thrown off from the externomedian vein, a superior branch appears also to be emitted; it scarcely parts from the vein and runs only a short distance along the interspace in a nearly straight line and then dies out. Beyond this the externomedian vein throws off two, so far as can be seen simple, branches, which are nearly straight, obliquely longitudinal, and part from the vein, one at the middle of the wing, the other a short distance before it or just below the branch of the scapular vein. 'The interspaces thus formed below the scapular vein are very unerual and variable in hrealth, giving the neuration a feeble uncertain appearance, which is heightened by the irregular distribution of the cross veins, which, although nearly always straight and transwerse, sometimes bridge the narrowest, sometines the broalest parts of the interspaces; they are exceedingly feeble and infirequent, the largest number being found in the interpace between the scapular and externomedian veins, although they may have been present in some of the areas where they cannot now be seen.

We shall seek in vain to accommodate this wing in any of the modern families of Neuroptera. There are none excepting the Ephemeridae, the Embidae and perhaps the Raphididae, in which the externomedian vein has such a preponderating importance, and in none of these do the scapular or externomedian veins have a structure at all similar. The structure of the seapular vein is somewhat similar to what we find in the sialina, but is widely different from it in the paucity of the offhoots of the seapular branch, in which this wing is comparable to Xeuoneura only. The structure of the externomedian vein is also distantly similar to that of the Sialina, but in this fimily, in modern times at least, the number of principal branches is always ferer, they never assume such a longitudinal course, and never cover so great an area. We must, therefore, separate this group from all known families, as one having its nearest affinities to Sialina in modern times, and perchance to Xenoneuridae in the ancient; and, considering it as in some sense a precursor of the Sialina, may call it Cronicosialina. ${ }^{1}$ It should be lookerl upon as a family of Neuroptera proper, of feeble neuration, in which the seapular vein emits a main branch near the middle of the wing, which, ruming nearly parallel to the main vein, emits one or at most two subsidiary, also longitudinal, simple offichoots. The externomedian vein, tolerably distant from the former throughout, terminates near the tip of the wing, emitting two or three branches at very unequal distances apart, all of them longitudinal and all but the basal simple; the irregular interspaces thus formed are crossed at very unequal distances by very feeble but straight cross veins. The lower veins are unknown.

This specimen is the most obscure of all the devonian insects and would have been overlooked by any less keen-sighted observer than the late Professor C. F. Hartt.

1 Kpovexós, old fashioned. 
Very few persons seeing it would recognize it as an insect, yet it was the first insect found by him which he recognized as such. It is on this account that I have selected this of all the devonian wings to commemorate his discovery. It comes from plant-bed No. 8, the highest in the series.

\section{Xenoneura nntiquorus. Pl. 1, figs. 5, 6, 7.}

Xenoneura antiquorum Scudd., Can. nat. geol., (n. s.) III, 206, fig. 5 (1867); - IB., Geol. mag., IV, 387-88, pl. 17, fig. 5 (1867); - IB., Daws., Acad. geol., 2d ed., 525-26, fig. 184 (1868); - IB., Amer. nat., II, 163, fig. 1 (1868); - IB., Geol. mag., V, 174, 176 (1868).

Mentioned without. name, as the fifth species, in my letter to Professor Hartt: On the devonian insects of New Brunswick, p. 1; Bailey, Obs. geol. south. New Br., 140; Amer. journ. sc., (2) xxxix, 357 ; Can. nat. geol., (n. s.) II, 235 ; Trans. ent. soc. Lond., (3) II, 117,-all in 1865; see also Amer. journ. sc., (2) xL, 271.

This fossil is represented by a fractured basal fragment of a wing, probably including a little more than half of it. It is the smallest of the devonian insects, the wing having probably measured only a little more than $18 \mathrm{~mm}$. in length. It was long and slender, broadest near the middle, and probably tapered to a rounded but somewhat produced extremity, as in certain species of Dictyoneura. The costal border in the preserved portion (probably a little more than half of the whole) is gently convex; probably beyond the middle it is straight nearly to the tip, as represented on the plate; the portions of the lower margin preserved indicate that this was more strongly arcuate but not full next the base; the direction of the margins and the course of the distant veins indicate, as stated, a tapering tip, which was probably rounded, and in no way angular.

The marginal vein forms the border. The mediastinal vein is simple and gently areuate; at first it curves gently in the opposite sense to the margin, from which it is somewhat distant, and with which it is comnected by faint, nearly transverse, or, away from the base, gently oblique cross veims, not very closely approximated. At the beginning of the second quarter of the wing, it is about as distant from the scapular vein as from the margin, ancl thereafter runs nearly parallel with the latter, but with a slightly stronger curve, to a little past the middle of the wing; where it suddenly terminates in a cross vein bent at a right angle, the upper half a little the longer, by which it is connected with the veins on either side of it; a somewhat similar termination of this vein is shown in Goldenberg's figure of Dictyoneura libelluloides.

The scapular vein is one of the most important in the wing. In the part of the wing preserved it is very straight. Next to the base it is in exceedingly close proximity to the mediastinal, diverging gently from it by the curve of the latter at about the end of the basal fifth of the fragnent, until it is as distant from the mediastinal as the mediantinal is from the margin, and again gradually approaches it; it is about equidistant from the border at the end of the fragment, and where the mediastinal diverges from it; beyond the tip of the mediastinal, it probably continues its straight course at first, or even trends slightly upward to take the place of the mediastinal vein, until it is in close proximity to the border, and then follows nearly the curve of the latter, gratually approaching it unt il 
near the tip; but the track of the vein beyond the tip of the mediastinal is of course conjectural.

At a little beyond the end of the first third of the wing, it emits at a considerable angle an inferior branch, which, at about half way from its base to the tip of the mediastinal, or at just about the middle of the wing, begins to curve, so as to assume a direction parallel to the main vein, and at the same time forks; this whole branch is very faint, and is almost effaced at the fork next which the wing is fractured. To judge from the course of the other veins, one and only one of the offshoots of that branch is again simply forked; which, it would be impossible to say; but the upper offshoot (with its upper fork, if it divides) most probably runs sub-parallel to, and at considerable distance from, the main scapular vein, very gradually approaching it, especially apically where it curves downward, until it terminates, probably at the very apex of the wing. The sketch in fig. 5, however, represents the lower branch as forked, at a little past its middle; there can be little doubt that the branches impinge upon the margin at about the distance apart that is indicated, or at a little less distance apart than the branches are seen to abut on the fragment of the lower margin which is preserved. The only question is concerning the basal attachment of the vein which strikes the border the second below the scapular vein itself; if not attached as represented in the plate, it originates from the branch of the scapular vein at probably a little less than half the distance between its first forking and the apex.

The vein lying next below this, and which appears on the plate (fig. 5) to have a double attachment to the scapular vein, seems to be the externomedian vein. That its basal half, like that of the preserved portion of the scapular branch, is very faintly indicated on the stone seems due to some accident of preservation, for its apical branching part is distinct. It appears to originate from the scapular vein at a little more than half way from the base of the wing to the origin of the scapular branch; its basal portion must therefore be either connate with the scapular vein, or be so closely connected with it by the accidents of preservation as to be inseparable from it. It diverges from the scapular at the same angle as the scapular branch, is very soon connected with the adjacent vein below by a short cross nervule of unusual distinctness, bends outward a little beyond this cross nervule, and at an equal distance beyond is again bent to its former course; here it is connected to the scapular vein by a faint oblique cross vein, which is almost exactly continuous with the subsequent part of the externomedian, and reaches the scapular vein directly above the distinct cross vein above mentioned; thus giving the mediastinal vein the appearance of having a double base, and enclosing between its basal attachments an elongated subhomboidal cell. Beyond these basal divisions the vein runs in a straight oblique course to just before the centre of the wing, where it forks widely, the upper branch being simple and excepting for a gentle arcuation at its base nearly straight and a little more longitudinal than the main stem; the lower branch nearly continues the direction of the main stem, and at a little less than half way to the margin forks, again widely, but symmetrically, the offshoot being simple, the upper again forked half way to the margin, the final upper fork being nearly horizontal and striking the border in the middle of the apical half of the wing. 
The internomedian vein seems to be represented hy two widely separated simple veins, the course of which, so far as they can be traced, would seem to indicate that they have a common origin very near or at the base of the wing, directly below the common stem of the scapular and externomedian veins. The upper branch first comes into view directly beneath this stem, rumning parallel to it, and not very far aray from it, but at double the distance from it that the mediastinal vein is at this point, which is before the end of the basal quarter of the wing; when the mediastinal vein curves upward from the scapular, this curves downward in about the same degree, until it reaches the distinct short cross vein which unites it, as before stated, to the externomedian vein; here it bends downward, becomes more distinct than any of the nervules between it and the main scapular vein (previously it had been rather inconspicuous), and runs in a nearly direct faintly arcuate conse to the middle of the lower margin of the wing, gently diverging throughout from the externomedian vein and its nearer branches. The lower branch is first seen in the very centre of the basal third of the wing, from which point it passes in a nearly straight course almost parallel to the distincter portion of the other branch, and is as heavily marked. The anal vein is perhaps simple, running at first downward and curving outward, sulparallel to but distant from the lower hatil margin. heeoming just before the middle of its regular course straight and distinct, when it divereses slightly from the borter of the wing, and inclines distinetly although not greatly toward the lower internomedian branch, continuing in this course until it reaches a distinct oblique cross vein which unites it to the latter in the middle of the basal half of the wing; here it bends abruptly downward at right angles to the cross vein, and runs doubtless into the margin; the cross vein is nearly transverse to the interspace in which it lies, and is about parallel to, and is of the same length as, the upper limb of the bent cross vein in which the mediastinal vein terminates. Next the basal margin of the wing is a brief simple shoot directed almost vertically downward, which may be an inferior basal branch of the anal vein. The other limes between the internomedian veins and the margin. seen in fig. 5, represent merely fractures in the stone.

Besides the three distinct cross veins mentioned,-(1) that in which the mediastinal vein terminates, (2) that between the upper internomedian branch and the externomedian vein; and (3) that connecting the lower internomedian branch and the anal vein and the weak cross veins visible in the interspace above the mediastinal vein (of which only those in the basal half are represented in fig. 5), there are in various parts of the wing exceedingly indistinct, very weak, very closely approximated, but unequally distant cross veins, transverse or nearly transverse to the interspaces, sometimes curved but never showing any tendency to unite so as to form any kind of reticulation; it is probable that they exist throughout the wing, or at least below the main scapular vein; they are most distinct in the externomedian interspaces, and in those on either side of the internomedian branches, especially next the nervules themselves, as may be seeu in fig. 5 on either side of the lower internomedian branch, where they are more distinct than in any other part of the wing; this mode of fracturing the interspaces, rather than reticulation, is the more matied from the exceedingly open and distant neuration. 
Besides these normal features of neuration there are some other characteristics in this wing, purposely left for description to the end. These are some peculiar marks near the base of the wing, originally described by me as "apparently independent veinlets, forming portions of concentric rings." "These ridged rings overlie the probable position, as here described, of the basal part of the lower internomedian branch, and lie just beneath the initial divergence of the mediastinal and scapular veins; they consist of an alternate series of broken concentric grooves and furrows, some faint, others in places very distinct, extending over nearly half the width of the wing at this point, $i$ e. almost reaching the upper branch of the internomedian vein on the one hand and the anal vein on the other; the most distinct are three short, shallow furrows, with very rounded low ridges between them upon the upper side, next the upper branch of the internomedian vein; the outer of these is distant from the extreme mark upon the opposite side about $2.2 \mathrm{~mm}$; the central region, rather less than a millineter in diameter, presents a slightly elevated, irregular. gramulated surfice, like many of the rougher parts of the stone outside the wing, and has no peculiar structure; the whole lies directly upon what would be the continuation of the lower branch of the internomedian vein were it present, and apparently obliterates it; one of the outermost grooves, an extremely faint and delicate one, crosses the anal vein at a very sharp angle. This peculiar feature in the wing $\mathrm{I}$ formerly compared to the stridulating apparatus of the Locustariac, and suggested that this insect therehy united characteristics now found only separated, some in Neuroptera and some in Orthoptera. Several naturalists, e.g., Darwin, Dawson, and Packard, following my sugerestion, have used this as a striking illustration of synthetic character in early types of animals, and have pictured this as the earliest example of stridulation. I am now obliged to confess that I have led them altogether astray; this peculiarity, although bearing a strong superficial resemblance to the stridulating organs in Locustariae, having, I believe, nothing whatever to do with the wing itself. The stridulating apparatus of Orthoptera, whenever it concerns the wings, is invariably based on a modification of existing veins; in its simplest forms it is the mere thickening of certain nervules, and furnishing them with a sharp or rough edge. In the original appearance of a stridulating organ in insects, we should look for some such simple form as the initial stage. But in this fossil wing we find nothing of the sort; no one of the concentric lines or grooves are continuous with any of the neighboring veins. The only appearances which favor such a view are: (1) the openness of the neuration at this point, which allows this great sear to lie at the hase of the wing without disturbing more than one of the veins; (2) the curve of the anal vein, which has the appearance of passing around this obstruction; but the course of which is in keeping with the curve of the lower margin of the wing, equally explaining it; and (3) the curve of the cross veins in the neighborhood of the scar, as seen on either side of the lower internomedian branch in fig. 5; which veins, however, when narrowly examined, are seen to form angles with the more prominent concentric grooves and ridges. 'These ridges, too, are not of a form suitable for the production of sound, the depressions or elevations being extremely smooth and gradual; they are also of very unequal size and thickness; they do not occur in the anal area, as in all Locustariae, but in the internomedian; 
and they have just sufficient regularity to render it most probable that the central, irregular, rough, and slightly elevated mass is either the relic of a foreign substance, which hat fallen upon the winge, sulserguent pressure upon which, when the menbrane of the wing formed, so to speak, a part of the floor upon which it lay, has caused the mud and membrane together to assume the present appearance; or, that we chance here to have stumbled on a wing which, in the nynph condition, has met with some arcident, producing in the intago a blister-like distortion, such as those figured by Mocquerys, as sugerested to me by Dr. Hagen, in the elytra of Carabus monitis, Mesomphatia gibba, Timarcha rugosa, and as must have been observed in the veined wings of insects of the other orders by all entomologists. This last supposition would better account for the greater prominences of the peculiar markings around one part of the scar than elsewhere, and for the apparent partial conformity of the cross venation to the contour of the scar. Whichever way it be considered, it does not now appear to me reasonable to maintain my former hypothesis of a stridulating organ, to which nevertheless there is, as stated, a remarkable general resemblance. That such a stridulating organ would be a great anomaly no one can question, and the proposition should not be maintained in the face of the objections which careful and prolonged study and comparison elicit.

But putting aside its extraneous features, we may discuss the affinities of this insect on the hasis of the unquestionable characteristics of its neuration, and shall find in these enough to excite our interest and even to perplex us. In its general features the wing is plainly nemropterous. It would appear from the strength of the margin to be an upper wing, and in its form to resmble that of many true Nemroptera; its sweeping forking branches with direct transverse cross venation attest the same proposition, but when we come to compare it with known types, we shall find it extremely difficult to place it. Its very open neuration is one general feature which is peculiar; the presence of two or three very prominent cross veins, with an extreme multitude of feeble cross veins never breaking up into an irregular reticulation, is certainly strange; so is the temination of the mediastinal vein, and still more the entire simplicity and extreme separation of the internomedian veins, occupying so large an area of the wing without a fork, and connected in so unusual a manner with the veins on either side; the apparent absolute amalgamation of the bases of the scapular and externomedian veins in such early insects is very unexpected; - and all combine to form an ensemble which is the odder for the general simplicity of the neuration. It would be hard to say which is the most prominent vein in the wing; the scapular, externomedian and internomedian occupy about equal areas, and while the two former branch more than the latter, their nervules are comparatively much feebler.

In the openness and sparseness of the neuration and in the paucity (but not at all in the position) of the principal cross veins, it bears a certain resemblance to the Coniopterygidae and to no other neuropterous family; but the differences are far greater and more important than the resemblances and scarcely need be stated.

There are also some features which give it a sialidan appearance; if we suppose, as we may, that the second nervule reaching the margin below the main scapular vein arises from the main scapular branch, we shall have a condition of the scapular vein very like that of the sialinil, excepting in the slight number of offshoots from its branch, which would be very abnormal; in the near or actual amalgamation of the externomedian 
with the scapular vein, there is also nothing to separate it from the Sialina, excepting their amalgamation for so great a distance; but the structure of all the other veins and the peculiarities of the cross renation is very different from the same points in the Sinlina.

In the course of most of the main veins and their mode of branching, it has some resemhlince to the Rilphidiidae, but it has no affinity whatever with that group in the peculiar directions of the nervules and their comnection by distant cross veins, so as to form large polygonal cells, which is one of the most striking of the characteristic features of Raphidiidae.

The apical two-thirds of the wing (exchuling, therefore, the attachments of most of the veins) are in sufficient harmony with these parts in the carhoniferous Dictyoneurae to presume, at first, that the wing will fall in the ancient order of Palacolictyoptera. As yet, however, we know too little of the extent and even of the peculiar characteristics of this group to say whether or not the structure of the base of the wing will allow its location here; certainly it will not admit its being placed in the same family with the genus Dietyoneura; and at present this is, perhaps, all that we can say until the structure of all the ancient wings shall have been most carefully studied.

It is in large measure in those points of structure which Dictyoneura shares with the Ephemeridae, that Xenoneura is comparable to the former, and we therefore see in this wing ephemeridan, sialidan, raphidian and coniopterygidan features, combined with others peculiar to itself. Whatever the closest affinities of the wing may prove to be, it must certainly, by its combination of characters, lridge over the gulf now separating the wing features of Neuroptera and Pseudoneuroptera; and these various considerations assure us of its family distinction from any known ancient or modern type of Neuroptera, and of the propriety of applying to the group it represents the family name of Xenoneuridae.

This species, with Gerephemera simplex, came from the lowest insect-producing beds of the Lancaster Shales, called plant bed No. 2, by Professor Hartt.

\section{X. General Sumiary.}

It only remains to sum up the results of this re-examination of the devonian insects, and especially to discuss their relation to later or now existing types. This may best be done by a separate consideration of the following points:

1. There is nothing in the structure of these earliest known insects to interfere with a former conclusion ${ }^{1}$ that the general type of wing structure has remained unaltered from the earliest times. Three of these six insects (Gerephemera, Homothetus and Xenoneura) have been shown to possess a very peculiar neuration, dissimilar from both carboniferous and modern types. As will also be shown under the tenth head, the dissimilarity of structure of all the devonian insects is much greater than would be anticipaterl; yet all the features of neuration can be brought into perfect harmony with the system laid down by Heer.

2. These earliest insects were hexapods, and as far as the record goes preceded in time both arachnids and myriapods. This is shown only by the wings, which in all known insects belong only to hexapods, and in the nature of thing's prove the earlice apparition of that group. 'This, however, is so improbable on any hypothesis, that we must conclude the record to be defective. 
3. They were all lower Heterometabola. As wings are the only parts preserved, we cannot tell from the remains themselves whether they belong to sucking or to biting insects; for, as was shown in the essay already referred to, this point must be considered undetermined concerning many of the oldest insects until more complete remains are discovered.

They are all allied or belong to the Neuroptera, using the word in its widest sense. At least two of the genera (Platephemera and Gerephemera) must be considered as having a closer relationship to Pseudoneuroptera than to Neuroptera proper, and as having indeded no special affinity to the true Neuroptera other than is found in Palaeodictyoptera. Two others (Lithentomum and Xenoneura), on the contrary, are plainly more nearly related to the true Neuroptera than to the Pseudoneuroptera, and also show no special affinity to true Neuroptera other than is foum in Palateolictyoptera. A fifth (Homothetus), which has comparatively little in common with the Palaconlictyoptera, is perhaps more nearly related to the true Neuroptera than to the Pseudoneuroptera, although its psendoneuropterous characters are of a striking nature. Of the sixth (Dyscritus) the remains are far too imperfect to jutge clearly, hut the choice lies rather with the Preudoneuroptera or with Homothetus. The devonian insects are then about equally divided in structural features betreen Neuroptera proper and Pseurloneuroptera, and none exhibit any special orthopterous, hemipterous or coleopterous characteristics.

4. Nearly all are synthetic types of a comparatively narrow range. This has been stated in substance in the preceding paragraph, but maly receive arditional illustration here. Thus Platephemera may be looked upon as an ephemerid with an odonate reticulation; Homothetus might be designated as a sialid with an odonate structure of the main branch of the scapular vein; and under each of the species will be found detailed accounts of any combination of characters which it possesses.

5. Nearly all bear marks of affinity to the carboniferous Palacodictyoptera, either in the reticulated surface of the wing, its longitudinal neuration, or both. But besides this there are some, such as Gerephemera and Xenoneura, in which the resemblance is markerl. Most of the species, however, even including the two mentioned, show palacodictyopteran characters only on what might be called the neuropterous side; and their divergence from the carboniferous Palaeodictyoptera is so great that they can scarcely be placed directly with the mass of palaeozoic insects, where we find a very common type of wing structure, into which the neuration of devonian insects only partially fits. For:

6. On the other hand, they are often of more and not less complicated structure than most Paldeodictyoptere. This is true of the three genera mentioned above with peculiar neuration, but not necessarily of the others, and it especially true when they are compared with the grenus Dictyonema and its immediate allies. There are other Palaeodictyoptera in the carloniferous period with more complicated neuration than Dictyoneura, but these three devonian insects apparently surpass them, as well as very nearly all other carboniferous insects. Furthermore:

7. With the exception of the general statement under the fifth head, they bear little special relation to carboniferous forms, having a distinet facies of their own. 'This is very striking; it would certainly not be possible to collect six wings in one locality in the carboniferous rocks, which would not prove, by their affinity with those already 
known, the carboniferous age of the deposit. Yet we find in this devonian locality not a single one of the Palaeoblattariae or anything resembling them; and more than half the known insects of the carboniferous period belong to that type. The next most prevailing carboniferous type is Dictyoneura and its near allies, with their reticulated wings. Gerephemera only, of all the devonian insects, shows any real and close affinity with them; and even here the details of the wing structure, as shown above, are very different. The apical half of the wing of Xenoneura (as I have supposed it to be formed) also bears a striking resemblance to the dictyoneuran wing; but the base, which is preserved, and where the more important features lie, is totally different. The only other wing which shows particular resemblance to any carboniferous form (we must omit Dyscritus from this consideration, as being too imperfect to be of any value) is Platephemera, where we find a certain general resemblance to Ephemerites Riickerti Gein., and Acridites priscus Andr., but this is simply in the form of the wing and the general course of the nervules; when we examine the details of the neuration more closely we find it altogether different, and the reticulation of the wing polygonal and not quadrate as in the carboniferous types. ${ }^{1}$ In this respect indeed, Platephemera differs not only from all modern Ephemeridae, but also from those of other geological periods.2 Another prevailing carboniferous type, the Termitina, is altogether absent from the devonian. Ifalf a dozen wings, therefore, from rocks known to be either devonian or carboniferous, would probably establish their age.

8. The devonian insects were of great size, had membranous wings, and were probably aquatic in early life. The last statement is simply inferred from the fact that all the modern types most nearly allied to them are now aquatic. As to the first, some statements have already been made; their expanse of wing probably varied from 40 to 175 $\mathrm{mm}$. and averaged $107 \mathrm{~mm}$. Xenoneura was much smaller than any of the others, its expanse not exceeding four centimetres, while the probable expanse of all the rest was generally more than a decimeter, only Homothetus filling helow this figure. Indeed if Xenoneura be omitted, the average expanse of wing was $121 \mathrm{~mm}$., an expanse which might well be compared to that of the Aeschnidae, the largest, as a group, of living Odonata. There is no trace of coriaceous structure in any of the wings, nor in any are there thickened and approximate nervules - one stage of the approach to a coriaceous texture.

9. Some of the devonian insects are plainly precursors of existing forms, while others seem to have left no trace. The best examples of the former are Platephemera, an aberrant form of an existing family; and Homothetus. which, while totally different in the combination of its chatracters from anything known among living or fossil incects, is the only palaeozoic insect posessing that peculiar arrangement of reins foumd at the base of the wings in Odonata, typified by the arculus, a strueture previonsly known only ats early as

1 Dr. II. B. Geinitz has kindly re-examined Ephemeriles Rückerli at my request, and states that the reticulation is in general tetragonal, but that at the extreme outer margin the cells appear in a few places to be elliptical five- or sixsided.
2 The Dictyoneurae and their allies, as may be inferred, are considered as belonging to the Palaeodictyoptera, although their ephemeridan affinities are not disregarded. 
the jurassic. Examples of the latter are Gerephemera, which has a multiplicity of simple parallel veins, next the costal margin of the wing, such as no other insect, ancient or modern. is known to posess; and Xenoneura, where the relationship of the internomedian branches to each other and to the rest of the wing is altogether abnormal. If too, the concentrie ridges, formerly interpreted by me as possibly representing a stridulating organ, should eventually be proved an actual part of the wing, we should have here a structure which has never since been repeated even in any modified form.

10. They show a remarkable variety of structure, indicating an abundance of insect life at that epoch. This is the more noticeable from their belonging to a single type of forms, as stated under the seventh head, where we have seen that their neuration does not accord with the commoner type of wing structure found in palaeozoic insects. ${ }^{1}$ These six wings exhibit a diversity of neuration quite as great as is found among the hundred or more species of the carboniferous epoch; in some, such as Platephemera, the structure is very simple; in others, like Homothetus and Xenoneura, it is somewhat complicated; some of the wings, as Platephemera and Gerephemera, are reticulated; the others possess only transverse cross veins more or less distinct and direct. No two wings can be referred to the same fimily, unless Dyscritus belongs with Ifomothetus - a point which camnot be determined from the great imperfection of the former. This compels us to admit the strong probability of an abundant insect fauma at that epoch; although many palaeozoic localities can boast a greater diversity of insect types, if we look upon their general structure as developed in after ages, not one in the world has produced wings exhibiting in themselves a wider diversity of neuration; for the neuration of the Palaeodictyoptera is not more essentially distinct from that of the Palaeoblattariae or of the ancient Termitina, than that of Platephemera or Gerephemera on the one hand is from that of Homothetus or of Xenoneura on the other. Unconsciously, perhaps, we allow our knowledge of existing types and their past history to modify our appreciation of distinctions between ancient forms. For while we can plainly see in the Palacoblattariae the progenitors of living insects of one order, and in other ancient types the ancestors of living representatives of another order; were we unfmiliar with the divergence of these orders in molern times, we should not think of separating ordinally their ancestors of the carboniferous epoch. It may easily be seen, then, how it is possible to find in these devonian invets - all Neuroptera or nemopterous Palaeodictyoptera - a diversity of wing structure greater than is found in the carboniferous representatives of the modern Neuroptera, Orthoptera and Hemiptera.

11. The devonian insects also differ remarkably from all other known types, ancient or modern; and some of them appear to be even more complicated than their nearest living allies. With the exception of Platephemera, not one of them can be referred to any family of insects previously known, living or fossil; and even Platephemera, as shown above, diflers strikingly from all other members of the family in which it is placed, both in general neuration and in reticulation; to a greater degree even than the most aberrant genera of that family do from the normal type. This same genus is also more complicated in wing structure than its modern allies; the reticulation of the wing in certain 
structurally defined areas is polyenonal and tolerably legular, instear of being simply quartrate; while the intercalated veins are all comnected at their base, instead of being free. Xenoneura also, as compared with modern Sialina, shows what should perhaps be deemed a higher (or at least a later) type of structure, in the amalgamation of the externomedian and scapular veins for a long distance from the base, and in the peculiar structure and lateral attachments of the internomedian veins; in the minuter and feebler cross venation, however, it has an opposite character.

12. We appear, therefore, to be no nearer the begiming of things in the devonian epoch, than in the carboniferous, so far as either greater unity or simplicity of structure is concerned; and these earlier forms cannot be used to any better advantage than the carboniferous types in support of ahy special theory of the origin of insects. All such theories have required some Zoaea, Leptus, Campodea, or other simple wingless form as the foundation point; and this ancestral form, according to Haeckel at least, must be looked for above the silurian rocks. Yet we have in the devonian no traces whatever of such forms, but on the contrary, as far down as the middle of this period, winged insects with rather highly differentiated structure, which, taken together, can be considered lower than the mass of the upper carboniferous insects, only by the absence of the very few Hemiptera and Coleoptera which the latter can boast. Remove those few insects from consideration (or simply leave out of mind their future development to very distinct types), and the middle devonian insects would not suffer in the comparison with those of the upper carboniferous, either in complication or in diversity of structure. Furthermore, they show no sort of approach toward either of the lower wingless forms, hypothetically looked upon as the ancestors of tracheate Articulata.

13. Finally, while there are some forms which, to some degree, bear out expectations based on the general derivative hypothesis of structural development, there are quite as many which are altogether unexpected, and cannot be explained by that theory, without involving suppositions for which no facts can at present be adduced. Palephemera and Gerephemera are unquestionably insects of a very low organization related to the existing may-flies, which are well known to be of inferior structure, as compared with other living insects; these may-flies are indeed among the most dergrarled of the sub-order to which they belong, itself one of the very lowest sub-orders. Dyseritus too may be of similar degradation, although its resemblance to Homothetus leaves it altogether uncertain. But no one of these exhibits any inferiority of structure when compared with its nearest allies in the later carboniferous rocks, ambl they are all higher than some which might be named. While of the remaining species it can be confidentially asserted that they are higher in structure than most of the carboniferous types, and exhibit syntheses of character differing from theirs. It is quite as if we were on two distinct lines of descent when we study the devonian and the carboniferous insects; they have little in common, and each its peculiar comprehensive types. Judging from this point of view, it would be impossible to say that the devonian insects showed either a broader synthesis or a ruder type than the carboniferous. This of course may be, and in all probability is, because our knowledge of carboniferous insects is, in comparison, so much more extensive; but, judging simply by the facts at hand, it appears that the carboniferous insects carry us back both to the 
more simple and to the more creneralized forms. We have nothing in the deronian so simple as Euephemerites, nothing so comprehensive as Eugereon, nothing at once so simple and comprehensive as Dictyonema. On the derivative hypothesis, we must presume, from our present knowlerge of devonian insects, that the Palacolictyoptera of the carboniferous are already, in that epoch, an old and persistent embryonic type (as the living Ephemeridae may be considered to-day, on a narrower but more lengthened scile); that some other insects of carboniferous times, together with most of those of the devonian, descended from a common stock in the lower devonian or silurian period; and that the union of these with the Palaeodictyoptera was even further removed from us in time; - carrying back the origin of winged insects to a far remoter antiquity than has ever been ascribed to them; and necessitating a faith in the derivative hypothesis, which a study of the records preserved in the rocks could never alone afford; for no evidence can be adduced in its favor based only on such investigations. The profound voids in our knowledge of the earliest history of insects, to which allusion was made at the close of my paper on the Early types of insects, are thus shown to be even greater and more obscure than had been presumed. But I should hesitate to close this summary without expressing the conviction that some such carlier unknown comprehensive types as are indicated ahove did exist and should be sought.

X. Note on the Geological Relations of the Fossil Irsects from the DevoNian of New Brunswick. By Principal Dawson, LL.D., F.R.S., \&c.

The heds affording these remains occur in the vicinity of the city of St. Joln, New Brunswick, and are well exposed on the shores of Courtney Bay, on the east side of the city, and at Duck Cove, Lancaster, on its western side. They consist of sandstones, shales, and conglomerates, having an aggregate thichness of about 7,500 feet, as shown in the following generalized section, in ascending order:-

1. Bloomstury Conglomerate - Reddish-gray conglomerate with interstratified hard red shale.

500 feet.

2. Dadoxylon Sondstone - (Lower part of Little River Group in my Acadian Geology). Gray sandstone and grit, with beds of gray and black graphitic shale - Fosil plants, etc. 2,800 feet.

3. Cordaite Shates - (Upper part of the Little River Group) - red, gray and black shales, with beds of sandstone and conglomerate - Fossil Plants, etc.

4. Mispec Conglomerate - Red conglomerate and shale. 2,400 feet. 1,800 feet.

In the vicinity of St. John, these beds rest on cambrian rocks of the Acadian (Menevian) sroup, and are overlain unconformathy by lower carboniferous ("sub-carboniferous") conglomerates, which in their extension eastivard are associated with the Albert shales holding fossil fishes and plants of characteristic lower carhoniferous types.. Elsewhere in

\footnotetext{
1 Report of Bailey and Mathew, Geol. Survey of Canada, 1871. In the author's Acadian Geology, the thickness is given as 9500 feet; but later observations have reduced the thickness of the lower members.
}

\footnotetext{
${ }^{2}$ See for details the author's Acadian Geology, $3 \mathbf{d}$ Edition.
} 
Southern New Brunswick, they overlie laurentian and huronian rocks, and are seen to rise unconformably from beneath the carboniferous rocks of the great central coal-formation area of New Brunswick. ${ }^{1}$ They are everywhere more disturbed and altered than the overlying carboniferous beds; and Messrs. Bailey and Matthew have shown that certain intrusive masies and dykes of granite, known to be of pre-carboniferous age, were erupted subsequently to the deposition of these beds.

The vegetable fossils of this formation are very numerous. I have catalogued or described from it upwaths of 50 species, belonging to the genera Datloxylon, Sigillaria, Calamites, Asterophyllites, Lepidodendron, Cordaites, Psilophyton, Neuropteris, Sphenopteris, Itymenophyllites, Pecopteris, \&e.; the whole constituting a well-marked devonian assemblage, distinguishable from the upper devonian flora of Perry in Matine, which is perhaps newer than the Mispec conglomerate, and still more distinct from the lower carboniferous flora of New Brunswick and Nova Scotia, while on the other ham it is incomparably better developed than any known flora of silurian age. Owing to the richness of this flora, and to the fact that some genera and species of plants appear earlier in North America than in Europe, some Europen jalacubotanists have been unwilling to admit the devonian age of this formation, but entrely without good reason.

That some of the species of the St. John beds, as Caltumites transitionis (=C. ructiutus of Brongniart), are found in the lower carboniferous of Europe, is not wonderful, as in the devonian as well as in subsequent periods the flora of Americi has been somewhat in advance of that of Europe. Still the prevalent plants in the St. Joln beds are distinctively erian or devonian and not carboniferous. Further, recent discoveries of tree-ferns and petioles of ferns in great abundance in the devonian of New York, and as low as the IIamilton group, have shown that the devonian must have been even more remarkable than the carboniferous for the aluundance and variety of its ferns. A few additional species of ferns found among specimens remaining in Professor IIartt's collections will shortly be described.

The crustaceans recognized in these beds are Euryplerus puticeris Salter; Amphipeltis paradoxus Salter, a precursor of the Stomapods; and a pyogidium of a small trilobite, unfortunately too imperfect for determination. A species of Spirorbis, which I have described as $S$. erianus, ${ }^{2}$ occurs attached to leaves of Cordaites, and is distinct from the common Spirorbis of the coal-measures (S. carbonarius or pusillus). A fragment of a spiral shell may possibly represent a devonian pulmonate, and will be noticed in a forthcoming paper on the pulmonates of the carboniferous. No other animal remains have been found in these beds, except the fossil insects. The comditions of deposit were probally estuarine rather than marine, and the abundant fossil plints testify to the proximity of land.

It is difficult to correlate the subdivisions of the devonian in eastern Canada, with those in the great erian area of New York and western Canada, owing to the absence of the marine limestones, so characteristic of the latter. In my report on the fossil plants of the devonian and upper silurian of Cantala, I have, however, stated some grounds

1 Bailey and Matthew's Reports, which see also for details of the structure and relations of the devonian and associated formations, in southern New Brunswick.
2 Report on devoniau plants. Geol. Surv. Canada, 1871.

${ }^{8}$ Geol. Survey of Canada, 1871. 
for helieving that the Dadoxylon sanditone and Cordaite shales may be equiralents of the Hamilton group in New York and Ohio, which has aforded some fosil plants comparable with those of the st. John heds, expecially trunks of conifers of the genus Dradorylon (Amueroroxylon). The horizon of the fussil insects of St. John would thus be middle devonian.

In the finer shales of this series, the remains of plants are very perfectly preserved, the most delicate leaves having not only their outlines but also their nervature represented by films and lines of shining graplite, resembling pencil drawings on a dark gray ground. 'The insect wings are preserved in a similar manner.

The discovery of the insect remains is wholly due to the late Prof. C. F. Hartt, who, with the aid of other gentlemen, members of the Natural History Society of New Brunswick, removed by blasting lange quantities of the richest fossiliferous beds and examined them with great care. The extreme rarity of these remains renders it probable that but for the large quantities of material examined by Professor Hartt, they would not have been found; while the extrene delicacy of the impressions would have prevented them from heing observed except by a very careful collector scrutinizing every surface in the search for leaflets of ferms, preserved in such a way as to be visible only under the most favorable light. These unusually perfect explorations should be taken into the account in any comparisons made of the fossils of this locality with those of other places.

The following detailed section of the Little River Group, at the Fern Ledges, Lancaster, N. B., where the insects occur, is derived from Professor Hartt's paper in Bailey and Matthew's report before alluded to, and is substantially the same as given in my Acadian Geology.

\section{Section at the "Fern Ledges." (Order ascending.)}

Heavy beds of gray sandstone and flags (Dadoxylon sandstone). Dadoxylon ouangondianum Daws., Calamites, etc. Thickness, by estimation, 300 feet. Under this head I have classed all the beds underlying the Plant-bed No. 1, which I am disposed to regard as the lowest of the rich plant-bearing layers, and the base of the Cordaite shales. These beds occupy the low ground lying between the ridge of the Bloomsbury group and the shore. They are covered by drift, and show themselves only in limited outcrops, and in the ledges on the shore. In the western part of the ledges they are thrown forward on the beach by a fault, forming a prominent mass of rock, in the summit of which a fine trunk of Dadoxylon is seen embedded in the sandstone. Recent excavations made in these beds in quarrying stone for building purposes, in the eastern part of the locality, where the rocks are very much broken up by dislocations, have exposed numerous badly preserved impressions of large trunks of this tree.

Plant-Bed No. 1 .

Thickness, 1 foot.

Black arenaceous shale, varying from a fissile sandstone to a semi-papyraceous shale, very fine-grained and very fistile, charged most richly with beautifully preserved remains of plants, among which are the following species:-

Calamites transitionis Goeppert. (C. radiatus $B r$. ) Occasional, in large, erect specimens.-Asterophyllites latifolia Daws. Extremely abundant, often showing ten or twelve whorls of leaves, sometimes with many branches.-A. acicularis Daws. Also 
very abundant- $A$. scutigera Daws. The curious stems of this species, with their scale-armed nodes, occur abundantly in this bed.-Sphenophyllum antiquum Daws.-Pecopteris obscura Lesqx.-Sphenopteris sp.?-Cardiocarpum cornutum Daws. Rare.-Psilophyton elegans Daws. Occasional. I have never detected any trace of Cordaites Robbii Daws., in this bed. It is extremely common in the overlying strata.

Gray sandstones and flags, with occasional ill-preserved plants, Calcmites transitionis Goeppt.-Cordaites Robbii Daws.-Asterophyllites and Stembergiae . 2 feet 6 in.

Black arenaceous shales of the same character as those of Plant-bed No. 1, but without fossils, so far as I have examined.

11 inches.

Compact flaggy, gray sandstone, with badly preserved plant remains, Calamites, etc.

Very soft, dark, lead-colored shales, much slicken-sided and charged with frag-

2 feet.

ments of plants. This bed is so soft that the action of the weather and the sea have everywhere denuded it to the level of the beach

4 feet.

Plant-bed No. 2.

1 foot.

At the point where the section crosses the bed, and where I first discovered it, it consists of very compact and hard, light lead-coloured, slate-like, arenaceous shale; but the character of the shale varies much in its different exposures, being sometimes very soft and fissile, and of a very black colour. The following is the list of species which it affords:-

Calamites transitionis Goeppt. Occasionally; never in good specimens.-C. cannaeformis Brongn. Occasionally; never in good specimens-Asterophyllites acicularis Daws. Rather rare-A. latifolia Daws. Rather rare.-A. longifolia Brongn. (?). Rather rare-A. parvula Daws. Whorls of a minute Asterophyllites, which may belong to this species, are not infrequent in this bed. - Sporangites acuminata Daws.-Pinmularia dispalans Daws. Abundant.-Psilophyton elegans Daws. Quite common, always in fragments, never in good specimens.$P$. glabrum Daws. Flattened stems, with a wavy woody axis traced in a brighter line of graphite, occur in this bed, but always in fragments.-Cordaites Robbii Daws. Extremely abundant, and very fine specimens may be obtained, especially from the upper part of the bed, and rarely specimens showing the base or the apex of the leaf.-Cyclopteris obtusa Lesqx. Occurs very abundantly in detached pinnules.-C. varia Daws. Rare.-Neuropteris polymorpha Daws. Extremely abundant, never in large frond-S - Sphenopteris Hoeninghausii Brongn. Quite abundant, often in fine fronds.-S. marginuta Daws. Abundant, in fine fionds. -S. Hartii Daws. Very rare-The original specimen came from this bed.IIymenophyllites G'ersclarffii Goeppt. Rather rare-II. obtusilobus Goeppt. Rare. -H. curtilobus Daws.-Alethopteris discrepans Daws. Amongst all the abundance of plants afforded by Plant-bed No. 2, I have detected only one or two pinnules of this fern, which appears first in abundance in Plant-bed No. 3. It is afterwards one of the most common species.-Pecopteris-ingens Daws. Very rare, only two or three fragments of pinmules having been found.-Trichomanites (?) Only a sincrle specimen, probably, as Dawson has suggested, only the skeleton of a fern.-Car- 
diocarpum cormutum Daws. Abundant, and very finely preserved, never attached -C. obliquem Daws. Quite abundant, also never attached.-Trigonocarpum racemosum Daws. Rare-Euryplerus pulicaris Salter. The occurrence in Plantbed No. 2 of this minute crustacean was first detected by my friend Mr. George Matthew. It is very rare, not more than four or five specimens having been found by Messrs. Matthew, Payne, and myself at the time of the description of the species by Salter. I have since that time succeeded in collecting nearly twice as many more, some of which, appear to belong to a new species.-Amphipeltis paradoxus Salter. The specimen figured in Salter's paper was found by Professor Dawson and inyself, in breaking a piece of shale in my cabinet, that came from this bed. Only one other specimen has since been obtained. It consists of two or more of the thoracic segments, and was collected by Mr. Lunn. It is in the collection of the Natural History Society of New Brunswick. In addition to the above species, this bed has aflorded the following:-Cyclopteris, sp. nov-Neuropteris, sp. nov. A single specimen collected by Mr. Lunn. - Sphenopteris, sp. nov.-Spirorbis eriamus Daws. The leaves of Cordaites in the upper part of the bed are as thickly covered with a little Spirorbis as are the fronds of the recent fucoids of the Ledges. The specimens are poorly preserved. - Trilobites. Mr. Payne collected a minute trilobite from from this bed, but it proved not determinable.-Insect Remains! In the summer of 1862, I discovered an organism in Plant-bed No. 2, which at the time I could make nothing of; but which I have since proved to be the wing of an insect. Several weeks after, I found in Plant-bed No. 8 an unequivocal insect's wing. 'This discovery was followed by that of others, my father, J. W. Hartt, finding another in this bed. [The insects of this bed are Gerephemera simplex and Xenoneura aytiquorum.]

Compact flaggy sandstone, quite barren . . . . . . 5 feet 10 inches. PlaNT-Bed No. 3. . . . . . . . . 10 inches.

Black and lead-colored shales, quite compact in upper part, but in lower very crumbling, splitting irregularly, slicken-sided, often with polished surfuces, and traversed by thin quartz-veins. These shales are so soft that the sea and weather have everywhere denuded them to the level of the beach. There are now no exposures of the bed workable. The following are the fossils which occur in it:-

Calamites transitionis Goeppt. Occasionally. - C. cannaeformis Brongn. - Asterophyllites latifolia Daws. Very beautiful whorls of this plant are very common here, the whorls, though usually detached, being sometimes found united three or four together.-Sporangites acuminata Daws. Common.-Pinmularia dispatans Daws. Common.-Psilophyton elegans Daws. Occasionally.-P.(?) glabrum Daws. Occasionally.-Cordaites Robzii Daws. Extremely abundant, but not so well preserved as in Plant-bed No. 2. Leaves usually appear as polished bands of graphite, with venation obliterated.-Cyclopteris obtusa Lesqx. Not very abundant. - Neuropteris polymorpha Daws. In beautiful specimens, common.-Sphenopteris marginata Daws. Notcommon.-S. Hoeninghausii Brongn. Not common.-Pecopteris (Alethopteris) discrepans Daws. It was here that I first discovered this species. It occurs quite abundantly, but always in fragments._Cardiocarpum cornutum Daws. Quite common.-C. obliquem Daws. Quite common. 
Coarse sandistone, full of obscure casts of Stembergicle and Calamites . 6 feet 6 inches. Soft shale and fissile sandstone, with Calamites . . . . . . $3 \frac{1}{2}$ " Sandstones .

Shale with obscure remains of plants.

Sandstones, barren, so far as examined

Sandstone and shale, with a few Calamites and Cordaites

Sandstone and coarse shale, with obscure markings

Light greenish, coarse shale, with fern-stems, Cordaites, and obscure

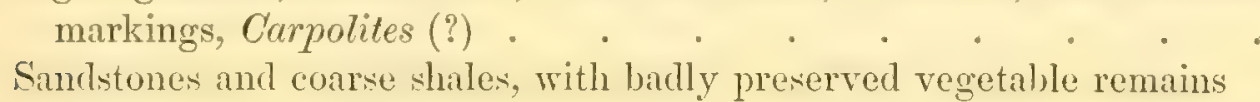

Plant-Bed No. 4.

2 feet $3^{2}$

$2 \frac{1}{2} \quad 66$

4 feet 10

96

5 feet 10 "6

Coarse shales, affording at the point where the line of section crosses it: -

Cordaites Robbii Dams.-Calamites transitionis Goeppt.-Nenropteris polymorpha

Daws.-Psilophyton glabrum Daws.-Pinmelaria dispalans Daws.

I have examined at two different points, in the eastern part of this locality, a bed which appears to correspond to this. It is characterized there by a very beautiful Neuropteris ${ }^{1}$ ( N. Dowsoni Intrt) with long linear lanceolate pinnules decurrent on the rachis, to which they form a broad wing. The pinnules are often four inches in length. This is one of the most beatiful ferns occurring at the locality. Several other new forms are associated with it. Among these is a magnificent Cardiocarpun, nearly two inches in diameter ( $C$. Baileyi Daws.).

Sandstone with obscure markings . . . . . . . 9 feet 6 inches.

Playt-Bed No. 5

Soft, fine-grained light-greenish shale.

Corlaites Robbii Daws. Extremely abundant. - Calamites camaeformis Brongn. Found occasionally.-Psilophyton (?) glabrum Daws.-(?) Asterophyllites acicularis Daws. - Alethopteris discrepans Daws. Quite abundant. Sphenopteris marginata Daws. Quite abundant.-Pecopteris, sp. nov. (?) - Hymenophyllites sp. (?)-Neuropteris polymorpha Daws. Very abundant-Spirorbis occurs in the bed, attached to the leaves of Cordaites. I have never detected it in any of the beds higher up.

Compact flaggy sandstones and coarse shales, with a few plants. . . . 8 feet. Plant-bed No. 6. . . . . . . . . . . 2 feet.

Fine-gramed and light-coloured shale, with great abundance of Cordrites Robbii, and Calamites transitionis; above that a layer of coarse shale, with Cordaites and stems of plants badly preserved; then a layer of soft, very friable shale, with few fossils; and lastly, a layer of coarse shale of a greenish-gray colour, with:-

Alethopteris discrepans Daws. Abundant.Cordaites Robbii Daws. Abundant.Calamites cannaeformis Brongn.-Neuropteris polymorpha Daws.-Cardiocarpum cormetum Daws.-Curdiocrerpmen obliqum Daws.-Pecopteris, sp. nov. Occurs abundantly in some of the overlying beds.

Sandstones and coarse shales, with abundance of plant remains, principally Cordaites and Calamites

5 feet.

${ }^{1}$ This plant belongs to a new genus, subsequently named Megalopteris. Report on devonian plants of Canada, 1871. 
Plant-Bed No. 7

2 feet.

This is one of the richest plant-beds of the section. The shales composing it vary much in character in different exposures. They are for the most part of a gray colour and compact, like a fine-grained sandstone, though they pass into a light brownish, very fissile, soft shale, and there are some layers of a very black colour.

Cordaites Robbii Daws. Very abundant, and in a beautiful state of preservation.Calmmites transitionis Goeppt. Not abunlant as good specimens.-C. crnncueformis Brongn. Rare.-(?)Asterophyllites acicularis Daws. In very beautiful specimens, very common in certain thin layers. There are two or three other species, occurring also in the overlying beds, which appear to be new.-Sporangites acuminata Daws. Extremely plentiful. - Pinmularia dispalans Daws. Extremely plentiful.(?) Psilophyton elegans Daws. I have obtained several specimens of a Psilophyton growing in tufts, and closely resembling this species.-Neuropteris polymorpha Daws. Occasional.-Alethopteris discrepans Daws. Abundant, and obtainable in good specimens._Cyclopteris obtusa Lesqx. Occasional.-Sphenopteris marginata Daws.-Hymenophyllites subfurcatus Daws._Cardiocarpum cormutum Daws. Quite abundant.C. obliquem Daws. Quite abundant. - C. Crampii Hartt. Alethopteris Perleyi Hartt.-Sphenopteris pilosa Daws.-Several other plants not yet determined.-Insects. A single insect's wing was obtained from this bed by my father and myself. [PLATEPHEMera antiQua.]

Compact sandstone and coarse shales (barren of fossils) . . . . . 3 feet. Plant-bed No. 8.

1 foot 10 inches.

Fine-rrained, tough, but fissile sandstones, rather coarse shales, often of a greenish cast, and at the top a thin layer of very black shale very rich in plants. The middle portion does not contain so many plant remains, but the lower is as well stocked as the leaves of an herbarium. The following are the fossils I have collected from it:-

Cordaites Robbii Daws. As usual in great profusion, and in very fine specimens.Calamites transitionis Goeppt. Occasional.—C. cannaeformis Brongn.-(?) Asterophyllites acicularis Daws. Quite common, together with one or two other species apparently new, which occur also in Bed 7.-Ammlaria acuminata Daws. Extremely common, especially in certain layers.-Pimularia dispalans Daws. Abundant.-(?) Lycopodites Mathewi Daws. Rare.-Cyclopteris obtusa Isesqx.-Cyclopteris, sp. nov.-Neuropteris polymorpha Daws. Quite frequent in detached pinnules. - Hymenophyllites subfurcatus Daws. Very common. - Alethopteris discrepans Daws. This is the most abundant fern in this bed. It occurs usually in detached pinnules, though not unfrequently in considerable fronds.-Alethopteris. Besides the above, there are three or four other species, some of which occur also in Beds 6 and $7^{1}$.-Cardiocarpum cormutum Daws. Not very common.-C. obliquum Daws. Also not very common.-C. Crampii Hartt. Quite common.-Several other species of plants not yet determined.-Insects. Two species, two specimens. One was obtained by my friend, Mr. James Hegan. [Three insects were obtained from the bed: Honotuetus fossilis, Discritus vetustus and Lithentomum Harttir.]

\footnotetext{
1 Probably the species afterwards described (Dr. Dawson's Report of 1871) as Alcthopteris Perleyi Hartt, Pecopteris
}

servilata Hart, and Pecopleris preciosa Hartt. 


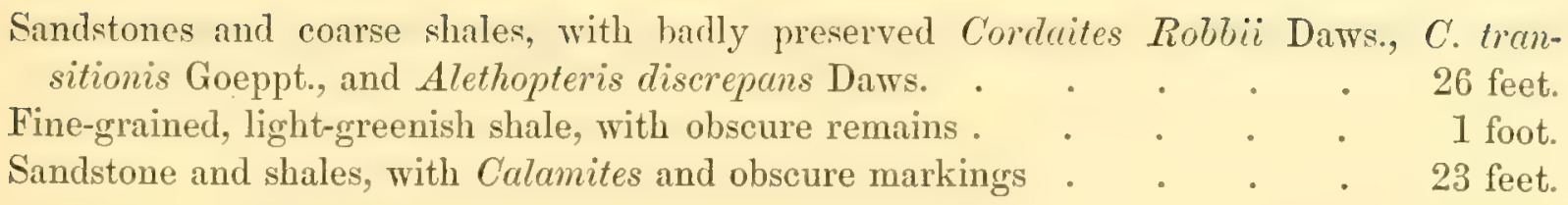

Total thickness of the beds embraced in this section . . . 440 feet, 11 inches.

\section{EXPLANATION OF PLATE.}

Fig. 1. Homothetus fossilis (magn. $\frac{2}{1}$ ). The dotted lines are conjectural ; the break in the dotted line representing the outer border indicates the presumed amount of separation at that point to account for the bending of the outer piece of the wing.

Fig. 2. The same (1). With no parts restored.

Fig. 3. Lithentomum Harttii (1). The dotted lines show the presumed connection of the basal veins with the other fragment.

Fig. 4. Dyscritus vetustus ( $\mathrm{t})$.

Fig. 5. Tenoneura antiquorum (f). The dotted lines indicate the supposed course of the veins and border where they are not preserved. A portion of the base is shaded to show the exact appearance of the concentric ridges; this basal portion is mostly drawn from the same stone as fig. 7 , but the small fragment unshaded, at the extremity of the anal vein, and the cross vein are drawn in from the reverse of fig. 5 , shown in fig. 6 ; so also is the larger apical piece with part of the lower margin, these two parts being more complete on the reverse than on the obverse.

Figs. 6 and 7. The same (1). With no parts restored. The apical fragment of fig. 7 is not represented; it exists, but is not so complete as in fig. 6 .

Figs. 8 and $8^{\mathrm{a}}$. Gerephemera simplex ( $\mathrm{t}$ ). The two independent lines at the extremity of the costal margin are inserted from a drawing made under the camera when only these lines and the outer margin with the tip of the reins were exposed; in working out the rest of the wing these were broken away, but are here restored. The arrow indicates the direction of $8^{2}$, which represents the contour of the surface of the wing, the upper dotted extremity indicating the costal margin (shown to the left of the arrow), and the dots along its course the position of the veins it crosses.

Fig. 9. Platephemera antiqua ( $t)$. The faint line of dashes above the marginal vein represents the margin of the wing, indicated on the stone by a slight darkening of the surface. The dotted lines at base and at tip indicate the presumed form of the wing.

Fig. 10. The same (ł). This figure, the reverse of fig. 9 , is so placed in relation to the preceding as to indicate the probable expanse of wing of this insect; a fragment at the lower angle of this specimen is not preserved in fig. 9 , which possesses a bit of the outer margin not found in this.

Figs. 1, 2, 4, 6, 8, 10 represent specimens preserved in the museum of the Natural History Society of St. John, N. B.

Figs, 3, 7, 9 represent specimens in the museum of the Boston Society of Natural History.

Fig. 5 is a composite drawing from the specimens in each museum. The Boston Society of Natural History possesses the reverse of a small portion of fig. 8 ; and the St. John Society the reverse of No.3, neither of which are engraved.

The plate was executed by Messrs. Sinclair \& Son of Philadelphia. 



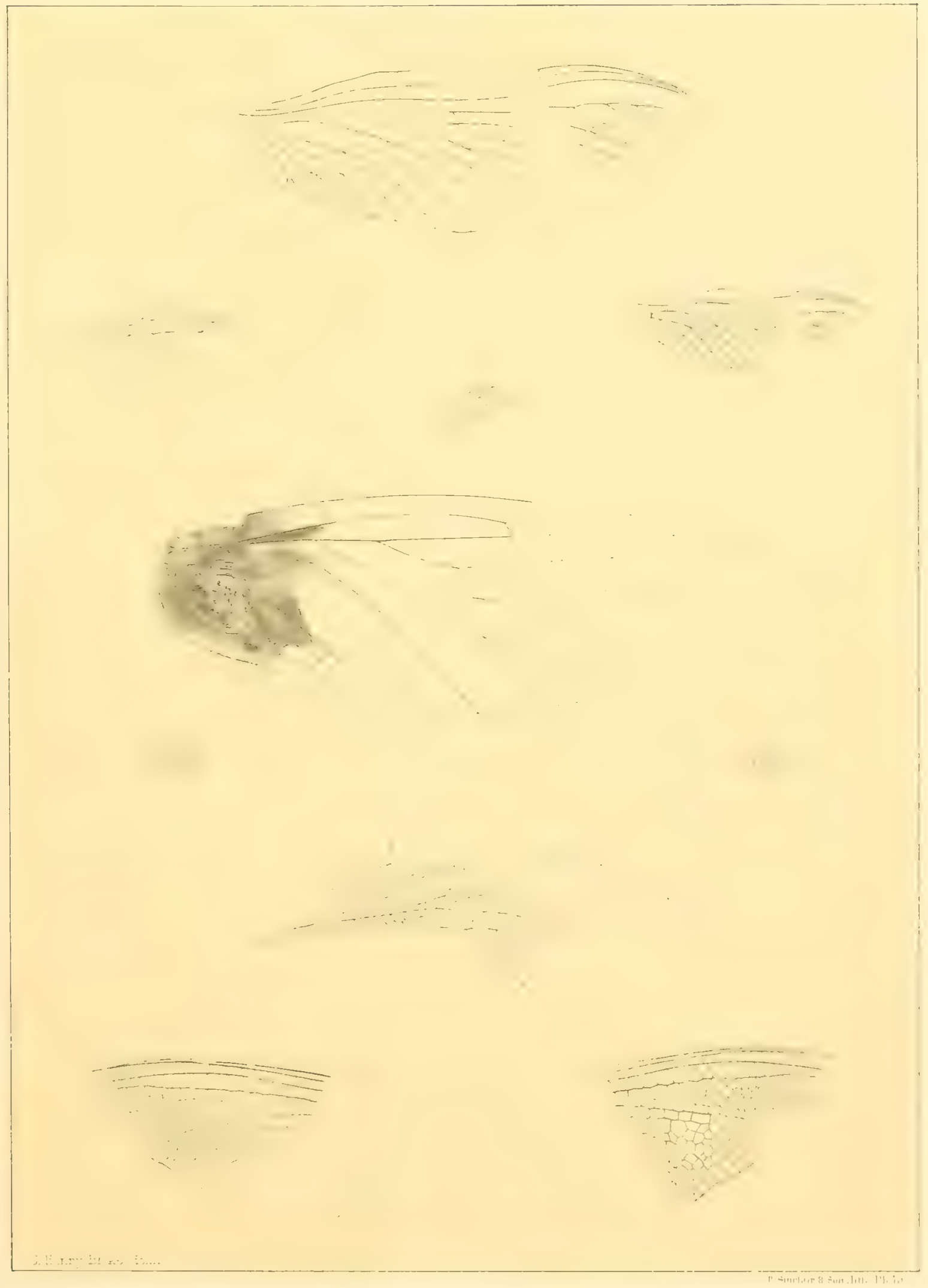

DEVONIAN INSECTS 

1830. ANNIVERSARY MENOIRS OF THE BOSTON SOCIETY OF NATULAL IISTORY. $18 S 0$.

\section{THE GYMNOSPORANGIA OR CEDAR-APPLES \\ OF THE UNITED STATES.}

BY W. G. FARLOW.

BOSTON :

PUBLISHED BY THE SOCIETY.

1880 . 



\section{Tite Grimosporangia or Cedar-apples of the United States.}

\section{BY W. G. FARLOW.}

THE UTEDINEAE or rusts include a large number of species which are parasitic on living plinti.. and, if we adopt the modern view as to thein development, they are remarkable for the trinfformations they undergo, which suggest rather the metamorphoses familiar to us in insects thin the ordinary phases of plant life. By earlier writers, the Uredincae were dividerl into different genera, which were supposed to be distinet, and not genetieally connected with one another. Thus, for instance, there were the genera Puccinia, Uredo, and A ecidium, each containing a large number of species. That species of certain genera usually preceded or accompanied species of other genera, as Puccinia, was well known, but the two were not supposed to have any genetic connection, and the relation hetween them was regarded as either quite accidental, or else cases of parasitism.

In 1848 Gasparrini ${ }^{1}$ observed the mode of germination of the spores in Podisoma, a genus closely related to Puccinia, and in 1554, Tulasne" extended the olservation to the spores of several other genera of Urenlineate. He also advanced the opinion that the so-called species of Lredo, Trichobasis, Leeythea, and related genera were merely early stages in the development of species of Puceinia, Phragmidium, Melampsora, etc. In a papee hy De Bary, ${ }^{3}$ pullished in 1869, it was maintained that not only were the species of Uredo and their allies forms of development of other genera, but that the so-called species of Aecidium as weli were not distinet, but that they too represented stages of development of Puccinia, Cromyces, and other grener: amil in point of time preceded the stage described by Tulasne as the stylosporic or uredo condition. The papers of Tulasne and De Bary, as might be supposed, gave a fresh interest to the sturly of the Uredineale and, while previously mycologists had heen mainly occupied with describing large numbers of species based on the microscopic character of the spores and the gross appearance of the spots produced in the host-plants, after the appearance of the two papers mentioned it became the fashion to try to ascertain the genetic connection hetween the rifferent forms known as Aecidia and Uredines and the different species of Puccinia, Uromyces, etc. The views of De Bary and Tulasne were, as a generil rule, accepted by all the learling mycolosists of the continent, but were not so readily received by those of Great Britain. At the present day, the

1 Osservazioni sulla generazione delle spore nel Podisoma fuscum. Rendiconto R. Accad. Scienze Napoli, 1818.

${ }^{2}$ Seconde mémoire sur les Urédinćes et les Ustitaginées. Annales des sciences naturelles. 4 Série. Tome 2.

\footnotetext{
${ }^{8}$ Recherches sur le développement de quelques champignons parasites. Annales des sciences naturelles. 4 Série. Tome 20.
} 
connection between the uretlo forms and other final forms is generally artmitted, and the relation of the aecidial stage to the others, as shown by De Bary, is considered to be proved beyond a dould by nearly all continental myeologist: although there are a few exceptions; but British botanists remain more or less sceptical on the subject.

In consequence of the prevalent view with regard to the development of the Uredineae, writers have ceased retaning such genera as Ureslo and Aceilinm exeept as receptacles for the forms which have not yet been connected with any definite final form, and on the continent a new nomenclature has arisen which has not as yet been adopted by American writers. For the purpose of illustration let us take Puccinia Graminis, the common

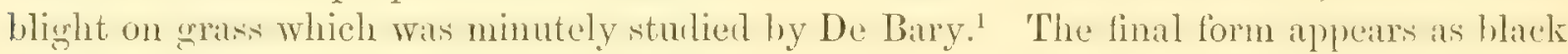
spots or lines on the leaves and stems of grasses, and is composed of dark colored, rather thick-walled spores, formed of two more or less conical cells united by their bases and attached at the lower end to a mycelium. These two-celled spores are called teleutospores and, in the case of Puccinia Graminis, are produced in the autumn. When left to themselves, they germinate the next spring in the following manner. From each cell is given off one, or occasionally two or three, delicate filaments, which scarcely exceed in length the length of the teleutospore. The upper part of the filanent becomes somewhat enlarged, and there are generally formed fiom two to four crosis partitions by which the filanents are divided into two to five cells. The upper cells grow out laterally and bear each a small ovoid cell which readily falls from it: attachment. The name griven by 'Tulasne to the grerminating filanents was promycelium, and he called the secontiary small ovoil cells sporictia. In the case of Puccinir Craminis, according to De Bary, the sporidia do not grow except on the common harberry, on which plant ther produce in the spring or early summer what is popularly called a cluster-cup, or in botanical languige an accidium. The so-called aecidimm is a complex affir. The mycelium from the geminating sporidia produces in spots a swelling and discoloration of the barberry leaves. The spots are more or less of a retdishyellow color, and there soon appears on the upper side of the leaves a number of minute, deep brown pustules called spermorgonia. A rection through the spermogrnia shows that they are cavities lined with slemler filments, the tips of which, called spermatia, separate and exalpe in masses from the spermogonia. Soon after the appeanance of the spermogrma on the upper side of the leaves, the lower surface swells and bears a number of cups, the aecidia proper. The cups are really formed inside the leaf, and are sacks composed of a cellular covering or peridium, and orange-colored spores arranged in rows arising from the base of the peridium. When they come to the surface, the peridia rupture and the spores readily escape. The aecidial spores germinate upon different grasses, and produce in summer what is called the rust, that is, spots or lines containing a rusty colored powder. The rust stage is called by botanists the uredo and consists of rather delicate, oval, unicellular spores of an orange-red colour, often called stylospores, attached to a mycelium. Like the aecidial-spores, the uredo-spores easily fall from their attachment, and germinate on grass and produce late in the season the pustules which bear the teleutospores already described.

As has already been remarked, these different stages were kept as distinct species by

\footnotetext{
${ }^{1}$ Recherches sur le déveloprement de quelques champironons parasites. Annales des Sciences naturelles. 1 Sèrie. 'lome 20, 1863.
} 
older writers. The teleutospore condition was called Puccinia Graminis ; the uredo condition Uredolinearis; and the aecidial condition Aecidium Berberidis. Recent writers merely speak of the species Pencinie Crimeninis, including by that all the different stages. To designate the old Accidium Berberidis they say Puccinia Graminis, fungus hymeniferus, and to designate the Uredo linearis they say Puccinia Graminis, fungus stylosporiferus. Or more briefly one says Puccinia Graminis (Uredo) or (Aecidium) as the case may be. To understand at once what is meant by the different expressions one must be acruainter with the literature of the development of the different species, and that is at difficult matter for us in America, since the observations on the subject are scattered in numerous journals, some of which are seldom met with in this country.

Since the development of Puccinia Graminis is probably as well known as that of any species of the order, and is furthermore, the species in which the development was first studied by De Bary, we may use that as a type in studying other members of the order. The development is represented in four different stages, viz:

1. Teleutospores on grass in the autumn.

2. Promycelium and sporidia produced in spring directly from the telento pores.

3. The Aecidium produced in May or June on the barberry, comprising two sets of organs, the Spermogonia with their spermatia and the cups or Aecidia proper.

4. The Uredo produced on grass from the spores of the Aecidia.

1. Teleutospores produced from the uredo-spores.

There is a cycle of four different stages, which, talsen together, constitute the life of the individual Puccinia. It will be remarked that two of the stages are found on grass, one on birtherry, and one is produced directly from the teleutospores wherever they may be. At present we are only interested in the genus Puccinia in so far as it is a type of the order, and we must next see how far the other species of the order agree with Puccinia Graminis. In the first place, if we consider the species of Puccinia alone, we find that it is only in certain species that aecidial and uredo conditions are supposed to exist. In some species, as $P$. Ifalenceurum Mont., only teleutospores are believed by some to occur. In $P$. anemones Pers., uredo-spores are unknown; in a large number of species aecidia are unknown. Furthermore, in case of the species in which all the different stages are known to occur, some have them all produced on the same host-plant, while others, as we have seen in $P$. Graminis, bear them on different plants. It may be asked whether in the cases where aecidial or uredo conditions are unknown, we are not to expect that they will be hereafter discovered. Such is probably true in most cases, hut still there are species, as $P$. malerecermen, in which it hat been supposen that they are absolutely wanting. For the purpose of expressing the presence or absence of the different stages and their relative position, Schroeter divided the genus as follows:

Eupuccinia. All stages known and all on the same plant.

Heteropuccinia. All stages known. Aecidia and spermogonia on one plant, uredo and teleutospores on another plant.

Hemipuccinia. Only stylospores and teleutospores known, and both occurring simultaneously on the same plant.

Pucciniopsis. Spermogonia, accidia, and teleutospores known and on different individuals of the same species. Uredo unknown. 
Micropuccisis. Only telmitospores. known. Spores quickly detached but not germinating except after a considerable interval.

Leptopuccinia. Only teleutospores known. Spores persistent, germinating quickly.

From the above named divisions it is evident that there is no want of variety in the genus Puccinia, or perhaps it would be better to say that there is a very considerable ignorance of the forms which may occur. Turning from Puccinia to other genera of the order, in Tromyces, of which the teleutospores difler from those of Puecinia in being onecelled, we have the sime variations in the presence or absence of the different stages and Schroeter divides the gemus in a similar way, into Euromyces, Hemiuromyces, etc. In the gemus Gymmoporamiun, which differs from Puecinia in its geditinous nature, only accidia and teleutospores are known. In Cronartium aecidia are unknown. In all the genera the teleutospores are supposed in germinating to produce the characteristic promycelium and sporidia, although as I shall have occasion to remark later, this is subject to modification, while the aecidial spores and stylospores germinate by giving out one or more germinal filaments as is the case with the spores of most fungi. In the aecidia the spores are always either orange colored or brownish, and are formed in chains which arise from a sort of placenta formed by the mycelium, at the base of the cellular sack known as the peridium. Spermogonia are present in the aecidial stage, and are dereloped earlier than the cups, or aecidia proper. The relative abundance and position of the spermogonia with respect to the aecidia themselves, vary in the different species.' They are sometimes on different sides of the leaves, as in Puccinia Graminis, sometimes mixed rarely on different parts of the plint. 'The uredo forms of the different generia vary more than the aecidial forms. As a rule the spores are borne singly, but in some genera, as Coleosporium, they are in chains. The so-called peridium found in the aecidia is wanting in the uredo forms, but there is sometimes a fille peridimn formed from the cells of the host plant, or the spots are surroumled by a circle of sterile cells, called paraphyses, derived directly from the mycelium. Spermogonia are usually wanting, hut are fouml in a few cases. The teleutospores of the different genera vary greatly in several respects; they may be unicellular, as in Uromyces and Melampsora; two-parted, as in Puccinia and Gymonospongium; or many-celled, as in Phragmidium and Xenodochus. They may

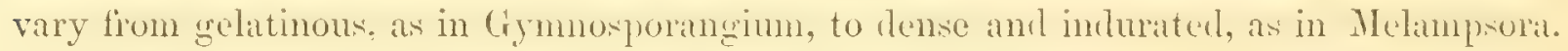
They may rise above the surface of the lost plants in columns, as in Cronartium, or may

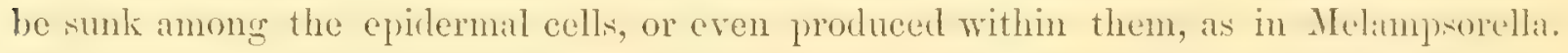
The principal generic listinctions are derived from the characters of the telentuspores, but as far as possible, continental writers have regard to the respective aecidial and uredo forms. The genera are perhaps not in all cases well marked, but they are at least quite as well defined as in the other orders of fungi.

In studying the Trerlineate of the Lnited states, one for several reasons, naturally begins with the genus Gymnosporangium. The species of the genus are comparatively few in number, and are, with us, found only on different Cupressineae. The teleutospores occur in spring or early summer, and resemble those of Puccinia in being generally though not always two-celled, but differ from them in being borne on very long hyaline stalks, the whole being imbeded in a mass of jelly which in moist weather swells up and forms the 
orange colored masses, which are supposed by many to be the flowers of the cedar-trees. Probably in no part of the world are the species so abundant as in the eastern United States, and material for study can be procured in the greatest abundance. In one respect this abundance has its advantages, in another it has its disadvantages. The Gymmosporangia of Europe, compared with our own, are few in number and much less abuntant, the number of species found in central and northern Europe being limited by Oersted and Reess to three. Oersted, of Copenhagen, wils the first to stuly their development. He connected the gelatinous teleutosporic stages which occur on species of Juniperus with the elongated cluster-cups placed formerly in the genus Roestelia, which are found in summer on the leaves of different Pomeae, thorns, pears, apples, etc. He went so fir as to connect each of the three species of Gymmosporingim found in Demmark with a particular species of Roestelia. The experiment; of Oersted consisted in sowing the germinating sporidia of the Gymmo-porangria on leaves of different Pomeae. I shall have occasion to return to this subject later, but it is sufficient to notice in this connection that Oersted's ${ }^{1}$ observations were afterwards confirmed by Da Bary an'l others in Gurmany, Cornu ${ }^{3}$ in France, and Cramer ${ }^{4}$ in Switzerland, and accor lingly the grenu. Roestelia has been suppresised by recent continental writer, who refer to the species formerly placed in that genus as the aecidial or hymeniferus stage of the dilferent Gymnospormutia.

If one then would study the American species of Gymnosporingium in the light of modern research, he must also take into account the different $R$ )esteliae of which we have an abundance. The first step is to settle the species of the two genera on anatomical grounds, and then by cultures or observations in the field to ascertain their genetic relations. I insist on the importance of first defining the species from their anatomical structure, for unless this is done any cultures which may be made can have very little value and one is constantly groping in the dark. One may afterward mo lify his view of the species in consequence of knowledge derived from artificial cultures, but one should not, for instance, conclude at once, because the sporidia of a given species of Gymnosporancium produce spermogonia when sown on the leaves of two plants which are known to have Roesteliae differing in their morphological characters, that the two Roesteliae are the same species in spite of their different appearance. In determining the species of the two genera one is obliged to ascertain which of our species are the same as those found in Europe, and here a difficulty arises, for one is not quite sure in some cases how fir a European species of fungus may vary from the type when growing upon a different host from the one on which it occurs in Europe. In this case one would glatly resort to artificial cultures to settle the question. Unfortunately for us who are ohliged to follow in the steps of Europeans in so fir as the determination of species common to both continents is concerned, European writers have not argeed amougst themselves as to the limit.s of

${ }^{1}$ Bot. Zeit., 1865, 291; and 1867, 222. Nouvelles observations sur un champignon parasite dont les générations alternantes habitent sur deux plantes hospitalières differentes. Bulletin de l' Académie Royale des Sciences de Copenlıague, 1866.

Nouveaux essais de senis faits avec des champignons parasites. Loc. cit., 1867.

Om en saeregen, hidtil ukjendt Udvikling hos visse Snyl- tesvampe og navnlig om den genetiske Forbindelse mellem Sevenbommens Baevrerust og Paeretraeets Gitterrust. Copenhagen, 1868.

2 Bot. 'Zeit., 1865, 222.

${ }^{3}$ Bull. Soc. Bot. Tome 25, pp. 122, 221, \&c.

4 Ueber den Gitterrost der Birnbüume and seine Bekảmpfung. Schweizer. Iandwirthschaft Z Zitschrif. Solothurn, 1876. 
their species. Reess ${ }^{1}$ is the most recent writer who has griven the synonymy in detail, and I have in most cases followed his account, and have only given in full the special American references.

The greater part of the present paper is devoted to an account of the morpholosical characters of the species of the two genera found in this country, and I have been umable by means of cultures to arrive at as definite results as I should desire; but a record of one's failures is hardly less important, than an account of one's success. I have myself collected large quantities of Gymnosporangia and Roesteliae in the region around Buston, and I am greatly indebted to Mr. II. W. Ravenel, of Aiken, and Dr. J. II. Mellichamps of Bluftion, for material from South Cirolina; to Mr. J. B. Ellis of Newfield, N. J., and Mr. C. H. Peck, the State Botanist of New York, for viluable notes as well as specinens; to Mr. C. B. Fuller for specimens from Portland, Me., and to Dr. II. W. Iarkness for specimens from California. I must particularly express my indebtedness to Dr. M. Cornu of Paris, for his notes on European and American species, as well as for a valuable series of specimens, and to Prof. C. Cramer, of Zurich. I have examined the specimens in IIerb. Curtis to which reference is made by Berkeley in Grevillea Vol. III., p. 5.)-j!), the specimens in the Sprague collection of the Boston Society of Natural History, and some original specimens of Schweinitz, which, however, were not in a good state of preservation, besides numerous series of Fungi Exsiccati published in Europe and this country.

\section{Grimosporangium De Cand.}

Spores yellow or orange-colored, usually two-celled, occasionally one- to six-celled, on long hyaline pedicels, imberded in a mass of jelly which when moistened swells into columnar or irregularly expanded masses. Mycelium parasitic in the leaves and branches of different Cupressineae, producing in them various distortions.

The different genera in which the species of the present genus were placed by writers previous to De Candolle, are given in detail in the paper of Reess and need not be repeated here. The genus was first described by De Candolle from unpublished papers of Hedwig in the Flore Française, Vol. II., 1S0.). Link ${ }^{2}$ in 1909 separated the species in which the gelatinous substance was more or less conical or cylindrical, from those in which it was irregularly shaped, placing the former in Podisoma and retaining the latter in Gymnosporangium. The two genera of Link have, until a comparitively recent time, been kept distinct by European writers, and they were adopted by Schweinitz in the Synopsis Fung. Am. Bor., and by nearly all recent American writers. That the distinction depending merely on the shape of the grelatinous masses should not be ealled greneric, is the opinion of probalbly a majority of the mycologists of the present day, although a number still keep the gremus Podisoma. Accepting Gymmosporangium in its widest sense as adopted by European writers, we have a genus whose telentospores are two-celled like those of Puccinia, but invested with a variable amount of colored jelly which assumes a more or less definite shape in the different species. Accepting also the opinion first advanced by Oer-

\footnotetext{
1 Die Rostpilzformen der deutschen Coniferen. Abhandl. Naturf. Gesellschaft. Vol. xr. Halle, 1869. 
sted the accidial stage is found in the so-called Roesteliae which are found on different species of Pomeae but no indications of a uredo-stage have as yet been detected.

An acquaintance with some of the more recently discovered American species shows that the original limits of the genus must be extended so as to include species in which the spores become several $(3-6)$ celled, and in which the amount of gelatinous substance found is comparatively small. In other words, as far as can be judged from the teleutosporic comlition, the genus evidently approaches Phragmidium in Gr. Ellisii, which species cannot well be placed in a separate genus, as was done by Körnicke ${ }^{1}$ in forming his grenus Inmaspora. The teleutosporic condition of Gymmosporangium unlike that of most of the other genera of Uredineac of temperate regions, is found in the spring, and the species of the United States occur only on species of Juniperus, Cupressus, ant in California on Lilhocedrus. The production of the promycelium and sporidia is seen with the greatest ease and, in fact, after a shower the orange-colored masses are covered with the latter. When, however, the masses after having been wet are quickly dried, instead of a production of sporidia from the promycelium, the latter divides quickly into a number of cells which separate from one another, and which on remoistening send out germinal tubes just like the sporidia. A similar transformation of the promycelium was noticed by Cramer, loc. cit., p. 7, in Gymnosporangium fuscum growing in Switzerland. In the Northern States the telentospores make their appearance usually from the middle of April to early in May according to the season, reach perfection in Nay and disappear at the end of June. In the South they are found considerably earlier.

The principal characters used in distinguishing the species are the shape and size of the gelatinous masses, the shape and size of the spores, and the number of cells of which they are composer, the number and position of the promycelia producer from each cell, and the form and character of the swellings or distortions produced in the plant on which they are parasitic. The particular shape of the gelatinous masses in any griven species depends considerably upon the age and amount of moisture, and in all species, after having been repeatedly expanded by numerous showers and again dried, they become amorphous. When first appearing after the rupture of the epidermis, or outer bark, they are in the form of cushions of a dark velvety color. As they reach perfection, the forms they assume may be divided into three; the cylindrical, which may be either blunt or acutely attenuated; the flattened or wedge-shaped, which are usually blunt and crenate or partly divided; and the irregularly expanded, which are broadly ovate or flattened and grenerally plicate. The usual number of cells is two, but even in species which normally have only two cells, one sometimes finds three or four cells. The single-celled spores are grenerally immature, but occasionally they hear promycelia. In two of our species the normal number of spores is greater than two. The number and position of the promycelia given off from each cell varies considerably in the same species. As a rule, they are not borne at the apex of the cells, but near the line of union of two cells. They are occasionally produced from the apex, and in one species, that seems to be the common position. In some species the usul number of promycelia to each cell is four, in others only one or two. The length of the promycelia depends upon the position of the spores in the gelatinous mass. Those on or

${ }^{1}$ Hedwigia. Vol. xvI, p. 22. 1877. 
near the surface have short promycelia, while those of the interior have very long ones, the object evidently being that the tips which bear the sporidia may reach the light and air.

One of the most curious and interesting phenomena connected with the growth of Gymnosporangia is the peculiar distortions which they produce in the plants on which they are parasitic. The mycelium does not differ much from that commonly found in the other Uredineae. It is irregular, much branched, and cross partitions are rather numerous. Linlike, however, the inycelium of some of the Pucciniae, that of the species of the present genus is limited in extent, and is not found throughont the whole of the plant on which it is growing, but is confined to certain portions of the stems or leaves. The mycelium of most of the species is perennial, that is, the mycelium which has produced a crop of spores one year, will the next year, under ordinary circumstances, produce another erop in or near the same place. One species, however, and possibly others are ammul, the spores of one year not following those of another in the same place. 'The kinds of distortion produced vary with the species, but it is probable, although not absolutely certain, that the same species produces different deformities when growing on different species of plants. This we might perhaps account for by a difference in the histolocrical character of the two plants, but exactly why two different species of Gymmosporangium parasitic on the same individual cedar, should produce two widely distinct deformities is less easily explained. In the mere appearance of the mycclimm itself, one cam not see any cause for the different growths produced.

The explanation is evidently to be sought in the amount and extent of the mycelium, the rapility of its growth, and its duration. Thus in a rapilly growing amminl species, as $G$. macropus, we have a large, rather spongy excresence which shrivels in drying. In $G$. fuscum var. globosum, which is peremial, ant of slower growth, the exerescence is more dense and scarred externally. In G. biseptatum the mycelium is comparatively limited in amount, and does not increase rapidly, and in consequence, the formation of the amnual woody layes is not prevented, nor the nutrition of the branches above much interfered with. The mycelium is found principally in the region of the cambium, and acts rather' as a stimulant than as a destructive agent, and the result is that a notose swelling is formed in consequence of the unusual development of the wood in the region of the fungus. In $G$. Ellisii, which like the previous species, grows on Cupressus thyoides, there is a more luxuriant and rapidly growing mycelium, which extends for some distance along the smaller branches, and is so abundant as to interfere with the mutrition and, in consequence, the branches above become short and stubby, and, at length, densely fisciculated, the branch below the fungus remaining unchanged, so that we have, instead of a nodose swelling, a dense tuft of short branches borne on the end of a normal branch. In other species the mycelium traverses the leaves, which are distorted throughout, so that the branches infested by the fungus and those free from the fungus, seem to belong to different species, so regular is the hypertrophy of the leaves. In this connection it may be remarked that in some places the distortions are not altogether due to the direct action of the fungi themselves, but are produced in part by the secondary action of the disordered nutrition combined with the effect of the weather. Nor can one infer from the 
amount of the gelatinons expansion on the exterior, how destructive a particular species is to the plant on which it is growing. G. macropus, for example, is much more striking to the eye thim $G$. clrevipes, but the latter is more destructive to the plants upon which it grows.

\section{Grinosporangium Elisim (Berk).}

Plate 2, figs. 13-17.

Poctisoma Ellisii Berke, Grevillea, Vol. II, p. 56; Farlow, Bull. Bnssey Inst., Vol. II, p. 226. Exsicc. 'Thüimen, Herb. Mycol. Oeconom., 440.

Hamaspora Ellisii Körnicke, Hedwigia, Vol. xvi, p. 22.

Gymnosporangium Ellisii, in Ellis's North American Fungi, Fasc. III, No. 271.

Sporiferous masies numerous, scatteren, cylindrical, filiform, from one-eighth to a quarter of an inch high; spores dark yellow, linear-fusiform, obtuse, usually 3-4 celled, sometimes 1-j) celled, 10u-16u in diameter, 7.ju-190u long, average 120u-150u; pedicels long and slender; promycelia short and much curved, usually one from each cell. Mycelium perennial, distorting the smaller branches.

On Cupressus thyoides.

Newfield, N. J. (Ellis); Newton, Dedham, Wood's Holl, Mass. (Farlow).

This is one of the many interesting species of fungi discovered by Mr. J. B. Ellis at Newfield, N. J. Previous to May, 1872, when it was first seen by Mr. Ellis, the species was quite unknown, although it is apparently not uncommon in the so-called cedar swamps along our eastern coast. It is the smallest and least gelatinous of the genus, but the trees attacked by it may be recognized, even at a considerable distance, by the peculiar distortions, which consist in a dense fasciculation of the smaller branches in different parts of the tree, so that, when viewed from a distance, one sees closely branching tufts of a somewhat fin-shaped or corymbose outline, which appear to terminate some of the branches. The fungus itself is only visible on close inspection. The branches affected are thickly covered with the sporiferous masses, which, when dry, are of a reddish-brown color, not very different from that of the bark itself, and which, when moistened, are orange-colored, and not generally more than from an eighth to a quarter of an inch long. The species is often associated with $G$. biseptatum which prorluces an entirely different distortion, affecting generally the larger branches. The leaves themselves are, however, but little distorted by the present species. The mycelium of $G$. Ellisii is of rather large size and in cross sections of the stems is seen to follow the medullary rays, sometimes extending nearly to the centre of the stem, and occasionally forming partial circles between the annual rings. In longitudinal sections of affected branches one sees the mycelium collected in brownish spots which extend far into the wood. The greater part of the mycelium is found near the cambium and it collects in masses in the bark to form the sporiferous bodies which originate at some little distance beneath the surface. The mycelium is perennial and extends gradually along the branches sometimes for a distance of eighteen inches, and they swell to about once and a half their normal diameter. 
The spores of $G$. Ellisii are very striking and differ from those of the rest of the grenus in being very long and narrow and in heing wisully more than two-celled, the most. usual numbers being three and four. The amount of jelly in the sporiferous masses is less than in other species, and in conseduence dried specimens give a better idea of the fungus ats it appears in nature than is generally the case in the present genus. The promycelia are very abundant and very short, the lower sterile part found in other species being almost wanting and the part bearing the sporidia being much curved, so that the promyeclia coming from the cells of one spore sometimes wind round and enclose another spore, making dissection difficult without tearing off the promycelia. One not unfrequently finds spores in which the upper cell is more or less deeply cleft, as in Pl. 2, fig. 17.

In spite of the fact that in certain details, $(r$. Ellisii differs from the majority of the other species of Gymmosporangium it seens to me that Kimicke ${ }^{1}$ is not warranted in establishing a new genus Hamaspora, founded on two species, G. Ellisai growing on Cupressus thyoides and Phragmidium longissimum 'Thiin. growing on Rubus rigidus at the Cape of Good IIope. In the first place, the grelatinous substance is not wanting in G. Ellisii, as can easily be seen in examining fresh specimens, and furthermore, the fact that the spores are more than two-celled is equally true of G. biseptatum, a species which moloubtedly belongs to Gymnosporangium. On the other hand, in $I I$. longissima Körnke, admitting that the teleutospores bear a great resemblance to those of G. Ellixii, the specimen in Mycotheca Universalis, No. 542, shows an abundance of uredospores surrounded by the circle of large paraphyses generally found in the urerlo-spots of Phragmidium, while in G. Ellisii there are no uredo-spores at all. When we consider also that the species of Phragmidium generally occur on species of Rubus or related genera, and Gymmosporangrium only on Coniferae, it would certainly seem that $I$. Tomgissima should be kept in Phraeniclium where it was placed by Von 'Thumen, and that G. Ellisiz should be retained in Gymmosporangium. I am perfectly willing to admit that the last named genus approaches the former, but the matter is not helped by creating a third genus less clearly marked than either of the others.

The present is more limited in its range than our other species, as far as at present known. It probably has often been overlooked, on account of its small size, and may oceur wherever the white cedir, Cupressus thyoides, is found. It is certainly common in snch localities in Masiachusetts, and in passing from Boston to Washington by railroad, I have seen the peculiar distortions along the whole route wherever the white cedar occurred.

\section{Grinosporangium clavariaeforme De Cand.}

Grymnospormangum clacarireforme D. C., Flore française, Vol. II, p. 217; Reess, loc. cit., p. 21. Exsicc. Ellis, North American Fungi., Fasc. III, 273.

Podisoma clacriraforme Duby, Bot. Gill., Vol. II, p. S81. Oersted, Nouveaux essais de semis. Pl. 3 and 4.

Podisoma Juniperi communis Fr., Syst. Myc., Vol. III, p. 548.

\footnotetext{
${ }^{1}$ Hedwigia, Vol. xvi, p. 22.
} 
Podisoma Juniperi Cooke, Decades of Maine Fungi, ${ }^{1}$ 1. 183 ; Notes on Podisoma, ${ }^{2}$ Pl. 19, fig. 1.

Sporiferous masses numerous, scattered or aggregated, yellowish-brown when dry, bright yellow when swollen, cylindrical or slightly compressed, acute or occasionally forked at the apex, from a quarter to half an inch high, spores narrowly lanceolate, those on the outside of gelatinous masies clavate, two-celled, $13, u-19 u$ broad, by $55,-90 u$ long ; promycelia usually one or two from each cell. Mycelium peremnial, causing long fusiform swellings of the branches.

On Juniperus communis.

Portland (C. B. Fuller); Cape Elizabeth, Me. (E. C. Bolles); Maine, without locality, in Herb. Curtis (M. B. Blake, No. 579). Northern and Central Europe.

Apparently not a common species in the United States and known to me only as occurring in Maine. It is said by Mr. C. B. Fuller to be common on the ground cedar in the islands in Portland Ilarbor, and some of the specimens collected by him were distributed by Ellis in North American Fungi. The species is not known to occur on leaves in the United States, but is found on the larger branches, which swell for a considerable distance to nearly twice their normal size, and become cracked on the surface. The sporiferous masses are quite yellow when swollen, and are not dark colored when dry, as in the case in G. fuscum. They are rather slender and pointed at the apex, and, although sometimes a little flattened, are not decidedly compressed as in some other species. I have never in American species seen the apex Aattened and expanded, as is shown in the figure of Bulliard referred to the present species by DeCandolle. The Portland specimens collected by Mr. Fuller bear the closest resemblance to No. 1088, of Rathenhorst's Fungi Europaei, Series Nova. The spores, compared with those of our other two-celled species, are long and narrow. Those borne on the outside of the gelatinous masses are clavate, or have the upper cell broader than the lower, and obtuse at the apex, but the spores in the interior are attenuated at both extremities as in Cr.macropus, but they are distinctly longer and more slender than the latter. The promycelia are, as a rule, fewer in number than in G. macropus, and one generally sees only one or two given off from each cell. In Europe the species is said also to occur on the leaves of Juniperus communis, and probably a close examination of plants affected will show that such is the case also in this country. The specimen in IFerb. Curtis collected by Mr. Blake, is not in sufficiently good condition to show the shape of the sporiferous masses, but the spores suffice to show that the specimen belongs to the present species rather than to G. fuscum.

\section{Gymnosporangium macropus Lk.}

Plate 2, figs. 1-6.

Grymnosporanginm Juniperi virginianae Schw., Syn. Fung. Carol., Sup., p. 7t, No. 504. 1822.

Gymnosporangium macropus Link, Species Plantarum, Vol. vi, part 2, p. 128. 1825. Exsicc. Ellis, North American Fungi, Fasc. 3, No. 270.

Podisoma Juniperi virginianae Fr., Syst. Myc., Vol. III, p. 57. 1832.

${ }^{x}$ Proc. Portland Soc. Nat. Hist. Vol. I, rr, 1869.

${ }^{2}$ Journal of Quekett Microscopical Club, Nov. 1871. 
Podisoma macropus Schw., Syn. Fung. Am. Bor., p. 307, No. 3096, 1831; London Jour. Bot., Vol. IV, Pl. 12, fig. 6; Sprague's Contributions to New England Mycology, ${ }^{1}$ p. 329; Curtis's Plants of North Carolina, p. 121; Peck's 23d Report, p. 57 ; Notes on Podisoma, Pl. xıx, fig. 3; Grevillen, Vol. 3, p. 56. Exsicc. Ravenel, Fung. Car., Fasc. I, No. S5; 'Thiimen, ${ }^{2}$ Mycoth. Univers., No. 148.

Sporiferous masses atgregated in globove tufts. suroumled at the base by a ring formed by the raised epirlemis and subepidemal tissue of the host-plant, orange-rellow, cylindrical, acuminate, half an inch to an inch long or, at times, longer; spores ovate-acute, twocelled, generally constricted at the septum and with a papilla at the apex, $15 u-20 \mu$ broad by t.su-(j)u long; promycelia generally four from each cell. Mycelium ammual, producing globose or reniform knots in the smaller branches.

On leaves and smaller branches of Jumperus virginiana.

Common from Masirhusetts to south Carolina (Raveneil. Mellichamps), and extending west to Missouri (Englemann), Colorado (Palmer), and Wisconsin (Lapham).

The common "cedar apple" of the Atlantic States, and the most striking species of the genus. It is very abundant along the seaboard, but becomes rarer in the west. The knots together with the sporiferous masses, often measure three inches across when swollen. When dry the sporiferons masses are much shrunken, and as the knots do not differ much in color from the branches, they are not well seen from a distance. The species was first described by Schweinitz, in 1822, under the name of $G$. Juniperi virginiance. Link in

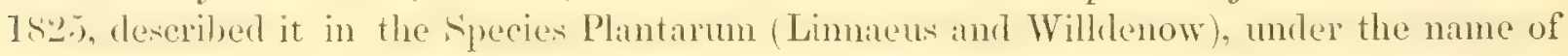
G. macropus, but why the Schweinitzian name was suppressed, or why Link placed the species in Gymnosporangium rather than Podisoma, a genus of his own creation, is not clear. In 1831, in the Syn. Fung. Am. Bor., Schweinitz adopted Link's specific name, but placed the species in Podisoma, and it has generally been known since as Podisoma macropus sichw. Fries, however, retained schweinitz's original specific name, and called our plant Porlisoma Juniperi virginirnate. Notwithstamling that Sohweinitz's name given in the Syn. Fung. Carol. Sup., is the oldest, it must be abandoned in consequence of the confusion and awkwardness which has arisen from applying the compound names Juniperi virginianae, Jumiperi communis, Juniperi Sabinae, etc., to denote the different species. The present species, moreover, is by no means the only one found on J. virginiana, and it is on all accomnts desirable to retain the name given by Link, and afterwards adopted by Schweinitz himself, at least as far as the specific name is concerned.

The mycelium of $G$. macropus is abundant, and easily seen. It is found principally in the leaves, and there are haustoria which enter the parenchymatous cells. 'The fungus causes the leaves to swell, and finally ruptures them at about the central portion. One then sees a rounded mass tipped with the comparatively unchanged apex of the leaf. In some cases the gelatinous columns are produced when the knot is quite small, so that not

\footnotetext{
${ }^{1}$ Proc. Boston Soc. Nal. Hist., Vol. v. 1856.

2 Streinz, Nomenclator Fungorum, p. 455, gives $W^{\top} y m a n$ as the authority for the species and in this error he is followed by Von Thümen. The Wyman in question was Prof. Jeffries Wyman, whose only connection with the species con-
}

sisted in sending a letter with a drawing of the fungus to Berkeley, asking the name of the species. The letter and Berkeley's reply that the fungus was l'odisoma macropus Schw. were published in London Jour. Bot., loc. cit. 
more than two or three columns can find attachment, but generally the knots grow to from half an inch to an inch and a half in diameter, before the gelatinous masses break through the surface. The latter arise a short distance below the surface, and the outer portion of the knot consisting of several layers of cork cells is raised in flattened papillae. By the growth of the gelatinous masses the centre of each papilla is ruptured, and the columns rise vertically. The margin of the raised papilla remains behind, as a sort of collar around the base of each sporiferous mass.

The shape of the fully developed knots is peculiar. In consequence of the fact that the cells of the outer part of the knots multiply more rapidly than those near the base, the knots become convex on the upper side and finally reniform, and are contracted beneath and attached by a small base. It has generally been supposed that the knots are usually outgrowths from the smaller branches, but such is not the case and, as far as I have been able to ascertain, they originate in a leaf. When the knots have attained a considerable size they appear to be terminal, because the branch above is pushed to one side. The young knots begin to appear about the end of August, and often reach a considerable size before winter. In the latitude of Cambridge, the gelatinous masses do not naturally appear before May or, exceptionally perhaps, in April, but if knots are gathered in February or March and placed in a warm, moist place, they may be made to appear in from ten days to a fortnight. The knots persist after the sporiferous masses have been quite wathed away, and from silvery-gray beeome brown and spongy, the surface being honeyeombed, the depressions being the spots from which the gelatinous malsose have disippeared. In by far the majority of cases, the knots gradually dry and drop off after having borne one crop of spores. In rare instances, however, a new knot may grow from one side of the old knot and bear a second crop of spores, but in this case the two portions remain quite distinct, one part being old, shrivelled and weather-worn, and the new part succulent, brownish-gray, and covered with sporiferous masses. By the nature of the knots alone one can distingui.h between this and the following species. The latter is peremial, and between the sporiferous columns of one year one can easily see the scars of the last year's masses.

As far as concerns the gross appearance presented by G. macropus, the account given by Schweinitz in the Syn. Fung. Am. Bor. is quite accurate. He states that the species is rare in North Carolina, but common in Pennsylvania. He remarks also "capitulum persistit per ammum," from which one may infer that he recognized that the rpecies was an annual, a fact which succeeding writers have not sufficiently regarded. His description of the cedar-apples themselves is so minute and accurate that there can be no doubt that Schweinitz had either never seen the form described on a succeeding page as $G$. fuscum var. globosum, or at any rate clearly distinguished it from $G$. macropus. In the letter of Wyman, published by Berkeley in the London Journal of Botany, Vol. 1v, p. 316, an account is given of the germination of the spores and the distortions supposed to be produced by $G$. macropus, but it is evident from the description that Wyman had confounded $G$. macropus and $G$. clavipes. He says "I have made numerous searches for these parasites, but have almost never detected them, except in the localities mentioned, viz: the tufts composed of acerose leaves and the "cedar apple." The tufts with acerose leaves are not identical, as I believe, with the variety of form which occurs in the young shoots of the 
J. rirginimen, describerl in Bigelow's Merl. Botany and by yourself' (Sir J. W. Hooker to whom the letter was originally addressed), in the Flora Boreal. Amer., also in the deseription of the J. bermudiane in the Lomiton Journal of Botany for Mareh 1s4.). The form of the leaf is in both cases acerose, but the tuft to which I refer forms a single dense mass, the twigs so crowled together as scarecly to allow the light to pass through, looking at a distance like the nest of some bird. These masses vary in size from that of the first to eighteen inches in diameter. Generally not more than one mass is seen on the same tree, sometimes, however, two or three. I have never seen a single tuft like those described in which the fungus in question was not present, and this is the result of a great number of observations." Ths description of the acerose leaves and the dense growth of the branches, which look in the distance like bird's nests, is excellent, but the species which causes this distortion of the branches is not $G$. macropus but $G$. clavipes, a distinct species as we shall see hereafter, and one having no connection with the cedar-apples proper. The figures of Wyman represent the spores of $G$. macropus, except that some of them appear to be germinating at the tip in the mode characteristic of $G$.clavipes.

The species is very widely distributed and is, as a rule, very common, but is not recorded in some localities where one would have expected it. Mr. Peck informs me that it is not common near Albany, N. Y., and it is not mentioned in Tuckerman's Catalogue of the Plants growing near Amherst. It is certainly very common in Eastern Massachusetts, New Jerwey, Pemnylvania and Maryland, and although said by Sehweinitz to be rare in North Cirrolina, has been found by Ravenel and Mellichamps to be common in South Callolina. The comparative scarcity of $J$. virginiana in the Western States would account for the absence of $G$. macropus in many Western localities. The injury done to the trees affected is comparatively slight, as was remarked by sichweinitz, and the reation for this is apparent if we consider the short duration and the mole of growth of the mycelium. The cedar-apples are said to be used as anthelmintics and the United states Dispensatory gives as the dose ten to twenty grains three times a day. In Missachusetts the use of the apples as medicine is, as far as I can ascertain, unknown, and the practice is probably confined to Pennsylvania and the Southern States.

The spores of $G$. macropus are pretty uniformly ovate and acute at both extremities, and although they bear a certain resemblance to those of $G$. clavariaeforme, they are markedly shorter and broader. Schroeter suspects that G. macropus is only a form of the last-named species, but the fact that there is a difference in the spores and that one is annual and the other perennial, not to mention the difference in habit, clearly forbids a union of the two.

\section{Grinosporangium fuscum De Cand.}

Gymnosporangium fuscum D. C., Flore française, Vol. II, p. 217; Reess, loc. cit., p. 16. Podisoma Juniperi Link., Observ. I, p. 9; Species Plantarum, Vol. VI, part II, p. 127; Sprague in Proc. Boston Soc. Nat. Hist., Vol. v, p. 329; Frost in Tuckerman's List of Plants of Amherst.

Podisoma Tuniperi Sabinae Fr., Syst. Myc., Vol. mr, p. 508. 
Podisoma fuscum Duby, Bot. Gall., Vol. II, p. 881; Cramer, Ueber den Gitterrost der Birnbäume, Pl. I.

Podisoma Sulinae Oersted, On en sacregen hidtil uljendt Udvilking, etc., Pl. I.

Sporiferous mases numerous, generally approximated, brownish when dry, dark orange when swollen, a quarter to half an inch high, compressed-conical, or wedge-shaped, upper margin thick, rounded, sometimes notched; spores roundish ovate, two-celled, fiequently constricted at the septum, $38 u-53 u$ long, by $15 u-22 u$ broad; upper cell either nearly hemispherical or obtuse; promycelia generally four from each cell. Mycelium perennial, causing long swellings of the branches.

On stems of Juniperus virginiana and $J$. communis.

Near Boston (Sprague); Amherst, Mass. (Frost); Catonville, near Baltimore, on inported species of Juniperus, (Farlow). Europe.

This species, although apparently common in Europe, is, in its typical form, rare in the United States. It has frequently been confounded with Crym. clavariaeforme from which it differs in the shape and color of the sporiferous masses, which are in Cr. fuscum usually thick and wedge-shaped with a blunt margin, and of rather a dark, blackish brown color, especially when dry, while in $G$. clavariaforme they are rather slender and cylindrical. It also differs in the shape of the spores, which are shorter and stouter in $G$. fuscum, and usually give off four promycelia from each cell. The spores vary considerably in outline, those on the surfice being more decidedly oval and with a thick dark cell-wall, while those in the interior of the jelly are more acute and with thimner cell-walls. As is the case with most of the species where the promycelia are given off near the septum, the two cells at maturity retract from one another at the outer margin and only remain slightly adherent at the centre. The mycelium is found principally in the stems which have attained a certain thickness and causes them to swell for a distance of several inches. The sporiferous masses rupture the outer bark in elliptical spots which may be isolated, or, as is more frequently the case, are rather closely approximated.

In American catalogues and herbaria one rarely finds the specific name fuscum applied to the present species, but it usually figures under the name Podisoma Juniperi Lk., and occasionally as $P$. Juniperi Fr., which is incorrect, as there is no proper $P$. Juniperi Fr., the name given by Fries to the present species being $P$. Juniperi Salinae. The name $P$. Juniperi Lk., it must be remarked, has been rather loosely applied in this country to several distinct species, and when occurring in catalogues of fungi allowance has to be made for the determination. In Herb. Curtis, for instance, of the different specimens marked $P$. Juniperi, Lk., one from Maine is Gr. clavariaeforme; one from Penn.ylvania (Michener, 949) and one from Ifillsboro, N. C., collected by Curtis himself, are G. clavipes, and one from Sprague is $G$. fuscum. Specimens which may with certainty be referred to $G$. fuscum are few in number. The specimens of Frost, which I have been unable to examine, were on $\pi$. communis. Of Spratgue's specimens one in the collection of the Boston Society of Natural History, and one in Herb. Curtis are the true $(r$. fuscum on what appears to be J. virginiand. The spores in Sprague's specimens are rather more slender than in European specimens, being $46 u-57 u$ long by $15 u-19 \mu$ broad, but in other respects they are quite typical. Whether the P. Juniperi of Schweinitz, Syn. Fung. Am. Bor., No. 3095, is to be referred to the present species or to $G$. claturiaeforme is uncertain, the original 
specimen which I have examined not being in condition to be determined with accuracy. The only instance where I have myself seen the species growing was on the estate of Mrs. Lerman at Catonville near Baltimore, where several imported Junipers were, in Nay 1879, badly affected by a fungus which was without doubt $G$. fuscum. I have never collected the present species on J. virginiana, but besides the specimens of Sprague already mentioned it was found by Tulasne on J.virginiana in France. I am indebted to wy friend Dr. Cornu for an opportunity of examining a portion of Tulasne's specimen and it seems to me that the fungus in that case is the same as that collected by Sprague and referred to $G$. fuscum. Dr. Comu, ${ }^{1}$ however, distinguishes between Podisoma Juniperi Sabinae and $P$. fuscum, and it is to the first named form that he thinks the specimens found by Tulasne on Jumperus virginiana should be referred. 'The $P$. fuscum on $J$. Ihotnice figured by Gatsperrini has been reparated by Cooke as a new rpecies under the name of G. Phoeniceae.

Grinosporangium fuscum, var. globosum Farlow.

$$
\text { Pl. 1, figs. 7-11. }
$$

Podisoma fuscum Cooke, in Notes on Podisoma, p. 10, 1871; Peck, in 25th Report, New York State Botanist, p. 89, 1873; Farlow, in Bull. Bussey Inst., Vol. II, p. 225.

Sporiferous masses dencely agregrated, dirk brown when dry yelluwish orange when swollen, a quarter to half an inch high, compresied conical or werge-shaped; spores orate,

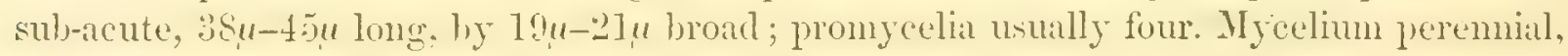
forming globose swellings in the branches.

On the smaller branches of J.virginiana.

From Massachusetts (Farlow) to South Carolina (Mellichamp).

The present form probahly passed for a variety of $P$. macropus with earlier writers provided it was observed by them at all. It was first noticed by Cooke from specimens collected by Peck, in Notes on Podisoma, and was referred by him to $P$. fiscum Duby. In Peck's lieport for 187 published in September, 1573, the species was also refereed to $P$. fuscum. It is very common in the Atlantic States on Juniperus virginiana, on which it

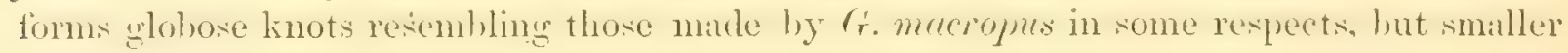
and less striking. The mycelium is perennial and abounds in the stems and leaves. 'The funcus, mlike G. macropus, does not break through the central part of the leaf. but hursts through the stem at the point of attachment of the leaves, and the knots formed do not assume the reniform outline so common even in the early stages of $G$. macropus, but are more nearly globose and on the surface. appear of a dark mahogany color, rather than silvery gray as in G. macropus. The knots grow comparatively slowly and last for several years, bearing several successive crops of spores. The sporiferous masses rupture the surface irregularly and they are not surrounded by so distinct a ring at the base as is the case in $G$. macropus. The gelatinous masses are broad and flatened at the

1 Présence du Podisoma Juniperi Sabinae sur le Juniperus virginiana et sur divers autres Genévriers: Bull. Soc. Bot.,

Vol. 25, 1. 122. 1878. 
base and taper upwards, but are comparatively broad and flattened even at the apex. The scars left by the sporifrous mases of the previous year are distinctly visible between the bases of the newly formed masses. The knots seldom attain a great size and rarely exceed an inch in diancter. They usually appear to be terminal on the sinaller branches, but sometimes they form nodes in the continuity of the branches. In course of time the surface of the knots becomes grayish and irregular by the action of the weather, but they are always more compact and harder than the knots of $G$. macropus. The leaves are not usually distorted by the fungus, but when the knots are large, the leaves on the upper branches above the knots become somewhat hypertrophied.

What we have called variety globosum, is certainly common in the Eastern States. It often accompanies (r.macropes, and is in Eastern Missachusetts about as common as that species, and Mr. Peck states that it is still more common in the region of Albany. How far west the variety extends is unknown. The southern limit, as far as I can ascertain, is Bluffon, S. C., where it was collected by Dr. Mellichanp. Although often accompanying G. macropus, and like it producing what are popularly called "cedar apples" there is no doubt that the present form is distinct from it as is shown by the fact that it is perennial and not annual, and by the very different character of the knots formed, and the appearance of the sporiferous masses. A very slight experience will enable any one to distinguish between the two at sight. The only question which can arise is whether the fungus in question is distinct from $(r$. fuscem, and on this point it is not so easy to grive a decided answer. The variety, if indeed it he not a distinct species, differs entirely from the type in the character of the distortions proluced on the same host-plant, oJ. virginiana, and it may be said with considerable truth that the same species of fungus could not produce two such different distortions in the branches of the same species of plant. The sporiferous masses, however, are in shape and color much like those of G. fuscum, and the spores themselves, the size and shape of which, at the best, are variable even in the same species, although in greneral smaller than in $G_{r}$. fuscum, are not sufficiently distinct to allow one on the strength of their smaller size alone, to separate the fungus as a distinct species. The question is, does not the smaller size of the spores in connection with the peculiar distortions caused by the fungus warrant one in regarding it as different from G. fuscum? I think it quite possible that the two are distinct, but am unwilling to speak positively without more information with regard to the morle of occurrence of $G^{*}$. fuscrem on $J$. virginiana in Europe. So far as I know, however, the globose distortions are unknown in Europe, the only case known to me where a globose mas's is figured, being in Cooke's notes on Podisoma, Pl. 19, fig. 2, but it is not there stated whether the figure was drawn from a European or an American specimen.

\section{Grmosporaygium biseptatum Ellis.}

$$
\text { Pl. 2, figs. 18-21. }
$$

Gymmosporangium biseptatum Ellis, in Bulletin of Torrey Club, Vol. v, p. 46, 1874; Farlow in Bull. Bussey Inst., Vol. II, p. 226; Vize in Grevillea, Vol. vir, p. 11; Harkness and Moore, Catalogue of the Pacific Coast Fungi, 1. 25. Exsicc. Ellis, North American Fungi, Fasc. III, No. 272. 
Sporiferous masses flattened and brownish when dry, becoming hemispherical or oval and rugose when swollen, and of a light yellow color, about a quarter of an inch high; spores linear-oblong, obtuse, two to six celled, most frequently three or four celled, $54 \mu-8 \mu$ long, by $15 \mu-20 \mu$ broad; promycelia one or two from each cell. Mycelium perennial, forming node-like swellings in the branches.

On leaves and stems of Cupressus thuyoides, Newton, Dedham, Wood's Holl, Mass. (Farlow); Newfield, N. J. (Ellis).

On Libocedrus, Yosemite, Cal. (Harkness and Moore).

A striking species first found by Mr. Ellis in New Jersey, and although only known apparently in a few localities it is probably common on Cupressus thuyoides throughout the Atlantic States. It often accompanies $G$. Ellisii for which, however, it camot possibly be mistaken. As in that species the distortions produced by (tr. biseptrtum can be seen at a considerable distance. The mycelium is peremnial, and is found in the leaves and branches, principally in the latter.

In the leaves the mycelium produces no perceptible distortion until the sporiferous masses appear. There is only one mass to a leaf, and it is first seen as a brownish elliptical protuberance emerging from the edge of the leaf. In the stem the distortions are marked and may be seen at a distance. The mycelium is found principally in the region of the cambium, and oval or oblong swellings are formed from one to two inches long, the bark becomes distended and cracked, and the sporiferous masses are found in the fissures, at first in small pulvinate tufts which on swelling form shapeless masses of rather a light yellow. The swellings increase year by year, and at length become very marked, the fungus growing constantly outwards, and producing fresh crops of spores year after year. The swellings are sometimes found in the main trunk of the tree, and I have seen them more than a foot in diameter. However large they may become, the heart wool generally remains firm and hard, and does not become spongy and ridlled with holes as is the case with the branches attacked hy (r. Ellisii, which on the whole is decidedly more injurious to the trees than $G$. biseptatum.

The spores of the present species are characterized by the great variability in the number of cells of which they are composed. The most usual number is three or four, two are rather common and occasionally there are as many as six. The spores are rather stout and obtuse, and generally constricted at the septa. When mature and about to produce the promycelia it is usual for the different cells to separate from one another either wholly or in part, as is well shown in Pl. 2, fig. 20. The spores of the present species when fully grown are not easily mistaken for those of any other species, but the young tufts on the leaves often bear spores which are all, or nearly all, two-celled. I have recered specimens from Mr. Ellis, with the fungus confined to the leares, and it was diflicult to say to what species to refer it. Large sets of specimens collected at Newton, however, show that while the young spots on the leaves may have principally two-celled spores, those on the smaller branches have about an equal proportion of two and three celled spores, and the still older spots have a large proportion of three-celled spores. In short, the variability is so great that without a large set of specimens, one would have difficulty in convincing himielf that the extreme forms belonged to the same species. 
Like C. Eltisii, the prescnt species, although occurring in localities as remote as Massachusetts and California, is known in only a few localities, but where it occurs it is generally abundant. 'There can be no doubt whatever, in spite of the unusually large number of cells of which the spores are composed, that the species should be placed in Gymmosporangimm, and the number of cells only goes to strengthen the view that IIamitspora cannot be kept as a distinct genus.

Grmmosporangium clavipes Cooke and Peck.

$$
\text { Pl. 2, figs. 22-27. }
$$

Podisoma gymnosporangium, var. clavipes C. and P., in Notes on Podisoma, 1871.

Crymmosporanginm clucipes C. and P. in Peck's 20.th Report, p. 80; Farlow. Bull. Bussey

Inst., Vol. II, p. 226 ; Exsicc. Ravenel's Fungi Americani Exsiccati, No. 272.

Poctisoma Jumiperi Herb. Curtis in part.

Gymnosporangium sp. Herb. Curtis in part.

Sprofiferous masses subpriform or irregularly grlobose becoming indefinitely expanderl, redrlish yellow when dry, orange when swollen, ahout a quarter of an inch high; spores broally ovate, obtuse, two-celled, generally constrieted at the septum; perlicels broad, much

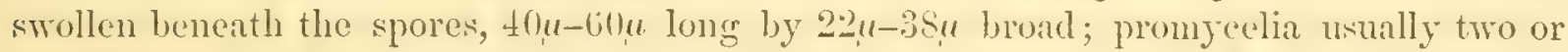
three from a cell. frepuently profluced from the apex of the cells. Mycelium perennial in the leaves and branches, producing nest-like distortions.

On Jumiperus virginiana.

Eastern Massachusetts (Farlow); New York (Peck); New Jersey (Ellis); Pemnylvania (Michener); North Carolina (Curtis); South Carolina (Ravenel).

One of the most unsightly species of the genus and certainly common in the Atlantic States from Massachusetts to Florida. The mycelium is abundant in the leaves and branches and produces peculiar distortions already referred to under (t. macropus. The leaves swell to double their original size and hecome sharp pointer and rather spreading. The effect prorluced will be seen by comparing figs. ⒉2 and 23 of Plate "2, where fig. 23 shows a twig with normal leaves, and 22 one attacked by $G$. clavipes. The branches are somewhat swollen and the branching of the affected ones becomes very dense, so that at a distance it appears as if there were bird's-nests in the boughs. The branches are often distorted for a distance of a foot or a foot and a half. The sporiferous masses are very abundant on the leaves and branches. 'Those on the leaves appear at their bases where they are adherent to the stems. They are at first broadly obovate, but soon become either subpyriform or irregularly globose and much wrinkled, and after having been exposed to a few showers they become quite amorphous, and form discoloured filns on the leaves and branches. On the branches the sporiferous masses are very similar to those on the leaves, but they are rather larger and more irregular in shape. When young and dry, they often are reddish rather than brown, and lack the deep brown color generally seen in the early stages of other species. The mycelium is apparently perennial, but I am not entirely certain on that point. 
The spores differ in several respect: from those of the species alrearly described. They are usually two-celled, but it is not at all unusual to find three cells, as is shown in Plate 2, fig. 25. They are broadly ovate, and attached to pedicels which, instead of being of nearly equal diameter throughout, as in the other species, are very much swollen just below the spores, in fact often more so than is shown in figs. 21 and 25 . The breadth of the upper part of the pedicels, however, varies with the state of expansion of the sporiferous mases, being especially broul when they are young, and stenderee when they are old. The base of the spores where the pedicels are attached is very broad, and when the masses are quickly swollen, especially by means of re-agents, the inner portion of the pedicels expands more rapidly than the outer part, and the latter is ruptured just below the spore, so that there is left a hyaline rings surrounding the pedicel at the bave of the spore.

The growth of the promycelia is peculiar in $G$. clavipes. As a rule the promycelia of the other species are given off from the cells near the part where they are in contact with one another, and they are either single or double, or, as is very frequently the case, four are given off at diametrically opnosite points. Oecasionally one sees a promycelium forming at the apex of the spore, and such a case, occurring in $G$. macropus, is shown in Pl. 1, fig. 6. In $G$. clavipes it is very common for promycelia to be formed at the apex as shown in Pl. II, fig. 27, and another promycelium near the septum. The most peculiar form is that shown in fig. 26, where the spore has fallen from its pedicel, and a promycelium is produced both at the apex and the hase. This form I have not found to be common, but it can be seen without difficulty.

The present species, in spite of some striking peculiarities, presents a general resenblance to $G$. conicum, which is common enough in Northern Europe, but is rare in this country, if indeed it occurs at all. $G$. clavipes was first separated from $G$. conicum in consequence of the swollen pedicels and the formation of promycelia at the apex observed by Peck. Curtis, judging from the specimens in his herbarium, did not distinguish $G$. clavipes from Podisoma Juniperi Lk. which is the same as the G. fuscum of the present article, for the specinen of Michener No. ts30, from Pemsylvania, and a specimen collected by Curtis himself at Hillsboro, N. C., certainly belong to G. clavipes. A

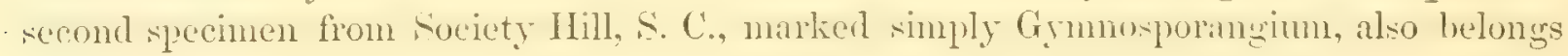
to the present species. The question whether $G$. clavipes is merely a form of $G$. conicum or not, is not easily answered. The general appearance of the sporiferous masses is the same, and if the distortions produced are different, it may be said that that may be accounted for by the fast that in Europe $G$. conicum grows on J. communis, while what we call $G$. clavipes grows on $J$. virginiana. The swollen pedicels, even admitting that the amount of the swelling varies in different specimens, has not been noticed in European specimens of $G$. conicum, and, although Oersted figures one spore in which the promycelium is given off from the tip in $G$. conicum, it seems nearly certain that no European species hats the apical form of acmination, unless exceptionally. Taking these facts collectively, I should think that $G$. clavipes was a distinct species peculiar to America, and that it was not quite certain that the true $G$. conicum occurs with us. A few forms which can hardly be included in $G$. clavipes, I should refer to $G$. conicum with a doubt. 


\section{Grinosporangium conicum, De Cand.}

Gymnosporangium conicum D. C., Flore française, Vol. II, p. 216 ; Reess, loc. cit., p. 26. Gymosporangum Juniperi Lk., Obs. I, p. 9; Species Plantarum, Vol. VI, part 2, p. 127 ; Schweinitz, Syn. Fung. Am. Bor., No. 3094; Berkeley, Outlines, Pl. II, fig. 5; Curtis, Plants of North Carolina; Peck, in 25th Report; Frost, in 'Tuckerman's Cat. Amherst Plants.

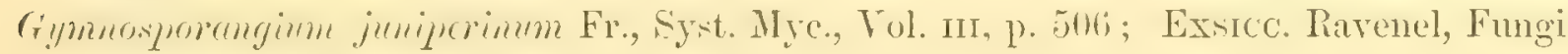
Carol., Fasc. V, 87.

Podisoma juniperinum Oersted, Nouvelles Observations, 1866.

Podisoma Gymnosporangium Cooke, Notes on Podisoma, PI. 18, figr. 2.

On Juniperus communis. Northern and Central Europe.

On Juniperus virginiana, Newton, Mass. (Farlow); New York State (Peck); South Carolima (Ravenel).

Sporiferous masses, subpyriform or indefinitely expanded, orange colorer, half an inch high; spores oblong, two-celled, constricted at the septum, $48 \mu-58 \mu$ long, by $15 \mu-18 \mu$ broad; promycelia either two or four from each cell, given off near the septum. Mycelium perennial, forming long swellings in the branches.

As before said, the determination of American specimens of the present species is very unsatisfactory. The name Gymnosporangium Juniperi Lk., to be sure, often appears in catalognes of Anerican fumci, but in many cases the retermination is evidently doubtful, and I have not thought best to accept it in several cases, but have formed my opinion rather on specimens actually collected by myself or belonging to authentic collections. In most instances the species is said to occur on Juniperus virginiana. In 'Tuckerman's Catalogue of Amherst Plants, it is reported by Frost as growing on J. commumis, but I have not been able to examine Frost's specincens, which probahly belong to the true $G$. conicum. In the Bulletin of the Minnesota Academy of Sciences for 1876, the species is said to have been found on living branches of various trees, a statement which is probably inaccurate, and tends to make the determination doubtful. As far as my own experience goes, I have only once found a form which was probably to be referred to $G$. conicum, and, in that case, the fungus was in such a condition that an accurate determination was out of the question. Of all the specimens which $I$ have examined, the No. 87, Fasc. 7 , of Ravenel's Fung. Carol., and two specimens in Herb. Curtis, collected by Ravenel on the Santee Canal in 1848 and 1850, come nearest to the true G. conicum. 'There is also a specimen in the Sprague collection which may belong to this species. Without larger sets of specimens in good condition one can not well say whether the specimens referred to may not belong to other species. Nost specimens marked G. Jumiperi Lk. which I have seen were gathered after the fungus had been exposed to the rain some time, and the only character by which one could be guided was the mode of germination of the spores, which, as $I$ have said is generally that found in $G$. clavipes, and I am not sure that all the so-called $G$. Juniperi recorded on $J$. virginiana is not to be referred to $G$. clavipes. Nore material and further study are necessary to settle that point, and it is not impossible that some European botanist may discover that $G$. conicum has at times the same swollen pedicels and apical germination as $G$. clavipes. If that turns out to be 
the case, our common Cr. claripes must be regarded as a variety of $G^{\prime}$. Jumiperi, but, as the matter now stands, I must believe that the two are distinct, and that the existence of $r$ r. conicum in the United States rests only on a few specinens resembling r $_{r}$. clavipes in habit, but which, as far as cam be made ont from specinens which as a whole are in poor condition, have longer and slenderer spores on pedicels which are not pereeptibly thickened below the spores, and whose promycelia are in twos or fours near the septum.

\section{Roestelia Rebent.}

Aecidia usually hypophyllous. lower part sunk in the swollen tissues of the leaves, forming, above, cylindrical, conical, or oblong projections which are often split and fringed in the upper part, peridium composed of large, colorles cells, spores brownish or orangecolored, subglobose when mature, formed in moniliform rows. Spernogonia punctiform, forming minute dark-colored pustules in discolored spots on the upper surface of the leaves. Mycelium infesting the leaves and stems of different Pomene.

The old genera Aecidium, Rocstelia, and Peridermium cannot be distinguished from one another except in an arbitrary way. The species of Periftrmim are parasitic on different Coniferae, the Roesteline on species of Pomeac, and Aceirlium proper is very widely diffused. Wolff ${ }^{1}$ considers that Peridermium Pini is the accidial form of Colensporium Senecionis, and De Bary and IIartig have comnected other Perilermia with Chrysumyia aud calyptosporia. The Roesteliae differ from the species of Aecilium in the fact that the peridium is elongated in a more or less tubular form, whereas in Aecidium it is short. But in forms like $R$. penicillate (Sow.) the peridium is comparatively short. while in Accidium Fraxini sichw. the peridium is so long that in the Syn. Fung. Am. Bor. it was placed by Schweinitz in Roestelia. In his work, Untersuchungen iiber die Brandpilze, De Bary considered it to be a distinguishing mark of Rocstelia that the spores were not formed from all the cells of the sporiferous filanents but from every other cell, so that the spores humg togrether for a short time by the shrivelled sterile cells. Reess adopts the sime view, but more recently De Bary" has stated that similar sterile cells are found in other grenera than hoestelia and they are certainly found in Caeoma luminatre Schw. and in species of Aecidium which I have examined. The cells which form the peridium are, like those found in Aecidium, large and colorless, with thick walls which generally have peculiar markings. They are only loosely adherent, and although they may cohere to one another in longitudinal rows, the rows, especially at the upper end of the peridium, soon separate from one another and form a fringed mouth to the peridium. In some species, however, the cells at the apex remain united and those below separate from one another so as to form a sort of lattice-work, through the meshes of which the spores escape.

The spores of Roestelia are more or less angular, when young, from mutual pressure, but when mature they generally become globose. 'They are almost always of a hrownish color, but in one of our species they are orange-colored. The wall of the spores is double, consisting of a rather thick endospore and a thin exospore. The endospore is perforated

${ }^{1}$ Beitrag zur Kentniss der Sehmarotzerpilze, Landwirthsch.

${ }^{2}$ Bot. Zeit., 1869, p. 786 . Jaturb., 1877 . 
with a number of holes, wrually from five to ten, and it is through these holes that the germinal tubes protrude. Reess considers that the number of pores can be used as a means of distinguishing species, but my experience shows that the number is variable in the same species. The spermogronia are small and found in clusters in discolored spots on the upper surface of the leaves, where they are seen as brownish black dots. The spermatia are punctiform and are almost identical in all the species of the genus.

The Roesteliae are very abundant on the leaves of our different thorns and fruit trees, and they are also found on the fruit. In some cases they cause distortions of the stems, which swell to twice their original size and become cracked and very irregular, or, if the stems attacked are small and flexible they often become much recurved. The presence of members of this genus in the leaves is indicated by yellowish or reddish spots in which the spermogonia appear first on the upper surfice, while the aecidia do not become visible until after a considerable interval in most cases. The amount of swelling produced in the leaves by the aecidia varies much in the different species. In some it is only slight, often in the form of a ring, but in others prominent ovois or conical projections are found. The duration of the mycelium is a point of importance in considering the connection between Roestelia and Gymnosporanguim. Certainly in some cases it seems to be perennial, but supposing that there is a genetic comnection between the two genera just naned, one would expect the Roesteliae to be annual products of the rerminating sporidia of the different Gymnosporangia. The date of the appearance of the different species is also of importance in attempting to connect any particular Roestelia with a given species of Gymnosporangium. Some species, as $R$. penicillatr, mature in May and June, almost simultaneously with the Gymmosporangia, while other species, as $R$. botryrpites, do not ripen until the middle of September or October. From an economical point of view, the Roesteliae are of considerable importance, since they attack the leaves of so many of ou finit trees, causing them to fall prematurely, and some of the species attack the yonng fruit as well as the leaves.

The determination of the species from their anatomical strueture is attended with many difficulties. The principal characters used are the gross appearance of the spots and swellings and the microscopic characters of the spores and the cells of the peridium. Too many species depend upon the amount of splitting of the peridium which evidently must depend to a large extent upon the age of the latter and accidental circumstances. The species of Roestelia are, moreover, not limited to a single host-plant, and one must naturally expect modifications of the swellings and of the peridium according as the Roestelia is parasitic on different hosts.

\section{Roestelia botryapites Schw.}

Caeoma (Roestelia) botryapites Schweinitz, Syn. Fung. Am. Bor., No. 2902.

Roestelic Ellisii Peck, Bull. Torrey Club, Vol. vir, p. 13. Exsicc. Mycoth. Univers., No. 431.

Roestelia botryapites Schw., Berkeley in Grevillea, Vol. v, p. 34; Firlow, Bull. Bussey Inst., Vol. II, p. 225.

Aecidia hypophyllous, borne in tuberculated or pyriform protuberances about an eighth of an inch high, sometimes solitary, usually densely aggregated or consolidated, 3-14, 
usually 7-S together; peridia cylindrical, contracted at the base, brownish-white, an eighth of an inch long, composed throughout of long, sinuous, smooth-walled cells, 12u-15u in diameter, which cohere at the apex and separate below in meshes so that the peridium is clathrate. Spores brownish, 15u-19u in dianeter, epispore slightly granular, pores indistinct. Spermogonia few in number in the depressed upper part of the leaves.

On the lenves of Amelanchier canadensis.

Eastern Massachusetts (Farlow); Newfield, N. J. (Ellis); Bethlehem, Pa. (Schweinitz).

A striking species which does not mature until the middle of September or the first of October, the spermogonia appearing in the latter part of August. It is distinguished from our other species by the large-sizad tubercles which appear in dense clusters on the under surfaces of the leaves, from which protrude the long peridia which resemble those of $R$. cancellata in having the eells coherent at the apex and separate below, so that the periclium becomes elathrate, the spores being discharged through the meshes. The peridia, however, are less hoad and bulging than in R. cancellata and the microscopic character of the colls is very different. In R. botryopites they are longer and more slender than in any of our other species, and the cell-walls are destitute of the papillose or gramular markingss found in most of the species. They are also so sinuous and so long that an accurate measurement of their length is out of the question. The different cells, instead of overlapping at the extremities as in $R$. cancelluta, fit clusely together, and the apical cells, instead of being shorter and broader than those below as in the speecies last named, are of about the same breadth and shape throughout. In fuct, so narrow and smooth are the cells and so closely are they united to one another at the extremities that, on seeing them for the first time under the microwcope, one woukd be more likely to suppose them to be some brownish mycelium than a collection of peridial cells. The spores of $R$. botryapites are, on the average, smaller than those of our other species. The fungus forms reddish-yellow spots on the leaves of Amelanchier in which the spermogonia are developed in comparatively small numbers, and when the swollen masses of the leaf in which the aecidia are borne appear, the upper surfice bearing the spermogronia becomes depressed. 'The tubercular masses are much contracted at the base, and when fully mature they drop from the leaves, only a small scar remaining. The cells of the tubercles abound in starch grains, in this respect resembling $R$. cancellata.

'The present species is very common in Eastern Massachusetts and has probably a wider range than one would infer from the very few recorded localities. It is frequently seen in entomological collections, and the large tubercles with their small bases certainly remind one more strongly of insect galls than the work of fungi, at least until the peridia have protruled. The Schweinitzian species remained for a long time obscure, but it was rediscovered by Ellis at Newfield, N. J., and named hy Peck (r. Ellisii. Berkeley is quoted in Grevillea, loc. cit., as having ascertained the identity of the two species from the examination of an original specimen of schweinitz. There is a specinen from Schweinitz in Herb). Curtis, but the peridia and spores are not mature. As fir, however, as can be judged from its present condition, it seems to be the same as specimens collected by Ellis. 


\section{Roestelia transformans Ellis.}

Roestelia transformans Ellis, Bull. Torrey Club, Vol. v, p. 3; Farlow, Bull. Bussey Inst., Vol. II, p. 255. Exsicc. Thümen, Mycoth. Univers., No. 1029.

Accidia hypophyllous, or covering the young shoots and fruit, borne in conical protuberances, occasionally $3-4$, generally 5-20 or more together, consolidated at the base ; peridium brownish-yellow, a tenth to a twelfth of an inch long, at first conical but soon becoming lacerated; cells of peridium isodiametric at apex, below long and narrow, 12, $4-15 u$ in diameter, not overlapping on the inner side, cell-wall papillose; spores globose, brownish, $18 u-22 u$ in diameter, cell-wall nearly smooth. Spermogonia few in number in purplishred spots on the upper side of the leaves.

On the leaves, fruit and young shoots of Pyrus arbutifolia and on the leaves of Pyrus malus.

Newfield, N. J. (Ellis); Newton, Gloucester, Wood's Holl, Mass. (Farlow).

This species, which occupies an intermediate position between $R$. botryapites and $R$. cancellata, is common on Pyrus arbutifolie in Eastern Massachusetts. It occurs in three forms. On the leaves it forms purplish-red spots and the aecidia are generally comparatively few in number and rather slender. On the fruit they are more numerous and shorter, and when the fungus is found on the young shoots they sivell to several times their original size, and become much curved and twisted and take on a yellow color. The number of aecidia produced on the stems is very large. The aecidial protuberances are rather acutely conical and more slender than in either $R$. botryapites or $R$. cancellata; they readily fall from the leaves as in the first-named species. It is only in the young condition that the cells of the peridia cohere at the apex, and, as generally seen, the peridia are lacerate. The peridial cells resemble those of $R$. cancellata but are more slender and do not project inwards. The spores resemble those of $R$. botryapites.

What seems to me the sane species was collected on apple leaves near the Bussey Institution, Jamaica Plain, Mass., but did not seem to be common. The species is probably common near the sea-shore, but is actually recorded in but few places. It is not likely to escape observation wherever it occurs for the purple spots on the leaves and the distorted shoots are very striking.

\section{Roestelia Cancellata Rebent.}

Rocstelia cancellata Rebent, Fl. Neom., p. 350, Pl. II, fig. 9; Curtis, List of Plants of North Carolina, p. 123; Oersted, Om en saeregen, etc., Pl. II and III ; Reess, loc. cit., p. 20 ; Decades of Maine Fungi, p. 180; Grevillea, Vol. v, p. 151.

Aecidium cancellatum Schweinitz, Syn. Fung. Carol., No. 433.

Caeoma roestelites Lk., Spec. Plant., Vol. vi, part 2, p. 161; Schweinitz, Syn. Fung. Am. Bor., No. 2900.

Aecirlia usually hypophyllous, borne in the swollen tuberculated substance of the leaves, consolidated at the base in clusters of $4-20$; peridia yellowish-white, a twelfth to an eighth 
of an inch long, hroally orate, acute and closerl at the apex, clathate helow ; peridial cells thick-walled, surface papillose, isodianetric, ahout 381, coherent at the apex of peridium, below united in longitudinal rows; cells about 20 thick by 60 m-80u long, the upper end of each cell projecting inwarls and overlapping the base of the cell above; spores brownish, roundish-angular, ¿5, to s0u in dianeter, cell wall thick, pores well marked. Spermogonia numerous in the discolored upper surface of the leaves.

On leaves of apple and pear trees.

Westlorook, Me. (Bolles); Bethlehem, Pa. (Schweinitz); North Carolina (Curtis); California (Harkness). Europe.

The typical R. cancellata is common in Europe and is easily distinguished. It has been published in several series of exiceati of which I need only mention Libert, No. 394, and Thümen, Mycoth. Univers. No. 537, where the specimens are very characteristic. The ateidia are borne in swollen parts of the under surfice of the leaves, but the swellings are by no means so large as those of $R$. botryngites and they are hoarl at the base, not constricted as in the last-named species. Although the peridium bears some resemblance to that of $R$. botryapites and $R$. transformans, it is distimet in having the upper end of the cells prolonged inwarks in the form of a papilla. The peridial cells are quite different from those of $R$. botryapites but resemble more closely those of $R$. transformans. $R$. cancellata must be considered a rare species in the United States as far as at present known. It is only known in doubtful cares in Eastern Massachusetts and it is not enmmerated by Peck among the Roesteliae of New York. The fungus mentioned under the name of $R$. cancellata in Bull. Bussey Inst., Vol. II, p. 225, does not seem to me really to be that species. The only specimens which I have examined of the Aecidium cancellatum of the Syn. Fung. Car. Sup. and of Caromn roestelites Syn. Fung. Am. Bor., were in poor condition, and certanly were not trpical $R$. concellute, and although mentioned in Curtis's list as occurring in North Carolina, there are no specimens in Herb. Curtis to mark the locality. Considering that the species is easily recognized from European specimens, there would probal,ly be no difficulty in recognizing it if it occurred with us. One thing is certain, that the very common Roestelia found on apples in the autumn in Eastern Massachusetts is not R. cuncellata. The present species is generally found on the leaves only, but is said also to attack the smaller branches.

\section{Roestelia cornuta (Ehrh.) Fr.}

Aecidium cornutum Pers. in Gmel. Syst. Nat.

Caeoma cylindrites Link, Species Plantarum, Vol. vi, part 2, p. 64, in part; Schweinitz in Syn. Fung. Am. Bor., in part?

Roestelia cornuta Fr., Summa Veget. Scand., Vol. II, p. 510; Oersted, Nouvelles Observ.,

Pl. IV; Reess, loc. cit., p. 2S; Peck, 24th Report; Farlow, Bull. Bussey Inst., Vol. II, p. 225 ; 'Tuckerman's Plants of Amherst.

Ceratitium cormutum Rabenh., Bot. Zeit., 1851, 452.

Centridium sp. Chevallier, Desmazières, et al. 
Aecidia hypophyllous, in pulvinate, orange-colored thickenings of the leaves, dencely agglomerated. 10-40 together, often arranged in a circle; peridia yellowish-brown, cylindrical-acute, recurved, genceally entire but when old becoming fimbriate; peridial eclls large, polygonal, coherent throughout, thick-walled, $38 n-1.5 \mu$ broad by $58 \mu-76 \mu$ long; spores yellowish-brown, surfice slightly papillose, roumdish-angular, 1Su-22 a in diameter; spermogonia numerous in reddish-yellow spots on the surface of the leaves.

On the leaves of Pyrus americana, Amelanchier canadensis, Crataegus sp.

Eastport, Maine (Farlow); Amherst, Mass. (Frost); New York (Peck); Ithaca, N. Y. (Dudley). Northern and Central Europe.

This species in its typical form is common on the leaves of Pyrus americana at Eastport. The spots on the leaves are of a brilliant reddish-yellow color, the spermogonia very numerous and the aecidia crowded together in a circle, the swelling of the leaf being in the form of a circular elevation and not at all tubercular as in the preceding species. The peridia are long and recurved and preserve their shape for a considerable time, becoming at length lacerate. In this, its typical form, it is more robust than $R$. lacerata, and the peridial cells are broader and thicker. The form which occurs on Amelanchier has fewer aecidia in a cluster, the substance of the leaf around their bases is more distinctly tubercular, and the peridia are shorter and more acute than in the form on the mountain ash, approaching, perhaps, $R$. lacerata. The occurrence of $R$. cormuta on species of Crataegus in the United States possibly requires confirmation. I have specimens on $C$. crus-galli which may perhaps be referred to $R$. cornuta but am not certain. None of the Schweinitzian specimens of Caeoma cylindrites which I have examined seem to belong to the present species, but possibly some of the varieties mentioned under that head in the Syn. Fung. Am. Bor. may be placed here.

\section{Roestelia lacerata (Sow.) Fr.}

Aecidium oxyacanthae Pers., Syn., 206.

Aecidium Mespili and oxyacanthae D.C., Flore française, Vol. vi, p. 98.

Aecirlium laceratum Sow., British Fungi, Pl. 318. Exsicc. Ravenel, Fungi Carol., Fase. $\mathrm{v}, 96$.

Aecidium crataegi var. oxyacanthae Schweinitz, Syn. Fung. Car. Sup., No. 432.

Caeoma cylindrites var. Crataegi punctatae, var. arborescentis and var. C. oxyacenthae Schweinitz, Syn. Fung. Am. Bor., No. 2899.

Roestelir letercte Fr., Summa Veget. Scand., Vol. Ir, p. 510; Sprague, Contrib. to New England Mycol., p. 329 ; Decades of Maine Fungi, p. 180; Peck, 22.d and 24th Reports; Farlow, Bull. Bussey Inst., Vol. II, p. 25j; Tuckerman, Plants of Amherst; Inarkness and Moore.

Aecidia hypophyllons, sometimes on the stems and young firuit, seated on the yellow pulvinate thickening of the leaves, slender, cylindrical or somewhat subulate, recurved, densely clustered, 5-30 together; peridia yellowish-white, rather delicate, soon splitting and becoming fimbriate, the divisions not extending to the base of peridium; cells of peridium narrow, $20 u$ broad by 5.ju-75u long; spores brownish, roundi-kh-oblong, surface 
finely granulated, 19u-21 $\mu$ in diameter. Spermogonia in yellowish spots on the upper surface of the leaves.

On leaves, stems, and fruit of Crataegus crus-galli, C. punctata, C. coccinea, C. tomentosa, C. oxyacantha, and other species; on leaves and fruit of Amelanchier candensis, and on leaves of wild and cultivated apples.

Common from Maine (Bolles) to South Carolina (Mellichamp), and west to Missouri (Engelmann).

This is decidedly the most common species found with us, and it abounds on all wild and cultivated species of Crataegus and apples. On the one hand the species approaches $R$. cormuta, from which it is distinguished by being more slender, and when young, splitting into segments which become fimbriate, and hy the namower peridial cells. On the other hand, it approaches $R$. penicillutr with which, in fact, it is united by some authors. $R$. lecerate is more variable than most of our species, and I can distingruish the following forms. On C. tomentosr and other species of Crataegus the aecidia are borne on small, slightly swollen spots, and the peridia are large and diverge from one another. Our form is precisely the No. 556 of Westendorp and Wallys. The form on Amelanchier is the Lecidium Mespili D.C., and the swellings of the leaves are more strongly marked, and the peridia shorter than in the form last described. Our smallest form is found on apple leaves. The spots are bright yellow and the aecidia are few in number, often only $1-3$, and occupy the centre of the spot. Possibly this last form might he separated as a distinct species. It is, apparently, not the variety Mati of the Syn. Fung. Am. Bor. The specimen in Mycotheca Universalis, No. 732, collected by Ellis at Newfield, N. J., lahelled R. laceratr, f. Mali, is said by Von Thünen to be synonymous with decidinm cancellatum of the Syn. Fung. Carol. Sup., but on what authority the statement rests is uncertain.

Roestelia penicillata (Sow.) Fr.

Aecidium penicillatum Pers., in Gmel. Syst.

Aecidium Mati Schum., Fl. Saell., Vol. II, 222.

Aecidium laceratum D. C., Flore Française, Vol. VI, p. 98.

Caeoma cylindrites, var. Mali Schweinitz, Syn. Fung. Am. Bor., No. 2899.

Aecidium pyratum Schweinitz, Syn. Fung. Am. Bor., No. 2896.

Roestelia penicillata (Sow.) Fr., Summa Veget. Scand., Vol. II, p. 510.

Ceratitium penicillatum Rabenh., Bot. Zeit., 1851. 452.

On leaves and fruit of P'yrus malus and Pyrus angustifolia and fruit of Amelanchier canciensis.

Eastern Massachusetts (Farlow); Santee Canal, S. C. (Ravenel).

Sime as $P$. lacerata, but aecilia smaller and frequently concentrically arranged, peridia splitting to the base, the divisions very numerous, revolute, fimbriate, formed of one or more rows of cells.

The present species, if indeed it is not a form of the one last described, does not appear in Ancrican Catalogues as distinct from $R$. lacerala. It is not uncommon and seems to 
attack the fruit more frequently than $R$. lacerate. The Aeridium pyratum of Schweinitz, Syn. Fung. Am. Bor., is probably the same as $R$. penicillata. I am indebted to the officers of the Acatemy of Natural sciences of Philadelphia for the privilege of examining the original specimen in their collection and I have also specimens from Ravenel and Curtis which do not differ from the type. Although it is musual to find $R$. penicillatre on Crataegus in this country, what seems undoubtedly that species was collected by Prof. W. R. Dudley on C. crus-galli at Ithaca, New York.

\section{Roestelia hyalina Cooke.}

Roestelia hyulina Cooke, in Bull. Bot. Soc., 1877, pp. 314, 315; Hedwigia, Tol. xvir, p. 38; Grevillea, Vol. vi, p. 137. Exsicc. Ravenel, Fungi Americani, No. 37.

Aecidia hypophyllous, borne few together in subpyriform tubercules; peridia pointed, cylindrical, delicate, splitting longitudinally ; peridial cells rhombic-ovate, ahout 35) broad by bŏu lonğ, cell-walls thin, nearly smooth; spores globose, $19 u-22 u$ in dimeter. Spermogonia few, in yellowish spots on the upper surface of the leaves.

On leaves of Crataegus.

Aiken, S. C. (Ravenel).

This species is only known to me by the single small specimen in the Fungi Americani Exsiccati, from which the description above given was taken. The specimen bears a close resemblance to some forms of $R$. lacerata, but the cells of the peridium are thin walled and destitute of the markings generally seen in the other species. The spores in my specimen are distinctly brownish and not orange colored as given in the description in IIedwigia, loc. cit. As it may be that there was an error in distribution, I quote the original description. "Epiphylla, vel amphigena. Maculis rufis. Soris convexis brumneis. Pseudoperidis cylindrico-acuninatis, longitudinaliter et unilateraliter dehiscentibus. Sporis globosis, aurantiacis, .02-.022 mm."

\section{Roestelia aURantiaca Peck.}

Roestelir aurantiacn Peck, in 25th Report, p. 64, Pl. I, figs. 10-12; Bull. Buffalo Soc. Nat. Sci., Vol. I, p. 68 ; Tuckerman's Plants of Amherst; Farlow, Bull. Bussey Inst., Vol. II, p. 225. Exsicc. Ravenel's Fungi Americani, No. 217.

Roestelia lacerata Herb. Curtis in part.

Aecidia densely aggregated on the young fruit and swollen stems; perumarecu or slightly recurved, an eighth to a quarter of an inch in length, cylindrical, tubular, shining white, coarsely toothed at the apex, teeth seldom extending more than a quarter of the length of the peridium; cells of peridium squarish-ovate, closely united, about j5: long by $36 \mu$ broad, cell wall very thick and striate. Spores bright orange, spherical or slightly angular, $27 u$ to $47, u$ in diameter, averige $30 u-40 u$, cell wall thick, punctate, pores distinct. Spermogonia in discolored spots on the leaves. 
On unripe fruit and stems of Crataegus crus-galli, C. punctata, C. oxyacantha and other species of Crataegus, on Amelanchier canadensis and on cultivated quinces and apples.

Not rare from Massachusetts (Farlow), Vermont (Frost), New York (Peck), to North Carolina (Curtis), South Carolina (Ravenel), and Missouri (Engelmann).

By far the most beautiful species of the genus which we have, at once attracting the popular eye by its brilliant oringe or almost cimnbar colored spores and shining white peridium. It is generally fouml on the young fruit, though it is occasionally foum on the stems and petioles, but I do not recollect having seen aecidia on the leaves. What I take to be spermogonia of this species are found on the leaves apart from the aecidia. $R$. aurantiaca is often accompanied by $R$. lacerata, but one cannot consider the former to be a form of the latter, which grows on the fruit rather than leaves, for the differences in the spores and cells of the peridium are too marked to warrant any such supposition. The peridia of the present species are more rigid than those of our other species, and the cells cohere throughout, except at the tip where the peridium splits into comparatively few short teeth, and does not become lacerate or penicillate as in most of the species. The spores are large for the genus Roestelia, and instead of the brownish tinge common in other species, they are bright orange. The cell-wall is quite thick and striate. In drying, the spores become pale, but their size and cell-wall even then are sufficient to distinguish present from other species.

$R$. aurentirce is represented in Herb. Curtis hy several specinens, including some collected by himself in North Carolina. He apparently considered them all forms of $R$. lacerreta, at least, they are so labelled. The species is particularly apt to attack the different species of Crataerus, and the peridia attain a large size on the small herries of that genus. It is reported by Peck to occur on Amelanchier, but I have never myself seen it on that host. Perhaps the most striking form is that which is often found on quinces in Eastern Massachusetts. I have collected specimens in Newton and I have received others from Pepperell, Miss Freeman; and from near Silem, Mr. Robinson; and there are rpecimens in Herl). Curtis and the Sprague collection from Mr. John Russell. One sometimes sees a quince two inches in diameter more than half covered by the bright orange aecidia and occasionally small apples are affected in a similar way. $R$. aurantiaca is generally found in midsummer, I have, however, seen it on $C$. crus-galli as late as October.

After the preceding detailed account of the species of Gymmosporangium and Roestelia of the United States, one naturally wishes to know how far the view first promulgated by Oersted is confirmed by cultures made with American species. Oersted recognized three species of Gymmosporangium, and, at first, four species of Roestelia growing in Demmark. He was afterwards induced to believe that two of the supposed Roesteliae, R. Tacerata and R. penicilluta, were only forms of a single species, and he considered that he had proved that $G$. fuscum was connected with $R$. cancellata; $G$. clavariaeforme with $R$. lacerata, including in that the form $R$. penicillata; and $G$. conicum with $R$. comuta. 'Thus, there were no superfluous species of either genus in Denmark, that is, there was no species of one genus which could not be matched with a species of the other genus. 
From the account alrearly given. it will be seen that I recognize the following species, and the question which I have unsuccessully tried to answer is, what species with us are genetically connected. To sum up the species, we have:

Gimosporangium.
G. Ellisii.
G. clavariaeforme.
G. macropus.
G. fuscum.
G. fuscum var. globosum.
G. biseptatum.
G. clavipes.
G. conicum?

\section{Roestelia.}

$R$. botryapites.

$R$. transformans.

$R$. cancellata.

$R$. cormuta.

R. lacerta.

R. penicillata.

R. hyatina.

R. aurantiaca.

It will be seen that I have mentioned eight species of each genus which could on anatomical grounds alone be considered distinct. Of the species enumerated, G. conicum is given as doultful, because it scemed to me that sufficiently alumdant material was wanting to enable any one to speak with certainty. $G$. fuscum var. globosum, it will also be borne in mind, is not by several writers considered distinct. With the possible exception of the two species just mentioned, the validity of the species of Gymmosporangium is not likely to be much questioned. 'Turning to the Roesteline, we have $R$. lacerata and $R$. penicilluta enumeraterl, which are by many writers united on anatomical grounds, apart from any developmental considerations, and $R$. concellata, a species whose presence, or, perhaps better, whose distribution in the United States is not sufficiently well known in my opinion. In speaking of $R$. lacerata, also, one must not forget that, even in the limited sense in which I have arlopted it, it appears under a good many different forms which some botanists on anatomical grounds alone might consider distinct.

If one is disposed to admit the eight species of each genus with the limitations I have given, he might suppose that the task of tracing the connection between them would be comparatively simple and interesting. A very slight experience, however, would convince him of the contrary. In the first place, if we accept the conclusions of Oersted as correct with regard to the Dinish species, lnowing that two and perhaps all three of the Danish Gymnosporangia are found in the United States, we are struck with the fact that, although $G$. fuscum, regarding var. globosum as distinct, and the true $R$. concelluta, its supposed aecidial form, are about equally common, or rather equally rare, with us, when we come to $G$. claverineforme, the case is different, for the Gymnosporangium is not at all common, while its presumed aecidium, $R$. lucerata, is very common, indeed being found hundreds and even a thousand miles from localities where $G$. cluctrineforme is known. About the comparative distribution of $G$. conicum, and its corresponting $R$. cometa, little can at present be said, since the localities of $G$. conicum are not well known. Yet, in general, what is supposed to be G. conicum is best known towards the South, while $R$. cormutu is northern in its range, unless, indeed, that species properly includes some of the forms now included in $R$. lacerata. If, on the other hand, with some writers we regard the var. globosum as identical with $G$. fuscum of Lurope we are, in looking at the distribution, met with the difficulty that $G$. fuescum var. globosem is very common in Massachusetts, for instance, whereas its supposed aecidium, $R$. cancellata, is not known with 
certainty to occur at all, and where, at least, the common Roestelia on apple leares is certainly not $R$. cancellata.

It first sight, then, we would not adnit the correctness of Oersted's views with regard to particular species without further infuiry, and one naturally resorts to artificial cultures. These may consist in sowing the serminating sporidia of the different species of Gymmosporangium either on leaves of lifferent Pomene, liept moist under bell-ghlasices, or on the young plants themselves. 'The former mode is more convenient, but has this oljection that, although after sowing sporidia on the leaves spermogonia may appear in from about eight days to a fortnight, yet the interval is so great between the production of spermogronia and the development of the aecidia. from which alone the species can be with certainty determined, that the leaves, kept in a moist place, are almost sure to be lestroyed by moulds before the accidia have developed. Cultures made with the young plants themselves permit the development of the aecidia, but for merhanical reasons they are less easy to manage, and one is also obliged to keep a series of plants on which no sowing has been made, in order to make it comparatively sure that the mycelium of the Roestelia was not in the plants before the cultures began. I have, as a rule, made use of leaves only because the amount of space at my control was limited, and because it was difficult for me to procure young plants of some of the species required for cultures. The season of the year when the subject must necessarily be studied, the latter part of the spring, is, moreover, one when numerous occupations prevent my devoting as much of my time to the cultures as I should like.

In the spring of 1875 , I procured two plants of Amelanchier canadensis about a foot high, and sowed upon the leaves the sporidia of $(r$. macropus which were seen by microscopic examination to be in good condition. Nothing resulted from it. I was led to begin with this experiment because the most striking Gymmosporangium in the region of Boston is Gr.macropus, and one of the most prominent lioesteline is R. botryaphites which grows only on Amelanchier, and both species are peculiar to America. Since 1875 I have repeatedly male attempts by cultures to demonstrate the comection between our different species. The species with which I have experimented are G.macropus, G. fuscum var. globosum, ${ }^{1}$ G. Ellisii, G. biseptatum, and $G$. clavipes, all common near Boston.

I. May, 1876 .

G. clavipes sown on 6 Amelanchier leaves. No result.

G. Ellisii on 6 apple leaves, three Amelanchier leaves, and two leaves of Cratcegus tomentosa. No result.

G. macropus on 3 leaves of Crutuegns tomentosa, 6 apple leaves, 4 Amelanchier leaves. Spermogonia formed on one leaf of $C$. tomentosa.

G. globosum on 3 leaves of Crataegus tomentosa, 3 of Amelanchier, and 3 of apple. Spermogonia appeared on all the leaves of Crataegus.

II. May, 1876 .

G. macropus on two small pear scedlings. No result.

G. globosum on one young plant of Crataegus oxyacantha. No result.

III. June, 1876.

G. globosum on 5 leaves of Crataegus tomentosa. No result.

$G$. macropus on 3 leaves of Amelanchier. No result.

${ }^{1}$ For sake of brevity this form is given under the name of $G$. globosum in the following tables. 
G. clavipes on 3 leaves of Amelanchier. No result.

Note. The cultures of 1876 were made at the laboratory of the Bussey Institution. Those made in June continued only 17 days, but no result being then obtained the laboratory was closed for the season.

IV. May, 1877.

G. macropus on 3 leaves of apple, 3 of Amelanchier, 3 of Crataegus tomentosc, and 3 of Pymus arbutifolia. Spermogonia appeared on one leaf of Amelanchier and one of C. tomentosa in ten days.

G. globosum on 3 leaves of apple, 3 of Amelanchier, 3 of Cratcegus tomentosa, and 3 of Pyrus arbutifolia. Spermogonia appeared on ali the leaves of Crataegus.

G. biseptatum on 3 leaves of Crataegus tomentosa, 3 of apple, 3 of Amelanchier, and 3 of Pyrus arbutifolia. Spermogonia appeared on one leaf of Crataegus in six days.

G. Ellisii on 3 leaves of apple and 3 of Amelanchier. No result.

Note. The cultures of 1877 were made at the Bussey Institution, and lasted from May 25th to July 4th. V. June, 1878.

G. macropus on 3 apple leaves, 3 of Crataegus oxyacantha, 3 of $C$. crus-galli, and 3 of pear. No result.

G. Ellisii on 3 apple, 3 pear, $3 C$. oxyacantha and $3 C$. crus-galli leaves. No result.

G. biseptatum on 3 apple, 3 pear, $3 C$. oxyacantha and $3 C$. crus-rjalli leaves. No result.

G. globosum on 3 pear, 3 C. oxyacantha, 3 C. crus-galli, and 1 apple leaf. No result. VI.

G. Ellisii on two pear seedlings and on two young plants of $C$. tomentosa. No result.

G. macropus on an apple seedling and 2 plants of $C$. tomentosa. No result.

Being absent from Cambridge in 1879, no cultures were made, and the cultures of 1880 present no result worth detailing, as no spermogonia were produced.

In reviewing the record given above, one is struck with the small number of cases in which spermogonia succerent the sowings on the different Poneac. Certainly a sufficient variety of leaves was selected, for it is on Amelanchier, Crataegus, Pyrus arbutifolia, and cultivated apples and pears that the greater part of our Roesteliae are found in nature. That the sporidia used were in good condition was shown by microscopical examination. In running over the list, it is seen that the only plants on which spermogonia were produced were Crataegus tomentosa and Amelanchier canadensis. 'Those on Amelanchier followed the sowing of the spores of $G$. macropus, but, inasmuch as three species of Roestelia are known on that plant, it is impossible to say to which the spermogonia belonged. What is surprising, however, is that of the three species of Gymnosporangium which were followed by spermogonia on $C$. tomentosa, viz: $G$. macropus, G. globosum, and $G$. biseptatum, not one is the species which, according to Oersted, ought to produce our common form on $C$. tomentosa, namely $R$. lacerata. Accepting his view one would hardly have been led to expect spermogonia on such a host plant from three species so distinct from $G$. clcwariceforme. Further, we are not allowed to suppose that the production of spermogonia on $C$. tomentosa indicates any close resemblance between the three different Gymnosporangia. It might, perhaps, be said, considering how much more frequently the spermogonia followed the sowing of $G$. globosum than of the other two species, that where the spermogonia appeared to follow the latter, it was really because some of the 
sporidia of $G$. globosum had become mixed with those of the two other species. Such a supposition is possible in the case of $G$. macropus which often grows in company with $G$. glousum, but it can hardly be true of the $G$. biseptatum in question, which grew in a deep swamp remote from $G$. globosum, and the specimens of which were collected and covered with care to prevent a mixing of the spores with those of other species.

Whether we consider the distribution of our species or the results of the cultures made, there is nothing to confirm the views of Uersted as to the connection of particular species. In this connection, I would refer to a paper by Rathay known to me only by the abstract given by Magnus in Bot. Zeit., 1880, p. 798. 'The method of culture adopted by Rathay is unknown to me, but he came to the conclusion that $R$. penicillata belonged not as a form of $R$. lacerata to $G$. clavariaeforme, but to $G$. fuscum. If then our $G$. fuscum var. globosum be really a variety of $G$. fuscum, and if $R$. penicillata be a form of $R$. cancellata as supposed by Rathay, then the spermogonia on r'. tomentosa, which so frequently followed the sowing of the sporiclia of $(r . g$ globosum, might be supposed to belong to what I have called $R$. pemirillate, which does occur on Cratacerus in the Lnited States. One conld not be at all certain, however, without seeing the fully developed aecidia, but it must not be foretten that those who are fully imbued with the helicf that the different aecirlial grenera as Aecidium, Roestelia, etc., are stages of Puccinia, Gymnosporangium, etc., accept the appearance of spermogonia alone, without having seen the aecidia, as strong proof of a connection between different forms. In fact the instances where the aecidia themselves have been produced by cultures of teleutospore forms are very few in number. But even if we admit that the spermogonia following the sowing of $G$. fuscum helonger to $R$. prenicillatu, what are we to say of those which followed the sowing of $G$. macropus and $G$. biseptatum? It is absolutely impossible to consider $G$. biseptatum a form of $G$. fuscum, nor, in my opinion, is there any reason to suppose that $G$. macropus is a form of that species.

Spermogonia followed sowings of $G$. macropus on both $C$. tomentosa and Amelanchier, and accordingly they might have belonged to $R$. lacerata or $R$. aurantiaca. $R$. comuta may be excluded as belonging, according to Oersted, to $G$. conicum, which is not in the least related to $G$. macropus, and the distribution of $R$. hyalina makes it very improbable that it is connected with the ubiquitous $G$. macropus. R. lacerata should be connected with $G$. clavariaeforme and, as has already been remarked, Schroeter has suspected that G. macropus may be a form of the last named species, but I have already stated my reasons on structural groumds for not considering them two forms of the same species, and I do not think that that belief should be altered in consequence of the results of my cultures. There remains then $R$. aurantiaca which might possibly be connected with $G$. macropus.

The case of $G$. biseptatum is still more desperate. It certainly cannot be commected with $R$. penicillata, or $R$. lacerata, and if we assume it probable or even possible that there is a connection between $G$. macropus and $R$. aurantiaca, there is only left $R$. cormuta to be matched with $G$. biseptatum, and this would imply that $G$. conicum and $G$. biseptatum were forms of the same species, which I presume that few botanists are willing to admit, for excellent anatomical reasons.

'The reader has probably in the last few pages been surfeited with if's and or's, and a choice of rather bewildering alternatives. 'There is only one more point to be suggested in this connection. That is, that the appearance of the spermogonia after sowing the 
sporidia of the three Gymmosporangia in question, was in consequence of the presence beforehand, in the leaves, of the mycelium of some Roestelia which was made to develop by the moist condition in which it was placed. I am strongly inclined to favor this view, because in many cases I have from the beginning had my suspicions that the leaves of Crataegus tomentosa used might contain the mycelium of a Roestelia.

$R$. lacerata is so common in the region about Boston at just about the date of the maturity of the Gymnosporangia that it has been with great difficulty, at times, that I have procured leaves of $C$. tomentosa which appeared even to the naked eye to be free from the fungus. In some cases pots of the young Crataegus used as control plants, showed a growth of spermogonia without any sowing at all, and it was necessary to reject from the cultures all the pots in consequence of the suspicion which was attached to them. In one case, furthermore, spermogonia appeared on a leaf on the fourth day after sowing, a suspiciously early date, muless one supposes that the mycelium was alrealy in the leaf at the time of sowing. Again, why was it that, with abundance of fresh sporidia of all our common species, in only one instance did spermogonia develop on any other leaves than those of $C$. tomentosa? The same pains were taken in sowing, the same care was exercised during the continuance of the cultures, yet in spite of that, spermogonia were only produced, one case excepted, on $C$. tomentosa, the very plant of all used whose leaves were in some cases doubtful, and produced, too, by three different Gymnosporangia, none of which is the species supposed by Oersted to be connected with $R$. lacerata, our common Roestelia on Crataegus. There is only one thing, viz.: the comparative frequency with which the spermogonia followed sowings of G. globosum, that prevents my expressing a strong belief that the results of my cultures indicate that the Roesteliae in question were originally in the leaves used, and did not follow as secondary stages of the Gymmosporangia experimented upon. It must be armitted that the accuracy of Oersted's views with regard to the development of the three Danish species is not so generally acknowledged at the present day as it was a few years ago, and the note of Reess on $R$. penicillute, and Rathay's recent observations, show that even if Oersted is in general correct in supposing that the Roesteliae are genetically comected with the Gymnosporangia, he has certainly failed to show the connection in the case of given species.

Much may be said on both sides of the question of the relations betrreen the so-called aecidial and final forms, but in this paper I have only considered the two comparatively small genera Roestelia and Gymnosporangium. Much more work remains to be done in this country. In the first place, more extended and accurate knowledge of the distribution of our species is to be desired, and many more cultures must be made. A few suggestions may be made with regard to the latter point. For the purpose of procuring pure spores of the different Gyınosporangia, a difficult matter if we consider how many of the species are parasitic on $J$. virginiana, one might gather specimens in March, in the latitude of Cambridge, and allow them to perfect under cover in the house. G. macropus is hardly likely to be connected with $R$. batryapites, which occurs on Amelanchier, because the young knots are formed in summer before the Roestelia makes its appearance. In studying $G$. Ellisii and $G$. biseptatum, which occur on the white cedar, and which are hardly known in the East except where found by Mr. Ellis and myself, it would be well to bear in mind that $R$. botryapites and $R$. transformans are species which have about the same range. It is also an important matter to ascertain the exact date of 
the earliest appearance of the spermogonia of the different Roesteline, and of the appearance of the sporiferous masses of Gymmerporangit in limited regions. This last point I think has not received sufficient attention from European botanists. Unless I am mistaken, I have seen the spermogonia of $R$. lacerata near the Bussey Institution, at a date preceding the maturing of any of the Gymnosporangia of the neighborhood.

Cornu ${ }^{1}$ has called attention to the fact that Roesteliae may be made to appear out of season by means of cultures. Another important fact is to ascertain how many of our Roesteliae are perennial. This, at least, appears to be the case with $R$. urrantiaca. If it should be shown that several of our Roesteliae are perennial, a fact true with regard to most of our Gymnosporangia, and to grow in regions remote from species of Juniperus and Cupressus, then one could not help feeling that any connection between the two genera was probably accidental rather than genetic.

\section{EXPLANATION OF PLATES.}

\section{Plate I.}

Figs. 1-6. Gymnosporangium macropus Lk. 1, Sporiferous masses fully expanded; 2, the same in a dry condition, showing the knot or cedar-apple, and the contracted sporiferous masses surrounded by the raised collar at the base; 3 and 4 , teleutospores, with a part of their pedicels; 5 and 6 , spores producing promycelia and sporidia, 6 showing a promycelium forming at the apex. 1 and 2 natural size, 3-6 magnified 350 diameters.

Figs. 7-11. Gymnosporangium fuscum var. globosum Farlow. 7, Sporiferous masses expanded; 8, the same contracted, and slowing the knot formed; 10 and 11, spores with pedicels; 9 , spore producing promycelia. 7 and 8 natural size, 9-11 magnified 350 diameters.

N. B. 9-11 have been drawn on too small a seale, and should be enlarged one fourth in comparing with the spores of other species.

\section{Plate II.}

Figs. 13-17. Gymnosporangium Ellisii Berk. 13, portion of a distorted branch of Cupressus thuyoides with sporiferous masses expanded; $14-17$, spores of the same; 17 , spore bearing promycelia; 16 , anomalous spore forking at the tip. 13 natural size, 14-17 magnified 350 diameters.

Figs. 18-21. Gymmosporangium biseptatum Ellis. 18, stem of Cupressus thuyoides, bearing expanded sporiferous masses; 19-21, spores of the same; 20 producing promycelia. 18 natural size, 19-21 magnified 350 diameters.

Figs. 22-27. Gymnosporangium clavipes C. and P. 22, twig of Juniperus virginianu, with sporiferous masses expanded, and distorted, acerose leaves, to be compared with 23 which represents a normal branch; 24, 25, spores with enlarged pedicels ; 26, spore which has fallen from pedicel and produced promyeelia at both extremities; 27, spore with terminal and lateral promycelia. 22 and 23 natural size, $24-27$ magnified 350 diameters. 


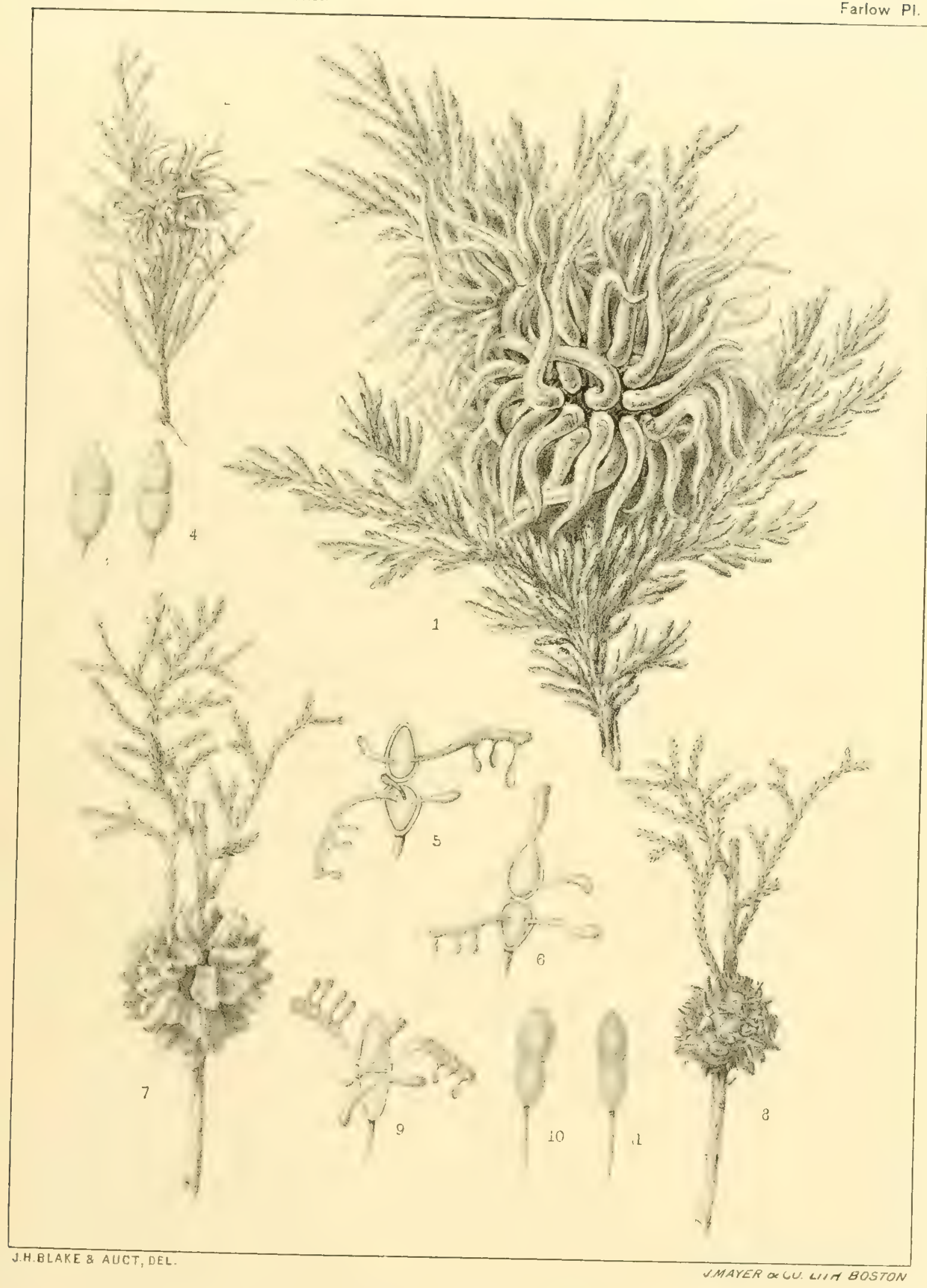

GYMNOSPORANGIA OF THE UNITED STATES 



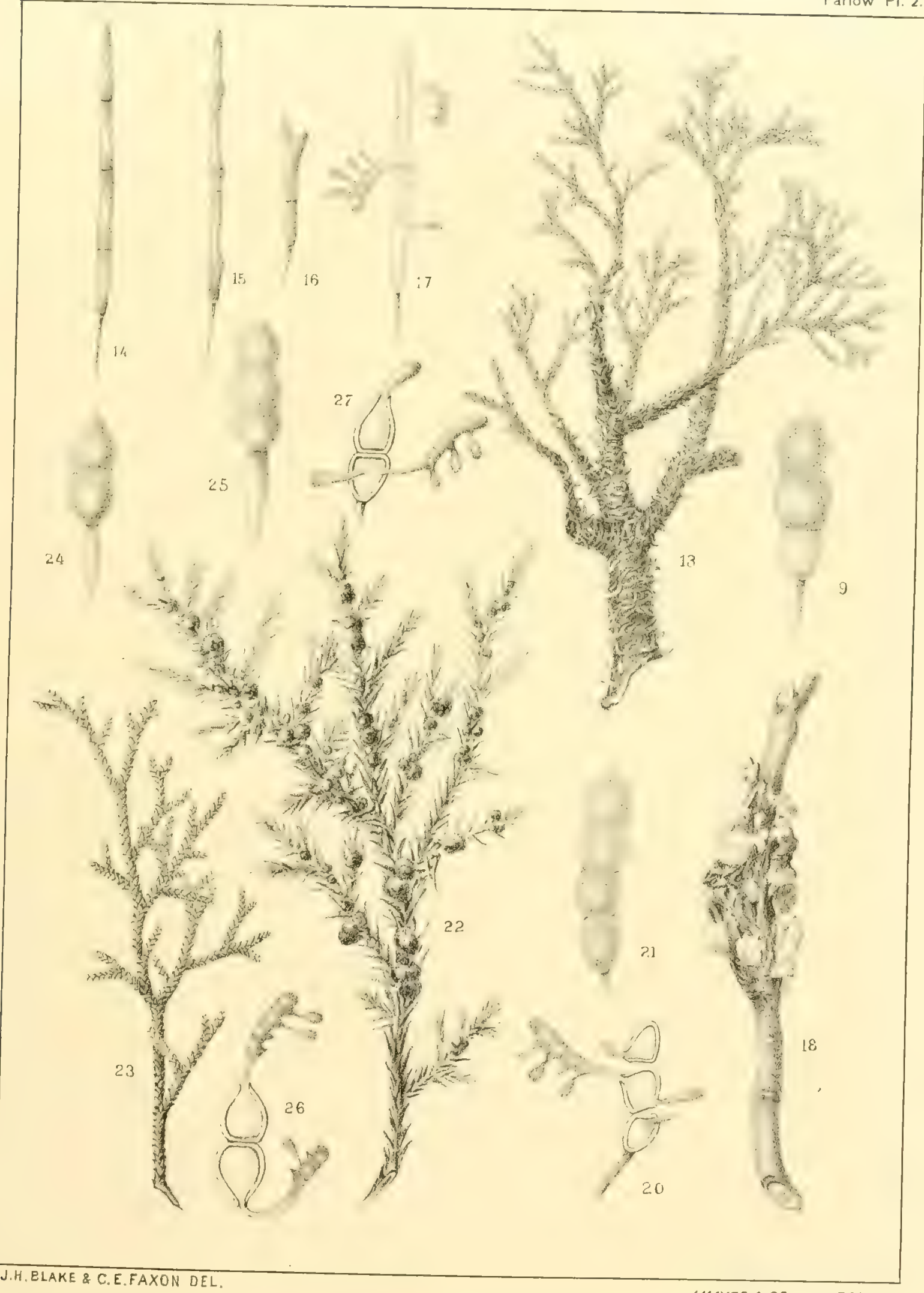





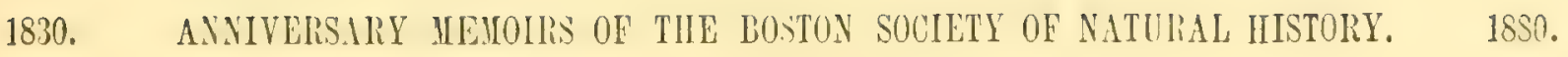

\title{
A STRUCTURAL FEATURE,
}

\section{IITTIERTO UNKNOWN AIONG ECIINODERIITA,}

FOUND IN

\section{DEEP-SEA OPHIURANS.}

\author{
BY THEODORE LYMAN.
}

BOSTON:

PURLISHED BY THE SOCIETY.

1880 . 



\section{A Structural Feature, mitmerto unknotwn among Echinoderinata, found in deep-sea Opinurans. By Theodore Lyman.}

I.)NG after the main collection of the "Challenger" expertition had arrivert, there were sent me several glass slides containing additional specimens of Ophiuridae. One of these, hastily examined with a weak lens, I labelled Ophiomyces, and set aside for further study. In the very last cast made by Mr. Alexander Agassiz, during the "Blake" expedition of 1878- 79 , near the Barbadoes, and in 82 fathoms, there came up a small soft Ophiuran, which seemed, under the microscope, to have little tufts resembling bunches of simple hydroids on the sides of the arms. Nore careful search, with a higher power, showed that these were bunches of minute spines, each enclosed in a thick skin-bag, and that they had a most extraordinary form, resembiing long-stemmed agarics, or parasols with small shades. On going back to the "Challenger" Ophiomyces, this too exhibited the same spines, and a third species, also brought back by the "Challenger," was found with similar appendages. Their form, however, was not the most curious thing. It was by their arrangement in two, or even three, parallel vertical rows, that they wholly differed from all Ophiuridae hitherto known. For, with all the variety exhibited by the hundreds of living species, there is not one that departs from the unvarying single row of articulated spines. Not even the double rows of hook-bearing grains among the Astrophytidae would be homologous, because these grains are not attached to the side arm-plates. In one species, these parasol-spines stood side by side with the normal arm-spines (Ophiotholia), while in the two others (Opliohelus), they took the place of the normal spines. Among known Echinodermata I have been able to find only a single instance of a somewhat similar spine, or pedicellaria. This is in Aceste bellidifera Wyv. Thom., and is to be figured in Mr. Alexander Agrassiz' forthcoming work on the Echini of the "Challenger," plate XL, fig. 66. The question whether these novel shapes are spines or pedicellariae is not a very important one, since a pedicellaria is only a spine peculiarly morlified. But it may be said that their supplementary character and abnormal shape give these paraso] spines the position of what used to be carefully distinguished as pedicellariae.

Ophiotholia is indeed an Ophiomyces with this peculiar character, while Ophiohelus is an allied but distinct form. Both may be considered low genera, with elaborate appendages. The want of radial shields and imperfect calcification suggest thcir position, which is confirmed by the embryonic character of their arm-bones, which are longitudinally divided into the two halves they theoretically should have. These bones are so large and independent, even close to the tip of the arm, that it is not easy to understand how they can be spurs of the small side arm-plates, as they should be according to one theory. Unfortunately I could nowhere find a terminal joint, which would have shown how the arm-bones take their rise. 
These soft little creatures illustrate how small an influence certain kinds of the notorious "environment" have in determining structure. Of the two species of this abnormal Ophiohelus, one comes from 82 fathoms, near the Barbadoes, and the other from 1350 fathoms, near the Fiji Islands. When we consider the differences of locality, light, pressure, and temperature (differences which are supposed to create varieties, or species so called), between these two stations, we may well be a little sceptical as to the potency of such environment.

These genera stand quite apart from others of the family and call for diligent renewal of the endless search after those constantly increasing missing links.

\section{Oрніотноцi ${ }^{1}$ gen. nov.}

Disk and arms capable of being raised vertically: the former covered by a delicate scaling set with minute spines. Mouth-angles clothed with several rows of wide, flat mouth-papillae, (as in Ophiomyces), and with a single row of slender, sharp teeth. On outer joints of arms near margin of each side arm-plate is a tuft of minute, translucent, supplementary spines or pedicellariae, which have the form of a long-handled parasol. They stand a little inside the true arm-spines, which are continuous to the end of the arm.

Ophiotholia supplicans sp. nov. Plate I, figs. 1-3.

Special marks. Three arm-spines. Pedicellariae beginning about the ninth joint and arranged in clusters of three or four.

Description of an individual. Diameter of disk (when the arms are raised vertically), 2 m.m. Height of same, $3.5 \mathrm{~m} . \mathrm{m}$. Width of arm without spines $0.8 \mathrm{~m} . \mathrm{m}$. Length of arm, about $13 \mathrm{~m} . \mathrm{m}$. The mouth-angles are high and narrow, so that the mouth-slits between them are wide: with their curved sides and sharp tooth at the apex the angles bear a resemblance to a bird's head with a pointed bill. Three acute spine-like teeth, outside which, and partly encircling the large three-sided jaw plate, as with a frill, is a transverse, curved, erect, close row of eight or ten long, narrow, flat papillac. Again outside these, and on the jaws and mouth-frames are three parallel transverse rows of erect foliate papillae - the first row has six papillae, which are smaller than some of those beyond, but, like them flattened and widest at the free end; the second row is similar; while the third usually consists only of two papillae much larger and wider than the others. 'These rows quite obseure the base of the mouth-angle and mouth-shields. In general, the arrangement is like that of Ophiomyces frutectosus. The above numbers are the maximum; some angles have ferver papillae; not more than four in a transverse row. In the fresh specimen, under arm-plates are not visible, but, on partial drying, their ontlines may be seen. They are narrow, much longer than wide, wider without than within, with a small angle within, lateral sides reënteringly curved, and outer side in a broken curve. In like manner the side arm-plates are seen to meet broadly below, and to form a slight spine-crest at their outer edge. Figure 2 shows the arm-joint from below, so covered by the natural skin that the junction of the side arm-plates on the central ridge cannot be seen. Disk sugar-loaf shaped and sparsely set with minute spines, each of which, in the

$$
1 \text { '0op, a snake; vodia, a parasol. }
$$


partly dried specimen, is seen to stand on a small, delicate scale. No radial shields visille, and there probably are none; which, as in Ophiomyces, may account for the fact that the arms are raised vertically, encircling the high disk like a fence. Three sharp, slightly flattened, microscopically rough arm-spines nearly as long as a joint, standing near the outer edge of side arm-plate, and on a low spine-ridge. At the ninth joint there appears, on inner side of spine-ridge, and close to base of spines, a cluster of three or four minute perdicellarize, searcely 0.5 m.m. long. They are shaped like long-handled parasols, or slender-stalked agaries (fig. 3) with a long shaft, surmounted by a disk divided into symmetrical radiating flutings, and with a slight bulb at the base articulated to a little mamelon. They are glassy and translucent, and naturally are enveloped in a skin-bag which, however, is easily stripped off, leaving them free, as shown in the figures. 'They are found on all the outer joints, to the tip of arm. The tentacles are long, smooth and translucent. The second mouth-tentacle has four flat scales similar to mouth-papillae. The next two pairs have each two smaller scales, one on the side arm-plate, the other on the under arm-plate. Fach pore beyond has one long, spine-like scale on its inner edge.

"Challenger;" Station 296, S. W. of Juan Fernandez; 1825 fathoms; 1 specimen.

\section{OpHIOHELUS, ${ }^{1}$ gen. nov.}

Disk covered with a delicate, film-like scaling, without radial shields. Arm-hones composed of two halves like curved hars, lying side by side, joined at their ends and enclosing an oval hole. Mouth-papillae spiniform and arranged in a single row; teeth similar; no tooth-papillae. On the outer joints of the arm, the true arm-spines cease, and are replaced hy two or more rows of minute spines or pedicellariae, which have the form of a long-handled parasol.

Ophiohelus umbella sp. nov. Plate I, figs. 4-10 and 16.

Special marks. Parasol-spines long and slender; about twenty altogether, arranged in two or three irregular rows. Disk beset with minute spines. One small, spiniform tentacle-scale.

Description of an individual. Diameter of disk $4.5 \mathrm{~m} . \mathrm{m}$. Arms long, slender and gradually tapering; in length about ten times diameter of disk. Wirth of arm without spines $1 \mathrm{~m} . \mathrm{m}$. Mouth-angles covered by a thick skin (fig. 5 ), which must be removed to see the hard parts, (fig. 6). The armature is all of short, sharp, spine-like papillae. The small jaw-plate carries a cluster of from three to five, whereof the central one is longest, and may be considered the lowest tooth; then, outside these, there are three, somewhat irregularly arranged on either margin, of which the outer one is longest, and may be consiclererl as a tentacle-seale of the second mouth-tentacle. On taking off the covering skin (fig. 6), there is seen a small mouth-shield as broad as long, three-sided, with an angle inward and the inner sides curved. Closely soldered to it are long, curved, side mouthshields which grow hroader without and are closely united within. First moler arm-plate nearly as large as those beyond, shield-shaped, with inner lateral side a little turnerl downward, and prolonged in an acute angle. From the third plate onward (fig. 7 ), the out-

\footnotetext{
1 " $0 \phi \iota 5$, a snake; $\eta^{\lambda} \lambda_{05}$, a a broad-hended nail.
} 
line is axe-shaped, with a wide, slightly curved edge without, and a narrow prolongation within, terminating in a small angle. Side arm-plates (figs. 5, 7), nearly meeting below, widely separated above; when stripped of skin, they present a base which has a long, curved projection forward, running along the side of the tentacle-pore and ending in a spine-ridge. Near tip of arm they have a wedge-shape (fig. 16), with the smaller end pointing inward and downward, while the wide end is flaring and forms a spine-ridge, having two or three rows of little elongated mamelons, each bearing a parasol-spine. Above lies a film-like upper arm-plate, of an ovoid outline with the small end forward. This, as well as the side plates, is composed of a translucent lime net-work, picreed with numerous holes. Surrounded by these parts are the very singular arm-bones, which, instead of the usual disk-like figure, are composed of two long, curved bars, lying side by side and joined at each end to make the articulating surfaces, the whole forming an elongated oval with terminal articulating surfaces. 'This embryonic division of the arm-bone into its two halves continues to the disk, but the bars become proportionately shorter and shorter, and the articulating surfaces approach, until, just at the margin of the disk, the central hole nearly or quite disappears, and the bone pretty much resembles the usual type. Disk slightly puffed, and uniformly covered with minute, delicate scales, some of which bear small, short spines (fig. 4). Well magnified, these scales are found to be tran-Lucent and film-like, and oval in shape, not more than $0.3 \mathrm{~m} . \mathrm{m}$. long and pierced with holes (fig. 9). Many of them throw up a small spine, composed of two spiculae joined by cross-bars. This scaling is continued quite to the bases of the arms, for there are no radiil-shields. 'Two wide genital openings extending from outer corner of mouth-shield to margin of disk. Three slender, tapering, somewhat flattened, translucent arm-spines, not quite as long as two arm-joints. 'They are composed of two spicules, slightly serrated and joined by their edges (fig. 8). At about the eighth joint the normal spines cease, and are replaced ly two or three crowded. irregular rows of paratsol-spines or pedicellariae, about twenty in all. Each of these parasol-spines is covered by a thick skin-bag, on removing which, the spine is seen to be about $1.2 \mathrm{~m} . \mathrm{m}$. long, translucent, with a regular agarie top radiatingly fluted. It is mounted on a high mamelon projecting from the side arm-plate (fig. 10). One short, spiniform tentacle-scale at inner angle of lower arm-plate.

Color in alcohol, straw.

"Blake" Expedition of 1878-79; Station 300 off Barbadoes; 82 fathoms; 3 specimens.

Ophiohelus pellucidus sp. nov. Plate I, figs. 11-15.

Special marks. Parasol-spines short and stout; in two rows, three or four in a row. Disk smooth. No tentacle-scales.

Description of an individual. Diameter of disk, 4 m.m. Length of arm, 12 m.m. Width of arm without spines, $1 \mathrm{~m} . \mathrm{m}$. Mouth angles prominent and separated by wide mouth-slits; at apex is a thick, rounded jaw-plate bearing three sharp, spiniform toothpapillae, above which are teeth of similar shape; on either side are two spiniform mouthpapillae, whereof the outer one is longer and serves as a tentacle-scale to the second mouth-tentacle. The condition of the single specimen did not allow the forms of the mouth-shiekls and side mouth-shields to be mate out, as they were pretty closely soldered and more or less covered with skin; they seemed, however, similar to those of 0 . umbella 
(fig. 6). Under arm-plates of a long axe-shape, much broader without than within, with a widely curved outer edge, deep reëntering curves on lateral sides, and a small angle within. Side arm-plates nearly meeting below, widely separated above, having a feeble spine-ridge on their outer margin; before partly drying the specimen it is hard to make out their ontline. No upper arm-plates, so that the curious double arm-bones show through the translucent skin (fig. 12). Disk, soft and delicate, slightly puflerl, covered miformly with scales so very thin that they can only be seen under the microscope by a cross-light. No radial shields. Three nearly equal, sharp, somewhat flattened, arm-spines, about as long as an arm-joint and a half. When cleaned with potash they appear as two parallel spiculae united by cross-bars (fig. 15). At the ninth joint there still are three spines standing near the outer margin of the side arm-plate, but at a large angle to the arm, and just inside their base is a single minute parasol-spine, or pedicellaria, about $0.6 \mathrm{~m} . \mathrm{m}$. long; and stouter and with a larger head than in 0. umbellu. On the joints beyond, there are no longer any common spines, but, instead, two close rows of parasolspines, three or four in each row (fig. 13). Tentacles large, long, smooth and not provided with scales.

Color in alcolıol, translucent bluish-white.

"Challenger," Station 175, near Fiji Islands, 1350 fathoms; 1 specimen.

Here follow six new species, not included in my Prodrome of the "Challenger" Ophiuridae, published in the Bulletin of the Museun of Companative Zoölogy (Vol. Y. Yo. T and Vol. VI, No. 2). Of Ophiacantha, Ophiopeza and Ophiactis, there is one representative each; and there are three new genera, Ophiocymbium, Ophiochytra and Ophianhix, each with a single representative. Among Ophiuridae and Astrophytidae the entire number of new species brought home by the "Challenger" is 167 ; and of new genera, 20.

\section{Ophiocrmbium ${ }^{1}$ gen. nov.}

Disk flat and covered with delicate overlapping scales, without radial shields externally visible. It overlies and is scarcely attached to the arms, like the borders of a Basque cap; and there seem to be no genital openings. Arm-spines along outer edge of side armplates. On jaw-plate, a tuft of small spines which correspond to teeth and tooth-papillae. Nouth-papillate squarish aurl arranged in a close line. Tentacle-pores very large; those of the second mouth-tentacles set in a socket, much like the rest.

Ophiocymbium cavernosum sp. nov.

Special marks. Four arm-spines. 'Two or three disk-scales in the length of $1 \mathrm{~m} . \mathrm{m}$. Side mouth-shields small and not meeting within.

Description of an individual. Diameter of disk, $7.5 \mathrm{~m} . \mathrm{m}$. Arms broken, but apparently about three times the diameter of the disk. Width of arm, without spines, $1.2 \mathrm{~m} . \mathrm{m}$. At aper of mouth-angle is a boss-like jaw-plate bearing a cluster of four or five short, blunt, irregularly placed spines, which correspond to teeth and tooth-papillate; inside these, and along the margin of the wide jaws, on either side, is a close line of three or four flat, squarish mouth-papillae, whereof the outemost stands on the margin of the socket of the

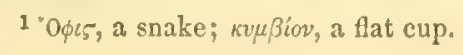


second mouth-tentacle. while the opposite margin, formed by a portion of the side mouth-

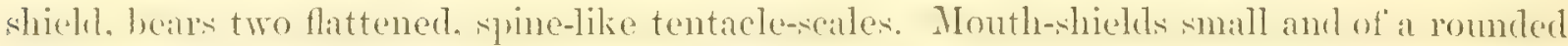
heart-shape; length to breadth, $1: 1$. Side mouth-shields small, wide without, but narrow and not meeting within. First under arm-plate pretty large and wide, three-siderd, with an angle inward. Those beyond are shaped like an axe, with a wide, curved cutting-edge, and a narrow body pointing inward. The narrowness of the inner portion comes from the encroachment of the large tentacle-pores. Sirle arm-plates long but not prominent; neeting above and below. Upper arm-plates small and triangular with an angle inward. Disk thin and flattened, with a tender skin covered by very thin, delicate, overlapping scales; two or three in the length of $1 \mathrm{~m} . \mathrm{m}$. No radial shields can be seen from the outside. There are apparently large genital openings, but these are merely the creases on either side of the arm; for, in reality, the under disk surface, with a very delicate scaling, is continuous over the arm, and there are no genital openings in their usual position. Four delicate, sharp, somewhat flattened, arm-spines which, though placed on outer edge of side arm-plates, have a considerable lateral motion. No tentacle-scales except to the mouth-tentacles.

Color in alcohol; disk, pale greenish-gray; arms, straw.

"Challenger," Station 157, east of Kerguelen Islands; 1950 fathoms; 1 specimen.

\section{Ophiochytra ${ }^{1}$ gen. nov.}

Disk covered with little, overlapping scales, and small radial shields. Teeth: no toothpapillae: a line of squarish, close-set mouth-papillae on each side. Large side arm-plates, which meet above and below, and bear on their outer edge small spines, which, however, stand at nearly a right angle to the arm.

Ophiochytra epigrus sp. nov. Plate II, figs. 17-19.

Special marts. Tro small peg-like arm-spines. One tentacle-scale. Very small radial shields, wider than long.

Description of an individual. Diameter of disk, $5.5 \mathrm{~m} . \mathrm{m}$. Length of arm about $13 \mathrm{~m} . \mathrm{m}$. Width of arm, without spines, $1.2 \mathrm{~m} . \mathrm{m}$. Teeth small, wide and short, closely soldered to a small and very thin jaw-plate. On either side of mouth-angle, a close row of three or four flattened, squarish mouth-papillae, whereof the outermost is largest and acts as tentacle-scale to the second mouth-tentacle. Mouth-shields small, of a pointed heartshape, with the angle inward; length to breadth 0.8:0.6. Side mouth-shields long, and extending far beyond the mouth-shields, tapering inward where they nearly or quite meet. First under arm-plate about as broad as long, with a curved, or slightly angular outer side, and a tapering angle inward; the plates beyond are axe-shaped, much wider without than within, bounded without by a curve, on the lateral sides by reëntering curves, and within by an obtuse angle. Side arm-plates long and meeting broadly above and below, thickened on their outer edge, but not flaring. Upper arm-plates small, with three nearly equal sides, and an angle inward. Disk round, slightly arched, covered above with pretty regular, rommled overlapping scales, two or three in the length of $1 \mathrm{~m} . \mathrm{m}$.; and helow

$$
\text { I. } 0 \text { pr } 5 \text {, a snake; Xirpa, a flat vase. }
$$


by larger and more angular scales. Ratlial shiclds very small, wider than long, and touching. Genital openings large, extending from mouth-shield to margin of disk. Two very short, peg-like arm-spines standing on outer edge of side arm-plates, but at nearly a right angle to arm. One oval tentacle-scale.

Color in alcohol, pale greenish gray; arms lighter.

"Challenger," Station 276, near Low Archipelago; 2350 fathoms, 1 specimen.

This solitary representative is highly interesting as almost the only deep-sea Ophiuran found by the "Challenger" in the immense distance between the Sandwich Islands and the S. W. coast of South America.

Ophiacantha placentigera sp. nov. Plate II, figs. 20-22.

Special marks. One very large, flat, tentacle-scale. Six cylindrical, tapering, nearly smooth arm-spines. At inner point of each under arm-plate is a diamond-shaped raised figure.

Description of an individual. Diameter of disk $9.5 \mathrm{~m} . \mathrm{m}$. Width of arm, close to disk without spines, $2 \mathrm{~m}$.m. Five spaced mouth-papillae on each side of mouth angle, the two outermost, large, squarish and flat, the three inner ones more pointed; and the one at the apex short and blunt. Mouth-shields broad triangular, with rounded corners, and a blunt angle inward. Side mouth-shields long and large, nearly or quite meeting within, where they taper; broad without where they join the side arm-plates and curve somewhat round the mouth-shield. Under arm plates of a wide axe-shape, with a curve without, reëntering curves on the lateral sides, and an obtuse angle within. At the innermost point on the median line, is a small raised figure in form of a transverse diamond. Side arm-ylates wide and thick, meeting fully below, just touching above. Upper arm-plates broad diamond-shape, with outer and inner angles somewhat rounded, and with a central longitudinal ridge; length to breadth, 1.5:2. Disk flat and thick, closely set above with short, thick, rounded, thorny stumps, four or five in $1 \mathrm{~m} . \mathrm{m}$. long, those in the centre being smaller; near the margin they are shorter; and below they take the form of scattered grains. Radial-shields small, of a short ovoid shape, widely separated and diverging inward. Six long cylindrical, scarcely rough, slightly tapering arm-spines; those above and below shorter than the two middle ones, which are as long as two arm-joints. One large, flat, wide, smooth, tooth-like tentacle-scale on the outer edge of the side arm-plate.

Color in alcohol, very pale brown.

"Challenger," Station 175, near Fiji Islands; 1350 fathoms; 1 specimen.

\section{Ophiopeza aequalis sp. nov. Plate II, figs. 23-25.}

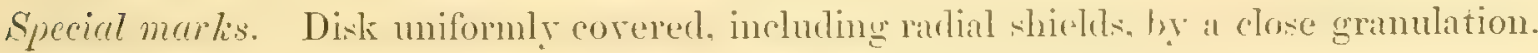
Ten flat crowded arm-spines nearly equal, except the lowest, which is larger.

Description of an individual. Diameter of disk $25 \mathrm{~m} . \mathrm{m}$. Length of arm about $150 \mathrm{~m} . \mathrm{m}$. Width of same, close to disk, without spines, $5 \mathrm{~m} . \mathrm{m}$. Fourteen to seventeen flattened, crowded mouth-papilae to each angle; those within small and pointed; the two outermost on either side much the broadest. Mouth-shicld short, rounded, heartshaped, with a blunt ancle inward. Length to breadth, 4:4. Side mouth-shields very small, occupying the outer lateral corners of the mouth-shield. Inder arm-plates wider 
than long, with a rounded. truncated angle within; slight reëntering curves on the lateral sides, and the outer edge curved. Side arm-plates, short and thick, with cleanly curved outer margin; separated above by the large upper arm-plates which are much broader than long, and strongly arched, with outer side straight, except at the corners where it is rounded; length to breadth 4.5:1.3. Disk thick but flat, with a notch over the arms; it is covered, including radial shields and space next mouth-papillae, with an even, fine granulation; thirteen grains in $1 \mathrm{~m} . \mathrm{m}$. long. Genital openings long, extending from outer edge of mouth-shield nearly to margin of disk. 'Ten short, flat arm-spines with rounded ends, about two-thirds as long as a side arn-plate, except the lowest which is longer and larger. Two small, round tentacle-scales, whereof one covers the base of the lowest armspine.

Color in alcohol nearly white.

"Challenger," Station 219, N. E. of New Guinea; 152 fithoms; 1 specimen.

This species agrees in the number of disk-grains with $O$. Yoldii, but has twice as many arm-spines. $\quad 0$. fallax and $O$. aster agree with each other as to grains, (about twenty-five in the length of $1 \mathrm{m.m}$.), $O$. aster, however, has six arm-spines, instead of eight, and the entire mouth-angle, including mouth-shield, is closely granulated. Finally O. Petersi has about eighteen grains in the length of $1 \mathrm{~m} . \mathrm{m}$. , six arm-spines, and naked radial shields.

Ophiactis pectorale, sp. nov. Plate II, figs. 26-28.

Special marks. Disk without spines, and covered with thick, rounded scales, whereof the largest are near the radial shields. Two small tentacle-scales.

Description of an individual. Diameter of disk, $7 \mathrm{~m} . \mathrm{m}$. Length of arm about 38 m.m. Width of same, close to disk, without spines, 2 m.m. Three large, flat, irregular mouth-papillae on either side of the mouth angle; and one long, thick, blunt papilla, or tooth, at the apex. Mouth-shields slightly swollen, wide diamond-shaped, with rounded angles and a slight lobe without; length to breadth, 1:1. Side mouth-shields short, wide and of nearly equal width, meeting fully within. First under arm-plate small, longer than wide, five-sided with rounded angles and curved outer edge; beyond, the plates are much broader than long, with an ill-marked angle within, short deep rëentering curves on the lateral sides, and outer side long and cleanly curved. Side arm-plates short; narrowly separated above and below. Upper arm-plates much wider than long, thick, slightly arched, with a broad rounded angle within, acute angles on the lateral sides, and outer edge gently curved. Disk thick, having deep radiating constrictions in the interbrachial spaces, extending even to the centre:-it is covered with large, thick, flat, rounded, overlapping scales; those in the centre being much finer than those without, and the largest are arranged in rows radiating from the radial shields. These are large and stout, about as broad as long, and of an irregular triangular shape, with the outer end rounded; length to breadth 1.4: 1.1; they are separated by a row of two or three large, rounded over-lapping scales. On the under surface the scaling is much finer than ahove. Four or five short, blunt, cylindrical, slightly tapering arm-spines; upper cne longest and somewhat longer than an arm-joint. Two tentacle-scales, one small and liplike, on the under arm-plate; the other oval and on the side arm-plate.

Color in alcohol, - straw. 
"Challenger," Station 214, N. E. of Celebes; 500 fathoms; 1 specimen.

This species stands nearest $O$. cuspidata, from which it differs in the scaling of the disk, and by having two tentacle-scales.

\section{OpHIAMBIX ${ }^{1}$ gen. nov.}

Disk flat; arms wide and flat; and both beset above with sharp grains, or spines. No radial shields or upper arm-plates externaly visible. Small, sharp, mouth-papillae and teeth; no tooth-papillae. T'entacle-pores very large. Side arm-plates willely separated above and below, hut occupying a considerable part of under surfice of arm. Arm-spines translucent, hollow, and with an uneven surface.

Ophiambix aculeatus sp. nov. Plate II, figs. 29-31.

Special marks. On upper side of disk and arms, sharp grains, which increase to short spines on margin. Interbrachial spaces below delicately scaled. Three sharp arm-spines.

Description of an individual. Diameter of disk $5 \mathrm{~m} . \mathrm{m}$. Width of arm without spines, $1.5 \mathrm{~m} . \mathrm{m}$. The rather small jaws, which are separated at their outer ends, bear each, three or four small, sharp, translucent papillae, while the apex is occupied by the lowest tooth, which is peg-shaped and much larger than the papillae. Mouth-shields very small, of a transerse oval shape, with a slight peak within. Silte mouth-shields short and small, tapering at each end, and wedged between cuter ends of jaws. First under armplate nearly as large as those beyond, somewhat longer than broad, bounded within by an olsture ingle, without by a gentle curve, and, on the lateral siles, by reintering curves. Langth to breadth of 4 th plate, 0.6:9.5. The wide space on either side of the under armplates is occupied partly by the very large tentacle-sockets, and partly by the side armplates which make narrow purtitions between the tentacles, and then enlarge into a strong but very low spine-crest. Upper surface of arm covered by skin, and evenly set with sharp, conical grains, about eight in the length of $1 \mathrm{~m} . \mathrm{m}$. Disk much flattened, and somewhat puffed in the interbrachial spaces; evenly set above with sharp conical grains, which are similar to those of the arm, and which are continued as minute conical spines, over the margin. Interbrachial spaces below destitute of spines and covered by a thin, delicate scaling. No radial-shichls are extemally visible. Genital openings large, extending from outer corner of mouth-shield to margin of disk. The extremely flattened arm bears, on either side, three translucent, hollow, slightly flattened, sharp, tapering armspines, whereof the two upper are as long as two joints, and the lowest about two-thirds as long. 'Three or four short. Harp, spine-like tentacle-scales, standing on the margin of the very large pores, from which protrude simple club-ended tentacles.

Color in alcohol, straw.

"Challenger," Station 175, near Fiji Islands; 1350 fathoms; 1 specimen.

$$
1 \text { " } 0 \phi \iota, \text {, a snake; } \check{\alpha} \mu \beta \iota \check{\xi} \text {, a cup. }
$$




\section{EXPLANATION OF PLATES.}

\section{Plate I.}

Fig. 1. Ophiotholia supplicans; whole animal, seen from the side, with its arms raised vertically, whereby the mouth-angles are turned down and outward, 5

Fig. 2. Ninth arm-joint, seen from the under side; in the centre two large tentacles, each with its long, spiniform scale; on each side two regular arm-spines, and a cluster of the peculiar parasol-spines, or pedicillariae. The central ridge is made by the junction of two side arm-plates, $x_{1}^{5}$

Fig. 3. A parasol-spine stripped of its skin-bag and mounted on its little mamelon, ${ }^{75}$

Fig. 4. Ophiohelus umbella; upper side of disk with bases of two arms, showing how the parasol-spines follow the normal ones; also the arm-bones, divided in parallel halves, $f$

Fig. 5. Lower side of disk, with mouth, ${ }_{1}^{\prime}{ }^{0}$

Fig. 6. A mouth-angle treated with potash, to show the underlying hard parts, On the sides are the first two under arm-plates, and, in the centre, the closely soldered mouth-shield and side-shields, the sockets of the second mouth-tentacles on cither side, and the jaws, jaw-plate and tooth-papillae within. The little circles indicate the bases of mouth-papillae, $\frac{20}{1}$

Fig. 7. Two arm-joints, also treated with potash, to show the under and side arm-plates, two arm-spines in position, and the articulation of the arm-bone above, $\frac{18}{1}$

Fig. 8. An arm-spine stripped of its skin, and showing the two parallel spicules that build it, st

Fig. 9. Scales of disk, one of them bearing a minute spine, cleaned with potash to show their open structure, and the mode of growth of the spine, $\frac{35}{1}$

Fig. 10. A parasol-spine stripped of its skin-bag and mounted on a little mamelon. 125

Fig. 11. Ophiohelus pellucidus; lower side of disk with month, showing the tentacles. $\frac{10}{1}$

Fig. 12. Upper side of disk, exhibiting the extremely delicate scales (to be seen only by a cross-light) and the arm-bones divided in parallel halves, po

Fig. 13. 9th, 10th and 11th arm-joints stripped of skin. On the 9th are three normal spines and one parasol-spine; on the 10 th and 11 th, only two rows of the latter form, $x_{1}^{0}$

Fig. 14. A parasol-spine stripped of skin and monnted on its little mamelon, ${ }^{25}$

Fig. 15. A normal spine, treated with potash, and showing that it is composed of two spicules like that of O. umbella, $\frac{20}{1}$

Fig. 16. Ophiohelus umbella; a joint close to tip of arm, digested with potash; seen from above. On the upper side is the film-like upper arm-plate pierced with numerous holes; to the right and left of it is a side arm-plate, also of open structure and having a spine-ridge which consists of two or three crowded, irregular rows of elongated mamelons. On the right, these mamelons are shown carrying their parasolspines. Underneath are the curious, curved, translucent bars that are the two halves of the arm-bone, united only at their articulating ends. $\frac{27}{1}$

\section{Plate II.}

Fig. 17. Ophiochytra epigrus, from below, 黄

Fig. 18. " " from above, $\frac{9}{2}$

Fig. 19. " " " arm-joints in profile, 8

Fig. 20. Ophiacantha placentigera, from below, $\frac{5}{2}$

Fig. 21. " " 6 " from above,

Fig. 22. " " " arm-joints in profile, $\frac{5}{2}$

Fig. 23. Ophiope $\approx$ a aqualis, from below, $\frac{3}{2}$

Fig. 24. " " " from above, $\frac{3}{2}$

Fig. 25. " " " arm-joints in profile, $\frac{3}{3}$

Fig. 26. Ophiactis pectorale, from below, $\frac{9}{2}$

Fig. 27. " " from above, $\frac{9}{2}$

Fig. 28. " " arm-joints in profile,

Fig. 29. Ophiambix aculeatus, from below,

Fig. 30. " " " from above, $\frac{8}{1}$

Fig. 31. " " $\quad$ " arm-joints in profile, o 


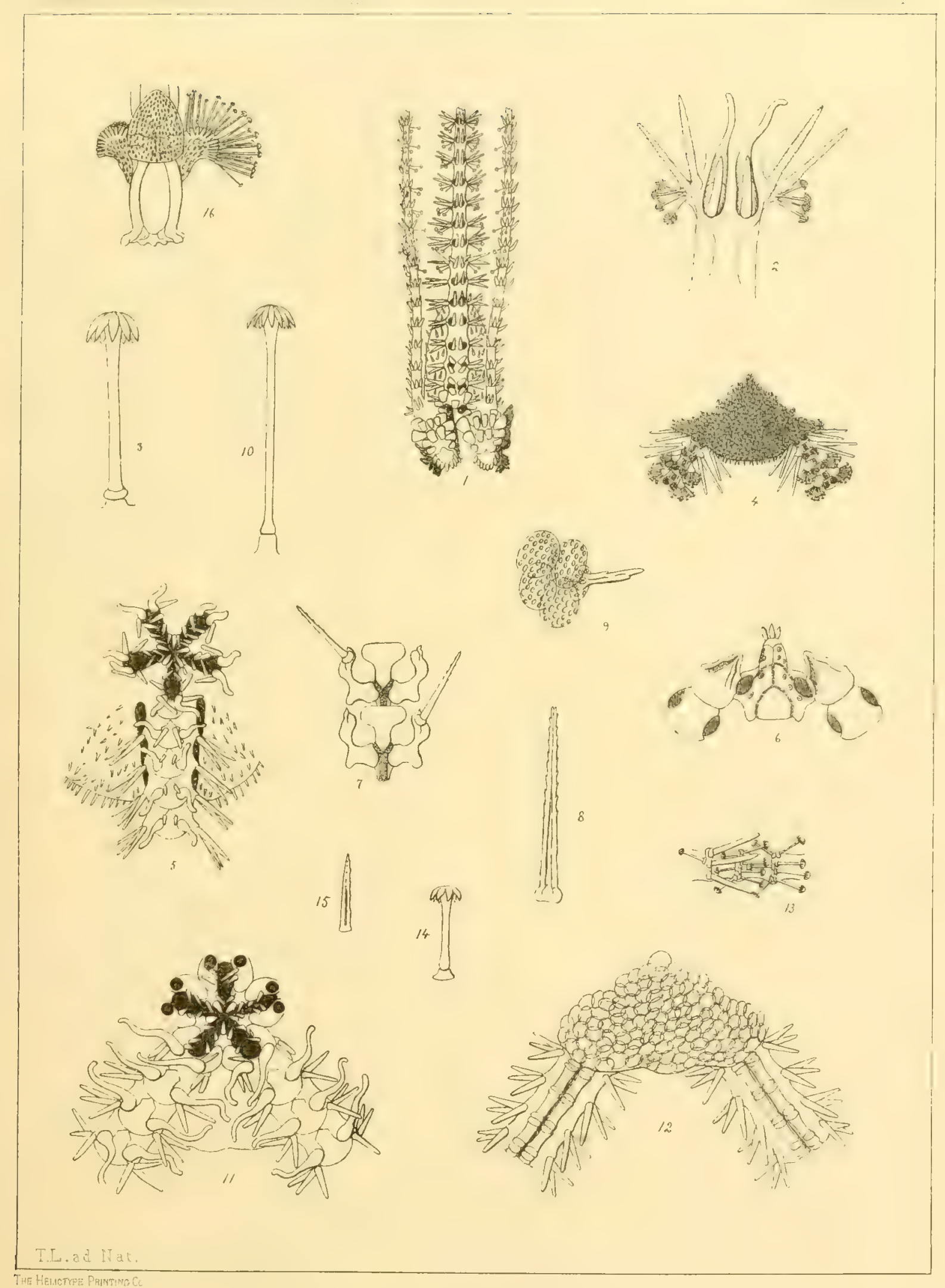




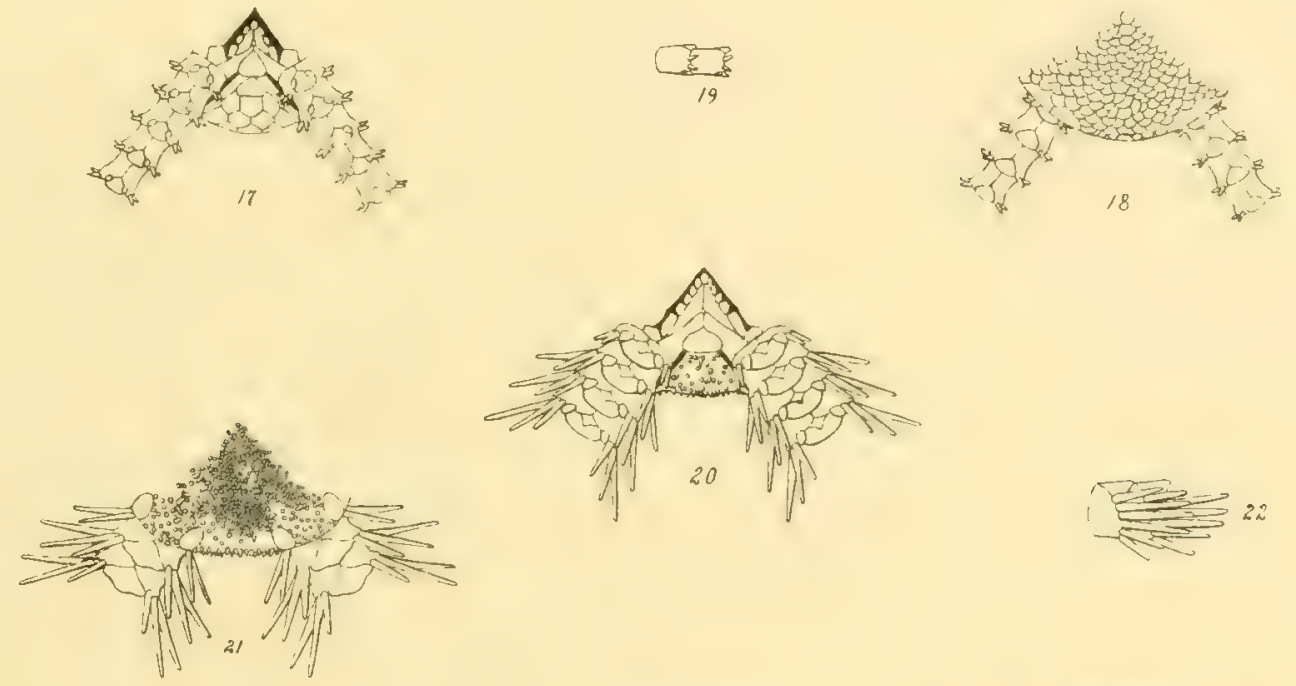

通缼 "
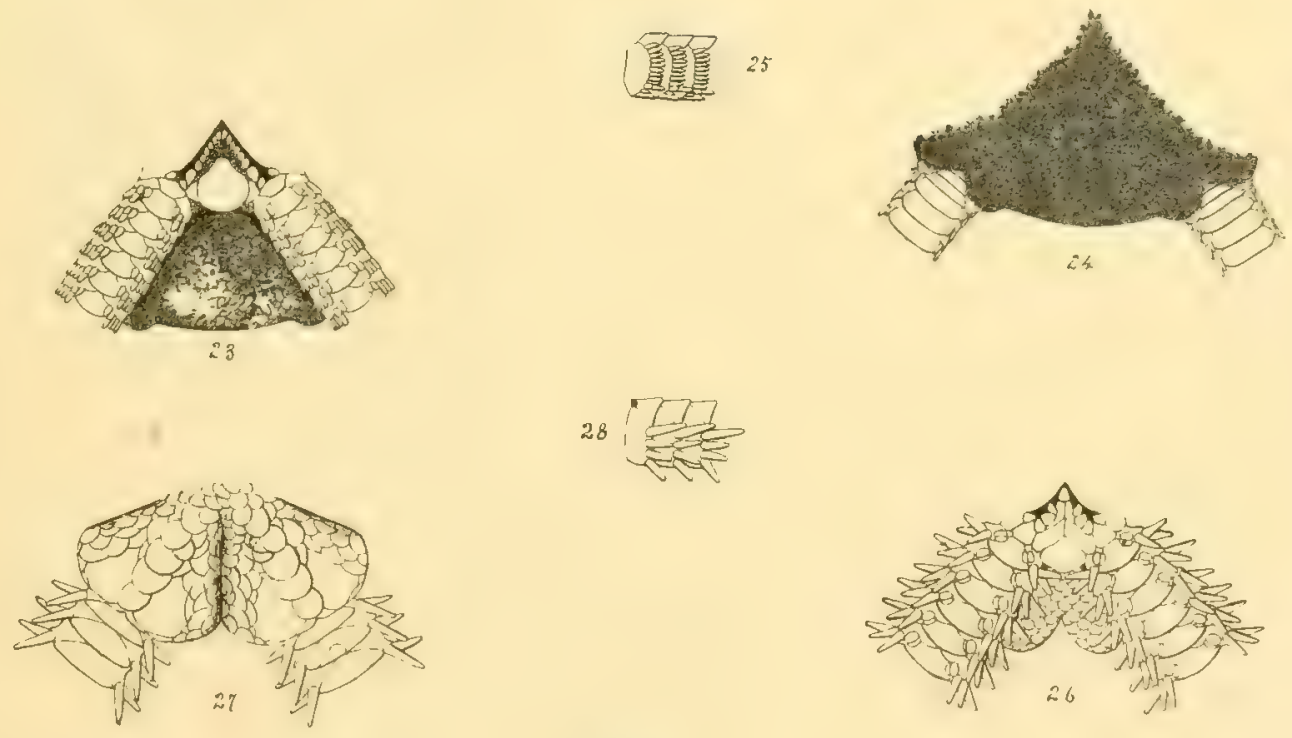

\%
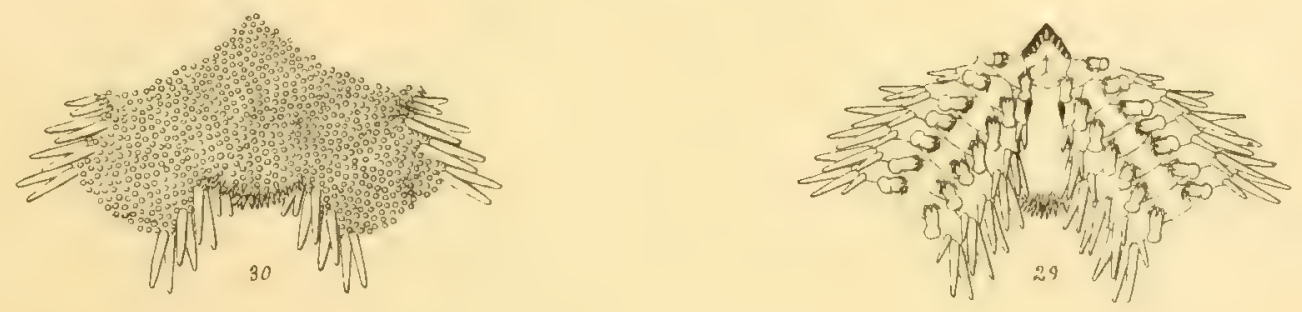

Kath. Peirson, ad Nat. 

1530. ANNIVERSARY MEMOIRS OF TIIE BOSTON SOCIETY OF NATURAL IIISTORY. 1880.

\title{
THE DEVELOPIENT OF TIIE SQUID.
}

\author{
LOLIG0 PEALII (LESUEUR).
}

BY W. K. BROOKS.

BOSTON :

PUBLISHED BY THE SOCIETY.

1880 . 
- 


\title{
The Developient of tie Squid. Loligo Penli (Lesueur).
}

\author{
BY W. K. BRooKs.
}

ALTIOUGII several author' have recorded important observations upon various points in the embryology of the Cephalopoda, our knowledge of the outlines of the process of development, as a whole, is almost entirely derived from the accounts which have been given by Kïllikes and Grenacher. Kölliker's paper contains an elaborate and exhaustive account of the external changes which are undergone by the developing embryo of Sepir officinalis, and Grenacher gives an equally valuable and complete history of the embryo of an unknown species of Decapor Cephalopod. Although these two forms of embryos are substantially alike in all essential particulars, they differ so greatly in all the details of the process of development that similar outline sketches of other Cephalopors are greatly needed, and until they are furnished we shall not be in a position to discuss the relation between the young forms of this group and the embryos of other molluses, or to speculate upon the manner in which the peculiarly direct and complex form of development exhibited by the Cephalopoda has originated.

The mode of development of the common Squid is essentially like that of Sepia and Grenacher's Cephalopod, but in minor points it is diflerent from each of them, and in many features it seems to be internediate between them, and although we have a number of figures, by various writers, of stages in the development of Loligo, there still remains a need for a continuous account of its history as a basis for comparison with other Cephalopods, and I hope this paper will furnish part of the necessary material for a general discussion of the subject.

The eggs and embryos which are described were, with two exceptions, obtained at the Chesapeake Zoological Laboratory of the Johns Iopkins University, during the summer of 1879 , by dredging in water five or six fathoms deep, in the lower part of Chesapeake Bay. They were collected through the aid of the steamer Lookout of the Maryland Fish Commission, under the command of Major T. B. Ferguson, of the United States Fish Commission, to whom I take pleasure in expressing my thanks for this and for much more valuable assistance which our party has received from him.

Two of the figures (17 and 18, plate 3) are from embryos which were obtained, during the summer of 1876, at Mr. Agassiz's laboratory at Newport.

The youngest egg which I observed is shown, magnified eighty diameters, in plate 1, fig. 1. It is surrounded by a well-defined wall or egg shell $a$, outside which was the gelatinous matter of the egg capsule. The egg shell is transparent, elastic, and is reflected inwards a little at one end, around an opening m, which may probably be regarded as a micropyle. As the embryo grows, the space inside the egg shell 
enlarges, and the shell itself is stretehed and pushed out, away from the embryo, as if this were hollowing out a place for itself in the surrounding gelatinous matter; but as both the outer and inner surfaces of the egg shell are well marked and clearly visible, there can be no doubt that it is a real membrane, and the albumen of the egg capsule must therefore either be absorbed through it or drawn in through the micropyle. One axis of the egg is nearly twice as long as the other; the micropyle is situated at one of the ends, and the two ends are alike in outline. The yolk $y$, is elongated in about the same proportion with the egg shell, and the long axis is nearly parallel to that of the egg shell, but its surface is not concentric with the inner surface of the latter, since one end of the yolk is much more rounded than the other. 'The pointed end is the one upon which the blastoderm makes its appearance, and is invariably turned towards the micropyle of the egg shell.

The space $b$, between the egg shell and the surface of the yolk, is filled by a clear, transparent, albuminous fluid, which does not, at first, present much difference from that outside the egrg shell, but as the emlnyo develops, the albumen inside the shell gradually trecones liquid. A number of small, spherical, highly refiactive particles were visible in this fluid, and they were especially abundant around the micropyle, and on the surface of the yolk. Owing to the spherical shape of the egg I was not able to use a magnifying power of sufficient strength to determine whether they were spermatozoa or not.

The yolk is transparent, highly refractive, and with a low power it appears perfectly homogeneous, but with higher powers it is seen to be packed with oil drops of various sizes, with very faintly marked edges, and a refractive index about the same as that of the more fluid portions of the yolk. At the earliest stage which I found, the blastoderm $c$, was well developed, and was perched, like a cap, upon the pointed end of the yolk, which, as already stated, is the end which is nearest the micropyle. The cells of the blastoderm are not very well marked in a living egrg, but when treated with borate of carmine fluid, to which a very small quantity of one-tenth per cent. solution of osmic acid has been added, they become very conspicuous. Figure 4, plate 1, represents the edge of the blastoderm of the egg shown in figure 1, after it has been thus treated. The centre of the germinal area is occupied by a number of small spherules which are irregularly spherical, and each of which contains a very large nucleus.

As we pass from the centre of the cap towards the periphery, the spherules become larger, and at its growing edge they are replaced by large flattened pyramids $b$, $b$, which radiate out on all sides, upon the surface of the yolk $a$, and gradually pass into the surface of the yolk, without any distinct boundary at their outer ends.

Careful examination shows that the segmentation spherules are pretty regularly arranged with reference to these pyramids. Just inside the broad imner ends of the pyramids there is a ring of large spherules, $c$, equal in number to the pyramids, and presenting every indication of having been just formed by the separation of the proximal end of each pyramid from the larger distal portion. Inside these there is a second ring of spherules, $d$, about half as large, and exactly twice as numerous as the first set, and so placed that a pair of the spherules of the second set are pretty nearly in a straight line with one of the first set and the base of a pyramid. Each pair of this set is obviously the product of the division into two of a spherule like those of the set $c$, 
formed by separation, somewhat earlier, from the end of a pyramid. Inside this set is another series, $d^{\prime \prime}$, equal in number to the set $d^{\prime}$, and arranged like this set, in pairs along the radii which end in the pyramids. Inside there is another set $d^{\prime \prime \prime}$, of the same kind, so that, as we pass inwards in the line of each pyramid continued, we have the following series: 1, the pyramids; 2 , one large spherule, $c$; 3 , two spherules, $d^{\prime} ; 4$, two spherules, $d^{\prime \prime}$; 5 , two spherules, $d^{\prime \prime \prime}$. I was not able to trace the arrangement any farther on account of the spherical shape of the egg, but the last series, $d^{\prime \prime \prime}$, was some distance from the centre of the blastoderm, which appeared to be occupied by somewhat smaller spherules than $d^{\prime \prime \prime}$. Although the earlier stages of segmentation were not observed, the phenomena presented at this stage are sufficient to show that, as Lankester has stated (Observations on the Development of the Cephalopodia), the eggr of Loligo undergoes sulsitantially the same form of segmentation as that described by Kölliker in the case of Sepia. My figures 1 and 2 obviously represent an egg a little older than Kölliker's figure 6, taf. 1, (Entwickelungsgeschichte der Cephalopoden) as copied in Bronn's Klassen und Ordnungen des Thierreichs, Band III, taf. cxxiii, fig. 13. Lankester states that the segmentation is not as regular in Loligo as it is in Sepia, but the arrangement of the spherules in our species seems to be perfectly regular, and the only important differences from Sepia are the greater relative size of the nuclei, and the separation of the radiating pyramids from each other by areas of unsegmented yolk, figure 2, $a, \alpha, \alpha$, in Loligo, while the pyramids are almost in contact with each other in Kölliker's figures, as copied by Bronn.

In an optical section of the egg at this stage, the blastoderm, figure $2, c$, is seen to be formed of a single layer of large spherules, resting directly upon the yolk, $d$, from which they are sharply separated in the centre, but less sharply at the edges. In the species which Lankester studied, the blastoderm at alout the same stage as our figure 1, is several cells thick at its edge, (see Lankester's figure $1, x$ ), but this is not the case in our species.

Figure 3 is a somewhat older egg in the same position as figure 1 ; $a$, is the egg shell; $b$, the space occupied by the albumen; $c$, the blastoderm; $d$, the yolk; and $m$, the micropyle as before. The blastoderm now covers a considerable area at the formative pole of the egg, and its edge is marked by two parallel lines around the yolk. The outermost of these lines appears to be the growing edge of the layer of ectoderm, which has been formed by the subdivision and increase of the segmentation spherules of an earlier stage, and the second or inner line I believe to be the growing edge of the lower layer of the blastoderm. The surface of the yolk below the blastoderm and inside this second line is covered by a number of large, well-defined, nucleus-like bodies, the autoplasts of Lankester, which are strictly confined to the area inside the inner one of the two circular lines noticed, and in no case reach to or beyond the growing edre of the hastoderm. The appearances indicate that these bodies are the muclei of the lower layer or endoderm, which is in process of formation on the surface of the yolk under the outer layer or ectoderm, but covering a smaller area, so that the ectoderm projects beyond the lower layer a little around the entire growing edge.

According to Lankester's observations (page 39 and plate 4, fig. 1), the autoplasts of the egg of Loligo cover the surface of the egg far beyond the growing edge of the 
blastoderm. Ile says that "when the cap of likstoplasts (ectoderm), has spread one-third over the egg, its marginal cells grow by a regular increase in size, and consequent fission, taking place equally all round the margin. But before the superficial extension of the cap of klastoplasts has commenced, there appear in a deeper stratum of yolk pellucid nuclei, at first arranged in a circle around the cap of klastoplasts." This is not the case in our species, where the autoplasts appear inside of, instead of outside of, the cap of segmentation spherules.

Lankester goes on to say, however, that he believes that in the eggs of Loligo there may be, according to season, an increase of nucleated cleavage segments, or, on the other hand, of these bodies - the autoplasts - they being reciprocally vicarious within small limits. If this is the case in one species at different seasons, it is not improbable that there may be still more difference between our species and the one which he studied; and to this difference may be due the lack of agreement between his observations and my own.

The outlines of the surface cells are now very obscure until treated with re-agents, but under the action of carmine and osmic acid, they become very conspicuous as shown in plate 1 , figure 5. The growing edge is now formed by a row of large polygonal nucleated cells, $b$, with well-marked outlines upon the sides which are turned towards the formative pole, but with faint outlines fading gradually into the unaltered yolk $a$, upon their distal sides. These cells are evidently growing by assimilation of the yolk substance, and are what remain of the pyramids shown in fig. 4. Inside these there is a row of smaller polygonal cells, which are arranged in pairs along the radii of the larger cells of the first row, as in figure 4, but the regularity of this arrangement is not quite so perfect as it was at the stage shown in that figure.

Inside this there are concentric rows, $d$, of much smaller cells, which have a somewhat peculiar artungement; they are usually irregular pentagons, but some of them have six or four sides; their shape is nearly triancular, one end heing pointed and the other blunt, and they are arranged in pairs, with the blunt ends in contact.

The nuclei, which are near the centres of the cells of the series $b$ and $c$, are at the blunt ends of the cells of the rows $d$, so that the nuclei of each pair of cells are nearly in contact. This peculiar arrangement indicates very clearly that each pair of cells of the series $d$, has been formed from a cell like that in the series $c$, by fission along a line parallel to one of the original radii of segmentation.

The condition of the surface cells of the blastoderm, at this stage of development, is thus seen to have been reached in a very simple manner, by cleavage in four ways, as follows: first the blastoderm is cut up by radial lines of cleavage into a number of radiating pyramids; second, the central ends of these pyramils are cut off by clearage at right angles to the first; third, each of the cells thus formed is divided into two by a cleavage parallel to the first; and fourth, each of the resulting cells is divided into two by a cleavage parallel to the first and third.

'The next embryo which is figured, plate 1, fig. 6, has advanced very far beyond the stage shown in fig. 3, and the position of the body of the future Squid is now indicated. The blastoderm has grown down around the yolk, which is now almost entirely covered, except at a point $y$, directly opposite the formative pole, where 
the process of segmentation was initiated. The growing edge of the blastoderm is marked by a ridge $b$, which is ciliated. This stage of development corresponds pretty nearly to the one given by Grenacher (Zur Entwickelungseseschichte der Cephalopoden) in his figure 3 ; and this figure has been copied and referred to as a trochosplece, and the line of cilia around the edge of the blastoderm has been spoken of as a rutimentary velum. Grenacher does not himself suggest any such comparison, which is certainly unwarranted and without basis, as there is no possibility of an homology between the molluscan velum and a ciliated line, which, if it be homologous with any part of the body of an ordinary molluse, can be compared only with the gastrula-mouth or orifice of invigination, a portion of the body which has no connection with the velun in any known mollusc.

At the stage shown in fig. 6, the embryo has become bilaterally symmetrical about a plane which passes through the long axis of the egg, and the blasturlerm has become raised into a circular area, the mantle, $m$, on that end of the egg where segmentation began.

The primitive condition of the mantle, as shown by the figme, will be seen to be quite different from its condition at the same stage in Grenacher's embryo, as shown in his fig. 3, in which the mantle area is indicated by the presence of numerous chromatophores, while the margins of the area are not at all marked, and the elevation from the general surfice of the yolk is very slight. In our species, the chromatophores do not make their appearance until much later, and the margin of the mantle-area is well defined at the time of its first appearance. Judging from Bromn's copies of Kölliker's figures, the mantle of Sepia seems to make its appearance about as it does in Loligo, which it resembles much more than it does that of Grenacher's form.

The rudimentary arms are indicated in fig. 6 , by a slight ridge or projection, a, upon each side of the embryo, a little nearer the mutritive pole of the yolk than the formative pole. The outline of the yolk, represented by a heavy black line in the figure, is no longer regularly rounded, but begins to conform to the shape of the body of the embryo, a decided prominence projecting into the mantle-area; and a large, rounded, projecting eminence on each side of the body in the space between the arm $a$, and the mantle, $m$, marking the position of the future eye-stalk.

The history of the later stages of development shows that the end of the egr which is uppermost in this figure, and which is the end where segmentation began, becomes what is usually spoken of as the posterior end of the botly of the adult, the extremity opposite the head. The surface which is shown in the figure, is that which is usually called ventral, the surface which carries the siphon. The lower end of the figure is that which is occupied by the head in the adult animal.

Without entering into a discussion of the homology of the Cephalopod body, which I shall return to at the end of this paper, I shall, for the present, - accepting the views of Leuckart and Huxley, which I believe to be essentially correct, - speak of that surface which is uppermost in fig. 6, as the dorsal surface; of the opposite end, as ventral ; of the surfice shown in this figure, as posterior; and of the surface opposite the siphon, as anterior. Fig. 6 is therefore a posterior, instead of a ventral, view.

Figure 7 is an opposite or anterior view of a somewhat older embryo. The mantle, $m$, is more elevated, and its margin is quite sharply defined, and nearly circular, when seen 
in a surfice view. In the centre of the mantle area there is a shallow circular clepresion, the shell area, s. The eye-stalk is much more prominent than it was at the previous stage, and the layer of integument which covers it is very much thickened, and the surface of the yolk at this point much further from the surface of the body than it was at the stage shown in fig. 6. Near the centre of the eye-stalk, a depression or invagination of the integument marks the position of the developing eye; which originates, as has been well described by Lankester and Grenacher, by the involution of the ectoderm of the eye-stalk. Between the mantle and the eye-stalk on each side of the body, another elevation or rifge has male its appearance, the outer siphon-fold, si.

Fig. 8 is a view of the left side of an embryo of about the same age as the one shown in fig. 7. As before, $m$ is the mantle; $e$, the eyestalk; $b$, the growing edge of the blastoderm; $y$, the uncovered end of the yolk; and $a$, the arm-ridge. The next two figures, plate 1 , fig. 9 , and plate 2, fig. 10, are of especial interest, since they represent two views of an embryo which exhibits more clearly than any other which has been figured, the relation between the Cephalopoda and the ordinary Gasteropod Molluses. The embryo scems to he in substantially the same stage of development as the one shown in Grenacher's figs. 6 and 7 , but the differences between the two are very considerable, as well as very instructive.

Kïlliker's figs. 17, taf. 1, and 25, taf. 2, as copied in Bromn's "Klassen u. Ortummgen," also represent an embryo at about the same stage of development; but the Sepia embryo differs much more from the Loligo embryo than Grenacher's form does. The latter and Sepia are extreme forms, with Loligo intermediate between them in most respects, but with much closer resemblance to the first than to Sepia. Plate 11, fig. 10, is a slightly oblique view of the anterior surface of an embryo which, like those shown in figs. 6 and 7 , has its dorsal surface above, and which is drawn in such a position as to show rather more' of the left side than of the right. Plate 1, fig. 9, is a foreshortened view of the same embryo, as seen from above, in such a position as to exhibit the dorwal and posterior surface.

The mantle, $m$, fig. 9, is now quite sharply defined, and its posterior edge, $m$, fig. 10, begins to overhang a little, arching over the rudimentary mantle cavity, which is thus seen to be formed in Loligo, as in most Gasteropods and Lamellibranchs, by the outgrowth of a flap of integument from the surface of the body. A reference to Grenacher's figures will show that the origin of the mantle cavity was quite different from this in the form which he studied. At a corresponding stage (see his figs. 6 and 7 ), the mantle area is much larger than in Loligo, and covers almost one half of the body of the embryo, and is more developed externally than it is in Loligo at the stage shown in our fig. 15. The mantle cavity, however, is barely indicated, and when it makes its appearance it is not formed, as it is in Loligo, hy the outgrowth of a mantle-fold, but by the involution of the integument under the mantle, after the latter has spread over a considerable area of the body. The resemblance between the manner in which the mantle cavity is formed in most Gasteropods and Lamallibranchs, and the way it is formed in Loligo, seem to indicate that the latter presents the primitive mode of development among the Cephalopoda; and the way it is formed in Grenacher's species must, therefore, be regarded as a modification of the primitive mode which has been retained by Loligo. 
It is interesting to notice that there are other groups of Mollusca, among which the mantle cavity is produced in more than one way. In Cyclas, Pisidium, and many other Lamellibranchs, a fold grows out from the body, and thus converts the space between the fold and the body into a mantle cavity precisely as in Loligo, but in Anodonta the shells are quite well advanced in their development before the mantle cavity is formed, and when this is produced it is formed by the retraction of the body wall into the space between the shells; and we have in Anodonta almost precisely the same modification of the primitive history which Grenacher describes in the Cephalopoda. In the oyster again, we have the mantle cavity produced by a process which is about midway between that met with in Cyclas, and that presented by Anodonta.

Projecting from under the overhanging edge of the mantle, on the posterior surfice of the body, at the stage shown in figs. 9 and 10 , are the rudimentary gills, $g$, one on each side of the middle line. They are formed as little papillae, or outgrowths from the surface of the body, and are covered with cilia. In position and method of formation they are very much like a single pair of the gill-tentacles of a Lamellibranch embryo, and their embryonic history would seem to indicate that they are to be regarded as greatly specialized gill filaments, rather than structures comparable to the entire gill of a Gasteropod or Lamellibranch.

The shell area in the middle of the mantle is now a deep pit, fig. 9, $s$, and its edges have begun to fold towards each other, as shown in fig. 10, s. As Lankester has pointed out, it originates in exactly the same manner as the shell-gland of a Gasteropod or Lamellibranch, and is strictly homologous with these structures.

The eye stalks, es, figs. 9 and 10, are now very conspicuous projections from the sides of the dorsal end of the embryo, and the eye-invaginations are well developed, and their external openings much smaller than the inner portion of the invaginated sac. In fig. 10, the left eye is shown in a surface view, and the right eye in profile. The lateral folds of the siphon, fig. $10,8 i^{\prime}$, are a little more definite than they were during the previous stage, and the two inner siphon-folds, fig. 9, si, have made their appearance on the posterior surfice of the body. They are not only separate from each other, but widely separated at this time from the lateral folds. Opposite the outer ends of the inner siphon-folds the ears, fig. 9, er, have mdae their appearance, as two almost spherical invaginations of the integument, communicating with the exterior by large openings. Nearly opposite the inner folds of the siphon, on the median line of the anterior surface of the body, the mouth, mo, fig. 10, is now visible as a blind sac with a large opening pointing downwards.

On each side of the mouth, there is a very faintly-marked undulating line or fold of the surface of the body, $v$, which runs from a point near the corner of the mouth, out into the eye-stalk, crossing the outer ventral edge of the eye. The line makes two well-marked dorsal undulations, and one ventral one, the latter near the middle of the line. Any small particles which are floating in the vicinity of this line are thrown into active motion in the direction of the arrows, thus showing the presence of cilia too small to be visible by any magnifying power which can be used. The position of this line, its relation to the mouth and eye-stalk, and the presence of cilia along it, all indicate that it is to be regarded as a rudimentary velum. 
The ridge, $a$, of figs. 6 and 7 , is now divided into three arms, fig. 9, $a$, upon each side of the body, about half-way between the mantle and the opposite pole of the egg, and therefore much nearer the mantle than at the stage of fig. 6. 'The yolk is now entirely surrounded by the blastoderm, and has departed still further from the regularly curved shape of fig. 1. 'The prolongations into the mantle and the eye-stalks are well defined, and the portion of the yolk contained within the body of the embryo, which is not quite half the whole, is separated by a well-marked constriction, just dorsal to the arms from the remainder, which is now nearly spherical. The thin layer of blastoderm which covers this external portion of the yolk is split into two layers, separated from eatch other by a cavity which is lamesest along the median plane of the body, and which is traveried hy a fer hrancher corpuscles, by the contraction of which, rythmical waves of the outer layer are set in motion on the surface of the yolk. 'The fact that the mantle is dorsal to the row of arms at this period is worthy of notice.

The next figure, plate 2, fig. 11, is a view of the posterior surface of a somewhat older embryo, represented, like the preceding ones, with its dorsal surface above. 'Ihe mantle, $m$, now overhangs the body considerably at the sides, as well as posteriorly, and the portion of the yolk which projects into it is more sharply marked off than before, and is drawn out to a point at the dorsal end. The eye-stalks, es, and their yolk protuberances, are much more prominent, and the constriction which separates the body from the external yolk is much more marked. 'The three pairs of arms are a little larger than before, and a cavity is visible in each of them. The inner siphon folds, si, have lengthened, and their outer ends now point towards the outer folds, si', from which, however, they are still widely separated. 'The most important differences between this and the preceding stage are differences of proportion and relative size, which are sufficiently well shown in the drawings, and do not call for description.

Plate 2, fig. 12, is a posterior view of an older embryo, figured with its dorsal surface below instead of above, in order to facilitate comparison with the figures which follow, and with the adult animal. 'The mantle, $m$, has extended its edge sufficiently to form a very well defined mantle-cavity, within which the bases of the gill tentacles, $g$, are now contained. The tail fins, $f$, have made their appearance upon the dorsal surface of the mantle, and the rectum, re, is now present as a raised, longitudinal, hollow rod, upon the median line of the posterior surface between the gills. 'The two inner siphon folds, si, have met upon the middle of the body, and their free edges have bent towards each other to form the opening of the siphon; but they have not yet united with each other, and the siphon has the characteristics of that of the adult Nautilus. The inner folds are still separated from the outer ones, si, si', but the latter have begun to bend around upon the posterior surface of the body. 'The eye-stalks, es, are now extremely prominent and conspicuous, and the yolk protuberances no longer entirely fill them, but have begun to decrease in size, thus leaving between the eye and the yolk a space in which the optic ganglion has made its appearance.

The three pairs of arms, $a$, are much elongated, and begin to bend away from the surface of the yolk, which is now divided into three well-marked regions; the external yolk, $y^{\prime}$; the portion within the head region and eye-stalks, $y^{\prime \prime}$; and the portion within the body and mantle, $y^{\prime \prime}$. During its development the embryo has undergone an increase in 
size, and although the drawing is less enlarged, the embryo shown in fig. 12 is actually much larger than that shown in fig. 10. The external yolk sac shares in this growth, and is very much larger at a somewhat later stare than the whole erger was at the beginning of the process of development.

The points of difference between Loligo, Sepia, and Grenacher's embryo are more conspicuous at this stage than at any previous time.

Kölliker's figures 20, 21, 23, of taf: 11, represent about the same stage as our fig. 12, and a comparison will show a rematsable difference in all the details of structure, while the general plan remains much the same.

The body of the embryo is very much smaller as compared with the external yolk, and is not separated from this by a constriction, but is flattened down upon it. The blastoderm does not yet cover the yolk, but only extends a short distance beyond the circle of arms. Five pairs of arms have made their appearance in the Sepia embryo, and only three pairs are present in Loligo. The outer and inner siphon folds of each side have been united to each other from their first appearance in Sepia, but in Loligo they do not unite until after the two inner folds have united on the middle line to form the mouth of the siphon. The mantle and mantle-cavity of Sepia are about like those of Loligo. Grenacher's figs. 8 and 9, taf. 40, are in about the same stage of development; and comparison will show that while this form is more like Loligo than it is like seppia, the differences are still numerous and considerable.

The external yolk is very small, and hardly projects beyond the tips of the arms. Grenacher, p. 454, is inclined to regard it as entirely wanting, but his "stirntheil," in figs. 7 and 8, is clearly the same as the external yolk of Loligo, and this again is obviously the same as that of Sepia. His argument that since the internal yolk of Sepia is divided into three regions, three divisions must be found in the internal yolk of his form, and that the "stirntheil" being necessary to make up the three, must therefore belong to the internal yolk, cannot carry much weight; for at this period the internal yolk of Loligo is only divided into two regions, although a third afterwards becomes recognizable. As regards the external yolk, then, Sepia, Loligo, and Grenacher's embryo form a series, with Loligo as the intermediate form. Grenacher's embryo differs from Sepia, and agrees with Loligo, in having only three pairs of arms at this time. The eyestalks are about equally prominent in the three forms, and the period of greatest prominence is about the same in all; but while the prominence began to be conspicuous in Loligo and Sepia at about the same time, its development is retarled in Grenacher's enloryo until some time after the siphon folds have all united. The outer and immer siphon folds unite with each other in Grenacher's embryo sometime before the two inner folds meet on the middle line; while in Loligo, the two inner folds not only meet but unite with each other before they join the outer folds. In this respect Grenacher's embryo is intermerliate between Loligo and Sepia, since the two sets of folds are united with each other from the first in the latter form. As it has four separate folds at one time, Grenacher's embryo would reem to resemble Loligo more than it does Sephit, so firr as the formation of the siphon is concerned.

At the stages shown in figs. 8 and 9, the mantle of Grenacher's embryo covers almost half the borly, and its surfice is thickly set with chromatophores, while the mantle- 
cavity is very shallow, and hardly extends beyond the edge of the mantle. In both Loligo and Sepia, the mantle is much smaller, the chromatophores are wanting, and the mantle-cavity extends nearly or quite to the dorsal extremity of the body.

The fins of Sepia and of Grenacher's embryos make their appearance at about the same time, and are developed later than they are in Loligo.

The fact that three such closely related forms, belonging to the same group of Cephalopods, differ from each other in the order of development of all organs of the horly, except the otocysts, is a striking comment upon the assumption that the order of development of parts, as observed in a single species, can give any information as to their morphological importance, or as to the order in which they were acquired in the evolution of the group. We must notice, too, that the series which these three forms furnish when any one organ is taken as a basis of comparison, may be quite different from that given by another organ, and it is clear, without comment, that we have no information at present which will allow us to generalize upon such questions as to which of these forms recapitulates the phylogenetic record most perfectly. There are a number of interesting points, however, in which all three agree. In all, the halves of the siphon are separate at first, and all pass through a stage in which the siphon resembles that of a Tetrabranch. In all, the eyes are at first open pits, like those of the Nautilus, and in all they are at some time carried upon long stalks. In all there is a time when only four of the five pairs of arms are present.

Passing now to the next stage in the development of Loligo, plate 11, fig. 13, is a view of the posterior surface of an embryo somewhat older than in fig. 12. The external yolk sac, $y$, has grown so much larger that only a small part of it is shown in this and the next three figures. The mantle, m, has grown so much that the gills, $g$, and the rectum are nearly contained in the mantle-cavity. A constriction across the base of each gill has separated the branchial heart, $h$, from the gill proper. The inner folds, $x i$, of the siphon, have united with each other to form the closed siphon tube, and the inner and outer folds, si, si', have met and are uniting with each other.

The walls of the otocysts, er, have grown thin, and their cavities have greatly enlarged; the otoliths have made their appearance, and the two chambers have begun to move towards the median line, under the end of the siphon.

The external openings of the otocysts have become constricted to long, tortuous, ciliated ducts, which are not visible with a low power, and are not shown in the figure.

The eye-stalks, es, are of about the same relative length as in the last figure, but the yolk prominences which have filled them up to this time are now almost entirely withdrawn or assimilated, and the cavity of the eye-stalk is nearly filled by the ball of the eye, $e$, the optic ganglion, ga, and the white body, wb.

The arms have lengthened, and suckers have appeared upon the longest pair, $a^{\prime \prime}$, and a new pair, $a^{\prime}$, have made their appearance upon the posterior or siphonal surfice of the body. In Grenacher's embryo this pair of arms make their appearance as buts upon the next pair, $a^{\prime \prime}$, but in Loligro they are listinct from the first, and make their appearance as elevations of the integument upon the surface of the body.

The yolk is now divided into four well-marked regions, the external yolk sac, $y^{\prime}$, which is still nearly spherical; the head yolk, $y^{\prime \prime}$, which is pretty nearly cylindrical, and 
which passes gradually into the external yolk kac; the body-yolk, $y^{\prime \prime \prime}$, much smaller than the head-yolk, and separated from it abruptly by a well markerl change of outline; and the little mass of yolk, $y^{\prime \prime \prime \prime}$, at the dorsal end of the body, constricted off from the mass, $y^{\prime \prime \prime}$, by a deep groove.

Fig. 14, plate 2, represents a view of the posterior surface of a somewhat older embryo, as seen from the left side.

The mantle is now large and bowl-shaped, and covers the greater part of the body dorsal to the eye-stalks. Chromatophores now begin to make their appearance around the posterior side of the edge of the mantle, and those which first appear are of a dark brown color.

The gills, $g$, have lengthened considerably, and are divided by constrictions into a series of enlargements, the dorsal one being much larger than the others, and becoming the branchial heart. The inner and lateral folds of the siphon have completely united with each other, and at the point of union the siphon is also united to the body wall, and the retractor muscle of the siphon, sm, now runs back to unite with the inner anterior surface of the mantle. The otocysts have almost met each other upon the median line, under the siphon, and their walls are now very thin. The eye-stalks, es, are most prominent at this stage, and soon begin to disappear.

A comparison of this figure with Grenacher's figure 10, which represents about the same stage of development, will show that certain organs are more accelerated in Loligo than in Grenacher's species, while others are retarded. The yolk sac of Grenacher's embryo has disappeared, while it is as large as ever in Loligo. The mantle is much further developed in Grenacher's embryo, and covers the whole base of the siphon, which is almost entirely uncovered in Loligo, even when the animal is retracted into the mantle. The posterior or siphonal pair of arms, $a^{\prime}$, are well developed in Loligo, and just making their appearance in Grenacher's embryo as buds from the next pair of arms.

The embryo shown, from the right side, in the next figure, plate 3, fig. 15, has assumed the general form of the adult, and the eye-stalks have almost disappeared, although, as shown in a posterior view, fig. 16, the eyes are very prominent still, and are directed more towards the ventral surface than they are in the adult.

The mantle now covers about one-half the entire length of the embryo, exclusive of the yolk-sac, and the neck-cartilage, nc, has made its appearance, forming a support for the edge of the mantle, on the middle line of the anterior surface of the head. The posterior surface of the mantle is now pretty well covered with chronatophores, which at this stage possess remarkable power of expansion and contraction, and render the living embryo a very beautiful and wonderful sight under a low magnifying power. They are, as yet, entirely absent from the anterior surface of the mantle.

About this time small polygonal areolations, much like epithelial cells, begin to make their appearance on the posterior surface of the mantle, and soon spread over the whole mantle, except the middle line of the anterior surface, as shown in the figure. At a later stage, figs. 17 and 18, they cover the head and arms as well as the mantle, and still later they make their appearance upon the surface of the siphon.

Upon cursory examination, they resemble epithelial cells so much that they might readily be mistaken for them; but when more carefully examined with a high power, 
they are seen to be due to the presence of minute branching tubes, which, spreading over the surface of the body and inosculating, divide it up into small polygonal areas.

No fluid could be seen to circulate in them, but as they appear at about the same time with the larger blood-vessels of the surface of the body, they are probably the indications of a system of capillary vessels.

The course of the larger blood-vessels on the posterior face of the mantle is shown, at a somewhat later stage, in fig. 17. A large vessel will be seen to enter the mantle on the median line near the dorsal end of the body. This is the pallial artery from the systemic heart. Passing forwards, it divides into three branches; a pair of large ones, and a median unpaired smaller one. The latter runs forwards, nearly to the lower edge of the mantle, and divides up into a number of smaller branches. The two larger branches diverge, and rumning out towards the free edge of the mantle, give rise, on their inner edges, to a number of irregular branches, and on their outer edges to a number of nearly parallel trunks, which communicate with a pair of large venous trunks, each of which receives a smaller trunk from the median tract of the mantle, and then, bending around the side of the body, runs inwards to open into the larger vena cava, from which the blood passes into the branchial heart, and is conveyed to the gills. The branchial. hearts appear at quite an early stage of development, but the systemic heart is not developed until about the stage shown in fig. 16. During the later stages of development, and in the adult also, the small size of the gills is no doubt compensated for, to a great degree, by the aeration of the blood while it is passing through the system of vessels near the exposed surface of the mantle.

At the stage shown in fig. 15, the siphon has substantially its adult form, and is made up of two lateral chambers, si", which have leeen formed from the lateral siphon folds, and which open into the mantle-chamber, hut have no external openings; and a single median chamber, si, on the posterior surface of the body, which has been formed by the union of the two inner siphon folds, and which opens into the mantle-chamber as well as externally.

At the point where the lateral chambers meet the median chamber, the wall of the siphon is united to the wall of the body, and the three chambers are thus shut off from communication with each other.

The animal is so perfectly transparent that the valve-like action of the two outer chambers can be perfectly seen, as their free inner edges are thrown out against the mantle so as to close it at each contraction, and the water, which passes in around the whole free erlge of the mantle, is thus concentrated in the fumel-shaped middle chamber of the siphon.

At about this time the valve of the siphon, figure $15, v$, is developed as a single unpaired flap, which arises from the posterior surface of the neck.

Considerable change has now taken place in the shape of that portion of the yolk which is contained in the head. It is reduced to a long narrow tube, $y^{\prime \prime}$, which connects the portions contained in the body proper, $y^{\prime \prime \prime}, y^{\prime \prime \prime}$, with the external yolk sac, $y^{\prime}$. The pulsatile space, $x$, between the outer wall and the surface of the yolk sac, is more plainly shown in this figure than in the preceding ones, although a profile view shows it with equal distinctness at earlier stages. 
The figures of the later stages hardly call for much description, since they show sufficiently well in themselves the gradual change of shape, and the approximation to the form and structure of the adult.

Fig. 16 is a posterior view of an embryo a little older than the one shown in fig. 15. A large rounded prominence on each side of the bed marks the position of the eye-stalk, and the eyes are farther forward than they are in older specimens, but in other respects the form is very similar to that of the adult. The ink sac, $i$, has appeared, and is filled with ink, and the tip of the free portion of the rectum is prolonged at its corners into the pair of ear-like anal valves.

Figr. 17, 18, are copies of drawings made at MIr. A grassiz's laboratory at Newport during the summer of 1876, from specimens which were found swimming at the surfice of the water of Narragansett Bay. $\Lambda$ s the arrangement of the chromatophores is like that of the other embryos, they undoubtedly belong to the same species and are given here to show the later stages of development. The external yolk-sic has almost disappeared in figg. 17, and it is entirely wanting in fig. 18.

There are considerable individual variations in the arrangement of the chromatophores, but there are curtain features which were observed in all the specimens, and which seem to be constant.

The first which make their appearance are dark brown in. color, and are placed in a ring of six or seven (plate 2, fig. 14), around the edge of the mantle on the posterior surface. They are a little smaller, and somewhat more excitable than thowe which appear subserquently, and they can be readily recognized in the later stages shown in fign. 15, 16, 17,18 . They are soon followed by larger spots of the same dark brown color, scattered irregularly over the posterior surface of the mantle (fig. 16).

The next spots to appear are upon the arms, and are also dark brown. At first there are two upon the first or siphonal pair of arms, and three upon the second pair (fig. 16). A fourth soon appears upon the second arm, and these four remain conspicuous until quite a late stage of development (fig. 18). Three large brown spots now appear upon the posterior surfice of the head (fig. 16), and they are soon followed by others (fig. 17).

$\Lambda$ second set of spots, more deep-seated and of a bright orange color, soon make their appearance, and are much more constant in position than the brown ones. The first pair which appear are just in front of, or ventral to the eyes. They are soon followed by a single one on the middle line of the head, at the bases of the first pair of arms, and another single one on the middle line of the edge of the mantle. About the same time a pair appear dorsally to the eyes, and another pair on the edge of the mantle, near the sides.

Four small orange spots next appear upon the second pair of arms (fig. 17, $a^{\prime \prime}$ ), alternating with the four larger brown spots, and soon after a ring of six or eight orange spots appears on the mantle, dorsal to the ink bag. Two orange spots next appear upon the first pair of arms, figure 18, $a^{\prime}$, alternating with the brown spots.

I was not able to procure specimens in sufficient numbers to follow the development of the spots to any later stage than this, but they do not seem to develop regularly at the later stages. 


\section{Tileoretical Discussion of tile Observations.}

In a general view of the facts which have been detailed, the most prominent and conspicuous feature seems to be the remarkable directness with which the embryo develops into the adult, and the total absence of anything like a metamorphosis. Everything which does not contribute to the formation of the adult animal has been dropped out of its life history. With the exception of the velum and the eye-stalks, there are no larval or rudimentary organs, and the whole process of development is wonderfully direct.

When we bear in mind that the Cephalopoda are almost the most highly specialized of Invertelurates, and that they must have had a long and complicated phylorgenetic history, I think we must acknowledge that the embryonic record has been simplified to a degree which is without a parallel in the animal kingdom, and it is hardly too much to say that the ontogenetic process furnishes us with no knowledge whatever of the phylogeny of the group.

The method of formation of the shell-area and of the shell; the mode of origin of the mantle and of the mantle-cavity, and the form and position of the gills of the Cephalopod embryo are all of them features which show closer relationship to a typical Gasteropod than could be inferred from the condition of these organs in the adult. They thus show the affinity of these groups to each other, and help us to a clearer understanding of the homology between the organs of the Cephalopod, and those of a typical Mollusc, but this is about all. I do not see that they furnish any basis whatever for speculation upon the origin of the Cephalopod, or grive us the least information as to the mamer in which its peculiar specializations of structure have been brought about.

We, undoubtedly, have an ancestral feature in the embryonic condition of the siphon, at the time when the siphon folds are separated from each other upon the median line, but in the present state of our knowledge it furnishes a very scanty basis for generalization. It is true that there is a resemblance between the adult condition of this organ in the Tetrabranch and its embryonic condition in the Dibranch, and the evidence therefore shows that in this respect, the former group is more embryonic, or less specialized, than the latter, but it certainly is not sufficient to warrant the conclusion that the one group has been derived from the other, rather than from a common ancestral form.

I think that this is true of the development of the eye as well as of that of the siphon. 'The history of this organ shows, as Grenacher has pointed out, that it is essentially similar to the ordinary molluscan eye, and that it is less specialized in the Tetrabranch than it is in the Dibranch, but the resemblance is not such as to indicate that the Tetrabranchs are the ancestors of the Dibranchs.

It is just such an embryonic resemblance as we should expect to find, if both are the descendints of an unspecialized form, and while it is not inconsistent with the idea that this common ancestry is very remote indeed, neither would it conflict with the riew that the divergence of the two groups was comparatively recent.

The arms of the Dibranch embryo are hardly, if at all, more like those of a Tetrabranch, than those of the adult, and although the shell is at first external, it is, in this respect, no more like the Nautilus shell than any other molluscan shell is. 
In a word, the case is hardly too strongly put, by the statement that the developing Dibranch has so completely lost all ancestral features that no traces of them remain.

In another point of view our embryo is more suggestive. Although it furnishes us no basis for phylogenetic speculations, it does furnish a safe ground for the discusion of cephalopod homology.

Homology, as I take it, is the resemblance which is due to common ancestry, while phylogeny is the study of the steps by which specializations of structure have been acquired. It is quite conceivable that a form of life should exhibit its relationship to a remote ancestor, without any indications of the manner in which the divergence from this ancestor has been brought about. This seems to be the case with the Cephalopoda. While the Squid embryo fails to give us any information as to the way in which a typical Molluse has been modified in order to convert it into a Cephalopod, or as to the transformations through which it has passed in reaching its present form, it nevertheless clearly shows the fundamental similarity of type which subsists between it and the ofler Mollusca.

The precise relation between the organs and regions of the borly of a Cephalopor and those of a more typical Mollusc, have always been as obscure as the close natural aflinity of these groups is obvious, and the obscurity has been increased by the disposition to regard the various Mollusca as modifications of a highly specialized architype, uniting in itself the characteristics of all its derivations. This tendency still retains a consilerable influence over the minds of morphologists, although it is now perfectly obvious that the architype, or proto-mollusc, must have been an unspecialized rather than a highly specialized form, and that the virious existing molluses must have been derived fiom this primitive form by gradual specialization. The only basis for an homology of the Mollusea, in the absence of a phylogenctic record, and of transitional forms, is therefore to be sought in the comparison of early stages in the development of individuals of the diflerent groups, at a time when the specializations of structure, characturistic of the adult forms, have not yet made their appearance.

In his paper on the development of an unknown Cephalopor, Grenacher has made such a comparison, and has attempted to furnish a sound basis for the discussion of the homology between the Cephalopoda and other Mollusca.

As the result of this comparison, he reaches conclusions, which, being the product of observation rather than of speculation, are much more valuable and natural than any which have been advocated by previous writers, although I believe them to be only partially correct.

Although his embryological record is very complete, it unfortunatuly lacks the stages which are of the greatest importance as a basis for generalization, and I have been so fortunate as to fill this gap by finding embryos which exhibit general molluscan characteristics mohseured by the presence of the distinctive features of the Cephalopod. For comparison with a Gasteroporl embryo I give in fig. 19 of plate 3 , a diagramatic side view of an embryo at the same stage as that shown in plate 2 , fig. 10 , but with the rectum and anus represented as they are found at a somewhat later stage.

The figure, like fig. 10, has the head and the yolk sac $y$, below; the so-called posterior end above; the surface upon which the siphon is to be developed at the left, and the so-called dorsal surface at the right. 
Fig. 20, plate 3, is the embryo of a fresh-water Pulmonate, in what I regard as a similar position. The foot, $f$, is below; the shell, sh, above; the mouth, $m$, the tentacles, $t$, and the head on the right, and the rectum, $r$, on the left. The figure therefore shows the right side of the body of the Gasteropod; and as the twist by which the rectum and the mantle-chamber are subsequently carried around the right side of the body on to the anterior surface has not yet appeared, the embryo is bilaterally symmetrical, and the mouth, the anus, the foot, the mantle, and the shell occupy substantially the sume positions, and bear about the same relations to each other, that they do in a Lamellibranch. A comparison with fig. 19, or with fig. 10, will show that there is, at the same time, an essential similarity to a Cephalapod.

In the Gasteropod, fig. 20, or in a Lamellibranch, we have the bilaterally symmetrical shell, sh, resting like a cap upon the dorsal surface of the body, and surrounded by a reflected ridge of integument, the margin of the shell area, $s \alpha$.

As Ray Lankester has pointerl out, the embryonic shell of a Cephalopod is rery similar, and in the Squid, fig. 19, we have the external shell, sh, surrounded by the reflected rim of integument, sa, exactly as in the Pulmonate.

Rumning around the shell and shell area in both Cephalopod and Gasteropod, is a second ridge of integument, the margin of the mantle, ma, ma, which already projects a little from the posterior, enemal surface of the boty of the Cephalopod, to form the outer wall of the rudimentary mantle chamber.

On the middle line of the posterior surface of the body, just below the mantle-ridge, in both Cephalopod and Pulmonate is the rectum, $r$, with its external opening, the anus; raised from the surfice of the body upon the anal papilla in the Cephalopod, but otherwise alike in the two forms.

On each side of the rectum of the Cephalopod is a single tentacular gill, $y$, underneath the overhanging edge of the mantle. There are no corresponding structures in the Pulmonate, and in the Prosobranch the gills do not nake their appearance until the symmetry of the body has been distorted by the twisting of the visceral mass into a spiral, hut the gill filmuents of a Lamellibranch are exiltly similar in form, structure and position to the gills of the Squid embryo.

On the anterior surfice of the body, the surface which is usually called dorsal in the Cephalopod, and which is on the right in both figures, we have first, the thickened mantle ridge, ma, which forms the angle between the dorsal and the anterior surface. Next we have in the Pulmonate and in most Gasteropods the large pulsatile "neck region," $h$. In the Cephalopod this region is short, not pulsatile, and it forms the "back" of the animal.

Below the neck region of the Pulmonate a tentacle, $t$, is developed on each side of the median line of the body, and the eyes subsequently make their appearance upon these tentacles. On each side of the corresponding region of the body of Squid embryo, the projecting eye-stalk, $t$, carries the rudimentary eye upon its rounded extremity, and there does not seem to be any doubt that the sensory tentacles of the Gasteropod, and the eye-stalks of the Cephalopod are strictly homologous.

In the Pulmonate the rudimentary velum, $v$, is marked by a line of granular ciliated cells, which crosses the middle line of the body just below the tentacles, and then running out upon the sides, bends up towards the dorsal surface, in such a way as to almost encircle the tentacles. 
When the corresponding surface of the body of the Cephalopod embryo, at the stage shown in plate 2, fig. 10, is carefully examined with the highest power which can be brought to bear upon such a large rounded opaque surface, a well defined line or groove, plate 3 , fig. $19, v$, will be found to run from the median line out upon the sides of the body, bending up towards the dorsal surfice in such a way as to partially encircle the eyestalks; and the motion of floating particles shows the presence of cilia along the line.

Immediately below it at the point where it approaches the median line of the body, the mouth, $m$, is situated, in the Cephalopod as well as in the Pulmonate, and the fact that the ciliated line bears exactly the same relation to the mouth and to the sensory tentacles in the Cephalopod that it bears in the Pulmonate seems to show beyond doubt that it is the same structure, a rudimentary velum, in both cases.

The mantle; the mantle-cavity; the shell area; the shell; the rectum and anus; the sensory tentacles; the velum, and the mouth are thus seen to be so similar in position, relations, mode of development and function, in these two Molluses, as to leave no doulst of their homology.

When used as a basis for comparison these various features furnish us with a sufficient number of points of orientation to assure us that the Cephalopor embryo must be placed as it is in plate 3 , fig. 19, and in plate 2 , figs. 10 and 11, in order to be in a position which is homologous with that of the Gasteropod embryo, shown in fig. 20.

The views which were advineed upon the morphology of the Cephalopoda, nearly thirty years ago, by Huxley, are therefore essentially correct in outline, although I shall now give my reasons for opposing certain of the homologies advocated by hirn.

There are few morphological questions upon which more conflicting views have been expressed than those of the various writers who have discussed the homology of the siphon and arms of the Cephilopod, and the equivalent, in this group, of the Gasteropod foot.

The history of opinion upon this subject has been treated at length by Grenacher, and more recently by Von Jhering (Vergl. Anat. des Nervensystems und Phylogenie der Mollusken, pp. 269-281), and I may therefore enter at once upon an examination of the morphological aspect of the question without first reviewing its historical side.

The molluscan foot, fig. $20, f$, is a median unpaired structure, on the ventral surface of the body, between the mouth and the anus. In the Pulmonate, and in many other Gasteropod embryos, a large sinus-space, $c$, separates the integument of the foot from the endoderm and its derivatives. This space contains blood corpuscles, and as the integunent is rythmically contractile the embryonic foot is a circulatory organ.

A glance at fig. 19, or fig. 10, will show that the only umpaired structure on the median line of the ventral surface of the body of the Cephalopod embryo is the large external yolk-sac, $y$, and to this, if anywhere, we must look for the homologue of the Gasteropod foot.

When the Cephalopod embryo is seen in a profile view, fig. 19, or fig. 15, the integument, $f$, of the yolk-sac will be found to be separated from the yolk by a space, $c$, and as the integument is rythmically contractile, the fluid which fills this space is liept in constant motion. Physiologically then, as well as in its position, the yolk-sac of the Squid resembles the foot of the Gasteropod, and I think we must conclude that, as a 
lonomutor organ, the funt of the Cephaloporl has been suppressed by the great development of a food-yolk at the point where it should be found.

The arms of the Śquil malie their appearnee as little protrusions, fig. 19, a, a, a, arranged in pairs around the neck or constriction which separates the external yolk-sac from the body proper. As they are, at first, ventral to the mouth, and as a true velum is present, they cannot be regarded as a velum, and as they are paired instead of median, they are not homologoms with the median muaired foot. They are pared outgrowthis from the foot region, and may perhaps be regarded as the equivalents of the cephaloconi of Clio, but there does not seem to be any evidence that they have been produced by the modification of any part of the body of a typical Gasteropod, and they are undoubtedly structures which have been acquired by the Pteroporls and Ceplatopods, after these diverged from the common ancestral form which united them to the Gasteropod stem.

The siphon originates as two pairs of folds, $s$ and $s^{\prime}$, of the integument of the lateral walls of the body, and if we regard these four folds as homologous with the epipodial folds of a Gasteropod, the arms must be regarded as independently acquired structures.

If we regard the arms as modilications of the epipodial folds we must consider the four siphon folds as independently acquired structures, and as we have nothing whatever to furnish us with a test, nothing seems to be gained by the uncertain homology of either the arms or the siphon, with any part of the body of a typical Gasteropod.

It seems certain that the common ancestor of the Gasteropods and Cephalopods must have been an minecialized form, rather than a highly complex architype, and if this is the case we cannot expect any valuable results to follow from the attempt to compare any part of the body of a Cephalopod with structures which, like the epipodial folds, are not common to the Gasteropoda, but somewhat exceptional; which, when they are found at all, as in Aplysia, are not rudimentary but functional; making their appearance very late in the history of the individual insteal of early, and presenting every indication of recent aequisition.

While we owe a great debt to Huxley's paper on the Morphology of the Cephalous Mollusat, for the demonstration of the general relations between the Cephalopod body and that of a Gasteropod, I think that confusion has resulted from his attempt to carry the homology into the details of Cephalopod structure.

The growth of opinion upon the homology of the siphon and arms may be stated briefly as follows:

Huxley regarded the arms as the true foot, and the siphon as the epipodial folds.

Grenacher shows that as the foot is an unpaired structure, it camnot be homologous with the arms, and he follows Lovén ( Beitrïge zur Kenntniss der Entwicklung der Mollusca Acephila Lamellibranchiata; reprint of 1879, p. 93), in regarding these as a modified velum. The foot he believes to be wanting, and the siphon he regards as the epipodium.

Von Jhering opposes Grenacher's view that the arms are homologous with the velum, and points out that the cephaloconi of Clio, which are undoubtedly homologous with the arms, are certainly not homologons with the velum, since an embryonic velum appears in the young Pteropod, and then disappears without forming any part of the adult body. He also calls aftention to the fact that in the Gasteropods, even when the velum is cut up into tentacles, these do not persist or become converted into any part of the adult body. He 
says, on p. 269, that the arms are tentacular appendages to the body, and does not appear to regard them as the equivalent of any part of the Gasteropod.

The innervation of the siphon from the pedal ganglion leads him to regard this as the foot, and he concludes that the valve of the siphon is the true foot or protopodium, and the two lateral folds pteropodia. He conjectures that Grenacher's two inner folds unite and give rise to the valve, but this is opposed to Grenacher's account, as well as to my own observations, and there can be no doubt that the two inner folds form the tube of the siphon and the two lateral folds its lateral chambers. The valve appears quite late, fig. 15, $v$, as an outgrowth from the inner wall of the siphon tube, and there is nothing in its history which gives any reason to believe that it has ever had any other function than that of a valve to the siphon-tube. Von Jherring's homology rests upon the assumption that similarity in the method of imnervation implies similarity of origin, but the bilateral character of the siphon seems to be an objection to its homology with the foot, even if it were in the right position upon the body, and if it is a new structure, as I believe, the origin of its nerves cannot have any profound morphological significance.

Beaufort, N. C., July 31, 1880.

\section{EXPLANATION OF THE PLATES.}

All the figures except plate 1, figs. 2, 4, and 5 and plate 3, figs. 19 and 20 were drawn from living specimens, swimming without restraint within the uncompressed egg, or, after their escape from the egg, in a sufficient quantity of water to allow perfect freedom of movement. As the use of a camera was thus rendered out of the question, the drawings are not all upon the same scale. Most of them were made, however, with an amplification of about eighty diameters.

\section{Plate I.}

Fig. 1. An egg in which the process of segmentation is somewhat advanced. $a$, Egg-shell; $b$, space between the shell and the yolk, filled with transparent albumen; $c$, cap of segmentation spherules; $m$, micropyle.

Fig. 2. More highly magnified view of the blastoderm of the egg shown in figure 1, as seen in optical section; $a, b$, and $c$ as before; $d$, yolk.

Fig. 3. A more advanced egg, with the blastoderm covering about a quarter of the surface of the yolk; $a, b, c, d$ and $m$, as in the preceding figures.

Fig. 4. More highly magnified view of the growing edge of the blastoderm of the egg shown in figure 1 after staining with osmic acid and borate of carnine; $a$, unsegmented yolk; $b$, segmentation pyramids; $c$, first row of cells, which have been formed by a separation from the ends of the pyramids; $d$, second set of cells, which have been formed by the division of cells like $c$; $d^{\prime}$, third set similar to $d$; $d^{\prime \prime}$, fourth set, similar to $d$, and $d t$.

Fig. 5. Highly magnified view of the edge of the blastoderm of the egor shown in figure 3, after staining with osmic acid and borate of carmine. $a$, $b$, and $c$, as in figure 4 ; $d$, cells which have just divided.

Fig, 6. View of the posterior surfice of an embryo, in which the yolk is almost covered by the blastoderm. $a$, arms; $b$, growing edge of blastoderm; $m$, mantle; $y$, uncovered portion of yolk.

Fig. 7. View of the anterior surface of a slightly older embryo; $m$, mantle; $s$, shell area; sit, lateral siphon folds; $e$, eye. 
Fig. 8. View of the left side of the same embryo. Reference letters as in figs. 6 and 7 .

Fig. 9. Foreshortened dorsal view of the posterior surface of the embryo shown in plate 2, figure 10. $a, y, s$, and $m$, as in the preceding figures; $e s$, eye stalk, $y$; gills ; er, otocysts; si, inner siphon folds.

\section{Plate II.}

The letters of reference have the following significance in all the figures of this plate; $a$, arms; $a^{\prime}$, posterior or siphonal pair of arms; $a^{\prime \prime}$, second pair; $a^{\prime \prime \prime}$, third pair; $e$, eyes; er, otocyst; es, eye stalk; $f$, fins; $g$, gills; $h$, branchial hearts; $m$, mantle; mo, mouth; re, rectum; si, inner siphon folds; $s i^{\prime}$, lateral siphon folds; sm, siphonal muscle; $v$, velum; $y$, yolk; $y^{\prime}$, external yolk sac; $y^{\prime \prime}$, yolk mass of the eye stalks and head; $y^{\prime \prime \prime}$, and $y^{\prime \prime \prime \prime}$, yolk masses of the body and mantle.

Fig. 10. Embryo a little older than the one shown in figures 7 and 8 , represented with its dorsal surface above, and showing the anterior surface of the body, as seen from the left side.

Fig. 11. The posterior surface of an older embryo with its dorsal surface above.

Fig. 12. A similar view of an older embryo, with its dorsal surface below.

Fig. 13. An older embryo in the position of figure 12. In this and the following figures, only a small portion of the external yolk sac, $y^{\prime}$, is represented.

Fig. 14. The posterior surface of an older embryo, as seen from the right side, with the dorsal surface below.

\section{Plate III.}

Fig. 15. A somewhat older embryo seen from the right side. The external yolk is now so large that only part of it is shown in the figure; $a^{\prime}, \alpha^{\prime \prime}, \alpha^{\prime \prime \prime}, a^{\prime \prime \prime \prime}$, the four arms of the right side; $f$, the fin; $g$, the gill; $n$, the branchial heart; $m$, the free edge of the mantle; $n c$, the neck cartilage; si, the siphon tube; $s i^{\prime}$, the lateral chamber of the siphon; $v$, the valve of the siphon; $x$, the space between the integument and the surface of the external yolk; $y^{\prime}, y^{\prime \prime}, y^{\prime \prime \prime}, y^{\prime \prime \prime \prime}$, the four divisions or regions of the yolk.

Fig. 16. Posterior surface of a somewhat older embryo; $e$, eye; $i$, ink bag; $r$, rectum. The other letters as in figure 15.

Fig. 17. A free swimming squid with the external yolk almost absorbed. The letters as in the preceding figures.

Fig. 18. A free swimming squid with the external yolk entirely absorbed. The letters as in the preceding figures.

Fig. 19. Dingrammatic view of the right side of a Pulmonate embryo, with its dorsal surface above; $f$, foot; $h$, neck region; $m$, mouth; ma, mantle; $c$, foot-sinus; $r$, rectum; sa, shell area; sh, shell; $t$, tentacle; $v$, velum.

Fig. 20. Diagrammatic view of the left side of a squid embryo, at the stage shown in figure $10 ; a, a, a$, arms; $c$, sinus space around the yolk sac; $e$, eye; $f$, integument of yolk sac; $g$, gill; $m$, month; $m a$, mantle; $v$, velum; $r$, rectum; $s$, inner siphon fold; $s^{\prime}$, outer siphon fold; $t$, eye-stalk; $y$, yolk sac. 

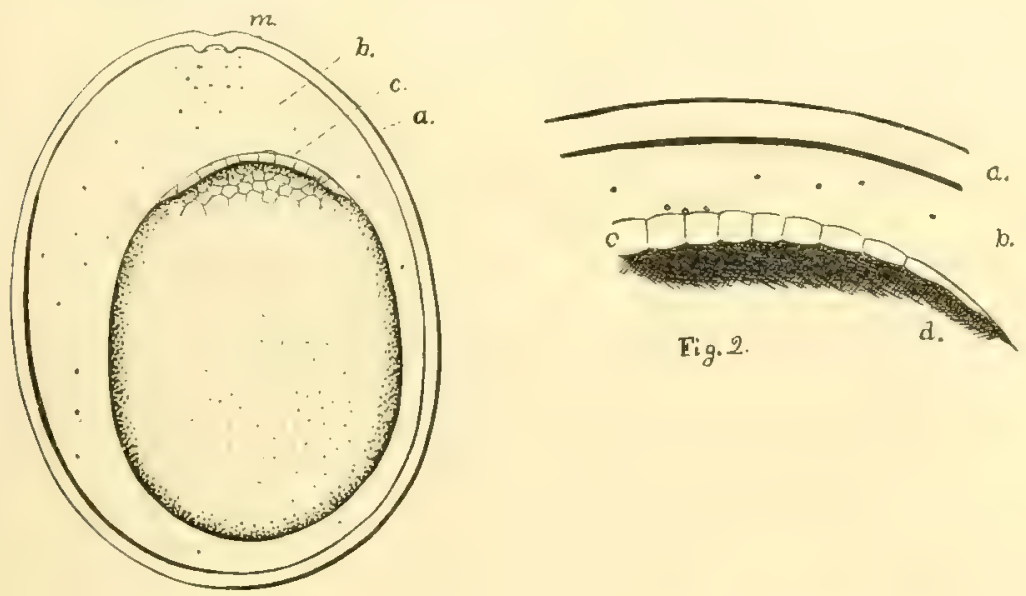

Fig. 2.
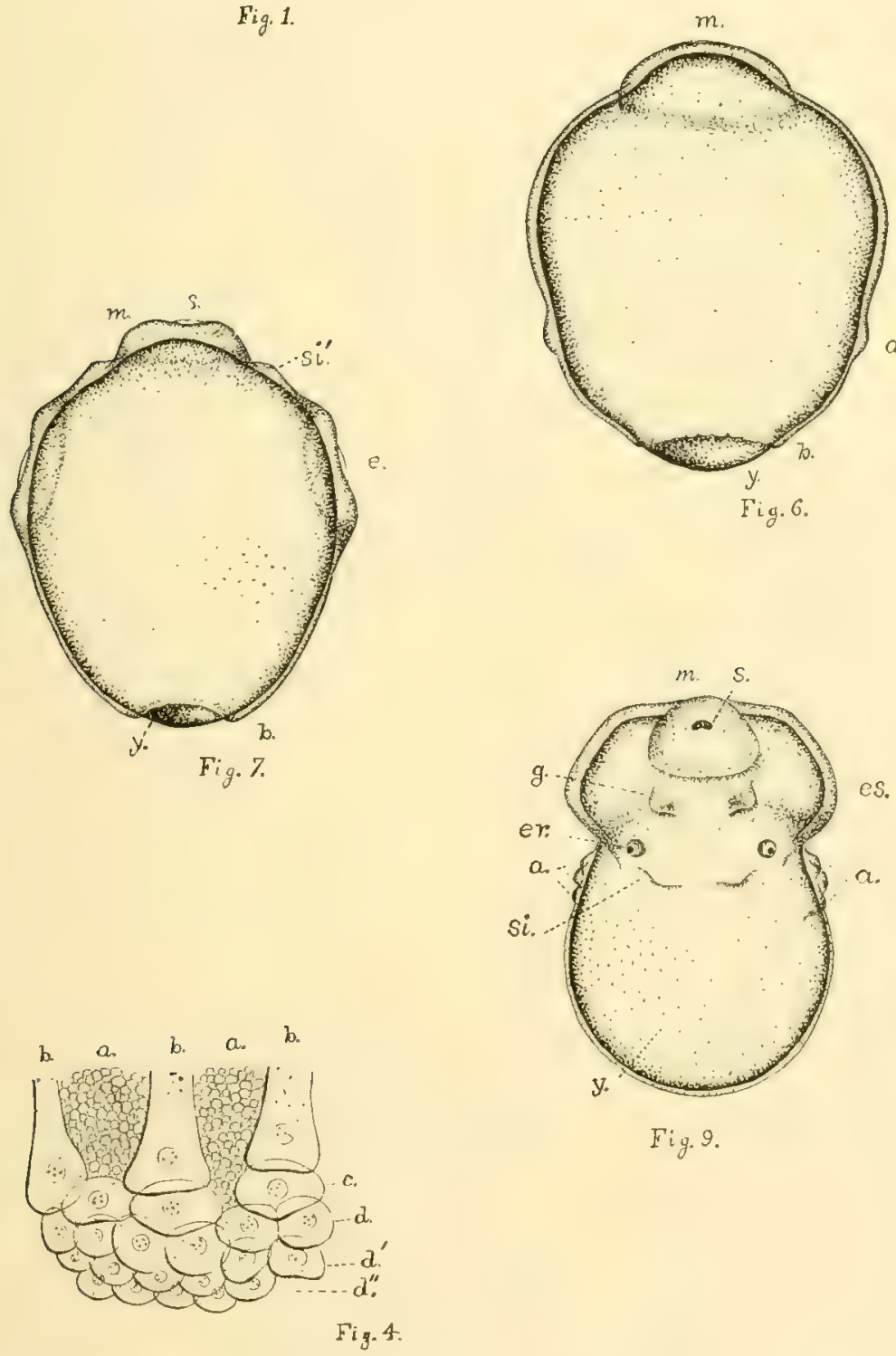

Fig. 9.

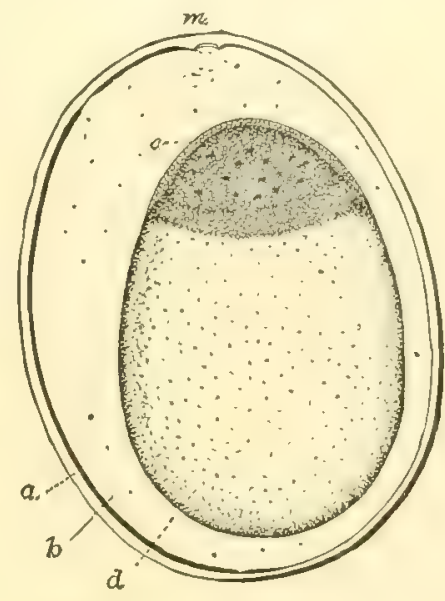

Fig.3.

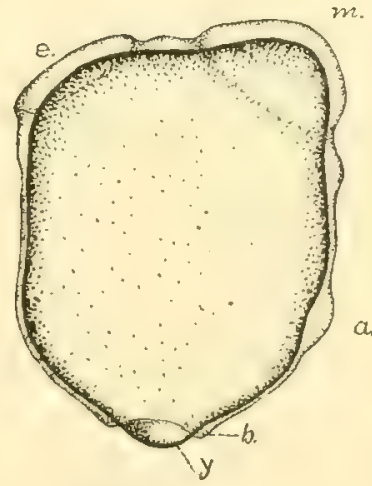

Fig. 8.

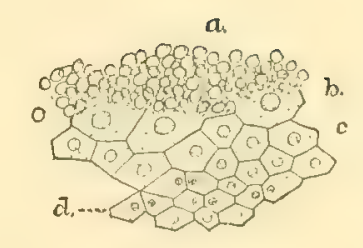

Fig. $\bar{~}$ 
. 


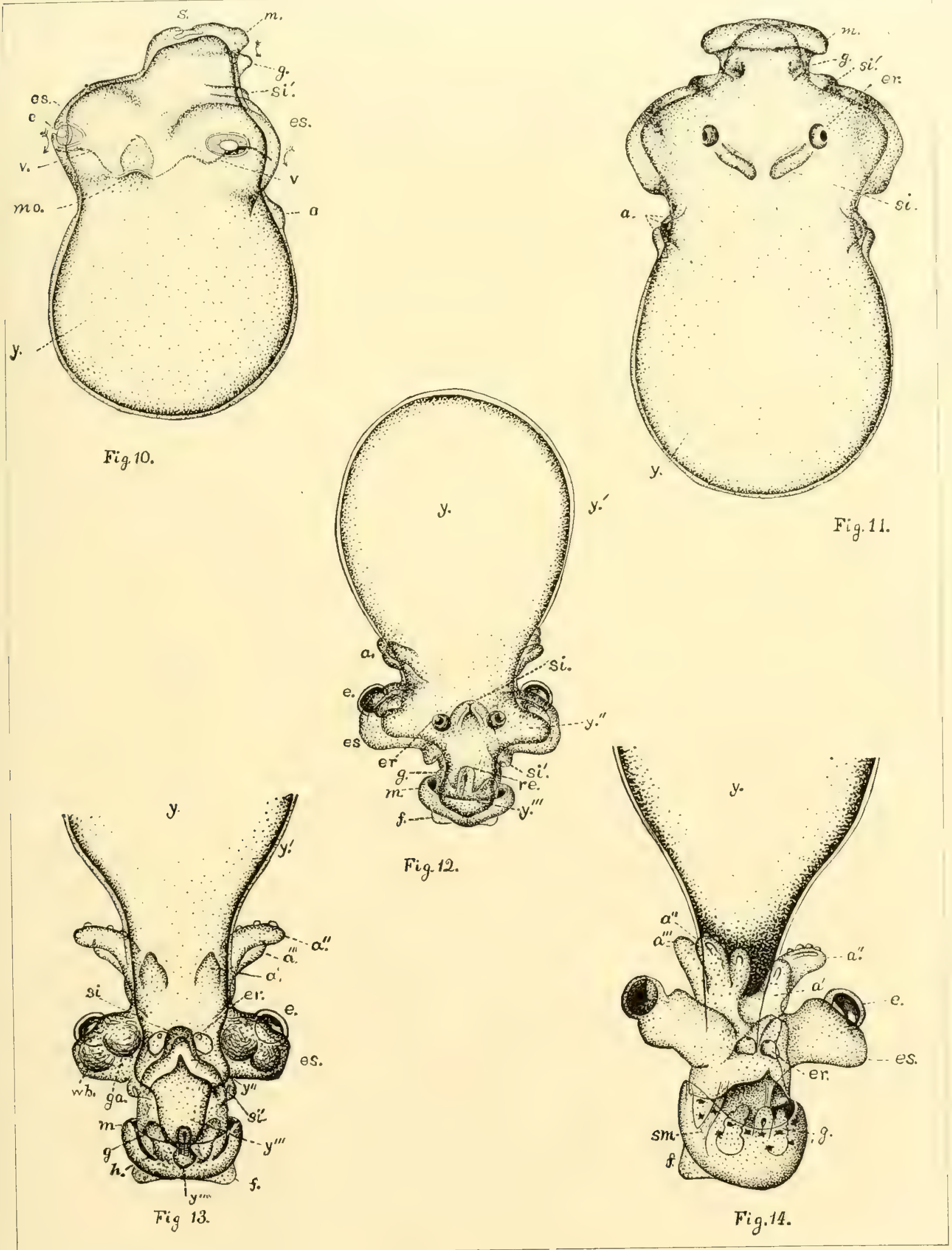



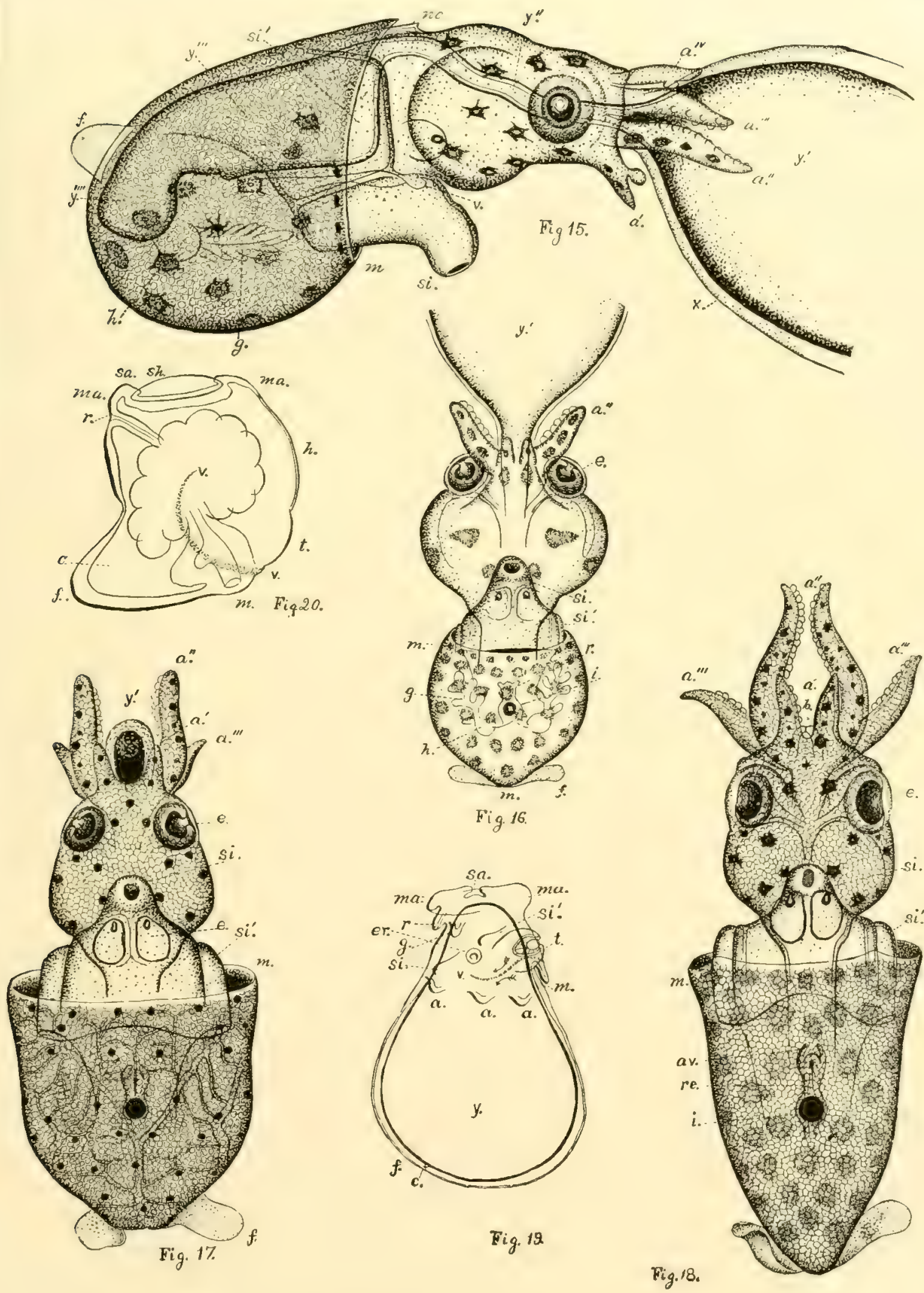

1830. ANNIVERSARY MEMOIRS OF THE BOSTON SOCIETY OF NATURAL IIIST RY. 1850.

\section{THE ANATOMI, HISTOLOGY, AND EIBRYOLOGY}

\section{LIMULUS POLYPHEIUS.}

BY A. S. PACKARD, JR., M.D.

BOSTON :

PUBLISHED BY THE SOCIETY.

1880 . 
. 


\section{The Anatomit, Histology and Embryology of Linulus Polypinemus.}

Bx A. S. Packard, Jr., M.D.

SIxCE the publication of my first paper on the development of the horse-shoe or king crab (Limulus polyphemus), in the Memoirs of this Society, ${ }^{1}$ I have, as opportunity allowed, made additional observations on the development of the larva, and also on the histology of the different organs, and especially the brain. In making the microscopic sections of the embryos and for a series of sections of a brain, the latter of which were unstained, I am indehted to Professor T. D. Biscoe. For mounting some of these sections for study, I am indebted to Dr. C. B. Johmson of Providence, R. I., who also kindly cut, stained, and mounted preparations of the digestive canal. Within the past year I again returned to a study of the brain, using the methods of staining employed by German observers, Dietl and Krieger, also by Mr. E. T. Newton. The sections of the brain were cut and stained, as also those of the eyes, parts of the stomach and rectum, kidneys and liver, ete., by Mr. Norman N. Mason, of Providence, R. I., who kindly devoted a great deal of time to the work. To his unusual skill and delicacy of manipulation, I am indebted for a large number of preparations much better than I could have made myself, and which have been of most essential aid in preparing this paper; so that portions of the histological part of this paper, especially that on the structure of the eyes, are really joint productions with Mr. Mason, as we together examined the preparations.

\section{Position of Limulus among Artmropoda.}

The researches of M. Alphonse Milne-Edwards on the anatomy of Limulus, proved that this animal, so far from being a genuine normal crustacean, is either the type of a group equal to all the other Crustacea, namely a sub-class of Branchiata; or, as several authors contend, should be regarded as the representative of a distinct class of Arthropoda.

Before arguing what we now believe to be the true position of Limulus and the allied fossil forms, including the Trilobites, let us take a review of the different opinions of the leading zoologists who have done special work on the animal. The titles of their work will be found in the bibliographical list at the end of this paper. 
Straus-Diirckheim was the first author to remove the genus Limulus from the Crustacea, and to regard it as the type of a distinct orler of Arachnida, which he called Gnathopodes. In his memoir, published in 1829, according to Van der Hoeven's statement, Straus claracterized the Arachnida by the disposition of the feet arranged in a circle around an interior cartilaginous sternum, and by the absence of antennae. Van der Hoeven, in 18:38, remarks that the branchiae are the principal characters of Crustacea, as insisted upon by Latreille and Milne-Edwards, who placed Limulus in this class; therefore Limulus should belong with these animals, and he shows that there are other characters which separate Limulus from the Arachnida, and which ally them with the Crustacea. These are the compound eyes, the position of the stomach in the front of the cephalothorax, "while it is contained in the abrlomen of Arachnida." He then says: "But whether we place the Limuli among the Crustacea, or with the Arachnida, they should always form a distinct order for themselves alone, which, in the actual state of our knowledge, is far from all the other orders of these two classes." Afterwards, in 1846, in lis Handbook of Zoology, and again in the second, English edition of 1856, he placed the Poecilopoda as the first order of Crustacea, referring, however, to their resemblance to Arachnida.

In 1871, Dr. A. Dohm, in his Untersuchungen iiber den Bau und Entwicklung der Arthropoden, concluded that Limulus, Eurypterida and Trilobita should be united under a common name, Gigantostraka, as originally proposed by Haeckel, in his Morphologie, for the Eurypterida alone; and that they should be placed near the Crustacea.

Most if not all the other leading zoologists, while recognizing the aberrant characters of the Limuli, have left them among the Crustacea, though in 1834 H. Mine-Edwards established a subclass (Xiphosura) for the group; this group being equivalent to any one of reveral other subclasses of Crustacea which he enumerates. For the views we held previous to the publication of H. Milne-Edwards' memoir, we would refer the reader to our Memoir on the development of Limulus, published in March, 1872.

In October, 1871, the following views of II. Élouard Van Beneden ${ }^{1}$ were published : "L'étude du développement embryonnaire de ces animaux et de leurs caractères anatomiques m’a conduit aux conclusions suivantes que je puis formuler dès ì présent:

I. Les Limules ne sont pas des Crustacés; ils nont rien de commun avec les Phyllopodes, et leur développement embryonnaire présente les plus grandes analogies avec celui des Scorpions et des autres Arachnides, dont on ne peut les séparer. Dans le cours de leur développement embryonnaire, on ne distingue aucune des phases caractéristiques du développement des Crustacés, et il ne peut être question de distinguer dans le cours de ce développement embryonnaire, ni phase nauplienne, ni phase cyclopéenne.

II. L'analogie entre les Limules et les Trilobites, et l'affinité qui relie entre eux ces deux groupes, ne peut être un instant douteuse pour celui qui a étudié le développement embryonnaire de ces animaux. Les lois de développement sont les mêmes chez les Trilobites et les Xiphosures, et l'analogie entre les jeunes Trilobites et

\footnotetext{
1 Journal de Zoologie. Par Paul Gervais. Tom. 1, p. 42, 1872. Paris.
} 
les jeunes Limules est d'autant plus grande, qu'on les considère ì une époque moins avancée de leur développement. A l'examen de jeunes Limules, MM. Packard et Woodward ont été frappés de ces analogies.

III. Les Trilobites, aussi bien que les Euryptérides que les Poecilopodes, doivent être séparés de la classe des Crustacés et former avec les Scorpionides et les autres Arachnides un rameau à part, dont l'origine est encore à déterminer."

In November, 1872, A. Milne-Edwards, in his beautiful memoir on the anatomy of Limulus, claimed that the central nervous system resembled that of Arachnida, and was surrounded by arterial coats, and that the brain supplied no limbs with nerves. His conclusions are stated in the following extracts: "L'après les faits que je viens de passer en revue, on voit que le système nerveux de la Limule diffère beaucoup de celui de tout autre animal articulé, et resemble moins à celui des Arachnides qu'à celui des Crustacés. Chez les premiers, les ganglions cephalothoraciques sont tellement serrés entre eux que le pertuis ménagé au milieu du collier oesophagien, pour le passage du tube alimentaire est d'une petitesse extrême, et qu'en arrière de cette masse médullaire, les deux moitiés de la chaine nerveuse sont réunies entre elles dans toute leur longreur, au lieu d'être attachées l'une à l'autre par des commissures ganģlionnaires seulement. Chez les Crustacés, on rencontre souvent une disposition analogue ì celle des Limules. Mais la coalescence des ganglions cérébroïdes et des ganglions posthuccaux n'est jamais portée aussi loin, et e'est en général entre ces deux systèmes des centres nerveux que les connectifs sont le plus allongés. Chez les Limules, au contraire, ces connectifs sont remarquablement courts, tandis que ceux situés à la partie antérieure de la région abdominale sont fort longss. Il est aussi ì noter que le système ganglionmaire viscéral, dont M. Blanchard a tiré des caractères anatomiques pour la distinction des Insectes, comparés aux Myriopodes et aux Arachnides, présente chez les Limules une disposition qui n'a encore été obsérvé nulle part ailleurs. Ces particularités anatomiques viennent donc ì l'appui de l'opinion que j’ai déjà émise, relativement à la nécessité de séparer ces animaux des autres Articulés, et d'en former une classe particulière, sous le nom de Merostomata, classe très-voisine, d'ailleurs, des Arachnides." He then states, in considering the external anatomy, that it is not only by their internal organization that the Limuli differ from the Crustacea and approach the Arachnides, without, however, being confounded with them ; for there are also in the general conformation of the Merostomata and the Scorpions, resemblances which seem to indicate in all these Entomozoa a community of primordial type.

The external characters which separate the Limuli from all other articulated animals are the absence of any preoral appendages, Milne-Edwards having shown that the nerves to the first pair of feet do not arise, as Van der Hoeven and Owen claim, from the brain, but from the oesophargeal collar. To use Edwards' own words: "J'eu conclus que, chez les Limules, il y a absence complète d'appendices frontaux, et ce caractère les distingue des Arachnides aussi bien que de tous les autres animaux articulés de la période actuelle."

Finally, he remarks that if the Limuli are not Crustacea, neither are they Arachnida. "They are distinguished, the latter not only by their mode of respiration, but by the existence of compound eyes, the absence of frontal appendages, the continuous 
prolongation of the ventral appendages on the adjacent part of the abdomen, and by several other organic characters. They are distinguished from all other articulated animals by the disposition of their circulatory system, and consequently, in spite of the small number of species of this group, the zoologist should consider them as constituting a particular class intermediate between the Crustacea and Arachnida. He claims with Mr. II. Woodward, that the fossil Pteryoti and Eurypteri should be united with the Limuli, under the name of Merostomata. Milne-Edwards then adds that "the Merostomata were contemporaries of the Trilobites, and there seems to be between these two groups, not only very strong resemblances, but intermediate forms which establish the passage from one to the other. Some authors. have thought it useful to unite them under a common name. 'This seems to me at least too premature, because we know nothing of significance on the subject of the appendicular system of Trilobites, and we cannot pronounce legitimately on this question; but it should be taken into consideration, that it seems very probalsle that the Tribohites differ from the Crustacea properly so-called, as we have seen the Merostomata differ from them, and that they should likewise constitute a particular class in the great natural division of Entomozoa."

In November, 1873, ${ }^{1}$ in the light of A. Milne-Edwards' researches, I stated that "I should no longer feel warranted in associating Limulus and the Merostomata generally with the Branchioporlat, but regard them as perhaps forming with the Trilobites a ristinet sub-class of Crustacea. In a second notice in the same Journal for December, 1879, I proposed the name Palaeocarida, for the sub-class; these comprising the Merostomata and Trilobites. We also proposed the term Neocarida for the remaining sub-class of normal Crustacea.

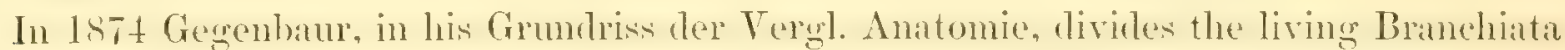
as opposed to the Arthropoda 'T'racheata, in two divisions: I. Crustacea, II. Poecilopoda. ${ }^{2}$

As regards the relations of the Merostomata to the Arachnida let us examine them and inquire whether they are not rather those of analogy, than of affinity. It is not necessary, in view of what has been published, for us to restate the essential anatomical characteristics of Limulus. 'The relations of the viscera to the body wall, and of the appendages may be seen by our figures in Plates $I$ and II.

The resemblances to the Arachnida in general, and the scorpion in particular, have been supposed to consist (1) in the want of antennae, and (2) the form of the central nervous system, as well as (3) the mode of development, while (4) the branchiae of Limulus have been homologized with the pulmonary sacs of spiders.

It should be borne in mind, however, that the Arachnida are a sub-class of Tracheata, with no antennae to be sure, but with two pairs of post-oral appendages, the mandibles and maxillae, which are constructed on the hexapodous type, and are also built upon the same plan of structure as the mouth-appendages of Myriopoda; so close indeed are the homologies between the Ifexapoda, or insects proper, and the Arachnida and Myriopoda,

\footnotetext{
1 Farther observations on the cmbryology of Limulus, with notes on its aflinities. Amer. Naturalist, November. 1873 .

${ }^{2}$ If we substitute for the term Poeciloporla, which applies only to the sub-order of which Limulus is the type, the term
}

Paleeocarila, and remard Gerenbaur's Crustacen as equivalent to my Nencarida; this would express my views as to the relations of the two sub-classes. This makes the terms Crustacea anl Branchiala synonyms from my point of view. 
all breathing by tracheae, excepting the few species which have no breathing organs at all, that it seems most advisable to retain them as sub-divisions or sub-classes of the class of insects or Tracheata.

There is little in common between the mouth-parts of Limulus and those of the Arachnida, either in their form or grouping; moreover, the mouth-parts of Limulus are not differentiated from the other cephalothoracic appendages. The six pairs are alike; morphologically true gnathopods; and in the embryo arise simultaneously; in the Arachnida, the two pairs of mouth-parts are, in adult life, quite different from the eight legr, and are soon differentiated in early embryonic life. Limulus resembles the Arachnida in the want of antennae, but so important are the differences in the mouth-orgams and legs, that it seems a violation of the principles of classification to associate together the two types within the limits of the same class.

The second Arachidan feature clained by authors to exist in Limulus is the alleged similiarity in the form of the nervous system to that of the Arachnida, especially the scorpions and spiders. The oesophageal collar of the horse-shoe crab has been homologized with the thoracic ganglionic mass of Arachnida, and the brain of Limulus has been likened to that of the spiders and of the scorpions.

The brain of Arachnida has heretofore been supposed to be a single pair of ganglia, and to send nerves not only to the simple eyes, but also to the first pair of mouth appendages. If this view is correct, as all who have studied the ardult Arachnids agree, then the brain of Limulus is not homologous with the arachnid brain (supra-oesophageal gamglion), as it supplies only the eyes, sending no nerves to the anterior gnathopods. As will be seen farther on (Plate 4, fig. $7 \mathrm{gn}$ ), the first pair of gnathopods is supplied in the larvat directly from an independent pair of ganglia. Very recently, however, Mr. Balfour ${ }^{1}$ has proved that the so-called supra-oesophageal ganglion or brain of the spider is formed of two pairs of ganglia which at first are quite distinct, as shown by his section of the embryo spider. Ir. Balfour concludes that "the evidence which I have got that the cheliceres are true postoral appendages, supplied in the embryo from a distinct postoral ganglion, confirms the conclusions of most previous investigators, and shows that these appendages are equivalent to the mandibles, or possibly the first pair of maxillae of other Tracheata."

In either case then, whether the brain of Arachnida is a single pair of ganglia, supplying the cheliceres (or mandibles), as well as the ocelli or two pairs of consolidated ganglia, the brain of these Arthropods can scarcely be homologous with the brain of Limulus.

Moreover, the position of the hrain in relation to the thoracic ganglionic mass of Arachnida is quite different from that of Limulus; in the former animals, judging from Blanchard's beautiful and accurate plates, and our own examination of the brain of the scorpion, it is invariably situated in a plane parallel to and much above the thoracic mass, and separated by long slender commissures; while the brain of Limulus is situated on the same plane as the oesophageal collar, in fact, closing up the front of what would otherwise be an open ring or collar.

\footnotetext{
1 Notes on the development of the Araneina. By F. M. Balfour. Quarterly Journal of Microscopical Science, 
The thoracic ganglionic mass of the Arachnida is likewise not homologous with the central cephalothoracic nervous system of Limulus. The thoracic mass in the former type sends off nerves to the maxillae, or second pair of mouth-appendages, and also to the four pair of limbs, and from this mass the abdomen, including the spinnerets (in our view morphologieally limbs), is supplied with nerves; there being no ganglia in the abdomen of any spiders (Araneina) as yet known. On the contrary, the oesophageal collar of Limulus supplies the nerves for the six cephalothoraic appendages alone (and this seems strong proof that these gnathopods should be regarded as either mouth-parts alone, or partly mouth appendages, and partly thoracic appendages), while there is a chain of six ganglia in the abdomen. Here, however, it should be borne in mind that in the scorpions there is a chain of abdominal ganglia, so that in this respect there is an interesting analogy between Limulus and the Pedipalpi. So far, however, as concerns the brain and thoracic mass, there seems to be a lack of homology in the two types of nervous system of Limulus and Scorpio.

In the mode of early development, Limulus resembles the Arachnida, but also in the embryonal membranes the insects, while it also recalls the development of certain Crustacea, notably Apus, as we attempted to show in our first memoir.

The fourth point of comparison, i.e., between the gills of Limulus and the pulmonary branchiae of spiders seems far-fetched. The gills and mode of respiration of Limulus are thoroughly crustacean, the gills being certainly not homologues of the "lungs" of the air-breathing spiders, which are tracheal sacs, formed by modified tracheae, and opening externally by stigmata.

From any point of view, developmental, anatomical or physiological, the relations of Limulus and its fossil allies to the Arachnida seem purely those of analogy, the fundamental differences being such as characterize and separate the Tracheate from the Branchiate Arthropods; the differences are so fundamental as to suggest the idea that the two types probably had a different origin, $i$. e. from some vermian ancestors.

In order to epitomize the differences and resemblances between the Merostomata and Arachnida, we have prepared the following tabular view:

\section{Comparison of the Merostomata with the Arachnida.}

\section{Arachnida.}

Head in adult soldered to thorax.

No compound eyes.

No antennae or morphological equivalents.

Mandibles on hexapodous type.

Maxillae with a palpus, on hexapodous type.

Four pairs of thoracic legs on hexapodous type.

No functional abdominal legs, the spinnerets being, however, modified legs.

Digestive canal on hexapodous type with a voluminous liver, and urinary tubes.

Brain formed of two pairs of ganglia supplying eyes and mandibles.

Maxillae and thoracic legs supplied from a concentrated postoesophageal ganglionic mass.

No abdominal ganglia in spiders, but present in scorpions.
Merostomata (Limulus).

Head separate from hind body.

Compound eyes.

No antennae or morphological equivalents.

Only their morphological equivalents (gnathopods).

No true thoracic legs; the gnathopods representing the mouth-parts and possibly the thoracic legs.

Six pairs of swimming respiratory legs, on the Crustacean type.

Digestive canal on Crustacean type, with a voluminous liver, but no urinary tubes.

Brain formed of a single pair of ganglia, supplying eyes alone, and free from the suboesophageal ganglion in embryo and adult.

Gnathopods supplied from a concentrated ganglionic oesophageal ring.

Six abdominal ganglia, much as in Crustacea. 
Turning now to the relations of the Merostomata to the normal Crustacen, we may inquire whether the former belong to the class of Crustacea, or should form the type of a distinct class. The latter view is that proposed by A. Milne-Edwards, and a number of zoologists have adopted this view.

'The facts that seem to us to point to the crustacean nature of Limulus and its allies are: (1) the nature of the branchiae, those of Limulus being developed in numerous plates overlapping each other on the second abdominal limbs; those of the Eurypterida being, according to $H$. Woodward, attached side by side, like the teeth of a rake; while the mode of respiration, as seen on plate 1, is truly crustacean; (2) the resemblance of the cephalothorax of Limulus to that of Apus; (3) the general resemblance of the gnathopods to the feet of the Nauplius or larva of the Cirripedia and Copepoda; (4) the digestive tract is homologous throughout with that of Crustacea, particularly the Decapoda, there being no urinary tubes as in 'Tracheata; (5) the heart is on the crustacean type as much as on the tracheate type, and the internal reproductive organs (oviries and testes) open externally, at the base of and in the limbs, much as in Crustacea.

'The resemblances and differences between the normal Crustacea (Neocarida) and the Palaeocarida (Merostomata and Trilobita) are shown in the following tabular view :-

\section{Comparison of Normal Crustacea (Neocarida) with limulus and otmer Palaeocarida.}

\section{Neocarida.}

Integument solid and calcareous, or thin and chitinous.

Usually in higher forms a cephalothorax, but in Phyllopods no genuine cephalothorax distinct from the abdomen.

Eyes of normal form, rods and cones present, but no corneal lenses.

T'wo pairs of antennae.

Mandibles normal.

Maxillae normal.

Maxillipeds normal.

Gills on thoracic feet, or thoracic or abdominal feet themsalves uroad and thin, and serving as gills.

Abdominal feet biramous.

IIeart polygonal or tubular.

Digestive canal with its three subdivisions of fore-, midand hind-gut.

Nervous system with a brain sending nerves to the antennae and eyes.

Oviduct opening at base of mildle thoracic feet ; male outlet at base of 5 tl thoracic feet.

Metamorphosis often complete.

Nauplius in some forms.

Zoea in Decapods.

\section{Palceocarida.}

Integument usually chitinous.

Ilead and abdomen alone; no thorax except in trilobites.

Eyes with no rods and cones, but corneal lenses.

No antenune, either functional or morplological.

No functional mandibles $=$ gnathopods.

No functional maxillae = gnathopods.

No functional maxillipeds $=$ gnathopods.

Gills on the abdominal feet.

\section{Abdominal feet biramous.}

Heart tubular, as in many Neocarida except Decapoda.

Digestive canal homologous with that of most higher Crustacea.

Nervous system with brain supplying eyes alone-first pair of gnathopods supplied from oesophareal collar, in larva from suboesophageal ganglion.

Oviduct and male outlet situated at base of first abdominal feet.

Metamorphosis absent, or partial.

No Nauplius.

No Zoea.

The difficulties which stand in the way of associating the Merostomata (throwing out the Tribobites for the sake of clearness of statement) with the Crustacea, are: (1) the nature of the limbs, and the absence of the pairs of antennae; but it may be observed that in the undiflerentiated gnathopods of Limulus we have a parallel in the larval 
Cirripedia and Copepoda, where what ultimately become autennae and mandibles are swimming feet; and in the zoea of Decapods, in which two pairs of antennae exist, and the temporary swimming fect ultimately become maxillae and maxillipedes; (2) the unique relations of the inferior blood system to the central nervous system (the brain and certain nerves alone excepted); and (3) the peculiar nature of the eyes of the Merostomata and Trilobites, which are constituted on a type peculiar to themselves.

Under all these circumstances, it may be claimed, as has been done by A. MilneEdwards, that the Merostomata should form a distinct cliss of Arthropoda. It should be borne in mind, however, that M. A. Milne-Edwards believes that a second class of Arthropods should be formed to receive the 'Trilobites. Taking all the facts into consideration, we should propose that the Merostomata and Trilobites should together form a subclass of Crustacea (i.e., Branchiate Arthropods) standing parallel to, and as the equivalents of, all the other Crustacea, the two groups being parallel and equally important branches of the same genealogical tree.

It should be bone in mind that the Palaeocarida are a generalized or synthetic type; Limulus is, so to speak, a sulyzoca, the cephalothorax having heen differentiated from the abdomen and prematurely developed, with the gills of a nomal crustacean; having the primitive appendages of a nauplius, and the compoumd eyes superficially like those of a zoea, but on an elementary, prematurely developed type; while the circulatory system is of a high order, and the nervous system well developed, though the brain is constituted on a simple plan, quite unlike that of the higher Crustacea, and probably the Crustacea in general. The subchass of Palacocarida apparently bears very much the same relation to the subclass Neocarida, as the subclass Elasmobranchii or Ganoidea do to the Teleostean fishes; as in these early synthetic forms certain organs are prematurely developed, while the skeleton and other parts are in a more or less embryonic or larval condition. They abounded most in the Palaeozoic ages, dying out in part, with but a few survivors; such was the case with the Palaeocarida. Under these circumstances we see no more reason for removing the Merostomata and Trilobita from the class of Crustacea, than to consider the Elasmobranchii or Gamoids as independent classes of Vertebrates, or the Arachnids or Myriopoda, as independent classes of Arthopoda.

Regarding, then, the Palaeocarida as an early offshoot of the Crustacean or Branchiate Arthropod tree or stem, we would venture to present the clasification on the following page, as proposed in 1879, in our little school book, "Loology."

The Neocarida may be characterized briefly as genume Crustacea with two pairs of antemua, biting month-parts and ambulatory or swimming thoracic feet; mostly modern types. The Palaeocarida, on the other hand, have the cephalothoracic appendages in the form of foot-jaws, rather than true jaws; no antennae, the brain supplying the compound eres and ocelli alone; the nerves to the cephalothoracic appendages sent off from an oesophageal ring or collar; and the nervous system, with the exception of the brain, ensheathed in a ventral system of arteries; they are mostly palaeozoic types.

The close homologies between the Merostomata and Trilobita were discussed in our first memoir. At that time (p. 1St), we advocated the view that the cephalothoracic limbs of the Trilohites must have been jointed, rounded rather than foliaceous, and ambulatory in function, and inclined to the views of Mr. Billings as to the nature of what he 
regarded the appendages of the Asaphus described by him in 1864. Since then the researches of $\mathrm{MI}$. C. D. Walcott ${ }^{1}$ on sections of Tribobites seems to have satisfactorily proved that Triblobites have rounded, jointed ambulatory apjendages developed from the head and possibly from the thorax. His observations, though from the nature of the case in some respects imperfect, have set at rest the question as to whether these extinct Palaeocarida had rounded, jointed limbs, though much yet remains unproved as to the homologies of these limbs with those of the Merostomata. It also appears that the hard parts of the eyes of Trilobites are directly homologous with thove of Limulus, as we attempt to show hereafter in this paper.

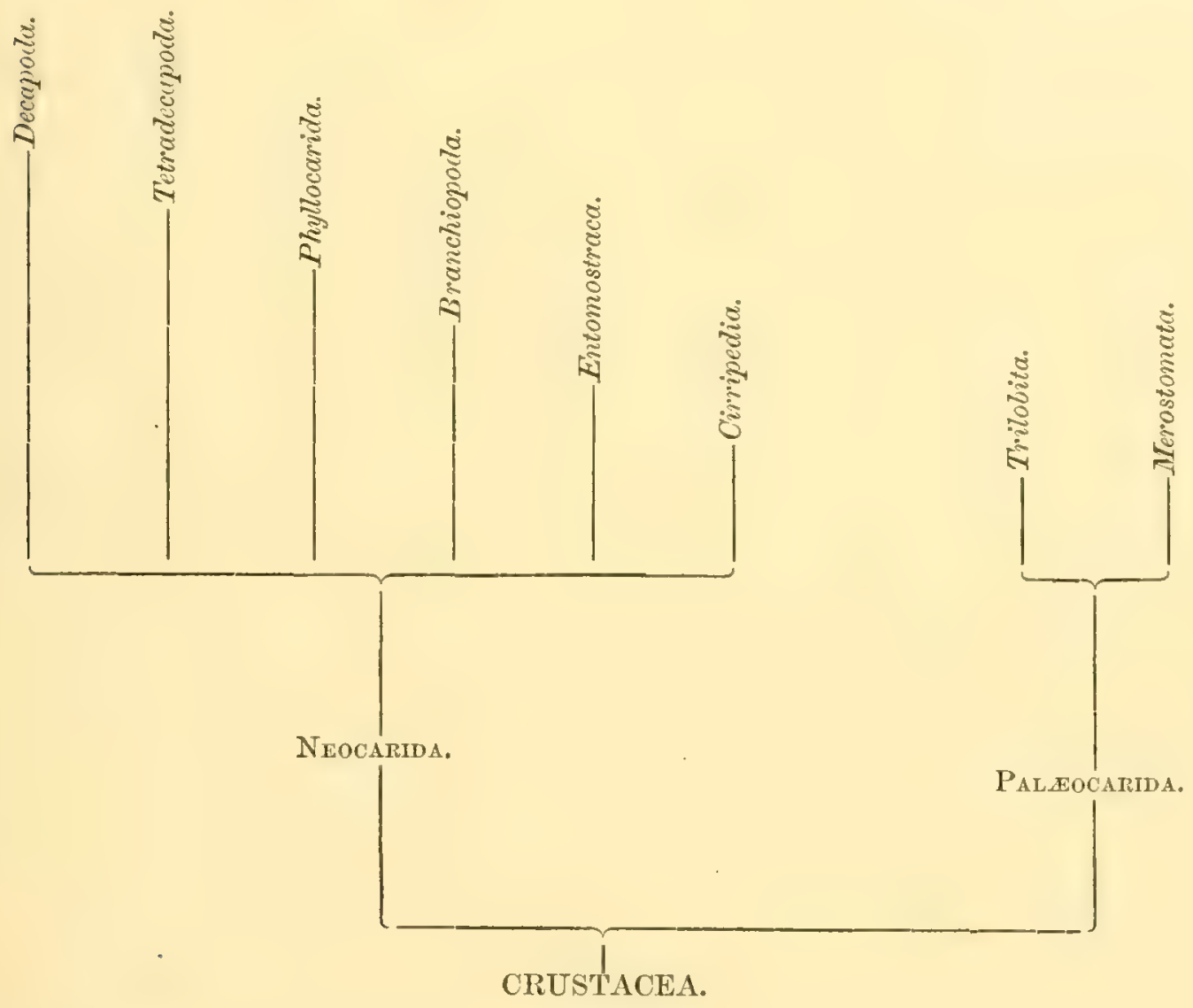

As to the general homologies of the body of Limulus, it seems to us that the facts presented further on confirm the position we have always taken, $i . e$., that there are no true antennae in Limulus; that the gnathopods are mostly modified mouthparts, the last pair possibly representing a pair of thoracic feet; that the fore region of the body corresponds to the cephalothorax of the Decapoda or of a

2 Preliminary notice of the Discovery of Natatory and Branchial appendages of Trilobites, and additional evidence upon the same. Twenty-eighth Annual Report, New York State Museum of Natural History, December, 1876. Notes on some sections of Trilobites from the Trenton Limestone, Sept. 20, 1877. See also Ann. Rep. N. Y. Mus. Nat. Hist., March, 1879. 
Nebalia, and that the posterior region is truly an abdomen, the spine of Limulus being simply the last body-segment, or ninth abdominal arthromere, as the history of the embryonic development of this segment proves. It then follows that the abdominal respiratory feet are, for example, homologues of the broad respiratory abdominal appendages of Isopoda. The view of Mr. Woodward, that what we regard as abdomen represents in part the thorax, or the opinion of Owen and Huxley that the spine represents the abdomen, and that what we call the abdomen is the thorax, in part at least, is, it seems to us, not based on sound induction.

\section{Histology of the Interinal Organs of the Adult Linulus.}

Histology of the digestive system. The general form of the digestive canal is seen in plate 3, fig. 1. The large mouth-opening is situated between the third to fifth pairs of limbs. The oesophagus is very long, and directed very obliquely forward and upwards from the mouth, entering the large crop or proventriculus at an angle to the general course of the latter, which is full and large, projecting anteriorly over the end of the oesophagus. It curves over backwards, growing smaller posteriorly, projecting above slightly over the beginning of the stomach or mid-gut. What we call the crop, is the "cardia" of Van der Hoeven, and the "cardiac end of the stomach" of Owen and A. Milne-Edwards. Communication with the chyle-stomach is effected by the large internal projection in the form of a truncated cone (plate 3, fig. 1, cone), by which the food, when partially digested, is strained, and passes from the proventriculus into the true stomach. The latter, externally, seems to form the beginning of the intestine, and extends from the base of the proventricular projection backwards as far as the first pair of biliary ducts; its histology is quite different from that of the proventriculus and its posterior conical process.

The beginning of the intestime is indicated externally by a slight contraction just before the origin of the anterior of the two pairs of biliary ducts. These are placed far apart by a distance nearly equal to twice the thickness of the intestine. The hind gut is divided into the intestine and rectum. The intestine is straight, and of uniform thickness as far as the begimning of the rectum, which is swollen, owing to the large rectal folds within.

On laying open the digestive canal of specimens collected in the winter, it is found to be filled with a jelly-like substance, which on examination proves to be the lining of the canal, which has been molted, and has undergone partial digestion.

Examining the inner walls of the digestive canal, and studying its histology, we find that there are three fundamental layers composing the canal, extending from the mouth to the vent. There are, begimning on the outside, (1) the muscular layer, (2) the mucous or epithelial layer, and (3) the chitinous layer. The muscular layer is made up of longitudinal muscles, the fibres striated, with scattered small bundles of trimsverse striated fibres, some of these isolated from the outer layer of longitudinal muscles and passing through the epithelial tissue.

The second or epithelial layer is thick, composed of pavement epithelium, arranged in fibrous masses or bundles, somewhat like muscular tissue." The nuclei are large and 
conspicuous where the preparations have been stained with haematoxylin; ${ }^{1}$ the cell walls are difficult to distinguish with a one-fifth objective. 'The pavement epithelium fills the spaces between the folds of the oesophagus and crop (or fore gut), and is succeeded by a single layer of columnar epithelium, which looks like a delicate ruffle, edging the folds, and lying between the pavement epithelium and the chitinous lining of the canal. The chitinous layer is very finely laminated, the laminae being parallel for the most part to the indentations and projections of the folds and the teeth of the fore-gut, showing plainly that it is secreted by the layer of columnar epithelium. Cross sections of the larva, after hatching, through the fore-, mid-, and hind-gut, when the appendages and internal organs have assumed their definite shape, show that the intestine then consists of only two layers, the muscular, which is comparatively thin, and the layer of columnar epithelium (plate 5, figs. 7, 7a), which rests directly upon the muscular layer, and consists of long cells projecting irregularly into the cavity of the canal. It would thus appear that the thick layer of pavement epithelium and of chitine is not developed throughout the intestine, until some time after hatching. Indeed, it is known that the larva lives for a long time, even months, after hatching, before it takes much, if any, food.

Returning to the oesophagus; it is seen to be lined with a pale yellowish chitinous layer gathered into about eight large deep folds. Plate 5, fig. 5, illustrates the structure of two of these folds and part of the adjoining ones. The muscular fibres are not represented. The cells $4,4 a$, of the pavement epithelium ( $p e$ ) are round or oval, with a liarge, distinct, dark nucleus; their walls are difficult to define. The projecting lobes consist of columnar epithelium, with large nuclei, much more distinct thim in the parement epithelium; the basal half of the cells are dark, being filled compactly with granular matter enclosing the nuclei, while on the outer half the cells are transparent; plate 5, fig. 3, $3 a$, represents these cells enlarged. The lobes are hollow, leaving a clear space, as shown in figure 5; the lobes are unequal in form and size, those figured being situated near the posterior end of the oesophagus. The columnar epithelium is succeeded by the chitinous layer $(c h)$, which is fincly laminated, the laminne corresponding to the direction of the lobes.

The crop or proventriculus consists of three parts; in the most anterior division the chitinous folds, continuous with those of the oesophagrus, are large and irregular and extend vertically upwards, until they bend backwards sudlenly at right angles to form the rows of thick, solid teeth lining the second or middle and larger part of the crop. There teeth are arranged in five sets of rows, each set or series consisting of three rows, and two series of two rows, the two latter sets situated on the under or ventral side of the stomach, and arranged on each side of the three-rowed series. The teeth in each row are nearly uniform in size, are transverse, being flattened antero-posteriorly. In the three-rowed series, especially on the ventral side, the teeth of the middle of the three rows are larger than those of the row on each side. There are abont 225 well marked teeth in this division of the crop, those at either end of the rows being small and sometimes double.

\footnotetext{
1 I am much indebted to Dr. C. B. Johnson, of Providence, for kindly cutting, staining, and mounting some excellent

preparations of the oesophagus, crop, and intestines, stained both with haematoxylin and carmine.
} 
The minute structure of the vertical folds of the first or anterior division of the crop may be seen at plate 5, figs. 1, 2, where the relations between the muscular, epithelial and chitinous layers are shown. The limits between the longitudinal striated muscular layer $(m)$ and the epithelial liyer are clear and well marked, the bundles of parement epithelium (pe) ruming at right angles to and abutting directly on the muscular layer. The pavement epithelium is also, in slices stained with haematoxylin, clearly demarked from the colummar epithelium (ce) by its pale lilac tint, the latter staining brownish and contrasting well with the purple-stained chitine, which is finely laminated, the lines of deposition being waved, the points of the waves under a low power appearing like fine lines paswing inward near but not quite to the firee edge of the tooth, the margin of the chitinous layer remaining unstained and pale yellowish. Fig. 2 represents the small central tooth $1 x$, still more enlarged, showing the lines of growth of the chitin, and the rufle of colummar epithelium, indicated by the row of large nuclei bordering the margin of the lobes of the columnar epithelium layer.

In the teeth of the middle region, which as we said, number some 225 , the columnar epithelium is wanting, though the corresponding tract is yet stained pale brown by haematoxylin or deep crimson by carmine, but the cells are of the same nature as in the adjoining pavement epithelium; it is also not scalloped, but the layer of chitine is much thicker than elsewhere in the digestive canal.

The proventricular cone or tulse has internally about thirteen unequal chitinous folds, continnous with and like those of the oesophagus, five large folds alternating with eight smaller ones. The folds are yellowish, and project rufle-like at the end, contrasting in structure and color with the whitish exterior of the cone or strainer. An examination of the cellular structure of the interior lining of this tube, shows that it has a chitinous lining continuous with that of the crop, and which stops at the rufle-like extremity of the tube; this chitinous layer is succeeded within by a ruffle-like layer of columnar epithelim, like that in the fore part of the crop. The chitin is entirely wanting in the papillose exterior of the tube, while the layer of columnar epithelium is deep, the cells being very long and slender. The structure, then, of this tuhe is externally like that of the stomach walls as described below, while internally it is histologically an extension of the structure of the oesophagus and proventriculus.

The beginning of the mid-grut or true stomach, as we regard it, is lined internally with a layer of large, long, erect papillae which extends nearly as far as opposite the end of the strainer, and is also extended along the outside of this organ. Just before a point opposite the end of the strainer, this layer of dense close-set papillae suddenly stops, and is succeeded by a division of the digestive canal lying between the point opposite the end of the proventricular strainer, and a point situated a little before the opening of the first pair of biliary ducts. This region, which we regard as the true stomach, has the imner surfice raised into ahout twelve transverse or circular folds. Just where this region of the digestive canal endw, it contracts, and this is jurlged to be the line of demarcation between the mid-gut and hind-gut, i.e., the true stomach and the intestine. It should be observed that the chitinous folds of the oesophagus and proventricle (usually called stomach) are continuous, alike morphologically, and stop at the posterior end of the proventricular strainer. It is evident that the food, such as worms, at first partly torn by 
the teeth at the base of the limbs, is further triturated by the numerons hard teeth of the crop, while the more nutritious fluid portions strain through the marrow passage of the singular hollow cone.

'The inner walls of the stomach are destitute of chitin, the long, close-set, large papillae being edged with a thick layer of columnar epithelium. The twelve circular folds of pavement epithelium are also lined with a similar columnar epithelium.

The four biliary ducts open into the intestine proper, which is lined as far as the rectal folds with an epithelial membrane, is divided by longitudinal and transvere lines into squares forming close-set, square, flattened papillae; on the posterior half of the intestine the longitudinal lines are nore numerous than the transverse, the latter being partially obsolete, so that the inner surface of the intestine is gathered into fine longitudinal folds, the free edges of the folds being irregularly serrated.

These folds consist of pavement epithelium (or mucous membrane), the free edges of which are of columnar epithelimm, the cells heing long and narrow, while the nuclei are not so large and distinct as in the proventricle.

The intestine within suddenly contracts at the beginning of the rectum, but becomes larger posteriorly to the vent; the interior is thrown up suddenly into ten large folds of unequal size, which become smaller posteriorly. These rectal folds have the same muscular and epithelial layers as in the other parts of the digestive tract, but the cells of the pavement epithelium, instead of being uniformly round, are in places irregularly diamond or spindle-shaped, as in plate 5, fig. 6. The columnar epithelium of the rectal folds is lined externally (in the rectal cavity or lumen) with a lining of a clear, structureless, somewhat chitinous membrane which stains purple with haematoxylin. It would thus appear that the secreting surface of the stomach-walls is, owing to these folds and large erect papillae, very much greater than in the intestine. We have seen that the stomach, like the intestine, lacks the chitinous lining, and this, together with the histological identity of strueture between what we regard as the stonnch and the intestine, may seem to some as opposed to the view that this region is the mid-gut, stomach or archenteron; lut the firct that it is divided from the intestine by a slight constrietion, that it lies in front of the biliary ducts, and that the appean rance and grosis andtomy of the lining" is unlike that of the intestine, coupled with the perfect continuity of structure in the venophagus and proventricle, are to our mind sufficient arguments for the position we hold. Moreover in the lobster the two capacious biliary ducts empty directly into the true stomach or mid-gut, the small straight intestine beginning at some distance behind the origin of these ducts.

Thus while the stomach and intestine of Limulus agree in the absence of the chitinous layer, the rectum in its longitudinal folds and lining of chitine repeats in a degree the structure of the oesophagus.

Comparing the digestive canal of Limulus with that of the lobster or Decapodous Crustacen in general, we find that the oesophagus and so-caller stomach (what we call in this paper crop or proventriculus), are continuous parts; that the true mid-gut or stomach has, like the intestine, no chitinous lining, though the rectum of the lobster, as we find on examination, has long rectal folds (besides large stuare raised projections), and is throughout lined with chitine. There is thus a general correspondence or homology between the Decapodous and Merostomatous digestive or enteric camal. Unfortunately we have been 
unable as yet to find any specimens of the young with the enteric canal in such an early stage of development as to throw any light on the morphology of the stomach. ${ }^{1}$

Stmcture of the liver. The tubules of the liver spread everywhere through the cephalothorax, reaching almost to the edge of the retina of the eyes, and when cut through, show in sections, as at plate 3, figs. 9, 9 $\alpha, 96$, a circular or oval layer of epithelium, surrounding a cavity more or less irregular in size and form. The cells are quite large and filled with brownish granules, being dark at base and transparent towards the end where they project into the cavity.

Plate 3, fig. 8, represents the end of a lobule from theliving horse-shoe crab. Compared with that of the lobster (plate 3, fig. 10), they are from one half to a third smaller, very, much longer, more intestiniform, and contracted irregularly, while the pigment granules are thicker, and the entire mass is blackish-brown. Figs. $8 a, 8 b$, Sc, represent the cells comprising the epithelium teased out and spherical in form. Fig. Sa, indicates a cell containing smaller nucleated cells of two kinds, the smaller clear and yellow, the larger, darker and horn-colored; 8b, a clear, nucleated cell; 8c, represents dark, clear amber-colored cells filled with the secretion, and with the nucleus no darker than the rest of the cell, and very clear. For purposes of comparison we give figures (plate 3, fig. 10) of the end of a liver-lobule of the lobster, which is pale green, with numerous epithelial cells, a few oil globules being scattered through them. In the living lobules of a species of Panopaeus common in Buzzard's Bay, some of the cells are colored yellowish-green, imparting the same color to the entire lobule; the cells in Panopaeus (plate 3, fig. $8 d$ ) are clear of granules, alnost as much so as the fat globules. The lobules of the liver of this crab are larger, more conical and shorter than in the lobster. From this it will be seen that fundamentally both the general and minute structure of the liver of the Decapoda and Limulus is nearly identical.

The glandular bodies supposed to be renal in their nature. These glands had remained undescribed, until in a paper read at the Philadelphia meeting of the National Academy of Sciences, held in November, $1874,{ }^{2}$ we drew attention to their occurrence and histological structure. Although we have nothing to add verbally to the account then given of the gross anatomy of these glands, we would refer to the figure (plate 3 , fig. 7 ) illustrating the form, and the cells (plate 3 , figs. $7 a, 7 b, 7 c$ ) composing these glands. They do not appear to huve been described by Van der Hoeven, Owen, or A. MilneEdwards, in their account of dissections of this animal.

These glands are quite large, and apparently of some physiological importance, and are easily found, as they are couspicuous from their bright red color, causing them to contrast decidedly with the dark masses of the liver, and the yellowish ovary or greenish testes, near which they are situated. 'The glands are bilaterally symmetrical, one situated on each side of the proventricle and stomach, and each is entirely separate from its fellow. Each gland (plate 3, fig. 7) consists of a stolon-

${ }^{2}$ American Nituralist, Ix, 511. September, 1875. 
like mass $(a)$, extending along close to the great collective vein, and attached to it by irregular bands of connective tissue, which also hold the grland in place. From this horizontal mass, four vertical branches $(b, b)$ arise, and lie between and next to the partitions at the base of the legs, which divide the latero-sternal region of the cephalothorax into compartments. The posterior of these four vertical lobes accompanies the middle hepatic vein from its origin from the great collective vein, and is sent off opposite the insertion of the fifth pair of feet. Half-way between the origin of the vein and the articulation of the limb to the body, it turns at a right angle, the ends of the two other lobes passing a little beyond it, and ends in a blind sac, less vertical than the others, slightly ascending at the end, which lies just above the insertion of the second pair of feet. 'The two middle lobes are directed to the collective vein. Each lobe is somewhat flattened out, and lies close to the posterior wall of the compartment in which it is situated, as if wedged in between the wall and the muscles between it and the anterior portion of the compartment. Each lobe also accompanies the bases of the first four tegumentary nerves.

I could not by injection of the gland discover any general opening into the coelom or body cavity, or perceive any connection with the hepatic, or with the great collective vein. The four lobes end in blind sacs, and have no lumen or central cavity.

'The lobes are irregular in form, appearing as if twisted and knotted, and with sheets and bands of connective tissue enclosing the muscles, among which the gland lies. Each lobe when cut across, is oval, with a yellowish interior and a small central cavity.

The gland externally is of a bright brick-red. The mass is quite dense, though yielding", and on this account hard to be cut with the microtome.

When examined under Hartnack's No. 9 immersion lens and Zentmayer's B eye-piece, the reddish external cortical portion when teased out from the living animal, is seen to consist of closely aggregated, irregularly rounded, mucleated cells of quite unequal size; and scattered about in the interstices between the cells, are dark reddish pigment masses (plate 3, fig. 7a) which give color to the gland. They are very irregular in size and form, and twenty hours after a portion of the living gland was submitted to microscopic examination moved to and fro. In other portions of the outer reddish part of the gland, where the pigment masses are wanting, the mass is made up of fine granular cells, which have no nucleus. Other cells have a large nucleus filled with gramules, and containing nueleoli.

In the yellowish or medullary portion are scattered about very sparingly certain spherical cells which probably are purely secretory (plate 3 , figs. $T b, T c$ ). The nucleus is very large and amber colored, with a clear nucleolus; others have no nucleolus, and the small ones are colorless.

I am at a loss to think what these glands, with their active secreting cells filled with a yellowish fluid, can be, mless they are renal and excretory in their nature. In general position they coincide with that of the shell glands of the Entomostraca and Branehiopoda, including the Phyllopoda, especially as worked out in Leptodora, by Weismann. ${ }^{1}$ But in lacking apparently an exeretory duct, and in their dense parenchym, with no lumen, as well as histologically, they seem to differ from the shell glands of the lower

\footnotetext{
${ }^{1}$ Ueber den Bau und Lebenserscheinungen von Leptodora hyalina. Zeitschr. fur wiss. Zoologie, Bd. xxIv. p. 385, 1874.
} 
Crustacea, and the green glands of the Decapoda. It should be remembered, nevertheless, how difficult it is to find the excretory duct of the green gland, though its inlet is very apparent. It is probable that we have here to deal with a new form of kidney, adding a fourth kind to the three forms of renal organs existing in the Crustacea. ${ }^{1}$

\section{Structure of tile Exes of Limulus.}

After we had made some researches on the structure of the compound eyes of Limulus, and had ascertained that their structure is quite unlike that of other Arthropodous eyes, having a chitinous lens and no rods and cones, we had the opportunity of examining Grenacher's elaborate work entitled Untersuchungen aiber das Sehorgan der Arthopoden, insbesonderer der Spimen, Insecten and Crustaceen. ${ }^{2}$

We have little to add to Grenacher's account of the histology of the compound eye, and our studies confirm the accuracy of his account and the three drawings he publishes of the structure of the retinula and the rhabdom, although we have failed to find the layer of epithelial cells extending up between the conneal lenses and next to the pigment layer; these are much less regular in their arrangement than drawn by Grenacher, and seem to be simply comective tissue cellw, which are as abundant away from the lenses as next to them. We have also not succeeded in observing that the optic nerve fibres end in the manner indicated in his drawing. We may here saly that we hat eximined sections of the compound eye of Limulus, and had made out the leading points in its structure before seeing Grenacher's work.

The following account is based upon observations made upon sections cut for us by Mr. Mason. They are taken in most cases from living specimens, placed in alcohol, and hardened in gum arabic; and either stained with picro-carmine, or else the pigment layer dissolved wholly or in part with nitric acid in order to uncover the ends of the corneal lenses and to show the structure of the retinula and rhabdom. The subdivisions of the optic nerve were best showed in slices stained with picro-camine, the nervous substance being but partially colored and contrasting well with the highly tinged connective tissue by which the nerves are surrounded. In order to study the eye of Limulus intelligently Mr. Mason kindly made for us numerous exquisite sections of the eye of the lobster. ${ }^{3}$

Plate 6, fig. 1, represents an actual section of the eye, with its exterior convex surface, its lenses, retina and nerves. The surface of the eye is convex, smooth and polished. The integument over the eye sudilenly diminishes in thickness to form the cornea; it is solid and chitinous as in the rest of the integument, and is composed of three layers: the outer and thinner more solid one $\left(1_{1}\right)$, which is clear yellow or amber-colored; the middle $\left(1_{2}\right)$, which is duller yellow and is finely laninated and softer, being partially

1 See Eug. Wassiliew. Ueber die Nieren des Flusskrebses. Zoologischer Anzeiger, p. 221, 1878.

Von H. Grenacher. Göttingen, 1879, 11 lith. taf. 40, pp. 188.

${ }^{8}$ These sections made by Mr. Mason were remarkably successful, the slices being thin enough to include a layer of hundreds of facets and rods and cones but one deep, with the optic ncrve-fibres, so that the structure of the eye could readily be studied. We did not perceive that the anatomy of the eye of Homarus americanus differed in any important respect from that of the European lobster as worked out by Mr. Edwin T. Newton. Quart. Journ. of Microseopical Science, 1873, p. 339. 
stained reddish by carmine; and a third $\left(1_{3}\right)$ thicker layer, less laminated and pierced by nutritive canals (p), filled with comnective tissue and directly communicating with the body cavity. From the cornea project obliquely inwards large, long, solid, conical processes $(c l)$. These are the "comeal lenses" of Grenacher, which he regards as homologous with the corneal lenses of larval insects and of Arachnida. We see no reason to dissent from this opinion. These comeal lenses are long, cylindrical, obtusely pointed, sometimes quite sharp, at the end. They point inwards more or less obliquely towards the centre of the eye. Those (as at fig. $2(\iota)$ near the periphery of the eye are longer and slenderer and more oblique than those in the centre, the latter being considerably shorter and blunter (plate 6, fig. 2). These lenses are developed from the third, a portion of the second or more laminated layer of the cormea filling up a conical space (firg. $2 a, h$, ) at the base of the cone; the laminae composing this shallow cone within the lirger cone are continuous with the laminated layer of the cornea, and like it are stained reddish by the carmine, while the cone itself remains unstained, of a clear amber color, and is structureless; sometimes one or two curved lines being seen parallel to the periphery of the end of the cone. That the corneal lens is solid is proved not only by its appearance, as seen in numerous sections, but by the frequent marks of the razor, and by the laminated structure of the imner conical portion. What relation, if any, the conical part $(h)$ has physiologically to the corneal lens, we are not prepared to state.

The terminal half, or sometimes third, of the corneal lens is enveloped in the pigment layer or retina, (plate 6, fig. $3, r t$ ), which is morphologically a contimuation or modification of the dark hypodermis (hy). The layer is continuous between the ends of the solid comeal lenses, but is produced at the ends of the latter into cones of corresponding size ( $v$ tc), which project into the body-cavity, and are enveloped by the dense comnective tissue. As stated by Grenacher, this pigment layer is composed of modified epithelial cells, which are very long and slender, with a minute uncleus (fig. $3, \mathrm{rcl}$ ). It is very difficult to make out these cells, and we should have overlooked them had not Grenacher described and figured them; finally, however, we could trace them, in preparations treated with acid, into the hypodermis, where the cells are also long and slender, though shorter than in the retina. Plate 6 , fig. 3 , rcl, represents these retinal cells, as seen at the end of an acute corneal lens, and their relation to the rhabdom ( $r h a b)$.

Besides the retina, the soft parts of the entire compound eye of Limulus consists of a large mass of connective tissue $(c t)$, lying under and next to the retina and finely granular, permeated by the irregular tortuous branches of the optic nerve. The cells and granules of this specialized subocular portion of the comnective tissue forming the parenchyma of the cephalothorax are smaller than elsewhere; they are nucleated, and the tissue stains paler crimson by the picro-carmine, than the comnective tissue beyond the subocular area, which remains darker brown, with coarser granules. The arteries, ovarian-tubes and liver-tubes, rarely penetrate into the subocular area; and the branches of the optic nerve do not wander into the region beyond. Fig. 1, ar, represents the cut ends of two minute arterial branches, ov represents the cell-eggss of the end of an ovarian tube, and $l$ indicates the much larger sections of a liver-tube; these vessels constitute the greater part of the soft portions of the cephalothorax, being brown or yellowish brown, and enveloped in a dense connective tissue. 
The subdivisions of the optic nerve can rarely be traced for a long distance continnously, owing to their irregular, tortuous course. In the drawing (fig. 1), I have delineated with the aid of the camera lucida an actual section; the clear spaces indicate the cut portions of the nerves distributed to each corneal lens. Histologically they present the same appearance as the nerve-fibres in the brain, those given off from the lower ganglionic cells. Under a low power ( $\frac{1}{2}$ inch), they appear to be structureless; under a $\frac{1}{5}$ they are seen to be finely granulated. After repeated search I could find no nuclei in these fibres; nor were there any ganglion cells to be discovered. Repeated cxaminations of numerous sections treated in different ways, have convineed me that there are throughout the subocular area no ganglion cells, such as are characteristic of the eyes of spiders and myriopods; hence, with Grenacher, we may state that a ganglion opticum is entirely wanting in Limulus; the irregular, tortuous subdivisions of the optic nerve are sent directly to the corneal lenses.

Coming now to the structure of the individual eye, or facet in the compound eye, we find that its anatomy is just as described by Grenacher, except that we have been led to doubt the existence of the layer of triangular (in outline) cells, which he represents as extending up between the conical comeal lenses, and it should be borne in mind that we examined eyes taken directly from living Limuli, as well as specimens that had been preserved in alcohol for several years. Grenacher's researches were made on eyes preserved for a long time in specinens of Limuli obtaned from German musemms, and his material was so poor that he did not attempt to study the simple eyes (ocelli).

The structure of the cone of pigment matter enclosing and extending beyond the end of the conical line has been described and illustrated in a masterly manner by Grenacher. Impinging on the end of the conical lens, and extending through the centre of the conical mass is a twelve-radiate semi-solid boty, called by Grenacher the rhahdom, and which he apparently homologises with the rhabdom or spindle-shaped body, suceeerling the rod of the ordinary Crustacean eye. Along a part of its length, this rhabdom (fig. 4, rhab) is enveloped by the retinula (plate 6, fig. 4, ret). Our figures show in sections the rhahdom, with its central axis and twelve or thirteen rays, forming a rosette extending into the substance of the retimula. That the retimula is, as Grenacher fignures, composed of as many large cells as there are rays of the rhabdom, we have proved by preparations treated with acid, as seen in fig. $4, a$.

How the optic nerve is connected with or impinges on the rhabdom, we have been unable to ascertain. We have only seen enough to convince us that the nerve reaches the end of the rhabdom, but the nature of the ending is unknown to us. The nerves, as seen in our drawing, fig. 1, sometimes appear as if they ran by the end of the retinal cones, and extended up between the corneal lenses. On the other hand, we have seen very plainly the mode of termination of the nerve in the ocellus. Grenacher, however, states that "a number of the nerve-fibres are distributed to each single-eye [facet], they diverge behind it, and I have repeatedly traced clearly the entrance of a fibre into the axial part of a retinula cell."

Grenacher concludes that perception in the typical Arthropod eye is performed according to the mosaic theory of Miiller, and that this applies to the eye of Limulus, although the eye of the latter is morphologically wholly different from the eyes of any other animal. 
According to Grenacher, the conical lenses are not homologues of the crystalline lenses of other Arthropods, and the eye of Limulus cannot, he holds, be compared with the eyes of any other Arthropoda. There can be, he claims, no genetic connection between the eye of Limulus and those of any other Arthropods, and the two types of eye, i.e., those of Limulus and all other Arthropods, agree only in the fact that they are compound. Among the Arachnida, he states, one may seek in vain for such an isolated type of eye. He adds: "But it is not only possible but also probable, that the Poecilopoda are related by their eyes to Myriopoda. In Cermatia, the eyes are wholly unlike those of the spiders or insects, and they seem to have something in common with those of Limulus." We shall see further on, however, that the type of eye of Cermatia is not fundamentally unlike that of Bothropolys, and other Myriopoda, as figured by Graber.

We have seen, then, that there is in the eye of Limulus an entire absence of rods and cones, a common feature of the Arthropod eye. The comeal lens of Limulus corresponds to the cornea or facet of each individual Arthropod eye, but there are no rods and cones, no optic ganglion, no scattered ganglionic cells, but the end of the long, solid, conical, corneal lens is simply enveloped by the pigment mass, and the end of the cone is succeeded by a rhabdom, partly enveloped by the retinula, the terminus of the optic nerve passing into the axial part of a retinula cell.

Comparison of the compromd eye of Limulus with that of Trilobites. Beyond the fact that the entire eye of certain Trilobites, and enlarged views of the outer surface of the comea of the eye, have been described and figured in Burmeister's work on the organization of Trilobites and in various palaeontological treatises in Europe and North America, especially by Barrande in his great work on Trilobites, I am not aware that any one has given a description of the internal structure of the hard parts of the eye of Trilobites.

The full bibliography of treatises relating to these animals in Broun's Die Classen und Ordnungen des Thierreichs, carried up to 1879 by Gerstiicker, contains references to no special paper on this subject, and the résumé by Gerstäcker of what is known of the structure of the eye, only refers to the external anatomy of the cornea, the form of the facets and their number in different forms of Trilobites. IIe shows that observers divide them into simple and compound; the former (ocelli) are found in the genus Harpes. These "ocelli" are said to be situated near one another, and are so large that the group formed by them can be seen with the unaided eye; the surface of the single "ocellus" appears, under the glass, smooth and shining. From the description and the figure of the eye enlarged, from Barrande, it would seem as if each eye was composed of three large simple ones; so that these eyes are really aggregate, and not comparable with the simple eye or ocellus of Limulus and the fossil Merostomata. ${ }^{1}$ Moreover, the situation of these so-called ocelli is the same as that of the compound eyes of other Trilobites.

The Trilobites with compound eyes are divided into two numerically very dissimilar groups; the first comprising Phacops and Dalmanites alone, and the second embracing

\footnotetext{
${ }^{3}$ The eyes of the fossil Merostomata (Eurypterus and Pterygotus) are evidently in external form and position,

judging by Mr. Woodward's figure, exactly homologous with the ocelli and compound eyes of Limulus.
} 
all the remaining Trilobites, excepting of course the eyeless genera, Agnostus, Dindymene, Ampyx and Dioride. The eyes of Phacops and Dalmanites are said by Quendstedt and Barrande not to be componnd eyes in the truest sense, but aggregated eyes (Oculi congregati). But judging by Barrande's figures of the eyes of Placopss fecundus and P. modestus (Barrande, Vol. I, Suppl. Plate 13, figs. 12 and 22), and our observations on the exterior of the eye of an undetermined species of Phacops, kindly sent us by Mr. J. F. Whiteaves, Palaeontologist of the Cimadian Geological Survey, we do not see any essential difference between the form and arrangement of the corneal lenses of Phacops and Asaphus, and are disposed to believe that the distinctions pointed out by the above named authors are artificial.

For my material I am mainly indebted to Mr. C. D. Walcott, who has so satisfictorily demonstrated the presence in Trilobites of jointed cephalothoracic appendages. On applying to him for specimens, and informing him that I wished to have sections mate of the eyes of Trilobites to compare with those of Limulus, he very generously sent me his own collection of sections of the eyes of Asaphus gigas and Bathymmes longistrinosus, which he had prepared for his own study, also other eyes, and especially the shell or carapace of a large Asaphus, from Trenton Falls, showing the eye and the projecting points of the corneal lenses. Prof. Samuel Calvin kindly sent me the eyes of an unknown Trilobite from the Trenton limestone, one specimen showing the pits made in the mud by the projecting ends of the corncal lenses, while to Mr. Whiteaves I am indebted for eyes of Calymene.

First turning our attention to the casts and natural sections; that of the interior of the carapace, including the molted cornea of Asaphus gigas, is noteworthy. When the concave or interior surfice of this specimen is placed under a magnifying power of fifty diameters, the entire surface is seen to be rough with the ends of the minute solid conical corneal lenses which project into the body-cavity. This is exactly comparable with the cast shell of Limulus and its solid corneal lenses projecting into the body-cavity (plate 6, fig. 1). Those of Asaphus only differ in being much smaller and more numerous, and perhaps rather more blunt. Without much doubt the ends of the corneal lenses of Asaphus, as in Limulus, were enveloped in the retina, the animal molting its carapace, the hypodermis with the retina being retained by the Trilobite, while the corneal lenses were cast with the shell.

In the specimen of the unknown Trilobite from Iowa received from Prof. Calvin, the corneal lenses, seen externally, are quite fur apart, arranged in quincunx order; the lenses are round and decidedly convex on the external surface. In a natural section, where the eye has been broken into two, the conical lenses are seen to extend through the cornea as cup-shaped or conical bodies, and are quite distinct from the cornea itself. In another broken eye of the same species, the cornea is partly preserved, and two of the comeal lenses are seen to extend down into and partially fill two hollows or pits; these pits are evidently the impressions made in the fine sediment which filled the interior of the molted eye or cornea!

Thus in the Asaphus gigas noticed above, we have the entire inside of the cornea with the cone-like lenses projecting from the concave interior; while in the last example we have the impressions mate by the cones in the Silurian mud which silted into the cornea after the Trilobite had cast its shell. 
Farther evidence that the Trilobite's eye was constructed on the same pattern as that of the living horse-shoe crab is seen in the sections made by Mr. Walcott. We will first describe, briefly, the eye of Limulus. Plate 6 , fig. 1 represents a section through the cornea of Limulus; cor, the cornea which is seen to be a thimned portion of the integument; pc, indicates one of the nutrient or pore canals, which are filled with connective tissue extending into the integument from the body cavity; $c l$, is one of the series of solid conical corneal lenses. These are buried partly in the black retina, and the long slender optic nerve just before reaching the eye subdivides, sending a branch to each facet or cornea, impinging on the lens. Fig. 6 represents a rertical view of the corneal lenses or facets, magnified fifty diameters, as seen through the transparent comea. It will be seen that they are slightly hexagonal and arranged in quincunx order; their external surface is flat, though that of the ocelli is slightly convex.

Now if we compare with the horse-shoe crab's eye that of the trilobite, Asaphus gigas, (plate 6 , figs. 8,9), we see that the eye is raised upon a tubercle-like elevation of the carapace; the integument ( $i n t$ ) is about as thick as that of Limulus, and it contains similar porecanals $(p c)$; the eye itself or cornea, occupies a rather small area; its exterior surface, instead of being smooth as in Limulus, is tuberculated, or divided up into minnte convex areas; these convexities are the external surfaces of the corneal lenses, which extend through the cornea, so that its surface is rough instead of smooth as in Linulus ; $c l$ indicates one of the cormeal lenses which are arranged side hy side; they are of slightly different lengths and thicknesses, and the rather blunt free ends project into the cavity of the eye, which in the fossil is filled with a translucent calcite.

It is quite apparent that we have here the closest possible homology between the hard parts of the eye of Limulus and of Asaphus. Another point of very considerable interest is a tolerably distmet dark line (fig. 9, $r t$ ), which seems to run across from one lens to another, and which may possibly represent the extermal limits of the retina or pigment mass in which the ends of the lenses were probably immersed; should this he found to be the indication of the outer edge of the retina, it would be a most interesting fact in favor of our view of the identity between the eyes of the two types of Palaeocarida under consideration.

Another section sent us by Mr. Walcott is represented by plate 6, fig. 8; it is from Asaphus gigas, but represents a less elevated and broader part of the eye than that seen in plate 6 , fig. 9 ; the section does not so well exhibit the free ends of the corneal lenses. Fig. 7 a represents a tranverse view of the eye of $A$ saphus gigus, showing the hexagonal form of the facets, and their quincunx arrangement; so much like that of Limulus (fig. 6).

This hexagonal appearance of the comeal lenses is still retained in natural vertical sections of eyes of the same genus, where with a good Tolles lens the sides of the cones are seen to be angular. Plate 6, fig. 10, represents a few such cones. I do not understand to what this hexagonal appearance is due; for both in Limulus and the Trilohites the corneal lenses appear usually to be round, and yet in making $a^{\circ}$ camera drawing (as are all those here represented) of the comea of Limulus from above, they present the same hexagonal appearance as in Trilobites. The cause of this I leave to others to explain. 
In a section (transverse) of the cornea of Bathyurus longistrinosus, received from Mr. Walcott, the lenses are seen to be very irregular, five- or six-sided, and very irregularly grouped, not arranged in distinct rows.

From the facts here presented, it would seem evident that the hard parts of the eye of the Trilobites and of Limulus are, throughout, identical. The nature of the soft parts will, as a matter of course, always remain problematical; unless the dark line indicated in plate 6, fig. $9(r t$ ?) really represents the outer edge of the pigment of the retina; but however this may be, judging by the identity in structure of the solid parts, we have, reasoning by analogy, good evidence that most probably the eye of the Trilobites had a retinal mass like that of Limulus, and that the numerous small branches of the long slender optic nerve (for such it must have been) impinged on the ends of the corneal lenses. It has been shown by Grenacher and myself that the eye of Limulus is constructed on a totally different plan from that of other Arthropods; I now feel authorized in claiming that the Trilobite's eye was organized on the same plan as that of Limulus; and thus when we add the close resemblance in the larval forms, in the general anatomy of the body-segments, and the fact demonstrated by Mr. Walcott that the Trilobites had jointed round limbs (and probably membranous ones), we are led to believe that the two groups of Merostomata and Trilobites are subdivisions or orders of one and the same subclass of Crustacea, for which we have previously proposed the term Palaeocarida.

Structure of the simple eyes or ocelli. Owing to insufficient material, Grenacher did not study the simple eye of Limulus. The structure of an ocellus repeats very closely that of one of the individual facets or members of the compound eye. At the point where a simple eye is situated, $i . e$, on each side of the median spine near the front edge of the carapace, the chitinous integument surdenly becomes much thimer; the integument is divided as in the cornea of the compound eye into three portions, an outer thin yellow clear portion; a much thicker finely laminated part with fine granules and capable of being stamed reddish; and a much thicker clear part, which has about a dozen layers, not seen in the third inner layer of the integument next to the edge of the compound eye. 'The integument is also penetrated throughout by canals filled with connective tissue. 'The surface of the cornea is slightly convex. Next to the base of the large corneal lens, there is a chitinous portion $(p)$ which is less dense than the adjoining clear part, becoming stained a pale crimson by picro-carmine. Just as in the facets of the compound eye the laminated part of the cornea extents conically into the. base of the corneal lens, forming a cone within the larger lens; this part $(h)$ is less dense than the lens, and is usually more distinctly conical than the lens itself. The latter is a large solid mass of chitin, with two curved lines (plate 5, fig. 13, cl) in some examples, showing a slight tendency to lamination; in form it is longer than thick, and very obtusely rounded at the end, being as thick near the end as at the base; in form therefore the lens differs decidedly from that of the comeal lenses of the compound eye. That the corneal lenses of both simple and compound eyes of Limulus are solid is proved by the fact that they do not stain reddish like the laminated portion of the cornea and arljacent integument, and also because they are excavated as solid cones projecting inwards from the cast 
chitinous crust of the animal. In a specimen (fig. 12), not treated with acid, the end of the cone is seen to be buried in pigment, and in one out of many sections, $i . e$, that figured 14, the cut went directly through the ocellar nerve, which, as seen in the figure, after leaving the branch distributed to the other ocellus, proceeds undivided to a distance about equal to the diameter of the corneal lens, when it gives off minute fibres which pass up and lose themselves in the pigment layer near the base of the cone. The main nervous trunk is seen to impinge directly on the end of the pigment mass surrounding the end of the lens, while branches pass up into the pigment on each side of the lens; so that the latter is immersed, so to speak, in a multitude of nervous fibres.

On treating the pigment with acid, and cutting a section on one side of the solid lens, as at plate 6 , fig. 5 , the entire mass of connective tissue and pigment is seen to be permeated with nerve-fibres, which end in slight, bulbous, partly hyaline expansions next to the chitinous integument.

Nothing like the rhabdom or retinula was to be observed, and I doubt much if they exist, or any nucleated ganglionic cells.

We have, then, in the simple eye or ocellus of Limulus a repetition of the general structure of any one of the individual eyes of the compound organ of vision, without the rhabdom and retinula. The simple eye, then, in the horse-shoe crab is apparently rather more rudimentary than one of the elements of the compound eye; and it is difficult to conceive of a much simpler form of eye in an arthropodous animal ; hence it can not be said of the ocellus of Limulus that it is not less primitive in structure than the compound eye; for we have here the eye reduced to a corneal lens, retina and optic nerve, the simplest association of elements in any organ of vision.

Comparison of the ocellus of Limulus with the eyes of Afyrioporls. When we compare the ocellus of Limulus with that of the Arachnida, and of larval insects, there is very considerable difference. In the form of the corneal lens, however, the ocellus of Limulus somewhat approaches that of the Myriopods, as lately worked out by Graber. ${ }^{1}$

An examination of the agglomerated eye ${ }^{2}$ of Bothropolys bipenctctus Wood - a genus allied to Lithobius, the species here named being common in Northern California at the base of Mount Shasta - shows us that the myriopod eye, as a whole, is entirely unlike that of Limulus.

The brain, in the first place, is on the usual Arthropod type; the hemispheres being symmetrical, and the relative position of the larger ganglion-cells being like those of hexapod insects. A large mass of ganglion-cells is situated at the origin of each optic nerve. As regards the eye or group of eyes, the individual eyes are abont eighteen in number and closely aggregated, though each simple eye or facet is circular and its surface convex. The cornea in the specimen examined, while externally convex, is concave on the inside, the cornea being no thicker in the middle than

\footnotetext{
1 Ueber das unicoreale Tracheaten- und speciell das Arachnoiden- und Myriopoden-Auge. Von V. Graber.
} 
on the sides, not being lens-shaped as usual in the Myriopod and Arachnidan eyes, as described by Graber and Grenacher. The cornea is laminated, as in the integument. That the cornea is apparently normally concave in this genus, seems evident from the fact that the soft parts next to be described fill the concavity of the cornea. The solid parts, then, of this Iyriopod, are quite unlike the larger comeal cones of Limulus; though in general, the comeal lens of the Myriopods examined by Graber appear to be homologous with the cones of Limulus.

When we compare the soft parts of the eye of Bothropolys and the Myriopods in general with those of Limulus, we find nothing in common.

In Bothropolys the soft parts consist of the layer of rather large, round, nucleated, epithelial cells, situated next to the cornea, and called by Graber the "Iens-epithelium or vitreous-body cells," (Glaskörperzellen). This layer (absent in Limulus) is suceeeded by the layer of short, slender-pointed rods, as figured by Graber, with large nucleated cells in the tissue enveloping them. This layer of rods, homologues of the rods of other Tracheate and Crustacean eyes (also absent in Limulus) is succeeded by the retina, a continuation of the hypodermal epithelial layer, the cells of the latter being much more distinct and larger than the hypodermal cells of Limulus.

The retina, whose structure differs from that of Limulus in having no "retinula," is succeeded by the ganglion opticum, (absent in Limulus), which consists of a layer of very large ganglion-cells rounded and overlapping each other; their fibres leading away from the eye, to form the optic nerve.

Eye of Cermatia forceps. The eye of this Myriopod appears to be constructed on the same plan as that of other myriopods though differing in some important respects. Though Cermatia is said to have compound eyes in contradistinction from the ocelli of other myriopods, the latter are truly aggregated or compound, the so-called "ocelli" being made up of contiguous ficets, the nerve fibres which supply them arising in the same general manner from the optic nerves.

The following description is made from sections made by Mr. N. N. Mason of Providence, and loaned me for description :-

The eye is composed of a hemispherical, many facetted cornea, the lenses of which are shallow, doubly convex, being quite regularly lenticular, the chitinous substance being laminated as usual.

Each corneal lens is underlaid by a retina about as thick as the cornea, the inner surface of each retinal mass being convex. Corresponding to each lens is a separate mass of connective tissue, which increases in thickness from the end of the optic nerve outwards towards the cornea, there being usually a clear interspace between each mass. Within the broad stratum of comnective tissue, next to the colneal lens within the retina, is a layer of rounded "vitreous cells" or "or lens-epithelium" of Graber. This layer is succeeded by the series of rather large visual rods, one in each mass corresponding to each corneal lens; these rods are long and sharp, conical at the end, the ends extending one-half to two-thirds of the distance inwards to the imner edge of the retinal mass; they each possess a nucleus, and the connective tissue enveloping the rods is nucleated, while there is an irregular layer of nucleated cells near or around the ends of the rods. 
This layer of cells is succeeded by a thin, slightly curvilinear, transverse strip of connective tissue, passing through the entire eye, and behind it are the loose, nucleated spherical cells forming the ganglion opticum, among which the fibres of the optic nerve pass.

The brain of Cermatia forceps, as shown by several sections, is modelled on the same plan as we have observed in Bothropolys and so far as we see, the myriopod brain corresponds more closely in its general form and structure with that of the Insects than of the Crustacea. The large, thick optic nerve arises from the upper side of each hemisphere. The median furrow above is deep, and on each side is a mass of small ganglion-cells; also a mass in the deep sinus below the origin of the optic nerve, and another mass on the inferior lobe extending down each side of the oesophagus, probably near or at the origin of the posterior commissure. These masses, i.e., those on the upper and under side of the brain, connect on each side of the median line, and in this respect the brain is as in Bothropolys. There are no large ganglion cells, as in the Crustacea and in Limulus.

It will be seen from this brief account that the eyes of Limulus differ from those of Myriopods in wanting the lens-epithelium, the rods, and a ganglion opticum, which are present in other Arthropods, both tracheate and branchiate.

\section{The Brain and its Internal Structure.}

Several years ago, before the present interest in the study of the brain of Arthropoda had arisen, I made an attempt to study the brain or supra-oesophageal ganglion of the horse-shoe or king crab. Mr. T. D. Biscoe kindly cut a number of sections for me. These were unstained, and owing to interruptions were not examined until the past winter, when with the aid of a large number of other sections made by Mr. N. N. Mason of Providence, R. I., I have been enabled to present the following result.s. The brain was in some cases stained with osmic acid in the manner described by Dietl ${ }^{1}$ and adopted by Newton - being taken from the living animal and allowed to remain in the osmic acid from twenty to forty hours.

The best results, however, were obtained from sections of two brains, one of which had been several years in alcohol, and which took the osmic acid stains very evenly; better results ensued by staining, after hardening the brain for two or three days in alcohol; the brain is so large that it does not harden readily, when put fresh and living in osmic acid alone.

When sections were not properly stained in the centre with osmic acid, they were further treated with a picro-carmine stain with good results. Mr. Mason embedded the brain, when

${ }^{1}$ The following articles bearing on the brain of the Arthropods have been consulted; the actual bibliography of the subject being somewhat fuller.

Ofsianniknff. Ueber die feinerer Structur des Kopfganglions bei den Krebsen, besonders beim Palinurus locusta. Von $\mathrm{Ph}$. Ofsiannikof. Mém. Acad. Imp. Sc. St. Petersbourg. Tom. VI. No, 10, 1863.

Dietl. Die Organization des Arthropodengehirns. Von M. J. Dietl. Zeitschr. wissensch. Zool. Bd. 27, 1876, p. 488.
Flögel. Ueber den einheitlichen Bau des Gehirns in den verschiedenen Insectenordnungen. Zeitschr. wissensch. Zoologie, Bd. xxx, Suppl. 1878, p. 556.

Newton. On the brain of the Cockroach, Blatta orientalis. By E. T. Newton. Quart. Journ. Microscopical Science, July, 1879, p. 340 .

Krieger. Ueber das Centralnervensystem des Flusskrebses. Von K. R. Krieger. Zeitschrift fir wissenschaft. Zoologie. Bd. Xxxır, Jan. 23, 1880, p. 527. 
hardened and after remaining twenty-four hours in gum water, in a mixture of equal parts of paraffine, wax and olive oil, so that the consistency of the imbedding substance was nearly as soft as the tissue to be cut. The sections were made by a microtome devised by Mr. Mason, and were mounted in glycerine jelly.

While between two hundred and three hundred sections were made, by far the best results were obtained by a series of fifty-six sections, cut by Mr. Mason from one brain, and forty-four from the upper four-fifths of another brain, the slices being either $\frac{1}{10} \overline{0}$ or $\frac{1}{5} \overline{0}$ of an inch in thickness; the best results of course were obtained from the thimer sections. These were deeply stained of a dark-brown, the ganglion-cells and nervefibres being much lighter than the nucleogenous masses forming the larger part of the brain, these being dark brown, the former tawny or yellowish brown.

The examination of a few sections of the brain of the lobster and the locust also kindly prepared by Mr. Makon, enabled me the more readily to undesstand the recent papers of Dietl, Newton and Krieger on the brain of the crawtish and insects, and afforded a standard of comparison with which to study the topography and histology of the brain of Limulus.

General anatomy of the brain. The position of the brain in relation to the body walls and digestive tract is seen in the section of the adult animal on plate 2, fig. 1, br. The central nerrous system consists of an oesophageal collar marle up by the consolidation of six pairs of postoral ganglia from which nerves are distributed to the six pairs of gnathopods. The ring is closed in front by the supra-oesophageal ganglion, or the partial homologue of that pair of brain-centres in the normal Crustacea and Insects. It will be remembered that in these Arthropods the brain is situated in the upper part of the head, in a plane parallel to, but quite removed from, that of the rest of the ganglionic chain; in Limulus, however, the brain is situated directly in front of and on the same plane with the horizontal oesophageal collar, and the abdominal portion of the central nervous system.

We now come to the singular relations of the ventral system of arterial vessels to the nervous system. This is fully described by A. Milne-Edwards. After describing the vascular ring surrounding the oesophagus he remarks: "Lorsqu'on ouvre cette portion du systeme artériel, on trouve dans con intérieur le collieur nerveux oesophagien, le reste de la chaine ganglionnaire et la plupart des principaux nerfs qui y sont baignés par le sang. Les artères ne sont par seulement appliquées sur le système nerveux, comme chez les scorpions, ou développées ì la surface de ce systéme de façon ì le recouvrir; elles loggent celui-ci dans leur cavité. Cette disposition rappelle celle du réservoir sanguin dans l'intérieur duquel M. de Quatrefages a constaté l'existence des ganglions cerébroides chez les Plimaires, et celle du vaisseau ventral dess Sangsues, découvert par Johmson." He then states that these singular relations of the apparatus of innervation with the arterial system of Limulus have been seen, but very incompletely, by Professor Owen, and are more intimate than this eminent anatomist thinks, and quotes as follows from Owen's Comparative Anatomy and Plysiology of Invertebrate Animals ( 1855, p. 320): "The two large lateral branches (celles qui j’appelle les crosses aortiques) form arches which curve down the side of the stomach and the oesophagus, giving branches to both those parts and 
to the intestine, and becoming intimately united with the neurilemma of the oesophageal nervous collar. They unite at the posterior part of that collar, and form a simgle vessel, which accompanies the abdominal nervous ganglionic chord to its posterior bifurcation, when the vessel again divides. Throughout all this course, the arterial is so closely connected with the nervous system as to be scarcely separable or distinguishable from it. The branches of the arterial or nervous trunks which accompany each other may be defined and studied apart." Afterwards in his "Anatomy of the King Crab," p. 24, Professor Owen thus writes of the arterial system: "On each side the origin of the 'ocellar artery arises one of double the size (ib., e.e), which, diverging from its fellow, curves outward and downward over the fore-part of the intestinal canal (plate $2, \Lambda$, fig. 1 s); it gives off, in this course, a branch which ramifies upon the gizzard, a second to the intestine and liver, the main trunk being continued to the nervous annular centre where it expands, and combines with its fellow of the opposite side to form a sheath for that centre analagous to a 'duramater.' This rather loose sheath is continued along the ganglionic ventral cord, and is prolonged, like a loose neurilemma, upon the nerves sent off therefrom, as it is upon those in connection with the annular centre." 1

Our own dissections and microscopic sections have taught us that the brain is enclosed by a thick neurilemma, which is different histologically from the arteries, containing no muscular layer. This layer closely envelops the brain-substance, and there is certainly no space between the brain and its neurilemma for the passage of the blood. Now the two lateral arteries descend from the anterior end of the heart, and open just behind the brain into the space between the oeosophagal ring, and its neurilemma, so that the latter is bathed in blood; the artery merges into the neurilemma, the sinus being largest on the upper side of the oesophageal ring. On each side of the back of the brain is a large artery for the supply of the brain, but there are no small arterial branches. The whole nervous cord behind the brain, including the ganglionic enlargements, is loosely invested by this neurilemma, the space being very wide between the nervous cord and its loose coat, so that the nervous cord and ganglia are directly bathed by the blood. This neurilemma (or perineurium) also invests the larger nerves sent off from the ganglia. That the nervous cord fills up but a portion of the space within this outer coat may be seen by reference to plate 6, figs. 12-14. In embedding the portions of the nervous cord to be cut, the interspace is filled with the paraffine preparations. We thus conclude, that while Owen and Milne-Edwards' view is substantially correct, it should be modified somewhat, viz., the blood does not flow around the brain itself, though it may flow around the nerves sent to the simple and compound eyes; and the nervous system appears to us not to be surrounded by a true artery, but that the thick perineurium becomes a vicarious arterial coat.

The brain in a Limulus ten inches long, exclusive of the caudal spine, is about six millimetres in diameter; it is broad and flat above, and on the under side full and

I Having only the first edition of Owen's Lectures on the Invertebrates in my library, I can not verify the quotation above made from the edition of 1855 . In a recent letter from that distinguished anatomist he quotes as follows from p. 309. "The sides of the great oeosophageal ring are united by two transverse commissural bands; but the most remarkable feature of the nervous axis of this Crustacean is its envelopment by an arterial trunk." From this it would appear that Professor Owen was the first to perceive that the nervous cord is enveloped by the artery, though these organs were afterwards elaborated described and figured by A. Milne-Edwards. 
rounded; on the upper side is a broad, shallow, median furrow, indicating that it is a double ganglion. Three pairs of nerves and a median unpaired one (the ocellar) arise from the upper third of the anterior face of the brain. The two optic nerves are the largest, arising very near the upper side of the brain, one on each side of the median furrow, so that the second and third sections made by the microtome, pass through them. Next below (from ahove downwards), is the origin of the single nerve sent to the two ocelli. We have not traced this nerve as far as the ocelli, but Milne-Edwards states that near the ocelli it divides into two branches. One of these two branches we figure in the drawing of the ocellus (plate 5, fig. 14). On each side of the ocellar nerve, and in nearly the same plane, arise two tegumental nerves, and directly below them a second pair of larger nerves (fronto-inferior tegumental) descend ventrally.

No nerves arise from the inferior half or two-thirds of the brain, which is smooth and rounded, with no indications of a median furrow.

It will thus be seen that, as stated by A. Milne-Edwards, there are no antennal nerves, such as usually exist in Arthropods with the exception of the Arachnida. This we have proved in the same manner as Milne-Elwards (though at the time ignorant that he had pursued the same method), by laying open with fine scissors the envelop (arterial or perineurial) which reaches to the posterior end of the brain, and seeing that the fibres of the nerves sent to the first pair of gnathopods originate quite independently of the brain itself. Moreover, after making sections of several brains, it is easy to see that only the commissures comnecting the brain with the oesophageal ring are present; the nerves to the first pair of gnathopods not arising from the brain itself, but from the anterior and outer part of each side of the oesophageal ring, $i . e$. , where the ring joins the brain; the commissure is very short in the larva, and obsolete in the adult.

Internal structure and histology of the brain. Most of the numerous stained and unstained transverse sections threw but little light on the topography; the nerve-fibres and ganglion-cells being apparently arranged horizontally, and mostly confined to the upper part of the brain; at any rate it was not until I had studied the horizontal sections, that I could gain an insight into the relation of parts as shown by sections cut vertically from in front backwards.

Finally a series of about fifty sections each, from two brains, cut by Mr. Mason horizontally from above, downwards, and carefully mounted in consecutive order, each section being numbered, has enabled me to arrive at a tolerably complete idea of the topography of the brain, so that I could mentally construct a model of the brain of Limulus, and compare it with the normal arthropod brain.

The histological elements are four in number:-

1. Large granglion-cells, filled densely with granules, and with a well defined nucleus similarly filled and containing a granulated nucleolus. These cells (plate 7, fig. 3c) may be crowded or loosely grouped; the granular contents varying in density, and the walls of the cell thick and loose or thimner and dense; they terminate in large nerve fibres. They are similar in form and size, though not in topographical arrangement, to the large ganglionic cells of the lobster's brain (see plate 7, fig. 1b). 
2. Smaller ganglion-cells, much more numerous than the larger, more hyaline, having much fewer granules and with the nuclei less distinctly outlined (plate 7 , fig. 1c). They are seen to be somewhat smaller, but otherwise like those in the brain of the lobster, which we also figure (plate 7 , fig. $1 d$ ).

3. Nerve fibres; these, like the large sized ganglion-cells from which they originate, are stained tawny yellowish brown with osmic acid. These fibres (plate 7 , figs. $3 a, 3 b$ ) are large and coarse, their fine granular contents homogeneous, and they closely resemble the nerve-fibres distributed to the compound and simple eyes of Limulus. Certain fibres near the origin of the optic nerves are distinctly nucleated at intervals (plate 7 , fig. 36 ).

4. Minute cells, or rather nuclei, very numerous and forming the large ruffle-like masses enveloped in connective tissue and constituting the greater part of the brain. They stain dark brown with osmic acid, so that these fungoid or ruffle-like bodies are readily distinguishable by their dark brown color from the surrounding tissues, which stain much lighter. In unstained sections simply hardened by alcohol, the tissue or bodies formed by these muclei is darker than the other tissue, which is white. As these masses or bodies appear to be wholly made up of nuclei, I propose that they be distinguished by the name of nucleogenous bodies.

The brain itself is enveloped by a very thick, dense membrane, which I am disposed to regard as a neurilemma, homologous with that of the lobster's brain, though much thicker. It is formed of a fibrous connective tissue, and probably some elastic tissue, which directly penetrates into the brain-substance, forming a network of connective tissue enclosing the nucleogenous bodies; with occasionally clear nucleated portions in the spaces between the balls of minute nuclei, i.e., the mucleogenous bodies. The fact that this envelop of the brain, a direct continuation of the so-called arterial coat of the oesophageal ring, is so intimately connected with the brain-substance itself, and that there is no space between it and the brain for the passage of the blood, and that an artery is sitnated outside of the brain (plate 7, fig. 4, ar), indicates strongly that this corresponds to the neurilemma of other invertebrates, or what Krieger designates as the "perineurium." It forms a fold on the upper side of the oesophageal ring, and thus becomes the direct continuation of the large lateral aortic branches; but it seems to be formed of short, tortuous fibres of connective tissue, with no true muscular fibres, such as are seen in transverse sections of the smaller arteries.

We will now describe the topography of the brain as seen in sections, beginning with the upper surface, at the origin of the optic nerves, and going downwards. After the microtome has made five slices $\frac{1}{1} \overline{0} \overline{0}-5^{\frac{1}{0}} \overline{0}$ inch thick, removing the upper part of the low elevations on each side of the broad, shallow median furrow, a section (plate 7, fig. 1) is obtained, which extends through the optic nerves, and also includes a part of the commissures by which the brain is connected with the oesophageal ring, the commissures being situated on the dorsal side of the central nervous system; while the brain is here rather short antero-posteriolly, the median cleft or anterior end of the oesophageal opening projecting well into the brain; the latter is more symmetrical in life than indicated in the figure, the brain being probably contracted a little in alcohol, and in the gum, while the razor made a slanting cut, so that while it passed through the middle of the right optic nerve, it merely grazed the edge of the opposite nerve. 
At the uppermost region of the brain the siles are occupied by the nucleogenous bodies $(n b)$, extending nearly to the back of the brain, but not reaching near the front. Within, but next to these nucleogenous bodies, are large sub-spherical masses of nucleated cells (fig. 1, cm), from which the optic nerves apparently arise. (Only the outer edge of the left mass has been cut through.) 'These cells are abundant and represented by fig. 2. They are hyaline, contain few granules, as do the nuclei. They are a little smaller than those of the lobster, which we have drawn to the same scale with the camera lucida, but it will be seen that they are identical morphologically. Enclosing in part the left mass of cells is a Y-shaped mass of fibres and nuclei $(y)$ which reminds one of the trabeculae of the cockroach's brain. This apparently is not of much importance, and is an off-shoot from the central mass of nerve-fibres, as in five sections below, it merges with the other fibres. Just behind the middle of the brain, on each side of the median line, is a group of large ganglion-cells arljacent to the romnded cellular masses. Behind each group of large ganglion-cells originate the fibres of the commissures connecting the brain with the oesophageal ring; on the outside of the commissural nerve-fibres is a group of large ganglion cells longitudinally disposed. As we descend from the top to the base or under side of the brain, the commissure is cut through and disappears, the brain extending considerably below the oesophageal ring.

In the next section the large ganglion-cells are seen to be scattered through the middle of the posterior fibrous portion of the brain.

In the tenth section two large rufle or fungus-like nucleogenous bodies appear, one on each side of the median line, with several smaller ones; and at the back part of the brain a bridge or transverse bundle of fibres now appears, comnecting the mass of nerve-fibres on each side of the brain. This bridge becomes thicker as seen in the fourteenth section (plate 7, fig. 2).

This latter section passes through the lower edge of the right optic nerve (op $n$ ). The fibrous region is now invaded more than above by the nucleogenous bodies (nb), the former being mostly restricted to the posterior half of the brain, the brain itself being longer, and the oesophageal opening not extending so far into the middle of the brain. Its bilateral symmetry is seen to be tolerably marked. The Y-shaped fibrous mass is broad and obscurely marked; while the nucleogenous bodies occupy nearly two-thirds of the area of the section, the area having extended from the sides around to the front, nearly meeting on the median line of the brain. There are two central areas containing large ganglionic cells, and two other similar areas farther back and nearer the sides of the brain.

Plate 7, fig. Ia, represents the size of the large ganglion-cells of Limulus, compared with fig. 16 of a similar cell from the lobster's brain; the two being identical in size and in density of the protoplasmic granules.

Plate 7, fig. 3, represents a section through the front part of the right side of the brain; it shows the origin of the optic nerve from the small sized ganglion-cells in the central region of the brain. 'That the nerve-fibres within the brain are sometimes nucleated is shown by the adjoining figures $(3 a, 3 b)$, where the nerves are cut transversely.

Plate 7, fig. 4 represents a section through the ocellar nerve, just grazing the right tegumental nerve. The fibrous portions are still more restricted, and they extend to the 
insertion of the nerves; the fibres are arranged into transverse as well as longitudinal bundles, of which the more important ones are figured, but of their origin and termination nothing definite has been ascertained.

Plate 7 , fig. 5 represents a section through the middle of the ocellar and two tegumental nerves, and though it is obvious that the razor cut tolerably even, as the nerves are quite evenly severed, yet it will be seen how unsymmetrical the brain at this point is, after allowing for unequal contractions due to reagents. The median line between the two sides is very obscure and irregular; the mass of large ganglion-cells is quite large, and disposed in an unbroken mass on each side of the median line, should one be drawn through the brain. On the right side the fibres are almost wholly confined to an area near the middle of the right half, while the left side of the brain is mostly oceupied with fibres, the nucleogenous bodies not extending to the back of the brain, as on the opposite side. At this part of the brain, in the more symmetrical specimen of the two brains specially studied, the nucleogenous bodies occupy nearly two-thirds of this plane of the brain; while the posterior group of large ganglion-cells is more extensive than above, and there are now but faint traces of the "bridge" of new fibres.

In a section lower down, near the middle plane of the brain, the nucleogenous bodies extend to the back of the brain, thus enclosing the mass of large ganglion-cells, which lies in front towards the middle of the brain; the nucleogenous bodies, at least the longer narrower masses, extend in towards the centre of the brain, so that they seem to radiate outwards from near the centre to the periphery.

In a section through the pair of lower tegumental nerves (fig. 6), in the same brain as represented at fig. 5, and on the same side, the fibrous masses are seen to be greatly reduced in extent, now filling up narrow spaces between the nucleogenous masses which converge towards the interior of the brain. The fibres evidently originate from the smaller and larger ganglion-cells, and pass forward and outward among the ruffle-like nucleogenous bodies. In the section here figured, the large ganglion-cells extend to the extreme back of the left side of the brain.

In another section below the nerves (tig. 7 ), the fibrous portion does not apparently reach the front, nor much beyond the middle of the brain, which at this point in one brain shows but slight symmetry, no fibres being visible in the right side.

Just below the section last figured, where no nerves are sent out from the brain, and before the sections diminish in size, the whole area seems to be filled with large rounded nucleogenous fungoid bodies, forming about eight irregular series passing from the back to the front of the brain, and arranged four on a side. A very few small bundles of nervefibres are to be seen, but with no determinate direction. This disposition of the histological elements extends downward to the bottom of the brain.

A transverse section of the brain from above downwards, cut just before the midille of the brain (fig. 8), shows nearly the same arrangement of parts as in horizontal sections; the upper part is seen to be occupied with the two larger groups of large ganglion-cells $(l g c)$, the nucleogenous bodies taking up most of the remainder of the brain, while a long bundle of nerve fibres ( $f(\ell)$ passes from above downwards between the nucleogenous bodies. 
To recapitulate and generalize from the foregoing facts: The brain is largely composed of masses of nuclei (nucleogenous bodies), enclosed by a mesh-work of connective tissue; these bodies nearly fill up the lower part of the brain, $i$. e., that part below the origin of the nerves. In the upper half or third of the brain whence the nerves originate, the larger and smaller ganglion-cells and bundles of nerve-fibres appear and preserve a more or less definite topographical relation to the entire brain. 'The nucleogenous borlies at and near the top of the brain are confined to each side of the brain, though masses of large ganglion-cells, associated with smaller ones, and nuclei, one on each side, just behind the middle, pass from below upwards; these groups of cells are more or less spherical as they grow smaller near the under side and at the top of the brain. The ganglion-cells altogether give rise to bundles of nerve-fibres; though it is probable that many nervefilses are without hesimming from cells. hut originally developed from nuclei, as the gancrlion-cells probably are in the beginning; since, in the larval brain, no fibres are to be seen, the brain substance consisting of cells alone. (See plate 3, fig. 3a.)

Thus the tract of nerve-fibres in each half of the brain is irregularly wedge-shaped, the apex situated near the centre of each hemisphere, and the base spreading out irregularly on the top, thus pushing aside, as it were, and crowding to the walls on each side the seemingly less dynamic portion of the brain, $i$. e., the masses of nuclei, or undeveloped cells (nucleogenous bodies). At the upper part of the back of the brain, just outside, at the origin of the posterior commisures, are two longitudinal groups of ganglion-cells on each side; these disappear below with the commissural nerves themselves.

The asymmetry of the brain, compared with that of other arthropods is remarkable; the large ganglion-cells are most abundant in the centre behind the middle, extemding from that point to the posterior side of the brain; a median line is only slightly indicated by the arrangement of the fungoid bodies. 'The tract composed of large nerve-fibres, with scattered ganglion-cells on the left side, is much more extensive than on the right.

Comparison with the brain of other Arthropods. So wholly unlike in its form, the want of antemul nerves, and its intemal structure, is the supra-oesophageal ganglion or hrain of Limulus, to that of the higher Crustacea ( $i . e$. . Decapoda, the brain of the lower Crustacea not yet having been examined), that it is difficult to find any points of comparison.

Histologically, judging by my few sections of the lobster's brain which are stained with carmine, the brain of Limulus agrees with that of other arthropods in having similar large and small gancrlion-cells, but the topography of the cell-masses essentially differs in the two types of brain. There are in Limulus no Ballensubstanz-masses, so characteristic of other arthropods, - the histological elements constituting these not having yet been discovered in Timulus.

We conclude, therefore, that, topographically, the internal structure of the brain of Limulus is constructed on a wholly different plan from that of any other arthropodous type known, so much so that it seems useless to attempt at present to homologize the different regions in the two types of brain. The plan is simple in Limulus; much more complex in other arthropods, especially in the brain of the decapodous, and probably most other Crustacea, the Decapoda having two pairs of antennal nerves beside the optic. In external appearance the two types of brain are entirely unlike. The symmetry of the 
brain of the crayfish and lobster and insects is beatifully matked (each hemisphere exactly repeating in its internal topography the structure of the opposite side), while that of Limulus is obscure and imperfect.

Structure of the oesophageal ganglia. (Plate 6, fig. 11.) A section through one side of the oesophageal ring, running through a ganglionic centre ant the origin of the nerve to one of the anterior (second?) gnathopods (gnn) shows that the toposraphy is quite simple. The central mass is mostly composed of nuclei and nerve fibres, the latter predominating until the nuclei disappear towards the base of the ganglion, where the nerve to the footjaw originates. On the outside of the ganglion, along nearly the whole length, are scattered large ganglion-cells $(\operatorname{lgc})$. Near the upper and outer side is a group of small, narrow nucleogenous bodies $(n b)$. There is a wide space for the passage of the blood between the ganglion with its nerve and the comnective-tissue envelope, which is thick and of the same structure as the perineurium of the brain itself. This space extends along the whole length of the nervous system to the termination of the cord, the nerves sent to the appendages being enveloped by a continuation of the same coat. Among the large ganglion cells are numerous smaller ones, some of which are truly bipolar, as represented in our drawing (fig. $1 \mathrm{l} a$ ); the nuclei have distinct edges, so that I regard them simply as small-sized ganglion-cells rather than nucleated nerve-fibres.

Structure of the abdominal ganglia. There are six abdominal ganglia, the last being larger and longer than the others. A section through the second abdominal ganglion (plate 6, fig. 12) shows that the central mass of the double ganglion consists of longitudinal fibres, with scattered nuclei. On the upper side in the median line is a group of large and small ganglion-cells, and beneath is a mass extenting to each side where they become most numerous. In some sections the central fibrous mass is enveloped by an irregular layer of ganglion-cells, some bipolar, with nerve-fibres forming a loose net work. In fig. 12 a nerve connected by its neurilemma with that of the ganglion has been cut through; in this nerve there are only fibres present. In fig. 13 a large nerve leading to the abdominal appendage is seen to be sent off from one side of the double central mass; the other side (gang) has been torn away from the one opposite.

In neither this nor in sections of the last elongated abdominal ganglion were any nucleogenous bodies to be seen, so it seems most probable that none occur in the abdominal ganglia.

The section here figured of the last abdominal ganglion (plate 6, fig. 14) is seen to pass through four nerves, two on each side. The ganglion is seen to be formed by the union of the two separate cords, which are separate just before the ganglion. Above the ganglion on each sicle of the median line is a mass of lirge ganglion cells, of the same size as those of the brain, associated with more numerous smaller ones. This mass extends around and beneath each hemisphere of the ganglion, forming a layer of cells and fibres, some of the cells distinctly bipolar, which becomes interrupted at the median line, indicated by the deep notch in the central fibrous nerve-mass. The fibres from the laterallysituated cells are distinctly seen passing in and mingling with the fibres of the central nerve-mass; thus the nerves are reinforced from the peripheral ganglion cells. The 
central masses are composed of nerves, with a few muclei; the fibres are mostly cut across, but occasionally short bundles of nerve fibres are seen lying across the cut ends of the others, though near the outer edge fihres are seen originating from the cells and passing in to the nerve mass.

\section{Further Contributions to the Eirbryology of Limulus.}

The blastodermic skin or serons membrene. In my paper in the Nemoirs of the Boston Society of Natural History I stated that the blastorlermic skin, just before being moulted, consisted of nucleated cells, and I also traced its homology with the so-called serous membrane or outer "Faltenhulle" of the ectoderm of insects. In $1873,{ }^{1}$ by making transverse sections of the egrig. I was able to study in a still more satisfactory manner these blastodermic cells, and to observe their nuclei before they became effaced during and after the moulting of the blastoderm.

On June 17 th (the egrg having been laid May 27th), the peripheral blastodermic cells began to harden, and the outer layer, that destined to form the outer or "serous" layer, to peel off from the primitive hand beneath. The moult is accomplished by the flattened cells of the blastodermic skin hardening, and peeling off from those beneath. During this process the cells in this outer layer lose their nuclei, contracting and hardening during the process. Plate 3, fig. 1ta shows at o the moulted empty cells with the nuclei empty and beginning to disappear, the walls being ragged and contracted; at $b$ is the layer underneath of lining cells, with granules and distinct nuclei. Figs. 14c and $14 d$ show the same cells during the moult, as seen from above and sideways; 146 represents the normal blastodermic cells, with a large, well-filled nucleus.

This blastodermic moult is comparable with that of Apus, as I have already observed, ${ }^{2}$ the cells of the blastodermic skin in that animal being nucleated. This blastodermic skin may also, in its mode of development, be compared with the serous membrane of the scorpion as described by Metschnikoff, and with that of insects, in which at first the blastodermic cells are nucleated, and appear like those of Limulus. A similar moult takes place in Apus.

On June 19th, in other egrgs. the cells of this membrane were observed to be empty, and the nuclei had lost their fine granules, and were beginning to disappear. The walls of the cells had become ragged through contraction, and in vertical sections short, peripheral, vertical, radiating lines could be perceived. At this time an interesting phenomenon was observed. In certain portions of the serous membrame the cells har become effaced, transitions from the rudiments of cells to those fully formed being seen. In insects and crustaceans, as a rule, the cells all finally disappear, the serous membrane being structureless and homogeneous. 'The relation of the blastodermic cells in the serous membrane of Limulus is due, without doubt, to the singular function this skin is destined to perform; i. e., its use as a vicarious chorion, the chorion itself splitting apart and falling off in consequence of the increase in size of the embryo.

\footnotetext{
1 The substance of this account appeared in the American Naturalist, Nov. 1873, vrr, p. 675.
}

${ }^{2}$ See Memoirs Bost. Soc. Nat. Hist., II, 161, foot-note. 
Development of the internul orgmes. Although a good many eggess were sliced, I was unable to discover any in the stage when the ectorterm and endoderm are differentiated, nor to examine the embryo in the gastrula condition, if there be such. The eggs were either in the stage of segmentation of the yolk, or the embryo was so far advanced that the indications of the segments had appeared. This period of development of the gastrula is evidently intermediate between the stagres, plate 3 , fig. 7 , and fig. 10 of my first memoir The succession in which the more important system of organs arise, is as follows:first the nervous'system; long afterwards the muscles and the heart. These organs are well developed before the larva hatches, though the first indications of the mesoderm were not observed. It is not for some time after hatching that the digestive canal as a whole is formed; although in the gastrula condition an archenteron may probably be developed, I have been mable to detect, after making numerous sections of engs and embryos, any traces of the stomach and intestine until long after the larva has hatched. The primitive liver-tubules and the ovaries seem to arise at about the same time after the digestive canal is indicated. The development of the renal organs was not traced, no indications of these organs being detected.

The eyes begin to form at the time of hatching, before the digestive tract is indicated. But little attention was devoted to the mode of development of the compound eyes. They are then very small black spots, the rudimentary corneal lenses few in number, and conical. The black retina is underlaid by a white mass; plate 4 , fig. 4 represents one of the ocelli at or soon after exclusion from the ergo; the external region is clear and made up of about twenty elongated epithelial cells, with a distinct refractive nucleus and granules; whether these are pigment cells or not we did not farther observe; underneath this area is the dark pigment mass in which no cells could be detected with a $\frac{1}{5}$ objective and B eyepiece; the ends of the epithelial cells seem to sink into the mass.

Development of the nervous system. ${ }^{1}$ After a number of unsuccessful attempts at discovering the first indications of the nervous system, I at length discovered, in thin sections kindly made for me by Prof. T. D. Biscoe, the nervous tract in a transverse section of an embryo in an early stage of development, corresponding to that figured on plate 6, fig. 10, of my first memoir. The period at which it was first observable was posterior to the first blastodermic moult, and before the appearance of the rudiments of the six pairs of cephalothoracic limbs (gnathopods). The primitive band now entirely surrounds the yolk, being much thicker on one side of the egg than on the other, the limbs budding out from this disk-like, thickened portion, most of which represents the ectoderm. At the time the nervous cord was observed it was entirely differentiated and quite distinct from the surrounding tissue of the ectoderm. ${ }^{2}$

At a later stage in the embryo, represented by plate 5, fig. 16, in my first memoir, at a period when the body is divided into a cephalothorax and abrlomen, and the limbs are developed, by a series of sections made parallel with the under surfice of the body, I could

\footnotetext{
1 The principal points in this section were originally printed in a short notice in the American Naturalist, July $1875,1 \times, 422$.
}

\footnotetext{
${ }^{2}$ Plate 4, fig. 3, represents the nerve cells, and fig. $3 a$, the cells of the mass of connective tissue in which the two cords are embedded, from a freshly hatched larva.
} 
make out the general form of the main nervous cord. Plate 3, fig. 3, shows the general relations of the cord to the body. It is large and broad, with three well-marked pairs of consolirtated gamglia in the abrlomen, the two basial ones supplying the nerves for the first and second abdominal feet. There are in the cephalothorax six pairs of consolidated ganglia, the commissures being as yet undeveloped; the ganglia are indicated by the minute openings in front of amb lrehind each parr of ganglia. 'The ganglia of the first pair of feet could be clearly distinguished; the brain or cephalic ganglion is probaljly represented at fig. $3 \mathrm{I}$; fig. $3 a$, the same enlarged. The number of ganglia, throwing out the brain, is nine, corresponding to the six pairs of cephalothoracic fect and the two abdominal segments, there being at this stage but two pairs of appendages in the abdomen.

The next important stage of development is seen in longitudinal sections of the larva after hatching, and when the digestive canal is marked out. To show the ganglia best, the section should be made on one side of the median line of the body, so as to pass through the middle of the ganglia on one side. Plate 3, fig. 2, shows a section thus mate and stamed with carmine; the nervous ganglia remaining white are very clearly indicated; the commissures are not shown, but they are now developerl, since the ganglia are mostly separate.

Now if we make a longitudinal section of the young horse-shoe crab when a little over an inch long, the disposition of the nervous cord is exactly as in the full grown individual, as figured by A. Milne-Edwards; see also our representation on plate 3, fig. 1, br, oe $r$. The nervous ganglia are then united into a nearly continuous nervous collar, the opening in front being filled up by the brain or cephalic ganglion. ${ }^{1}$

Turning now to the nervous system of the larva (plate 3, fig. 2), the section here figured shows a most important and interesting difference as regards the ganglia which supply nerves to the appendiges of the cephalothorax. They are at this time entirely separate, the spaces between the four posterior ones, which are comnected by commissures, heing as wide as the granglia themselves are thick. There are behind the oesophagus six ginglia, corresponding to each of the six pairs of gnathopods; while the brain is rather larger than the others, and the first post-oesophageal ganglia are the smallest of the six, corresponding to the more diminutive size of the first pair of gnathopods.

Reference may also be made here to plate 5, fig. 8 , which shows the mode of origin of the nerves distributed from the first post-oesophageal ganglion to the feet; this section certainly very clearly demonstrates that the first pair of gnathopods belong with the postoral series, that they can in no sense be regarded as homologues of the antennae of other Arthropods, and that in fict there are no antennae in Limulus, and without doubt, in the Merostomata in general. But this subject has been already discussed in the chapter on morphology.

It is not until after the second moult that the adult condition of the nervous system is attained, as Dr. Dohrm ${ }^{2}$ has figured the separate ganglia in a larva which had evidently moulted once, the abdominal spine being well developed. This is certainly an interesting

\footnotetext{
1 For the nature of the brain and the oesophageal ganglionic collar, the reader is referred to the section of this paper on the structure of the adult brain.
}

${ }^{2}$ Dohrn, Zur Embryologie und Morphologie des Limulus polyphemus. Ite also represents the fourth pair of abdoninal appendages; the larva has but three before the first moult. 
instance of the metamorphosis and cephalization of the nervous system, which is carried on internally, though the other organs and outer body-form remain unchanged.

Development of the digestice comal. Unfortunately the mode of formation of the primitive digestive cavity or archenteron was not olserved, as egrgs showing the formation of a gastrula could not be obtained. From this early period until after the larva has hatched the entire canal remains unorganized, the entire body-cavity being filled between the heart and nervous tract with yolk granules.

The earliest stage when the enteric canal was observed at all was after the different parts - oesophagus, crop, stomach, intestines, and cloaca or rectum - had assumed their definitive shape. Plate 4, fig. 2, illustrates a section of the larva before its first moult, through the head. The space around the heart and digestive canal and over the nervous cord is filled with a very loose connective tissue; the cells, which are nucleated, spindleshaped or triangular, being scattered, and forming a very open net-work of cells. In afterlife the cells multiply, becoming very numerous and round or oval in form. This connective tissue extends throughout the entire hody-cavity, the ovarian or testicular tubes ramifying throughout the mass, as well as the liver tubules.

The section at plate 5, fig. 8, passes through the oesophagus and the crop. The former (figs. 10, 11, enlarged) is apparently filled with a few large epithelial cells, which represent the folds of the lining of the oesophagus. The walls of the proventriculus are very thick; the lumen or passage is lined with the altemating larger and smaller folds of spherical epithelial cells, and with a thin semi-chitinous layer; the muscular layer, representing the endoderm built up around the originally invaginated ectodermal layer forming the fore gut or protenteron (plate 5 , figs. $7, T(1)$, shows the epithelium of the intestine, the cells being very irregular in size and length.

Origin of the liver. Plate 4, fig. 7, represents a section through the middle of the cephalothorax, passing through the intestine and one of the pairs of biliary ducts. The ducts are seen to open directly into the stomach, the duct being large, and at first there is a primary liver-tube, which bends downward at quite an angle before passing to the outer edge of the carapace. There are thus four primary biliary tubes, these in after life subdividing and ramifying throughout the body-cavity to an indefinite extent. The tubes are clear, transparent, with dark granules.

Development of the ovary. The same section represented in plate 4 , fig. 7 , also passes two bodies, one on the outer side of and just below the heart, on each side of the mid-gut. These are the rudimentary ovaries. One section (fig. 8) shows the ovarian follicles attached to the walls of the gland, and, in fig. Sa, the ovarian eggrs are just beginning to form, constituting a mass apparently free from the walls of the ovarian tubules.

Structure of the testes and development of the spermatozoa. In our first memoir on Limulus we figured the spermatozoa; since then Profeswor Lankester has also described them.

The argument that Limulus is not a Crustacean because the spermatozoa have tails is somewhat vitiated lyy the fact that those of the barnacles have exceedingly long, well 
developed tails. We introduce a figure of those of a species of Lepas collected at Penikese, an island at the mouth of Buzzard's Bay. The hear is hroad and flat, plainly simuons seen sidewise, the centre being filled with granules. The spermatocysts (plate 3, fig. 5) are spherical, usually containing five spermatozoa.

The tubules of the testis of Limulus are yellowish; this color is due to the presence of numerous yellow pigment gramules. Fig. $4 a$ represents the epithelial tissue forming the walls of the follicles (fig. 4). The spermatocysts (fig. $4 d$ ) are spherical, containing four immature spermatozoa, while the earlier condition of the same is seen at fig. $4 b$, where the sperm-cells are nucleated.

We introduce for comparison drawings (fig. 6) of the spermatocysts of a decapod Crustacean (Libinid combliculatu), the spermatozoa (fig. Gf) being tailless and nucleated. Certain larger cells have a large nucleus, with a small nucleolus; the nature of these cells we do not understand.

\section{BIBLIOGRAPHY.}

VAx der Hoever. Recherches sur l'Histoire Naturelle et l'Anatomie des Limules, par J. Van der Hoeven. Aree sept planches. Leyde, 1838. fol. pp. 38.

GEGEnbadr. Anatomische Untersuchung eines Limulus, mit besonderer Berücksichtigung der Gewebe. Von C. Gegenbaur. Mit einer tafel. Besonders abgedruckt aus dem 4. Bande der Abhandlungen der naturforschenden Gesellschaft in Halle. Halle, 1858. 4\% pp. 24.

Lockwood. The Horse-foot Crab. By Rev. S. Lockwood. American Naturalist, Iv, July, 1870.

Packard. The Embryology of Limulus polyphemus. By A. S. Packard, Jy. American Naturalist, Iv, pp. 257-274. July, 1870. American Naturalist, Iv, pp. 498-502. October, 1870. Proceedings Bost. Soc. Nat. Hist., June, 1871. Vol. xiv, p. 60.

- On the Embryology of Limulus polyphemus. By A. S. Packard, Jr. Proceedings American Association Adv. Science, 19th Meeting, Troy, N. Y., July, 1871. $8^{\circ}$. pp. 8.

Morphology and Ancestry of the King Crab. By A. S. Packard, Jr. American Naturalist, Iv, pp. $754-756 . \quad$ Feb., 1871.

The Development of Limulus polyphemus. By A. S. Packard, Jr. Memoirs Bost. Soc. Nat. Hist., II, pp. 155-202. March, 1872.

- Further Observations on the Embryology of Limulus, with Notes on its Affinities. By A. S. Packard, Jr. Amer. Nat., vir, pp. 675-678. Nov., 1873. Proceedings Amer. Assoc. Adv. Science. Portland Meeting, 1874.

— On the Development of the Nervous System in Limulus. By A. S. Packard, Jr. Amer. Nat., IX, pp. 422-424. July, 1875 .

- On an Undescribed Organ in Limulus, supposed to be renal in its nature. By A. S. Packard, Jr. Amer. Nat., Ix, pp. 511-514. Sept., 1875.

- Structure of the Eye of Limulus. Amer. Nat, xrv, pp. 212-213. March, 1880.

- Internal Structure of the Brain of Limulus. Amer. Nat., xiv, 1p. 445-448. June, 1880.

VAX BeNeDEN. De la place qui les Limules doivent occuper dans la Classification des Arthropodes d'apres leur developpement embryonnaire; par Édouard van Beneden. Communiqué à la Soc. Ent. de Belgique, 14 Oct. 1871. Gervais, Journ. Zoologie, I, 1872, pp. 41-44. Annals and Mag. Nat. Hist., 1872.

Donrs. Untersuchungen über den Bau und Entwickelung der Arthropoden. Von Anton Dohrn. Abdruck aus der Jenaischen Zeitschrift Wissensch., Band vr, Heft 4. pp. 582-640. 1871.

Milime-Edwards. Recherches sur l'Anatomie des Limules. Par A. Milne-Edwards. Annales des Sciences Nat., xvir, pp. 67. 11 plates. Nov. 1872. Commission Scientifique du Mexique. 
Owen. Anatomy of the King Crab. (Limulus polyphemus Latr.) By R. Owen. London, 1873. Trans. Linn. Society, London. 5 plates. $4^{\circ}$. pp. 50.

LAnkester. Mobility of the Spermatozoids of Limulus. By E. R. Lankester. Quart. Journ. Mier. Science. Oct., 1878. pp. 453-15t.

See also Strauss-Dürckheim's 'Traité d'Anatomie Comparative. 1842.

Owen's Lectures on the Invertebrate Animals. 1843-1855.

Woodward's papers on Merostomata. Palaeontol. Society. 1866-1878.

Huxley's Anatomy of the Invertebrate Animals. 1877.

W. Grenacher's Untersuchungen über das Sehorgan der Arthropoden. 1879.

\section{EXPLANATION OF THE PLATES.}

\section{Plate I.}

Fig. 1. Under side of a Limulus, a little over two inches long without the spine, injected to show the abundance of the arterial twigs in the limbs and caudal spine as well as the body. The injection was made at Penikese by the late Edwin Bicknell. J. S. Kingsley, del.

Fig. 2. Camera lucida drawing of a living larva, showing the circulation of the blood-corpuscles in the right under-side of the abdomen and on the left first abdominal limb. Author, del.

Fig. 3. Camera lucida drawings, showing the actual course taken by the blood corpuscles in the first abdominal appendage of the same larval Limulus. The arrows show the direction of the currents of blood, with the corpuscles; the blood passing from the heart down along the inner side of the appendage, and passing by tortuous, irregular courses around by the outside, back along the base, and returning to the pericardial chamber through the venous opening. This mode of circulation is much as we have seen take place in the amphipodous Crustacea. Author, del.

\section{Plate II.}

Fig. 1. Transverse section of adult male Limulus, natural size, through the proventriculus $[\mathrm{pr}]$, showing the cone $[c]$, the oesophagus $[o e]$, and the brain $[b r] ; a$, aorta, or frontal artery; col, collective venous sinus. From a drawing made for the anthor at Penikese by P. Roetter.

Fig. 2. Section through the cephalothorax in front of the heart, brain, and first pair of gnathopods; $m$, muscles. J. S. Kingsley, del.

Fig. 3. Section through the cephalothorax behind the first pair of gnathopods; $h t$, heart; $m$, great longitudinal adductor muscle; $c p$, supraneural cartilaginous plate protecting the central nervous system. The latter not shown. J. S. Kingsley, del.

Fig. 4. Transverse section through the abdomen, showing the second abdominal, or first respiratory, foot; $h t$, heart, beneath which is the intestine; $b$, origin and middle of branchio-cardiac veins, which carry the blood from the limb to the heart. J. S. Kingsley, del.

\section{Plate III.}

Fig. 1. Longitudinal section through a Limulus about two inches long, exclusive of the caudal spine; $h t$, heart; $m$, mouth, leading by the oesophagus to the proventriculus [pr]; cone, proventricular cone; st, stomach; in, intestine; $\alpha$, anus; $b r$, brain, or suprnoesophageal ganglion, behind which is a part of the oesophageal ring $[o e . r]$; $n g$, ganglionated cord; ct, supraneural cartilagimous plate; enlarged about twice.

Fig. 2. Longitudinal section through the larva of Limulus on one side of the heart and digestive tract, passing through the brain and cephalothoracie ganglia; $b r$, brain; the six other ganglia [1-6] separate from one another, and afterwards consolidate to form the "oesophageal ring"; 1, the first ganglion which supplies a pair of nerves to the first pair of gnathopods. [Compare plate 4, fig. $7, g n$.] 
Fig. 3. A horizontal section through the embryo long before it hatches, before the body has become flattened, before the heart and digestive canal have appeared, and soon after the embryo has reached the stage represented by plate 4, figs. $19,19 a$, of our first memoir. There are six ceplalothoracic ganglia [I-VI] besides the brain, and three abdominal ones [I-III]; the first two abdominal ones corresponding to the rudiments of the first and second abdominal appendages. 1-6, the six pairs of gnathopods; I, II, the two pairs of abdominal legs.

Fig. $3 a$. Enlarged riew of the brain [?], the nerve cells [b] forming the ganglion, which is enveloped by connective tissue cells $[c t]$. (Is it these latter which are destined to form the nucleogenous bodies of the adult brain?)

Fig. 4. Follicles at end of a seminal tubule of testis of Limulus; $4 \alpha$, epithelial cells of seminal tubules, nucleated and highly refractive; $X$ 'Tolles' $\frac{1}{3}$ objective $C$ eye piece, magnified 725 diameters; $4 b$, ambercolored pigment cells of testis; $4 c$, similar but larger cells; $4 d$, spermatocysts of Limulus; 4 , cells associated with the spermatocysts, with a large nucleus and a distinct nucleolus; $X$ Hartnack No. 9, B eyepiece.

Fig. 5. Spermatocyst of a barnacle [Lepas], $5 a$, side view, and $5 b$, front view, of a spermatozoon of the same; $\times \frac{1}{10} \mathrm{~B}$.

Fig. 6. Spermatocysts of different shapes, $a, b, c, d, c\left(\times \frac{1}{5} \mathrm{~B}\right)$, and $[f]$ tailless spermatozoon of Libinia canaliculata; $\times$ Hartnack No. 9.

Fig. 7. Supposed renal glands of Limulus; $b$, one of the four lobes extending upwards from the main stem $[a] ; c$, chitinous bases of the gnathopods. $7 a$, reddish pigment bodies coloring the cellular mass of the gland, the cells being nucleated. $7 b, \tau c$, two amber-colored yellow secreting cells scattered through the cellular mass, composed of nucleated cells, as at $7 a ; \times$ Hartnack No. $9, \mathrm{~B}$.

Fig. 8. Tubules of liver of living Limulus; $\times 30$ diameters; $8 a$, a parent cell of the smaller liver cells; the shaded ones horn-colored, those unshaded clear; $8 b$, free liver cell; $8 c$, the same with pale nuclei. $8 d$, liver cells of Panopæus; $\times \frac{1}{5}$ Tolles B.

Fig. 9. Sections of lirer tubes stained with carmine; $\times \frac{1}{2} \mathrm{~A}$.

Fig. 10. End of a liver tubule of Homarus umericanus; $\times \frac{1}{5} \mathbf{B}$.

Fig. 11, 11 $\alpha$. Striated musele near insertion of leg of Limulus; $\times \frac{1}{3} \mathrm{C}$ (725 diameters).

Fig. 12, 12a, 12b. Sections through minute peripheral arteries near the compound eye; $\times \frac{1}{2} \mathrm{~A}$.

Fig. 13. White fibrons cartilage of the supraneural cartilaginous plate; longitudinal section showing the fibres on one edge and the nucleated cells in the dense structureless portion.

Fig. 14. Portion of the blastoderm lying next to the chorion $[c h]$ with yolk granules; $14 a$, the same after the outer layer $[0]$ has begun to moult, the cells beginning to. wrinkle on the edges, and being without the protoplasmic granules $[14 b]$ seen in the deeper layer of blastodermic cells; $14 c$, vertical, and $14 d$, profile view of the same cells after moulting, the walls contracted and wrinkled, and with the nuclei partly absent or absorbed; $\times \frac{1}{5} \mathrm{~A}$.

\section{Plate IV.}

Fig. 1. Section through the larva some time after hatching; $h$, heart; int, intestines; $n c$, donble nervous cord; the muscular system well developed; am, undereloped adductor muscle. The parenchym of the body consists of incipient connective tissue and liver-cells.

Fig. 2. Section through the cephalothorax of the same larva as represented at Fig. 1, the section passing through the compound eye $[c c]$, the heart $[h t]$, proventriculus $[\mathrm{pr}]$, and the double nervous cord; as yet the neurilemma is unformed, the nervous cord not being enveloped by it, this being represented by connective tissue $[c t]$.

Fig. 3. Nerve cells of nervous cord of a freshly hatched larva, before the digestive tract and heart are indicated; $3 a$, connective tissue cells enveloping the nervous cord of 3 ; from these cells the neurilemma is probably formed.

Fig. 4. An ocellus of a larval Limulus, showing the epithelial cells $[e]$ and the dark pigment of the retina $[r] ; \times \frac{1}{5} B$. The ocelli are at this stage quite far apart.

Fig. 5. Section of nervous cord $[n]$ embedded in connective tissue [ct], the section passing through the body near the eyes of an advanced larva, in which the heart and digestive tract are developed.

Fig. 6. Section through a ganglion $[g]$ of the same larva as represented in Fig. 5, the ganglion completely surrounded by the connective tissue $[c t]$. 
Fig. 7. Section through an advanced larva showing the origin of a pair of liver ducts from the intestines [int], and a single primitive liver-duct $[l d]$, of which there are two pairs; $h t$, heart; gn, a pair of nerves sent from the ganglion $[g]$ to each second gnathopod.

Fig. 8. Section of an ovarian tube, with the ovarian follicles on the side; $8 a$, another section showing the cell-eggs.

\section{Plate V.}

Fig. 1. Section through the vertical folds or teeth of the fore part of the crop or proventriculus; $m$, mus cular layer; pe, pavement epithelium; ce, columnar epithelium; ch, chitinous layer.

Fig. 2. The central tooth of Fig. 1 magnified; $\times \frac{1}{2} \mathrm{~A}$; lettering as before.

Fig. 3. Columnar epithelium from section of end of the oesophagus.

Fig. 4. Nucleated cells and fibres of the parement epithelium of intestine; $\times \frac{1}{5} \mathbf{B} ; 4 a$, the same somewhat enlarged.

Fig. 5. Section from posterior part of the oesophagus, showing the chitinous layer [ch]; the empty spaces in the lobes surrounded by columnar epithelium [ce]; the pavement epithelium [pe] supporting the former.

Fig. 6. Pavement epithelium of rectal folds.

Fig. 7, $7 a$. Section of stomach of larva where the chitinons lining is absent, showing the irregularity of the epithelium.

Fig. 8. Section through an advanced larval Limulus, the figure indicating only the portion lying under the central lobe; $h t$, heart ; $p r$, proventriculus ; oe, oesophagus; $g$, first pair of ganglia, the oesophageal ring not yet being consolidated; gn, nerve to the first gnathopod [gp], demonstrating that the brain does not supply the nerves to the first pair of feet; ct, connective tissue, the neurilemma not yet formed.

Fig. 9. Section of inner part of the proventriculus showing the larger teeth $[t]$ alternating with the smaller ones $[t] ; \times \frac{1}{5} \mathbf{A}$.

Fig. 10. Section through the oesophagus; $\times \frac{1}{8} \mathbf{A}$.

Fig. 11. Another section of the same.

Fig. 12. Section through the simple eye or ocellus of Limulus; 3 , third layer of the integument, clear and laminated; $\times \frac{1}{5} \mathbf{A} ; 2$, second layer of integument finely granulated and laminated; $p c$, pore canals filled with connective tissue $[c t]$; $c l$, corneal lens; $h$, cup-shaped depression in the base of the corneal lens.

Fig. 13. Another section of an ocellus more enlarged; lettering as in fig. 12.

Fig. 14. Section through an ocellus showing the relations of the ocellar nerve and its branches [ocn]; 1, first and outer clear layer of the convex cornea; 2, second layer, finely laminated; 3, third, clear layer, with a few laminæ; rt, pigment layer in retina; $h$, hypodermis, of which the retina is a modification; $c l$, corneal lens; $c t$, connective tissue.

\section{Plate VI.}

Fig. 1. Section through the entire compound eye of Limulus, stained with picro-carmine, showing the relations of the cornea and corneal lenses and retina to the branches of the optic nerve; cor, cornea; 1 , outer clear, 2 , middle laminated, and 3, inner clear portion of the chitinous cornea, seen to extend into the integument; $p c$, pore or nutritive canals filled with connective tissue; $c l$, corneal lenses; rt, retina; hy, hypodermis, of which the retina is a modification. Below is the mass of connective tissue cells [ct], through which the tortuous branches of the optic nerve pass and impinge on the ends of the conical corneal lenses; owing to the tortuous course of the nerve-fibres, they appear not to be continuous in the thin section of which this is a drawing. ov, ovary with cell eggs; ar, two arterial twigs; $l$, two liver tubes; ict, inner, darker brown connective tissue of the interior of the cephalothorax.

Fig. 2. Sections of corneal lenses in the middle of the eye; the retina has been removed by acid; $c l$, corneal lcnse : $h$, cup-shaped depression in base of lens; $2 a$, the same from near the periphery of the eye, where the corneal lenses are longer and more oblique directed inwards towards the middle of the eye.

Fig. 3. Epithelium of the retina around the end of a cone; rhab, rhabdom; rcl, retinal cells.

Fig. 4. Section of two retinulas, with the rhabdom $[\mathrm{rhab}]$ in the centre; $\times \frac{1}{3} \mathbf{A} ; 4 a$, a retinula [ret] od with acid to show the twelve cells into each of which a ray of the rhabdom projects; $\times \frac{1}{6} \mathrm{~B}$. 
Fig. 5. Section of soft parts of ocellus of Limulus, showing the subdivisions and mode of termination of one branch of the ocellar nerve $[\mathrm{on}]$; the branches are enveloped in connective tissue [ct]. The section passes on one side of the corneal lens.

Fig. 6. Optical section of corneal lenses of Limulus, as seen through the transparent cornea, showing their slightly hexagonal appearance; $\times 50$ diameters.

Fig. 7. Artificial section through the eye of Asaphus, a trilobite, to show the close similarity to the corneal lenses of Limulus; $\times \frac{1}{2} \mathrm{~B}$ eye-piece.

Fig. 8. Longitudinal section through the eye of Asaphus showing the corneal lenses; $\times \frac{1}{2} \mathbf{A}$. (Compare with Fig. 1, 2, 2a, the corneal lenses of Limulus.)

Fig. 9. Longitudinal section through the eye of Asaphres gigas; $c$, corneal lenses; pc, pore canal; $r t$ ? probable indications of the upper edge of the retina?

Fig. 10. Section of part of the cornea of an Asaphus gigas which has been broken, showing several entire corneal lenses side by side.

Fig. 11. Section through one side of oesophageal ring passing through the nerve to one of the gnathopods or cephalothoracic feet; $n l$, neurilemma; $s p$, space between neurilemma and the ganglion; $n b$, small nucleogenous bodies at top of section or upper side of oesophageal ring; lgc, longitudinal group of large ganglion cells, extending along the outside of the oesophageal ring; gn n, gnathopodal nerve; magnified 30 diameters.

Fig. 11a. A large ganglion cell $[\operatorname{lgc}]$, surrounded by smaller bipolar ganglion cells, magnified 224 diameters.

Fig. 12. Section through second abdominal ganglion, $n$, nerve to one of the abdominal feet; $f a$, fibres of central nerves; lgc, layer of large ganglion cells and nerve fibres arising from them; $\times 30$ diam.

Fig. 13. Section through the same ganglion showing origin of nerve $[n]$ to second abdominal foot.

Fig. 14. Section through the sixth or last abdominal ganglion passing through the nerves $[n] ; n f$, shows the nerve fibres arising from the large ganglion cells and reinforcing the nerves making up the central mass, which is seen to be composed of the union of two separate nervous ends; $\times 30$ diameters.

Fig. 15. Transverse section through the middle of the brain, showing the arrangement of the fibres [fa], nucleogenous bodies $[n b]$ and groups of large ganglion-cells $[\operatorname{lgc}]$.

\section{Plate VII.}

Fig. 1. Section through upper part of brain of Limulus, passing through the optic nerves [op $n] ; c m$, groups of cells from which the optic nerves appear to arise; $y$, Y-shaped bundle of nerve-fibres; $n b$, nucleogenous bodies on each side of the brain; $l g \mathrm{c}$, groups of large ganglion-cells; $\mathrm{cm}$, commissures uniting the brain with the oesophageal ring; $n l$, neurilemma. The lettering the same for all the figures. Magnified 15-20 diameters. 1a, A large ganglion cell of Limulus; $1 b$, the same of the lobster; $1 c$, small ganglion cells of Limulus; $1 d$, the same of the lobster; all magnified 225 diameters to show their relative size and form.

Fig. 2. Section lower down, just grazing the under side of one optic nerve; the nucleogenous ruffleshaped bodies in front as well as on the sides; the $\mathrm{Y}$-shaped bundle of nerves nearly merged with the rest of the fibrous portion; the groups of large ganglion-cells $[\mathrm{lgc}]$ limited in extent.

Fig. 3. Section of portion of brain magnified 30 diameters showing the origin of left optic nervo; $f$, bundle of nerve-fibres, without cells and nuclei; $n^{1}$, a nerve of which an enlarged section is scen at fig. $3 a$, showing the nucleated fibres cut across; $n^{2}$, a large bundle of nerve-fibres, of part of which, fig. $3 b$, is an enlarged view, shoring the nucleated fibres in section, and seen longitudinally with a few nuclei visible; - 225 diameters; $3 c$, a group of large ganglion-cells, with branched nerve-fibres arising from them; $n$, nucleus; $n c$, nucleolns, magnified 205 diameters; $3 d$, a single large ganglion cell, giving origin to a branching nerve.

Fig. 4. Section of right side of brain passing through the ocellar nerve, $o c n$; $c$, commissure with large ganglion-cells and fibres at this point, surrounded by a distinct neurilemma; ar, artery passing down the back of the brain. Magnified 30 diameters.

Fig. 5. Section of brain of Limulus through the ocellar nerve $[o c n]$ and the two tegumental nerves $[t n]$; $c$, section of lower part of commissure to oesophageal ring; $f a^{1}$ the small area on the right side composed of nerve-fibres, showing the asymmetry of the brain; magnified 30 diameters. 
Fig. 6. Section of left side of brain of Limulus, below the ocellar nerve, passing through the lower set of tegumental nerves. The fibrous area $[f \alpha]$ much branched, and still much grenter than on the right side $\left[f a^{\prime}\right]$. A number of large ganglion cells are present at the posterior outer portion of the brain. Magnified 30 diameters.

Fig. 7. Section through left side of brain of Limulus, below any of the nerves, quite near the base of the brain, and showing how much the nucleogenous bodies have encroached on the fibrous area $[f a]$.

Figs. 1 and 2, were cut from the same brain; figs. 3, 4, 5, 6 and 7 from another brain ; and were selected from about ninety other sections.

NoTE.-All the figures in plates 1-7 were drawn by the author, except plate 2, fig. 1, drawn by P. Roetter ; and plate 1, fig. 1, and all the figures on plate 2 (except fig. 1), which were drawn by J. S.Kingsley.

\footnotetext{
Zoological Laboratory of Brown University, Providence, R. I., May, 1880.
}

\section{ERRATA.}

Page 10, line 30, for Arthopoda read Arthropoda.

Page 16, line 1 from bottom of footnote, for Tottennia read Tottenia.

Page 23, line 25, for (Fig. 9, rt) read (Fig. 9, rt ?).

Page 26, line 6 from bottom for "or lens-epithelium " read "lens-epithelium."

Page 29, line 14, for analagous read analogous.

Page 29, line 37, after the word but dele that. 



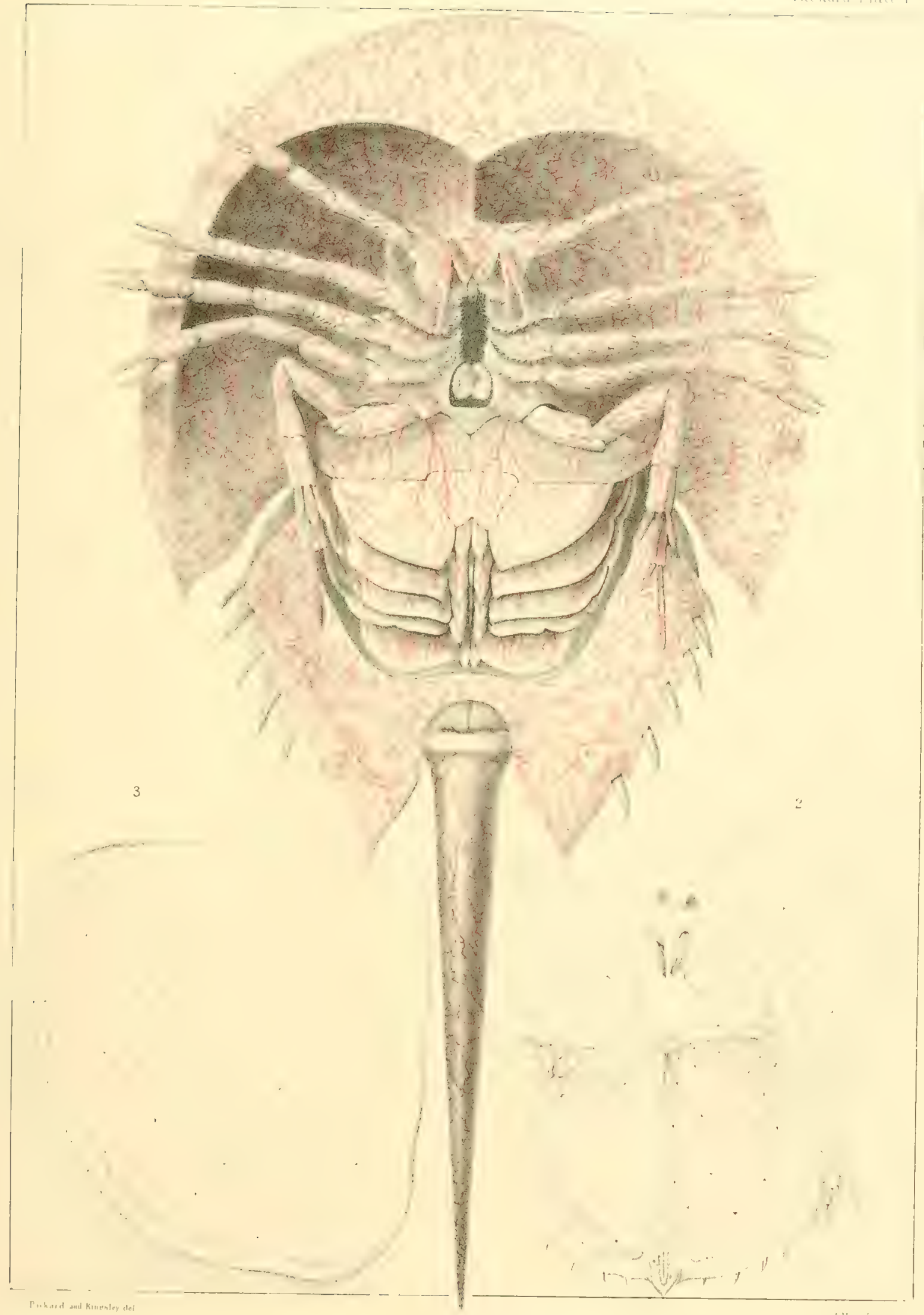

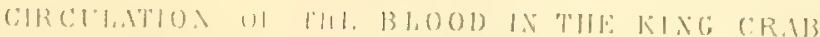




$$
\text { - }
$$




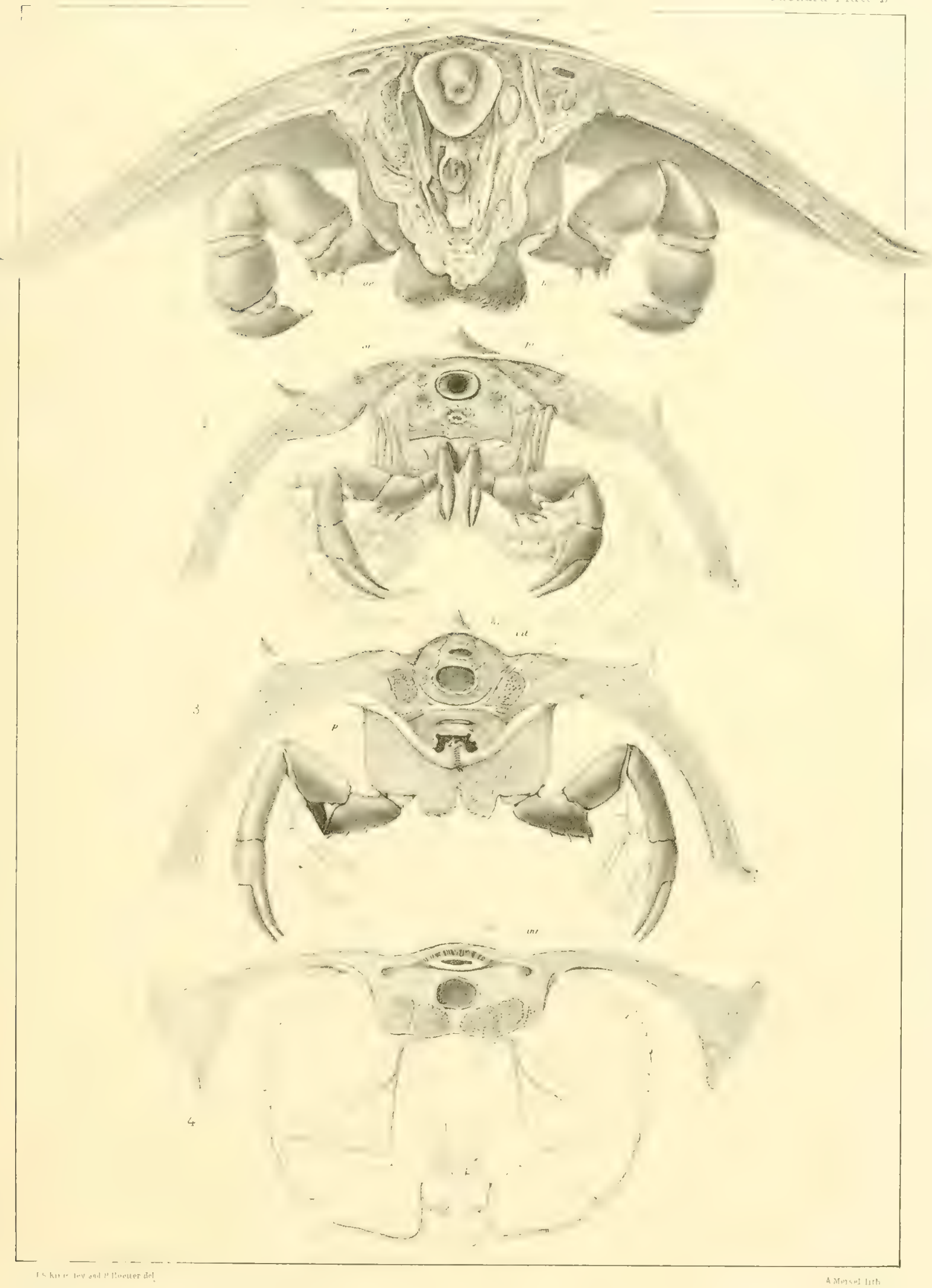

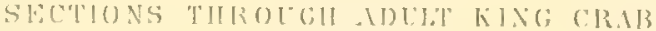





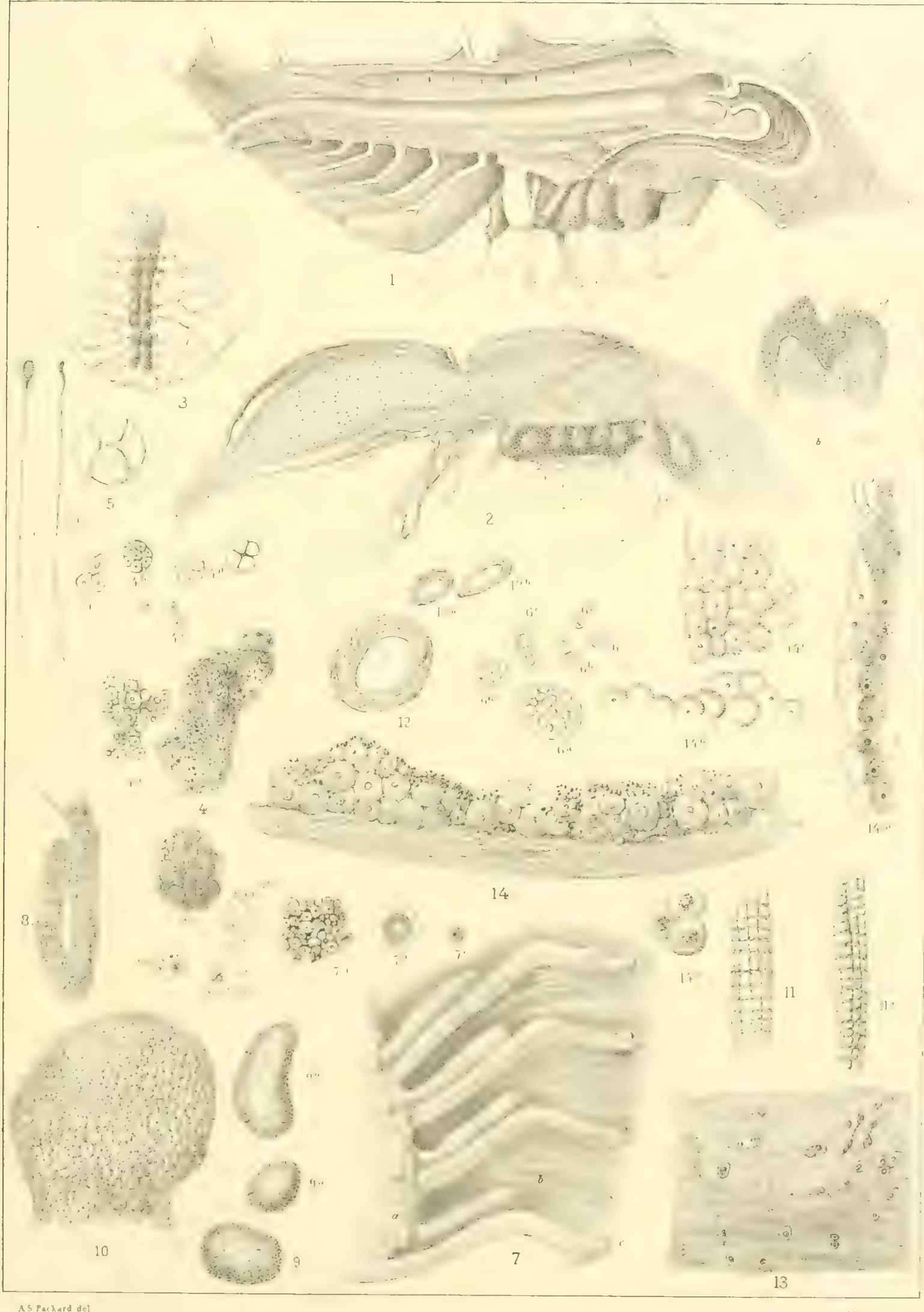




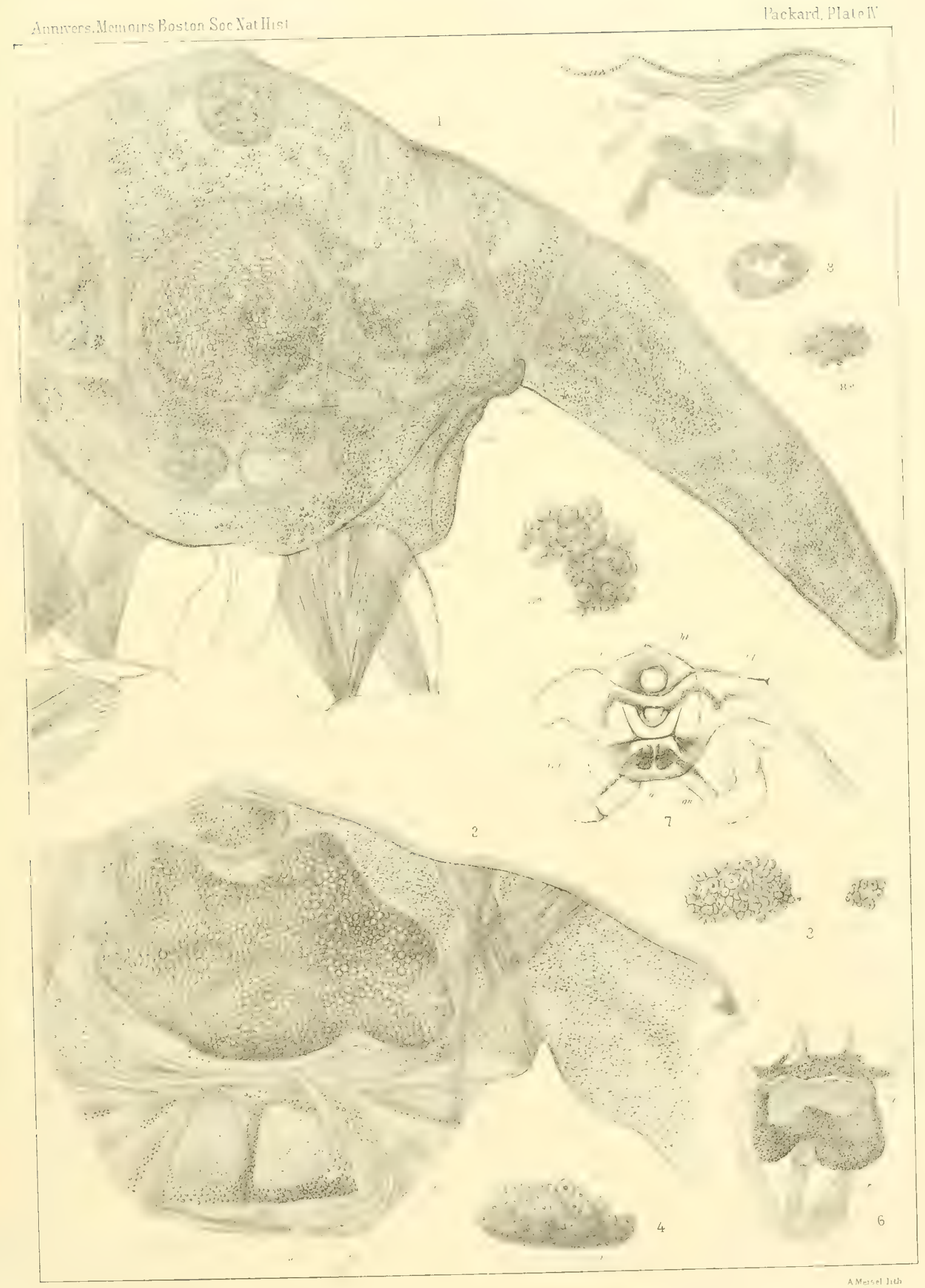


. 


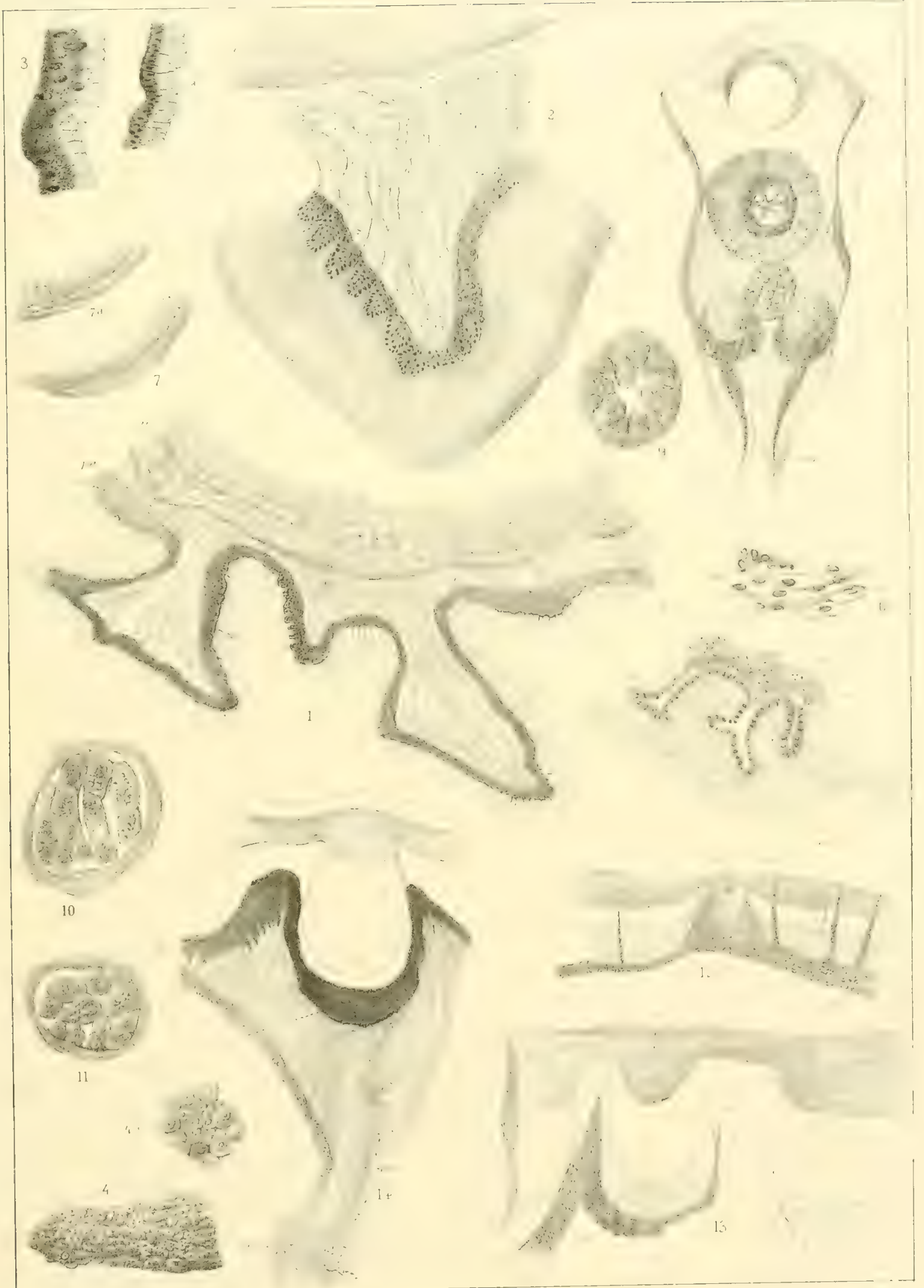





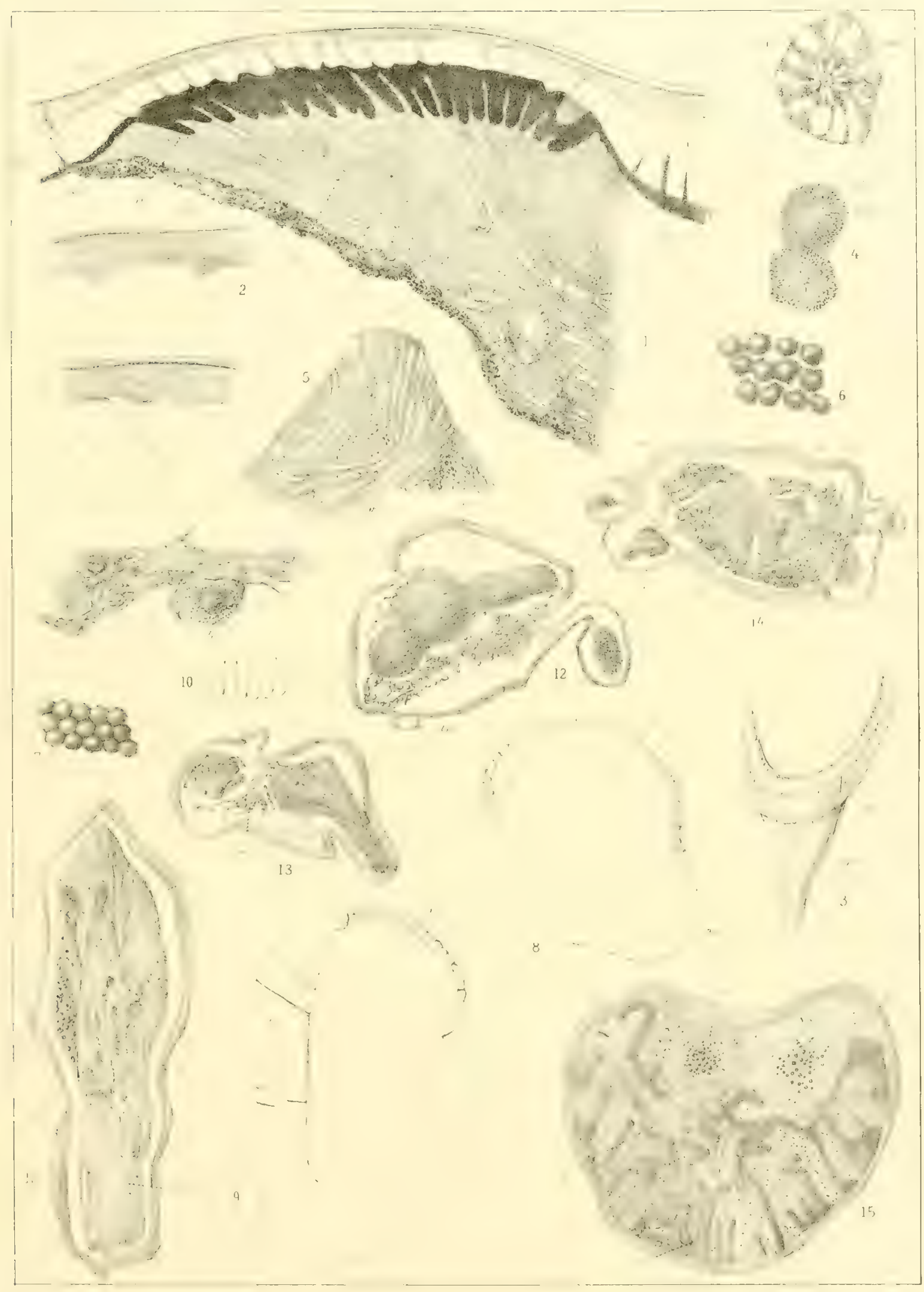





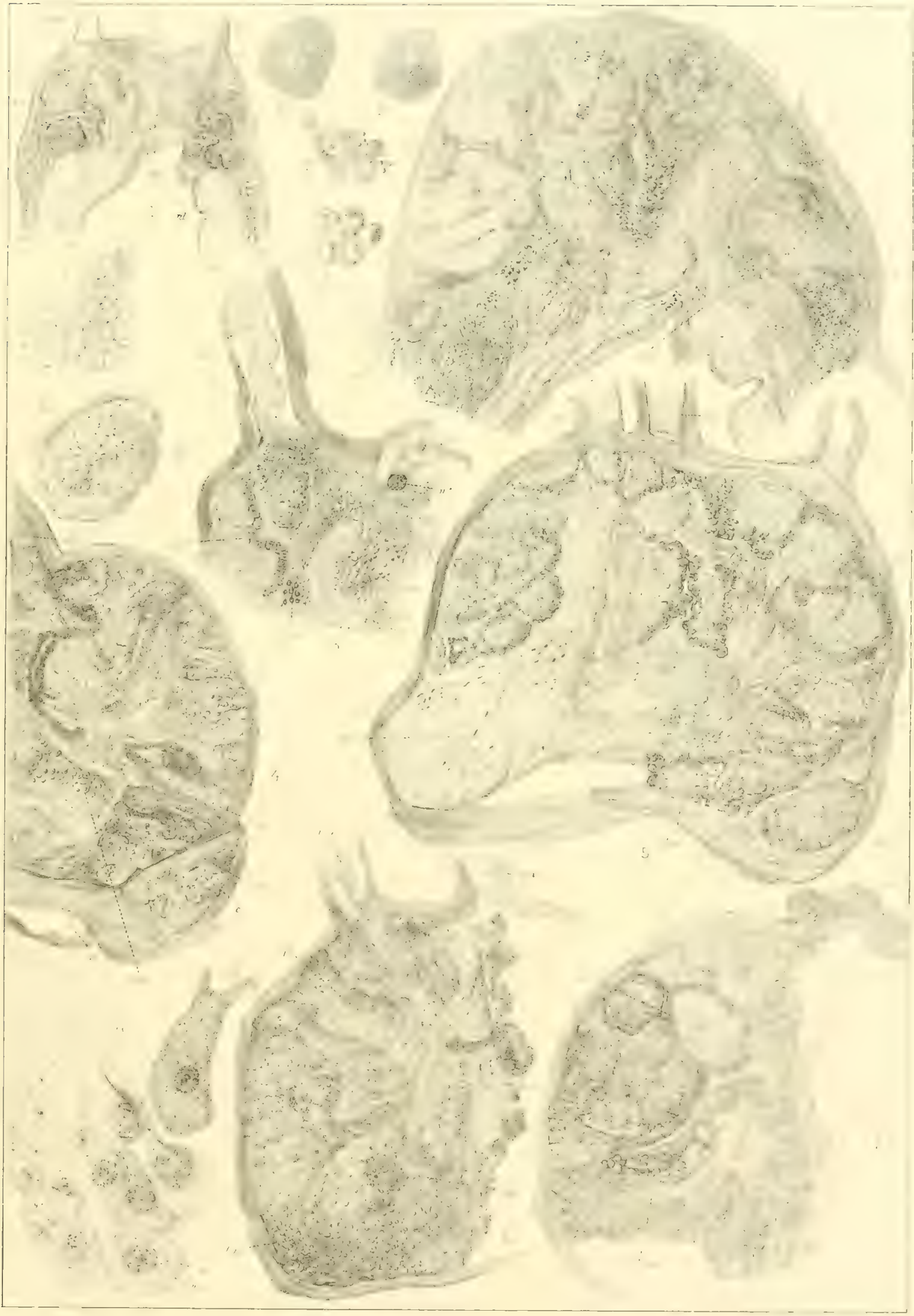



1830. AMIIVERSARY MEMOIRS OF THE BOSTON SOCLETY OF NATURAL IIISTORY. 18 .

\section{CONTRIBUTIONS}

TO THE

\section{ANATOMY OF TIIE IILK-WEED BUTTERFLY}

DANAIS ARCHIPPUS (Fabr.).

BY EDWARD BURGESS,

SECRETARY OF THE BOSTON SOCIETY OF NATURAL HISTORY.

BOSTON:

PUBLISHED BY THE SOCIETY.

1880. 



\section{Coxtributions to the Axatomy of the Milk-meed Butterfer (Danais Archippus Fabr.). Br Edward Burgess.}

GENERAL students of comparative anatomy wishing to gain some knowledge of the structure of the Lepidoptera find their way blocked by the lack of some suitable modern monograph on any species of this group to which they may turn. I have, therefore, attempted to fill this gap to some extent by a preliminary sketch of the anatomy of the Milk-weed Butterfly (Danais Archipmes Fahr.), choosing this species as a trpe of the order, partly on account of its large size, common occurrence and wide distribution - for it is found nearly the world over-and, partly, because the anatomy of no species of Danaidae has yet been studied.

The present paper treats only of the general anatomy of the perfect insect, leaving the consideration of the larval and pupal structure and development, as well as the histology, to the future investigations of myself or others.

The special student, already acquainted with the present state of our knowledge of butterfly anatomy, will find new observations on the maxillae and suctorial mechanism of these insects; on the course of the dorsal vessel; and on the structure and mechanism of the male genital armature.

\section{Structure of the Exoskeletor.}

Head. (See pl. 1, figs. 1 and 3.) The roof of the head is formed by the epicranium, which bears on its sides the large eyes, and, in front, the antennae. The posterior aspect of the epicranium is called the occiput, while the front is the region immediately above and between the antemnae. The small triangular areas, on either side, and below the face are the cheeks or genae (g.). The face includes the region below the antennae, and is formed chiefly by the large, vaulted clypeus $(c$.$) , whose arc-shaped lateral boundaries are$ well-marked, while above it passes directly into the epicranium, without any suture or line of demareation as found in many insects. The compound eyes (oc.) are very large and protruding; the ring-like ridges on which they are borne are termed the orbits (or.). Simple eyes, or ocelli, are not found in the butterflies, although there are two in moths.

The antennae articulate with the epicranium by a "ball and socket" joint; the ball being formed by the large first and smaller second antennal joints (see fig. 3), is deeply inserted in the antennal fossa or socket. The succeeding joints are cylindrical, and of much less diameter than the ball; they are about forty-five in number, and of nearly uniform size till towards the tip, where the last ten gradually expand, becoming also shorter, and form the "club." which characterizes the antennae of the diurnal Lepidoptera. 
To the slightly concave lower edge of the clypeus is soldered the upper lip, or labrum (7b.), a small, flat triangular piece, with a somewhat projecting apex, which overlies the base of the proboscis. On either side the labrum, and soldered to the cheeks, are seen two small triangular, almost thorn-like, pieces, the rudimentary mandibles (md.). 'I'hey are immovable and of course functionless; their inner margin bears a row of stiff bristles. Behind the mandibles are the movillue (me.). of compensatingly enormous development, forming the tubular proboscis, used by the insect to suck up the honey or other vegetable juices forming its food in the imago stage.

Each maxilla is a long, slender, flexible organ, tapering gently to the tip, and having a deep groove along its inner surface, which surface being applied to that of the opposite maxilla, and locked in that position by hooks provided for the purpose, a canal is formed traversing the proboscis from base to tip. When not in use the proboscis is coiled into a spiral like a watch spring, and lies under the head, protected on either side by the large hairy labial palpi, which are specially developed for this service. In the Milk-weed Butterfly the proboscis is about $15 \mathrm{~mm}$. long, and at the base, about $0.6 \mathrm{~mm}$. wide. The tip is rather bluntly pointed. Superficially (pl.2, fig. 8), the proboscis presents a sort of coat of mail appearance from its composition of an immense number of rings, or rather segments of rings, since a portion on the inner side is of course wanting. The separation of these rings by intervening and more yielding spaces of cuticle, is evidently to permit the spiral coiling of the proboscis, while imparting at the same time the necessary stiffiness. The rings are not perfectly regular, but are here and there broken, or branch and anastomose. They are themselves made up of quadrangular plates joined side to side, except near the inner edges of the maxillae, where, especially in front, they become separated, more or less hexagonal and irregularly seattered; on the hinder side each plate sends off a stout, spinelike process, which is directed inwards (see fig. 10). These plates, as will be seen in sections of the proboseis (figs. 9, 10 and 11), are the bases of little pyramids, or in some regions, stout nail-shaped bodies imbedded in the cuticle, each one in its own prismatic block of cuticle, which probably corresponds to a single underlying hypodermic cell, its matrix. 'The blocks may occasionally be demonstrated by the separation of one of them from its neighbor in the process of section cutting, (fig. 1lc). The dividing boundary line between the blocks can also generally be seen in successful sections (see figs. $11 a, b$ and $c$; $c u$. cuticle, and hy. hypoderm). The cuticular lamination too is evident in such sections. The pyramids are opaque, black, or dark brown, and the rest of the blocks colorless and transparent.

Dotted over the surface of the proboscis but more thickly toward the tip are little circular plates with a minute papilla in the centre (see fig. 8). These are regarded as modified hair structures, and in many butterfies are curiously and greatly developed, ${ }^{1}$ forming toothed or notched spines, believed by Breitenbach to serve as the teeth of a saw or file, enabling the insect to work the proboseis through plint tiswes in search of the contained juices. These organs are reenforeed in the case of the Orange moth (Oplliteres fullonica), by large spines developed from those which serve simply to lock the maxilla together in

\footnotetext{
1 See Breitenbach, Katter's Entomol. Nachr. v, 238; Arch. Mikr. Anat, $\mathbf{x v}, 8$ and $\mathrm{xv} \mathbf{1}, 308$. Also F. Darwin,' Quart. Journ. Mier. Sci., Xv, 385, and F. J. Comstock's
}

Report on Cotton Insects, U. S. Agric. Dopt. 1879, p. 86 (proboscis of Aletia). 
other Lepirloptera. They are too small for mechanical use in Archippus, and perhaps the papillae are, in this case, organs of taste or touch, as suggested by Fritz Muiller, which appears more likely from the fact that they oceur, though in much less number, within the central canal of the proboscis. This canal is not lined with rows of little blocks like the exterior, but with the much narrower solid edges of semiannular plates, which give the canal the appearance of a large trachea (fig. 9). In transverse sections it is seen (fig. 10) that the ends of these semiannular plates form behind hooked teeth, which are snugly dove-tailed together, while their anterior ends are produced into long spines which simply interlock like the fingers of the two hands. There arrangements serve to hold the two maxillae together to form a continuous tube.

Each maxilla is traversed through its whole length by a nerve and a trachea (figs. 9 and $10, n$. and $t r$.), both giving off numerous lateral hranchlets to the muscles which fill the rest of the interior of these organs. The muscles form narrow bands and are arranged in two sets, both running from the anterior to the posterior aspect, and descending in this course. One set, however, is inserted on the outer side of the anterior face, while the other is inserted on the inner, and both converge in their downward and backward course, and thus, when seen through the wall of the maxilla from the front, they form a series of $V_{s}$ one above the other. Seen laterally, only one set is visible at a time, diagonally crossing the maxilla, as shown in the section (pl. 2, fig. 9). From the attachment of these muscles, their apparent action is to shorten the posterior wall of the maxilla, which of course must produce the spiral coiling of the organ. This unfortunately, leaves the explanation of its extension in the dark, unless we suppose elasticity, or possibly the injection of the somatic fluids, to bring this about. Many authors have assumed that the proboscis was coiled by its elasticity, but if we admit the possibility of such action at all, we can as easily require it to account for extension as for flexion. It seems more probable, however, that we fail to see, or to correctly interpret, some proper muscular mechanism for both movements of the proboscis. ${ }^{1}$

Maxillary palpi are often well developed in Lepidoptera, though in some they are wanting, or at least reduced to a little wart on the base of each maxilla (fig. 3, mx.p.).

The labial palpi are, as already said, very large, and conceal the proboscis in repose The first joint is short, stout, rather pedicellated, and is curved upwards; the second is long, tapering somewhat from the base to the tip; and the last joint is small and pointed.

Thon 1 . A slender neck well separates the head from the thorax, whose first somite, or prothorax, (fig. 1, x.), is very small and feebly developed, and the homologies of its skeletal parts are not easy to recognize. The scutum (fig. $1, s_{\circ}{ }^{1}$ ) is divided by a median furrow into two tumid, bolster-like pieces (called by Mr. Scudder the pro-thoracic lobes), entirely separated from each other. Behind them is a small triangular plate, representing the scutellum; and behind this are two rounded and knob-like processes which form an articular surface resting in a corresponding depression in the mesothorax. These probably rep-

\footnotetext{
1 I have found few references to the myology of the lepidopterous proboscis; the most extensive is that of Newport, Nerv. System of Sphinx ligustri, Phil. Trans., 1834, p. 398, whose whole conception, however, seems to me erroneous.
}

See also his article in Todd's Cycl. Anat. II; and Gersteldt. Ueber die Mundtheile der saugenden Insecten, Dissert. inang. Dorpat, $8^{\circ} \cdot 1853$. 
resent the post-scutellum. A continuous osified collar encircles the prothorax beneath, composed of the episternal and sternal elements fusert into one piece. Behind and heneath this collar are attached the long cylindrical coxae of the first pair of legs. Epimera are not recognizable.

A broad membranous neck separarates the prothorax posteriorly from the mesothorax (II.). The scutum $\left(s^{2}\right)$ in this segment is very large, oblong, and vaulted. In front there is a rather deep pentagonal depresied area, with a rounded central portion, fitting against the articular surface between the meso- and pro-thorax, as already described. 'Ihis area is perhaps the praescutum, and is, as it were, wedged into the scutum. Just below the anterior corners of the scutum are attached, by a small stalk, two leaf-like epaulets, the patayia ${ }^{1}(p t$.$) . These are nearly semicircular in shape, with a conical piece projecting back-$ ward from the lower corner. The great development of the patagia is characteristic of the Lepidoptera. Behind the scutum, which is slightly emarginated posteriorly, is the lozenge shaped, tumid scutellum $\left(\mathrm{sm}^{2}{ }^{2}\right)$, whose lateral corners project under the base of the scutum. A narrow membranous area separates the scutellum from the post-scutellum $\left(p s m^{2}\right)$, which is an arch shaped piece mostly concealed by the posthorax; it sends a long process forward on each side under the scutum and reaching the epimera, while behind it extends into the interior of the thorax for the attachment of the great thoracic muscles (see fig. 2, l.m.). The episterm (eps.2) is triangular, with two sides convex, its base resting on the stemum. $\left(s t^{2}\right)$, which is an irrregularly six-sided, transverse piece covering the chest. 'The sicles of the prothorax behind the episterna are formed by the epimera $\left(\right.$ epm. $\left.{ }^{2}\right)$ shaped something like an hour-glass in outline, being emarginated deeply above for the sub-alar membrane, and, beneath for the coxre $\left(c x^{2}\right)$ of the second pair of legs, which are immovably united with the epimera and sternum.

The scutum $\left(\mathrm{sm}^{3}\right)$ of the meta-thorax (III.) is divided into two lateral triangular wedges somewhat like the prothoracic lobes, between which in front the scutellum and postscutellum of the mesothorax are wedged, and behind the triangular scutellum of its own segment $\left(s m .^{3}\right)$. The episterne $\left(e p s .^{3}\right)$ and the sternum show no dividing suture, and embrace the base of the coxae above and in front; while, in similar fashion, the epimera.(epm. $\left.{ }^{3}\right)$ send projections backwards above and behind. The shape will be better understood from the figures, than from any description.

The roots of wings $\left(w_{0^{1}}\right.$ and $\left.w .^{2}\right)$ are inserted in broad, membranous areas occupying the sides of the meso- and meta-thorax above the epimera and below the scuta of those segments. The hinder pair of wings in the male are distinguished by a sort of pocket, on the upper side, forming a small blister on the rib, known as the first branch of the median vein, opening by a narrow slit and containing scales and hairs. ${ }^{2}$

The legs show the usual five divisions into the coxa, trochanter, femur, tibia and tarsus. 'The first pail, however, are much smaller, and, indeed, functionless, as in all the higher butterflies. 'They also are different in the two sexes; the tarsi of the males are

\footnotetext{
1 Westwool, Newport and other authors have erroneously described the patagia as attached to the prothorax, and this is accordingly often repeated in our text books. Packard, Guide to the Study of Insects, gives the correct statement. ${ }^{2}$ In making sections through the wings at this point, sev-
}

eral good sections of scales were made, showing their upperand lower membrane, the former bearing the rib-like markings. Fig. 6 on pl. 1 shows two of these sections - fig. 6 through the middle of the seale, and $6, a$, lower down, passing through the pedicel. 
(rather indistinctly) two-jointed, the second joint being very small; while in the females there are four tarsal joints, the first quite large, much stouter at the apex, the next two very short, and the fourth or last very minute and indistinct. The first three joints in the female have each two spurs on their inner extremity. The fore tarsi are clawless in both sexes.

The middle and hind pairs of legs are alike except for the somewhat larger size of the former. The coxal joints are conical, immovably united to the thorax. They are divided into two parts, the coxa and trochantine. The tarsi are five-jointed, all very spiny beneath. The last joint has two long and rather straight claws.

Abdomen. Nine somites (fig. 1, numbered 1 to 9 ) are evident in the abdomen of the Lepidoptera. The first is small, forming a sort of neck which is wider than high; the dorsum is developed into a large bolster, shield-shaped from above, and somewhat overhanging the base of the second somite. The pleural region presents rather complicated folds, and there is no sternal onification, leaving a broad membranons surfice between the thorax and the sternum of the second abdominal somite. The next three somites increase gradually in height, but each is somewhat shorter than its predecessor. The sternal and dorsal regions are of about equal development. The second sternum shows underneath two shallow furrows, in which the knees of the last pair of legs seem to fit. The fifth and sixth somites decrease gradually in size. 'The last three somites require a different description for the two sexes. In the female the dorsum of the seventh somite is longer than the preceding, and the sternum is produced backwards to a point, and its posterior border emarginated. The eighth tergum is shorter than the seventh, and the whole somite much less high; its flat sternum looks forward, opposing the hollow posterior aspect of the seventh; thus forming with the latter a wide, cave-like vestibule, in which the orifice of the vagina is situated. The ninth, and last, somite is very small, and in repose, almost wholly retracted within the eighth. Inferiorly and laterally it is produced into two bluntly triangular lobes, or flaps, between which lie the openings of the digestive and reproductive organs. The ninth sternum is reduced to a simple ring, connecting these flaps inferiorly.

In the male the seventh somite is simply smaller than the preceding. The eighth, however, is remarkably developed, for its sternum is produced laterally far beyond the tergum forming two filse clasps with bifid tips, the inferior tooth being the stouter, and both teeth strongly incurved. The ninth segment resembles that of the female. exeept in being somewhat larger. To its sternum, however, are articulated the true male claspers, to be described farther on, and between these projects the penis. The anus lies within the flaps above the sexual organs as in the female.

\section{INTERNAL ANATOMY.}

From this brief description of the exoskeleton we may pass to the internal anatomy of our butterly. To best study it, the insects should be hardened for a few days in alcohol, made grathally stronger, and then some specinens should be eut with a razor into longitudinal halves, which will show the natural position of the internal organs. It is well to dratw the razor slightly on one side of the median line, as in this way the first part of the digestive tract, the nerve chain and the dorsal vessel are left intact. Some preparations should 
also be made by merely cutting through the integument near the median line with a razor, and in places, with a fine pair of scissors, and then gently tearing it away on one side, thus leaving the principal organs perfectly uninjured, and in their natural position. By carefully removing the fat body and the tracheae they will, one by one, gradually become evident. ${ }^{1}$ A preparation thus made is figured on pl. 1, fig. 2. Of course one single dissection will not show every point, as some organs must be removed in order to get at others beneath them; thus in fig. 2, all the tracheae, one set of ovaries, the urinary tubes, etc., have been dissected out. It is therefore well to make several dissections, each having in view one or two organs more particularly, and the study of the separate preparations will give the knowledge of the whole internal anatomy. Besides these preparations, many sections, some coarse, and some thin, must be made, (as describer in text-bookis of histology and microsenpic technique), and mounterl for sturly with the compound microscope. Many points in the anatomy of small parts of the body, and of course the histology in general, are only to be learned from such preparations.

The Alimentary Canal and its Appendages. 'The canal traversing the proboscis opens into a pharymx enclosed in a muscular sac, which occupies much of the lower part of the head. The sac itself is nearly round, and is hung in position by five principal muscles, (figs. 4, 5 and 7 ), two dorsal ( $d . m$.), two lateral (l.m.), and a frontal (f.m.) which is really a pair of muscles closely united. A more feeble muscle is also inserted on the lower aspect of the sac. The sac itself is very muscular, and shows two principal layers of muscles, an outer, of longitudinal annular fibres, and an inner, of transverse fibres. The pharyngeal cavity extends obliquely upward in the sac, from front to back, and is much broader than high. The floor, or hypopharynx, is convex ou each side of a median furrow, (fig. 5, hph.) and somewhat resembles in shape the human breast. The convex areas are dotted over with little papillate which posibly may be taste orwans. although I have not succeeded in making out any nervous supply. "The cuticular layer of the hypopharynx is very thick, while that lining the superior wall of the pharynx is, on the contrary, delicate, and is thrown into slight transverse ridges. The suspensory muscles of the pharyngeal sac pierce the muscular layer of the latter, and are attached to its internal wall. At the anterior border of the pharynx is a triangular muscular flap, the epipharymx (fig. 5, ep.) overlying the opening into the proboscis, and serving as a valve to close the latter.

The pharyngeal sac, as is evident from its structure, sterves as a pumping organ to suck the liquid food of the animal through the proboscis, and force it backwards into the digestive canal, the process being as follows: 'The proboscis is umolled and inserted in the nectary of a flower; at this moment the muscles which suspend the pharynx contract, and its cavity is thus extended, creating a vacuum which must be supplied by a flow of honey through the proboscis, into the pharynx. When the latter is full its muscles contract, the valve closes the aperture to the proboscis, and the honey is forced backward into the oesophagus. The pharyns is then again opened and the same process repeated. To prevent the food being sucked back from the oesophagus, it is probable that some of the numerous fibres in the muscular sac near the origin of the former can, by contraction, close its opening, but in any case as the proboscis presents a free tube, and

\footnotetext{
${ }^{1}$ This work should, of course, be done under water, the small glass disl. preparation being pinned to the wax-covercel buttom of a
} 
the oesophagus learls into the elosed alimentary canal, it is evirlent that the former offers the easiest route for a supply to fill the vacuum produced in the pharynx.

The organ just described has hitherto escaped the notice of insect anatomists, and its functions have therefore been conjecturally ascribed to other parts. The so-called "sucking stomach" thus received its name from the earlier writers, and when its structure was better known, and such a purpose negatived, the capillarity of the fine canal of the proboscis, and even a peristaltic action of the latter have been sucgested to explain the power possessed by the butterfly to suck up its food. ${ }^{1}$

At the upper extremity of the pharynx opens the narrow oesophagus and at the lower edge of the hypopharynx the common duct of the sativary glands discharges into the canal of the proboscis at its base. These glands consist of two tubes arising in the base of the abdomen, and passing, with many convolutions, on either sile of the oesophatgur, into

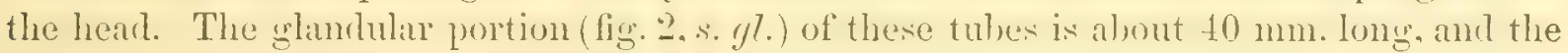
more slender anterior and non-glandular portion, or duct, (s.d.) about $12 \mathrm{~mm}$. The two ducts unite into one in the base of the head; the common duct, as just said, opening below the hypopharynx.

The oesophlagms (oe.) is a slenter and delicate tube leading from the pharynx above, and after piercing the nerve commissure between the brain and the succeerling ganglion, passes straight through the thorax into the abdomen, in the very base of which it opens, above, into the food-reservoir, and below, and a little farther back, into the stomach. The food-reservoir, (f.r.) or so-called sucking stomach, is a large, bladder-like sac, occupying the upper part of the anterior half of the abdomen. Its walls are delicately membranous, well supplied with longitudinal and transverse slender museular fibres, particularly the former. Clothing the upper surfice of the interior, more thickly in the median line, are long hair-like processes of the cuticle (pl. 2, fig. 12), whose points are directed forward, that is towards the neck of the reservoir. These processes have broad corrugated bases and end in long slender tips, appearing therefore, as if formed by being pulled out of the membrane they cover, or as if each were a bunch of hairs clotted together at the tip. Their use is not obvious. The food-reservoir is generally found to contain nothing but air ; but Newport states that it is filled with food after feeding, and as it is not glandular, it probably serves simply as a reservoir for the temporary reception of food. The neck of the reservoir is large, and by the contraction or extension of its muscular fibres, it is evident that food may be easily expelled from, or drawn into, its interior.

Below and just behind the neck of the food-reservoir, the oesophagus opens into the stomach (st.), a straight tube ruming along the ventral region of the abdomen from the base of the second, into the filth segment. Its walls are thick and composed of muscular and glandular layers. The stomach is overlaid with the convolutions of the urinery, or Malpighirm, vessels, (nee fig. 2, m.v.) six in number, three of which on either side unite and open by a short common duct into the posterior eud of the stomach. The urinary tubes are about $90 \mathrm{~mm}$. long. At the end of the stomach begins the small intestine,

IFor the previous literature of the mouth parts in Lepi-
doptera, see Gerstfeldt, loc. cit.; Milne Edwards, Physiol-
ogie; Newport, Phil.Trans., 1834, p. 397; Savigny, Mémoires
sur les Animaux sans Vert., I ; Graber, Insecten, I, 154;
and the general works of Westwood, Burmeister, Siebold,
Kirby and Spence, etc.

Compare also the structure of the pharynx in Diptera and Hemiptera as described by Graber, Insecten I, 316, and Amtl. Ber. Vers. deutsch. Naturforschersamml. München, 1877, p. 187. 
(itcum, i.), a tube about one-quarter of the dianeter of the former, running first hackwards, then upwards and forwark, then turning backwark again, thus making a flattened s. curve in the fifth and sixth segments. The intestine in this course passes to the left of the bursa copulatrix of the female, and of the testis and penis in the male (see figs. 2 and 14, $i$ ). The intestine passes, in the dorsal region of the sixth segment, into the colon, or large intestine (c.), which in some Lepidoptera is expanded anteriorly into a large coecal sac. In the milk-weed butterfly the colon is somewhat pyriform in the female (fig. 2, c.), but is longer and more cylindrical in the male (fig. 14, c.). It is dotted over with numerous little glands of doubtful function. ${ }^{1}$ 'The colon narpows posteriorly and is followerl by a short cylindrical division, the rectum $\left(r_{0}\right)$. The amus $\left(\alpha_{\text {. }}\right)$ opens between the triangular lappets of the ninth segment.

The Haenal Srsteu. The heart $\left(h_{0}\right)$ is a small tube lying immediately under the dorsal wall of the abdomen, and hung in this position by triangular muscular sheets (the alary muscles), which are placed in pairs, apices inwards, on either' side of the heart. 'The walls of the heart contain two sets of muscular fibres ruming spirally in opposite directions. Slight constrictions divide the heart into a number of segments, corresponding to those of the abdomen. Each segment has probably a pair of clefts for the entrance of the blood, but I have not succeeded in clearly making out their exact number.2

In the basal segment of the abdomen, the heart narrows slightly, making the beginning of the aorta ( $a \circ$.$) . This after entering the thorax runs upwards, passing between$ the right and left sets of thoracic muscles, and then under the suture between the mesosentum and scutellum, and expands rather suddenly into a large chamber (ao.c.), which is hung in position by a net-work of fibrous connective tissue. This aortal chamber is somewhat peal-shaped, with the greater dimeter posterior. The forward end bends downwards and again contracts into a slender tube, which runs backwards and downward until it reaches the first part of the aorta, and after passing along the anterior face of this for a short distance, it bends suddenly forward and runs along, and just above, the ocsophagus, passing with the latter into the head and through the oesophageal nerve collar. The aorta then seems to bend upwark, but I have not attempted to trace it beyond this point. ${ }^{3}$ The aortal walls. including those of the chamber, are provided with muscular fibres in spiral layers, as in the heart.

The aorta is very realily demonstrated throughout its whole course, and the chamber forms a conspicuous object in a good longitudinal section; it is therefore very remarkable that its peenliar character ${ }^{4}$ should have hitherto escaped the notice of anatomists. Newport's figure of Sphinx lignstrin represents the arta distinctly following the curve of the

\footnotetext{
1 For the structure of these glands, see Chun, Abhandl. d. Senckenb. Naturforsch. Gesellsch. Bd. x.

${ }^{2}$ Newport (Cycl. Anat. and Phys. 11, 977) states that there are eight pairs of openings in Sph inx ligustri.

${ }^{3}$ Newport (Cycl. Anat. and Phys., II, 978) says of $S p$. ligustri and Vanessa urlicae "the aorta after passing beneath the cerebrum gives off laterally two large trunks, which are each equal in capacity to about one-third of the main vessel. These pass one on each side of the head, and are divided into three branches, which are directed baekward, but have not been traced farther in consequence of their extreme deli-
}

cacy. Anterior to these trunks are two smaller ones, which appear to be joined to the parts of the mouth and antennae, and nearer the median line are two others which are continuations of the aorta. These pass upwards and are lost in the integuments."

* No other case in which any portion of the aorta runs backwards has been described among insects, nor in which it dilates into a chamber. Cornalia MLnografia del Bombix del Gelso. Mem. Ist. Lomb., vi. 4. Milano, 1856) figures a slight dilatation, but no recurving, in Bombyx mori.

${ }^{5}$ Phil. Trans. 1834, pl. Xrv. 
thorax, and with no chamber: and hence at first I thought that the features presenter by Archippus were peculiar to its funily, or perhaps to the hutterlies. I have, however, since dissected Trunsest ITnerer., a sphingid and a noctuid, and found the same conditions as in the Milkweed Butterny, so it is probable they are characteristic of the Lepirloptera, as one would indeed expect from the general uniformity in the anatomy of the group. How Newport in his minute and numberless dissections could have overlooked so striking a feature remains inexplicable, unless we presume that his figure represents what he took for granted to be the case rather than what he saw. The pulsating ventral blood sinus I have not studied in Archippus.

Nervous Srstex. Newport's beautiful monograph of the nervous system in Syphin ligustri renders anything more than a brief description of its main features. as shown in fig. 2, unnecessary. The brain $(\mathrm{b} r$.) immediately overlies the oesophagus, occupring nearly the centre of the head and giving rise to the optic and antemal nerves. The commisures between it and the next or suboesophangal sanglion, forming the oesophageal nerve-collar, are short and stout. From the latter ganglion arise the nerves of the mouth organs. The thorax contains only two ganglia in the perfect insect, two of the original three thoracic ganglia haviug been fused into one during pupation. The first of them, that is the second post-oral ginglion, is the smaller, and nearly round, the next being double its length and oval. The important nerves arising in the thorax are those of the leg pairs, and those of the wings. The latter arise from the nerve cord between the two ganglia.

The second to the sixth abdominal segments each contain a ganglion; these gradually increase in size to the last, which is compound and of considerable size.

The stomato-grastric nerves are not shown in the figure owing to their small size and difficulty of representation. A small ganglion, the frontal ganglion, lies in front of and below the brain hemispheres, with which it is comnected by a recurved cord on either side. Posteriorly it gives off a single median cord, the nervus recurrens, which passes backward over the oesophagus and through the oesophageal nerve-collar. A pair of ganglia also lie hehind the brain hemispheres, connected with the nervus recurrens. The latter runs backward over the oesophagus, innervating it and the dorsal vessel. On reaching the stomach it divides into three branches, which run over and either side of this oriman. Branchlets are also given off to the food-reservoir.

Female Organs of Reproduction. The external opening of the oviduct $(0.0$.$) is sit-$ uated immediately below the anus and hardly separated from it, between the lappets of the ninth segment. It leads into a short oviduct, which near the middle of the seventh segment diviles into two lateral hranches, each of which is ahout as long as the common duct, and each in turn gives rise to the four branches forming the ovaries. These ovarian tubes from their union in the sixth segment run forward almost to the third segment, just above the stomach; they then curve upward and run backwards to the end of the sixth, again curve upwards and pass forward into the fourth segment, when their slender tips become solid cords, gradually unite together, and become attached to the dorwal wall of

${ }^{1} \mathrm{Mr}$. Scudder informs me that in dissections of chrysalids of $D$. Archippus, Vanessa Io and other butterflies, made some years ago, he observcd and noted these peculiarities of the aorta.

${ }^{2}$ Phil. Trans. 1834. 
the segment. This is the course of the orarian tubes hefore sexual maturity. Each tube contains a line of eggs diminishing in size from base to tip, in corresponding degrees of development. As the eggs increase in size, the tubes become more or less spirally coiled, and fill a large portion of the abdomen.

In the roof of the large vestibule on the ventral surface of the abdomen between the seventh and eighth segment, already described above, is the opening of the vagina. The vagina $(v$.$) is a curved canal, with horny walls, which opens into a large and very mus-$ cular organ, the copulatory pouch. This pouch is oblong oval in shape, with a shallow constriction about the midlle, the areatest dianester being posterior to the constriction. The walls are very thick and muscular, and the lining of the internal cavity is covered with conical teeth above, and is elsewhere thrown into numerous longitudinal folds or ridges.

On the upper side of the pouch. and just beyond its hergimmen is a small tube opening into it. After two or three convolutions this tube passes a into the oviduct some distance below its fork; it expands near the middle into a pear-shaped chamber, - the sperm reservoir or spermatheca (sp.).

Besiles these organs are also a pair of tubular glants. and a single one which discharge into the viaduct, behind the orifice of the sperm duct. They are known as the accessory, or colleterial glands. Each of the paired glands has a curious, twisted, somewhat cornucopia-shaped dilatation near its orifice; each gland is about twenty-five mm. long. The single gland is nearly twice as long as the others, and has a corrugated external surface. The three glands lie in coils over the other organs in the seventh and eighth segments. Their function is supposed to be comnected with the formation of the egr shell.

Male Organs of Reproduction. The intermal male organs are very simple in the Lepidopteral they consist (see pl. ". fig. 17. natural size). of a single larece crobular testis, $(t)$, formed by the consolidation of the two kidney-shaped testes of the larva; of two efferent ducts (erose deferentire), e.d., into each of which. shortly hefore their union into the ductus ejaculatorius (d.e.), a single gland ( $g l$.$) opens.$

The compound testis lies in the fifth somite, immediately behind the food-reservoir; the intestine passes to the left of it and its ducts, etc., corresponding to the position of the former in the female. It is supported by the tracheate arising from the fifth ablominal spiracles, five branches from which extend to the testis on either side, and on reaching it divide into innumerable minute branchlets, which spread over its surface (see fig. 18). The diameter of the testis is nearly $3 \mathrm{~mm}$. The efferent ducts arise close together on the posterior face of the testis. They are about $30 \mathrm{~mm}$. long, and $0.15 \mathrm{~mm}$. in diameter, to their junction with the glands. As shown in fig. 17, the ducts seem to lead into the glands, and the basal ends of the latter then continue to the point of union into the ductus ejaculatorius. The glands are tubes about $40 \mathrm{~mm}$. long, and have an average diameter of $0.5 \mathrm{~mm}$; they are somewhat larger at the tip. The portion of the duct between the glands and the ductus ejaculatorius is $10 \mathrm{~mm}$. in length, of the same diameter as the glands, but tapering gradually to the point of junction. The ductus ejaculatorius is about $120 \mathrm{~mm}$. long, and slightly stouter than the first division of the eflerent ducts. It ends in a bulblike expansion ( $p . b$ ) at the base of the penis. 
This latter organ is a dirk, horny, slightly curved tule, ahout $6 \mathrm{~mm}$. in length. The tip expands into a small trumpet shaped mouth, which is twisterl more or less asymmetrically. At rest, the tip lies between, and a little beyond the triangular flaps of the anal somite, just below the anus, and is inclosed in a membranous sheath $(p . s$.$) , to permit of$ its protrusion beyond the borly. This protrusion is worked by two extensor muscles (ep.), one on each side, whose attachments and mode of action will become sulficiently evident by the inspection of fig. 16 .

The ventral arch of the ninth somite sends a process into the abdomen immediately underneath the penis, for the support of the latter, and the attachment of a large bind of muscular fibres (r.p.) which embraces the penis, holds it in place, and accomplishes its retraction.

Time External Male Arnature in tue Lepidoptema. The secondary male organs of the Lepidoptera are constructed on a simple plan, which is modified after various fashions in the different groups, and these modifications are often serviceable as characters of classificatory inportance.

Their typical structure is well illustrated by the Satyrid butterflies, (see the adjoining figure), in which the dorsum of the anal or ninth abdominal segment is produced into a simple terminal hook directed downwards, recalling the telson of Crustacea. The sternum of the same somite is reduced to a narrow, U-shaped piece, which may be called the ventral arch. To this ventral arch are articulated two, more or less pincer-like, clasping organs, termed simply "claspers." As already stated, the anus lies just beneath the hook, and the penis projects helow the anus. Anal cerci are never present in the Lepidoptera.

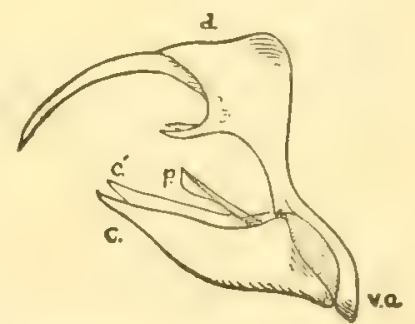

External armature of Satyrus alope, male; $d$, dorsum, and v. a., ventral arch of ninth somite ; l', lenis; $c$. and $c^{\prime}$, right and left claspers.

Remarkably enough, the eighth abdominal somite sometimes closely imitates the ninth. For instance in the yellow butterflies (Pierids), its florsum is produced into a hook exactly like that of the ninth segment; while on the other hand in the subject of this paper, the posterior border of the sternum is extended into two false claspers (figs. 19, 14, etc., f.c.) in close imitation of the genuine organs, except that they are not articulated. ${ }^{1}$

The terminal hook is often bifid, sometimes very long, or at others curiously armed with spines, etc. The clasps are equally various in shape, and armature, and in Nisoniades ${ }^{2}$ very remarkable for their asymmetrical development.

External Male Armature in Arcmipres. In the Milk-weed Butterfly, the hook is entirely obsolete, but the dorsum of the ninth somite projects into two rather triangular lateral flaps, just as in the female, except that they are longer and slenderer. Between the flaps the segment is emarginaterl above. The ventral arch (see fig. 15, at the numeral 9 ) is wider than usual, and sends a stout cylindrical process ( $\mathrm{fm}$.) into the abdomen, for the support of the penis and the attachment of its retractor muscle as already described.

\footnotetext{
1 The real claspers are, presumably, true arthropodan appendages, but the existence of the false claspers sugrests a mere possibility of independent development. For if a joint could arise between the false clasp and its segment, we should have organs indistinguishable from the ordinary
}

claspers, and yet not homologous with true abdominal appendages.

${ }^{2}$ See Scudder and Burgess, Proc. Bost. Soc. Nat. Hist., XIII, 282. 
The claspers are articulated to the ventral arch on either side and above the process. In profile, the clasper shows a rather large rectangular body, with a small triangular projection from its posterior edge above; while lower down there is an inwardly curved stout and hard process, which is continuous with a stout rib on the internal surface of the clasper. 'The lower edge of the clasper is tumid, and in thickness the clasper is here over a third of its width. 'The upper edge is on the contrary only a thin plate. 'The concave side of the process is tumed outwards (see fig. 16), and at its tip), which is black and hard, is a transverse series of file-like ridges, while the inner surface of the process is smooth. Powerful muscles lie in the interior and are attached to the ventral arch. The muscular comnection between the latter and the preceding segment is also powerful. From its structure it seems as if the claspers were probably inserted within the copulatory vestibule of the female, and then presed outwarl against the walls of the latter, the two sexes heing held in this way instead of hy the ordinary pincer-like action of the claspers in most insects.

Yet another apparatus distinguishes the male Danaids among butterflies. A brush or pencil of long delicate hairs lies on either side hetween the eighth segment and the upper portion of the clasper, piercing the membrane between the eighth and ninth segments. These hairs are attached to the bottom of a sac-like sheath (see figs. 14-16 h. s.), which can be everted at will, as the drawn in finger of a glove may be extended by blowing into the interior, thus projecting the hair pencil out beyond the tip of the alrlomen. A muscle $\left(r . m_{0}\right)$ is attached to the bottom of the sheath and runs downward to the anterior ventral erge of the seventh segment; this muscle retracts the pencil into its ruiescent position. The uses of this apparatus are unknown; a somewhat similar one has been noticed in some other Lepidoptera, but needs anatomical study.

The false claspers, though immovalie, have a greater resemblance to the ortinary form of genume claspers, than do the latter themselves in Archippus. They are formed by the production of the lateral edges of the sternum of the eighth regment. In shipe they are oblong and the posterior edge is emarginate, leaving at the comers two processes or teeth of considerable size, the upper of which is rectangular ant the lower rather trimnerular. Both are strongly incurved. The stemm between and below the fitse claspers is deeply emarginated and its edge carries out the regular sweep of the lower edge of the false claspers. The edge is rendered stiff by its shape, which in section is much like that of a T-rail of a railroad.

Resphatomy Apparatus. The air tubes, or tracheae, present no peculiar features in the Lepidoptera. The very short main trunk into which the stigmata open soon divides into branches which run to the special organ to be aerated and there often branch abruptly into a great number of fine tubes, as shown in the tracheae of the testis (fig. 18). Air sacs such as are found in the Orthoptera, etc., do not occur. The stigmata of the first pair lie in the sides of the prothorax behind the prothoracic lohes. Succeding pairs of stigmata are situated in the pleurae of the first seven abdominal somites, the pair in the first segment being rather hard to find owing to the folds in the integument of its sides. 


\section{EXPLANATION OF THE PLATES.}

\section{Plate 1.}

Fig. 1. Lateral riew of Danais Archippus, female, $\times 6$.

Head. a., Antenna; o., Occiput; $c l$., Clypeus ; mx., Proboscis; $p$. , Labial palp.

Thorax. I, Pro-, II, meso-, III, meta-thoracic somites. s., scutum; sm., scutellum; psm., post scutellum; epm., epimerum; eps., episternum; cx., coxa ; tr., trochanter; $f$., femur; these parts are marked ${ }^{1}{ }_{2}^{2}$, or $^{3}$, as they belong to the pro-, meso-, or metathorax, respectively. Sp. ${ }^{1}$, first spiracle; $w_{.}{ }^{1}$ and $w_{.}{ }^{2}$, fore and hind wings.

Ardomex. 1 to 9 , the nine somites of the abdomen; $s p .{ }^{8}, s p .{ }^{8}$, second and seventh abdominal spiracles i.e., the spiracles of the third and eighth pair. $\times 6$.

In this figure the membranous portions of the integument are dotted.

Fig. 2. Lateral interior view ( $\times 6$ ), showing the internal organs in their natural relations, after the removal of the right half of the integument, together with the tracheae, and fat-body. I to III, somites of the thorax; 1 to 9 , of the abdomen.

Almextanx Canal and Appendages. ph., pharynx; s.d., and s.gl., salivary duct and gland of the right side; oe, oesophagus; f.r., food reservoir; st., stomach; $i$, small intestine; $c$, colon ; $r$, rectum ; $\alpha$., anus; $m . v$. malpighian vessels.

HaEmal Sxstem. h., heart or dorsal vessel; ao., aorta ; a.c., aortal chamber.

Nervous Srstem. (Dotted in the figure). br., brain; $g \cdot{ }^{1}$, sub-oesophageal ganglion; t.g., compound thoracie gangla; $\alpha . g_{.}{ }^{1}, \alpha \cdot g_{*}^{4}$, first and fourth abdominal ganglia.

Female Reproductive Orgats. c.p., copulatory pouch; $v$., vagina; 0. , oviduct, and 0.0 , its external opening; r.ov., base of the right ovarian tubes turned down to expose the underlying organs; $1.0 v$., left ovarian tubes in position, and ov.c., their termination in four cords; $s p$., spermatheca; a.gl. ${ }_{0}^{1}$, part of the single accessory gland; a.gl. ${ }^{2}$, one of the paired accessory glands; only the base of its mate is shown. Other letters as in fig. 1 .

Fig. 3. Front view of head, $\times 10$. oc., compound eyes; $\alpha$, antennae; $c l$, clypeus; $l b$., labrum; md., mandibles; $m x$., base of proboscis; $m x . p$. , tubercle representing maxillary palp; s.g., cheek; or., orbit.

Fig. 4. Interior view of the bottom of the head, the top having been cut awny, showing in the middle the pharyngeal sac with its fire muscles - the frontal, $f m$., the dorsal pair, $d m$., and the lateral pair, $I m$.; $c l$., clypeus; cor., cornea of the compound eye (the left eye is not drawn); oe., oesophagus; $p m_{.,}$one of the large muscles which move the labial palp.

Fig. 5. Horizontal section of head through the pharyngeal sac. ph., pharynx; hph, hypopharynx, showing the papillae dotted over it; f.m., frontal muscle; $m$., labial palp muscles; s.d., salivary duct.

Fig. 6. A section through a bit of wing and a scale; and fig. 6a, the same, the section passing through a scale pedicel; cu., cu. ${ }^{1}$, the upper and lower cuticular membranes of the wing. With $\frac{1}{15}$ inch objective.

\section{Plate 2.}

Fig. 7. Longitudinal section through the head giving a view of the interior of the left half; $m x$, the left maxilla whose canal leads into the pharynx; $h p h$, floor of the latter showing some of the papillae of taste; oe., oesophagus; cl., clypeus; ep.v., epipharyngeal valve; s.d., salivary duct; $d . m$. and f.m., one of the dorsal and the frontal muscles which hold the pharyngeal sac in its position.

Fig. 8. Tip of the proboscis showing the arrangement of the cuticular rings and blocks, with the interspersed papillae. With $\frac{1}{4}$ inch objective.

Fig. 9. Longitudinal section of proboseis; the canal, $c$., is shown above; lower down the trachea, $t r$, and the nerve, $n$; while the diagonal muscles, $m$., overlie them. These are spaced somewhat wider than in nature, for the sake of clearness. 'The right edge is the outer one. $\frac{1}{6}$ inch objective.

Fig. 10. Transverse section of proboscis, showing the two maxillae united by the dove-tail joint, and forming the interior canal, $c_{.}$; the air tubes, $t r . ; n$., nerve; $m_{\text {. and }} m_{.}{ }^{2}$, the two sets of muscles, more or less displaced in the cutting. $\frac{1}{6}$ inch objective. 
Fig. 11a, b, $c$ and d. Sections through the integument of the proboseis, showing the different shapes of the cuticular elements and the lamination of the cuticle, cu.; hy., hypoderm or matrix. Fig. 11e shows two of the cuticular elements separating from each other. $\frac{1}{15}$ inch objective.

Fig. 11e. Cuticle of posterior region of the proboscis from outside; each cuticular block being here prolonged into a spine. $\frac{1}{15}$ inch objective.

Fig. 12. Cuticular processes clothing the upper central portion of the food-reservoir. The longitudinal and transverse muscular fibres are seen beneath. $\frac{1}{6}$ objective.

Fig. 13. Lateral view of the tij of the abdomen in the male; 7,8,9, seventh, eighth and ninth somites of the abdomen; $p$., penis; f.c., false clasper, overlying the real clasper, $c$., which is shown uncovered in fig. 13a, by the removal of the whole 8th somite; h.s., hair sheath torn open above, showing the protruding bundle of hairs; $m$, muscle. $\times 8$.

Fig. 14. Lateral internal view of the male abdomen, showing the genitalia in situ; $t$., testis; v.d., the double vas deferens; d.e., ductus ejaculatorius; p.b., interior view of the penis bulb; p.s., penis sheath; r.p., retractor penis; $\mathrm{m}$., internal process of the ninth somite affording the attachment of the retractor penis; the posterior wall of the process is ent away; co, clasper; f.c., false clasper; other letters as in fig. 2. $\times 8$.

Fig. 15. Interior of the exoskeleton of the seventh, eighth and part of ninth abdominal somite, male. The figure 9 is placed on the ventral arch of the ninth somite, which sends forward the process, $p r$., for the attrehment of the retractor penis as shown also in the preceding figure. The dotted surface represents the membrane, connecting the eighth and ninth somites. This membrane is pierced above by the hair-bundle; h.s., hair-bundle sheath; r.m., its retracting muscle. $\times 8$.

Fig. 16. Horizontal section through the tip of the male abdomen showing the penis, $p$, and its extensor and retractor, $c . p$., and $r . p . ; p . b$., penis bulb; $p . s$. , sheath; d.e., ductus ejaculatorius; $h . b$., cut through hairbundle; s.m., intersegmental muscles. $\times 8$.

Fig. 17. Male organs, natural size; $t$., testis, with its supporting tracheae, $t r_{0}$; v.d., vas deferens; $g l$., gland; d.e., ductus ejaculatorius.

Fig. 18. Portion of testis showing the distribution of the tracheae of the left fifth abdominal spiracle. The branching of only one of the main tracheal stems is figured. 


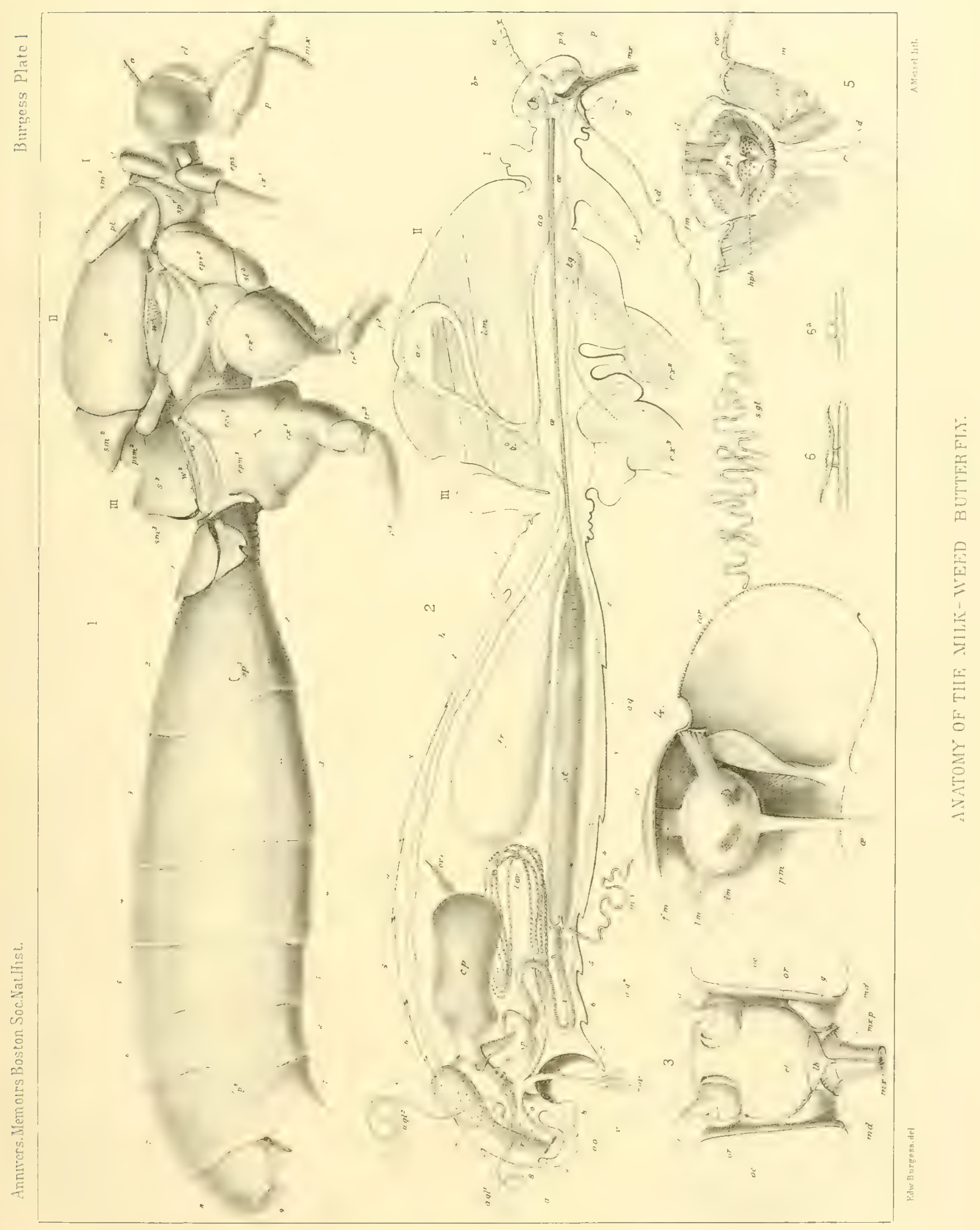





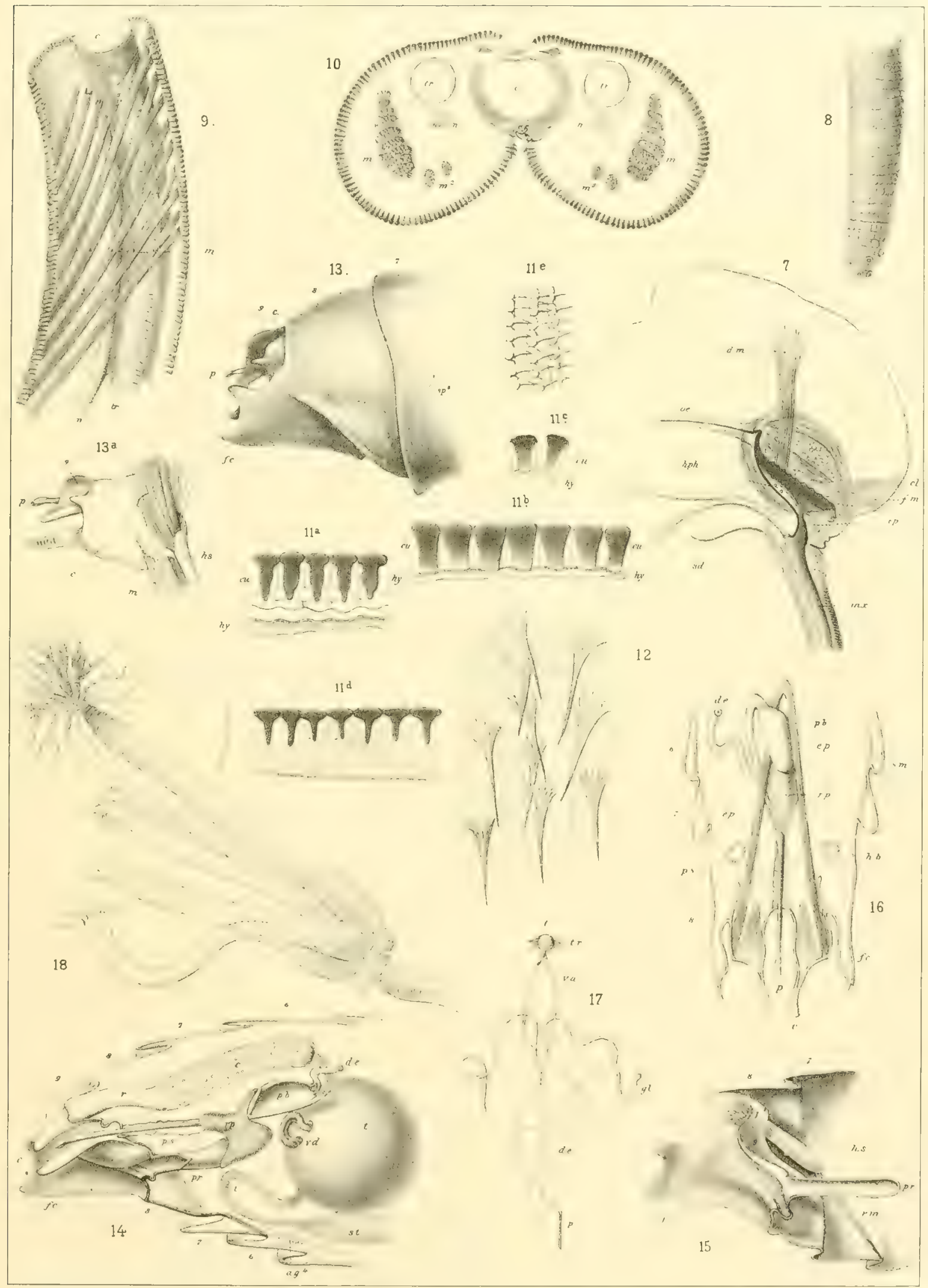




$$
\text { , }
$$




\title{
THE DEVELOPMENT
}

OF A

\section{DOUBLE-HEADED VERTEBRATE.}

\author{
By SAMUEL F. CLARKe, Рн.D.,
} ASSISTANT IN BIOLOGY, JOHNS HOPLINS UNIVERSITY, BALTIMORE, MD.

BOSTON:

PUBLISHED BY THE SOCIETY. 1880 . 


\section{The Developinent of a Double-Headed Vertebrate.}

\section{By Sameel F. Clatrke, Pri.D.}

THE mode of origin and development of duplex monstrosities in the vertebrates is one of those interesting questions so beset with difficulties that it is seldom we can gain any direct observations with which to test the existing theories. Any one who examines a considerable number of these double forms cannot fail to notice the varying degrees to which the duplicity is carried. It is generally agreed that two beings who are in the slightest way comnected by a band of flesh represent one extreme of the series of double monsters, - as, for example, the Siamese trvin:, - while the other extreme consists of a nearly normal form in which there are but the slightest indications of duplicity. Between these extremes one finds all degrees of variations from the normal. One of the most generally accepted methods of explaining the origin of these monstrosities is by supposing that two egrgs are fertilized and developed at the same time. This theory would account very well for ordinary twins, or for such as the celebrated Siamese twins, where the physical band is slight; but for other forms, in which the duplicity is but partly expressed, this theory does not answer so well. According to this view, the origin of such a form as is represented in plate 1, fig. 5, would be explained as follows: Two eggrs fertilized at the same time had been thrown together, remained united, and developed in such a way as to form the two-headed monster represented. Now this satisfactorily accounts for the anterior portion only, - the two heads. Why there should not be also two bodies and four pairs of limbs as well as two heads is explained (?) by saying that the two ova became united in such a way as to prevent the development of more than the ordinary arrangement posterior to the head. How is it, then, that the part of the animal which is single is so regularly and symmetrically developed? This would seem highly improbable if two eggs at a very early stage had been thrown together. Each egg, of course, has the tendency to develop one symmetrical organism, like that from which it came. Now, when two eggs become united, it does not seem very reasonable to suppose that these tendencies will remain intact in certain parts of the united mass, so as to produce two heads or two tails, etc., while in other parts we find a perfectly normal development. To account for this, we must suppose that either a part of the mass of one egre loses its tendency to develop and takes no active part in the progressive changes, being merely absorbed by the protoplasm of the other egg, which has retained its tendency or power to develop, or that both portions have become intermingled, and in this enlarged mass there 
exists, either as a newly formed or as a product of the union of the two individual tendencies, the ability to develop one normal form. Still less probable does this reem when we consider the forms in which duplicity is but rery slightly indicated, fas, for example, where there are two thumbs on each hand. In this case one would be forced to believe that these small appendages were the only expression of that strong tendency of each ovum to produce a being like the one from which it had its origin. In other cases where the duplicity is much more complete, as in the Siamese twins, it may be supposed that the embryos did not come in contact until after they were considerably advanced. This would seem somewhat more reasomable. Moreover, if two ovil are mited intimately and then develop into a monster but slightly duplex, we should expect to find the animal of unusual size. This, however, is very often not the case. In the Ichthyopsida, and especially in the Teliostr, where many egges are hatched at the same time, and among which specimens of duplicity are not uncommon, these latter are often, though not always, smaller than their hrothers of the same age. This would reen to indicate that, in some instances, duplex monstrosities arose from the union of two eggrs, while others came from a single egg.

The idea that one egg may give rise to two animals, or to a duplex form, has also been often advanced. This theory would account for all such forms of every degree, and this is certainly a strong point in its favor, as there exists a complete series between the extreme former, by supposing that there existed in some eggs an unusual amount of developmental activity, so that, instear of developing in the regular way, it pushed beyond its bounds and formed additional parts. By this theory one can explain all cases of duplicity by supposing a greater or less degree of extra derelopmental power. A small anomit might produce only a secondary thumb, while an extreme amount might give rise to a nearly or quite complete form like itself.

This theory that double monsters originate from one egr has better support than any other. In the first place, as there is a continuous series of these forms from one extreme of duplicity to the other, a theory that shall be satisfactory must explain them all. That is true of this theory. Secondly, these forms are not (so far as I have had a chance to investigate) any larger, and not often so large, as other individuals borm at the same time. Were they the product of two eggs this would probably not be the case. Thirdly, all double monsters in which the bodies are sufficiently developed are both invariably of the same sex.

A very interesting case in connection with this question in Teratology came under my notice in the spring of 1879. I had in ny aquarium a large collection of between two and three thousand eggs of Amblystoma junctutum, of which I was studying the development. Examining great numbers of them daily, I chanced to find one in which the medullary folds were nearly completed, but in which the latter had not mited at the cephalic end, and in which they appeared so much elevated and romeded at their anterior ends, with well defined instead of ordinary vague outlines, that I kept the egge by itself and watched its development. When first found it was in about the comdition represented in plate 1, fig. 1. Figs. 1 and 2 are from menory. The original sketches from life were unvittingly destroyed. Having watehed the development and made sketehes of the embryo my memory is very clear on the subject; so that, while it is much to be regretted 
that the original sketches are gone, I feel that the two griven are accurate in all the essential points. I have also given tiro figures froni life of normal development at the same stages for comparison. As the medullary folds clesed in, they failed to unite along a certain part of the thickened cephalic end. Then each free portion of the medullary folds developed a perfect head, which at first partly uniterl, gradually became more so, until they were connected throughout their entire lengths. Posterior to the heads, however, there are no indications of duplicity. There is but one body with the rearular appendages and cloaca. One of the heads, the right, is larger than the left, and somewhat more in a direct line with the body than the smaller hearl of the left side. Each head has a pair of well-formed eyes and a mouth. The branchiae of the right head are quite normal; those of the right side of the left head are unusually small and crowded down by the branchiae of the left side of the right head; the brimchiate of the left side of the left head are abnormally large, sufficiently so to make good the want of size of those of the right side. The right head is much nearer the plane of the body than the left, as will readily be seen from the position of the eyes and mouth. The smaller head, however, is so twisted, or rotated, that its left side is in about the same plane as the ventral side of the body. Having reached the stage indicated in figs. 5 and 6 , the animal died.

The interesting point in this observation lies in the fict that a two-headed monster, with one regularly symmetrical body, was developed from one egg, and that the anterior portion of each medullary fold gave origin to a head.

It is a point in favor of the theory of a tendency of singleness toward duplicity; that is of one egg having a tendency to develop into two animals, more or less completely.

It is quite surprising to find that the portion of each medullary fold which ordinarily gives rise to a definite half of the head, with its sense organs and appendages, should, in this case, have developed a perfect head with paired eyes and ears and branchiae.

\section{EXPLANATION OF PLATE.}

Figs. 1-4. All the figures enlarged to thirty diameters.

Fig. 1. Dorsal view of the earliest stage in which the embryo of the monstrous form was observed. $A$, the space separating anterior ends of medullary folds, and across which they never united; $m f$, medillary folds; $m p$, medullary plate; $m r$, medullary groove.

Fig. 2. A later stage of the same embryo. A indicates the region along which the folds remained separate. Other letters as before. Figs. 1 and 2 are from memory; see above.

Fig. 3. An embryo of same stage as fig. 1 ; but developing normally. Letters as before. Here the medullary folds have united anteriorly. From life.

Fig. 4. An embryo in corresponding stage with fig. 2, showing normal development. In this there is no separation between the cephalic portions of the medullary folds. Letters as before. From life. 
Figs. 5, 6. Figures from life. Enlarged twelve diameters.

Fig. 5. Dorsal view of the double monster. $m$, mouth of right or larger head; $m^{\prime}$, mouth of left or smaller head; $e b$, left eye of larger head; $c a$, right eye of larger head; $c c$, outline of cranial cavity as externally indicated; $b r$, branchiae of right side of larger head; those of the left side of larger head are not marked, to avoid confusing the figure; $a$, anterior limb of right side; e $a^{\prime}$, right eye of left or smaller head; $b r a^{\prime}$, branchiae of right side of smaller head; $b r b^{\prime}$, branchiae of left side of smaller head; $a l^{\prime}$, anterior limb of left side; $s c$, median line and indication of spinal column. It is worthy of notice that there seems to be externally no connection between the smaller head and the spine. $c f$, caudal fin.

Fig. 6. Ventral view of the same. $e b^{\prime}$, left eye of left or smaller head; $p l$, posterior limb; $c l$, cloaca. The figure is not completed posteriorly, as the structure of these parts is fully shown in fig. 5 . Other letters as in fig. 5 . 


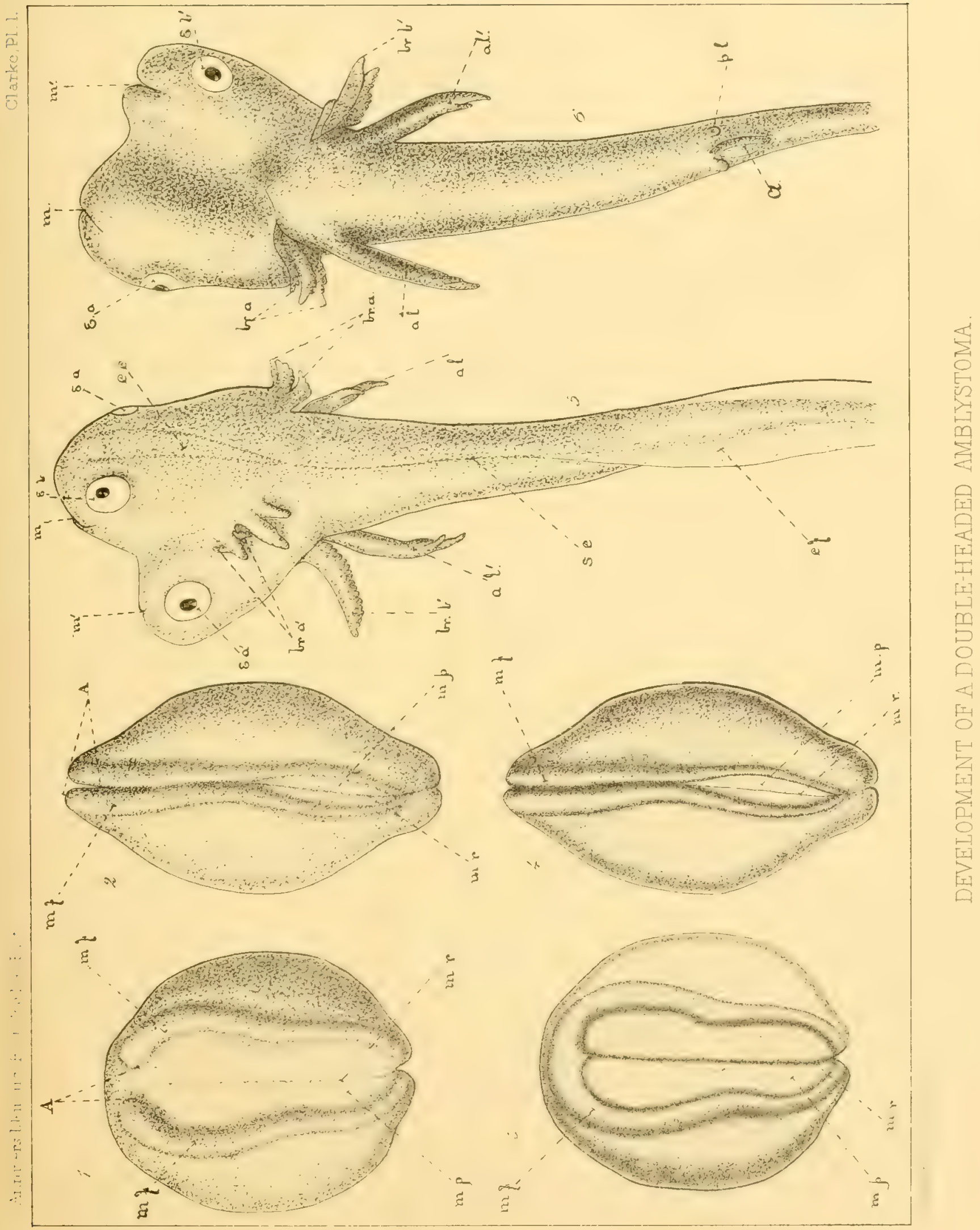


1830. ANNIVERSARY MEMOIRS OF TIIE BOSTON SOCIETY OF NATORAL HISTORY. 1880.

\title{
STUDIES ON THE TONGUE
}

\author{
REPTILES AND BIRDS.
}

Bx CHARLES SEDGWICK MINOT.

BOSTON:

PUBLISHED BY THE SOCIETY. 1880. 


\section{Studies on the Tongue of Reptiles and Birds.}

\section{By Charles Sedgitick Minot.}

THE following paper consists principally of a description of the soft parts of the tongue of the moccasin snake, Ancistrodon piscivorus. I have added some observations made for comparison, upon the tongue of the rattlesnake, Crotalus durissus, our common garter snake, Eutuenir sertutis, also Chumaeteon ditepis, and Ameiva surinamensis, and finally the mocking bird, Mimus polyglottus. The immediate object in view was to investigate the muscles of the ophidian tongue; the other observations reported are therefore incidental only, which explains their fragmentariness.

For my material, I am especially obliged to Dr. S. W. Garman, the curator of the herpetological collection of the Museum of Comparative Zoology, whose kindness I have the greatest pleasure in acknowledging. I am also indebted to Prof. Semper of Wiirzburg, to Prof. Hyatt and Mr. Van Vleck of this Society, and finally to my brother, Wm. Minot, Jr., for valuable specimens. I am glad to have this opportunity to thank them. To the kindness of Dr. H. P. Bowditch, I owe the opportunity of carrying on these researches in the physiological liboratory of the Harvard Hedical School, where I enjoyed every convenience for histological work.

The tongue of reptiles has been comparatively little studied; most of the papers, which deal with its anatomy, are thirty or more years old, and there is no published investigation, so far as I am aware, upon its microscopic anatomy and histology.

The most accurate paper I have found is that by Duvernoy $(\nabla)^{1}$, published in 1830 , and supplemented by a second memoir (vi) which appeared in 1832. The same author incidentally gives some further observations on the lingual muscles in an article on the poison glands of snakes, ( $\nabla \mathrm{VI})$. The principal article besides these, is that by Dugès, (III) contained in the Annules des Sciences Naturelles for 1827. Dugès' experiments and observations on the function of the ophidian tongue, as an organ of touch rather than taste, are particularly valuable, and may be easily confirmed. A paper by Bendz (I) dated 1843, also deserves special mention, on account of its valuable descriptions of the glossopharyngeal and hypoglossal nerves of reptiles.

The Roman numerals refer to the bibliographical list at the end of the article. 


\section{MINOT ON THE TONGUE}

\section{Anatomy of the Snake's 'Tongue.}

The mouth of snakes is a spacious cavity leading into the wide oesophagus. Upon its lower floor, a short distance behind the anterior end of the mandibles, are two openings in the median line; one, the anterior, leads into the sheath of the tongue; the other immediately behind the first, is the rime glottidis. The surfice of the floor has numerous longitudinal folds, which partially disappear when the mandibles are divaricated. Over the trachea there is a ridge in the floor of the mouth, which is also flattened out when the jaws are pulled apart laterally. By these means the extension of the inelastic epithelium is provided for.

A vertical transverse section, cut 1 , through the opening of the trachea, shows the relative size and position of the parts. The folds of the buccal epithelium are each sup-

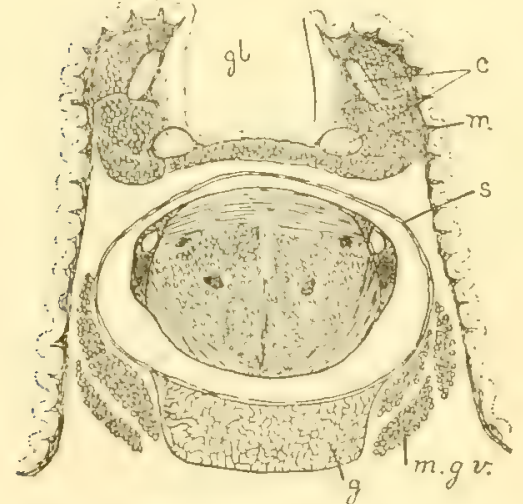

Cut 1. Frontal ceetion through the Fima glottidis and Jingual sheath of Eutaenia serta-

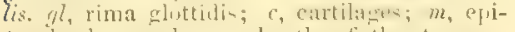
tricheal mu-cle; sheath of the trintre; ported by an extension of the fibrous submucosa, the epithelium itself consisting of beaker cells. The folds cease abruptly at the entrance of the glottis, $g l$, and the height of the epithelium rapidly diminishes. Two cartilages, $c$, lie on either side of the rima, which is also surrounded by longitudinal muscular fibres, arranged in seven bundles, one underneath, and three on each side. I could find no trace of circular fibres. 'The sheath, $s$, of the tongue follows immediately underneath the muscle, but in my sections has been pressed away in mounting. It is more than twice the diameter of the rima glottidis, but further back the trachea and the lingual sheath are of the same diameter. In the interior of the sheath lies the tongue, at this point entirely free. Underneath the sheath is a very large gland, $g$, which I have seen in Eutaenia only. I overlooked it at first, and cannot therefore say, whether it occurs in Ancistrodon or Crotalus. As far as I am aware, no similar glands have heen previously noticed in the Ophidia. It extends for a considerable distance along the median line. Further observations are necessary to determine whether it is homologrous with the sublingual glands of other vertebrates. On either side are the cut ends, $m . g \cdot v$., of $\boldsymbol{M}$. genio-vaginii, the fibres being united into three bundles on either side. The $\boldsymbol{M}$. genio-tracheales and retractor tracheae do not appear in this section, the former being too distant laterally, the latter not extending so far forward.

The tongue, as a whole, may be said to consist of three parts:- 1 , the free part forked in front; 2, the base, or attached portion, lying under the trachea, and connected with the hyoid cornu; 3, the sheath, into which the free part can be withdrawn. The following points must be mentioned, because they have hitherto been either overlooked, or insufficiently described. If the tongue and sheath be cut out, they appear as in fig. 1, which represents the tongue of the rattlesnake, Crotalus durissus. The same figure shortened by about three-quarters of an inch, would correctly represent the tongue of the moccasin. The distance to which the tongue is free, is shown by the pigment on its dorsal surfice; the dark color shines through the sheath, but does not 
extend behind the point $a$, where the tongue and sheath unite. Three pairs of nerves enter the tongue, each being accompanied by an artery. The first, $A$, goes to the sheath a short distance in front of the attachment, $a$, of the tongue; the second, $B$, enters about the same distance behind the attachment as the nerve $A$ before it. The third, $C$, enters about half way between the point, $a$, and the posterior extremity of the tongue. Its point of entry marks a division line in front of which the tongue has both longitudinal and transwerse muscles, fig. 10, and back of which it has only longitudinal fibres, fig. 11. In the latter region the fibres form two distinct bundles, separated at first by slight depresions above and helow, which deepen posteriorly until they finally meet, forming a fissure, which divides the two muscles, c. gl., the cerato-glossi, one for each hyoid cornu.

The upper half of the free portion of the tongue is somerhat expanded, and is marked off from the lower surface by a shillow longitudinal furrow on either side of the tongue. These furrows face downward, and extend from the level of the fork half way or more to the point of attachment.

When the tongue is extended, the point of attachment moves forwards, and the free part of the tongue lengthens. It is probable that, when the tongue is retracted, the nerves are thrown into sinuosities, which are straightened out when the tongue is exserted. This disposition occurs in other nerves in snakes, to allow for the distension of the part, because the nerve-tubes, not being elastic, would be injured by stretching.

In the Ophidia, as is well known, the hyoidean apparatus of cartilages and bones is reduced to a single cartilaginous piece, consisting of a thicker median part often with an anterior spine, and of two unusuilly long thread-like comua, to which the ceratoglossal muscles are attached. In the amniote vertebrates, and also in the Amphibia, there are usually numerous distinct muicles differentiated in the intermandibular area. Of these muscles, the mylo-hyoid, genio-hyoid, genio-rglossus, sterno-hyoid, omo-hyoid, and costohyoid are the most constant, but in the snakes they are all fused to form a single uninterrupted layer. Dugès, it is true, figures and describes several distinct muscles, but Duvernoy $(\nabla)$ who makes no mention of Dugès' earlier paper, found a single layer, extending from the transverse processes of four or five of the anterior vertebrae, and from the anterior ribs, downwards over the whole intermandibular region. Dumeril and Jacquart (IV) state that the fibres from the ribs are continuous with $\boldsymbol{M}$. obliquus internus; they figure (IV, plate 20, fig. 2, and plate 21, fig. 3) that connection in the boa. My own observations entirely agree with those of Duvernoy. The layer is quite thin, and separated from the ectoderm by the dermis only. Its fibres run, 1, transversely between the anterior ends of the mandibles; 2 , from near the anterior ends of the mandibles to the hyoid cartilage; 3 , from the hyoid to the ribs and vertebrae; 4 , from the posterior portion of the mandibles to the vertebrac. Different parts of this layer, therefore, serve to draw the mondibles together, to protract and retract the hyoid cartilage, and to lower the under jaw.

It is interesting to find a whole group of muscles represented only by a single unbroken layer. This is perhaps an instance of arrested development or more properly reversion, consequent upon the reduction of the shoulder girdle and the visceral skeleton. Vetter (xIV) has shown that in the selachians, there is a constrictor superficialis, which in its 
simplest known form resembles to a striking extent the disnuition I have just described in the snakes. According to the view that the lower jaw is a modified visceral arch, an mportant part of the mandibular muscles. must be modifications of the $\boldsymbol{M}$. constrictor superficialis; - a reversion, therefore, seems possible. It must, however, be further assumed, that the longitudinal ventral muscles ${ }^{1}$ are also fused with the general muscular layer. I could not satisfy myself that any fibres were attached to the base of the tongue, certainly no fibres enter the tongue itself. I am therefore unable to confirm Dugès' statement that there is a distinct muscle homologous with the genio-glossus.

Underneath (ahove) the general linger just dercribed, are four distinct pairs of muscles, all of small size. First, the genio-raginii. ruming from the front ends of the mandibles to the sides of the sheath, along which they pass on to the attached part of the tongue, extending some distance backwards. A transverse section through the sheath shows that the only muscular fibres it contains belong to these muscles. A section through the base of the tongue shows them lying at the sides, but without connection with the proper lingual muscles. Second, the genio-tracheal, also arising from the mandibles, but further back, and running obliquely backwards and invards to be inserted into the trachea, some distance behind the glottis. Third, the retractores tracheae, inserted above and in front of the grenio-tracheal muscles and ruming obliquely backwards and outwards. Fourth, the epi-tracheal muscles, short longitudinal bands placed laterally and ventrally upon the trachea, immediately behind the glottis (cf. cut 1). Of these four muscles, the genio-vaginii are the only ones directly concerned with the movements of the tongue.

The sheath of the tongue is lined by a continuation of the buccal epithelium, and has a fibrous tunica propria. As already mentioned, the only muscles of the sheath are the longitudinal genio-vaginii.

Transverse sections which are now to be considered, enable us to study the disposition of the muscles and tissues of the tongue.

Such a section, taken a short distance behind the fork of the tongue, at the level of the line 7 , in 11. 1, fig. 1, is represented in fig. 7. The section is limited by an epithelium, supported by a fibrous submucosa, which is thickest on the upper and lower surfaces, and least developed at the sides, but is nowhere sharply limited against the underlying connective tissue. This last is distinctly adenoid, being formed of fibres, so disposed as to make a mesh work of fusiform interspaces; among the fibres are scattered, first, large numbers of small, round, darkly stained nuclei; second, a smaller number of paler granular nuclei, three times the size of those first named; third, ramified pigment cells, most numerous dorsally, and sometimes entirely wanting on the ventral surface; some of these cells appear to send their processes in between the epithelial cells. In parts of some preparations, I have observed around each small nucleus, a clear space, which I consider the cell body, marked off by a distinct outline, which I regard as the cell wall. The cell closely resembles the red blood globules. An irregular granular cell body is sometimes distinctly visible around the larer nuelei. Finally the tissue contains numerous vascular spaces. The adenoid tissue is bounded internally by the common fibrous sheath of the

\footnotetext{
1 In Selachiaus the coraco-aruales, coraco-hyoidecus and coraco-mandibulare.
} 
muscles, which lie closely compacted in a continuous core. The sheath is composed of connective fibres, ruming transversely but irregularly, crossing one another at slight angles, and not united into bundles. From the common sheath arise fascix and partitions of comnective tissue, which extend around the single muscles, and in between the fibres and bundles of fibres, of which they are composed.

The muscular fibres are long, and their striation very distinct. In the preparation now under examination, they show no tendency to unite in bundles, differing in this respect not only from the other muscles of snakes, but also from the lingual muscles of Ameiva, Chamaeleon, Mimus, and mammals. In some sections through a retracted tongue there appears a slight tendency to form bundles of filnes. In transverse sections it can be very plainly seen, that the sarcolemma is well developed, that the "Grundsubstanz" is pale and transparent, and that the darkly stained fibrillulce are ench entirely distinct, and scattered irregularly, though always tending to unite in fibrillre, and sometimes plainly so united. The nuclei are about the same diameter as the fibrillae. They occupy varying positions inside the fibre, but rarely lie in the centre, and never, so far as I have observed, against the sarcolemma.

The muscles of the tongue are five:-Longitudinal, 1, Ceratoglossi. 2, Lingualis. Transverse. 3, Transversus superior. 4, Transversus inferior. 5, Verticalis.

The ceratoglossi, c.gl, are inferior; the lingualis, $l$, superior, as is also the transversus superior, tr.s; the verticalis, $v$, is median; the transversus inferior, tr.i, is lateral, but in the posterior part of the tongue, fig. 10, lateral and inferior.

The muscular tissue is abundantly supplied with blood vessels, which run parallel to the fibres, and are for the most part about half their diameter. The vessels have an elastic fibrous tunica propria, and endothelial intima. In some places, where the larger arteries have been cut through, the endothelium is shown in section with perfect distinctness, fig. 13. The thin endothelium is quite pale, with few granules and pale oval nuclei, over each of which the endothelium is thickenerl or bulging. The elastic coat is thick and darkly stained; it contains annular connective fibres, and small, round, darkly stained nuclei.

In figs. 7 and 8 there appears two pairs of nerves $B$ and $C^{\prime}$. I think $B$ is probably the lingual nerve; $C^{\prime}$ is the hypoglossus. $B$ is accompanied by an artery, and considerable loose connective tissue. $C^{\prime}$ lies in the midst of the ceratoglossal muscle. Each nerve is inclosed in a fibrous sheath, the neurilemma, and cousists entirely. of medullated fibres, in sections of which the three component parts, axis-cylinder, medullary sheath, and Schwann's sheath, all appear very plainly, fig. 4.

The epithelium extends of course only over the free part of the tongue. Near the point of attachment, the epithelium resembles that of the sheath of the tongue, being distinctly divided into a mucous and horny layer, and is of nearly uniform thickness and character upon all points of the section ( $c f$. fig. 9). The horny layer extends with certain exceptions over the whole of the tongue, but in no part of it is the cellular character of the layer so much obscured, as is the case when the cornification is complete, as upon the tongue of Mimus. In sections through the middle of the free part of the tongue, the epithelium presents several characteristic peculiarities, fig. 8. The corneous layer is interrupted at the furrows, $F$. The mucous layer is much thimer on the ventral than 
on the dorsal surface; it is especially thickened in the merlian dorsal line, again just over the upper and outer corners of the muscular core, and in the furrow. Still further forward there are also two thickenings, fig. 7, on either side below the furrow. As these thickenings all appear upon many successive sections, they must each correspond to a longitudinal ridge. Along the ridges and the two furrows, the corneous layer is represented by a stratum of somewhat flattened cells. The main thickness of each ridge is oceupied hy large polyonal cells, which in the hasal part, become cylinder-cells, and are there mingled with smaller cells with smaller nuclei. Thus, on the inner surface of the epithelimm, there are seven longitulinal ridges, distinguished by their histological character. As the thickenings in the furrows resemble the ridges, except in their position, it seems to me correct to call them ridges also, — making nine in all, as follows : - three dorsal, two in the furrows, four lateral below the furrows. None of these ridges extend upon the forks of the tongue.

A short distance behind the fork, the epithelium on the under side assumes a follicular character, the corneous layer becomes very thin, while the mucuous increases in thickness, fig. 14. The cells of the middle portion are quite distinct, and have polygonal outlines; they are of two kinds, one smaller, with nuclei of the usual character, the other larger with clear vesicular nuclei. The basal or follicular portion consists of much smaller cylinder cells, some with pale oval, others with long darkly stained nuclei.

Upon the base of the forks the epithelium, fig. 15, has the general character shown in fig. 14 , except that the middle layer of polyronal cells is more distinctly separated into an outer and inner structure, the cells of the former heing flattened. The follicles partially disappear a short distance from the base of the fork.

The muscles of the tongue are all intrinsic, excepting the ceratoglossi, and are five in number, counting the paired muscles once only. They all lie in close proximity to one another, forming a continuous flechy mass, the muscular core, occupying the centre of the tongue, and invested by a common fascia or sheath, into which the muscular fibres are inserted. The general appearance in transverse sections has been described above.

The courses and proportions of the various muscles can be most readily followed upon a series of transverse sections, figs. 5-11. Fig. 5 is the most anterior, fig. 11, the most posterior section figured. Figs. 5-9 are through the free part of an extended, figs. 10-11 through the attached part of a retracted tongue. The transverse lines through fig. 1, show approximately the level at which the sections were taken, the lines being numbered to correspond with the figures. Fig. 1 represents the tongue of Crotalus durissus, while all the sections are from Ancistrodon.

The $M$. ceratoglossi arise from the posterior ends of the hyoid cornu, between which they rum, each entirely isolated from its fellow, forward to the point, fig. 1, $c$, where the hypoglossal nerve enters the muscle; at which spot they become encased by the superior and inferior transverse muscles, and separated from one another by the $\boldsymbol{M}$. verticatis, fig. 10. It may properly be said that at this point they enter the tongue, through the length of which they extend, nowhere mingling with or penetrated hy other muscles, or by each other. ${ }^{1}$ At first the muscle occupies the largest part of the tongue; it lies on

\footnotetext{
${ }^{1}$ In the Crocodilia the two genio-glossi cross one another in a peculiar manner, which Duvernoy (VI, p. 17, pl. V,

fig. 3), has described and illustrated. The same peculiar arrangement may be readily observed in the alligator.
} 
the ventral side of the tongue, and maintains that position throughunt figs. 5-9. The single fibres of the muscle are at first some distance apart, fig. 9, but they soon become more compact in the free part of the tongue, fig. 7. The ceratoglossi gradually taper. towards the tip, while the other muscles increase in relative bulk. Towards the fork the two muscles under consideration divaricate and each, greatly reduced in size, enters the $\operatorname{tips}^{1}$ of the same side, fig. 5, and terminates in a tendon, which first appears on the under side of the muscle not far from the base of the fork, and extends as the direct continuation of the muscle forwards in the tip.

The lingualis is confined to the free part of the tongue; it begins near the point of attachment, fig. 1, $a$, occupies the dorsal portion of the muscular core, above the transversus superior, fig. 8, and extends forwards, at first increasing in diameter, fig. 7 , then slowly diminishing as the tongue tapers, fig. 6. At the fork, fig. 9, it divides into two portions which become the superior longitudinal muscles of the tips, in which they are much more voluminous than their antagonists, the ceratoglossi. The lingualis is cut up by muscular septa, formed by the transversi and verticalis. These septa are more prominent in the tips than in the body of the tongue.

The verticalis is at first, $i$. e., posteriorly, entirely distinct, fig. 10, $v$, arising dorsally from the lower side of the transversus superior, and inserted ventrally directly into the common fascia of the lingual muscles, thus separating not only the two ceratoglossi, but also the two transversi inferiores. The inferior attachment is retained up to the fork of the tongue, but is there lost, the lower end of the vertical muscle becoming grarlually more and more interwoven with transverse fibres. The upper end on the contrary soon begins to interlace with the superior transverse muscle, fig. 8 .

The transversi can be best described together, although at the posterior extremity of the tougue they are absolutely distinct, fig. 10. In Eutrenire sertrilis exactly the same relation exists, as will be recognized by comparing cut 1, with fig. 10. Further forward the three transversi fuse around the base of the free part of the tongue, fig. 9. They form a continuous layer of annular fibres. The upper segment corresponding to the transversus superior attains predominance, and is divided into two portions by the nerves, (lingual?) figs. $9,8,7, B$, and the arteries and tissues which accompany them. Still further forward, the upper segment is foreed down into the middle of the core, by the lingualis above it, fig. 8. At the same time the transverse or annular fibres disappear from the ventral side, and those which correspond to the transversi inferiores assume a vertical position at the sides of the tongue, fig. 7. Before the forking takes place, the intermingling of the various transverse and vertical fibres becomes so complex that the component muscles camnot be distinguished, there being besides many oblique fibres, two systems of vertical and transverse fibres distinguishable, fig. 6 .

From the disposition of the muscles, we may conclude that the tongue is thrust out, first by pulling forward the base of the tongue by the grenio-hyoid portion of the constrictor, and especially by the genio-vaginii; and second by the elongation of the tongue by the contraction of the transversi and verticalis. The retractors are, first, the longitudinal linguatis and ceratoglossi, and second, the retractors of the hyoid, namely the vertebroand costo-hyoid portions of the constrictor, and Dumeril's "peaussier" (paniculus), the

"Tip" is used to designate the two forks or branches of the tongue, and refers to the whole branch, and not to the extremity. 
fibres of which are longitudinal and attached anteriorly to the hyoid. None of the ntrinsic muscles have been, so far as I am aware, previously described, and the elongation of the tongue itself has not been hitherto taken iuto account.

My own observations upon the nerves which supply the tongue are fragmentary and unsatisfictory, as I have unfortunately been mable to obtain sufficient material for dissection. I therefore reproduce the figure, ent 2, and deweription given by Bendz, the Danish ${ }^{1}$ original being inaccessible to many readers. Bendz's account refers exclusively to the common snake, Tropidonotus natrix, of Europe.

"The united nervus glossopharyngeus and vagus arise by three or four small roots from the sides of the medulla, and pass out together through a special opening of the skull. After it appears outside (of the cranium) it receives a small anastomising branch from the nervus communicans; a little below, it gives off a considerable branch, the largest part

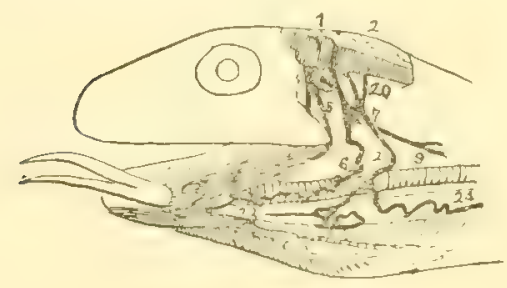

CuT 2. Head of Tropidonotus natrix $\$$ nat. size, after Bendz. 1, cerebellum; 2, medulla; 4, anastomosis with N. communicans; 5 , N. communicans; $6, \mathrm{~N}$. laryngeus superior et glossopharyngeus; 7, Ganglion radicis vagi; 9 , vagus; 21 , hypoglossus, -23 , its front branch, -24 , its hind branch. The'branch from which 23 springs receives a branch from N. alveolais inferioris. part of which is equivalent to the n. laryngeus superior, of the higher animals, but is perhaps at the same time the analogue of $n$. glossopharyngens, although I have been unable to discover a ganglion, comparable to the $g$. petrosum. This branch runs, like all nerves in this region, because of the variability of the organs in volume and position, in manifold curves down over the neck to the anterior part of the tracheae, and along the sides of which it runs to the glottis. Here it sends a small branch along the sides of, and back to the front end of the trachen, while the main stem is lost upon the glottis and the mucous membrane. Close below the origin of this branch arises the stem of the vagus, with its Ganglion radicis a little above, which gives off a tolerably thick branch to the happoglossus, which last desecnding from above crosses the vagus at this point. The trunk of the vagus runs backward between the arteria carotis, and the vena jugularis," etc., p. 130-131.

"The hypoglossal nerve arises by two roots from the anterior columns of the medulla oblongata. These unite outside the cranium, to form a single trunk, which immediately crosses the vagus trunk, from which it receives a considerable branch. Past this it descends and divides at the side of the trachea into two nearly equal branches, an anterior and posterior. The anterior branch lies in many curves upon the sides of the trachea, gives off' a fine branch to the muse. genioglossus, and receives a branch which comes from the $n$. alecoleris inferior; this last comes out near the middle of the inner surface of the ramus of the lower jaw, and runs backwards and inwards over the muscles of the regio submentalis, before making the above-mentioned anistomosis. The oontinuation of the anterior branch enters, and can be followed even to the tips. The posterior branch goes to the musc. ceratoglossus, most of the branch pressing into the muscle, and following its axis backward; while a smaller branch passes batckward upon the same muscle superficially." p. 132.

\footnotetext{
I I must beg indulgence for this translation, which I have made with the assistance of a dictionary, and witlout previous knowledge of the language, circumstances that are
}

certainly unfavorable; I had however, no other resource. Dr. II. Hagen had the kindness to explain a difficult passage to me. 
The nervus glossopharyngeus is, in most reptiles, a distinct nerve; but in some it does not have this independence, and is then always united with the vagus." p. 137. Desmouslins (II. Pt. 463, 6) states that it is wanting in Ophidia; Bendz, as we have seen, found it united with the vagus in Tropidonotus, while Vogt (xvI, 44, 49) says it is distinct in Crotalus horridus and Coluber siculus.

"The trunk" (of the hypoglossus) "usually forms two branches, of which the anterior supplies the muscles of the tongue, the posterior the 1 . sternohyoidens and omo-hyoideus. In snakes, I found that the lingual branches enter into anistomosis with a hranch firom the $N$. alveolaris inferior, $N$. trigemini. Desmouslins (II, II, 455), has made a similar observation upon Crotalus, where he describes a communication with the $N$. lingualis, $N$. vagi; but since he denies (the presence of) the hypoglossus in Ophidia, I shall therefore make no close comparison with what I have found in Tropidonotus and Lacerta." p. 148.

The observations of previous observers contain, as far as I am aware, no mention of the three nerves, fig. $7, A, B, C$, which enter the tongue, but only of the third, $C$, the hypoglossal. Bendz makes no reference to a lingual branch of the glossopharyngeal. As regards the trigeminal lingual nerve, it has been said to be wanting, a statement which is repeated by Stannius in his Lehrbuch. Bendz (vide supra) states that the hypoglossal receives a communicating branch from the $\mathrm{V}$. alveolaris inferioris, by which the tongue is indirectly supplied with trigeminal fibres.

The hypoglossus, fig. 1, $C$, runs backward beside the tongue, fig. 10, $C$, before penetrating the muscle, which it does immediately behind the point where all the transverse lingual muscles stop. As it enters, it separates into the two branches already described by Bendz (vide supra); 1, a smaller one running backwards along the outside of the ceratoglossus, fig. 11, $\mathrm{c}^{\prime \prime} ; 2$, a larger one which penetrates into the substance of the ceratoglossus, and then runs forward in the midst of that muscle, giving off branches as it goes. The main trunk is surrounded by a vascular fibrous connective tissue, which is very distinct from the muscular fibres around it, fig. 10. This same figure also shows the hypoglossus upon the outside of the tongue, occupying the same relative position which is held further forward by the nerve $B$, and still further forward by the nerve $A$. The amount of connective tissue around the hypoglossal nerve in the tongue gradually diminishes, becoming hardly more than a sheath of the nerve in the free part of the tongue. At the level of the fork the nerve is reduced to a few hardly distinguishable branchlets.

I am unable to say what is the origin and distribution of the other two nerves, Fig. 1, $B$ and $A$. From analogy with mammalia, they are the lingual branches respectively of the glossopharyngeus and trigeminus.

The anterior nerve, fig. $1, \mathcal{A}$, enters the sheath, penetrates underneath the $\boldsymbol{M}$. geniovagineus, and runs backwards, immediately underlying the sub-mucosia of the sheath, to the point where the sheath and the tongue unite. Further than this I have not followed it: course with certainty, but I think it probably bends forward, and runs along the side of the tongue, outside of the muscular core, where there is a nerve, fig. $9, A$, which however, appears only in sections through the base of the free part of the tongue, and not further forward, and therefore is apparently distributed to the side of the base. If these 
suppositions are correct it is to be expected that this nerve will be found to be the glossopharyngeus, which has a similar distribution in mammals.

The middle nerve, fig. $1, B$, I have also not succeeded in following satisfactorily, but I consider it probable that it is continuous with the nerve marked $B$, figs. 4-11. 'This latter lies in the midst of the $M$. transversus superior, and runs straight forward to the fork, without giving off any branches; but there, beginning to divide and sub-divide, it enters the fork of the same side to which it is distributed. The nerve is accompanied through the body of the tongue, by an artery of about the same diameter as itself. The nerve and artery are surrounded by connective tissue which divides the Musc. transversus superior into two parts ( $c f$. figs 9-7). The tissue on either side is separated from that on the other by the vertical muscle, so that the transverse partition is incomplete. As with the first nerve so with the second; we make from its distribution, which is to the tips of the tongue, an inference, namely: that it is homologous with the mammalian lingualis.

\section{II. 'Tongue of Ameiva.}

The tongue of Ameiva surinamensis, is, in proportion to the size of the animal, both shorter and much thicker than that of the snakes. It tapers from the base and divides into two forks, each of which consists of a basal portion with corneous epithelium, and a more delieate and almost threal-like, darkly piemented tip. The main borly of the tongue is flattened and expanded above, the upper surface being entirely covered by diamond shaped scales, so disposed as to form rows extending from the sides obliquely backwards. These rows are not perfectly regular. The effect produced, in the alcoholic specimen I have examined, is of the back of the tongue being crossed by two oblique systems of pale lines. The scales also extend forwards to the tips, and downwards a little way to the underside of the tongue, whlch is smooth, but with two longiturlinal ridger, separated by at median depression, and corresponding to the large ceratoglossal muscles. On the outer side of each ceratoglossal ridge is a longitudinal furrow, homologous with the lateral furrow of the suake's tongue, which divides the smooth ventral, from the upper scaly surface. At the anterior end of the under side there are two scales, attached by their posterior and median edges, but otherwise entirely free. They lie one at the base of each fork. As shown by transverse sections they are duplicatures of the epidermis, supported by an extension of the cutis. Upon the outer, $i$. $e_{\text {, }}$ ventral surface of these scales, both the cormeous and mucous layers of the epithelium are considerably thickened. What the possible function of these singular structures may be, I cannot surmise. The posterior part of the underside of the tongue serves for its attachment to the floor of the mouth. The division of the forks into two parts is striking, and the horny epidemis must prevent any bending or change of length in the basal part. The formation of small scales on the body of the tongue permits freedom of motion. The last mentioned scales are quite peculiar, being fingiform, with a broad flat horny top and a thick stalk, which has a thick dermal core, with numerous ramified pigment cells (fig. 12). From the above description it is evident that the tongue of Ameiva differs considerably from that of snakes; nevertheless the arrangement of the muscles within the free part is almostidentical in both, the principal difference being in the proportions. 
$\Lambda$ transverse section (fig. 12) through the tongue of Ameiva a short distance behind the fork, closely resembles a section from the corresponding part of the ophidian tongue (fig. 8). The upper part of the tongue is expanded, and separated from the lower part by a longitudinal furrow. The verticalis forms a median partition, and its fibres spread out fan-like above, intermingling with those of the transeersi and forming septa which divide up the linguatis, which lies directly underneath the dorsal skin. The divisions of the lingualis are smaller and more numerous in Ameiva than in Ancistrodon. The transversi inferiores extend from the lower end of the verticalis along the lower surface and the sides of the tongue, around the ceratoglossi, and also spread out fan-like above. The transversatis superior extends across the. tongue above the ceratoglossi, but is not very distinct, being closely interwoven with the fibres of the verticalis and transversi inferiores. The ceratoglossi are large, and occupy the lower part of the tongue, and in Ameiva are gathered into distinct bundles, which is not the case in Ancistrodon. The nerves in fig. 12 are drawn black. The hypoglossus lies in the midst of the ceratoglossal muscles. The lingualis lies just above and outside of the same muscle, and underneath the $\boldsymbol{M}$. transversi. It is already divided into two branches, one, the superior, considerably the largest; both branches are surrounded by connective tissue. In the snake, fig. 8, the lingual nerve is separated from the ceratoglossal muscle by a layer of fibres belonging to the transversus superior, but in Ameiva this layer is wanting, and the nerve and the connective tissue accompanying it lie, not in the midst of, but entirely below the superior transverse muscle. 'The epithelium is most developed on the upper surface, whichs is scale bearing in Ameiva. All the muscles are enclosed in a common sheath, but the limitation of the muscular core is less conspicuous than in the snake, there being less adenoid tissue separating it from the epithelium.

\section{Tongue of the Chamaeleon.}

The peculiarities of the Chamaleon's tongue are so great that I was particularly desirous of examining it, and through the kindness of Mr. S. W. Garman I obtained a tongue of $C$. dilepis. My hope of being able to homologize the muscles with those of the moccasin and the Ameiva, has unfortunately been annulled by unexpected complications of the disposition of the fibres. The chamaeleon's tongue has been the subject of sereral investigations. 'The anusing speculations of the French Acalemicians reporter by the famous Perrault (xIII) were followed after a long interval by the more valuable researches of Duvernoy and Houston (XI.)

Duvernoy's observations and conclusions appear to me the most accurate and valuable, and remarkably trustworthy. The memoir of Mivart (xII) must also be mentioned, as it contains a description of the muscles of the hyoidean apparatus.

I give a figure, fig. 2, and description of the general form of the chamaeleon's tongue, to spare the necessity of consulting Duvermoy, ( $\nabla$ and $V I)$. The tongue is cylindrical with the tip enlarged, and has three distinct divisions: 1, basal, only partly represented in the figure, with transverse folds; 2, middle, with a smooth surface; both these parts are extensile; 3, the bulky tip, glandular and not extensile; called la massue,-by Duvernoy. A cylindrical extension of the hyoidean apparatus traverses the two extensile 
portions and enters the tip. The upper surface of the tip has a deep frontal fissure, and is thown into fine transverse folds, behind which is a bromel flattened median dorsal ridge; fig. 2, $\alpha$, narrow posteriorly but widening frontwards. Duvernoy (V, p. 11), considered this ridge ( $d$ in his figure $H$ ) to be the posterior extension of the glandular portion, but in $C$. ditepis it is entirely muscular.

A transverse section, through the line 2, of fig. 2 , is represented in the accompanying cut 3. The whole upper half is strongly pigmented. The extension $H$, of the hyoid, occupies the centre of the lower part of the section; its structure is noteworthy. Its core

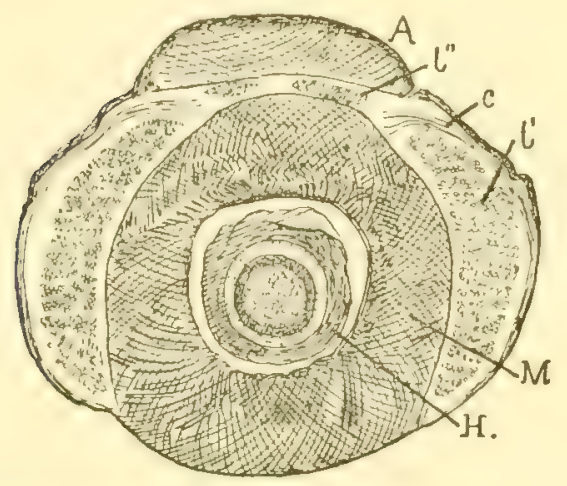

Cur 3. Transverse section of the tongue of

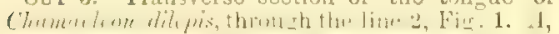
dryal ri! cular muscles; $m$ museular cylinder around the liyoid, $\mathrm{H}, \mathrm{x} 12$ lism. is composed of loose parenchymatous tissue, somewhat resembling that of the vertebrate chorda dorsalis, in that it consists of thick walled cells, having only a very loose sarcodic network, and a protoplasma " IIof" around the nucleus. A similar tissue fills, as will presently be described, the hyoid bones and cartilages of the mocking bird (Mimus polyglottus). The question therefore arises, whether this form of the medulla ossium is general among the Sauropsida. Around the parenchymatous core is a sheath of circular fibres or perhaps elongated cells. Outside of this follows a layer of longitudinal fibres, which from their distinctness and consilerable dianeter, I at first thought might be muscular, but I could not observe any striae, or indications of fibrillar structure, so that I am uncertain as to their nature. Entirely surrounding this layer is a thick fibrillar sheath. The extension of the hyoid therefore consists of four parts. It lies in a distinct space, apparently, though perhaps not really, a cavity, which is limited by a fibrous wall, that gives rise to two obliquely radiating systems of nuscular fibres, $\lambda /$, forming a thick cylinder, Duvernoy's "muscle ammulaire," which is not composed of circular fibres as he believed. Upon the outside, as upon the inside, this eylinder is bounded by a connective filrous sheath, which grives insertion to the muscular fibres. These last have a clisposition for which I know no parallel whatsoever. At every point they are inclined to the radius of the cylinder at about $40^{\circ}$, one set to one, the other to the other side. Moreover, the fibres form laminae, each consisting of a single row of curving fibres, all nearly parallel and of uniform thickness, not only between themselves, but also throughout the length of each fibre. Finally, the laminae do not extend at right angles to the axis of the cylinder, but lie in oblique planes. What advantage this extraordinary arrangement offers, I am unable to suggest.

'There are four distinct longitudinal muscles, two large ones, $l^{\prime}$, at the sides of the cylinder, and two smaller ones $l^{\prime \prime}$, above the cylinder, and below the ridge $A$. The first one probably the cerato-glossi, the latter perhaps the homologues of the $\boldsymbol{M}$. hyoglossi of birds. A few circular fibres, $c$, lie at either side directly under the dermis, and spread out above the large longitudinal muscles.

The ridge, $A$, is separated by a layer of transverse fibres of connective tissue, and is entirely occupied by a double system of curving muscular fibres, each of uniform thick- 
ness throughout. They run obliquely downwards, one set from left to right, the other from right to left, crossing the first at nearly right angles.

In a section further back, the ridge is wanting, but the other differences are less important.

A section further forward through the line 1 of fig. 2, presents the following peculiarities, requiring especial notice, cut 4. The ridge $A$ has grown broader, and at the same time thinner in the median line and thicker at the sides. Immediately underneath it are two small bundles of longitudinal fibres, probably the continuation of $l^{\prime \prime}$ in cut 2 . The principal longitudinal muscles, $l^{\prime}$ are still of considerable size, but lie more to the upper side. The circular fibres, $c$, are much reduced. An additional pair of longitudinal muscles, $l^{\prime \prime \prime}$, appear at the sides, and I think must correspond to Duvernoy's longitudinal lingual muscle (VI, plate 5, figs. 6 and 7,6 ). The muscular sheath of the extension of the hyoid, has separated into two portions, one, $M I^{\prime}$, superior, triangular in section (the apex pointing upwards), the muscular fibres running all transversely and nearly parallel to one another; the second, $\boldsymbol{I}^{\prime \prime}$, inferior, the filmes circular in direction and also approximatcly parallel among themselves. From the examination of these sections it is evi-

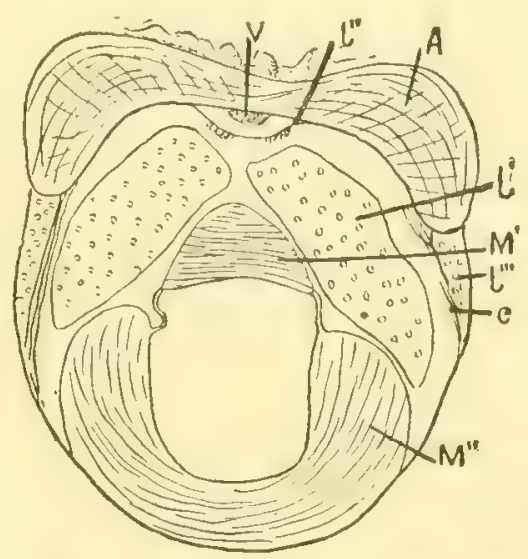

Cert 4. Chemallem dilly is. Siection of the

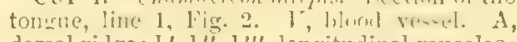
dorsal ridge; $I, 1 / 1,1 / 1$, longiturlinal muscles;

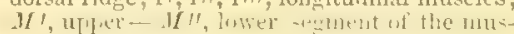
cular cylinder around the hyoid, which has fallen out. $\times 12$ diam. dent that Duvernoy's description is very far from complete.

It is impossible to trace in the Chamaeleon, as could so readily be done in Ameiva, the homologies with the smake's tongue, from the mere comparison of transvere sections. I therefore the more regret that I had no material to study the origin of muscles and the structure of the hyoidean apparatus more accurately. It is also unfortunate that the single tongue which I obtained was not sufficiently well preserved to permit miking sections thin enough for a proper histological examination. The large longitudinal and circular muscles are, it may be conveniently assumed in default of positive knowledge homologous with the somewhat similar mucles of Ameiva and Aneistrodon. The dorial muscular ridge, and the remarkable central cylinder appear to be special adaptations as is also the strangely constructed extension of the hyoid.

I hope that some European naturalist, more favorably circumstanced for obtaining fresh material, will investigate the structure of this very singular and extremely interesting tongue.

\section{The Tongue of Mimus.}

The tongue of Mimus, fig. 3 , has the typical avian peculiarities. Its base is supported by the hyoid and its cornu, - the free portion by the double entoglossum. The general shape of the tongue is sufficiently shown in fig. $3, A, B$. 'The two sections represented in cuts 5 and 6 , were taken approximately in the planes indicated respectively by the lines 1 and 2 , on fig. $3 B$. The first section cut 5 , is through the 
basal portion, at the point where the cornu are just separating from the body of the hyoid, the three forming a triangular central bone, $H y$, which contains a number of medullary cavities, filled with a peculiar tissue, which oc-

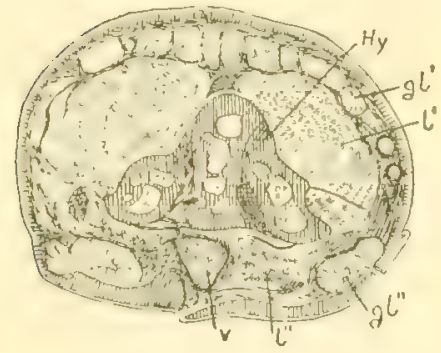

Cur 5. Mimus polynlottus; section throngh the base of the tongue (Fig. 3, line 1) ${ }_{y y}$. hyoid; gll, dorsal, gl", muscles; $V$, blood vessel. 29 diam. curs also in the other bones of the hyoidean apparatus. This tissue consists of numerous large, clear spaces, separated from one another by thin partitions - I think each space must be a liarge vesicular cell, for I can oceasionally see a small nucleus lying against one of the partitions. The tissue is permeated by numerous blood-vessels, which can be easily seen passing in and out among the clear spaces (cells?) of the tissue. The epithelium is quite thick, with a well-developed corneous layer, and is thicker on the under, than on the upper, side. The break below is an accidental injury. In this part of the tongue there are only longitudinal muscles, the large $l^{\prime}$ above, and the small $l^{\prime \prime}$ below. Under the dorsal epithelium is a layer of conglobate glands, $g l$, which open by short ducts directly upon the upper surface. These glands, which are not mentioned by previous observers, are probably homologous with the glands on the back of the mammalian tongue. Laterally and ventrally, are two long and tubular glands, $g l$ ", with follicular walls. They are oval in section, have a rather small lumen and a fibrous tunica propria, which sends up partitions between the follicles, which make the principal part of the walls of the glands. The follicles are narrowest at their mouth, and widen towards the base, the height of the lining cylinder epithelium increasing, but there is no marked separation of duct and gland in the follicles. I first noticed these glands in sections, and cannot say where they open. The epithelium of the tongue is moderately thick, and has a well developed corneous layer, in which all trace of cellular structure has disappeared. Picrocarmine dyes the corneous layer bright yellow, the mucous layer red. A large blood vessel $V$, lies under the hyoid bone.

A section through the back part of the free flattened portion of the tongue, through the m. transtersus linguae, is figured in cut 6. The section is, roughly speaking, triangu-

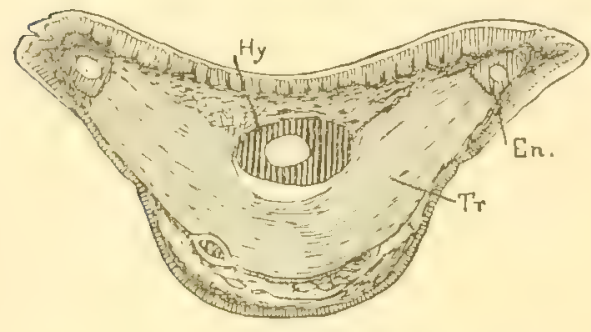

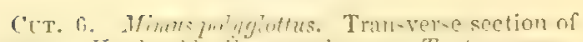

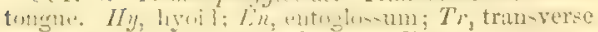
muscle. (cf. line 2, Fir, 3. B). $\times 29$ diam. lar, the broadest side corresponding to the upper surface of the tongue. The epithelium is very much thickened above, both the corneous and mucous layers having increased; the latter sends down rounded papillae into the cutis. At the sides, the epithelium rapidly diminishes in height, becoming quite thin underneath, where the corneous layer is not differentiated. In the centre is the section of the basihyal, IIy, and at the sides in the superior angles, the entoglossi, En. From these last arises the powerful transverse muscle, running from one entoglossum to the other; its fibres curve downwards to pass under the hyoid, with which it has no connection. 'The remainder of the section is oceupied by comnective and vascular tissue. The free flattened portion of the tongue contain no glands. 
In a section nearer the tip, the transverse muscle is wanting, but there are a few longitudinal fibres, which perhaps represent the lingualis muscle of snakes. The epithelium of the upper surface is still more thickened, and its follicles longer than in the regrion of the transverse muscle, cut 5.

The epithelium on the flattened or free portion of the tongue, consists, like the epithelium on the tip of the tongue of Ancistrodon, of four distinct and quite sharply limited layers, viz.:-1, a basa? row of columnar cells, upon which rests 2, a layer of polygonal cells; 3 , a stratum of cells, considerably flattened; 4, the corneous layer. The three lower layers correspond to the mucosa of the round part of tongue.

\section{Conclusion.}

There are a few generalizations to be drawn from the preceding observations, but which must be confirmed by further research, before the can be considered definitely established. This limitation applies to the following remarks.

The tongue is to be defined as a projection of the floor of the mouth, capable of independent motion; with special intrinsic muscles; free in front; supported posteriorly by the hydoillean apparatus, from which the principal longitudinal lingrual muscles arise.

The tongue is supplied with three pairs of nerves; 1, the lingual, a branch of the fifth pair or trigeminal, which runs above the longitudinal hyo-(cerato-) glossal muscles, and is distributed to the tip of the tongue; 2 , the glossopharyngeal, distributed to the mucous membrane at the side of the base of the tongue, (but not supplying any of the muscles); 3, the hypoglossal, ruming to the cerato-glosial muscle, together with which it enters the tongue.

The tongue is covered by a stratified epithelium, which is thinnest and simplest posteriorly, but is thickened towards the tip, where it is further characterized in reptiles birds and mammals, by two peculiarities, 1, the formation of epidermal papillae or follicles, which project into the dermis; 2, the presence of enlarged transparent vesicular nuclei, which might at the first glance of a microscopical examination, be readily taken for the sections of vessels or gland ducts. The sense organs connected with the lingual epithelium I have not studied.

The tongue may be roughly divided into three parts; 1 , the base, which is supported by the hyoidean apparatus, in snakes withriawn behind the sheath and under the floor of the mouth, in hirds pushed well forward, hut not incluling the free portion supported hy the entoglossum; 2, the middle or movable muscular portion, covered by a stratified epithelium, but little differentiated, except when glands are developed, and perhaps at the sides where the glossopharyngeus is distributed; 3, the tip, upon which the organs of touch and taste are especially developed. These three parts might also be termed, from the nerves, whose distribution respectively preclominates in each part, the hypogloswal, glossopharyngeal and lingual areas. The distinction is real, though not very definite, the three regions having no precise boundaries. 
VI. Sumiry.

I give a brief summary of the anatomy of the snake's tongue. It is long and cylindrical, tapering behind, forked in front. Its anterior portion can be retracted within a sheath, which opens on the floor of the mouth in front of the glottis. The upper surface upon the front half of the free part of the tongue, is somewhat expanded and flattened, and is separated from the lower surface by a shallow longitudinal furrow, which faces downwards. 'The epithelium of the mouth is continuous with that of the sheath and of the tongue. 'The lingual epithelium is stratified and has a follieular structure on the anterior part of the tongue, where it is also much thickened, and further characterized by containing cells with peculiar clear nuclei. Upon the front half of the free segment of the tongue, the epithelium is thickened along nine longitulinal lines, three dorsal, two on the furrows, and two on each side below the furrows. The tongue receives three pairs of nerves; the anterior, probably the lingualis trigemini, goes first to the sheath, in the walls of which it runs backwards, being finally distributed to the (tip of the tongue); the middle enters the attached portion of the tongue and is. distributed to the sides of the tongue (?); the third pair, the hypoglossals, enters at the posterior extremity of the tongue, and send, each, a larger branch forwards in the midst of the ceratoglossus muscle within the tongue, and a smaller hranch hackwarks along the outside of the same muscles. The muscles of the tongue are five, three single, and two paired, of which one pair only, the ceratoglossi, arise extrinsically. The ceratoglossi take their origin from the posterior ends of the hyoid cornu, run straight forward into and through the body of the tongue along the under half, and enter the tips. There is a dorsal longitudinal muscle, the lingualis, confined to the free part of the tongue. A median verticalis divides the tongue into symmetrical halves, right and left. There are three transverse muscles, one superior lying above the ceratoglossi, and, in the free part of the tongue, below the lingualis. The transversi inferiores may be considered parts of one muscle. The transverse muscles and the vertical are all distinctly separated in the posterior part of their tongue, but anteriorly their fibres interlace in a very complicated manner. All the muscles are united to form the fleshy core of the tongue, and are encased in a common fascia. At the fork, the core also divides to furnish a core for each tip. The muscular core is separated from the epithelium of the tongue by highly vascular adenoid tissue. Two nerves lie in the midst of the muscles, the hypoglossus in the ceratoglossus, the linguatis (?) in the transversus superior. The third nerve, the glossopharyngeus (?), lies in the adenoid tissue at the side of the core.

'I'he tongue of Ameiva closely resembles that of the snakes, being forked in front; it differs principally in having scales above, and two pereuliar scales underneath, at the hase of each tip. Its upper surface is expanded and separated from the lower surface by a longitudinal furrow. In sections the muscles are seen to be precisely the same in number and general disposition at in corresponding sections from the snake, the differences being only of proportions and in details. (Cf: figs. 8 and 12.)

'The tongue of the Chamaeleon is constructed upon another type altogether, and its muscles camnot at present be homologized with those of Ancistrodon and Ameiva. There are three pairs of longitudinal muscles, one pair resembling the transversi inferiores of 
snakes; there is a peculiar dorsal ridge upon the front part of the tongue, which Duvernoy considered glandular, but really it is composed of two sets of muscular fibres. Around the rod-like extension of the hyoid there is a muscular cylinder composed of two distinct sets of radiating fibres, the very extraordinary arrangement which I endeavored to render clear by word and drawing, (pp. 14-15).

In Mimus the posterior and anterior parts of the tongue are distinguished by peculiarities in the epithelimm, similar to those observed in snakes, but the birl is distinguished by the glands on the back portion of the tongue, numerous small conglobate ones ahove, two large tubular ones below. The bones and muscles conform to a third distinct type, and were correctly described by Duvernoy.

\section{LITERATURE.}

I. BENDz, H. Bidrag til den sammenlignende anatomie af nervus glossopharyngeus, vagus, accessorius willisii og hypoglossus, hos Reptilierne. K. Danske Vidensk. Selsk. Afh。 x (1843) 113-152. Tab. I-IX.

Cuvier, G. See VIII Duvernoy.

II. Desmoulins. Anatomie du Système nerveux des animaux à vertèbres. Paris, 1825.

III. Duges, Axt. Recherches anatomiques et physiologiques sur la déglutition dans les reptiles. Ann. Sci. Nat., xII. (1827) 337-395 Pl, XLVI.

IV. Dumeril, Auguste et Jacquart, Henri. Mémoire sur la Déglutition chez les Ophidiens. Robin. Journ. de l'Anat, et Physiol., II (1865) 56-71, Pl. Xx-xxI.

V. Duvernoy, G. I. De la langue considérée comme organe de préhension des alimens. Mém. Soc. d'Hist. Nat. Strassbourg, I. (1830). Mémoire F. de la première livraison, pagination separée $1-20$, arec 5 planches.

VI. - Mémoire sur quelques particularités des organes de la déglutition de la classe des Oiseaux et des Reptiles. Mém. Soc. d'Hist Nat., Strassbourg, II (1832), paginat. separ. 1-24. Pl. I-Y.

VII. - Mémoire sur les caractères tirés de l'anatomie pour distinguer les serpens venimeaux des serpens non venimeaux. Ann. Sci. Nat., xxvI, (1832), 113-157. Pl. V-X.

VIII. L Leçons d'anatomie comparée de Georges Cuvier,2me Ed., Tome Iv, 1re Partie. Paris, 1835 De l'Hyoïde et de ses muscles. P. 451-548.

De la langue considerée comme organe mobile. p. 548-593.

IX. Hente, —. Vergleichend-anatomische Beschreibung des Kehlkopfes. Leipzig, 1839.

X. Hesse, Fr. Ueber die Muskeln der menschlichen Zunge. Zeitschr. f. Anat. Entwges. x. (Leipzig, 1876) 80-106. Taf. III-IV.

XI. Houstov, Jorn. On the structure and mechanism of the tongue of the Chameleon. Edinb. New Phil. Journ., vir (1829), 161-177. 1 plate.

Jacguart, Henri, - see Duméril, Auguste.

XII. Mivart. On the myology of Chamaeleon parsonii. P'roc. Zool. Soc. London, 1870. p. 850.

XIII. Penrault. Mlémoires pour servir à l'histoire naturelle des animeaux. Première Partie. Contenant:- Description anatomiqne de trois chamaeleons, p. 34-68. arec Pl. v, vI, (la langue p. 57.) Mém. Acad. R. Sci., III. 1re partie (1733).

XIV. Vetter, Bensamix. Untersuchungen zur vergleichenden Anatomie der Kiemen- und Kiefer-musculatur der Fische. Jena. Zeitschr. f. Nat. wiss, viII (1874), 405-458. Taf. xIV-xv.

XV. - Dasselbe. Zweiter Theil im Bd. XII, (1878) 431-550. Taf. XII-XIV.

XVI. Vogt, C. Beiträge zur neurologie der Reptilien. Nenchâtel, 1840.

XVII. Weber, E. H. Anatomia comparata nervi sympathici. Lipsiae, 1817. 


\section{EXPLANA'TION OF' THE PLATE.}

The figures are all taken from Ancistrodon piscivorus, excepting Figs. 1, 2,3 and 12. The magnification, when the figures are not natural size, is given on the plate itself. The outlines of all the dratwings taken from microscopical preparations, were made with the camera lucida. The minuter details were originally not drawn with entire accuracy. In the lithograph the minuteness and finish of the original drawings is lost, and the figures are not faithful except in their gross effect.

Fig. 1. Crotulus clurisus. 'Tongue and its sheath, scen from the dorsal surface, the floor of the mouth having been removed except around the opening of the sheath, $m$, out of which, projects the forked extremity of the tongue; $\alpha$, point where the sheath and the tongue unite. $A, B, C$, first, second and third pairs of lingual nerves, each nerve is accompanied by connective tissue and an artery; $H_{y}$; hyoid cartilage.

Fig. 2. Dorsal view of the tongue of Chamaeleon dilepis, retracted.

Fig. 3. Mimus polyglottus. 'Tongue. $A$, dorsal $-B$, lateral view.

All the remaining figures, except fig. 12, are from Ancistrodon.

Fig. 4. Enlarged view of part of the nerve B, in fig. 5 .

Fig. 5. Section through the base of tip.

Fig. 6. Section just behind the fork.

Fig. 7. Section through the anterior portion of the free segment of the tongue.

Fig. 8. Section through the middle of the free segment.

Fig. 9. Section a short distance in front of the point of attachment.

Fig. 10. Section taken a little in front of the entrance of the hypoglossal nerve, fig. $1, C$, into the tongue.

Fig. 11. Section some distance behind the entrance of the hypoglossal nerve into the tongue (fig. 1. $C$ ).

N.B. Figs. 5-9 are through an extended, figs. 10-11 through a retracted tongue. The levels at which the sections represented in figs. 7-11, were taken, are approximately indicated by the numbered transverse lines in fig. 7 .

Fig. 12. Ameiva surinamensis. Transverse section through the middle of the free part of the tongue; to compare with fig. 8 .

Fig. 13. Transverse section of the wall of a lingual artery, to show the lining endothelium, ep.

Fig. 14. Epithelium near the fork of the tongue.

Fig. 15. Eqithelium from the base of one of the tips.

\section{EXPLANA'TION OF THE LET'TERING ON 'THE PLATE.}

a. Point where the tongue and sheath unite.

$A$. Anterior lingual nerve.

B. Middle lingual nerve.

C. Posterior lingual nerve, the hypoglossus.

$C^{\prime} \quad$ Anterior lingual branch of the hypoglossus.

$C^{\prime \prime}$ Posterior lingual branch of the hypoglossus.

C.gl. Ceratoglossal muscle.

Ep. Epithelium. f. Furrow.

Hy. Hyoid cartilage.

l. m. Lingualis.

m. Opening of the lingual sheath.

P. Thenica propria.

tr.i.m. Transversus inferioris.

tr.s.m. Transversus superioris.

v. Verticalis. 


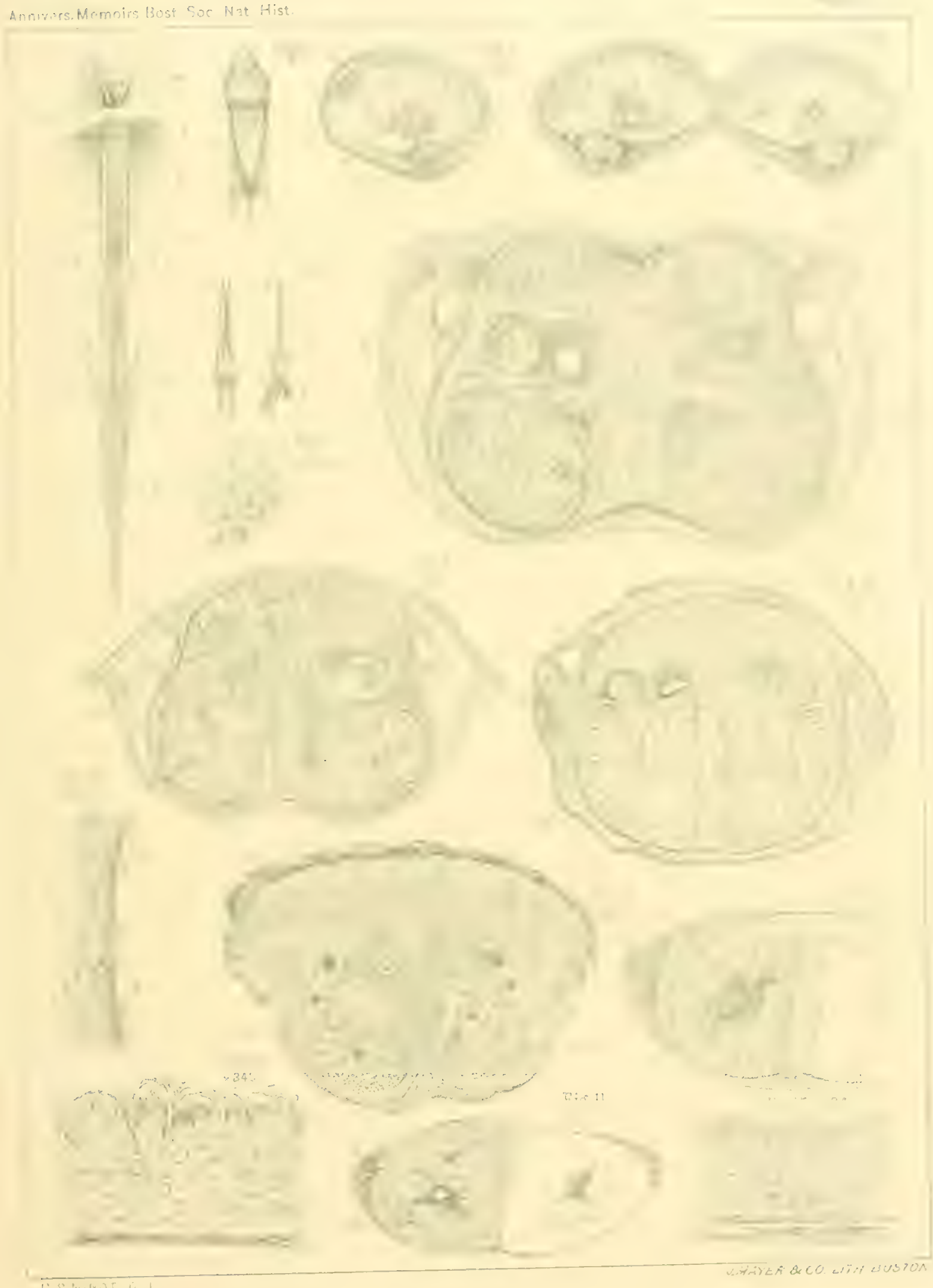

STRUCTURE OF THE TONGUE IN REPTILES 

1830. ANIVERSARY MEMOLRS OF TIIE BOSTON SOCLETY OF NATURAL IIISTORY. 1890.

\author{
ON THE IDENTITY
}

OF THE

\title{
ASCETDING PROCESS OF TIIE ASTR LGILUS IN BIRDS
}

\section{WITH TIIE INTERJEDIUI.}

BY EDWARD S. MORSE,

BOSTON :

PUBLTSHED BY THE SOCIETY.

1880. 

On the Identity of the Ascending Process of the Astragalus in Birds with the Intermedum. Br Edtard S. Morse.

FROM the time that Hermann Von Meyer, fifty years ago, first recognized that the Triassic reptiles had characters which removed them widely from living forms, anatomists and palaeontologists have been diligently at work defining with greater exactness the anatomical features of these early animals. The results of these labors have been to increase the distinctions between these forms and their supposed living representatives, and to erect for some of them new orders in the old class of Reptiles. Nor has this been

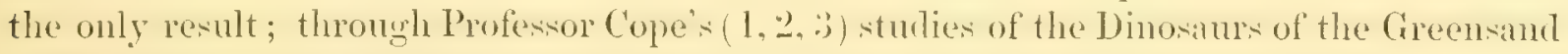
of New Jerwey, avian alfinities were pointed out which were subsequently and indepentently confirmed by Professor Huxley $(4,5)$.

With the gradual unfolding of these features, the mnquestionalule reptilian charaster of the group with its unmistakable avian pelvis and hind limb became evident.

The birds whose affinities with other classes had been so obscure as to have caused them to be designated as a closed type, became better understood; for the key to their mysterious affinities was found in the rocks of the Iezozoic age, and in the transient features of their own embryos.

With the closer approximation of the Reptiles and Birds by Huxley, under the greater division Sauropsida, our only wonder is that relationships so plain had never before been recognized. Gegenbaur's (6) determination of the more important elements of the tarsus in Birds, and the rapid growth of our knowledge of the Dinosaurians through the labors of Leidy, Cope, Marsh and IIuxley, have gradually strengthened the conviction that among the Dinosaurs, or closely related forms, we were to look for the progenitors of the present birds.

Professor II. G. Secley ( 7 ), in a lecture on the Dinosauria, delivered before the Scientific Club of Vienna, while admitting for them a few avian characters, considers that some relations have been overrated, and that the avian affinities of the Dinosaurians were not so strong as had been supposed. It seems to me, however, that he does not give sufficient importance to the fact that some of these relations have been based on the characters presented by birds in an advanced stage of embryonic growth, that is to say in embryos so far advanced, that all the leading avian features had been established.

While Professor Seeley admits certain avian characters in the hind limbs of some Dinosaurians, he says that they are limited to two points: "First, the development of a strong anterior crest, which is directed forward and outward, so as to extend in front of 
the fibula, is a Dinosaurian character met with to some extent among birds, but quite as well marked in mammals. Secondly, the shape of the distal end of the bone is birdlike; but that form is found in no adult bird, and is only to be detected in the young bird before the tarsus had become blended with it, so that while it might go to show, perhaps, that birds are descended from a common stock with Dinosaurs, it would be misleading to regard it as altogether avian, since the character is lost in the adult bird's skeleton" (page 57). And furthermore, he says, "But when the tarsus, or rather, the astragalus, is closely applied to the tibia, as in Megalosaurus, Poecilopleuron, Laelaps, or Iguanodon, it gives the bone a resemblance to the birds which is almost convincing, since the parallel extends to nearly every detail. The character, however, is shorn of much of its importance, when we remember that there are many Dinosaurs in which there is an os calcis, or heel-bone, placed side by side with the astragalus."

Professor Seeley is aware that in Laelaps the hour-glass shaped tarsal bone represents the os calcis and astragalus comnate; also that Prof. Cope shows that these two bones are ankylosed in Ornithotarsus.

The memoir of Gegenbaur on the 'Tarsus and Carpus of Birds had, for the moment, probably escaped the attention of Prof. Seeley. In this contribution of Gegenbaur's the separation of the tarsal portion into two bones, the upper and under tarsal bone, is clearly pointed out. Furthermore, Gegenbaur shows two centres of ossification in the upper, or proximal bone, which he rightly infers to represent the tibiale and fibulare (these names are used in preference to those of astragalus and os calcis, as better defining the relations existing between them and the tibia and fibula). These demonstrations were based on an examination of the chick at a late stage of embryonic growth.

In my memoir (s), on the 'Tarsus and Carpus of Birds, I not only fully confirmed the observations of Gegenbaur, but showed the absolute separation of these two elements as tibiale and fibulare, based on an examination of a number of species of birds at an earlier stage than those examined by Gegenbaur. Figures of these were also given, showing the fibula, with the same length as the tibia, and nearly approximating to the fibulare.

While preparing the memoir above alluded to, Prof. Wyman kindly sent me some observations of his on the tarsus of the embryo Heron, which he generously allowed me to incorporate with my paper. Briefly, these consisted in his finding a long styleshaped bone, broadest at its distal extremity, lying in front, and at the distal end of the tibia, which he believed to represent the so-called ascending process of the astragalus, but which was shown to have an independent centre of ossification in the embryo, and to remain free from the other tarsal bones till the young had left the egg; when it appeared attached to the coëssified tibiale and fibulare, and presented the appearance not unlike that shown by Iuxley in the young ostrich.

My interpretation at the time was that this new tarsal bone represented the intermedium, a tarsal bone which is clearly seen in the salamanders as ocöupying a position between the tibia and fibula, and indeed with half its length forced up, as it were, between these two bones.

I have previously shown that as the proximal series of tarsal bones became united, the fibula diminished in size proportionally with the rapid increase of the tibia, and became 
finally a splint bone, with its attemuated distal extremity far removed from the tarsus; the tibia on the contrary, enlarging, so that its distal extremity equalled in transverse diameter the two tarsal bones, which formed a cap on the end of the tibia, like an epiphysis, and finally became merged with it. The intermedium, while occupying its proper position between the tibiale and fibulare, and finally uniting with them, became apparently displaced, so to speak, by standing in front of the tibia.

This could be stated at the time with certainty: Namely, that the ascending process of the astragalus was an independent bone, which finally united with the proximal series of tarsal bones, and that a similar process in the young chick and ostrich, as figured by Huxley, and a similar spur or process as seen in the astragalus of Laelaps and some other Dinosaurs, was to be looked upon as of the same nature.

To prove the correctness of this interpretation as to whether this bone was the intermedium, it was necessary to examine the early embryo, and to find, if possible, the bone occupying its true position in the tarsal series, and between the distal extremity of the tibia and fibula.

Believing that low aquatic birds would more readily yield these evidences, a visit was marle to Grand Menan, at the mouth of the Bay of Fundy, and at that place were obtained the embryos of the razorbill auk, eider duck, sea pigeon, herring gull and petrel.

At Penikese Island in Buzzard's Bay, an opportunity was offered of examining the embryos of the tern. Through the courtesy of the Smithsonian Institution, I had the gratification of examining embryos of the southern black-backed gull, and the large penguin collected by Dr. Kidder at Kerguelen Island, during the U. S. Tran-it of Venus Expedition, and the results of these examinations were communicated verbally at the meetings of the American Association for the Advancement of Science in 1874 (9) and 1875 .

With the hope of making these observations more complete, their publication was withheld at the time. Finding the opportunity of studying other aquatic birds still uncertain, these results, slight though they may be, are given.

The accompanying plate presents in outline the tarsal joint of the following birds: The common Tern, sterna hirundo; Petrel, Procellarin pelajica; Eider Duck, Somateria mollissima; Sea Pigeon, Uria grylle; Common Guillemot, Lomvin troite; Herring Gull, Larns. argentatus; Raizor bill Auk. Utamania torda; Southern black backed Gull, Larus dominicanus, and Great Auk, Aptenodytes Pennanti.

An additional figure is added of the right hand limb of the Sea-pigeon, as it shows the appearance of rudimentary nails on the second and third fingers.

In the figures of Sterna limudo, figs.1-4), different stages of the tarsus are represented. Fig. 1 shows the intermedium distinctly wedged between the tibia and fibula, with its distal end in line with the distal margins of the tibiale and fibulare. The centrale is still small. In a later stage, as represented in figs. 2, 3, and 4, the tibia has widened considerably, though the tibiale and fibulare have not yet united. The intermedium now appears in front of the tibia, though still on a line with the tibiale. The separation of the distal end of the fibula and its tarsal bone has increased. The centrale has slightly increased in size. In fig. 2, the tibiale and fibulare have coalesced. The 
intermedium has been crowded out and up, so that its distal end is on a line with the proximal margin of the tibiale and fibulare. The centrale has increased in size so that its transverse diameter is equal to that of the three metatarsals, to which it finally becomes attached at a later stage.

In the Petrel, Procellaria pelarjica, fig. 5, a stage is represented, similar to that of the 'Tern, fig. 2. A new tarsal bone appears (indicated on the plate with a question mark), corresponding to the rudimentary first toe. This bone was clearly defined in both legs. In appearance it looks like the proximal end of the first metatarsal bone, with its corresponding tarsal. In only one other bird has a bone at all resembling this been seen, and that is shown in the figure of the Eider Duck (fig. 8, indicated by a query mark). In this case it appears like a second tarsale. In both cases this bone appears on the tibial side of the leg. It will be unsafe to hazard a conjecture as to what this bone represents, without further examination of other species.

In the Sea Pigeon, Uria grylle, the intermedium is a prominent, wedge-shaped bone, and quite separate from the other tarsal bones, though the embryo was far advanced. Its large size is interesting in comnection with the fact that the fore limb shows conspicuous rudimentary nails on the second and third fingers. (See figs. 11, 12.)

In fig. S, the tarsus and a portion of the other bones of the leg of the Eider Duck, Somateria mollissima, are represented. In this embryo the intermedium was clearly seen between the tibia and fibula, the tibiale and fibulare being widely separated.

In the Herring Gull, Larus argentatus, the intermedium is not large, the near tarsal bones are about uniting, yet the intermedium is still free, and somewhat removed from them.

In the Southern Black backed-Gull, Lams clominicames, the intermedium is in nearly the same condition. In the Great Auk, Aptenodytes Pemunti, the appearance of the very short metatarsal bones, and the short square phalangeal bones, is extremely interesting. 'The embryo was far advanced, as indicated by the long and prominent claws tipping the toes. Yet the bones composing the foot are very rudimentary.

The embryo of this species, and also that of the Southern Black-backed Gull, had been preserved in strong alcohol for several years, and the cartilaginous portion of the tarsus was so opaque that nothing definite could be made ont in regard to the other tarsal bones. The intermedium, however, in both species, was very distinct.

From these observations it is seen that the intermedium is present in embryo birds as a distinct tarsal bone; that at first it is in line with the near tarsal series, that is to say with the tibiale and fibulare, and also between these two bones, and consequently between the distal extremities of the distal ends of the tibia and fibula. As the tibiale and fibulare coalesce, the intermedium is crowded outward and upward, the tibia widening at the same time to an extent equal to the transverse diameter of the near tarsal series; the intermedium occupies a position in front of the tibia, and fills a groove which is seen on the anterior face of the tibia. It is seen, furthermore, that the intermedium is the last bone to unite with the coössified tibiale and fibulare.

The intermedium varies greatly in size in the embryos of different species. It will probably be found of more common occurrence among the lower birds. 
In young birds of certain species it is seen as an ascending spur occupying the fossa on the lower anterior face of the tibia. In mature birds, as far as I have discovered, it becomes absorbed.

The wide, oblique, tendon-like bridge, which spans the fossa in the heron and many other birds, has no relation with the intermedium.

In Laelaps and some other Dinosaurian Reptiles, this bone is seen as an ascending spur of the coössified tibiale and fibulare. In Ornithotarsus, as figured by Professor Cope, an appearance of the tarsus is represented, which is not unlike that shown in the early stages of the Tern. See plate, fig. 1.

It is possible that the intermedium in Ornithotarsus was a separate bone, and that it has been lost in the fossil, as a distinct grove or fossa is seen on the lower anterior face of the tibia, while no corresponding spur is seen on the tibiale, a slight elevation only being discernible.

Professor Marsh (10), in a paper on the Limbs of Sauranodon, an animal related to Ichthyosaurus, has presented some novel views in regard to the homologies of the intermedium.

The fore limb is there figured with the femur of the usual character. Its distal face having, however, three articular surfaces, to which are applied three bones in the shape of irregular formed disks; these he interprets as tibia, intermedium and fibula.

He suggests that the intermedium belongs to the epipodial, or second series of bones represented by the radius and uhnt, and tibia and fibula, and that in the process of differentiation the intermedium has been crowded down into the mesopodial or first series of tarsal bones.

My interpretation, haser on the admirable figure he prevented, would be that the bone which he indicates as the intermedium is really the fibula, and the bone which he represents as the fibula, is an outer tarsal bone, which, with its metatarsal and phalangeal bone in series becomes obliterated in time; that in the process of differentiation the intermedium is as likely to be partially compassed by the distal extremities of the tibia and fibula, as that a third bone of this segment had been crowded down into the tarsal series. However this may be, Professor Marsh has discovered a most interesting stage in this highly primitive condition of the bones as shown in Sauranodon.

In the following outlines, figures are presented of a portion of the leg of a salamander, a number of embryo birds, young birds, and Dinosaurian reptiles. These are given in series, so that a comparison may be made between the different stages of the intermedium in each of these forms. In the first series, figs. 1, 2, 3, 4, the intermedium is seen as a separate bone. In the second series the intermedium has united with the other tarsal bones and assumes the appearance which has been rescribed as the ascending process of the astragalus. In the third series a similar condition is seen.

For explanation of lettering, see explanation of plate. The lettering being the same with the exception that $t f$ indicates the tibiale and fibulare connate. 


\section{Adult Salajaxder and Embryo Bimds.}

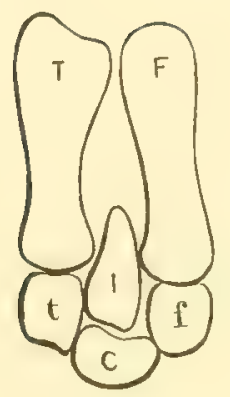

Fig. 1. Salamander.

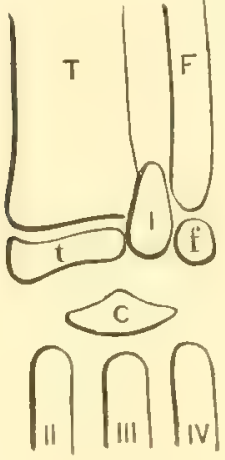

Fin. 2.

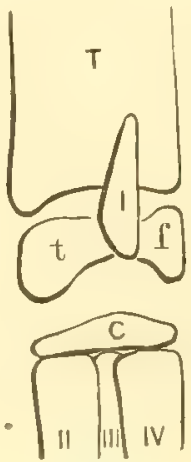

Fig. 3.

Sea Pidgeon.

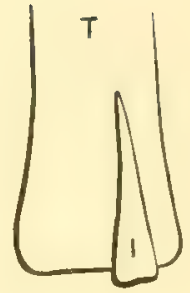

Fig. 4. Blue Heron.

Fig. 1. Fore leg of Salamandra maculosa, showing the intermedium, $i$, in its position between the distal ends of the tibia and fibula.

Fig. 2. Portion of leg of common 'Tern from an embryo, showing the appearance of the intermedium between the distal ends of the tibia and fibula.

Fig. 3. Portion of leg of the Sea Pigeon from an embryo with the intermedium in front of the tibia, from the widening of the tibia so as to compass in width the tarsal bones.

Fig. 4. Distal extremity of the tibia of the Blue Heron from an advanced embryo. In this figure only the intermedium is shown. Its distal end had not yet coüssified with the other tarsal bones.

\section{Young Birds.}

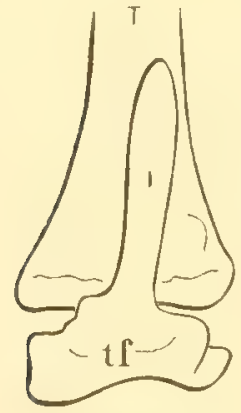

Fir. 5 .

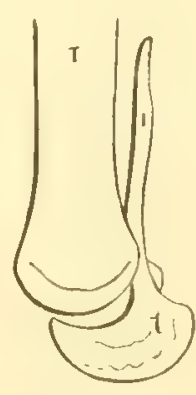

Fig. 6.

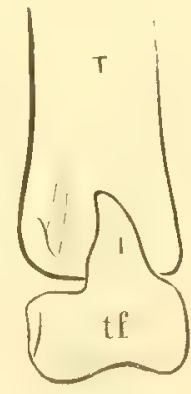

Fig. 7.

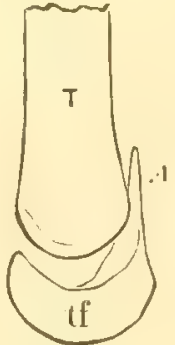

Fig. 8.

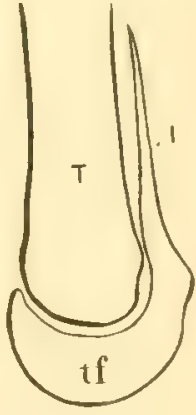

Fis. 9. Foung Blue Heron.

Figs. 5 and 6. Front and side views of the distal end of the tibia and tarsus of a young ostrich. From a figure of Professor Huxley's in Quarterly Journ. Geological Soc., above referred to. These figures show the tarsal bones including the intermedium ankyloser together; the intermedium appearing as an ascending spur or process of the other tarsal bones.

Figs. 7 and 8. Front and side views of the distal end of tibia and tarsus of a young fowl, from Huxley's Anatomy of Vertebrated Animals, p. 253, fig. 88. The condition and general appearance are the same as in the figures of the young ostrich. 
Fig. 9. Side view of the distal end of tibia and tarsus of a young Blue Heron. The intermedium, as in the case of the youmg Otrich and young fowl, has the appearance of an ascending spur from the other tarsal bones.

\section{Dinosacriax Reptiles.}

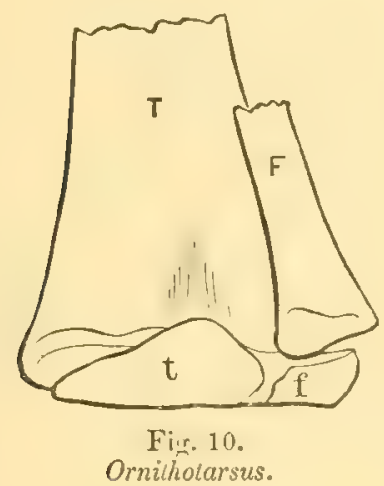

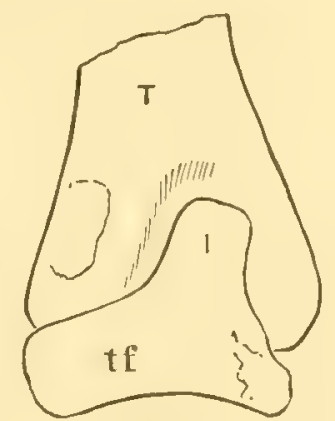

Fig. 11.

The "Honfleur Reptile."

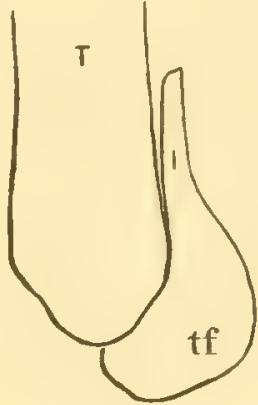

Fig. 12.

Laelaps.

Fig. 10. Distal extremities of the tibia and filulis of Ornithotarsus, after Cope's figure in Trans. Amer. Phil. Soc., Vol. xIV, fig. 35, page 122. The tibiale and fibulare are coössified. Whether the intermedium is represented by the enlargement of the tibiale in front, or was a separate bone which occupied the fossa on the anterior face of the tibia, is a matter of doubt. Ornithotarsus certainly presents a mumber of features thit warrants its name.

Fig. 11. Distal end of tibia and tarsus of the "Honfleur Reptile," reduced from a figure in Cuvier's Ossemens Fossiles, described by Cuvier under the general head of Megalosaurus, without identifieation, afterwarks named by Cope Laelaps gallicus. The intermedium is seen as a blunt portion ascending from the other tarsal bones.

Fig. 12. Distal end of tibia and tarsal bones of Laelaps; side view. Reduced from Cope's figure in Trans. Amer. Phil. Soc., Vol. xiv., plate 9. In this figure the intermedium is argin seen as a long ascending spur in front of the tibia, but the coüssified tibiale and fibulare occupy a far different position in relation to the distal articular fice of the tibia from what is seen in birds.

\section{WORTS REFERRED TO.}

1. On the Anomalons Relations existing between the Tibia and Fibula in certain of the Dinosauria as illustrated by the genus Laelaps. Prof. Cope. Proc. Philad. Acad. of Sciences, Dec. 1866, p. 317.

2. An Account of the Extinct Reptiles which approach the Birds. Prof. Cope. Proc. of the Philad. Acad. of Sciences, Dec. 1867, p. 234.

3. Synopsis of the Extinct Batrachia, Reptilia and Ares of North America. Prof. Cope. Transactions of the American Philosophical Society, read Sept. 18, 1868, and April 2, 1869. 
4. On the Animals which are most Intermediate between Birds and Reptiles. Prof. IIuxley. The Popular Science Review, No. xxvin, p. 237; being a Lecture delivered before the Royal Institution, Feb. 7 . 1868.

5. Further Evidence of the Affinity between the Dinosaurian Reptiles and Birds. Prof. Iuxley. Quart. Journ. Geological Soc. of London. Vol. XxvI. 1870.

6. Untersuchungen zur vergleichenden Anatomie der Wirbeltheire. Erstes Heft; Carpus und Tarsus. Prof. Gegenbaur. Leipzig, 1864 .

7. The Dinosauria. Prof. Secley. The Popular Science Reviet, Jan. 1880, p. 44; being originally a Lecture delivered at the Scientific Club at Vienna, on the 10th of April, 1879.

8. On the Tarsus and Cnrpus of Birds. E. S. Morse. Annals of the Lyceum of Nat. IIist. N. Y., vol. 10 Art. virr. Read Jan. 29, 1872.

9. On the Ascending Process of the Astragalus in Birds. E. S. Morse. Meeting of the American Association for the Advancement of Science. IIartford, 1874.

10. On the Limbs of Sauranodon. Prof. Marsh. American Journal of Science and Arts, vol. xIx, Feb. 1880 .

\section{EXPLANATION OF PLATE I.}

Fig. 1. Portion of left leg of embryo Tern.

Fig. 2. "6 "6 "6 "6 "6 "

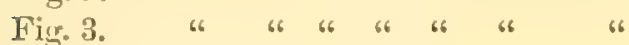

Fig. t. "6 " 6 " 6 " 6 " 6

Fig. 5. Portion of right leg of embryo Petrel.

Fig. 6. " " left " " " Sea Pigeon.

Fig. 7. " " " " " " " "

Fig. 8. " " " " " " " "

Fig. 9. " " right " " "

Fig. 10. " " " " " " Penguin.

Fig. 11. " " right wing of embryo Sea Pigeon.

Fig. 12. " " " " " " " "

\section{EXPLANATION OF IETTERS.}

$F e$, femur; $T$, tibia; $F$, fibula; $t$, tibiale; $f$, fibulare; $I$, intermedium; $c$, centrale ; ? tarsal bone of the second series? $U$, ulna; $R$, radius; $u$, unare; $r$, radiale; 3,4 , third and fourth carpal bones; I, II, III, IV, metacarpals. 


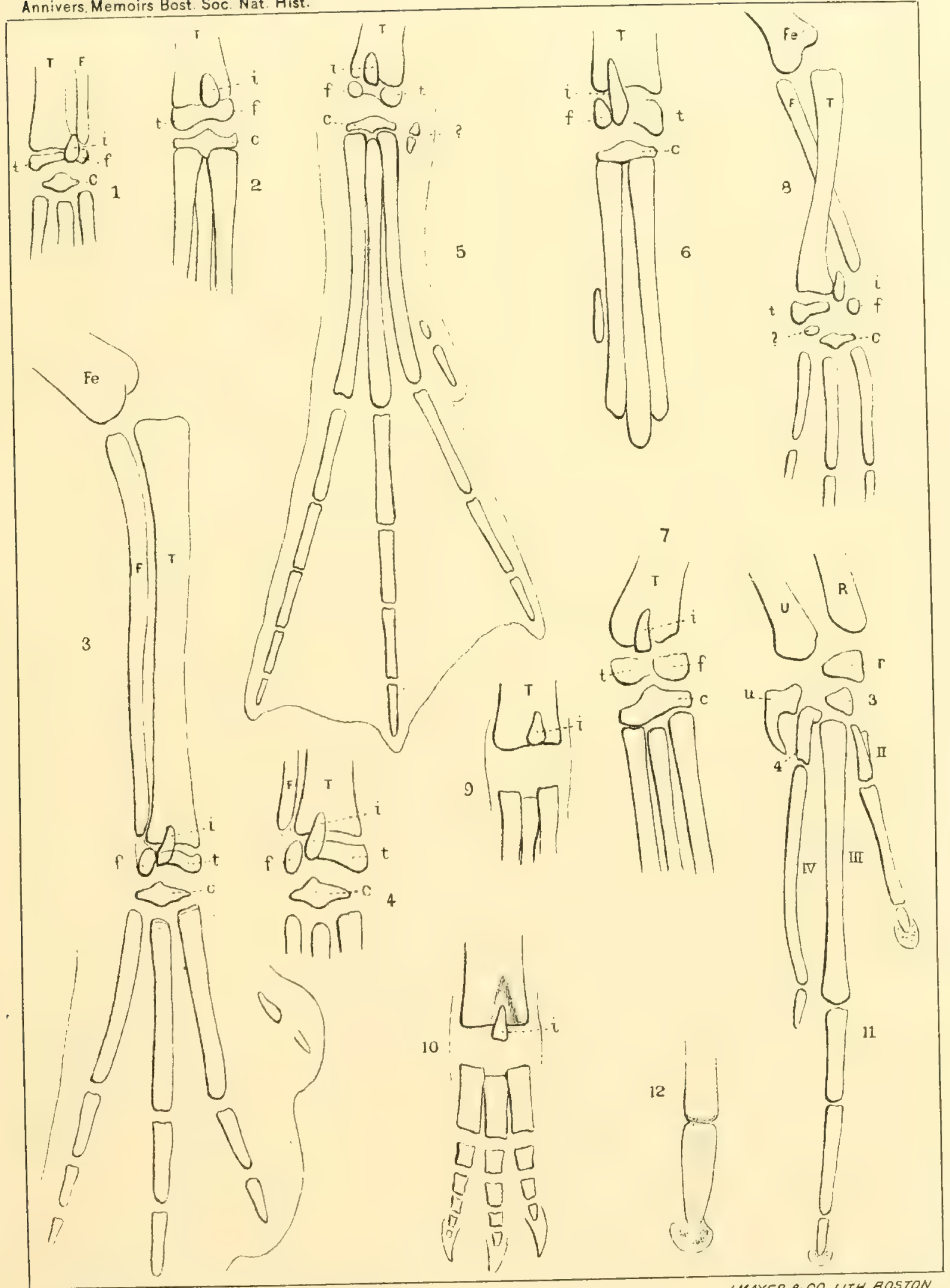

E S.M.ad. nat.

THE INTERMEDIUM IN BIRDS. 

1830. ANNIVERSARY MEMOIRS OF THE BOSTON SOCIETY OF NATURAL HISTORY. 1880.

\title{
NOTES ON
}

\section{THE CRANIA OF NEW ENGLAND INDIANS.}

\author{
BY LUCIEN CARR,
}

AsSistant CURATOR, PEABODY MUSEUM OF AMFILAN ARCHEOLOGY AND ETHNOLOGY, CAMBRIUGE, MASS.

$$
\text { BOS'TON: }
$$

PUBLISHED BY THE SOCIETY. 1880. 
This similarity in language, appearance and customs, justifies the treatment of the collection of crania under consideration as a whole, even if a line of demarcation could be established among them by which it would be possible to assign any special form of skull to a particular tribe; but this cannot be done. The number of crania from any given

Table I. Crania of New England Indians. Males. ${ }^{1}$

\begin{tabular}{|c|c|c|c|c|c|c|c|c|c|c|c|c|c|c|c|c|c|}
\hline 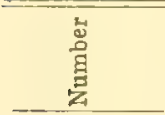 & $\begin{array}{l}\text { 芯 } \\
\text { 悹 } \\
\end{array}$ & 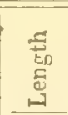 & 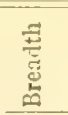 & 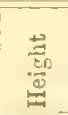 & 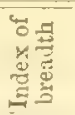 & 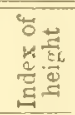 & $\begin{array}{l}z \\
\text { a }\end{array}$ & $\dot{4}$ & | & 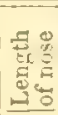 & 记 & 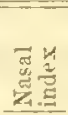 & 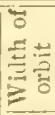 & 苟 & 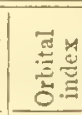 & 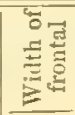 & 密 \\
\hline 1 & 1393 & 170 & 143 & & .841 & & & & & & & & & & & & R. I. \\
\hline 2 & 1335 & 184 & 130 & 126 & .707 & .684 & 100 & 106 & 1.06 & 52 & 30 & .57 & 39 & 34 & .87 & 97 & " \\
\hline 3 & 1325 & 174 & 134 & 141 & .770 & .810 & 104 & 98 & .94 & 52 & 30 & .57 & 39 & 37 & .94 & 92 & " \\
\hline 4 & 1475 & 172 & 138 & 137 & .802 & .767 & 100 & 98 & .98 & 51 & 27 & .52 & 40 & 37 & .92 & 98 & " \\
\hline 5 & 1375 & 178 & 140 & 141 & .787 & .792 & 96 & 98 & 1.02 & 152 & 25 & .48 & 39 & 38 & .97 & 98 & "6 \\
\hline 6 & 1370 & 170 & 134 & 134 & .788 & .788 & 96 & 94 & .97 & 54 & 26 & .48 & 39 & 38 & .97 & 100 & " \\
\hline 7 & & 186 & 146 & 130 & .785 & .699 & 99 & 97 & .98 & & & & 39 & 36 & .92 & 96 & " \\
\hline 8 & & 186 & 142 & 148 & .763 & .796 & 108 & 106 & .98 & & & & 41 & 37 & .90 & 95 & " \\
\hline 9 & 1595 & 194 & 142 & $1+1$ & .732 & .727 & 110 & 101 & .91 & 53 & 25 & .47 & & & & 101 & Mass. \\
\hline 10 & 1610 & 192 & 137 & 140 & .714 & .729 & 112 & 102 & .91 & 55 & 25 & .45 & 41 & 37 & .90 & 96 & " \\
\hline 11 & & 188 & 137 & 133 & .729 & .007 & 108 & 106 & .98 & 50 & 26 & .52 & 42 & 36 & .85 & 100 & " \\
\hline 12 & & 196 & 135 & 142 & .689 & .719 & & & & 52 & 26 & .50 & 41 & 34 & .82 & 92 & " \\
\hline 13 & & 178 & 141 & 130 & .792 & .730 & & & & & & & & & & & " \\
\hline 14 & 1435 & 186 & 133 & 135 & .715 & .726 & 106 & 104 & .98 & 52 & 26 & 50 & 41 & 34 & .82 & 92 & " \\
\hline 15 & & 168 & 132 & 142 & .786 & .845 & & & & & & & & & & & 4 \\
\hline 16 & 1690 & 187 & 144 & 142 & .774 & .763 & & & & 57 & 26 & .45 & 41 & 42 & 1.02 & 99 & " \\
\hline 17 & 1230 & 176 & 128 & 132 & .727 & .750 & 97 & 92 & .94 & 51 & 25 & .49 & 38 & 32 & .84 & 97 & $" 6$ \\
\hline 18 & 1520 & 174 & 138 & 144 & .793 & .828 & 104 & 99 & .95 & 53 & 24 & .45 & 43 & 34 & .79 & 97 & "6 \\
\hline 19 & 1450 & 178 & 133 & 142 & .747 & .798 & 113 & 108 & .95 & 54 & 26 & .48 & 44 & 36 & .81 & & 6 \\
\hline 20 & 1280 & 171 & 134 & 130 & .784 & .760 & - & & & 52 & 22 & .42 & 41 & 34 & .82 & & 6 \\
\hline 21 & & 178 & 144 & 140 & .809 & .787 & 105 & 101 & .96 & 52 & 28 & .53 & 41 & 35 & .85 & & " \\
\hline 22 & 1390 & 178 & 140 & 133 & .787 & .747 & 100 & 106 & 1.06 & 50 & 26 & .52 & 37 & 32 & .86 & & " \\
\hline 23 & & 181 & 133 & 138 & .735 & .762 & 105 & 93 & .88 & 51 & 25 & .49 & 42 & 36 & .85 & & " \\
\hline 24 & 1660 & 181 & 144 & 140 & .796 & .773 & 110 & 100 & .90 & 55 & 33 & .60 & 42 & 35 & .83 & & “ \\
\hline 25 & 1490 & 176 & 140 & 142 & .795 & .807 & 110 & 105 & .95 & 55 & 30 & .54 & & & & 92 & ". \\
\hline 26 & & 170 & 146 & 154 & .859 & .906 & 107 & 98 & .91 & 55 & 25 & .45 & 38 & 34 & .89 & 91 & " \\
\hline 27 & & 173 & 133 & 136 & .769 & .786 & 108 & 97 & .94 & 53 & 26 & .49 & 39 & 36 & .92 & 94 & “ \\
\hline 28 & 1220 & 173 & 134 & 130 & .775 & .751 & & & & & & & 41 & 33 & .80 & 90 & 6 \\
\hline 29 & 1485 & 186 & 131 & 139 & .704 & .741 & 98 & 94 & .95 & 53 & 27 & .50 & 40 & 37 & .92 & 97 & “. \\
\hline 30 & 1320 & 182 & 136 & 130 & .747 & .714 & 107 & 104 & .97 & 57 & 30 & .52 & 41 & 35 & .85 & 108 & Maine. \\
\hline 31 & 1375 & 187 & 140 & 139 & .749 & .743 & & & & 49 & 23 & .46 & 39 & 35 & .89 & 94 & , \\
\hline 32 & 1271 & 181 & 184 & & .740 & & & & & & & & & & & 90 & “ \\
\hline 33 & 1310 & 170 & 129 & 138 & .759 & .812 & 98 & 91 & .92 & 47 & 24 & .51 & 40 & 34 & .85 & 91 & "6 \\
\hline 34 & 1470 & 194 & 134 & 138 & .691 & .711 & 110 & 100 & .90 & 57 & 23 & .40 & & & & 95 & "6 \\
\hline 35 & 1325 & 173 & 142 & 132 & .821 & 763 & & & & & & & 39 & 39 & 1.00 & & Conn. \\
\hline 36 & 1440 & 172 & 142 & 142 & .826 & .826 & 105 & 100 & .95 & 54 & 26 & .48 & 39 & 36 & .92 & 91 & 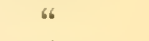 \\
\hline 37 & & 186 & 140 & & .753 & & & & & & & & & & & & \\
\hline 38 & 1920 & 194 & 162 & 140 & .835 & .722 & & & & & & & & & & & Vermont. \\
\hline & 436 & 180 & 138 & 137 & .7 & .761 & 104 & 100 & .96 & 53 & 26 & .49 & 40 & 35 & 88 & 95 & \\
\hline & $19 \div 0$ & 196 & 162 & 154 & 8 & .906 & 113 & 108 & 1.06 & 57 & 30 & .60 & 44 & 42 & 1.02 & 108 & \\
\hline Minim & 1220 & 168 & 129 & 126 & 689 & .684 & 96 & 92 & .88 & 49 & 22 & .40 & 37 & 32 & .79 & 90 & \\
\hline lange & 700 & 28 & 33 & 28 & .170 & .222 & 17 & 16 & .18 & 8 & 8 & 20 & 7 & 10 & .23 & 18 & \\
\hline
\end{tabular}

place is too small to enable us to set up a standard by which to judge the others, and even if it were not so, the historical evidence of admixture between the different tribes is too plain to admit. of any sweeping generalizations. Indeed, if we bear in mind the roving

\footnotetext{
${ }^{1}$ In these measurements the metric system is used, capacity being given in cubic centineters, and length etc., in millimeters.
} 
habits of the Indians, the proximity to each othel of the village sites ${ }^{1}$ even of the different tribes, and then consider how frail was the tie that hound the savage to his Sachem, ${ }^{2}$ it will at once be seen that such a state of affairs must have existed as would make it unsafe to say of any particular cranium that it belonged to a member of this or that tribe.

Table II. Crania of Netw England Indians. Females.

\begin{tabular}{|c|c|c|c|c|c|c|c|c|c|c|c|c|c|c|c|c|c|}
\hline 岕 & 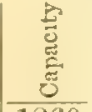 & 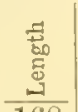 & 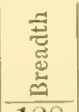 & 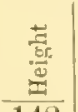 & 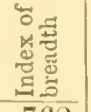 & 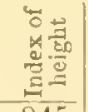 & $\begin{array}{l}\text { 兄 } \\
0\end{array}$ & $\begin{array}{l}\dot{4} \\
\dot{\phi}\end{array}$ & $\begin{array}{l}\overline{0} \\
\bar{\alpha} \\
\end{array}$ & 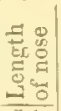 & 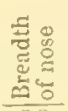 & 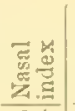 & 曹䓂 & 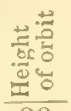 & 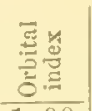 & 要 & 离 \\
\hline 1 & 1260 & 168 & 128 & 142 & .762 & .845 & 101 & 104 & 1.03 & 51 & 28 & .54 & & 39 & 1.00 & 95 & Mass. \\
\hline 2 & 1200 & 172 & 126 & 130 & .733 & .756 & 100 & 101 & 1.01 & .52 & 25 & .48 & 39 & 34 & .87 & 88 & \\
\hline 3 & 1425 & 171 & 37 & 32 & .801 & 772 & 102 & 95 & .93 & 52 & 39 & .55 & 37 & 39 & 1.05 & 94 & \\
\hline 4 & & 174 & 135 & 135 & .776 & .776 & 103 & 102 & 99 & 54 & 25 & .46 & 42 & 40 & .95 & & 6 \\
\hline 5 & 1310 & 181 & 130 & 132 & .718 & 729 & 99 & 9 & .92 & 6 & 25 & .54 & 41 & 33 & .80 & & ' \\
\hline 6 & 1380 & 174 & 134 & 129 & .770 & .741 & 103 & 104 & 1.01 & 51 & 25 & .49 & 41 & 35 & .85 & & . \\
\hline 7 & 1390 & 180 & 131 & 134 & .728 & 744 & 101 & 102 & 1.01 & 6 & 5 & .54 & 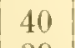 & & .87 & & \\
\hline 8 & 1450 & 178 & 134 & 136 & .753 & .764 & 99 & 101 & 1.02 & 49 & 26 & .53 & 39 & 37 & .94 & 94 & 6 \\
\hline 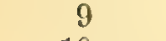 & & & & & & & & & & & 05 & .48 & 30 & & .92 & & \\
\hline 10 & & 181 & 128 & & .707 & & & & & 45 & 3 & .51 & 36 & 34 & .94 & 93 & \\
\hline 1 & 1268 & 172 & 133 & 136 & .773 & .791 & 98 & 96 & .98 & 2 & 23 & .44 & 3 & & .94 & & \\
\hline 12 & 1268 & 180 & 138 & 136 & .767 & .756 & & & & 51 & 27 & .52 & 39 & 38 & .97 & 92 & ، \\
\hline & & 178 & 129 & & .725 & & & & & 51 & 27 & .52 & 3 & & .91 & & \\
\hline 1. & 1250 & $\mid 174$ & 126 & 134 & .724 & .770 & 102 & 106 & 1.03 & & & & 40 & 38 & .87 & 87 & 6 \\
\hline & 1265 & 172 & 128 & 138 & .744 & .802 & & & & 53 & 25 & .47 & 3 & & .94 & & \\
\hline 11 & 1205 & 172 & 128 & & .744 & & 109 & 102 & .93 & 53 & 26 & .49 & 3 & & .86 & 88 & \\
\hline & 1255 & 170 & 135 & 129 & .794 & .759 & 99 & 96 & .97 & 56 & 25 & .44 & 4 & & .85 & 94 & Maine \\
\hline 18 & 1182 & 174 & 132 & 126 & .759 & .724 & 104 & 105 & 1.01 & 0 & 26 & .52 & 3 & & .86 & 95 & \\
\hline 19 & & 187 & 127 & 130 & .679 & .695 & 108 & 108 & 1.00 & 52 & 22 & .42 & & & .94 & 92 & Mass. \\
\hline 2 & 1425 & 182 & 134 & 130 & .736 & .714 & 101 & 98 & .97 & 49 & 25 & .51 & $3 !$ & & .94 & 96 & R. I \\
\hline 2 & 1445 & 183 & 138 & 143 & .754 & .781 & 100 & 9 & .90 & 47 & 29 & .61 & & & .9 & & \\
\hline & 315 & 165 & 13 & 13 & .8 & .812 & 97 & 96 & .99 & & 27 & .5 & & & .9 & 8 & ، \\
\hline 2 & E & 174 & 139 & 130 & .7 & .747 & 96 & 94 & .97 & 4 & 24 & .5 & 3 & & .88 & 89 & ' \\
\hline 2 & & 184 & 12 & 1 & .6 & .696 & & & & & 28 & 5 & & & .94 & & s. \\
\hline 2 & 580 & 178 & 142 & 136 & .7 & .764 & 103 & 100 & .97 & 5 & 2 & .52 & & 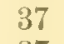 & .97 & 93 & \\
\hline 26 & & 170 & 132 & 132 & .7 & .7 & 102 & 102 & 1.00 & 52 & 9 & .50 & 3 & 7 & 1.00 & 90 & \\
\hline 2 & 0 & 176 & 133 & 134 & .756 & .761 & 104 & 105 & 1.01 & 50 & 31 & .62 & t & 36 & .85 & & M \\
\hline 28 & & 178 & 133 & 130 & .747 & .73 & 104 & 104 & 1.00 & 52 & 27 & .5 & 43 & $3-$ & .79 & 94 & $\mathrm{Ma}$ \\
\hline 29 & 1323 & 177 & 136 & 134 & .768 & .757 & 92 & 96 & 1.04 & 57 & 24 & .42 & 33 & 39 & .84 & 98 & Mass. \\
\hline & & 17 & 18 & 13 & & & 10 & 10 & & & & & & & & & \\
\hline & & 18 & 14 & 14 & .8 & .8 & 109 & 108 & 1.04 & 06 & 31 & .6 & $x$ & 00 & 1.05 & & \\
\hline & $118^{\circ}$ & 165 & 122 & 126 & .663 & .6 & 96 & 90 & .90 & 45 & 22 & 4 & 33 & 32 & .80 & 8 & \\
\hline & 398 & 22 & 20 & 17 & .261 & .150 & 13 & 18 & .14 & 12 & 9 & 1.20 & 10 & 7 & .25 & 14 & \\
\hline
\end{tabular}

Of course the presumption is in favor of some nember of the tribe that formerly inhabited the locality where it was found, and yet for reasons given ahove, this conclusion might be far from correct. In view then of the impossibility of discriminating between the skulls

$1 \mathrm{Mr}$. Gallatin estimates the Indian population within the present boundaries of the states of New Hampshire, Massachusetts, Rhode Island, and Connecticut "to have been from thirty to forty thousand souls, before the epidemic disease which preceded the landing of the Pilgrims." He thinks that this population, "principally along the seacoast between the old Plymouth Colony and the Hudson River, was much greater in proportion to the extent of territory, than was found any where else on the shores of the Atlantic, or, with the exception perhaps of the flurons, in the interior parts of the United States"; and he ascribes "this greater accumu- lated population to the greater and more uniform supply of food afforied by fisheries than by hunting", and to the fact "that the Indians along the seacoast had been driven away from the interior and compelled to concentrate themselves in order to be able to resist the attacks of the more warlike Indians of the Five Nations." Archaeologia Americana, Vol. 1I, p. 37.

26 These Sachems have not their men in such subjection, but that very frequently their men will leave them upon distaste or harsh dealing and go and live under other Sachems." Gookin, l. c., p. 154. 
of the diflerent tribes, and of the linguistic and othere evidence of the identity of the people formerly inhabiting this region, I am led to treat this entire series of crania as having belonged to one race. Considered in this light, there is of course a large increase in the number of specimens upon which to base a conclusion, and to this extent, that conclusion is strengthened.

In accordance with this plan the tables on pages 4 and 5 have been compiled from measurements made upon crania now in the Academy of Natural Sciences of Philadelphia, the Army Medieal Museum at Washington City, the Peaborly Muremm of Archateology and

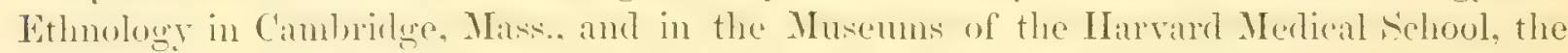
Boston Society for Medical Improvement, and in the private collection of the late Dr. Warren of Boston. ${ }^{1}$. In them I have endeavored to separate these skulls according to the features that distinguish the sexes, and also according to the localities whence they were deriverl. It must not he forgotten, however, that this latter chasification is intended simply to facilitate future reference, and does not carry with it any ulterior significance whatever.

Aside from the brief historical sketch given above, there is but little known as to the precise age of any of these crania. T'wo of them, No. 22, 'Table I, ${ }^{2}$ and No. 38, T'able I, ${ }^{3}$ belonged to Indians whose deaths are matters of record, and in the case of some others glass beads and other articles of European manufacture were found in the graves. Whenever this occurs, the burial must, of course, have been subsequent to the arrival of the whites.

One calvarium, No. 13, Table I, (Peabody Museum, No. 10,259) was found under a shell heap near Salem, Mass., from which circumstance Mr. Putnam has concluded it to be the oldest skull yet found in New England. It is mesaticephalous though verging very closely on brachycephalous and resembles the crania found in the Florida Mounds. ${ }^{4}$ Of the rest we know nothing, except perhaps, some of the circumstances of their burial. These silent revelations of the spade and pickaxe, however, indicate their origin most unmistakably; and although it is possible that some of the more recent specimens may belong to persons of mixed (Indian and White) blood, yet the skulls themselves do not show it, and the chances of such admixture are so small as scarcely to merit recognition. Except when such mixed unions have taken place on a large scale and been continued for a long period of time, as is the case to-day with some of the Indian tribes of the United States and Spanish America, the presumption as to any single skull found as these were, is always in favor of its being of pure Indian origin.

Referring now to the preceding tables, it will be seen that the average cranial capacity

\footnotetext{
${ }^{1}$ In this connection I desire to return my thanks to $\mathrm{Mr}$. Parker of the Pliladelphia Academy, to the late Mr. Caleb Cook of Salem, to Dr. J. C. IVarren of Boston, and to Mr. Applegate and Dr. Wm. F. Whitney of the Harvard Mechical School. To the latter gentleman I am under special obligations for practical aid in the work of measurements and for many valuable suggestions.

2 This is No. 3274 of the Warren Anatomical Museum of Boston, and is the skull of "Qualish, a New England Indian who died and was buried in Dellbam, Masso, in 1774, aet. 68 .
}

\section{Every tooth in place."}

8'This is No. 1560 of the Army Medical Museum at Washington Clty, and is said to be the skull of an Indian basket maker who was killed during the Revolutionary war. In a note to the writer", Dr. Otis, the Curator of that Museum, says "it las the largest internal capacity of any North American Inlian skull I have ever measured, and is, moreover, extraordinarily brachycephalic."

4'Tenth Annual Report of the P'eaborly Museum of American Archaeology and Ethnology. Cambridge, Mass., 1877 
of the 29 supposerl adult females is 1.319 cubic centimeters and of the 38 supposed adult males 1,436 c.c., showing a difference of 117 c.c. in favor of the latter. The smallest skull in the collection is No. 18, Table II (Peabody Mus., No. 12,350) from a shell heap on Great Deer Island, Maine, which measures 1182 c.c.; and the largest is No. 38, Table I, ${ }^{1}$ (Army Medical Museum No. 1560) which reaches the enormous size of 1920 c.c. The range or difference between the two extremes amounts to 738 c.c., which is less than that of the Indians of the Santa Barhara Islands, Califomia, or of the Momnhuilders of the Cumberland valley. ${ }^{2}$ Assuming, with Dr. J. Aitken Meigs, 1376 c.c. to be the average of the North American Indian, ${ }^{3}$ it will be seen that the mean of the two sexes, 1377 c.c., as given above, accords with it in a striking manner. This is greater than the Indians from the Santa Barbara Islands, 1310 c.c., the Tennessee Moundbuilders, 1341 c.c., ${ }^{5}$ or the Peruvians of the coast, 1230 c.c. ${ }^{6}$ but does not equal the Eskimos of Greenland, 1392 c.c., or of Alaska, 1404 c.c. $\quad$ Of the entire series, twenty-five are below 1350 c.c., or microcephalic, and thirteen above 1450 c.c., or macrocephalic, and thirteen are between the two, or mesocephalic, to which class the collection taken as a whole also belongs. ${ }^{8}$

The index of breadth, ${ }^{9}$ or the relation of the greatest breadth between the parietals, to the length meastred through the glabellit to the most prominent point of the oceiput, is .767 for the males, and .752 for the females; or , taking the mean of the two sexes and leaving off the fraction, 759 for the whole collection. This hrings them within the chiss of mesaticephali, though by a very narrow margin. Of the entire collection, twenty-six have an index below .750, and hence may be classed as dolichocephali; nine have an index greater than .800 and are, therefore to be ranked among the brachycephali or short skulls. whilst the remaining thirty-one have indices ranging between these limits and thus, of course, belong to the mesaticephali. Of this last group, the index is .775. The females are, however, slightly more dolichocephalic than the males, the figures being . 771 for the former and .779 for the latter.

1 Notwithstanding the very unusual size of this skull, I have not felt at liberty to omit it from the table for the following reasons: 1st, its history is pretty well known; $2 d$, there are crania of undoubtedly aboriginal origin now in the Peabody Museum of Cambridge, $i_{\text {. }}$, one from San Clemente Island, California, that measures $1747 \mathrm{c.c}$, and one from a mound in Tennessee that reaches 1825 c.c., that are abnormally large when compared with the averages from their respective localities; $3 \mathrm{~d}$, it is equalled, if not surpassed, by other specimens in the Peabody Museum, in the measurements of length, breadth and height, respectively, though none of them equals it when all the measurements are taken together. It is proper to add that the capacity of this skull was measured with No. 8 shot, whilst in all the others selected peas of nearly uniform size were used. This, of course, to a certain extent, vitiates the comparison, as very different results, are obtained when different materials are used; but it is believed that the excess of this skull over the one next to it in point of size, No. 16, Table I (a Natick Indian in the collection of the Philadelphia Academy) which measures 1690 c.c., is so great as to allow a very wide mar- gin for the inequality caused by using different methods of measurement. Be this as it may, my object in singling out this particular skull, was to mark the differences rather than to institute a comparison where surely none exists.

2 Twelfth Annual Report of the Peabody Museum, 1880.

${ }^{8}$ Catalogue of Human Crania in the Collection of the Philadelphia Academy of Natural Sciences, p. 10.

${ }^{4}$ Check-list of the Army Medical Museum. Washington, 1876. Twelfth Annual Report of the Peabody Museum, pp. 498 et seq.

${ }^{5}$ Eleventh Annual Report of the Peabody Museum, pp. 224 and 361.1878.

${ }^{6}$ Fourth Annual Report of the Peabody Museum, p. 18. 1871.

' Check-list of the Army Medical Museum, Washington, 1876.

${ }^{8}$ For this classification see Prof. Wm. H. Flower, in the Osteological Catalogue of the Royal College of Surgeons, Part 1, Man. p. 252. London, 1879.

${ }^{9}$ Index of breadth $=$ breadth $\times 1000 \div$-length. 
As was to have been expected in a collection, composed as this is of the crania of different tribes, the lange is very wille, extending from .859, No. 26, Table I, (Boston Society for Medical Improvement. No. 1376) to .663. No. 24. Table II (Academy of Natural Sciences of Philadelphia. No. 1040). This latter specimen is catalogued as "a woman aetat T0, with a singulitrly clongated head." Upon examination, the sagittal, coronal and lamboidal sutures were found to be closed. This may have been due to the age of the woman, and hence the peculiarly elongated form of the cranium cannot be ascribed to the premature closing of the sagittal suture, though that, of course, is possible. IIowever, there are in this collection other perfectly nomal crania that approach it too closely in this respect, e.g. No. 19, Table II, and No. 12, Table I (Peabody IIuseum, Nos. 660 and 10,249), to justify us in rejecting it as an aberrant form.

The index of height for the males is .761, for the females .758, and for the two sexes taken together .759. Compared with the indices of breadth, as is done in order to get at the shape of the head, we find that among the former the height is less than the breadth, whilst among the latter it is greater. The difference, however, is very small, amounting in either case to only $1 \mathrm{~m} . \mathrm{m}$. actual measurement. Taking the collections as a whole, and the indices of brealth and height are found to be erqual, but if the skulls be considered singly. twenty-seven of them have the index of breadth greater than that of height, whilst in twenty-nine the reverse is the case.

Coming now to the ficial measurements, and begiming with the alveolar index or the relation of the basi-nasal length to the basi-alveolar, estimating the former at 100 , and it will be found to be in the males .96 , and in the females $.99 .^{1}$ of the entire collection, twenty-six are orthognathous, twenty mesognathous, and only three that can be called strictly prognathous. Taking the two sexes together, the index of the whole is .975, or orthognathic with a strong tendeney to mesognathism.

The nasal index of the males is .49 , and of the females .51, which brings them both, when considered either separately or together, anong the mesorhine. There are, however, in the sories fourteen that have an index below 48 or are leptorhine, twelve with an inder above .5 .3 or platyrhine, and thirty that are within these limits or mesorhine.

The orbital index is . Ss for the males and .91 for the females, or 895 for the two. This classes them with the megareme, though just within the limits. ${ }^{2}$ As is usually the case, the orbit among the females is proportionately more open than among the males.

Summing up the result of these measurements, the average skull of this series is found to be of medium capacity and mesiticephalic, with a decided tendency towards dolichocephalism. It is orthognathic, mexorhine and megaseme, but by very small margins. These measurements and the technical description based upon them are believed to be correct; in fact they agree so closely with those made by Dr. Wilson upon a number (30) of skulls ${ }^{3}$ of the same people that there can be little doubt as to their accuracy; and yet after all it must be admitted that, in point of fact, so far as this collection is concerned, the

\footnotetext{
1 Prof. Flower, of the Royal College of Surgeons, prefers this methor of estimating the forward projection of the face for the reason that it is easy of application, "and if in some cases not strictly accurate, in the large majority it certainly gives the desired information." He classifies all below 980 as orthognathous. From .980 to 1.030 mesognathous. Above
}

1.030 as procrnathous. In the first of these classes are to be found most Europeans, and in the last most negroes.

${ }^{2}$ Below .840 is microseme; above .890 is megaseme; between the two is mesoseme.

${ }^{8}$ Prehistoric Man, p. 186. London, 1876. 
typical cranium, as adduced from the measurements, has no real existence. Undoubtedly there are skulls in the collection that unite many of the characteristic features indicated by the above measurements, and it is possible that there may be a few which combine them all, but the variations are so great that the eye is hartly able to single out any one form as typieal. For this purpose one will do as well as another, but not one is satisfactory. In this respect there is a marked differenee between this collection and those from some other localities. Take for instance, the crunia from the stone graves of Tennessee now in the Peabody Museum, or those from Greenland, now in the Army Medical Museum, and there runs through each series a certain prevailing form which is at once recognized. Here, however, no such unifornity exists. The crania differ among themselves in every possible way; and, in their distinguishing fentures, are so hopelessly mixed, that even though the range, or difference between the different extremes is no greater than in either one of the other collections, yet the entire series, judged by the eye, is too colorless to permit of the recognition of any type or standard save that furnished by the calipers and the "rule of three." These, however, do give us rather a solir foundation upon which to build, and justify us in asserting that, whilst the entire series considered with reference to the index of breadth does not supply us with sufficient data to reconstruct the typical prehistoric Indian skull of New England, granting such a thing to have existed, it does indicate an admixture of the different forms such as might be looked for in a collection made from the potter's field of London or New York. This is in accord with what is known of the existence of different forms of crania among the American aborigines, and of the circumstances under which this collection was made. It is, as has been said, composed of crania from different tribes (though belonging perhaps to the same linguistic family) and it contains skulls that range from the extreme of dolichocephalism to a moderate degree of brachycephalism. Though, strictly speaking, it occupies a medium position between these two classes, yet the tendency is so decidedly to the former that it may be said partially to bear out the conclusion of Dr. Busk as to the prevalence of the dolichocephalic form of skull upon the Atlantic coast of North America. ${ }^{1}$

As a matter of interest and for the sake of comparison the following table of mean measurements of crania has been added. It might have been indefinitely extended, but for obvious reasons it was deemed best to limit it to crania from North America. Numbers 1, 2 and 3 are taken from Dr. Wilson's Prehistoric Man; Nos. 6 and 7 are made up from the check-list of the Army Medical Museum, and Nos. 4 and 5 are from the records of the Peabody Museum of Ethnology at Cambridge.

1 Journal of the Anthropological Institute of London, for April, 1873, p. 95. 
Table III. Mean Measurements of Crania of Americay Indians.

\begin{tabular}{|c|c|c|c|c|c|c|c|c|c|c|c|}
\hline & 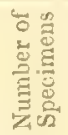 & $\begin{array}{l}\text { 总 } \\
\text { हैं } \\
\text { है }\end{array}$ & 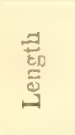 & 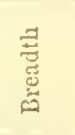 & 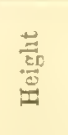 & 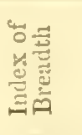 & 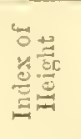 & 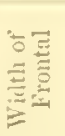 & 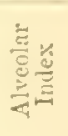 & 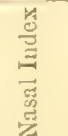 & \\
\hline 1. Huron-Males & $\overline{39}$ & & 187 & 139 & 139 & .743 & .743 & & & & \\
\hline Females & 18 & & 179 & 132 & 131 & .737 & .732 & & & & \\
\hline 2. Iroquois-Males & 8 & & 187 & 140 & 140 & .749 & .749 & & & & \\
\hline Females & 2 & & 175 & 137 & 133 & .783 & .760 & & & & \\
\hline 3. Algonkin Lenapé - Males & 19 & & $18: 2$ & 140 & 138 & .769 & .758 & & & & \\
\hline Females & 4 & & 173 & 139 & 133 & .803 & .769 & & & & \\
\hline 4. Santa Barbara-Males & 80 & 1372 & 181 & 137 & 131 & .760 & .725 & 93 & .99 & .48 & .92 \\
\hline Females & 54 & $1 \cdot 248$ & 174 & 135 & 126 & .777 & .727 & 89 & .99 & .49 & .93 \\
\hline 5. Tennessee Mounds ${ }^{1}-$ Males & 43 & 1401 & 164 & 146 & 145 & .891 & .886 & 95 & & & \\
\hline Females & 34 & 1301 & 159 & 142 & 140 & .893 & .871 & 90 & & & \\
\hline 6. Greenland-Males & 55 & $14: 33$ & 186 & 132 & 141 & .710 & .755 & & & & \\
\hline Females & 21 & 1275 & 180 & 127 & 133 & .709 & $.7+1$ & & & & \\
\hline 7. Alaska_Males & 31 & 1449 & 177 & 148 & 131 & .835 & .743 & & & & \\
\hline Females & 10 & 1281 & 170 & 141 & 127 & .836 & .747 & & & & \\
\hline 8. New England-Nales & $\begin{array}{l}38 \\
29\end{array}$ & $\begin{array}{l}1436 \\
1319\end{array}$ & $\begin{array}{l}180 \\
175\end{array}$ & $\begin{array}{l}138 \\
132\end{array}$ & $\begin{array}{l}137 \\
133\end{array}$ & $\begin{array}{l}.767 \\
.752\end{array}$ & $\begin{array}{l}.761 \\
.758\end{array}$ & $\begin{array}{l}95 \\
91\end{array}$ & $\begin{array}{l}.96 \\
.99\end{array}$ & .49 & .88 \\
\hline
\end{tabular}

2 Flattened posteriorly.

\section{EXPLANATION OF THE PLATES.}

The figures on the accompanying plates were drawn by means of Broca's Stereograph, from two Indian crania in the collection of the Peabody Museum, and are reproduced at one half their diameters. Figures 1 and 2 of each plate represent different views of skull No. 14, Table I (P. M. No. 11,249), and figures 3 and 4 were taken from No. 11, Table II (P. M. No. 10,231). 

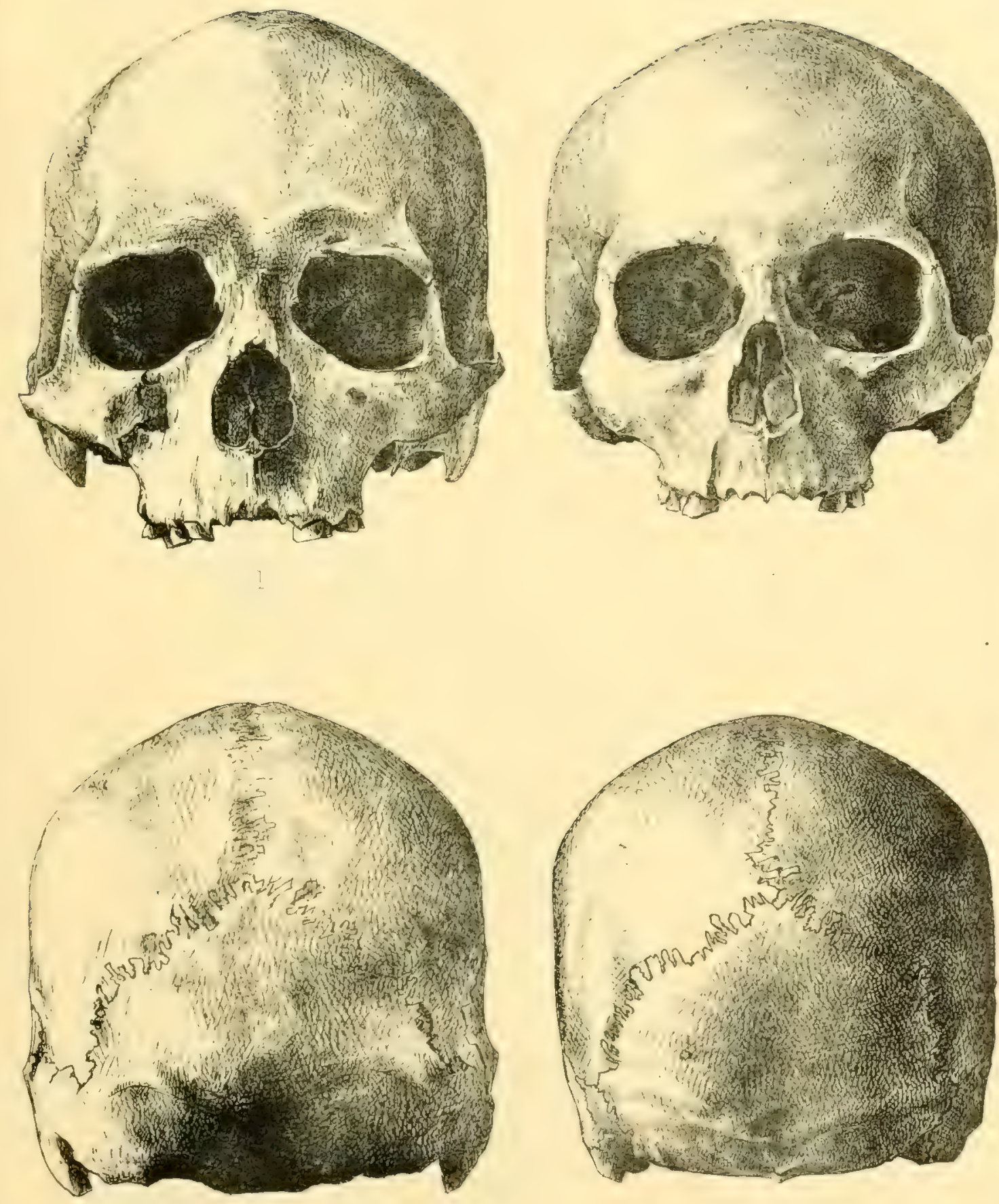


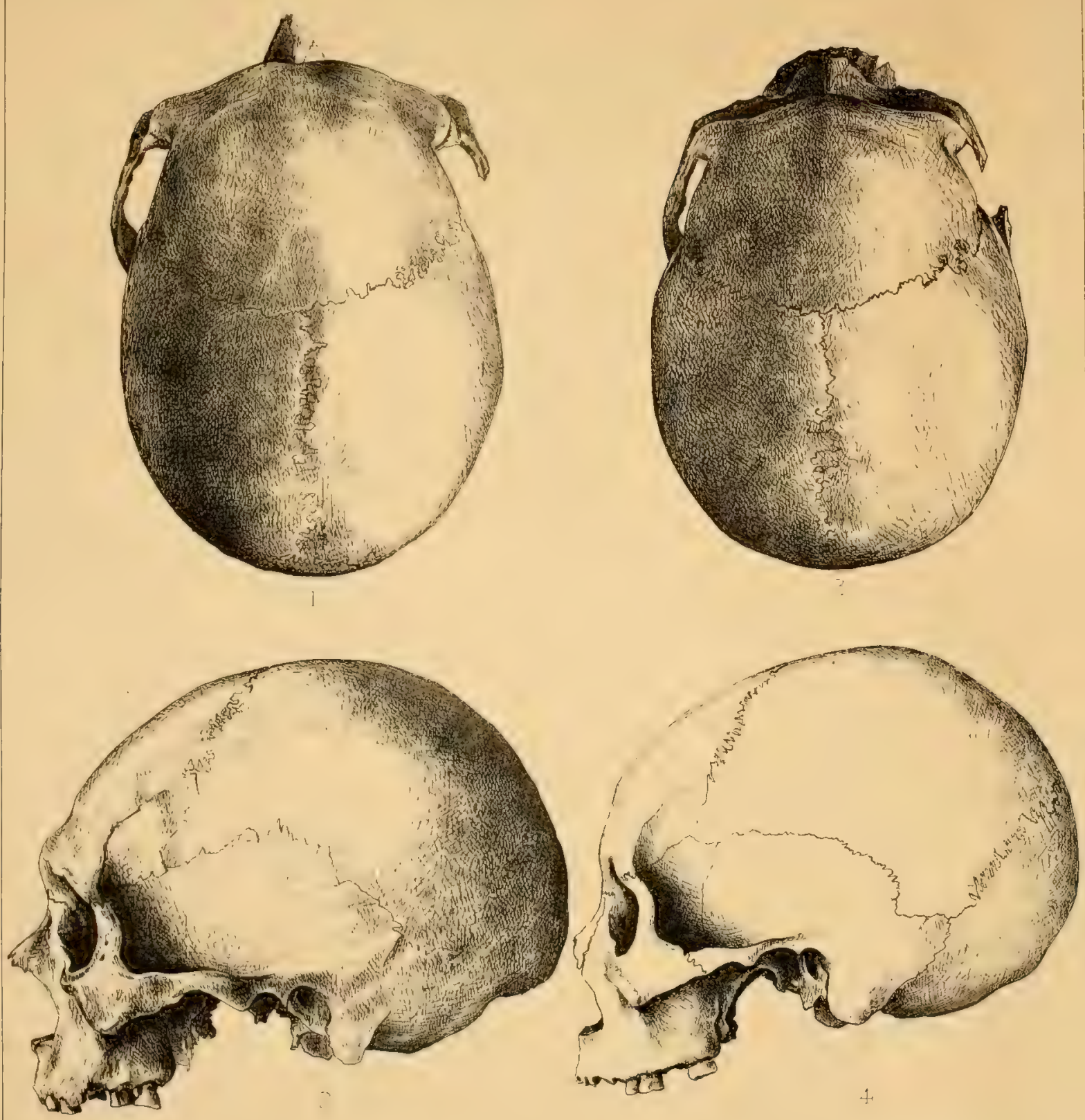

NE:. ENGLAND CRANIA

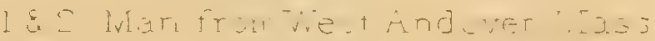

$3 \& 4$. Woman from Saugus, Mass 
1830. ANNIVERSARY MEMOTRS OF THE BOSTON SOCIETY OF NATURAL IIISTORY. 1880.

\title{
THE FEELING OF EFFORT.
}

\author{
BY WILLIAM JAMES, M.D.,
}

ASPISTANT PROFESSOR OF PHYSIOLOGY IN HARVARD UNIVERSITY.

BOSTON :

PUBLISHED BY THE SOCIETY.

1880 . 
. 


\section{The Feeling of Effort. By William James.}

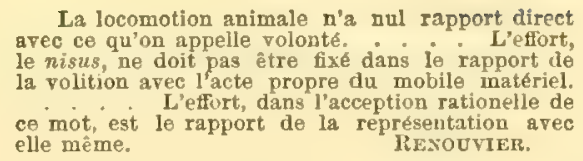

I propose in the following pages to offer a scheme of the physiology and psychology of volition, more completely worked out and satisfactory than any I have yet met with. The matter is a little intricate, and I shall have to ask the reader to bear patiently a good deal of detail for the sake of the importance of the result.

That we have a feeling of effort there can be no doubt. Popular language has sufficiently consecrated the fact by the institution of the word effort, and its synonyms exertion, striving, straining. The difference between a simply passive sensation, and one in which the elements of volition and attention are found, has also been recorded by popular speech in the difference between such verbs as to see and to look; to hear and to listen; to smell and to scent; to feel and to touch. Effort, attention, and volition are, in fact, similar elements of Feeling differing all in the. same generic manner from its receptive, or simply sensational elements; and forming the active as distinguished from the passive parts of our mental nature. 'This distinction is styled by Bain the most vital one within the sphere of mind; and at all times psychologists of the a priori school have emphasized the utter opposition between our consciousness of spontaneity or out-going energy, and the consciousness of any mere impression whatever.

Fully admitting the feelings of active energy as mental facts, our question simply is of what nervous processes are they the concomitants? As the feeling of effort is nowhere more coarsely and obviously present than in the phenomenon of muscular exertion, let us limit our inquiry first to that.

\section{MUSCULAR EXERTION AN AFFERENT FEELING.}

Johannes Miiller was, so far as I linow, the first to say ${ }^{1}$ that the nerve-process accompanying the feeling of muscular exertion, is the discharge from the motor centre into the motor nerve. The supposition is a most natural and plausible one; for if afferent nerve processes are felt, each in its characteristic way, why should not efferent processes be felt by equal right, and with equally characteristic qualities? Accordingly we find in writers of all nations since Mitler's time, repetitions implicit or explicit, of his suggestion. 
But the authors who have most emphatically insisted on it, and raised it to the position of a fundamental doctrine, are Bain, Hughlings Jackson and Wundt.

Bain says: "The sensibility accompanying muscular movement coincides with the outgoing stream of nervous energy, and does not, as in the case of pure sensation, result from any influence passing inwards, by incarrying or sensitive nerves."1

Jackson writes: "Sensations, in the sense of mental states, arise, I submit, during energizing of motor as well as of sensory nerve processes — with the outgoing, as well as with the ingoing current."2

Wundt separates the feeling of force exerted, from the feeling of effected movement. ${ }^{3}$ And in later writings he adopts the term Innervationsgefiihl to designate the former in relation to its supposerl cause, the efferent discharge. Feelings of inmervation have since then become household words in psychological literature. Two English writers only, so far as I know, Dr. Charlon Bastion, and Dr. Ferrier, have expressed sliepticism as to the existence of any feelings connected with the efferent nervous discharge. But their arguments being imperfect, and in the case of Bastian rather confusedly expressed, have passed unnoticed. Lotze in Germany has also raised a skeptical voice, but has not backed his doubts by many arguments. ${ }^{4}$ The notorious existence of the feeling of effort in muscular exertion; the fact that the efferent discharge there plays the principal rote, and the plausibility of the postulate so often insisted on by Lewes that identity of structure involves identity of function, have all conspired to make us almost helieve, as a matter of course, that motor cells when they discharge into motor fibres, should have their own "specific energy" of feeling, and that this should be no other than the senve of energy put forth.

In opposition to this popular view, I maintain that the feeling of muscular energy put forth is a complex afferent sensation coming from the tense muscles, the strained ligaments, squeezed joints, fixed chest, closed glottis, contracted brow, clenched jaws, etc., etc. That there is over and ahove this another feeling of effort involved, I do not deny; but this latter is purely moral and has nothing to do with the motor discharge. We shall study it at the end of this essay, and shall find it to be essentially identical with the effort to remember, with the effort to make a decision, or to attend to a disagreeable task.

First then, let us disprove the notion that there is any feeling connected with the motor or efferent nervous discharge. We may begin by asking: Why should there be? Even accepting Lewes's postulate in the abstract, what degree of "identity" should be demanded between the afferent and efferent nerve apparatus, to insure their being both alike, "sentient?" Even to our coarse optical examination, the sensory and the motor cells are widely different. But apart from a priori postulates, and however strange to logic it may appear, it is a fact that the motor apparatus is absolutely insentient in an afferent direction, although we know that the fibres of the anterior root will propagate a disturbance in that direction as well as in the other. Why may not this result from

${ }^{1}$ The Senses and the Intellect. 3d edition, p. 77.

2 Clinical and Physiological Researches on the Nervous System. (Reprinted from the Lancet, 1873). London, J. \& A. Churchill, p. xxxiv. See also this author's very original though somewhat obsture paper on Aphasia in Brain for October, 1879 , p. 351.

\footnotetext{
${ }^{8}$ Beiträge zur Theorie der Sinneswahrnehmung, p. 420. Physiologische Psychologie, p. 316.

4 See his Metaphysik, 1869, p. 589. See also Revue Philosophique, t. iv, p. 359.
} 
a true insentiency in the motor cell, an insentiency which would accompany all action there, and characterize its normal discharges as well as the mnatural irritations made by the knife of the surgeon or the electrorles of the physiologist upon the motor nerve.

Plausibility accrues to this presumption when we call to mind this general law: that consciousness seems to desert all processes where it can no longer be of any use. The tendency of consciousness to a minimum of complication is in fact a dominating law in Psychology. The logical law of parsimony is only its best known case. We grow unconscious of every feeling which is useless as a sign to lead us to our ends, and where one sign will suffice, others drop out, and that one remains to function alone. We observe this in the whole history of sense perception, and in the acquisition of every art. We ignore which eye we see with, because a fixed mechanical association has been formed between our motions and each retinal image. Our motions are the ends of our seeing, our retinal images the signals to these ends. If each retinal image, whichever it be, can suggest automatically a motion in the right direction, what need for us to know whether it be in the right eye or the left? 'The knowledge would be superfluous complication. So in acquiring any art or voluntary function. The marksman thinks only of the exact position of the goal, the singer only of the perfect sound, the balancer only of the point in space whose oscillations he must counteract by movement. The associated mechanism has become so perfect in all these persons, that each variation in the thought of the end, is functionally correllated with the one movement fitted to bring the latter about. Whilst they were tyros, they thought of their means as well as their end; the marksman of the position of his gun or bow, or the weight of his stone, the pianist of the visible position of the note on the keyboard, the singer of his throat or breathing, the balancer of his feet on the rope, or his hand or chin under the pole. But little by little they succeeded in dropping all this supernumerary consciousness, and they hecame secure in their movements exactly in proportion as they did so.

Now if we analyze the nervous mechanism of voluntary action, we shall see that by virtue of this principle of parsimony in consciousness, the motor discharge ought to be devoid of sentience. The essentials of a voluntary movement, are : 1, a preliminary idea of the end we wish to attain; 2, a "fiat;" 3, an appropriate muscular contraction ; 4, the end felt as actually accomplished. In man, at any rate, it is admitted that the idea of the end and the muscular contraction were originally coupled by empirical association; that is to say, the child with his end in view, made random movements until he acciclentally found one to fit. This movement awakened its own characteristic feeling which thenceforward remained with him as the idea of the movement appropriate to thit particular end. If the man should acquire a million distinct ends, he must acquire a million such motor ideas and a million connections between them and the ends. But one such connection, sulserved by an exclusive nerve tract user for no other purpose, will be enough for each end. The end conceiver, will when these associations are formed, always awaken its own proper motor idea. As for the manner in which this idea awakens its own proper movement - the one which will convert it from an idea into an actual sensation - the simplest possible arrangement would be to let it serve directly, (through its peculiar neural process) as a stimulus to the special motor centre, the ultimate sensible effect of whose discharge it prefigures and represents. 
The ordinary theory, however, makes the matter much more complicated. The idea of the end is supposed to awaken first a feeting of the proper motor innervation, and this, when adjudged right, to discharge the muscular combination.

Now what can he gained by the interposition of this second relay of feeling between the idea and the movement? Nothing on the score of economy of nerve tracts; for it takes just as many of them to associate a million ideas with a million motor feelings, ${ }^{1}$ each specific, as to associate the same million ideas with a million insentient motor centres. And nothing on the score of precision; for the only conceivable way in which they might further precision would be by giving to a mind whose notion of the end was vague, a sort of halting stage with sharper imagery on which to collect its wits before uttering its fiat. But not only are the conscious discriminations between "ends" much sharper than any one pretends the shades of difference between feelings of innervation to be, but even were this not the case, it is impossible to see how a mind with its end vaguely conceived, could tell out of a lot of Innervationsgefuihle, were they never so sharply differentiated, which one fitted that end exactly, and which did not. A sharply conceived end will on the other hand directly awaken a distinct movement as easily as it will awaken a distinct feeling of innervation. If feelings can go astray through vagueness, surely the fewer steps of feeling there are interposed, the more securely we shall act. We ought then on a priori grounds alone to regard the Innervationsgefiihl as a pure encumbrance.

Let us turn now to a posteriori evidence.

It is a notorious fact, recognized by all writers ${ }^{2}$ on voluntary motion, that the will seems concerned only with results and not with the muscular details by which they are executed. But when we say "results," what is it exactly that we mean? We mean of course. the movements objectively considered, and revealing themselves (as either accomplished or in process of heing accomplished), to our sensible pereeptions. Our inlea, notion, thought, of a movement, what we mean, whenever we speak of the movement, is this sensible pereeption which we get of it when it is taking place, or has completely occurred.

What then is this sensible perception?

What does it introspectively seem to be? I unhesitatingly answer: an aggregate of afferent feelings, coming primarily from the contraction of muscles, the stretching of tendons, ligaments and skin, and the rubbing and pressing of joints; and secondarily, from the eye, the ear, the skin, nose or palate, any or all of which may be indirectly affected by the movement as it takes place in another part of the body. The only idea of a movement which we can possess is composed of images of these, its afferent effects. By these differences alone, are movements mentally distinguished from each other, and these differences are sufficient for all the discriminations we can possibly need to make, when we intend one movement rather than another.

The recent writers who have been prompt to recognize the fact that volition is directed only to results, have hardly been sensible of the fin-reaching consequences of this admission, - consequences which will develop themselves as our inquiry proceeds. Meamwhile

\footnotetext{
1 'The association between the two orders of feeling being of course brought about by a separate neural connexion. between the tracts supporting each.
}

${ }^{2}$ By no one more clearly set forth than by II me himself in his essay on the Idea of Necessary Connection. The best recent statement $\mathrm{I}$ know is by Jaccoud: Des Paraplegies et de l'Ataxie du Mouvement. Paris, 1864. p. 591. 
one immediate conclusion follows: namely, thit there are no such things as efferent feelings, or feelings of inmervation: These are wholly mythological entities. Whoever salys that in raising his arm he is ignorant of how many muscles he contracts, in what order of sequence, and in what degrees of intensity, expressly avors a colossal amount of unconsciousness of the processes of motor discharge. Each separate muscle at any rate cannot have its distinct feeling of inmervation. Wundt, who makes such enormous use of these hypothetical feelings in his psychologic construction of space, is himself led to admit that they have no differences of quality, but feel alike in all muscles, and vary only in their degrees of intensity. ${ }^{2}$ They are used by the mind as guides, not of what movement, but of how strong a movement it is making, or shall make. But does not this virtually surrender their existence altogether ?

For if anything be obvious to introspection it is that the degree of strength of our muscular contractions is completely revealed to us by afferent feelings coming from the muscles themselves and their insertions, from the vicinity of the joints, and from the general fixation of the larynx, chest, face and body, in the phenomenon of effort, objectively considered. When a certain degree of energy of contraction rather than another is thought of by us, this complex aggregate of afferent feelings, forming the material of our thought, render's absolutely precise and distinctive our mental image of the exact strength of movement to be made, and the exact amount of resistance to be overcome.

Let the reader try to direct his will towards a particular movement, and then notice what constituted the direction of the will. Was it anything over and above the notion of the different feelings to which the movement when effected, would give rise? If we abstract from these feeling;, will any sign, principle, or means of orientation be left, by which the will may innervate the right muscles with the right intensity, and not go astray into the wrong ones? Strip off these images of result, ${ }^{3}$ and so far from leaving us with a complete assortment of directions into which our will may launch itself, you leave our consciousness in an absolute and total vacuum. If I will to write "Peter" rather than "Paul," it is the thought of certain digital sensations, of certain alphabetic sounds, of certain appearances on the paper, and of no others, which immediately precedes the motion of my pen.

If I will to utter the word Paul rather than Peter, it is the thought of my voice falling on my ear, and of certain muscular feelings in my tongue, lips and larynx, which guide the utterance. All these feelings are afferent, and between the thought of them, by which the act is mentally specified with all possible completeness, and the act itself, there is no room for any third order of mental phenomenon. Except, indeed, what I have called the fiat, the element of consent, or resolve that the act shall ensue. This, doubtless, to the reader's mind, as to my own, constitutes the essence of the voluntariness of the act. This fiat will be treated of in detail farther on. It may be entirely neglected here, for it is a constant coefficient, affecting all voluntary actions alike, and incapable of serving to distinguish them. No one

${ }^{1}$ Leidesdorf u. Meynert's Vierteljsch. f. Psychiatrie Bd. i, Heft i, S. 36-7. 1867. Physiologische Psychologie, S. 316.

${ }^{2}$ Harless, in an article which in many respects forestalls what I have to say, (Der Apparat des Willens, in Fichte's Zeitschrift fo Philos., Bd. 38, 1861) uses the convenient

word Effectsbild to designate our idea of this sensory result of a movement.

a We speak here only of the muscular exertion, properly so called. The difficulty often involved in making the fiat still remains a reserved question. 
will pretend that its quality varies according as the right or the left arm, for example, is used.

So far then, we seem free to conclude that an anticipatory image of the sensorial consequences of a movement, hard or easy, plus the fiat that these consequences shall become actual, ought to be able to discharge directly the special movement with which in our past experiences the particular consequences were combined as effects. Furthermore, there is no introspective evidence whatever of the existence of any intermediate feelings, possessing either qualitative or quantitative differences, and accompanying the efferent discharge. ${ }^{1}$

Is there, notwithstanding, any circumstantial evidence? At first sight, it appears as if the circumstantial evidence in favor of efferent feelings were very strong. Wundt says, ${ }^{2}$ that were our motor feelings of an afferent nature, "it ought to be expected that they would increase and diminish with the amount of outer or inner work actually effected in contraction. This, however, is not the case, but the strength of the motor sensation is purely proportional to the strength of the impulse to movement, which starts from the central organ innervating the motor nerves. This may be proved by observations made by physicians in cases of morbid alteration in the muscular effect. A patient whose arm or leg is half paralyzed, so that he can only move the limb with great effort, has a distinct feeling of this effort: the limb seems to him heavier than before, appearing as if weighted with lead; he has, therefore, a sense of more work effected than formerly, and yet the effected work is either the same or even less. Only he must, to get even this effect, exert a stronger innervation, a stronger motor impulse than formerly."

In complete paralysis also, patients will be conscious of putting forth the greatest exertion to move a limb which remains absolvitely still upon the bed, and from which of course no afferent muscular or other feelings can come. ${ }^{3}$

Dr. Ferrier in his Functions of the Brain, (Am. Eil. pp. 222-4) disposes very easily of this line of argument. He says: "It is necessary, however, to exclude movements altogether before such an explanation [as Wundt's] can be adopted. Now, though the hemiplegic patient cannot move his paralyzed limb, though he is conscious of trying hard

1 The various degrees of difficulty with which the fiat is given form a complication of the utmost importance, reserved for discussion further on.

2 Vorlesungen über Menschen und Thierseele, Bd. i, p. 222.

${ }^{3}$ In some instances we get an opposite result. Dr. $H$. Charlton Bastian (British Medical Journal, 1869, p. 461, note) says:-

"Ask a man whose lower extremities are completely paralyzed, whether, when he ineffectually wills to move either of these limbs, he is conscious of an expenditure of energy in any decrree proportionate to that which he would have experienced if his muscles had naturally responded to his volition. He will tell us rather that he has a sense only of his utter powerlessness, and that his volition is a mere mental act, carrying with it no feelings of expended energy such as he is accustomed to experience when his muscles are in powerful action, and from which action and its consequences alone, as $I$ think, he can derive any adequate notion of resistance."

Dr. J. J. Putnam has quite recently reported to me a case of this sort of only a few months standing. Many amputated patients who still feel their lost limbs are unable to make any conscious effort to move them. One such case informs me that he feels more able to will a distant table to move, 
yet he will be found to be making powerful muscular exertion of some kind. Vulpian has called attention to the fact, and I have repeatedly verified it, that when a hemiplegic patient is desired to close his paralyzed fist, in his endeavors to do so he unconsciously performs this action with the sound one. It is, in fact, almost impossible to exclude such a source of complication, and unless this is taken into account very erroneous conclusions as to the cause of the sense of effort may be drawn. In the fact of muscular contraction and the concomitant centripetal impressions, even though the action is not such as is desired, the conditions of the consciousness of effort exist without our being obliged to regard it as depending on central innervation or outgoing currents.

"It is, however, easy to make an experiment of a simple nature which will satisfactorily account for the sense of effort, even when these unconscious contractions of the other side, such as hemiplegics make, are entirely excluded.

"If the reader will extend his right arm and hold his forefinger in the position required for pulling the trigger of a pistol, he may without actually moving his finger, but by simply making believe, experience a consciousness of energy put forth. Here, then, is a clear case of conscionsness of energy without actual contraction of the muscles either of the one hand or the other, and without any perceptible bodily strain. If the reader will again perform the experiment, and pay careful attention to the condition of his respiration he will observe that his conscionsness of effort coincides with a fixation of the muscles of his chest, and that in proportion to the anount of energy he feels he is putting forth, he is keeping his glottis elosed and actively contracting his respiratory muscles. Let him place his finger as before, and continue breathing all the time, and he will find that however much he may direct his attention to his finger, he will experience not the slightest trace of consciousness of effort until he has actually moved the finger itself, and then it is referred locally to the muscles in action. It is only when this essential and ever present respiratory factor is, as it has been, overlooked, that the consciousness of effort can with any degree of plausibility be ascribed to the outgoing current. In the contraction of the respiratory muscles there are the necessary conditions of centripetal impressions, and these are capable of originating the general sense of effort. When these active efforts are withheld, no consciousness of effort ever arises, except in so far as it is conditioned by the local contraction of the group of muscles towards which the attention is directed, or by other muscular contractions called unconsciously into play in the attempt.

"I am unable to find a single case of consciousness of effort which is not explicable in one or other of the ways specified. In all instances the consciousness of effort is

than to exert the same volition over his acutely-felt lost leg. Others, on the contrary, (Vide Weir Mitchell's book on Gunshot Injuries to Nerves), say they can not only will, but, as far as their feeling is concerned, execule, movements of their amputated limbs. It would be extremely interesting to unravel the causes of these divergences. May it be that in recent cases with the recollection of varied movements fresh in the mind, the patient has a stock of distinct images of position on which to base his fiat; while in an inveterate case, either of paralysis with contraction, or amputation with consciousness of the limb in an invariable position, reminiscences of other positions have through long desuetude become so incapable of revival that there is no preliminary idea of an End for the fiat to knit itself to. Such a supposition conforms well to the utterances of two amputated porsons with whom I have conversed. 'They sail it was like "willing into the void," they "did not know how to set about it," and so forth. The recency of Dr. Putnam's case above mentioned seems, however, to conflict with such an explanation and I only make the suggestions in the hope that some one with better opportunities for observation than I possess, may become interested in the matter. I may add that in teaching a new and unnatural movement, the starting point is to awaken by its passive production a distinct sense of what the movement, if effected, would feel like. This defines the direction of the exertion the pupil is to make. 
conditioned by the actual fact of muscular contraction. That it is dependent on centripetal impressions generated by the act of contraction, I have already endeavored to show. When the paths of the centripetal impressions, or the cerebral centres of the same, are destroyed, there is no vestige of a muscular sense. That the central organs for the apprehension of the impressions originating from muscular contraction, are different from those which send out the motor impulse, has already been established. But when Wundt argues that this camnot be so, because then the sensation would always keep pace with the energy of muscular contraction, he overlooks the important factor of the fixation of the respiratory muscles, which is the basis of the general sense of effort in all its varying degrees."

To these remarks of Ferrier's I have nothing to add. Any one may verify them, and they prove conclusively that the consciousness of muscular exertion, being impossible without movement effected somewhere, must be an afferent and not an efferent sensation, a consequence, and not an antecedent of the movement itself. An idea of the amount of muscular exertion requisite to perform a certain movement can consequently be nothing other than an anticipatory image of the movement's sensible effects.

Driven thus from the body at large, where shall the circumstantial evidence for the feeling of innervation lodge itself? Where but in the muscles of the eye, from which last small retreat it judges itself inexpugnable. And, to say the truth, it may well be excused for its confidence; for Ferrier alone, so far as I know, has ventured to attack it there, and his attack must be deemed a very weak failure. Nevertheless, that fastness too must fall, and by the lightest of bombardments. But, before trying the bombardment, let us examine the position with a little care, laying down first a few general principles about optical vertigo, or illusory appearance of movement in objects.

We judge that an object moves under two distinct sets of circumstances:

1. When its image moves on the retina, and we know that the eye is still.

2. When its image is stationary on the retina, and we know that the eye is moving. In this case we feel that we follow the object.

In either of these cases a mistaken judgment about the state of the eye will produce optical vertigo.

If in case 1, we think our eye is still when it is really moving. we shall get a movement of the retinal image which we shall judge to be due to a real outward motion of the object. This is what happens after looking at rushing water, or throngh the windows of a moving railroad car, or after turning on one's heel to giddiness. The eyes, without our intending to move them, go through a series of involuntary rotations, continuing those they were previously obliged to make to keep objects in view. If the objects had been whirling by to our right, our eyes when turned to stationary objects will still move slowly towards the right. 'The retinal image upon them will then move like that of an object passing to the left. We then try to catch it by voluntarily and rapidly rotating the eyes to the left, when the involuntary impulse again rotates the eyes to the right, continuing the apparent motion, and so the game goes on. 
If in case 2, we think our eyes moving when they are in reality still, we shall judge that we are following a moving object when we are but fixating a steadfast one. Illusions of this kind occur after sudden and complete paralysis of special eye muscles, and the partizans of feelings of efferent innervation regard them as experimenta crucis. Helmholtz writes:1 "When the external rectus muscle of the right eye, or its nerve, is paralyzed, the eye can no longer be rotated to the right side. So long as the patient turns it only to the nasal side it makes regular movements, and he perceives correctly the position of objects in the visual field. So soon, however, as he tries to rotate it outwardly, $i . e$., towards the right, it ceases to obey his will, stands motionless in the middle of its course, and the objects appear flying to the right, although position of eye and retinal image are unaltered. ${ }^{2}$

"In such a case the exertion of the will is followed neither by actual movement of the eye, nor by contraction of the muscle in question, nor even by increased tension in it. The act of will produced absolutely no effects beyond the nervous system, and yet we judge of the direction of the line of vision as if the will had exercised its normal effects. We believe it to have moved to the right, and since the retinal image is unchanged, we attribute to the object the same movement we have erroneously ascribed to the eye. * * * These phenomena leave no room for doubt that we only judge the direction of the line of sight by the effort of will with which we strive to change the position of our eyes. 'There are also certain weak feelings in our eyelids, * * * * and furthermore in excessive lateral rotations we feel a fatiguing strain in the muscles. But all these feelings are too faint and vague to be of use in the perception of direction. We feel then what impulse of the will, and how strong a one, we apply to turn our eye into a given position."

Partial paralysis of the same musele, paresis, as it has been called, seems to point even more conclusively to the same inference, that the will to innervate is felt independently of all its afferent results. I will quote the account given by a very recent authority, ${ }^{3}$ of the effects of this accident :

"When the nerve going to an eye muscle, $e . g$., the external rectus of one side, falls into a state of paresis, the first result is that the same volitional stimulus, which under normal circumstances would have perhaps rotated the eye to its extreme position outwards, now is competent to effect only a moderate outward rotation, say of $20^{\circ}$. If now, shutting the sound eye, the patient looks at an object situated just so far outwards from the paretic eye that this latter must turn $20^{\circ}$, in order to see it distinctly, the patient will feel as if he had moved it not only $20^{\circ}$ towards the side, but into its extreme lateral position, for the impulse of innervation requisite for loringing it into view is a perfectly conscious act, whilst the diminished state of contraction of the paretic muscle lies for the present out of the ken of consciousness. The test proposed by von Graefe, of localization by the sense of touch, serves to render evident the error which the patient now makes. If we direct him to touch rapidly the object looked at, with the fore finger of the hand of the same side, the line through

'Physiologische Optik, p. 600.

2 The left and sound eye is here supposed covered. If both eyes look at the same field there are double images which still more perplex the judgment. The patient, how- ever, learns to see correctly before many days or weeks are over.

W. J.

${ }^{3}$ Alfred Graefe, in Handbuch der gesammten Augenheilkunde, Bil. vI, S. 18. 
which the finger moves will not be the line of sight directed $20^{\circ}$ outward, but will approach more nearly to the extreme possible outward line of vision."1

A stone cutter with the external rectus of the left eye paralysed, will strike his hand instead of his chisel with his hammer, until experience has taught him wisdom.

It appears as if here the judgment of direction could only arise from the excessive innervation of the rectus when the object is looked at. All the afferent feelings must be identical with those experienced when the eye is sound, and the judgment is correct. The eye ball is rotated just $20^{\circ}$ in the one case as in the other, the image falls on the same part of the retina, the pressures on the eyeball and the tensions of the skin and conjunctiva are identical. There is only one feeling which can vary, and lead us to our mistake. That feeling must be the effort which the will makes, moderate in the one case, excessive in the other, but in both cases an efferent feeling, pure and simple.

Beantiful and clear as this reasoning seems to be, it, is based on an incomplete inventory of the afferent data. 'The writers have all omitted to consider what is going on in the other eye. This is kept covered during the experiments to prevent double images, and other complications. But if its condition under these circumstances be examined, it will be found to present changes which must result in strong aflerent feelings. And the taking account of these feelings demolishes in an instant all the conclusions which the authors from whom I have quoted, base upon their supposed absence. This I will now proceed to show.

Take first the case of complete paralysis and assume the right eye affected. Suppose the patient desires to rotate his gaze to an object situated in the extreme right of the field of vision. As Hering has so beautifully shown, both eyes move by a common act of innervation, and in this instance both move towards the right. But the paralyzed right eye stops short in the middle of its course, the object still appearing far to the right of its fixation point. The left sound eye, meanwhile, although covered, continues its rotation until the extreme rightwarl limit thereof has been reached. To an observer looking at both eyes the left will seem to squint. Of course this continued and extreme rotation produces afferent feelings of rightward motion in the eychall, which momentarily overpower the fint fechings of central position in the diseased and uncovered eye. The patient fecels by his left eye-ball as if he were following an object which by his right retina he perceives he does not overtake. All the conditions of optical vertigo are here present: the image stationary on the retina, and the erroneous conviction that the eyes are moving.

'The objection that a feeling in the right eyeball ought not to produce a conviction that the left eye moves, will be considered in a moment. Let us meanwhile, turn to the case of simple paresis with apparent translocation of the field.

IIere the right eye succeeds in fixating the object, but observation of the left eye will reveal to an observer the fact that it squints just as violently inwards as in the former case. The direction which the finger of the patient takes in pointing to the object, is the direction of this squinting and covered left eye. As Graefe says (although he fails to seize the true import of his own observation), "It appears to have been by no means sufficiently noticed how significantly the direction of the line of sight of the secondarily deviating eye, [i.e., of the left,] and the line of direction of the pointed finger agree." 
The translocation would, in a word, he perfectly explained, could we suppose that the sensation of a certain degree of rotation in the left eyeball were able to suggest to the patient the position of an object whose image falls on the right retina alone. Can then, a feeling in one eye be confounded with a feeling in the other?

Not only Donders and Adamük, by their vivisections, but Hering by his exquisite optical experiments, have proved that the apparatus of imnervation for both eyes is single, and that they function as one organ - a double eye, according to Hering, or what Helmholtz calls, a Cyclopenauge. Now the retinal feelings of this double organ, singly innervated, are also to a great extent absolutely indistinguishable, namely, where they fall in corresponding points. But even where they are numerically distinguishahle, they are indistinguishable with respect to our knowing whether they belong to the left retina or to the right. When, as so often happens, part of a distant object is hidden from one eye by the edge of an intervening body, and seen onily by the other eye, we rarely know by our spontaneous feeling that this is the case, nor when we have noticed the fact can we tell which eye is seeing and which is eclipsed. If the reader will hold two needles in front of his nose, one of them behind the other, and look at the distant one with both eyes, the near one will appear to him double. But he will be quite unable by his mere feeling, to say to which eye either of the double images belong. If he gives an opinion, he will probably say the right image belongs to the right eye, the reverse being really the case. ${ }^{1}$ In short, we use our retinal sensations indifferently, and only to tell us where their objects lie. It takes long practice directed specially ad hoc, to teach us on which retina the sensations respectively fall.

Now the different sensations which arise from the positions of the eyeballs are also used exclusively as signs of the position of objects; an object directly fixated, being localized habitually at the intersection of the two optical axes, but without any separate consciousness on our part that the position of one axis is different from another. All we are aware of is a consolidated feeling of a certain "strain" in the eyeballs, accompanied by the perception that just so far in front and so far to the right or to the left, there is an object which we see. This being the case, our patient paretic of the right external rectus, might be expected to see objects, not only transposed to the right, but also nearer because the intersection of his sruinting axes is nearer, and smaller because a retinal image of fixed size awakens the judgment of an object small in proportion as it is judged near. Whether paretic patients of this kind are subject to this additional illusion remains to be discovered by examinations which ophthalmologists in large practice alone have the opportunity of making. ${ }^{2}$ It is

\footnotetext{
1 See also W. B. Rogers, Silliman's Journal, 1860, for other curious examples of this incapacity.

${ }^{2}$ In three recent cases examined for me by opthalmological friends this additional delusion seemed absent, and I also found it absent in a case of paralysis of the external rectus with translocation which, by Dr. Wadsworth's kindness, I lately examined at the lospital. The "absence" spoken of was in all these cases a vacillating and uncertain judgment rather than a steadfastly" positive judgment that distance and size werc unaltered.
}

The extraordinary vacillation of our judgments of size and distance will be noticed by any one who has experimented with slightly concave, convex or prismatic glasses. The most familiar example is that of looking at the moon through an opera glass. It looks larger, so its details are more distinctly seen; being so distinct it looks nearer, and because it seems nearer it is also judged smaller. (Aubert's secundare Urtheils(äuschung). Many experiments may be devised by which the left eye may be made to converge by a prism whilst the right looks eithor at the same object or sees 
worth while to observe, however, that the feeling of accommolation and the knowledge of the true size of the object conspire with the feeling of convergence to give the judgment of distance. And where the convergence is an altogether abnormal one, as in the paretic squint, the feeling of the left eyeball being excessive, might well simply overpower all other feelings and leave no clear impression whatever save a general one of looking far towards the right.

The only thoroughly crucial test of the explanation here proposed of the paretic translocntion, would be a case in which the left eye alone looked at the object whilst the right, looking at nothing, strongly converged. Since, however, the only way of making a normal eye converge, is to give it an object to look at, it would seem at first sight as if such a case could never be obtained. It has occurred to me, notwithstanding, that slight atropinization of one eye might cause such strong accommodative immervation. that the convergent muscles might sympathetically contract, and a squint tend to occur. The squint would be steadfast, and situated in the non-atropinized eye, if it were covered and the poisoned eye alone made to fixate a near object. And if under these circumstances the object thus monocularly seen were translocated outwardly, we should have a complete verification of the explanation I present. The innervation is wholly different from that in paresis, and the only point the two cases have in common is the covered eye rotated nasalwards. Probably it would not be easy to find the patient, or the dose of atropia just fitted for producing the squint. But one positive instance would outweigh a hundred negative ones. I have had a chance to experiment on but one person. A large needle was stuck in a horizontal board, whose edges touched the face, the needle being from eight to twelve inches in front of the right atropinized eye. The subject was told to touch with her finger the under surface of the board, just beneath the needle. The results were negative, - no well-marked squint being perceptible, - but on the third day after the atropinization, the patient regularly placed her finger from one-half to three-cuarters of an inch too far to the right. Other observations ought to be made.

There seems meanwhile to be a very good negative instance by which to corroborate our arguments. If we whirl about on our heel to the right, objects will, as above-mentioned, seem to whirl about us to the left as soon as we stand still. 'This is due to the fact that our eyes are unwittingly making slow movements to the right, corrected at intervals by quick voluntary ones to the left. There is then in the eyes a permanent excess of rightward innervation, the reflex resultant of our giddiness. The intermittent movements to the left by which we correct this, simply confirm and intensify the impression it gives us of a leftward whirling in the field of view: we seem to ourselves to be

one of the double images of a more distant object whose other double image is cut off by a screen from the left retina. Under these circumstances we get translocations which may be similar to those in paresis but they prove nothing to our purpose, for the moment the prism is introtuced before the left eye, altering its convergence, the right eye moves sympathetically, giving rise to a translation of its retinal image, which of course suggests translocation of the object.
The only experiment capable of proving the theory advanced in the text would be one in which no shifting of the image on the right retina accompanied the turning inwards of the left eye. The experiment without prisms mentioned by Hering, (Lehre vom binocularen Sehen, pp. 12-14), seems the nearest approach which we can make to this, but there both eyes fixate the same objects, and there is some trans. lation of the image. 
periodically pursuing and overtaking the objects in their leftward flight. Now if we convert this periodic voluntary action into permanent action, by holding the eyeballs still in spite of their reflex tendency to rotate, $(i . e$, by using such an excess of leftward voluntary innervation as would keep us fixating one object), we ought, if truly conscious of the degree of our voluntary innervation, to feel our eyes actually moving towards the left. And this feeling should produce in us the judgment that we are steadily following with our gaze a leftward moving field of view. As a matter of fact, however, this never happens. What does happen is that the field of view stops its motion the moment our eyes stop theirs. ${ }^{1}$ Nothing could more conclusively prove the inability of mere innervation, (however complex or intense) to influence our perception. Nothing could more completely vindicate the irlea that effected movement; through the afferent sensations they give rise to, are alone what serve as premises in our motor judgments. ${ }^{2}$

\section{IDEO-Motor ACtion.}

So far then, so good. We have got rid of a very obstructive complication in relegating the feeling of muscular exertion properly so called, to that vast and well known class of afferent feelings, none of whose other members are held by any one to be especially connected with the mysterious sentiments of effort and power, which are the subjects of our study. All muscle feelings eliminated, the question stands out pure and simple: What is the volitional effort proper? What makes it easy to raise the finger, hard to get out of bed on a cold morning, harder to keep our attention on the insipid image of a procession of sheep when troubled with insomnia, and hardest of all to say No to the temp-

1 The subject of optical vertigo has been best treated by Breuer in Stricker's Medizinische Jahrbücher, Jahrg. 1874. 1 Heft. (See also 1875, 1 Heft). Hoppe's more recent work "Die Scheinbewegungen," I have not seen. I ouglit to say that Mach (Grundlinien der Lehre von den Bewegungsempfindungen, 1875, pp. 83-5) denies that in his case fixating a point causes the apparent movement of objects to stop. II is case is certainly exceptional, but need not invalidate in the least our theory. The eye-motions in all cases are reflex results of a sensation of subjective whirling of the body due most probably to excitement of the semi-circular canals. This is not arrested in any one by fixing the eyes; and persisting in Mach with a constant field of view, may in him be sufficient to suggest the judgment that the field follows him in his flight, whilst in the average observer the further addition of a moving retinal image may be requisite for the full production of that psychic impression. All the feelings in question are rather confused and fluctuating, while the nausea which rapidly supervenes stands in the way of our becoming adepts in their observation.

${ }^{2}$ Let it not be objected that the involuntary rightward motion of the eyeballs which misled us, after standing still, into the impression that the world was moving, was "effected" and ought to have given us afferent sensations strong enough to prevent our being deluded by the image passing over the retina. No doubt we get these afferent sensations and with sufficient practice would rightly interpret them. But as the experiment is actually made, neither they nor the moving image on the retina, (which far overpowers them in vivacity of impression,) are expected. When we intend a movement of the eyes, the world being supposed at rest, we always expect both these sensations. Whenever the latter has come unexpectedly we have been in presence of a really moving object, and every moment of our lives moving objects are giving us unexpectedly this experience. Of prolonged unexpected movements of the eyes we never under normal circumstances have any experience whatever. What wonder then that the intense and familiar sensation of an unexpectedly moving retinal image should wholly overpower the feeble and alınost unknown one of an unexpected and prolonged moveinent of the eyeballs and be interpreted as if it existed alone. I cannot doubt however that with suflicient practice we should all learn so to attend to and interpret the feelings of the moving eyeballs as to reduce the retinal experience to its proper signification. 
tation of any form of instinctive pleasure which has grown inveterate and habitual. In a word what is the nature of this fiat of which we have so often spoken ? ${ }^{1}$

In our bed we think of the cold, and we feel the warnth and lie still, but we all the time feel that we can get up with no trouble if we will. The difficulty is to will. We say to our intemperate acquaintance, "You can be a new man, if you will." But he finds the willing imposible. One who talks nonsense moler the influence of hasheesh, realizes all the time his power to end his sentences soberly and sensibly, if he will. But his will feels as yet no sufficient reason for exerting itself. A person lying in one of those halftrance like states of immobility not infrequent with nervous patients, feels the power to move undiminished, but cannot resolve to manifest it. And cases might be multiplied indefinitely in which the fiat is not only a distinct, but a difficult and effort-requiring moment in the performance.

On the other hand cases may be multiplied indefinitely of actions performed with no distinct volitional fiat at all, - the mere presence of an intellectual image of the movement, and the absence of any conflicting image, being adequate causes of its production. As Lotze says:2 6 The spectator accompanies the throwing of a billiard ball, or the thrust of the swordsman with slight movements of his arm; the untaught narrator tells his story with many gesticulations; the reader while absorbed in the perusal of a battle scene feels a slight tension run through his muscular system, keeping time as it were with the actions he is reading. of. These results become the more marked the more we are absorbed in thinking of the movements which suggest them; they grow fainter exactly in proportion as a complex consciousness, under the dominion of a crowd of other representations, withstands the pasing over of mental contemplation into outward action. * * * We see in writing or piano-playing a great number of very complicated movements following quickly one upon the other, the instigative representations of which remained scarcely a second in consciousness, certainly not long enough to awaken any other volition than the general one of resigning oneself without reserve to the passing over of representation into action. All the actions of our daily life happen in this wise:

\footnotetext{
1 The philosophic importance of clearing the ground for the question may be shown by the example of Maine de Biran. This thoroughly original writer's whole life was devoted to the task of showing that the primordial fact of conscious personality was the sentiment of volitional effort. This intimate sense is the self in each of us. "It becomes the self by the sole fact of the distinction which establishes itself between the subject of the effort and the term which resists by its own inertia. The ego cannot begin to know itself or to exist for itself, except in so fur as it can distinguish itself as subject of an effort, from a term which resists." (Euvres Inédites, Vol. 1, pp. 208, 212). Maine de Biran makes this resisting term the muscle, though it is true he does not, like so many of his successors, think we have an efferent sense of its resistance. Its resistance is known to us by a muscular sensation proper, the effect of the contraction (p.213). We shall show in the sequel that this sensation resists our fiat or volitional effort proper in no degree quâ muscular, but simply quâ disagreeable. Any other disagreeable sensation whatever may equally well
}

serve as the term which resists our fiat that it become real. M. de B.'s giving such a monstrous monopoly to the muscular feelings is a consequence of his not having completed the discrimination I make in the text between all afferent sensations together on the one land, and the fiat on the other. Muscle feelings for him still occupy an altogether singular hybrid and abnormal sort of position.

2Medicinische Psychologie, 1852, p. 293. In his admirably acute chapter on the will this author has most explicitly maintained the position that what we call muscular exertion is an afferent and not an efferent feeling: "We must affirm universally that in the muscular feeling we are not sensible of the force on its way to produce an effect, but only of the sufferance already produced in our moveable organs, the muscles, after the force has, in a manner unobservable by us, exerted upon them its causality." (p. 311.) How often the battles of psychology have to be fought over again, each time with leavier armies and bigger trains, though not always with so able generals. 
Our standing up, walking, talking, all this never demands a distinct impulse of the will, but is adequately brought about by the pure flux of thought."

Dr. Carpenter has proposed the name ideo-motor for these actions without a special fiat. And in the chapter of his Mental Physiology bearing this title may be found a very full collection of instances. ${ }^{1}$ It is to be noted that among the most frequent cases of this sort are those acts which result from ideas or perceptions, intercurrent as it were to the main stream of our thought, and it may be logically disconnected therewith. I am earnestly talking with a friend, when I notice a piece of string on the floor. The next instant I have picked it up, with no deliberate resolve to do so, and with no check to my conversation. Or, I am lying in my warm bed, engrossed in some revery or other, when the notion suddenly strikes me "it is getting late," and before I know it, I am up in the cold, having executed without the smallest effort of resolve, an action which, half an hour previous, with full consciousness of the pros and the cons, the warm rest and the chill, the sluggishness and the manliness, time lost and the morning's duties, I was utterly unable to decide upon.

I then lay it down as a second corner-stake in our inquiry, that every representation of a motion awakens the actual motion which is its abject, unless inhibited by some antagonistic representation simultaneously present to the mind.

It is somewhat dangerous to base dogmatic conclusions on the experiments so far made on the cerebral cortex, nevertheless they may help to confirm conclusions already probable on other grounds. Munk's vivisectional experiments on the cortical centres seem much the most minute and elaborate which have yet been reported. Now Munk concludes from them that the so-called motor centres of Hitzig and Ferrier, each of which, when electrically irritated, provokes a charicteristic movement in some part of the body, are sensory centres, - the centres for the feelings of touch, pressure, position, and motion of the bodily parts in question. The entire zone which contains them is called by him the Fiuhlsphäre of the cerebral surface, and is made coördinate with the Sehsphäre and Hörsphäre. ${ }^{2}$

Electric excitement of the fore paw centre can then only give us an image of the paw in some resultant state of flexion or extension. And the reason why motor effects occur like clock-work when this centre is irritated, would be that this image is awakened with such extraordinary vivacity by the stimulus that no other idea in the amimal's mind can be strong enough to inhibit its discharging into the insertient motor centres below.

Now the reader may still shake his head and say: "But can you seriously mean that all the wonderfully exact adjustment of my action's strength to its ends, is not a matter of outgoing imnervation? Here is a cammon ball, and here a pasteboard box: instantly and accurately I lift each from the table, the hall not refusing to rise because my innervation was too weak, the box not flying abruptly into the air because it was too strong.

1 Prof. Bain has also amply illustrated the subject in his work on the Senses and Intellect, $3 \mathrm{I}$ edition, pages 336 to 343. He considers that these facts prove that the ideas of motion inlabit ilentical nerve tracts with the actualized motions.

2II. Munk (Du Bois-Reymond's Archiv für Physiologie, 1878, pp. 177-8 and 549). It is true that Munk still believes in the Innervationsgefilhl, only he supposes it to be a result of the activity of the lower motor centres, not coming to consciousness in sifu, but transmitted upwards by fibres to the zone in question, and there perceived along with the passive feelings of the part involved. It is needless to say that there is not an atom of objective ground for the belief in these afferent innervation feelings - even less than for the efferent ones ordinarily assumed. 
Could representations of the movement's different sensory effects in the two cases be so delicately foreshadowed in the mind? or being there, is it credible that they should, all unaided, so delicately graduate the stimulation of the unconscious motor centres to their work?" Even so! I reply to both queries. We have a most extremely delicate foreshadowing of the sensory effects. Why else the start of surprise that runs through us, if some one has filled the light seeming box with sand before we try to lift it, or has substituted for the camnon ball which we know, a painted wooden imitation? Surprise can only come from getting a sensation which differs from the one we expect. But the truth is that when we know the objects well, the very slightest difference from the expected weight will surprise us, or at least attract our notice. With unknown objects we begin by expecting the weight made probable by their appearance. The expectation of this sensation innervates our lift, and we "set" it rather small at first. An instant verifies whether it is too small. Our expectation rises, $i$. e., we think in a twinkling of a setting of the chest and teeth, a bracing of the back, and a more violent feeling in the arms. Quicker than thought we have them, and with them the burden ascends into the air. Bernhardt ${ }^{1}$ has shown in a rough experimental way that our estimation of the amount of a resistance is as delicately graduated when our wills are passive, and our limbs made to contract by direct local faradization, as when we ourselves innervate them. Ferrier ${ }^{2}$ has repeated and verified the observations. They admit of no great precision, and too much stress should not be laid upon them either way, but at the very least, they tend to show that no adderd delicacy would accue to our pereeption from the conscionsness of the efterent process, even if it existed.

\section{The Inscrutable Psycho-physic Nexus is identical in all Innervation AND lies outside the SPHere of the WiLL.}

On the ordinary theory, the movements which accompany emotion, and those which we call voluntary, are of a fundamentally different character. The emotional movements are admitted to be discharged without intermediary by the mere presence of the exciting idea. The voluntary motions are said to follow the idea only after an intermedinte conscious process of "innervation" has been aroused. On the present theory the only difference lies in the fact that the emotions show a peculiar congenital comnection of certain forms of idea with certain very specially combined movements, largely of the "involumtary" muscles, but also of the others - as in fear, anger, etc.-such connection being noncongenital in voluntary action; and in the further fact that the discharge of idea into movement is much more readily inhibited by other casually present ideas in the case of voluntary action, and less so in the case of emotions; though here too inhibition takes place on a large scale. ${ }^{3}$

\footnotetext{
1 Archiv für Psychiatrie, III, 618-635. Bernhardt strangely enough seems to think that what his experiments disprove is the existence of afferent muscular feelings, not those of efferent innervation - apparently because he deems that the peculiar thrill of the electricity ought to overpower all other afferent feelings from the part. But it is far more natural to interpret his results the other way, even aside from the cer-
}

tainty yielded by other evilence that passive muscular feelings exist. This other evidence is compendiously summed up by Sachs in Reichert und Du Bois' Archiv, 1874, pp. $174-188$.

2 Functions of the Brain, p. 228.

${ }^{3}$ Witness the evaporation of manifestations of disgust in the presence of fear, of lust in the presence of respect, etc., etc. 
That one set of ideas should compel the vascular, respiratory, and gesticulatory symptoms of shame, another those of anger, a third those of grief, a fourth those of laughter, and a fifth those of sexual excitement, is a most singular fict of our organization, which the labors of a Darwin have hardly even begun to throw light upon. Where such a prearrangement of the nerve centres exists, the way to awaken the motor symptoms is to awaken first the idea and then to dwell upon it. The thought of our enemy soon brings with it the bodily ebullition, of our loss the tears, of our blunder the blush. We even read of persons who can contract their pupils voluntarily by steadily imagining a brilliant light - that being the sensation to which the pupils normally respond.

"It is possible to weep at will by trying to recall that peculiar feeling in the trigeminal nerve which habitually precedes tears. Some can even succed in sweating voluntarily, by the lively recollection of the characteristic skin sensations, and the voluntary reproduction of an indercribable sort of feeling of relaxation, which ordinarily precedes the flow of perspiration. Finally, it is well known how easily the thought of gustatory stimuli excites the activity of the salivary glands. This capacity to indirectly excite activities usually involuntary, is much more pronounced in certain discases. Hypochondriacs know well how easily the heart-beat may be made to alter, or even cramps of single muscles, feelings of aura, and so forth, be brought about in this way, which no doubt in the religious epidemies of the Middle Agres, led to the imitative spread of ecstatic convulsions, from one person to another." 1 It suffices to think steadily of the feeling of yawning, to provoke the act in most persons; and in every one in certain states, to imagine vomiting is to vomit.

The great play of individual idiosyneracy in all these matters, shows that the following or not following of action upon representation is a matter of connections among nervous centres, which connections may fluctuate widely in extent. The ordinary "voluntary" act results in this way: First, some feeling produces a movement in a reflex, or as we say, accidental way. The movement excites a sensorial tract, causing a feeling which, whenever the sensorial tract functions again, revives as an idea. Now the sensorial and motor tracts, thus associated in their actions, remain associated forever afterwards, and as the motor originally aroused the sensory, so the sensory may now arouse the motor (provided no outlying ideational tracts in connection with it prevent it from so doing). Voluntary acts are in fact nothing but acts whose motor centres are so constituted that they con be aroused by these sensorial centres, whose excitement was originally their effect. Acts, the immervation of which cannot thus rum up its primal stream, are not voluntary. But the line of division runs differently in different individuals.

Now notice that in all this, whether the act do follow or not upon the representation is a matter quite immaterial so far as the willing of the act represented goes. I will to write, and the act follows. I will to sneeze, and it does not. I will that the distant table slide over the floor towards me; it also does not. My willing representation can no more instigate my sneezing centre, than it can instigate the table, to activity. But in

${ }^{1}$ Lotze, Medicinische Psychologie, p. 303. 
both cases, it is as true and good willing as it was when I willed to write. In a word, volition is a psychic or moral fact pure and simple, and is absolutely completed when the intention or consent is there. The supervention of motion upon its completion is a supernuneraly phenomenon belonging to the department of physiology exclusively, and depending on the organic structure and condition of executive ganglia, whose functioning is quite unconscious.

In St. Vitus' dance, in locomotor ataxy, the representation of a movement and the consent to it take place normally. But the inferior executive centres are deranged, and although the ideas discharge them, they do not discharge them $x_{0}$ as to reproduce the precise sensations which they prefigure. In aphasia the patient has an image of certain words which he wishes to utter, but when he opens his mouth, he hears himself making quite unintended sounds. This may fill him with rage and despair - which passions only show how intact his will remains. ${ }^{1}$

Paralysis only groes a step farther. The associative mechanism is not only deranged but altogether broken through. The volition occurs, but the hand remains as still as the table. The paralytic is made aware of this by the absence of the expected change in his afferent sensations. He tries harder, $i$. e., he mentally frames the sensation of muscular "effort" with consent that it shall occur. It does so: he frowns, he heaves his chest, he clenches his other fist, but the palsied arm lies passive. ${ }^{2}$ It may then be that the thought of his impotence shall make his will, like a Rarey-tamed hore, forever afterwards cowed, inhibited, impossible, with respect to that particular motion. ${ }^{3}$

The special case of the limb being completely anæsthetic, as well as atactic, curiously illustrates the merely external and quasi-accidental comnection between muscular motion and the thought which instigates it. We read of cases like this:

"Voluntary movements camnot be estimated the moment the patient ceases to take note of them by his eyes. Thus after having made him close his eyes, if one asks him to move one of his limbs either wholly or in part, he does it but cannot tell whether the effected movement is large or small, strong or weak, or even if it has taken place at all. And when he opens his eyes after moving his leg from right to left, for example, he declares that he had a very inexact notion of the extent of the effected movement. . . . If, having the intention of executing a certain movement, I prevent him, he does not perceive it, and supposes the limb to have taken the position he intended to give it." 4 Or this:

\footnotetext{
${ }^{1}$ In ataxy it is true that the sensations resultant from movement are usually disguised by anasthesia. - This has led to false explanations of the symptom (Leyden, Die graue Degeneration des Riuckenmarks, 1863). But the undeniable existence of atactics without a trace of insensibility proves the trouble to be due to disorder of the associating machinery between the centres of ideation and those of discharge. These latter cases have been used by some authors in support of the Innervationsgetiul theory: (Classen: das Schlussverfahren des Sehactes, 1863, p. 50); the spasmodic irregular movements being interpreted as the result of an imperfect sense of the amount of innervation we are exerting. There is no subjective evidence whatever of such
}

a state. The undoubtedly true theory is best expounded by Jaccoud: Des Paraplegies et de l'Ataxie Motrice, 1864, part iii, chapter ii.

${ }^{2}$ A normal palsy occurs during sleep. We will all sorts of motions in our dreams, but seldom perform any of them. In nightmare we become conscious of the non-performance, and will the "effort." "This seems then to occur in a restricted way, limiting itself to the occlusion of the glottis and producing the respiratory anxiety which wakes us up.

3 Vide supra, p. 8, note 3.

4 Landry: Mémoire sur la Paralysie du Sens Musculaire, in Gazette des Hopitaux, 1855, p. 270. 
"The patient when his eyes were closed in the middle of an unpractised movement, remained with the extremity in the position it had when the eyes closed and did not complete the movement properly. Then after some oscillations the limb gradually sank hy reason of its weight (the sense of fatigue being absent). Of this the patient was not aware, and wondered when he opened his eyes, at the altered position of his limb." 1

In the normal state of man there is always a possibility that action may not occur in this simple ideo-motor way. The motor ideas may awaken other ideas which inhibit the discharge into the executive ganglia. But in the state called hypnotism we have a condition analogous to sleep in so far forth that the ideas which turn up do not awaken their habitual and most reasonable associates. Their motor effects are therefore not inhibited, and the hypnotized sulbject not only believes everything that is told him, however improbable, but he acts out every motor suggestion which he receives. The eminent French philosopher, Renouvier, as early as 1859 , expressly aswimilated these facts of hypnotism to the ordinary ideo-motor actions, and to those effects of moral vertigo and fascination which make us fall when we are on heights, laugh from the fear of laughing, etc., etc. His account of the psychology of volition ${ }^{2}$ is the firmest, and in my opinion, the truest connected treatment yet given to the subject by any author with whom I am acquainted.

\section{The Will connects Terms in the Mental Spmere only.}

We must now leave behind us the cases of extremely uncomplicated mental motivation, which we have hitherto consiclered, and take up others where the tendency of a particular motor idea to take effect is arrested or delayed. These are the cases where the fict, the distinct decision, or the volitional effort, come in; and we find them of many degrees of complexity.

First there are cases with no effort properly so called, either of muscle or resolution: Shall I put on this hat or that? Shall I draw a horse or a man on the sheet of paper which this amusement-craving child brings me? Shall I move my index finger, or my little finger to show my "liberm arbitrim indifferentice?" In the mountains, in youth, on some intoxicating autumm morning, after invigorating slumber, we feel strong enough to jump over the moon, and casting about us for a barrier, a rock, a tree, or any object on which to measure our bodily prowess, we perform with perfect spontaneity feats which at another time might demand an almost impossible exertion of muscle and of will.

Both of these exertions are present in a vast class of actions. Exhausted with fatigue and wet and watching, the sailor on a wreck throws himself down to rest. But hardly are his limbs fairly relaxed, when the order "to the pumps!" again sounds in his ears. Shall

1 Tàkacs. Ueber die Verspätung der Empfindungrleitung. Archiv fur Psychiatrie $\mathrm{Bd} . \mathbf{X}$, Heft 2, p. 533.

${ }^{2}$ Essais de Critique Générale; 2 me Essai, Psychologie rationelle, pp. 237 and following. 2me Édition, 1875. Tome I, pp. 367-408. Heidenhain, in an interesting pamphlet (Der sogennante thierische Magnetismus, Leipzig,
1880), has recently propounded the opinion that in lyypnotized subjects the hemispheres are thrown entirely out of gear and no ideas whatever awakened. This opinion is so much at variance with that of English and French observers that further corroboration is required. 
he, can he, obey it? Is it not better just to let his aching body lie, and let the ship go down if she will? So he lies on, till, with a de:perate heave of the will, at last he staggers to his legs, and to his task again.

Again, there are instances where the volitional fiat demands great effort though the mu*cular exertion be insignificant, $e . g$, the getting out of bed and bathing oneself on a cold morning.

Finally, we may have the fiat in all its rigor, with no motor representation whatever involved, or one so remote as not to count directly at all in the mental motivation.

Of the former class are all resolutions to be patient rather than to act. Such a one we have to make in the dentist's chair: The alternatives are a state of inward writhing, and mental swearing, coupled with spasmodic respiration, and all sorts of irregularly antagonistic muscular contractions - a state of shrinking and protest in a word, on the one hand; and on the other a state of muscular relaxation and free breathing, a sort of mental welcoming of the pain, and the elated consciousness that be it never so savage, we can stand it. This is a state of consent, and the passage from the former state to it, not the passage the other way, is in this instance the one requiring the fiat, and characterized by the mental "click" of resolve.

As examples of the last class, take Regulus returning to Carthage, the priest who decides to break with his church, the girl who makes up her mind to live single with her ideal, rather than accept the good old bachelor who is her only suitor, the embezzler who fixes a certain day on which to make public confession, the deliberate suicide, yea the wretch who after long hesitation, resolves that he will put arsenic into his wife's cup. These pass through one moment which like a knife-edge parts all their past from all their future, but which leads to no immediate muscular consequences at all.

Now if we analyze this great variety of cases, we shall find that the knife-edge moment where it exists, has the same identical constitution in all. It is literally a fiat, a state of mind which consents, agrees, or is willing, that certain represented experiences shall contimue to be, or should now for the first time become, part of Reality. The consent comes after hesitation. The hesitation came because something made us imagine another alternative. When both alternatives are agreeable, as in the intoxication of the mountain morning, or the liberum arbitrium indifferentice, the hesitation is but momentary; for either course is better than delay, and the one which lies nearest when the sense that we are uselessly delaying becomes pungent, is the one which discharges into act - thus no mental tension has time to arise.

But in other cases both alternatives are images of mixed good and evil. Whatever is done has to be done against some inhibitory agency, whether of intrinsic unpleasantness in the doing, or of represented odiousness of the doing's fruits: the fiat has to occur against resistance. Volition then comes hand in hand with the sentiment of effort, and the proper problem of this essay lies before us.

What does the effort seem to do? To bring the decisive volition. What is this volition? The stable victory of an idea, although it may be disigreeable, the permanent suppression of an idea although it may be immediately and urgently pleasant.

What do we mean by "victory"? The survival in the mind in such form as to constitute unwavering contemplation, expectation, assent, or affirmation. What do we mean by 
"suppression"? Either complete oblivescence, or such presence as to eroke the stcady sentiment of aversion or negation.

Volition with effort is then incidental to the conflict of ideas of what our experience may be. Conflict involves those strange states or general attitudes of feeling, which when we speak logically or intellectually, we call affirmation and negation, but when we speak emotionally, we call assent and refusal. Psychologically of coure, like every other mental modification, these attitudes are feelings sui generis, not to be described, but only labelled and pointed out. What they are in se, what their confliet is, and what its decision and resolution are, we know in every given case introspectively with an absolute clearness that nothing can make clearer. But what forms of cerebral nerve-process correspond to these mind-processes is an infinitely darker matter, and one as to which I will here make no suggestion except the simple and obvious one that they and volition with them are sulserved by the ideational centres exclusively and involve no downward irradiation into lower parts. The irradiation only comes when they are completed.

In the dentist's chair, one idea is that of the manliness of enduring the pain, the other is that of its intolerable character. We assent to the manliness, saying, "let it be the reality," and behold, it becomes so, though with a mental effort exactly proportionate to the sensitiveness of our nerves. To the sailor on the wreck, one idea is that of his sore hands, and the nameless aching exhaustion of his whole frame which further pumping involves. The other, is that of a hungry sea ingulfing him. He says : " rather the former!' and it becomes reality, in spite of the inhibiting influence of the comparatively luxurious sensations of the spot in which he for the moment lies.

To the sinner in the agony of his mind, one idea is of the social shame and all the outward losses and degradations to which confession will expose him, the other is that of the rescue from the dimmed unending inward foulness to which concealment seems to doom him. He says to the confession, "fiat! with all its consequences," and sure enough, when the time comes, fit, but not without mental blood and sweat.

Everywhere the difficulty is the same: to keep affirming and aclopting a state of mind of which disagrecableness is an integral factor. The disagreeableness need not be of the nature of pain; it may be the merely relative disagreeableness of insipidity. When the spontaneous course of thought is to exciting images, whether sanguine or lugubrious, loving or revengeful, all reasonable representations come with a deadly flatness and coldness that strikes a chill to the soul. To cling to them however, as soon as they show their faces, to consent to their presence, to affirm them, to negate all the rest, is the characteristic energy of the man whose will is strong. If on this purely mental plane his effort succeeds, the outward consequences will take care of themselves, for the representation will work unaided its motor effects. The simplest cases are the best for illustrating the point, and in the case of a man afflicted with insomnia, and to whose body sleep comes through the persistent successful diversion of the mind from the train of whirling thoughts, to the monotonous contemplation of one letter after another of a verse of poetry, spelled out synchronously with the acts of respiration, we have all the elements that can anywhere be found: a struggle of ideas, a victory of one set and certain bodily effects automatically consequent thereon. To sustain a representation, to think, is what requires the effort, and is the true moral act. Maniacs know their thoughts to be 
insane, but they are too pressing to be withstood. Agrain and again sober notions come, but like the sober instants of a drunken man, they are so sickeningly cadaverous, or else so still and small and imperceptible, that the lunatic can't bear to look them fully in the face and say: "let these alone represent my realities." Such an extract as this will illustrate what I mean:

"A gentleman of respectable birth, excellent education, and ample fortune, engaged in one of the highest departments of trade .... and being induced to embark in one of the plausible speculations of the day .... was utterly ruined. Like other men he could bear a sudden overwhelming reverse better than a long succession of petty misfortunes, and the way in which he conducted himself on the occasion met with unbounded admiration from his friends. Ile withdrew, however, into rigid seclusion, and being no longer able to exercise the generosity and indulge the benevolent feclings which had formed the happiness of his life, male himself a substitute for them by daydreams, gradually fell into a state of irritable despondency, from which he only gridually recovered with the loss of reason. He now fancied himself possessed of immense wealth, and gave without stint his imaginary riches. He has ever since been under gentle restraint, and leads a life not merely of happiness, but of bliss; converses rationally, rearls the newpapers, where every tale of distress attracts his notice, and being furnished with an abundant supply of blank checks, he fills up one of them with a munificent sum, sends it off to the sufferer, and sits down to his dinner with a happy conviction that he has earned the right to a little indulgence in the pleasures of the table; and yet, on a serious conversation with one of his old friend, he is quite conscious of his real position, but the conviction is so exquisitely painful that he will not let himself believe it."1

Now to turn to the special case of the decision to make a muscular movement. This decision may require a volitional effort, or it may not. If $\mathrm{I}$ am well, and the movement is a light one (like the brushing of dust from my coat-sleeve), and suggests no consequences of an unpleasant nature, it is effortless. But if unpleasant consequences are expected, that effective sustaining of the idea which results in bringing the motion about, and which is equivalent to mental consent that those consequences become real, involves considerable effort of volition. Now the unpleasant consequences may be immediate -, my body may be weary, or the movement violent, and involve a great amount of that general and special afferent feeling which we learned above to constitute muscular exertion. Under these circumstances the idea of the movement is the imagination of the massively umpleasant feelings, and nothing else. The willing of the movement is the consent to these imagined feelings becoming real, - the saying of them, "futent." The effort which the willing requires is the purely mental transition from the mere conception of the feelings to their expectation, stendfastly maintaining itself before the mind, disagreeable though it be. The motor idea, assuming at last this victorious status, not only uninhibited by remote associations, but inhibited no longer even by its own unpleasuntnes, discharges by the preappointed mechini-m into the right muscles. Then the motor sensations accrue in all their expected severity, the and muscular effort as distinguished from the volitional effort has its birth.

1 The Duality of the Mind, by A. L. Wigan, M. D., p. 123. 
It is needless after this to say what absolutely different phenomena these tro efforts are, or to expatiate upon the unfortunateness of their being confoumled under the same generic name. Muscular feelings whenever they are massive, and the body is not "fresh," are rather disagreeable, especially when accompanied by stopped breath, congested head, bruised skin of fingers, toes, or shoulders, and strained joints. And it is only as thess disagreedble that the mind has difficulty in consenting to their reality. That they happen to be made real by our bodily activity is a purely accidental circumstance. A soldier standing still to be fired at, expects disagreeable sensations engendered by his bodily passivity. The action of his will, in consenting to the expectation, is identical with that of the sailor rising to gro to the pumps. What is hard for both is facing an idea as real.

The action of the will must not be limited to the willing of an act. To exert the will and to make soft muscles hard, are not one thing, but two entirely different things. Extremely frequent association may account for, but not excuse their confusion by the psychologist. The represented disagreeableness of a muscular motion may often be that which an exertion of will is called on to overcome; but as well might a cook, who daily associates the burning of the fire with the boiling of the potatoes, define the inward essence of combustion as the making of hard potatoes soft.

The action of the will is the reality of consent to a fact of any sort whatever, a fact in which we ourselves may play either an active, or a suffering part. The fact always appears to us in an idea: and it is willed by its idea becoming victorious over inhibiting ideas, banishing negations, and remaining affirmed. The victorious idea is in every case whatsoever built up of images of feelings afferent in their origin. And the first philosophical conclusion properly so-called, into which our inquiry leads us, is a confirmation of the older sensationalist view that all the mind's materials without exception are derived from passive senvibility. Those who have thought that sensationalism abdicated its throne and mental spontaneity came in when Prof. Bain admitted a "sensation of energy exerted by the outgoing stream,"' have rejoiced in the wrong place altogether. There is a feeling of mental spontaneity, opposed in nature to all afferent feelings; but it does not, like the pretended feeling of muscular innervation, sit among them as among its peers. It is something which dominates them all, by simply choosing from their midst. It may reinforce either one in turn - a retinal image by attending to it, a motor image by willing it, a complex conception, like that of the world having a divine meaning, by believing it. Whatever mental material this element of spontaneity comes and perches on, is sustained, affirmed, selected from the rest; though but for the feeling of spontaneous psychic effort, which thus reinforces it, we are conscious every moment that it might cease to be. The whole contrast of a priori and empirical elements in the mind lies, I am fully convinced, in this distinction. All our mind's contents are alike empirical. What is a priori is only their accentuation and emphasis. This greeting of the spirit, this accuiescence, connivance, partiality, call it what you will, which seems the inward gift of our selfhood, and no essential part of the feelings, to either of which in turn it may be given, - this psychic effort pure and simple, is the fact which a priori psychologists really have in mind when they indignantly deny that the whole intellect is derived from sense. 


\section{No Conscious Dynamic Connection between trie Inner and Outer Worlds.}

Now if we take this psychic fact for just what on the face of it it seems to be, namely, the giving to an idea the full degree of reality it can have in and for the mind, we are led to a curious view of the relations between the inner and the outer worlds. The ideas, as mere representatives of possibility, seem set up midway between them to form a sort of atmosphere in which Reality floats and plays. The mind can take any one of these ideas and make it its reality - sustain it, adopt it, adhere to it. But the mind's state will be Error, unless the outer force "backs" the same idea. If it backs it, the mind is cognitive of 'Truth; but whether in error, or in truth, the mind's espousal of the idea is called Belief. The outer force seems in no wise constrained to back the mind's adoptions, except in one single kind of case, - where the idea is that of bodily movement. Here the outer force (with certain reservations) obeys and follows the mind's lead, agreeing to father as it were every child of that sort which the mind may conceive. And the act by which the mind thus takes the lead is called a Volition.

The ideas backed by both parties are the Reality; those backed by neither, or by the mind alone, form a residuum, a sort of limbo or no-man's land, of wasted fancies and aborted possibilities.

But is it not obvious from this that the difference between Belief and Volition is not intrinsic? What the mind does in both cases is the same. It takes an image, and says, "so far as I am concerned, let this stand; let it be real for me." The behavior of the outer force is what makes all the difference. Generally constrained in the case of the motor volition, it is independent in the case of the belief. It is true that volition may be impotent and belief delusive; - but be they however never so filse or powerless, by their inward nature they are ejusdem farince, - beliefs and volitions still.

Belief and Will are thus concerned immediately only with the relation between possibilities for the mind, and realities for the mind. The notion of reality for the mind, becomes thus the pirotal notion in the analysis of both. To analyze this notion itself . seems at present an impossible task. Professor Bain has exerted his utmost powers upon it, but, to our mind, without avail ; and what J. S. Mill says ${ }^{1}$ still remains true, that when we arrive at the element which makes a belief differ from a mere conception, "we seem to have reached as it were, the central point of our intellectual nature, presupposed and built upon in every attempt to explain the more recondite phenomena of our being."

The sense of reality must then be postulated as an ultimate psychic fact. But we know that it may come with effort, or without, in the theoretic as well as in the motor sphere; and the reader who has had the patience to follow our study of effort as far as this, will not object to going on now to consider it in both spheres together.

Hume said that to believe an idea, was simply to have it in a lively manner. We, on our part, have seen the ideo-motor cases in which to will an idea is simply to have it. But a moment's reflexion shows that such spontaneous belief and will are possible only where the mind's contents are at a minimum of complication. In the trance-subject's mind

\footnotetext{
${ }^{1}$ His edition of James Mills' "Analysis." Vol. i., p. 423. hiș Emotions and Will.

Bain's reply is in the chapter on Belief in the $3 \mathrm{~d}$ edition of
} 
any simple suggestion will be both believed and acted on, because none of its usual associates are awakened. Bain ${ }^{1}$ and Taine ${ }^{2}$ Lave beautifully shown how in the normal subject all ideas taken per se are hallucinatory or held as true. Doubt never comes from any intrinsic insufficiency in a thought, but from the manner in which extrinsic ideas conflict with it, or in 'Taine's phrase, serve as its reductive. Before they come we have the primal state of theoretic and practical immocence.

But wider suggestions bring the fall, and turn the simple credulity to doubt and the fearless spontaneity to hesitation. A stable faith, a firm decree, can then only come after reflection, and be its fruits. What is reflection? A conflict between many ideas of possibility. During the conflict the sense of reality is lost or rather the connexion between it and each of the ideas in turn. The conflict is over when the sense of reality returns, like the tempered steel, ten times more precious and invincible for its icy bath in the waters of uncertainty. But why and how does it return? and why does it so often return with the symptom of effort by its side? Is it an independent entity which merely took its flight at the first alarm of the battle, and which now with effort as its ally and affirmation at its right hand and negation at its left, comes back to give the victory to one idea? Or is it a simple resultant of the victory which was a foregone conclusion decided by the intrinsic strength of the conflicting ideas alone?

We stand here in the presence of another mighty metaphysical problem. If the latter alternative be true there is no genuine spontaneity, no ambiguous power of decision, no real freedom either of faith or of act. The effort which seems to come and reinforce one side, endowing it with the feeling of reality, can be no new force adding itself to those already in the arena. It can only be a sort of eddy or derivative from their movement, whose semblance of independent form is illusory, and whose amount and direction are implicitly given the moment they are posited.

This has been the doctrine of powerful schools. The ideas themselves and their conflict have been held to constitute the total history of the mind, with no unaccounted-for phenomenon left over. Long before mutual inhibition by nerve processes had been discovered, the inhibitions and furtherances of one idea by another, had by IJerbart been erected into a completely elaborated system of puchic staties and druamies. The Finglish associationist school, without using the word inhibition, and in a much less outwardly systematic, though by no means less successful way, had also represented choice and decision as nothing but the resultant of different ideas failing to neutralize each other exactly. Doubt, fear, contradiction, curiosity, desire, assent, conviction, affirmation, negation and effort, are all alike, on this view, but collateral products, incidents of the form of equilibrium of the representations, as they pass from the oscillating to the stable state.

This is of course conceivable; - and to have the conception in a lively manner, (as Hume says), may well in us as in so many others, carry the sense of reality with it, and command conviction. But still the other alternative conflicts, and may reduce this conception to one of mere possibility, degrading it from a creed to an hypothesis. It seems impossible, if our minds are in this open state, to find any crucial evidence which may decide. I shall, therefore, not pretend to dogmatize myself, but close this essay by a

\footnotetext{
1 Emotions and IVill. 3d Ed. pp. 511-517.
}

${ }^{2}$ De l'Intelligence. Part i, Buok ii, Chap. i. 
few considerations, which may give at least an appearance of liveliness to the alternative notion, that the mental effort with which the affirmation of reality so often comes conjoined, may be an adventitious phenomenon, not wholly given and pre-determined by the ideas of whose struggle it accompanies the settlement.

A little natural history becomes here necessary. When outer forces impinge upon a body we say that its resultant motion follows the line of least resistance, or of greatest traction. When we deliberately symbolize the mental drama in mechanical language, we also say that belief and will follow the lines of least resistance, or of most attractive motivation. But it is a curious fact that our spontaneous language is by no means compatible with the law that mental action always follows lines of least resistance. Of course, if we proceed a priori and define the line of least resistance, as the line that is followed, the law must hold good. But in all hard cases either of belief or will, it seems to the agent as if one line were easier than another, and offered least resistance, even at the moment when the other line is taken. The sailor at the pumps, he who under the surgeon's knife represses cries of pain, or he who exposes himself to ostracism for duty's sake, feels as if he were following the line of greatest temporary resistance. He speaks of conquering and overcoming his impulses and temptations.

But the sluggard, the drunkard, the coward, never talk of their conduct in that way or say they resist their energy, overeome their sobriety, conquer their courage and so forth. If in general we class all motives as sensual on the one hand and moral on the other, the sensualist never says of his behavior that it results from a victory over his conscience, but the moralist always speaks of his as a vietory over his appetite. The sensualist uses terms of inactivity, says he forgets his ideal, is deaf to duty and so forth; which terms seem to imply that the moral motives per se can be ammulled without energy or effort, and that the strongest mere traction lies in the line of the sensual impulse. The moral one appears in comparison with this, a still small voice which must be artificially reinforced to prevail. Effort is what reinforces it, making things seem as if, while the sensual force were essentially a fixed quantity, the moral might be of various amount. But what determines the amount of the effort when by its aid moral force becomes victorious over a great sensual resistance? The very greatness of the resistance itself. If the sensual impulses are small, the moral effort is small. The latter is made great by the presence of a great antagonist to overcome. And if a brief definition of moral action were required, none could be given which would better fit the appearances than this: It is action in the line of the greatest resistance.

The facts may be most briefly symbolized thus. S standing for the sensual motive, II for the moral and $\mathrm{E}$ for the effort:

$$
\begin{aligned}
& \mathrm{M} \text { per se }<\mathrm{S} . \\
& \mathrm{II}+\mathrm{E}>\mathrm{S} .
\end{aligned}
$$

In other words, if $\mathrm{E}$ adds itself to $\mathrm{M}, \mathrm{S}$ immediately offers the least resistance, and motion occurs in spite of it.

But the $\mathrm{E}$ does not seem to form an integral part of the M. It appears adventitious and indeterminate in advance. We can make more or less as we please, and if we make enough we can convert the greatest mental resistance into the least. 
Now the question whether this appearance of ambigruity is illusory or real, is the question of the freerlom of the will. Many subtle considerations may be brought to prove that the amount of effort which a moral motive comports as its ally, is a fixed function of the motive itself, and like it, determined in advance. On the other hand, there is the notion of an absolute ambiguity in the being of this thing, and its amount, sun-clear to the consciousness of each of us. He who loves to balance nice doubts and probabilities, need be in no hurry to decide. Like Mephistopheles to Faust, he can say to himself, "dazu hast du noch eine lange Frist," for from generation to generation the evidence for both sides will grow more voluminous, and the question more exquisitely refined. But if his speculative delight is less keen, if the love of a parti pris outweighs that of keeping questions open, or if, as a French philosopher of genius ${ }^{1}$ says, " $l$ " amour de la vie qui s'indigne de trut de discours," awakens in him, craving the sense of either peace or power; then taking the risk of error on his head, he must project upon one of the alternatives in his mind, the attribute of reality for him. The present writer does this for the alternative of freedom. May the reader derive no less contentment if he prefer to take the opposite course!

Only one further point remains, but that is an important one philosophically. There is no commoner remark than this, that resistance to our muscular effort is the only sense which makes us aware of a reality independent of ourselves. The reality revealed to us in this experience takes the form of a force like the force of effort which we ourselves exert, and the latter after a certain fashion serves to measure. ${ }^{2}$ This force we do not similarly exert when we receive tactile, auditory, visual and other impressions, so the same reality cannot be revealed by those passive senses.

Of course if the foregoing analysis be true, such reasoning falls to the ground. The "muscular sense" being a sum of afferent feelings is no more a "force-sense" than any other sense. It reveals to us hardness and pressure as they do colour, taste, smell, sonority, and the other attributes of the phenomenal world. To the naive consciousness all these attributes are equally objective. To the critical all equally subjective. The physicist knows nothing whatever of force in a non-phenomenal sense. Force is for him only a generic name for all those things which will cause motion. A falling stone, a magnet, a cylinder of steam, a man, just as they appear to sense, are forces. There is no supersensible force in or behind them. Their force is just their sensible pull or push, if we take them naturally, and just their positions and motions if we take them scientifically. If we aspire to strip off from Nature all anthropomorphic qualities, there is none we should get rid of quicker than its "Force." How illusory our spontaneous notions of force grow when projected into the outer world becomes evident as soon as we reflect upon the phenomenon of muscular contraction. In pure objective dynamic terms (i.e., terms of position and motion), it is the relaxed state of the muscle which is the state of stress and tension. In the act of contraction, on the contrary, the tension

1 J. Lequier: La Recherche d'une Première Vérité, 1865. p. 90 .

2 See for example, Psychology, Part VII,Chaps. XVI and VII; Herschel's Familiar Lectures, Lecture XII ; an article on "the Force behind Nature," by Dr. Carpenter, reprinted in the Pop. Sc. Montlyly for March, 1880; Martineau's lieview of Bain; Mansel's Metaphysics. pp. 105, 346. 
is resolved, and disappears. Our feeling abont it is just the other way, - which shows how little our feeling has to do with the matter.

The subject has an interest in connection with the free-will controversy. It is an admitted mechanical principle that the resultant movement of a system of bodies linked together in definite relations of energy, mar vary according to changes in their collocation, brought about by moving them at right angles to their pre-existing movements; which changes will not interfere with the conservation of the system's energy, as they perform work upon it. Certain persons desiring to harmonize free will with the theory of conservation, have used this conception to symbolize the dynamic relations of will with brain, by saying that the mental effort merely determines the moment and the spot at which a certain molecular vis viva shall start, by a sort of rectangular pressure which plays the part of an independent variable in the equations of movement required by the principles of conservation. Thus free will may be conceived without any of the internal energy of the system being either augmented or destroyed.

Now so long as mental effort in general was supposed to have a particular connection with muscular effort, and so long as muscular effort was supposed to reveal to us behind the resistance of bodies, a "force" which they contained, there was a ready reply to all this speculation. Your will, it could be said, is doing "work" upon the system. "Work" is defined in mechanics as movement done against resistance, and your will meets with a resistance which it has to overcome by moral effort. Were the molecular movements brought about by the will, rectangular to pre-existing movements, they would not resist, and the volition would be effortless. But the volition involves effort, and since according to the will-muscle-force-sense theory, its effort is an inner force which overcomes a real outer force, since, indeed, without this antagonism we should be without the notion of outer force altogether, why then the effort, if free, must be an absolutely new contribution and creation so far as the sum of cosmic energy is concerned. The only alternative then (if one still held to the will-muscle-force-sense theory) was either with Sir Joln Herschel, frankly to avow that "force" may be created anew, and that "conservation" is only an approximate law; or else to drop freewill, in favor of conservation, and suppose the ego in willing, to be merely cognitively conscions, in the midst of the universal force-stream, of certain currents with which it was mysteriously fated to identify itself.

To my mind all such discussions rest on an anthropomorphization of outward force, which is to the last degree absurd. Outward forces so far as they are anything, are masses in certain positions, or in certain movements, and nought besides. The muscular "force-sense" reveals to us nothing but hardness and pressure, which are subjective sensations, like warmth or pain. The moral effort is not transitive between the inner and the outer worlds, but is put forth upon the inner world alone. Its point of application is an idea. Its achievement is "reality for the mind," of that idea. That, when the idea is realized, the corresponding nerve tracts should be modified, and so de procke en proche, the muscles contract, is one of those harmonies between inner and outer worlds, before which our reason can only avow its impotence. If our reason tries to interpret the relation as a dynamic one, and to conceive that the neural modification is

$$
1 \text { Loc. cit., p. } 468 .
$$


brought ahout by the idea shoving the molecules of the ganglionic matter sideways from their course, well and grood! Only we had better assume ourselves unconscious of the dynamism. We are unconscious of the molecules as such, and of our lateral push as such. Why should we be conscious of the "force" as such, by which the molecules resist the push? They are one thing, and the consciousness which they subserve is always an idea of another thing. The only resistance which the force of consciousness feels or can feel, is the resistance which the idea makes to being consented to as real.

\section{Conclusions.}

1. Muscular effort, properly so called, and mental effort properly so called, must be distinguished. What is commonly known as "muscular exertion," is a compound of the two.

2. The only feelings and ideas connected with muscular motion are feelings and ideas of it as effected. Muscular effort proper, is a sum of feelings in afferent nerve tracts, resulting from motion being effected.

3. The pretended feeling of efferent innervation does not exist - the evidence for it drawn from paralywis of single eye muscles, vanishing when we take the position of the sound eye into account.

4. The philosophers who have located the human sense of force and spontaneity in the nens between the volition and the muscular contraction, making it thus join the inner and the outer worlds, have gone astray.

5. The point of application of the volitional effort always lies within the inner world, being an idea or representation of afferent sensations of some sort. From its intrinsic nature or from the presence of other ideas, this representation may spontaneously tend to lapse from vivid and stable consciousness. Mental effort may then accompany its maintenance. That (being once maintained) it should by the connection between its cerebral seat and other bodily parts, give rise to movements in the so-called voluntary muscles, or in glands, vesisels, and viscera, is a subsidiary and secondary matter, with which the psychic effort has nothing immediately to do.

6. Attention, belief, affirmation and motor volition are thus four names for an identical process, incidental to the conflict of ideas alone, the survival of one in spite of the opposition of others.

7. The surviving idea is invested with a sense of reality which cannot at present be further analyzed.

8. The question whether, when its survival involves the feeling of effort, this feeling is determined in advance or absolutely ambiguous and matter of chance as far as all the other data are concerned, is the real question of the freedom of the will, and explains the strange intimateness of the feeling of effort to our personality.

9. T'o single out the sense of muscular resistance as the "force sense" which alone can make us acquainted with the reality of an outward world is an error. We cognize outer reality by every sense. The muscular makes us aware of its hardness and pressure, just as other afferent senses make us aware of its other qualities. If they are too anthropomorphic to be true, so is it also. 
10. The ideational nerve tracts alone are the seat of the feeling of mental effort. It involves no discharge downward into tracts connecting them with lower executive centres; though such discharge may follow upon the completion of the nerve processes to which the effort corresponds. 



